
LIBRARY

UNIVERSITY CALIFOR :

SANTA CRUZ 

Digitized by the Internet Archive in 2007 with funding from Microsoft Corporation 




\section{NEW MANUAL OF BOTANY}

OF THE

\section{CENTRAL ROCKY MOUNTAINS}

\section{(VASCULAR PLANTS)}

BY

JOHN M. COULTER, Ph. D.

PROFESSOR OF BOTANY, THE UNIVERSITY OF CHICAgo

REVISED BY

AVEN NELSON, Ph. D.

PROTESSOR OF BOTANY, THE UNIVERSITY OF WYOMING

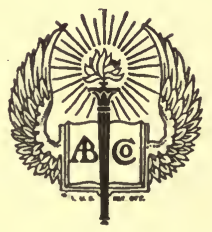

NEW YORK • :• CINCINNATI •:• CHICAGO

A M E R I CA N B OOK COM PANY 
COPYRIGHT, 1909, BY JOHN M. COULTER

Entered at Stationers' Hall, London

W. P. 2 


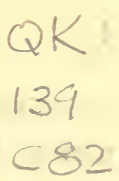

\section{PREFACE}

IN 1885 the Manual of the Botany of the Rocky Mountain Region was published. It was based upon general explorations of the region concerned, and was confessedly tentative. During the last twenty-four years, general explorations of the vascular flora have merged into more or less intensive studies, and the manual long ago became inadequate.

It was the original purpose to revise it as frequently as new material justified, but the author's time and attention became absorbed in other kinds of botanical work, so that no revision has appeared. As the book continued to be in demand, it seemed necessary, in justice to its users, to bring it up to date. This work has been undertaken by Professor Aven Nelson of the University of Wyoming (Laramie), whose great familiarity with the flora of the Rocky Mountain region suggested his fitness for the task.

Professor Nelson has completely rewritten the book, and in such a way that it is as far from being a compilation as so general a manual can be. He has checked up the descriptions by an examination of the plants and by his extensive field experience. Descriptions and keys have been tested repeatedly, and are believed to be workable.

The manual is intended to represent current knowledge in reference to the flora for the benefit of the ordinary user of a manual. The professional taxonomist will not find in it all of the subdivisions of genera and species that he might wish, but it is thought that this will make it more serviceable to the general user, and that it presents an adequate account of the flora from the more conservative viewpoint.

The sequence of families is that known as Engler's, which is in general use by botanists; and the nomenclature, so far as practicable, is that adopted by the Vienna Congress. Names following the descriptions, but without citation or parenthesis, are those of the old manual, which have been changed. Names with citation and parenthesis represent what are regarded as synonyms. When new combinations have been found necessary, the discarded 
combinations are indicated as are other synonyms. Common names have been used sparingly, for it has not been deemed wise to propose them when they are not already in general use.

The area covered can be outlined somewhat more exactly than in the previous edition, as the natural boundaries of our floras are now better understood, which do not always coincide with the boundaries of States and Territories. The purpose has been to use Colorado as the center of the flora included in the manual, and to present complete the flora of that State, of Wyoming, of Yellowstone Park, and of the Black Hills of South Dakota; also to include most of Montana, southern Idaho, the eastern half of Utah, and the northern half of New Mexico and adjacent Arizona. Naturally the manual will also cover fairly well an indefinite border to the territory outlined.

It is not possible to acknowledge all the sources of information in the preparation of a manual, but the following list of authors may be cited, from whose publications, descriptions and keys have been obtained: LeRoy Abrams, L. H. Bailey, N. L. Britton, F. V. Coville, M. L. Fernald, L. N. Goodding, Asa Gray, E. L. Greene, J. M. Greenman, H. M. Hall, Thomas Howell, W. L. Jepson, Elias Nelson, C. V. Piper, B. L. Robinson, J. N. Rose, P. A. Rydberg, J. K. Small, William Trelease, Sereno Watson, and many others.

The University of Chicago.

JOHN M. COULTER.

Ever since Professor Coulter invited me to undertake the revision of his well known Manual I have had his advice and encouragement. The work has gone through the press under his direct supervision, and all of the proof sheets have passed through his hands. I take great pleasure, therefore, in acknowledging my indebtedness and in expressing my gratitude for his courtesy and helpfulness. If this new edition serves its purpose as well as the first, a large measure of credit must be given to Professor Coulter. For any errors that the book may contain, I assume entire responsibility.

AVEN NELSON.

The UNIVERSITY OF WYOMING. 


\section{CONTENTS}

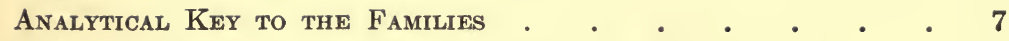

Pteridophytes (Families 1-7) . . . . . . . . . 17

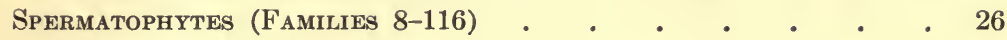

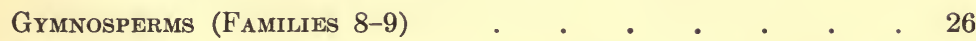

Angiosperms (Families 10-116) . . . . . . . . . 31

Monocotyledons (Families 10-27) . • • • . . 31

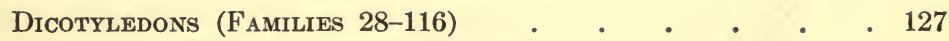

Archichlamydeae (Families 28-85) . . • • . 127

Sympetalae (FAmilies 86-116) . . . . . . . 366

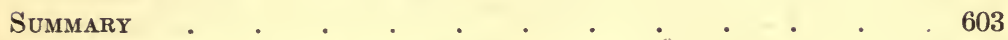

Abbreviations of Authors' Names . . . . . . . . 606

List of New Names and Combinations . • • • • . 608

GLOSSARY • • • • • • • • • • • . 611

$\operatorname{INDEX} \cdot \quad \cdot \quad \cdot \quad \cdot \quad \cdot \quad \cdot \quad \cdot \quad \cdot \quad \cdot \quad 623$ 



\section{ANALYTICAL KEY TO THE FAMILIES*}

\section{Division I. PTERIDOPHYTES}

Fern-like, moss-like, or rush-like vascular plants without true flowers or seeds.

Stems conspicuously jointed, their nodes covered by toothed sheaths;

sporangia on the scales of terminal dry cone-like spikes 4. Equisetaceae, 23

Stems without conspicuously sheathed joints.

Leaves closely imbricated or very narrow; sporangia sessile, axillary.

Stem short, corm-like; leaves subulate to long-linear

Stems elongated, creeping or branching; leaves very short, crowded or imbricated.

Sporangia of two kinds, some containing many minute spores (microspores), others bearing few (usually 3-4) much larger spores (megaspores)

7. Selaginellaceae, 27

Sporangia bearing uniform minute spores

6. LYCOPODIACEAE, 25

Leaves (fronds) not closely imbricated; if narrow without axillary sporangia.

Leaves (fronds) 4-foliate, sporocarps (inclosing the sporangia) stalked from the creeping stem

3. Marsileaceae, 23

Leaves (fronds) not 4-foliate, simple or variously cleft; sporangia borne on the underside of the ordinary fronds (leaves) or on sporophylls (specialized spore-bearing leaves).

Sterile segment of the frond simple; the fertile a long-stalked simple spike

1. Ophioglossaceae, 17

Sterile and fertile fronds or segments more or less cleft, either conspicuously unlike or essentially similar

2. Polypodiaceate, 18

\section{Division II. SPERMATOPHYTES}

Plants with seeds and mostly true flowers.

\section{SUBDIVISION I. GYMNOSPERMS}

Ovules not in a closed ovary. Trees and shrubs with needle-shaped, linear, or scale-like leaves (mostly evergreen), and monoecious or dioecious cones.

Staminate and pistillate cones with no true flowers (perianth none), the pistillate becoming dry or berry-like

8. Pinaceane, 26

Staminate flowers in aments; pistillate single or in pairs; perianth urn-shaped; low shrubs with jointed branches, and leaves reduced to sheathing scales

9. Gnetaceate, 30

*Adapted from Gray's New Manual of Botany, as revised by Dr. B. L. Robinson and Professor M, L, Fernald. 


\section{Subdivision II. ANGIOSPERMS}

Ovules borne in a closed ovary, which at maturity becomes the fruit.

\section{CLASS 1. MONOCOTYLEDONS}

Stems mostly without central pith or annular layers, but having the woody fibers in small separate bundles which appear, in cross section, irregularly dispersed throughout the cellular tissue. Leaves mostly parallel-veined. Embryo with a single cotyledon and the first leaves in germination alternate. Parts of the flower usually in threes or sixes, never in fives. Our species herbaceous.

\section{THALLOID AQUATICS WITHOUT TRUE STEMS OR LEAVES}

The plant body lens-shaped, ellipsoidal, or flask-shaped, floating

18. LemNACEAE, 105

\section{PLANTS WITH STEMS AND LEAVES}

\section{PERIANTH FREE FROM THE OVARY OR WANTING}

Perianth wanting, or of scale-like or bristle-form divisions.

Flowers inclosed or subtended by imbricated chaff-like scales

(glumes); grass-like plants with jointed stems, sheathing and

mostly narrow leaves, and one-seeded fruit.

Stems hollow, round, or flattened; leaf-sheaths split; anthers attached by the middle

16. Gramineae, 38

Stems solid, usually more or less triangular; leaf-sheaths not split; anthers attached at the base

17. Cyperaceate, 84

Flowers not inclosed in chaff-like scales (though sometimes in involucrate heads).

Immersed aquatics, branching and leafy, the upper leaves often floating

12. Naiadaceae, 33

Terrestrial or marsh plants.

Flowers monoecious or dioecious.

Flowers in cylindrical spikes

10. TyPhaceae, 31

Flowers in lateral heads

11. Sparganiaceae, 32

Flowers perfect.

Ovaries 3-6, separating at least when ripe

13. JunCAGINACEAE, 36 Ovary single, of 3 carpels

21 JunCACEAE, 108

Perianth always present, herbaceous or colored, never scale-like nor bristleform.

Pistils numerous, in a head or ring

14. Alismaceae, 37

Pistil 1, cells or placentae mostly 3 .

Stamens all alike and fertile.

Ovary of nearly separate carpels

Ovary often angled or lobed but not deeply cleft.

Flowers perfect; plants not climbing.

Divisions of the perianth alike or nearly so.

Plant rush-like; perianth small, greenish or purplishbrown

21. Juncaceae, 108

Plant not rush-like. 
Styles united, often short, or rarely wanting; capsule loculicidal.

Plants with bulbs, corms, erect rootstocks, or caudices, or bundles of fleshy roots

22. Liliaceae, 113

Plants with elongated horizontal rootstocks

24. Convallariaceae, 119

Styles distinct; capsule septicidal

23. Melanthaceae, 117

Divisions of the perianth unlike ( 3 green sepals and 3 col-

ored petals); leaves linear and the flowers in umbels

19. Commelinaceae, 107

Flowers dioecious; plants scrambling or climbing 25. Smilacaceae, 121 Stamens dissimilar, or only 3 with fertile anthers.

Perianth of 3 herbaceous sepals and 3 colored ephemeral petals

Perianth tubular, 6-lobed

19. Commelinaceae, 107

20. Pontederiaceae, 108

\section{PERIANTH PRESENT, ADNATE TO THE OVARY}

Stamens 3 or more; flowers regular or nearly so.

Aquatics, ripening their fruit under water; flowers dioecious or polygamous

15. Hydrocharitaceae, 38

Terrestrial plants with perfect flowers, and 2-ranked equitant leaves

26. IRIDACEAE, 121

Stamens 1 or 2; flowers irregular.

Sepals usually 3 ; petals usually 3 , one of which (the lip) is generally spurred

27. Orchidaceae, 122

\section{Class 2. DICOTYLEDONS}

Stems with central pith inclosed by a zone of wood. Leaves net-veined. Embryo with a pair of opposite cotyledons. Parts of the flower mostly in fours or fives.

\section{COROLLA WANTING; OFTEN THE CALYX ALSO}

FLOWERS MONOECIOUS OR DIOECIOUS; ONE OR BOTH SORTS IN AMENTS

Staminate or pistillate flowers (not both) in aments or in ament-like clusters.

Trees; the leaves alternate.

The sap not milky.

Fruit a samara, winged all around

Fruit a nut or an achene

31. Ulmaceae, 143

The sap milky

30. Fagaceae, 141

Herbs or herbaceous vines, mostly with opposite leaves.

Styles and stigmas 2

Style and stigma 1

32. Moraceae, 143

32. Moraceae, 143

33. Urticaceae, 144

Staminate and pistillate flowers both in aments.

Ovary becoming a 1-celled, many-seeded pod; the seeds hairy-tufted

Ovary becoming a 1-seeded nut, achene, or berry.

28. SALICACEAE, 127

Trees or shrubs, not parasitic

Plants parasitic on trees

29. Betulaceae, 139

34. Loranthaceate, 145 


\section{FLOWERS NOT IN AMENTS}

\section{Ovary or its cells 1-2 (rarely 3-4)-ovuled.}

Pistils more than 1 , distinct or nearly so.

Stamens inserted on the calyx; leaves with stipules

Stamens inserted on the receptacle; calyx present, usually petal-

like

45. Ranunculaceae, 189

Pistil 1, simple or compound.

Ovary free from the calyx, which is sometimes wanting.

Stipules (ochreae) sheathing the stem at the nodes 36. Polygonacear, 147

Stipules (if present) not sheathing the stem.

Herbs.

Aquatics, submerged or nearly so.

Leaves whorled, dissected; style 1

44. Ceratophyllaceae, 189

Leaves opposite, entire; styles 2

65. Callitrichaceae, 311

Not aquatics.

Style (if any) 1 and stigma 1.

Flowers unisexual; ovary of the fertile flowers 1-celled

33. URTICACEAE, 144

Flowers perfect; pod 2-celled and 2-seeded, Lepidium in

48. Cruciferae, 207

Styles 2-3, or branched; ovary 1-4-celled.

Ovary and pod 3-celled; juice usually milky

64. Euphorbiaceae, 308

Ovary not 3-celled; juice not milky.

Flowers in an involucrate head; fruit a 3-angled achene, Eriogonum in

36. Polygonaceae, 147

Flowers not involucrate.

Leaves covered, at least beneath, with stellate hairs

64. Euphorbiacean, 308

Leaves without stellate hairs.

Leaves opposite.

Plant fleshy, Salicornia in 37. Chenopodiacene, 160

Plant not fleshy.

Flowers in heads or spikes; anthers 1-celled

38. Amaranthacene, 170

Flowers sessile in forks of branching inflorescence, Paronychia in

42. Caryophyllaceate, 180

Leaves alternate.

Flowers and bracts scarious

38. Amaranthaceate, 170

Flowers chiefly greenish, no scarious bracts

37. Chenopodiaceate, 160

Shrubs or trees.

Leaves opposite.

Fruit 3-celled, not winged

Fruit winged.

Fruit 2-celled, a double samara

Fruit 1-celled, a single samara

70. Rhamnaceate, 314

69. Aceraceae, 313

Leaves alternate.

Ovary 3-celled

Ovary 1-celled

91. Oleacea E, 378

70. Rhamnaceate, 314 31. Ulmaceae, 143 
Ovary inferior or so closely and permanently invested by the calyx as to appear so.

Parasites on the branches of trees

34. Loranthaceae, 145

Not parasitic.

Aquatic herbs

82. Haloragidaceae, 345

Terrestrial.

Herbs with the calyx corolla-like.

Leaves opposite

Leaves alternate

Shrubs or trees with scurfy leaves

39. Nyctaginaceae, 172

35. Santalaceae, 146

79. Elaeagnaceat, 331

Ovary or its cells containing many ovules.

Ovary or ovaries superior.

Ovaries 2 or more, separate

Ovary 1.

Ovary 3-5-celled; leaves opposite or whorled

45. Ranunculaceate, 189

Ovary 1-2-celled.

Leaves compound

Leaves simple.

Sepals distinct

Sepals more or less united.

Calyx 5-toothed or -cleft, Glaux in

Calyx 4-toothed or -cleft, Synthyris in

Ovary and pod inferior, Chrysosplenium in

45. Ranunculaceate, 189

42. Caryophyllacene, 180

90. Primulaceae, 372

104. Scrophulariaceae, 437

51. SAXIfRAGACEAE, 233

\section{CALYX AND COROLLA BOTH PRESENT}

COROLLA OF SEPARATE PETALS

Stamens numerous, at least more than 10 (rarely 9-10 in Polanisia) and more than twice as many as the sepals or calyx-lobes.

Calyx entirely free and separate from the pistil or pistils.

Pistils several to many, wholly distinct, or united at base into a

strongly lobed or several-beaked ovary.

Aquatics with peltate leaves

43. Nymphateaceae, 188

Terrestrial plants.

Usually climbers, with opposite leaves, Clematis in

Not climbing, the leaves alternate.

45. Ranunculaceat, 189

Filaments united into a tube

72. Malvaceae, 316

Filaments distinct, on the calyx

54. Rosaceae, 245

Pistils strictly 1 as to ovary; the styles and stigmas sometimes more numerous.

Leaves punctate with pellucid dots

75. Hypericaceat, 320

Leaves not punctate.

Ovary simple, 1-celled.

Ovules 2, seed solitary

56. Drupaceae, 269

Ovules many; leaves 2-3-ternately compound or dissected

45. Ranunculaceate, 189

Jvary compound as shown by the number of its cells, placentae, styles, or stigmas.

Ovary 1-celled.

Placentae parietal; juice watery, milky, or yellow.

Sepals 2 (rarely 3 )

47. Papaveraceae, 205 
Sepals 4

Placentae central; juice watery; sepals 2 Ovary several-celled.

Calyx valvate in bud; stamens united

Calyx imbricate in bud; stamens not united

Calyx more or less united to a compound ovary.

Ovary 1-5-celled (10-celled in one genus of Pomaceae).

Fleshy-stemmed, without true leaves; petals numerous

Leaves present.

Sepals or calyx-lobes 2; ovules arising from the base of a

1-celled ovary

41. Portulacaceae, 176

Sepals or calyx-lobes more than 2.

Leaves opposite; stipules none

53. Hydrangeaceate, 243

Leaves alternate.

Stipules present.

Carpels distinct, free from the calyx-tube; fruit achenes, follicles, or drupelets.

Carpels several or numerous, or if solitary becoming an achene

54. Rosaceat, 245

Carpel solitary, becoming a drupe

56. Drupaceae, 269

Carpels united, inclosed by and adnate to the calyxtube; fruit a pome

55. Pomaceae, 265

Stipules wanting; herbage rough-pubescent
77. LOASACEAE, 324

Stamens not more than twice as many as the petals.

Stamens of the same number as the petals and opposite them.

Ovary 2-4-celled.

Calyx-lobes minute or obsolete; petals valvate

71. Vitaceate, 315

Calyx 4-5-cleft; petals involute

70. Rhamnaceae, 314

Ovary 1-celled.

Anthers opening by uplifted valves

46. Berberidaceat, 204

Anthers not opening by uplifted valves.

Style 1, unbranched; stigma 1

Styles, style branches, or stigmas more than 1; sepals or calyx-lobes 2

41. Portulacaceae, 176

Stamens not of the same number as the petals, or if of the same number alternate with them.

Calyx free from the ovary, i. e., ovary wholly superior.

Ovaries 2 or more, wholly separate or somewhat united.

Stamens united with each other and with a large thick stigma common to the two ovaries

95. Asclepiadaceae, 386

Stamens free from each other and from the pistils.

Stamens on the receptacle, free from the calyx.

Leaves punctate with translucent dots; shrubs

62. Rutaceae, 306

Leaves without translucent dots; herbs.

Leaves fleshy

50. Crassulaceae, 232

Leaves not fleshy.

Ovary or lobes of the ovary $2-5$, with a common style.

Ovary 2-3-lobed

66. LimNANTHACEAE, 312

Ovary 5 -lobed

58. Gerantacean, 302

Ovaries with separate styles or sessile stigmas

45. Ranunculaceae, 189 
Stamens inserted on the calyx.

Plant fleshy; stamens just twice as many as the pistils

50. Crassulaceae, 232

Plant not fleshy; stamens not twice as many as the pistils.

Stipules present

54. ROSACEAE, 245

\section{Ovary 1.}

Stipules wanting

51. Saxifragaceae, 233

Ovary simple, with 1 parietal placenta

57. Leguminosae, 270

Ovary compound, as shown by the number of its cells, pla-

centae, styles, or stigmas.

Ovary 1-celled.

Corolla irregular.

Petals 4; stamens 6, Corydalis in

Petals and stamens 5

47. Papaveraceae, 205

76. Violaceae, 320

Corolla regular or nearly so.

Ovule solitary; trees or shrubs

Ovules more than 1.

67. Anacardiceae, 312

Ovules at the center or bottom of the cell.

Petals not inserted on the calyx 42. Caryophyllaceae, 180

Petals inserted on the throat of a bell-shaped or tubular calyx

80. Lythraceae, 332

Ovules on 2 or more parietal placentae.

Leaves punctate with translucent dots 75. HYPERICACEAE, 320

Leaves not punctate.

Petals 4 or 5 ; stamens 6 .

Stamens essentially equal.

Calyx persistent; fruit a capsule 74. Frankeniaceat, 319

Calyx deciduous; fruit a stipitate pod

49. Capparidaceae, 231

Stamens unequal, two being shorter than the other four; pod sessile

48. Cruciferae, 207

Petals 4 or 5 ; stamens as many; fruit a berry

52. Grossulariaceae, 241

Ovary 2-several-celled.

Flowers irregular; anthers opening at the top 63. Polygalaceae, 307

Flowers regular or nearly so.

Stamens neither just as many nor twice as many as the petals.

Trees or shrubs.

Stamens usually fewer than the 4 petals

Stamens more numerous than the petals.

91. Oleaceate, 378

Woody throughout; fruit a double samara 69. Aceraceae, 313

Woody at base only; fruit a capsule 74. Frankiniaceate, 319 Herbs.

Petals 5

75. HyPERICACEAE, 320

Petals 4

48. Cruciferae, 207

Stamens just as many or twice as many as the petals.

Ovules and seeds only 1 or 2 in each cell.

Herbs.

Flowers monoecious or dioecious

Flowers perfect and symmetrical.

64. Euphorbiaceae, 308

Cells of the ovary as many as the sepals.

Ovary 2-3-celled

66. Limnanthaceat, 312 
Ovary 5-celled

58. Geraniacean, 302

Cells of the ovary twice as many as the sepals.

Leaves abruptly pinnate

Leaves simple

61. ZYGophyllaceae, 306

Shrubs or trees, with opposite leaves.

Leaves palmately veined

Leaves pinnately veined

60. Linaceae, 304

69. Aceraceat, 313

68. Celastraceae, 313

Ovules and usually seeds several or many in each cell.

Leaves compound; the leaflets 3 , obcordate

Leaves simple.

59. Oxalidaceae, 304

Stipules present between opposite leaves

73. Elatinaceae, 319

Stipules none when the leaves are opposite.

Style 1.

Stamens free from the calyx.

With broad green leaves

Without green leaves

86. Pyrolaceae, 366

Stamens inserted on the calyx

87. Monotropaceae, 368

80. Lythraceae, 332

Styles 2-5; leaves opposite 42. Caryophyllaceae, 180

Calyx-tube adherent to the ovary, at least to its lower half.

Tendril-bearing and often succulent herbs

112. Cucurbitaceae, 472

Not tendril-bearing.

Ovules and seeds more than 1 in each cell.

Ovary 1-celled.

i Sepals or calyx-lobes 2; ovules borne at the base of the ovary

41. Portulacacene, 176

Sepals or calyx-lobes $4-5$; placentae $2-3$; fruit a berry

Ovary 2-many-celled.

52. Grossulariaceae, 241

Stamens inserted on or about a flat disk which covers the ovary

68. Celastraceae, 313

Stamens inserted on the calyx.

Style 1 ; stamens 4 or 8

Styles 2-3; stamens 5 or 10

81. Onagraceae, 333

Ovules and seeds only 1 in each cell.

Stamens 5 or 10.

Trees or shrubs.

Leaves simple, Crataegus in

55. Pomaceae, 265

Leaves compound or prickly

Herbs.

83. Araliacene, 346

Fruit dry, splitting at maturity; styles 2 84. UMBeLLIFERAE, 346

Fruit berry-like; styles 2-5, separate or united 83. Araliaceas, 346

Stamens 4 or 8 .

Style and stigma 1; fruit a drupe

51. Saxifragaceae, 233

Fruit not drupaceous.

Style 1; stigma 2-4-lobed

Styles or sessile stigmas 1 or 4

85. Cornaceat, 365

81. Onagraceat, 333

82. Haloragidaceae, 345

COROLLA OF MORE OR LESS UNITED PETALS

Stamens more numerous than the lobes of the corolla.

Ovary 1-celled.

Placenta 1, parietal

57. Leguminosae, 270 
Placentae 2, parietal, Corydalis in

47. Papaveraceae, 205

Ovary 3-several-celled.

Stamens free from the corolla.

Style 1; leaves simple.

Ovary superior; fruit a capsule or berry

88. Ericacene, 369

Ovary inferior; fruit a berry

89. VACCINIACEAE, 372

Styles 5; leaves 3-foliolate

59. Oxalidaceae, 304

Stamens attached to the base or tube of the corolla.

Saprophytic herbs, without green foliage

87. Monotropacene, 368

Not saprophytic; foliage green.

Filaments united into a tube

72. Malvaceae, 316

Filaments free from each other.

Low shrubs, with simple leaves

Low herbs, with radical leaves ternate

89. VACCINIACEAE, 372

111. Adoxacene, 472

Stamens not more numerous than the corolla-lobes.

Stamens of the same number as the corolla-lobes and opposite them

Stamens alternate with the corolla-lobes, or fewer.

90. Primulaceae, 372

Ovary free from the calyx-tube (superior).

Corolla regular.

Stamens as many as the corolla-lobes.

Ovaries 2, or, if 1, 2-horned.

Stamens distinct

Stamens united

95. Asclepiadacene, 386

94. Apocynacene, 385

Ovary 1.

Ovary deeply 4-lobed.

Leaves alternate

Leaves opposite

100. Boraginaceat, 410

102. Labiatae, 426

Ovary not deeply lobed.

Ovary 1-celled; seeds several-many.

Leaves entire, opposite

Leaves toothed, lobed, or compound.

Whole upper surface of the corolla white-bearded;

leaflets 3 , entire

93. Menyanthaceae, 384

Corolla not conspicuously bearded; leaves, if compound, with toothed leaflets 99. HydropHyLlaceae, 405

Ovary 2-10-celled.

Leafless, twining parasite

96. Cuscutacene, 389

Leaves alternate, or, if opposite, without stipules.

Stamens free from the corolla, or nearly so 88. Ericacene, 369

Stamens on the tube of the corolla.

Stamens 4.

Stem with opposite leaves; corolla petaloid

101. Verbenaceae, 424

Stem wanting; corolla scarious 108. Plantaginacfae, 464

Stamens 5.

Fruit of 2 or 4 seed-like nutlets 100. Boraginaceas, 410

Fruit a few-many-seeded capsule, or berry.

Styles 2.

Capsule few (mostly 4)-seeded

97. Convolvulacean, 392

Capsule many-seeded

99. HyDRophyllacea e, 405 
Style 1, often branched.

Branches of the style (or at least the lobes of the stigma) 3 98. Polemoniacene, 394

Branches of the style or lobes of the stigma 2, or wholly united 103. SolanaCeaE, 433

Stamens fewer than the lobes of the corolla.

Stamens with anthers 4 , in pairs

101. Verbenaceae, 424

Stamens with anthers only 2 , or rarely 3 .

Ovary 4-lobed, Lycopus in

102. IJABIATAE, 426

Ovary 2-celled, not 4-lobed.

Stemless; corolla scarious

108. Plantaginaceate 464

Leafy-stemmed; corolla not scarious, Veronica in

Corolla irregular.

104. Scrophulariaceate, 437

Stamens with anthers 5, Verbascum in

Stamens with anthers 2 or 4 .

Ovules solitary in the 1-4 cells.

Ovary 4-lobed; style rising from between the lobes 102. LabiataE, 426

Ovary nọt lobed; style from its apex

Ovules 2-many in each cell.

Ovary imperfectly 4-5-celled

101. Verbenaceae, 424

Ovary 1-2-celled.

Parasites, without green foliage

104. SCROPH ULARIACEAE, 437

Not parasitic.

Ovary 1-celled; stamens 2; aquatics 105. Prnguiculaceae, 462

Ovary 2-celled; placentae in the axis, usually manyseeded

104. Scrophulariaceate, 437

Ovary adherent to the calyx-tube (inferior).

Tendril-bearing herbs; anthers often united

Not tendril-bearing.

Stamens separate.

Stamens free from the corolla, or nearly so; as many as its lobes

113. Campanulaceate, 473

Stamens inserted on the corolla.

Stamens 1-3, always fewer than the corolla-lobes

115. Valerianaceae, 475

Stamens 4-5; leaves opposite or whorled.

Leaves opposite or perfoliate, but neither whorled nor provided with stipules

110. CAPRIFoliaceae, 468

Leaves either opposite and stipulate, or whorled and without stipules

109. Rubiaceae, 466

Stamens united by their anthers; these joined in a ring or tube.

Flowers separate, not involucrate; corolla irregular

Flowers in an involucrate head

114. Lobeliaceae, 474

116. Сompositae, 476 


\section{DESCRIPTIVE FLORA}

\section{PTERIDOPHYTES}

\section{OPHIOGLOSSACEAE Presl. AddeR's-tongue Family}

Leafy plants; the leaves (fronds) simple or branched, erect in vernation. Spores of one kind, borne in special spikes or panicles in sporangia (without an elastic ring) which are formed by groups of cells in the interior of the fruiting segments of the frond. Prothallia underground, destitute of cholorophyll.

\section{BOTRYCHIUM Swartz. Grape Fern. Moonwort}

Fronds with a posterior pinnatifid or compound sterile segment and an anterior panicled fertile segment, the separate sporangia in a double row on the branches of the panicle. Bud inclosed in the base of the stalk.

Leaf borne above the middle of the stem.

Leaf near the middle of the stem, its lobes lunate or fan-shaped . 1. B. Lunaria.

Leaf near the summit of the stem, triangular . . . - 2. B. lanceolatum.

Leaf borne near the base of the stem.

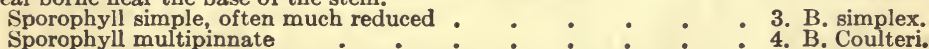

1. Botrychium Lunaria (L.) Sw. Schrad. Journ. Bot. 2: 110. 1800. Plant 1-3 dm. high, very fleshy: leaf rising near the middle of the stem, pinnate with 2-8 pairs of lunate or fan-shaped lobes which vary from crenate to entire, overlapping each other or somewhat distant: sporophyll 2-3-pinnate, often dense, 2-4 cm. long; in vernation apex of leaf bent over sporophyll.-Colorado, north to Canada and thence across the continent.

2. Botrychium lanceolatum (Gmel.) -Augs. Bot. Notiser 1854: 68. Plant $5-25 \mathrm{~cm}$. high, scarcely fleshy: leaf sessile near the summit, deltoid, once or twice pinnatifid, with oblique oblong-lanceolate acute segments: sporophyll slightly longer than the leaf, short-stalked, 2-3-pinnate, in vernation recurved with the leaf reclined upon it.-Across the continent northward and south in the mountains to Colorado.

3. Botrychium simplex E. Hitch. Am. Journ. Sci. 6: 103. 1823. Plant smooth, fleshy, 5-15 cm. high: leaf rising near the base, short-petioled, varying from simple and rounded obovate $(4-6 \mathrm{~mm}$. long) to triangular-ovate and deeply 3-7-lobed, and even to fully ternate with incised divisions; the segments broadly obovate-cuneate or somewhat lunate: sporophyll a simple or slightly compound spike, sometimes reduced to only a few sporangia: spores large, minutely tuberculate.-Wyoming to Montana and thence across the continent.

4. Botrychium Coulteri Underw. Bull. Torr. Bot. Club 25: 537. 1898. Stout and fleshy, with numerous fleshy roots: stem only $2-3 \mathrm{~cm}$. long, swollen with the contained bud of the succeeding season: leaf short-petioled, broader than long, 3-parted and each division tri- or quadripinnatifid; the segments obliquely ovate, about $10 \mathrm{~mm}$. long, with entire or barely repand margin: sporophyll large, paniculate, $3-6 \mathrm{~cm}$. long; the numerous pinnae crowded: sporangia numerous, bright yellow, with copious yellow spores.-On the geyser formations; Yellowstone Park and Montana. 


\section{POLYPODIACEAE R. Br. Fern Family}

Leafy plants; the leaves (fronds) often much branched, circinate in vernation, rising from a rootstock. Spores of one kind, borne on the under surface or margins of the leaves in sporangia (with an elastic ring), which are developed from a single epidermal cell. Prothallia above ground, green.-The sporangia are usually collected in little masses (fruit dots or sori), which are - often covered by a scale (indusium), which is produced by a cellular ougrowth from the frond, or by a general involucre formed from the infolded margin of the frond.-Eaton, Ferns of North America.

Leaves of two kinds; the sterile broader than the fertile

Leaves all alike.

Indusium wholly wanting.

Sori dorsal, roundish.

Leaves 2-3-pinnatifid

Leaves simply pinnate

Sori marginal, elongated

Indusium present.

Formed from the inflexed leaf-margin.

Sporangia on the underside of the reflexed portion of the leaf .

Sporangia in a continuous vein-like groove, or receptacle, which connects the ends of the veins.

Large plants of moist copses

Small plants of cliffs and rock slides. Pinnae tomentose or scaly beneath Pinnae smooth beneath

Formed from epidermal cells (not from the leaf-margin) and variously attached.

Sori round.

Indusium superior, reniform or peltate, attached by a central stalk.

- Sori near the midvein of the leaf Sori near the margin of the leaf

Indusium inferior or partly so.

Hood-like, attached to the inner side, soon open on the other

Cup-like, attached underneath, bursting above into a

Sori oblong or linear fimbriated margin

\section{CRYPTOGRAMMA R. Br. ROCK Brake}

Rootstocks short, bearing numerous light-green small smooth fronds of two kinds; the sterile much broader than the taller fertile ones; all with stramineous stipes. Sori extending down the free veins. Involucre very broad, at length flattened out and exposing the now confluent sori.

Stipes tufted; fronds 3-4-pinnate

Stipes scattered; fronds 2-3-pinnate

1. Cryptogramma acrostichoides R. Br. App. Frank, Journ. 767. 1823. Fronds 5-10 cm. long, chartaceous, ovate, closely 3-4-pinnate; pinules ovate or obovate, adnate-decurrent, those of the fertile fronds narrower and longer, the involucres very broad: sori extending far down the veinlets.-In dense patches among rocks; California to Colorado, thence far northward and east to Lake Superior.

2. Cryptogramma Stelleri (Gm.) Prantl, Engler's Bot. Jahrb. 3: 413. 1882. Rootstock very slender, creeping, nearly naked: fronds very delicate, $5-10 \mathrm{~cm}$. long, oblong-ovate, pinnate with a few once or twice pinnatifid pinnae; segments oblong or obovate; involucres broad and delicate. Pellaea gracilis.Crevices of damp and shaded limestone rocks; Colorado, northward and eastward to Labrador, and thence south to Pennsylvania.

\section{PHEGOPTERIS Fee}

Medium sized ferns with leaves 2-3-pinnate, triangular-ternate, the primary divisions stalked and the rachis not winged. Sori small, on the back of the veins below their attenuate apices. Indusium wholly wanting. 
1. Phegopteris Dryopteris (L.) Fee, Gen. Fil. 243. 1850-52. Fronds smooth and thin, 1-2 dm. wide and long, lateral divisions divergent, all triangular and pinnate; the pinnae pinnatifid into oblong, obtuse, entire or even pinnately lobed segments; lowest inferior pinna of the lateral divisions equal to the second pinna of the middle division.-Open rocky woods; reported from Colorado; across the continent northward.

\section{POLYPODIUM L. POLYPODY}

Stipes articulated to the branching rootstocks. Leaves pinnate. Veins uniformly free. Sori large, round, on the veins or at their ends, without indusium.

1. Polypodium hesperium Maxon, Proc. Biol. Soc. Wash. 13: 200. 1900. Leaves subcoriaceous, $5-20 \mathrm{~cm}$. long, ovate-oblong to oblong-linear, pinnatifid into linear-oblong obtuse or acute segments, the lowest ones rarely diminished: veins branched into three or four veinlets, the lowest ones on the upper side of the vein bearing at their thickened ends the subglobose sori midway between the midrib and the margin of the segments. $P$. vulgare.-From the Rocky Mountains eastward to the Atlantic; also westward.

\section{NOTHOLAENA R. Br.}

In ours the leaves are 3-5-pinnate, and covered beneath with a white or yellow powder, the primary and secondary pinnae distinctly stalked, and the ultimate pinnules very small, oval or 2-3-lobed. Sori somewhat elongated, often of very few sporangia, situated below the tips of the veins near the margin of the lobes of the fronds.

1. Notholaena Fendleri Kunze, Farrnkr. 2: 87. 1851. Leaves densely tufted, 5-15 cm. long, broadly deltoid ovate, 4-5-pinnate; the stipes dark brown; rachis and all its branches flexuous and zigzag; the pinnae alternate; ultimate pinnules $2-4 \mathrm{~mm}$. long.- In clefts of cliffs; Colorado to Arizona and Texas.

\section{ADIANTUM L. Maidenhair}

Stipe mostly blackened or very dark purple-brown, and commonly highly polished. Sporangia borne at the ends of the veins, on the underside of the reflexed margin of the frond. Midvein of the pinnules eccentric, dissolving in the forking veinlets.

Fronds bipinnate, ovate-lanceolate

Fronds dichotomous, orbicular in outline

1. A. capillus-veneris.

1. Adiantum capillus-veneris L. Sp. Pl. 1096. 1753. Fronds pyramidal, with the rachis continuous to the terminal pinnule, 2-4 dm. long, often pendent, ovate or ovate-lanceolate, 2-3-pinnate at base; pinnules wedgeobovate or rhomboid, 1-2 cm. long, deeply and irregularly incised, smooth: involucres lunulate or transversely oblong. - In moist rocky places; southern California across the continent to Virginia and Florida; rare if at all within our range.

2. Adiantum pedatum L. Sp. Pl. 1095. 1753. Frond often $2-3 \mathrm{dm}$. broad: stipe forked at the top, the branches recurved, and bearing several pinnate divisions on the upper side; primary divisions 6-14, bearing numerous oblong or triangular-oblong pinnules, which have the lower margin entire and the upper more or less lobed: involucres oblong-lunate or transversely linear.Across the continent and far northward; within our immediate range reported only from the Black Hills of Dakota, and from Utah.

\section{PTERIdium Scop. Bracken or Brake}

In ours the rootstock is stout, cord-like, and extensively creeping. Fronds scattered, ternate, with decompound divisions, and pale green stipe. Sporangia 
borne on a continuous vein-like marginal receptacle which connects the ends of the veins. Indusium membranous, formed of the reflexed margin of the leaf.-Pteris.

1. Pteridium aquilinum (L.) Kuhn, Decken's Reisen III. Bot. Ost-Afrika 11. 1879. Leaf often very large, the stipe and frond usually more than $1 \mathrm{~m}$. in length and often $2 \mathrm{~m}$.: frond broadly triangular, primary divisions stalked; pinnae mostly pinnately lobed, with several to many rather short obtuse lobes, and with a sometimes very long subentire apex.-Frequent in the northern half of the United States and in Canada.

\section{CHEILANTHES Swz. LIP FeRN}

Small ferns, with 2-4-pinnate fronds, and the under surface either smooth or variously covered with hair, wool, scales, or waxy powder. Ours belong to the section in which the involucres are continuous around the greater part of the margin of the very minute and bead-like ultimate segments, and the lower surface of the fronds tomentose or scaly.

Fronds tomentose beneath, but not scaly . $\quad . \quad$. . . . . . 1. C. Feei.

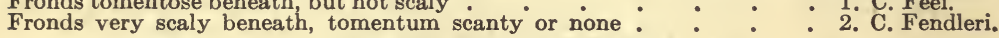

1. Cheilanthes Feei Moore, Ind. Fil. 240. 1857. Fronds 5-12 cm. long, ovate-lanceolate, tripinnate or bipinnate with pinnatifid pinnules; ultimate segments less than a line long; upper surface scantily tomentose, the lower surface matted with jointed woolly hairs: involucres herbaceous, very narrow. C. lanuginosa.-In dense tufts, on dry exposed rocks; Arizona to Colorado, northward and eastward to the Great Lakes.

2. Cheilanthes Fendleri Hook. Sp. Fil. 2: 103. 1858. Rootstock slender, its scales loose and nerveless: frond $8-15 \mathrm{~cm}$. long, tripinnate; ultimate pinnules rounded and entire, or obovate and 2-3-lobed, covered beneath with broadly ovate acuminate "scales, which are sometimes sparingly ciliate at base.-In crevices of rocks; Colorado to Arizona and Texas.

\section{Pellaea link. Cliff Brake}

Rock-loving small or medium-sized ferns with pinnate or pinnatifid leaves, glabrous, having neither tomentum nor scales. Sori marginal and ultimately in a confluent line. Involucre membranous and continuous around the pinnules.

Fronds herbaceous or subcoriaceous; the veins clearly visible.

Pinnae 6-8, membranous

Pinnae 2-5, subcoriaceous

Fronds coriaceous; the veins not perceptible.

Closely tripinnate, 4-5 cm. long

Bipinnate, $10-20 \mathrm{~cm}$. long

1. P. Breweri.

2. P. occidentalis.

3. P. densa.

4. P. Wrightiana.

1. Pellaea Breweri DC. Eat. Proc. Am. Acad. 6: 555. 1866 . Rootstock short, densely covered with narrow fulvous chaff: fronds membranous, $5-15 \mathrm{~cm}$. long, simply pinnate with mostly unequally 2-lobed pinnae; the segments obtuse, in the fertile frond narrower: indusium continuous, pale: veins repeatedly forked.-From California to Utah and Colorado.

2. Pellaea occidentalis (E. Nels.) Rydb., Underw. in Our Native Ferns 98. 1900. Rootstock short and thick, densely covered with rusty hair-like scales: stipes caespitose, 1-4 cm. long, dark brown, glabrous, shining, very slender: fronds $3-8 \mathrm{~cm}$. long, oblong, simple-pinnate; pinnae $2-5$ pairs, oblong, mostly obtuse, dark green, shining, firm and somewhat coriaceous, entire, or the lower with 1 or 2 lobes at the base: indusium broad, wholly covering the sori. $P$. atropurpurea in part. (P. pumila Rydb. Mem. N. Y. Bot. Gard. 1:4. 1900.) - Colorado to Montana, and west to Washington.

3. Pellaea densa (Brack.) Hook. Sp. Fil. 2: 150, t. 125. 1858. Rootstock slender, chaffy with blackish scales: stipes densely tufted, wiry, very slender, 
brown, 8-20 cm. long: fronds 3-5 cm. long, ovate, closely tripinnate; the ultimate segments linear, 6-12 $\mathrm{mm}$. long, sessile; the sterile ones serrate.-In clefts of rocks; northwestern Wyoming to Oregon and California.

4. Pellaea Wrightiana Hook. 1. c. 142, t. 115. Rootstock short, thick, densely chaffy: stipes crowded, purplish-brown: fronds 1-2 dm. long, lanceolate to triangular-ovate, bipinnate; pinnae longer than broad, having 3-13 oval or oblong-oval pinnules; fertile ones with the margins rolled in to the midvein.Exposed rocky places in cañons; Colorado to Arizona and Texas.

\section{DRYOPTERIS Adans. SHield FERN}

Rather large coarse ferns; in ours the fronds bipinnate and subcoriaceous. Indusia roundish-reniform with a narrow sinus, attached to the middle of the sorus by a short central stalk. Veins free and the large sori borne near the midvein.-Aspidium in part.

1. Dryopteris Filix-mas (L.) Schott. Gen. Fil. 1834. Fronds $3-8 \mathrm{dm}$. long, broadly oblong-lanceolate, somewhat narrowed and twice pinnate towards the base; pinnae lanceolate-acuminate from a broad base; pinnules or segments oblong to ovate-lanceolate, obtuse or acute, toothed or incised, not glandular but sometimes slightly chaffy beneath, the upper confluent: sori near the midvein, commonly only on the lower half of each segment: stalks more or less chaffy with large scales. Aspidium Filix-mas. MaLE Fern.-Somewhat variable; cosmopolitan, and not infrequent in our range.

\section{POLYSTICHUM Roth. Holly FerN}

Ferns with pinnate leaves and numerous large contiguous round sori; the indusium orbicular and entire, fixed by the depressed center to the middle of the sorus. Pinnae and pinnules often auricled on the upper side of the base. Veins all free and the large sori borne near the margin of the leaf.-Aspidium in part.

1. Polystichum Lonchitis (L.) Roth, Tent. Fl. Germ. 3: 71. 1800. Fronds simple pinnate, $1-4 \mathrm{dm}$. long (stalks only 3-7 cm.), linear-lanceolate; pinnae broadly lanceolate, falcate, sharply spinulose-serrate, the lower ones symmetrically triangular and shorter, the upper ones strongly auricled.-Mountains of Colorado, Utah, and Wyoming, north to Canada and east to the great lakes.

\section{FILIX Adans.}

Tufted ferns with slender and delicate twice or thrice pinnate fronds and cut-toothed lobes. Indusium delicate, hood-like, or arched, attached by a broad base on the inner side partly under the sorus, free at the other side and early thrown back or withering away. Veins free.-Cystopteris.

1. Filix fragilis (L.) Underw. Our Native Ferns 119. 1900. Fronds 1-3 dm. long, broadly lanceolate, usually bipinnate; pinnae oblong-ovate, pointed; pinnules ovate or oblong, variously toothed or incised. Cystopteris fragilis. BRITTLE FERN.-Usually in shaded rock-crevices; throughout North America.

\section{WOODSIA R. Br.}

Small tufted ferns growing on exposed rocks. Ours have the stipes not articulated to the rootstock, and the fronds are glandular-pubescent or smooth, not chaffy. Indusium situated beneath the sorus and partly or wholly inclosing it, soon dividing into irregular lobes or bursting into a delicate fringe above. 
1. Woodsia scopulina D. C. Eat. Can. Nat. 2: 90. 1865. Fronds 1-2 dm. long, puberulent beneath with minute jointed hairs and stalked glands, oblongovate and crenulate: indusia deeply cleft into narrow segments terminating in jointed hairs.- In dense masses on rocks and in crevices; Minnesota to California, south in the mountains to Colorado.

2. Woodsia oregana D. C. Eat. 1. c. Very similar, but with smooth fronds, the fertile taller than the sterile: the indusium reduced to a few moniliform hairs.-From Arizona and Colorado to British Columbia and Lake Superior.

\section{ASPLENIUM L. Spleenwort}

Plants very variable in size, with simple pinnate, 2-3-pinnate, or pinnatifid leaves. Sori oblong or linear, borne on veins more or less oblique to the rachis or the midrib, not confluent. Indusium straight or sometimes curved, opening toward the midrib when single (sometimes double). Veins free.

Fronds simply pinnate.

Pinnae 12-30 pairs, oval, ovate, or rhomboidal, obtuse. Rachis purple-brown Rachis green

Pinnae only $2-5$, linear-cuneate

Fronds 2-3-pinnate or pinnatifid.

Fronds 3-10 cm. long, terniate and bipinnate

Fronds 2-4 dm. long, bipinnate

1. A. trichomanes. 2. A. viride.

- 3. A. septentrionale.

4. A. Andrewsii.

5. A. Filix-femina.

1. Asplenium trichomanes L. Sp. Pl. 1080. 1753. Fronds 1-2 dm. long, narrow, simply pinnate, with 15-30 pairs of subsessile, roundish-oval, or ovaloblong pinnae; these obtusely cuneate or truncate at base, entire or crenulate, rarely slightly incised, falling separately from the persistent rachis: stipes purple-brown, shining.-Colorado, Wyoming, and across the continent.

2. Asplenium viride Huds. Fl. Angl. 385. 1762. Stipes densely tufted, 5-10 $\mathrm{cm}$. long, naked, the lower part chestnut-brown, merging into the green of the rachis: fronds narrow, 5-15 cm. long, with 12-20 pairs of ovate or rhomboidal pinnae; these obliquely truncate at base and crenate on the outer edge: rachis naked: sori numerous.-Idaho, northern Wyoming, and across the continent.

3. Asplenium septentrionale (L.) Hoffm. Deutsch. Fl. 2: 12. 1795. Stipes densely tufted, 8-15 cm. long, slender, naked, ebeneous toward the base: fronds irregularly forking, consisting of 2-5 narrowly linear-cuneate rather rigid segments, which are entire or sometimes cleft at the ends into a few narrow teeth: sori elongated, placed near the margin, usually facing each other in pairs, commonly only 2 or 3 to each segment. Ácrapteris septentrionale (L.) Link.-In clefts in exposed rocks; southern Wyoming to New Mexico and Arizona.

4. Asplenium Andrewsii A. Nels. Proc. Biol. Soc. Wash. 17: 174. 1904. Rootstock enveloped in matted roots: stipes few to several, ebeneous below, passing into the green of the rachis: frond thin-herbaceous, deltoid-ovate, often ternate; pinnae lanceolate, tapering gradually into the pinnatifid tip; pinnules ovate-lanceolate, sharply incised and somewhat incisely serrate: sori short but almost connecting with those in the successive lobes, forming nearly a continuous sorus from the base to the apex of the pinnule: indusium straight, finally forced back and concealed by the sporangia.-Type locality, sandstone cliff, Boulder Cañon, Colorado.

5. Asplenium Filix-femina (L.) Bernh. Schrad. Neues Journ. Bot. 1: 26. 1806. Fronds 3-8 dm. long: delicate and softly membranaceous, oblonglanceolate, 2-3-pinnate; pinnules adnate to the secondary rachis, ovate to elongated-lanceolate, variously toothed or incised: indusia more or less curved, of ten crossing the fertile veinlet and continued a short distance down the other side of it, lacerate-ciliate. LADY FERN.-Widely distributed; not rare in our range. 


\section{MARSILEACEAE R. Br.}

Perennial herbaceous plants rooting in the mud, with slender creeping rootstocks, and 4-foliate or filiform long-petioled leaves. The sporocarps borne at the base, either sessile or on a stipe (petiole), crustaceous, ovoid or beanshaped, 2-valved, several-celled and containing both megaspores and microspores; the former give rise to prothallia producing archegonia; the latter to prothallia producing antheridia.

\section{MARSILEA L.}

Characters of the family:

Sporocarp toothed above Sporocarp rounded above

1. Marsilea vestita Hook. \& Grev. Ic. Fil. Pl. 159. 1831. Slender, 8-15 $\mathrm{cm}$. high: leaflets broadly cuneate, entire or slightly toothed: sporocarp 4-7 $\mathrm{mm}$. long, 3-5 $\mathrm{mm}$. wide, densely covered with soft spreading hair-like scales; the lower tooth short and blunt; the upper acute, longer, sometimes curved: sori in each valve 10-11; megaspores in each sorus 12-20 (usually 15-18).Variable and widely dispersed but rare; possibly not within our range.

2. Marsilea oligospora L. N. Good. Bot. Gaz. 33: 66. 1902. Plant 4-7 cm. high: leaflets woolly or becoming glabrous, $6-10 \mathrm{~mm}$. long, 3-7 $\mathrm{mm}$. wide: sporocarp solitary, 4-6 mm. long, 4-5 mm. wide, covered with long, straight and appressed (rarely somewhat woolly) pubescence: raphe short: lower tooth short and blunt, upper a mere rounded papilla or wanting: peduncle 5-8 $\mathrm{mm}$. long: sori 5-8 in each valve; megaspores oval to barely oblong, 6-9 in each sorus.-Northwestern Wyoming (Jackson's Hole and Yellowstone Park). Possibly the Rocky Mountain specimens all belong to this rather than to the preceding species.

\section{EQUiSETACEAE Michx. Horsetail Family}

Perennials with subterranean rootstocks. Stems rush-like, simple or branched, striate, jointed, usually hollow. Leaves of two kinds: the sterile reduced to toothed sheaths at the nodes; the fertile shield-shaped and forming a short spike terminating the stem. Occurring mostly in moist or sandy situations.

\section{EQUiSETUM L. Horsetail. Scouring Rush}

Stems simple or branched, the joints having closed ends. Leaves of the fruiting cones 5-7-angled, with sporangia hood-like. Spores round, furnished with two slender filaments attached by the middle and clavate at the free ends. Prothallia above ground, green, usually dioecious.

Stems dying down to the ground each year.

Stems of two kinds; the fertile simple; the sterile with whorls of slender branches at the nodes.

Fertile stems withering early

Fertile stems persisting for the season.

Stems all alike, simple.

Sheaths with about 8 white-margined teeth

Sheaths with about 18 dark-brown teeth

Stems perennial, evergreen.

Stems many-grooved.

Rough with conspicuous tubercles.

Stems thick, often $1-3 \mathrm{~m}$. high

Stems slenderer, mostly less than 5 dm. high

Nearly smooth, the tubercles inconspicuous.

Stems with only 5-10 grooves

1. E. arvense.

2. E. pratense.

3. E. palustre.

4. E. fluviatile.
5. E. robustum.

6. E. hiemale.

7. E. laevigatum.

8. E. variegatum. 
1. Equisetum arvense L. Sp. Pl. 1061. 1753. Stems of two kinds; the fertile in early spring, soft, pale or brownish, with loose and usually distant 8-12-toothed sheaths, 1-2 dm. high, crowned by the short spike of sporophylls, withering early; the sterile stems slender, becoming 3-5 dm. high, 10-14furrowed, with numerous verticillate 4-angled solid slender branches with 4-toothed sheaths. Common Horsetall.-Across the continent; also in Europe and Asia.

2. Equisetum pratense Ehrh. Hanov. Mag. 138: 1784. Differing from the preceding in that the fertile stem is persistent, withering (after the spores are shed) only at summit, then putting out branches and becoming like the sterile in appearance: branchlets triangular with 3-toothed sheaths.- Reported from Colorado, but rare in our range.

3. Equisetum palustre L. Sp. Pl. 1061. 1753. Stems all alike, slender, 2-4 dm, high, deeply 5-9-grooved, with conspicuous wing-like ridges: sheaths with about 8 lance-subulate teeth: branches few, short; their sheaths about 5-toothed.-Scarcely within our range, but possibly occurring from Wyoming to Montana and thence across the continent, and northward.

4. Equisetum fluviatile L. Sp. Pl. 1062. 1753. Stems 5-8 dm. high, at first simple and then tipped with the short spike of sporophylls, later producing erect yellow branches; furrows numerous, inconspicuous: sheaths appressed with about 18 dark brown, short, acute, rigid teeth.- In bogs. and in the borders of shallow ponds, northwestern Wyoming and Montana and thence across the continent northward.

5. Equisetum robustum A. Br., Engelm. Am. Journ. Sci. 46: 88. 1844. Stems evergreen, usually very stout and tall, often $1 \mathrm{~m}$. or more high and $2 \mathrm{~cm}$. in diameter: the ridges narrow, rough with one line of tubercles: sheaths short, with a black girdle above the base, rarely with a black limb, teeth about 40, 3-keeled, ovate-subulate, deciduous.-In many parts of North America north of Mexico; also in Asia.

6. Equisetum hiemale L. 1. c. Stems lower and slenderer, 3-8 dm. high: the ridges roughened by two more or less distinct lines of tubercles: sheaths elongated, with a black girdle above the base and a black limb of about 20 (17-26) narrowly linear teeth, 1-keeled at the base and with subulate deciduous points: spikes tipped with a rigid point. The common Scouring Rush.-Nearly throughout North America; also in Europe and Asia.

7. Equisetum laevigatum A. Br., Engelm. Am. Journ. Sci. 46: 87. 1844. Stems 3-10 dm. high, sometimes with numerous branches: the ridges convex, obtuse, smooth or barely roughish with minute tubercles: sheaths elongated, with a narrow black limb and about 22 linear-subulate caducous teeth, 1-keeled below.-From New Mexico to Canada and across the continent.

8. Equisetum variegatum Schleich. Cat. Pl. Helvet. 27. 1807. Stems in tufts from a branched base, slender, ascending, 2-5 dm. high, usually simple, only 5-10 grooved: sheaths green, variegated with black above; the 5-10 teeth tipped with a deciduous bristle.-Colorado to Utah and Wyoming and almost across the continent.

\section{ISOETACEAE Underw. Quillwort Family}

Mostly aquatic plants, with a short solid corm-like stem (trunk) and elongated grass-like leaves, the bases of which are expanded and have thin stipulelike infolded margins (the velum), which inclose large simple ovoid thin-walled sporangia; the outer ones containing large spherical megaspores; those of the inner leaves filled with very minute grayish microspores.

\section{ISOETES L. QUILLWORT}

Characters those of the family. For an elaboration of the genus, see Underwood's Our Native Ferns, Our species (as reported at present) belong to the 
group with bilobed trunks, are all submerged, with quadrangular leaves and an incomplete velum.

Leaves acute, not long-pointed; stomata absent

1. I. lacustris.

Leaves with a long fine point; stomata present .

2. I. Bolanderi.

1. Isoetes lacustris L. Sp. Pl. 1100. 1753. Leaves stout, rather rigid, acute but scarcely tapering, dark or olive-green, 10-25 in number, 5-15 cm. long, with no stomata: sporangium orbicular to broadly elliptical, not spotted, with a rather narrow velum; megaspores $0.5-0.8 \mathrm{~mm}$. in diameter, marked all over with distinct or somewhat confluent crests: microspores smooth, $0.035-0.046 \mathrm{~mm}$. in the longer diameter.-Generally distributed throughout northern America.

1a. Isoetes lacustris paupercula Engelm. Trans. St. Louis, Acad. 4: 377. 1882. Leaves fewer (10-18), thinner, shorter: spores smaller; megaspores 0.50-0.66 mm. in diameter; microspores somewhat granulated, 0.026-0.036 mm. long.-Grand Lake, Middle Park, Colorado, and near Mt. Shasta, California.

2. Isoetes Bolanderi Engelm. Am. Nat. 8: 214. 1874. Leaves erect, soft, bright green, tapering to a fine point, 5-25 in number, $5-10 \mathrm{~cm}$. long, generally not many stomata: sporangium broadly oblong, mostly without spots, with a narrow velum; megaspores $0.30-0.40 \mathrm{~mm}$. thick, marked with minute low tubercles or warts; microspores $0.026-0.031 \mathrm{~mm}$. long, generally spinulose, rather smooth.- In ponds and shallow lakes in the Rocky Mountains, Sierra Nevada of California, and Cascades.

\section{LYCOPODIACEAE Michx. Club Moss Family.}

Moss-like plants, with small leaves imbricated in 4-many rows on the pinnately or dichotomously branching stems, and (in ours) with reniform 1-celled sporangia in the axils of bracts, forming stalked or sessile spikes. Spores all alike. Prothallia subterranean.

\section{- 1. Lycopodium L. Club Moss. Ground Pine}

Characters those of the family. In ours the leaves (bracts) of the spike are yellowish, ovate or heart-shaped, very different from the other leaves.

1. Lycopodium annotinum L. Sp. Pl. 1103. 1753. Stems prostrate and creeping, 3-10 cm. long; the ascending branches similar, dichotomous, 10$15 \mathrm{~cm}$. high; leaves in several ranks, equal, spreading, rigid, lanceolate, pointed, serrulate, 4-5 mm. long: spikes solitary at the ends of leafy branches. -From Colorado to Washington, northward and eastward across the continent.

\section{SELAGINELLACEAE Underw.}

Moss-like terrestrial annual or perennial plants with slender branching stems and small leaves arranged in 4 or several ranks. Sporangia solitary, in the axils of the leaves of the somewhat quadrangular spike, minute, subglobose; some containing 4 megaspores; others numerous microspores. From each of these spores are developed the prothallia bearing archegonia and antheridia respectively.

\section{SELAGINELLA Beauv.}

Characters those of the family. In ours the leaves are all alike, arranged in many ranks, those of the fruiting spikes 4-ranked. 
Stems very short, densely tufted

Stems creeping, 5-10 cm. long.

Leaves with a conspicuous white awn

Leaves obtuse, not awned

1. S. densa.

2. S. rupestris.

3. S. mutica.

1. Selaginella densa Rydb. Mem. N. Y. Bot. Gard. 1: 7. 1900. Densely tufted; sterile branches very short: leaves crowded and many-ranked, 3-5 mm. long, ciliate on the margin and tipped with a white bristle: fertile branches 1-2 cm. long; bracts imbricated, 4-ranked, triangular-ovate, deeply grooved dorsally; tipped with a bristle shorter than those of the leaves. - The most frequent species in our range; Colorado and Utah to Montana.

2. Selaginella rupestris L. Sp. Pl. 1101. 1753. Stems creeping, 5-10 cm. long, somewhat flexuous, with ascending tips, rooting throughout their whole length, more or less branched: leaves imbricated in 8 ranks, ciliate-margined and tipped with a white awn: spikes sharply quadrangular, 10-20 mm. long.Across the continent northward; apparently in Colorado, though ours belong mostly to the following variety.

2a. Selaginella rupestris Fendleri Underw. Bull..Torr. Bot. Club 25: 127. 1898. Differs from the species in the laxer leaves which are tipped with a shorter awn and have denticulate cilia on the margins: spikes flabby and flexuous: megaspores coarsely areolate.-Colorado and New Mexico.

3. Selaginella mutica D. C. Eat., Underw. Bull. Torr. Club 25: 128. 1898. Stems creeping, rather rigid, $8-15 \mathrm{~cm}$. long, pinnately branched: leaves 6ranked, closely imbricated, only $1 \mathrm{~mm}$. long, obtuse, grooved on the back, devoid of terminal seta but with spreading marginal cilia: spike quadrangular, its bracts acute and sometimes submucronate.-Colorado to Arizona and New Mexico.

\section{GYMNOSPERMS}

Trees and shrubs representing an ancient and at one time very abundant flora, now reduced to a relatively small number of genera and species, mostly Evergreens. Plants monoecious or dioecious. Ovules naked, i. e.; not inclosed by the carpel; the latter is represented by a scale or a bract or in some instances is wholly wanting. Cotyledons two or often several in a whorl.

\section{PINACEAE Lindl. Pine Family}

Trees or sometimes shrubs, evergreen, more or less resinous. Leaves needleshaped or scale-like. Staminate and pistillate cones on the same individual (except in Juniperus); the staminate clusters of an indefinite number of stamens only; the pistillate of few to many scales which become in fruit a dry cone, with two or more ovules at or on the base of each scale. In Juniperus the fruit is small, semi-fleshy, and berry-like.

Fruits large, becoming dry cones.

Leaves in bundles of 2-5 (rarely solitary); cones of thickened corky

scales, the seeds maturing the second year
Leaves single, usually less than $3 \mathrm{~cm}$. long; cones coriaceous; seeds maturing the first year.

Branchlets rough from the prominent persistent leaf-bases; cones

pendulous
Branches smooth, the leaves disarticulating close to the bark leaving a smooth oval scar.

Cones erect; the bracts aristate or mucronate

Cones pendulous; the bracts exserted and 3-pointed

Fruits small, semi-fleshy and berry-like .

1. Pinus.

\section{Picea.}

3. Abies.

4. Pseudotsuga.

5. Juniperus.

\section{PINUS L. Pine}

Trees. Leaves of two kinds, the primary ones early deciduous, the secondary (ordinary foliage) slender, needle-shaped, in bundles of 2-5 (mostly soli- 
tary in No. 5), united at the base by a sheath formed from the bud-scales. Cones large, the scales becoming thick and woody and bearing two seeds on the base of each scale, not maturing till the second year.

Leaves 5 in each fascicle; seeds winged.

Scales not tipped with a prickle.

Cones narrowly ovoid or subcylindrical; the scales separating at maturity and discharging their seeds

Cones ovoid; their scales remaining closed at maturity

Scales tipped with a prickle

Leaves in fascicles of $2-3$ (rarely 1 ); scales usually spiny-tipped; seeds winged or wingless.

Leaves 4-7 cm. long.

Leaves subterete or triangular with smooth edges; seeds wingless. Two leaves in each fascicle

Some or most of the fascicles reduced to one leaf
Leaves regularly in pairs, semiterete, with flat faces and serrulate

edges
Leaves $10-18 \mathrm{~cm}$. long

1. P. flexilis.

2. P. albicaulis.

3. P. aristata.

1. Pinus flexilis James, Long's Exp. 2: 34. 1823. A tree with furrowed gray bark, short trunk, 5-10 dm. in diameter, freely branched upward, becoming 12-25 m. high: leaves in fascicles of 5, 4-7 cm. long, rather stout and rigid: cones narrowly ovoid to subcylindrical, greenish, 8-15 $\mathrm{cm}$. long; the scales unarmed, broad, moderately thickened at the ends, opening at maturity and the seeds soon falling out. (A pinus flexilis Rydb. Bull. Torr. Bot. Club 32: 598. 1905.) Limber Pine.-On wind-swept ridges and slopes, situations to which its remarkably flexible branches adapt it; at high elevations much reduced in size, or depressed; New Mexico to Montana and westward.

2. Pinus albicaulis Engelm. Trans. Acad. Sci. St. Louis 2: 209. 1868. Very similar to the preceding in aspect: cones oval or subglobose, sessile, dark purple; the scales with thickened ends, often sharp-beaked, but not awned, remaining closed at maturity. (A pinus albicaulis Rydb.1.c.) WhIтеBARK PINE.-Usually lower and with more rounded head than the preceding; from middle elevations to timber line; northwestern Wyoming, far northward and westward.

3. Pinus aristata Engelm. Am. Journ. Sci. II. 34: 331. 1862. A tree 12-15 m. high, 4-7 dm. in diameter, in alpine stations usually much dwarfed: leaves in fascicles of 5 , erect, curving, 3-angled, smooth, submucronate, green, each side with a white glaucous stripe: cones violet-brown, narrowly ovoid, resinous, $7-10 \mathrm{~cm}$. long; scales with thickened rhombic ends, with small beak and tipped with a lanceolate-subulate often recurved awn, opening and discharging the seeds. BRIstLe-CONE Pine.- Subalpine; from Colorado to Nevada and California.

4. Pinus edulis Engelm. Bot. Wisliz. Rep. 88. 1848. A low round-topped tree branched from or near the base, 4-6 m. high: leaves mostly in pairs (rarely in threes), $3-5 \mathrm{~cm}$. long, rigid, curved or nearly straight, spreading: cones sessile, subglobose, about $5 \mathrm{~cm}$. long; the tips of the scales thick, truncate, raised-pyramidal but without awns or prickles: seeds large, brown, wingless, edible. (Caryopitys edulis Small, Fl. S. U. S. 29. 1903.) PIÑoN or Nut Pine.-From Texas and Colorado to Utah and Arizona.

5. Pinus monophylla Torr. \& Frem. Fremont's 2d Rep. 319, t. 4. 1845. Closely resembling the preceding: leaves usually only one from each sheath. (Caryopitys monophylla Rydb. 1. c. 597.) Single-Leaf Piñon.-From the Wasatch in Utah to Nevada and Arizona.

6. Pinus Murrayana Oreg. Com. in Murray Rep. Bot. Exp. Oreg. No. 740, t. 3. 1853. Usually growing in dense groves or forests and then tall (15$30 \mathrm{~m}$.) and very slender, nearly devoid of branches except at the summit; if growing in more open ground, more freely branched and stockier: leaves semiterete, rather rigid, about $5 \mathrm{~cm}$. long: cones small, adhering tenaciously to the branches, which are often marked by the dead, persistent cones of the previous years; scales closely compacted, with quadrangular ends, armed with slender more or less recurved prickles which are often deciduous: seeds red-brown, winged. Lodge Pole Pine.-Used to some extent for lumber, but especially 
the source of the millions of poles used for fences in our range. Supplying most of the tepee poles of the past generations of Indians. Common in our range; extending to Alaska.

7. Pinus scopulorum (Engelm.) Lemmon, Gard. \& For. 183. 1897. Very variable in size but often becoming a large tree $25-40 \mathrm{~m}$. high; the trunk 1-2 m. in diameter: bark thick, deeply furrowed: leaves in fascicles of 2 or 3 (normally 3), 1-1.5 dm. long, crowded brush-like on the ends of the branchlets: cones 7-12 cm. long; scales much thickened at the outer end and bearing a sharp recurved prickle: seeds brown, winged, broadest above the middle. ROcK PINE.-Closely allied to P. ponderosa Dougl., of more northern and western range and by many considered a variety of it. Throughout our range.

\section{PICEA Link. SPRUCE}

Spire-shaped trees, often tall and slender. Leaves spirally arranged, jointed near the base, falling when dry and leaving the branchlets rough with the projecting bases. Cones pendulous, oblong, of numerous scales bearing two ovules.

Branchlets pubescent; leaves flexible and abruptly acute .

1. P. Engelmannii. Branchlets smooth and shining; leaves rigid, spinescent

2. P. Parryana.

1. Picea Engelmannii (Parry) Engelm. Trans. Acad. Sci. St. Louis 2: 212. 1863. A tall pyramidal tree, 25-40 m. high, becoming much dwarfed or even depressed-spreading and shrub-like at high elevations: branches verticillate, horizontal or the upper ascending; branchlets puberulent; bark light reddish: leaves 15-30 mm. long, singly and somewhat uniformly distributed over the branchlets, compressed quadrangular, abruptly acute: cones oval or oblong, about $5 \mathrm{~cm}$. long; scales thin, tough, truncate and entire or denticulate. ENGELmann SPRUCE.-A valuable tree, often occurring in extensive almost unbroken forests; middle elevations to timber-line. Throughout the Rocky Mountain region and west to the coast ranges.

2. Picea pungens Engelm, London Gard. Chron. 1879: 334. Of strictly conical growth with spreading branches: bark thick, smooth and gray, in older trees becoming very thick, hard and rigid: branchlets smooth and shining: leaves $2-3 \mathrm{~cm}$. Jong, very pungent: staminate aments $3-4 \mathrm{~cm}$. long, with pale shining rounded scales: cones abundant, solitary or clustered, cylindrical, drooping, 6-10 cm. long, light brown; scales oval or subrhombic, more or less elongated above, undulate and retuse. [P. Parryana (Andre) Parry, Gard. Chron. 2: 725. 1883.] BluE SPRUCE. - This is a comparatively small tree, with soft wood; the foliage usually blue-green; the needles sharply 4 -angled. It is used extensively for ornamental planting, and as the chosen "State Tree" of Colorado it is of interest. Found also in Wyoming and Utah.

\section{ABIES Juss. Fir}

Trees of pyramidal form and rapid growth, but with brittle and easily decaying wood. Leaves on the horizontal branchlets appearing 2 -ranked by a twist near the base, in ours bearing stomata on both sides, with two longitudinal resin-ducts. Scales of cone much wider than long, twice as long as the entire pointed
bract

Scales of cone suborbicular, three times as long as the lacerate-margined abruptly acuminate bract

1. A. concolor.

2. A. lasiocarpa.

1. Abies concolor (Gord.) Parry, Am. Nat. 9: 204. 1875. A large tree 25-50 $\mathrm{m}$. high, with a diameter of 6-12 dm. and a rough grayish bark: leaves mostly obtuse, pale green, with the 2 resin-ducts close to the epidermis of the lower surface: cones oblong-cylindrical, 7-12 cm. long and 3-4 cm. in diameter, pale green or sometimes dull purplish; scales $25-30 \mathrm{~mm}$. wide, nearly twice wider than high: seeds 8-12 mm. long, acute at the base, dark or dull brown, with rose-colored wings. White Fir.-From southern Colorado to California and thence northward to Oregon. 
2. Abies lasiocarpa (Hook.) Nutt. Sylva 3: 138. 1849. Not so tall, 20$30 \mathrm{~m}$. high, with very pale and thin, smooth, or only in very old trees cracked, and ashy-gray bark: leaves dark green above, sharp-pointed, with the two resin-ducts about equidistant from upper and lower surface: cones oblongcylindrical, 6-7 cm. long and 3-4 cm. in diameter, purplish-brown; scales nearly orbicular or sometimes quadrangular, $12-20 \mathrm{~mm}$. long and broad: seeds about $6 \mathrm{~mm}$. long, with dark lustrous wings covering nearly the entire surface of the scales. A. subalpina. AlPINe FIR.-Bark usually containing many balsam reservoirs or pustules which has given rise to one of its common names, BALSAM. Colorado and Wyoming and far westward and northward.

\section{4. pseudotsuga Carr. False Hemlock Spruce}

A large, stately tree, occurring in the mountains at middle elevations, on moist slopes and plateaus. Leaves with short petioles, twisting on the base so as to appear comb-like on the branches, which are smooth when the leaves have fallen and marked only by oval scars; stomata on the lower surface only, close to the epidermis of which are the two lateral resin-ducts. Fruit an ovateoblong pendulous cone maturing in one season; the bracts longer than the scales. Seeds winged.

1. Pseudotsuga mucronata (Raf.) Sudw. Contrib. U. S. Nat. Herb. 3: 266. 1895. A large tree, $35-80 \mathrm{~m}$. high, $1-4 \mathrm{~m}$. in diameter, with very thick brown deeply fissured bark: leaves flat, linear, $15-25 \mathrm{~m}$. or more long: cones 5-10 cm. long, subcylindrical; bracts more or less exsert and spreading or reflexed, giving a fringed appearance to the cones: seeds triangular, on the upper side convex and reddish-brown, on the lower flat and white, $6 \mathrm{~mm}$. long. $P$. Douglasii. Douglas Spruce.-Throughout the Rocky Mountains and westward to the coast ranges; reaching its greatest proportions in Oregon.

\section{JUNIPERUS L. JUNIPER}

Trees or shrubs with subulate or scale-like leaves, often of two forms. Cones dioecious or rarely monoecious, in short lateral aments; the staminate oblong or ovoid, with 2-6-celled anthers; the pistillate of a few opposite somewhat fleshy scales. Ovules solitary on each scale. Fruits globose, berry-like by the coalescence of the fleshy scales. Seeds 1-6, large, bony, wingless.

Trees or tree-like, 2-several $\mathrm{m}$. high; leaves scale-like.

Seeds solitary; berry $8-10 \mathrm{~mm}$. in diameter.

Leaves opposite (rarely in threes); seed acute at apex, rounded at base.

Flesh of berry thin and resinous . Flesh of berry dry and sweet . . . . . . . 2. J. utahensis.

Leaves 3-ranked; berry dry but resinous; seed large with obtuse 3 . J. Knightii.

Seeds $2-4$, berries smaller $: \quad: \quad: \quad \vdots \quad: \quad: \quad 4$. J. scopulorum.

Shrubs, usually in caespitose clumps.

Leaves subulate, about $1 \mathrm{~cm}$. long

Leaves scale-like at least in part

5. J. communis.

1. Juniperus monosperma (Engelm.) Sarg. Silva. N. Am. 10: 89. 1889. A tree, occasionally 12-15 m. high, freely branched, forming an open irregular head: bark thin, gray, broken into shreddy scales: leaves in pairs, or rarely in threes, acute, rounded or thickened on the back, usually less than $3 \mathrm{~mm}$. long; on young plants or vigorous shoots longer, sharp-pointed and glandular on the back: staminate ament with 8-10 stamens; the pistillate with spreading pointed scales: fruit globose or oblong, dark blue or copper-color with bloom, thin resinous flesh, and a solitary (rarely 2) 4-angled obtusish seed.-Southern Colorado to Texas and west to Nevada and Arizona.

2. Juniperus utahensis (Engelm.) Lemm. 3rd Bien. Rep. Cal. St. Bd. For. 183. 1890. A bushy tree $5 \mathrm{~m}$. or more high; the many erect contorted branches forming a broad open head: leaves opposite, rarely in threes, acute or acuminate, rarely glandular on the back, persistent for many,years: berries subglo- 
bose or oblong, marked by the tips of the flower-scales, 3-6 $\mathrm{mm}$. long; the flesh dry and sweet: seeds usually solitary, ovate, acute, conspicuously acutely angled, the apex brown. UTAH Juniper.-From the Wasatch Mountains in Utah to California and Arizona.

3. Juniperus Knightii A. Nels. Bot. Gaz. 25: 198. 1898. A scraggy shrub or small tree, 3-7 m. high, much branched from the base, i. e., trunkless or breaking up into several subequal trunks also freely branched; the branches widely spreading, the lowest almost resting upon the ground: leaves 3-ranked, closely appressed, rhomboidal in outline, thick, not pitted or glandular, long persistent: branches and fruiting branchlets thick and rather rigid: berries blue-green or copper-colored, marked by the points of the flower scales, ovoid or subglobose, 7-10 mm. in diameter; the flesh dry and closely adherent but more or less resinous (not sweet): 'seed solitary, ovate, obtuse, slightly grooved above, rounded or tumid at base, probably not maturing till the autumn of the second year. DEserT JuNIPER.-Common in arid situations (cañons and slopes); central to southwest Wyoming, probably adjacent Utah, and in similar situations in western Colorado.

4. Juniperus scopulorum Sarg. Gard. \& For. 10: 423. 1897. A tree 10$20 \mathrm{~m}$. high, with short, stout trunk, or sometimes branched from the base (in very exposed situations), often a mere shrub: leaves opposite, appressed, acute (in seedlings long and subulate), glandular on the back, dark green or pale and glaucous: fruit ripening at the end of the second season, globose, bright blue, with glaucous bloom; the flesh resinous: seeds usually 2 (often more), acute, prominently grooved and angled. J. virginiana. Rocky Mountain JunIPER.-Widely distributed in the mountains and table-lands of western America, at middle elevations.

5. Juniperus communis L. Sp. Pl. 1040. 1753. A low tree or more often an erect shrub: leaves in threes, subulate, rigid, prickly pointed, straight and slender, 1-2 cm. long: berry dark blue.-Only the shrubby form within our range and that passing into the variety

5a. Juniperus communis sibirica (Burgsd.) Rydb. Contrib. U. S. Nat. Herb. 3: 533. 1896. A low spreading shrub, rarely $1 \mathrm{~m}$. high, forming dense, usually circular patches: leaves in threes, crowded, rigid, channeled, and often whitish above: berries small, fleshy, bluish, 1-3-seeded. J. communis alpina.Rocky hillsides and mountain slopes: throughout our range.

6. Juniperus Sabina L. Sp. Pl. 1039. 1753. A depressed shrub usually less than $1 \mathrm{~m}$. high, in our range wholly prostrate, the stems creeping and rooting: leaves short and scale-like, 4-ranked, on young plants subulate and spinytipped: berry light blue, glaucous, borne on short pedunsle-like branchlets: seeds 1-4.-On banks and slopes; not frequent; Wyoming and Montana, east to New York.

\section{GNetACEAE Lindl. Joint Fir Family}

Shrubs or small trees, mostly with jointed opposite or fascicled branches and foliaceous or scale-like opposite (or ternate) exstipulate leaves, the flowers mostly dioecious, with decussate persistent bracts. Staminate flowers in aments, with solitary or monadelphous stamens within a membranous bifid calyx-like perianth, the anther-cells dehiscent by a pore or chink at the apex. Pistillate flower an erect sessile ovule terminated by an exserted style-like process, included within a perianth which becomes hardened and often thickened in fruit.

\section{EPHEDRA L. JOINT FIRS}

Shrubs with numerous Equisetum-like branches. Leaves reduced to sheathing scales, persistent or deciduous. Inflorescence axillary; the 3-8 filaments united into a clavate stamineal column. 
Scales and branches opposite; bracts connate .

Scales and branches in threes; bracts hardly connate.

Scales short (2-3 mm.); fruit scabrous

Scales long (6-12 mm.); fruit smooth
1. E. antisyphilitica.

2. E. Torreyana.

3. E. trifurca.

1. Ephedra antisyphilitica Mey. Monog. Ephedr. 101. 1846. Stems mostly lax and slender, declinate and nearly prostrate: bark not shreddy or fibrous: scales distinct, subpersistent, very short and triangular-ovate, or when young setaceously tipped and slightly sheathing (sometimes $4 \mathrm{~mm}$. long): aments on short bracteate peduncles: filaments distinct above the perianth: pistillate flowers with 3 or 4 pairs of bracts: fruit $5-6 \mathrm{~mm}$. long.-Colorado to Texas and New Mexico.

2. Ephedra Torreyana Wats. Proc. Am. Acad. 14: 299. 1899. Erect, 3$10 \mathrm{dm}$. high or more, the branches often somewhat flexuous, not spinose, usually ternate: scales short, sheathing, ternate, with broad and acutish or rarely narrow lobes, subpersistent, not becoming shreddy: staminate aments nearly sessile, of 6-8 whorls of broad bracts; perianth round-ovate, slightly exserted; anthers 5-8, stipitate: pistillate flowers 6-10 $\mathrm{mm}$. long, on a very short peduncle, of 5-6 whorls of thin broadly dilated unguiculate more or less crenulate bracts: fruit solitary or in threes, oblong-lanceolate, scabrous, $8 \mathrm{~mm}$. long or less.-Colorado to California.

3. Ephedra trifurca Torr. Bot. Emory Rep. 152. 1848. Erect, much branched, 4-16 dm. high, the straight rigid branches spinosely tipped: scales conspicuous, sheathing, 6-12 $\mathrm{mm}$. long, sharply acuminate, persistent, becoming whitish and shreddy: staminate aments on a very short peduncle, of 5 whorls of ovate bracts about equaling the cuneate-oblong perianths: anthers (4 or 5) stipitate: fertile flowers nearly sessile, $10-12 \mathrm{~mm}$. long, of numerous whorls (8-10) of very thin and scarious entire round-cordate unguiculate bracts: fruit solitary, $12 \mathrm{~mm}$. long, 4-sided, attenuate upward, smooth.Texas to Arizona and north to Colorado.

\section{ANGIOSPERMS}

The prevailing seed-plants of the present flora, characterized by ovules being inclosed by the carpel.

\section{TYPHACEAE J. St. Hil. Cat-tail Family}

Rootstocks creeping. Leaves long, sheathing the base of the simple jointless stems, erect, thickish. Flowers in a long and very dense cylindrical spike terminating the stem; the upper part consisting of stamens only, inserted directly on the axis, and intermixed with long hairs; the lower part consisting of stipitate 1-celled ovaries, the stipes bearing club-shaped bristles, which form the copious down of the fruit. Nutlets minute, very long stalked. Spathes merely deciduous bracts, or none.

\section{TYPHA L.}

Characters of the family.

1. Typha latifolia L. Sp. Pl. 971. 1753. Stout and tall, 1-2 m. high: leaves flat, sheathing, 1-2 cm. broad, exceeding the stem: spike 1-3 dm. long; the upper half staminate; the lower pistillate, dark brown, $2-3 \mathrm{~cm}$. thick: pistillate flowers without bractlets; stigma rhombic-lanceolate: pollen grains in fours.In marshes throughout North America.

2. Typha angustifolia L. 1. c. Leaves narrower: spike brown, the staminate and pistillate portions distant, the pistillate with bractlets: stigmas lin- 
ear: pollen grains simple.-Reported from Denver; abundant on the Atlantic coast; also in Europe and Asia.

\section{SPARGANIACEAE Agardh. Bur-REed Family}

Rootstocks creeping and stoloniferous: roots fibrous. Stems simple or branching, sheathed below by the base of the linear leaves. Flowers collected in separate dense and spherical leafy-bracted heads, which are scattered along the summit of the stem; the upper sterile, consisting merely of stamens, with minute scales irregularly interposed; the lower or fertile larger, consisting of numerous sessile 1-2-celled pistils, each surrounded by 3-6 scales much like a calyx. Fruit wedge-shaped or club-shaped, more or less corky toward the summit, the hard endocarp perforated at the apex.

\section{SPARGANIU M L.}

Characters of the family.

Fruits sessile, angular

Fruits stalked, terete or fusiform.

Emergent and erect. Inflorescence branched Inflorescence simple

Submersed or floating. Inflorescence branched Inflorescence simple.

1. Sparganium eurycarpum Engelm. Gray, Man. Ed.2.430. 1856. Stems stout, erect, 5-10 dm. high, with branched inflorescence: leaves mostly flat and merely keeled: pistil attenuate into a short style bearing 2 elongated stigmas: fruit heads $2-6$ or more, 2-3 cm. broad: fruit many-angled, sessile, when mature with a broad and depressed or retuse summit, abruptly tipped in the center.-Borders of ponds and streams; across the northern part of the United States.

2. Sparganium androcladum (Engelm.) Morong, Bull. Torr. Bot. Club 15: 78. 1888. Stems erect, slender, $3-5 \mathrm{dm}$. high, sparingly or freely branched: pistillate heads $3-7$, sessile or the lowest peduncled; style and stigmas $6 \mathrm{~mm}$. long: fruiting heads 12-25 $\mathrm{mm}$. in diameter: fruits fusiform, 5-6 mm. long, smooth or angled at the summit, often contracted in the middle; the stipe 3 $\mathrm{mm}$. long.- - In bogs and shallow water; northeastern part of our range to New England.

3. Sparganium simplex Huds. Fl. Angl. Ed. 2. 401. 1788. Stems slender, erect, 2-4 dm. high: leaves more or less triquetrous: fertile heads $(1-4)$ of the usually simple inflorescence often above the axils, sessile or peduncled, 12$15 \mathrm{~mm}$. wide in fruit: stigma linear, equaling the rather slender style, or shorter: nutlets pale, fusiform or narrowly oblong, about $4 \mathrm{~mm}$. long, more or less contracted in the middle.-Northern Wyoming and thence across the continent.

4. Sparganium angustifolium Michx. Fl. Bor. Am. 2: 189. 1803. Floating in shallow or deep water: stems slender: leaves long and narrow, flat, with sheaths often inflated at base: inflorescence 3-10 cm. long: staminate heads $1-4$; pistillate 1-4, usually above the axil, sessile or the lower pediceled: mature fruiting heads $7-15 \mathrm{~mm}$. in diameter; nutlets often contracted in the middle.-Seemingly frequent in our range; from New Foundland to California.

5. Sparganium minimum Fries. Summa Veg. Skand. 2: 560. 1846. Usually floating, with very slender stems and thin flat narrow leaves: fertile heads 1 or 2 , axillary, sessile or peduncled, $8-10 \mathrm{~mm}$. wide: stigma oval, about as long as the short style, scarcely surpassing the oval or obovate denticulate scales: fruit oblong-obovate, $2-4 \mathrm{~mm}$. long, pointed, somewhat triangular, the stipe very short.-Colorado to New England. 


\section{NAIADACEAE Lindl. Pondweed Family}

Marsh or mostly immersed aquatic plants with jointed, leafy stems, and the leaves sheathing at base or stipulate. Flowers perfect, monoecious or dioecious, often spathaceous. Perianth of 4 segments, or membranaceous, or wanting. Stamens 1-4. Ovaries 1-9, distinct, 1-celled, 1-ovuled.-Naiadaceae in part.

Flowers perfect; leaves alternate; anthers 2 or 4 , sessile.

Perianth-segments 4 , distinct; ovaries sessile

Perianth wanting; ovaries at length stipitate
Flowers monoecious or dioecious; leaves opposite or fascicled; stamen

1. Potamogeton. solitary.

Leaves entire; flowers clustered in the axils

2. Ruppia.

Leaves spiny-toothed; flowers solitary in the axils

3. Zannichellia.

4. Naias.

\section{POTAMOgETON L. Pondweed}

Herbs of fresh or saline ponds and streams, with jointed mostly rooting stems, and 2-ranked leaves, which are usually alternate or imperfectly opposite: the submersed ones pellucid, the floating ones often dilated and of firmer texture. Stipules membranous, more or less united and sheathing. Spikes sheathed by the stipules in the bud, mostly later raised on a peduncle to the surface of the water. Flowers perfect. Sepals 4, rounded, valvate in the bud. Stamens 4, opposite the sepals; anthers nearly sessile, 2-celled. Ovaries 4 (rarely only one), with an ascending campylotropous ovule; stigma sessile or on a short style. Fruit drupe-like when fresh, more or less compressed; endocarp (nutlet) crustaceous.

Some of the leaves floating.

Floating leaves elliptic to oblanceolate, petioled.

Submerged leaves bladeless

Submerged leaves with a proper blade.

Of two forms-elliptic and lanceolate.

Of one form-all alike.

Linear.

Filiform, with adnate stipules

Broadest at base; with free stipules

Not linear.

Petiole of floating leaves long $(3-10 \mathrm{~cm}$.)

Petiole of floating leaves short (3-15 mm.).

Blade elliptic

Blade oblanceolate

None of the leaves floating.

Leaves with lanceolate or broader blade.

Amplexicaul

Sessile or nearly so

Leaves linear.

Stipules free; style present. Leaves glandular at base Leaves not glandular at base

Stipules adnate.

Style present, deciduous; fruit plump.

Style wanting; stigma sessile, persistent

1. P. natans.

2. P. amplifolius.

3. P. diversifolius.

4. P. heterophyllus.

5. P. lonchites.

6. P. Zizii.

7. $\mathbf{P}$ alpinus.

8. P. perfoliatus.

9. P. lucens.

10. P. pusillus.

11. P. foliosus.

12. P. pectinatus.

13. $P$. filiformis.

1. Potamogeton natans L. Sp. Pl. 126. 1753. Stem rather stout, simple or sparingly branched: floating leaves thick, ovate-elliptic to lanceolate, acutish, slightly cordate at base, 21-29-nerved, mostly shorter than the petiole; stipules long and conspicuous; upper submerged leaves rarely with a small lanceolate blade, the lower (formed early in the season) reduced to phyllodia: peduncle stout, bearing an emersed spike: fruit turgid, obliquely obovate, acute: nutlet with a small deep pit on each side.-Across the continent, in ponds and ditches. In deeper or flowing water the plant becomes more slender and of ten wholly submerged.

2. Potamogeton amplifolius Tuckerm. Am. Journ. Sci. II. 6: 225. 1848. Stems often stout, simple: floating leaves (sometimes wanting) 30-50-nerved, elliptic to oblong-lanceolate, acute, mostly rounded or slightly cordate at

ROCKY MT. BOT. -3 
base, on stout petioles about equaling the blade; submerged leaves of ten very large, mostly falcate and somewhat undulate, acute, attenuate to a usually short petiole: spike thick, on a very stout peduncle: fruit large, 3 -keeled, with a broad, stout beak: sides of the nutlet not pitted.-In ponds and streams; from New Mexico to the Atlantic States; also in California and Oregon.

3. Potamogeton diversifolius Raf. Med. Rep. II. 5: 354. 1808. Floating leaves oval to lance-oblong, often acute, longer than the filiform petioles, with about 5-7 nerves beneath, deeply impressed; submerged leaves very numerous, almost setaceous, $2-10 \mathrm{~cm}$. long, very rarely $1 \mathrm{~mm}$. wide; stipules obtuse: emersed spikes 8-14 mm. long; submersed spikes 1-4-flowered, their peduncles (of their own length) frequently recurved: fruit minute, about 8-toothed on the margin.-Montana, probably Wyoming, east to New Brunswick and Florida.

4. Potamogeton heterophyllus Schreb. Spicil. Fl. Lips. 21. 1771. Stems very slender, branching: floating leaves rather thin, 9-15-nerved, small, oblongelliptic, acutish, rounded or cuneate at base, on slender petioles mostly equaling or exceeding the blade; submerged leaves linear-lanceolate, variable in length, more commonly short, acute or acuminate, narrowed at base: spikes rather loose, on stout often elongated peduncles: fruit round-obovate, acute, scarcely keeled.-In still or flowing water; from the Yellowstone eastward; also in Nevada and California.

5. Potamogeton lonchites Tuckerm. Am. Journ. Sci. II. 6: 226. 1848. Stem rather slender, branching: floating leaves thickish, 11-23-nerved, long elliptical to oblong-lanceolate, acute or acutish, rather abruptly narrowed into a petiole usually longer than the blade; submerged leaves thin and long, mostly linear-lanceolate, attenuate at base, the lower sessile: spikes on stout peduncles: fruit obliquely obovate, carinate, acute: nutlet somewhat 3-keeled, the sides scarcely impressed.-Usually in streams; from Mexico to the Atlantic States; also in the Pacific States.

6. Potamogeton Zizii Roth, Enum. 1: 531. 1827. Stems branching, slender: floating leaves -many-nerved, narrowly elliptic, 4-10 cm. long, mostly acute, short-petioled or often nearly sessile; submerged leaves lanceolate or oblanceolate, thin, acute, longer than the floating leaves, 7-17-nerved: peduncles thicker than the stem, long: spike often $5 \mathrm{~cm}$. long: fruit obliquely ovoid, rather large, dorsally 3-keeled.-Wyoming and Montana, east to the Atlantic States.

7. Potamogeton alpinus Balbis, Misc. Bot. 13. 1804. Floating leaves (often wanting) rather thin, 11-17-nerved, narrowly oblong-elliptic or oblanceolate, acutish, attenuate into a very broad, short petiole; submerged leaves as large as the floating, sessile or nearly so, narrowly oblong-lanceolate, obtuse or acute: spikes rather slender, on stout often elongated peduncles: fruit round-obovate, acutely margined, beaked by the rather long style: nutlet pitted on each side. $P$. rufescens.-In ponds and streams; Colorado to Montana, and in the Atlantic States.

8. Potamogeton perfoliatus L. Sp. Pl. 126. 1753. The large leaves longlanceolate from a cordate-clasping base, and acuminate, wavy, 8-12 cm. Jong: peduncles thickened upward: fruit irregularly obovate, obtusely margined, the sides with a shallow indentation. $P$. perfoliatus lanceolatus.-Colorado to Montana, thence across the continent.

9. Potamogeton lucens L. Sp. PI. 127. 1753. Stem stout, branching: leaves usually large, $5-15 \mathrm{~cm}$. long, oblong-lanceolate or oblanceolate, abruptly acute or acuminate, often undulate-serrate, narrowed at base to a short petiole or subsessile; stipules large: peduncles of ten elongated: fruit acute, slightly keeled.-From New Mexico to California; also eastward to Florida and New England.

10. Potamogeton pusillus L. Sp. Pl. 127. 1753. Stem slender, flattish or nearly cylindrical, often very branching: leaves narrow or setaceous-linear, acuminate, acute or subacute, 1-3-nerved, furnished with translucent glands on each side at the base; stipules at first obtuse: spikes interrupted or capitate, 2-8-flowered, on rather long peduncles: fruit obliquely elliptical, scarcely 
keeled: apex of embryo incurved and directed obliquely downward.-In ponds and slow streams; almost throughout North America, but rare in our range.

11. Potamogeton foliosus Raf. Med. Rep. II. 5: 354. 1808. Stem filiform, somewhat flattened, freely branching: leaves narrowly linear, $3-5 \mathrm{~cm}$. long, 1-2 mm. broad, acute, obscurely 3-nerved; stipules obtuse: spikes capitate, 1-4-flowered, on short club-shaped peduncles: fruit roundish-lenticular, the back more or less crested.-Mostly in still water, of ten in stagnant and alkaline ponds; Colorado to Montana, and across the continent.

12. Potamogeton pectinatus L. Sp. Pl. 127. 1753. The slender stems freely branched, 3-8 dm. long; the branches repeatedly dichotomous: leaves tapering to the setaceous apex, 1-nerved, 5-15 cm. long, sometimes capillary and nerveless; sheaths of the stipules with scarious margins: fruit obliquely ovoid, with a hard thick shell, 3-4 mm. long, not keeled but with obscure lateral ridges on the back, the sides full and convex.-In fresh or saline waters; very common in our range; across the continent.

13. Potamogeton filiformis Pers. Syn. 1: 152. 1805. Resembling narrowleaved forms of the last species, low and very leafy: peduncles much elongated: fruit much smaller ( $2 \mathrm{~mm}$. long) and thinner, round-obovate, not keeled upon the rounded back, tipped with the broad sessile stigma. P. marinus.-Similar habitat and about the same range as the last.

\section{RUPPIA L.}

Aquatic herbs, growing under water, with long and thread-like forking stems, and slender almost capillary alternate leaves, sheathing at the base. Flowers rising to the surface at the time for expansion, perfect, 2 or more approximated on a slender spadix, which is at first inclosed in the sheathing spathe-like base of a leaf, entirely destitute of floral envelopes, consisting of two sessile stamens, each with 2 large and separate anther-cells, and 4 small sessile ovaries. Stigma sessile, depressed. Fruit small obliquely ovate, pointed drupes, each raised on a slender stalk which appears after flowering; the spadix itself also then raised on an elongated thread-form peduncle.

Pedicels 1-3 cm. long; fruit conical-ovoid

Pedicels 3-6 cm. long; fruit gibbous at base and strongly curved $\quad$ : $\quad 2$. R. curvicarpa.

1. Ruppia maritima L. Sp. Pl. 127. 1753. Leaves linear-capillary: fruiting peduncles capillary, $7-15 \mathrm{~cm}$. long; pedicels $1-3 \mathrm{~cm}$. long: fruit (drupe or nut) conical-ovate, sometimes somewhat gibbous at base and obliquely erect.Shallow bays and in marshes along the Atlantic and Pacific coasts; apparently aiso in salt springs and creeks in the interior.

2. Ruppia curvicarpa A. Nels. Bull. Torr. Bot. Club 26: 122. 1899. Stems light green, $6 \mathrm{dm}$. or more in length, capillary and fragile at maturity: leaves variable in length, $3 \mathrm{~cm}$. or more: peduncles long: pedicels several in a cluster, capillary, fragile, from 3-6 cm. long: drupes black at maturity, oblong, $2 \mathrm{~mm}$. in length, gibbous at base, hence appearing obliquely placed on the pedicel, increasing slightly in diameter upward to the abruptly bent beak which is tipped with a sharp acumination.-Alkali lakes, southern Wyoming; probably in similar waters elsewhere in the interior table-lands.

\section{ZANNICHELLIA L.}

Very slender and branching, with very narrow or filiform opposite leaves, not sheathing and with small stipules. Flowêrs monoecious, axillary, sessile or nearly so. Sterile flowers of a single naked stamen with slender filament. Fertile flowers solitary, usually in the same axils, with a cup-shaped membranous spathe or perianth; ovaries nearly sessile, becoming more or less stipitate; stigmas peltate. Fruit an obliquely oblong beaked nutlet.

1. Zannichellia palustris L. Sp. Pl. 969. 1753. Stems 1-5 dm. long or more, leafy: leaves 1-7 cm. long: fruit somewhat incurved, often more or less toothed on the back.-In fresh-water ponds and slow streams; from New 
Mexico and southern Colorado northward, and in both the Pacific and the Atlantic States.

\section{NAIAS L.}

Slender branching herbs, growing under water, with opposite and linear leaves somewhat crowded into whorls, spinulose-toothed, sessile and dilated at base. Flowers very small, solitary, but often clustered in the axils; dioecious or monoecious, axillary, solitary and sessile; the sterile consisting of a single stamen inclosed in a little membranous spathe; anther at first nearly sessile, the filament at length elongated. Fertile flowers consisting of a single ovary tapering into a short style; stigmas 2-4, awl-shaped. Fruit a little seed-like nutlet, inclosed in a loose and separable membranous epicarp.

Leaves acuminate; seeds with 30-50 rows of faint reticulations Leaves abruptly acute; seeds with 16-20 rows of conspicuous reticulations

1. Naias flexilis (Willd.) Rost. \& Schmidt. Fl. Sed. 354. 1824. Stems very slender: leaves linear, becoming acuminate, minutely serrulate, $1-3 \mathrm{~cm}$. long; sheaths obliquely rounded, with 5-10 teeth on each edge: dioecious: fruit ellipsoid, about $3 \mathrm{~mm}$. long, tipped with the long style and the 3 short stigmas: seeds smooth and shining, sometimes faintly sculptured with 30-50 rows of reticulations.-Said to occur in most parts of North America.

2. Naias guadalupensis (Spreng.) Morong, Mem. Torr. Club 32: 60. 1893. Very similar, but the stems long (3-6 dm.) and freely branched: leaves shorter, the edges parallel, abruptly acute: fruit dull (not shining) and strongly marked with 16-20 rows of reticulations which are transversely oblong.-Widely distributed but not common; Colorado to Florida and Oregon.

\section{JUNCAGINACEAE Engler \& Prantl. Arrow Grass FAMILY}

Rush-like plants growing in wet or marshy places, ours in saline soils. Leaves rush-like or cylindrical. Flowers in simple spikes or racemes, perfect; perianth segments 3-6; stamens 3-6. Ovaries 3-6, more or less united when immature.-Naiadaceae in part.

\section{TRIGLOCHIN L. ARROW Grass}

Perennials, with rush-like fleshy leaves, below sheathing the base of the wand-like naked and jointless scape. Flowers small, in a spiked raceme, bractless. Sepals and petals nearly alike (greenish), ovate, concave, deciduous. Stamens 3-6; anthers oval, on very short filaments. Pistils united into a 3-6-celled compound ovary; stigmas sessile; ovules solitary. Capsule splitting when ripe into $3-6$ carpels, which separate from a persistent central axis.

Carpels 6; fruit obtuse at base

Carpels 3 ; fruit attenuate at base

1. Triglochin maritima L. Sp. Pl. 339. 1753. Rather stout, 2-10 dm. high: leaves shorter than the scape, $2-4 \mathrm{~mm}$. broad: raceme usually crowded, 1-3 dm. long: flowers $2 \mathrm{~mm}$. broad: fruit obtuse at base, 6-carpeled, 3-5 $\mathrm{mm}$. long, and about equaling the pedicels. - In saline places across the continent.

2. Triglochin palustris L. Sp. Pl. 338. 1753. Slender, 1-3 dm. high: leaves less than $2 \mathrm{~mm}$. broad: flowers smaller: fruit attenuate at base, 3 carpeled, 5-8 $\mathrm{mm}$. long, exceeding the pedicels, separating from below upward.-From the Rocky Mountains eastward across the continent. 


\section{Alismaceae DC. Water Plantain Family}

Marsh herbs, with scape-like stems, sheathing leaves, and perfect or monoeeious flowers not on a spadix, furnished with both calyx and corolla. Sepals and petals each 3, distinct. Ovaries numerous, distinct, becoming achenes in fruit.-Roots fibrous; leaves radical, petiolate, strongly nerved with transverse veinlets, the earlier sometimes without blade; flowers in a loose raceme or panicle.

Leaves elliptic-ovate; flowers perfect

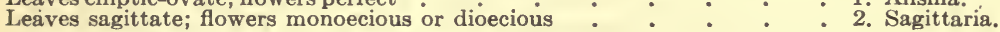

\section{1. alisma L. Water Plantain}

Roots fibrous. Leaves all from the root, several-ribbed, with connected veinlets. Scape with whorled panicled branches. Flowers small, white or pale rose-color, perfect. Petals involute in the bud. Stamens definite, mostly 6. Ovaries many in a simple circle on a flattened receptacle, forming flattened coriaceous achenes, which are dilated and 2-3-keeled on the back.

1. Alisma Plantago-aquatica L. Sp. P1. 342. 1753. Perennial by a stout proliferous corm: leaves long-petioled, ovate, oblong, or lanceolate, or even linear, acute, mostly rounded or heart-shaped at base, 3-9-nerved: panicle loose, compound, many-flowered, 3-5 dm. long: carpels obliquely obovate, forming an obtusely triangular whorl in fruit. ( $A$. brevipes Greene, Pitt. 4: 158. 1900.) - In shallow water or on muddy banks; North America, Europe, and Asia.

\section{SAgitTARIA L. ARrowhead}

Marsh or aquatic mostly perennial stoloniferous herbs, with milky juice and fibrous roots; the scapes sheathed at base by the bases of the long cellular petioles, of which the primary ones, and sometimes all, are flattened, nerved, and destitute of any proper blade (i. e., are phyllodia); when present the blade is arrow-shaped or lanceolate, nerved and with cross-veinlets as in Alisma. Flowers monoecious, or often dioecious. Petals imbricated in the bud. Stamens indefinite, rarely few. Ovaries many, crowded in a spherical or somewhat triangular depressed head on a globular receptacle, in fruit forming flat membranaceous-winged achenes.

Beak of achene wanting or merely an erect tooth in the margin of its wing.

Basal-lobes of leaf shorter than the blade.

Basal-lobes acute

Basal-lobes obtuse

Basal-lobes of leaf much longer than the blade

Beak of achene $\frac{1}{1}$ to $\frac{1}{3}$ as long as the body

1. S. arifolia.

2. S. hebetiloba.

3. S. longiloba.

4. S. latifolia.

1. Sagittaria arifolia (Nutt.) J. G. Smith, Ann. Rep. Mo. Bot. Gard. 6: 32. pl. I. 1894. Glabrous or nearly so: leaves sagittate, usually broad, with curved margin, rather abruptly acute; the lobes acute or acuminate, divergent but incurved, usually less than half as long as the blade: bracts lanceolate, as long as the fertile pedicels or longer: petals white, 6-10 $\mathrm{mm}$. long: filaments glabrous: achene obovate, $2 \mathrm{~mm}$. long, winged, with a short tooth-like beak at one side of the summit. S. variabilis in part.-On muddy banks or in shallow ponds; frequent in our range, and extending from Michigan to California.

2. Sagittaria hebetiloba A. Nels. Bull. Torr. Bot. Club 26: 6. 1899. Very similar to the preceding but usually larger in every way: leaves broad, with curved sides and rounded abruptly acutish apex; the lobes broad and abruptly rounded, very obtuse: beak of achene oblique or erect, very short, merely a blunt tooth at the side of the rounded summit of the body.-Type locality, Platte Cañon, eastern Wyoming; possibly local or a mere form of the preceding. 
3. Sagittaria longiloba Engelm. in Torr. Bot. Mex. Bound. 212. 1859. Glabrous: petioles and scapes rather long and slender: leaves with short lanceolate blade and usually very long linear-lanceolate acute lobes, 2-3 times as long as the blade: bracts lanceolate, acuminate: stamens numerous; the filaments longer than the anthers: achene quadrate-obovate, winged all around, beak wanting or nearly so.-Nebraska and Colorado to Mexico.

4. Sagittaria latifolia Willd. Sp. Pl. 4: 409. 1806. Monoecious, as are all of ours, glabrous or nearly so, 2-10 dm. high: leaves broad and abruptly contracted to the acute apex; basal lobes usually broad, divergent and often slightly out-curved, about half as long as the blade: bracts acute or obtuse: flowers rather large, $2-3 \mathrm{~cm}$. broad: achene with broad wing on either side narrowed into the nearly horizontal slender beak, one third as long as the body.-Very variable; throughout North America; infrequent in our range.

\section{HYDROCHARITACEAE Aschers. Tape Grass Family}

Represented in our range by a single genus, which see for characters.

\section{PHILOTRIA Raf. WATERWEED}

Perennial slender submerged herbs, with elongated branching stems thickly beset with pellucid and veinless, 1 -nerved, sessile, whorled or opposite leaves. The staminate flowers (rarely seen) commonly break off, as in Vallisneria, and float on the surface, where they expand and shed their pollen around the stigmas of the fertile flowers, raised to the surface by the prolonged calyx-tube.-(Elodea Michx.)

1. Philotria canadensis (Michx:) Brit. Science II. 2: 5. 1895. Leaves in threes or fours, or the lower opposite, varying from linear to oval-oblong, minutely serrulate: stamens 9 in the sterile flowers, 3-6 almost sessile anthers in the fertile. [P. angustifolia (Muhl.) Brit. and $P$. minor (Engelm.) Small.] Slow streams and ponds, common; widely distributed in North America; rather rare in our range.

\section{GRAMINEAE Juss. Grass Family}

Annual or perennial herbs of various habit, rarely shrubs or trees. Stems (culms) generally hollow or sometimes solid, the nodes closed. Leaves sheathing, the sheaths usually split to the base on the side opposite the blade, a scarious or cartilaginous ring (ligule) borne at the base of the leaf-blade. Inflorescence spicate, racemose, or paniculate, consisting of spikelets composed of two-many 2-ranked imbricated bracts, the 2 lowest in the complete spikelet always empty (glumes), 1 or both sometimes wanting. One or more of the upper bracts (lemmas) usually contains in the axil a flower, which is usually inclosed by a bract-like awnless organ called the palet, placed opposite the lemma with its back to the axis (rachilla) of the spikelet, generally 2-keeled. Flowers perfect or staminate, sometimes monoecious or dioecious, subtended by $1-3$, usually 2 minute hyaline scales (lodicules) placed at the base of the ovary opposite the palet. Stamens 1-6, usually 3; anthers 2-celled, versatile, longitudinally dehiscent. Ovary 1-celled, 1-ovuled; styles 1-3, usually 2 and lateral; stigmas hairy or plumose. Fruit a seed-like grain (caryopsis). Endosperm starchy.

Various terms have been used to designate the bracts (glumes) of the spikelets. In the treatment here Mr. C. V. Piper's suggestion has been adopted, 
as follows: The two empty glumes are merely the glumes; the flowering glume is the lemma; the additional glume in the Paniceae (the so-called third glume) is the sterile lemma; palet and lodicule are used as heretofore.

\section{Key to the Tribes *}

Spikelets falling from the pedicels entire, naked or inclosed in bristles or bur-like involucres, 1-flowered, or if 2-flowered the lower flower staminate; no upper empty lemmas; rachilla not extending above the sterile lemma.

Spikelets round or somewhat compressed dorsally; glumes manifest; hilum punctiform.

Lemma and palet hyaline, thin, much more delicate in texture than the glumes.

Spikelets in pairs, one sessile and the other pedicellate Spikelets not in pairs (Alopecurus, Polypogon, Cinna, etc.)

Tribe

I. Andropogoneae.

Tribe VI. Agrostideae.

Lemma, at least that of the perfect flower, similar in texture to the glumes, or thicker and firmer, never hyaline and thin.

Lemma and palet membranous; the first glume usually larger than the rest

Lemma and palet chartaceous to coriaceous, very different in color and appearance from the glumes.

Spikelets much compressed laterally; glumes none or rudimentary; hilum linear . . . . . .

Spikelets with the glumes persistent, the rachilla articulated above them, 1-many-flowered; frequently the upper lemmas are empty; rachilla often produced beyond the sterile lemma.

Spikelets borne in an open or spike-like panicle or raceme, usually upon distinct pedicels.

Spikelets 1-flowered.

Glumes 4; palet 1-nerved

Glumes 2, rarely 1; palet 2-nerved (except in Cinna)

Tribe

V. Phalarideae.

Tribe VI. Agrostideat.

Spikelets 2-many-flowered.

Lemma usually shorter than the glumes; the awn dorsal and usually bent

\section{-}

Lemma usually longer than the glumes; the awn terminal and straight (rarely dorsal in Bromus) or none

Spikelets in two rows, sessile or nearly so.

Spikelets on one side of the continuous axis, forming onesided spikes . . . . . • . .

Spikelets alternately on opposite sides of the axis, which is often articulated

\section{Tribe I. ANDROPOGONEAE}

Rachis-internodes not sulcate; branches of the simple panicle paired, or rarely single or variously branched.

Some or all of the racemes sessile

All of the racemes more or less peduncled.

Pedicellate spikelets wanting .

Pedicellate spikelets present and usually staminate

Tribe VII. Aveneae.

Tribe IX. Festuceae.

Tribe VIII. Chlorideae.

Tribe X. Hordeae.

Rachis-internodes sulcate

\section{Tribe II. ZOYSIEAE}

\section{Andropogon.}

3. Sorghastrum.

4. Sorghum.

2. Amphilophis.

Inflorescence in terminal spikes

5. Hilaria.

* This excellent key to the tribes represented in our range is taken without change (except in terms used) from Rydberg's Flora of Colorado. The generic kevs have been adapted from those of Rydberg's Fl, Colo,; Piper's Fl. Wash,; and Britton's Man. 


\section{Tribe III. PANICEAE}

Spikelets without a subtending involucre of bristles or valves.

Spikelets in one-sided racemes or spikes.

First glume well developed

First glume small or abortive.

Plant annual

Plant perennial

Spikelets not in one-sided racemes or spikes.

Glumes awned

Glumes not awned

Spikelets involucrate.

The involucre consisting of bristles . . . . .

The involucre consisting of spine-bearing valves forming a bur. .

6. Paspalum.

7. Syntherisma.

8. Brachiaria.

9. Echinochloa.

10. Panicum.

11. Chaetochloa.

12. Cenchrus.

13. Homalocenchrus.

14. Phalaris.

15. Hierochloe.

Uppermost floret perfect, the others empty .

Uppermost floret perfect, the others staminate

\section{Tribe VI. AGROSTIDEAE}

Lemma with a long terminal awn, and closely embracing the grain.

Spikelets not in pairs.

Fruiting lemma thin and membranous

Fruiting lemma firm and indurated.

Awns 3-branched

Awns simple.

Twisted, persistent on the lemma

Straight, deciduous from the lemma.

Lemma glabrous or appressed-pubescent

Lemma long silky-pubescent

Spikelets paired, in a spike-like raceme . . . .

Lemma awnless or short-awned, and loosely investing the grain.

Inflorescence a dense spike.

Spikelets persistent; lemma awnless or with a short terminal awn.

Spikes cylindrical

Spikes ovoid

Spikelets early deciduous; lemma with a dorsal awn

27. Polypogon.

23. Alopecurus.

Inflorescence a loose panicle.

Pericarp discharging the seed at maturity.

A diminutive alpine perennial

Larger and mostly at middle and lower altitudes.

Nerves of lemma not pilose

20. Muhlenbergia.

16. Aristida.

17. Stipa.

18. Oryzopsis.

19. Eriocoma.

21. Lycurus.

Nerves of lemma pilose

Pericarp permanently investing the seed.

Palet 1-nerved; stamen 1

Palet 2-nerved; stamens 3.

Lemma naked at the base

Lemma with a tuft of long hairs at the base.

Thin-membranous

Chartaceous

\section{Tribe VII. AVENEAE}

Awn of the lemma dorsal.

Spikelets less than $1 \mathrm{~cm}$. long.

Lemma erose-truncate

Lemma 2-toothed, with awn twisted and bent .

24. Phippsia.

25. Sporobolus.

26. Blepharineuron

28. Cinna.

29. Agrostis.

30. Calamagrostis.

31. Calamovilfa.

Spikelets more than $1 \mathrm{~cm}$. long

Awn of the lemma terminal, between the teeth

32. Deschampsia.

33. Trisetum.

35. Avena.

36. Danthonia, 


\section{Tribe VIII. CHLORIDEAE}

Spikelets with perfect flowers.

Spikelets deciduous as a whole, the articulation below the glumes.

Spikelets much flattened; glumes unequal, keeled

40. Beckmannia.

Spikelets subterete; glumes equal, convex

37. Spartina.

Spikelets in part persistent, the articulation above some of the glumes.

Spikes few (1-4)

Spikes numerous.

Spikes long, very slender; plant annual

Spikes short, one-sided

Spikelets with imperfect flowers, the pistillate very different from the staminate and on very short culms

\section{Bouteloua.}

34. Schedonnardus.

39. Atheropogon.

41. Buchloe.

42. Scleropogon.

44. Phragmites.

43. Munroa.

Lemma 3-lobed and 3-awned

\section{Tribe IX. FESTUCACEAE}

Lemma entire or 2-lobed.

Rachilla long-hirsute .

Rachilla glabrous or with short hairs

Plant prostrate, with spinescent leaves

Plants erect, leaves not spinescent.

Lemma 3-nerved (or rarely 1).

Lateral nerves hairy.

Inflorescence a congested raceme; leaves with cartilaginous margins .

Inflorescence a panicle; leaves not cartilaginous on the margins

Lateral nerves glabrous.

Lemma long-hirsute at base . . . . . .

Lemma glabrous at base.

Glumes similar.

Inflorescence spike-like .

Inflorescence an open panicle.

Rachilla continuous; flowering glumes deciduous, the palet persistent

45. Tricuspis.

47. Diplachne.

46. Redfieldia.

50. Koeleria.

Rachilla articulated; flowering glume and palet both deciduous

Glumes very dissimilar

48. Eragrostis.

51. Catabrosa.

49. Eatonia.

Lemma 5-nerved or more.

Spikelets with the upper florets sterile and folded about each other

52. Melica.

Spikelets with the upper floret perfect, or narrow and abortive

Stigmas arising below the apex of the ovary .

60. Bromus.

Stigmas arising at the apex of the ovary.

Lemma compressed and keeled.

Awn-pointed

54. Dactylis.

Pointless.

Glumes 1-3-nerved.

Scarious-margined

Membranous .

Glumes 5-nerved or more

Lemma convex or rounded on the back.

Acute or awned

Obtuse and scarious at apex.

Prominently 5-7-nerved

Obscurely 5 -nerved

65. Poa.

56. Graphephorum.

53. Distichlis.

59. Festuca.

67. Glyceria.

58. Puccinellia.

Tribe X. HORDEAE

Spikelets mostly solitary at each joint of the rachis.

Spikelets placed edgewise on the rachis

61. Lolium. 
Spikelets placed flatwise on the rachis .

Spikelets 2 or more at each joint of the rachis.

Spikelets 1-flowered

Spikelets 2-many-flowered.

Rachis continuous

Rachis readily separating into joints

\section{Agropyron.}

63. Hordeum.

64. Elymus.

65. Sitanion.

\section{ANDROPOGON L. Beard Grass or Blue-stem}

Perennials, usually with long narrow leaves, and terminal and axillary racemes. Spikelets in pairs at each node of the jointed hairy rachis, one sessile and perfect, the outer with a pedicel and either staminate, empty, or reduced to a single glume. Perfect spikelet consisting of 4 glumes; the outer 2 coriaceous, the second keeled and acute; the two inner hyaline, the fourth more or less awned and subtending a palet and perfect flower. Stamens 1-3. Grain free.

Racemes solitary, distinct, 1-3 at each node . . . . . . 1. A, scoparius. Racemes in pairs or approximate.

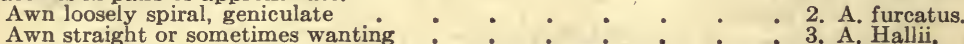

1. Andropogon scoparius Michx. Fl. Bor. Am. 1: 57. 1803. Culms tufted, 6-12 dm. tall: sheaths sometimes glaucous: leaves $15-30 \mathrm{~cm}$. long, scabrous: spikes 25-50 mm. long, loose, distinct, and 1-3 at each node, on long-exserted slender peduncles: rachis slender, flexuous; joints and pedicels ciliate with long spreading hairs: outermost glume of sessile spikelet about $6 \mathrm{~mm}$. long; awn spiral, 10-12 mm. long; pediceled spikelet a single awn-pointed glume.-Dry, sandy soid; throughout our range.

2. Andropogon furcatus Muhl. Willd. Sp. Pl. 4: 919. 1806. Culms stout, 9-18 dm. tall: sheaths smooth and glabrous: leaves $15-45 \mathrm{~cm}$. long: spikes 2-5, in pairs or approximate, 5-10 cm. long; joints of the rachis and pedicels ciliate with short hairs: outermost glume of sessile spikelet $6-8 \mathrm{~mm}$. long; awn of the sterile lemma loosely spiral, geniculate, 10-14 $\mathrm{mm}$. long; pediceled spikelet of 4 glumes.-Eastern part of our range and eastward.

3. Andropogon Hallii Hack. Sitz. Akad. Wiss. Wien 89: 127. 1884. Culms robust, 9-18 dm. tall, more or less glaucous: sheaths somewhat glaucous: leaves $3 \mathrm{dm}$. long or less: spikes $2-5$, in pairs or approximate, $5-10 \mathrm{~cm}$. long: joints of the rachis and pedicels villous with long hairs: outermost glume of sessile spikelet about $8 \mathrm{~mm}$. long, acuminate, glabrous at base, from sparingly to copiously silky-pubescent toward the apex; awn of the sterile lemma straight, 4-10 mm. long, or sometimes wanting; pediceled spikelet consisting of 4 glumes, generally larger than the sessile spikelet and inclosing three stamens.-Dry, sandy soil of the plains and foothills; along the eastern border of the Rocky Mountains.

\section{AMPHILOPHIS Nash}

Perennials, usually with flat leaves and showy, often silvery-white panicles, the axis short, making the panicle appear fan-like, or elongated with the branches more scattered. Racemes usually numerous, the internodes with manifestly thickened margins, the median portion thin and translucent; the pedicels of the same structure, the margins ciliate with long hairs. Sessile spikelets of 4 glumes, the first one 2-keeled, the second 1-keeled, the lemmas hyaline, the latter very narrow, stipe-like, somewhat thickened, gradually merging into a usually geniculate, contorted or spiral awn, or the awn rarely wanting. Pedicellate spikelets staminate and similar to the sessile, or sterile and smaller. Stamens 3. Styles distinct; stigmas plumose. Grain free, inclosed in the lemmas.

1. Amphilophis Torreyanus (Steud.) Nash, Brit. Man. 71. 1901. Culms erect, 4-10 dm. tall, the nodes naked: sheaths more or less glaucous: leaves 7-17 cm. long, glaucous: spikes $25-35 \mathrm{~mm}$. long, in a terminal long-exserted panicle 4-10 cm. long; outermost glume of sessile spikelet 3-4 mm. long, about 
equaling the terminal hairs of the rachis-joints, lanceolate, acute; awn 8-16 $\mathrm{mm}$. long, spiral; pediceled spikelet rudimentary. (Andropogon Torreyanus Steud.)-Kansas and Colorado; extending southward and westward to Nevada.

\section{SORGHASTRUM Nash}

Annual or perennial, generally tall grasses, with long narrow flat leaves and terminal panicles. Spikelets in pairs or threes at the end of the branches; one sessile and perfect; the lateral pediceled, empty, or reduced to the pedicel only. Perfect spikelet consisting of 4 glumes; the two outer indurated and shining; the inner hyaline, the fourth awned and subtending a palet and perfect flower, or the palet sometimes wanting. Stamens 3. Styles distinct; stigmas plumose. Grain free.

1. Sorghastrum nutans (L.) Nash, in Small Fl.66. 1903. Stout perennials, 9-18 dm. high: lower leaves $3 \mathrm{dm}$. or more in length: panicle 1-3 dm. long, brownish-yellow; branches $5-10 \mathrm{~cm}$. long, erect-spreading: spikelets erect or somewhat spreading; first glume of sessile spikelet $6-8 \mathrm{~mm}$. long, pubescent with long hairs; second glume glabrous; awn 1-2 cm. long, the column having but a single bend; lateral spikelets wanting. Chrysopogon nutans.-Extending into our range from the eastern United States.

\section{SORGHUM Pers.}

Annual or perennial grasses, with long, broad, flat leaves and terminal, ample panicles. Spikelets in pairs at the nodes, or in threes at the ends of the branches, one sessile and perfect, the lateral pediceled, staminate or empty. Sessile spikelet consisting of 4 glumes, the outer indurated and shining, obscurely nerved, inner hyaline, the fourth awned and subtending a small palet and perfect flower, or palet sometimes wanting. Stamens 3. Styles distinct. Grain free.

1. Sorghum halepense (L.) Pers. Syn. 1: 101. 1805. Stout perennial, 9-20 dm. tall: sheaths smooth; leaves $3 \mathrm{dm}$. or more long, 6-25 mm. wide: panicle 15-45 cm. long: outer glumes of sessile spikelet 4-6 $\mathrm{mm}$. long, usually purplish, pubéscent with long appressed hairs; awn when present 8-16 mm. long. Johnson Grass.-Introduced in fields and waste places.

\section{Hilaria H.B.K. Black Bunch-grass}

Caespitose or decumbent perennials, often stoloniferous, with flat or involute leaves and terminal solitary spikes. Spikelets sessile, in groups of three at each joint of the zigzag continuous rachis, forming terminal spikes, the several groups falling off entire; the two outer or anterior spikelets staminate and 2-3-flowered, the posterior or inner one pistillate or hermaphrodite, and 1-flowered. Glumes firmer in texture than the lemmas, unequal, many-nerved, more or less connate below, entire at the apex or more often divided, usually unequally 2-lobed with one to several intermediate awns or awn-like divisions; lemmas much narrower. Stamens 3. Styles connate below; stigmas shortly plumose. Grain ovate or oblong, included within the lemmas, free.

1. Hilaria Jamesii (Torr.) Benth. Journ. Linn. Soc. 19: 62. 1881. Rather coarse, branching, 3-5 dm. high: spikes erect, often purplish, $5-8 \mathrm{~cm}$. long: spikelets 8-10 mm. long, hairy at base; staminate spikelets 2-flowered, the glumes 5-nerved, the outer glume with an awn from the back longer than the spikelet, the inner unawned.-Mesas and table-lands from southern Wyoming to New Mexico and southern California.

\section{PASPALUM L.}

Perennials, various in habit; with usually flat leaves and 1-flowered spikelets borne singly or in pairs in 2 rows on 1-sided spikes, which are single, in 
pairs or panicled. Spikelets oblong to orbicular, flat on the outer surface, convex on the inner. Glumes 3 , the outer ones membranous, the inner one indurated and plumose. Grain ovoid or oblong, free.

1. Paspalum setaceum Michx. Fl. Bor. Am. 1: 43. 1803. Culms mostly erect, $3-6 \mathrm{dm}$. tall, slender, smooth: sheaths and leaves generally very pubescent; the latter 7-20 $\mathrm{cm}$. long, 2-6 $\mathrm{mm}$. wide, erect, acuminate: spikes 4-8 cm. long, more or less curved, generally solitary, occasionally 2 , on a longexserted slender peduncle, with usually 1 or 2 additional shorter peduncles from the same upper sheath: spikelets about $1.5 \mathrm{~mm}$. long, in 2 narrow rows, broadly obovate, very obtuse; empty glumes 3-nerved, glabrous or pubescent, third glume obovate, shining.-Colorado and eastward.

\section{SYNTHERISMA Walt.}

Annuals, with flat leaves and spikelets borne in pairs or sometimes in threes, in secund spikes which are digitate or approximate at the summit of the culm. Spikes often purplish. Glumes of the spikelet 4, sometimes 3 by the suppression of the lowest one; the fourth or innermost glume chartaceous, subtending a palet of similar texture and a perfect flower. Stamens 3. Stigmas plumose.

1. Syntherisma sanguinalis (L.) Dulac. Fl. Hautes-Pyr. 77. 1867. Culms 3-8 dm. high, becoming prostate at base and rooting at the lower nodes: lower sheaths densely papillose-hirsute: leaves $4-20 \mathrm{~cm}$. long, 4-10 $\mathrm{mm}$. wide, more or less papillose-hirsute on both surfaces: racemes 3-10, 5-18 cm. long: spikelets $25-30 \mathrm{~mm}$. long and about $0.8 \mathrm{~mm}$. wide, elliptic-lanceolate, acute, in pairs, the first glume minute, triangular, the second 3-nerved, about one half as long as the spikelet, the third 7-nerved, the fourth yellowish-white, acutely apiculate. Panicum sanguinale. Cra B Grass.-Generally introduced in fields and waste grounds.

\section{BRACHIARIA Ledeb.}

Annuals or perennials with flat leaves and a panicle composed of alternate scattered one-sided racemes with the spikelets borne in 2 rows. Spikelets 1 -flowered, articulated to the pedicel below the glumes. Glumes 4, the outer 3 membranous, the fourth chartaceous, inclosing a palet of similar texture and a perfect flower. Stamens 3. Styles distinct; stigmas plumose. Grain free.-Panicum in part.

1. Brachiaria obtusa (H.B.K.) Nash, Brit. Man. 77. 1901. Glabrous stoloniferous perennial, the culms $3-6 \mathrm{dm}$. high, simple or branching at base: leaves $6-22 \mathrm{~cm}$. long, $2-6 \mathrm{~mm}$. wide, usually erect, long-acuminate: panicle 5-15 cm. long, composed of 3-5 erect racemes 18-37 mm. long: spikelets about $3 \mathrm{~mm}$. long, crowded, oval or obovoid, obtuse, turgid; first glume shorter than the rest, obtuse, 5-nerved; second, third and fourth glumes about equal, the second and third 5-nerved, the fourth chartaceous.-Colorado and southward.

\section{ECHINOCHLOA Beauv.}

Commonly annuals with broad leaves and a terminal inflorescence consisting of one-sided racemes racemosely or paniculately arranged. Spikelets 1-flowered, singly disposed, or in smaller racemes or clusters on the ultimate divisions of the inflorescence. Glumes 4 , the outer 3 membranous, hispid on the nerves, the third and usually also the second awned or sometimes merely awn-pointed, the awn often very long; fourth glume indurated, shining, frequently pointed, inclosing a palet of similar texture and a perfect flower. Stamens 3. Styles distinct; stigmas plumose. Grain free--Panicum in part.

1. Echinochloa Crus-galli (L.) Beauv. Agros. 53. 1812. Annuals, 4-12 dm. high, the culms often branching at base: sheaths smooth and glabrous: leaves 
15-60 cm. long, 6-25 $\mathrm{mm}$. wide, smooth or scabrous: panicle composed of 5-15 sessile, erect or ascending branches, or the lower branches spreading or reflexed: spikelets ovate, green or purple, densely crowded in 2-4 rows on one side of the rachis; second and third glumes about $3 \mathrm{~mm}$. long, scabrous or hispid, the second awnless or with a long rigid awn, the third awnless or short awned, the fourth ovate, abruptly pointed. BARNYARD GRAss.-Introduced in fields and waste grounds.

\section{PANICUM L. Panic Grass}

Annuals or perennials, various in habit, with open or contracted panicles. Spikelets 1-2-flowered, when 2-flowered the lower one staminate. Glumes 4, the 3 lower membranous, empty, or the third with a staminate flower, varying in the same species; the inner or fourth glume chartaceous, shining, inclosing a palet of similar texture and a perfect flower; awns none. Stamens 3. Styles distinct; stigmas plumose. Grain free, inclosed in the hardened fruiting glume and palet.

Spikelets acuminate.

Annual; spikelets $2-2.5 \mathrm{~mm}$. long .

Perennial; spikelets 4-4.5 mm. long

Spikelets obtuse or barely pointed.

Leaves smooth above, scabrous beneath; spikelets about $3 \mathrm{~mm}$. long

Leaves more or less pubescent on both surfaces; spikelets 1.5-2.5 $\mathrm{mm}$. long

1. Panicum capillare L. Sp. Pl. 58. 1753. Culms erect or decumbent, 3-6 dm. tall, simple or sometimes sparingly branched: sheaths papillosehirsute: leaves $15-30 \mathrm{~cm}$. long, 6-16 mm. wide, pubescent: panicles widely spreading, capillary, the terminal one $20-25 \mathrm{~cm}$. long; the lateral panicles, when present, smaller: spikelets $2-2.5 \mathrm{~mm}$. long, acuminate; first glume one fourth to one half as long as the spikelet; second and third glumes nearly equal, very acute; the fourth $1.5 \mathrm{~mm}$. long. WrTch Grass.-Dry soil; a weed in cultivated fields.

2. Panicum virgatum L. Sp. Pl.59. 1753. Stout, erect, glabrous, perennial, 9-15 dm. high, usually forming large tufts, with strong creeping rootstocks: leaves elongated, $3 \mathrm{dm}$. long or more, 6-12 $\mathrm{mm}$. wide, flat, long-acuminate, narrowed toward the base, glabrous, rough on the margins: panicle $15-50 \mathrm{~cm}$. long, the lower branches 10-25 $\mathrm{cm}$. long, more or less widely spreading or sometimes nearly erect: spikelets ovate, acuminate, 4-4.5 mm. long; first glume acuminate, about one half as long as the spikelet, 3-5-nerved; second glume generally longer than the others, 5-7-nerved; the third similar and usually subtending a palet and staminate flower. SwITCH Grass.- Sandy river bottoms; extending into our range from the eastern United States.

3. Panicum Scribnerianum Nash, Bull. Torr. Bot. Club 22: 421. 1895. Perennial, 2-4 or more dm. high: culms erect, finally branching, sparingly pubescent: sheaths usually papillose-pilose: leaves more or less spreading, flat, smooth above, scabrous beneath, 5-10 cm. long, 6-12 $\mathrm{mm}$. wide: panicles small, ovoid, 3-7 cm. long: spikelets turgid, obovoid, obtusish, about $3 \mathrm{~mm}$. long, sparsely pubescent or nearly glabrous.-Throughout our range.

4. Panicum scoparium Lam. Encycl. 4: 744. 1797. Perennial, 1-4 or more dm. high: culms erect or ascending and finally more or less branched, usually densely pubescent with spreading hairs as also the sheaths, the nodes bearded and with a glabrous ring immediately below: leaves more or less softly pubescent on both surfaces and often somewhat villous, scabrous on the margins, 5-15 cm. long, 5-10 mm. wide: panicles ovoid or subpyramidal, 4-7 cm. long: spikelets ovate, subacute, $1.5-2$, rarely $2.5 \mathrm{~mm}$. long, pubescent.-Throughout our range.

\section{CHAETOCHLOA Scribn.}

Annuals or perennials with erect culms, few leaves, and bristly spike-like panicles. Spikelets 1-flowered, or rarely with a second staminate flower, the 
basal bristles single or in clusters below the articulation of the rachilla, and therefore persistent. Glumes of the spikelet 4, the other three membranous, the third often subtending a palet and rarely a staminate flower; inner or fourth chartaceous, subtending a palet of similar texture and a perfect flower. Stamens 3. Styles distinct, elongated; stigmas plumose. Grain free, inclosed in the lemmas.-Setaria.

Annual; panicle dense

Perennial; panicle more or less interrupted

1. C. viridis.

1. Chaetochlo viridis (L Scribn. U. D. Dept. Agr. 1. Chaetochloa viridis (L.) Scribn. U. S. Dept. Agr. Div. Agros. Bull. 4: 39. 1897. Erect glabrous caespitose annuals, $2-9 \mathrm{dm}$. high: leaves $7-25 \mathrm{~cm}$. long, 4-12 mm. wide: spikes compound, $3-10 \mathrm{~cm}$. long: spikelets about $3 \mathrm{~mm}$. long, elliptic, much shorter than the green or sometimes yellowish bristles; first glume less than one half as long as the spikelet, 1-3-nerved; second and third glumes obtuse, 5-nerved; fourth glume equaling or slightly exceeding the second. Green FoxtaIL.-Introduced into cultivated grounds and waste places.

2. Chaetochloa composita (H.B.K.) Scribn. U. S. Dept. Agr. Div. Agros. Bull. 4: 39. 1897. Pale glaucous caespitose perennial, 3-10 dm. high, much branched from the base: culms scabrous and of ten pubescent, rarely glabrous, the nodes bearded with a ring of silky appressed hairs: leaves 10-25 cm. long, 2-5 mm. wide, scabrous on both sides or sometimes nearly glabrous: spikes usually more or less interrupted, $5-16 \mathrm{~cm}$. long: spikelets 2 or rarely $3 \mathrm{~mm}$. long, narrowly ovate, acute, much shorter than the single or rarely paired, green, flexuous bristles; first glume one half as long as the spikelet, 3-nerved; second and third glumes acute or apiculate, 5-nerved; fourth glume slightly exceeding the second. Setaria setosa caudata. - Southwestern Colorado.

\section{CENCHRUS L. SAND Bur}

Annuals or perennials, usually with flat leaves. Spikelets 1-4 together in terminal spikes or racemes, subtended by a spiny involucre which is deciduous with them at maturity. Glumes 4 ; the first hyaline; the second and third membranous, the latter sometimes having a palet and staminate flower in its axil; the fourth chartaceous, subtending a palet of similar structure which incloses a perfect flower. Stamens 3. Styles united below; stigmas plumose. Grain free, inclosed in the lemmas.

1. Cenchrus tribuloides L. Sp. Pl. 1050. 1753. Culms erect or decumbent from an annual root, 2-5 or more $\mathrm{dm}$. high: sheaths usually loose, compressed, smooth: leaves $6-12 \mathrm{~cm}$. long: spikes $2-6 \mathrm{~cm}$. long, sometimes partially included in the upper sheath: involucres crowded on the scabrous rachis, 2-flowered, globose, pubescent except at the base, forming spiny burs, the spines stout: spikelets about $6 \mathrm{~mm}$. long.- Sandy fields and waste grounds; extending into our range from the eastern and southern United States.

\section{HOMALOCENCHRUS Mieg.}

Marsh grasses with flat, narrow, generally rough leaves and paniculate in. florescence. Spikelets 1-flowered, perfect, strongly flattened laterally, and usually more or less imbricated. Glumes 2, chartaceous, the outer one broad and strongly conduplicate, the inner much narrower. Stamens 1-6. Styles short, distinct; stigmas plumose. Grain ovoid, free.

1. Homalocenchrus oryzoides (L.) Poll. Hist. Pl. Palat. 1: 52. 1776. Rather stout rough much-branched perennial, $3-12 \mathrm{dm}$. high: leaves 7-25 cm. long, 4-10 mm. wide: terminal panicle 12-22 cm. long, finally long-exserted, its branches lax, and later widely spreading; lateral panicle generally included: spikelets $4-5 \mathrm{~mm}$. long, about $1.5 \mathrm{~mm}$. wide, elliptic; glumes pubescent, the outer one hispid on the keel and on the margins: stamens 3. RrCE CUT-GRASS.In swamps and along streams in the eastern part of our range; rare. 


\section{PHaLARIS L. Canary Grass}

Annuals or perennials with flat leaves, inflorescence spike-like, capitate, or a narrow panicle. Spikelets crowded, 1-flowered. Glumes 5; the first and second about equal in length, strongly compressed laterally, usually wingkeeled; third and fourth glumes much smaller or reduced to mere rudiments; fifth glume subtending a palet similar to itself and a perfect flower. Stamens 3. Styles distinct; stigmas plumose. Grain oblong, free, smooth, inclosed in the indurated glume.

Outer glumes not winged; inflorescence a narrow panicle Outer glumes broadly winged; inflorescence a spike-like panicle :

1. P. arundinacea.

2. P. caroliniana.

1. Phalaris arundinacea L. Sp. Pl. 55. 1753. Stout erect glabrous perennial, 6-15 dm. high: leaves 8-25 cm. long, 6-16 mm. wide: panicle 7-20 $\mathrm{cm}$. long, dense and contracted: spikelets $5-6 \mathrm{~mm}$. long; outer glumes 3-nerved; third and fourth glumes less than one half as long as the fifth; fifth glume about three fourths as long as the spikelet, pubescent with long appressed silky hairs. REed CanARY GRass.-Throughout our range.

2. Phalaris caroliniana Walt. Fl. Car. 74. 1788. Comparatively slender annual, 3-10 dm. high: leaves rather short, 5-15 cm. long, 4-10 mm. wide: spike-like panicle oblong, densely flowered, $2-10 \mathrm{~cm}$. long: spikelets $5 \mathrm{~mm}$. long; third and fourth glumes less than one half as long as the fifth; fifth glume about two thirds as long as the spikelets, acuminate, pubescent with long appressed hairs.-Infrequent in our range.

\section{HiEROChloE Gmel. Holy Grass. Vanilla Grass}

Aromatic perennials with flat leaves and contracted or open panicles. Spikelets 3-flowered, the terminal flower perfect, the others staminate. Glumes 5; the first and second nearly equal, acute, glabrous; the third and fourth somewhat shorter, obtuse, entire, emarginate, 2-toothed or 2-lobed, with or without an awn, inclosing a palet and perfect flower. Stamens in the staminate flowers 3 , in the perfect 2 . Styles distinct; stigmas plumose. Grain free, inclosed in the glumes.-(Savastana Schrank.)

1. Hierochloe odorata (L.) R. \& S. Syst. 2: 513. 1817. Slender sweetscented stoloniferous perennial, 3-6 dm. high: lower leaves elongated, 1-2 dm. long, 2-6 mm. wide; the upper ones 1-5 cm. long: panicle brownish, open, 4$10 \mathrm{~cm}$. long, the branches in pairs: spikelets yellowish-brown and purple, 4-6 $\mathrm{mm}$. long; first and second glumes acute; third and fourth villous and strongly ciliate, awn-pointed. Hierochloe borealis.-Throughout our range.

\section{ARISTIDA L. Three-A WNed Grass}

Tufted annuals or perennials with narrow, often involute-setaceous leaves. Spikelets narrow, 1-flowered, in terminal more or less expanded panicles. Glumes narrow, carinate; lemma rigid and convolute, bearing three awns occasionally united at the base, the lateral awns rarely wanting or reduced to rudiments; palet 2-nerved. Stamens 3. Styles distinct; stigmas plumose. Grain free, tightly inclosed in the lemma.

First and second glumes subequal

First glume about one half as long as the second

1. A. oligantha.

1. Aristida oligantha Michx. Fl. Bor. Am. 1: 41. 1803. Tufted annual, 2-4 dm. high, with slender dichotomously branched culms and loose sheaths: leaves smooth, 2-15 cm. long, 1-2 mm. wide: spikelets few, in a lax spike-like raceme or panicle; first glume 5-nerved, occasionally 7-nerved at base, equaling or somewhat shorter than the second, which bears an awn 4-8 mm. long; lemma shorter than the first glume; awns divergent or spreading, middle one 4-6 cm. long, lateral ones somewhat shorter.-Infrequent; Colorado. 
2. Aristida longiseta Steud. Syn. Pl. Gram. 420. 1855. Densely tufted glabrous perennial, 1-4 dm. high, with numerous involute basal leaves, and erect simple culms: panicles few-flowered, 1-2 dm. long, its branches solitary or 2 or 3 at the lower nodes, each bearing 1-3 spikelets (usually 1): spikelets 20-25 mm. long; empty glumes unequal, acute or with a mucronate tip $1 \mathrm{~mm}$. long; the first shorter than the lemmas and about one half the length of the second; the second much exceeding the lemma; setae nearly equal, about $7 \mathrm{~cm}$. long.-Sandy soil; throughout our range.

2a. Aristida longiseta robusta Merrill, U. S. Dept. Agr. Div. Agros. Cir. 34. 5. 1901. Stout, 3-4 dm. high, with more rigid inflorescence and usually longer leaves than in the species: glumes prominently cleft at apex, bearing in the cleft a scabrous awn about $2 \mathrm{~mm}$. long.-Same range.

2b. Aristida longiseta Fendleriana (Steud.) Merrill, l. c. Two to four dm. high: basal leaves numerous: panicle strict: glumes generally cleft at the apex and bearing a short awn; second glume equaling or slightly exceeding the lemma; setae subequal, $2-3 \mathrm{~cm}$. long.-Eastern Wyoming, Colorado, and southward.

\section{Stipa L. Feather Grass}

Tufted perennials, the leaves usually convolute, rarely flat, the inflorescence paniculate. Spikelet 1-flowered, narrow. Glumes narrow, acute or acuminate, obtuse or awned; lemma rigid, convolute, with a hairy callus at base, and bearing a more or less bent awn, which is spiral at the base and articulated to the glume; palet 2-nerved. Stamens 3, rarely fewer. Styles short, distinct; stigmas plumose. Grain narrow, free, tightly inclosed in the lemma.

Awn less than $5 \mathrm{~cm}$. long.

Panicle loose.

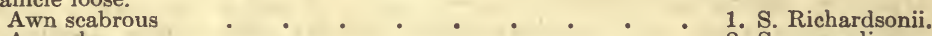

Awn plumose

Panicle contracted and spike-like.

Awn plumose, the hairs over $1 \mathrm{~mm}$. long.

Glumes 16-18 mm. long

Giumes 10-12 mm. long

Awn not plumose, pubescence, if any, less than $1 \mathrm{~mm}$. long.

Lemma with a distinct crown of hairs at apex. Glumes 10-14 mm. long

Glumes 7-10 mm, long indistinct.

Sheaths pubescent

Sheaths smooth.

Very tall, 8-18 dm. high

Less than $10 \mathrm{dm}$. or rarely $12 \mathrm{dm}$. high. Awn 35-40 mm. long Awn less than $35 \mathrm{~mm}$. long. Margins of sheaths pilose

Margins of sheaths not pilose

Awn $5 \mathrm{~cm}$. or more in length.

Awn plumose

Awn not plumose.

Glumes 24-36 $\mathrm{mm}$. long

Glumes 18-24 mm. long

1. S. Richardsoni
2. S. mongolica.

3. S. speciosa.

6. S. occidentalis.

4. S. Scribneri.

5. S. Lettermanii.

8. S. Williamsii.

10. S. Vaseyi.

9. S. Nelsonii.

11. S. viridula.

7. S. columbiana.

12. S. neo-mexicana.

13. S. spartea.

14. S. comata.

1. Stipa Richardsonii Link, Hort. Berol. 2: 245. 1833. Erect, slender, 6-9 dm. high: leaves long and narrow, involute: panicle loose and open, more or less nodding, 7-12 cm. long, with very slender, few-flowered branches: spikelets 8-9 mm. long, broadly lanceolate, acute; glumes unequal, the lower about $9 \mathrm{~mm}$. long, the upper one fourth shorter, both 3-nerved; lemma $6 \mathrm{~mm}$. long, sparsely hairy, brown; awn slender, scabrous, 12-20 mm. long.-Throughout our range and northward.

2. Stipa mongolica Turcz. in Trin. Gram. Suppl. 42. 1836. Slender, densely tufted, about $3 \mathrm{dm}$. high, with short, setaceous leaves and loosely few-flowered purplish panicles 7-10 $\mathrm{cm}$. long: glumes $5 \mathrm{~mm}$. long, equal, obtuse, smooth. subhyaline; lemma about $4 \mathrm{~mm}$. long, thinly hairy below and at the 2-toothed apex; callus short, obtuse; awn 12-16 mm. long, geniculate and twisted below, long-plumose-hairy.-Mountains of Colorado. 
3. Stipa speciosa Trin. \& Rupr. Agrostidea 3: 45. 1842. Erect and rather stout, densely tufted, 3-6 dm. high, with long narrow radical leaves, and erect contracted panicle 12-16 cm. long: glumes 16-18 $\mathrm{mm}$. long, nearly equal, acuminate, hyaline, the first 3-, the second 5-7-nerved; lemma silky-pubescent, 10-12 mm. long; callus short, curved; awn 3-4 cm. long, geniculate below the middle, the twisted portion plumose with white silky hairs $3-6 \mathrm{~mm}$. long.Extending into Colorado from the southwest.

4. Stipa Scribneri Vasey, Bull. Torr. Bot. Club 11: 125. 1884. Stout, erect and smooth, 4-8 dm. high, with rather long, narrow, involute-pointed culm leaves, and contracted panicles 12-16 cm. long: uppermost culm-leaf almost equaling the panicle: glumes unequal; the first $12-14 \mathrm{~mm}$. long; the second about $10 \mathrm{~mm}$. long, both 3-nerved, acuminate; lemma 6-10 $\mathrm{mm}$. long and crowned with a tuft of rather long hairs; awn once or twice bent, twisted in the lower half, 16-18 mm. long.- Southern Colorado and New Mexico.

5. Stipa Lettermanii Vasey, Bull. Torr. Bot. Club 13: 53. 1886. Slender and glabrous, with wiry culms 2-6 dm. high, filiform leaves, and slender, fewflowered, interrupted, shortly exserted panicles 5-15 cm. long: glumes narrow, more or less hyaline, equal or nearly so, smooth or very minutely scabrous on the back, 7-9 or rarely $10 \mathrm{~mm}$. long; lemma 4-5 $\mathrm{mm}$. long, pilose, the hairs spreading and forming a more or less distinct crown at apex; the callus acute.In dry soil throughout our range.

6. Stipa occidentalis Thurb. in Bot. King's Exp. 380. 1871. Slender, erect and tufted, 3-8 dm. high, with narrow setaceously pointed leaves and erect, contracted panicles 8-16 $\mathrm{cm}$. long: glumes about equal, thin-membranous and carinate above, 10-12 mm. long; lemma clothed with a thin, short pubescence, 5-6 mm. long; awn twice bent, twisted to the second bend, pubescent or subplumose on the lower half, the upper half minutely scabrous, $25-35 \mathrm{~mm}$. long. -Extending into Wyoming from the far west.

7. Stipa columbiana Macoun, Cat. Can. Pl. Part IV. 191. 1888. Erect and slender or rather stout, 4-9 dm. high, glabrous or the culms minutely pubescent below the nodes, with long narrow leaves and usually purplish panicles 15-20 cm. long: glumes somewhat unequal, 7-9 mm. long, usually more or less purplish; lemma 4-5 $\mathrm{mm}$. long, thinly pilose; the callus short and acute; awn usually twice bent, twisted to the second bend, minutely scabrous, 15$25 \mathrm{~mm}$. long. [S. minor (Vasey) Scribn.]-Common in the mountains throughout our range.

8. Stipa Williamsii Scribn. U. S. Dept. Agr. Div. Agros. Bull. 11: 45. 1898. Erect and rather stout, 7-9 dm. high, with long flat leaves and strict panicles 10-22 cm. long: culms pubescent at least near the nodes: sheaths softly pubescent, at least the lower ones: glumes nearly equal, about $9 \mathrm{~mm}$. long, smooth or very minutely scabrous; lemma about $6 \mathrm{~mm}$. long, clothed with appressed hairs, the callus sharply pointed; awn usually twice bent, twisted to the second bend, minutely scabrous, 2-3 cm. long.-Infrequent; Wyoming, Montana, and eastern Idaho.

9. Stipa Nelsonii Scribn. U. S. Dept. Agr. Div. Agros. Bull. 11: 46. 1898. Rather stout, glabrous, 6-9 dm. high, with long, narrow leaves: panicles strict, $10-25 \mathrm{~cm}$. long, pale and of a silvery and comose appearance: glumes narrow, thin and hyaline excepting the nerves which are quite prominent, smooth or minutely scabrous on back, the first about $10 \mathrm{~mm}$. long, the second a little shorter; lemma 6-7 mm. long, clothed with soft, silky hairs; the callus rather acute; awn usually twice bent, twisted to second bend, scabrous, $35-40 \mathrm{~mm}$. long. - Throughout our range.

10. Stipa Vaseyi Scribn. U. S. Dept. Agr. Div. Agros. Bull. 11: 46. 1898. Stout, erect, 8-18 dm. high, with long flat leaves and erect, densely flowered panicles 20-45 cm. long: sheaths usually pilose at the throat and of ten sparsely so on the margins: glumes nearly equal, about $10 \mathrm{~mm}$. long, firm in texture, minutely but distinctly scabrous on the back; lemma pubescent, 6-7 $\mathrm{mm}$. long; the callus acute; awn scabrous, usually twice bent, twisted to the second bend, 25-35 mm. long.-Colorado and southward.

11. Stipa viridula Trin. Gram. Suppl. 39. 1836. Erect and rather stout, ROCKY MT. BOT. -4 
6-12 dm. high, with involute pointed leaves, and narrow greenish contracted panicles $10-15 \mathrm{~cm}$. long: sheaths pilose about the throat and on the margins: glumes equal, with prominent green nerves, smooth or nearly so, subulatepointed, 8-9 $\mathrm{mm}$. long; lemma pubescent, about $4 \mathrm{~mm}$. long; the callus blunt or subacute; awn usually twice bent, twisted to the second bend, minutely scabrous, $25-30 \mathrm{~mm}$. long.-At the lower altitudes throughout our range.

12. Stipa neo-mexicana (Thurb.) Scribn. U. S. Dept. Agr. Div. Agros. Bull. 17: 132. 1899. Erect, rather stout and densely tufted, 3-9 dm. high, with involute leaves, and narrow racemose panicles $8-10 \mathrm{~cm}$. long: glumes nearly equal, long-setaceous-pointed, 5-7-nerved, 3-4 cm. long; lemma 10-14 mm. long, clothed with a close appressed pubescence; awn 8-12 $\mathrm{cm}$. long, plumosehairy excepting near the base.-Extending into Colorado from the south.

13. Stipa spartea Trin. Mem. Acad. St. Petersb. VI. 1: 82. 1831. Stout and erect, with simple culms $6-10 \mathrm{dm}$. high, long narrow leaves and contracted few-flowered panicles 10-20 cm. long: glumes subulate-pointed, slightly unequal, 24-36 $\mathrm{mm}$. long; lemma 16-20 $\mathrm{mm}$. long, including the barbed and very sharp-pointed callus, sparsely pubescent below and crowned with a few short hairs; awn stout, twisted and pubescent below, twice bent near the middle, $8-17 \mathrm{~cm}$. long. Porcupine Grass. - Extending into our range from the northeast.

14. Stipa comata Trin. \& Rupr. Agros. 3: 75, 1842. Rather stout, erect, tufted, 3-9 dm. high, with mostly involute leaves and loosely-flowered panicles 16-24 cm. long: sheaths loose, the uppermost inflated and inclosing the base of the panicle; ligule conspicuous, acute, $4-6 \mathrm{~mm}$. long: glumes nearly equal, long-attenuate-pointed, 18-24 mm. long; lemma 8-15 mm. long, including the long, sharp callus, thinly pubescent; awn obscurely twice bent below, variously curled and twisted or only slightly flexuous above, sparsely pubescent below, $10-15 \mathrm{~cm}$. long (S. Tweedyi Seribn. U. S. Dept. Agr. Div. Agros. Bull. 11: 47. 1898). Needle Grass.-New Mexico to British Columbia.

\section{ORYZOPSIS Michx. RICE GRAsS}

Usually tufted, the leaves flat or convolute and the inflorescence paniculate. Spikelets 1-flowered, broad. Glumes about equal, obtuse or acuminate; lemma shorter or a little longer than the glumes, broad, bearing a terminal awn which is early deciduous, the callus at base of the lemma short and obtuse, or a mere scar. Stamens 3. Styles distinct; stigmas plumose. Grain oblong, free, tightly inclosed in the convolute lemma.

Leaves $1-2.5 \mathrm{~mm}$. wide.

Awn less than $2 \mathrm{~mm}$. long

Awn more than $2 \mathrm{~mm}$. long.

Panicle narrow

Panicle open

Leaves 4-8 mm. wide

1. Oryzopsis juncea (Michx.) B. S. P. Prel. Cat. N. Y.67. 1888. Erect, glabrous, slender, tufted, $15-60 \mathrm{~cm}$. high, with erect involute leaves and narrow panicles $2-5 \mathrm{~cm}$. long: sheaths crowded below; leaves filiform, smooth or scabrous: spikelets 3-4 mm. long: glumes about equal, glabrous, whitish; lemma pubescent with short appressed silky hairs; awn $2 \mathrm{~mm}$. long or less.Colorado and northward and eastward.

2. Oryzopsis exigua Thurb. in Wilkes U. S., Explor. Exped. 17: 481. 1874. Slender, densely tufted, 15-40 cm. high, with filiform leaves, and narrow simple few-flowered panicles 2-6 cm. long: spikelets 4-5 $\mathrm{mm}$. long, on short appressed branches: glumes nearly equal, abruptly mucronate-pointed; lemma thinly pubescent; awn about $4 \mathrm{~mm}$. long, twisted below, curved or geniculated when mature.--In the mountains; Wyoming and northwestward.

3. Oryzopsis micrantha (Trin. \& Rupr.). Thurb. in Gray, Proc. Acad. Nat. Sci. Phila. 1863: 78. Erect and slender, 3-7 dm. high, with narrow scabrous leaves, and small-flowered spikelets in open panicles $8-16 \mathrm{~cm}$. long: spikelets 20-25 mm. long, much crowded at the ends of the branches of the panicles: 
glumes broadly ovate, acute, nearly equal, smooth or scabrous on the keel; lemma acuminate, the strongly scabrous midrib excurrent in a short point; awn slender, $6 \mathrm{~mm}$. long.-Throughout our range.

4. Oryzopsis asperifolia Michx. Fl. Bor. Am. 1: 51. 1803. Erect and slender, with smooth or scabrous culms $25-50 \mathrm{~cm}$. long, long rough flat evergreen leaves, and narrow simple few-flowered panicles 6-10 cm. long: sheaths crowded at the base; leaves 4-8 mm. wide: spikelets 6-8 $\mathrm{mm}$. long: glumes glabrous, green, the margins whitish; lemma whitish, sparingly pubescent; awn slightly twisted, 10-12 mm. long.-Colorado and northward.

\section{ERIOCOMA Nutt.}

Densely tufted perennials with rigid culms, and contracted or open panicles. Spikelets 1-flowered. Glumes membranous, broad; lemma firm, becoming hard in fruit, broadly oval to elliptic, densely pubescent with silky hairs and bearing a terminal readily deciduous awn; the callus at the base short and obtuse. Stamens 3. Styles distinct; stigmas plumose. Grain free, inclosed in the lemma.

Panicle diffuse, the divisions filiform, flexuous and widely spreading Panicle more or less open, the branches erect or ascending
1. E. cuspidata. 2. E. caduca.

1. Eriocoma cuspidata Nutt. Gen. 1: 40. 1818. Culms 3-6 dm. high: leaves narrow, involute, smooth or somewhat scabrous: panicle dichotomously branched, diffuse, $12-15 \mathrm{~cm}$. long: spikelets $6-8 \mathrm{~mm}$. long, on filiform and flexuous pedicels: glumes pubescent, 3-5-nerved, broad and ventricose below, attenuate-pointed; lemma about one half as long as the glumes, broadly oval, densely pubescent with long silky erect hairs about one and a half times its own length; awn 4-6 mm. long, readily falling off. Indian Millet.-Throughout our range.

2. Eriocoma caduca (Scribn.) Rydb. Mem. N. Y. Bot. Gard. 1: 25. 1900. Culms $3-5 \mathrm{dm}$. high: leaves narrow, smooth or somewhat scabrous: panicle more or less open; the branches erect or ascending, 5-15 cm. long: spikelets 5-6 mm. long: glumes scabrous or attenuate-pointed, 3-nerved; lemma about one half the length of the glumes, elliptic, densely clothed with silky hairs of less than its own length; awn 7-9 mm. long, readily falling off.-Infrequent; northern Colorado and northward to Montana.

\section{MUHLenbergia Schreb. Drop-seme. Hair Grass}

Perennials (rarely annuals) of greatly varying habit, with flat or involute leaves, small spikelets, and narrow or open panicles. Rootstocks often scaly. Spikelets 1-flowered, very rarely 2 -flowered. Glumes 2, membranous or hyaline, acute and sometimes awned; lemma 3-5-nerved, subtending a palet and perfect flower and rarely an empty lemma, obtuse, acute, or very often produced into a capillary awn; callus minute; palet 2-keeled. Stamens often 3. Styles distinct; stigmas plumose. Grain narrow, free, tightly inclosed in the lemma.

Panicle contracted, spike-like, the short branches rarely spreading.

Without scaly rootstocks.

Awn 2-20 mm. long

Awn less than $2 \mathrm{~mm}$. long.

Panicles 2-5 cm. long; second glume 3-nerved

Panicle 5-9 cm. long; second glume 1-nerved

With scaly rootstocks.

Culms more or less branched

Culms simple

Panicle open, its branches long and spreading.'

Secondary branches of the panicle single; awn 2-4 $\mathrm{mm}$. long

Secondary branches of the panicle fascicled; awn 1-2 $\mathrm{mm}$. long

1. M. gracilis.

2. M. filiculmis.

3. M. Wrightii.

4. M. racemosa.

5. M. comata.

6. M. gracillima.

7. M. pungens.

1. Muhlenbergia gracilis Trin. Unifl. 193. 1824. Slender but rather rigid, densely caespitose, $15-60 \mathrm{~cm}$. high, with narrow involute leaves and con- 
tracted panicles 8-15 $\mathrm{cm}$. long: leaves scabrous, 6-10 $\mathrm{cm}$. long, 1-2 mm. wide: spikelets sessile or pedicellate, 3-4 $\mathrm{mm}$. long: glumes nearly equal in length; the first about one half as long as the lemma, 1-nerved, acute or erose at apex; the second a little longer than the first, 3-nerved and 3-toothed, rarely entire at apex; lemma pubescent or scabrous on the back, ciliate on the margins; awn flexuous, 8-20 mm. long.-Colorado and southward.

1a. Muhlenbergia gracilis breviaristata Vasey, Contr. U. S. Nat. Herb. 3: 67. 1892. Slender, $15-30 \mathrm{~cm}$. high: panicle about $5 \mathrm{~cm}$. long: awn $2-4 \mathrm{~mm}$. long.-Wyoming and southward.

2. Muhlenbergia filiculmis Vasey, Contr. U. S. Nat. Herb. 1: 267. 1893. Low and tufted, with scape-like culms $15-35 \mathrm{~cm}$. high, short setaceous radical leaves, and narrow spike-like panicles $2-5 \mathrm{~cm}$. long: 'first 'glume 1-nerved, $1 \mathrm{~mm}$. long; the second 3-nerved, 3-toothed, $5 \mathrm{~mm}$. long; lemma ciliate on the margin of the lower half, 3-nerved, $2.5 \mathrm{~mm}$. long, shading into an awn about $1 \mathrm{~mm}$. long.-Colorado.

3. Muhlenbergia Wrightii Vasey, Coult. Man. Rocky Mt. Bot. 409. 1885. Erect or decumbent, 30-75 cm. high, with keeled sheaths and densely flowered, cylindrical, spike-like panicles $5-9 \mathrm{~cm}$. long: leaves rigid, 8-12 $\mathrm{cm}$. long, the tips filiform: spikelets often 2-flowered: glumes subequal, 1-nerved, about $2 \mathrm{~mm}$. long, thin at base, ovate, awn-pointed; lemma a little thicker and longer, very short-pubescent, 3-nerved, ovate, acute, tipped with a very short stiff awn.-Colorado and southwestward.

4. Muhlenbergia racemosa (Michx.) B. S. P. Prel. Cat. N. Y. 67. 1888. Rather stout and upright, 6-9 dm. high, with very tough and densely scaly rootstocks, simple or more or less branched culms, and densely-flowered narrow panicles 5-10 cm. long: leaves 5-12 cm. long, 2-6 mm. wide, scabrous: spikelets much crowded: glumes of the spikelet acuminate, 4-6 mm. long, including the awn, smooth or scabrous (especially on the keel); lemma one half to two thirds as long, acuminate, the strongly scabrous midrib excurrent in a short point.- Throughout our range.

5. Muhlenbergia comata (Thurb.) Benth. Journ. Linn. Soc. 19: 82. 1881. Either stout or slender, upright, 3-9 dm. high, with flat leaves and densely flowered, more or less lobed or interrupted panicles 8-10 cm. long: leaves 6-12 $\mathrm{cm}$. long, 2-4 mm. wide, erect, rough: glumes of the spikelet equal, or the second a little longer, smooth, scabrous on the keel; lemma shorter, smooth and glabrous, bearing an awn 2-3 times its length, the basal hairs silky, erect, fully as long as the scale.-Throughout our range and far westward.

6. Muhlenbergia gracillima Torr. Pac. R. R. Rept. 45: 155. 1857. Densely tufted, with slender culms $2-4 \mathrm{dm}$. high, numerous involute basal leaves and open capillary panicles $10-20 \mathrm{~cm}$. long: leaves $3-5 \mathrm{~cm}$. long, smooth or somewhat scabrous, secondary branches of the panicle fascicled: spikelets about as long as the filiform pedicels, which are clavate-thickened at the apex: glumes unequal, usually awn-pointed or short-awned, slightly scabrous; lemma 2.5-3 mm. long, longer than the glumes, sometimes twice as long, scabrous; awn 2-4 mm. long.-Colorado and southward.

7. Muhlenbergia pungens Thurb. in Gray, Proc. Acad. Nat. Sci. Phila. 1863: 78. Culms 2-4 dm. high, from creeping rootstocks, erect from a decumbent branching base, rigid, minutely pubescent: leaves $3-5 \mathrm{~cm}$. long, involutesetaceous, rigid, scabrous: panicle open, 7-15 $\mathrm{cm}$. long, the primary branches solitary, much divided from near the base, the divisions apparently fascicled: spikelets on long pedicels which are clavate-thickened at the apex: glumes when mature equaling or often shorter than the body of the lemma, scabrous, especially on the keel; lemma, when mature, 1.5-2 mm. long, scabrous; the awn shorter than its body.-Infrequent in our range; south to Texas and Arizona.

\section{LYCURUS H.B.K. TEXaN Trmothy}

Caespitose erect or ascending perennials with narrow or often convolute leaves and cylindrical, usually densely flowered, spike-like terminal panicles. Spikelets 1-flowered, usually in pairs. Glumes 2, 3-nerved, the nerves often 
produced into awns; lemma 3-nerved, awned, broader and longer than the glumes; palet a little smaller and more slender, 2-nerved, 2-keeled, very shortly 2 -toothed. Stamens 3. Styles short, distinct; stigmas plumose. Grain included within the lemma, free.

1. Lycurus phleoides H.B.K. Nov. Gen. et Sp. Pl. 1: 142, t. 45. 1815. Slender, wiry, $20-45 \mathrm{~cm}$. high, much branched and often geniculate at the base, with narrow, long-pointed leaves and cylindrical spike-like panicles 3-6 cm. long: spikelets $4 \mathrm{~mm}$. long, with awned glumes; the first glume often terminating in two unequal awns; the lemma terminating in an awn as long as its body.-Colorado to Texas and westward.

\section{PHLEUM L. Timothy}

Annual or perennial grasses with flat leaves and spicate inflorescence. Spikelets 1-flowered. Glumes membranous, compressed, keeled, the apex obliquely truncate, the midnerve produced into an awn; the lemma much shorter, broader, hyaline, truncate, denticulate at the summit; palet narrow, hyaline. Stamens 3. Styles distinct, somewhat elongated; stigmas plumose. Grain ovoid, free, inclosed in the lemma and palet.

Spikes usually elongated; upper sheath not inflated

Spikes not elongated, ovoid to oblong; upper sheath inflated

1. P. pratense. 2. P. alpinum.

1. Phleum pratense L. Sp. Pl. 59. 1753. Perennial, with erect simple culms 3-12 dm. high: upper sheath long and not inflated or very slightly so: leaves smooth or scabrous, 8-20 cm. long, 4-6 mm. wide: spike usually elongated cylindric, 4-15 $\mathrm{cm}$. long, 5-8 mm. in diameter: glumes of the spikelet (exclusive of the awn) 2-5 mm. long, ciliate on the keel, the awn less than half their length. Trмотну.-Cultivated and becoming naturalized in fields and waysides.

2. Phleum alpinum L. Sp. Pl. 59. 1753. Perennial, 15-45 cm. high, the culms simple, erect or sometimes decumbent: upper sheath usually much inflated; leaves smooth beneath, scabrous above; the lower ones 5-7 cm. long, 2-8 $\mathrm{mm}$. wide; the uppermost less than $25 \mathrm{~mm}$. long: spike short, ovoid to oblong and cylindric, 13-50 mm. long, 6-12 $\mathrm{mm}$. in diameter: glumes of the spikelet (exclusive of the awn) $3 \mathrm{~mm}$. long, strongly ciliate on the keel, the awn about one half their length. Mountain Timothy.-Moist soil in the mountains.

\section{ALOPECURUS L.}

Annuals or perennials, with erect or ascending culms, flat leaves and densely flowered cylindrical or ovoid spike-like or capitate inflorescence. Spikelets 1-flowered, flattened. Glumes acute, sometimes short-awned, more or less united below, compressed-keeled; keel ciliate or somewhat winged; lemma truncate or obtuse, hyaline, 3-nerved, awned on the back, subtending a perfect flower and usually a palet; palet hyaline, acute, sometimes wanting. Stamens 3. Styles distinct or rarely united at base; stigma elongated, hairy.

Spikes 5-8 cm. long, 4-6 mm. broad - . . . . . . . 1. A. fulvus.

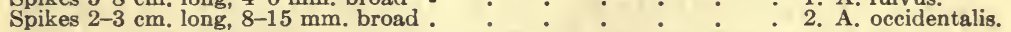

1. Alopecurus fulvus Smith, Eng. Bot. 21, t. 1467. 1793. Glabrous or very nearly so: culms $1-4 \mathrm{dm}$. high, erect, or sometimes decumbent at the base: leaves $2-15 \mathrm{~cm}$. long, 1-4 mm. wide, scabrous especially above, the uppermost sometimes exceeding the spike: spikes $5-8 \mathrm{~cm}$. long, 4-6 mm. broad: spikelets about $3 \mathrm{~mm}$. long; glumes slightly united at base, obtuse or subacute, smooth, glabrous except for the pubescent lateral nerves and the strongly ciliate keel; lemma equaling or slightly longer than the glumes, obtuse, smooth and glabrous; awn inserted very little below the middle of the glume and equaling or slightly exceeding it. A. geniculatus fulvus.-In wet swales; throughout our range. 
2. Alopecurus occidentalis Scribn. Bot. Gaz. 11: 170. 1886. Erect, rather slender, 6-9 dm. high: leaves flat, $5-15 \mathrm{~cm}$. long, $4-7 \mathrm{~mm}$. wide: spikes $2-3 \mathrm{~cm}$. long, 8-15 mm. broad: spikelets $3.5-4.5 \mathrm{~mm}$. long, compressed: glumes subequal, acute, silky-hairy on the keels and pilose on the sides; lemma a little shorter than the glumes, the margins connate to near the middle, pubescent near the apex; awn inserted below the middle, about $6 \mathrm{~mm}$. long.-In the high mountains.

\section{PHIPPSIA R. Br.}

Low tufted perennial, with flat leaves and slender few-flowered panicles. Spikelets 1-flowered. Glumes minute, the first often wanting; lemma thinmembranous, keeled; palet somewhat shorter, 2-keeled. Stamen 1, rarely 2 or 3. Styles short, distinct; stigmas plumose. Grain oblong, inclosed in the lemma and palet, which readily split and allow it to drop out.

1. Phippsia algida (Soland.) R. Br. Suppl. App. Parry's Voy. 275. 1824. Smooth and glabrous throughout, $2-10 \mathrm{~cm}$. high: leaves narrow and soft, $25 \mathrm{~mm}$. in length or less, $0.5-2 \mathrm{~mm}$. wide; obtuse: panicles contracted, simple, 6-35 mm. long, scarcely exceeding the leaves: spikelets 1-1.5 mm. long: glumes minute, unequal, acutish; lemma broad, 1-nerved, obtuse or subtruncate and somewhat erose, the palet about two thirds as long, broad, 2-keeled, erose-truncate.-High mountain peaks of Colorado, and probably of Wyoming; in the arctic regions generally.

\section{SPOROBOLUS R. Br. Drop-seed Grass. Rush Grass}

Perennials or rarely annuals, with flat or convolute leaves and open or contracted panicles. Spikelets generally small, 1-flowered, occasionally 2-3flowered. Glumes of the 1-flowered spikelets 2, membranous, unequal, the first somewhat shorter; lemma equaling or longer than the glumes; palet 2-nerved. Stamens 2-3. Styles very șhort, distinct; stigmas plumose. Grain free, and often early deciduous.

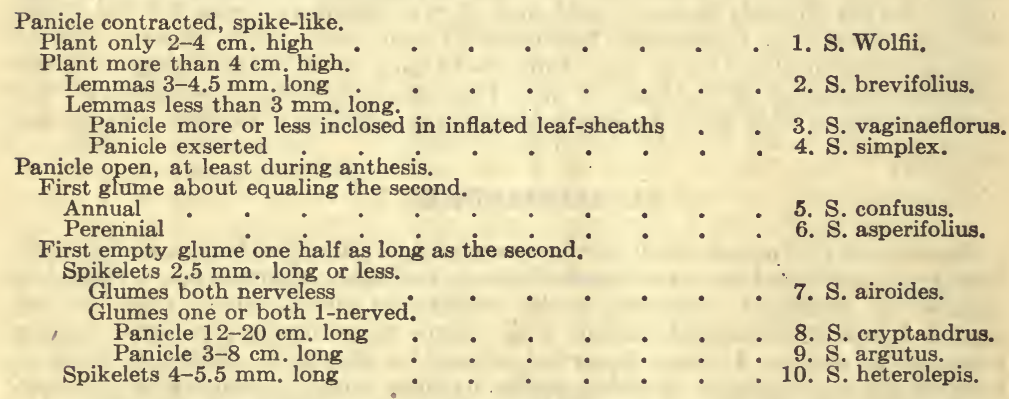

1. Sporobolus Wolfii Vasey, Bull. Torr. Club 10: 52. 1883. Slender annual, branching at base, $2-4 \mathrm{~cm}$. high: leaves mostly radical, flat or involute, 3-12 mm. long: panicles spike-like, simple, few-flowered, terminal and lateral; the lateral ones partly inclosed in the loose sheaths: spikelets about $1 \mathrm{~mm}$. long: glumes oval, subequal, $0.7 \mathrm{~mm}$. long; lemma about $1 \mathrm{~mm}$. long.-Twin Lakes, Colorado.

2. Sporobolus brevifolius (Nutt.) Scribn. Mem. Torr. Bot. Club 5: 39. 1895. Smooth glabrous perennial: culms 15-45 $\mathrm{cm}$. high, arising from a horizontal rootstock, branching at base, slender, erect or geniculate: leaves 1-5 cm. long, involute-setaceous: panicle 1-7 cm. long, linear, its branches 6-12 mm. long, erect or appressed: spikelets 2.5-3 mm. long: glumes unequal, less than half as long as the lemma, obtuse or acute, scabrous on the keel and at the apex; lemma long-acuminate, somewhat cuspidate, scabrous toward the apex.-Throughout our range. 
3. Sporobolus vaginaeflorus (Torr.) Wood, Classbook 775. 1861. Slender caespitose annual, 2-4 dm. high: leaves $2 \mathrm{~mm}$. wide or less, smooth and glabrous beneath, scabrous and hairy near the base above, attenuate into a slender involute point: panicles spike-like, terminal and axillary, about $2 \mathrm{~cm}$. long, mostly inclosed in the somewhat inflated leaf-sheaths: spikelets 3.5-4.5 $\mathrm{mm}$. long: glumes unequal, acuminate; lemma scábrous, sparingly appressedpubescent, about as long as the second glume and equaling or slightly exceeded by the very acute palet.--Infrequent; extending into our range from the east.

4. Sporobolus simplex Scribn. U. S. Dept. Agr. Div. Agros. Bull. 11: 48. 1898. Very slender densely tufted annual, 5-30 cm. high, with short narrow leaves, scape-like culms, and linear, few-flowered panicles $2 \mathrm{~cm}$. long, exserted nearly half their length: spikelets about 1.5-2 mm. long: glumes unequal, 1-nerved, obtuse and usually erose-dentate at summit; lemma 3-nerved, acuminate and cuspidate. [S. filiformis (Thurb.) Scribn. U. S. Dept. Agr. Div. Agros. Bull. 17: 173. 1899.] -Extending into our range from the west.

5. Sporobolus confusus (Fourn.) Vasey, Bull. Torr. Bot. Club 15: 293. 1888. Slender branching tufted annual, 8-20 cm. high, with capillary ovoid or oblong panicles $8-15 \mathrm{~cm}$. long: leaves flat, $1-4 \mathrm{~cm}$. long, $1.5 \mathrm{~mm}$. or less wide: spikelets $1.25-1.5 \mathrm{~mm}$. long: glumes obtuse, nearly equal, one half to two thirds as long as the lemma, glabrous or pubescent; lemma obtuse, usually pubescent; sometimes glabrous.-Throughout our range.

6. Sporobolus asperifolius (Nees \& Mey.) Thurb. in Wats. Bot. Cal. 2: 269. 1880. Slender leafy perennial, $10-35 \mathrm{~cm}$. high, with erect culms from a decumbent and branched base and diffuse panicles $6-10 \mathrm{~cm}$. long: leaves numerous, $2-8 \mathrm{~cm}$. long, $2-3 \mathrm{~mm}$. wide at base, acuminate, strict, often erect, flat glabrous, smooth beneath, very rough above: spikelets $1.5 \mathrm{~mm}$. long; occasionally 2-3-flowered: glumes subequal, acute, glabrous, sparingly scabrous; lemma obtuse or acute, glabrous, somewhat exceeding the second glume.Throughout the western half of North America.

7. Sporobolus airoides Torr. Pac. R. R. Rept. 73: 21. 1856. Stout coarse and rigid densely caespitose perennial, 3-9 dm. high, with long, narrow leaves and open spreading pyramidal panicles $10-25 \mathrm{~cm}$. long: leaves smooth beneath, scabrous above and sometimes sparingly hairy near the base, 1-3 mm. wide at the base, attenuate into a long slender involute point; the basal about one half as long as the culm; the upper culm leaves 5-12 cm. long: spikelets 1.5-2 mm. long: glumes acute, glabrous, nerveless, unequal, the first about half as long as the second; lemma equaling the second glume and the palet.From Mexico to Dakota and west to the Pacific States.

8. Sporobolus cryptandrus (Torr.) Gray, Man. 576. 1848. Erect glabrous perennial, 4-7 dm. high: sheaths with a dense pilose ring at the summit; leaves 7-15 cm. long, 2-4 mm.. wide, flat, scabrous above, long-acuminate: panicles 12-20 cm. long, spreading in flower, usually narrow, more or less inclosed in the upper sheath: spikelets 2-2.5 mm. long: glumes acute, glabrous, the first one half as long as the second, which is about as long as the lemma.Across the continent northward, and south in the interior to Mexico.

9. Sporobolus argutus (Nees) Kunth, Enum. 1: 215. 1833. Caespitose perennial, 2-4 dm. high, with flat leaves and open panicles $3-8 \mathrm{~cm}$. long, the branches verticillate and spreading in flower: leaves $25-50 \mathrm{~mm}$. long, $2-4 \mathrm{~mm}$. wide at the base, acuminate, smooth and glabrous beneath, scabrous and often sparingly hairy at the base above: spikelets $1.5 \mathrm{~mm}$. long:"glumes smooth and glabrous, the first rounded or obtuse, one fourth as long as the acute second one; lemma about equaling the second glume, acute.-Colorado and southward.

10. Sporobolus heterolepis Gray, Man. 576. 1848. Rather stout erect caespitose perennial 3-9 dm. high: leaves involute-setaceous, glabrous, the margins and upper part of the midrib very rough; the basal about three fourths as long as the culm, occasionally equaling it; those of the culm shorter: panicle loose and open, $7-25 \mathrm{~cm}$. long: spikelets $4-5.5 \mathrm{~mm}$. long: glumes very unequal, sharply acuminate-pointed, the first subulate, about 
half the length of the broad second one; lemma glabrous, acute or obtuse shorter than the second glume.-Dry soil; in the eastern part of our range and eastward.

\section{BLEPHARINEURON Nash}

Tufted perennial with simple culms, long leaves, and terminal loosely flowered open panicles. Spikelets 1-flowered. Glumes membranous, 1-nerved, acute, smooth and glabrous, the first narrower and shorter than the second; lemma 3-nerved, the nerves densely pilose with long silky hairs for nearly their entire length, the midnerve often shortly excurrent at apex; palet as long as the lemma, 2-nerved, densely pilose between the nerves. Stamens 3. Styles 2, distinct; stigmas plumose.

1. Blepharineuron tricholepis (Torr.) Nash, Bull. Torr. Bot. Club 25: 88. 1898. Erect and slender, 3-6 dm. high, with narrow, glabrous leaves, and more or less spreading panicles 6-18 cm. long: spikelets $2.5-3 \mathrm{~mm}$. long: glumes thin, carinate; lemma equaling or a little longer than the second glume, entire or minutely 2 -toothed at the obtuse apex.-Colorado, Utah, and southward.

\section{POLYPOGON Desf. Beard Grass}

Mostly annuals with decumbent or rarely erect culms, flat leaves, and spikelike panicles. Spikelets 1-flowered. Glumes each extended into an awn; lemma smaller, generally hyaline, short-awned from below the apex, subtending a shorter palet. Stamens 1-3. Styles short, distinct; stigmas plumose. Grain free, inclosed in the glume and palet.

1. Polypogon monspeliensis (L.) Desf. Fl. Atl. 1: 67. 1798. Caespitose glabrous annual 1-6 dm. high: leaves 4-15 cm. long, 3-6 mm. wide, scabrous; especially above: panicle $2+10 \mathrm{~cm}$. long, dense, spike-like, the branches about $1 \mathrm{~cm}$. in length, ascending: spikelets crowded: glumes about $2 \mathrm{~mm}$. long, obtuse, slightly bifid, scabrous, bearing a more or less bent awn 4-6 mm. long; lemma much shorter, erose-truncate, hyaline, bearing a delicate awn about $0.5 \mathrm{~mm}$. long, inserted below the apex. BEARD Grass.-Introduced into fields and waste places; infrequent.

\section{CINNA L. INDIAN REED}

Tall perennials with numerous flat leaves and many-flowered, nodding panicles. Spikelets 1-flowered. Glumes keeled, acute; the lemma similar but usually short-awned on the back, subtending a palet and a stalked perfect flower; palet a little shorter, 1-nerved. Stamens 1. Styles short, distinct; stigmas plumose. Grain narrow, free, inclosed in the lemma and palet.

Panicle contracted, its branches erect Panicle lax, its branches drooping

1. C. arundinacea.

1. Cinna arundinacea I. Sp. Pl. 5. 1753. Culms 1-2 m. high, rather robust, leafy to the top: panicle 2-3 dm. long, quite dense: spikelets $4-6 \mathrm{~mm}$. long: glumes scabrous throughout; lemma about equaling the second glume; awn seldom exceeding the lobes of the emarginate lemma.-Swamps; across the continent.

2. Cinna latifolia (Trev.) Griseb. in Ledeb. Fl. Ross. 4: 435. 1853. Rather slender, smooth, 6-12 dm. high, the culms erect and simple: leaves 10-25 cm. long, 4-12 mm. wide, scabrous: panicles 1-2 dm. long, open, the capillary branches generally spreading, flexuous and of ten drooping: spikelets $3 \mathrm{~mm}$. long: glumes scabrous, the outer acute, strongly hispid on the keel, about equaling the second; lemma usually exceeded by the second glume, bearing a rough awn 1-2 mm. long from the 2 -toothed apex.-Damp woods; rare within our range; northward and cast to Newfoundland; also in Europe. 


\section{Agrostis L. Bent Grass. Herd's Grass}

Tufted annuals or perennials with flat or bristle-like leaves and small spikelets in open, usually diffuse panicles. Spikelets 1-flowered. Glumes membranous, keeled, acute; lemma shorter, obtuse, hyaline, sometimes bearing a dorsal awn, subtending a perfect flower; palet distinct, short. Stigmas plumose. Grain free, inclosed in the lemma.

Rachilla prolonged behind the palet

Rachilla not prolonged behind the palet.

Palet evident, 2-nerved.

Plant usually $30 \mathrm{~cm}$. or more high

Plant low.

Erect, scarcely stoloniferous

Low and spreading by stolons .

Palet wanting, or a small nerveless scale.

Panicle narrow, either strict or open but not diffuse.

Plant 20-30 cm. high .

Plant 10-20 cm. high

Panicle diffusely spreading.

Lemma awnless.

Plant $20-80 \mathrm{~cm}$. high

Plant 10-20 cm. high

Lemma awned
1. A. Thurberiana.

-2. A. alba.

3. A. humilis.

4. A. depressa.

5. A. asperifolia.

-6. A. Rossae.

- 7. A. hiemalis.

-8. A. idahoensis.

9. A. melaleuca.

1. Agrostis Thurberiana A. S. Hitch. U. S. Dept. Agr. Bu. Pl. Ind. Bull. 68. 1905. Culms tufted, slender, 20-40 cm. high, somewhat decumbent at base: basal leaves numerous, lax, slightly scabrous; culm leaves 2 or 3 ; ligule semicircular, $6 \mathrm{~mm}$. long: panicle narrow and lax, more or less drooping, 5-8 $\mathrm{cm}$. long, somewhat scabrous on the branches which are flower-bearing from the middle: spikelets $2 \mathrm{~mm}$. long: glumes equal, acute; lemma nearly as long as the glumes, obtuse, faintly 5-nerved; palet about $1.3 \mathrm{~mm}$.long; callus obscurely hairy.-From western Wyoming to Washington.

2. Agrostis alba L. Sp. Pl. 63. 1753. Perennial, variable in habit, often stoloniferous, with smooth culms 3-9 dm. high, flat leaves, and erect manyflowered open panicle 4-18 cm. long: leaves 5-20 cm. long, 2-6 mm. wide, scabrous: spikelets 2-2.5 mm. long: glumes about equal, acute, smooth and glabrous, except on the hispid or scabrous keel; lemma shorter than the glumes, obtuse or acute; palet one half to three fourths as long as the glume. REDTOP.- Naturalized in meadows and on wet banks.

3. Agrostis humilis Vasey, Bull. Torr. Bot. Club 10: 21. 1883. Culms slender, tufted from a perennial root, $10-40 \mathrm{~cm}$. high: leaves mostly basal, $2-10 \mathrm{~cm}$. long, $2 \mathrm{~mm}$. wide, flat and thin or rarely conduplicate and filiform: panicles $2-8 \mathrm{~cm}$. long, narrow, or in rank-growing plants open and loosely flowered: spikelets usually purple, 1.5-2 mm. long: glumes equal, abruptly pointed, smooth or nearly so; lemma as long as the glumes, awnless; palet two thirds as long as the lemma.-Colorado to Montana and west to the Pacific States.

4. Agrostis depressa Vasey, Bull. Torr. Bot. Club 13: 54. 1886. Tufted and freely stoloniferous from the base: culms geniculate-decumbent, becoming erect, usually $12-20 \mathrm{~cm}$. high: leaves $3-5 \mathrm{~cm}$. long, $1 \mathrm{~mm}$. wide; the culm leaves very scabrous; ligule conspicuous, $2-3 \mathrm{~mm}$. long: panicles narrow and spike-like: glumes equal, acute, roughish on the keel above; lemma shorter, with a minute prickle on the back below the tip; palet half as long as the lemma.-Colorado to California and Washington.

5. Agrostis asperifolia Trin. Gram. Uniff. 207. 1824. Erect tufted perennial, 3-9 dm. high, with rough leaves and contracted panicles $6-25 \mathrm{~cm}$. long: leaves $3-20 \mathrm{~cm}$. long, 2-8 mm. wide: panicles often interrupted or glomerate, the branches erect and crowded, spikelet-bearing to the base: spikelets $2-2.5$ $\mathrm{mm}$. long: glumes scabrous, especially on the keel; lemma about three fourths the length of the second glume; palet minute. A. exarata, at least in part.Throughout our range and westward.

6. Agrostis Rossae Vasey, Contrib. U. S. Nat. Herb. 3: 76. 1892. Culms rather stout, 10-20 cm. high, tufted but not stoloniferous: leaves mostly basal, 2-5 cm. long, 1-2 mm. wide; sheaths rather conspicuous: panicle contracted, 
3-6 $\mathrm{cm}$. long; the branches appressed: spikelets green or purple, $2 \mathrm{~mm}$. long: glumes subequal, acute, scabrous; lemma $1.5 \mathrm{~mm}$. long, awnless, a few short hairs at the base; palet very minute.-From Wyoming to Washington and California.

7. Agrostis hiemalis (Walt.) B. S. P. Prel. Cat. N. Y. 68. 1888. Erect slender tufted biennial or perennial, 3-6 dm. high: leaves 5-12 cm. long, 1-3 $\mathrm{mm}$. wide, usually erect, roughish: panicle $2-7 \mathrm{~cm}$. long, usually purplish, the capillary scabrous branches ascending, sometimes widely spreading, or often drooping, the divisions spikelet-bearing at the extremities: spikelets 1.5-2 mm. long: glumes acute. scabrous toward the apex on the keel; lemma two thirds the length of the first or equaling it, obtuse, rarely bearing a short awn; palet usually very small. A. scabra.-In most parts of North America.

8. Agrostis idahoensis Nash, Bull. Torr. Bot. Club 24: 42. 1897. Erect slender loosely or densely tufted perennial, 6-25 cm. high: leaves flat or conduplicate, $2-8 \mathrm{~cm}$. long, 1-2 mm. wide: panicle pyramidal or more or less contracted, often purplish, $2-8 \mathrm{~cm}$. long: spikelets $1.5-2.5 \mathrm{~mm}$. long: glumes acute, nearly equal; lemma slightly shorter than the glumes, awnless, obtuse, often minutely toothed at apex, 3-4-nerved above, 5-nerved below; palet usually wanting, when present minute or two thirds as long as the lemma.In the mountains; from Colorado to California.

9. Agrostis melaleuca (Trin.) A. S. Hitch. 1. c. Plants scattered, of single or few. culms, 30-50 cm. high, leafy: panicle copper-colored, oblong, open: lemma awned.-This species, which belongs primarily to the sphagnum swamps of the far Northwest, has been reported from alpine stations in Colorado.

\section{CALA MAgROSTIS Adans. Reed Grass}

Perennials or rarely annuals, various in habit, with flat leaves and small spikelets in open or contracted panicles. Spikelets 1-flowered, the rachilla usually prolonged beyond the flower and pubescent. Glumes carinate, membranous; lemma hyaline, shorter than the outer glume, obtuse, usually copiously long-hairy at the base, or rarely the hairs scanty or short, and bearing a straight, bent, or twisted dorsal awn; palet shorter, 2-nerved. Stamens 3. Styles short, distinct; stigmas plumose. Grain free, inclosed by the glume and palet, and more or less adherent.-Deyeuxia.

Panicle more or less open, the lower rays often long and spreading.

Lemma 4-toothed, with short stout awn

Lemma bifid, with weak slender awn

Panicle rather narrow and dense, all the rays short, ascending or erect.

1. C. Scribneri.

2. G. canadensis.

Leaves more or less involute, at least at tip.

Erect, rigid and taper-pointed.

Smooth

Scabrous.

Awn bent and twisted

Awn stout and straight

Lax and almost filiform

Leaves flat or nearly so.

Sheaths smooth.

Culms densely tufted

Culms scarcely tufted

Sheaths rough

1. Calamagrostis Scribneri Beal, Grasses N. A. 2: 343. 1896 . Culms 5-8 dm. high, slender: leaves flat, 2-3 dm. long: panicle contracted, 10-15 cm. long, the branches somewhat spreading: spikelets 4 mn. long, brown or purplish: glumes lanceolate, acute, scabrous on the back; lemma shorter, 4-toothed at apex; the awn straight, attached below the middle, equaling the outer glume; palet as long as its lemma, irregularly 2-toothed; callus hairs about one-half as long as the lemma.-Wyoming and Montana to Washington.

2. Calamagrostis canadensis (Michx.) Beauv. Agrost. 157. 1812. Culms erect, smooth, 8-12 dm. high, rarely branching below: leaves about $3 \mathrm{dm}$. long, 4-8 mm. broad, flat; ligule short, lacerate; sheaths appressed, shorter than the internodes: spikelets 2-3 $\mathrm{mm}$. long: glumes unequal, lanceolate, 
acute; lemma nearly as long, 2-toothed at apex; awn very slender, attached near the middle, about as long as its lemma; palet shorter than the lemma; callus hairs as long as the glumes.-Across the continent northward; frequent in our range.

2a. Calamagrostis canadensis acuminata Vasey, Bull. U. S. Div. Agrost. 5: 26. 1897 . Sheaths rarely slightly bearded at junction with the blade which is short-scabro-pubescent above, panicle smaller, more flexuous and densely flowered, usually dark purple: spikelets $3.5-4 \mathrm{~mm}$. long: glumes attenuateacuminate, sometimes subfalcate, very scabrous or substrigose; awn longer than the lemma.-The more usual form in our range.

3. Calamagrostis Suksdorfii Vasey, Monog. Grasses U. S. 82. 1892. Culms tufted, 5-8 dm. high: leaves of culm mostly $3,12-15 \mathrm{~cm}$. long, with slender, acuminate points; upper ligules 3-5 cm. long, the lower sheaths shorter and the upper longer than the internodes: panicle erect, 6-12 cm. long, moderately close, pale or purplish; the rays glomerate, unequal, the shorter ones crowded with the almost sessile spikelets: glumes $3-4 \mathrm{~mm}$. long, acute, whitish, translucent, smooth except on the midnerve; lemma thin, 4-nerved and 4-toothed, shorter than the glumes; palet about as long as its lemma, 2-toothed; hairs of callus very short.-Northwestern Wyoming to California and Washington.

4. Calamagrostis purpurascens R. Br. Rich. App. Frank. Journ. 731. 1823. Culms tufted, erect, rigid, 3-5 dm. high: leaves numerous, crowded near the base, rigid; the radical half as long as the culm; the upper attenuatepointed, very scabrous, thick and involute; ligule truncate or lacerate; sheath rough, striate: panicle spike-like, dense, generally purplish; rays mostly in fives, appressed: spikelets 5-6 $\mathrm{mm}$. long: glumes ovate-lanceolate, acute, 4-toothed; the awn near the base, twisted below and bent at the middle, longer than the glumes; hairs of the callus scanty and very short.-From Colorado far northward, and thence across the continent.

5. Calamagrostis montanensis Scribn. Vasey, 1. c. Culms stoloniferous, 2-3 dm. high, rather rigid, erect: radical leaves involute-setaceous, $12-15 \mathrm{~cm}$. long; culm leaves similar but shorter, scabrous: panicle linear to oblong, 5-7 cm. long; rays short, fascicled: glumes narrowly lanceolate, acute, 4-5 $\mathrm{mm}$.long, with the pedicels scabrous, whitish; lemma shorter bifid; hairs of callus much shorter than the glume.-Wyoming to Canada and west to the Pacific.

6. Calamagrostis neglecta (Ehrh.) Gaertn. Fl. Wetterau 1: 94. 1799. Glabrous throughout: culms 4-6 dm. high, erect, simple, slender: sheaths shorter than the internodes; leaves narrow; the basal one third as long as the culm; those of the culm 4-10 cm. long, erect: panicle contracted, 5-10 cm. long; the rays erect, $2-3 \mathrm{~cm}$. long: spikelets $4 \mathrm{~mm}$. long: glumes scabrous; lemma obtuse, shorter than the glumes, its awn exceeding the body.-Colorado and far northward and thence across the continent.

7. Calamagrostis hyperborea Lange, Fl. Dan. 50: t. 3. 1880. Culms densely tufted, rigid, stout, 4-10 dm. high: sheaths smooth and glabrous; leaves stiff and very rough on both surfaces, flat, or often involute at the tip, 1-3 dm. long: panicle contracted, $7-14 \mathrm{~cm}$. long, its branches short, usually erect: spikelets 3-4 mm. long: glumes scabrous, acute; lemma nearly as long and usually equaled by the callus hairs; awn about as long as the lemma.-Colorado to Greenland and Alaska.

7a. Calamagrostis hyperborea elongata Kearney, Rev. Calamagr. 41. 1898. Taller and less tufted.

7b. Calamagrostis hyperborea americana (Vasey) Kearney, 1. c. Panicle very dense and the spikelets usually only $3 \mathrm{~mm}$. long.-This form occurs very frequently in our range.

8. Calamagrostis inexpansa Gray, Gram. \& Cyp. 1: No. 20. 1834. Culms but little tufted, 8-12 dm. high: sheaths smooth and glabrous; leaves rough, 2-3 dm. long: panicle 15-20 cm. long, usually nodding at the summit, the rays rather long, erect: spikelets $4-5 \mathrm{~mm}$. long: glumes rigid, hispid on the keel, acute; lemma scabrous; callus hairs as long as the glume or shorter; awn 
variable, sometimes exceeding the lemma.-From our range to the Atlantic States.

9. Calamagrostis scopulorum Jones, Proc. Cal. Acad. Sci. II. 5: 722.1895. Culms densely tufted, 5-7 dm. high: leaves coarse, striate-nerved, $6 \mathrm{~mm}$. broad and about $3 \mathrm{dm}$. long; ligule scabrous: inflorescence spicate, $8-15 \mathrm{~cm}$. long; rays about 5 , pubescent: spikelets pale, appressed, about $4 \mathrm{~mm}$. long: glumes equal, ovate-lanceolate, acute, glabrous and hyaline except the scabrous nerve; lemma 4-toothed at apex, scabrous throughout, equaling the glabrous 2-toothed hyaline palet; callus hairs shorter than the palet. - Southwestern Colorado to Nevada.

\section{CALA MOVILFA Hack.}

Rather tall, rigid perennials with stout horizontal rootstocks, elongated leaves and loosely spreading panicles. Spikelets 1-flowered, the rachilla not prolonged beyond the flower. Glumes 1-nerved, acute, unequal; lemma longer or shorter than the second glume, with a ring of hairs at the base; palet strongly 2-keeled. Stamens 3 . Styles distinct; stigmas plumose. Grain free.

1. Calamovilfa longifolia (Hook.) Hack. True Grasses 113. 1890. Culms 3-9 dm. long, erect, simple, stout, smooth and glabrous: sheaths crowded and overlapping, glabrous or rarely pilose; leaves $2-3 \mathrm{dm}$. long or more: panicle narrow, often $3 \mathrm{dm}$. long or more, pale, the branches erect or ascending, the lower 10-25 cm. long: spikelets 6-8 mm. long: glumes acute, smooth, the first shorter than the second; lemma a little longer or slightly shorter than the second glume, and nearly twice the length of the copious basal hairs; palet slightly shorter than the lemma.-Sandy soil; more or less frequent throughout our range.

\section{DESCHA MPSIA Beauv. HaIr Grass}

Annuals or perennials with flat or involute leaves, and rather small, shining spikelets in terminal or lateral, narrow or loose panicles. Spikelets 2-flowered, both flowers perfect, the hairy rachilla extended beyond the flowers or rarely terminated by a staminate one. Glumes keeled, acute, membranous, shining, persistent; the lemmas of about the same texture, deciduous, bearing a dorsal awn, the apex toothed; palet narrow, 2-nerved. Stamens 3. Styles distinct; stigmas plumose. Grain oblong, free, inclosed in the lemma.

Panicle open, its branches spreading

Panicle strict, its branches erect or appressed

1. D. caespitosa.

1. Deschampsia caespitosa (L.) Beauv. Agrost. 91, t. 18. 1812. Densely caespitose, with very numerous basal leaves: stems erect, slender, 6-10 dm. high: sheaths much shorter than the internodes; leaves flat, smooth beneath, scabrous above; the basal about one third as long as the stem: panicle open, $8-15 \mathrm{~cm}$. long, the branches widely spreading, often somewhat flexuous, the lower 5-12 cm. long: spikelets 3-4 mm. long: glumes unequal, 1-3-nerved, lanceolate, acute; lemmas oblong, erose, truncate at the apex; awn straight, inserted above the middle, $2-4 \mathrm{~mm}$. long. - Frequent in moist meadow-like grounds; throughout our range, far northward and across the continent. The species is variable and some varieties have been named, but they are in turn variable.

2. Deschampsia elongata (Hook.) Munro, in Benth. Pl. Hartw. 342, t. 228. 1857. Culms slender, tufted, $2-4 \mathrm{dm}$. high: leaves narrow, mostly smooth, 4-10 $\mathrm{cm}$. long: panicle narrow, simple or branching, about one third as long as its culm; the rays capillary, scabrous, appressed, bearing spikelets from the middle up: glumes equal, ovate-lanceolate or narrower, 3-nerved, green and scabrous on the keel; lemma broad, 5-toothed, indistinctly or not nerved; palet 2-toothed; awn slender, from near the base, about $4 \mathrm{~mm}$. long.-Northern Wyoming to California and Washington. 


\section{TRISETUM Pers. OAt Grass}

Tufted perennials (rarely annuals) with flat leaves and dense and spikelike or narrow panicles. Spikelets $2-4$-flowered, the flowers all perfect, or the uppermost staminate; rachilla glabrous or pilose, extended beyond the flowers. Glumes membranous, unequal, acute, persistent; lemmas 2 or more, usually shorter than the glumes, deciduous, 2-toothed, bearing a dorsal awn below the apex, or the lower one sometimes awnless; palet narrow, hyaline, 2-toothed. Stamens 3. Styles distinct; stigmas plumose. Grain free, inclosed in the lemma.

Panicle spike-like; first glume 3-nerved Panicle open; first glume 1-nerved

1. Trisetum subspicatum (L.) Beauv. Agrost. 180. 1812. Softly pubescent to glabrous: stems simple, erect, $2-5 \mathrm{dm}$. high: sheaths shorter than the internodes; leaves 3-10 cm. long, 2-4 mm. wide: panicle spike-like, $3-10 \mathrm{~cm}$. long, sometimes interrupted below; the rays erect: spikelets 2-3-flowered: glumes hispid on the keel, shining; lemmas acuminate, scabrous; awn inserted below the sinus on the 2-toothed palet which it usually distinctly surpasses.-Very common on mountain slopes in most parts of North America.

2. Trisetum montanum Vasey, Bull. Torr. Bot. Club 13: 118. 1886. Culms smooth, slender, 2-5 dm. high: leaves $12-25 \mathrm{~cm}$. long, somewhat scabrous; lower sheaths pubescent: panicle loose and open but not spreading; rays in fascicles of 5 , unequal, 1-4 cm. long, suberect: spikelets $5 \mathrm{~mm}$. long, 2flowered: glumes unequal; lemmas about $4 \mathrm{~mm}$. long and surpassing the glumes, acuminate and terminating in two short, fine setae, indistinctly 5nerved; palet narrow, bidentate.-In the mountains from Colorado to New Mexico.

\section{SCHEDONNARDUS Steud. Crab GRASs}

Annual with branching culms, narrow leaves, and slender spikes arranged along a common axis. Spikelets 1-flowered, sessile and alternate on the rachis. Glumes narrow, membranous, acuminate; lemma longer, of similar texture; palet narrow, shorter. Stamens 3. Styles distinct; stigmas plumose. Grain linear, free, inclosed in the rigid lemma.

1. Schedonnardus paniculatus (Nutt.) Trelease in Branner \& Coville, Rept. Geol. Surv. Ark. 18884: 236. 1891. Culms 20-45 cm. long, erect, slender, rigid, branching at the base, scabrous: sheaths crowded at the base of the culm, compressed, smooth and glabrous: leaves plane or folded, spirally twisted, smooth, 5-8 cm. long, $2 \mathrm{~mm}$. wide or less: spikes numerous, rigid, widely spreading, alternate, the lower 5-10 cm. long, the axis and branches triangular: spikelets $2.5-3 \mathrm{~mm}$. long, sessile and appressed, alternate: glumes hispid on the keel, the second longer than the first and exceeded by the acute lemma.-Dry prairies in the eastern part of our range, and south to Texas.

\section{5. avena L. True Oat Grass}

Annual or perennial grasses with flat leaves. Spikelets panicled, 1-2 or sometimes many-flowered; the lower perfect; the upper mostly staminate. Glumes unequal; lemma 1 (rarely more), rounded on the back, mostly 5-11nerved, bearing a long, usually bent or twisted awn on the back or between the two acute teeth at the apex. Stamens 3. Style short, distinct; the stigmas plumose. Grain oblong-linear, deeply grooved, free but inclosed in the palet.

Annual

Perennial.

Panicle open; the spikelets on rather long capillary rays .

Panicle narrow and spike-like.
1. A. fatua.

2. A. striata.

3. A. Mortoniana. 
1. Avena fatua L. Sp. Pl. 80. 1753. A glabrous annual much resembling the common cultivated oat (A. sativa): leaves flat, long, broad and scabrous: panicle open, of few spikelets on filiform unequal rays: spikelets 2-3-flowered: glumes ovate-lanceolate, $20-25 \mathrm{~mm}$. long, with 9 prominent nerves; lemma 9-nerved; the awn from near the middle, twisted, abruptly bent near the middle; palet shorter than the glumes, pubescent. Wild OATs.-An occasional weed in cultivated fields; widely introduced from the Mediterranean region.

2. Avena striata Michx. Fl. Bor. Am. 1: 73. 1803. Glabrous and smooth throughout, slender, 3-6 dm. high: leaves narrow: panicle simple, loose, with spikelets on capillary pedicels: lower glume 1-nerved; the upper 3-nerved; flowers short-bearded at base; the soon bent or divergent awn inserted just below the tapering very sharply cuspidate 2-cleft tip of the palet.-Colorado to Montana and thence eastward and westward.

3. Avena Mortoniana Scribn. Bot. Gaz. 21: 133. 1896. A smooth, erect perennial, 1-4 dm. high: ligule ovate, acute; blades narrow, 5-20 $\mathrm{cm}$. long: spikelets 4-5-flowered: glumes lanceolate, subequal, 3-nerved; lemma $12 \mathrm{~mm}$. long, 5-nerved; the awn near the middle, surpassing the glume by 7-10 $\mathrm{mm}$.; palet shorter than the lemma, keel ciliate. (A. americana Scribn. Bull. Agrost. U. S. Dept. Agr. 7: 183. 1897 may be distinct, but seems rather to be merely the more robust form occurring in the same range.)-Colorado to Montana, in the mountains.

\section{Danthonia DC. OAt Grass}

Mostly perennials of strict habit and with either flat or convolute leaves, and open or contracted panicle. Rachilla hairy and extending above the flowers. Spikelets of 3 or more perfect flowers. Glumes subequal, acute, longer than the 7-11-nerved lemmas; awn composed of the 3 middle nerves, flattish and spirally twisted at base, inserted between the sharp-pointed teeth of the lemma.

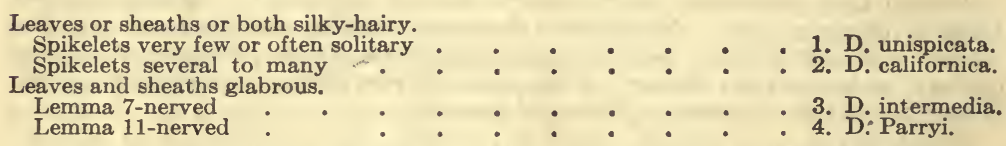

1. Danthonia unispicata Munro, Vasey, Cat. Gr. 59. 1885. Culms 1-2 $\mathrm{dm}$. high, more or less tufted: leaves in dense radical tufts, sparsely softly silky-villous; the sheaths densely villous with white spreading hairs, arising in small clusters from minute white papillae: spikelets very few, usually solitary-terminal; otherwise much as in the following.-Rather frequent in our range and extending west to California.

2. Danthonia californica Boland, Proc. Cal. Acad. 2: 182. 1863. Stems sometimes decumbent at base, 5-7 dm. high: leaves, especially the lower, convolute and setaceously pointed, with sheaths silky pubescent and bearded at the throat: panicle mostly a simple raceme: glumes usually purplish with scarious margins, pointed, the upper 5-7-nerved; lemma broad, its teeth about half its own length, with marginal tufts of long silky hairs at or below the middle; awn about equaling the lemma; palet obtuse, hairy on the nerves.Colorado to Montana and west to California.

3. Danthonia intermedia Vasey Bull. Torr. Bot. Club 10: 52. 1883. Culms 2-4 dm. high, leafy below: ligule a hairy ring; blades $15-25 \mathrm{~cm}$. long, mostly narrow: panicle narrow, dense, 3-5 cm. long: spikelets 5-flowered: glumes subequal, 5-nerved, with cross-veins; lemma 7-nerved, sharply toothed, hairy on the margins; palet 2-toothed: grain flattened, obovate. D. spicata, as to this range.-Colorado to Manitoba and California.

4. Danthonia Parryi Scribn. Bot. Gaz. 21: 133. 1896. Very similar but larger in every way, 3-6 dm. high: panicle more lax, of fewer and larger spikelets: glumes ovate-lanceolate, 3-nerved or at base 5-7-nerved; lemma about 
11-nerved, with long acuminate teeth and long pilose on back and margins; palet shorter, bidentate. D. sericea as to this range.-Colorado and Wyoming.

\section{SPARTINA Schreb. Cord or Marsh Grass}

Perennials, with simple and rigid reed-like stems, from extensively creeping scaly rootstocks, very smooth sheaths, and long tough leaves. Spikelets 1-flowered, very much flattened, jointed and sessile in 2 ranks on the outer side of a triangular rachis. Glumes unequal, acute or bristle-pointed; palet thin, equaling or longer than the lemma. Stamens 3. Styles long, more or less united. Grain free.

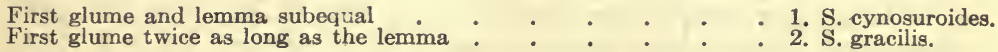

1. Spartina cynosuroides (L.) Willd. Enum. 80. 1809. Stems 4-10 dm. high: leaves 3-6 dm. long, tapering to a long slender involute point: spikes 5-20, scattered and spreading, at least at maturity, the pedicels and common axis strongly hispid on the angles: lower glume very narrow; the upper broad, spinulose hispid on the keel and tapering to a rough awn; lemma very rough on the midrib which terminates just below its tip.-Across the continent along the borders of lakes and rivers.

2. Spartina gracilis Trin. Mem. Acad. St. Petersb. 6: 5. 1840. Stems more slender, 2-6 dm. high, exceeding the spreading distichous rough and rigid leaves: spikes 4-10, mostly sessile, closely appressed to the nearly smooth rachis: glumes very unequal, the lower acuminate, the upper acute, they and the lemma ciliate and hispid upon the keel.-In saline soils from Oregon to Texas.

\section{BOUteloua Lag. Grama Grass}

Annual or perennial grasses with slender culms and narrow flat or convolute leaves and slender dense one-sided spikes. Spikelets 1-2-flowered, arranged in two rows on one side of a flat rachis; the rachilla bearing 1-3 empty lemmas or bristles (or rarely staminate flowers) above the single perfect flower. Glumes acute and keeled; lemma broader and 3-toothed; palet hyaline. Stamens 3. Styles distinct. Grain oblong, free.

Glumes hirsute or villous.

Rachilla with rudimentary lemma glabrous

Rachilla with rudimentary lemma bearing a tuft of hair at apex

Glumes glabrous.

Lemma 4-lobed

Lemma 3-lobed

1. B. hirsuta.

2. B. oligostachya.

3. B. polystachya.

4. B. prostrata.

1. Bouteloua hirsuta Lag. Var. Cienc. 2: 141. 1805. Tufted, 1-4 dm. high: leaves flat, lance-linear, papillose hairy or glabrous: spikes 1-4, oblong-linear, very dense: upper glume hispid with strong bristles from dark warty glands; lemma pubescent, 3-cleft; sterile lemma and its pedicel glabrous, the 3 awns longer than the glumes and fertile flower.-Colorado to Mexico, and eastward to Texas and Illinois.

2. Bouteloua oligostachya (Nutt.) Torr. in Gray Man. 553. 1856. Glabrous, 1-4 dm. high: leaves very narrow: spikes $1-5$, oblong-linear, very dense: glumes sparingly soft-hairy; pedicel of the sterile lemma copiously villoustufted at the summit; the 3 awns equaling the larger glume.-From the Saskatchewan to Texas, Mexico, and southern California.

3. Bouteloua polystachya (Benth.) Torr. Pacif. R. R. Rep. 5: 366. 1857. Stems. 1-3 dm. long: leaves scabrous: spikes 3 to 6 or more, narrowly linear, dense, the scabrous rachis hispid-ciliate; lemma and rudimentary lemma 4-lobed, 3-awned and ciliate on the nerves.-Reported from southern Colorado and Utah; New Mexico to southern California.

4. Bouteloua prostrata Lag. 1. c. A similar slender tufted annual 1-2 dm. high: leaves short and narrow: spikes solitary, terminal, curved, 1-2 cm. 
long: glumes very unequal, 3-lobed and 3-awned, pubescent on the back below.-Colorado to Mexico.

\section{ATHEROPOGON Muhl.}

Slender perennials with narrow leaves and numerous short straight scattered often reflexed spikes arranged in a long one-sided raceme. Spikelets 1flowered; the rachilla surpassing the flower and bearing awns or scales at its summit. Glumes unequal, narrow, keeled; lemma broader, 3-toothed and awned, inclosing the 2-toothed palet. Stamens 3. Styles distinct, with plumose stigmas. Grain free, inclosed in the lemma.-Bouteloua in part.

1. Atheropogon curtipendula (Michx.) Fourn. Mex. Pl. En. Gram. 138. 1881. Stems tufted, 3-6 dm. high, simple, smooth: leaves narrow, flat or involute, rough at least above: spikes about $1 \mathrm{~cm}$. long, nearly sessile, 20-60 in number, in a loose one-sided general spike or raceme: glumes scabrous on the keel: anthers orange-red. Bouteloua racemosa.-Dry soil, hillsides and fields; very widely distributed in North America.

\section{BECKMANNIA Host.}

An erect perennial grass with flat leaves and a long terminal narrow panicle. Spikelets subsessile, broad, compressed, 1-2-flowered. Empty glumes membranous, compressed, concave-inflated, obtuse or abruptly acute, 1-2-flowered; lemma narrow, membranous; palet hyaline, 2-keeled. Stamens 3. Styles distinct, with plumose stigmas. Oblong grain free but inclosed in the lemma and palet.

1. Beckmannia erucaeformis (L.) Host. Gram. Austr. 3: 5. 1805. Stems stout, 3-10 dm. high: leaves 1-3 dm. long; ligules elongated: panicle 1-3 dm. long, erect, strict, secund, the short crowded branchlets densely flowered from the base: spikelets nearly orbicular, the upper rudimentary floret minute, stipitate.-In wet swales; widely distributed west of the Mississippi.

\section{BUChloE Engelm. Buffalo Grass}

Perennial, creeping or stoloniferous. Spikelets dioecious (rarely monoecious), very unlike: staminate spikelet 2-3-flowered, sessile in two rows in short one-sided spikes; glumes 1-nerved, subacute, the second larger but shorter than the florets; lemma 3-nerved, slightly exceeding the palet: pistillate spikelets 1-flowered, in short spikes; glumes nearly equal, united at the base, 3-toothed, indurated, larger than the floret; lemma narrow, membranaceous, 2-cleft or nearly entire, inclosing the palet and large grain.-(Bulbilis Raf.)

1. Buchloe dactyloides (Nutt.) Engelm. Trans. St. Louis Acad. 1: 432. 1859. Culms 1-2 dm. high from a tufted leafy base, propagating chiefly by runners: leaves flat, 1-2 mm. wide, attenuate: staminate spikelets in pectinate spikes $1 \mathrm{~cm}$. long or less; pistillate spikelets (rare) in terminal or axillary clusters, subtended by inflated involucral sheaths.-Formerly one of the important grasses of the plains, from Texas to Minnesota, but now rapidly disappearing.

\section{SCLEROPOGON Philippi}

Slender stemmed grasses with short flat leaves, from matted rootstocks. Spikelets dioecious (rarely monoecious), very unlike, narrowly paniculate: staminate spikelets compressed, linear, many (10-14)-flowered; glumes lanceolate, acute, subequal, nearly equaling the contiguous florets; lemma 3toothed or subentire, equaled by the palet: pistillate spikelets narrowly cylindrical, 3-5-flowered; glumes lanceolate, the upper larger; lemma rigid, 
cylindrical, enveloping the palet; long internode of the rachilla 5-nerved, the three prominent nerves terminating in 3 long straight twisted awns.

1. Scleropogon Karwinskianus (Fourn.) Benth. Wats. Proc. Am. Acad. 18: 181. 1883. Culms 1-3 dm. high, generally simple above the caespitose leafy base: staminate spikelets $5-8,1-3 \mathrm{~cm}$. long; pistillate spikelets $1-2 \mathrm{~cm}$. long; awns rigid, several times longer than the florets.-Colorado to Texas and Arizona.

\section{MUNROA Torr.}

A low tufted grass, with flat rather thick leaves fasciculately crowded at the nodes. Spikelets 3-5-flowered, perfect or the upper florets sterile, sessile in leafy clusters at the nodes and ends of branches. Glumes thin, lanceolate, subequal, slightly shorter than the contiguous florets; lemmas herbaceous or coriaceous, obtuse or dentate, mucronate, convex, enveloping the palet and stamens. Grain translucent, broadly spindle-shaped.

1. Munroa squarrosa (Nutt.) Torr. Pac. R. R. Rep. 4: 158. 1856. Culms 1-2 dm. high, spreading, fasciculately branched: leaves $2-3 \mathrm{~cm}$. long, rigid and pungent: spikelets 2-5-flowered, the flowers perfect: glumes shorter than the 3-toothed lemma; palet obtuse.-From Montana to Texas and Arizona.

\section{Phragmites Trin. Reed Grass}

Tall stout broad-leaved grasses from long perennial rootstocks. Spikelets 3-7-flowered, cuneate, in large plume-like panicles. Glumes lanceolate, the second one a third longer than the first and about equaling the florets; lemma lanceolate, attenuate, entire, glabrous, much longer than the palet; internodes of rachilla pilose with silky hairs as long as the florets.

1. Phragmites communis Trin. Fund. Agrost. 134. 1820. Culms 2-3 m. high: leaves narrowed at the base: spikelets nearly $1 \mathrm{~cm}$. long.-Wet land throughout the United States; often improperly called Pampas Grass.

\section{TRICUSPIS Beauv.}

Tufted perennial grasses with short pointed strongly keeled leaves and simple or compound panicles. Spikelets (in ours) compressed, in short subcapitate panicles on the simple nearly naked culms, bleaching white at maturity. Stamens 3. Styles short, with plumose stigmas. Grain free, inclosed in the lemma.-Triodia in part.

1. Tricuspis acuminata Munro, Gray Proc. Acad. Phila. 1863: 335. Stems simple, $1 \mathrm{dm}$. or more high, usually with but a single node, which bears a very short leaf: radical leaves $3-5 \mathrm{~cm}$. long; those of the stem shorter: panicle dense, ovoid, 3-4 cm. long, with a few erect branches: spikelets 8-12-flowered: glumes acuminate, the upper subaristate; lemma scarcely bifid, with a central seta one fourth its length, densely silky below, with a conspicuously silky tuft near the base. Triodia acuminata.-Colorado and Utah to Texas and Arizona.

\section{REDFIELDIA Vasey}

A tall perennial grass with long narrow, leaves and an ample panicle. Spikelets 1-3-flowered, the flowers perfect. Glumes about equal, 1-nerved; lemmas membranous, 5-nerved, with a ring of hairs at the base; palet 2-nerved, shorter than the lemma. Stamens 3. Styles long, distinct; stigmas short, plumose. Grain free, oblong.-Graphephorum in part.

1. Redfieldia flexuosa (Thurb.) Vasey, Bull. Torr. Bot. Club 14: 133. 1887. Stems 5-7 dm. high, smooth: leaves 3-5 dm. long, setaceous-acuminate: panicle loosely flowered; branches scattered: spikelets ovate, 3-6-flowered, ROCKY MT. ВOT. -5 
much shorter than the pedicels: glumes 1-nerved, acute, half shorter than the spikelet; lemma keeled, 3-nerved (lateral nerves prominent), scabrouspubescent, erose denticulate at apex, mucronate, villous at base. Graphephorum flexuosum.-Plains of Colorado and adjacent regions.

\section{DIPLACHNE Beauv.}

Perennial grasses with abundant narrow leaves. Spikelets 2-12-flowered, linear, compressed or subterete, sessile or short-pediceled, on the lower sides of the rays of the racemose panicle (rarely in a simple spicate panicle): rays horizontal to nearly erect, spikelet-bearing to the base. Glumes 1-nerved, acute or somewhat tridentate, the second larger but not exceeding the adjacent floret; lemma membranaceous, rarely rigid, obtuse, truncate or acute, sometimes short-awned or 3-toothed, often pubescent on the 3 nerves near the base, slightly exceeding the palet. Grain translucent, amber-colored, oblong, or subterete. Internodes of rachilla glabrous.

1. Diplachne acuminata Nash, Brit. Man. 128. 1901. Culms tufted, 3-6 $\mathrm{dm}$. high, simple or branching: leaves very rough, usually involute when dry: racemes numerous, ascending: lemma 6-7 $\mathrm{mm}$. long, entire and acuminate or sometimes obscurely 2-toothed, the midnerve extending into an awn. $D$. fascicularis.-Colorado to Nebraska and south to Arkansas.

\section{ERAGROSTIS Beauv.}

Perennials or annuals, usually with numerous leaves somewhat pilose at the ligule. Spikelets 3-30-flowered, compressed, awnless, perfect except the upper floret. Panicle usually large and spreading, rarely contracted or subcapitate; rachilla usually persistent with the palets. Glumes ovate, acute, or subobtuse, smooth or slightly hispid on the keel; palets arched, 2-keeled, slightly shorter than the lemma. Grain oblong or globose, semitranslucent, ambercolored, terete or with a shallow channel.

Spikelets 2-3 mm. wide Spikelets 1-2 mm. wide

1. Eragrostis major Host. Gram. 4: t. 14. 1809. Culms 2-5 dm. high, leafy: leaves flat, 4-8 $\mathrm{mm}$. wide: panicles rather densely flowered, oblong, 1-2 dm. long: spikelets sessile or short-pediceled, 6-15 mm. long, 6-20-flowered: upper glume somewhat 3-nerved; lemma obtuse, prominently nerved, one fourth longer than the ciliate palet: grain subglobose, $0.8 \mathrm{~mm}$. in diameter. Introduced everywhere in the United States and northern Mexico.

2. Eragrostis pilosa (L.) Beauv. Agrost. 71. 1812. Culms 2-5 dm. high, rather weak: leaves usually pilose at the ligule: panicle $1-2 \mathrm{dm}$. long, diffuse; branches $5 \mathrm{~cm}$. long or less: spikelets 3-6 mm. long, 4-8-flowered; florets rather loose on the elongated rachilla: glumes unequal, about one half as long as the contiguous florets; lemma nearly smooth, subacute, slightly exceeding the smooth palet: grain oblong, smooth, nearly $1 \mathrm{~mm}$. long.-The native form, which has been called. $E$. Purshii, does not seem to be distinct from the introduced species here described; one or both of the forms occur in most portions of the United States.

\section{EATONIA Raf.}

Erect grasses with slender simple culms and usually flat puberulent leaves. Spikelets usually 2-flowered, with a naked pedicel-like rudiment, compressed, cuneate, awnless, perfect, numerous, short-pediceled or nearly sessile on the verticillate branches of the rather slender panicles; rachilla smooth, articulated above the thin herbaceous glumes. First glume narrowly lanceolate, 1-nerved; second glume broad, obovate, 3-nerved; lemma lance-oblong, her- 
baceous with membranaceous margins, nearly smooth, indistinctly 3-nerved, slightly exceeding the very thin palet. Grain lance-oblong, yellow, nearly opaque.

Panicle dense

Panicle lax

1. E. obtusata.

2. E. pennsylvanica.

1. Eatonia obtusata (Michx.) Gray Man. 558. 1856. Culms 4-8 dm. high: panicle 1-2 dm. long; branches short, erect: spikelets short-pediceled, about $2.5 \mathrm{~mm}$. long: upper glume broadly obovate, obtuse, exceeding the lower, nearly one third shorter than the lower floret; lemma slightly exceeding the palet. Aira obtusata Michx.-Moist land, central Texas to Minnesota and eastward. Var. robusta Vasey is robust and scabrous throughout (5-10 dm. high), with panicle dense, interrupted spike-like, and spikelets about $3 \mathrm{~mm}$. long.-Frequent in our range; across the continent.

2. Eatonia pennsylvanica (DC.) Gray, 1. c. Culms 5-10 dm. high: panicle 1-2 dm. long, often slightly nodding; branches ascending: spikelets $3 \mathrm{~mm}$. long: empty glume oblong-obovate, often subacute, about equaling the lower in length, one third shorter than the lower floret; lemma slightly exceeding the palet.-Extending through the northern part of our range from the eastward.

50. KOELERIA Pers.

Erect pereninial grasses with simple culms, and numerous usually flat leaves at the base. Spikelets 2-4-flowered, with an obscure naked pedicel-like rudiment, compressed, awnless, short pediceled, in narrow subspicate panicles: rachilla hispidulous, articulating above the glumes. Glumes lanceolate, acute carinate, herbaceous with membranaceous margins, subequal, the first 1nerved, the second 3-nerved, nearly smooth, equaling or slightly exceeding the thin, hyaline palet.

1. Koeleria cristata (L.) Pers. Syn. 1: 97. 1805. Culms 3-6 dm. high: panicle subspicate, sometimes interrupted near the base and usually tapering near the apex: spikelets mostly 2-flowered, 4-6 mm. long: glumes about equaling the lower floret; lemma acute or mucronulate.-Very common in our range; on hillsides and bench lands.

\section{CATABROSA Beauv.}

A creeping perennial aquatic grass, erect or spreading, with flat leaf-blades and an open panicle with capillary branches. Spikelets 2 , rarely 3-4-flowered; the rachilla smooth, articulated between the flowers. Glumes thin, membranaceous, broad, unequal, very obtuse; lemma firm-membranaceous, obtuse or barely 3-toothed, longer than the glumes, conspicuously 3-nerved; palet 2-keeled, about as long as its lemma. Stamens 3. Styles distinct. Grain obovoid-oblong.

1. Catabrosa aquatica (L.) Beauv. Agrost. 97. 1812. Stems 1-5 dm. high, rather stout, ascending: leaves $5-15 \mathrm{~cm}$. wide, scabrous on the margin: panicle uniform, branchlets numerous, divided: flowers light brown: glumes purplish.-In the Rocky Mountains.

\section{MELICA L.}

Slender leafy perennial grasses with large spikelets. Panicle open. Spikelets short-pediceled and somewhat racemose along the few branches, 3-12flowered, oblong or conical, awnless; the upper 1-5 florets imperfect, unlike the lower perfect ones and convolute around each other forming a clavate or oblong rudiment. Glumes thin, broad, the upper usually larger, 7-9-nerved; lemma ovate, scarious at the obtuse or subacute apex, 5-15-nerved, one third longer than the palet. Grain oblong or broadly spindle-shaped, channeled, opaque. 
Panicle lax or the spikelets spreading; stems not bulbous at base. Spikelets at length pendulous

Spikelets ascending on the long lax branchlets of the panicle

Panicle dense and narrow; stems with bulbous base.

Second glume evidently shorter than the lemma

Second glume and lemma subequal

1. M. parviflora.

2. M. Smithii.

3. M. spectabilis.

4. M. bulbosa.

1. Melica parviflora (Porter) Scribn. Mem. Torr. Club 5: 50. 1894. Culms 5-8 dm. high: leaves narrow, 2-3 dm. long: spikelets racemose, pendent on the few slender branches, 8-12 mm. long, 2-4-flowered: glumes equal, about one third shorter than the lower floret: grain oblong, subacute, $2.5 \mathrm{~mm}$. long. M. Porteri.-Colorado to Arizona and Texas.

2. Melica Smithii (Porter) Vasey, Beal's Grasses N. A. 2: 509. 1896. Culms slender, 5-10 dm. high: leaves flat, thin, scabrous, 15-20 cm. long, 6-8 mm. broad: panicle open, $15-20 \mathrm{~cm}$. long; the rays mostly single, distant, at length spreading, bearing rather few spikelets mostly above the middle: spikelets 2-5-flowered: glumes scabrous; lemma 7-nerved, 2-toothed; palet linear, longer than its lemma.-Northern part of our range and thence eastward and westward.

3. Melica spectabilis Scribn. Proc. Phila. Acad. 45. 1885. Panicle nodding, loosely few-flowered, the slender branches erect-spreading: terminal floret acute: lemma very broadly acuminate, obtuse or notched at the tip. $M$. bulbosa of Bot. King's Exp. and Fl. Colorado. This differs from $M$. bulbosa Geyer in its usually taller and more slender stems, more open and nodding panicle, more slender and flexuose pedicels, shorter glumes, and broader lemmas which taper abruptly to a rounded and usually twolobed summit.-In the mountains, from Colorado and Utah to Montana and Idaho.

4. Melica bulbosa Geyer, Hook. Journ. Bot. 8: 19. 1873. Stems single or densely tufted, usually 4-5 dm. high, simple: sheaths and upper surface of the leaves scabrous: panicle erect, the branches appressed, few-flowered: spikelets 10-12 mm. long, with 5-8 perfect flowers, the terminal floret acute.-From Wyoming and Montana to Oregon and Washington.

\section{DISTICHLIS Raf.}

Rather low rigid leafy grasses from perennial running rootstocks. Dioecious. Spikelets 6-15-flowered, compressed, linear or narrowly oval, smooth, awnless, in small subspicate panicles. Second glume slightly larger than the first, but shorter than the lower floret; lemma rather rigid, ovate, acute, indistinctly $7-$ 11-nerved, slightly larger than the thin palet. The pistillate spikelets more turgid, otherwise alike. Grain oblong, oblique, subacute, opaque.

1. Distichlis spicata (L.) Greene, Bull. Cal. Acad. 2: 415. 1887. Culms erect, $2-4 \mathrm{dm}$. high: leaves usually crowded, distichous and rigid: panicle 4-8 cm. long: spikelets about $1 \mathrm{~cm}$. long.-Common in saline soil throughout our range and far to the northwestward.

\section{DACTYLIS L. Orchard Grass}

Rather stout tufted perennial grasses with numerous rough leaves. Spikelets 2-4-flowered, with a glumiferous rudiment, perfect, compressed, sessile or very short-pediceled in glomerate clusters in a rather dense branching panicle; bracts all herbaceous, or the lower ones submembranaceous, carinate and hispid-ciliate on the keel. Glumes lanceolate, acute, subequal, shorter than the lower florets; lemma mucronate, 5-nerved, slightly exceeding the hyaline palet. Grain linear, yellow, opaque, channeled or triquetrous.

1. Dactylis glomerata L. Sp. Pl. 71. 1753. Culms 6-10 dm. high, simple: leaves flat, hispid, 2-4 dm. long: panicle 1-2 dm. long, irregularly pyramidal: spikelets .5-8 mm. long.-Introduced; a valuable grass in cultivation. 


\section{POA L. Meadow Grass. Spear Grass. Blue Grass}

Annual or perennial grasses with flat or convolute leaves and numerous spikelets in contracted or open panicles. Spikelets 2-10-flowered with a glumaceous rudiment, perfect, compressed, ovate, awnless, in a contracted or open panicle. Glumes membranaceo-herbaceous, lance-ovate, subacute, the first 1-nerved, the second 3-nerved; lemma thin, herbaceous, subacute or obtuse, 5-nerved, usually pubescent on the keel and with cobwebby hairs at the base, longer than the hyaline palet. Grain oblong, linear, much shorter than the floret.

Annual; lemma without cobwebby hairs at the base

Perennials.

Stems flattened, 2-edged; panicle small

Stems cylindrical.

Lemma webbed, i. e., with a tuft of fine hairs at the base (except No. 8).

Panicle large.

Its branches not reflexed.

Lemmas acute

Lemmas obtuse.

Broader than the second glume

Not broader than the second glume

Its branches reflexed

Panicle small, its fruiting branches reflexed.

Leaves more or less conduplicate

Leaves flat.

Lemma copiously pubescent on the mid- and lat-

Lemma glabrate and cobweb nearly or quite wanting Lemma not webbed.

Leaves short and broad; panicle small, open; spikelets

rounded at the base
Leaves normal; panicle various; spikelets acute at base.

Low alpine grasses.

Lemma pubescent on the mid-and lateral nerves. Lemma glabrous

Taller grasses of subalpine or lower stations.

Spikelets strongly flattened; lemmas acute.

Flowers perfect; lemmas hairy on the nerves and internerves.

Plants with creeping rootstocks; panicle open. Leaf-sheaths retrorsely strigose . . .

Leaf-sheaths glabrous
Plants tufted, no creeping rootstocks; panicle narrow.

Lemmas strongly purple-tinged

Lemmas mostly greenish.

Glumes subequal Glumes unequal

Flowers dioecious; internerves glabrous.

Ligules short, rounded or truncate at apex. Panicle narrow, long-peduncled

Panicle more open, and with shorter peduncle

Ligules longer and acute.

Spikelets rounded (scarcely at all flattened); lemmas narrow but not acute.

Lemmas scabrous throughout.

Lemmas and glurnes unequal; leaves narrow and involute

Lemmas and glumes subequal; leaves broader and usually flat

Lemmas scabrous above only, strigose below.

Leaves pale (yellowish), very narrow and usually involute

Leaves dark green.

Leaves plicate

Leaves flat
1. P. annua.

2. P. compressa.
3. P. pratensis.

4. P. flava.

5. P. interior.

6. P. platyphylla.

7. P. arctica.

8. P. reflexa.

9. P. laxa.

10. P. alpina.

11. P. Pattersonii.

12. P. Lettermannii.

13. P. Wheeleri

14. P. nervosa.

15. P. subpurpurea.

16. P. subaristata.

17. P. epilis.

18. P. longipedunculata. 19. P. Fendleriana. 20. P. longiligula.

21. P. laevigata.

22. P. nevadensis.

23. P. lucida.

24. P. Buckleyana.

25. P. Sheldonii.

1. Poa annua L. Sp. Pl. 68. 1753. Culms 5-30 cm. tall, from an annual root, erect or decumbent at base, somewhat flattened, smooth: sheaths loose, usually overlapping; leaves $1.25-10 \mathrm{~cm}$. long, $1.5-3 \mathrm{~mm}$. wide, smooth: panicle 1.25-10 cm. in length, open; branches spreading, 6-35 mm. long, naked at base: spikelets.3-5-flowered, $3-5 \mathrm{~mm}$. long: glumes smooth, the first narrow, acute, 1-nerved, about two thirds as long as the broad and obtuse 3-nerved 
second one; lemma 2.5-3 mm. long, distinctly 5-nerved, the nerves pilose below.-More or less frequent in waste and cultivated grounds throughout North America.

2. Poa compressa L. Sp. Pl. 69. 1753. Pale bluish-green, glabrous: culms 1.5-6 dm. tall, decumbent at the base, from long horizontal rootstocks, much flattened: sheaths loose, flattened, shorter than the internodes; leaves 2.5-10 $\mathrm{cm}$. long, about $2 \mathrm{~mm}$. wide, smooth beneath, rough above: panicle usually contracted, the branches erect or ascending, $2.5 \mathrm{~cm}$. long or less, spikeletbearing nearly to the base: spikelets 3-9-flowered, $3-6 \mathrm{~mm}$. long: lower glumes acute, 3-nerved; lemma $2-2.5 \mathrm{~mm}$. long, obscurely 3 -nerved, the nerves sparingly pubescent toward the base.--Infrequent in our range; common eastward.

3. Poa pratensis L. Sp. Pl. 67. 1753. Culms 3-12 dm. high, sending out numerous running rootstocks from the base: sheaths compressed, overlapping below, ligule $1.5 \mathrm{~mm}$. long; blades $1-6 \mathrm{~mm}$. wide, those of the culm $5-15 \mathrm{~cm}$. long, the basal ones much longer: panicle pyramidal, the slender branches in rather remote fascicles of $3-5$, ascending, naked at base: spikelets crowded, 3-5-flowered, 4-5 mm. long: lemmas $3 \mathrm{~mm}$. long, copiously webbed at base; intermediate nerves strong, glabrous. Kentucky Blue Grass. June Grass. (P. pseudopratensis Scrib. \& Rydb. Contrib. Nat. Herb. 3: 532. 1896; P. phoenicea Rydb. Bull. Torr. Bot. Club 32: 605. 1905.)-Europe, Asia, and America; mostly as an introduced hay and pasture grass, but indigenous also in our range.

4. Poa flava L. Śp. Pl. 68. 1753. Culms 4.5-15 dm. tall: leaves 5-15 cm. long, 2-4 mm. wide, smooth or rough: panicle 1.5-3 dm. in length, open, the branches spreading or ascending, 5-12 cm. long, divided and spikelet-bearing above the middle: spikelets 3-5-flowered, 3-4 $\mathrm{mm}$. long, exceeding their pedicels, acute: lemma obtuse, somewhat webby at the base, 2-3 mm. long, silky-pubescent on the lower half of the marginal nerves and the mid-nerve, the intermediate nerves obscure or wanting. P. serotina. [P. crocata Michx. (?).]-Same ranges as the preceding; known as FALSE REDTOP and FowL Meadow Grass.

5. Poa interior Rydb. Bull. Torr. Bot. Club 32: 604. 1905. Culms 1.5-6 $\mathrm{dm}$. tall, erect, slender, sometimes rigid: leaves $2.5-10 \mathrm{~cm}$. long, $2 \mathrm{~mm}$. wide or less, erect, smooth or rough: panicle $5-12.5 \mathrm{~cm}$. in length, open, the branches erect or ascending, rarely spreading, $2.5-5 \mathrm{~cm}$. long: spikelets 2-5-flowered, 3-5 mm. long: glumes acute or acuminate, 1-3-nerved; lemma obtuse or acute, 2-2.5 mm. long, faintly 5-nerved, somewhat webby at base, the midnerve and the marginal nerves silky-pubescent on the lower half. $P$. caesia strictior. ( $P$. memoralis of Am. authors as to the western plants; not $P$. nemoralis L. P. glauca Vahl. also is here included.)-Very common; Rocky Mountains to the Atlantic States.

6. Poa platyphylla Nash. \& Rydb. Bull. Torr. Bot. Club 28: 266. 1901. Culms 5-8 dm. high, with slender roots: leaves flat; culm leaves 5-6, rather broad and flat; the lower short; the upper 12-15 $\mathrm{cm}$. long, sheathing the base of the panicle; sheaths flattened, scabrous: panicle large and loose; its branches distant, the lower mostly in threes, or rarely in fives and 10-12 cm. long, capillary, erect at first but soon spreading: spikelets closely racemed on the slender branchlets, mostly 3-flowered, 4-5 mm. long: glumes acute, unequal, 3 -nerved, scabrous on the keel; lemma 5-nerved, slightly pubescent below and on the keel and slightly webbed on the base. (P.occidentalis Vasey, Contrib. U. S. Nat. Herb. 1: 274. 1893, the earlier but untenable name. Lately frequently distributed as $P$. leptocoma.)-Montana to Utah and New Mexico.

7. Poa arctica R. Br. in Parry's 1st Voyage, Supp. 288. 1824. Smooth and glabrous: culms 1-4 dm. tall, erect, slender: leaves $2.5-10 \mathrm{~cm}$. long, 1-2 mm. wide: panicle $2.5-10 \mathrm{~cm}$. in length, open, the branches generally widely spreading and more or less flexuous, $2.5-6 \mathrm{~cm}$. long: spikelets $3-5$-flowered, $5-7 \mathrm{~mm}$. long: glumes acute or acuminate, 1-3-nerved; lemma about $4 \mathrm{~mm}$. long, faintly 5 -nerved, the nerves short-pilose on the lower half, minutely pubescent between the nerves, somewhat webbed at the base.-In the mountains of Colorado and far northward. 
8. Poa reflexa Vasey and Scribn. Contrib. U. S. Nat. Herb. 1: 276. 1893. Culms 2-4 dm. high, slender, erect, smooth: leaves of the culm about 3 , mostly narrow, acute, $5-8 \mathrm{~cm}$. long: sheaths long, smooth; ligule obtuse, about $2 \mathrm{~mm}$. long: panicle pyramidal, 5-10 $\mathrm{cm}$. long, with about 6 nodes; the branches capillary, rather distant, the lower ones 5-8 cm. long, smooth, spreading and becoming reflexed, spikelet-bearing near the end: spikelets 2-3-flowered, 3-4 mm. long: glumes acute, smooth; lemma ovate-lanceolate, acute, obscurely nerved, pubescent on the nerves and at the base; palet pubescent on the keels. (P. acuminata Scribn. Beal's N. Am. Gr. 2: 538. 1896; P. pudica Rydb. Bull. Torr. Bot. Club 32: 603. 1905.) - Wet sandy soils, at middle or higher elevations; Montana to New Mexico.

9. Poa laxa Haenke, Sudet. 118. 1791. Culms 3 dm. tall or less, erect, simple: leaves $2.5-7.5 \mathrm{~cm}$. in length, the branches usually erect, sometimes ascending, $2.5 \mathrm{~cm}$. long or less: spikelets 3-5-flowered, 4-5 mm. long: glumes usually 3-nerved, acute, glabrous, rough on the keel at its apex; lemma 3-3.5 mm. long, obtuse, 3-nerved, or sometimes with an additional pair of obscure nerves, the mid-nerve pilose on the lower half, rough above, the lateral ones pilose for one third their length.-In the Rocky Mountains and in those of New England and New York; infrequent in our range.

10. Poa alpina L. Sp. Pl. 67. 1753. Smooth and glabrous: culms $1-4.5 \mathrm{dm}$. tall: ligule $2 \mathrm{~mm}$. long, truncate; leaves $2.5-7.5 \mathrm{~cm}$. long, $2-4 \mathrm{~mm}$. wide, abruptly acute: panicle $2.5-7.5 \mathrm{~cm}$. in length, the branches generally widely spreading, $2.5 \mathrm{~cm}$. long or less: spikelets 3-5-flowered, 5-6 $\mathrm{mm}$. long: glumes broad, glabrous, rough on the keel, acute; lemma about $4 \mathrm{~mm}$. long, obtuse, pilose for half the length, pubescent between the nerves toward the base.Frequent in the mountains and extending northward and eastward.

11. Poa Pattersonii Vasey, 1. c. 275. Culms low, densely tufted, 15-25 cm. high, slender, naked above: radical leaves numerous, $5-8 \mathrm{~cm}$. long, very narrow, flat or conduplicate, smooth: panicle dense, weakly erect, or nodding; branches mostly in twos, subappressed: spikelets 4-6 mm. long, 2-3-flowered: glumes nearly as long as the lemma, acute; lemma purplish, acute, $4 \mathrm{~mm}$. long, pubescent on the lateral nerves and below the middle but not webbed at the base; palet pubescent on the keels. ( $P$. rupestris Vasey, a name replaced by $P$. rupicola Nash, Mem. N. Y. Bot. Gard. 1: 49. 1900.)-Alpine; Colorado and Wyoming.

12. Poa Lettermannii Vasey, Contrib. Nat. Herb. 1: 273. 1893. Dwarf, densely tufted, $5-10 \mathrm{~cm}$. high: leaves mostly radical, flat, $3-5 \mathrm{~cm}$. long; ligule rather conspicuous, acute; cauline leaves 1 or 2 : panicle $10-25 \mathrm{~mm}$. long, rather dense; branches mostly in twos, short, erect, with 1-3 spikelets: glumes nearly as long as the spikelets, acute, nearly smooth, 3-4 mm. long; lemma shorter, ovate-oblong, acute, obscurely nerved, smooth; palet 2 -toothed at the acuminate apex.-Alpine summits, Colorado to Washington.

13. Poa Wheeleri Vasey, Rothr. Rep. 6: 291. 1878. Culms 3-8 dm. high, from running rootstocks: ligules about $2 \mathrm{~mm}$. long; leaves of sterile shoots 15-24 cm. long, 2-4 mm. wide, rigid, conduplicate or involute, with a firm oblique point: panicle open, $10-15 \mathrm{~cm}$. long, its slender branches mostly in pairs, the longer about $5 \mathrm{~cm}$. long: spikelets lance-elliptic, $.4-6 \mathrm{~mm}$. long, 3-flowered: glumes subequal, 3-nerved; lemma oval, subacute, about as long, ciliate on the lateral nerves and below; palet truncate, ciliate on the keel.Frequent in our range and extending to Washington.

14. Poa nervosa (Hook.) Vasey, Ill. N. Am. Gr. 2: 81. 1893. Culms 4-8 $\mathrm{dm}$. high, rather slender, smooth: radical leaves narrowly linear, $15-25 \mathrm{~cm}$. long; those of the culms about 3 , rather distant, erect, flat, $3-8 \mathrm{~cm}$. long, 2-4 mm. wide: panicle 5-12 cm. long, branches spreading, the lower 2-5 together, filiform, naked below, few-flowered near the ends: spikelets 3-8flowered, 4-5 mm. long: lemma linear-lanceolate, strongly 5-nerved, minutely scabrous on the nerves; palet and lemma subequal. [ $P$. Traceyi Vasey, Contrib. U. S. Nat. Herb. 1: 276. 1893; P. flexwosa occidentalis Vasey; $P$. occidentalis (Vasey) Rydb.; P. callichroa Rydb. Bull. Torr. Bot. Club 32: 603. 1905.] - Idaho and Montana to Colorado. 
15. Poa subpurpurea Rydb. Bull. Torr. Bot. Club 32: 606. 1905. A tufted, erect, somewhat wiry perennial: culms 2-4 dm. high: leaves flat: panicle oblong or pyramidal, dense, 4-6 cm. long: spikelets ovate, 3-5-flowered, 6-8 mm. long: lemma oval, obtuse, minutely scabrous on the back and hispid-ciliate on the keel; palet about $5 \mathrm{~mm}$. long. ( $P$. purpurascens Vasey, Bot. Gaz. 6: 297. 1881; the name preoccupied.)-Alpine; Colorado (?) to British Columbia.

16. Poa subaristata Scribn. Beal's N. Am. Gr. 2: 533. 1896. Slender, densely tufted, 2-5 dm. high: leaves of sterile shoots conduplicate, scabrous, 6-12 cm. long; sheaths of the stem 2, smooth, the upper one nearly half as long as the stem; the upper leaf pungent, $4-5 \mathrm{~cm}$. long: panicle dense, somewhat interrupted, 4-7 cm. long: spikelets 4-7-flowered, 6-10-mm. long: glumes subequal, linear-lanceolate, 5-6 mm. long, 1-nerved; lemma as long, scabrous on the nerves; palet shorter, ciliate on the keels.-Colorado to Montana and Idaho.

17. Poa epilis Scribn. Circ. U. S. Dept. Agr. Div. Agrost. 9: 5. 1899. Densely tufted, 5-10 dm. high: basal leaves numerous, slender, acute, flat (or convolute when dry), those of the sterile shoots 1-2 dm. long; sheaths much shorter than the internodes: panicle dense, bronzed or purple: spikelets somewhat compressed, about $5 \mathrm{~mm}$. long: glumes smooth, unequal, acute, or acuminate; the lower 1 -nerved; the upper 3 -nerved, $3 \mathrm{~mm}$. long and exceeding the lower; lemma 5-nerved, rough-hispid on the back, obtuse; palet ciliate on the keels, with 2-toothed apex: grain acute at both ends, with a white tubercle at the apex.-Colorado to Wyoming and Montana.

18. Poa longipedunculata Scribn. Bull. U. S. Dept. Agr. Div. Agrost. 11: 54. 1898. Slender, tufted, erect, 4-7 dm. high, with short creeping rootstocks, smooth except on the axis of the panicle: leaf blades of the sterile shoots 5-20 cm. long; those of the culm two or three, the uppermost sometimes reduced to a mucronate point: panicle dense, $5-7 \mathrm{~cm}$. long; its branches 1-2 cm. long: spikelets somewhat compressed, 3-5-flowered, about $6 \mathrm{~mm}$. long: glumes scabrous on the keels, the first 2-nerved, the second 3-nerved, with broadly subhyaline margins; lemma roughened on the keel above and finely pubescent toward the base, about 4-nerved; palet shorter than its lemma.-Frequent throughout our range on mountain slopes.

19. Poa Fendleriana (Steud.) Vasey, Ill. N. Am. Gr. 2: 74. 1893. Pale green, strict and nearly smooth, 2-5 dm. high, from short rootstocks: leaves as in the last but less harsh and rigid: panicle spike-like, lanceolate or slightly spreading, 5-10 cm. long: spikelets ovate-lanceolate, compressed, 4-8-flowered, 7-8 mm. long: glumes subequal, oval, acute, irregularly toothed or obtuse, 1-3-nerved, 4-5 $\mathrm{mm}$. long; lemma about as long, pubescent below on the keel and marginal nerves, otherwise smooth. $P$. californica; $P$. andina Nutt. (P. brevipaniculata S. \& W. Circ. U. S. Dept. Agr. Div. Agrost. 9: 2. 1899.) New Mexico to Wyoming and westward.

20. Poa longiligula S. \& W. Circ. U. S. Dept. Agr. Div. Agrost. 9: 3. 1899. Glaucous, tufted, $3-5 \mathrm{dm}$. high: culms rather rigid and harsh: basal leaves numerous, flat or conduplicate, 1-2 dm. long, with a conspicuous decurrent ligule; the cauline féw and short: panicle dense, ovate, erect: spikelets compressed, ovate-lanceolate, 4-6-flowered, 6-10 mm. long: glumes unequal, rough-hispid on the back; the lower 1-nerved; the upper 3-nerved and about $5 \mathrm{~mm}$. long; lemma 5-nerved, somewhat scabrous on the back and woollypubescent on the lower half of the back and the marginal nerves, usually erose-dentate, with broad hyaline margins; palet shorter than its glume, with green hispid pubescent keels.-Frequent in our range.

21. Poa laevigata Scribn. Bull. U. S. Dept. Agr. Div. Agrost. 5: 31. 1897. Culms densely tufted, 6-8 dm. tall, erect, slender, the innovations 1-2 dm. long: sheaths smooth and glabrous; leaves $1 \mathrm{dm}$. or less long: panicle very slender, 8-14 cm. long, its larger branches 3-5 cm. long: spikelets 5-7 mm. long, 3-4-flowered, lemmas 3-4 $\mathrm{mm}$. long, hispidulous all over, obtuse to acutish.-Very nearly related to the preceding; same range.

22. Poa nevadensis Vasey, Scribn. Bull. Torr. Bot. Club 10: 66. 1883. 
Culms 5-10 dm. high, scabrous below the panicle: sheaths and leaves scabrous, very narrow and folded when dry; the radical $15-25 \mathrm{~cm}$. long; the upper 3-6 $\mathrm{cm}$. long; ligule scabrous, about $4 \mathrm{~mm}$. long: pahicle narrow, dense, $10-15 \mathrm{~cm}$. long; branches 2 or more at each node, the lower often 4-5 cm. long and branched: spikelets 3-8-flowered, 6-8 mm. long: glumes scabrous, subequal, obtuse or subacute, 3-nerved; lemma shorter, scarious margined above, the nerves obscure; palet ciliate on the keels, scabrous between them.- Not infrequent, especially in the western part of our range.

23. Poa lucida Vasey, 1. c. 274. Culms 6-8 dm. tall, erect, the innovations 2-3 dm. long: sheaths smooth and glabrous; leaves of the culms $1 \mathrm{dm}$. or less long, those on the innovations much longer: panicle 1-2 dm. long, its larger branches 3-5 cm. long: spikelets 6-10 mm. long, 4-6-flowered: the lemmas about $4.5 \mathrm{~mm}$. long, appressed-pubescent below with long hairs, obtuse or acutish. (P. planifolia S. \& W. 1. c. 3.)-Moist hillsides and meadows; Montana to Colorado and Nebraska.

24. Poa Buckleyana Nash, Bull. Torr. Bot. Club 22: 465. 1895. Culms 1.5-4 dm. tall, rarely taller, erect, rigid: ligule 4-6 $\mathrm{mm}$. long, acute; leaves 2.5-10 cm. long, about $2 \mathrm{~mm}$. wide, erect, flat, becoming involute, smooth or rough: panicle $2.5-10 \mathrm{~cm}$. in length, contracted, the branches erect, $3.75 \mathrm{~cm}$. long or less, spikelet-bearing nearly to the base: spikelets 2-5-flowered, 4-6 $\mathrm{mm}$. long: lemmas about $4 \mathrm{~mm}$. long, obtuse or acutish, appressed-pubescent below with long hairs. P.tenuifolia. [P. gracillima Vasey (?), Contrib. Nat. Herb. 1: 272. 1893; P. Sandbergii Vasey, 1. c. 276.]-Very common in our range, and westward to California.

25. Poa Sheldonii Vasey, Contrib. Nat. Herb. 1: 276. 1893. Culms 3-6 dm. tall, erect, rigid: sheaths usually overlapping; ligule $2-4 \mathrm{~mm}$. long, acute; leaves smooth beneath, rough above, 1-2 mm. wide, flat or folded, pungently pointed, those of the culm $1.25-2.5 \mathrm{~cm}$. long, erect, the basal leaves $7.5-15 \mathrm{~cm}$. long: panicle contracted, 5-12.5 $\mathrm{cm}$. in length, the branches erect, spikeletbearing nearly to the base, $3.75 \mathrm{~cm}$. long or less: spikelets 4-7-flowered, 5-7 $\mathrm{mm}$. long: lemmas 3-4 mm. long, erose-truncate at apex, strongly silkypubescent on the nerves for half their length, the lower part very pubescent between the nerves; intermediate nerves very obscure. ( $P$. arida Vasey, l. c. 270, name untenable; $P$. pratericola Rydb. \& Nash, Mem. N. Y. Bot. Gard. 1: 51. 1900; P. juncifolia Scribn. Bull. U. S. Dept. Agr. Div. Agrost. 11: 52. 1898 , seems to be only the large forms of the species.)-Common and varying greatly under the extremely variable environments found within our range.

\section{GRAPHEPHORUM Desv.}

Slender erect grasses, with flat leaves and a usually contracted nodding panicle. Spikelets 2-4-flowered, flattened, the rachilla hirsute and extending beyond the flowers. Glumes somewhat shorter than the lemmas; thinmembranous, acute, keeled: lemmas membranous, obscurely nerved, entire, sometimes short-awned just below the apex. Stamens 3. Styles distinct; stigmas plumose. Grain glabrous.

1. Graphephorum Wolfii Vasey, Desc. Cat. Gr. U. S. 55. 1885. Culms erect, 3-6 dm. high: leaves scabrous, flat, 15-20 cm. long: panicle upright, subspicate, 6-15 cm. long: spikelets 2-3-flowered, purplish: glumes subequal, 5-6 mm. long, the first 1-nerved, the second 3-nerved; lemma nearly as long, faintly 5-nerved, bearing an awn $1 \mathrm{~mm}$. or less long; palet usually shorter than its lemma: grain linear-oblong. G. melicoides, as to our range.-Colorado, Utah, Wyoming, and northward.

\section{GLYCERIA R. Br. Manna Grass}

Rather coarse broad-leaved grasses, the florets early deciduous. Spikelets 4-15-flowered, slightly compressed, linear or oblong, smooth or slightly hispid, awnless, in narrow or open spreading panicles. Glumes unequal, persistent, 
thin, one half as long as the adjacent florets; lemma herbaceous, membranaceous at the obtuse apex, 7-9-nerved, nearly equaled or slightly exceeded by the bidentate palet. Grain linear or fusiform, narrowly channeled.-(Panicularia Fabr.)
Spikelets ovate to oblong.
Panicle at length nodding, 10-20 cm. long. Floral glume 7-nerved, $1.5-2 \mathrm{~mm}$. long Floral glume 5-nerved. 2-3 mm. long :
Panicle erect or nodding, $20-40 \mathrm{~cm}$. long Spikelets linear.
Floral glume thin, hispidulous on the nerves
Floral glume firm, hispidulous all over

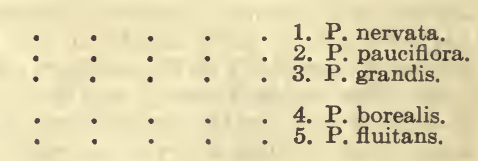

1. Glyceria nervata (Willd.) Trin. Mem. Acad. St. Petersb. VI. 1: 365. 1831. Stems 4-10 dm. high: leaves variable, sometimes $3-4 \mathrm{dm}$. long, usually roughish above, as are the closed sheaths: panicle 1-2 dm. long, its flexuose capillary branches in twos or threes, and soon diffusely spreading and pendulous: spikelets 2-4 $\mathrm{mm}$. long, 5-7-flowered, sometimes purplish: lemma 7-nerved, finely scabrous, strongly convex near the apex.--In moist meadows and along water courses, across the continent.

2. Glyceria pauciflora Presl. Rel. Haenke, 1: 257. 1830. Stems 3-10 dm. high, from a creeping root: leaves $1-3 \mathrm{dm}$. long, scabrous on the margins; sheaths split: panicle 1-2 dm. long, loose, its capillary branches in threes below, in pairs above, flower-bearing from near the middle: spikelets $4-5 \mathrm{~mm}$. long, 4-6-flowered: lemma 5-nerved, scabrous, its scarious tip serrulate or toothed, more or less purplish.-From Colorado and Utah northward and westward.

3. Glyceria grandis Wats. in Gray. Man. Ed. 6. 667. 1890. Stems stout, erect, $8-15 \mathrm{dm}$. high: leaves large, $3-6 \mathrm{dm}$. long: panicle ample, 2-4 dm. long, much branched, the numerous branches ascending, spreading with age: spikelets 4-6 mm. long, 5-9-flowered, usually purplish: flowering glume 7-nerved, entire. G. aquatica.- - In wet grounds, from Colorado to California and Oregon, thence eastward across the continent; called Reed Meadow Grass.

4. Glyceria borealis (Nash). A. Nels. Glabrous: culms erect from a creeping base, $4.5-15 \mathrm{dm}$. tall: sheaths overlapping, smooth or roughish, the uppermost one inclosing the base of the panicle; leaves linear, abruptly acuminate, 1-5 dm. long, 2-10 $\mathrm{mm}$. wide: panicle slender, the exserted portion $1.5-5 \mathrm{dm}$. long, its branches appressed or nearly so? spikelets $1-1.8 \mathrm{~cm}$. long, 7-13-flowered, appressed: glumes 1-nerved, unequal; lemma thin, 4-5 mm. long, 7-nerved, the nerves only scabrous; palet slightly shorter than the scale. (Panicularia borealis Nash, Bull. Torr. Bot. Club 24: 348. 1897.)-In shallow water; Wyoming to Montana, and thence across the continent.

5. Glyceria fluitans (L.) R. Br. Prodr. Fl. Nov. Holl. 1: 179. 1810. Very similar to the preceding, the culms 6-10 dm. high, slender, erect, or somewhat spreading: spikelets 7-13-flowered, linear, 1-2 cm. long: lemma hispidulous all over, shorter than the bidentate palet.-In shallow water; Colorado to Canada, thence eastward and westward.

\section{PUCCINELLIA Parl.}

Perennial grasses, with flat or involute leaves and contracted or open panicles. Spikelets 3-several-flowered. Glumes obtuse or acute, unequal; lemma obtuse or acute, rounded on the back, 5-nerved, the nerves very obscure or almost wanting; palet about equaling the lemma. Stamens 3 . Styles wanting; stigmas sessile, simply plumose. Grain compressed, usually adhering to the palet.

1. Puccinellia airoides (Nutt.) Wats. \& Coult. in Gray Man. 668. 1890. Stems tufted, 2-5 dm. high: leaves short and narrow, mostly convolute and glaucous: panicle very variable, erect, narrow and one-sided, its rays in fives or fewer: spikelets 3-12-flowered: glumes from narrow and acute to broad and obtuse, 3-nerved or the lower 1-nerved; lemma oblong-linear, minutely pubes- 
cent at base, with broadly scarious apex, faintly 5-nerved, truncate or erosedentate: stigmas with simple hairs. Glyceria distans.-Wet saline soil; New Mexico to Montana and thence in similar situations to the coasts.

\section{FESTUCA L. Fescue}

Erect simple-stemmed grasses. Spikelets 4-15-flowered, perfect except the glumiferous rudiment, compressed, short-pediceled or nearly sessile, in narrow or open spreading panicles. Glumes acute, narrow, unequal, about one third shorter than the adjacent florets; lemma herbaceous or coriaceous, obscurely 5-nerved, hispidulous, slightly pubescent or smooth, acute or awned, convex, often involute; palet bidentate, nearly equaling the lemma. Grain narrowly linear or fusiform, channeled, usually adhering to the enveloping glume and palet.

Annual; stamens 2

Perennial; stamens 3.

Plants with narrow involute leaves, usually tufted.

Densely tufted, not rhizomatous nor stoloniferous.

Lemmas more than twice as long as the first glume. Awn long (equaling or longer than the glume) Awn short

Lemmas less than twice as long as the first glume: More open, rhizomatous or stoloniferous

Plants with flat broad leaves.

The second glume 3-5-nerved.

Panicle with spreading or reflexed branches; awns long

Panicle with ascending branches; awns short or wanting

The second glume 1-nerved, or 3-nerved at base only. Panicle open

Panicle spike-like

1. F. octoflora.
- 2. F. ovina.
2. F. ovina.
4. F. brachyphylla.
: $\quad$ 5. F. Frabra.

1. Festuca octoflora Walt. Fl. Car. 81. 1788. Stems often filiform, 1-4 dm. high: the erect leaves $3-7 \mathrm{~cm}$. long; sheaths sometimes pubescent: panicle 4-6 $\mathrm{cm}$. long, simple, often secund: spikelets, including awns, 8-10 mm. long, 7-13-flowered: glumes subulate, very acute, the lower at least half the length of the upper; lemma involute, rough, $4 \mathrm{~mm}$. long exclusive of its awn; which is mostly shorter than the palet and often very short. $F$. tenella.-Across the continent.

2. Festuca ovina L. Sp. Pl. 73. 1753. Stems 2-5 dm. high, glaucous: leaves all setaceous or the upper flat; ligule 2-lobed and auriculate: panicle short, more or less compound, somewhat one-sided, the branches mostly solitary: spikelets 3-8-flowered: lemma about $6 \mathrm{~mm}$. long, ternate, mucronate or with an awn half its own length.-Many varieties of this common species have been designated, but the distinctions between them can be drawn with difficulty. Across the continent northward and south in the mountains.

2a. Festuca ovina ingrata Hack. Beal's Grasses 2: 598. 1896.' Near the preceding, densely tufted, 1-3 dm. high: leaves setaceous, $3-8 \mathrm{~cm}$. long; the sheaths entire to the throat, splitting with age: panicle dense, linear, simple, racemose, 3-6 cm. long: spikelets elliptical, $6 \mathrm{~mm}$. long, 1-4-flowered: glumes subequal; lemma 3-4 mm. long, smooth or scabrous, its awn 1-2 mm. long; palet oblong, acute, 2-toothed. [F. ingrata (Hack.) Rydb. Bull. Torr. Bot. Club 32: 608. 1905.] Throughout the Rocky Mountains.

3. Festuca arizonica Vasey, Contrib. Nat. Herb. 1: 27\%. 1893. Firm and tufted, 5-7 dm. high: leaves very numerous, stiff, filiform-setaceous, scabrous margined; the upper two or three with long sheaths, and blades $15-25 \mathrm{~cm}$. long; ligules short, with prominent auricles: panicle narrow, 6-12 cm. long; the branches alternate, erect and appressed: spikelets about $10 \mathrm{~mm}$. long, lance-linear, on short pedicels, 4-5-flowered: glumes unequal, 3-nerved; lemma longer, thick, acuminate, with an awn 1-2 mm. long, obscurely 5-nerved; palet equaling its lemma, scabrous on the keels.-Colorado to New Mexico and Arizona.

4. Festuca brachyphylla Schultes, Mant. 2: 646. 1824. Smooth and glabrous: culms densely tufted, $2 \mathrm{dm}$. tall or less, slender, erect, much exceeding the short basal leaves: sheaths coarsely striate; leaves very narrow, in- 
volute, at least when dry, those on the culm $1.25 \mathrm{~cm}$. or less long, erect or ascending: panicle $2.5 \mathrm{~cm}$. or less long, nearly simple, its branches appressed: spikelets 2-4-flowered: glumes acuminate, the first 1-nerved, the second 3-nerved; lemma acute or acuminate, rough toward the apex, 4-5 mm. long, exclusive of the scabrous awn, which is $1-2.5 \mathrm{~mm}$. long. ( $F$. minutiflora Rydb. 1. c.)-Alpine stations throughout our range; also northeastern America.

5. Festuca rubra L. Sp. Pl. 74. 1753. Culms 4.5-7.5 dm. tall, from running rootstocks, erect, simple: basal leaves involute-filiform, 7.5-15 cm. long; culm leaves shorter, erect, flat, or involute in drying, minutely pubescent above: panicle 5-12 cm. in length, sometimes red, open at flowering time, contracted in fruit: spikelets 3-10-flowered, 8-12 mm. long: glumes acute, unequal, the first 1-nerved, shorter than the 3-nerved second; lemma about $6 \mathrm{~mm}$. long, obscurely 5-nerved, sometimes scabrous, bearing awns of less than their own length. ( $F$. vallicola Rydb. Mem. N. Y. Bot. Gard. 1: 57. 1900; F. Earlei Rydb. Bull. Torr. Bot. Club 32: 608. 1905.)-Rather frequent in the mountains of our range; across the continent northward.

6. Festuca Jonesii Vasey, l. c. Culms slender or stoutish, 4-8 dm. high: culm leaves 3-5, flat, 1-3 dm. long, 4-8 mm.wide; sheaths shorter than the internodes: panicle ample, very open, $15-30 \mathrm{~cm}$. long; the branches 'mostly in pairs at the 5-8 distant nodes, slender, flexuous, 8-15 cm. long, at length spreading or reflexed: spikelets numerous, 3-5-flowered: glumes lanceolate, unequal; lemma 3-nerved, minutely scabrous, terminated by a slender awn longer than its body; palet as long as its lemma, with 2 narrow teeth at apex.Northwestern Wyoming and westward.

7. Festuca elatior L. 1. c. 75 . Culms 6-15 dm. tall, erect, simple: leaves 1-4 dm. long, 4-8 mm. wide, flat, smooth beneath, more or less rough above: panicle $1-3.5 \mathrm{dm}$. in length, often nodding at the top, simple to very compound, the branches ascending or erect, 5-20 cm. long: spikelets 5-9-flowered, 9-12 mm. long: glumes acute, the first 1-3-nerved, the second 3-5-nerved; lemma acute or short-pointed, smooth and glabrous, 5-6 $\mathrm{mm}$. long, indistinctly 5-nerved. TALL Fescue.-A valuable introduced hay grass; fields and waste grounds.

8. Festuca scabrella Torr. in Hook. Fl. Bor. Am. 2: 252. 1840. Culms 3-6 dm. tall, erect, usually rough below the panicle: sheaths overlapping, smooth; leaves rough, $2 \mathrm{~mm}$. wide or less, those of the culms $2.5-7.5 \mathrm{~cm}$. long, erect, the basal flat, much longer and readily deciduous from the sheaths, involute in drying: panicle 7.5-10 $\mathrm{cm}$. in length, open, its branches ascending or the lower widely spreading: spikelets 3-5-flowered, about $8 \mathrm{~mm}$. long: glumes scarious, unequal, smooth, the first 1-nerved, the second longer, 3-nerved; lemma about $6 \mathrm{~mm}$. long, scabrous, often bearing a short awn 2 mm. long or less. ( $F$. Thurberi Vasey, Rothr. Rep. 292. 1878; $F$. campestris Rydb. Mem. N. Y. Bot. Gard. 1: 57. 1900.)-In the mountains from New Mexico to Montana; apparently across the continent northward.

9. Festuca confinis Vasey, Bull. Torr. Bot. Club 11: 126. 1884. Culms tufted, erect, rigid, the base clothed with dry leafless sheaths: sheaths smooth and glabrous; leaves erect, stiff, smooth beneath, rough above, $2.5 \mathrm{dm}$. long or less, $2-4 \mathrm{~mm}$. wide, those on the culm much shorter than those of the innovations: panicle strict, narrow, 10-12 cm. long, its branches erect or appressed: spikelets usually 3-flowered, 7-8 mm. long: the glumes acute, the lemmas strongly scabrous. [F.Kingii (Wats.) Scribn.; F. Watsonii (Nash)].Sandy banks; throughout our range.

\section{BROMUS L. BRome Grass}

Rather coarse grasses with flat leaves. Spikelets 5-15-flowered, large, perfect except the upper florets, in open panicles, the triquetrous pedicels thickened upward, at length drooping. Glumes subequal, two thirds as long as the adjacent florets, acute or subacute, the first 1-3-nerved, the second 39-nerved; lemma herbaceous, rather rigid, convex or carinate, acute, denticulate or obtuse, short-awned or awnless; palets ciliate on the two keels, 
at length adhering to the prominent groove in the linear smooth ambercolored grain.

Annuals (introduced).

Lemma awned.

Awn longer than the glume

Awn shorter than the glume

Lemma not awned

Perennials (indigenous except No. $\dot{4}$ )

Lower glume 1-nerved; the upper 3-nerved.

Sheaths and leaves smooth or nearly so

Sheaths and leaves more or less pubescent or scabrous.

Panicle erect

Panicle drooping.

Leaves pilose on both sides or nearly glabrous

Leaves scabrous above, glabrous below

Lower glume 3-nerved; the upper 3-7-nerved.

Panicle drooping

Panicle erect.

Sheaths and Jeaf-blades pilose

Sheaths and leaf-blades smooth or scabrous

1. B. tectorum.

2. B. secalinus.

3. B. brizaeformis.

4. B. inermis.

5. B. Pumpellianus.

6. B. ciliatus.

7. B. Richardsonii.

8. B. Porteri.

9. B. marginatus.

10. B. polyanthus.

1. Bromus tectorum L. Sp. Pl. 77. 1753. Culms 1.5-6 dm. tall, erect from an annual root: sheaths, at least the lower ones, softly pubescent; leaves $2.5-10$ $\mathrm{cm}$. long, 2-4 mm. wide, softly pubescent: panicle 5-15 cm. in length, open, the branches slender and drooping, somewhat one-sided: spikelets numerous, 5-8-flowered, on capillary recurved slender pedicels: glumes acuminate, usually rough or hirsute, the first 1-nerved, the second longer, 3-nerved; lemma 8-12 $\mathrm{mm}$. long, acuminate, 7-nerved, usually rough or hirsute; awn $1.2-1.6 \mathrm{~cm}$. long. - A weed naturalized from Europe; rare in our range.

2. Bromus secalinus L. 1. c. 76 . Culms 4-8 dm. high: panicle 1-2 dm. long, pyramidal; branches mostly in fours or fives, verticillate, nearly smooth: spikelets 1-2 cm. long, 5-10-flowered; florets turgid: glumes obtuse or subacute; lemma obtuse, denticulate, mucronate or short-awned, smooth, 7nerved: grain concavo-convex. Closely allied and probably to be referred here is B. racemosus L. 1. c.-This is the Chess or ChEAT so often found in wheat fields.

3. Bromus brizaeformis Fisch \& Mey. Ind. Sem. Hort. Petrop. 3: 30. 1836. Culms 2-6 dm. tall: sheaths, at least the lower, pubescent with soft villous hairs; leaves $2.5-17.5 \mathrm{~cm}$. long, 2-6 mm. wide, pubescent: panicle $4-20 \mathrm{~cm}$. in length, open, the branches ascending or often drooping, flexuous: spikelets few, 1.25-2.5 cm. long, laterally much compressed: glumes very obtuse, often purplish, glabrous or minutely pubescent, the first 3-5-nerved, the second larger, 5-9-nerved; lemma 6-8 mm. long, very broad, obtuse, 9-nerved, shining, glabrous or sometimes minutely pubescent, awnless. QUAKE BROME GRAss.-An introduction from northern Europe or Asia; only occasionally found in our range.

4. Bromus inermis Leyss. Fl. Hal. 16. 1761. Culms tufted, 8-12 dm. tall: sheaths smooth and glabrous; leaves 1.5-2.5 dm. long, 4-6 mm. wide, smooth and glabrous: panicle 1.5-2.5 dm. long, oblong, the axis scabrous, its scabrous branches ascending, in clusters: spikelets $2-2.5 \mathrm{~cm}$. long, about $5 \mathrm{~mm}$. wide, oblong, erect: first glume 1-nerved, the second 3-nerved; lemma 10-12 mm. long, 5-7-nerved, awnless, or rarely awn-pointed. SMOOTH or HuNGarian Brome Grass.- Introduced and extensively grown for hay; often an escape from cultivation.

5. Bromus Pumpellianus Scribn. Bull. Torr. Bot. Club 15: 9. 1888. Stout erect perennial, with creeping rootstocks: culms smooth or sparingly pilosepubescent: leaves smooth below, scabrous or pubescent above, 1-2 dm. long: panicle narrow, erect, $10-20 \mathrm{~cm}$. long: spikelets 7-11-flowered, $2-3 \mathrm{~cm}$. long: glumes smooth; the lower 1-nerved, acuminate, 6-8 $\mathrm{mm}$. long; the upper broader and longer, 3-nerved; lemma 5-7-nerved, 10-12 $\mathrm{mm}$. long, densely and coarsely ciliate-pubescent on the margin nearly or quite to the apex and across the back at the base, the awn usually $2-3 \mathrm{~mm}$. long; palet nearly as long as tie glume; rachilla pilose-pubescent.-Colorado and far northward and westward. 
6 Bromus ciliatus L. 1. c. Culms 6-12 dm. tall, glabrous or pubescent: sheaths often softly pubescent, or the lower sometimes sparingly hirsute; leaves 1-3 dm. long, 4-12 mm. wide, smooth beneath, scabrous and often pubescent above: panicle open, 1-2.5 dm. in length, its branches widely spreading or often drooping: spikelets 5-10-flowered, $2.5 \mathrm{~cm}$. long or less: first glume 1-nerved, the second longer, 3-nerved; lemma 8-12 mm. long, obtuse or acute, 5-7-nerved appressed-pubescent on the margins or over the entire surface; awn 4-8 mm. long. (B. purgans L. is here included.)-In moist woods; in the northern part of our range and eastward to Newfoundland.

7. Bromus Richardsonii Link. Hort. Berol. 2: 281. 1833. Tufted, erect, robust, 6-12 dm. high: sheaths usually smooth below and pilose at the throat; leaves $15-25 \mathrm{~cm}$. long, usually scabrous above and glabrous beneath: panicle effuse and drooping, 15-25 cm. Jong: spikelets drooping, 6-11-flowered, 2-3 $\mathrm{cm}$. long: glumes smooth; the lower 1-nerved, 8-10 $\mathrm{mm}$. long; the upper 3- or rarely 5-nerved, 9-12 $\mathrm{mm}$. long; lemma obtuse, emarginate, 7 -nerved, 12-15 $\mathrm{mm}$. long, appressed ciliate-pubescent; the awn 3-5 mm. long; palet shorter than its lemma.-From New Mexico north into British America.

8. Bromus Porteri (Coult.) Nash, Bull. Torr. Bot. Club 22: 512. 1895. Culms 4.5-9 dm. tall, pubescent below the nodes: sheaths glabrous or sometimes softly pubescent; leaves $2-6 \mathrm{~mm}$. wide, rough, those of the culm 1-3 dm. long, the basal narrow and about one half the length of the culm: panicle $7.5-15 \mathrm{~cm}$. in length; its branches drooping and flexuous, at least when old, the nodes of the axis pubescent: spikelets 5-10-flowered, 1.8-3 cm. long, on slender flexuous pedicels: glumes pubescent, 3-nerved; lemma 1-1.2 cm. long, obtuse, 5-7-nerved, densely pubescent with long silky hairs; awn $2-4 \mathrm{~mm}$. long.Open hillsides; throughout our range.

9. Bromus marginatus Nees in Steud. Syn. Pl. Gram. 322. 1854. Culms 3-12 dm. tall, sometimes pubescent below the panicle: sheaths pubescent, at least the lower ones; leaves 1.5-3 dm. long or more, 4-12 mm. wide, rough and often pubescent: panicle 1-4 dm. in length, its branches erect or ascending, the lower 5-15 cm. long: spikelets 5-10-flowered: glumes acute, pubescent, the first 3-5-nerved, the second longer, 5-9-nerved; lemma compressed, keeled, 1.2-1.4 cm. long, acute, 7-9-nerved, appressed-pubescent; awn 4-6 mm. long. $B$. breviaristatus. (B. Kalmii occidentalis Vasey.)-Very common in the hills and mountains; New Mexico to Manitoba.

10. Bromus polyanthus Scribn. Bull. U. S. Dept. Agr. Div. Agrost. 23: 56. 1900. Stout and erect, smooth, or puberulent at the nodes, 5-10 dm. high: sheaths smooth or sparsely pilose; leaves mostly somewhat scabrous: panicle elongated, erect, its branches usually short and erect but sometimes spreading: spikelets 3-4 cm. long, 7-11-flowered: glumes broad, smooth, or somewhat scabrous; the lower 3-nerved, 6-8 $\mathrm{mm}$. long; the upper 3-7-nerved, obtuse, 10-12 mm. long; lemma 7-nerved, 12-14 mm. long, smooth or scabrous, obtuse, emarginate, with broad hyaline margins; awn 4-8 mm. long.-In open woods, especially among fallen timber; Wyoming to Washington.

\section{LOLIUM L.}

Coarse erect grasses with numerous flat leaves. Spikelets 5-10-flowered, perfect, compressed, with the edge to the axis, sessile, and alternately 2 -ranked in long rigid terminal spikes. Upper glume external, rigid, 5-7-nerved; lower glume wanting except in the terminal spikelet; lemma coriaceous, 3-5-nerved, obtuse or subacute, short-awned or awnless, convex, smooth, nearly equaled by the palet and large adherent grain.

Glume shorter than the floret

Glume longer than the floret

1. L. perenne.

2. L. temulentum.

1. Lolium perenne L. Sp. Pl. 83. 1753. Culms 4-8 dm. high: root perennial: spikelets 1-2 cm. long, exceeding the intervals: glume about equaling the adjacent floret. Perennial RYe Grass.-Sparingly introduced; sometimes cultivated. 
2. Lolium temulentum L. 1. c. Culms rather stout, 5-10 dm. high: spikelets 1-2 cm. long, of ten shorter than the intervals: glumes usually exceeding the spikelet: florets short, obtuse. DARnel.-Adventive from Europe; sometimes a troublesome weed.

\section{AGROPYRON Gaertn. Wheat Grass}

Annual or perennial grasses with flat or involute leaves and terminal spikes. Spikelets 3-many-flowered, sessile, single, and alternate at each notch of the usually continuous rachis, the side of the spikelet turned toward the rachis. Glumes empty; lemma rigid, rounded on the back, 5-7-nerved, usually acute or awned at the apex; palets 2-keeled, the keels often ciliate. Stamens 3. Styles very short, distinct; stigmas plumose. Grain pubescent at the apex, usually adherent to the palet.-Our species perennials.

Caespitose, without creeping rootstocks or stolons.

Rachis of the spike breaking up at maturity

Rachis of the spike continuous.

Spikelets strongly compressed, 8-20 mm. distant

Spikelets nearly cylindrical, 3-10 mm, distant.

Basal culm leaves longer than the upper ones.

Awns when present straight or but little divergent.

Spikes 8-20 cm. long.

Flowering glumes awned

Flowering glumes awnless or short-awned

Spikes $3-10 \mathrm{~cm}$. long

Awns widely spreading

Basal culm leaves shorter than the upper ones

Culms from creeping rootstocks, not caespitose.

Spikelets 7-13-flowered, compressed

Spikelets 3-8-flowered, subcompressed or nearly cylindrical.

Glumes half or less than half as long as the spikelets.

Spikelets $16-20 \mathrm{~mm}$. long, culms rather stout

Spikelets 10-16 $\mathrm{mm}$. long, culms slender

Glumes about equaling or two thirds as long as the spikelets :

1. A. Scribneri.

2. A. spicatum.

$\sqrt{20}$

1. Agropyron Scribneri Vasey, Bull. Torr. Bot. Club 10: 128. 1893. A densely tufted perennial with ascending culms, 2-5 dm. high: leaves rigid, attenuate-pointed, $2-3 \mathrm{~cm}$. long, $2-4 \mathrm{~mm}$. wide, the upper sheath thrice as long as the blade; pubescent on both surfaces or smooth and glaucous: spikes 4-7 cm. long, readily breaking up at maturity, the joints falling with the spikelets: spikelets 3-5 mm. distant, 3-6-flowered, the awns and glumes often purplish: glumes linear-lanceolate or narrowly oblong, 5-8 $\mathrm{mm}$. long, extended into an awn 7-25 mm. long, about 3-nerved, scabrous or hispid, little scarious on the margins; lemma smooth or granulose-scabrous on the back below, scabrous or hispid above, the strong mid-nerve extended into a spreading or recurved hispid awn 15-35 mm. long.-High mountains; Montana to Colorado and Arizona.

2. Agropyron spicatum (Pursh) Rydb. Mem. N. Y. Bot. Gard. 1: 61. 1900. A slender and often wiry, densely tufted, usually glaucous perennial, 3-9 dm. high: leaves narrow setaceous, flat or involute, with scabrous margins and smooth surfaces or minutely strigose-pubescent above; those of the culms 3-4, 4-20 cm. long, 1-3 mm. broad: spikes 6-14 cm. long: spikelets 4-12, remote, 8-20 mm. distant, erect or somewhat diverging, 3-6-flowered, 12-20 mm. long: glumes smooth, 3-5-nerved, narrowly oblong to broadly linear, acute, rarely obtuse or acuminate, prominently scarious-margined, 6-12 mm. long; lemmas smooth on the back below, 5-nerved and rarely scabrous above, 7-10 $\mathrm{mm}$. long, terminating in a stout, diverging awn 12-24 mm. long; palet as long as its glume or longer. (A. divergens Nees.) - Dry, rocky soil and bench lands; throughout our range and westward.

2a. Agropyron spicatum Vaseyi (Scribn. \& Smith) E. Nels. Bot. Gaz. 38: 378 . 1904. Culms rigid and wiry, $3-5 \mathrm{~cm}$. high: leaves $1-2 \mathrm{~mm}$. wide; those of the culms 3-8 mm. long: spikelets 4-8, 8-15 mm. long.-Range of the species.

3. Agropyron caninum (L.) Beauv. Agrost. 102. 1812. An erect smooth tufted perennial, 6-9 dm. high: leaves smooth beneath, usually rough above, 
8-25 cm. long, 2-8 mm. wide: spikes erect or nodding at the top, often onesided, 8-20 cm. long, light green or the empty glumes and awns often purplish: spikelets $4-8 \mathrm{~mm}$. distant, 3-6-flowered: glumes about as long as the spikelet, linear-lanceolate, acuminate, tipped with an awn 2-8 mm. long, 3-5-nerved, scarious on the margins, scabrous or nearly smooth, 7-9 $\mathrm{mm}$. long; lemma smooth on the back below, scabrous and 5-nerved above, extended into a slender awn 2-3.5 $\mathrm{mm}$. long, often bidentate below the origin of the awn.-Throughout our range.

4. Agropyron violaceum. (Hornem.) Lange, Consp. Fl. Groenland 154. 1880. Erect, tufted, 3-9 dm. high: leaves scabrous or sometimes smooth beneath, 5-20 cm. long, 2-6 mm. wide: spikes comparatively stout, $3-10 \mathrm{~cm}$. long: spikelets 3-8 mm. distant, 3-5-flowered: glumes usually purplish, narrowly oblong to oblong-linear, acute, rather thin, usually broadest above the middle, obtuse and toothed at apex, scarious on the margins, 3-7-nerved, scabrous, 8-13 mm. long; lemmas acuminate or tipped with a short weak awn, the awn rarely as long as the body, often purplish.-Throughout our range and northward.

4a. Agropyron violaceum andinum Scribn. \& Smith, U. S. Dept. Agr. Div. Agrost. Bull. 4: 30. 1897. Densely tufted, 20-45 cm. high: spikes short and compact: the awns as long or longer than the flowering glumes.-High mountains of Colorado.

5. Agropyron Bakeri E. Nels. Bot. Gaz. 38: 378. 1904. Smooth, tufted, the culms stout, $3-5 \mathrm{dm}$. high: leaves flat, rigid, prominently striate-nerved; those of the culms $12-20 \mathrm{~cm}$. long, $2-4 \mathrm{~mm}$. wide, those of the innovations somewhat longer: spikes scarcely exserted, equaled or exceeded by the uppermost leaf, 9-12 cm. long: spikelets terete, 5-9 mm. distant, 5-flowered, 15-19 $\mathrm{mm}$. long: glumes two thirds as long as the spikelets, narrowly oblong, somewhat abruptly narrowed into an awn $2-8 \mathrm{~mm}$. long and with or without a tooth at the base of the awn, 5-nerved, scabrous, 11-12 mm. long; lemma scabrous, or nearly smooth, the strong mid-nerve extended into a rigid widely spreading awn 10-35 mm. long, often bidentate below the origin of the awn. Southern Colorado.

6. Agropyron Gmelini (Griseb.) Scribn. \& Smith, U. S. Dept. Agr. Div. Agros. Bull. 4. 30. 1897. A rather slender, glabrous, tufted perennial 6-12 $\mathrm{dm}$. high: leaves flat, glabrous below, scabrous above; the basal ones $2-8 \mathrm{~cm}$. long, 4-6 mm. wide; those of the culm much longer: spikes slender, 10-25 cm. long: spikelets 6-20, somewhat crowded, subterete or compressed, 5-9flowered: glumes two thirds as long as the spikelet, oblong-lanceolate, acuminate and short awned, 10-14 mm. long; lemma acuminate, awned from or just below the apex with a slender, divergent scabrous awn 16-30 mm. long.Moist soil, mountains; Washington to western Wyoming.

6a. Agropyron Gmelini Pringlei Scribn. \& Smith, l. c. 31. Low and tufted, 2-3 dm. high: leaves rigid, glaucous below, strigose above, $5-10 \mathrm{~cm}$. long: spikes loose, few-flowered.-High mountains; Wyoming and California.

7. Agropyron tenerum Vasey, Bot. Gaz. 10: 258. 1885. A slender, tufted, glabrous perennial, 6 $-9 \mathrm{dm}$. high: sheaths glabrous; leaf-blades narrow, flat or involute, scabrous, $7-25 \mathrm{~cm}$. long, $2-5 \mathrm{~mm}$. wide: spikes slender, cylindrical, $8-18 \mathrm{~cm}$. long: spikelets usually erect and appressed to the rachis, $5-10 \mathrm{~mm}$. distant, 3-5-flowered. glumes from about as long as the spikelets to two thirds their length, usually broader below the middle, linear-lanceolate or narrowly oblong, acute or acuminate, often awn-pointed, scarious on the margins, 3-5-nerved and scabrous on the back, 8-12 $\mathrm{mm}$. long; lemma smooth or smoothish on the back below, scabrous and 5-nerved above, muticous or tipped with a stiff straight awn 1-4 mm. long.- Sandy soil, throughout our range.

7a. Agropyron tenerum ciliatum Scribn. \& Smith, U. S. Dept. Agr. Div. Agros. Bull. 4: 30. 1897. Sheaths pubescent or the lower ones densely hairy.-Minnesota to Utah.

8. Agropyron pseudorepens Scribn. \& Smith, U. S. Dept. Agr. Div. Agrost. Bull. 4: 34. 1897. Erect and rather stout, light green, with or without creep- 
ing rootstocks, often tufted, 3-9 dm. high with prominently striate-nerved sheath and leaves, and strict spikes: leaves rough on both surfaces, acuminate, 12-25 cm. long, 2-7 mm. wide: spikes 8-20 cm. long: spikelets 5-10 $\mathrm{mm}$. distant, the lower ones often $2-4 \mathrm{~cm}$. distant, a little compressed, 3-7-flowered: glumes equaling or one third shorter than the spikelet, linear-lanceolate, acuminate or awn-pointed, scarious on the margins, strongly 5-7-nerved, the nerves scabrous or hispidulous, 8-12 mm. long; lemma acuminate or tipped with a weak short aristate awn 1-3 mm. long, smooth and shining on the back below, 5-nerved and usually scabrous above.-River bottoms; throughout our range.

8a. Agropyron pseudorepens magnum Scribn. \& Smith, 1. c. Robust, 9-12 dm. high, the leaves and spikes longer than in the species: spikelets crowded, 24. mm. long.-Colorado and Idaho.

9. Agropyron occidentale Scribn. U. S. Dept. Agr. Div. Agrost. Cir. 27: 9. 1900. A rigid upright, glaucous perennial 3-12 dm. high, from creeping rootstocks, with strongly striate-nerved sheaths, culms, and leaf-blades: leaves rigid, smooth or slightly scabrous on the back, rough-scabrous on the margins and along the prominent nerves above, becoming involute, 10-18 cm. long, 4-6 $\mathrm{mm}$. wide; those of the innovations narrower and often half as long as the culms: spikes straight, beardless, 6-14 cm. long: spikelets compressed, spreading, 6-10 mm. distant, 7-13-flowered, 12-20 mm. long: glumes one half to two thirds as long as the spikelets, rigid, narrowly lanceolate-acuminate, usually tipped with an awn less than $3 \mathrm{~mm}$. long, 3-nerved, the mid-nerve usually strong and prominent, scarious on the margins at the middle and below, scabrous on the nerves, 7-18 mm. long; lemma smooth or granuloseroughened on the back, acute or acuminate, mucronate or tipped with an awn 2-3 mm. long.-Plains, bench lands and river bottoms; throughout our range.

9a. Agropyron occidentale molle Scribn. 1. c. Rachis, glumes, and lemma more or less villous-pubescent.-Throughout our range.

10. Agropyron dasystachyum (Hook.) Scribn. Bull. Torr. Bot. Club 10: 78. 1883. Rather stout, glaucous, from running rootstocks, smooth or finely pubescent or scabrous on the lower sheaths and on the leaf-blades above, 4-9 dm. high: leaves flat or becoming involute, 5-25 cm. long, 2-6 mm. wide; those of the innovations narrower and longer: spikes 7-17 cm. long: spikelets subcompressed or nearly cylindrical, 8-10 $\mathrm{mm}$. distant, 4-8-flowered, 16-20 $\mathrm{mm}$. long: glumes half or less than half as long as the spikelets, narrowly lanceolate or oblanceolate, acuminate or short-awned, 3-5-nerved, with rather prominent scarious white margins, villous-pubescent, 6-10 $\mathrm{mm}$. long; lemma acute, awnless, mucronate or short-awned, rarely bidentate, 5-nerved toward the apex, villous.-Sand hills and dunes; Hudson Bay to Wyoming and Idaho.

11. Agropyron subvillosum (Hook.) E. Nels. Bot. Gaz. 38: 378. 1904. A light green or somewhat glaucous perennial with running rootstocks, smooth or finely pubescent on the lower sheaths and the leaf-blades above, the culms slender, 2-7 dm. high: leaves narrow, becoming 4-18 cm. long, 1-3 mm. wide: spikes 5-16 cm. long: spikelets compressed or nearly cylindrical, 4-11 $\mathrm{mm}$. distant, 3-7-flowered, 10-16 mm. long: glumes one third to one half as long as the spikelets, lanceolate, acuminate or cuspidate-acuminate, 3-nerved, scarious on the margins, scabrous or pubescent or nearly smooth, 4-7 mm. long; lemma relatively broad, acute, truncate, mucronate or bidentate, 3-5nerved toward the apex, sparsely villous, scabrous or nearly smooth on the back.-Plains and bench lands; throughout our range, extending northward and westward.

\section{HORDEUM L. BARLEY}

Coarse erect grasses with numerous flat leaves. Spikelets 5-10-flowered, perfect, compressed with the edge to the axis, sessile and alternately 2-ranked in long rigid terminal spikes. Upper glume external, rigid, 5-7-nerved; lower glume wanting except in the terminal spikelets; lemma coriaceous, 3 -5-nerved, obtuse or subacute, short-awned or awnless, convex, smooth, nearly equaled by the palet and large adherent grain.

ROCKY мт. Вот. -6 
Spikes bushy, with spreading awns

Spikes narrow, with nearly erect awns.

Glumes aristiform

Glumes dilated above :

1. H. jubatum.

2. H. nodosum.

3. H. pusillum.

1. Hordeum jubatum L. Sp. Pl. 85. 1753. Short-lived perennial or annual: culms $2-5 \mathrm{dm}$. high: spike $1 \mathrm{dm}$. long or less, light green or yellow, very fragile; lateral flowers reduced to awns slightly exceeding the perfect floret: glumes aristiform, slightly exceeded by the awn of the perfect floret.Prairies, Texas to Minnesota and westward; a very troublesome weed, in meadows; commonly called FoxtaIL, but more properly SQUIRRELTAIL Grass.

2. Hordeum nodosum L. Sp. Pl. Ed. 2. 56. 1762. Perennial (?): culms 4-8 dm. high: spike narrow, 4-8 dm. long, usually dark green or purple; lateral spikelets staminate or neutral, awnless: glumes aristiform, about $1 \mathrm{~cm}$. long, equaling the awn of the perfect floret. WILD BARLEY.-Common in our range in saline soils; extending to Arizona and Alaska.

3. Hordeum pusillum Nutt. Gen. 1: 87. 1818. Annual:-culms 3-5 dm. high, slender, weak: spikes 3-6 cm. long; lateral spikelets staminate or neutral, awnless: four anterior empty glumes broadened above the narrow stalk-like base, tapering above into a rigid awn about $1 \mathrm{~cm}$. long, equaling the awn of the perfect floret.-From Idaho to Arizona and eastwand through the southern States.

\section{ElyMUS L. Wild Rye. Lyme Grass}

Rather coarse grasses with flat rough leaves. Spikelets 2-7-flowered, all perfect except the upper florets, compressed, sessile in clusters or 2 to 4 at each node in the spike. Glumes nearly side by side in front of the spikelets, 2 for each, thickened and nervose or aristiform; lemma coriaceous or rigid,' convex, very acute or awned, nearly equaled by the palet. Grain linear, channeled, adhering to the palet and enveloping lemma.

Lemma conspicuously awned.

Spikelets divergent from the rachis of the broad spike

Spikelets appressed to the rachis of the narrower spike. Spikelets 3-6-flowered

Spikelets 1-3-flowered

Lemma short-awned or merely acute.

Relatively low and slender, usually less than $1 \mathrm{~m}$. high.

Spike densely villous-pubescent

Spike glabrate.

Flowering glume 7-nerved above

Flowering glume indistinctly 5-nerved. Leaves smooth or merely roughened Leaves pubescent beneath

Tall and coarse, tufted, often $2 \mathrm{~m}$. high

1. E. canadensis.

2. E. glaucus.

3. E. Macounii.

4. E. innovatus.

5. E. triticoides.

6. E. ambiguus.

7. E. salinus.

8. E. condensatus.

1. Elymus canadensis L. Sp. Pl. 83. 1753. Culms stout, 5-10 dm. high: spike usually nodding, 1-2 dm. long: spikelets mostly in pairs, 3-5-flowered, hispid or pubescent throughout: glumes narrowly lanceolate, indistinctly 3 -nerved, tapering into a rather rigid awn 1-2 cm. long and about one half as long as the divergent awns of the 5-nerved lemma. The following are very closely related if indeed they be not mere forms of this: $E$. robustus Scribn. \& Sm. U. S. Dept. Agr. Div. Agrost. Bull. 4: 37. 1897; E. hirsutiglumis Scribn. \& Sm. 1. c. 11: 56. 1898; E. brachystachys Scribn. \& Ball, 1. c. $24: 47$. 1900Across the continent northward, and south through our range to $\mathrm{New}$ Mexico and Texas.

2. Elymus glaucus Buckley, Proc. Acad. Phila. 1863: 99. Culms 6-15 dm. tall: sheaths rarely pubescent: leaves 1-3 dm. long, 4-16 mm. wide, smooth beneath, sometimes rough above: spike 7.5-20 cm. in length, narrow, slender: spikelets appressed to the rachis, 3-6-flowered: glumes narrowly lanceolate, 8-12 mm. long, acuminate or awn-pointed, rigid, 3-5-nerved; lemmas smooth or slightly rough, 1-1.2 cm. long, bearing a slender straight rough awn 1.2-1.8 $\mathrm{cm}$. in length. $E$. sibiricus. - Throughout our range and west to the Pacific States.

3. Elymus Macounii Vasey, Bull. Torr. Bot. Club 13: 119. 1886. Culms 
3-9 dm. tall: leaves 5-15 $\mathrm{cm}$. long, 2-5 mm. wide, rough, especially above: spike 5-12.5 cm. in length, narrow, slender, often somewhat flexuous: spikelets appressed to the rachis, single at each node, or the lower sometimes in pairs, 1-3-flowered: glumes (occasionally 3) awn-shaped, 3-nerved, rough, 6-8 mm. long, bearing a slender straight rough awn, 6-10 mm. in length; lemmas 7-10 $\mathrm{mm}$. long, rough toward the apex, bearing a slender straight awn 6-10 $\mathrm{mm}$. long.-From New Mexico into British America.

4. Elymus innovatus Beal, N. Am. Gr. 2: 650. 1896. Culms slender, erect, rather rigid, 5-8 dm. high: basal leaves scabrous, flat or involute, $2-3 \mathrm{dm}$. long; culm leaves about 3 , the sheaths shorter than the internodes; ligule very short; the blades 4-10 cm. long: spike erect, densely ciliate-pubescent: spikelets 3-6-flowered, 10-15 mm. long, 2 at each node: glumes mere bristles, 4-12 $\mathrm{mm}$. long; lemma ovate-lanceolate, $8-9 \mathrm{~mm}$. long; palet as long as its lemma. -Wyoming to Dakota and British Columbia.

5. Elymus triticoides Buckley, 1. c. Culms from rootstocks, rather slender, 5-8 dm. high: leáves $15-25 \mathrm{~cm}$. long, erect, often loosely flowered: spikelets 1-3 at each node, 4-8-flowered: glumes equal, linear-lanceolate, rigid, acuminate, 6-10 $\mathrm{mm}$. long, equaled by the floret; lemma firm, lanceolate, acuminate or short-awned, nerves indistinct below, 7 above.-Colorado to Montana, west to the Pacific States.

6. Elymus ambiguus Vasey \& Scribn. Contrib. Nat. Herb. 1: 280. 1893. Rigid and densely tufted, 5-10 dm. high: leaves of the sterile shoots erect, 3-4 $\mathrm{dm}$. long, involute, smooth or scabrous; culm leaves about 4, 1-2 dm. long; the ligule short: spikes erect, $8-12 \mathrm{~cm}$. long, rachis scabrous: spikelets 2 at each joint, or sometimes single near the end, scabrous, 5-9-flowered: glumes subulate, 12-15 mm. long; lemma firm, obscurely 5-nerved, 8-12 mm. long, the short teeth unequal; awn about $2 \mathrm{~mm}$. long; palet as long as the lemma.Colorado to Montana.

7. Elymus salinus Jones, Proc. Cal. Acad. II. 5: 725. 1895. A rigid wiry erect densely caespitose perennial 3-6 dm. high: leaves rather rigid, involute, narrow and spreading: spikes erect, $5-10 \mathrm{~cm}$. long: spikelets usually only one at each node, about $12 \mathrm{~mm}$. long, 5-9-flowered: glumes nearly subulate, unequal; lemma short-awned, about $8 \mathrm{~mm}$. long. (E. simplex S. \& W. U. S. Dept. Agr. Div. Agrost. Bull. 11. 57. 1898.)-Saline situations; Wyoming and Utah.

8. Elymus condensatus Presl. Reliq. Haenk. 1: 265. 1830. Culms 6-30 $\mathrm{dm}$. tall: leaves $1.5-3 \mathrm{dm}$. long or more, 6-24 $\mathrm{mm}$. wide, scabrous, at least above: spike 1-4 dm. in length, usually stout, strict, of ten interrupted below, sometimes compound at the base: spikelets 3-6-flowered, 2-several at each node of the rachis: glumes awl-shaped, 9-12 $\mathrm{mm}$.long, generally awn-pointed, usually rough, sometimes smooth.-Valleys, banks, and ravines mostly in saline situations; throughout our range and westward.

\section{SITANION Raf.}

Tufted grasses with flat or involute leaves and a terminal dense spike with the rachis articulated and readily breaking up. Spikelets numerous, in twos or threes at each joint, 1-5-flowered. Glumes entire or divided, the divisions extending often to the base, the lemmas or their divisions bearing long slender awns; palet 2-keeled. Stamens 3. Styles distinct, short; stigmas plumose. Grain adherent to the palet.

Leaves and sheaths glabrate or scabrous.

Leaves long and flexuous

Leaves short and rigid

Leaves and sheaths more or less pubescent.

Leaves pubescent on both sides

Leaves pubescent beneath, scabrous above
1. S. longifolium. 2. S. brevifolium.

3. S. hystrix.

4. S. montanum.

1. Sitanion longifolium J. G. Smith, U. S. Dept. Agr. Div. Agrost. Bull. 18. 1899. Tufted, $3-5 \mathrm{dm}$. high: leaves of the innovations $1.5-3 \mathrm{dm}$. long, often as long as the culms, glabrous and glaucous or obscurely pubescent: spike sub- 
flexuous or somewhat nodding: spikelets usually 2 at each node: glumes setaceous, divaricate; lemma scabrous, tipped with a stout scabrous awn 5-6 cm. long.- -New Mexico to Wyoming and westward.

2. Sitanion brevifolium J. G. Smith, 1. c. 17. Tufted, 2-4 dm. high: culms faintly striate, glaucous: innovations not more than half the length of the culms: sheaths smooth; leaves flat or involute, 5-10 cm. long, smooth beneath, subscabrous above: spike long-exserted: glumes divergent, 5-9 $\mathrm{mm}$. long, scabrous above; lemma 8-10 mm. long, linear-lanceolate, tipped with a stout scabrous awn 4-8 cm. long; palet obtuse, as long as its lemma. The following, published in the revision of the genus by J. G. Smith, do not seem readily separable from this species, at least in so far as the plants of our range are concerned: S. pubeflorum, S. rigidum, S. glabrum.

3. Sitanion hystrix (Nutt.) J. G. Smith, 1. c. 15. Softly and minutely pubescent, low, 1-3 dm. high, in dense spreading tufts: innovations very leafy, about half as long as the culms: leaves flat or at length involute, prominently 9-nerved, erect or ascending, 7-12 cm. long: spikes 5-7 cm. long: spikelets 3-4-flowered: glumes bifid, unequally 2-awned, the awns divergent, 3-4 cm. long; lemma 7-8 $\mathrm{mm}$. long, 3-awned, the middle awn slender, recurved; palet 2-awned.-In the desert areas of our range, especially in dry saline soils.

4. Sitanion montanum J. G. Smith, 1. c. 16. Culms $2-4 \mathrm{dm}$. high, scabrous above: sheaths and leaves more or less finely scabrous; blades $5-10 \mathrm{~cm}$. long: spike 5-10 cm. long: glumes subulate, scabrous, long-awned; lemma 10-11 mm. long, linear-lanceolate, scabrous above, trifid, 3-awned; the middle awn 4-7 cm. long; the two lateral quite short and slender. (S. molle J. G. Smith, 1. c. 17.) - This may be the original of Rafinesque's Sitanion elymoides (Elymus Sitanion Schult.), but this is mere conjecture. The segregates of Sitanion elymoides, a few of which have been here given, are none too distinct, and it is perhaps better to retain the old name for the group.-Frequent; Wyoming and Montana to Oregon.

\section{CyPERACEAE J. St. Hil. Sedge Family}

Grass-like or rush-like herbs. Stem leaves when present 3-ranked. Stems (culms) usually solid, triangular, quadrangular, flattened or terete. Leaves with closed sheaths, mostly narrow. Flowers perfect or imperfect, arranged in spikelets one in the axil of each scale (glume, bract); the spikelets solitary or in spicate clusters. Scales 2-ranked or spirally imbricated. Perianth wanting or of hypogynous bristles (rarely calyx-like). Stamens 1-3. Styles 2-3. Fruit a lenticular or trigonous achene.

Flowers perfect; the spikes capitate or umbellate.

Spikelets flattened, with the scales in 2 ranks; perianth wanting.

Spikelets not flattened, the imbricated scales all around; perianth,

1. Cyperus.

in the form of bristles, usually present.

Stamens mostly 3; perianth of 1-several bristles.

Bristles few and short, at the base of the achene. Leaves (at least the basal) well developed

Leaves reduced to only a sheathing base

Bristles many, long-exserted

Stamens 1; perianth wanting

Flowers imperfect (monoecious or dioecious); spikelets solitary, spicate or paniculate.

Achene naked

Achene inclosed in an inflated sac-like persistent perigynium $\quad$ : 7. Carex.

\section{CYPERUS L.}

Mostly with triangular and nearly naked simple stems, sheathed at base by the nearly radical leaves. Inflorescence subtended by a mostly conspicuous leafy involucre, usually irregularly umbellate with unequal rays, the spikelets 
in spikes solitary or clustered upon the rays, the central spike or cluster always sessile, and the whole often contracted into a single more or less dense head. Scales concave or keeled, often decurrent upon the rachis. Achene lenticular or triangular, not beaked, usually smooth.

Small annual; stamen 1

Perennials; stamens 3.

Spikes in a dense head

Spikes in an unequal-rayed umbel :

1. C. inflexus.

2. C. filiculmis.

3. C. Schweinitzii.

1. Cyperus inflexus Muhl. Gram. 16. 1817. Low annuals, with a 2-3leaved involucre: spikes oblong, becoming linear, 7-13-flowered, in 1-5 ovate heads: scales nerved, tapering into a long recurved point: stamen 1: achene obovate, obtuse. C. aristatus. Said to be sweet-scented in drying.-Frequent in our range; across the continent.

2. Cyperus filiculmis Vahl. Enum. 2: 328. 1806. Perennial, with hard clustered corm- or bulb-like tubers at the base of the stem: stem slender, wiry, often reclined: leaves linear: spikes numerous and clustered in one sessile dense head, or in 1 to 7 additional looser heads on spreading rays of an, irregular umbel: joints of the axis naked: scales blunt, greenish, strongly 7-11 nerved: stamens 3: achenes gray, 3-angled, obtuse, apiculate--Extending into Colorado from the east.

3. Cyperus Schweinitzii Torr. Ann. Lyc. N. Y. 3: 276. 1836. Perennial: culms with thickened corm-like bases, rough on the angles, $2-5 \mathrm{dm}$. high: leaves linear: umbel simple, 4-8-rayed: spikes crowded along the upper part of the mostly elongated rays, erect: scales awl-pointed: joints at the axis narrowly-winged: stamens 3: achene brown, sharply 3-angled, acute at each end.-Colorado, northward and eastward to New York.

\section{SCIRPUS L. Rush. BulRush}

Tufted plants, with creeping rootstocks, the stem sheathed or leafy at base, and the spikelets in an apparently lateral cluster, or compound umbel-like panicle, or solitary. Hypogynous bristles 3-6, barbed or ciliate, or wanting. Style 2-3-cleft. Achene lenticular or more or less triangular, obovoid.

Spikelets solitary, terminal.

Marsh plant; achene reticulated

Terrestrial plant; achene smooth

Spikelets normally more thain 1.

Spikelets few-several, sessile or nearly so, in crowded capitate cluster.

Leaves reduced to sheathing bracts at the base . . . . Leaves well developed.

Involucral leaves flat and broad.

Rootstocks often tuberous; bristles longer than the achene
Rootstocks not tuber-bearing; bristles shorter than the

achene or wanting
Involucral leaves folded-triangular, narrow.

Stem terete

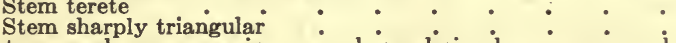

Spikelets several-numerous, in unequal-rayed simple or compound umbellate panicles.

Leaves reduced to sheaths or the lowest sheath developing a blade

Leaves well developed.

Bristles more or less barbed.

Achene 3-angled; styles 3. Spikes large

Spikes small and very numerous

Achene plano-convex, carinate on back;

Bristles not barbed, long and tortuous

1. S. pauciflorus.

2. S. caespitosus.

3. S. Olneyi.

4. S. paludosus.

5. S. campestris.

6. S. nevadensis.

7. S. americanus.

8. S. lacustris.

9. S. fluviatilis.

11. S. microcarpus.

12. S. lineatus.

1. Scirpus pauciflorus Light. Fl. Scot. 1078. 1777. Perennial by filiform rootstocks: stems very slender, little tufted, 1-2 dm. high, upper sheaths truncate: spikelets solitary, oblong, 4-10-flowered, 4-6 mm. long; scales brown with lighter margins and midrib, lanceolate, acuminate: bristles 2-6, hispid, as long as the achene or longer: stamens 3: style 3-cleft: achene obovoidoblong, gray, rather abruptly beaked, its surface finely reticulated.-Extends across the continent; occasionally in our range, especially northward. 
2. Scirpus caespitosus L. Sp. Pl. 48. 1753. Stems terete, filiform, in compact turfy tufts, densely sheathed at the base, the upper sheath bearing a very short awl-shaped leaf: scales of the ovoid spike rust-colored: involucral bract a rigid-pointed scale, resembling the lowest proper scale of the spike: bristles 6 , smooth, longer than the smooth abruptly short-pointed achene.-Colorado and Wyoming; across the continent northward.

3. Scirpus Olneyi Gray, Bost. Journ. Nat. Hist. 5: 238. 1845. Stem 3-wingangled, with deeply excavated sides, 4-12 dm. high, the upper sheath bearing a short triangular leaf or none: spikes 6-12, closely capitate, overtopped by the short involucral leaf: scales orbicular, smooth, mucronate-pointed: anthers with a very short and blunt minutely-bearded tip: bristles 6 , downwardly barbed: achene obovate, plano-convex, brown, mucronate.-Across the southern part of the continent (possibly reaching Colorado) and northward in the Atlantic States.

4. Scirpus paludosus A. Nels. Bull. Torr. Bot. Club, 26: 5. 1899. Perennial from corm-like tubers and horizontal rootstocks: culms 4-8 dm. high, triangular, one face narrow and grooved: leaves equaling or exceeding the culms, 5-8 mm. wide, strongly nerve-grooved: involucral leaves 2, unequal, long: spikelets 3-several, sessile in a dense cluster, ovate or oval, 10-20 mm. long, brown: scales narrowly ovate, membranous, puberulent, 2-toothed and the midrib prolonged into an awn: bristles usually 2, twice as long as the achene: achene lenticular, $3 \mathrm{~mm}$. long, broadly and truncately obovate, tipped with a tooth; the surface shiny, finely pitted (under a lens). S. maritimus.-Margins of alkali ponds and lakes; said to range eastward to New England.

5. Scirpus campestris Britton, Ill. Fl. 1: 267. 1896. Very similar to the preceding, 3-5 dm. high: leaves pale green, smooth, $2-4 \mathrm{~mm}$. wide: involucral leaves $2-3$, the longer one much surpassing the inflorescence: spikelets $3-10$, oblong-cylindric, 15-25 mm. long, pale brown: scales ovate, 2-toothed and awned: bristles 1-3, much shorter than the achene or none: style 2-cleft: achene lenticular, obovate or oblong-ovate, mucronulate, yellow-brown, its surface strongly cellular-reticulated.-On the prairies and coming into our range from the east; said to extend west to Nevada.

6. Scirpus nevadensis Wats. King's Exp. 360. 1871. Stems clustered, from running rootstocks, 1-5 dm. high, somewhat flattened above, leafy: leaves nearly equaling the stem, deeply channeled or revolute, very rough on the margins, sharply acute, 1-2 cm. long: scales brown and shining, ovate, sharply carinate, acutish: bristles 1-3, not half the length of the achene: style 2-cleft: achene broadly ovate, plano-convex, acute, $2 \mathrm{~mm}$. long.-Wet saline soils; Wyoming to California.

7. Scirpus americanus Pers. Syn. 1: 68. 1805. Stem sharply 3-angled throughout, 2-10 dm. high, with concave sides: leaves 1-3, elongated: spikes 1-6, capitate, usually long, overtopped by the pointed involucral leaf: scales ovate, sparingly ciliate, 2-cleft at the apex and awl-pointed from between the acute lobes: anthers tipped with an awl-shaped minutely fringed appendage: bristles 2-6, about equaling the obovate dark brown plano-convex smooth mucronate achene. S. pungens.-From the Atlantic to the Pacific, and not infrequent in our range.

8. Scirpus lacustris L. Sp. Pl. 48. 1753. Stems $0.5-2 \mathrm{~m}$. high, leafless or the lower sheaths bearing imperfect leaves: spikes rusty or chestnut-brown, numerous and clustered in a one-sided compound umbel-like panicle, tho principal rays of which mostly surpass the involucral leaf: scales with a salient midrib extending into a mucronate point, often pubescent, especially on the mid-vein; usually pale with fine brown lines: bristles not exserted: achene broadly obovate, terminating abruptly in a rather short beak.-Widely distributed in North America and frequent in our range.

9. Scirpus fluviatilis (Torr.) Gray, Man. 527. 1848. Stem stouter and taller: leaves flat, broadly linear, the upper and those of the very long involucre much exceeding the compound umbel: rays 5-9, elongated, recurvedspreading: scales less lacerate and their awns less recurved: achene obovate, sharply and exactly triangular, conspicuously pointed, dull, scarcely equaling 
the bristles.-Borders of lakes and streams; from western Vermont to Illinois and Wisconsin, and extending into our range at its northeastern border.

10. Scirpus atrovirens Muhl. Gram. 43. 1817. Leaves somewhat more rigid: spikelets dull greenish-brown, densely conglomerated (10-30 together) into close heads, these also usually densely clustered in a less compound panicle: scales pointed: bristles sparsely and strongly downwardly barbed above the middle, naked below, nearly straight, as long as the conspicuously pointed and obovate-oblong triangular achene.-Wet meadows and bogs; Colorado and northward, and then across the continent.

11. Scirpus microcarpus Presl. Rel. Haenk. 1: 105. 1823. Stem tall and very leafy: the umbel-like or cymose panicle irregular, compound or decompound: the longer leaf of the inflorescence exceeding the panicle: spikelets ovoid-oblong, acute, 3-25 together in capitate clusters: scales brown with a green midrib, obtuse or acute: bristles 4 , barbed to the base: stamens 2: style 2-cleft: achene oblong-obovate, plano-convex, somewhat ridged on the back. $S$. sylvaticus digynus.-Frequent in our range and extending west to California.

12. Scirpus lineatus Michx. Fl. Bor. Am. 1: 32. 1803. Stem triangular, leafy, 2-8 dm. high: leaves linear, flat: umbels terminal and sometimes axillary, loose, drooping, the terminal with a 1-3-leaved involucre much shorter than the long slender rays: spikes oblong, becoming cylindrical, on filiform drooping pedicels: bristles at maturity scarcely exceeding the green-keeled and pointed scales, capillary, naked, not barbed, elongating, becoming tortuous and entangled, much longer than the triangular achene.-From New England to Wisconsin and southward, coming into our range from western Kansas.

\section{EleOCHARIS R. Br. Spike Rush}

Stems tufted, from matted or creeping rootstocks, terete or angular, the base covered with closely appressed sheaths: lower scale of the spikelet sometimes enlarged and bract-like. Scales closely imbricated all around the rachis. Perianth of 3-9 short retrorsely barbed bristles, rarely none. Style 2-3-cleft, the conical or flattened tuberculate base persistent and mostly jointed upon the summit of the turgid-triangular or lenticular achene.

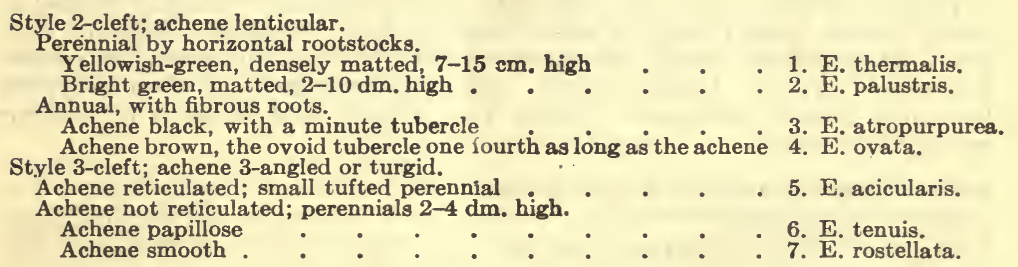

1. Eleocharis thermalis Rydb. Mem. N. Y. Bot. Gard. 1: 69. 1900. Perennial from a slender creeping rootstock, mostly tufted and matted, yellowish green: culms 3-10 cm. high, somewhat flattened, striate: upper sheath with a hyaline limb: head obovate, obtuse, about $4 \mathrm{~mm}$. long and $3 \mathrm{~mm}$. in diameter, light yellowish green; scales very thin, ovate, acutish: achenes lenticular, broadly obovate, dark brown, smooth and shining, about $1 \mathrm{~mm}$. long, about four times as long as the conic acute tubercle. E. olivacea.-Wyoming, Yellowstone Park, Montana.

2. Eleocharis palustris (L.) R. \& S. Syst. 2: 151. 1817. Stems usually slender, terete, striate, $2-10 \mathrm{dm}$. high: spike oblong-lanceolate to linear, acute, 10-25 mm. long: scales obtuse or the upper acutish, thin, brown with white margin and greenish keel: bristles 4 , about equaling the achene: achene obovate, turgid, smooth; tubercle broad-deltoid, acutish or acute, rarely acuminate. - Throughout the continent, and in most parts of the Old World.

3. Eleocharis atropurpurea (Retz.) Kunth. Enum. 2: 151. 1837. Annual, 
roots fibrous: culms tufted, very slender, $2-9 \mathrm{~cm}$. high: spikelet ovoid, manyflowered, subacute, 3-4 mm. long: scales minute, ovate-oblong, persistent, purple-brown with green mid-vein: stamens 2-3: style 2-3-cleft: bristles 2-4, fragile, white, minutely downwardly hispid, about as long as the achene: achene jet black, shining, $0.5 \mathrm{~mm}$. long, smooth, lenticular; tubercle conic, minute.-From Colorado to Nebraska and Iowa.

4. Eleocharis ovata (Roth) R. \& S. Syst. 2: 152. 1817. Culms nearly terete, 1-3 dm. high: spikelets globose-ovoid to ovate-oblong, obtuse, 2-10 $\mathrm{mm}$. long, dull brown: scales very obtuse, densely crowded in many ranks: style 3-cleft: achene obovate, with narrow base, pale brown, shining, shorter than the 6-8 bristles, broader than the short-deltoid acute and flattened tubercle.-Muddy shores; probably within the eastern part of our range.

5. Eleocharis acicularis (L.) R. \& S. 1. c. Stems with fibrous roots and very slender running rootstocks, usually setaceous, 3-20 cm. high: spike 3-9flowered: scales acutish, more or less deeply tinged with brown: bristles 3 or 4 , of ten wanting: achene oblong-obovate, obscurely triangular and faintly ribbed on the sides; tubercle broad, short and blunt, contracted at its junction with the achene.- On sandy or muddy stream banks across the continent.

6. Eleocharis tenuis (Willd.) Schultes, Mant. 2: 92. 1824. Culms almost capillary, erect from running rootstocks, 4-angular and flattish, the sides concave: spikelet elliptical, acutish, 20-30-flowered: scales ovate, obtuse, chestnutpurple, with a broad scarious margin and green keel: achene obovate, roughishwrinkled, crowned with a small depressed tubercle, persistent after the fall of the scales: bristles one half as-long as the achene or none.-On our eastern border and throughout the eastern half of the United States.

7. Eleocharis rostellata Torr. Fl. N. Y. 2: 347. 1843. Culms flattened and striate-grooved, wiry, erect, the sterile ones reclining, rooting and proliferous from the apex, the sheath transversely truncate: spikelet spindle-shaped, 12-20-flowered: scales ovate, obtuse, light brown: achene obovate-triangular, narrowed into the confluent pyramidal tubercle, which is overtopped by the 4-6 bristles.-Across the continent; infrequent in our range.

\section{ERIOPHORUM L. CotTON GRASS}

Perennials with creeping rootstocks and sometimes enlarged corm-like bases. Stem (culm) leafy or often nearly naked. Spikelets single or clustered, or umbellate, usually involucrate, with erect scale-like membranaceous 1-3-nerved bracts. Bristles naked, usually very numerous, often silky and becoming greatly elongated. Style very slender and elongated. Achene acutely triangular.

Achene obovate; bristles more than $2 \mathrm{~cm}$. long.

Bracts oval or ovate, obtuse .

Bracts ovate-lanceolate

Achene linear-oblong; bristles less than $2 \dot{\mathrm{cm}}$. long

1. E. ocreatum.

2. E. polystachyon.

3. E. gracile.

1. Eriophorum ocreatum A. Nels. Bull. Torr. Bot. Club 29: 400. 1902. Culms growing singly from the corm-like crowns of the short slender rhizomes, finely striate, smooth, slender, 2-3 dm. high: sheaths 2-3, 2-3 cm. long, all blade-bearing; blades broadly linear, rather rigid, short, $5-10 \mathrm{~cm}$. long: leaves of the involucre $2-4$, the longer usually surpassing the inflorescence: spikelets $3-6$, subumbellate, the longer-peduncled ones drooping: scales oval or ovate, obtuse or scarious-lacerate, brown: bristles numerous, glistening-white, 4-6 times as long as the scales: achene broadly obovate, obtuse, dark brown.-Cold, wet subalpine parks; Wyoming and Colorado.

2. Eriophorum polystachyon L. Sp. Pl. 52. 1753. Stems stiff, smooth, triangular above, nearly terete below, 3-8 dm. high, leafy: leaves flat, shorter than the stem, tapering to a triangular rigid point: involucre of 2-4 leaves, commonly equaling or exceeding the inflorescence: spikelets $3-12$, ovoid or oblong, nodding, in a terminal more or less compound umbel; rays filiform: scales ovate-lanceolate, acute, or acuminate, purple-green or brown: bristles 
numerous, bright white, 25-30 $\mathrm{mm}$. long: achenes obovoid, obtuse, light brown.-In cold bogs; from Colorado to Canada and east to the Atlantic States.

3. Eriophorum gracile Koch, Roth, Cat. Bot. 2: 259. 1800. Culms slender, 2-4 dm. high, somewhat triangular: leaves slender, channeled-triangular, rough on the angles: involucre short and scale-like, mostly 1-leaved: peduncles rough or roughish-pubescent: spikelets $3-7$, small, when mature the copious white wool 12-15 mm. long: scales light.brown, 3-nerved: achene linearoblong.-Cold bogs; across the continent through the northern tier of States.

\section{HEMICARPHA Nees.}

Spikelet, flowers, etc., as in Scirpus except that there is a minute translucent scale (readily overlooked) between the flower and the axis of the spikelet. Stamen only one. Styles 2-cleft. Bristles or other perianth none.

1. Hemicarpha aristulata (Coville) A. Nels. Bull. Torr. Bot. Club 29: 460. 1902. Annual, glabrous, culms few to several, erect, $8-15 \mathrm{~cm}$. high, filiform or capillary, exceeding the capillary leaves: involucral leaves $2-3$, unequal, 5-20 mm. long: spikes 2 (sometimes only 1 ), ovoid, $3-5 \mathrm{~mm}$. long: scales rhombic, acuminate, the body nearly $1 \mathrm{~mm}$. long, scarious-margined, some of the margins turning brown, with a green midrib and inconspicuous nerves; the acumination green, subulate, somewhat spreading, nearly as long as the body of the scale or in the lower ones longer: sepal large, as long as the ovule, obtuse or even with a truncate or toothed apex: filament barely exceeding the ovule: style short, its branches inconspicuously if at all barbellulate: achene obovoid, shorter than the body of the scale.-Rare; moist sandy cañons: eastern part of our range, to Kansas and Texas.

\section{ELYNA Shrad.}

Perennial herbs with filiform leaves, radical or sheathing the stems at base. Lowest glume inclosing an ovary with a long trifid style; the next one, or rarely the next two, inclosing 3 stamens; often a rudimentary glume or awn terminating the rachis; occasionally only one glume to a spikelet.

1. Elyna Bellardii (All.) Koch, Linnaea 21: 616. 1848. Stems caespitose, 1-3 dm. high, striate-angled: leaves shorter than the stem: spikelets few, small, and brown, in a somewhat clavate spike 20-25 $\mathrm{mm}$. long. Kobresia scirpina.-The Colorado mountains.

\section{CAREX L.* SEDGE}

Perennial grass-like herbs, with 3-ranked leaves, mostly triangular culms, and spikes in the axils or exserted from the sheaths of leaf-like or scale-like bracts. Flowers in spikes, imperfect, the staminate and pistillate in different parts of the same spike (spike androgynous), or in separate spikes on the same culm (plant monoecious), or rarely on entirely distinct plants (plants dioecious). Staminate flower composed of three stamens borne beneath a bract or scale. Pistillate flower composed of a single pistil bearing 2 or 3 exserted styles, forming in fruit a lenticular or triangular achenium which is inclosed in a more or less inflated sac (perigynium) borne in the axil of a scale.

Theoretically each flower is entirely destitute of floral envelopes, and borne on a branch which springs from the axil of a scarious bract (the scale of the following descriptions), the inclosing perigynium of the fertile flowers answering to one (or two) connate bractlet. In the subgenus Vignea of the present

* The treatment of this genus remains essentially unchanged. As prepared for the original Manual by Dr. L. H. Bailey, both the keys and the full diagnoses have proven unusually satisfactory. Relatively few new species have been described in the meantime. some of these have been inserted and some of the seemingly extralimital ones have been excluded. Changes in nomenclature are of course noted. Though the treatment is not quite in harmony with the rest of this volume, it seems well to retain both the artificial and the natura: keys. 
elaboration, the spikelets or spiculae of authors are called spikes, which they truly are, and they are conglomerated into heads. The genus is an exceedingly critical one and its study should not be attempted with unripe or imperfect specimens.

I. Spike one, terminal, strictly simple, staminate at the top, or in dioecious plants ( $4 \& 33$ ) all staminate or all pistillate.

Stigmas three.

Perigynium spindle-shaped or lanceolate, dark brown or purple

Perigynium short, mostly ovate or elliptic.

Perfectly smooth.

Perigynia 1 to 3 , conspicuously spreading, or remote from the staminate portion. Obovate, obtuse

Elliptic, sharply beaked

Perigynia several, continuous with the staminate portion.

Scales leaf-like

Scales short, ciliate

Scales short, entire.

Very broad, covering the perigynium

\section{Scabrous or hairy.}

Perigynia 1 to 4 , scabrous above Stigmas two

Perigynia several to many, hairy

II. Spikes all aggregated into a round or ovoid uninterrupted head, stigmas two.

Spikes densely packed, the individual ones scarcely discernible.

Head tawny or brown.

Subtended by 1 or 2 long leafy bracts.

Naked or nearly so.

Perigynium nearly orbicular, dark . . . . . . . . . 57

Perigynium ovate or lanceolate.

Spikes staminate at base . • • • • • • . 63,64,65,66

Spikes staminate at top.

Perigynium rough-angled

Head green

Perigynium smooth.

Spikes simply aggregated, the individual ones readily recognized.

Spikes nearly linear, light colored

Spikes oval or ovoid.

Perigynium wing-margined.

Broadly ovate or oval

Lanceolate

Perigynium wingless.

Nerved, beak longer than the body.

Nerveless.

Heads small, globular

Heads oblong

III. Some or all of the spikes distinct.

Terminal spikes staminate above (staminate flowers inconspicuous), spikes often all

approximated into an interrupted head or panicle, stigmas always two.

Perigynium strongly nerved

Perigynium nerveless or nearly so

Terminal spike staminate below.

Stigmas two.

Spikes very dark

Spikes tawny or whitish.

Perigynium lanceolate.

Thin and scale-like

More or less thick and rounded.

Heads fulvous

Heads silvery or silvery-tawny

Perigynium ovate, wing-margined

Perigynium ovate, not margined 
Spikes oblong or long-cylindrical.

Perigynium ovate, green or brown-purple - . - . 27, 28, 29, 31, 32 Stigmas three.

$27,29,31,32$

Perigynium hairy.

Pistillate spikes few-flowered, almost globular, mostly sessile.

Scales ciliate

Scales not ciliate.

Spikes greenish; culms slender . • • • • • • . $6 a, 6 b$

Spikes colored

Pistillate spikes several to many-flowered, oblong or cylindrical.

Perigynium conspicuously nerved

Perigynium nerveless or nearly so.

Plant hairy throughout

Plant smooth

Perigynium smooth.

Pistillate spikes pendulous or nodding.

Beak slender, longer than body of perigynium; spikes greenish-white $\quad . \quad 17$

Body of perigynium as long or longer than beak.

Spikes small, 6 or fewer-flowered; plant delicate . • . . . 15

Spikes oblong, pendulous, dark

Spikes thick and long; perigynium infiated.

Perigynium greenish straw-colored, slender-beaked, conspicuously more than 10-nerved

Perigynium straw-colored or often purplish.

More or less ascending

Spikes all erect.

Conspicuously squarrose

Short-oblong, densely flowered.

Beak short, stout, truncate

Beak longer than body

Cylindrical; perigynium beaked.

Perigynium lanceolate, flattened

Perigynium thin, inflated, straw-colored or purple. More or less ascending

Conspicuously squarrose

Subgenus I. Eucarex. Staminate flowers forming one or more terminal linear or club-shaped spikes which are often pistillate at base or apex, or occasionally having a few pistillate flowers intermixed. Pistillate flowers usually in distinct and normally simple mostly peduncled spikes which are seldom aggregated into heads. Cross-section of the perigynium circular or obtusely angular in outline. Style commonly 3-parted and the achenium trigonous or triquetrous.

\$ 1. Spike single (in our species), androgynous, staminate at the top, the rhachis conspicuously jointed: perigynium lanceolate or spindle-shaped, longer than the scale, deflexed at maturity: stigmas very rarely two.-DEFLEXOCARPAE. Low and mostly slender species.

* Perigynium brown, spindle-shaped or narrowly ovate, stipitate, little longer than the scale.-PuBlicares Tuckm.

1. Carex pyrenaica Wahl. Vet. Akad. Nya Handl. Stockh. 24: 139. 1803. Culms 5-15 cm. high, slender: spike dense, oblong, brown or purple, the fertile flowers erect until full maturity: leaves narrow, mostly involute-filiform, shorter than the culms: staminate flowers few, occupying one third or less the length of the spike: perigynium few-nerved or nerveless, usually shining at maturity.- High mountains of Colorado, Utah, and northward.

2. Carex nigricans C. A. Mey. Mem. Acad. St. Petersb. 1: 210. t. 7. 1831. Stouter: leaves nearly flat, $2 \mathrm{~mm}$. broad: staminate flowers usually conspicuous and occupying about half the spike: perigynium somewhat ventricose, dull: otherwise as in the last, with which it grows.-Evidently the more common species.

\$2. Spikes one or more: staminate spike always single, usually distinct, sessile or nearly so, sometimes androgynous with all the pistillate flowers borne at its base: pistillate spikes, if any, small and globular, mostly sessile, more or less approximate: bracts short or none, sheathless: perigynium ovate or globular, hirsute (thin and scabrous in No. 3), tightly surrounding the ache- 
nium, usually bearing a beak half its length: pistillate scales acute (except in Nos. 3 and 4): stigmas rarely 2.-SPHAERIDIOpHORAE Drejer. Low species in dry places, the leaves all radical. No. 4 is dioecious.

* Spike one, androgynous.-FilifoliaE Tuckm.

3. Carex filifolia Nutt. Gen. 2: 204. 1818. Caespitose: culms slender, obtusely angled and smooth, 1-3 dm. high, when full grown longer than the filiform rigid leaves, their bases surrounded by dry brown leafless sheaths which at length break up into fibers: spike 1-3 cm. long, ferruginous or whitish, bractless, the staminate portion sometimes nearly free from the pistillate portion: perigynium broadly triangular-obovoid, thin, few-nerved or nerveless, scabrous or slightly hairy above, abruptly contracted into a short, stout, whitehyaline entire beak, about the length or shorter than the very broad hyalinemargined clasping scale: perigynium containing a short serrate racheola. $(C$. oreocharis Holm. Am. Jour. Sci. IV. 9: 358. 1900.)-Dry plains and mountains from Colorado westward and northward.

3a. Carex filifolia miser Bailey, Proc. Am. Acad. 22: 122. 1886. Low, usually 5-10 cm. high, the leaves very rigid: pistillate portion of the spike not conspicuous: pistillate scales much narrower than in the species, the margins scarcely hyaline: perigynium much smaller and flatter, entirely concealed under the scale, oblong-obovate, smooth. ( $C$. elynoides Holm. l. c. 356.)Alpine in Colorado and westward to the Sierras.

4. Carex scirpoidea Michx. Fl. Bor. Am. 2: 171. 1803. Creeping: culms in flower short, elongating, 1-4 dm. high in fruit and exceeding the broad and flat leaves, more or less scabrous on the angles at least above, the basal sheaths not splitting into fibers: spike ferruginous, linear or club-shaped, $1-5 \mathrm{~cm}$. long, occasionally with 1 or 2 accessory spikes at base: perigynium ovate or obovate, hairy, lightly nerved, about the length (or a little longer) of the ciliate more or less obtuse scale: scales on the staminate plant hyaline-margined, not ciliate.-High mountains; Colorado and Utah, northward and westward.

* * Spikes two to several, the lower occasionally peduncled or sometimes rad-
ical: perigynium contracted below, usually bearing tuo prominent ribs, the
very short or often prolonged beak slightly 2-toothed.-MoNTANAE Fries (in
part).
+ Culms upright, as long or longer than the leaves: spikes closely flowered,
mostly aggregated at the top of the culm.

5. Carex pennsylvanica Lam. Encycl. 3: 388. 1789. Extensively creeping: culms few, slender, 1-3 dm. high: staminate spike conspicuous, 1-2 cm. long, often club-shaped, sessile or shortly peduncled, sometimes pistillate at the top: pistillate spikes $1-4$, the lower one very rarely $2-3 \mathrm{~cm}$. remote, the upper ones bractless, the lower sometimes subtended by a short and subulate brown bract: perigynium globose or roundish-obovoid, abruptly contracted into a short or often long beak, usually shorter than the acute or cuspidate brown or rarely whitish scale.-Dry, sandy plains; a variable species, widely distributed.

6. Carex deflexa Hornem, Plantel. Ed. 3. 1: 938. 1821. This species does not occur in our range, but the following varieties are rather common.

6a. Carex deflexa Farwellii Brit. Fl. 1: 334. 1896. Rather stiff, 1-3 dm. high, in dense tufts: most of the culms somewhat exceeding the leaves: staminate spike prominent and erect, 6-10 $\mathrm{mm}$. long, sessile or very shortpeduncled: pistillate spikes two or three, all scattered, the uppermost at or near the base of the staminate spike, the lowest usually very prominently peduncled and subtended by a conspicuous bract which surpasses the culm, all rather compactly 3-8-flowered, green, or brown and green: radical spikes usually abundant: perigynium oval, obtusely 3 -angled, pubescent, the beak as long as the body: scales large and sharp, equaling or exceeding the perigynium. C. deflexa media Bailey.-Mountains; Montana and Colorado to Oregon. 
$+\leftarrow$ Culms mostly shorter than the leaves: spikes looser flowered and more scattered, often radical.

6b. Carex deflexa Rossii (Boott) Bailey, Mem. Torr. Bot. Club 1: 43. 1889. Stiff throughout, very strict, the leaves mostly equaling or exceeding the culms, the whole plant usually light-colored: staminate spike much as in the last, often larger: pistillate spikes 1-3, distinct or sometimes scattered, loosely 1-4-flowered: radical spikes usually abundant: scales very sharp, greenish-white or very rarely bearing an inconspicuous colored margin. ( $C$. Rossi Boott.)-Mountains; Colorado to British Columbia.

7. Carex umbellata Schk. Riedgr. Nachtr. 75. f. 171. 1806. Rootstock stout, mostly horizontal: culms many, mostly very short and crowded and concealed among the leaves, sometimes $1 \mathrm{dm}$. long: leaves many, generally short, stiff and curved, sometimes weak and straggling and $10-15 \mathrm{~cm}$. long: staminate spike $12 \mathrm{~mm}$. or less long, not usually distinct and conspicuous: pistillate spike usually crowded among the bases of the leaves, sometimes one or more of them exserted and clustered with the staminate spike: perigynium globose-elliptic, more or less flattened, produced into a flattened toothed beak as long as the body.-Colorado to Oklahoma; and common eastward.

7a. Carez umbellata brevirostris Boott, Illustr. 2: 99. 1860. Beak much shorter and minutely toothed, the perigynium rounder or somewhat 3-sided.Mongollon Mountains, New Mexico, and near Golden City, Colorado; also in California and British America.

\section{§ 3. Spikes androgynous, staminate above: pistillate flowers few, often remote,} usually on a more or less zigzag rachis: scales prolonged and leaf-like (scarious and of ten short in No. 8): perigynium smooth, or slightly hispid above, mostly tightly inclosing the achenium, the beak, if any, straight.-PHYLLOSTACHYS Carey.

* Culms all as long or nearly as long as the leaves: staminate flowers conspicuous: pistillate flowers very few and large: beak very short.-PhyLlostachYAE Bailey.

8. Carex Geyeri Boott, Linn. Trans. 20: 118. 1846. Stoloniferous: culms very slender, angled, rough, about $3 \mathrm{dm}$. high, about the length of the flat rough-edged leaves: staminate portion of the spike usually appearing distinct, 1-3 cm. long: pistillate flowers 1-2, large, erect with the rachis: perigynium triangular-obovoid, $6 \mathrm{~mm}$. long, the conspicuous angles obtuse, one-nerved on the two inner sides, very smooth, with a very short entire erose and hyaline beak: scales thin and brown, acute, two to four times the length of the perigynium.-Mountains of Colorado, Utah, and Montana.

* * Culms mostly much shorter than the leaves: staminate flowers inconspicuous: perigynium small, the beak produced to half its length (or more): scales very green and much dilated, often concealing the perigynia, and readily mistaken for bracts.-BRACTOIDEAE Bailey.

9. Carex durifolia Bailey, Bull. Torr. Bot. Club 20: 428. 1893. Caespitose: culms $3-15 \mathrm{~cm}$. high, sharply angled: leaves lax and smooth: staminate portion of the spike about 3-flowered: pistillate flowers 2-4, aggregated, more or less spreading: perigynium globose-ovate, inconspicuously nerved, smooth or very slightly scabrous above: lower scales longer than the culm. C. Backii.-Dry and rocky hills; Colorado to British America.

8. Spike one (in our species), small, the pistillate flowers few: perigynium smooth (sometimes minutely dentate on the angles), firm or horny, mostly shining or glossy, lightly nerved or nerveless, bearing a short beak: scales obtuse with hyaline margins: stigmas 3.-LAMPRochlaknaE Drejer. Small plants, with creeping rootstocks. Our species all fall under the group $R u$ pestres Tuckm.

10. Carex rupestris All. Fl. Ped. 2: 264. 1785. Caespitose and somewhat stoloniferous: culms obtusely angled, erect, 3-10 cm. high, usually a little 
longer than the long-pointed and mostly channeled leaves: spike linear or clavate, 1-3 cm. long: perigynium upright, plano-convex, obovate or elliptic, firm in texture, dull, very lightly nerved, abruptly contracted into a short and stout truncate beak, hidden by the amplectant and very broad dark scale.Colorado and far northward.

11. Carex obtusata Lilj. Kongl. Acad. Hand. 69. t. 4. 1793. Very extensively creeping by long and slender brownish rootstocks: culms $5-15 \mathrm{~cm}$. high, longer than the flat and long-pointed leaves: spike at maturity ovate or narrowly ovoid, $12 \mathrm{~mm}$. or less long, the pistillate flowers 4-10: perigynium at first pale, brownish at the top, when mature spreading and becoming brown or dark brown-purple, glossy, very horny in texture, turgid-ovate, stipitate, contracted into a stout obliquely-cut and conspicuously white-hyaline beak, longer and broader than the membranaceous, acute, and often deciduous scale: achenium short and broadly triangular.-South Park, Colorado, to Montana, westward and northward.

\$5. Spikes 2 or more (1 in No. 12), more or less peduncled: staminate spike one in our species: pistillate spikes mostly compactly flowered and cylindrical, erect: bracts leafy, sheathing or sheathless: perigynium firm in texture, smooth, slightly inflated, very shortly and stoutly beaked or sometimes beakless, conspicuously nerved.-BRACHYRHYNCHAE. Slender, not very leafy species. * Spike one, staminate above: perigynium beakless.-PoLYTRICHOIdEAE

12. Carex leptalea Wahl. Kongl. Vet. Acad. Handl. II. 24: 139. 1803. Caespitose: culms many, almost capillary, usually longer than the very narrow leaves: staminate flowers very few: perigynia 2-8, alternate and appressed, green, triangular below, flattened towards the top, blunt or emarginate at the apex, much longer than the ovate acute scale: stigmas rarely 2 . C. polytrichoides.-Low ground, Colorado and northward.

* * Staminate spike in our species sessile or short-stalked: pistillate spikes
short: perigynium obtuse or short-beaked, straight at the apex, longer than
the white or tawny acute scale.-PALLESCENTES Fries.

13. Carex abbreviata Prescott, Boott, Trans. Linn. Soc. 20: 141. 1846. Culms 2-4 dm. high, sharply angled, longer than the hairy leaves: pistillate spikes 1-3, roundish, approximate, almost sessile: perigynium round-obovate, sunken at the top, very abruptly tipped with a short stout hyaline-margined beak: bracts short, about the length of the culm, sheathless. C. Torreyi.Colorado and northward into British America.

** Staminate spike usually long-peduncled: pistillate spikes scattered, all (at least the lower) on exserted stalks: bracts shorter than the culm (longer in No. 14), sheathing: perigynium glaucous-green before maturity, becoming pale or yellow, the apex oblique or bent and short-beaked (or nearly beakless in No. 14).-Paniceat Tuckm.

14. Carex aurea Nutt. Gen. 2: 205. 1818. Stoloniferous: culm 4-25 cm. high, slender, sharply angled, longer or shorter than the flat and narrow glaucous leaves: bracts leaf-like, the lower much exceeding the culm: spikes $3-6$, the staminate often nearly sessile, the pistillate loosely flowered, the lower remote, often on radical peduncles: scales colored on the margins, ovate, shorter than the turgid, globose or pear-shaped, bright yellow or strawcolored and wholly obtuse or slightly pointed perigynium: stigmas commonly two.-Common throughout on moist grassy hillsides and low mountains. A delicate and pretty species, readily distinguished when mature by its bright colored, often almost fleshy perigynia. The staminate spike is occasionally pistillate at the apex.

\$6. Staminate spike mostly solitary and peduncled, pistillate spikes several or many, more or less loosely flowered, all or the lower on filiform weak or 
nodding peduncles: bracts foliaceous and sheathing: perigynium thin and membranaceous, usually slender or oblong, tapering gradually into a distinct or long minutely toothed straight beak, smooth and shining (in No. 16 usually hairy on the angles and not lucid), mostly light-colored, somewhat inflated; scales thin, white, tawny, or brown.-Hymenochlaenae Drejer. Mostly slender and open-flowered lax-growing species.

* Terminal spike all staminate: pistillate spikes oblong, club-shaped or cylindrical (very small in No. 15): perigynium few-nerved or nerveless, tawny or whitish.-FLEXILES Tuckm.

15. Carex capillaris L. Sp. Pl. 977. 1753. Usually densely caespitose: culms very slender, varying from $3-30 \mathrm{~cm}$. in height, much longer than the numerous very narrow radical leaves: pistillate spikes 1-4, loosely 3-10flowered, long-exserted and nodding, the lower often very remote: perigynium small, ovate or ovate-oblong, contracted into a nearly entire beak of about half its length, about the length or longer than the white or tawny hyaline scale.-High mountains from Colorado westward and northward. A delicate species, variable in size and in the length and shape of the pistillate scales.

16. Carex ablata Bailey, Bot. Gaz. 13: 82. 1888. Stoloniferous: culm slender, 3-5 dm. high, much longer than the short and rather broad, many-nerved, lax radical leaves: bracts conspicuously and loosely sheathing, the lower more or less leaf-like, the upper setaceous: pistillate spikes ferruginous, $2-3 \mathrm{~cm}$. long, the lower club-shaped and long-exserted, the upper more or less cylindrical and often sessile or nearly so and approximate: perigynium lanceolate, slightly inflated, flattened, at first wholly or partly green, at length becoming more or less ferruginous, obscurely nerved, hairy on the angles, tapering and 2-toothed, longer than the acute scale. C. frigida.-Utah and Wyoming to Oregon.

17. Carex longirostris Torr. Ann. Lyc. N. Y. 1: 71. 1824. Caespitose: culm rather strong, 2-5 dm. high, obtusely angled, rather longer than the flat and soft leaves: pistillate spikes 2-3, greenish-white, short, thick, nearly erect: perigynium large, 2-nerved, green and shining, produced into a slender whitetipped toothed beak of half or more its length: scale white, acute or cuspidate, about the length of the perigynium.-Colorado.

\$ 7. Staminate spikes one or more: pistillate spikes two to several, stout, erect, mostly shortly peduncled, somewhat squarrose or comose in appearance: perigynium thick in texture, hairy, more or less spreading, distinctly and stoutly straight-beaked, the teeth short: scales prominent.-LASIOCARPAE Fries. Stout, mostly tall species, in wet or grassy places. Our species falls under the group Lanuginosae Carey.

18. Carex lanuginosa Michx. Fl. Bor. Am. 2: 175. 1803. Stoloniferous: culms 3-8 dm. high, strong: leaves flat, $2-4 \mathrm{~mm}$. broad, about the length or longer than the culm: staminate spikes 1-3, the lower small and aggregated at the base of the terminal one: pistillate spikes 1-4, remote, sessile or nearly so, or the lower peduncled, $1-5 \mathrm{~cm}$. long, often loosely flowered at the base: bracts leaf-like, usually much exceeding the culm, the upper sheathless: perigynium ovate or shortly ovoid, abruptly contracted into a very short, erect, divergently and very shortly toothed beak: scales ovate, purple, acute or cuspidate, shorter or longer than the turgid and densely hairy perigynium. C. filiformis latifolius. - Swampy places, in most parts of the northern half of the continent.

\$ 8. Staminate spikes two or more, long-stalked: pistillate spikes two to several, usually all peduncled, long and heavy, loosely flowered, erect or nodding: perigynium large, thick in texture, strongly nerved, hairy or smooth, produced into a long beak which terminates in very conspicuous awl-like erect or spreading teeth.-EchinostachyaE Drejer. Coarse species.

19. Carex aristata R. Br. Frank. Journ. 751. 1836. Culms very stout, sharply angled: sheaths and under side of the leaves sparsely hairy: staminate spikes $3-8$, usually considerably separated; the scale very long, loose and 
pointed: pistillate spikes 5-8 cm. long, $8 \mathrm{~mm}$. or more broad, upright, scattered, loosely flowered at the base: perigynium very strongly nerved, smooth, ovatelanceolate, terminated by very conspicuous, divaricate, smooth, and slender teeth, usually longer than the rough-awned scale. C. trichocarpa aristata.Colorado and northward, thence across the continent.

\$ 9. Sterile and fertile spikes one to several or many: fertile spikes mostly large and compactly flowered: perigynium much inflated (cross section nearly twice or much more than twice the width of the mature achenium), membranaceous, smooth, conspicuously nerved (or nearly nerveless in No. 21), tapering into a toothed beak as long as the body or longer.-Physocarpae Drejer. Mostly large and stout species. No. 21 is the least developed of the section, and in some forms it appears to ally itself with other and very dissimilar sections.

* Staminate spikes commonly more than one: pistillate spikes usually long and densely cylindrical (short in No. 21 and occasionally in No. 24): perigynium smooth and shining, long-beaked, at maturity yellow or straw-colored, or occasionally partly reddish-purple.-VESICARIAE Tuckm.

- Staminate spike one: pistillate spikes comose, cylindrical and drooping or spreading: bracts sheathless or nearly so: beaks long.

20. Carex hystricina Muhl. Willd. Sp. Pl. 4: 282. 1805. Plant rather slender, pale, 3-5 dm. high: spikes 2-4, narrow, 2-5 cm. long, nodding or the upper one nearly erect or spreading, decidedly comose in appearance: perigynium 15-nerved, not prominently inflated, prolonged into a very slender and setaceously toothed beak, the lobes of which are spreading: scales awn-like, shorter than the perigynium.-Wet places; New Mexico and northeastward to Nebraska and Wyoming.

+ + Staminate spike one, rarely two: pistillate spikes short, erect, more or less purplish: beaks short: stigmas usually two.

21. Carex saxatilis L. Sp. Pl. 976. 1753. Stoloniferous: culm 1-3 dm. high, sharply angled, about the length of, or a little longer than, the narrow and sharp-pointed leaves: pistillate spikes $1-3$, the upper sessile or nearly so, the lower mostly more or less peduncled, all dark purple or at maturity becoming brown: bracts narrow, long-pointed, shorter or a very little longer than the culm: perigynium ovate-oblong or elliptic, nerveless or very inconspicuously nerved at the apex, rather abruptly contracted into a very short nearly entire beak, mostly longer than the more or less obtuse membranaceous scale. C. pulla Gooden. C. vesicaria alpigena Fries.-Rocky Mountains, from Colorado to British America.

21a. Carex saxatilis Grahamii Hook. \& Arn. Brit. Fl. 8th Ed. 510. Stouter, 3-5 dm. high: perigynium lighter colored, often nearly straw-colored, prominently few-nerved, the beak longer and more conspicuously toothed.-High mountains of Colorado, Utah and northward.

+++ Staminate spikes two or more: 'pistillate spikes normally long, spreading or drooping: stigmas three.

++ Perigynium conspicuously turgid, ascending at maturity.

22. Carex Engelmannii Bailey, Proc. Am. Acad. 22: 132. 1877. Culms slender but erect, $10-15 \mathrm{~cm}$. high, about the length of the numerous very slender bristle-like leaves: spike small, nearly globular, 4-6 $\mathrm{mm}$. broad, the staminate flowers inconspicuous: perigynium lanceolate, about $4 \mathrm{~mm}$. long, very delicate in texture, flat, somewhat shining, nerveless, the long apex empty, the beak entire or nearly so, about the length of the thin brown acute scale.-Alpine slopes, Colorado.

23. Carex monile Tuckm. Enum. Meth. 20. 1843. Culms usually more slender and leaves a little narrower: spikes more slender: perigynium subglobose, much inflated towards the base, one half or more as broad as long, 
abruptly short-beaked, 10 or less-nerved: otherwise as in the last.-Colorado and Wyoming.

23̈a. Carex monile colorata Bailey, Mem. Torr. Bot. Club 1: 39. 1889. Smaller: spikes shorter than in the species, dark brown: perigynium very much less turgid and shorter beaked: scales shorter and not so sharp.-Colorado, northward and westward.

\section{++ Perigynium not conspicuously turgid, squarrose at maturity, and the spikes comose in appearance.}

24. Carex utriculata Boott, Hook. Fl. Bor. Am. 2: 221. 1840. Somewhat stoloniferous: culm very stout, 3-10 dm: high, acutely angled above, very thick and spongy at the base: leaves broad, 4-12 mm., carinate at the base, much exceeding the culm, conspicuously nodulose-reticulated: pistillate spikes 2-6, more or less remote, the upper sessile, the lower often on weak peduncles $3-5 \mathrm{~cm}$. long, long-cylindrical or terete, $3-15 \mathrm{~cm}$. long, thick and compactly flowered (sometimes loosely flowered at the base), often staminate at the top: perigynium ellipsoid or globose-ovoid, usually gradually tapering into a short beak, broader and commonly longer than the very acute or rough-awned scale. Var. minor Sartwell, is a form smaller in all its parts, with spikes $2-3 \mathrm{~cm}$. long.-Common in swamps from Colorado and Utah northward.

\$10. Staminate spikes one or more, long: pistillate spikes one to several, brown, purple or greenish, commonly approximate, sessile or peduncled, oblong or linear, mostly elongated: perigynium not inflated, biconvex, minutely beaked or beakless, smooth: stigmas 2.-MicrorhyNCHAE Drejer. Paludose and alpine species of upright habit, often growing in tufts or tussocks. Our species fall under the group Acutae Fries.

\section{* Perigynium strongly nerved.}

25. Carex nebraskensis Dewey, Am. Journ. Sci. II. 18: 102. 1854. Glabrous: culms stout, sharp-angled, $3-6 \mathrm{dm}$. tall: leaves pale green, $3-5 \mathrm{~mm}$. wide, rough-margined, their sheaths more or less nodulose: lower bract sometimes equaling the culm, the upper much shorter and narrower: staminate spikes commonly 2, stalked: pistillate spikes 2-4, dense, oblong-cylindric, erect, 2-3 $\mathrm{cm}$. long, about $6 \mathrm{~mm}$. in diameter, sessile or the lower short-stalked: perigynia elliptic or obovate, prominently several-ribbed, short-beaked, the beak 2toothed: scales ovate or lanceolate, acute or mucronate, brown with green midvein or green all over, the upper shorter than the perigynia: stigmas 2.Nebraska to Oregon and New Mexico.

$$
\text { * * Perigynium slightly nerved or nerveless. }
$$

+ Robust species: bracts leaf-like, usually exceeding the culm.

26. Carex aquatilis Wahl. Kongl. Acad. Handl. 24: 165. 1803. Stoloniferous: culm obtusely angled, 5-10 dm. high, smooth, leafy: leaves flat, pale, scarcely longer than the culm: pistillate spikes $2-4$, erect, thick and compactly flowered throughout or more commonly inclining to club-shaped with a gradually attenuate base, the upper sessile, the lower more or less peduncled and of ten long exserted: perigynium broadly elliptic or obovate, rarely circular, nerveless, tipped with a minute and entire point, green or light-colored, wider and either longer or shorter than the green or purple-margined acutish scale.A large species, in wet places; generally distributed northward.

++ Low, or tall and slender species: bracts mostly short and narrow, often setaceous.

+ Culms slender and tall: leaves with more or less revolute margins when dry.

27. Carex physocarpa Presl. Relig. Haenk. 1: 205. 1830. Culms erect, 2-3 dm. high: peduncles relatively long, rough, 3-10 cm.: spikes oblong, brown, ROCKY MT. BOT. -7 
with broad obtuse scales: perigynium short, nerveless, with entire beak, exceeding the scale.-In the higher Rocky Mountains of British America and extending south into Wyoming.

28. Carex acutina Bailey, Mem. Torr. Bot. Club 1: 52. 1889. Stems erect, 4-5 dm. high, smooth or rough above, leaves flat and thin, about as long as the stem: the lower 1 or 2 bracts flat and leaf-like, about equaling the stem, the margins mostly. serrate: spikes $4-5$, the upper 1 or 2 staminate, all approximate and sessile or the lower short-peduncled, 3-5 cm. long: perigynia thin and soft, yellowish, somewhat inflated, the small beak entire, shorter, or longer and broader than the obtuse or muticous scale. [C. rhomboidea Holm, Am. Journ. Sci. 16: 35. 1903 (?).]-On stream banks and lake shores; Colorado to Oregon.

29. Carex variabilis Bailey, Mem. Torr. Bot. Club 1: 18. 1889. Glaucous, mostly low, 3-5 dm. high, stout: culm sharply angled, roughish on the angles: leaves rather broad: spikes 3-4, short and stout, borne near the top of the culm, erect, the lower one or two conspicuously attenuated at the base, and appearing clavate; the upper sessile, lower peduncled: bracts leaf-like and broad, the lower one or two equaling or exceeding the culm: perigynium small and broadly ovate, abruptly and very shortly beaked, nerveless, beak entire, green or whitish, conspicuously broader and usually shorter than the obtuse or muticous black scale. C. aperta divaricata.-Wet places; Colorado to Montana and Idaho.

\section{+ Culms 1-4 dm. high: leaves more or less involute when dry.}

30. Carex Bigelovii Torr. Ann. Lyc. N. Y. 1: 67. 1824. Culms mostly stout, sharp-angled, smooth except near the top, longer than the narrow leaves: staminate spike one: pistillate spikes 3-5, slender, lax, loosely flowered at the base, the lower peduncled and often remote, black-purple or fuscous-purple: perigynium narrow, mostly elliptic, almost pointless, entire at the orifice, very faintly nerved towards the base, shorter or rarely a little longer than the acute or acutish dark purple scale. C. vulgaris hyperborea.-Alpine regions; Colorado, northward and westward.

31. Carex rigida Gooden. Linn. Trans. 2: 193. 1794. Leaves $4 \mathrm{~mm}$. broad, flat: staminate spikes sometimes 2 , usually 1 : pistillate spikes $3-5$, short and thick, 5-20 mm. long, erect, approximate or the lowest sometimes remote and shortly peduncled, dark purple; auricles very prominent: perigynium obovate or nearly circular, nerveless, shortly beaked, pale below, usually more or less purple above, commonly shorter than the dark, acute scale. $C$. vulgaris alpina.-Same range as the last.

32. Carex scopulorum Holm. 1. c. Plant rather stout, from a dense and woody root, 3-6 dm. high: leaves very broad for the group, deep green, conspicuously pointed, shorter than the culm: staminate spike usually 1 , mostly short-peduncled: pistillate spikes 2-4, sometimes contiguous or partially scattered, oval or oblong, 1-4 cm. long, the two lowest usually on slender peduncles $3-5 \mathrm{~cm}$. long, the others sessile or nearly so: lowest bract leaf-like and equaling or exceeding the culm: perigynium compressed-trigonous, ovate or round-ovate in outline, pale and more or less discolored or even covered with purple dots (or rarely almost yellow), produced into a very short and entire beak, mostly shorter than the obtuse or muticous purple scale: stigmas 2 or 3. C. vulgaris in part. (C. Tolmiei and vars.)-Colorado to Montana and west to the coast States.

\$11. Staminate spike one, short, either pistillate above or not conspicuous (except in No. 33): pistillate spikes none to several, short and thick, mostly dark-colored, commonly aggregated (often only approximate), sometimes staminate at the base: perig? nium biconvex or very obtusely 3-angled, with a very short entire or emarginate beak, or beakless: stigmas 2 or 3.-MELANOSTACHYAE Tuckm. Mostly mountain or boreal species, distinguished by the aggregated spikes and inconspicuous or androgynous terminal spike and nigrescent color. 
* Terminal spike all staminate (in No. 33 often with a few pistillate flowers at base or apex, or rarely all pistillate and dioecious), cylinulrical: pistillate spikes approximate, erect: stigmas usually 3.-STYLOSAE.

33. Carex Parryana Dewey, Am. Journ. Sci. 27: 239. 1835. Stoloniferous: culms rigid, 1-4 dm. high, stout, obtusely angled, smooth or nearly so, granulated, longer than the rigid, long-pointed, narrow leaves: terminal spike usually largest, about $2 \mathrm{~cm}$. long, brown, with 1-5 small, globular, oblong, or cylindrical erect spikes near its base (or sometimes entirely solitary), the lower usually subtended by a narrow bract shorter than the culm and of ten more or less remote and shortly peduncled: perigynium obovate or triangular-obovoid, somewhat plano-convex, scabrous above, lightly nerved, especially on the outer side, very abruptly short-beaked, the orifice entire or erose-hyaline, shorter and about the width of the very obtuse, brown, white-nerved, hyalinemargined, sometimes minutely apiculate and ciliate scale.-Colorado, and northward in the mountains; rare.

34. Carex Reynoldsii Dewey, Am. Journ. Sci. II. 32: 39. 1861. Stoloniferous: culms 3-10 dm. high, sharply angled, longer than the flat, glaucous leaves: staminate spike sessile, about $12 \mathrm{~mm}$. long: pistillate spikes 3-6, short and thick, $8 \mathrm{~mm}$. wide, not commonly more than twice as long as broad (and usually less), sessile or short-peduncled, aggregated, or the lowest 2-5 cm. remote and exserted: lower bract about the length of the culm, bearing conspicuous purple auricles: perigynium large, obovoid, 3-angled, prominently nerved, green or light-colored, abruptly narrowed into a nearly entire purple beak, somewhat spreading, when mature much longer and broader than the acute black'scale.-Mountains; Utah to Wyoming.

\section{* * Terminal spike staminate: pistillate spikes ovoid or oblong and drooping: stigmas 3.-LimosaE Tuckm.}

35. Carex misandra R. Br. Suppl. Parry's Voy. 283. 1823. Glabrous: culms 2-40 cm. tall: leaves $2-3 \mathrm{~mm}$. wide, clustered, seldom over $6 \mathrm{~cm}$. long: bracts narrowly linear, sheathing, not overtopping the spikes: terminal spike slender-stalked: pistillate spikes 1 or 2, filiform-stalked, 6-15 mm. long, about $4 \mathrm{~mm}$. thick, rather few-flowered, drooping: perigynia narrowly lanceolate, acuminate, narrowed at the base, $3 \mathrm{~mm}$. long, dark brown, denticulate above: scales obtuse, purple-black with white margins, somewhat shorter than the perigynia: stigmas 2 or 3.-Throughout Arctic America, extending south in the Rocky Mountains to the higher summits of Colorado.

\section{*** Terminal spike club-shaped, staminate below: lateral spikes occasionally \\ bearing a few staminate flowers at base: scales broad, not conspicuously acute.- Atratae Kunth.}

36. Carex atrata L. Sp. Pl. 976. 1753. Caespitose: culm 1-6 dm. high, sharply angled, smooth or roughish, longer than the long-pointed leaves: bracts about equaling the culms, mostly with conspicuous auricles: spikes 2-4, densely flowered, clavate or oblong, thick, 1-4 cm. long, black or dark brown, approximate or often aggregated, all more or less peduncled, at first upright or spreading, at length usually drooping and of ten exserted, and the top of the culm appearing as if bent over: perigynium broadly ovate or orbicular, nerveless, bearing a short notched beak, commonly a little broader and about the length or a little shorter than the black or dark brown obtuse or acutish scale. (C. chalciolepis Holm. Am. Journ. Sci. 16: 28. 1903.)--High mountains; Colorado and Utah and northward.

37. Carex bella Bailey, Bot. Gaz. 17: 153. 1892. Tall and slender: spikes narrowly cylindrical, $3-4 \mathrm{~cm}$. long and $1 \mathrm{~cm}$. or less wide, the lower one or two on slender peduncles or even radical, the terminal one bearing a very long and much contracted staminate portion: perigynium greenish-white, conspicuously broader and usually longer than the black-purple and faintly white-nerved scale. C. atrata ovata.-Wyoming to Arizona.

38. Carex nova Bailey, Mem. Torr. Club 1: 10. 1889. Resembling the pre- 
ceding but the spikes ( 3 or 4 ) globular, strictly sessile, and very densely aggregated into an ovoid-triangular head, the lower spikes of which are squarrose, or the lower one rarely distinct: perigynium broadly ovate or nearly circular in outline, thin and whitish, very conspicuously squarrose, broader than the ovate and muticous black scale. [C. melanocephala Turcz.(?)]-Mountains; Wyoming and Colorado to California.

39. Carex alpina Swartz, Lilj. Sv. Fl. Ed. 2. 26. 1798. Culms very slender, 1-5 dm. high, smooth, longer than the narrow leaves: spikes 2-4, small, 5-12 $\mathrm{mm}$. long, mostly compactly flowered, black or black and green, closely aggregated, erect and capitate, the lowest very short-stalked and usually subtended by a green bract: perigynium ovate or elliptic, obscurely nerved or nerveless, with a short slightly notched beak, green or fuscous, commonly a little longer than the ovate, black, nearly obtuse scale.-High mountains, Colorado and northward.

Subgenus II. Vignea. Staminate flowers few and inconspicuous, borne at the base or apex of the pistillate spikes. Pistillate flowers in short, sessile spikes (spike single in No. 40), which are commonly more or less aggregated into heads, or even panicled. Cross section of the perigynium plano-convex in outline. Styles two and achenium lenticular.-The spikes, and especially the terminal one, usually have contracted bases when the staminate flowers are borne below, and empty scales at the top when the staminate flowers are borne above.

\$12. Staminate flowers borne at the top of the pistillate spikes; or in the Arenariae spikes often wholly staminate and the plants occasionally dioecious.Acroarrhenae Anderss.

* Spike one and simple: plants very small.-NARdinaE; Tuckm.

40. Carex Redowskyana C. A. Mey. Cyp. Nov. t. 4. 1831. Creeping: culms 1-2 dm. high, longer than the rigid, erect or spreading leaves: spike $5-15 \mathrm{~cm}$. long, loosely flowered: perigynium ovate, prominently nerved, gradually and conspicuously beaked, spreading at maturity, longer than the acute scale. C. gynocrates.-In the high mountains; Colorado to British America.

$$
\begin{aligned}
& * \text { * Spikes green when mature, more than one. } \\
& \text { - Spikes few-flowered, distinct, often remote. }
\end{aligned}
$$

41. Carex tenella Schk. Riedgr. 23. f. 104. 1801. Tufted and stoloniferous: culms very slender, almost capillary, 1-4 dm. high, about the length of the narrow, loose leaves: spikes scattered, 1-6-flowered: perigynium shortly oval, rounded on the outside, finely nerved, abruptly and minutely beaked, longer than the very thin scale.-Swamps throughout our range.

42. Carex vallicola Dewey, Am. Journ. Sci. II. 32: 40. 1861. Culm 1-2 $\mathrm{dm}$. high, very slender, slightly scabrous: leaves $1 \mathrm{~mm}$. broad, shorter than the stem: bracts roughly cuspidate from a broad hyaline-margined base, the lowest equaling or exceeding its spike: head 1-3 cm. long, linear-oblong, composed of 4-7 narrowly oblong contiguous sessile spikes which have a conspicuous column of staminate flowers at the apex: scales chestnut-colored, membranaceous with very broad hyaline margins, clasping at the base, broadly ovate, acute or the scabrous keel prolonged into a short mucro: perigynium pale brown, obovate, abruptly attenuated to the base and to the obliquely cut entire beak, convex on the outer side and concave on the inner, nerveless, sparsely serrate above on the obtuse margins, about as long and narrower than the scale.-Colorado and Wyoming to Idaho.

43. Carex eleocharis Bailey, Mem. Torr. Club 1: 6. 1889. Very slender but stiff, $1.5 \mathrm{dm}$. high, both leaves and culm filiform and smooth: spikes 2 or 3 , each bearing 1-3 flowers, closely aggregated into a very small and apparently monostachyous head, evidently staminate above: perigynium short-ovate, tur- 
gid, flat on the inner face, marginless and nerveless, dull brown, beak entire or nearly so, as long as or longer than the thin hyaline scale.-Wyoming to the plains of the Saskatchewan.

+ - Spikes several to many-flowered, aggregated into a globular or oblong head.

44. Carex gravida Bailey, Mem. Torr. Club 1: 5. 1889. Light green: culms 4-9 dm. tall, 3-angled, rough above: leaves flat, 3-6 mm. wide: bracts usually very short: spikes several, in a dense heavy head $2-3.5 \mathrm{~cm}$. long, pale, subglobose: perigynia flat, broadly ovate or suborbicular, 3-4 mm. long, rounded at the base, narrowed into a 2-toothed beak about one third as long as the body, several-nerved on the outer face or nerveless: scales acute, cuspidate or short-awned, about as long as the perigynia. C. cephaloidea.-Possibly coming into our éastern border.

\section{*** Spikes tawny or broun, somewhat chaffy in appearance, closely aggregated or densely capitate: perigynium ovate or ovate-lanceolate, not conspicuously nerved.-Foetidae Tuckm.}

\section{+ Perigynium conspicuously rough on the angles above.}

45. Carex Hoodii Boott, Hook. Fl. Bor. Am. 2: 211. t..211. 1840. Tall and slender, but erect, the culm 3-6 dm. high, prolonged beyond the leaves: spikes several to many, very few-flowered, compacted into an ovoid or oblong head $1-2 \mathrm{~cm}$. long: perigynium spreading, small and narrow, gradually contracted at both ends, green, nerveless or nearly so, conspicuously wing-margined, rough on the angles, about the length of the brown or tawny scale. C. muricata confixa.-Colorado to Montana and west to Washington.

46. Carex occidentalis Bailey, 1. c. Glaucous: leaves narrower than in the last, and relatively longer: spikes more or less aggregated into a very slender head $2-3 \mathrm{~cm}$. long, the lowest one or two usually wholly distinct: bracts scalelike, inconspicuous: perigynium larger than in the last, turgid-ovate, abruptly short-beaked, nearly marginless and often smooth: scales muticous. $C$. muricata.-Colorado to Montana.

47. Carex Hookeriana Dewey, Am. Journ. Sci. 29: 248. 1836. Very slender: head interrupted, castaneous, small, the spikes sometimes alternately arranged: bracts of the two or three lower spikes produced into long awns, which surpass the spikes: perigynium small, green, usually lightly nerved, gradually produced into a beak which is cut into sharp awl-like teeth. C. muricata gracilis.-Colorado to California.

\section{$+\div$ Perigyrium smooth or slightly scabrous.}

48. Carex foetida All. Fl. Ped. 2: 265. 1785. Creeping: culm 1-4 dm. high, rather stout, scabrous, longer than the long-pointed leaves: spikes very densely aggregated into a globose or ovoid brown head: perigynium lanceolate or ovate-lanceolate, toothed at the apex, about the length of the acute or mucronate brown scale.-Mountains; Colorado, Utah, and Wyoming.

49. Carex incurva Lightf. Fl. Scot. 544. 1777. Extensively creeping: culm stiff and short, 3-15 cm. long, smooth, usually curved, about the length of the narrow and stiff curved leaves: spikes $2-5$, crowded into a short ovoid or globular brown or tawny head which is only $3-15 \mathrm{~mm}$. long: perigynium large and turgid, stipitate, broadly ovate, conical above, purple towards the top, faintly many-nerved on one side at least, narrowed into a short and stout entire beak, not covered by the acute, thin scale.-Colorado and far into British America.

50. Carex stenophylla Wahl. Kongl. Acad. Handl. II. 24: 142. 1803. Stoloniferous: culms stiff, $3-15 \mathrm{~cm}$. high from a mass of fibrillose sheaths, usually longer than the stiff involute filiform leaves: spikes $3-6$, short, 4-8 $\mathrm{mm}$. long, nearly globose, loosely conglomerated into a small subglobose or shortly oblong head, each spike subtended by a scarious mucronate bract of less than its own length: perigynium ovate, brown, nerved, gradually contracted into a short, blunt, entire beak, tightly inclosing the achenium, at maturity longer 
than the hyaline, brown, acutish scale.-Dry plains and hills; New Mexico and far northward and eastward.

51. Carex teretiuscula Gooden. Trans. Linn. Soc. 2: 163. 1794. Rather light green: culm very rough, at least above, 3-7 dm. long: leaves mostly less than $2 \mathrm{~mm}$. wide: bracts small or none: spikes several or numerous, in a narrowly oblong cluster $2-5 \mathrm{~cm}$. long: perigynia ovate-oval, smooth, dark brown, hard, shining, the body slightly more than $1 \mathrm{~mm}$. long, truncate or rounded at the head, short-stalked, tapering into a flat conic beak about its own length: scales thin, ovate, brownish, acute or short-awned, about equaling the perigynia.-Across the continent northward.

\section{**** Spikes yellow or tawny when mature, aggregated into more or less com- pound heads or panicles: perigynium many-nerved, stipitate, tapering from a spongy base into a more or less conspicuous beak, twice the length of the body, or more.-VuLPINAE Kunth.}

52. Carex stipata Willd. Sp. Pl. 4: 233. 1805. Caespitose: culms thick and spongy, 3-6 dm. high, very sharply 3-angled, almost winged, about the length of the broad light green canaliculate rough-edged leaves: spikes 10-20, loosely aggregated into an oblong pyramidal head $2-6 \mathrm{~cm}$. long, which is somewhat branching or occasionally nearly simple at the base: perigynium lanceolate, finely nerved, the rough beak about twice the length of the rounded base, the whole about twice (or a little more) as long as the scale.-Pastures and wet places throughout our range.

53. Carex Jonesii Bailey, Mem. Torr: Bot. Club 1: 16. 1889. Slender, but erect and somewhat stiff, $2-5 \mathrm{dm}$. high: culm sharply angled and rough, somewhat exceeding the narrow leaves: spikes several to many, densely aggregated into a small oblong or ovoid head which is bractless: perigynium small, lanceolate from the truncate base, stipitate, very strongly many-nerved, marginless, smooth or but slightly rough on the angles above, the long and brown beak nearly entire: scale brown, muticous or obtuse, somewhat shorter than the perigynium.-Wyoming to California.

$* * * * *$ Staminate flowers variously situated, usually some of the intermediate or terminal spikes all staminate, or the plant entirely dioecious: spikes aggregated in more or less chaffy heads, straw-colored or brown.-ARENARIAE Tuckm.

\section{- Spikes short: scales ovate, not awned or conspicuously acute.}

54. Carex siccata Dewey, Am. Journ. Sci. 10: 278. 1826. Extensively creeping: culm erect, $2-5 \mathrm{dm}$. high, sharply angled, rough, mostly longer than the rather narrow leaves: spikes 4-12, simple, alternate, ferruginous, longer than the scale-like bracts, the middle ones or sometimes the lower ones all staminate, loosely aggregated into an oblong or cylindrical head 2-4 cm. long: perigynium green, nerved, the margins slightly incurved, ovate below, contracted into a rough and slightly toothed beak which is longer than the body, the whole longer than the hyaline-margined acute scale.-Dry places, Colorado and northward. The forms with the lower spikes all staminate resemble those species of the next section with a single terminal spike which is prolonged and staminate at the base.

55. Carex marcida Boott, Hook. Fl. Bor. Am. 2: 212. 1840. Culm erect, 3-6 dm. high, sharply angled, scabrous, longer than the narrow leaves: spikes $4-15$, ferruginous or dark brown, the lower usually somewhat compound, staminate at the apex or nearly dioecious, spreading and imbricated into an oblong-conical or broadly cylindrical head: perigynium brown, becoming very dark at maturity, nerved, ovate or orbicular-ovate, with incurved and serrate margins, contracted into a beak shorter than the body, about the length of, or a little shorter than, the acute or cuspidate scale.-Sandy meadows and mountains throughout our range.

56. Carex Sartwellii Dewey, Am. Journ. Sci. 43: 90. 1842. Extensively creeping: culm stout, $3-10 \mathrm{dm}$. high, sharply angled, rough above, mostly 
longer than the leaves: spikes 10-25, globose or ovoid, compactly flowered, ferruginous or straw-colored, usually all simple, the middle or terminal ones staminate, loosely aggregated (the two or three lowest sometimes distinct) into a cylindrical or oblong thick and heavy head 3-7 cm. long, which is sometimes subtended by a bract of its own length: perigynium tawny, ovate, prominently nerved, scarcely wing-margined, rough above, shortly beaked (the orifice nearly entire), bearing a conspicuous fissure on the outer side, commonly longer than the acute brown scale. C. disticha.-Dry places; Utah, Colorado, and northward and eastward.

57. Carex Gayana Desv. Fl. Chili 205. 1853. Creeping: culms slender, 3-6 dm. high, longer than the leaves: spikes 4-15, globose or loosely ovoid, dark brown, simple, nearly dioecious (rarely staminate at the top), rather loosely aggregated into a small ovoid head $15-25 \mathrm{~mm}$. long: perigynium triangular-obovoid, about as wide as long (sometimes wider), gibbous below, rough on the top, squarely contracted into a very short entire beak, obscurely nerved below, brown and shining at maturity, shorter than the acute chaffy scale.-Wyoming and southward.

\section{++ Spikes mostly nearly linear or narrowly oblong, chaffy: the scales long, attenuated or awned: heads pale.}

58. Carex Douglasii Boott, Hook. Fl. Bor. Am. 2: 213. 1840. Creeping: culm 1-3 dm. high, obtusely angled and mostly smooth, longer or shorter than the long-pointed leaves: spikes usually many, simple or compound, pale and chaffy, dioecious or nearly so, densely aggregated into a conspicuous and heavy head $3-5 \mathrm{~cm}$. long and often ' $2-3 \mathrm{~cm}$. wide, which is sometimes subtended by a setaceous bract of nearly its own length: perigynium ovatelanceolate, nerved, produced into a slender toothed beak, much shorter and entirely concealed by the long, acute, scarious scale: stamens and stigmas long and conspicuous.-Common especially in Wyoming; Colorado, Utah, and southward.

813. Spikes staminate at the base (No. 62 sometimes has spikes staminate at the top).-Hyparrhenae Anderss.

* Spikes silvery-green or tawny when mature, distinct, mostly small; perigynium not wing-margined nor conspicuously broadened, mostly nearly flat on the inner surface.-Elongata E Tuckm.

- Perigynium nearly linear or ovate-lanceolate, in loose spikes.

59. Carex Deweyana Schw. Ann. Lyc. N. Y. 1: 65. 1824. Caespitose: culms weak and slender, $3-8 \mathrm{dm}$. high, longer than the flaccid and flat leaves: spikes 3-6, silvery-green, erect, 4-8-flowered, the two or three upper ones approximate, the lower more or less remote, the lowest subtended by a setaceous bract of more than its own length, all uniformly staminate at the base: perigynium oblong-lanceolate or ovate-lanceolate, very thin in texture, spongy at the base, nerveless or very nearly so, nearly erect, prolonged into a long and rough toothed beak, little longer than the very acute or awned white scale.Moist copses throughout.

++ Perigynium ovate or nearly so, not sharp-margined, firm in texture, erect in closely flowered and rounded spikes.

60. Carex canescens L. Sp. Pl. 974. 1753. Culms slender, 3-6 dm. high often weak, rough, about the length or a little longer than the leaves: spikes $3-10$, pale or glaucous, scattered or remote (the upper usually approximate), small and densely 10-20-flowered, obovoid or ellipsoid, mostly conspicuously narrowed at the base with staminate flowers: perigynium small, short-ovate or oval, whitish and granular, mostly obscurely nerved, abruptly and minutely beaked, rather longer than the acutish scale. $C$. elongata in part; the vars. alpicola Wahl. and dubia Bailey seem to run into the species by numerous gradations. [C. brunnescens (Pers.) Poir is $C$. canescens alpicola Wahl.]Widely distributed; throughout our range at various elevations. 
61. Carex lagopina Wahl. Kongl. Acad. Handl. II. 24: 145. 1803. Caespitose: culms 1-2 dm. high, erect, rather longer than the leaves: spikes usually 3 , often 5 or 6 , subglobose or ovoid, reddish-brown, compactly flowered, contiguous or the lowest a little remote, all small, longer than the scale-like bracts: perigynium small, obovate or elliptical, usually colored above, thick in texture, nerved, tapering towards the base, often curved, rather abruptly shortbeaked, the beak with a closed fissure on the outer side, longer than the ovate, broad, brown, hyaline-margined acute scale.-A small alpine species distinguished by its heads of few dark-colored spikes, its narrow leaves, and caespitose habit; Colorado and Utah.

+++ Perigynium ovate, sharp-margined, firm, often thickened at the base, spreading, in open and at maturity stellate spikes.

62. Carex sterilis Willd. Sp. Pl. 4: 208. 1805. Caespitose: culms sharply angled, smooth or rough, slender and erect, 1-5 dm. high, usually longer than the narrow, pale leaves: spikes small, about 8-15-flowered, scattered, globular, the upper one conspicuously contracted below with staminate flowers, or rarely all the spikes staminate or all pistillate: perigynium ovate or ovatelanceolate, gradually narrowed into a sharp-edged, rough, toothed beak, nerved, spreading or reflexed, about the length or longer than the acute scale. C. echinata. (C. stellulata Gooden.)-Colorado to British America.

* * Spikes tawny or dark, rather large, sometimes crowded: perigynium with a more or less thin or winged margin which is mostly incurved at maturity, rendering the perigynium concave inside.-Ovales Kunth.

\section{+ Spikes aggregated into a more or less dense head.}

63. Carex tenuirostris O̊lney, Am. Nat. 8: 214. 1874. Low, 1-2 dm. high, stiff and erect, the leaves very narrow and long-pointed, somewhat shorter than the culm: head small, ovate, 8-12 mm. long, very light brown: perigynium lanceolate and nearly terete below, slightly concave but marginless above, gradually narrowed into a point, lightly many-nerved, particularly on the back, about the length of the lanceolate and acute hyaline-margined scale. C. Bonplandii in part.-Western Wyoming and westward.

64. Carex illota Bailey, Mem. Torr. Bot. Club 1: 15. 1889. Stoloniferous: culm slender and nearly naked (3 dm. or more high), longer than the grasslike leaves: spikes $3-6$, small and chaffy, crowded into a small capitate dark brown head which is $12 \mathrm{~mm}$. or less long: bracts scale-like, often setaceouslypointed, sometimes inconspicuous, never longer than the head: perigynium ovate or ovate-lanceolate, somewhat colored, narrowed into a serrate beak about as long as the body, nerved, narrowly winged, about the length of the acutish scale or a little longer and about as wide. C. Bonplandii angustifolia.In the mountains; Colorado to Montana and west to Utah.

65. Carex festiva Dewey, Am. Journ. Sci. 24: 246. 1835. Caespitose: culms usually slender, 2-8 dm. high, longer than the flat stem-leaves: spikes 6-15, roundish, small, densely aggregated (occasionally somewhat loosely) into a fulvous dark brown or green and brown ovoid head, which is $1-3 \mathrm{~cm}$. in diameter: bract usually inconspicuous, sometimes as long as the head, narrow: perigynium varying from broad-ovate at base to long-lanceolate, greenish, conspicuously winged (half its width or more being consumed in the thin margins), narrowed gradually into a rough beak about as long as the body, nerved or almost nerveless, longer and broader than the acute or somewhat obtuse brown scale. (C. ebenea Rydb. Bull. Torr. Bot. Club 28: 266. 1901.) A number of varieties have been proposed, but they are distinguished from the species with difficulty.-Frequent throughout the Rocky Mountain region.

66. Carex multinoda Bailey, Bot. Gaz. 21: 5. 1896. Similar to the preceding but much slenderer, with very slender leaves: spikes small and massed into a little tawny or dark head: points of the narrow perigynia generally conspicuously spreading.- Same range as the preceding.

67. Carex athrostachya Olney, Proc. Am. Acad. 8: 393. 1868. Differs from 
C. festiva in the presence of elongated bracts which are expanded and strongly nerved at the base, the two or three lower much exceeding the mostly paler head: lowest spike rarely distinct.-Common throughout our range.

++ Spikes mostly separated, or if aggregated the individual spike well defined. ++ Perigynium thin and scale-like, with little distinction between the margin and the body, mostly greenish.

68. Carex scoparia Schk. Riedgr. Nachtr. 20. f. 175. 1806. Culms slender, erect, roughish above, $1.5-7.5 \mathrm{dm}$. tall: leaves less than $3 \mathrm{~mm}$. wide: spikes 3-10, oblong, narrowed at both ends, bright brown, 6-16 $\mathrm{mm}$. long, usually aggregated into an ovoid head: perigynia lanceolate, 4-6 mm. long, rather less than $2 \mathrm{~mm}$. wide, narrowly wing-margined, several-nerved on both faces, tapering into the ciliate two-toothed beak: scales thin, brown, acuminate or cuspidate, shorter than the perigynia.-Extending into Colorado from the eastern States.

++ Perigynium thickened in the middle, with conspicuous wing-margins which are more or less incurved, mostly tawny or brown.

69. Carex petasata Dew. Am. Journ. Sci. 29: 246. 1836. Caespitose: culm erect, 1-4 dm. high, scabrous above, mostly longer than the leaves: spikes 3-6, erect, ovoid, all contiguous into an oblong dark brown head: lower bracts often green and as long as the head, but usually all scale-like: perigynium ovate or oviate-lanceolate, broadly winged, nerved, rough on the margins, contracted into a beak scarcely as long as the body, the whole not longer than the thinmargined scale. C. leporina.-Frequent in our range.

70. Carex Liddonii Boott, Hook. Fl. Bor. Am. 2: 214. 1840. Culm erect or nearly so: spikes $3-6$, ovoid or oblong, pointed, erect, chaffy at the base, conspicuously fulvous in color, contiguous, or loosely aggregated into an oblong head 2-3 cm. long: perigynium large and conspicuous, greenish or tawny, firm in texture, lanceolate, $8-12 \mathrm{~mm}$. long, thrice as long as the elliptic brown achenium, few-nerved when mature, rough on the narrowly winged and incurved margins, very gradually beaked, about the length of the acute and thin-margined scale. C. adusta congesta W. Boott.-Mostly at high altitudes; Colorado to Montana; said to occur in Arizona.

71. Carex festucacea Willd. Sp. Pl. 4: 242. 1805. Culms nearly or quite smooth, erect, 3-10 dm. tall: leaves erect, $2-4 \mathrm{~mm}$. wide, shorter than the culm: spikes 3-8, green-brown, oblong or nearly globular, clustered, 4-8 mm. in diameter: perigynia orbicular or very broadly ovate, broadly wing-margined, about $3 \mathrm{~mm}$. in diameter, several-nerved on both faces, the roughish beak about one third the length of the body: scales acute or obtusish. C. straminea. -On the plains at the eastern base of the Rocky Mountains.

72. Carex praticola Rydb. Mem. N. Y. Bot. Gard. 1: 84. 1900. Culm very slender towards the top, weak and nodding at maturity, erect when young: leaves narrow, very long-pointed: spikes all silvery-brown, long attenuated at the base, the lower rather remote: perigynium thin and papery, ovatelanceolate, nearly nerveless. C. adusta minor; $C$. pratensis Drej.-Colorado and into British America.

The following have also been reported from this range but probably some of the specimens so reported are referable to other species: $C$. magellanica Lam.; C. viridula Michx.; C. retrorsa Schkur.; C. microglochin Wahl.

\section{LemnaCeae Dumort. Duckweed Family}

Minute aquatic plants without stems or leaves, but a flat or disk-like irregular plant-body which may be called the thallus or frond. These float on or near the surface and increase vegetatively by lateral growth and branching, the branches being lightly connected by slender stalks which soon allow them to 
separate as distinct thalli (the stalk, if it remains attached, constituting the stipe). Each produces one or more roots from the under side and on the edge or upper surface is borne the inflorescence which consists of 1 or more naked monoecious flowers. Each flower is either a single stamen, with 2-4-pollen sacs, producing barbellate pollen grains, or a single flask-shaped pistil, producing 1-6 ovules. Fruit a utricle and seeds large.

Thallus 1-3-nerved, or nerveless; rootlet solitary

1. Lemna. Thallus 7-12-nerved; rootlets several, fascicled

2. Spirodela.

\section{LEMNA * L. DUCKWEED}

Flowers produced from a cleft in the margin of the thallus, usually three together surrounded by a spathe; two of them staminate, consisting of a stamen only; the other pistillate, of a simple pistil; the whole therefore imitating a single diandrous flower. Anther cells transversely divided by a partition, each cavity opening transversely. Seeds 1-6.

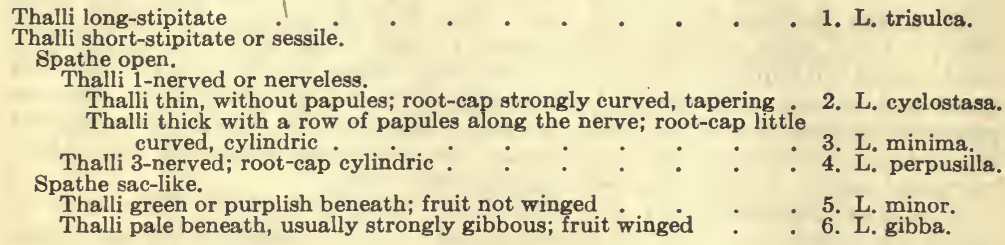

1. Lemna trisulca L. Sp. Pl. 970. 17.53. Thallus lanceolate, submerged and devoid of stomata in the primary aquatic form, ovate to oblong-lanceolate, 5-15 $\mathrm{mm}$. long, floating and provided with stomata in the later flowering stage: the later and more common form is narrowed at the base to a slender stipe, thin, denticulate, with or without rootlets, and slightly 3-nerved: several individuals often remain connected, so as to form a chain-like series: root-cap pointed: fruit symmetrical: seed deeply 12-15-ribbed.-Across the continent; also in the Old World.

2. Lemna cyclostasa (Ell.) Chev. Fl. Par. 2: 256. 1827. Thallus oblongelliptic, 2-4.5 mm. long, thin, subfalcate and shortly stalked at the base, provided with numerous stomata, except on the borders, nerveless: root-cap blunt: spathe reniform: fruit ovoid-oblong, unsymmetrical: seeds prominently 12-29-ribbed.-Pools and slow-flowing streams; northern Wyoming, and across the continent.

3. Lemna minima Philippi, Linnaea 33: 239. 1864. Thallus oblong to elliptic, 2-4 mm. long, obscurely 1-nerved, or nerveless, with a row of papules along the nerve, the lower surface flat, or slightly convex, the apex rounded: root-cap usually short, a little curved, rarely perfectly straight, cylindric, blunt: spathe open: pistil short-clavate; stigma concave: ovule solitary: seed oblong, pointed, about 16-ribbed, with many transverse striations.Wyoming to Florida and to California.

4. Lemna perpusilla Torr. Fl. N. Y. 2: 245. 1843. Thallus small, 2-3.5 mm. long, obovate, of ten purplish tinged beneath, unsymmetrical and abruptly narrowed to a very short stalk, provided throughout with numerous stomata, obscurely 3-nerved: root-cap straight, pointed: fruit ovoid: seed 12-20ribbed.-Frequent; northern Wyoming to New York.

5. Lemna minor L. Sp. Pl. 970. 1753. Thallus obovate or subcircular, 1.5-5 mm. long, thickish, rarely reddish or purplish tinged, short-stalked when young, provided throughout with stomata, nearly symmetrical, obscurely 3-nerved, very rarely 4-5-nerved: root-cap obtuse or subtruncate:

* The Key and specific descriptions have been taken without change from Britton's Manual. 
fruit symmetrical, subturbinate: seed with a prominent protruding hilum, deeply and unequally 12-15-ribbed: ovule 1.-Cosmopolitan; lakes and stagnant ponds.

6. Lemna gibba L. Sp. Pl. 970. 1753. Thallus unsymmetrical, obovate or short-obovate, 2-6 mm. long, thickish or more or less strongly gibbous beneath, short-stalked when young, soon separating, provided with stomata which are sparse beneath, obscurely 3-5-nerved: root-cap mostly shortpointed, cylindrical, rarely long-pointed or obtuse: fruit symmetrical: seed thick, deeply and unequally ribbed.-World-wide in distribution.

\section{SPIRODELA Schleiden. Greater Dückweed}

Anther-cells bilocellate by a vertical partition and longitudinally dehiscent. Ovules 2. Thallus 7-11-nerved or more; rootlets several, with axile vascular tissue. Otherwise as Lemna.

1. Spirodela polyrhiza (L.) Schleid. Linnaea 13: 392. 1839. Thallus 2-10 $\mathrm{mm}$. long, thick, flat and dark green above, slightly convex and purple beneath, palmately 5-15-nerved, bearing a central cluster of from 4-16 elongated roots: root-cap pointed.-In still water; widely distributed and occurring occasionally in our range.

\section{COMMELINACEAE Reichenb. Spiderwort Family}

Herbs, with fibrous or sometimes thickened roots, jointed and often branching leafy stems, and chiefly perfect and 6-androus, often irregular flowers, with the perianth free from the 2-3-celled ovary, and having a distinct calyx and corolla of 3 persistent sepals and as many ephemeral or deciduous (in ours blue) petals. Style 1; stigma undivided. Pod 3 to several-seeded. Leaves ovate, lanceolate, or linear, parallel-veined, flat, sheathed at the base; the uppermost often forming a kind of spathe.

Flowers irregular; 3 of the 6 stamens anther-bearing Flowers regular; stamens all anther-bearing

- 1. Commelina.

\section{COMMELINA L. DAY Flower}

Stems branching, often procumbent and rooting at the joints. Floral leaf heart-shaped and clasping, folded together or hooded, forming a spathe inclosing the flowers, which expand for a single morning and are recurved on their pedicels before and afterwards. Sepals somewhat colored, unequal; the two lateral partly united by their contiguous margins. Two lateral petals rounded, on long claws, the old one smaller. Sterile stamens with imperfect cross-shaped anthers.

1. Commelina crispa Wooton, Bull. Torr. Bot. Club 25: 451. 1898. Stems slender, erect, or reclined and rooting towards the base: leaves oblong or linearlanceolate: spathes peduncled, conduplicate, orbicular-cordate when expanded, in fruit somewhat hood-like. Commelina virginica.-Colorado and southwestward.

\section{TRADESCANTIA L. SPIDERWORT}

Freely branched; filaments folded: ovary pubescent in rib-like lines Simple; filaments straight; ovary pubescent at apex

1. T. laramiensis. 2. T. occidentalis.

1. Tradescantia laramiensis L. N. Goodding, Bot. Gaz. 33: 68. 1902. Stems glabrous, freely branched, $3-4 \mathrm{dm}$. high: leaves widely spreading, linear; the radical $5-10 \mathrm{~mm}$. wide; the cauline narrower; the involucral only 2-3 mm. wide and very long: umbels sessile, terminating stems and branches: flowers numerous, often as many as 50 in each umbel, pendent in age; pedicels 
2-3 cm. long, glandular-pubescent as are also the oblong acute sepals: petals dark blue, broad, obtuse, $2 \mathrm{~cm}$. long, twice as long as the sepals: filaments once or twice sharply folded on themselves and immersed in the copious wool arising from their lowest segments: ovary ribbed with rows of glandular hairs.-Eastern Wyoming.

2. Tradescantia occidentalis Britton, Rydb. Mem. N. Y. Bot. Gard. 1: 87. 1900. Stems solitary, erect, simple, 3-8 dm. high: leaves linear, involutely folded; sheaths 1-4 cm. long: pedicels 1-2 cm. long, glabrous: sepals oblong or elliptic, sparsely pilose-glandular, $8-10 \mathrm{~mm}$. long: petals blue or reddish, twice as long as the sepals: filaments nearly or quite straight, sparsely pilose at base: ovary pubescent at summit. T. virginiana. ( $T$. scopulorum Rose, Contrib. Nat. Herb. 5: 205. 1899, as to the specimens from Colorado and northward.) - From the eastern base of the Rocky Mountains in Colorado to Iowa.

\section{PONTEDERIACEAE Dumort. Pickerel Weed 'Family}

Aquatic herbs, with perfect more or less irregular flowers from a spathe. The petal-like 6-merous perianth free from the 3-celled ovary; the 3 or 6 mostly unequal or dissimilar stamens inserted in its throat. Fruit a perfectly or incompletely 3-celled many-seeded capsule, or a 1-celled 1-seeded utricle.

\section{1. heteranthera Ruiz \& Pav. Mud Plantain}

Creeping, floating, or submerged low herbs, in mud or shallow water, with a 1-few-flowered spathe bursting from the sheathing side or base of a petiole. Perianth salver-form from a slender tube; the limb somewhat equally 6-parted, ephemeral. Stamens 3, in the throat, usually unequal: anthers erect. Capsule 1-celled or incompletely 3-celled by intrusion of the placentae, many-seeded.

1. Heteranthera limosa (Sw.) Willd. Neue. Schrift. Ges. Nat. Fr. Berlin, 3: 439. 1801. Stems branched from the base, 1-3 dm. long: leaves oval or ovate, on long petioles: flowers white or blue: anthers linear, often sagittate.Reaching the eastern border of our range.

\section{JUNCACEAE Vent. Rush Family}

Annual or perennial grass-like herbs: Stems simple, hollow or spongy. Leaves alternate, sheathing, narrow, flat or terete. Flowers lily-like in structure, sedge-like in aspect, small, dry, perfect, disposed in terminal or apparently lateral heads, spikes, súbumbellate clusters, or panicles. Perianth consisting of 6 distinct similar glume-like segments. Stamens 6 or sometimes 3. Ovary superior, 3 or sometimes 1-celled; stigmas 3 , filiform; ovules 3 to many. Fruit a loculicidally 3-valved capsule.

Leaves soft, flat; stems hollow; capsule 1-celled and 3 -seeded
Leaves stiff, terete or flat; stems usually with spongy pith; capsule 3-or 1-celled, many-seeded

1. Luzula.

2. Juncus

\section{LUZULA DC.}

Perennial herbs with simple hollow leafy stems, grass-like flat leaves and numerous small flowers in loose involucrate umbels or panicles, or more or less densely clustered or spicate. Floral bracts small and scarious. Stamens always 6. Capsule 1-celled, with 3 parietal placentae and 1-3 seeds. (Juncoides.)

Inflorescence an open panicle, the flowers solitary or in clusters of 2-3 1 . L. parviflora. Inflorescence congested, capitate or spicate.

Nodding, usually a single spike

2. I. spicata.

Erect. in 2-several subglobose or oblong heads

3. L. intermedia. 
1. Luzula parviflora (Ehrh.) Desv. Journ. Bot. 1: 144. 1808. Stems slender, tufted, 3-6 dm. high: leaves narrowly lanceolate, 7-15 cm. long, 6-12 $\mathrm{mm}$. wide: inflorescence a loose decompound panicle, commonly $7-10 \mathrm{~cm}$. high, its lowest bract foliaceous, seldom more than one fourth the length of the panicle: flowers borne singly or 2-3 together on the branches of the panicle, on slender pedicels; bractlets ovate: perianth 2-3 mm. long, its segments ovvate, acuminate, slightly exceeded by the green to brown ovoid capsule.-Either moist or dry ground in the woods; throughout our range and across the continent northward.

2. Luzula spicata (L.) DC. Fl. Fr. 3: 161. 1805. Closely tufted, without rootstocks: stems erect, 1-4 dm. high, distantly 1-3-leaved, tapering to a filiform summit: leaves $4-6 \mathrm{~mm}$. wide, often involute, tapering to a sharp apex: inflorescence a nodding spike-like often interrupted panicle, commonly 15-30 $\mathrm{mm}$. long, usually exceeded by the lowest leaf-like bract, ovate-lanceolate, acuminate, equaling the perianth: segments of the perianth brown with hyaline margins, $2-3 \mathrm{~mm}$. long, lanceolate, aristate-acuminate: capsule broadly ovoid, about two thirds as long as the perianth.- In the high mountains of our range, and across the continent northward.

3. Luzula intermedia (Thuill.) A. Nels. Stems slender, 1-4 dm. high, leafy: leaves $6-10 \mathrm{~cm}$. long, $2-6 \mathrm{~mm}$. wide; the foliaceous bract usually exceeding the narrow panicle: peduncles $2-12$, unequal, the longer $3-5 \mathrm{~cm}$. long: spikes simple, usually oblong, loosely-flowered: perianth pale or somewhat tinged with brown, about $3 \mathrm{~mm}$. long; its segments narrowly acuminate, equaling the obtuse capsule: anthers small, as long as the filaments: seed dark brown with a white caruncle. L. comosa. [Juncus intermedius Thuill. Fl. Env. Paris, Ed. 2. 178. 1799; Juncoides intermedium (Thuill.) Rydb. Bull. Torr. Bot. Club 32: 610. 1905].-From the Rocky Mountains to California and Alaska.

\section{JUNCUS L. Rush. Bog, RUSH}

Chiefly perennials, and in wet soil or water, with pithy or hollow and simple (rarely branching) stems, and panicled or clustered small (greenish or brownish) flowers, chiefly in summer. Plant never hairy. Capsule many-seeded, 3 -celled, or 1-celled by the placentae not reaching the axis. Stamens when 3 opposite the 3 outer sepals.

Leaves knotted by internal cross-partitions; panicles terminal.

Leaves compressed and equitant.

Stamens 3

Stamens 6.

Heads two or more.

Heads solitary
Leaves terete or only slightly compressed.

Stamens 6; seeds pointed.

Perianth-segments and capsule obtuse

Perianth-segments and capsule acute or acuminate.

Inner segments longer than the outer

Outer segments longer than the inner.

Heads pale

Heads dark brown

Stamens 3 ; seeds caudate
Leaves not knotted, the cross-partitions at least not externally evident, flat, terete or semiterete.

Panicle terminal.

Flowers capitate.

Leaves fistulous.

Leaves flattened upward

I.eaves terete, channeled at base

Leaves flat, not fistulous.

Stamens 6.

Perianth-segments smooth

Perianth-segments rough .

$$
\text { Stamens } 3
$$

Flowers solitary, in panicles.

Stems simple, naked.

Leaf-blade terete

Leaf-blade flat.

Perianth-segments pale

Perianth-segments brown with green midrib

1. J. ensifolius.

2. J. saximontanus.

3. J. Mertensianus.

4. J. Richardsonianus.

5. J. nodosus.

6. J. Torreyi.

7. J. nevadensis.

8. J. Tweedyi.
9. J. triglumis.

10. J. castaneus.

11. J. longistylis.

12. J. orthophyllus.

13. J. marginatus.

14. J. Vaseyi.

15. J. tenuis.

16. J. confusus. 
Stems diffusely branched, leafy

Panicles apparently sessile and lateral; stems naked, scapose.

Flowers few, in panicles simple or nearly so.

Stems leafless

Stems somewhat leafy.

Perianth-segments white-margined; capsule retuse

Perianth-segments green; capsule pointed

Flowers many, in more or less compound panicles.

Perianth-segments with a brown stripe either side of the midrib

Perianth pale green throughout

17. J. bufonius.

18. J. subtriflorus.

19. J. Hallii.

20. J. Parryi.

21. J. balticus.

22. J. filiformis.

1. Juncus ensifolius Wiks. Kong. Vet. Akad. Hand. 2: 274. 1823. Stems 2-5 dm. high, leafy, from thick rootstocks: leaves equitant: heads several to numerous, panicled, globose, usually dark brown: perianth-segments lanceolate, acuminate, $3 \mathrm{~mm}$. long: stamens 3: capsule 3-angled, acute, hardly exceeding the perianth.-Wet banks; Colorado to Oregon.

2. Juncus saximontanus A. Nels. Bull. Torr. Bot. Club 29: 401. 1902. Stems from a creeping rhizome, erect, 3-5 dm. high, 2-edged: leaves compressed and equitant, 1-3 mm. wide, mostly auricled at base: heads panicled, few to several, brown, 3-10-flowered: flowers 2-3 mm. long, few to many in each head; the inner segments shorter and mostly acute; the outer ones equaling the long-mucronate capsule: stamens 6 . seeds more or less reticulated. $J$. xiphioides montanus.-Very common near stream banks throughout our range.

3. Juncus Mertensianus Bong. Veg. Sitcha in Mem. Acad. St. Peter. VI. 2: 167. 1833. Stem from a thick creeping rootstock, caespitose, 2-4 dm. high, compressed, weak; leaves compressed, usually 1-2 $\mathrm{mm}$. wide, sheath auricled: flowers 15-25, dark brown, pediceled, single, rarely $2-3$ in rather loose head, $8-12 \mathrm{~mm}$. broad: sepals ovate-lanceolate, the outer acuminate-subulate, the inner obtuse and mucronate or rarely acute and equaling the outer ones, exceeding the 6 stamens, equaling the broadly-obovate, obtuse, mucronate capsule: anthers oblong or oblong-linear, usually mucronate, equaling the filament or shorter: style mostly shorter than the obtuse ovary: seeds oblanceolate, obovate, fusiform, short-tailed at each end, reticulate-costate.-Wet places in the mountains.

4. Juncus Richardsonianus R. \& S. Syst. 7: 201. 1829. Stems leafy, 2-5. dm. high: leaves knotted by internal cross-partitions, terete or slightly compressed: panicle terminal, erect, elongated, greenish or light brown: heads few-flowered: sepals obtuse: stamens 6: capsules light brown, obtuse, mucronate, 3-celled: seeds spindle-shaped.-From Colorado northward, also eastward to New York.

5. Juncus nodosus L. Sp. Pl. Ed. 2. 466. 1762. Stems erect, 1-5 dm. high, slender from a creeping thread-like and tuber-bearing rootstock, mostly with 2 or 3 slender leaves: heads few to several, rarely single, 8-20-flowered, 6-8 mm. wide, overtopped by the involucral leaf: flowers brown, $3-4 \mathrm{~mm}$. long: sepals lance-linear, awl-pointed (the 3 outer mostly a little shorter), nearly as long as the slender triangular taper-pointed 1-celled capsule: anthers oblong, shorter than the filaments: style very short: seeds obovate, abruptly mucronate.-From our range to New England.

6. Juncus Torreyi Coville, Bull. Torr. Bot. Club 22: 303. 1895. Plant 4-10 dm. high, not caespitose: rootstock slender, tuberiform-thickened at intervals of a few centimeters, each tuber supporting a single stem: stem terete or slightly compressed, stout, 1-4-leaved: blades stout, terete, in most cases abruptly divergent from the stem: inflorescence usually congested, a few centimeters in length and consisting of 1-6 heads, occasionally only $10 \mathrm{~cm}$. long and bearing 15-20 heads, exceeded by the involucral leaf: heads $10-15 \mathrm{~mm}$. in diameter: perianth 4-5 $\mathrm{mm}$. long, its parts subulate, the outer longer than the inner: stamens about one half as long as the perianth: capsule subulate, 1-celled, its beak barely exceeding the perianth and holding the valves together throughout dehiscence: seed oblong, acute at both ends, reticulated: J. nodosus megacephalus.-Throughout our range.

7. Juncus nevadensis Wats. Proc. Am. Acad. 14: 303. 1879. Scape very 
slender, from a slender horizontal rootstock, somewhat compressed, 2-5 dm. high: leaves very narrow, subterete; ligules present: spathe short and very narrow: heads small, few to rather many in a short open panicle, frequently solitary: perianth-segments brownish, lanceolate, acuminate, $4 \mathrm{~mm}$. long: stamens 6; anthers longer than the filaments: stigmas long-exserted: capsule oblong, abruptly contracted into the stout style, which nearly equals the perianth: seeds minute, oblong, apiculate at each end.-From the Rocky Mountains to the Sierras.

8. Juncus Tweedyi Rydb. Mem. N. Y. Bot. Gard. 1: 90. 1900. Stem about $3 \mathrm{dm}$. high, strict, light green, $2-3 \mathrm{~mm}$. in diameter: leaves terete or slightly flattened, more or less distinctly septate, with conspicuous scarious sheaths, the basal ones short; stem leaves, except the upper ones, about $1 \mathrm{dm}$. long: heads in a contracted panicle, brown and shining, 5-8-flowered: perianthsegments subequal, about $4 \mathrm{~mm}$. long, narrowly lanceolate, acute or acuminate: bracts ovate, cuspidate-acuminate: stamens 3 , about two thirds as long as the perianth; anthers much shorter than the filaments: style rather short: capsule dark brown and shining, oblong, acute, sharply 3-angled, about one fourth longer than the perianth: seeds light-colored, about $1 \mathrm{~mm}$. long, tailed at both ends. J. canadensis coarctatus.-Yellowstone Park.

9. Juncus triglumis L. Sp. Pl. 328. 1753. Stems 5-15 cm. high, somewhat tufted on a branching rootstock, erect, terete: leaves radical, subulate, somewhat terete, channeled at base: flowers capitate, in a terminal erect mostly 3 -flowered head, the lowest 2 or 3 bracts nearly equal, divergent, about as long as the flowers: perianth-segments rather obtuse, shorter than the oblong obtuse mucronate capsule: filaments many times longer than the capsule: seeds oblong, abruptly contracted into long slender tails.-High mountains in our range and across the continent far northward.

10. Juncus castaneus Smith, Fl. Brit. 1: 383. 1800. Stems erect, 1-4 dm. high, terete, leafless or nearly so: basal leaves 2-4, rather short, tapering from an involute tubular base to a slender channeled acutish apex: heads 1-3, fewflowered, brown or black: perianth-segments lanceolate, 5-6 $\mathrm{mm}$. long: stamens nearly as long; the anthers about $1 \mathrm{~mm}$. long: capsule brown, narrowly oblong, acute, much longer than the perianth: seeds' contracted into long slender tails.-Range of the preceding.

11. Juncus longistylis Torr. Bot. Mex. Bound. 223. 1859. Stems 3-5 dm. high, caespitose, stoloniferous, terete, somewhat minutely scabrous above, leafy: leaves flat, grass-like: heads few, clustered in a contracted panicle, 3-5 $\mathrm{cm}$. long, or rarely single, 3-12-flowered: flowers 5-6 mm. long, the larger ones greenish, with brown striae, smooth, pediceled: sepals equal, ovate-lanceolate, very acute or cuspidate, twice longer than the stamens: ovary equaling the stamens and style; stigma exserted: capsule ovate, obtuse, mucronate or rostrate, chestnut-colored, shining, 3-celled, equaling or a little longer than the calyx: seeds oblanceolate or obovate, acute at each end, costate-reticulate. -Frequent throughout our range.

12. Juncus orthophyllus Coville, Contrib. U. S. Nat. Herb. 4: 207. 1893. Stems 3-8 dm. high, from creeping rootstocks: leaves flat, about $2 \mathrm{~mm}$. wide, pale green, shorter than the sheaths, with ligules: heads panicled few-flowered: perianth-segments straw-color, lanceolate, acuminate, scarious-margined, rough, $7 \mathrm{~mm}$. long: stamens 6: capsule triangular, oblong, acute, shortbeaked.-Mostly to the northwest of our range.

13. Juncus marginatus Rostk. Monog. Junc. 38. 1801. Tufted, 1.5-7.5 $\mathrm{dm}$. high from branching rootstocks: leaf-sheaths auriculate; blades 1-3 mm. broad, $2-4$ conspicuous veins in addition to the midrib: inflorescence $1 \mathrm{dm}$. high or less, the panicle composed of 2-20 tubinate to subspherical 5-10flowered heads: perianth $2.5-3.5 \mathrm{~mm}$. long; the outer parts ovate, acute, the inner slightly longer, obtuse, with hyaline margins: stamens 3 ; anthers ovate, much shorter than the filaments: capsule equaling the perianth, obovoid, truncate or retuse, almost 3-celled, the placentae deeply intruded: seed oblong, 0.4-0.5 mm. long, pointed at either end, 12-16-ribbed.-Colorado to the Atlantic States. 
14. Juncus Vaseyi Engelm. Trans. St. Louis Acad. 2: 448. 1866. Caespitose: stems $2-5 \mathrm{dm}$. high, slender, rigid, striate, covered with brown sheaths at base, sometimes leaf-bearing: leaves elongated, setaceous, terete, striate, sulcate toward the base: spathe equaling or rarely longer than the small, contracted panicle: panicle 1-3 cm. long, green: sepals equal, lanceolate, $3-4 \mathrm{~mm}$. long, outer ones subulate-tipped, inner ones broader, mucronate, more than twice longer than the six stamens: anthers equaling the filaments: stigma scarcely equaling the ovate ovary with its short style: capsule straw-colored, ovate, retuse, 3-celled, equaling or a little longer than the sepals: seeds very slender.-Colorado to New England.

15. Juncus tenuis Willd. Sp. Pl. 2: 214. 1799. Plant perennial, closely tufted, 2-7 dm. high: leaves all basal, except those of the inflorescence; blades flat, sometimes involute in drying: inflorescence exceeding or exceeded by its lowest leaf: perianth $3.5-5 \mathrm{~mm}$. long, its parts lanceolate, acuminate: stamens 6, about one half as long as the perianth; the anthers shorter than the filaments: capsules usually about one fifth shorter than the perianth, ovate to obovate, obtuse, mucronate, 3-celled: seeds narrowly oblong, with oblique apiculations, reticulated in about 16 longitudinal rows. ( $J$. interior and $J$. Dudleyi Wiegand, Bull. Torr. Bot. Club 27: 516 and 524. 1901, at least as to our specimens.)-Common eastward and rather frequent in our range, though in part replaced by the following.

16. Juncus confusus Coville, Proc. Biol. Soc. Wash. 10: 137. 1897. Densely tufted, 2-7 dm. high, erect: sheaths of the leaves with well-developed ligules, the blades about one half the length of the stem, flat, usually involute: spathe much longer than the inflorescence, usually involute: panicle congested into a turbinate cluster $2-3 \mathrm{~cm}$. long: perianth-segments ovate-lanceolate, acute, brown, with a green midrib: stamens 6 , the anthers shorter than the filaments: capsule oblong, equaling the perianth, retuse, completely 3-celled: seeds light brown.-Meadows; Colorado to Montana and west to Oregon.

17. Juncus bufonius L. Sp. Pl. 328. 1753. Plant annual, branching from the base, erect, seldom exceeding $20 \mathrm{~cm}$. in height, the stems in larger plants with one or two leaves below the inflorescence: leaf-blade in the larger plants flat, in depauperate ones filiform-involute: inflorescence about one half as high as the plant: flowers inserted singly on its branches: perianth parts $4-7$ $\mathrm{mm}$. long, lanceolate, acuminate: stamens usually 6 , sometimes 3 , seldom half as long as the perianth: capsule narrowly oblong, obtuse, mucronate, 3-celled: seeds broadly oblong, with straight apiculations, finely reticulated.-Margins of ponds, etc., frequent; widely distributed.

18. Juncus subtriflorus (Mey.) Coville, Contrib. U. S. Nat. Herb. 4: 208. 1893. Caespitose: stems 3-5 dm. high, terete, filiform: sheath bristle-pointed: spathe 1-4 cm. long, mostly surpassing the simple, about 3-flowered panicle: sepals lanceolate, acute, or the outer ones acutish and scarcely longer than the inner ones, more than twice exceeding the 6 stamens, $5 \mathrm{~mm}$. or more long: anthers linear, a little longer than the filament: stigmas shorter than the slender prismatic ovary, crowned with a very short style: capsule ovate-oblong, triangular, retuse, 3-celled, equaling or a little shorter than the sepals: seeds ovate, striate-reticulate, long-tailed. J. Drummondii.-Colorado to Montana.

19. Juncus Hallii Engelm. Trans. St. Louis Acad. 2: 446. 1866. Caespitose: stems 1-3 dm. high, terete, filiform, much longer than the setaceous, terete leaves: leaves $5-12 \mathrm{~cm}$. long, grooved just above the sheath: spathe scarcely or a little surpassing the subsimple, few-flowered, contracted panicle: sepals lanceolate, acute, $4 \mathrm{~mm}$. long, outer ones a little longer, twice exceeding the 6 stamens: stigma subsessile, equaling the ovate ovary, included: capsule ovate, angled, retuse, 3-celled, scarcely exserted, deep brown: seeds oblonglinear, striate-reticulated, long-tailed.-Hall and Harbour, near Lake Ranch, Colorado.

20. Juncus Parryi Engelm. 1. c. Caespitose: stems very thin and wiry, 1-2 dm. long: leaves sulcate, one half or two thirds their length, terete above: spathe surpassing the very simple, 1-3-flowered panicle: sepals 5-7 mm. long, lanceolate-subulate, the outer ones longer, bristle pointed, three times longer 
than the 6 stamens: anthers linear, 2-3 times longer than the filament: stigmas scarcely equaling the linear-prismatic ovary, attenuated into the style, included: capsule prismatic, very acute, brown, exserted, 3-celled: seed oblong, delicately striate-costate.-Frequent in our whole range.

21. Juncus balticus Willd. Berlin. Mag. 3: 298. 1809. Stems erect, 4-8 dm. high, arising at intervals from stout creeping rootstocks: sheaths green or tinged with dark brown: spathe slender, 10-15 $\mathrm{cm}$. long: panicle commonly loosely branching, 3-8 cm. long: perianth 3-5 mm. long, its segments lanceolate, acute, or the inner sometimes obtuse, brown with green midrib and hyaline margins: stamens 6, about two thirds the length of the perianth; anthers much longer than the filaments: capsule about as long as the perianth, pale to dark brown, narrowly ovoid, conspicuously mucronate: seeds usually with a loose coat.- Sandy shores and slopes; very common; across the continent.

22. Juncus filiformis L. Sp. Pl. 326. 1753. Stems slender, 1-5 dm. high, many of them sterile and appearing like leaves, from stout matted rootstocks: sheaths purplish, obtuse, with a short bristle-like appendage: spathe usually longer than the stem: panicle rather few-flowered, 2-3 cm. high: segments of the perianth 2-4 $\mathrm{mm}$. long, green with hyaline margins, narrowly lanceolate, acuminate: stamens 6, about half the length of the perianth; anthers shorter than the filaments: capsule obovoid, green, barely pointed, about three fourths as long as the perianth, 3-celled: seeds oblong, pointed at each end.In marshes; across the continent.

\section{LILIACEAE Adans. Lily Family}

Herbs; stems scapose or leafy, from bulbs or fleshy roots (a woody caudex in Yucca). Leaves mostly linear. Flowers perfect; perianth of 6 distinct segments. Stamens 6, on the receptacle or the tube of the perianth. Styles united; stigma 3-lobed or entire; ovary 3-celled, becoming a capsule.

With fleshy fascicled roots from a short rootstock .

1. Leucocrinum.

With tunicated scaly or corm-like bulbs.

Flowers with scarious bracts and persistent perianth.

Flowers in terminal umbels.

Bracts 2 or 3 ; perianth of distinct segments .

Bracts several; perianth funnelform .

Flowers in a terminal raceme

Flowers bractless or the bracts foliaceous.

Perianth-segments all alike.

Anthers versatile; flowers large and èrect _ . . . . 5. Lilium.

Anthers fixed by the base.

Stem leafy.

Flowers dull purple, or yellow; nodding

Flowers white, streaked with purple, erect :

Leaves only 2 , basal

Outer perianth-segments smaller than the inner:

With large woody caudex and rigid dagger-pointed leaves

\section{LEUCOCRINUM Nutt. White Mountain Lily}

Stemless, the numerous fleshy roots from a short rootstock which bears the several linear leaves. Flowers few to many from the crown of the rootstock.

1. Leucocrinum montanum Nutt. Gray, Am. Lyc. N. Y. 4: 110: 1837. Leaves thick, surrounded at base by scarious bracts: flowers white, the tube slender, 3-5 cm. long, the segments spreading; stamens on the tube: style long, with dilated stigma. - The fragrant blossoms appear just above the ground in early spring; frequent in our range.

\section{ALLIUM L. WILD ONION}

Herbs with coated bulbs and a basal cluster of leaves, having a very characteristic odor and taste (alliaceous). Leaves mostly linear, either flat or

ROCKY MT. ВOT. -8 
terete (sometimes hollow). Flowers in a simple terminal umbel, deep rose color to white. Perianth segments 1-nerved, usually spreading. Base of the style inclosed between the lobes of the capsule and jointed upon the short axis. Filaments usually dilated at the base. Capsule 3-celled, loculidical, several-seeded.

Leaves hollow, terete .

Leaves not hollow, flat or terete.

Bulb-coats fibrous reticulated.

Valves of capsule crested.

Perianth-segments acute

Perianth-segments acuminate

Valves of capsule not crested.

Bulblets freely produced in the umbel

Bulblets rarely produced in the umbel Bulb-coats thin-membranous, sometimes reticulate-veined but not
fibrous.

Umbel nodding .

Umbel erect.

Bulb oblong, and rhizomatous below

Bulb small, subglobose. Leaves longer than the short scape. Leaves shorter than the scape

1. A. sibiricum.

2. A. reticulatum.

3. A. Geyeri.

4. A. rubrum.

5. A. Nuttallii.

6. A. cernuum.

7. A. brevistylum.

8. A. Brandegei.

9. A. acuminatum.

1. Allium sibiricum L. Mant. 562. 1767. Bulbs more or less caespitose: leaves terete, hollow, shorter than the stout 3-6 dm. high scape: umbel crowded, subcapitate: flowers rose-color; the segments $8-10 \mathrm{~mm}$. long, acuminate: stamens included: capsule not crested. A. Schoenoprasum. - Wet meadow-lands; northern Wyoming to Canada, and east to the Great Lakes.

2. Allium reticulatum Fraser, Hook. Fl. Bor. Am. 2: 184. 1839. Bulbs rather large, usually single, the coats strikingly fibrous-reticulate: leaves narrow, channeled: scapes 1-2 dm. high: flowers white or pinkish; the pedicels slender, 4-12 $\mathrm{mm}$. long: bracts (spathe) 2: perianth-segments thin, acute: capsule shorter than the perianth, each valve with two short crests at summit.- Throughout our range, and north into Assiniboia.

3. Allium Geyeri Wats. Proc. Am. Acad. 14: 227. 1879. Resembling the preceding but taller and stouter, 2-4 dm. high: flowers rose-colored, 6-8 $\mathrm{mm}$. long; the segments broad, acute or acuminate, strongly nerved and rigid in fruit; pedicels rather stout, 10-20 mm. long: stamens and style usually but little shorter than the perianth: capsule crested. (A. dictyotum Greene, Pl. Baker. 1: 52. 1901.) - From Colorado to Montana and west to Washington.

4. Allium rubrum Osterh. Bull. Torr. Bot. Club 27: 506. 1900. Bulbs usually single, fibrous-reticulate coated: scape 2-3 dm. high: leaves rather narrow, flat or channeled: spathe 2 or 3-bracted: most of the flowers of the umbel replaced by small red spherical bulblets: perianth-segments ovate to lanceolate, usually obtusish, the outer often with a dark green midnerve, narrowly ovate, $6-7 \mathrm{~mm}$. long: pedicels about $1 \mathrm{~cm}$. long: stamens and style equaling the perianth. A. canadensis. (A. fibrosum Rydb. Bull. Torr. Bot. Club 24: 188. 1897.) - Throughout our range.

5. Allium Nuttallii Wats. Proc. Am. Acad. 14: 227. 1879. Bulb usually smaller, very fibrous: scape low, 1-2 dm. high: pedicels 8-12 mm. long, rather stout: perianth-segments acute or acuminate, rose-colored or white, rather rigid in fruit, $6 \mathrm{~mm}$. long: capsule not crested: bulblets occasionally replacing the flowers in the umbel. (A. arenicola Osterh. 1. c.)-From Texas and New Mexico to Wyoming.

6. Allium cernuum Roth. Roem Arch. 13: 40. 1798. Bulbs mostly single: leaves flat, $2-8 \mathrm{~mm}$. wide: scape 1-5 dm. high: umbel open, nodding: flowers numerous, on very slender pedicels, rose-colored or white; segments 4-6 mm. long, broad, acutish: stamens and style exserted: capsule crested. (A. recurvatum Rydb. Mem. N. Y. Bot. Gard. 1: 94. 1900.)-Frequent; throughout our range and across the continent northward.

7. Allium brevistylum Wats. King's Rep. 350. 1871. Scape $3-5 \mathrm{dm}$. high, from a stout elongated bulb with rhizomatous base: leaves flat, 4-10 $\mathrm{mm}$. broad: spathe 1-valved: umbel erect, few-flowered; pedicels 10-25 mm. long: flowers deep rose-color; segments 8-12 mm. long, narrow, long-acuminate, 
nearly twice longer than the stamens and style: capsule not crested.-Utah, Colorado, and Wyoming.

8. Allium Brandegei Wats. Proc. Am. Acad. 17: 380. 1882. Bulbs small, the coats membranous, reticulate-veined but not fibrous: leaves 2 , exceeding the angular scape: pedicels slender, equal, about $8 \mathrm{~mm}$. long: flowers rosecolor; the segments broadly lanceolate, acute, nearly twice longer than the. stamens, not serrulate.-From Colorado to Idaho and Montana.

9. Allium acuminatum Hook. Fl. Bor. Am. 2: 184. 1839. Outer bulb-coats with a distinct coarse quadrate to hexagonal reticulation: pedicels $15-25 \mathrm{~mm}$. long: flowers deep rose-color; segments lanceolate, with acuminate recurved tips, rigid in fruit, a third longer than the stamens, the inner ones undulateserrulate.-Colorado, Utah, and Wyoming.

\section{BRODIAEA Smith}

Perennial herbs from corm-like bulbs with fibro-membranous brown coats. Scape erect. Leaves linear. Flowers in terminal umbels with several bracts; pedicels jointed. In ours the perianth is broadly tubular; blue. Stamens 6 , in 2 rows. Capsule ovate to oblong.

1. Brodiaea Douglasii Wats. Proc. Am. Acad. 14: 237. 1879. Scape smooth, 3-6 dm. high, erect and usually stout: leaves carinate: perianth tube subsaccate, about equaling the lobes: anthers oblong; the lower on the throat opposite the outer segments, the upper on the inner segments, on a short free filament which forms below a prominent wing within the tube: capsule $6 \mathrm{~mm}$. long, a little exceeding the stipe and slender style: seeds several in each cell.-From western Wyoming to Washington and Oregon

\section{CAMASSIA Raf. Quamash}

Scape slender, from a tunicated bulb. Leaves linear-lanceolate, carinate. Flowers in a simple raceme, with narrow scarious bracts; pedicels jointed at the summit. Perianth blue or white, of 6 distinct oblanceolate segments. Stamens 6 , on the base of the slightly gibbous perianth, shorter than the'segments. Style slightly trifid at the apex. Capsule subglobose, 3-lobed and angled, with several black shining seeds in each cell.

1. Camassia esculenta Lindl. Bot. Reg. 18: t. 1486.1832 . Scape stout, a foot or two high: pedicels rather stout, mostly shorter than the usually dark blue flowers: perianth-segments scarcely exceeding the style, a little longer than the stamens.-Western Wyoming and west to California; the bulb formerly largely collected for food by the Indians.

\section{LILIUM L. LILY}

Bulb scaly, stem leafy, simple. Leaves narrow, sessile, whorled or scattered, net-veined. Flowers large and showy, in ours usually solitary and erect. Perianth-segments oblanceolate, with a linear nectariferous groove, usually spotted. Anthers versatile. Style undivided.

1. Lilium montanum A. Nels. Bull. Torr. Bot. Club 26: 6. 1899. Bulb depressed-globose, of thick fleshy scales: stem 3-4 dm. high: leaves smooth, dark green, alternate except the uppermost whorl of 5-7, lanceolate, sessile: the segments of the single erect flower elliptic-oblong, tapering to both ends, brownish-red to orange-red, the base of the inner face dotted with purplishblack spots: stamens and stigma purplish: capsule oblong-cylindric. L. philadelphicum.- In moist thickets near mountain streams; throughout our range.

\section{FRITILLARIA L.}

Bulbs of numerous thick scales. Stems erect, leafy, simple. Perianth mostly campanulate, deciduous, of 6 equal ovate or oblong distinct segments; 
the flowers often nodding, solitary or racemed, much smaller than in Lilium, often mottled. Nectary a shallow pit at the base of the segments. Styles united to the middle or throughout.

Flowers purple and mottled

Flowers yellow or orange

1. Fritillaria atropurpurea Nutt. Journ. Acad. Phila. 7: 54. 1834. Bulb of numerous thick scales: stem $2-4 \mathrm{dm}$. high or more, 1-6-flowered: leaves 6-20, scattered or somewhat verticillate: flowers dull purple with more or less of yellowish-green: styles distinct above; stigmas linear: capsule acutely angled, broadly obovate.-From Wyoming to the Sierra Nevada.

2. Fritillaria pudica (Pursh) Spreng. Syst. 2: 64. 1825. Bulb of numerous very small rounded scales: stem 1-2 dm. high, 1-6-flowered: leaves 3-8, scattered or somewhat verticillate: flowers usually solitary, nodding, yellow or orange and tinged with purple: styles connate and stigma shortly 3-lobed: capsule oblong to subglobose.-From Utah and Montana to the Sierra Nevada and British Columbia.

\section{LLOYDIA Salisb.}

The bulb upon an oblique rhizome, covered by the persistent scarious bases of the nearly filiform leaves. Stem leafy, usually 1-flowered. Perianth small, spreading, white with purplish veins and base. Style undivided.

1. Lloydia serotina (L.) Sweet, Hort. Brit. Ed. 2. 52. 1830. Stems 5-15 $\mathrm{cm}$. high, equaling the leaves: flowers erect: perianth-segments oblanceolate, obtuse, obscurely pitted at base: capsule obovate, obtusely angled: seeds chestnut-colored.-Mountains of Colorado and northward throughout the alpine and arctic regions of the northern hemisphere.

\section{ERYTHRONIUM L. Dogtooth VIOLET}

Herbs with deep-set bulbs. Leaves only 2, smooth, flat, shining, sheathing the base of the naked stem. Flowers 1 or more, nodding. Perianth of six separate and recurved segments; these oblanceolate, callous-toothed each side of the grooved nectary. Styles usually distinct above. Capsule obovoid or oblong. Seeds usually several in each cell.

Leaves acute; anthers yellow

Leaves obtuse; anthers dark-purple

1. E. parviflorum.

1. Erythronium parviflorum (Wats.) L. N. Good. Bot. Gaz. 33: 67. 1902. Bulb slender, 3-5 cm. long: scape 1-3 dm. high: leaves oblong, tapering gradually to the acute ends, $10-15 \mathrm{~cm}$. long: flowers usually solitary; the peduncle hook-curved at summit; segments lanceolate-acuminate, $2-3 \mathrm{~cm}$. long, bright yellow, with greenish base, strongly recurved: filaments narrowly linear; the anthers pale yellow: capsule from oblong to oval, $2-3 \mathrm{~cm}$. long. $E$. grandiflorum minor.-Subalpine in the central Rocky Mountains.

2. Erythronium obtusatum L. N. Good. 1. c. Very similar but with larger, thicker bulb: leaves oblong-elliptical, obtuse but sometimes apiculate: peduncle stout, usually 2-3-flowered (1-5); the perianth-segments pale yellow, drying with a purplish tinge: filaments dilated at base and tapering to the acute apex; anthers dark purple: stigma deeply 3-lobed.-Northern Wyoming and adjacent Idaho and Montana.

\section{CALOChORTUS Pursh. Mariposa LiLy}

Stems usually flexuous and branching, from coated corms. Leaves few, linear-lanceolate, radical and cauline, the latter alternate and clasping, all with many nerves and transverse veinlets. Flowers few, showy; in ours the flowers are open-campanulate, white or lilac, with densely hairy glands, and the capsule narrowly oblong with thick obtusely angled lobes. Outer perianth- 
segments narrow and calyx-like; the inner broad and usually bearded. Anthers basifixed. Stigma sessile. Capsule septicidal.

Anthers obtuse, gland circular

Anthers acute, gland transversely oblong
1. C. Nuttallii.

2. C. Gunnisonii.

1. Calochortus Nuttallii, T. \& G. Pac. R. R. Rep. 2: 124. 1855. Stem slender, bulbiferous at base, with a single narrow cauline leaf (sometimes 2 or 3 ), umbellately 1-5-flowered: sepals of ten with a dark or hairy spot: petals $3-4 \mathrm{~cm}$. long, white tinged with greenish-yellow or lilac, with a purplish spot or band above the yellow base, and hairy around the circular or oblong gland: anthers obtuse.-From New Mexico and Colorado to Dakota and California.

2. Calochortus Gunnisonii Wats. Bot. King's Rep. 348. 1871. Like the last but with acuminate anthers and a broad transverse gland: petals light lilac, yellowish-green below the middle, banded and lined with purple.Mountains from Wyoming to New Mexico.

\section{YUCCA L.}

Ours are acaulescent plants with rosulate rigid and pungent leaves and large racemose flowers on thick erect scapes. Perianth open-campanulate, of nearly distinct lanceolate or oval segments. Filaments nearly free, thickened above; the anthers short, sagittate. Ovary oblong, mostly longer than the stout or swollen style; the stigma unequally 6-lobed. Fruit capsular, 6-valved above, nearly or quite 6-celled. Seeds numerous.

Fruit an erect hard dehiscent capsule.

Style green; leaves long, narrow and rigid . . . . . 1. Y. glauca.

Style white; leaves short, lanceolate-spatulate $: \quad: \quad: 2$. Y. Harrimaniae. Fruit pendent, fleshy, edible

3. $\mathbf{Y}$. baccata.

1. Yucca gla uca-Nutt. Fraser's Cat. No. 89. 1813. Leaves filamentose on the margin, very stiff and pointed, usually $3-6 \mathrm{dm}$. long by $6-15 \mathrm{~mm}$. wide, smooth: raceme usually simple, nearly sessile, 3-10 dm. long: flowers greenishwhite or tinged with brown; segments broadly ovate, $3-5 \mathrm{~cm}$. long: capsule erect, somewhat 6 -sided: seeds thin, smooth, broadly margined. $Y$. angustifolia.-From New Mexico to Montana and Dakota.

2. Yucca Harrimaniae Trel. Rept. Mo. Bot. Gard. 13: 59. 1902. Acaulescent and often caespitose: leaves linear to spatulate-lanceolate, 6-40 m. wide, thin but rigid, spreading, pungent, brown-bordered, with coarse marginal fibers: scape 2-5 dm. high, simple, flowering from near the base: flowers greenish, with large often obtuse segments: style slender: capsule brown, about $40 \mathrm{~mm}$. long, constricted, flaring above.-From Utah to southern Colorado.

3. Yucca baccata Torr. Mex. Bound. Surv. 221. 1859. Leaves coarsely filamentose on the margin, very thick and rigid, 5-10 dm. long by 3-5 cm. wide, channeled or concave, rough especially on the back, tipped by a very stout brown spine: panicle pedunculate: perianth-segments narrow, $5-8 \mathrm{~cm}$. long: fruit oval or cylindric, dark purple, often long-beaked: seeds thick and rugose.- Southern Colorado, New Mexico, and west to Nevada.

\section{MELANTHACEAE R. Br. Bunch-Flower Family}

Herbs with leafy stems arising from rhizomes or bulbs. Leaves nerved. Flowers regular, solitary or in racemes or panicles; the perianth-segments distinct, usually persistent. Stamens 6 , with cordate or reniform versatile confluently 1-celled anthers, or the anthers small and with 2 distinct cells. Ovary 3-celled, with 3 distinct or more or less united styles. Seeds usually tailed or appendaged.

Anthers 2-celled; oblong or ovate.

Raceme very long and many-flowered

Raceme short, few-flowered

1. Xerophyllum. 2. Tofieldia. 
Anthers confluently 1-celled, cordate or reniform.

Stems from a bulb; perianth-segments with gland or spot near the base

Stems from a rootstock; perianth-segments not gland bearing

3. Zygadenus.

4. Veratrum.

\section{XEROPHYLLUM Michx.}

Stem from a bulbous base, bearing a compact raceme of showy white flowers, and thickly beset with needle-shaped leaves, the upper of which are reduced to bristle-like bracts; those from the root very many in a dense tuft.

1. Xerophyllum tenax (Pursh) Nutt. Gen. 1: 235. 1818. Stems 6-10 dm. high: leaves often $5-8 \mathrm{dm}$. long: flowers white; pedicels $2-4 \mathrm{~cm}$. long: perianth scarcely equaling the stamens; segments oblong, 8-10 $\mathrm{mm}$. long, 5-7-nerved: capsule cordate-ovate, 6 -valved, the abruptly acute cells separating and then dehiscing.-Montana, possibly Wyoming, and west to Oregon.

\section{TOFiEldia Huds. False Asphodel}

Mostly tufted, with fibrous roots, and simple stems leafy only at base, bearing small flowers in a close raceme. Leaves linear, grass-like. Ours has stem and inflorescence pubescent, and pedicels fascicled.

1. Tofieldia intermedia Rydb. Bull. Torr. Bot. Club 27: 528. 1900. Stem slender, viscid-pubescent above: leaves linear: raceme short, few-flowered: flowers yellow: sepals obovate, $4-5 \mathrm{~mm}$. long: petals narrower and longer: capsule ovoid: seeds unappendaged: T. glutinosa.-Wyoming and far northward and westward.

\section{ZYGADENUS Michx.}

Glabrous herbs, with leafy or somewhat scape-like stems from a tunicated bulb, and long narrow keeled leaves. Flowers greenish-yellow or nearly white in a terminal raceme or panicle. Perianth withering-persistent; the segments with a glandular spot near the base. Stamens free or attached to the base of the segments. Capsule 3-celled, dehiscent to the base. Seeds numerous, oblong or linear, angled.-(Toxicoscordion and Anticlea, c. f. Bull. Torr. Bot. Club 30: 272-3. 1903.)

Gland obcordate; base of ovary adnate to the perianth

Gland obovate or semiorbicular; ovary free.

Perianth-segments more or less clawed; filaments attached to the base of the segments.

Flowers small; leaves narrow; gland orbicular

Flowers larger; leaves broader; gland semiorbicular

Perianth-segments not clawed; filaments free

\section{Z. elegans.}

1. Zygadenus elegans Pursh, Fl. Am. Sept. 241. 1814. Bulb ovate: stem 2-8 dm. high: leaves glaucous, 4-12 $\mathrm{mm}$. broad: raceme simple or sparingly branched below, often few-flowered: bracts ovate-lanceolate, usually purplish: perianth adnate at base; segments broad, greenish, $8-10 \mathrm{~mm}$. long; the inner abruptly contracted to a broad claw; gland obcordate: styles $4 \mathrm{~mm}$. long or more: seeds oblong, angular, $4 \mathrm{~mm}$. long. $(Z$. dilatata Greene, Pl. Baker. 1: 51. 1901; Z. coloradensis Rydb. Bull. Torr. Bot. Club 27: 534. 1900.) - The whole Rocky Mountain region from Colorado northward.

2. Zygadenus venenosus Wats. Proc. Am. Acad. 14: 279. 1879. Bulb elongated-ovoid: stem slender, strict, 1-5 dm. high: leaves narrow, 4-6 mm. broad, scabrous on margin and midrib, with scarious sheathing base (except the uppermost): raceme simple, short, with narrow scarious bracts: perianth free from the ovary; segments triangular-ovate to elliptic, obtuse or acutish, 4-6 mm. long, all abruptly contracted to a short-glandular claw; the blade rounded or subcordate at base; the gland with a well-defined irregular margin: stamens somewhat adnate to the claw: pedicels suberect in fruit: capsule 8-12 mm. long: seeds 3-5 mm. long. (Z. gramineus Rydb. 1. c.)-Northern Wyoming and Montana and west to the Pacific States. 
3. Zygadenus intermedius Rydb. Bull. Torr. Bot. Club 27: 535. 1900. Bulb elongated-ovoid: stem rather stout, 2-5 dm. high: leaves light green, scabrous on margin and midrib, 1-3 dm. long, 5-9 mm. wide, keeled and of ten more or less folded, with scarious sheathing base: flowers greenish or yellowishwhite: perianth free from the ovary; segments ovate or oblong, obtuse or acutish, 5-8 $\mathrm{mm}$. long, short-clawed; the outer subcordate at base; the inner acute or rounded; gland semiorbicular, the upper margin thin and not well defined: capsule ovoid-cylindrical. (Z. falcatus Rydb. l. c. 536.)-Colorado and Wyoming.

4. Zygadenus Nuttallii Gray, Wats. 1. c. Bulb ovoid: stem stout, 3-6 dm. high: leaves $6-15 \mathrm{~mm}$. broad: raceme simple or rarely branched below, manyflowered, with narrow membranous bracts: perianth free from the ovary; segments 6-10 mm. long, not clawed, with an ill-defined gland at base: stamens wholly free: capsule about $12 \mathrm{~mm}$. long: seeds large, $5 \mathrm{~mm}$. long, usually flattened.-Scarcely within our range; eastern Colorado (probably) to Arkansas.

\section{VERATRUM L. FALse HeLlebore}

Tall perennial herbs with thick rootstocks, broad, strongly veined leaves and rather large flowers in a terminal pubescent panicle. Perianth of 6 distinct similar segments. Capsule membranous, 3-beaked by the persistent diverging styles. Seeds compressed, margined or winged.

1. Veratrum speciosum Rydb. Bull. Torr. Bot. Club 27: 531. 1900. Stem 5-15 dm. high: upper leaves lanceolate, but rarely acuminate: branches of the sometimes compound panicle ascending: perianth-segments obtuse, whitish with greener base, of ten denticulate above. $V$.californicum.-From Colorado and Wyoming to northern California and Oregon.

\section{CONVAlLARIACEAE Link. Lily of the Valley Family}

Ours are leafy-stemmed herbs, simple or branched, from simple or branched creeping rootstocks. Flowers solitary, racemose or panicled, regular and perfect. Leaves broad, nerved. Perianth 6-parted, the segments distinct. Stamens 6. Ovary 3-celled, superior; stigma entire, or 3-lobed. Fruit a fleshy berry.

Flowers axillary, solitary or 2 together.

Perianth-segments distinct

Perianth-segments united.

Flowers terminal.

Solitary or very few in an umbel

Racemose or panicled

1. Streptopus.

2. Polygonatum.

3. Disporum.

4. Smilacina.

\section{STREPTOPUS Michx. Twisted-STALK}

Stem rather stout, with forking and divergent branches, ovate and taperpointed rounded-clasping membranaceous leaves, and small flowers on slender peduncles, which are abruptly bent or contorted near the middle. Flowers axillary, greenish-white, 'or purplish. Anthers sagittate, cuspidate, on short deltoid or subulate filaments. Ovary with numerous ovules in 2 rows in each cell.

1. Streptopus amplexifolius (L.) DC. Fl. France 3: 174. 1805. Stem 6-10 $\mathrm{dm}$. high: leaves very smooth, glaucous underneath: anthers tapering to a slender point: stigma entire, truncate.-Across the continent in northern latitudes and ranging south in the mountains to New Mexico.

\section{POLYGONATUM Adans. Solomon's Seal}

Rootstocks horizontal, thick, scarred. Stems simple, arching or erect, leafy. Leaves alternate, ovate or lanceolate, sessile. Flowers white or green- 
ish, axillary, solitary or in small fascicles. Perianth tubular, 6-lobed at the summit. Stamens 6, on the tube. Style slender, deciduous. Berry blue or black; the cells 1-2-seeded.

1. Polygonatum commutatum (R. \& S.) Dietr. Otto and Dietr. Gartenz. 3: 223 . 1835. Glabrous throughout: stem 5-10 dm. high: leaves broadly ovate to lanceolate, usually clasping by a broad base: pedicels jointed below the base of the flower. P. giganteum.-From the Rocky Mountains to the north Atlantic States.

\section{DISPORU M Salisb.}

Low and pubescent, divergently branched above, with closely sessile ovate and membranaceous leaves, and drooping flowers. Flowers solitary or few in a fascicle, terminating the branches, or apparently in the uppermost leaf-axils, white or greenish. Anthers oblong, obtuse, on slender filaments. Stigma 3-cleft, in ours.-Prosartes.

1. Disporum trachycarpum (Wats.) B. \& H. Gen. Pl. 3: 832. 1883. Leaves ovate to oblong-lanceolate, acute or rarely acuminate: perianth-segments whitish, slightly spreading, acute: fruit broadly obovate, obtuse and rather deeply lobed, papillose. Prosartes trachycarpum.-Colorado, far northward and westward.

\section{Smifacina Adans. Solomon's Seal}

Stems simple, leafy, from running rootstocks. Leaves mostly sessile, oblong or lanceolate. Flowers white, with distinct perianth-segments, in a racemose panicle or simple raceme, pedicels jointed at the summit. Stamens 6 ; the filaments subulate. Style short, thick, persistent; the stigma 3-lobed at the summit; ovules 2 in each cell.-(V agnera Adans.)

Flowers in compound racemes (panicles).

Leaves short-petioled; flowers very numerous $\quad \cdot \quad \cdot \quad ! \quad$ : 1. S. racemosa.
Leaves sessile and clasping; flowers fewer $\quad \cdot \quad \cdot \quad$.

Flowers in a simple raceme.

Leaves acute, ascending, more or less folded .

Leaves acuminate, spreading, usually flat :

3. S. stellata.

4. S. sessilifolia.

1. Smilacina racemosa (L.) Desf. Ann. Mus. Paris 9: 52. 1807. Minutely downy, 3-8 dm. high: leaves numerous, oblong or oval-lanceolate, acuminate, ciliate, abruptly somewhat petioled: flowers crowded, very short-pediceled: stamens exceeding the short perianth-segments: berries pale red speckled with purple, aromatic.-Moist copses; from the mountains in Colorado to the Atlantic States.

2. Smilacina amplexicaulis Nutt. Journ. Acad. Phil. 7: 58. 1834. Resembling the preceding in size and habit: the leaves sessile and clasping: flowers fewer, in an open panicle: stamens exserted: style long, nearly as long as the ovary: berry reddish.-Throughout our range and west to California.

3. Smilacina stellata (L.) Desf. 1. c. 52 . Stem smooth, 1-4 dm. high: leaves smooth above, minutely pubescent below, oblong-lanceolate, sessile and somewhat clasping, 3-8 cm. long, usually folded on the midrib: filaments shorter than the perianth: berry at first green with dark stripes, becoming red when ripe. (Vagnera leptopetala Rydb. Bull. Torr. Bot. Club 28: 268. 1902.)-In moist woods and meadows; from New Mexico north to the boundary and thence across the continent.

4. Smilacina sessilifolia Nutt. ex Baker, Journ. Linn. Soc. 14: 566. 1875. Rootstock slender: stem a foot or two high: leaves lanceolate, acuminate, sessile, usually flat and spreading, somewhat puberulent: raceme larger and pedicels longer $(6-12 \mathrm{~mm}$.): segments of the perianth lanceolate, twice as long as the stamens: berries usually black when mature. (Unifolium liliaceum Greene, Pitt. 1: 280. 1889.)-Northwestern Wyoming to Montana and west to the coast. 


\section{SMILACEAE Vent. Smilax Family}

Shrubby or ours herbaceous plants, climbing or supported by a pair of tendrils on the petiole of the ribbed and netted-veined simple leaves. Flowers small, dioecious. Perianth regular, of 6 similar deciduous sepals, free from the ovary, with as many stamens as sepals, and introrse 1-celled anthers. Ovary with 3 cells and as many elongated spreading sessile stigmas.

\section{NEMEXIA Raf. Smilax}

Unarmed vines, with knotted or tuberous rootstocks and annual stems. Leaf-blades membranous, broad, sometimes hastate. Umbels on long and slender peduncles. Pedicels inserted in small pits in a conic or globose receptacle. Stamens 6, more or less reduced in pistillate flowers. Ovary 3celled, wanting in staminate flowers; ovules two in each cavity. Berry blueblack.-SMiLAX.

1. Nemexia herbacea (L.) Small, Fl. S. E. U. S. 281. $1903 . \quad$ Stems elongated, climbing, glabrous: leaves numerous; blades ovate, triangular-lanceolate to lanceolate, essentially alike throughout the plant, 4-8 cm. long, shortacuminate, 7-9-nerved, rounded or truncate at the base: bracts subtending the peduncles like the leaves: peduncles much surpassing the subtending bracts at maturity: flowers carrion-scented: sepals and petals greenish, oblong or broadened upward, acutish: filaments twice or thrice as long as the anthers: berries subglobose, bluish-black, 6-8 mm. in diameter. CARRION Flower.Eastern Wyoming and thence far eastward and northward.

1a. Nemexia herbacea melica A. Nels. Proc. Biol. Soc. Wash. 17: 175. 1904. Very similar but the leaves very thin and more decidedly ovate: peduncles usually shorter; tendrils very slender: flowers sweet or honey-scented. SwEET SMiLAX.- In cañons; northern Colorado.

\section{IRIDACEAE Lindl. Iris Family}

Perennial herbs, with equitant sheathing 2-ranked linear leaves, and perfect triandrous regular flowers, the six divisions of the superior perianth petallike. .Flowers showy, few or solitary. Style 3-cleft at the apex. Stamens on the base of the sepals, with extrorse anthers. Ovary 3-celled, becoming a 3-lobed or triangular capsule with few or many seeds.

Style branches large and petaloid . . . . . . . . 1. Iris.

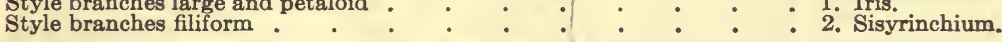

\section{IRIS L. Flag. Blue Flag}

Stems from usually thickened rootstocks. Flowers large and showy, solitary or few in a forked corymb. Perianth tube prolonged above the ovary. Stamens beneath the arching, petal-like branches of the style; filaments distinct. Base of the style connate with the perianth tube; the divisions stigmatic at the thin apex, above which is a broad 2-parted.crest, which is decurrent on the inner side to the base of the style. Capsule oblong. Seeds numerous, flattened.

1. Iris missouriensis Nutt. Journ. Acad. Phila. 7: 58. 1834. Stem slender, the leaves few, mostly basal, shorter than the stem: flowers 1-2, with scarious dilated bracts, light blue; parts of the flower 5-7 cm. long: capsule oblong, obtusely angled, 2-3 cm. long. (I. pelogonus L. N. Good. Bot. Gaz. 33: 68. 1902.) - Frequent on wet lands throughout our range; not rarely also on sandy hillsides. 


\section{SISYRINCHIUM L. BLUE-EYED GRASS}

Stems simple or branched, usually geniculate and winged, with linearlanceolate or grass-like radical leaves, and fugacious flowers on slender pedicels, clustered within 2 sheathing herbaceous bracts, with a scabrous bractlet subtending each pedicel. Perianth 6-parted. Capsule membranaceous, subglobose.

Flowers and fruits all terminal on normal (scapes) stems.

Bracts very unequal; the outer (lower) much surpassing the inflorescence.

Plant large throughout

Plant slender, scapes and leaves very narrow:

Bracts moderately unequal, the outer not much longer than the inflorescence

1. S. montanum.

2. S. angustifolium.

3. S. occidentale.

4. S. heterocarpum.

1. Sisyrinchium montanum Greene, Pitt. 4: 33. 1899. Plant stout, erect, more than $3 \mathrm{dm}$. high, herbage light green, glabrous, not glaucescent: foliage rather copious but short, less than half the length of the scapes, the broad leaves about 9-striate, the alternate lines commonly rather obscure: scapes ancipital, each of the broad, sharp-edged subentire wings strongly 3-striate: spathes mostly solitary, their bracts very unequal, the outer more than twice the length of the inner and 4-5 cm. long: perianth dark purple: capsules large (about $5 \mathrm{~mm}$. in diameter), almost globose.-Western Colorado.

2. Sisyrinchium angustifolium Miller, Dict. Ed. 7. 1759. Pale green and glaucous: stem 2-edged but scarcely winged, 1-3 dm. high: leaves very narrow, the edges either rough or smooth, much shorter than the stem: bracts very unequal, sometimes purplish, the outer about twice as long as the inner and usually much surpassing the flowers and fruit: capsules subglobose. $S$. mucronatum and S. anceps. (S. alpestre Bickn. 1. c. 453.)-Moist grassy banks and fields; Colorado to the New England States.

3. Sisyrinchiurn occidentale Bickn. Bull. Torr. Bot. Club 26: 447. 1899. Rather stiffly erect, $15-30 \mathrm{~cm}$. high: leaves narrow, rigid and pungently acute, much shorter than the stem: bracts more or less hyaline-margined, somewhat unequal; the outer $2-3 \mathrm{~cm}$. long, equaling or but slightly longer than the inflorescence: capsule subglobose, light brown.-Colorado to Idaho and Montana.

4. Sisyrinchium heterocar pum Bickn. l.c. 348. Resembling S. angustifolium but greener and the stems somewhat stouter: leaves short, mostly less than half as long as the stems, rather rigid: bracts very unequal, the outer usually much surpassing the inflorescence: flowers and fruits of two kinds, terminal and basal; the latter more or less concealed among the bases of the leaves: perianth violet-purple, $10 \mathrm{~mm}$. long: capsule obovoid-subglobose: seeds black, angled and rugulose-pitted.-Throughout Wyoming and probably extending into Colorado.

\section{ORCHIDACEAT Lindl. ORChid Family}

Perennial herbs, often with tuberous or fleshy roots, sometimes parasitic; the leaves mostly alternate, sheathing and entire. Flowers perfect, irregular, bracteate, solitary or in a spike or raceme, often showy and singular in shape, adapted to cross-pollination by means of insects. Perianth-segments in two series or sets; the 3 outer (sepals) similar or nearly so; the lateral ones of the 3 inner (petals) alike; the third of the inner set very dissimilar and often spurred, and known as the lip (labellum). Before the lip, in the axis of the flower, is the column, composed of a single stamen, or in Cypripedium 2, variously coherent with or borne on the style or thick fleshy stigma. Pollen united by elastic threads into 2 clavate or pear-shaped úsually stalked masses (pollinia), one to each anther cell, and attached by the base of the stalk to a 
viscid disk (gland). Stigma a broad glutinous surface facing the lip or in a cavity between the anther sacs. Ovary inferior, 1-celled, usually twisted, many-ovuled. Capsule 3-valved.

Anthers 2; lip a large inflated sac

Anthers solitary.

Flowers solitary-terminal

Flowers more than one, generally racemose or spicate.
Green leaves present.

Stem leafy, at least below.

Leaves alternate and more than 2.

Capsule erect or ascending.

Spike not spirally twisted.

Petals lanceolate

Petals very narrow

Spike spirally twisted.

Long and slender; flowers greenish

Short and crowded; flowers white Capsule deflexed at maturity

Leaves opposite, a single pair just below the raceme

Leaves all basal.

Only one

Several

No green leaves present

1. Cypripedium.

2. Calypso.

\section{CYPRIPEDIUM L. LADY's SLIPPER}

More or less glandular pubescent herbs with leafy stems and thick fascicled roots. Leaves many-nerved and usually large. Flowers solitary or several, large and showy, with an inflated sac-like lip. Anthers 2, one on either side of the column and a sterile one above covering the summit of the style. Pollinia granular; the caudicle and glands wanting. Stigma 3-lobed.

Flowers yellow, usually solitary .

Flowers dark purple, 2-3 in a cluster

1. C. parviflorum.

1. Cypripedium parviflorum Salisb. Trans. Linn. Soc. 1: 77. 1791. Stem 2-4 dm. high: leaves several, oval or ovate-lanceolate, acute or acuminate: sepals from ovate to ovate-lanceolate: lip flattish from above, bright yellow, 2-3 cm. long: sterile stamen triangular and purple spotted like the lip.- In damp woods and thickets; Colorado, far northward and east to the Atlantic.

2. Cypripedium Knightae A. Nels. Bot. Gaz. 42: 48. 1906. Stem short, 3-7 cm. high, sparsely and coarsely villous, bearing a single pair of nearly opposite leaves at its summit: leaves oval, generally rounded and obtuse, thickish, 4-7 cm. long: peduncle glandular-viscid, 3-10 cm. long, usually naked, rarely with a lanceolate bract near the middle: floral bracts rather large, elliptic-lanceolate: flowers 2 or 3 in a cluster, dark purple or dark brownish-purple: lower sepals united nearly to the tip, ovate-lanceolate, the two together no broader than the other sepal: petals similar, a little broader than the sepals: lip 10-12 mm. long, somewhat shorter than the sepals and petals, the deeply infolded free margin deep purple, the lower part of the sac ochroleucous or greenish-yellow: sterile anther elliptic, obtuse, much shorter and smaller than the large conspicuous stigma.- In the Medicine Bow Mountains of Colorado and Wyoming.

\section{CALYPSO Salisb.}

A low herb, in wet or boggy woods, with showy flowers, a scaly-sheathed stem, and a single radical broad thin leaf. Petals and sepals ascending, similar and nearly equal; lip with two short spurs below the apex. Column petaloid, oval and concave. Lower pair of pollen masses smaller, compressed.

1. Calypso bulbosa (L.) Oakes, Cat. Ver. Pl. 28. 1842 . Stems 6-12 cm. high, with two or three membranaceous brownish-green sheaths, and a linear acuminate bract at the summit: the radical leaf broadly ovate or slightly cordate: flower drooping: sepals and petals light rose-color: lip usually longer, 
brownish-pink mottled with purple, the edge margined at the apex and bifid or entire, about equaling the tooth-like spurs and with a tuft of yellow hairs at base. C. borealis.-From Colorado to Oregon and British America; thence eastward to the North Atlantic States.

\section{LIMNORCHIS Rydb. ORCHIS}

Leafy plants with thick fleshy roots and small greenish or white spicate flowers. Leaves persisting until the maturity of the fruit. Sepals and petals free and spreading; lip entire. Beak of the stigma without appendage:: Anther sacs nearly parallel, wholly adnate; glands naked; pollinia granular. - Habenaria in part.

Connective of the anther narrow; spur not longer than the lip.

Flowers greenish or purplish.

Spur shorter than the lip

Spur equaling the lip

Flowers white; spur clavate and shorter than the lip

Connective of the anther broad; spur exceeding the lip.

1. L. stricta.

2. L. viridiflora.

3. L. borealis.

4. L. sparsiflora.

1. Limnorchis stricta (Lindl.) Rydb. Mem. N. Y. Bot. Gard. 1: 105. 1900. Stem strict, 2-7 dm. high, from fusiform tuberous roots: leaves lanceolate; the lower obtuse: spike often long (1-3 dm.); bracts linear-lanceolate, only the lower longer than the flowers: sepals green: petals purplish; lip linear or lanceolate, obtuse; spur thickened at the apex and somewhat shorter than the lip. (L. purpurascens Rydb. Bull. Torr. Bot. Club 28: 269. 1901.)-From Colorado to Alaska.

2. Limnorchis viridiflora (Cham.) Rydb. Bull. Torr. Bot. Club 28: 616 . 1901. Stems rather stout, from elongated thick tuberous roots: leaves oblanceolate and obtuse below, lanceolate and acute above: spike rather short and dense $(5-10 \mathrm{~cm}$.); bracts about equaling the green flowers: upper sepal ovate, erect, shorter than the lanceolate lateral ones: petals erect, lanceolate, acute, shorter than the upper sepal; lip lanceolate, obtuse, 4-5 mm. long; spur clavate, curved, about equaling the lip. Habenaria hyperborea.-Bogs; Colorado and far northward.

3. Limnorchis borealis (Cham.) Rydb. 1. c. Slender, 3-6 dm. high, from thickened tuberous roots: lower leaves oblanceolate and obtuse; the upper lanceolate and acute: spike variable, dense, or few-flowered and lax; the bracts mostly longer than the flowers: flowers usually white, sometimes ochroleucous or greenish-tinged: upper sepal ovate, obtuse, 4-5 mm. long; the lateral oblonglanceolate, spreading: petals lanceolate, exceeded by the sepals; lip rhombiclanceolate, as long as the sepals and usually somewhat longer than the scarcely clavate spur. Habenaria dilatata.-Middle Rocky Mountains.

4. Limnorchis sparsiflora (Wats.) Rydb. 1. c. 631. Slender stemmed, 4-6 dm. high: lower leaves oblanceolate, obtuse, 8-16 cm. long; the upper lanceolate and acute: spike 1-2 dm. long, with scattering flowers; bracts about as long as the flowers, linear-lanceolate: flowers greenish, 10-14 mm. long: upper sepal ovate to obovate, obtuse; the lateral lanceolate: petals lanceolate, almost as long as the upper sepal; lip linear, obtuse, 6-8 mm. long, the slender spur a little longer. (L. laxiflora Rydb. 1. c. 630.)-From Colorado to California and Oregon.

\section{COELOGLOSSUM Hartman}

Leafy plants with biennial 2-cleft tubers. Flowers greenish, in a long leafybracted spike. Sepals free, but bent together forming a hood. Petals narrow; lip oblong, obtuse, 2-3-toothed at apex; spur much shorter than the lip, blunt and sac-like. Pollinia with long caudicles.-Habenaria in part.

1. Coeloglossum bracteatum (Willd.) Parl. Fl. Ital. 3: 409. 1858 (?). Stem leafy, rather stout, 1-2 dm. high: leaves from oval to lanceolate, the lower often obtuse, 4-10 cm. long: floral bracts foliar and conspicuous: spikes loosely 
flowered: flowers green: sepals ovate-lanceolate, spreading: petals narrow, even filiform; lip oblong spatulate, more than twice as long as the white sac-like spur.-Northern Wyoming, eastward and to the Atlantic.

\section{PIPERIA Rydb.}

Slender strict plants from rounded tuberous roots, and with mostly basal leaves, those of the stem being reduced and bract-like. Leaves short-lived, usually withering or dead at anthesis. Flowers greenish or white. Sepals and petals 1-nerved or obscurely 3-nerved, linear-lanceolate to ovate, truncate or hastate at base. Stigma a small beak in the angle between the anther cells. Capsule ellipsoid.-Habenaria in part.

1. Piperia unalaschensis (Spreng.) Rydb. Bull. Torr. Bot. Club 28: 270. 1901. Stem very strict and slender, $3-5 \mathrm{dm}$. high, leafy below only: leaves oblanceolate, obtusish or acute; stem leaves bract-like: bracts lanceolate or broader, shorter than the spirally arranged flowers: sepals and petals lanceolate, greenish or the lateral purplish; lip oblong, obtuse, subhastately lobed near the base; the spur linear or slightly clavate, barely longer than the lip. Habenaria unalaschensis.-From Colorado to far northwestern America.

\section{SPIRANTHES Richard. Ladies' Tresses}

Erect strict herbs with fleshy usually fascicled roots and slender more or less leafy stems. Flowers white, crowded-spicate, in 1-3 spirally arranged rows. Perianth oblique upon the ovary, the sepals and petals connivent; lip oblong, embracing the column, with 2 callosities at base, and dilated spreading undulate summit. Columns very short, terminating in a stout terete stipe. Anther erect and subsessile at top of column. Stigma with a bifid beak.

1. Spiranthes stricta (Rydb.) A. Nels. Glabrous, rather stout, 1-3 dm. high: leaves oblong-lanceolate to linear: spike dense, 3-ranked, conspicuously bracteate, $3-8 \mathrm{~cm}$. long: perianth curved: lip recurved, contracted below the rounded wavy-crenulate summit; callosities smooth, often obscure. Spiranthes Romanzoffiana. (Gyrostachys stricta Rydb. Mem. N. Y. Bot. Gard. 1: 107. 1900.) - Colorado to Montana and thence across the continent.

\section{EPIPACTIS R. Br.}

Stems leafy, stout, from creeping rootstocks. Flowers few, pediceled, with conspicuous divergent bracts and spreading perianth. Sepals and petals nearly equal; lip narrowly constricted and somewhat jointed in the middle, concave and auriculate at base, dilated above. Column short, erect. Capsule at maturity deflexed.

1. Epipactis gigantea Dougl. Hook. Fl. Bor. Am. 2: 220. 1839. Three to $10 \mathrm{dm}$. high, nearly smooth: leaves from ovate below to narrowly lanceolate above, somewhat scabrous on the veins beneath: raceme pubescent: flowers greenish, strongly veined with purple: saccate base of the lip with erect winglike margins, strongly nerved; the nerves callous-tuberculate near the base.Western Texas and southwestern Colorado to California and Washington.

\section{LISTERA R. Br. Twayblade}

Stems from fibrous and creeping roots, low, with a pair of broad sessile leaves, near the middle. Flowers small, in a loose raceme. Perianth spreading. Sepals and petals similar; lip flat, 2-lobed, free, longer than the sepals. Column free and naked.- In cold damp woods and thickets.

Raceme pubescent

Raceme glabrous

1. Listera convallarioides (Sw.) Torr. Comp. 320. 1826. Stem slender, $10-25 \mathrm{~cm}$. high, naked excepting one or two sheaths at base and the pair of 
orbicular or ovate leaves just below the raceme: inflorescence pubescent: sepals and petals linear; lip oblong-ovate and cuneate, with a small tooth on each side near the base.-From the Sierra Nevada eastward across the continent.

2. Listera nephrophylla Rydb. Mem. N. Y. Bot. Gard. 1: 108. 1900. Slender, 1-2 dm. high, glabrous: leaves rounded-reniform, strongly veined and reticulate, mucronate: flowers greenish, with oblong sepals and petals, much shorter than the cleft lip: stamen incurved and depressed over the stigma: capsule obovoid. L. cordata.-The central Rocky Mountains.

\section{LYSIELLA Rydb.}

Small plant with a short rootstock and thick root fibers. Stem scapose, with a single obovate leaf at the base. Flowers greenish-yellow. Lateral sepals reflexed-spreading. Petals lanceolate; lip entire, linear-lanceolate; spur shorter than the arcuate ovary. Beak of stigma not appendaged. Capsule obovoid.-Habenaria in part.

1. Lysiella obtusata (Pursh) Rydb. Mem. N. Y. Bot. Gard. 1: 104. 1900. Leaf obovate or spatulate-oblong: upper sepal very broad and rounded: lip deflexed, about the length of the tapering and curving spur: anther-cells arcuate and widely separated.-Colorado and northward, thence eastward across the continent.

\section{PERamiUm Salisb. Rattlesnake Plantain}

Leaves thickish, all rosulate at the base, petioled, white-reticulate. Rootstock creeping, with fibrous fleshy rootlets. Scapes few-bracteate, $2-4 \mathrm{dm}$. high. Flowers spicate, bracted. Lateral sepals free, the upper one united with the petals into a galea. Lip saccate, entire, without callosities and free from the column.-Goodyera.

Lip with incurved margins, scarcely saccate .

Lip with recurved margins, plainly saccate:

1. P. Menziesii.

1. Peramium Menziesii (Lindl.) Morong, Mem. Torr. Club 5: 124. 1894. Scape and inflorescence pubescent: leaves smooth, ovate-oblong to oblonglanceolate, reticulated with light greenish markings: spike many-flowered, rather dense, secund: perianth white, puberulent: column short and straight: gland and bifid beak very narrow and elongated.-From Colorado northward, thence eastward to western New York; also in the Pacific States.

2. Peramium ophioides (Fernald) Rydb. in Brit. Man. 302. 1901. Scape 1-2 dm. high, glandular-pubescent: leaf-blade 1-2 cm. long, broadly ovate, abruptly contracted into a short-winged petiole, dark green, generally with the white blotches most conspicuous along the cross veins: flowers greenishwhite, 4-5 mm. long: galea concave with a short strongly recurved tip; lip deeply saccate, with recurved margins and tip: anthers blunt.-Moist mountain woods; Colorado to New England.

\section{CORALlORHIZA R. Br. Coral Root}

Without green herbage, the solitary scape with 2-4 membranaceous sheaths, and bearing a simple raceme of brownish, yellowish, or purple flowers; pedicels reflexed in fruit. Petals and sepals ascending, similar and nearly equal, but the lateral sepals oblique at base and either decurrent in a short spur adnate to the side or summit of the ovary, or forming a projecting gibbosity above it. Column narrowly margined, broader at base, somewhat incurved.

Spur present, small or sac-like, at summit of the ovary.

Lip deeply 3-lobed

Lip 2-toothed or 2-lobed above the base

Spur absent; the lip entire 
1. Corallorhiza multiflora Nutt. Journ. Acad. Phil. 3: 138. pl. 7. 1823. Scape 2-5 dm. high, many-flowered: flowers brownish-purple: sepals and petals 3-nerved; spur manifest, but wholly adnate to the ovary; lip nearly sessile, 3-lobed by a deep cleft on each side, the middle one rounded or emarginate, with undulate or denticulate margin: capsule 10-14 $\mathrm{mm}$. long, narrowed to a short rather stout pedicel. (C. ochroleuca Rydb. Bull. Torr. Bot. Club 31: 402. 1904.)-Across the continent in north temperate latitudes, and in the Rocky Mountains southward to Utah and Colorado.

2. Corallorhiza innata R. Br. in Ait. Hort. Kew, Ed. 2. 5: 209. 1813. Scape slender, 1-2 dm. high, 3-15-flowered: sepals and petals 1-nerved, dull purple; spur very short; lip somewhat 3 -lobed by lateral clefts, abruptly attenuate to the base; column stout, constricted in the middle: capsule 4-8 mm. long, abruptly narrowed to a short very slender pedicel.-From Colorado to Washington and thence eastward to Canada and the Atlantic States, and northward to the Arctic regions.

3. Corallorhiza striata Lindl. Gen. \& Sp. Orch. 534. 1840. Scape stout, 3-6 dm. high, many-flowered: flowers often $12-15 \mathrm{~mm}$. long: spur none, the lateral sepals and base of the column strongly gibbous over the top of the ovary: flowers larger, purple and veined, not spotted: lip fleshy, entire, somewhat narrowed below, reflexed above the base and bearing the prominent laminae upon the arch. (C. Vreelandii Rydb. 1. c. 8: 271. 1901.)-From Washington and Oregon eastward to the Great Lakes.

\section{SALICACEAE Lindl. Willow Family}

Trees and shrubs with simple, alternate, stipulate leaves. Flowers dioecious, arranged in aments (catkins), these falling off as a whole, the staminate after anthesis, the pistillate after the ripening of the fruit and dispersion of the seeds. Bracts of the ament scale-like. Perianth none. Stamens 1 to several. Ovary 1-celled; stigmas 2. Fruit a 2-valved capsule, inclosing many seeds furnished with a tuft of hairs at base. Bracts lacerate; flowers with a broad or cup-shaped disk; stamens numerous;
buds scaly

Bracts entire; flowers with small glands; disks none; stamens few; buds with a single scale.

\section{Populus L. Poplar. Cottonwood. Aspen}

Deciduous dioecious trees, often low, with pale furrowed bark, and terete or angular branchlets. Leaves varying from broadly deltoid-cordate to narrowly lanceolate. Buds scaly, usually covered with a resinous varnish. Both kinds of flowers in drooping aments appearing before the leaves; bracts lacerate. Flowers with a broad or cup-shaped disk. Stamens numerous. Stigmas elongated. Fruit a dehiscent capsule with many seeds, each bearing a tuft of white hairs.

Petioles flattened laterally.

Leaves suborbicular

Leaves broad, more or less deltoid.

Abruptly acuminate, crenately serrate Gradually acuminate, deeply sinuate-dentate

Petioles round or furrowed.

Leaves pale beneath
Leaves green, scarcely lighter beneath.

- Oblong-lanceolate

Ovate, abruptly long-acuminate:

1. Populus.

2. Salix.

1. Populus tremuloides Michx. Fl. Bor. Am. 2: 243. 1803. A small tree, 6-20 m. high, usually in dense groves and rarely attaining the maximum size; bark smooth, greenish-white: leaves small, roundish heart-shaped, with a 
short sharp point and small regular teeth, smooth on both sides, with downy margins; petioles slender, flattened laterally, causing movement of the leaves in the lightest breeze: lobes of the bracts linear, silky: stamens 6-20: capsule conic. Aspen or AMerican Aspen.-Very common on moist slopes and valleys in the hills and mountains.

2. Populus occidentalis (Rydb.) Brit. Man. Ed. 2. 320. 1905. Becoming a large tree, with thick rough furrowed bark; the branchlets more or less angulate: leaves broadly deltoid, with subcordate or truncate base, abruptly long-acuminate, crenately serrate, the teeth mostly obtuse; petioles often as long as the blade: staminate aments $7-15 \mathrm{~cm}$. long; the pistillate as long or longer, in fruit with several to many ovoid capsules. $P$. angulata. The common CotTonwood; nearly related to the great CotTonwood, $P$. deltoidea, of the valleys of the Mississippi and its tributaries.-Frequent on stream banks along the eastern base of the Rocky Mountains.

3. Populus Wislizenii (Wats.) Sarg. Man. Trees N. A. 165. 1905. Becoming a large tree, with gray and furrowed bark: leaves subreniform or deltoid, the triangular acumination entire, usually puberulent especially upon the margin, rather deeply sinuate-dentate: staminate aments with slender pedicels and laciniate bracts, $12 \mathrm{~cm}$. long; the pistillate as long: stigmas 3, dilated and irregularly lobed: capsule ovoid, the short pedicel abruptly dilated into the broad disk-like receptacle.-Stream banks; southern Colorado to Texas and west to California.

4. Populus balsamifera L. Sp. PI. 1034. 1753. Becoming a tall tree with nearly smooth bark, with round branches and very resinous-viscid balsamic buds: leaves glabrous, dark green above, pale beneath, ovate, acute or acuminate, rounded or subcordate at base, crenulate: aments and bracts somewhat pubescent: stamens 18-30: capsule 2-valved. BaLsam.-From Wyoming far northward and eastward.

5. Populus angustifolia James, Long's Exp. 1: 497. 1823. Becoming a medium sized tree, $10-20 \mathrm{~m}$. high, rarely $1 \mathrm{~m}$. in diameter; bark thick, rough, and furrowed: leaves mostly narrowly lanceolate or oblong, sometimes ovatelanceolate, rounded at base, acute at apex, finely crenulate the whole length; petiole semiterete or furrowed: staminate aments oblong-cylindric; the bracts obovate, laciniate: stamens 12-20, with large reddish anthers: stigma with broad lobes.-The prevailing cottonwood on the banks of mountain streams at middle elevations; known as the NARROW-LEAF COTTONWOOD.

6. Populus acuminata Rydb. Bull. Torr. Bot. Club 20: 50. 1893. A slender tree with much smoother and lighter-colored bark than the preceding: leaves rhomboid-ovate, long-acuminate, the base rounded or cuneate, crenulatedentate, long-petioled and somewhat drooping: pistillate aments slender: the capsules ovoid, pediceled. A clean-looking, well-shaped, and rapid-growing tree now largely grown for shade and ornament; known as the SMOOTH-BARK СоттоNWOod. Probably short-lived.-Indigenous on some of the streams on the eastern slope of the Rocky Mountains.

\section{SALIX L.* WILLOW}

Leaves mostly narrow, short-petioled. Buds covered by a single scale. Aments (catkins) mostly erect, appearing before (precocious) or with (coetaneous) the leaves; bracts entire or merely denticulate. Stamens few, accompanied by 1 or 2 little glands. Pistillate flowers with a gland at the base of the ovary; stigmas short.

CAPSULES GLABROUS.

\section{Key to the Sections}

Scales pale yellow, deciduous.

Stamens 3-5, filaments hairy below; leaves lanceolate, finely serrulate; trees.

Petioles and leaf-bases not glandular

Petioles and leaf-bases glandular

* This treatment of the genus Salix has been contributed by Mr. Carleton R. Ball, of the U. S. Department of Agriculture, Washington, D. C. 
Stamens 2, filaments hairy below; leaves linear or narrowly elliptical, remotely denticulate; shrubs

Scales not pale yellow, mostly brownish to black, persistent.

Styles none; minute prostrate plant

Styles distinct; erect or ascending shrubs.

Styles 0.3-0.7 mm. long; aments pedunculate; leaves and capsules glabrous

Styles 1-2.5 mm. long (sometimes shorter in No.18), leaves more or less tomentose, at least above; capsules glabrous to tomentose.

Styles 1-1.5 mm. long; aments pedunculate (if sessile, the leaves not glandular)

Styles 1.5-2.5 mm. long; aments stout, sessile; leaves glandular

CAPSULES HAIRY.

Scales yellow, deciduous; filaments hairy below; styles none (in our species)

Scales not yellow, mostly brown or black, at least at the tip, persistent.

Styles elongated, $0.5-2 \mathrm{~mm}$. (over $1 \mathrm{~mm}$. long, except in one species of Commutatae).

Leaves usually gray-tomentose on both sides, sometimes on the upper surface only; aments mostly on long leafy peduncles; capsules gray- or white-tomentose.

Capsules thinly villous-tomentose; stigmas entire, short (two species of)

Capsules densely white-tomentose; stigmas entire or usually divided, much elongated, about $1 \mathrm{~mm}$. long

Leaves glabrous on both surfaces or densely silverypubescent on the lower surface only; aments dense, sessile or on short, leafy peduncles; capsules silverypubescent.

Leaves densely clothed with a fine satiny pubescence below, glabrate above; aments on short leafy peduncles.

Leaves glabrous on both surfaces, bright green; aments closely sessile

Style obsolete, or only $0.2-0.3 \mathrm{~mm}$. long.

Tall erect shrubs; capsule conic-rostrate.

Aments stout, dense, sessile or subsessile; scales dark, long-villous; pedicel short or none; stigmas long,
slender

Aments slender and lax, the staminate small, on short leafy peduncles; scales pale, thinly villous; pedicel elongated; stigmas short

Low depressed or creeping shrubs; capsules short, ovateconic, subsessile; aments small, few-flowered, shortpeduncled; leaves obovate, reticulate on both sides

III. LONGIFOLLAE.

IV. RETUSAE.

V. CORDATAE.

VI. COMMUTATAE.

VII. LANATAE.

III. LONGIFOLIAE.

VI. COMMUTATAE.

VIII. ARCTICAE.

\section{ARGENTEAE.}

X. PHYLICIFOLIAE.

\section{CAPREAE.}

\section{ROSTRATAE.}

\section{RETICULATAE.}

I. Amygdalinae.-Trees 3-15 m. high; bark brown; twigs long and slender, often drooping, usually gray: leaves linear-lanceolate to broadly lanceolate, acuminate, closely and finely serrulate, glabrous; stipules small and deciduous or none: aments coetaneous, slender cylindrical, terminal on lateral leafy twigs: scales deciduous, light-yellow, lanceolate or broader, mostly glabrous outside, crisp-villous within: stamens 3-7, filaments hairy below: capsule small, glabrous, pedicellate; styles 0.3-0.5 mm. long; stigmas short.

Leaves linear-lanceolate, deep green beneath

Leaves lanceolate or broader, glaucous beneath
1. S. nigra.

2. S. amygdaloides.

1. Salix nigra Marsh, Arb. Am. 139. 1785. Dark green; twigs gray or brownish: leaves linear-lanceolate, long-acuminate, often falcate, deep green on both sides, 6-11 cm. long, 7-12 mm. wide (often oblanceolate while unfolding); petioles short, 3-6 mm. long: staminate aments yellow, $2-5 \mathrm{~cm}$. long; pistillate aments $2-6 \mathrm{~cm}$. long in fruit: capsules ovate or ovate-lanceolate, 3-4 $\mathrm{mm}$. long; pedicels 1-1.5 mm. long. BLACK WrLlOw. (S. Wrightii Anders. founded on a monstrous form with compact and distorted aments.)-River banks, common; plains of eastern Colorado to New Mexico and California.

2. Salix amygdaloides Anders. Ofv. Handl. Vet. Akad. 114. 1858. Yellowish green; twigs gray. or the youngest yellow: leaves lanceolate to ovatelanceolate (frequently obovate or broadly oblanceolate and obtuse when unfolding), gradually or abruptly acuminate, green above, glaucous beneath, 5-12 cm. long, 1.5-3 cm. wide; petioles slender, 5-15 or $20 \mathrm{~mm}$. long: staminate ROCKY MT. BOT. -9 
aments yellow, 3-5 cm. long; pistillate aments lax in fruit, 4-8 cm, long: capsules lanceolate, 4-5 mm. long; pedicels filiform, $2 \mathrm{~mm}$. long. Peach-Leaved WiLLOW.-Common on banks of streams and wet ground throughout to an altitude of $2,000 \mathrm{~m}$. A form with very narrow leaves, scarcely $1 \mathrm{~cm}$. wide, is found on the high plains east of the Rocky Mountains.

II. Pentandrae.-Tall shrubs or small trees (within our range) with sparingly caespitose stems, 3-6 m. high, and reddish-brown bark; twigs and obtuse buds stouter than in AMYGDALINAE, olive to reddish-brown, lustrous: leaves large, lanceolate or elliptical, acute to long-acuminate, closely glandular-serrate, especially near the base, glabrous; petioles stout, glandular near the distal end or naked; stipules small or none: aments coetaneous, stout, dense, oblong, on short lateral leafy twigs, 1-2 cm. wide; scales pale yellow, deciduous, lanceolate to obovate, thinly pilose at the base: capsules rather large, 5-9 $\mathrm{mm}$. long, glabrous; pedicels 1-2 $\mathrm{mm}$. long; styles about $0.5 \mathrm{~mm}$. long; stigmas short, notched or bifid.

Fruiting in early summer; capsules thin-walled, 5-7 mm long. Leaves short-acuminate, glaucous beneath

Leaves long-acuminate, scarcely paler beneath

Fruiting in late summer; capsules thick-walled, 7-9 mm. long

3. S. lasiandra

4. S. Fendleriana. 5. S. serissima.

3. Salix lasiandra Benth. Pl. Hartw. 335. 1849. A small tree within our limits; twigs rather stout, deep red, lustrous: leaves lanceolate to broadly lanceolate or sometimes oblanceolate, acuminate at the apex, acute to rounded at the base, dark green and shining above, glaucous beneath, 6-10 $\mathrm{cm}$. long, 1.5-3.5 cm. wide; stipules small, acute, glandular: aments on peduncles 1-6 (usually 2-3) cm. long; staminate aments $2-6 \mathrm{~cm}$. long, $1-1.3 \mathrm{~cm}$. wide; pistillate aments $3-10 \mathrm{~cm}$. long, $1.2-2 \mathrm{~cm}$. wide; scales lanceolate to ovate, sometimes glandular at the apex: capsule pale straw-color or light brown, lanceolate, 5-7 mm. long; pedicel 1.5-2 mm. long, 4-6 times as long as the gland.-Rare in our limits; Sante Fe, New Mexico, to California, and northward.

4. Salix Fendleriana Anders. 1. c. 115. Twigs long but not slender, shining, reddish or reddish-yellow: leaves narrowly lanceolate to lanceolate, longacuminate, dark green on both sides or somewhat paler but never glaucous beneath, 6-13 cm. long, $1.2-3 \mathrm{~cm}$. wide; stipules usually none, if present, small, semicordate to reniform: staminate aments $2-4 \mathrm{~cm}$. long, $1-1.2 \mathrm{~cm}$. wide; pistillate $2-5.5 \mathrm{~cm}$. long, $1.5 \mathrm{~cm}$. wide; scales lanceolate to oblanceolate: capsule pale straw-color or brownish, 5-7 mm. long; pedicels 1-1.5 mm. long; styles $0.5-0.7 \mathrm{~mm}$. long. Fendler's Willow. [S. lasiandra caudata (Nutt.) Sudw.]-Mountain streams and wet places, at 1,500 to $3,000 \mathrm{~m}$. altitude, common; New Mexico to Canada and west to the coast.

5. Salix serissima (Bail.) Fern. Rhodora 6: 6. 1903. A shrub or small tree, sometimes $4 \mathrm{~m}$. in height; twigs lustrous, bright red or brownish: leaves elliptic-lanceolate, acute at both ends or short-acuminate at the apex, closely glandular-serrulate, dark green and shining above with the midrib whitish, pale or subglaucous beneath, coriaceous, 4-8 cm. long, 1-25 cm. wide; petioles more slender than in the related species: aments very short and stout; the staminate 1-2 cm. long, 1-1.2 cm. thick; scales broad, obtuse; pistillate ament 1.5-3 cm. long, $2-2.3 \mathrm{~cm}$. wide, usually loosely flowered: capsules lustrous, long-conic, thick-walled, olive-brown to deep brown, 7-9 mm. long: pedicels thick, 1-15 mm. long, 2-3 times as long as the gland. AUtumn Willow.Wet ground; Montana to Alberta, eastward to New Jersey and New England.

III. LONGIFOLIAE.-Shrubs 2-5 m. high, with densely caespitose stems and gray or light brown bark; twigs slender, brown or reddish, often lustrous: leaves linear to linear-lanceolate or narrowly elliptical, remotely denticulate or entire; petioles very short; stipules none: aments serotinous, terminating lateral leafy branches, the staminate often and the pistillate occasionally in pairs or threes; scales light yellow, deciduous: stamens 2, filaments hairy below: capsules glabrous to thinly villous, 4-7 $\mathrm{mm}$. long; styles none; stigmas short (in our species), divided. 
Leaves linear, acuminate; pistillate aments $1-2 \mathrm{~cm}$. wide.

Leaves canescent, entire or remotely denticulate; capsules mostly 5 $\mathrm{mm}$. long; pedicels $0.5-0.7 \mathrm{~mm}$. long

Leaves brignt green, denticulate; capsules mostly 6-7 mm. long; pedicels $0.5-1.5 \mathrm{~mm}$. long

Leaves elliptical-oblanceolate, rather closely denticulate; pistillate aments 7-8 $\mathrm{mm}$. wide

6. S. exigua.

7. S. fluviatilis.

8. S. melanopsis.

6. Salix exigua Nutt. Sylva 1: 75. 1842. Color effect grayish: leaves linear, acute at both ends or acuminate at the apex, 5-12 cm. long, 2-10 $\mathrm{mm}$. wide, entire or remotely denticulate, opaque, more or less canescent on both surfaces or silky with a fine silvery tomentum beneath, or on both surfaces on young shoots (then frequently mistaken for $S$. argophylla); petioles $2-7 \mathrm{~mm}$. long: peduncles sometimes $7 \mathrm{~cm}$. long; staminate aments $2-4 \mathrm{~cm}$. long, about $7 \mathrm{~mm}$. wide; the pistillate $3-6 \mathrm{~cm}$. long, $1-1.3 \mathrm{~cm}$. wide; scales lanceolate in the pistillate aments, broader in the staminate, mostly acute, nearly glabrous or white pilose on the margins, occasionally on the back also: capsules narrowly lanceolate, 4-6 (mostly 5) $\mathrm{cm}$. long, sessile or on pedicels $0.5-0.7 \mathrm{~mm}$. long, especially at the base of the ament, glabrous or thinly villous; gland about $0.5 \mathrm{~mm}$. long; stigmas divided. (S. stenophylla Rydb. Bull. Torr. Bot. Club 28: 271. 1901, an inconstant form; S. luteosericea Rydb. Brit. Man. 316. 1901.) - Very common along mountain streams and in wet places throughout our range and westward; variable in foliage characters and sometimes very difficult to distinguish from the next.

7. Salix fluviatilis Nutt. 1. c. 73. Color effect bright green or slightly grayish: leaves linear or linear-lanceolate, acute or acuminate at the apex, acute at the base, 5-12 $\mathrm{cm}$. long, $2-15 \mathrm{~mm}$. wide, remotely denticulate to spinulose-denticulate; pure green and veiny on both sides, glabrous when mature, often thinly villous with long white hairs when young; petioles 2-9 $\mathrm{mm}$. long: aments and scales as in the preceding but the pistillate $1.2-3 \mathrm{~cm}$. wide (sometimes $10 \mathrm{~cm}$. long in low humid regions); scales more nearly glabrous: capsules 5-8 (mostly 7 ) $\mathrm{mm}$. long, longer east of our limits, glabrous, or silky with long white hairs, especially when young, pedicellate; pedicels 0.5-1.5 mm. long; gland often $1 \mathrm{~mm}$. long. S. longifolia. SandBar Willow. (S. interior Rowlee, Bull. Torr. Bot. Club 27: 253. 1900; S. linearifolia Rydb. l. c.)-Most common in eastern Colorado and Wyoming, and in Montana and Idaho, but not abundant anywhere in our limits; exceedingly abundant eastward across the continent.

8. Salix melanopsis Nutt. 1. c. 78. A tall, dark green shrub or small tree, 3-5 $\mathrm{m}$. high, more divaricately branched than the related species; twigs brown or blackish, often lustrous: leaves oblanceolate or elliptical, acute at both ends, 4-7 or $8 \mathrm{~cm}$. long, 6-15 $\mathrm{mm}$. wide, rather closely denticulate, of ten spinulose-denticulate, especially near the apex, or subentire, the margin somewhat revolute in drying, dark green and glabrous above, paler, strongly veined, and usually thinly silky-villous beneath; stipules lanceolate to semicordate, dentate: aments slender, $3-4 \mathrm{~cm}$. long, the staminate 5-6 mm. wide, the pistillate $7-8 \mathrm{~mm}$. wide; scales oblong to obovate, sometimes erose at the apex, thinly pilose, the pistillate often plainly striate with $3-5$ nerves: capsules ovate-lanceolate, glabrous, sessile or subsessile, $4-5 \mathrm{~mm}$. long. Dusky Willow.-Type locality, old Fort Hall near Pocatello, Idaho. Common in northeastern Oregon, eastern Washington, and British Columbia as far east as the Selkirks.

IV. RETUSAE.-Low, depressed, or creeping species, less than $1 \mathrm{dm}$. high: leaves minute, entire, glabrous: aments 2-4-flowered: capsules glabrous; stigmas sessile. A single species within our limits.

9. Salix Dodgeana Rydb. Bull. N. Y. Bot. Gard. 1: 277. 1899. Delicate, suffruticose, $2 \mathrm{~cm}$. high or less, from short, slender, subterranean stems; twigs yellowish-green, very leafy: leaves oblong or oval, 4-5 mm. long, acutish or obtuse, light green, strongly veined: staminate ament generally 3-4-flowered; stamens 2; filaments glabrous; pistillate aments generally 2-flowered; scales oblong, truncate, sparingly villous-ciliate: capsule oblong-ovoid, glabrous; stig- 
mas sessile, 2-cleft.-Covering acres of ground on Electric Peak, Yellowstone National Park, at 3,200 m. altitude; also on Sheep Mountain, Teton Forest Reserve.

V. Cordatae.-Shrubs 2-5 m. high; stems densely caespitose; twigs brown to yellow, mostly slender, lustrous: leaves linear-lanceolate to ovate or broadly oblanceolate, acute to long-acuminate, stipulate, glabrous; buds and slender petioles yellowisi: aments precocious or coetaneous, rather slender, subsessile or on short, bracted peduncles; scales tawny to fuscous: capsules glabrous, pedicellate; styles distinct.

Leaves glaucous or at least distinctly pale beneath.

Leaves linear-lanceolate; young branches with bluish bloom; capsules subsessile

Leaves lanceolate or broader; branches without bloom; capsules distinctly pedicellate.

Pedicels 1-2.3 $\mathrm{mm}$. long.

Leaves lanceolate, dark green above, mostly sharply serrate

Leaves broadly lanceolate or ovate-lanceolate, yellowishgreen, crenate-serrulate or subentire

Pedicels 3-4 mm. long; leaves oblanceolate or obovate

Leaves deep rich green on both surfaces, never pale beneath.

Leaves ovate or obovate, thin; pedicels $2.5-4 \mathrm{~mm}$. long

Leaves elliptic-lanceolate or oblong, thick; pedicels $1-2 \mathrm{~mm}$. long

10. S. irrorata.

11. S. cordata.

12. S. lutea.

13. S. Mackenziana.

14. S. pyrifolia.

15. S. pseudomyrsinites.

10. Salix irrorata Anders. 1. c. 117. Shrub 2-3 m. high; twigs dark brown to yellowish, glabrous or downy-puberulent, often covered with a bluish glaucous bloom, not shining: buds stout, broadly ovate, brown to yellow: leaves linear-lanceolate or linear-oblanceolate, acute to acuminate at both ends, 6-10 cm. long, 0.7-1.7 cm. wide, entire or undulate-serrulate, glabrous, dark green and veiny above, with the whitish midrib prominent; glaucous and finely reticulate beneath; stipules none: aments precocious, sessile, without bracts; the staminate $1-2 \mathrm{~cm}$. long; the pistillate $2-4.5 \mathrm{~cm}$. long, 7-10 $\mathrm{mm}$. wide, densely-flowered: capsules ovate-conic, 3-4 mm. long, subsessile, glabrous; pedicels $0.5-1 \mathrm{~mm}$. long; styles $0.5-0.7 \mathrm{~mm}$. long; stigmas short, entire or emarginate: scales small, fuscous, obtuse, clothed with long white woolly hairs. - Fairly common along streams and in wet places in the mountains, at 1,200-2,500 m. elevation; southwestern Texas to southern Arizona northward to northern Colorado. Shoots with large leaves resemble S. lasiolepis very strongly.

11. Salix cordata Muhl. Neue Schrift. Ges. Nat. Fr. Berlin 4: 236. 1803. Shrub 2-5 m. high; twigs long, stoutish, brown or often yellowish, glabrous to pubescent: leaves lanceolate or oblong-lanceolate or somewhat oblanceolate, acute to long-acuminate, usually narrowed at the base, 6-10 cm. long, $2-3 \mathrm{~cm}$. wide, shallowly to deeply serrate, dark green above, glaucous and reticulate beneath; stipules large, ovate to reniform, serrate: aments on short, bracted peduncles; staminate $2-3 \mathrm{~cm}$. long, $7-9 \mathrm{~mm}$. wide; pistillate $2-3.5 \mathrm{~cm}$. long, 1-1.3 cm. wide; scales tawny, or fuscous at the tip, thinly pilose: capsules $5-7 \mathrm{~mm}$. long; styles $0.3-0.5 \mathrm{~mm}$. long; pedicels $1-2$ (mostly 1.5 ) $\mathrm{mm}$. long. - Sparingly distributed throughout the Rocky Mountains and westward, up to $2,000 \mathrm{~m}$.

11a. Salix cordata angustata (Ph.) Anders. Mon. Sal. 159. 1867. Leaves narrower, about $1 \mathrm{~cm}$. wide, acute or acuminate at both ends.- Wet places on the high plains and in the foothills east of the Rocky Mountains.

11b. Salix cordata Watsonii Bebb, Bot. Cal. 2: 86. 1879. Twigs often yellow, shorter and more divaricate: leaves smaller and more slender, subentire, mostly dark green above, pale or subglaucous beneath: pedicels 1.5-2 mm. long. [S. flava Rydb. Bull. Torr. Bot. Club 28: 273. 1901; S. Watsonii (Bebb) Rydb. 1. c. 33: 157; S. Ormsbyensis v. Seem. Bull. Torr. Bot. Club 31: 403. 1904.]-Rocky Mountains, westward to the coast. Intermediate in some respects between $S$. cordata and $S$. lutea.

12. Salix lutea Nutt. 1. c. 63. pl. 19. Shrub 2-5 m. high; twigs mostly yellow, reddish-brown on the sunny side, glabrous to puberulent: leaves 
lanceolate to ovate-lanceolate, acute to short-acuminate at the apex, rounded to cordate at the base, $4-8$ or $10 \mathrm{~cm}$. long, $1.5-4 \mathrm{~cm}$. wide, entire to serrulate, mostly yellowish-green, glaucous beneath; stipules ovate to lunate, entire to serrulate: aments nearly sessile, on very short-bracted peduncles; staminate 2-3 cm. long; pistillate 2-4 cm. long, $1 \mathrm{~cm}$. wide; scales oblanceolate, acute to obtuse, tawny, thinly pilose: capsules ovate-conic, $4 \mathrm{~mm}$. long; pedicels 0.7-2 mm. long; styles less than $0.5 \mathrm{~mm}$. long.-Common plants of stream banks and wet places; Colorado to California, northward to Canada. Distinguished only with difficulty from $S$. cordata and may perhaps prove to be only a variety of that species.

13. Salix Mackenziana Barr. Hook. Fl. Bor. Am. 2: 149. 1839. Shrub 2-4 m. high; twigs usually divaricate, lustrous: leaves oblanceolate or narrowly obovate, sometimes lanceolate, mostly acuminate at the apex, cuneate to rounded at the base, $3-6$ or $7 \mathrm{~cm}$. long, 1-1.8 cm. wide, entire or serrulate, light green above, glaucous beneath, reticulate on both sides; stipules lunate, entire to serrate-dentate: aments coetaneous, on leafy peduncles $0.5-1 \mathrm{~cm}$. long; pistillate aments $2-6 \mathrm{~cm}$. long, $1.5 \mathrm{~cm}$. wide, rather lax in fruit; staminate aments $2-4.5 \mathrm{~cm}$. long; filaments free, or united only at the base; scales mostly oblanceolate, tawny or fuscous, thinly pilose: capsules ovate-conic, 4-5 mm. long, greenish; pedicels $3-4 \mathrm{~mm}$. long, about three times as long as the scales; styles $0.3-0.4 \mathrm{~mm}$. long; stigmas entire or sometimes emarginate. Very closely related to $S$. cordata and S. lutea.-Fairly common along streams and in wet places; northwestern Wyoming to Saskatchewan, west to Nevada and California.

14. Salix pyrifolia Anders. Vet. Acad. Handl. Stockh. 6: 162. 1867. Shrub 1-3 m. high; twigs slender, glabrous, bright chestnut to brown, lustrous: leaves ovate-lanceolate, ovate, or obovate-oval, abruptly cuspidate to shortacuminate at the apex, rounded or cordate at the base, 3.5-7 cm. long, 1.5-3.5 $\mathrm{cm}$. wide, shallowly glandular-serrulate, thin, translucent, pure dark green and reticulate with slender veins on both sides; stipules lunate or broadly ovate, glandular-serrate to dentate: peduncles short, leafy; aments coetaneous, long, lax; the staminate slender, flexuous, 4-6 cm. long, 8-10 mm. wide; filaments united for one third to three fourths their length; pistillate aments 3-6 cm. long, 1.2-1.8 mm. wide: capsules 3-4.5 mm. long; pedicels $2.5-4 \mathrm{~mm}$. long, about three times as long as the scales; styles $0.3-0.7 \mathrm{~mm}$. long; stigmas usually deeply divided. (S. rotundifolia ovata Nutt.)-Fairly common, mountains of Idaho, Oregon, Washington, and British Columbia.

14a. Salix pyrifolia obscura Anders. 1.c. Leaves obovate-oval to subrotund, abruptly cuspidate to rounded at the apex: pedicels $2-3 \mathrm{~cm}$. long: stipules more ovate. (S. rotundifolia Nutt. 1. c. 75.) Presenting a transition to $S$. pseudomyrsinites.-Vicinity of Yellowstone Park and northward.

15. Salix pseudomyrsinites Anders. Oefvers. Vet. Akad. Foerhandl. 15: 129. 1858. Shrub 1-3 m. high; twigs slender, mostly short, divaricate, leafy, bright chestnut to dark brown, lustrous: leaves elliptic-oblanceolate to lanceolate-oblong, acute to acuminate at the apex, mostly rounded at the base, 3-6 cm. long, 1-2 cm. wide, shallowly glandular-serrulate or subentire, dark green above, pure green, scarcely paler and coarsely reticulate with broad veins beneath; petioles $3-8 \mathrm{~mm}$. long, glabrous or thinly villous; stipules lanceolate to ovate, acute or acuminate, glandular-serrate, 4-8 $\mathrm{mm}$. long: peduncles $0.5-1 \mathrm{~cm}$. long, leafy; aments coetaneous (?), small, $2-3 \mathrm{~cm}$. long in both sexes; scales oblong or oblanceolate, acutish to truncate, thinly clothed with long white woolly hairs: capsules greenish, 4-5 $\mathrm{mm}$. long; pedicels 1-1.5 mm. long; styles 0.5-0.7 mm. long; stigmas thick, entire.-At middle to high elevations, infrequent; New Mexico to Saskatchewan, west to eastern Oregon and eastern Washington.

15a. Salix pseudomyrsinites equalis Anders. Leaves smaller, entire, less strongly reticulate: capsules subrostrate, 5-7 $\mathrm{mm}$. long, green or rufescent. Young leafy shoots strongly resemble those of $S$. Wolfii, but the leaves differ in being glabrous and less oblanceolate.-Southeastern Wyoming to the Uinta Mountains, Utah, and north to Yellowstone Park. 
VI. Commutatae.-Shrubs 1-4 m. high; stems densely caespitose; twigs dark brown, lustrous: leaves oblanceolate to obovate-oval or elliptic-oval, entire or shallowly serrulate, densely to thinly villous-tomentose, at least above, stipulate: aments on leafy peduncles (sessile in No. 16), precocious or coctaneous: scales fuscous, broad, obtuse, villous: capsules ovate or rostrate, glabrous or tomentose; pedicels 0.5-1.5 $\mathrm{mm}$. long; styles 1-1.5 $\mathrm{mm}$. long (except in No. 18).

Leaves glabrate above, glabrous and glaucous beneath, crenate or serrulate.

Aments sessile

Aments leafy-pedunculate

Leaves densely villous-tomentose to glabrate on both sides, dull green beneath.

16. S. monticola. 17. S. Barclayi.

18. S. Wolfii.

16. Salix monticola Bebb in Coult. Man. 336. 1885. Shrub 3-6 m. high; twigs rather stout and divaricate, usually glabrous, deep reddish-brown, lustrous: leaves at first oblanceolate, obovate or oval, finally more elliptical or oblong-elliptical, acute or abruptly short-acuminate at the apex, usually narrowed and rounded at the base or sometimes subcordate, 5-7 or more $\mathrm{cm}$. long, 2-4 cm. wide, crenate-serrulate, dark green above, subglaucous to glaucous beneath, glabrous or thinly puberulent or pubescent above, especially on the pale yellow midrib and the primary veins, strongly reticulate beneath; stipules large, ovate or semicordate, acute, serrate: buds large: aments sessile, stout, naked or the pistillate, with a few broad bracts at the base, 2-3 cm long, the pistillate becoming $3-5 \mathrm{~cm}$. long in fruit; scales dark, obovate-oval, obtuse, densely villous with long white hairs: capsule glabrous, sessile or subsessile, rostrate, rufescent, 5-7 mm. long; styles 1-1.5 mm. long. (S. padifolia Rydb. not Anders.; S. padophylla Rydb. 1. c. 28: 499. 1901).Common at high elevations, 2,400-3,500 m.; New Mexico to Montana and Alberta.

17. Salix Barclayi Anders. 1. c. 125. Shrub 1-4 m. high; twigs short, stout, divaricate, blackish, tomentose to glabrate: leaves ovate-lanceolate to oval or obovate, acute or cuspidate at the apex, cuneate to rounded at the base, or cordate on vigorous shoots, $3-7 \mathrm{~cm}$. long, $1.5-2.5$ or more $\mathrm{cm}$. wide, crenateserrulate, the glandular teeth inflexed, or subentire, thinly tomentose above, especially on the midrib and veins, becoming glabrate, glabrous, reticulate and mostly glaucous beneath; stipules large, ovate-acuminate, serrate: aments stout, on leafy peduncles $1-3 \mathrm{~cm}$. long; staminate aments $1-3$, and the pistillate $2-6 \mathrm{~cm}$. long, $1.5 \mathrm{~cm}$. wide; scales fuscous, mostly acute, thinly to densely villous with long hairs: capsules glabrous, or sometimes thinly sericeous, greenish, rostrate, $\triangle-7 \mathrm{~mm}$. long; pedicels $0.5-1 \mathrm{~mm}$. long; styles $1-1.5$ $\mathrm{mm}$. long. (S. conjuncta Bebb, Bot. Gaz. 13: 111. 1888).-High elevations, mountains of Colorado and southeastern Wyoming to Oregon, Washington, and Alaska.

18. Salix Wolfii Bebb, Bot. Wheeler Exp. 241. 1878. Low shrub 6-10 dm. high; twigs chestnut, leafy, the younger yellowish, lustrous: leaves oblanceolate or rhomboid-oblanceolate, or elliptical, acute at the apex, rounded at the base, $2-4.5 \mathrm{~cm}$. long, 8-13 mm. wide, entire, dull green and silky-villous with shining hairs on both sides, becoming somewhat glabrate; petioles yellow, villous; stipules small or wanting: peduncles short, bearing several leaf-like bracts which often exceed the ament; pistillate aments 1-2.5 cm. long, subglobose to oblong, densely flowered; staminate aments $0.5-1.5 \mathrm{~cm}$. long; scales dark, obovate, sparsely long-villous: capsules glabrous, greenish or rufescent, 3.5-4.5 $\mathrm{mm}$. long; pedicels about $0.5 \mathrm{~mm}$. long; styles variable, 0.5-1 mm. long. S. desertorum Wolfii.-At middle to high elevations; southern Colorado to Wyoming and Idaho.

18a. Salix Wolfii idahoensis Ball, Bot. Gaz. 40: 378. 1905. Leaves larger, 3-6 cm. long, 1-1.8 cm. wide, oblanceolate: aments longer, 1-3.5 cm. in length; peduncles proportionate: capsules about $5 \mathrm{~mm}$. long, greenish, thinly tomentose. This includes most of the material called " $S$. glauca villosa" in herbaria.-Big Horn Mountains of north Wyoming to east Oregon and north Idaho; abundant in the region of the Yellowstone National Park. 
VII. Lanatae.-Mostly shrubs 1-4 m. high; twigs stout, divaricate, tomentose: leaves large, broadly elliptical to obovate-oval or suborbicular, more or less tomentose: aments very large, stout and dense, sessile or short-peduncled, 3-8 cm. long, lateral or terminal: capsules large, sessile or subsessile, glabrous (in our species) or tomentose; styles much elongated. Only one species certainly within our limits.

19. Salix Tweedyi (Bebb) Ball, Bot. Gaz. 40: 377. 1905. Low (?) shrub; the youngest twigs more or less tomentose with long hairs: leaves broadly elliptical to oval or ovate, acute or obtuse at both ends to rounded or cordate at the base, 5-7 cm. long, 2-4 cm. wide, green above, paler but not glaucous beneath, glabrous throughout or sparsely gray-tomentose above, finely glandular-denticulate or mature leaves irregularly spinulose-denticulate; petioles tomentose, $8-15 \mathrm{~mm}$. long; stipules large, clasping, broadly reniform, glandular-denticulate: aments precocious, the pistillate sessile, 4-6 cm. long, $1.5 \mathrm{~cm}$. or more wide; scales obovate, black, clothed with long white hairs: capsule large, green, glabrous or finely pubescent at the apex, 7-8 $\mathrm{mm}$. long; pedicels $1 \mathrm{~mm}$. long; styles $1.5-2.5 \mathrm{~mm}$. long; stigmas divided; gland $1 \mathrm{~mm}$. long. (S. Barrattiana Tweedyi Bebb, Contrib. U. S. Nat. Herb. 3:572. 1896.) - In bogs and along mountain streams, 2,500-3,000 m. altitude, not common; known only from the Big Horn Mountains of northern Wyoming, the Yellowstone Park, and Teton Basin.

VIII. Arctica E.-Low, erect, or creeping alpine.shrubs, 1-10 or $15 \mathrm{dm}$. high; branches full of leaf-scars: leaves small to medium, narrowly elliptic or oblanceolate, occasionally broader, entire, more or less tomentose; stipules small or none: aments appearing with the leaves, on short, leafy peduncles; scales brown, brown-tipped, villous: capsules sessile or short-pediceled, gray- or white-tomentose; styles 1-1.5 $\mathrm{mm}$. long; stigmas medium, notched.

Erect or spreading subalpine shrubs 2-15 dm. high.

Capsules and leaves gray- or yellowish-tomentose or leaves glabrate. Aments much longer than broad; leaves gray-tomentose, drying

black
Aments subglobose, leaves yellowish-tomentose beneath, not drying black

Capsules and lower leaf-surfaces densely white-tomentose

Depressed, creeping alpine plants, less than $1 \mathrm{dm}$. high.

Leaves broadly elliptical to obovate, pale beneath, $2-4 \mathrm{~cm}$. long

Leaves narrowly elliptical or obovate, scarcely 10-12 $\mathrm{mm}$. long

20. S. glaucops.

21. S. brachycarpa.

22. S. candida.

23. S. petrophila.

24. S. tenera.

20. Salix gla ucops Anders. DC. Prodr. 162: 281. 1868. Subalpine shrub, 4-15 dm. high; branches and twigs short and stout, shining, chestnut-brown or darker, the bark separating from the older branchlets in thin gray papery flakes: leaves elliptic-lanceolate, or oblanceolate to oblong-ovate, entire, obtuse or subacute at the apex, obtusish to subcordate at the base, $3-5$ or $6 \mathrm{~cm}$. long, 1-1.7 or $2 \mathrm{~cm}$. wide, gray-tomentose or glabrate on both sides, dark green above, glaucous and reticulate beneath; petioles yellowish, 5-10 $\mathrm{mm}$. long; stipules minute, ovate or semicordate: peduncles $2-3 \mathrm{~cm}$. long, tomentose; staminate aments $1-3 \mathrm{~cm}$. long, $1-1.5 \mathrm{~cm}$. wide; pistillate $3-5 \mathrm{~cm}$. long and $1.5 \mathrm{~cm}$. wide; scales oblong, dark to pale brown, villous: capsules conic, gray-tomentose, 6-7 or $8 \mathrm{~mm}$. long; pedicels stout, pubescent, $1-1.5 \mathrm{~mm}$. long; styles fuscous or yellowish, $0.7-1 \mathrm{~mm}$. long. (S. pseudolapponum v. Seem. Engl. Jahrb. XXIX, Beibl. 65: 28.1900; S. Seemannii Rydb. Bull. N. Y. Bot. Gard. 2: 164. 1901; S. wyomingensis Rydb. Bull. Torr. Bot. Club 28: 271. 1901.) - Common in boggy places at middle to high elevations; New Mexico to Canada and westward.

$20 a$. Salix glaucops glabrescens Anders. Leaves more rigid, glabrate, intensely glaucous beneath: aments stouter, capsules sometimes glabrescent. -Range of the species but less common.

21. Salix brachycarpa Nutt. N. Am. Sylva 1: 69. 1842. A small alpine shrub, scarcely more than $1 \mathrm{~m}$. high; branches stoutish and divaricate within our limits, longer and more slender northward, reddish-brown to yellowish or gray; twigs tomentose: leaves elliptical-oblong or oblanceolate 
to narrowly obovate, obtusish to abruptly acute at the apex, acute to semicordate at the base, entire, light green and somewhat tomentose above, pale yellowish-green and densely yellowish-tomentose to glabrate beneath, not glaucous, $2-3.5 \mathrm{~cm}$. long, $6-12 \mathrm{~mm}$. wide; petioles $3-5 \mathrm{~mm}$. long; stipules none: aments numerous, of ten crowded, subglobose to oblong, $0.5-2 \mathrm{~cm}$. long, mostly about $1 \mathrm{~cm}$. long: capsules ovate-lanceolate, subsessile, $5-7 \mathrm{~mm}$. long, densely gray- or white-tomentose; styles 1-1.5 mm. long; stigmas medium. S. desertorum. [S. stricta (And.) Rydb. Bull. N. Y. Bot. Gard. 1: 273. 1899.] -Wet places in the mountains above $2,000 \mathrm{~m}$., fairly common; Colorado and northward to the plains of Canada.

22. Salix candida Fluegge, Willd. Sp. Pl. 4: 708. 1806. A low, branching shrub, 2-10 dm. or more high; branches stout, divaricate, glabrous, light brown or yellowish; twigs densely white-tomentose: leaves linear-oblong to narrowly oblanceolate or occasionally much broader, usually acute at both ends, margins revolute, entire, or rarely crenulate and glandular, dark green, dull and thinly tomentose above, with deeply impressed veins, resembling sage leaves, densely white-tomentose beneath, $3.5-8$ or $10 \mathrm{~cm}$. long, $0.7-2 \mathrm{~cm}$. wide; petioles short, tomentose; stipules very narrow, acute, glandular, tomentose: aments on short leafy tomentose peduncles, the pistillate 1-3 cm. long, 1-1.3 $\mathrm{cm}$. wide: capsule lanceolate, short-pediceled, white-tomentose, 6-8 $\mathrm{mm}$. long; scales obovate, white-woolly; styles reddish or orange, 1-1.5 mm. long; stigmas short, divaricate, notched. SAGE-LEAved or HoARY Willow.-Infrequent, in cold bogs; east of the Divide, from southern Wyoming to Alberta, Saskatchewan, and eastward.

23. Salix petrophila Rydb. Bull. N. Y. Bot. Gard. 1: 268. 1899. Stems horizontal, creeping; branches erect, glabrous, brown or yellowish, 5-10 cm. high: leaves broadly elliptical to obovate, abruptly acute to obtuse, entire, deep green above, distinctly pale to subglaucous beneath, rather strongly veined, $1.5-4 \mathrm{~cm}$. long, 1-1.5 $\mathrm{cm}$. wide, glabrate or glabrous; petioles slender, yellow: staminate aments 1-2, the pistillate $2-4 \mathrm{~cm}$. long, slender, lax at base: capsules lanceolate, sessile, gray-tomentose, 4-6 mm. long; styles 1-1.5 $\mathrm{mm}$. long. S. arctica petraea Anders.-Among rocks, alpine summits, above $3,500 \mathrm{~m}$.; Colorado, Utah, and northward.

24. Salix tenera Anders. 1. c. 288 . Scarcely $5 \mathrm{~cm}$. in height, from horizontal creeping stems: leaves narrowly elliptical to obovate, acute at both ends or sometimes obtuse at the apex, deep green and shining on both sides or slightly paler beneath, very strongly nerved, $0.8-12 \mathrm{~mm}$. long, $4-8 \mathrm{~mm}$. wide; petioles $2-3 \mathrm{~mm}$. long: aments subglobose, few-flowered, the staminate 5-10 mm. in length, the pistillate 7-20 mm. long: capsules sessile, 4-5 mm. long, gray-tomentose.-Rare; alpine summits from Wyoming to Washington. Perhaps only a variety of the preceding.

IX. Argenteae.-Shrubs 1-3 or $4 \mathrm{~m}$. high; twigs rather long, brownish or yellowish, often lustrous and mostly pruinose: leaves narrowly oblong or oblanceolate, acute, entire or subentire, densely silvery-sericeous or silverytomentose beneath: aments sessile or very short-pedunculate, 1-4 cm. long: stamens 2: scales brown or black, hairy: capsules small, silvery-sericeous, sessile or short-pediceled; styles elongated.

25. Salix subcoerulea Piper, Bull. Torr. Bot. Club 27: 400. 1900. Erect shrub 1-3 m. high; twigs glabrous, usually covered with a dense bluish bloom: leaves oblong-lanceolate or oblanceolate, acute or acuminate at the apex, acute at the ibase, $2-5$ or $7 \mathrm{~cm}$. long, $0.8-2.5 \mathrm{~cm}$. wide, entire or slightly crenulate, green and sparsely pubescent above, densely covered with a fine short silvery pubescence beneath; petioles $2-7 \mathrm{~mm}$. long; stipules none, or occasionally very small and lanceolate on vigorous shoots: pistillate aments sessile or short-pedunculate (peduncles sometimes $5 \mathrm{~mm}$. long, with 1 or 2 small bract-like leaves at base), 2-4 cm. long, densely flowered; staminate aments sessile, stout, 1-2 cm. long; stamens 2; scales brown or black, oblong, ovate or obovate, acute or obtuse, thinly pilose: capsules ovate or ovatelanceolate, subsessile or șhort-pediceled, 3-5 mm. long, silvery sericeous; ped- 
icels never more than $1 \mathrm{~mm}$. long; styles 1-1.5 mm. long, brown or yellowish. (S. pellita of authors, not Anders.; S. Covillei East. Zoe 5: 80. 1900; S. pachnophora Rydb. Bull. Torr. Bot. Club 31: 403. 1904.)-Mountain streams and wet meadows; from New Mexico and California north to Montana and Oregon. The pruinose branches and oblanceolate, acuminate leaves suggest $S$. Geyeriana very strikingly.

X. Phylicifoliae.-Much-branched alpine or subalpine shrubs, 1-3 m. high; twigs short, divaricate, lustrous, brown: leaves small, elliptic-ovate, obovate or oblanceolate, usually entire, bright green and shining above, pale or subglaucous beneath, glabrous throughout, or very thinly villous beneath with short silvery hairs: aments sessile, stoutish, densely compact: capsules sessile, gray-pubescent; styles elongated; stigmas thick.

Leaves broadly elliptic-ovate or obovate, mostly obtuse at the apex; styles $1-1.5 \mathrm{~mm}$. long

Leaves oblanceolate, acute at both ends; styles $0.5-1 \mathrm{~mm}$. long

26. S. chlorophylla. 27. S. Nelsonii.

26. Salix chlorophylla Anders. Vet. Acad. Handl. Stockh. 6: 138. 1867. Twigs glabrous, bright chestnut to deep rich brown: leaves broadly ellipticovate or obovate, $2-3.5 \mathrm{~cm}$. long, $0.8-2 \mathrm{~cm}$. wide, obtuse at both ends or acutish at the base and abruptly acute at the apex, entire or occasionally somewhat glandular-crenulate or serrulate; petioles 2-5 $\mathrm{mm}$. long, glabrous; stipules none: buds large, chestnut or darker: aments appearing with the leaves, $1-3 \mathrm{~cm}$. long, $1-1.3 \mathrm{~cm}$. wide; scales ovate, acute, clothed on both sides with long white hairs: capsules ovate-conic, 4-6 mm. long; styles 1-1.5 $\mathrm{mm}$. long, somewhat pubescent at the base; stigmas thick, mostly entire, rather long.-Fairly common at 2,500-4,000 m.; from New Mexico, Utah, and California northward into Canada.

27. Salix Nelsonii Ball, Bot. Gaz. 40: 379. 1905. A shrub 1-3 m. high, similar to the preceding: leaves oblanceolate or rarely narrowly lanceolate, acute or short-acuminate at the apex, cuneate at the base, $2-5.5 \mathrm{~cm}$. long, $0.8-1.5 \mathrm{~cm}$. wide, entire or the apical somewhat glandular-crenulate, rather strongly veined on both surfaces; stipules none: pistillate aments naked or sometimes with 1-3 small bracts at the base, 1.5-5 cm. long; scales black, ovate, acute, clothed on both sides with long white hairs: capsules $5-6 \mathrm{~mm}$. long; styles $0.5-1 \mathrm{~mm}$., somewhat pubescent at the base; stigmas, long, stout, glabrous. Nelson's Willow.-Fairly common at high altitudes 2,500$4,000 \mathrm{~m}$.; from central Colorado to Alberta.

XI. Capreae.-Tall shrubs of wide distribution, 2-4 m. high; bark gray, twigs dark brown to black: leaves rather large, lanceolate-oblong to obovate, entire to crenulate or crenulate-dentate, more or less pubescent to tomentose, especially beneath, glabrate in age, dark green above, glaucous and strongly reticulate beneath: aments precocious, stout, dense, sessile or subsessile; scales broad, blackish, long-villous: capsule gray-pubescent, long-rostrate, $7-9 \mathrm{~mm}$. long; pedicels 1-2.5 mm. long; styles short or none; stigmas long, divided.

Leaves elliptic-lanceolate to oblong, obtuse or acute at base, acute or

short-acuminate at apex
Leaves oblanceolate to obovate, cuneate at base, obtuse or abruptly acute at apex

28. S. discolor.

29. S. Scouleriana.

28. Salix discolor Muhl. 1. c. 234. Shrub with rather stoutish brown to blackish twigs, glabrous or the youngest pubescent: leaves lanceolate-oblong to elliptic-oblong, acute or rounded at the base, short-acuminate at the apex, 4-8 cm. long, $1.5-2.5 \mathrm{~cm}$. wide, shallowly crenulate-serrate to dentate, mostly glabrous at maturity, dark green above, glaucous and reticulate beneath; stipules mostly large, semicordate, acute, irregularly dentate: aments stout, the staminate sessile, the pistillate very short-pedunculate and rather lax in fruit, 3-5 or $6 \mathrm{~cm}$. long, 1-2 cm. wide; scales brown or darker, oblanceolate to obovate, villous with long white hairs: capsules lanceolate-rostrate, 7-9 or $10 \mathrm{~mm}$. long, pubescent; styles $0.5 \mathrm{~mm}$. long; stigmas $0.5-0.8 \mathrm{~mm}$. long, entire 
or bifid.-Streams and wet places in the Black Hills and in Montana. A common species in the eastern and central States.

29. Salix Scouleriana Barr. 1. c. 145. Shrub with rather slender twigs, glabrous to densely pubescent: leaves obovate or oblanceolate, obtuse or mostly abruptly acute at the apex, cuneate at the be,e, $3-8 \mathrm{~cm}$. long, 1.5-3.5 $\mathrm{cm}$. wide, entire or shallowly crenulate-serrulate, dark green and glabrate above, glaucous, strongly reticulate-veined, and sometimes densely tomentose beneath; stipules minute, entire, or small, finely dentate: staminate aments sessile, $2-3 \mathrm{~cm}$. long, $1.5 \mathrm{~cm}$. wide; pistillate longer, short-peduncled, $3-5 \mathrm{~cm}$. long, 1.2-1.5 cm. wide; scales black, obovate, long-villous: capsules rostrate, 7-9 mm. long, tomentose; pedicels 1-2 mm. long, pubescent; stigmas about $1 \mathrm{~mm}$. long. S. flavescens. (S. Nuttallii Sarg. Gard. \& For. 8: 463. 1895.) Forms with short, stout aments may be referred to var. crassijulis Anders. - Common along mountain streams at elevations of 1,500-3,000 m.; New Mexico to Alberta and west to the coast.

XII. Rostratae.-Shrubs 2-5 m. high; twigs slender, divaricate, full of leaf-scars, the younger very leafy: leaves linear-oblanceolate to elliptic-oval, mostly entire, more or less pubescent on both sides; istipules usually none: aments coetaneous; the staminate small, subsessile with small leafy bracts at the base; the pistillate on pubescent leafy peduncles, rather lax in fruit; scales linear-oblong, acute, thinly pilose, tawny, reddish at the tips: capsules long-pediceled, conic-rostrate, 5-10 mm. long, pubescent; styles short or none; stigmas short, divided.

Leaves elliptic-oval, pedicels 2-5 mm. long; branches without bloom Leaves linear-oblanceolate, pedicels $1.5-2.5 \mathrm{~mm}$. long; branches with bloom.

30. Salix Bebbiana Sarg. Gard. \& For. 8: 463. 1895. A tall shrub with few stems, or a small tree, $2-5 \mathrm{~m}$. high; twigs short, brown or darker, pubescent or glabrate: leaves small to medium, narrowly elliptical and acute at both ends to broadly oblanceolate or obovate-oval and abruptly shortacuminate, $2-4$ or $5 \mathrm{~cm}$. long, 1-2 or $2.5 \mathrm{~cm}$. wide, entire or occasionally glandular-crenulate, dull green above, paler or subglaucous and reticulated beneath, more or less pubescent on both surfaces or glabrate in age; stipules none, or small, dentate: staminate aments subsessile or on short peduncles, slender, 1-2 cm. long, 5-7 mm. wide, yellowish; filaments capillary; pistillate aments (on peduncles $0.5-2 \mathrm{~cm}$. long) 2-4 or $6 \mathrm{~cm}$. long, 1-2 cm. wide, very lax in fruit; scales in both sexes lanceolate-oblong, 1-2 mm. long, acute: capsules $6-9$ or $10 \mathrm{~mm}$. long, thinly pubescent; pedicels slender, pubescent, 2-5 mm. long; stigmas deeply divided. (S. perrostrata Rydb. in Bull N. Y. Bot. Gard. 2: 163. 1901.)-Along streams and in wet ground, throughout our range; ascending to $3,000 \mathrm{~m}$. altitude.

31. Salix Geyeriana Anders. Oefvers. Vet. Akad. Foerh. 15: 122. 1858. Shrub 1-3 or $4 \mathrm{~m}$. high; twigs glabrous, very leafy, black with a bluish bloom: leaves small, linear-oblanceolate or elliptical, acute or short-acuminate at apex, acute at base, 2-4 or $6 \mathrm{~cm}$. long, 5-10 mm. wide, dark green above, more or less glaucous beneath, thinly or densely silky-pilose on both surfaces, margins entire, revolute; stipules none: aments on pubescent leafy peduncles, $0.5-1 \mathrm{~cm}$. long, the leaves often exceeding the ament, the staminate $1 \mathrm{~cm}$. or less, oblong; the pistillate subglobose, numerous, 1 or occasionally $2 \mathrm{~cm}$. long, $1-1.3 \mathrm{~cm}$. wide; scales linear-oblong, acute, thinly pilose, the base tawny, the tip red:capsules $5-7 \mathrm{~mm}$. long, rostrate; pedicels stout, pubescent, 2-2.5 mm. long; styles short or none; stigmas short, divided. S. macrocarpa Nutt.-A plant of stream banks and wet places, at middle altitudes; Colorado to Montana, west to the coast.

XIII. ReticulataE.-Densely caespitose, low or creeping alpine shrubs, 0.5-8 dm. high, with ellipticcl-oblong, obovate or suborbicular leaves, strongly reticulate and glcucous beneath; petioles slender, channeled; stipules none: aments on naked peduncles arising opposite the last leaf: capsules small, sessile, tomentose; styles none; stigmas shc: , divided, 
Ascending, 3-9 dm. high; leaves long-villous beneath

Creeping, 0.3-1 dm. high; leaves glabrous beneath.

Leaves $1.5-2.5 \mathrm{~cm}$. long; aments many-flowered

Leaves 7-12 mm. long; aments few-flowered .
32. S. vestita.

33. S. saximontana.

34. S. nivalis.

32. Salix vestita Pursh, Fl. Am. Sept. 2: 610. 1814. A shrub with rather stout, light brown to yellowish, glabrous, angular twigs: leaves elliptic to oblong-obovate or suborbicular, rounded to retuse at the apex, acute to obtuse at the base, 3-4.5 cm. long, 2-3.5 cm. wide, obscurely crenulate, deep green and glabrous above, clothed beneath with long white silky hairs, especially on the midrib and veins; petioles $2-10 \mathrm{~mm}$ long: buds large, obtuse, light brown: aments on villous peduncles; the staminate linear, 2-3.5 cm. long, $0.5 \mathrm{~cm}$. wide; pistillate aments $2 \mathrm{~cm}$. long, $1 \mathrm{~cm}$. wide; scales oblong-ovate, tomentose: capsules ovate-conic, $4-5 \mathrm{~mm}$. long. (S. Fernaldii Blankinship, Mont. Agr. Coll. Sci. Studies Bot. 1: 46. 1905.)-Among rocks, not common; eastern Oregon and Montana to British Columbia and Alberta.

33. Salix saximontana Rydb. Bull. N. Y. Bot. Gard. 1: 261. 1899. Densely caespitose and much branched, 3-6 $\mathrm{cm}$. high: leaves elliptic-oblong to suborbicular, obtuse or abruptly acute at the apex, acutish to rounded at the base, $1.5-2.5 \mathrm{~cm}$. long, $1-1.5 \mathrm{~cm}$. wide, light green above, glabrous throughout, margin entire and revolute: aments 1-2 cm. long, many-flowered; scales broadly obovate, obtuse or rounded at the apex, cuncate at the base, yellowish, nearly glabrous: capsules $3-4 \mathrm{~mm}$. long, densely white-tomentose. S. reticulata. (S. aemulans v. Seemen, 1. c. 28.)-Alpine summits, 3,000 m. altitude and upward; southern Colorado to Montana and west to California and Oregon.

34. Salix nivalis Hook. Fl. Bor. Am. 2: 152. 1839. Scarcely $2 \mathrm{~cm}$. high, from buried stems: leaves elliptic, oblong-obovate, or suborbicular, acute, obtuse or retuse, 7-12 $\mathrm{mm}$. long, $4-8 \mathrm{~mm}$. wide, green and shining above, margins entire and revolute; petioles $2-7 \mathrm{~mm}$. long, yellowish: aments globose or oblong, 3-6-flowered, $1 \mathrm{~cm}$. or less in length; scales oblong-obovate, obtuse, yellowish, nearly glabrous: capsules $2.5-3 \mathrm{~mm}$. long, tomentose.-Alpine summits; Montana to Alberta and westward.

\section{BetulaceaE Agardh. Birch Family}

Trees or shrubs, with alternate simple leaves and deciduous stipules, and monoecious flowers in aments, the staminate pendulous. Staminate flowers 1-3 in the axil of each bract. Calyx membranous and 2-4-parted, or wanting. Stamens 2-10, the filaments sometimes dichotomous above with an anther cell on each branch. Pistillate aments spike-like or capitate, with or without a calyx, adnate to the solitary 1-2-celled ovary. Fruit a small 1-seeded nut, with or without an involucre.

Pistillate flowers with a calyx; nut inclosed in a large thick involucre . Pistillate flowers without a calyx; nut naked, of ten winged.

Stamens 2; filaments bifurcate; nutlets winged.

Stamens 4; filaments not forked; nutlets not winged :

1. Corylus.

2. Betula. 3. Alnus.

\section{CORYLUS L. Hazelnut}

Shrubs with double-toothed leaves, flowering in early spring. Sterile aments single or fascicled, from scaly buds of the axils of the preceding year; the fertile terminating early leafy shoots. Sterile flowers in drooping cylindrical aments, destitute of a true calyx, consisting of several stamens included under and more or less adnate to a bract; anthers 1-celled. Fertile flowers in a scaly bud or ament, two under each fertile bract, each with 1 or more bractlets which form a foliaceous involucre to the large bony nut.

1. Corylus rostrata Ait. Hort. Kew 3: 364. 1789. Shrub 6-16 dm. high: leaves ovate or ovate-oblong, somewhat heart-shaped, abruptly pointed: in- 
volucre of united bracts, much prolonged above the ovoid nut into a narrow tubular beak, densely bristly.-From Colorado to Washington; also northward and eastward.

\section{BETULA L. Birch}

Outer bark usually separable in sheets, that of the branchlets dotted. Twigs and leaves often spicy-aromatic. Staminate flowers 3 , and bractlets 2 , under each shield-shaped scale or bract of the aments, consisting each of a calyx of one scale bearing 2 two-parted filaments. Pistillate flowers without bractlets or calyx. Bracts 3-lobed, becoming coriaceous and caducous. Nutlets winged.

Bark of trunk white or gray.

Trunk single (simple at base) . $\quad . \quad 0_{0} \quad$. 1. B. papyrifera. Trunks few-several (in stools or clumps) : $\quad: \quad \vdots \quad: \quad$ : 2. B. Andrewsii.

Bark of trunk greenish-brown or brown.

Low bushy shrub; nutlets orbicular-winged _. . 3. B. glandulosa.

Taller and slender, becoming tree-like; nutlets with broad lateral wings 4 . $\mathbf{B}$. fontinalis.

1. Betula papyrifera Marsh, Arb. Am. 19. 1785. A large tree eastward but in our range much reduced: bark chalky-white, peeling into thin layers: leaves ovate, acute, dentate and incised, glabrous above, pubescent on the veins beneath: staminate aments slender, 5-10 $\mathrm{cm}$. long; pistillate cylindric, 2-5 $\mathrm{cm}$. long, with puberulent or ciliate bracts. PAPER or CANOE BIRCH.-Northeastern Wyoming, northward and eastward.

2. Betula Andrewsii A. Nels. Bot. Gaz. 43: 281. 1907. Near B. papyrifera but growing in clumps or stools, the coördinate trunks few to several, each attaining a maximum diameter of 10-15 cm., after which they die and are replaced by new shoots from the same root: bark on the old trunks silverygray, exfoliating as in the preceding: branches reddish-brown, conspicuously marked by the transversely disposed oval white lenticels; twigs pale brown: leaves ovate, abruptly short-acuminate, sharply and irregularly serrate with short teeth: fruiting bracts deeply 3-lobed, the middle one longer and narrower than the lateral: nut oblong-obovate, with very thin wings nearly twice as broad as the body.-Known only from type locality, Green Mountain, Boulder, Colorado.

3. Betula glandulosa Michx. Fl. Bor. Am. 2: 180. 1903. A low bush, 15$20 \mathrm{dm}$. high or less, the dark-colored branches usually more or less resinousglandular: leaves small, obovate to oblong-obovate, mostly cuneate at base, rounded and crenate above, smooth and often resinous-coated: the deeply 3-lobed bracts slightly ciliate: seed orbicular-winged. Mountain Bog Birch. -From California to Sitka, and eastward through British America to the Atlantic, and southward in the mountains to New Mexico.

4. Betula fontinalis Sarg. Bot. Gaz. 31: 239. 1901. Ranging in size from a tree-like shrub to a tree $12 \mathrm{~m}$. or more high, usually slender and freely branched: bark smooth, dark; branches gracefully drooping: leaves thin, broadly ovate, with small gland-tipped teeth, smooth above, lightly pubescent beneath: wings of the nutlet as broad as the body. $B$. occidentalis. RockY Mountain BIRCH.-Throughout our range and westward

\section{ALNUS Gaertn. Alder}

Shrubs or small trees with dentate or serrulate leaves, and flowers of both kinds in aments. Sterile flowers 3 , and bractlets 4 or 5 under each shortstalked shield-shaped scale, consisting each of a 3-5-parted calyx and as many stamens, with the filaments short and simple. Fertile flowers with a calyx of 4 little scales adherent to the scales or bracts of the ament.

1. Alnus tenuifolia Nutt. Sylva 1: 32. 1842. A large shrub or small tree, usually several-stemmed from the base: leaves ovate, with prominent veins, rather large, sharply double-toothed: aments begin their development the summer preceding the season in which they.open and hang naked upon the 
branches during the winter, opening in the spring before the leaves develop: fertile aments erect, their scales becoming woody, persistent for a time after the small, compressed, scarcely winged nuts have fallen.-The common ALDER on all the streams of this region.

\section{FAgaCEAE Drude. Beech Family}

Shrubs or trees, with deciduous or evergreen alternate petioled leaves. Flowers monoecious; the staminate in aments; the pistillate solitary or few in a cluster, subtended by an involucre (of more or less united bracts) which becomes a bur or cup. Petals none. Staminate flowers with a 4-7-lobed perianth and 4-20 stamens on slender filaments; the pistillate with an urnshaped perianth adnate to the few-celled ovary; ovules 1-2 in each cell, only 1 maturing; styles linear, as many as the cells in the ovary. Fruit a 1-seeded nut, with coriaceous or bony exocarp.

\section{QUERCUS L. OAK}

Shrubs or trees. Leaves in ours mostly deciduous. Flowers small, green or - yellowish; the staminate numerous, in slender drooping aments; the pistillate solitary, in many-bracted involucres. Staminate flowers subtended by caducous bracts, consisting of a mostly 6-lobed perianth and 5-12 stamens. Pistillate flowers with an urn-shaped calyx adnate to a 3-celled ovary. Fruit consisting of the imbricated and united bracts of the involucre (cup), subtending or nearly inclosing the coriaceous nut (acorn).

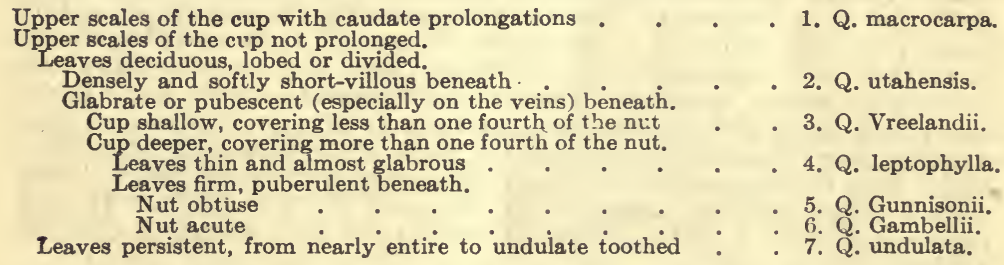

1. Quercus macrocarpa Michx. Hist. Chens Am. No. 2. 1801. Becoming a large tree with gray flaky bark: leaves variable, obovate or oblong-obovate, irregularly lobed, or pinnatifid, or deeply undulate, at maturity green and shining above, grayish-white tomentulose below, $8-16 \mathrm{~cm}$. long: styles short: fruit subsessile; cup subglobose or hemispheric, $14-20 \mathrm{~mm}$. in diameter; its bracts floccose, hard, thick, the upper subulate-tipped forming a fringe around the ovoid acorn, which is from half to almost wholly immersed in the cup. BuR OAK or MOSSY-CUP.-This valuable tree comes into our range in the Black Hills of South Dakota and Wyoming, where it usually attains fair size, though occasionally scarcely more than a shrub.

2. Quercus utahensis (DC.) Rydb. Bull. N. Y. Bot. Gard. 2: 202. 1901.* A small tree often $10 \mathrm{~m}$. high or more or sometimes only a shrub: bark of young branches light brown and pubescent, bark of the older branches brown or gray; bark of the trunk rough and furrowed: bud-scales thin, brown, somewhat hairy and puberulent: petioles about $1 \mathrm{~cm}$. long, puberulent; leaf-blade 6-10 cm. long, broadly obovate, deeply divided, of ten to near the midrib; lobes oblong, rounded at the apex, the larger usually again lobed or undulate; upper surface sparingly stellate, in age glabrate, dark green and glossy; lower

* In his paper, "The Oaks of the Continental Divide," north of Mexico, Rydberg has given the species most exhaustive treatment. Indebtedness to lis descriptions is gratefully acknowledged. 
surface brownish, pale, densely and softly pubescent, almost velvety, strongly veined: fruit subsessile; cup hemispheric, $12-15 \mathrm{~mm}$. in diameter; scales pubescent, ovate, with much thickened corky backs; acorn ovoid, barrelshaped, mostly obtuse, 15-20 mm. long, light brown.-From Wyoming to New Mexico and Arizona.

3. Quercus Vreelandii Rydb. 1. c. 204. 1901. A small shrub, 1-1.5 m. high: bark of young branches brown, puberulent; that of the older branches and trunks ashy gray: bud-scales brown, thin, puberulent on the margins: petioles 5-10 cm. long, puberulent; leaf-blades 5-7 cm. long, obovate, deeply lobed about two thirds to the midrib, thick, firm; lobes rounded, the larger often lobed or sinuate; upper surface slightly stellate, soon glabrate, bright green but not glossy; lower surface slightly paler and somewhat brownish and puberulent: fruit subsessile; cup very shallow, covering one fifth or one sixth of the acorn; scales ovate and very corky on the back; acorn barrelshaped or slightly ovoid, obtuse, about $15 \mathrm{~mm}$. long, light brown.-Colorado and New Mexico.

4. Quercus leptophylla Rydb. 1. c. 205. A tree 10-15 m. high: bark of young twigs brownish or purplish, slightly pubescent at first; that of the older branches gray; that of the trunk rough and furrowed: bud-scales very thin, brown, glabrous: petioles about $1.5 \mathrm{~cm}$. long, sparingly stellate; leaf-blades broadly obovate, very thin, pinnately 5 -9-lobed scarcely more than halfway to the midrib; lobes rounded; upper surface at first sparingly stellate, soon glabrate, bright green, but not very glossy; lower surface paler, almost perfectly glabrous, or pubescent on the veins: fruit subsessile; cup hemispheric, about $15 \mathrm{~mm}$. wide, covering about half the acorn; scales ovate-lanceolate, obtuse, only slightly thickened on the back; acorns short, barrel-shaped, obtuse or even depressed at the apex.-Colorado and New Mexico.

5. Quercus Gunnisonii (Torr.) Rydb. 1. c. 206. A low shrub 1-3 m. high: bark of young branches light brown, puberulent, of the older branches and the trunk gray, somewhat shreddy: bud-scales brown, pubescent: petioles about $1 \mathrm{~cm}$. long, puberulent; leaf-blades oblong, elliptic or narrowly obovate in outline, lobed halfway to the midrib or more with rounded lobes, very thick, green above, sparingly stellate or soon glabrate, shiny; lower surface paler, puberulent, veined: fruit subsessile; cup 12-15 $\mathrm{mm}$. in diameter, hemispherical, covering about one third of the acorn; scales ovate with a lanceolate tip, at least the lower much thickened and corky on the back; acorns barrelshaped, obtuse or even depressed at the apex $(Q$. nitescens and $Q$. novomexicana Rydb. 1. c. 207 and 208).-Colorado and New Mexico to Utah and Arizona.

6. Quercus Gambellii Nutt. Journ. Acad. Phila. II. 1: 179. 1848. A shrub 3-5 m. high: bark of young twigs light brown and puberulent; that of the older branches and trunk gray: bud-scales brown, puberulent: petioles about $1 \mathrm{~cm}$. long, puberulent; leaf-blades broadly obovate in outline, lobed one half or two thirds the distance to the midrib, thinner than in the preceding; upper surface glabrate, green, not very glossy; lower surface only slightly paler, puberulent or nearly glabrous; lobes rounded: fruit subsessile: aup hemispheric or somewhat turbinate; acorn ovoid, acute, half inclosed in the cup, about $15 \mathrm{~mm}$. long, light brown (Q. Eastwoodae Rydb. 1. c.).-Utah to Colorado and New Mexico.

6a. Quercus Gambellii Fendleri (Liebm.) A. Nels. The shrub smaller and reduced in all its parts: lobes of the leaves mostly acute: the acorn varying from obtuse to acute (Q. Fendleri Liebm., Rydb. I. c.; Q. venustula Greene, Rydb. 1. c.).- Colorado to New Mexico and Texas.

7. Quercus undulata Torr. Ann. Lyc. N. Y. 2: 248. 1828. A shrub 1-3 m. high: bark of the trunk gray, rough and much cracked; that of the branches light gray and with numerous lenticels; that of the young twigs sparingly stellate-pubescent: petioles $2-6 \mathrm{~mm}$. long; leaf-blades firm, pale bluish or brownish-green and shining above, pale brownish beneath, stellate when young, almost glabrous in age on both sides or even densely stellate-pubescent beneath, only sinuately dentate, acute at both ends; teeth mucronate, scarcely 
spinulose: cup hemispheric, 7-10 $\mathrm{mm}$. broad; scales ovate, strongly corkythickened on the back; acorn barrel-shaped or cylindric, 10-15 mm. long, 6-7 mm. in diameter, brown (Q. pungens Liebm., Rydb. 1. c.).-Colorado to Texas and Arizona.

\section{ULMACEAE Mirbel. Elm Family}

Trees or shrubs with alternate serrate pinnately veined leaves, with fugacious stipules. Flowers small, monoecious, dioecious, or polygamous, clustered or the pistillate solitary. Perianth of 4-9 distinct sepals. Stamens as many as the sepals. Ovary 1-celled, superior. Fruit a samara, drupe, or nut.

All the flowers clustered; fruit a samara . . . . . . . . . . 1. Ulmus.

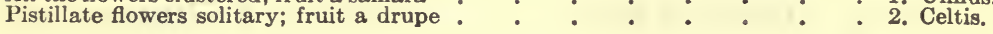

\section{ULMUS L. ELM}

Trees with polygamous purplish or yellowish flowers in lateral clusters, appearing before the short-petioled oblique or unequally somewhat heart-shaped leaves. Perianth campanulate. Stamens slender, 4-9. Styles 2, diverging, stigmatic along the inner margin. Fruit 1-seeded, winged all around.

1. Ulmus americana L. Sp. Pl. 226. 1753. Large and well-known ornamental tree, usually with spreading branches and drooping branchlets: buds and branchlets glabrous: branches not corky: leaves obovate-oblong or oval, abruptly pointed, sharply and often doubly serrate $(5-10 \mathrm{~cm}$. long), softpubescent beneath, or soon glabrous: flowers in close fascicles: calyx with 7-9 roundish lobes: fruit glabrous except the margins (12 $\mathrm{mm}$. long), its sharp points incurved and closing the notch.-Probably not indigenous in our range, but largely grown as a shade tree.

\section{CELTIS L. HACKBERRY}

Leaves pointed, petioled. Flowers greenish, axillary, the fertile solitary or in pairs, peduncled, appearing with the leaves; the lower usually staminate only, in little fascicles or racemose along the base of the branches of the season. Calyx 5-6-parted. Stamens 5-6. Ovary 1-celled. Fruit globular.

1. Celtis occidentalis L. Sp. Pl. 1044. 1753. Leaves reticulated, ovate, cordate-ovate and ovate-lanceolate, taper-pointed, sharply serrate, sometimes sparingly so or only towards the apex, scabrous but mostly glabrous above, usually soft-pubescent beneath, at least when young: fruit reddish or yellowish, becoming dark purple.-From Colorado to Wisconsin and eastward. A small or middle-sized tree with the aspect of an elm.

\section{MORACEAE Lindl. Mulberry Family}

Trees, shrubs, or herbs with opposite lobed leaves (our only native genus an herbaceous vine). Flowers dioecious. Calyx 5-parted. Petals none. Stamens 5. Ovary superior, 1-celled, 1-ovuled, becoming a glandular or resiniferous achene.-Ulmaceae in part.

\section{HUMULUS L. HoP}

Twining rough perennials, with stems almost prickly downwards, and mostly opposite, heart-shaped, and palmately 3-7-lobed leaves. Sterile flowers with 5 sepals and 5 erect stamens. Fertile flowers in short spikes with leafy im- 
bricated bracts, each 2-flowered. Achene invested with the enlarged scale-like calyx.

1. Humulus lupulus L. Sp. Pl. 1028. 1753. Leaves commonly longer than the petioles: the fruiting calyx, achene, etc., sprinkled with yellow resinous grains, giving the bitterness and aroma of the hop.-In the mountains from New Mexico to British America and eastward across the continent.

1a. Humulus lupulus neomexicanus Nels. \& Ckll. Proc. Biol. Soc. Wash. 16: 45. 1903. Leaves divided or sometimes parted, the segments varying from broadly lanceolate to nearly linear, acuminate, freely sprinkled with resin particles on the lower face: fruiting bracts ovate-lanceolate, usually acuminate, finely pubescent.-This is the common form in Colorado and New Mexico.

\section{URTICACEAE Reichenb. Netrle FAMILy}

Herbs with simple alternate or opposite leaves, and small greenish apetalous, monoecious, dioecious, or polygamous flowers variously clustered. Calyx 2-5 cleft, or of distinct sepals. Stamens as many as the lobes of the calyx and opposite them; filaments wrinkled and inflexed in the bud. Stigma simple, penicillate or filiform; ovary always 1-celled and 1-ovuled, becoming an achene.-Ulmaceae in part.

Leaves alternate; no stinging hairs _ _ . . . . . . . . 1. Parietaria.

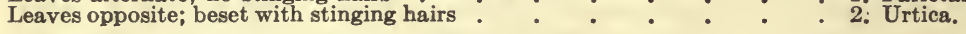

\section{PARIETARIA L.}

Annual herbs without stinging hairs. Leaves alternate, 3-nerved, petioled and without stipules. Flowers axillary, polygamous, and glomerate in a leafy involucre. Calyx of the staminate flowers 4-parted; the fertile tubular or campanulate (4-lobed), and permanently inclosing the ovary. Stigma penicillate.

1. Parietaria pennsylvanica Muhl. Willd. Sp. Pl. 4: 955. 1806. Low, simple or sparingly branched, minutely downy: leaves oblong-lanceolate, thin, veiny, roughish with opaque dots: flowers shorter than the leaves of the involucre.-From Colorado to Wyoming; across the continent.

\section{URTICA L. NeTtLE}

Perennial herbs armed with stinging hairs, with distinct stipules, monoecious (rarely dioecious) greenish clustered flowers, mostly in racemes or spikes or loose heads. Sterile flowers with four stamens inserted around the cupshaped rudiment of a pistil. Fertile flowers with the 2 outer sepals smaller. Stigmas sessile. Achene flattened and ovate.

Leaves broadly ovate, cordate

Leaves ovate-lanceolate, base rounded or barely subcordate.

Tomentose beneath

Glabrate or slightly pubescent and hispid :

1. U. dioica.

2. U. holosericea.

3. U. gracilis.

1. Urtica dioica L. Sp. Pl. 984. 1753. A coarse weedy perennial 5-15 dm. high, very bristly and stinging: leaves ovate, cordate, acute, deeply serrate, downy beneath as is also the upper part of the stem: spikes much branched.Naturalized from Europe and now widely distributed in the United States, mostly in waste grounds.

2. Urtica holosericea Nutt. Journ. Acad. Phila. N. S. 1: 183. 1847. Tall and stout, more or less bristly, finely and densely tomentose especially on the lower side of the leaves: leaves thick, oblong to ovate-lanceolate, rounded at base, on short stout petioles: staminate flowers in loose slender diffuse panicles 
nearly equaling the leaves: pistillate panicles denser and shorter.-Abundant in the Wasatch and westward throughout California.

3. Urtica gracilis Ait. Hort. Kew 3: 341. 1789. Usually tall and rather strict, slender, sparingly bristly: leaves ovate-lanceolate, serrate, 3-5-nerved from the rounded or scarcely heart-shaped base, glabrate or slightly pubescent, the veins and the elongated slender petioles more or less hispid: spikes slender and loosely panicled. (U. cardiophylla Rydb. Bull. Torr. Bot. Club 24: 191. 1897 and $U$.gracilipes Greene are forms only; the former with subcordate leaves; the latter with leaves glabrous, more elongated, and more slenderly petioled.)Montana to New Mexico and far eastward.

\section{LORANTHACEAE D. Don}

Evergreens, parasitic on shrubs or trees, dull yellowish-green or brownish, with dichotomous branches and swollen joints, the opposite thick and coriaceous exstipulate and entire leaves reduced to mostly connate scales. Flowers small and inconspicuous, greenish, dioecious, of 2-5 sepals coherent at base. Anthers as many as the sepals and inserted upon them. Ovary inferior, 1-celled. Fruit a berry with glutinous endocarp.

Anthers a single globose cell; berry compressed, fleshy _ . . 1. Arceuthobium. Anthers 2-celled; berry globose, pulpy $\quad$ - : : : 2. Phoradendron.

\section{ARCEUTHOBIUM Hoffm. Lesser Mistletoe}

Parasitic on conifers, glabrous with rectangular branches and connate scalelike leaves. Flowers of ten crowded into apparent spikes or panicles, opening in summer or autumn and maturing their fruit in the second autumn, when the berries suddenly and forcibly eject the glutinous seed to the distance of several yards. Flowers axillary or terminal, solitary or several from the same axil.

Staminate flowers on peduncle-like joints in a paniculate cluster. i. 1. A. americanum.

Staminate flowers in the axils of the scales of a simple or compound spike.

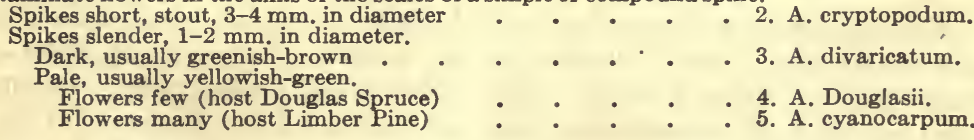

1. Arceuthobium americanum Nutt. ex. Gray, Bost. Journ. Nat. Hist. 6: 214. 1850. Slender, dichotomously and verticillately much branched, greenish-yellow: staminate plants $5-10 \mathrm{~cm}$. high: fertile plants much smaller: flowers small; the staminate $2 \mathrm{~mm}$. broad, lobes ovate-orbicular, acutish; the pistillate 1-2 mm. broad: berry $4 \mathrm{~mm}$. long. On Pinus flexilis, P. Murrayana, and probably $P$. edulis.-Idaho to Colorado.

2. Arceuthobium cryptopodum Engelm. in Gray, Pl. Lindh. 2: 214. 1850. Stout, 5-10 cm. high, 3-5 mm. thick at base, paniculate, much branched, brownish-yellow to dark olive-brown: staminate plants smaller than the pistillate ones; staminate spikes with much compressed buds: flowers mostly 3-parted, 3-4 mm. broad: anthers attached above the middle of the ovate acute lobes: fruit 4-5 mm. long. On Pinus scopulorum.-Colorado and southward.

3. Arceuthobium divaricatum Engelm. Bot. Wheeler Survey, 253. 1878. Rather slender, the branches spreading, often recurved, 5-10 cm. long, olivegreen or light brown: staminate flowers few and scattered, or in 3-7-flowered spikes, $2 \mathrm{~mm}$. in diameter, with ovate acute lobes: inflorescence often bearing sterile branches from the same axils as the fertile ones: fruit $3-5 \mathrm{~mm}$. long. On Pinus edulis.-Colorado and to the southwestward.

4. Arceuthobium Douglasii Engelm. 1. c. Greenish-yellow: stems slender, 6-24 mm. high, much branched but not verticillately: spikes short, mostly 
5-flowered: staminate flowers 1-2 mm. wide, with round-ovate acutish lobes, axillary, forming simple or compound spikes: accessory branchlets of fruiting plant flower-bearing: berries $5 \mathrm{~mm}$. long. On Pseudotsuga mucronata. -Idaho to California and New Mexico.

5. Arceuthobium cyanocarpum A. Nels. ex. Rydb. Fl. Col. 101. 1906. Stems simple or branched from the base; the staminate branchlets somewhat paniculate above, sharply four-angled when dry, 2-3 cm. long, greenish-yellow; the pistillate olive-green: scales suborbicular, appressed, obtuse or subacute, about $1.5 \mathrm{~mm}$. broad: staminate flowers axillary and one-terminal, densely clustered, from a few to 20 or more; calyx segments usually 3 , fleshy, slightly carinate; pistillate similarly disposed but more open in fruit: berry obovate, its somewhat truncate summit toothed with the brown, wrinkled calyx-lobes, blue-green. On Pinus flexilis.-Wyoming and Colorado.

\section{PHORADENDRON Nutt.. Mistletoe}

Yellowish-green dioecious parasites on the branches of trees, with jointed much-branched stems, thick and firm persistent leaves (or only scales in their place), short catkin-like jointed axillary spikes (usually several to each short fleshy bract or scale and sunk in the joint). Calyx globular, 3-lobed. Anthers sessile on the base of the :.lyx-lobes and opening by a pore. Stigma sessile, obtuse. Berry semitransparent and crowned by the persistent sepals.

1. Phoradendron juniperinum Engelm. Gray, Pl. Fend. 58. 1848. Glabrous, stout, densely branched, 1-3 dm. high: branches terete, the ultimate branchlets quadrangular: sciles broadly triangular, connate or distinct, ciliate: staminate spikes of a ingle 6-8-flowered joint: pistillate spikes 2flowered: berry whitish or light red. On different species of Juniperus.Colorado to New Mexico, and westward.

\section{SaNtalaCEAE R. Br. Sandalwood Family}

Herbs or shrubs, with angled or striate branches, entire alternate exstipulate and mostly sessile leaves. Flowers (in ours) perfect, usually greenish-white or purplish; the perianth 3-5-cleft, and adherent to the 1-celled ovary. Corolla wanting. Stamens as many as the perianth-lobes and inserted near their bases or opposite them between the lobes of the epigynous disk. Style slender with cleft or capitate stigma. Ovary 2-4-ovuled, becoming a 1-seeded nut-like fruit.

\section{COMANDRA Nutt. Bastard TOADFlax}

Low herbaceous smooth perennials with subterranean rootstocks. Leaves glabrous and often glaucous, the lowest scale-like. Flowers greenish-white, in small terminal or axillary umbellate clusters: perianth campanulate or urnshaped with a 5-lobed persistent limb. Disk with a free lobed margin. Stamens included, inserted between the lobes of the disk to which they are attached by tufts of hairs. Fruit drupaceous, crowned by the persistent calyx.

Leaves green; fruit globose . . . . . . . . . 1. C. umbellata.

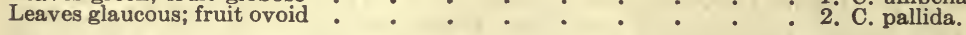

1. Comandra umbellata (L.) Nutt. Gen. 1: 157. 1818. Light green, 1-3 dm. high: stems leafy: leaves from oblong to lanceolate, $2-4 \mathrm{dm}$. long, sessile, often acute at both ends: flowers in small corymbosely clustered cymes at the summit of the stem; the perianth lobes erect or spreading, about as long as the green tube which is continued conspicuously above the ovary: fruit globular, 5-6 mm. in diameter.-Rare in our range; transcontinental. 
2. Comandra pallida A. DC. Prodr. 14: 636. 1857. Stems 1-2 dm. high, arising at somewhat regular intervals from the horizontal rootstock, usually simple: leaves glaucous, from oblong to nearly linear, usually acute, often cuspidate: cymes corymbosely clustered, several-flowered; the perianth greenish-white or purplish: fruit ovoid, $6-8 \mathrm{~mm}$. high, sessile or on short stout pedicels.-Frequent on dry sandy slopes and banks; widely distributed.

\section{POLYGonaCEAE Lindl. •Buckwheat Family}

Herbs (ours), trees, or shrubs with alternate or sometimes opposite or verticillate entire leaves, and stipules in the form of sheaths above the swollen joints of the stems, or none. Flowers rather small, mostly perfect, with a more or less persistent calyx (perianth), consisting of 3-6 segments, the inner ones or often all petaloid. Petals wanting. Stamens 4-9. Ovary 1-celled, bearing 2 or 3 styles or stigmas. Fruit an achene, with a single erect seed.

Flowers subtended by an involucre; sheaths none.

Flowers without involucre; sheaths present

Stigmas tufted.

Sepals 4; stigmas 2 ; achene orbicular-winged . . . . . 2. Oxyria.

Sepals 6; stigmas 3; achene triangular . . . . . 3. Rumex.

Stigmas capitate, 2 or 3 ; achene lenticular or triangular : : : 4. Polygonum.

\section{ERIOGONUM Michx.}

Annuals, or herbaceous or somewhat woody perennials, with radical or alternate or verticillate leaves. Flowers small, fascicled, cymose, umbellate or capitate, subtended by 5-8-toothed oblong, turbinate, or campanulate involucres. Perianth 6-parted, usually colored; its segments equal or unequal. Stamens 9. Styles 3, with capitate stigmas. Achene mostly 3-angled.

ANNUALS.

Stem leafy.

Flowers white $\quad . \quad$. . . . . 1. E. annuum.

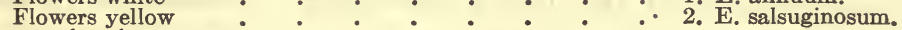

Leaves basal.

One or more nodes of the stem inflated . . . . . 3. E. inflatum.

The whole stem normal.

Flowers erect Flowers.nodding

\section{PERENNIALS.}

BRACTS SEVERAL, FOLIACEOUS; LEAVES BASAL.

Achenes not winged.

Flowers glabrous, umbellate at summit of the scape-like peduncle.

Peduncle with a medial whorl of leaves

Peduncle naked.

Flowers distinctly yellow.

Leaves glabrate, at least above Leaves tomentose on both sides .

Flowers ochroleucous. Calyx 8-9 mm. long Calyx 4-5 mm. long

Flowers pubescent, umbellate on long scapes, or (in No. 17) depressed-acaulescent.

Umbel irregularly proliferous.

Flowers yellow

4. E. Gordonii.

5. E. cernuum.

6. E. alatum. Flowers white

Umbel regular.

Bracts conspicuous, 1-3 cm. long.

Leaves thick; perianth narrowed abruptly at base. Crowns of caudex enlarged but not woolly Crowns of caudex enlarged and woolly Leaves thinner; perianth narrowed to a stipelike base

Bracts inconspicuous, less than $1 \mathrm{~cm}$. long. Depressed-acaulescent

Subcaespitose with long slender scapes

7. E. heracleoides.

8. E. umbellatum.

9. E. Rydbergii.

10. E. latum.

11. E. subalpinum.
12. E. Bakeri.

13. E. Jamesii.
14. E. flavum.

15. E. crassifolium

16. E. Piperi.

17. E. acaule.

18. E. lachnogynum. 
BRACTS TERNATE, NOT FOLIACEOUS.

FLOWERS NOT YELLOW.

Peduncles unbranched, terminated by a capitate cluster of involucres.

Leaves white-tomentose.

Oval or elliptic.

Outer perianth-segments suborbicular

Outer perianth-segments oblong Oblanceolate

Leaves glabrate above, linear : : : : :

Peduncles branching di- or trichotomously, often several times.

Caudex subterranean; leaves clustered on its crowns. Peduncle simple or simply dichotomous. Sepals dissimilar Sepals similar

Peduncle di- or trichotomously branched

Caudex woody, branched, leafy.

Branches few; erect, leafy up to the short corymbose cyme.

Leaves elliptic, undulate-dentate

Leaves linear-oblong, entire

Branches numerous; peduncle long and naked, bearing a repeatedly forked cyme. Styles and stamens included Styles exserted

FLOWERS YELLOW.

Involucres in terminal capitate clusters.

Leaves short, less than $2 \mathrm{~cm}$.

Oval to elliptic

Oblong.

Ovary pubescent above

Ovary glabrous

Leaves 4-8 cm. long, oblanceolate

Involucres in a dichotomous cyme.

Cyme short, subumbellate

Cyme long, freely branched

- 23. E. tenellum.

24. E. racemosum.

25. E. Simpsonii.

26. E. Jonesii.

27. E. salinum.

28. E. effusum.

29. E. corymbosum.

19. E. ovalifolium.

30. E. caespitosum.

31. E. andinum.

32. E. chrysocephalum.

33. E. orendense.

34. E. campanulatum.

1. Eriogonum annum Nutt. Trans. Am. Phil. Soc. II. 5: 164. 1833-37. Annual, white floccose-tomentose throughout, rather stout, simple or branched, 3-8 dm. high: leaves narrowly oblanceolate or oblong, attenuate to a short petiole, mostly flat: inflorescence cymose: the flowers white: the perianthsegments very unequal, the outer oblong-obovate.-Montana to Texas and Mexico.

2. Eriogonum salsuginosum Hook. Kew Journ. 5: 264. 1853. Low glabrous annual 4-12 cm. high: stem leafy, di- or trichotomously divided: leaves spatulate-oblanceolate, the bracts becoming linear: involucres divided: flowers pubescent, yellow: sepals narrow, closely appressed to the acutely triangular glabrous achene.-From southwestern Colorado to Utah and western Wyoming.

3. Eriogonum inflatum Torr. Frem. 2d Rep. 374. 1845. Glabrous annual, diffusely branched above, 1-3 dm. high, one or more of the internodes of the stem much inflated: leaves all radical or nearly so, rounded, usually cordate and mostly undulate, pubescent: involucres few-flowered, smooth; the teeth erect: flowers yellowish; pubescent; the pedicels about $1 \mathrm{~mm}$. long; the achene twice as long. (E. fusiforme Small, Bull. Torr. Bot. Club 33: 56. 1906.)-In dry desert districts; southwestern Colorado to Arizona.

4. Eriogonum Gordonii Benth. in DC. Prodr. 14: 20. 1856. Annual, glabrous throughout, or the petioles slightly pubescent: leaves basal, longpetioled, broadly ovate: peduncle di- or trichotomously slender branched, 15-30 cm. high: involucre broadly campanulate, 5-toothed: flowers glabrous, light rose-color: outer sepals ovate; the inner oblong.-Rare; in the region of the Platte in Nebraska, and in Colorado and Wyoming.

5. Eriogonum cernuum Nutt. Journ. Acad. Phila. II. 1: 162. 1848. Glabrous annual, diffusely di- or trichotomously branched, 1-3 dm. high: leaves broadly ovate, acute: involucres turbinate-campanulate: pedicels deflexed: calyx white, campanulate, $1 \mathrm{~mm}$. long, 6-parted; the segments narrowed near middle; the outer ones broader above and retuse: achene rounded at base and rough on the angles.-Frequent throughout our range. 
6. Eriogonum alatum Torr. Sitgr. Rep. 168. pl. 8. 1853. Loosely silkyvillous throughout, or the leaves nearly glabrous except on the margin and midrib, perennial, rather stout, branched above, 5-10 dm. high: leaves alternate, long-oblanceolate: involucres pedunculate, cymose at the ends of the branches of the rather ample panicle, turbinate, with 5 erect teeth: flowers about $2 \mathrm{~mm}$. long, yellowish, nearly glabrous, abruptly contracted at the base: achene winged the whole length. (E.triste Wats. Proc. Am. Acad. 10: 347. 1875.)-Montana to Texas and Arizona.

7. Eriogonum heracleoides Nutt. Journ. Acad. Phila. 7: 49. 1834. Tomentose perennial, from a diffusely branched caudex, 2-5 dm. high: stems slender, more or less tufted, with some sterile decumbent branches below: leaves largely basal, the upper part of the stems scapose-pedunculate and bearing an umbellate cluster of yellow flowers subtended by a conspicuous involucre of foliar bracts; the peduncle usually with a verticil of similar bracts near the middle also: leaves glabrate above or glabrous, spatulate oblong to oblanceolate: involucre 6-8-cleft: flowers pale yellow.-Colorado and Wyoming to the north Pacific States.

8. Eriogonum umbellatum Torr. Ann. Lyc. N. Y. 2: 241. 1828. Stems depressed and shrubby below, much branched: leaves oblong to obovate-spatulate, 3-4 cm. long, petioled, white-tomentose below, green and glabrate above: scapose peduncles 1-3 dm. long: umbel simple, a whorl of foliar bracts subtending it: involucres deeply lobed, the lobes becoming reflexed: flowers yellow, glabrous. (E. neglectum Greene, Pitt. 5: 69. 1903.)-Exceedingly common throughout our range at low or middle elevations, and westward to the Pacific States.

$8 a$. Eriogonum umbellatum intectum A. Nels. Leaves glabrate on both faces at maturity. (E. umbelliferum Small, Bull. Torr. Bot. Club 33: 51 . 1896.) Same range.

9. Eriogonum Rydbergii Greene, Pitt. 5: 68. 1892. Resembling the last but lower and densely white-tomentose on leaves, peduncles, and the smaller bracts: leaves elliptic-ovate or rhomboid, 1-2 cm. long: umbel simple, fewrayed: flowers yellow or greenish-yellow, glabrous.-Yellowstone Park, in the Geyser regions.

10. Eriogonum latum Small, Mem. N. Y. Bot. Gard. 1: 121. 1900. Shrubby at base and branching freely, forming mats: leaves from oblong to oval, somewhat floccose-pubescent below, glabrous above: scapes $2 \mathrm{dm}$. or less long: umbel 3-8-rayed; bracts oblong or spatulate, at length reflexed: involucres ribbed, with 6-10 unequal reflexed lobes: flowers in dense heads, pale yellow or purple-tinged, tapering into a slender stipe-like base.-Northwestern Wyoming to Montana and Idaho.

11. Eriogonum subalpinum Greene, Pitt. 3: 18. 1896. Closely resembling $E$. umbellatum, quite as matted and more woody at base: peduncles stouter, often 3-4 dm. long: leaves mostly glabrate above, rarely below also: flowers pale yellow, tinged with rose in drying; the inner segments accrescent and finally surpassing the outer ones.-Middle elevations to timber line; throughout our range.

12. Eriogonum Bakeri Greene, Pl. Baker. 3: 15. 1901. The base woody, branched, clothed with old leaf-bases: peduncles white-tomentose, becoming glabrate, 1-2 dm. high: leaves from oval to spatulate, $2-5 \mathrm{~cm}$. long, whitetomentose, tending to become glabrate above: inflorescence a single large sessile involucre at summit of the peduncle (scape) and from the base of this a pair of rays (very variable in length) at the summit of which is another involucre and another pair of proliferating rays (or pedicels), such proliferation sometimes occurring a third and even a fourth time with constantly shortening rays: bracts large, resembling the leaves: flowers yellow, somewhat villous; the inner segments longer than the outer. E. Jamesii flavescens. $[E$. arcuatum Greene, Pitt. 4: 319. 1901; E. vegetius (T. \& G.) A. Nels. Bull. Torr. Bot. Club 31: 239. 1904.]-Wyoming to New Mexico.

13. Eriogonum Jamesii Benth. DC. Prodr. 14: 7. 1856. Rather slender, herbaceous with branching caudex, 1-3 dm. high, white-tomentose: leaves and 
bracts oblong-lanceolate; the latter shortly petiolate: inflorescence a very fewrayed irregularly proliferous umbel: flowers whitish, silky, 4-5 mm. long: achene $4 \mathrm{~mm}$. long.-Colorado to New Mexico and Arizona.

14. Eriogonum flavum Nutt. Fras. Cat. 1813. White-tomentose throughout, 1-2 dm. high; caudex branching, the crowns enlarged and scaly: leaves oblanceolate: umbel of 3-9 rays, often short, but quite regular: involucres turbinate, nearly entire; bracts spatulate, foliaceous: flowers yellow, villous; the segments obovate: stamens and style branches exserted: achene constricted at middle, long-villous at the summit. (E. chloranthum Greene, Pl. Baker. 3: 15. 1901; E. polyphyllum Small, Mem. N. Y. Bot. Gard. 1: 119. 1900; E. xanthum Small, Bull. Torr. Bot. Club 33: 51. 1906; all of these are reduced subalpine states of $E$. flavum.) - From Nebraska through the Rocky Mountains and far to the northwest.

15. Eriogonum crassifolium Benth. Trans. Soc. Linn. 17: 408. 1837. Resembling the foregoing but the caudex more indurated and densely clothed in leaf-bases involved in a woolly tomentum: leaves broader, mostly elliptic, very white, thick and leathery: umbel short-rayed (subcapitate): flowers yellow, very villous.-Frequent in the more desert areas in the region of the North Platte in Wyoming.

15a. Eriogonum crassifolium tectum A. Nels. Bot. Gaz. 34: 23. 1902. Merely an extreme form with inordinately protected crowns; the flowers even so involved in wool as to hide the yellow calyx-segments.-Hot sandy banks, Wyoming.

16. Eriogonum Piperi Greene, Pitt. 3: 263. 1898. Allied to the two foregoing but taller and scape slender: villous rather than tomentose, except on the lower face of the thin elliptic or oblanceolate leaves which are shorter than the slender petioles: bracts narrow and petioled: umbel of 5-8 equal rays: perianth greenish-yellow, hirsute, narrowed to a stipe-like base: achene villous at apex.-From northwestern Wyoming and Montana to Washington.

17. Eriogonum acaule Nutt. Journ. Acad. Phila. II. 1: 160. 1847. Very dwarf and densely matted, scarcely rising above the surface of the ground: leaves crowded, 4-5 mm. long: peduncle $1 \mathrm{~cm}$. high, bearing a head of 1-5 nearly sessile involucres, each with 5 short erect teeth; bracts small: flowers yellow, abruptly narrowed at base, pubescent: achenes densely villous.Colorado through Wyoming to Idaho.

18. Eriogonum lachnogynum Torr. ex Benth. DC. Prodr. 14: 8. 1856. Caespitose and densely tomentose: leaves oblong-lanceolate: peduncle slender, 2-3 dm. high, sparingly dichotomous above; bracts small: involucres solitary, sessile or long-pedunculate, short-toothed: flowers densely tomentose, yellow: achene attenuate above, $4 \mathrm{~mm}$. long. (E. tetraneuris Small, l.c. 52.)-Colorado and New Mexico.

19. Eriogonum ovalifolium Nutt. Journ. Acad. Phila. 7: 50. 1834. Low, densaly tomentose and caespitose, with a short closely branched caudex: leaves elliptic to orbicular, 7-20 mm. long, petioled: bracts ternate, very small, and connate at base: involucres in a single close head, on slender erect peduncles 3-15 cm. high, cylindric-turbinate, more or less strongly 5-6-nerved and with as many erect teeth: flowers yellow: the outer sepals oblong, becoming orbicular; the inner spatulate, often retuse. (E. orthocaulon Small, 1. c. 53.)Colorado to Montana and far to the westward. Ours belong mostly to the following variety.

19a. Eriogonum ovalifolium purpureum (Nutt.) A. Nels. Bot. Gaz. 34: 23. 1902. Flowers white, shading to rose-color or passing even into deep purple.-Frequent on the open plains and ridges of our range, and westward with the species.

20. Eriogonum ochroleucum Small, Mem. N. Y. Bot. Gard. 1: 123. 1900. Tufted perennial with the habit of $E$. ovalifolium: leaves crowded, densely tomentose, obovate-spatulate, cuneately narrowed into the slender, often twisted petiole: scapes ercet, slender, 1-3 dm. high: involucres sessile, in capitate clusters, ribbed and with short teeth: flowers numerous, ochroleucous, 
becoming $4 \mathrm{~mm}$. long; the outer segments oblong; the inner longer and spatulate: achene glabrous.-Wyoming, Montana, and westward.

21. Eriogonum multiceps Nees, Max. Reise N. A. 2: 446. 1841. Densely white-tomentose perennial; the caudex short-branched, and more or less tufted: leaves crowded below: scapes simple, slender, erect, $3-12 \mathrm{~cm}$. high: leaves spatulate or oblanceolate, narrowed into petioles: involucres in a terminal capitate cluster, with short spatulate foliaceous bracts: flowers white or rose-color, somewhat villous, $3-5 \mathrm{~mm}$. long; the segments cuneate, obtuse or emarginate: stamens and style branches exserted.-Dry plains; Colorado to Montana and east to Nebraska.

22. Eriogonum pauciflorum Pursh, Fl. Am. Sept. 735. 1814. Densely caespitose, at first more or less tomentose throughout: the narrowly linearoblanceolate leaves revolute and soon glabrous above, 4-6 cm. long: the turbinate involucres nearly glabrous, about $4 \mathrm{~mm}$. long, in capitate clusters at the ends of the peduncles; bracts ternate, minute: calyx campanulate, white, glabrous; its segments ovate: achene glabrous, about $3 \mathrm{~mm}$. long.Dry clayey ridges; Colorado to Montana.

23. Eriogonum tenellum Torr. Ann. Lyc. N. Y. 2: 241. 1828. Caudex caespitosely branched, depressed and spreading, covered with the numerous white-tomentose leaves: leaves oblong to elliptic, 6-15 $\mathrm{mm}$. long, shortpetioled: scapes 1-2 dm. high, glabrous as is also the inflorescence, sparingly paniculate-branched: flowers white or pinkish, becoming $3 \mathrm{~mm}$. long: outer sepals broadly ovate or orbicular; the inner linear oblong: achene 4-5 $\mathrm{mm}$. long. - Southern Colorado to Texas and New Mexico.

24. Eriogonum racemosum Nutt. 1.c. 161. 1847. Floccose-woolly perennial; scapes solitary or few from the summit of the subterranean caudex, stout, 2-6 $\mathrm{dm}$. high, naked or leafy-bracted at the lower nodes: leaves 3-6 $\mathrm{cm}$. long, on long $(5-10 \mathrm{~cm}$.) petioles, ovate or oblong, sometimes subcordate, white-woolly beneath: involucres tubular-campanulate, obtusely 5-toothed, many-flowered, appressed and strictly spicate along the few rigid subsimple branches: calyx rather large ( $4 \mathrm{~mm}$. long), pinkish or white, acute at base, very glabrous; its segments obovate: ovary glabrous.-New Mexico through Colorado to Utah.

25. Eriogonum Simpsonii Benth. in DC. Prodr. 14: 18. 1856. Subcaespitose; the branches of the caudex few, short, leafy: leaves broadly linear, 5-10 cm. long, attenuate into a short petiole, greenish and thinly pilose above, white-pilose beneath: peduncle 1-2 dm. long, dichotomously branching into the broadly paniculate cyme: lower bracts sometimes foliar, long-linear; the upper subulate: involucres turbinate, glabrous, pubescent on the teeth within: calyx white, glabrous, with broad obtuse lobes. [E. lonchophyllum T. \& G. Proc. Am. Acad. 8: 173. 1870; E. nudicaule (Torr.) Small, Bull. Torr. Bot. Club 33: 54. 1906; E. scoparium Small, 1. c. 54.]-In the arid districts; southern Colorado and New Mexico.

26. Eriogonum Jónesii Wats. Proc. Am. Acad. 21: 454. 1886. A woodybased branched tomentose perennial, 3-8 dm. high: leaves alternate, ovate to elliptic, white-tomentose beneath, greener above; the blade $2-4 \mathrm{~cm}$. long, shorter than the petiole: bracts subtending the open dichotomous corymb somewhat foliaceous: involucre mostly sessile and solitary, tomentose, scarcely $2 \mathrm{~mm}$. long: calyx $2 \mathrm{~mm}$. long, slightly exserted, glabrous, white or pinkish; the inner sepals oblong; the outer obovate and emarginate.-Arid places in western Colorado, through Utah to Arizona.

27. Eriogonum salinum A. Nels. Bull. Torr. Bot. Club 31: 220. 1904. Caudex woody, branched: stems herbaceous, strict, leafy up to the short corymbose cyme, 1-2 dm. long: leaves narrowly lanceolate, mostly erect, subsucculent, short-petioled, $2-4 \mathrm{~cm}$. long, white with a fine tomentum beneath, glabrate but pale above: cyme mostly trichotomous; the bracts linear: involucres turbinate, several-flowered, lightly tomentose: calyx white; the inner segments obovate, longer than the outer oblong-elliptic ones: stamens and style branches included.- Saline districts; southern Wyoming.

28. Eriogonum effusum Nutt. Journ. Acad. Phila. II. 1: 164. 1848. Shrubby below and diffusely much branched from the base, densely but 
floccosely tomentose, leafy below only: leaves from oblong to linear, mostly obtuse at the apex, nearly sessile or short-petioled: inflorescence a corymbose compound cyme, often quite large, effusely branched and carried on a long rigid naked peduncle: calyx white or rose-colored, seldom more than $2 \mathrm{~mm}$. long, at length constricted near the middle: stamens and style-branches included. (Includes E. microthecum Nutt. 1. c. $172 ; E$. tristichum Small, 1. c. 55; E. salicinum Greene, Pl. Baker 3: 16. 1901.)-From Nebraska and New Mexico to the Pacific.

29. Eriogonum corymbosum Benth. in DC. Prodr. 14: 17. 1856. Allied to the foregoing but stouter, less branched, the branches more rigid and often erect, leafy to near the shorter and more compact cyme: leaves oblong or narrower, obtuse and inclined to be undulate-crisped on the margins: bracts triangular-subulate: calyx broadly campanulate, at length constricted near the middle; the inner segments emarginate, shorter than the outer: style branches exserted. [E. Fendleriana (Benth.) Small; E. divergens Small, 1. c. 55.]-From Kansas to Arizona and Oregon.

30. Eriogonum caespitosum Nutt.Journ. Acad. Phila. 7: 50. 1834. Mattedcaespitose: leaves $6-12 \mathrm{~mm}$. long, mostly rosulate on the prostrate branches of the caudex, spatulate, hoary-tomentose on both sides, the margins more or less revolute: scapes leafless, $3-8 \mathrm{~cm}$. high: involucre solitary, naked, deeply 6-8-cleft; the lobes narrow, spreading and at length reflexed: calyx 4-6 mm. long, yellow or tinged with purple, slightly silky-villous, abruptly contracted at base; its segments oval, the inner and the filaments more or less villous at base: ovary sparingly hirsute above.-Wyoming to Washington.

31. Eriogonum andinum Nutt. Journ. Acad. Phila. II. 1: 160. 1847. Very similar to the preceding, more depressed-caespitose: leaves smaller and densely pilose-lanate: peduncle short and weak: ovary (achene) glabrous.Western Wyoming to Nevada.

32. Eriogonum chrysocephalum Gray, Proc. Am. Acad. 11: 101. 1876. Caudex diffusely branched, woody, tomentose throughout: leaves narrowly oblanceolate, $3-5 \mathrm{~cm}$. long, sometimes nearly glabrous above: peduncle simple erect, 5-15 cm. high; the inflorescence capitate or but slightly branched: involucres narrowly turbinate, firm, about $3 \mathrm{~mm}$. long, short-toothed, somewhat tomentose: flowers yellow, glabrous. (E. laxifolium A. Nels. Bot. Gaz. 34: 23. 1902.)-Western Wyoming and Utah.

33. Eriogonum orendense A. Nels. Bot. Gaz. 34: 21. 1902. Caudex woody, almost wholly subterranean, tufted, tomentum uniform and rather dense throughout: stems numerous, short: leaves crowded, narrowly oblong or oblanceolate, subacute, slender-petioled: scapes 7-15 cm. high; the inflorescence subumbellate, with short subulate bracts; the rays unequal: involucres few in each cyme, short-peduncled, turbinate, merely toothed around the summit, $3 \mathrm{~mm}$. long, many-flowered: calyx bright-yellow; the segments similar, oblong, obtuse, scarcely $2 \mathrm{~mm}$. long; the pedicels intermingled with setae bearing stipitate glands and a few fine slender hairs: filaments pubescent: styles long-exserted: ovary glabrous.-Desert areas; Wyoming to Utah.

34. Eriogonum campanulatum Nutt. Journ. Acad. Phila. II. 1: 163. 1848. Caespitose shrubby, the woody leafy branches short, bearing a naked elongated herbaceous scape-like peduncle: leaves $3-6 \mathrm{~cm}$. long, from linear to spatulateoblanceolate, attenuate into a slender petiole, white-woolly on both sides or becoming glabrate above, the margins at length mostly revolute: scapes rigid, 1-2 dm. long, the cyme repeatedly trichotomous, calyculately bracted at the nodes: involucres 5-toothed, soon glabrate: calyx yellow, its lobes oblong or fiddle-shaped: style and style-branches exserted.-From Nebraska to New Mexico and west to Oregon.

\section{OXYRIA Hill., Mountain Sorrel}

Perennial alpine and arctic herbs, erect, with long-petioled round-reniform mostly radical leaves, and small obliquely truncate sheaths. Flowers small and greenish, in narrowly panicled racemes, perfect. The two inner sepals erect, 
appressed, and unchanged in fruit. Stamens 6. Stigmas 2, tufted. Achene orbicular-winged:

1. Oxyria digyna (L.) Camptdera, Rumex, pl. 3, fig. 3. 1819. Rather stout and fleshy, $8-40 \mathrm{~cm}$. high, glabrous: flowers in scarious-bracted fascicles, on short capillary pedicels: sepals of ten reddish, the outer carinate and darker than the inner.-At high altitudes in cold wet places among rocks throughout the northern hemisphere.

\section{RUMEX L. Dock. SORReL}

Coarse perennial herbs: stems leafy, with obliquely truncate cylindrical naked sheaths. Flowers small, fascicled or verticillate in paniculate racemes, perfect, polygamous, or dioecious, without involucre. Sepals 6 ; the outer spreading; the inner somewhat colored and developing reticulate wings. Stamens 6. Stigmas 3, peltate, tufted. The foliage in some species is distinctly acid.

Flowers dioecious; inflorescence slender and leafless.

Inner sepals becoming winged; achene granular

Inner sepals not winged; achene smooth

Flowers perfect or polygamo-monoecious; inflorescence with stouter often leafy branches.

Inner perianth-segments (valves) very large $(10-30 \mathrm{~mm}$. broad), usually rose-colored.

Perennial from rootstocks

Perennial from large clustered tuber-like roots.

Fruiting valves cordate-reniform

Fruiting valves ovate-cordate.

Inner perianth-segments (valves) medium size (less than $10^{\circ}$ mm.), green or rose-color.

One or more of the valves bearing a callosity or tubercle on the back.

Wings entire, not toothed or fringed.

Leaves flat, entire or merely undulate-margined. Stems tufted Stems single

Leaves decidedly crisped on the margin. Tubercles 3 Tubercle 1

Wings toothed or fringed. Lower leaves cordate at base Lower leaves narrowed at base

Valves without tubercles.

Perennial from horizontal rootstocks

Perennial from vertical roots. Roots several, fascicled, fleshy Root single

1. R. Acetosella.

2. R. paucifolius.

3. R. venosus.

4. R. salinus.

5. R. hymenosepalus.

1. Rumex Acetosella L.Sp. Pl. 338. 1753. Dioecious, 1-3 dm. high: leaves small, rarely $5 \mathrm{~cm}$. long; the lower mostly hastate, with a large decurrent auricle on each side; the upper gradually reduced and entire: panicle more or less compound, usually reddish, the filiform ascending branches leafless: pedicels capillary, once or twice as long as the flower, articulated at summit; flowers about $1.5 \mathrm{~mm}$. long, the outer sepals granular.-Naturalized from Europe; not infrequent as a weed. Known as Field or Sheep Sorrel.

2. Rumex paucifolius Nutt. Wats. King's Rep. 314. 1871. Somewhat tufted, 2-4 dm. high: leaves linear to lanceolate or oblanceolate, attenuate to a slender petiole: inflorescence with suberect branches: flowers reddish, in loose fascicles; pedicels filiform, jointed near the base: valves about $4 \mathrm{~mm}$. in diameter, sometimes with a minute basal tubercle: achene small. [R. Geyeri (Meis.) Trel. Rep. Mo. Bot. Gard. 3: 78. 1892.]-Mountain parks; Colorado and Utah and far northward.

3. Rumex venosus Pursh, Fl. Am. Sept. 733. 1814. Stem erect, $3 \mathrm{dm}$. high or less, from running rootstocks, stout and leafy, with conspicuous dilated stipules: leaves on short but rather slender petioles, ovate or oblong to lanceolate, 8-15 cm. long, only the lowest acute or somewhat cordate at base: panicle nearly sessile, short, dense in fruit: valves entire, cordate-orbicular 
with a deep sinus, $15-30 \mathrm{~mm}$. in diameter, bright rose-color: pedicels long, slender, jointed near the base: achene 4-7 mm. long.-Sandy ravines and banks; Kansas and Colorado, and far westward and northward.

4. Rumex salinus A. Nels. Bull. Torr. Bot. Club 25: 549. 1898. Perennial by a horizontal woody rootstock on which are borne large fascicled, oblongelliptic tubers, glabrous throughout: stem stout, nearly erect, conspicuously grooved, 2-4 dm. high: leaves large, moderately thick, somewhat crisped on the edges, crowded at the base, smaller and more distant upwards, all shortpetioled; the lower oblanceolate-oblong, $10-15 \mathrm{~cm}$. long, 3-5 cm. wide, upper lanceolate; sheaths large and thin: racemes erect, at length naked and interrupted: calyx red, conspicuously winged at maturity: pedicels filiform, as long or longer than the wings, which are cordate, $10-13 \mathrm{~mm}$. long, deep red: achene $10 \mathrm{~mm}$. long, smooth with margined angles.-In dry densely saline (alkali) soils; Colorado and Wyoming.

5. Rumex hymenosepalus Torr. Bot. Mex. Bound. 177. 1858. Stems 4-10 dm. high, from a cluster of deep-seated dahlia-like tuberous roots, subsimple, papillate to glabrous, often red: leaves rather succulent, more or less wavy margined, often 5-20 cm. long or longer, elliptical to oblanceolate, obtuse to very sharply acuminate, the acute base decurrent on the short thick petioles: inflorescence ample, compound, with elongated suberect branches; pedicels slender, about as long as the fruit, less tumidly jointed below the middle: valves flexible, ovate, about $10-15 \mathrm{~mm}$., obtuse to subacute, with an open sinus: achene about $5 \mathrm{~mm}$. long.-Colorado to California and southward.

6. Rumex mexicanus Meisn. DC. Prodr. 14: 47. 1856. Stems tufted, ascending, 3-6 dm. high: leaves rarely over $15 \mathrm{~cm}$. long, lanceolate, often plicate, acute at both ends: pedicels scarcely equaling the fruit, or a few in each cluster longer, jointed near the base: valves 4-5 $\mathrm{mm}$. long, triangular-ovate, acute, more delicately veined; callosities variable in number, smooth or mostly pitted, often nearly as long as the valve, $1 \mathrm{~mm}$. or more broad, leaving typically a very narrow margin on each side: achene $2 \mathrm{~mm}$. long. $R$. salicifolius.-Throughout the Rocky Mountains and across the continent northward.

7. Rumex brittanica L. Sp. Pl. 334. 1753. Stout, erect, 5-10 dm. high, somewhat branched, glabroús: leaves large, somewhat undulate, rounded or acute at base and decurrent, tapering gradually to the apex: panicle ample, dense in fruit, the whorls overlapping: pedicels about twice as long as the fruit, jointed near the base: valves 5-6 mm. long, round-ovate, scarcely cordate; tubercles 3, low and broad: achene $2-3 \mathrm{~mm}$. long.-Seemingly extending into Colorado and Utah from the eastward.

8. Rumex crispus L. 1. c. 335 . Erect, rather stout, $6 \mathrm{dm}$. high, simple: leaves bluish-green, the petiole and principal veins papillate, very wavy margined, the lowest ample, elliptical to mostly oblong-lanceolate, rather obtuse, rounded or decurrently acutish at base: flowering branches strict, somewhat leafy; whorls dense and approximated; pedicels about one half longer than the fruit, swollen-jointed near the base: valves $3-5 \mathrm{~mm}$. long, round-ovate, barely cordate, minutely erose or exceptionally broadly dentate below; callosities 3 , often rosy, smooth, ovoid, reaching to the middle of the valve: achene $2.5 \mathrm{~mm}$. long.- Introduced everywhere into cultivated and waste grounds. CURLED Dock.

9. Rumex Patientia L. 1. c. 333 . A stout erect perennial much like the preceding but. only one of the rather larger valves developing a tubercle.-Extensively introduced in this country; sparingly in our range.

10. Rumex obtusifolius L. 1. c. Erect, 6-9 dm. high: stem usually and sometimes strongly papillate: leaves somewhat undulate, ample or the lowest very large, broadly ovate, cordate, frequently acute, the often purple veins papillate, especially beneath: flowering branches suberect, sparingly leafy below: pedicels slender, about twice as long as the fruit, swollen-jointed toward the base: valves flexible, not very heavily veined, $4-5 \mathrm{~mm}$. long, ovateoblong, with 3-5 thin triangular teeth on each side; callosities smooth, the largest one about $1 \mathrm{~mm}$. broad, the other two usually very small: achene 
about $2 \mathrm{~mm}$. long.-Introduced everywhere in the east, and to some extent in our range.

11. Rumex persicarioides L. 1. c. Annual, simple, or diffusely branched, the low stems erect or procumbent, minutely pubescent: leaves linearlanceolate, usually truncate or cordate at base, 3-10 cm. long, mostly on short petioles, somewhat wavy-margined: flowers in numerous dense verticils along the slender branches: valves ovate-lanceolate, with 2 or 3 long-awned teeth on each side, all grain-bearing. R. maritima.-Mostly in saline soils; transcontinental.

12. Rumex densiflorus Osterh. Erythea 6: 13. 1898. Stout erect glabrous scarcely branched perennial, from thick horizontal rootstocks; stems clustered, grooved, 5-10 dm. high: lower leaves very large, 1.5-3 dm. long, 10-15 cm. wide, usually very obtuse, long-petioled; upper leaves gradually reduced: flowers in dense clusters, terminating the stem and its branches, polygamous or dioecious: calyx usually red; the anthers brown: valves naked; the wings broadly ovate, shorter than the pedicels: achene ash-color.-Stream banks at high elevations; Colorado and Wyoming.

13. Rumex polyrrhizus Greene, Pitt. 4: 305. 1901. Slender sparingly leafy perennial, 5-10 dm. high: stem solitary from a short vertical crown surmounting a small fascicle of fleshy roots, usually a whorl of fibrous roots near summit of crown: leaves from lanceolate to linear, 12-20 cm. long, on petioles usually shorter than the blade, flat or crisped near the base: panicle strict but rather loose; pedicels slightly enlarged upward, jointed well above the base: valves thin, venulose, the margin obscurely crenate-dentate. (R. Bakeri Greene, Pl. Baker. 3: 15. 1901; R. praecox Rydb. Buli. Torr. Bot. Club 33: 137. 1906.)Wet mountain meadows; Colorado and Montana.

14. Rumex occidentalis Wats. Proc. Am. Acad. 12: 253. 1876. Mostly 6-9 dm. high, rather stout, subsimple: leaves somewhat fleshy, glabrous, glossy, bluish-green, wavy margined, the lower very large, ovate or mostly oblong-ovate, truncately cordate, the apex rounded to subacute: panicle strict, dense and rosy in fruit, naked or with a few small leaves below; whorls somewhat remote but overlapping; pedicels 2 to 3 times as long as the fruit: valves sometimes rosy, 5-6 $\mathrm{mm}$. long, deltoid-ovate, often only slightly cordate, remotely erose or denticulate, rounded or obtuse at apex, without callosities. [R. subalpina Jones, Proc. Cal. Acad. II. 5: 720. 1895.]-Texas to Ontario and California.

\section{POLYGONUM L. KNOTWEed}

Terrestrial, amphibious, or aquatic herbaceous (ours) annuals or perennials with fibrous roots, or tuberous or thickened rootstocks. Stem simple or branched, more or less swollen at the numerous nodes, erect, prostrate or climbing. Leaves alternate and entire; sheaths truncate or oblique at summit, lobed, lacerate, or fringed. Flowers axillary-racemose or spicate; pedicels jointed. Calyx mostly 5-parted, the divisions often petal-like, all erect in fruit, persistent. Stamens 4-9. Styles or stigmas 2 or 3; achene accordingly lenticulate or 3-angular.

\section{Key to the Sections}

Flowers in terminal spikes, with scarious bracts; filaments filiform.

Roots tuberous, or fleshy rhizomes.

I. BISTORTA.

Roots fibrous - $\quad$ - : II. PERSICARIA.

Flowers axillary, or racemose with foliar bracts. Stems not climbing

Stems climbing

III. AVICULARIA.

IV. BILDERDYKIA (TINIARIA).

BISTORTA.-Perennials of northern or subalpine distribution. Rootstock elongated; spike floriferous throughout

Rootstock corm-like; spike bearing bulblets
PERSICARIA.-Annuals or perennials, mostly of southern and

1. P. bistortoides. of middle to lower altitudes. 
Spike usually solitary, short and thick.

Sheaths neither spreading at summit nor fringed.

Leaves obtuse or subacute

Leaves acute or acuminate

Sheaths spreading at summit and somewhat fringed

Spikes several or many, rarely few.

Sheaths cylindric, naked.

Spikes erect; styles 2-parted; achene orbicular

Spikes drooping (at least at tip); style 2-parted; achene ovoid.

Calyx and style each parted to below the middle

Calyx and style each parted nearly to the base

Sheaths cylindric, fringed with bristles.

Spikes erect.

Achene lenticular or triangular; spike dense. Achene smooth, broadly ovoid

Achene granular, narrowly ovoid

Achene triangular; spike slender, open

Spike drooping; achene lenticular or triangular.

Achene dull and granular.

Achene smooth and shining

AVICULARIA. - Mostly annuals, usually rather smali, with nar-

row leaves; achene triangular

Plants prostrate-spreading .

Plants erect.

Flowers axillary throughout.

Achenes conspicuously exserted

Achenes included.

Branched throughout, the branches spreading.

Leaves from oblong to oval

Leaves from oblong to linear.

Branched from the base.

Pedicels erect.

Achene oblong

Achene ovoid

Pedicels deflexed.

Achene ovoid.

Upper bracts small and subulate

Upper bracts foliaceous

Achene oblong

Flowers in terminal bracteate spicate-racemes.

Styles evident.

Raceme long and interrupted

Raceme very short, subcapitate.

Bracts winged

Bracts not winged

Styles wanting or nearly so

BILDERDYKIA. - Annual or perennial, the stem herbaceous and twining (Tiniaria).

Outer calyx-segments unchanged in fruit

Outer calyx-segments developing wings

3. P. amphibium.

4. P. emersum.

5. P. Hartwrightii.

6. P. pennsylvanicum.

7. P. lapathifolium.

8. P. incarnatum.

9. P. Persicaria.

10. P. persicarioides.

11. P. hydropiperoides.

12. P. Hydropiper.

13. P. punctatum.

14. P. a viculare.

15. P. exsertum.

16. P. erectum.

17. P. ramosissimum.

18. P. sawatchense.

19. P. tenue.

20. P. Douglasii.

21. P. montanum.

22. P. Engelmannii.

23. P. spergulariaeforme.

24. P. polygaloides.

25. P. Watsonii.

26. P. Kelloggii.

27. P. Convolvulus.

28. P. scandens.

1. Polygonum bistortoides Pursh, Fl. Am. Sept. 271. 1814. Herbaceous perennial with thick creeping chaffy rootstock; stem $2-6 \mathrm{dm}$. high: leaves few, glabrous or with a minute hispid pubescence beneath; the radical on long petioles, oblong, oblong-lanceolate to linear, either acute or obtusish at both ends; the cauline much reduced and sessile upon the sheath, the margin often revolute: flowers rose-color to white, on slender pedicels, in very dense ovate to oblong spikes, and usually long-pedunculate: stamens and styles exserted: achenes smooth and shining. [P. lilacina (Greene); P. calophylla (Greene), both under Bistorta in Leaflets 1: 18 \& 19. 1904.]-New Mexico to Montana and far northward and westward.

1a. Polygonum bistortoides linearifolium (Wats.) Small, Bull. Torr. Bot Club 19: 252. 1892. Slender reduced alpine form with leaves tending to linear: raceme ovoid. [P. linearifolia (Greene), under Bistorta, 1. c.]-Alpine; same range.

2. Polygonum viviparum L. Sp. Pl. 360. 1753. Perennial from a short corm-like rootstock: stems 1-2 dm. high: leaves glabrous or rarely hispidulous beneath; the radical oblong or lanceolate, $2-8 \mathrm{~cm}$. long, varying from acute to subcordate at base; cauline from narrowly lanceolate to linear, revolute: flowers rather small, nearly sessile in linear spikes $2-5 \mathrm{~cm}$. long, the lower flowers at least replaced by sessile bulblets about $2 \mathrm{~mm}$. long. [P.scopulina (Greene), 
under Bistorta, 1. c. 20.]-Subalpine and alpine in our range; arctic America, Europe, and Asia.

3. Polygonum amphibium L. Sp. Pl. 361. 1753. Aquatic, stout, glabrous or nearly so, not branching above the rooting base: leaves floating, thick, smooth and shining above, usually long-petioled, elliptical to lanceolate, cuneate or cordate at base; sheaths leaf-bearing about the middle: spike terminal, dense, ovate or oblong; 1-3 cm. long, on a usually short peduncle: flowers bright rose-color: the 5 stamens and 2-cleft style exserted. ( $P$. plattensis, $P$. subcoriacea, $P$. laetevirens, $P$. psychrophila, under Persicaria by Greene, Leaflets 1: 29-31. 1904.)-Colorado, north to the boundary, thence across the continent. In shallow water or on muddy banks the stems become erect, the petioles shorter, and the whole plant often more or less strigosepubescent.

4. Polygonum emersum (Michx.) Brit. Trans. N. Y. Acad. Sci. 8: 73. 1889. In muddy or wet places, scabrous with short appressed or glandular hairs, especially upon the leaves and upper part of the simple stem: leaves thinner and longer, rather broadly lanceolate, acute or narrowly acuminate, usually rounded or cordate at base: spikes more elongated, 5-7 cm. long, often in pairs: flowers and fruit nearly as in the last. P. Muhlenbergii. $[P$. Wardii (Greene), under Persicaria, 1. c. 40.]

5. Polygonum Hartwrightii Gray, Proc. Am. Acad. 8: 294. 1870. Closely allied to the two preceding species, growing usually in the mud, the ascending stems rooting at the base and very leafy, more or less rough, hairy, at least on the sheaths and bracts: leaves rather narrow, on very short petioles, not punctate, adnate to the middle of the sheath: flowers bright rose-color: sepals not glandular-dotted: style 2-cleft, and achene somewhat flattened. ( $P$. muriculata Greene, under Persicaria 1. c. 47.)-Transcontinental through the northern States.

6. Polygonum pennsylvanicum L. Sp. Pl. 362. 1753. Stem 3-8 dm. high, smooth below, the branches above and especially the peduncles beset with bristly-stalked glands: leaves lanceolate, roughish on the midrib and margins: spikes oblong, obtuse, erect, thick: flowers bright rose-color: stamens mostly 8, somewhat exserted: style 2-parted; achene lenticular. ( $P$. omissum Greene, Pitt. 5: 200. 1903.) - Colorado and eastward to the Atlantic States.

7. Polygonum la pathifolium L. l. c. 360. Annual, branching, 3-12 dm. high, glabrous or the peduncles often minutely glandular: leaves lanceolate, attenuate upward from near the cuneate base and acuminate, somewhat scabrous with short appressed hairs on the midrib and margin, or rarely floccose-tomentose beneath; sheaths and bracts rarely somewhat ciliolate: spikes oblong to linear ( 1.5 to $5 \mathrm{~cm}$. long), dense, erect or nearly so: flowers white or pale rose-color: stamens 6 : achene ovate, rarely $2 \mathrm{~mm}$. broad.-In most parts of North America.

7a. Polygonum la pathifolium incanum (Schmidt) Koch. Syn. Fl. Germ. 711. 1837. Lower, with shorter and less pointed leaves, which are lanceolate, obtuse and white-downy beneath; sheaths often somewhat hairy or ciliolate: spikes shorter, oblong and blunt.-In the Wasatch, on the Saskatchewan, and eastward to New York; rare.

7b. Polygonum la pathifolium nodosum (Pers.) Small, Monog. Polyg. 55. 1895. Generally robust and glabrous: stems red or reddish, marked with purple spots and dark rings below the sheaths, much thickened at the nodes. $P$. nodosum.-Range about that of the species.

8. Polygonum incarnatum Ell. Bot. S. C. \& Ga. 1: 456. 1817. Stem 4-10 $\mathrm{dm}$. high, nearly glabrous, the peduncles, etc., often minutely rough with scattered sessile glands: leaves rough on the margins and midrib, elongatedlanceolate: spikes linear, nodding, becoming slender: flowers smaller than in the last, lighter rose-color shading to white: stamens 6 and styles 2, both included: achene lenticular, biconcave, black, smooth and shining.-Colorado and Wyoming and eastward to the Atlantic States.

9. Polygonum Persicaria L. Sp. Pl. 361. 1753. Nearly smooth and glabrous, $3-5 \mathrm{dm}$. high: sheaths more or less bristly-ciliate; leaves lanceolate, 
pointed, roughish, often marked with a dark triangular or lunar spot near the middle: spikes ovoid or oblong, dense, erect, on smooth (or at least not glandular) peduncles: stamens mostly 6: styles 2-3-cleft below the middle; achene gibbous-flattened or sometimes triangular, smooth and shining.-Naturalized from Europe; not frequent in our range.

10. Polygonum persicarioides H.B.K. Nov. Gen. 2: 197. 1817. Glabrous or often strigulose, erect, decumbent or creeping; the stems $3-6 \mathrm{dm}$. long: leaves from lanceolate to linear-lanceolate, acuminate at both ends, punctate, petioled or sessile; sheaths conspicuously fringed with short bristles: inflorescence paniculate, somewhat compound: spikes erect, $2-6 \mathrm{~cm}$. long, loosely flowered: calyx rose-color, tinged with green: achenes narrowly ovoid or oblong, somewhat granular but shining.--On our southeastern border to Mexico; also in South America.

11. Polygonum hydropiperoides Michx. Fl. Bor. Am. 1: 239. 1803. Perennial, not acrid; stem smooth, 3-8 dm. high, branching: the narrow sheaths hairy; leaves narrowly lanceolate, sometimes oblong: spikes erect, slender, sometimes filiform, often interrupted at base, $2-5 \mathrm{~cm}$. long: flowers small, flesh-color or nearly white: sepals not dotted: stamens 8: achene sharply triangular, smooth and shining.-Wet places and in shallow water; across the continent.

12. Polygonum Hydropiper L. Sp. Pl. 361. 1753. Smooth, 3-6 dm. high, juice very acrid: leaves punctate: spikes nodding, usually short or interrupted: flowers mostly greenish: sepals conspicuously dotted: stamens 6: style 2-3parted; achene dull, strongly granular, either flat or obtusely triangular.Ranging across the continent northward, where it is probably indigenous.

13. Polygonum punctatum Ell. 1. c. 445. Annual, branching, 3-12 dm. high, glabrous or the peduncles often minutely glandular: leaves lanceolate, attenuate upward from near the cuneate base and acuminate, somewhat scabrous with short appressed hairs on the midrib and margin, or rarely floccose-tomentose beneath; sheaths and bracts rarely somewhat ciliolate: spikes oblong to linear ( 1.5 to $5 \mathrm{~cm}$. long), dense, erect or nearly so: flowers white or pale rose-color: stamens 6 : achene ovate, rarely $2 \mathrm{~mm}$. broad.-Wet places; across the continent, mostly southward.

14. Polygonum aviculare L. Sp. Pl. 362. 1753. Slender, mostly prostrate or ascending, bluish-green: leaves oblong to lanceolate, 6-20 $\mathrm{mm}$. long, usually acute: sepals scarcely $1 \mathrm{~mm}$. long, green with pinkish margins: stamens 8 (rarely 5): achene dull and minutely granular, mostly included. ( $P$. buxiforme Small, Bull. Torr. Club 33: 56. 1906.)-Variously called KNotgrass, Goose Grass, Door-WEed; introduced from Europe and growing everywhere about yards and roadsides.

15. Polygonum exsertum Small, Bull. Torr. Bot. Club 21: 172. 1894. Annual, slender, glabrous, erect, $3-8 \mathrm{dm}$. high, somewhat flexuous and ribbed: leaves from obovate to narrowly lanceolate or linear: sheaths silvery or brownish and much lacerate: flowers in small axillary clusters, greenish and inconspicuous: style 3-cleft or the stigmas often nearly sessile; achene triangularpyramidal, rounded at the base, much exserted from the calyx.-From the eastern part of our range to Maine.

16. Polygonum erectum L. Sp. Pl. 363. 1753. Stout, erect or ascending, 3-6 dm. high, yellowish: leaves oblong or oval, 1.5-6 mm. long, usually obtuse: flowers mostly $3 \mathrm{~mm}$. long, often yellowish, on more or less exserted pedicels: stamens 5 or 6: achene dull, included.-Texas and Colorado to the Northwest Territory.

17. Polygonum ramosissimum Michx. Fl. Bor. Am. 1: 237. 1803. Erect or ascending, 6-12 dm. high, yellowish-green: leaves lanceolate to linear, 2.5-6 $\mathrm{cm}$. long, acute, much reduced above: flowers and achenes as in the last, but sepals more frequently 6 , the stamens $3-6$, and the achene mostly smooth and shining. (P. rubescens Small, Bull. Torr. Bot. Club 33: 56. 1906.)-Sandy shores and banks of streams extending from Texas to the far north and west.

18. Polygonum sawatchense Small, Bull. Torr. Bot. Club 20: 213. 1893. Annual, somewhat scurfy: stem erect, 5-15 cm. high, usually somewhat 
branched from the base, striate, or wing-angled below the sheaths: leaves from linear to oblanceolate, 1-2 cm. long, sessile, flat or revolute, conspicuously articulated to the funnel-form lacerate sheath: flowers in small axillary clusters, green: stamens 6-8: stigma 3-cleft, nearly sessile; achene triangular, oblong, smooth and shining.-Colorado to Dakota and west to Washington.

19. Polygonum tenue Michx. Fl. Bor. Am. 1: 238. 1803. Stem slender, angled, erect, 1.5-4.5 dm. high, slightly scabrous at the nodes: leaves narrowly linear to lanceolate, $2.5-5 \mathrm{~cm}$. long, 3-nerved, acute at each end and often cuspidate, the margins somewhat scabrous and at length revolute: flowers often solitary, nearly sessile: stamens 8: achene ovate, included, black and shining.-New Mexico to Canada and east to the Atlantic States.

20. Polygonum Douglasii Greene, Bull. Calif. Acad. Sci. 1: 125. 1884. Erect and slender, 1-4 dm. high, glabrous and somewhat glaucous, sometimes slightly scabrous at the nodes: sheaths with a close somewhat herbaceous base, sparingly scarious and lacerate above; leaves linear to lanceolate, usually much reduced above: flowers often solitary and usually distant, soon reflexed, the sepals margined with white or rose-color: stamens 8: achenes ovate, black and shining. $P$. tenue.-From Arizona to British Columbia and eastward across the continent.

21. Polygonum montanum (Small) Greene, Pl. Baker. 3: 13. 1901. Low, fastigiately branched from the base, $7-15 \mathrm{~cm}$. high, the branches floriferous from the base, but the flowers few among the proper leaves, most of them forming a mere bracted spike beyond the foliage, all the angles of stem and branches denticulate-scaberulous and other parts also more or less scabropuberulent: leaves oblong-lanceolate, very acute, often $2-3 \mathrm{~cm}$. long, 1-nerved, the nerve sharply carinate beneath the leaf: fruiting perianth subsessile but nodding, its segments dark green or purplish except marginally and partly or completely inclosing the achene, which is black, smooth and shining. (P.commixtum Greene, 1. c. 14.)-Colorado.

22. Polygonum Engelmanii Greene, Bull. Calif. Acad. Sci. 1: 126. 1884. Slender, somewhat wiry scurfy annual; stems diffusely branched at the base; spreading-assurgent, $5-15 \mathrm{~cm}$. high; the branches simple or branched: leaves from narrowly oblanceolate to linear; sheaths somewhat lacerate: flowers in axillary clusters of $2-4$; the pedicels at length deflexed: calyx green, its segments scarious-margined: stamens 5-8, included: style 3-parted, at length somewhat exserted; achene triangular, oblong, smooth and shining. ( $P$. consimile Greene, Pitt. 5: 202. 1903.) - High mountains of Colorado and Wyoming.

23. Polygonum spergulariaeforme Meis. Small, Bull. Torr. Bot. Club 19: 366. 1892. Slender, wiry scurfy annual, 1-3 dm. high, simple or corymbosely branched: leaves linear-oblong or linear-lanceolate, $5-25 \mathrm{~cm}$. long, conspicuously articulated to the lacerate sheaths: flowers clustered-axillary but confined mostly to the ends of the branches and appearing as interrupted spicate-racemes by the shortening of the internodes: calyx whitish or pink, 5 -parted to near the base; the segments obtuse, each with a green nerve: stamens 8: style 3-parted; achene triangular, black, smooth and shining except on the margins.-Colorado; also in the north Pacific regions.

24. Polygonum polygaloides Meis. in DC. Prodr. 14: 101. 1856. A slender glabrous light green annual; stem erect, 1-2 dm. high, simple or corymbosely branched, slightly flexuous and angled: leaves linear, 1-3 cm. long: flowers axillary but the terminal internodes so short as to give a spicate or subcapitate inflorescence; bracts oblong, obtuse, scarious-winged and somewhat imbricated: the calyx parted nearly to the base, white or pinkish: stamens 8, included: achene ovoid, triangular.-Northern Wyoming and Montana; and west to the Pacific States.

25. Polygonum Watsonii Small, Monog. Polyg. 138. pl. 56. 1895. Low slender annuals, $3-15 \mathrm{~cm}$. high, smooth or slightly scabrous at the nodes: leaves linear, 1-4 dm. long; sheaths rather large, 2-parted or lacerate above the short scarious base: bracts sometimes scarious on the margin: flowers axillary but appearing as short densely terminal spikes, with imbricated bracts, nearly sessile: the calyx green, the segments ovate, more or less rose-colored on the 
margins: stamens 3-5: achene triangular, narrowly ovoid, prominently granular in ridges. $P$. imbricatum. ( $P$. unifolium Small, Mem. N. Y. Bot. Gard. 1: 129. 1900.)-Alpine and subalpine; Colorado and Wyoming west to the Pacific States.

26. Polygonum Kelloggii Greene, Fl. Francis. 134. 1891. Low slender glabrous annual, divergently branched from the base; the branches $2-5 \mathrm{~cm}$. long: leaves linear or nearly so, crowded but spreading rather than imbricated; sheaths lacerate: flowers axillary (because of the short internodes the inflorescence appears like a leafy raceme): calyx green, its obtuse segments whitish or cream-color: stamens about 5, included: stigmas sessile or nearly so; achene triangular, rhombic-ovoid, light brown, granular, and somewhat striate.Colorado and Wyoming and west to the coast States.

27. Polygonum Convolvulus L. Sp. Pl. 364. 1753. Annual, twining or procumbent, low, roughish, the joints naked: leaves halberd-heart-shaped, pointed: flowers in small interrupted corymbose racemes: outer calyx-lobes keeled: achenes smoothish. BLACK BINDweED.-Cultivated and waste grounds throughout the United States.

28. Polygonum scandens L. 1. c. Perennial, smooth: sheaths naked: leaves cordate or slightly halberd-shaped, pointed: racemes interrupted, leafy: the outer calyx-lobes strongly keeled and winged in fruit, the wings somewhat crenate, but often one or all three wantin $:$ : achene over $3 \mathrm{~mm}$. long, smooth and shining. P.dumetorum scandens. Climbing False Buckwheat.-Moist thickets; from our range to the Atlantic States.

\section{CHENOPODIACEAE. Goosefoot Family}

Annual or perennial, herbaceous or shrubby, usually with simple alternate exstipulate leaves. Flowers perfect or unisexual, small, green or greenish, regular or nearly so, variously clustered or more rarely solitary in the axils, ebracteate or with herbaceous bracts, which may become either a thin or coriaceous pericarp inclosing the fruit. Perianth of 5 or fewer usually herbaceous and persistent sepals. Stamens as many as the sepals and opposite, distinct, with 2-celled anthers. Ovary 1-celled, with a solitary ovule, becoming an achene or utricle. Mostly plants of saline soils.

Embryo annular or folded on itself.

Flowers perfect, bractless.

Perianth wingless, persistent.

Two-five parted or divided.

Lobes herbaceous, keeled _ . . . . . . 1. Chenopodium.

Lobes becoming fleshy and red : $\quad$ : $\quad$ : $\quad$ 2. Blitum.

One sepal only.

Herbaceous and bract-like

Hyaline and scale-like

Perianth horizontally winged.

Plant annual

Plant perennial
Perianth saccate, fleshy; stems fleshy, leafless

Flowers monoecious or dioecious; perianth in fertile flowers wanting.

Fruiting bracts compressed

Fruiting bracts obcompressed.

Pericarp naked.

Orbicular, wing-margined

Subhastate, 2-toothed at apex

Pericarp silky-pubescent

Embryo spirally coiled.

Flowers monoecious; plant shrubby; fruit winged

Flowers perfect; plants herbaceous.

Leaves spiny at maturity; fruit winged

Leaves not spiny; fruit not winged

3. Monolepis.

4. Corispermum

5. Cycloloma.

6. Kochia.

7. Salicornia.

8. Atriplex.

9. Grayia.

10. Suckleya.

- 11. Eurotia.

12. Sarcobatus.

13. Salsola.

14. Sueda.

\section{CheNOPODIUM L. Goosefoot. Pigweed}

Annual herbs with alternate petioled leaves. Florrers small, green, sessile, in axillary terminal or panicled spikes; lobes of the perianth usually somewhat 
keeled or crested, becoming dry and inclosing the utricle, at least in part. Stamens 5. Styles 2-3. Pericarp membranous, closely investing the lenticular seed. Many are introduced weeds.

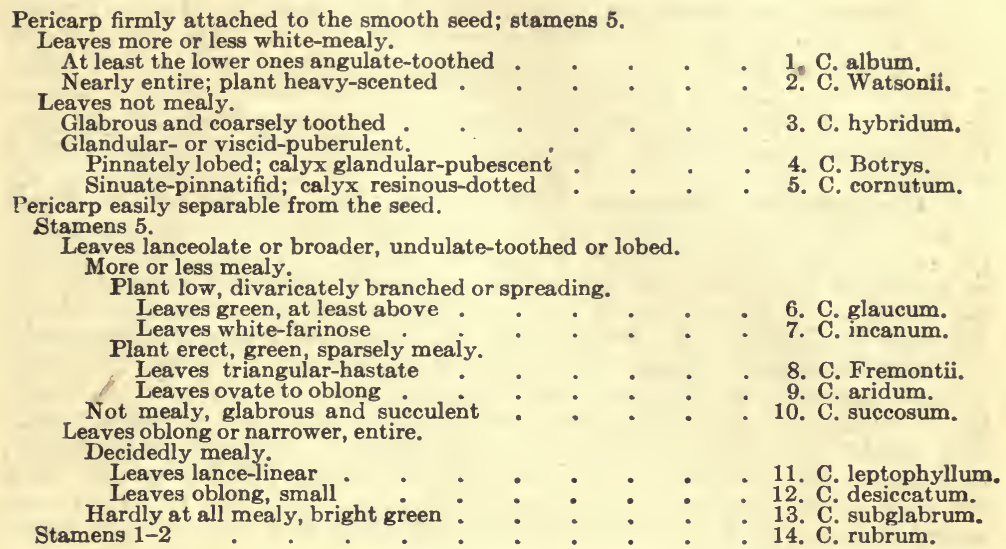

1. Chenopodium album L.Sp. Pl. 219. 1753. Stem erect, branched above, 3-10 dm. high, light green: leaves generally pale green above, white-mealy beneath, rhombic-ovate to narrowly lanceolate, at least some of them angulatetoothed: flowers in terminal and axillary spikes: perianth wholly inclosing the utricle, the black shining seed adherent to the pericarp.-An introduced weed common in waste places; commonly known as LAMB'S QUARTERS.

2. Chenopodium Watsonii A. Nelson, Bot. Gaz. 34: 362. 1902. Moderately mealy throughout, heavy-scented, more or less branched, $2-5 \mathrm{dm}$. high: leaves dull green, rather thick, oblong to ovate, often subhastate, margin entire or nearly so, $15-20 \mathrm{~mm}$. long, on slender petioles: flowers in close clusters arranged in open panicles: pericarp mealy and adherent to the large seed. C. olidum Wats. Proc. Am. Acad. 9: 96. 1874.-Indigenous from New Mexico to Utah and Wyoming.

3. Chenopodium hybridum L. Sp. Pl. 219. 1753. Glabrous throughout or only the inflorescence mealy, erect, 4-8 dm. high: leaves thin, bright green, rhombic-cordate, acuminate at apex, with 1-4 large acute teeth on each side, $3-5 \mathrm{~cm}$. long, the uppermost smaller and entire: flowers large, in large spreading panicles: perianth-segments somewhat keeled, not wholly inclosing the utricle: seed with acutish margin, firmly united to the pericarp.-A widely distributed weed but probably indigenous in our range.

4. Chenopodium Botrys L. Sp. Pl. 219. 1753. Glandular-pubescent or even viscid, strong-scented: stem leafy below, branching above into the dense naked inflorescence, 2-5 dm. high: leaves ovate or narrower, deeply pinnatelytoothed or -lobed, obtuse, truncate or cuneate at base, reduced upward: flowers very small in numerous axillary panicles: calyx-lobes acute, loosely inclosing the fruit.-Generally introduced; from Europe.

5. Chenopodium cornutum Benth. \& Hook. Gen. Pl. 3: 51. 1880. More or less glandular-puberulent, aromatic, not mealy, diffusely branched: leaves thin, lanceolate, repand-dentate or coarsely sinuate-pinnatifid: flowers minute and solitary, axillary and terminal upon the repeatedly dichotomous nearly naked branches: calyx resinous-dotted. (Teloxys cornuta Torr. Pac. R. R. Rept. 4: 129. 1856.) - Through the southern part of our range to California.

6. Chenopodium glaucum L. Sp. Pl. 220. 1753. A succulent, low spreading or often prostrate annual, glaucous-mealy, the upper surface of the leaves smooth and green: leaves ovate to ovate-lanceolate, sinuate-dentate, 10-20 $\mathrm{mm}$. long, on slender petioles: flowers clustered in axillary spikes shorter ROCKY MT. BOT.-11 
than the leaves: calyx about $1 \mathrm{~mm}$. broad, its segments obtuse, not keeled, not fully covering the depressed sharp-edged utricle.-Widely distributed as an introduced weed, but undoubtedly indigenous in saline areas of our range.

7. Chenopodium incanum (Wats.) Heller, Cat. N. A. Pl.45. 1898. Densely mealy throughout, low and diffusely branched, 1-2 dm. high: leaves rather thick, somewhat fleshy and white-farinose, ovate, sinuate or hastately lobed, 7-14 mm. long: flowers crowded in close contracted panicles: sepals carinate and mealy, covering the seed which readily separates from the pericarp. C. Fremontii incanum Wats. Proc, Am. Acad. 9: 94. 1874.-Dry loose soil of the plains.

8. Chenopodium Fremontii Wats. King's Rep. 5: 287. 1871. Erect, slender, more or less branched, 2-6 dm. high, light green but somewhat mealy, the stem striate: leaves broadly triangular-hastate, $7-20 \mathrm{~mm}$. long, truncate or cuneate at base, narrower and reduced upward: the small flowers in slender spikes of the open panicle: the strongly carinate sepals nearly inclosing the easily separable seed.-Frequent; in the Rocky Mountains and westward.

9. Chenopodium aridum A. Nels. Bull. Torr. Bot. Club 31: 240. 1904. Annual, sparingly mealy: stem erect, 3-4 dm. high, often branched, striate: leaves moderately thick, dark green, only slightly mealy; petioles about $1 \mathrm{~cm}$. long; blades 1-3 cm. long, oblong to ovate-lanceolate, entire or rarely slightly hastately toothed, obtuse: inflorescence dense, narrow; flowers small: seeds less than $1 \mathrm{~mm}$., usually $0.75 \mathrm{~mm}$. in diameter: pericarp thin and easily separated from the seed. (C. Wolfi Rydb. Bull. Torr. Bot. Club 30: 240. 1903.) - Colorado and Wyoming.

10. Chenopodium succosum A. Nelson, Bot. Gaz. 34: 361. 1902. Stout, erect, 5-8 dm. high, freely branched, with ascending straw-colored branches; the whole plant fleshy and exceedingly succulent: leaves lanceolate to oblanceolate or even linear, irregularly toothed, $2-5 \mathrm{~cm}$. long, on petioles about half as long, green on both sides and not noticeably mealy: flower-clusters axillary, crowded-spicate, very numerous: calyx membranous; the sepals usually 3, suborbicular: pericarp thin, rather loosely covering the dark brown seed.-Wet saline soil; southern Wyoming.

11. Chenopodium leptophyllum (Moq.) Nutt. DC. Prod. 132: 71. 1849. Usually densely mealy, the leaves sometimes glabrate and green above; stems slender, erect, striate, branched, 2-4 dm. high: leaves linear, entire, 1-3 cm. long, acute or mucronate, shortly petioled: the small flowers clustered in dense or interrupted spikes: the carinate sepals scarcely covering the $1 \mathrm{~mm}$. broad seed.- Wyoming to Utah and southward to Mexico.

11a. Chenopodium leptophyllum oblongifolium Wats. Proc. Am. Acad. 9: 95. 1874. Densely mealy, lower, stouter, more widely branched: leaves oblong, often slightly hastate: flowers in dense clusters in short close spikes. - Colorado and New Mexico.

12. Chenopodium desiccatum A. Nels. Bot. Gaz. 34: 362. 1902. Densely white-mealy throughout, freely branched, low and spreading, about $1 \mathrm{dm}$. high (broader than high): leaves from linear to oblong, mostly acute, 1-2 cm. long: floriferous throughout; the small clusters in dense panicles which are naked towards the apex: calyx thickened and inclosing the rather large shining-black seed, which is easily separable from the pericarp.- Southern Wyoming and northern Colorado.

13. Chenopodium subglabrum (Wats.) A. Nels. Bot. Gaz. 34: 362. 1902. Glabrous, bright green, loosely and slenderly branched, the branches very widely divaricate: leaves linear-acutc, 2-4 cm. long: flowers single or in 2-3flowered clusters, scattered on the branches. C. leptophyllum subglabrum Wats.-Wyoming to Oklahoma.

14. Chenopodium rubrum L. Sp. Pl. 218. 1753. Stout, erect, branching: leaves triangular-hastate to lanceolate, cuneate at base, sparingly sinuatedentate, the upper narrowly lanceolate and entire: flower-clusters densely spicate upon the leafy branchlets: sepals $2-5$, rather fleshy: stamens 1 or 2: stigmas short: seed horizontal, shining, separating from the pericarp.-In saline soil; across the continent, especially northward. 
14a. Chenopodium rubrum humile (Hook.) Wats. Bot. Cal. 2: 48. 1880. Smaller, prostrate or ascending: leaves ovate to lanceolate, often hastate, much smaller, 1-3 cm. long, rarely toothed: flowers in axillary or somewhat spicate clusters.-Colorado to Nevada and Washington.

\section{BLITUM TOURN.}

Annual fleshy herbs, branched, often from the base. Leaves alternate, hastate and petioled. Flowers small, crowded in axillary capitate clusters or the uppermost subspicate. Calyx more or less fleshy in fruit and usually highly colored. Stamens 1-5. Seed subglobose, vertical, shining; embryo a complete ring.

1. Blitum capitatum L. Sp. Pl. 4. 1753. Glabrous, usually branched from the base, the branches ascending, 2-5 dm. long: leaves from broadly triangulár to lanceolate, usually sharply sinuate-toothed and more or less hastate, cordate at base, $2-7 \mathrm{~cm}$. long: flower-clústers large, often $12 \mathrm{~mm}$. in diameter, becoming bright red and by their appearance suggesting berries: seed compressed, acutely margined, separable from the pericarp. Chenopodium capitatum Wats. Bot. Cal. 2: 48. 1880. (B. hastatum Rydb. Bull. Torr. Bot. Club 28: 273. 1901.)-Frequent; moist mountain valleys.

\section{MONOLEPIS Schrad.}

Low annuals more or less branched, with alternate, entire, toothed, or lobed leaves. Flowers polygamous; a single persistent sepal, 1 stamen and 2 styles. The pericarp of the flat utricle thin and adherent to the vertical seed.

1. Monolepis Nuttalliana (R. \& S.) Engelm. Pl. Upp. Miss. 206. 1861. More or less mealy, branched from the base, 1-2 dm. high: leaves lanceolatehastate or sometimes narrowly spatulate, entire or sparingly sinuate-dentate, cuneate or attenuate at base; lower petioles elongated: flower-clusters of ten reddish: pericarp fleshy, becoming dry and minutely pitted; seed $1 \mathrm{~mm}$. broad, the margin acutish. M. chenopodioides Moq.-Mostly in saline soil; throughout our range and west to the coast.

2. Monolepis pusilla Torr. in Wats. King's Rep. 5: 289. 1871. Somewhat mealy and often tinged with red, slender and freely branched from the base, 5-15 cm. high: leaves oblong, obtuse, entire, scarcely petioled, 10-15 $\mathrm{mm}$. long: the small clusters 1-5-flowered: sepal obtuse: pericarp adherent and minutely tuberculate; seed as in the preceding but only about one half as large.-Rare in our range; alkali basins Colorado and westward.

\section{CORISPERMUM A. JusS. BUGSEED}

Annuals, with alternate sessile linear 1-nerved leaves. Flowers perfect, solitary in the axils of reduced leaves on the spicate branches. Calyx reduced to a single hyaline sepal, or none. Stamens 1-3 (rarely more), if more than one unequal. The ovate ovary with 2 styles, becoming oblong in fruit. Pericarp adherent to the vertical acute-margined seed.

Fruit distinctly wing-margined.

Bushy-branched throughout, floriferous above only

Divaricately branched below, floriferous nearly to the base.

The branches branched

The branches simple, spike-like:

Fruit wingless or nearly so.

Plant glabrous

Plant somewhat villous

1. Corispermum nitidum Kit. ex. Schult. Oestr. Fl. Ed. 2. 1: 7. 1814. Rather pale green, somewhat pubescent when young, slender-branched and erect, 2-4 dm. high: leaves narrowly linear, $2-4 \mathrm{~cm}$. long: spikes terminating the slender branchlets, at first short and crowded, becoming longer and rather 
lax in fruit: utricle narrowly but clearly winged, about $2 \mathrm{~mm}$. broad and usually broader than the subtending leaf or bract. C. hyssopifolium.Throughout the middle west.

2. Corispermum marginale Rydb. Bull. Torr. Bot. Club 30: 247. 1903. Annual; stem glabrous, much branched, $2-5 \mathrm{dm}$. high: leaves narrowly linear, $2-5 \mathrm{~cm}$. long, $1.5-2 \mathrm{~mm}$. wide: spike $3-8 \mathrm{~cm}$. long, rather dense: bracts usually overlapping each other, the lower lanceolate, about $1 \mathrm{~cm}$. long, the upper ovate, $5 \mathrm{~mm}$. long, all more or less acuminate, with a strong midrib and conspicuous scarious margins, slightly pubescent when young or glabrate: fruit about $4 \mathrm{~mm}$. long and $2.5 \mathrm{~mm}$. wide, with a broad wing-margin.-Wyoming to New Mexico.

3. Corispermum imbricatum A. Nels. Very glabrous throughout; branches spreading from the crown of the annual root, 1-2 dm. long, simple, spike-like and floriferous nearly to the base: leaves crowded-imbricate, lanceolate to ovate, $7-15 \mathrm{~mm}$. long, broadly scarious-margined: fruit oval, about $3 \mathrm{~mm}$. long, narrow wing-like margin, yellowish. Characters much like the preceding but of very different habit.-Southeastern Wyoming.

4. Corispermum emarginatum Rydb. Bull. Torr. Bot. Club 31: 404. 1904. Annual, perfectly glabrous or with a few hairs on the bracts, branched near the base, 3-4 dm. high: leaves narrowly linear, $2-4 \mathrm{~cm}$. long, 1-2 mm. wide, cuspidate-pointed: bracts except the lowest ovate, 5-7 $\mathrm{mm}$. long; acuminate, scarious-margined, much broader than the fruit: fruit plano-convex, $2.5-3 \mathrm{~mm}$. long and about $2 \mathrm{~mm}$. wide, almost without a trace of a wing-margin.-Wyoming and Colorado.

5. Corispermum villosum Rydb. Bull. Torr. Bot. Club 24: 191. 1897. Stem 2-4 dm. high, much branched from near the base, the branches divergent, striate, when young with the leaves and bracts villous with many branched hairs, in age glabrate: leaves linear, 2-4 cm. long, 1-3 mm. wide, cuspidate-mucronate: spikes rather dense, with more or less imbricated bracts: lower bracts linear-lanceolate, 5-10 cm. long, the upper ovate-acuminate and cuspidate, 4-5 $\mathrm{mm}$. long and about $3 \mathrm{~mm}$. wide, with broad scarious margin: achene $2-2.5 \mathrm{~mm}$. long and $2 \mathrm{~mm}$. wide, acutely margined but scarcely at all winged.-Throughout our range.

\section{CYCLOLOMA Moq.}

An erect herbaceous annual with thin leaves and small flowers in interrupted panicled spikes. Flowers perfect or pistillate; the urn-shaped calyx with 5 concave acute carinate lobes, around the base of which develops a membranous wing. Stamens 5. Styles 3. Seed lenticular.

1. Cycloloma atriplicifolium (Spreng.) Coult. Mem. Torr. Club 5:- 143. 1894. More or less arachnoid-pubescent, becoming glabrate, diffusely branched, 1-3 dm. high, generally light green or purple-tinged: leaves lanceolate, acute, coarsely sinuate-toothed, on slender petioles: calyx cleft to the middle, $4 \mathrm{~mm}$. broad, including the irregular wing, wholly covering the utricle. C. platyphyllum Moq.-Throughout our range in sandy soil; not common.

\section{KOCHIA Roth}

Low plants from a shrubby base, with terete leaves. Flowers solitary or few in the axils, with globose, transversely winged perianth, 5 usually exserted stamens, a depressed ovary, and 2 filiform styles. The pericarp membranous. base; stems villous-tomentose or nearly glabrous: flowers $1-3$ in the axils, mostly with abortive stamens: perianth densely white-tomentose, persistent; lobes of the membranous wing cuneate-rounded, nerved and somewhat crenu- 
late: ovary tomentose above and seed horizontal.-Wyoming and Colorado and westward.

2. Kochia vestita (Wats.) A. Nels. Habit of the preceding: densely villous throughout and subtomentose: ovary oblong, nearly equaling the calyx, very pubescent. (K. americana vestita Wats. Proc. Am. Acad. 9: 93. 1874.)Colorado to Nevada.

Kochia scoparia Schrad. Annual, pubescent or becoming glabrate; stem erect, slender, leafy, 3-8 dm. tall: leaves linear-lanceolate or linear, ciliate, acuminate, 2-5 cm. long, 2-4 $\mathrm{mm}$. wide, the upper gradually smaller: flowers sessile in the axils of the upper leaves, forming short dense bracted spikes: fruiting calyx-segments each with a short triangular horizontal wing.-An introduction from the old world; occasionally in our range.

\section{SALICORNIA L. SAMPHIRE}

Low fleshy saline plants, mostly herbaceous, and with jointed stems, opposite branches, and scale-like leaves. Flowers mostly perfect, immersed by threes in the depressions of a close cylindrical spike. Calyx a fleshy rhomboidal sac with an anterior opening, adherent by a narrow line to the rachis. Stamens 1 or 2, exserted in flower. Ovary oblong; styles 2-3. Pericarp adherent to the vertical seed.

1. Salicornia rubra A. Nels. Bull. Torr. Bot. Club 26: 1899. Annual with a strong taproot, erect, pyramidal in form, closely and divaricately branched from base to summit, the opposite branches regularly at right angles to the preceding pair and gradually shorter upward, the lower branches themselves similarly branched, rather stout, about $3 \mathrm{~mm}$. in diameter when green, joints about as long as broad: scales short, approaching triangular, much wider than long, subacute: fruiting spikes $2-4 \mathrm{~cm}$. long, very numerous, assuming a ruby red at maturity: middle flower higher than the lateral ones, reaching to the summit of the joint: the calyx broadly ovate, about $1.5 \mathrm{~mm}$. long: utricle obscurely pubescent, oval, $1 \mathrm{~mm}$. long. $S$. herbacea.-Strongly alkaline and saline shores; Rocky Mountain ponds and lakes.

\section{ATRIPLEX L. Saltbush. Orache}

Annual or perennial, herbaceous or shrubby, usually more or less mealy or scurfy-silvery. Leaves alternate or some of them opposite. Flowers monoecious or dioecious, in axillary clusters or panicled spikes; the staminate ebracteate, and with 3-5-cleft perianth; the pistillate without perianth, inclosed in a pair of more or less united compressed bracts which become enlarged and inclose the fruit. Styles two; pericarp thin and membranous; seed free and vertical. For satisfactory determination of the species well-matured fruiting bracts are necessary.

Annuals; radicle inferior or subascending.

Fruiting bracts very thin, broadly oval .

Fruiting bracts triangular-ovate, herbaceous, with free tips.

Plant low (2-3 dm.), several stemmed from the base .
Plant tall (4-10 dm.), freely branching upward.

Very fleshy, usually rubescent and glabrate

Annuals; radicle superior.

Fruiting bracts ovate, small, $2 \mathrm{~mm}$. long.

United, thin, unappendaged

Margin free, truncately 3-toothed

Fruiting bracts rhombic-orbicular, or obovate-truncate, larger, $3 \mathrm{~mm}$. or more broad.

Apex truncate, with 3-toothed margin

Indurated and sides appendaged. Appendages more or less herbaceous Appendages short fleshy processes.

Perennials; radicle superior.

Shrubs: bracts margined or winged. Bracts suborbicular, thick and scurfy Bracts broadly winged

Base shrubby: bracts thickened.

1. A. hortensis.

2. A. subspicata

3. A. carnosa.
4. A. spatiosa.

5. A. Suckleyana. 6. A. Wolfii.

7. A. truncata.

8. A. argentea.

9. A. philonitra.

10. A. confertifolia. 11. A. canescens. 
Bracts indurated, with flattened processes. Flattened vertically Irregularly flattened

Bracts spongy.

Sides appendaged with spongy crests

Sides rarely appendaged, apex toothed

1. Atriplex hortensis L. Sp. Pl. 1053. 1753. An erect annual, somewhat branched above, fruiting profusely: the bracts large and thin, broadly oval or ovate, mucronate, united only at the base.-An escape from cultivation in many places in our range.

2. Atriplex subspicata (Wats.) Rydb. Fl. Colo. 117. 1906. A scurfy annual, low and usually branched from the base, spreading or ascending, 1-3 dm. high: leaves 1-3 cm. long, lanceolate, often hastately lobed: bracts rather small, thick, deltoid or lanceolate, acute. A. patula subspicata.-From the Saskatchewan to Nebraska.

3. Atriplex carnosa A. Nels. Bot. Gaz. 34: 361. 1902. Annual, stout, at length widely and diffusely branched, sometimes nearly $1 \mathrm{~m}$. high; stems green, subglabrous: leaves thick and fleshy, oblong-lanceolate or broader, 3-7 cm. long, on petioles less than half as long, mostly entire, the larger ones subhastate or with 1 or more large teeth near the base: fruiting spikes numerous, more or less panicled, at first dark green, becoming dark purple at maturity; the large fleshy clusters closely approximate in a spike of ten $1 \mathrm{~cm}$. in diameter: fruiting bracts triangular-ovate, about $5 \mathrm{~mm}$. long and broad, usually 1 or more small teeth on the margins, smooth on the back or with 1 or 2 fleshy tubercles.--Saline areas; Colorado and Wyoming and westward to Utah.

Atriplex hastata L. Sp. Pl. 1053. 1753. This species, common on both the Atlantic and Pacific coasts, probably occurs sparingly as an introduction on wet alkali soil. It may be known by its thin hastate-triangular slender-petioled leaves; small clusters in interrupted slender spikes; otherwise much like the foregoing.

4. Atriplex spatiosa A. Nels. Bot. Gaz. 34: 360. 1902. A large erect annual, freely and divergently branched, often $1 \mathrm{~m}$. high, greenish-gray, minutely scurfy throughout: leaves ovate, $2-5 \mathrm{~cm}$. long, coarsely and irregularly toothed, cuneate at base, rarely subhastate, nearly sessile, acute at apex with a minute cusp; the floral gradually reduced, becoming lanceolate and bract-like: monoecious, androgynous at least above, the flowers in small axillary clusters and in ebracteate terminal spikes: calyx deeply 5-cleft: fruiting bracts small, rarely $5 \mathrm{~mm}$. long, ovate-triangular or orbicular, appressed, free above, with green border, hastately toothed near base or with several smaller teeth, the back usually crested with a semicircle of small slender green appendages.-Waste grounds, loose banks and grades; Utah and Wyoming to Colorado and Kansas.

5. Atriplex Suckleyana (Torr.) Rydb. Mem. N. Y. Bot. Gard. 1: 134. 1900. Erect, 1-2 dm. high, somewhat mealy, branching from the base: leaves thin, lanceolate, sessile, entire, acute, $15-20 \mathrm{~mm}$. long: sterile flower-clusters arachnoid; the calyx urceolate, with inflexed dorsally crested teeth; pistillate flowers solitary in the lower axils, sessile: fruiting bracts ovate, $2 \mathrm{~mm}$. long, membranous, pubescent: ovary surrounded by $3-4$ short hyaline sepals. (Endolepis ovata Rydb. Bull. Torr. Bot. Club 30: 248. 1903.)-From Montana through Wyoming.

6. Atriplex Wolfii Wats. Proc. Am. Acad. 9: 112. 1874. Slender, 10-15 cm. high, branching from the base, scurfy-canescent and reddish: leaves linear, 8-12 mm. long, acute, sessile: flowers very small, in androgynous axillary clusters: calyx deeply 5-cleft: fruiting bracts oblong, scarcely more than $1 \mathrm{~mm}$. long, the herbaceous summit broader than the body, with a quadrilateral tooth on each side and a small acute tooth in the center.-Alkaline flats; Colorado.

7. Atriplex truncata (Torr.) Gray, Proc. Am. Acad. 8: 398. 1872. Scurfycanescent, either strict or freely and widely branched, $2-5 \mathrm{dm}$. high and often as broad: leaves broadly ovate, $12-30 \mathrm{~mm}$. long, truncate or cordate at base, mostly acute, sessile or the lower short-petioled: spikes more or less leafy: 
calyx mostly 3-4-parted: fruiting bracts about $3 \mathrm{~mm}$. long, oblong-obovate, united up to the herbaceous truncately 3-toothed summit, the sides rarely subtuberculate.-Wyoming to Oregon.

8. Atriplex argentea Nutt. Gen. 1: 198. 1818. Grayish-scurfy or silveryglabrate; starved and young plants often nearly simple and erect and only 1-2 dm. high; well-nourished ones intricately and divaricately branched, subspherical masses 3-8 dm. in diameter: leaves deltoid or triangular-ovate or subrhombic, of ten subhastate, $2-5 \mathrm{~cm}$. long: fruiting bracts short-pediceled, united up to the dilated free margin which extends nearly to the base; the free margin variously toothed or acutely lobed; the sides irregularly appendaged with herbaceous-tipped teeth or lamellae. (A. volutans A. Nels.'Bull. Torr. Bot. Club 25: 203. 1898.) - From the Missouri River west to Oregon and California.

9. Atriplex philonitra A. Nels. Bot. Gaz. 34: 358. 1902. Annual, silverywhite, with a dense scurfiness, freely branched throughout, widely spreading and forming low tangled masses, $2-6 \mathrm{dm}$. high: leaves in young plants from broadly ovate to orbicular, 3-nerved, 1-3 cm. long, on petioles mostly exceeding the leaves; in older plants very numerous, rhombic-ovate or subcordate, sessile, on the branches becoming acute, gradually smaller and bractlike: monoecious, androgynous, and also with unisexual clusters, floriferous and leafy-bracted throughout, the crowded clusters at the closely approximated nodes of the spike-like branches: calyx small, only the tips of the sepals free: anthers large: fruiting bracts suborbicular, about $5 \mathrm{~mm}$. broad, barely united above by the irregularly toothed narrow margins, the backs appendaged by short thick flat processes.-Saline plains; Colorado, Wyoming, and westward.

10. Atriplex confertifolia (Torr.) Wats. Proc. Am. Acad. 9: 119. 1874. Densely appressed-scurfy diffusely branched shrub, somewhat spinescent, 3-12 dm. high: leaves ovate to obovate, 5-20 $\mathrm{mm}$. long, usually obtuse at apex and with cuneate base: flower-clusters small, axillary: bracts sessile, united at the cuneate base-around the seed and broadly margined above: seed $2 \mathrm{~mm}$. broad; filling the cavity.-Alkaline plains and valleys throughout the Rocky Mountain States.

11. Atriplex canescens (Pursh) James, Wats. Proc. Am. Acad. 9: 120. 1874. A rather rigid freely branched shrub, 4-10 dm. high: leaves oblanceolate to narrowly oblong, entire, $2-5 \mathrm{~cm}$. long: flowers mostly dioecious, in naked panicled spikes: calyx 5-cleft: bracts at first ovate, becoming indurated, adherent below to the pedicel of the ovary, bifid at apex and with 4 distinct broadly dilated but variable wings. [A. occidentalis (Torr.) Diet. Syn. 5: 537; A. odontophora Rydb. Bull. Torr. Bot. Club 31: 404. 1904.]-Clay and marl cliffs and banks; Dakota to Lower California.

12. Atriplex aptera A. Nels. Bot. Gaz. 34: 356. 1902. Perennial, from a woody base, the annual stems tufted, decumbent at base or even depressed, more or less branched, 1-3 dm. high: leaves narrowly oblong, 2-4 cm. long, 5-8 mm. broad, mostly obtuse, cuneately narrowed to a subsessile base: fruiting spikes paniculate, crowded, bracteate; the bracts linear-lanceolate, gradually reduced upward or wanting: dioecious, the fruiting bracts united, scarcely stipitate, somewhat indurated, densely-scurfy, appendaged with 3-4 more or less vertical rows of short vertically flattened processes, some of them often expanded but scarcely wing-like.-Alkali flats; southern Wyoming.

13. Atriplex cuneata A. Nels. Bot. Gaz. 34: 357. 1902. Perennial, with woody base, 2-several dm. high, branched from the base, the branches decumbent: leaves numerous, on the erect branches of the current year, 1-4 cm. long, entire, thick or' semifleshy, narrowly to broadly elliptic, obtuse at apex, cuneately tapering into a short petiole: flowers dioecious; the staminate densely clustered in the upper leaf-axils and in terminal spikes; the pistillate axillary, 1 or more in each cluster: fruiting bracts united except at the tip, thickened and forming an ovate or subglobose fruit, rather thickly covered with irregular rigid flattened processes.-Southwestern Colorado, southward and westward. 
14. Atriplex Nuttallii Wats. Proc. Am. Acad. 9: 116. 1874. Perennial, with more or less woody base, diffusely branched, $2-5 \mathrm{dm}$. high, greenish but moderately appressed scurfy: leaves oblong-spatulate to narrowly oblanceolate, entire: staminate flowers in dense leafless spikes; pistillate clustered in the axils and in terminal spikes: fruiting bracts ovate, strongly convex, united, with toothed margins and irregularly crested or tubercled sides. (A. oblanceolata Rydb. 1. c. 403.) -The "Great Plains;" on alkali free or moderately saline soil.

14a. Atriplex Nuttallii corrugata (Wats.) A. Nels. Lower and more closely branched: leaves smaller and more crowded: fruiting bracts obovate and smaller. (A. corrugata Wats. Bot. Gaz. 16: 345. 1891.)-Arid plains; Colorado.

15. Atriplex pabularis A. Nels. Bull. Torr. Bot. Club 25: 203. 1898. Closely appressed white-scurfy, the slender branches tufted on a lignescent base, mostly erect, $2-5 \mathrm{dm}$. high, usually but slightly branched: leaves oblong to almost linear, $2-5 \mathrm{~cm}$. long: flowers panicled, densely clustered: fruiting bracts united, oblong-cuneate, decidedly compressed, 4-5 mm. long, almost as broad at the 3-toothed summit, their sides not muricate.-Moist strongly alkaline soil; Wyoming and south into Colorado.

15a. Atriplex pabularis eremicola (Osterh.) A. Nels. Base more shrubby, more divaricately branched: fruiting bracts often broader and not rarely with accessory teeth on the rounded summit. (A. eremicola Osterh. Bull. Torr. Bot. Club 25: 284. 1898.)-Same range as the species.

\section{GRAYIA H. \& A.}

Slightly scurfy or mealy and often spiny undershrubs, with entire alternate leaves, small flowers in axillary clusters or terminal spikes. Flowers dioecious; calyx mostly 4-parted. Fruiting bracts completely united, obcompressed, orbicular-flattened, entire and wing-margined, the sides naked and somewhat reticulate-veined. Radicle inferior.

1. Grayia spinosa (Hook.) Moq. in DC. Prodr. 132: 119. 1849. Erect, diffusely branched, $3-8 \mathrm{dm}$. high, the branchlets frequently spinescent: leaves rather fleshy, glabrous or at first with the young branches somewhat mealy, oblanceolate, spatulate or obovate, 10-25 mm. long, obtuse or acute, narrowed at base and sometimes petioled: staminate flowers in axillary clusters, the pistillate mostly spicate: fruiting perianth $5-10 \mathrm{~mm}$. in diameter, sessile, smooth, emarginate, thin, white or pinkish, the seed usually central. $G$. polygaloides H. \& A.-Alkaline soil; throughout our range and westward.

2. Grayia Brandegei Gray, Proc. Am. Acad. 11: 101. 1876. Lower and unarmed, more mealy: leaves linear-spatulate: fruiting bracts smaller, slightly mealy, retuse at base, sometimes 3-winged, sessile: style short, included. -Southwest Colorado.

\section{SUCKLEYA Gray}

A nearly glabrous annual, with branching prostrate stems, and suborbicular leaves on long petioles. Monoecious, the flowers in axillary clusters. Pericarp naked, subhastate, with crested margins and 2-toothed apex.

1. Suckleya Suckleyana (Torr.) Rydb. Mem. N. Y. Bot. Gard. 1: 133. 1900. Smooth, or somewhat scurfy; the stems prostrate or ascending, $2-3 \mathrm{dm}$. long: leaves $12-25 \mathrm{~mm}$. long, on somewhat longer slender petioles, acutely repanddentate: flowers in axillary clusters, the staminate above: calyx parted to the base: fruiting bracts 5-6 $\mathrm{mm}$. broad, flattened, surrounded by a narrow crenate-denticulate margin: seed large, filling the cavity. S. petiolaris Gray: -Throughout our range but rare.

\section{EUROTIA Adans.}

Low pubescent undershrubs with alternate entire leaves and monoecious or dioecious flowers in small axillary and somewhat spicate clusters. Calyx 
4-parted. Stamens with slender exserted filaments. Styles 2, somewhat hairy, exserted. Pericarp conical, of obcompressed united densely-hairy 2-horned bracts.

1. Eurotia lanata (Pursh) Moq. Enum. Chenop. 81. 1840. White-tomentose throughout with stellate hairs (often turning reddish-brown), at least the base shrubby: leaves linear to narrowly lanceolate, with revolute margins: calyx-lobes hairy: fruiting bracts lanceolate, nearly covered by 4 dense spreading tufts of long silvery-white hairs.-New Mexico to Oregon and Manitoba; known as Winter Fat or White SAGE, and valued as forage.

\section{SARCOBATUS Nees. Greasewood}

A subspinescent rigidly branched shrub with alternate linear fleshy leaves, and bractless monoecious or dioecious flowers. Staminate flowers without calyx, in close terminal spikes; stamens $2-5$, irregularly arranged under a stipitate peltate scale. Pistillate flowers solitary, axillary; the perianth adherent at the contracted somewhat 2-lipped apex to the base of the stigmas, laterally margined by a narrow erect slightly 2-lobed border, which at length becomes a broad circular horizontal membranous veined wing; style lateral, terminated by two thick exserted unequal stigmas.

1. Sarcobatus vermiculatus (Hook.) Torr. Emory's Rep. 150. 1848. Glabrous or slightly pubescent on young branches, with smooth white bark, 5-25 dm. high: leaves pale green, somewhat 3-angled, $2-5 \mathrm{~cm}$. long: fruiting calyx coriaceous, about $5 \mathrm{~mm}$. long, the winged margin $7-12 \mathrm{~mm}$. broad. -Moist saline flats; throughout our range and west to Nevada.

\section{SALSOLA L.}

Ours an introduced saline annual, with fleshy sessile subcylindrical leaves and sessile solitary 2-bracted perfect flowers. Calyx 5-sepaled, becoming horizontally 5-winged, inclosing the fruit. Stamens 5. Stigmas 2. Fruit a flattened utricle enveloping the horizontal seed.

1. Salsola pestifer A. Nels. Bushy-branched, at first soft and succulent, in age rigid, often $1 \mathrm{~m}$. broad and high: leaves and outer branches bright red at maturity; the linear leaves becoming rigid and prickle-tipped: calyx membranous, conspicuously veiny on the wings. (S. Tragus of Am. authors, not $S$. Tragus L.)-The now widely distributed Russian ThistLe.

\section{SUAEDA Forskal.}

Annuals or frutescent perennials with subterete fleshy leaves and axillary clustered or solitary flowers. Flowers perfect or polygamous, minutely bracteolate. Calyx 5-cleft, its lobes unappendaged or more or less strongly keeled or crested, or at length somewhat winged. Stamens 5. Seed compressed, the testa shining, black and crustaceous.

Wholly herbaceous.

Erect annuals; calyx cleft to below the middle. Calyx lobes unappendaged Calyx lobes carinate-crested

Decumbent perennial [sometimes annual (?)] Woody-based perennial

1. Suaeda diffusa Wats. Proc. Am. Acad. 9: 88. 1874. Smooth or more or less pubescent, green or often purple, erect, diffusely branching, $3-5 \mathrm{dm}$. high: leaves subterete, $1-4 \mathrm{~cm}$. long; the florąl ones similar but shorter, usually rather distant on the branchlets: clusters 2-4-flowered: calyx cleft below the middle, fleshy but not carinate.-From the upper Missouri to Mexico.

2. Suaeda erecta (Wats.) A. Nels. Erect with ascending branches, 3-6 dm. high: leaves smooth, linear, broadest at base, 1-3 cm. long; the floral shorter, 
linear-subulate: calyx-lobes carinate-crested: seed $1 \mathrm{~mm}$. broad, lightly reticulated. Suaeda depressa erecta Wats. (Dondia erecta A. Nels. Bot. Gaz. 34: 364. 1902.) - Strongly alkaline soil; from the Dakotas to southern California.

3. Suaeda depressa (Pursh) Wats. 1. c. 89 . Perennial from a deep-set slender root or more rarely annual; branched from the base, the branches decumbent or ascending, 3-4 dm. high: leaves linear, 1-3 $\mathrm{cm}$. long, broadest at base, the uppermost shorter, and broader, becoming ovate: one or more of the calyx-lobes keeled in fruit: seed dull, minutely reticulated.-Saline soil; throughout the Rocky Mountain States.

4. Suaeda Moquinii (Torr.) A. Nels. Perennial from a woody base, with erect herbaceous branches, 3-7 dm. high: leaves linear, subterete, $1-4 \mathrm{~cm}$. long; the floral similar: calyx rather large, deeply cleft: seed finely tuberculate. Suaeda Torreyana Wats. (Dondia Moquina A. Nels. l.c. 363.)-From Colorado and Wyoming to California.

\section{Amaranthaceae J. St. Hil. Amaranth Family}

Ours annuals with simple mostly entire leaves destitute of stipules. Flowers small, perfect or unisexual, solitary or clustered, usually subtended by scarious bracts (mostly 3 ). Perianth of $2-5$ either herbaceous or scarious segments (sepals) which are distinct or united at the base. Stamens as many as the sepals, or rarely fewer. Ovary 1-celled, 1-ovuled, utricular in fruit. Seed mostly smooth; the embryo annular.

Anthers 2-celled; leaves alternate.

Flowers monoecious or dioecious, all with $3-5$ sepals

Flowers dioecious; calyx wanting in the fertile flowers .

Anthers 1-celled; flowers perfect; leaves mostly opposite.

Leaves sessile; flowers spicate

Leaves petiolate; flowers axillary

\section{AMARANTHUS L. AMaranth}

More or less branched annuals, either glabrous or pubescent, with thin veiny pinnately-veined petioled leaves. Flowers small, monoecious, polygamous, or dioecious, green or purplish, in axillary or spiked clusters or spikelets. Staminate flowers usually mingled with the more numerous pistillate ones. Sepals 2-5, distinct or united at the base. Utricle ovate or oblong, 2-3-beaked, usually circumscissile. Nearly all the species are troublesome weeds, many of them introduced.

Utricle circumscissile, the top coming off as a lid.

Flowers in dense spikes, mostly terminal; stamens 5.

Plants pubescent, at least upward. Spikes thick, erect Spikes slender, panicled

Plant glabrous, or nearly so.

Spine-bearing in the leaf-axils

Not spine-bearing
Flowers in small axillary clusters or spikes; stamens $\dot{3}$.

Plant erect but bushy-branched

Plant prostrate matted

Utricle indehiscent, falling away inclosed in the perianth.

Bracts not exceeding the sepals

Bracts twice as long as the sepals

1. Amaranthus retroflexus L. Sp. Pl. 991. 1753. Roughish and more or less pubescent; stems erect, stout, 3-12 dm. high, more or less branched: leaves ovate to rhombic-ovate, dull green, with undulate margins, $5-10 \mathrm{~cm}$. long, cuneately narrowed at base and often decurrent on the long petiole: flowers green, monoecious, in stout thick crowded erect spikes; the bracts lanceclate and attenuate to a rigid awn, twice as long as the scarious sepals: utricle scarcely equaling the sepals, slightly wrinkled.--Now common as a weed everywhere, 
2. Amaranthus hybridus L. Sp. P1. 990. 1753. Very similar, but slender and with smaller leaves, darker green or purplish: spikes linear-cylindric, axillary and forming crowded terminal panicles, ascending or somewhat spreading or drooping: sepals oblong, acute or cuspidate--Like the preceding, naturalized from tropical America and now widely distributed.

3. Amaranthus spinosus L. Sp. Pl. 991. 1753. Stem stout and rigid, freely branched, 3-10 dm. high: leaves ovate to lanceolate, tipped with the excurrent midrib and bearing a pair of rigid stipular spines in the axils: flowers in terminal spikes and axillary clusters: the subulate bracts, 1-nerved sepals, and the thin imperfectly circumscissile utricle subequal.-Infrequent weed in our range.

4. Amaranthus Powellii Wats. Am. Acad. 10: 347. 1875. Glabrous, erect and slender, with ascending branches and spikes, reddish, 5-8 dm. high or more: leaves thin, 2-several $\mathrm{cm}$. long, oblong to narrowly lanceolate, on slender petioles: terminal compound spike erect, narrow and somewhat leafy; bracts solitary, subulate, rigid, pungent: utricle equaling the oblong obtuse sepals: seed orbicular, $1 \mathrm{~mm}$. broad. (A. Wrightii Wats. 1. c. 12: 275.)Colorado, in the Arkansas Valley.

5. Amaranthus graecizans L. Sp. Pl. 990. 1753. A pale glabrous annual, with whitish stems; diffusely branched from the base: leaves oblong-spatulate to obovate, obtuse or retuse: flowers polygamous in small axillary clusters; bracts subulate, rigid, pungently awned, the lateral ones much smaller or wanting: utricle rugose, exceeding the 3 membranous sepals: seed less than $1 \mathrm{~mm}$. broad. A. albus L.-Known as Tumbleweed, since it is freely uprooted when mature and driven about on the plains by the wind.

6. Amaranthus blitoides Wats. Proc. Am. Acad. 12: 273. 1876. Branched from the base; the branches prostrate, forming mats: leaves small, 5-20 $\mathrm{mm}$. long, obovate-spatulate, tapering into the slender petiole: spikelets short; bracts ovate-oblong, short-acuminate, nearly equal: utricle not rugose: seed about $1 \mathrm{~mm}$. broad.-A very troublesome weed in waste and cultivated ground.

7. Amaranthus Torreyi (Gray) Benth., Wats. Bot. Cal. 2: 42. 1880. Glabrous, erect, with grooved stem, 3-8 dm. high: leaves mostly lanceolate, narrowed to an obtuse apex: flowers either monoecious or dioecious, in slender terminal spikes and in axillary clusters: sepals of the sterile flowers oblonglanceolate, acute; the fertile obovate-spatulate, entire, retuse or emarginate, deciduous with the indehiscent utricle: bracts cuspidate, scarcely equaling the fruit.-Colorado and southward.

8. Amaranthus Palmeri Wats. Proc. Am. Acad. 12: 274. 1876. Somewhat pubescent above, stout, branching, 5-8 dm. high: leaves oblong-rhomboid, 3-5 cm. long, equaled by the petiole, the upper reduced and narrow: spikes elongated-linear, leafy at base; bracts solitary, rigid, narrowed into an awn: flowers dioecious: sepals 5, spatulate, half as long as the bracts: utricle dry, indehiscent.--Rare in our range; to be expected in southern Colorado.

\section{ACNida L. Water Hemp}

Ours an annual glabrous herb, with alternate petioled pinnately-veined long-petioled leaves. Flowers dioecious, small, green, 3-bracted, in elongated spikes. Staminate flowers of 5 thin oblong and mucronate sepals, longer than the bracts, and as many stamens with oblong anthers; the cells of the latter united only at the middle. Pistillate flowers with lance-subulate bracts longer than the ovary; the calyx wanting. Fruit a thin membranous utricle, smooth and even. Seed erect, smooth and shining.

1. Acnida tamariscina (Nutt.) Gray, Am. Nat. 10: 489. 1876. Tall and erect, with slender flexuous branches, often 1 or $2 \mathrm{~m}$. high: flowers in elongated panicled spikes: utricle indehiscent, ovoid, somewhat tubercled: stigmas very long, divergent, plumose-hispid. A. tuberculata.-Low wet sandy shores; rare in our range; Colorado and southeastward. 


\section{FROELICHIA Moench}

Erect woolly or silky annuals, with narrow opposite leaves, perfect 3-bracted flowers in panicled spikes. Calyx tubular, 5-cleft at the summit, 2-5-crested on the tube or sometimes tuberculate in fruit. Stamens 5 , the united filaments forming a tube 5-cleft at summit and bearing the 1-celled anthers between the lobes. Ovary ovoid; the utricle indehiscent and inclosed in the stamen-tube.

Spikes all opposite

Spikes alternate, at least in part

1. F. floridana.

1. Froelichia floridana (Nutt.) Moq. in DC. Prodr. 132: 420. 1849. Stout, Euberect, with slender branches, 3-5 dm. high: leaves from oblanceolate below to linear on the pedunculate stem: spikes opposite: fruiting calyx vertically wing-crested.-From Colorado to Texas and Florida.

2. Froelichia gracilis Moq. in DC. Prodr. $13^{2}: 420.1849$. Similar but smaller and slenderer: leaves linear or the lower spatulate and subpetioled: spikes (at least some of them) alternate: fruiting calyx with vertical rows of tubercles or these confluent into crests.-Colorado to Kansas and Texas.

\section{CLADOTHRIX Nutt.}

Low annual, or erect and woody at base, with small rounded entire petiolate leaves. Flowers 3-bracted; bracts concave, hyaline. Perianth of 5 erect equal oblong rigid-scarious sepals, somewhat pilose with verticillately branched hairs. Anthers large, oblong. Utricle ovate-globose, indehiscent.

1. Cladothrix lanuginosa Nutt. Moq. in DC. Prodr. $13^{2}: 360$. 1849. Prostrate or ascending, diffusely branched: leaves round-obovate to rhomboidal, more or less attenuate at base, of ten in threes: flowers mostly in pairs: sepals twice longer than the broader hairy-tipped bracts.-From S. California eastward through S. Colorado to Arkansas and Texas.

\section{NYCTAGINACEAE Lindl. Four-o'Clock FAmily}

Herbs, with stems more or less swollen at the joints and mostly opposite entire leaves. Calyx tubular or funnelform, 4-5-lobed, usually delicate in texture and more or less colored like a corolla, its persistent base constricted above the 1-celled, 1-seeded ovary and becoming indurated into a nut-like pericarp. Corolla wanting. Flowers umbellately clustered and subtended by an involucre (in our genera). Stamens few, slender. Fruit grooved, ribbed or winged.-(Allioniaceae.)

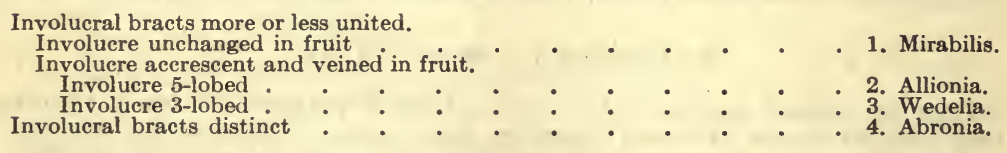

\section{MIRABILIS L. Four-o'ClOCK}

Perennial herbs with opposite leaves nearly equal in the pairs. Peduncles solitary in the axils or paniculate. Involucre calyx-like, 5-lobed, not changed in fruit, 3-6-flowered. Perianth tubular-funnelform. Stamens as long as the perianth; the filaments united at the base. Stigma capitate, granulate. Fruit globose to ovate-oblong, smooth or only slightly ribbed or furrowed. -(Includes Allioniella Rydb.) 
1. Mirabilis multiflora (Torr.) Gray, Bot. Mex. Bound. 173. 1859. Somewhat pubescent but not glandular, widely branched, 3-6 dm. high: leaves broadly ovate or deltoid, 3-7 cm. long, mostly rounded at base, on petioles much shorter than the blades: involucres usually 6-flowered: perianth tubularfunnelform, 3-5 cm. long, pale rose to purple, the ovate lobes shorter than the somewhat greenish tube: fruit 6-8 mm. long, obtuse, slightly ribbed below. Quamoclidion multiflorum Torr.-Colorado to Texas and California.

2. Mirabilis oxybaphoides Gray, 1. c. -Stems procumbent, diffuse, slender: leaves all deeply cordate, on rather long petioles, lowest reniform, upper ones acuminate, often subangled: involucre 3-flowered, deeply 5-cleft, very viscidglandular as is also the peduncles in the loose panicle; lobes ovate, rather acute, a little shorter than the campanulate perianth: stamens 3: fruit subglobose-obovoid, glabrous, destitute of ribs or angles, blackish. (Allioniella oxybaphoides Rydb.) - Colorado to Texas and California.

\section{ALLIONIA Loefl.}

Herbs, simple-stemmed or dichotomously branched, with opposite leaves and flowers in terminal panicles. Involucres mostly 5-lobed, 3-5-flowered, becoming enlarged and reticulate-veined in fruit. Perianth campanulate. Stamens usually 3 , sometimes 5 . Fruit obovoid or clavate, strongly ribbed, pubescent in our species.-Oxybaphus in part.

Stems more or less hirsute from base to summit.

Leaves also hirsute.

Leaves glabrous or nearly so

Stems glabrous below, more or less viscid-puberulent upward.

Leaves ovate or cordate.

Leaves lanceolate to linear.

Perianth-lobes 4, deeply bifid

Perianth-lobes 4-5, entire (?).

Branched from the base; the stems diffuse

Mostly simple and erect.

All the leaves linear

Some of the leaves broadly lanceolate

1. A. hirsuta.

2. A. pilosa.

3. A. nyctaginea.

4. A. glandulifera.

5. A. diffusa.

6. A. linearis.

7. A. lanceolata.

1. Allionia hirsuta Pursh, Fl. Am. Sept. 2: 728. 1814. Rather roughly hirsute or pilose throughout, with jointed hairs, $2-5 \mathrm{dm}$. high: leaves from broadly to narrowly lanceolate or oblong, sessile or the lowest short-petioled: inflorescence rather short: involucre pubescent: stamens 3 or 5: fruit narrowly ovoid, with obtuse ribs, pubescent. Oxybaphus hirsutus.-Minnesota, westward and southward to Colorado.

1a. Allionia hirsuta aggregata (Ortega) A. Nels. A reduced form with the involucres solitary in the axils of the upper leaves. See the analogous forms $2 a$ and $6 a$ below. (Calyxhymenia aggregata Ortega, Nov. or Rar. Pl. 8: pl. 11. 1798.)-Wyoming to the Dakotas.

2. Allionia pilosa (Nutt.) Rydb. Bull. Torr. Bot. Club 29: 690. 1902. Resembling the preceding, but the stem less hirsute, often glabrate except below the nodes: leaves glabrate or finely hirsute, lanceolate or narrower, narrowed but blunt at apex, sessile or nearly so: involucral lobes acute: calyx white, $1 \mathrm{~cm}$. broad: fruit obovoid, 5-ribbed and transversely rugose.-Same range as the preceding and farther south.

2a. Allionia pilosa decumbens (Nutt.) A. Nels. Stems low, with decumbent base: leaves narrower and glabrate: the inflorescence reduced to involucres solitary in uppermost axils. Calymenia decumbens Nutt. Gen. 1: 26. 1818. - The upper Missouri region and said to extend to Mexico.

3. Allionia nyctaginea Michx. Fl. Bor. Am. 1: 100. 1803. Stems somewhat 4-angled, nearly glabrous, 4-8 dm. high: leaves broadly ovate, acute with cordate or rounded base, 4-8 cm. long, petioled, glabrous or glabrate: inflorescence more or less pubescent: perianth red: stamens and style exserted: fruit oblong, pubescent. Oxybaphus nyctaginea. [Allionia floribunda (Choisy) Kuntze, Rev. Gen. 553. 1891.]-New Mexico to Wyoming and far to the eastward. 
4. Allionia glandulifera A. Nels. 'Bot. Gaz. 34: 364. 1902. Erect; simple or branched perennial; stems minutely striate, white, glabrous and shining below, greener upward, 3-5 dm. high: leaves linear to lanceolate, glabrous or the uppermost viscid-pubescent: inflorescence a freely branched cyme, nearly naked, usually densely viscid or glandular-pubescent: involucre about $1 \mathrm{~cm}$. broad, with elliptic-ovate subacute bracts: calyx white or pinkish, broadly funnelform, 7-10 $\mathrm{mm}$. long; its limb deeply 4-lobed, each lobe bifid, giving 8 subequal obtuse. elliptic segments:.fruits ribbed and pubescent.-Throughout the central Rocky Mountains.

5. Allionia diffusa Heller, Minn. Bot. Stud. 2: 33. 1898. Branched from the base and diffusely spreading: stems whitened and glabrous below, the middle part often marked with hairy lines, the inflorescence glandularpubescent: leaves lanceolate to linear: involucres in close terminal cymes, with triangular-lanceolate lobes: calyx rose-color, its lobes broadly obovate.Said to occur from N. Dakota to Kansas and Arizona.

6. Allionia linearis Pursh, Fl. Am. Sept. 2: 728. 1814. Glabrous except for a glandular-puberulence above; stems slender, erect, 3-6 dm. high: leaves linear, thick, 3-9 cm. long: involucral lobes broadly ovate, obtuse: calyx campanulate, purple, with ovate lobes: stamens and style exserted as is also the case in the two preceding species: fruit oblong-ovoid, ribbed and tuberculate, pubescent. Oxybaphus angustifolius. ' (A. divaricata Rydb. 1. c.)From the base of the Rocky Mountains eastward into the plains and south to Texas.

6a. Allionia linearis Bodinii (Holz.) A. Nels. A low form with reduced inflorescence, the lower involucres often solitary in the axils. Oxybaphus Bodinii Holz. Contrib. U. S. Nat. Herb. 1: 287. 1893.-From Wyoming to New Mexico.

7. Allionia lanceolata Rydb. 1. c. 691. 1902. A branched perennial; stems erect or ascending, glabrous below, viscid-pubescent with short hairs, 4-15 dm. high: lower leaves short-petioled, the upper sessile; blades lanceolate or ovate-lanceolate to almost linear, 3-10 cm. long, very thick, obtuse or blunt at the apex: involucres numerous, in terminal cymes, 1-1.5 cm. wide, lobes rounded-ovate, sometimes acutish: perianth pink, about $10 \mathrm{~mm}$. broad: fruit obovoid, $4.5-5 \mathrm{~mm}$. long, with usually 4-5 broad ribs and finely tuberculate faces. (A. sessilifolia Osterh. Bull. Torr. Bot. Club 32: 611. 1905.) -Minnesota to Colorado and Texas.

\section{WEDELIA Loeff.}

Annual or perennial herbs, with opposite very unequal leaves, and axillary pedunculate flowers. Perianth with an oblique 4- or 5-lobed limb. Fruit ovate, compressed, smooth and convex on the inner side.

1. Wedelia incarnata (L.) Kuntze, Rev. Gen. Pl. 533. 1892. Stems slender, branching, prostrate; pubescence viscid, short or floccose: leaves ovate: lobes of the involucre concave: calyx rose-colored or white: fruit with a double line of tubercles on the back, surrounded by a rigid winged margin, toothed and inflexed: stamens 3. Allionia incarnata.-Southern Colorado to Texas and California.

\section{ABRONIA Juss.}

Often prostrate, and usually more or less viscid-pubescent, with thick opposite unequal leaves, and elongated axillary and terminal peduncles; flowers usually very fragrant and showy. Tube of the perianth elongated, and the limb of 5 (or 4 ) obcordate or emarginate segments. Stamens unequal, adnate to the tube. Fruit coriaceous or indurated, 1-5-winged, mostly reticulately veined, inclosing a smooth cylindrical achene.-(Includes Tripterocalyx Hook.) 
Perennials; fruit coriaceous, the narrow wings not encircling the fruit.

Flowers white, 2-3 cm. long.

Leaves glabrous; fruit-wings narrow

Leaves puberulent; fruit-wings broad

Flowers greenish, $2 \mathrm{~cm}$. or less long.

Involucral bracts 4-5 mm. long; fruit biturbinate

Involucral bracts 7-15 mm. long; fruit turbinate

Annuals; wings of fruit broad, orbicular, net-veined.

Wings of fruit double; terminating above in disks

Wings of fruit single; completely encircling it.

Prostrate; wings of fruit emarginate

Erect; wings of fruit entire
1. A. fragrans.
2. A. salsa.
3. A. ammophila.
4. A. elliptica.
5. A. Carletonii.
6. A. micrantha.
7. A. cycloptera.

1. Abronia fragrans Nutt. Hook. Kew Journ. Bot. 5: 261. 1853. From nearly glabrous and somewhat glaucous to moderately white-hirsute and viscid; perennial, with branched ascending or erect stems, $2-6 \mathrm{dm}$. high: leaves from oval to oblong-elliptic, obtuse, the base rounded or cuneate, 3-7 cm. long: involucral bracts ovate-oblong or obovate, 1-2 cm. long: flowers very numerous, white, $2-3 \mathrm{~cm}$. long: fruit coriaceous, with $2-5$ narrow wings.From Montana to New Mexico and eastward to the Missouri.

1a. Abronia fragrans gla ucescens A. Nels. Bot. Gaz. 34: 364. 1902. Stems glabrous at least below, slightly puberulent and viscid toward the inflorescence: leaves glabrous, pale green above and more or less glaucous beneath: fruit terminating in a conical beak one third as long as the narrowly winged obconical body.- Northern Colorado to Montana and westward to Oregon.

2. Abronia salsa Rydb. Bull. Torr. Bot. Club 29:684. 1902. Resembling the preceding, but densely viscid-pubescent especially above, and with very evident puberulence on the oval or elliptic leaves: bracts rounded obovate, $15 \mathrm{~mm}$. long: flowers many, $2 \mathrm{~cm}$. long; the limb $4 \mathrm{~mm}$. broad: fruit cuneateobpyramidal, $8 \mathrm{~mm}$. long, $6 \mathrm{~mm}$. broad including the rather thick wing. (A. fallax Heimerl, Rydb. 1. c.)-Western Colorado and Utah.

3. Abronia ammophila Greene, Pitt. 4: 226. 1900. Glandular-puberulent throughout: stems decumbent or prostrate, 2-4 dm. long: leaves oblongelliptic, obtuse: involucral bracts membranous, oblong, acute, 4-5 mm. long: flowers numerous, greenish or ochroleucous: fruit tapering to both ends, with about 5 low and rounded crests, densely glandular-pubescent. (A. pumila Rydb. Bull. Torr. Bot. Club 29: 683. 1902.) - On the sandy beaches of Yellowstone Lake.

4. Abronia elliptica A. Nels. Bull. Torr. Bot. Club 26: 7. 1900. Glabrous except for a minute viscid puberulence upon the stems and inflorescence; stems decumbent at base, assurgent-erect, 1-3 cm. long: leaves elliptic or ovate, obtuse, the base rounded or subcordate: involucral bracts mostly obovate, obtuse or acutish, 7-15 mm. long: flowers greenish-white, numerous, 15-20 mm. long: fruit obscurely pubescent, turbinate; wings usually 5 , narrow, with rounded obtuse summits. (A. Bakeri Greene, Pl. Baker. 3: 32. 1901; A. glabra Rydb. Bull. Torr. Bot. Club 29: 685. 1902.)-Desert areas; Wyoming and northern Colorado and Utah.

5. Abronia Carletonii Coult. \& Fish. Bot. Gaz. 17: 349. 1892. Stems procumbent, slender, whitish, minutely glandular, $2.5-4 \mathrm{dm}$. long: leaves very thick, linear-oblong or oblong-ovate, with cuneate base and revolute margins: peduncles very slender, as long as the leaves: involucral bracts 5 , rosecolor, oblong-lanceolate, attenuate or cuspidate, $6 \mathrm{~mm}$. long: flowers numerous: perianth rose-color, with obcordate lobes: fruit longer than broad, scarcely coriaceous, with the 5 wings coarsely reticulated and terminating above in disks.-Eastern Colorado.

6. Abronia micrantha (Torr.) Chois. in DC. Prodr. 132: 436. 1849. Annual, prostrate: peduncles shorter than the petioles: flowers small and inconspicuous, reddish-green, the limb scarcely $4 \mathrm{~mm}$. broad: fruit with 3 thin wings, emarginate above and below, the body rather broad and with a light spongy exterior.-On sandy plains; Montana to New Mexico.

7. Abronia cycloptera Gray, Am. Journ. Sci. II. 15: 319. 1853. Annual, stouter: flowers large and showy, upon elongated peduncles: fruit with firmer and more prominently veined wings, emarginate at neither end, the firm 
smooth narrow body usually 3-nerved. (A. carnea Greene, Pitt. 3: 343. 1898.) -Southern Colorado, New Mexico, and Texas.

\section{AizoACEAE A. Br. Carpet Weed Family}

A miscellaneous group, chiefly of fleshy or succulent plants, with mostly opposite leaves and no stipules; differing from Caryophyllaceae and Portulacaceae by having distinct partitions to the ovary and capsule. Stamens sometimes numerous, as in Cactaceae. Petals wanting in ours.-Ficoideae.

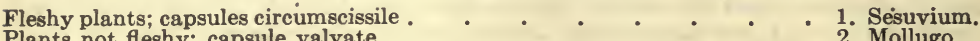

Plants not fleshy; capsule valvate $: \quad 0^{-}: 0^{-} 2$. Mollugo.

\section{Sesuvium L.'Sea Purslane}

Smooth branching mostly prostrate herbs. Leaves opposite, linear to spatulate, entire. Flowers axillary and terminal, solitary or clustered. Calyxtube turbinate; the lobes apiculate on the back near the top, membranously margined. Styles 3-5. Capsule ovate-oblong.

1. Sesuvium sessile Pers. Syn. 2: 39. 1805. Erect and dichotomously branched; stems smooth or nearly so: leaves linear-oblong to spatulate, subacute or obtuse, 2-4 cm. long: flowers sessile, 6-10 $\mathrm{mm}$. long: sepals horned on the back near the apex: stamens many. S. Portulacastrum.-On saline plains; southern Colorado and throughout the southwest.

\section{Mollugo L. Carpet Weed}

Low and much branched, glabrous annuals. Leaves spatulate to linearoblanceolate, entire, opposite and apparently verticillate. Flowers mostly on long pedicels, axillary. Stamens hypogynous. Styles 3 . Seeds longitudinally sulcate on the back.

1. Mollugo verticillata L. Sp. Pl. 89. 1753. Prostrate-spreading, glabrous, not fleshy: leaves $5-6$ in each verticil, obtuse: pedicels umbellately fascicled at the nodes: capsule oblong-ovoid: seeds shining.- Colorado and New Mexico, and across the continent.

\section{PORTUlaCaceae Reichenb. Purslane Family}

More or less succulent herbs, with simple and entire leaves (either opposite or alternate) and regular but unsymmetrical perfect flowers. Sepals (except in Lewisia) 2. Petals $2-5$ or more. Stamens opposite the petals or numerous. Ovary 1-celled, in fruit becoming capsular; style 2-8-cleft. Stipules none or scarious or reduced to hairs. Flowers open only in sunshine or bright daylight.

Ovary free from the calyx; capsule valvate, except in Lewisia.

Sepals herbaceous; capsule 3-valved from summit, with 3 stigmas. Calyx deciduous and the petals ephemeral

Calyx persistent and the petals often marcescent.

Roots cormose or fleshy

Roots fibrous or rhizomatous
Sepals somewhat scarious; capsule 2-valved, with 2 stigmas. Annuals; style short or wanting.

Perennials; style very long
Stamens 5-40; capsule circumscissile near base

Ovary adnate to calyx below the middle; capsule circumscissile near the middle.

1. Talinum.

2. Claytonia.

3. Montia.

4. Calyptridium.

5. Spraguea.

6. Lewisia.

7. Portulaca. 


\section{TALINUM Adans.}

Low glabrous herbs, mostly with linear leaves (clustered near the base), without stipules, and usually white or pink cymose flowers. Sepals deciduous (tardily in ours). Petals 5 , fugacious. Stamens adherent to the base of the petals. Style 3-lobed or 3-cleft. Seeds numerous.

1. Talinum parviflorum Nutt. T. \& G. Fl. N. A. 1: 197. 1838. Stem short, from thick fleshy branching roots: leaves terete or nearly so, broadened at the base: scape-like peduncles slender, $5-20 \mathrm{~cm}$. high: flowers pink, in loose cymes: sepals ovate: stamens 5 : capsule ovoid. T. teretifolium.-In dry soil; Minnesota to Colorado and southward.

\section{Claytonia L. Spring Beauty}

Low glabrous succulent perennial herbs with a pair of opposite stem leaves (alternate in $C$. megarrhiza) and usually 1 or more radical ones. Flowers white, yellow, or rose-colored, in naked loose terminal simple or paniculate racemes. Sepals 2, persistent. Style 3-cleft. Capsule 3-valved. Seeds not more than 6, compressed, orbicular or reniform.

Radical leaves and the stems from a tuber-like corm.

Flowers yellow.

Flowers white or pink, with pink or purple veins.

Radical leaves usually more than 1, always present

Radical leaves only 1 , or wanting.

Petals retuse or obcordate; sepals obtuse

Petals rounded-obtuse; sepals subacute

Radical leaves and stems from a thick caudex

1. Claytonia aurea A. Nels Bull Torr. Bot. Club 27: 260. 1900. Corm 1. Claytonia aurea A. Nels. Burl. Torr. Bot. Club 27: 260. 1900. Corm large, deep-set: radical leaf oblong or oblanceolate, not more than half as long as its slender petiole; cauline sessile by a narrowed base, linear-lanceolate, 2-4 cm. long: stems 1-5 from each corm, rather stout, 1-2 dm. high: raceme many-flowered, rather long-peduncled: sepals rhomboidal or suboval: petals large, golden-yellow, oval, abruptly narrowed into a short claw.-Type locality, Henry's Lake, Idaho; probably in Wyoming and Utah.

2. Claytonia multicaulis A. Nels. 1. c. Corms large, $15-25 \mathrm{~mm}$. in diameter, near the surface of the ground: radical leaves usually more than one (often several), oblong or lanceolate, as long as the petiole; cauline similar, sessile: raceme short-peduncled, 5-9-flowered; pedicels subumbellate, slender, the lowest with an obtuse green bract at the base: sepals obtuse, half as long as the elliptic or oval short-clawed petals, turning yellowish in drying: petals white with purplish veins, yellowish at base when dry.-Collected first in Yellowstone Park; apparently from Colorado to Montana.

3. Claytonia lanceolata Pursh, Fl. Am. Sept. 1: 175. 1814. Corm rather small, 7-15 $\mathrm{mm}$. in diameter: radical leaf, when present, oblong-lanceolate, scarcely half as long as the slender petiole; cauline sessile, oblong-lanceolate to elliptic: raceme few-several-flowered, sessile between the paired leaves, rarely longer than the leaves: sepals elliptic, obtuse: petals retuse or emarginate or obcordate. C. caroliniana.-From northern Wyoming far northward and westward.

4. Claytonia rosea Rydb. Bull. Torr. Bot. Club 31: 404. 1904. Much like the preceding: cauline leaves oblong-lanceolate or narrower, $2-5 \mathrm{~cm}$. long: raceme peduncled, surpassing the leaves: sepals subacute: petals spatulate to obovate, entire, rounded-obtuse, pale rose-color, with purple veins. $C$. caroliniana sessilifolia.-Common on moist slopes; throughout our range.

5. Claytonia megarrhiza (Gray) Parry, in Wats. Bibl. Index 118. 1878. Perennial, with a thickened caudex: root fusiform, very large: leaves fleshy; radical ones petioled; cauline lanceolate or linear-lanceolate, sessile: racemes secund: flowers large, profuse, white with pinkish veins: petals obovate, subemarginate.-High alpine, growing in crevices of the rock, its large purple tap-root penetrating to a great depth; mountains of Colorado, Utah, and Wyoming.

ROCKY MT. BOT. -12 


\section{MONTIA Micheli}

Low glabrous and succulent herbs with delicate pale or white flowers in loose axillary or terminal simple or compound racemes. Sepals 2, rarely 3, persistent. Petals usually 5, rarely 3 or wanting, more or less united at base, usually unequal, 3 of them a little smaller than the other 2. Stamens 3-5, inserted un the base of the corolla, opposite its lobes. Ovary 3-ovuled. Capsule 3-valved, 1-3-seeded.-Claytonia in part.

Perennial by stolons, also rooting at the joints .

Annuals.

Leaves all linear

Cauline leaves connate, forming a disk-like involucre

1. M. Chamissonis.

2. M. linearis.

1. Montia Chamissonis (Eschs.) Greene, Fl. Francis 180. 1891. Stems weak, decumbent, 1-3 dm. long, stoloniferous at base and rooting at the nodes, often bearing bulblets at the ends of short branchlets or in the axils of the lower leaves: leaves oblong, or oblanceolate, 1-2 cm. long, somewhat fleshy: calyx small: petals white, obovate-oblong, entire, 3-4 times as long as the sepals: seeds tuberculate-roughened.-In cold springy or boggy places; frequent in our range and west to the Pacific.

2. Montia linearis (Dougl.) Greene, 1. c. Stems branching, erect or diffuse, 5-12 cm. high: all the leaves linear, $2-3 \mathrm{~cm}$. long: racemes several or many: petals white, unequal, scarcely longer than the rather large obtuse sepals: stamens 3: seeds large, orbicular, compressed, smooth and shining.-Possibly extending into our range at the northwest.

3. Montia Viae A. Nels. Bot. Gaz. 42: 48, 1906 . Annual, with fibro: 3 roots; stems and petioles weak, suberect, 10-15 $\mathrm{cm}$. high: leaves delicately thin, pale green; the radical several, slender-petioled, the short blades from linear to oval, acute; the single pair of cauline connate and forming a circular disk 10-20 $\mathrm{mm}$. broad, involucre-like below the inflorescence: raceme peduncled, with a pair of green bracts at the base of the lower pedicels: flowers very small, several: sepals broadly oval, even in fruit less than $2 \mathrm{~mm}$. long: petals 5 , spatulate, barely equaling the sepals, very delicate, apparently often wholly wanting: stamens 5 , very short: ovule solitary; the seed small, oval, slightly compressed and subcarinate, minutely but distinctly papilloseroughened and with a waxy-looking conspicuous strophiole.-On shady muddy banks; northern Wyoming to Utah.

\section{CALYPTRIDIUM Nutt.}

Glabrous and rather succulent herbs, with alternate leaves, and small ephemeral flowers in scorpioid solitary or clustered scorpioid spikes. Sepals 2, broadly ovate or cordate-orbicular, scarious, usually persistent. Sepals 2-4. Stamens 1-3. Style bifid: Capsule membranaceous, 2-valved, 6-12-seeded.

1. Calyptridium roseum Wats. Bot. King's Exp. 44. 1871. Diffuse and nearly prostrate, branches 5-12 cm. long: leaves oblong-spatulate, obtuse: sepals unequal, nearly orbicular, scarious margined: petals 2 , minute, broadly obovate, with narrowed base: capsule oblong-ovate, not exceeding the calyx.Western Wyoming and westward.

\section{SPRAGUEA Torr.}

Glabrous biennials, with mostly radical fleshy leaves and ephemeral flowers in dense scorpioid spikes umbellate-clustered on scape-like peduncles. Sepals unequal, -orbicular-cordate. Petals 4. Stamens 3. Style 2-cleft. Capsule 2-valved.

1. Spraguea multiceps Howell, Erythea 1: 39. 1893. Depressed branching perennial: stems $3-12 \mathrm{~cm}$. long, very leafy below: leaves 7-12 $\mathrm{mm}$. long, or 
more on young plants, spatulate or oblanceolate, with short thick petiole: peduncle solitary, terminating the short lateral branchlets: flowers in dense capitate clusters: sepals scarious, $4-8 \mathrm{~mm}$. broad, as long as the obqvate petals: stamens and style conspicuously exserted. S. umbellata.-Northwestern Wyoming to Oregon.

\section{LEWISIA Pursh. Bitterroot}

Low somewhat fleshy perennials with a thick fleshy root and caudex (in L. triphylla a small corm), the crown bearing a rosulate cluster of leaves and short-1-flowered scapes or scapose stalked panicles. Flowers conspicuous, varying from white to red. Sepals 2-8. Petals 3-16. Style-branches slender, 3-8. Capsule thin, globose-ovate, circumscissile near the base and splitting upwards from the line of dehiscence. Seeds usually many. - Lewisia in part, Calandrinia, and also Erocallis Rydb.

Sepals large, 6-8

Sepals smaller, only 2 .

Root vertical, somewhat fusiform.

Leaves linear; seeds 60-80

Leaves spatulate-lanceolate; seeds 10-20

Root a small corm

1. L. rediviva.

2. L. minima.

3. L. pygmaea.

4. L. triphylla.

1. Lewisia rediviva Pursh, Fl. Am. Sept. 2: 368. 1814. Leaves densely clustered, linear-oblong, subterete, smooth and glaucous: scapes but little longer, jointed at the middle, and with 5-7 subulate scarious bracts verticillate at the joint: petals rose-colored or white--Arizona, Utah, Wyoming, Montana (in the Bitter Root Mountains), and westward; the specific name refers to the fact that the roots are wonderfully tenacious of life; the state flower of Montana.

2. Lewisia minima A. Nels. Root short conical or napiform: leaves fewseveral, narrowly linear, 4-7 cm. long: scapes rarely equaling the leaves, each with a small pair of bracts about one third its length from the base, geniculately and divergently flexed near the node: sepals suboval, abruptly acuminated into a short tooth, sometimes with one or two smaller lateral teeth, no glandulosity: petals white: capsule large: seeds smooth and shiny, 60-80 in each capsule. (Oreobroma minima. A. Nels. Bull. Torr. Bot. Club 27: 260. 1900.)-Yellowstone Park.

3. Lewisia pygmaea (Gray) Robins. Syn. Fl. 1: 268. 1897. Root fusiform with a thickened farinaceous caudex: leaves broadly linear to spatulate or lance-oblong: scapes mostly well surpassing the leaves: sepals somewhat truncate, erose-dentate, with gland-tipped teeth: petals 6-8, rose-red: ovules and seeds 10-20. Calandrinia pygmaea.-Alpine; in our range and northward and westward.

4. Lewisia triphylla (Wats.) Robins. 1. c. Stems slender, from a small globular corm: cauline leaves a pair or usually a whorl of 3 , linear, sessile, 3-5 cm. long: racemose cyme several-flowered; the pedicels slender, erect in fruit: petals $3-10$, about $4 \mathrm{~mm}$. long: capsule oblong-conical. (Claytonia triphylla Wats. Proc. Am. Acad. 10: 345. 1875; Erocallis triphylla Rydb. Bull. Torr. Bot. Club 33: 140. 1906.) This plant has the appearance of a true Claytonia and would be placed in that genus but for the structure of the capsule. -Subalpine; from Colorado northward and west to California and Washington.

\section{PORTUlaca L. Pursllane}

Fleshy diffuse or ascending annuals with terminal or axillary ephemeral yellow flowers. Sepals 2, united below and adnate to the ovary, the free upper portion at length deciduous. Petals 4-6. Stamens 7-20. Capsule circumscissile near the middle.

1. Portulaca oleracea L. Sp. Pl. 445. 1753. Glabrous; stems terete: leaves cuneate, obtuse: calyx-lobes ovate, acute: stamens 7-12: style-lobes 5-6: 
seeds black, tuberculate. $P$. retusa (?).-A weed now more or less common in cultivated grounds in many parts of the world.

\section{CARYOPHYLLACEAE Reichenb.-PINK FAmily}

Herbs with opposite stipulate or exstipulate leaves and regular and mostly perfect flowers. Stems usually swollen at the nodes. Sepals 4 or 5, persistent. Petals 4 or 5 (or rarely wanting), often with a spreading blade and a distinct claw crowned with an appendage at its summit. Stamens commonly twice as many. Ovary 1-celled, with a free central placenta. Seeds reniform, many, or by abortion few. Fruit a capsule, mostly 3-valved, opening to the base, or the valves bifid and opening by six teeth at the summit.

Sepals united, forming a tubular or ovoid calyx.

Ribs or nerves of calyx 10 or more.

Calyx-teeth foliaceous

Calyx-teeth short.

Styles 3

Styles 5

Ribs or nerves of calyx 5

Sepals distinct or nearly so.

Petals deeply emarginate or bifid.

Capsule dehiscent to the base; styles mostly 3 . . . . 5. Stellaria.

Capsule dehiscent to the base; styles mostly 3
Capsule opening at summit only, by teeth; styles mostly $5^{\star}$ : $\quad$ - $\quad$ 6. Cellaria.

Petals entire or barely emarginate.

Stipules wanting.

Styles 5

Styles 3.

Seeds not appendaged at the hilum

Seed with an appendage (strophiole)

Stipules present, usually scarious and conspicuous.

Capsule opening by 3 valves to the base

Capsule indehiscent, or essentially an achene

1. Agrostemma.

2. Silene.

3. Lychnis.

4. Saponaria.

7. Sagina.

8. Arenaria.

9. Moehringia.

10. Spergularia.

11. Paronychia.

\section{AgROSTEMMA L. CoRN COCKLE}

An herbaceous annual (or biennial), with linear leaves and purplish-red flowers. Calyx ovoid, strongly 10-ribbed; its teeth prolonged into foliaceous appendages. Petals 5, unappendaged. Stamens 10. Styles 5.

1. Agrostemma Gigatho L. Sp. Pl. 435. -1753. Densely silky-pubescent, 3-5 dm. high, somewhat branched: leaves 5-10 cm. long: flowers few, large, long-peduncled: calyx-lobes 2-3 cm. long: petals obovate.-A troublesome weed; introduced into fields in seed grain.

\section{Silene L. Catchfly. Campion}

Herbaceous annuals or perennials, with opposite leaves and white, yellowish, or purple flowers. Calyx tubular, 5-toothed, 10-nerved or sometimes manynerved. Petals bifid or sometimes 4-cleft, with a conspicuous claw and usually an appendage (crown) at the base of the blade, borne with the stamens on a stipe (carpophore) under the ovary. Capsule dehiscent at the mostly 6-toothed summit. Styles 3. Seeds many.

\section{Annuals.}

Viscidly hirsute-pubescent . . . . . . . . 1. S. noctiffora.

Nearly glabrous; glutinous on one or more of the upper internodes : 2. S. antirrhina.

Perennials.

Acaulescent-caespitose . . . . . . . . . 3. S. acaulis.

Stems 1-7 dm. high.

Flowers in a paniculate leafy cyme

Flowers in a narrow mostly leafless cyme or thyrse.

Petals cleft into 4 or more segments

4. S. Menziesi

Petals 2-cleft.

Plants low (1-3 dm.); flowers few, mostly in 5-flowered longpedunculate cymes. 
Calyx short, less than $1 \mathrm{~cm}$.

Calyx 10-15 mm. long

6. S. tetonensis.

Plants taller (3-7 dm.); flowers usually many, in a spike-like 7. S. multicaulis. thyrse.

Flowers nodding; petals purple

Flowers erect; petals white or purplish

8. S. Hallii.

9. S. Scouleri.

1. Silene noctiflora L. Sp. Pl. 419. 1753. A coarse viscid-pubescent or hirsute weed, 3-5 dm. high: leaves lanceolate or broader: flowers few, in loose cymes, fragrant: calyx ovoid, white with green nerves and attenuate teeth: petals bifid, white or pinkish. Night-Blooming Catchfly.-Waste and cultivated grounds; sparingly introduced in our range.

2. Silene antirrhina L. Sp. Pl. 419. 1753. Glabrous annual, with one or more of the upper internodes glutinous: stems erect, slender, somewhat branched, 2-5 dm. high: leaves lanceolate or linear: flowers in a dichotomous panicle, on long pedicels: calyx becoming expanded by the enlarging capsule: petals pink.-Across the continent.

3. Silene acaulis L. Sp. Pl. Ed. 2. 603. 1762. DDwarf tufted perennial, glabrous or nearly so: leaves linear, 8-12 mm. long, crowded: flowers solitary, terminal, usually nearly sessile, sometimes naked-pedunculate: calyx campanulate: petals entire or emarginate; purple or purplish, a small scale at the summit of the claw: capsule equaling or surpassing the calyx.-Alpine summits throughout the Rocky Mountains.

4. Silene Menziesii Hook. Fl. Bor. Am. 1: 90. pl. 30. 1830. Glandularpuberulent: stems dichotomously branched, leafy, spreading or decumbent, 1-3 dm. high: leaves ovate-lanceolate or oblong: peduncles lateral or in the forks of the branches, 1-flowered, equaling the leaves: petals white or pink, crownless, longer than the calyx: capsule equaling the calyx: seeds black, obscurely tuberculate. (S. stellarioides Nutt.) - From New Mexico far northward and westward to the coast.

5. Silene oregana Wats. Proc. Am. Acad. 10: 343. 1875. Viscid-pubescent and with fetid odor: stems solitary or several, erect, simple, with racemiform or paniculate inflorescence: leaves oblanceolate, tapering to long petioles; the upper narrower, tending to become lance-linear: calyx cylindrical, contracted at base around the stipe of the capsule: petals white, clawed, bearing a crown of two ear-like appendages at the summit of each claw; the blades 4-6-cleft into linear segments: capsule distinctly stipitate.-From northern Wyoming to Oregon.

6. Silene tetonensis E. Nels. Bot. Gaz. 30: 117. 1900. Minutely pubescent and above also glandular, 1-2 dm. high: stems several, erect: leaves connatesheathing at base, linear, or narrowly oblanceolate, $2-8 \mathrm{~cm}$. long; the lower with ciliate-margined petioles: calyx obovoid, 7-10 $\mathrm{mm}$. long, purple-nerved: petals 9-12 mm. long, greenish-white or rose-color, crownless, deeply emarginate or cleft to the middle: stipe very short.-Northwestern Wyoming and probably in the mountains of Idaho and Montana.

7. Silene multicaulis Nutt. T. \& G. Fl. N. A. 1: 192. 1838. Grayishtomentulose and sparingly glandular: stems usually several to many, erect, slender, 2-3 dm. high: leaves narrowly lanceolate or oblong, suberect and tapering to both ends, the upper much reduced: flowers mostly in short 3-flowered cymes, pale red: calyx ovate-cylindrical, $12-15 \mathrm{~mm}$. long: petals bifid and crowned with short auriculate appendages.-From the western slopes of our mountains to the Pacific.

8. Silene Hallii Wats. Proc. Am. Acad. 21: 446. 1886. Densely glandularpubescent, 2-5 dm. high: stems several, from a stout root: leaves oblanceolate, tapering to the base, the lower part of the midrib prominent: flowers verticillately spicate, more or less nodding: calyx oblong-campanulate, becoming obovate, strongly green or purple nerved; its teeth triangular, acute, with thin incurved margins: petals purple, with broad ciliate claws and short bifid blades: capsule ovate, short stipitate.-In the high mountains of Colorado and Wyoming,

9. Silene Scouleri Hook. Fl. Bor. Am. 1: 88. 1830. Pubescent and above 
glandular-viscid: stems from a stout root, simple, erect, 4-8 dm. high: leaves from oblanceolate to lance-linear: flowers verticillate, in a long spikelike thyrsus: calyx clavate; its teeth short, ciliate, and with broad membranous margins: petals white or purplish, with slightly laciniate auricles: capsule stipitate.-Frequent in the mountains; from Colorado to the far northwest.

\section{LYCHNIS L. CockLE}

Perennials with the aspect and many of the characters of Silene. Leaves linear to oblanceolate. Calyx more or less inflated, 5-toothed or 5-lobed. Styles 5. Capsule 5-10-toothed. Seeds with a loose membranous margin or tuberculate.

Dwarf and caespitose, with 1-flowered stems.

Petals included, the claw narrow

Petals exserted, the claw broad

Tall, erect, with simple stems

1. L. montana.

2. L. Kingii.

3. L. Drummondii.

1. Lychnis montana Wats. Proc. Am. Acad. 12: 247. 1877. A dwarf caespitose alpine perennial with 1-flowered stems; glandular pubescent above, nearly glabrous below: petals included or nearly so, the emarginate blade not broader than the very narrow claw; appendages very small: seeds rather broadly membranous margined.-Mountain peaks of 'Colorado and Utah.

2. Lychnis Kingii Wats. 1. c. Pubescent throughout: petals exserted, with a broad, ciliate, rather broadly auricled claw and a short broad bifid blade: filaments ciliate.-Northern Utah and probably Idaho and Wyoming.

3. Lychnis Drummondii Wats. Bot. King's Exp. 37. 1871. Finely glandularpubescent above: stems rather stout, 1 or more, 2-5 dm. high, from a stout vertical root: basal leaves oblanceolate; the upper lance-linear: flowers few, on stout often elongated appressed pedicels: petals included or slightly exserted, white or purple; the entire or emarginate blade narrower than the auricled claw: seeds tuberculate. (L. striata Rydb. Bull. Torr. Bot. Club 31: 408. 1894.)-From New Mexico northward and westward.

\section{SAPONARIA L. WHEAT CockLe}

Ours a rather handsome annual weed with sessile and somewhat connate leaves and a broad open flat-topped corymb of showy rose-red flowers. Calyx tubular or ovoid, strongly 5-angled. Petals 5, not crowned. Stamens 10. Styles 2. Capsule dehiscent at apex by 4 teeth.

1. Saponaria Vaccaria L. Sp. Pl. 409. 1753. Glabrous: stem branched above, 2-4 dm. high: leaves ovate-lanceolate: calyx sharply 5-angled, enlarged in fruit. [Vaccaria Vaccaria (L.) Brit.]-Naturalized from Europe; not infrequent.

\section{Stellaria L. Starwort. Chickweed}

Low herbs, mostly somewhat tufted and diffuse, with solitary or cymose white flowers. Sepals distinct or nearly so. Petals 2-cleft (or wanting), without crown or claw and inserted with the stamens on the margin of a disk under the sessile ovary. Stamens 10 or fewer. Styles usually 3. Capsule globose to oblong, dehiscent by twice as many valves as there are styles. -Alsine of recent American authors.

Floral bractlets small and scarious.

Petals wanting; pedicels subumbellate

Petals present, equaling or surpassing the calyx; seeds smooth.

Flowers in a diffuse cyme, on filiform widely spreading or deflexed pedicels

Flowers solitary or few, on erect or ascending pedicels.

Pedicels filiform; unequal

Pedicels stout, subequal

1. S. umbellata.

2. S. longifolia.

3. S. longipes.

4. S. valida. 
Floral bractlets foliar or the pedicels axillary to true leaves.

Petals shorter than the sepals or wanting.

Stems erect; leaves lanceolate.

Stems prostrate; leaves ovate.

Petals equaling or exceeding the sepals. Glabrous

Viscid-pubescent

1. Stellaria umbellata Turcz. Bull. Soc. Nat. Mosc. 89. 1838. Glabrous: stems slender, weak, ascending from a decumbent rooting base: leaves from elliptic-oblong to lance-linear: flowers in a simple or compound subumbellate cyme; the pedicels filiform-elongated; the bractlets minute and scarious: sepals small, 2-3 mm. long, glabrous: petals wanting: capsule twice as long as the sepals. (Alsine baicalensis Coville, Contrib. U. S. Nat. Herb. 4: 70. 1893.) - From New Mexico to Montana and west to California.

2. Stellaria longifolia Muhl. Willd. Enum. 479. 1809. Stems sharply 4-angled, 1-2 dm. high, mostly slender and weak: 'leaves linear or broader, narrowed to both ends, 2-4 cm. long: cyme open, many-flowered; the pedicels filiform, widely divergent or deflexed; the bractlets minute and scarious: petals and capsule longer than the calyx.-Throughout our range, and across the continent to the northward.

3. Stellaria longipes Goldie, Edinb. Phil. Journ. 6: 327. 1822. Shining or somewhat glaucous, very smooth: leaves ascending, lanceolate or linearlanceolate, broadest at the base: cyme terminal, few-flowered; the long unequal pedicels erect.-Colorado and northward, thence across the continent.

$3 a$. Stellaria longipes laeta Wats. Smaller, only $5-12 \mathrm{~cm}$. high, usually very glaucous, leafy below, the cyme often reduced to a solitary long-pediceled flower; as in the species the capsule is dark-colored and somewhat acute.Same range.

4. Stellaria valida L. N. Good. Bot. Gaz. 33: 69. 1902. Glabrous: stems 4-angled, 1-2 dm. high, branched: leaves lanceolate, tapering from the base, 1-3 cm. long: cyme compound, its rays and pedicels subequal; the bractlets small and scarious; pedicels rigid, spreading: petals deeply bifid, scarcely longer than the sepals: the dark brown capsule twice as long as the sepals: styles recurved and crested with fine short bristles.-Type locality, Centennial Valley, southern Wyoming.

5. Stellaria borealis Bigel. Fl. Bost. Ed. 2: 182. 1824. Glabrous or pubescent, erect or spreading: stems weak, somewhat branched: leaves oblong to lance-linear, thin, their margins often ciliate: cyme dichotomously compound, with foliose bracts and slender pedicels: petals shorter (or wanting) than the ovate-lanceolate sepals which are much surpassed by the oblong capsule: seeds smooth. (Alsine calycantha Rydb. Bull. Torr. Bot. Club 24: 244. 1897.)-Frequent in the mountains; from Colorado northward.and across the continent.

6. Stellaria obtusa Engelm. Bot. Gaz. 7: 5. 1882. Glabrous: the short stcms prostrate: leaves ovate, acute, $6-8 \mathrm{~mm}$. long: flowers solitary, on short axillary peduncles: petals wanting: capsule obtuse, longer than the obtuse sepals: seeds brown, covered with minute oblong tubercles with fringed edges (visible only under a strong lens).-Infrequent; in the mountains, Colorado, northward and westward.

7. Stellaria crassifolia Ehrh. Hannov. Mag. 8: 116. 1784. Glabrous: the stems weak, erect or diffuse: leaves slightly fleshy, from linear-lanceolate to oblong: flowers terminal or in the forks of the stem or the axils of the foliar bracts: petals longer than the lance-oblong acute sepals: capsule ovoid, longer than the sepals: the seeds rough.-Throughout our range and extending to eastern and arctic America.

8. Stellaria Jamesiana Torr. Ann. Lyc. N. Y. 2: 169. 1828. Viscidpubescent above: stems sharply 4-angled: leaves lanceolate, 5-10 cm. long, attenuate, broadest at the sessile base: flowers in a leafy terminal panicle: petals twice as long as the oblong acute sepals: seeds rough.-From New Mexico to Wyoming and westward. 


\section{CERASTIUM L. ChICKWEed}

Mostly low pubescent or hirsute herbs with white flowers in terminal leafy or scariously bracted dichotomous cymes. Sepals distinct. Petals emarginate or bifid. Stamens 10. Styles 5. Capsule often incurved, twice or thrice the length of the sepals, opening by about 10 apical teeth. Seeds rough.

\section{Annuals.}

Leaves less than $20 \mathrm{~mm}$. long; pedicels not longer than the capsule.

Rays and pedicels strongly swollen at base

Rays and pedicels same diameter as the node

Leaves more than $20 \mathrm{~mm}$. long; pedicels much longer than the capsule.

Capsule long-exserted

Capsule nearly wholly included

Perennials.

Petals scarcely longer than the sepals.

Leaves sparse

Leaves imbricated below

Petals about twice as long as the sepals.

Mature capsule scarcely surpassing the sepals

Mature capsule about twice as long as the sepals

1. C. Buffumae.

2. C. brachypodium.

3. C. longipedunculatum. 4. C. elongatum.

5. C. beeringianum.

6. C. fuegianum.

7. C. arvense.

8. C. oreophilum.

1. Cerastium Buffumae A. Nels. Bull. Torr. Bot. Club 26: 239.' 1899. Annual, yellowish-green, glandular-pubescent, and very leafy: stems crowded upon the slender root and freely branched, becoming matted: leaves narrowly oblong to elliptic, 5-12 mm. long: the few-flowered cymes very numerous; the peduncles and pedicels dilated or swollen at the base into an ellipticoblong foot: petals one half longer than the oblong obtusish sepals: capsule about twice as long as the sepals.-Type locality only, Big Horn Mountains, Wyoming.

2. Cerastium brachypodium (Engelm.) Robins. in Brit. Mem. Torr. Club 5: 150. 1894. Annual, pale green, viscid-pubescent: stems erect, simple or sparingly branched, 1-2 dm. high: leaves oblong or spatulate, $1-2 \mathrm{~cm}$. long: cymes terminal, rather few-flowered; pedicels, even the lower ones, scarcely exceeding the capsule, from nearly erect to widely spreading or decurved: capsule usually slightly curved, 2-3-times as long as the calyx.- Not infrequent in our range, and eastward and westward.

3. Cerastium longipedunculatum Muhl. Cat. 46. 1813. Annual, bright green, more or less viscid-pubescent: stems weak, branched, ascending or almost prostrate: leaves oblong to spatulate below, lanceolate or narrower upward, 2-5 cm. long: cyme several to many-flowered; the pedicels slender, much longer than the mature capsule: petals twice as long as the nodding capsule. $C$. nutans.-Across the continent.

4. Cerastium elongatum Pursh, Fl. Am. Sept. 321. 1814. Annual, glandular-pubescent, 1-2 dm. high: stems many from the base, somewhat branched: leaves linear-lanceolate, $15-30 \mathrm{~mm}$. long, very numerous below: cyme usually trichotomous; the pedicels rather stout, variable in length, usually much longer than the mature capsule: petals large, often more than twice as long as the acute sepals: capsule short, subglobose and scarcely exserted.-Northern Wyoming, Montana, and westward.

5. Cerastium beeringianum Cham. \& Schlecht. Linnaea 1: 62. 1826. Perennial, tomentulose and somewhat glandular-viscid above: stems usually several from the slender branches of the caudex, low and spreading, ovateelliptic, oblong or lanceolate, 3-10 $\mathrm{mm}$. long: flowers few, in a narrow cyme, with short pedicels: petals and capsule but little longer than the sepals.- In the mountains; from New Mexico to Alaska.

6. Cerastium fuegianum (Hook.) A. Nels. Perennial, with slender rootstock; the slender strict stem only $5-10 \mathrm{~cm}$. high: leaves short, thickish and imbricated on the lower part of the stem: flowers solitary or few: petals and capsule but slightly longer than the calyx. (C. arvense fuegianum Hook. Bot. U. S. Expl. Exp. 1: 129; Hol. \& Brit. Bull. Torr, Bot. Club 14: 50.)一In Yellowstone Park, also in Fuegia. 
7. Cerastium arvense L. Sp. Pl. 438. 1753. Perennial, downy with reflexed hairs, caespitose: leaves linear to linear-lanceolate, clasping: cyme few-flowered; pedicels erect or nodding: petals nearly twice longer than the sepals: capsule little exceeding the calyx, nearly straight. (C. effusum Greene, Pitt. 4: 298. 1901.) - Colorado and northward through Utah, Montana, and Wyoming, and across the continent.

8. Cerastium oreophilum Greene,* Pitt. 4: 297. 1901. More or less glandular-pubescent, with somewhat tufted stems; pubescence either minute and strigose (deflexed upon the lower part of the stem) or spreading and hispidulous, becoming minutely glandular or viscid above: leaves mostly lance-linear, 1-3 cm. long, pubescent or glabrate, numerous below, sparser and smaller upward: flowers large, $8-12 \mathrm{~mm}$. broad, in strict or at length more open cymes: petals twice as long as the sepals: capsule about twice as long as the calyx.-Throughout our range.

\section{SAGINA L. Pearlwort}

Low green herbs, with subulate or filiform glabrous leaves, and small terminal usually long-pediceled flowers. Petals entire or wanting. Styles alternate with the 4 or 5 sepals. Capsule 4 - or 5 -valved. Seeds several to many.

1. Sagina saginoides (L.) Brit. Mem. Torr. Club 5: 151. 1894. A glabrous tufted perennial, only a few $\mathrm{cm}$. high: stems slender, decumbent: leaves linear, mucronate, $5-15 \mathrm{~mm}$. long: flowers $3-5 \mathrm{~mm}$. broad, with 5 sepals, petals, and styles: petals scarcely longer than the sepals: stamens 10: capsule ovoidoblong, twice as long as the obtuse sepals. S. Linnaei.-Moist spots and banks in the mountains; New Mexico to arctic America.

\section{ARENARIA L. SANDWORT}

Mostly low more or less tufted or densely caespitose perennials, with sessile usually subulate and more or less rigid leaves, and white cymosely panicled or capitate flowers. The five sepals distinct or nearly so. Petals 5, entire, not clawed. Stamens 10. Styles 3. Capsule globose, or short-oblong, many-seeded. Seeds not appendaged at the hilum.-Includes Alsinopsis Small.

Valves of the capsule entire; plants low, tufted or caespitose.

Glandular-hirtellous throughout.

Filiform stems 1-4 cm. long . . . . . . . 1. A. aequicaulis,

Slender stems 7-15 $\mathrm{cm}$. long $: \vdots \quad \vdots \quad \vdots \quad \vdots \quad 2$. A. Nuttallii.

Leaves glabrous or nearly so.

Sepals acute

Sepals obtuse
Valves of the capsule 2 -cleft at summit.

Leaves oblong or elliptic, not pungent.

Leaves less than $1 \mathrm{~cm}$. long

Leaves more than $1 \mathrm{~cm}$. long

Leaves linear, more or less rigid and pungent.
Petals distinctly longer than the sepals.

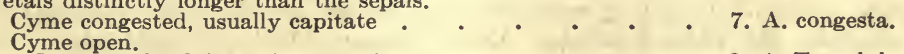

Densely glandular-pubescent above

Nearly glabrous throughout
Petals shorter than or merely equaling the sepals.

Plants low, broadly and densely caespitose; cyme very dense $\quad$ 10. A. Hookeri.
Plants tufted, usually $1-2 \mathrm{dm}$. high; cyme open

1. Arenaria aequicaulis A. Nels. Perennial from a very slender woody root, glandular or viscid-pubescent throughout, only 3-6 cm. high: stems filiform,

* A number of other segregates of $C$. arvense have been published. The writer finds himself unable to discern in them distinguishing characters. Students are referred to the original
descriptions as follows: $C$. Earlei Rydb. Bull. Torr. Bot. Club 30:249. 1903; C. 8copulorum Greene, Pitt. 4: 288; C. occidentale Greene, 1. c. 299. If these be distinct, then the above description of $C$. oreophilum is that of an aggregate, 
intricately branched at the decumbent base, erect, nearly uniform in length on a given plant: leaves crowded at the base, linear-subulate, not pungent, semicylindric, 3-nerved: sepals linear-lanceolate, strongly 3-nerved, longer than the petals: valves of capsule entire, considerably longer at maturity than the sepals. A. verna hirta. (A. verna equicaulis A. Nels. Bull. Torr. Bot. Club 26: 352. 1899; Alsinopsis propinqua Rydb. Bull. Torr. Bot. Club 33: 140 . 1906; not $A$. propinqua Rich.) - Not infrequent on open stony slopes; central Rocky Mountains and westward.

2. Arenaria Nuttallii Pax in Engl. Jahrb. 18: 30. 1893. Glandular-puberulent or tomentulose throughout; root single, vertical, rather stout: stems numerous, slender, loosely matted and much branched near the base; branches ascending or erect, leafy: leaves subulate-acerose, rigid, pungent, tending to be squarrosely spreading, connate, $7-10 \mathrm{~mm}$. long: flowers usually numerous, in a spreading cyme: sepals acuminate, of ten purplish, exceeding the subacute petals: capsule ovoid, shorter than the sepals. A. pungens. - In the mountains, especially on slides; our range and west to California.

3. Arenaria macrantha (Rydb.) A. Nels. A diffusely branched spreading glabrous caespitose perennial; branches $1 \mathrm{dm}$. long or less: leaves subulatefiliform, obtuse, $5-10 \mathrm{~mm}$. long, 1-nerved: pedicels $1 \mathrm{~cm}$. long or less: sepals lanceolate, 4-5 $\mathrm{mm}$. long, acute, scarious margined, strongly 3-nerved: petals oblong, exceeding the sepals and the capsules. (Alsinopsis macrantha Rydb. Bull. Torr. Bot. Club 31: 407. 1904.) - La Plata Mountains, Colorado.

4. Arenaria sajanensis Willd. in Schlecht. Berl. Gesell. Nat. Fr. Mag. 7: 200. 1816. Densely but finely glandular-hirsute: caespitose, with stems decumbent at base and leafy below, 2-6 cm. high, 1-3-flowered: leaves linear, obtusish, rather rigid, $4-8 \mathrm{~mm}$. long, usually glabrous: sepals linear-oblong, nerved, glandular-pubescent, $3-5 \mathrm{~mm}$. long: petals usually exceeding the sepals: capsule oblong, exceeding the sepals. A. biflora obtusa. (Alsinopsis obtusiloba Rydb. 1. c.)-Common and variable; in alpine regions.

5. Arenaria saxosa Gray, Pl. Wright. 2: 18. 1853. Finely puberulent, green or glaucescent: stems many, spreading from a rather stout root, decumbent or creeping at the base, $5-15 \mathrm{~cm}$. long: leaves numerous, slightly fleshy, lance-oblong, acute, mucronate, 5-15 $\mathrm{mm}$. long: flowers terminal and subsolitary on short simple peduncles, or in stouter individuals numerous and paniculate: sepals ovate-lanceolate, acuminate, equaling the petals. ( $A$. polycaulos Rydb. Bull. Torr. Bot. Club 31: 406. 1904.) - Colorado, New Mexico, and Arizona.

6. Arenaria confusa Rydb. Bull. Torr. Bot. Club 28: 275. 1901. Puberulent caespitose perennial, with slender diffuse stems, $3-5 \mathrm{dm}$. long: leaves linear-lanceolate, acute, with conspicuous midrib: pedicels (in fruit) divergent, slightly bent under the calyx, about $1 \mathrm{~cm}$. long: sepals linear-lanceolate, scarious margined, about $3 \mathrm{~mm}$. long: petals shorter than the sepals and the ovoid capsule.-Colorado, New Mexico, and Arizona.

7. Arenaria congesta Nutt. T. \& G. Fl. 1: 178. 1838. Glabrous or obscurely glandular-puberulent: stems slender, simple, 1-3 dm. high, more or less tufted: basal leaves gramineous-setaceous, $1-5 \mathrm{~cm}$. long, ciliolate-serrate near the base; cauline few, gradually shorter: flowers sessile, in 1-3 dense heads, subtended by 1 or more scarious bracts: sepals carinate, scarious, exceeded by the oblong petals.-Very common in the mountains; Colorado, Wyoming, and westward.

$.7 a$. Arenaria congesta subcongesta Wats. Bot. Calif. 1: 69. 1885. Smaller, the base subligneous; the stems usually glandular-puberulent; the flowers fewer and tending to form an open dichotomous cyme.-Range nearly the same as the species.

8. Arenaria Tweedyi Rydb. Bull. Torr. Bot. Club 31: 406. 1904. Caespitose, with ligneous base: leaves fleshy, linear-filiform, $2-3 \mathrm{~cm}$. long: stems glandular-puberulent, especially above, $7-12 \mathrm{~cm}$. high: flowers in an open cyme, with lanceolate scarious bracts; pedicels about $1 \mathrm{~cm}$. long: sepals lanceolate, acute, densely glandular-puberulent, about $5 \mathrm{~mm}$. long and distinctly surpassed by the petals.-La Plata Mountains, Colorado. 
9. Are zaria uintahensis A. Nels. Bull. Torr. Bot. Club 26: 7. 1899. Caespitose, with subligneous multicipital caudex, nearly glabrous throughout: leaves mostly basal, narrowly linear, acerose, $10-25 \mathrm{~mm}$. long: stems slender, crect, $10-15 \mathrm{~cm}$. high, glabrous or obscurely glandular-puberulent above: cyme open, subpaniculate: sepals ovate or narrower, nerveless, scarious, keeled by the broad green midrib: petals oblong, obtuse, $5 \mathrm{~mm}$. long, longer than the sepals.-Western Wyoming, Utah, probably Colorado and Idaho.

10. Arenaria Hookeri Nutt. T. \& G. Fl. 1: 178. 1838. The multicipital caudex forming broad mats surmounting the woody root: stems $3-12 \mathrm{~cm}$. high, glandular-puberulent: leaves linear-subulate, rigid and pungent, $2-4 \mathrm{~cm}$. long: cymes short and dense, the scarious bracts conspicuous: sepals rigid, pungent, $5-7 \mathrm{~mm}$. long, exceeded by the oblong petals. (A. pinetorum A. Nels. Bull. Torr. Bot. Club 26: 350. 1899.) -Common on bleak hilltops in our range.

11. Arenaria Fendleri Gray, Pl. Fendl. 13. 1848. Pale and somewhat glaucous, more or less glandular-pubescent, especially above: stems numerous, erect, leafy, closely aggregated upon the summit of a thick root: basal leaves setaceous-gramineous, either ciliolate or smooth, 4-8 cm. long, somewhat pungent; the cauline gradually shorter, sheathing at base: inflorescence dichotomous, few-many-flowered: the glandular sepals attenuate, but little shorter than the obovate white or ochroleucous petals: capsule shorter than the sepals. (A. Eastwoodiae Rydb. Bull. Torr. Bot. Club 31: 406. 1904.)- New Mexico to Wyoming, and westward.

\section{MOEHRINGIA L.}

Low slender perennials with thin oblong or ovate-lanceolate leaves and small white flowers axillary or in terminal cymes. Parts of the flower sometimes in fours. Valves of the capsule bifid. Young ovary 3-celled. Seed with a light-colored spongy appendage at the hilum.

1. Moehringia lateriflora (L.) Fenzl. Verbr. Alsin. Table, p. 18. 1835. Glabrate or puberulent: stems erect, sparingly branched: leaves ovate to oblong, obtuse, 1-2 cm. long: peduncles usually 2-flowered, soon becoming lateral: petals white, entire or nearly so, longer than the oblong sepals: capsule twice as long as calyx, opening by three 2 -cleft valves. Arenaria lateriflora.Moist shaded places; Colorado, northward and across the continent.

\section{SPERgularia J. \& C. Presl.}

Somewhat fleshy-leaved annuals or perennials of wet saline soils, with white or purplish solitary-axillary or terminal cymose flowers. Sepals 5. Petals 5. Stamens 10. Styles 3 ; ovary 1-celled, with 3 valves.

1. Spergularia sparsiflora (Greene) A. Nels. A glandular-hirsutulous annual, freely branched, erect, or with lax spreading stems, diffuse, slender, the lower internodes longer, the upper rather shorter than the narrowly linear acute leaves: stipules thin, very short, broadly ovate and acutish, varying to obtuse and truncate: flowers mostly solitary, one to each pair of leaves, on slender pedicels shorter than the leaves: petals small, lilac: capsule ovate, obtusish, exceeding the sepals: seeds minute, red-brown. Tissa sparsiflora Greene, Erythea 3: 46. 1905. - Not infrequent in wet strongly saline places; Wyoming and Colorado.

\section{PARONYCHIA Adans. Whitlowwort}

Tufted herbs, with lignescent base, opposite leaves, and dry, silvery stipules. Flowers small, apetalous, and scarious-bracted. Sepals 5, linear-oblong, concave and awned at the apex. Stamens 5, sometimes alternating with linear staminodia. Ovary ovoid, narrowed into the 2-cleft style.

Flowers terminal, solitary or subcymose and sessile.

Leaves oblong, obtuse

Leaves linear-subulate 
Flowers axillary, solitary or cymose

Flowers in terminal dichotomous cymes. Stems erect

Stems prostrate-spreading
3. P. depressa.

4. P. Jamesii.

5. P. diffusa.

1. Paronychia pulvinata Gray, Proc. Acad. Phila. 58. 1863. Mattedcaespitose from a woody root, forming dense cushion-like tufts: stipules broadly ovate, entire, pointless; leaves thick, oblong, obtuse, equaling the stipules, and with them densely covering the short stems: flowers immersed among the leaves: sepals oval, awned a little below the apex.-Alpine; Colorado, Utah, and Wyoming.

2. Paronychia sessilifolia Nutt. Gen. 1: 160. 1818. Very densely caespitose from a woody root, much branched and crowded, branches very dense: stipules 2-cleft; leaves imbricated, linear-subulate, the lowest erect, obtuse, the upper longer, recurved-spreading, acute or mucronate, longer than the stipules: sepals oblong-linear, with divergent awns rather shorter.-Colorado and northward to the headwaters of the Missouri and the Saskatchewan.

2a. Paronychia sessilifolia brevicuspis A. Nels. Bull. Torr. Bot. Club. 26: 237. 1899. More densely tufted: the lower leaves obtuse: flowers subcymose: calyx with a swollen turbinate base; sepals closely valvate, forming a short cylindrical tube closed at the summit by their short arched tips, the awn very short.-Open stony ridges; southern Wyoming.

3. Paronychia depressa (Nutt.) A. Nels. Bull. Torr. Bot. Club 26: 236. 1900. Spreading in a close mat from the crown of a woody root; silvery throughout by reason of the large scarious stipules and the short silvery scabrous pubescence: leaves linear, cuspidate or bristle-pointed, scarcely longer than the stipules: flowers single in the axils or in small cymes, subsessile and surpassed by the subtending bracts and leaves: sepals with a cone-shaped awned tip half as long as the body: filaments very short, exceeded by the slender staminodia.-Rare; dry hills near the Platte, in Wyoming.

4. Paronychia Jamesii T. \& G. Fl. N. A. 1: 170. 1838. Very minutely scabrous-pubescent, caespitose and freely branched from the base: stems $7-15 \mathrm{~cm}$. high, erect or nearly so, more or less dichotomously branched above: leaves longer, linear-subulate, obtuse, about the length of the internodes: cymes few-flowered, with a central subsessile flower in each division: sepals linear-oblong, with very short cusps. (P. Wardii Rydb. in Small, Fl. 400. 1903.) - Colorado.

5. Paronychia diffusa A. Nels. Bull. Torr. Bot. Club 26: 237. 1900. Allied to the preceding but wholly prostrate-spreading: leaves generally longer than the internodes, acute and mucronate: stipules lanceolate, silvery, shorter than the internodes: cymes small, congested at the ends of the brittle branches: calyx with minutely hirsute turbinate base; its cusps short and arched within: filaments exceeded by the staminodia.-Barren slopes and ridges, frequent; Wyoming and Colorado.

\section{NYMPHAEACEAE DC. WATER Lily FAMily}

Aquatic herbs, with horizontal trunk-like rootstocks or sometimes tubers. The leaves (in ours) deeply cordate. Flowers with all the parts distinct and free, solitary and axillary on long peduncles. Stamens numerous. Carpels several or many, united into a compound pistil.

\section{NymphaEa L. Yellow Pond Lily. Spatterdock}

In shallow water, sending up large leathery leaves which are usually upright but sometimes floating. Sepals 5-12, persistent, usually yellow within and partly green without. Petals and stamens short and numerous, densely crowded around the ovary. Ovary 8-20-celled, crowned by a radiate stigma, the cells many-seeded.-Nuphar. 
1. Nymphaea polysepala (Engelm.) Greene, Bull. Torr. Bot. Club 15: 84. 1887. Petioles stout, the floating leaves oval, with narrow or nearly closed sinus, 1-3 dm. long: calyx subglobose, when fully expanded $8-12 \mathrm{~cm}$. broad; sepals 9-12, yellow, or at length tinged with red: petals 12-18, obovate, cuneate, truncate: fruit subglobose, with a constricted neck and convex umbonate 15-24-rayed stigmatic disk.-High mountain lakes; Colorado, Wyoming, and northwestward. Nymphaea (Nuphar) advena, reported from Wyoming, is probably this species.

\section{CERATOPHyllaceaE L. Hornwort Family}

Aquatic herbs, with whorled finely dissected leaves, and minute axillary and sessile monoecious flowers without floral envelopes, but with an 8-12-cleft involucre in place of a calyx. Fertile flower a simple 1-celled ovary.

\section{CERATOPHYLLUM L.}

Submersed plants, in ponds or slow flowing streams, the sessile leaves cut into thrice-forked thread-like divisions. Sterile flowers of 12-24 stamens, with sessile anthers. Fruit an achene, beaked with a slender persistent style.

1. Ceratophyllum demersum L. Sp. Pl. 992. 1753. Stems very slender, 3-5 dm. long: leaves in numerous whorls of 6-8: achene elliptical, shortly stipitate, with a short spine or tubercle on each side near the base.-California and northward, thence eastward across the continent.

\section{RanunCUlaceae Juss. Buttercup Family}

Herbs or rarely climbing shrubs with acrid sap. Leaves usually alternate, simple or compound, without stipules but often dilated at base of petioles. Flowers regular or irregular, the parts all distinct and free. Sepals 3-15, often petal-like, usually caducous, imbricate (in two genera valvate). Petals 3-15, or wanting. Stamens numerous or rarely few. Pistils many, few, or solitary, becoming achenes, follicles, or berries.

Pistils becoming follicles or berries with several seeds.

Flowers regular.

Leaves simple (sometimes deeply lobed or divided); follicles many, forming a head in fruit.

Leaves undivided

Leaves deeply lobed or divided

Leaves compound.

Petals not spurred; fruit a berry

Petals spurred; fruit follicular.

Flowers irregular; carpels 3-5.

Posterior (upper) sepal spurred

Posterior sepals hooded (helmet-like)

Pistils becoming achenes.

Petals none or inconspicuous; sepals large and petal-like.

Flowers subtended by an involucre; sepals imbricated.

Styles short, glabrous or pubescent

Styles becoming elongated and plumose

Flowers without involucre; sepals valvate; styles elongated and plumose; leaves opposite

Petals as well as sepals present, except in the last.

Minute annuals: sepals spurred

Perennials; sepals not spurred.

Flowers white

Flowers yellow; or petals wanting.

Leaves simple but often lobed or divided; petals with a nectariferous pit at the base; achenes compressed. Achenes smooth or hispid; petals broad Achenes longitudinally striate; petals narrow

Leaves ternately compound or decompound. Petals present Petals wanting

1. Caltha.

2. Trollius.

3. Actaea.

4. Aquilegia.

5. Delphinium.

6. Aconitum.

\section{Anemone.}

8. Pulsatilla.

9. Clematis.

10. Myosurus.

11. Batrachium.

12. Ranunculus,

13. Halerpestes.

14. Cyrtorhyncha.

15. Thalictrum. 


\section{CALtha L. Marsh Marigold}

Smooth perennial herbs with thickish somewhat succulent round or oblong leaves with cordate base. Sepals large and petal-like, white or pink, early deciduous. Petals none. Stamens numerous. Pistils several or many, becoming follicles with several seeds.

1. Caltha rotundifolia (Huth.) Greene, Pitt. 4: 80. 1899. Leaves all radical, rather thick and firm, broadly ovate, elliptic or oblong, cordate at base with narrow sinus, entire or dentate, 3-8 cm. long: scapes $2-15 \mathrm{~cm}$. high, 1-flowered: sepals 5-15, oblong or obovate, white (bluish without): filaments flattened: follicles flattened and somewhat spreading. $C$. leptosepala. $(C$. chionophila Greene 1. c.)-Throughout our range and northwestward.

\section{TROLLIUS L. GLOBEFlower}

Perennial herbs with palmately parted or incised leaves, thickened fibrous roots, and large solitary terminal flowers. Sepals 5-15, petal-like. Petals 5-15, small, narrow, with a minute nectariferous pit at the base. Stamens numerous. Pistils several, many-ovuled.

1. Trollius albiflorus (Gray) Rydb. Mem. N. Y. Bot. Gard. 1: 152. 1900. Stems slender, 1-2 dm. high: leaves palmately 5-7-parted, 4-8 cm. broad, all petioled except the uppermost, the segments obovate, variously cleft or toothed: flowers white, 2-4 cm. broad: sepals obovate: petals minute, much shorter than the stamens: follicles many, flattened, many-seeded, tipped with a divergent slender beak.- Not infrequent at subalpine and higher stations throughout our range.

\section{ACTAEA L. BANEBERRY}

Perennial herbs with leaves twice or thrice ternately compound. Flowers numerous, white, in a simple raceme. Sepals caducous, small, 4-6, petal-like. Petals small, 4-10. Stigma sessile, 2-lobed. Pistil 1, becoming a large somewhat poisonous berry with many seeds.

Leaflets thin, sharply incised, the teeth acuminate . . . . . 1. A. arguta. Leaflets thicker, the incisions few, the teeth rounded or mucronate : . 2. A. rubra.

1. Actaea arguta Nutt. T. \& G.Fl. 1: 35. 1838. Glabrous or nearly so, erect, bushy-branched, 3-6 dm. high: basal leaf long-petioled, ternate; the divisions long-petioled, pinnate; leaflets ovate, 5-12 cm. long, sharply incised and toothed, the teeth acute or acuminate: flowers white, numerous, in an ovoid raceme which elongates in fruit: petals spatulate: berries $6-8 \mathrm{~mm}$. long, oval or subspherical, red or white. (A. eburnea Rydb. Mem. N. Y. Bot. Gard. 1: 153. 1900.) - In rich soil of moist woods; New Mexico and far to the north and west.

2. Actaea rubra (Ait.) Willd. Enum: 561. 1809. Very similar to the preceding, but the leaflets less sharply incised, the teeth mostly rounded or mucronate, or acutish: petals rhombic-spatulate: berries smaller, cherry-red, or sometimes white. (A. viridiflora Greene, Pitt. 2: 108. 1890.)-Northeastern Wyoming, northward and eastward.

\section{AQUILEgIA L. Columbine}

Perennial herbs, with leaflets twice or thrice ternately compound, the leaflets lobed. Sepals 5, petaloid, deciduous. Petals of the same number, the blade small, each produced backward between the sepals as a large hollow spur. Stamens indefinite, some of the inner sterile and dilated-petaloid or reduced to scarious scales. Pistils 5; the ovules numerous, in two rows. 
Spur longer than the calyx.

Flowers red in whole or in part

Flowers never red.

Flowers blue or white

Flowers yellow or bluish.

Spurs long (5-7 cm.), yellow

Spurs shorter (4 cm. or less), bluish

Spur shorter than the calyx.

Stem leafy or not wholly naked-scapose; flowers several.

Flowers yellow or yellowish.

Plant tall (more than $2 \mathrm{dm}$.). Spur as long as lamina . Spur nearly wanting

Plant lower (less than $2 \mathrm{dm}$. high)

Flowers blue

Stem scapose, 1-flowered

1. A. elegantula.

2. A. coerulea.

3. A. chrysantha.

4. A. oreophila.

1. Aquilegia elegantula Greene, Pitt. 4: 14. 1899. Erect, glabrous, slender, 2-4 dm. high: leaves mostly radical, long-petioled, glaucous beneath; cauline small, subsessile: flowers solitary or few, about $3 \mathrm{~cm}$. long: sepals and limb of petals yellowish-green, or becoming red like the spurs: spurs inflated above, straight, longer than the sepals: filaments short: styles exserted. $A$. canadensis.-Colorado and New Mexico.

2. Aquilegia coerulea James, in Long's Exp. 2: 15. 1825. Glabrous, rather slender, 3-6 dm. high: leaves most radical and long-petioled, glaucous beneath; the leaflets deeply cleft: flowers solitary or several, terminating the pedunclelike stems, large, deep blue, or rarely pale: sepals rhomboid-ovate, acute, longer than the obtuse petals: spurs straight, slender, twice as long as the limb: style shorter than the petals.-Frequent in the mountains; northern New Mexico to Montana; the state flower of Colorado.

2a. Aquilegia coerulea leptocera (Nutt.) A. Nels. Not readily distinguished from the species except by the nearly white flowers and the broader and very obtuse lobes of the leaflets. A. leptocera Nutt. Journ. Acad. Phil. 7: 9. 1834.Western Wyoming and Utah, at lower elevations than the species.

3. Aquilegia chrysantha Gray, Proc. Am. Acad. 8: 621. 1873. Resembling the preceding in habit, but often taller (3-10 dm. high): flowers many, a pure yellow: sepals lanceolate-oblong, scarcely longer and not broader than the lamina of the petals: spurs long, straight and slender. (A. thalictrifolia Rydb. Bull. Torr. Bot. Club 29: 145. 1902.)-Southern Colorado, New Mexico, and Arizona.

4. Aquilegia oreophila Rydb. Bull. Torr. Bot. Club 29: 146. 1902. Resembling the two preceding and the following, smaller, 2-4 dm. high: flowers few, 3-4 cm. long: sepals oblong-lanceolate, acute, pale blue, longer than the oval obtuse ochroleucous limb of the petals: spurs straight, widening regularly to the throat, ochroleucous or bluish, about twice as long as limb.-Middle elevations; northwestern Wyoming to Idaho and Montana.

5. Aquilegia flavescens Wats. Bot. King's Exp. 10. 1871. Glabrous except above, branching freely, 3-5 dm. high: flowers lemon-yellow, sometimes tinged with scarlet: sepals oval or oblong, spreading or reflexed, longer than the obovate obtuse limb of the petals: spur about equaling the petals, more or less curved but scarcely hooked, knobbed, 6-8 mm. long: stamens longer than the petals.-Probably in the western part of our range in the higher mountains.

6. Aquilegia Eastwoodiae Rydb. Bull. Torr, Bot. Club 29: 146. 1902. Pubescent with soft spreading hairs: leaves triternate on long slender petioles; leaflets cuneate, thin, somewhat 3-lobed, petioled: sepals and petals lanceolate, subequal. $15 \mathrm{~mm}$. long: the petals merely saccate at base and not truly spurred: sterile filaments united into a tube: follicles reticulate-veiny, 12$15 \mathrm{~mm}$. long. (A. ecalcarata Eastwood, Zoe 2: 226.)-Southwestern Colorado to Utah and southward.

7. Aquilegia laramiensis A. Nels. First Rep. Fl. Wyo. 78. 1896. Manystemmed from a rather large semifleshy root, 1-2 dm. high; stems and petioles more or less decumbent and diffuse: leaves biternate; the leaflets large, with crenate lobes, slightly pubescent below: inflorescence and fruits pubescent: flowers 10-15 mm. long: sepals greenish-white, lanceolate, with emarginate 
apex: lamina of the petals cream-color, elliptical, obtuse, longer than the slender hooked knobbed spurs.- Shaded cliffs in the Laramie range, Wyoming.

8. Aquilegia saximontana Rydb. in Robins. Syn. Fl. 1: 43. 1895. Glabrous, 12-18 cm. high: stems several from a scaly rootstock: leaves small, twice ternate, even the upper slender-petioled: flowers small, 12-18 $\mathrm{mm}$. long; the lamina of the petals yellowish, shorter than the blue sepals and much longer than the blue spurs: carpels glabrous. A. brevistyla.-High peaks in the central Rocky Mountains.

9. Aquilegia Jonesii Parry, Am. Nat. 8: 211. 1874. Minutely softpubescent: scape 3-6 $\mathrm{cm}$. high, naked, 1-flowered: leaves all crowded and the persistent scale-like dilated bases of their petioles imbricated on the stout ascending branches of the rootstock; the partial petioles short or wanting, so that the 9 small obovate entire leaflets are in a dense cluster: lamina of petals only half as long as the obtuse sepals; the spurs shorter than the sepals: follicles large, $2 \mathrm{~cm}$. long.-Rare alpine plants; high peaks in the central Rocky Mountains.

\section{DELPHINIUM L. LARKSPUR}

Erect herbs, usually with palmately lobed, cleft, or dissected leaves, and racemose flowers which are white, blue, or purple. Sepals 5, petal-like. Petals 2 or 4, irregular; when 4, the upper pair are developed backwards into a spur which is inclosed in the spur of the upper sepal; the lower pair with slender claw and broad blade. Pistils few, becoming erect or divergent follicles with several to many seeds.

Roots fasciculate-tuberous and easily detachable from the slender stem.

Stem strict, 3-4 dm. high; flowers many, in a spicate-raceme

Stem lower; flowers few, in a lax raceme

Roots thickened and fascicled but not tuberous; plants low $(1-\dot{-5} \mathrm{dm}$. high).

Stems glabrous, at least below.

Leaves basal and cauline . . . . . . . . . 3. D. bicolor.

Leaves all basal . . . . . . . .

Stems pubescent to the base.

Radical leaves numerous, tufted $\quad: \quad: \quad \cdot \quad \cdot \quad$

Roots large, deep-set, woody, with 1 or more crowns; plants often coarse and tall (1-20 dm. high).

Leaf-segments laciniately multifid; the lobes linear.

Flowers green or greenish and purple-streaked .

Flowers blue.

Stem glabrous below

Stem puberulent to the base :

Leaf-segments 5-9, these and their divisions oblong to obovatecuneate.

Pubescence more or less viscid-villous, yellowish.

Raceme crowded, spicate; flowers blue. Mature follicles glabrous Mature follicles viscid-pubescent
:

Raceme open; flowers few (5-10).

Plant tall; flowers purple.

Pubescence finely canescent, not viscid or glandular. Raceme dense, spicate, finely villous Raceme more open, pilose

1. D. strictum.

2. D. Nelsonii.

4. D. scaposum.

5. D. Geyeri.

6. D. carolinianum.

7. D. sapellonis.

8. D. scopulorum.

9. D. robustum.

1. Delphinium strictum A. Nels. Bull. Torr. Bot. Club 27: 263. 1900. Finely pubescent: root tuberous-fasciculate or solitary-cormose: stem very strict, 3-4 dm. high: leaves trifoliolate; the leaflets again 3-parted or variously lobed; the segments oblong to linear: raceme spicate, $5-10 \mathrm{~cm}$. long; pedicels short, erect, stout: flowers blue: spur straight, with deflexed tip, standing at right angles to the rachis; lateral petals deeply cleft, sparsely long-villous: follicles 3, pubescent, 6-8 $\mathrm{mm}$. long: seeds wing-angled.-Wet meadows; Jackson's Hole, Wyoming.

2. Delphinium Nelsonii Greene, Pitt. 3: 92. 1896. Finely puberulent, at 
least above; stem slender, simple, 1-3 dm. high, from a cluster of tuberous, easily detachable roots: leaves firm, divided into linear segments: flowers blue, slightly villous, slender-pediceled: sepals oblong, shorter than the slender spur: lower petal 2-cleft, pubescent and with a tuft of hairs about the middle: follicles pubescent or glabrate: seeds wing-angled above. (D. dumetorum Greene, Pl. Baker. 3: 4. 1901.)—Western Nebraska through Wyoming and Colorado to Utah.

3. Delphinium bicolor Nutt. Journ. Acad. Phila. 7: 10. 1834. Glabrous or pubescent, 2-3 dm. high, rather stout, from thickish fascicled deep-set roots: leaves deeply parted, the segments cleft or parted into linear lobes: raceme open, few-flowered, the lower pedicels elongated: flowers about $2 \mathrm{~cm}$. long: upper petals yellowish and copiously blue-veined: mature follicles glabrous, erect or recurving.-Northern Wyoming, west to Oregon.

4. Delphinium sca posum Greene, Bot. Gaz. 6: 156. 1880. Glabrous; stems scapose, 2-4 dm. high, from thickish branching roots: leaves clustered at the base, short-petioled, round or reniform in outline, and mostly oblong or subcuneate divisions and lobes: raceme several-flowered; the flowers blue: sepals oblong, 10-14 $\mathrm{mm}$. long, shorter than the somewhat curved spur: follicles oval, erect: seeds with rugose and ariliform coat.-Western Colorado to Nevada.

5. Delphinium Geyeri Greene, Erythea 2: 189. 1894. Canescently tomentulose throughout; stems usually several or many from a bundle of woody deepset roots, 2-5 dm. high: basal leaves numerous and tufted, petioled; the cauline diminishing upward; all rather thick, cut into many linear segments, these tipped with a white callosity: raceme long, with many azure-blue flowers: spur horizontal or ascending, stoutish. This is the species that is commonly known as Porson WeED. The tuft of radical leaves develops early and these if eaten freely produce fatal bloating in cattle unless the animal is relieved promptly by the use of a trochar.- Very abundant on the plains in our range.

6. Delphinium carolinianum Walt. Fl. Car. 155. 1788. Puberulent or pubescent; stem solitary, strict, simple or nearly so, $2-5 \mathrm{dm}$. high: leaves 3-5-parted or cleft, usually into linear lobes: raceme spiciform, many-flowered: flowers varying from blue to white or even greenish-white: sepals sometimes tipped with brown: spur horizontal or ascending; petals rather heavily pilose: follicles oblong, erect. $D$. azureum. (D. albescens Rydb. in Brit. Man. 417. 1901.)-From the eastern base of the Rocky Mountains far to the eastward.

6a. Delphinium carolinianum Penhardii (Huth.) A. Nels. A form with flowers mostly white and the spurs curved and erect. (D. Penhardii Huth. Helios 10: 27. 1893; D. camporum Greene, Erythea 2: 183. 1894.)-On the great plains, eastward of the Rocky Mountains.

7. Delphinium sapellonis Ckll. Bot. Gaz. 34: 453. 1902. Very glandular or viscid-pubescent, especially above; stem strict 8-18 dm. high: leaves tripartite; the lateral divisions large and themselves almost tripartite; the segments mostly linear: racemes long, narrow, many-flowered; flowers rather small, dull-colored, greenish-brown and more or less streaked with dull purple: spur ascending; petals somewhat pilose with yellow hairs.-New Mexico, and may reach Colorado.

8. Delphinium scopulorum Gray, Pl. Wright. 2: 9. 1853. Glabrous below, minutely pubescent in the inflorescence; stem usually simple, $3-8 \mathrm{dm}$. high: leaves laciniately multifid; the primary and secondary divisions cuneiform in outline, laciniately many-cleft into lance-linear very acute segments: flowers rather large, indigo-blue, in a strict raceme: spur longer than the sepals: follicles erect, nearly glabrous.-New Mexico and probably in southern Colorado.

9. Delphinium robustum Rydb. Bull. Torr. Bot. Club 28: 276. 1901. Puberulent throughout; stem stout, often $2 \mathrm{~m}$. or more high: leaves divided into 5-7 segments which are 6-12 $\mathrm{cm}$. long and twice cleft into linear lobes: inflorescence branched, many-flowered: sepals elliptical, dark blue, as long as 
or longer than the spur: lateral petals 2-cleft at the apex, slender-clawed, and bearded within.-Southern Colorado.

10. Delphinium subalpinum (Gray) A. Nels. Bull. Torr. Bot. Club 27: 263. 1900. Tawny pubescent especially above and in the inflorescence, more or less viscid; stems simple, erect, 5-15 dm. high: leaves deeply cleft into about 5 segments which are variously incised or gash-toothed, nearly glabrous: raceme simple, short and compact $(1 \mathrm{dm}$. long); pedicels longer than the spurs of the uniformly very deep blue flowers: lower petals with narrow claw and oval deeply notched blade; the lobes dentate: ovaries glabrate, bluish: follicles short-oblong, glabrous. [(?) D. Barbeyi Huth. Bull. Herb. Boiss. 1: 335. 1893.]-In large dense beds at subalpine stations; Colorado and Wyoming.

11. Delphinium reticulatum A. Nels. 1. c. 231. Near the preceding, more pubescent but viscid in the inflorescence only; stems usually several from the large woody root, 5-10 dm. high, and more or less branched above: leaves with 3-5 broadly cuneate divisions which are 3-cleft into more or less toothed lobes: raceme simple or branched, becoming elongated; flowers dull or dark blue, more or less streaked with white: spur longer than the sepals; lower petals with ovate, bifid, more or less bearded blade: follicles erect, $10 \mathrm{~mm}$. long, conspicuously reticulated with dark lines, slightly pubescent or viscidpubescent. (D. multiflorum Rydb. Bull. Torr. Bot. Club 29: 147. 1902; D. occidentale Wats. as to our range.)-From northern Colorado to Montana and Idaho.

12. Delphinium Cockerellii A. Nels. Bot. Gaz. 42: 51. 1906. Tawny pubescent on stems and in the inflorescence, densely and viscidly so above, the leaves obscurely pubescent: stems nearly simple or bushy-branched, 6-12 dm. high: leaves large, often $12-18 \mathrm{~cm}$. in diameter, the veins strikingly superficial, about 5-cleft or parted into broadly oblong or oblong-cuneate divisions, these merely coarsely toothed or incised above the middle: racemes often several, open, with rather long peduncles and pedicels and few flowers (5-10); flowers bright purple, large (3-4 cm. long): sepals oblong-lanceolate, acute, about as long as the thick curved spur: petals small; the upper yellowishwhite, concealed within the upper sepal; the lower purple, with suborbicular blade, cleft and sparsely hirsute-ciliate.-Mountains of southern Colorado and of New Mexico.

13. Delphinium alpestre Rydb. Bull. Torr. Bot. Club 29: 146. 1902. Puberulent, viscid above, caespitose, only 1-2 dm. high: leaves digitate, the divisions cuneate-obovate, divided halfway into oblong mucronate lobes: inflorescence short, few-flowered, viscid: sepals blue as are also the upper petals: lower petals 2-cleft; the lobes lanceolate.-Alpine, among rocks; Colorado and New Mexico.

14. Delphinium cucullatum A. Nels. Bull. Torr. Bot. Club 27: 262.1900. Stems numerous, clustered on thick woody roots, 8-15 dm. high, glabrous nearly to the inflorescence, leafy: leaves finely pubescent, 10-18 $\mathrm{cm}$. in diameter, 3-7-divided, the segments cuneate and very irregularly cleft and gashed at the apex: racemes usually several, very closely flowered, densely pubescent (not viscid or glandular): sepals yellowish-white or bluish, all distinctly hooded, shorter than the spur: petals blue, the lower pair with slender claw having a conspicuous saccate nectary at base; the blade cleft to near the middle: ovaries densely white-pubescent.-Known as yet only from northwestern Wyoming, on Snake River.

15. Delphinium glaucescens Rydb. Mem. N. Y. Bot. Gard. 1: 155. 1900. Stems several or many from a thick caudex, pubescent, especially above, or in age glabrate and glaucous, 3-8 dm. high: leaves finely puberulent, more or less glaucous and tending to become glabrous, with 5-8 cuneate divisions which are mostly 3-cleft: raceme simple, rather short; the lower bracts exceeding the flowers: flowers blue, or variegated with white, finely pilose: spur as long as the lower petal: ovaries densely hairy: follicles erect, oblong, pubescent. (D. ramosum Rydb. Bull. Torr. Bot. Club 28: 276. 1901; D. elongatum Rydb. 1. c. 29: 148; D. quercetorum Greene, Pl. Baker. 3: 4. 1901.)Montana to Colorado. 


\section{ACONitum L. Aconite. Monkshood}

Perennial herbs, with palmately lobed or dissected leaves, and showy flowers in terminal racemes or panicles. Sepals 5, petal-like; the upper one large, helmet-shaped or prolonged saccate. Petals 2-5; the upper two with long nectariferous claws and irregular spur-like blades concealed within the hood; the 3 lower very minute or obsolete. Follicles $3-5$, with several to many squamellose seeds.

Primary leaf-segments rarely cleft below the middle.

Flowers blue, sometimes very pale.

Raceme open or paniculate, few-flowered .

Raceme dense, subspicate.

Flowers ochroleucous

Primary leaf-segments cleft nearly to the base :

1. A. columbianum.

2. A. Bakeri.

3. A. lutescens.

4. A. ramosum.

1. Aconitum columbianum Nutt. T. \& G. Fl. N. A. 1: 34. 1838. More or less pubescent above with short spreading viscid hairs: stem stout, 9-18 dm. high: divisions of the leaves broadly cuneate, laciniately toothed, lobed, or cleft to near the middle: flowers blue, sometimes pale or nearly white, somewhat pubescent, rather few, in a loose terminal panicle-like raceme: hood 12-15 mm. long, the helmet-shaped portion higher than broad; the beak variable, porrect or downwardly curved. (A. insigne Greene, in herb.)-Moist open woods; from New Mexico to British Columbia.

2. Aconitum Bakeri Greene, Pl. Baker. 3: 5. 1901. The whole upper portion of the plant, even the flowers, short-hirsute with glandular hairs, or somewhat viscid-villous: root semifleshy, short, fusiform: stem stoutish, erect, simple and rather strict, 5-7 dm. high: leaves mostly 5-parted, the cuneate divisions doubly about 3-cleft to near the middle: raceme compact or subspicate, the flowers usually dark blue: hood 15-18 $\mathrm{mm}$. long, scarcely higher than broad; beak subulate, usually projecting horizontally: follicles glabrous, about 4. (A. atrocyaneum Rydb. Bull. Torr. Bot. Club 29: 150. 1902; A. porrectum Rydb. 1. c.)-Moist subalpine stations; Colorado mountains.

3. Aconitum lutescens A. Nels. Bot. Gaz. 42: 51. 1906. Root small, fusiform-tuberous: stems slender, simple, erect, only 3-6 dm. high, glabrous nearly to the inflorescence: leaves $3-5 \mathrm{~cm}$. broad; the 5 broadly cuneate divisions deeply and incisely toothed above the middle: raceme narrow, long for the plant, rather open; the flowers a pure cream-color, becoming nearly white or pinkish in drying; rachis and pedicels softly hirsute-ciliate with straight viscid hairs standing out at right angles.-Wyoming, Colorado, and New Mexico.

4. Aconitum ramosum A. Nels. Bull. Torr. Bot. Club 26: 8. 1899. Pubescent above only, obscurely glandular: stems $3-5 \mathrm{dm}$. high, more or less branched above: leaves 3-4-parted; the segments 2- or 3-cleft much below the middle; these divisions also incised, the leaf thus appearing incisely multifid with linear-lanceolate lobes: flowers in short terminal, capitate racemes, blue: hood 12-16 mm. long; the beak short: follicles cylindrical-oblong, reticulately veined, nearly glabrous.-As yet only from northeastern Wyoming.

\section{ANEMONE L. ANemone. Windflower}

Erect perennial herbs. Basal leaves lobed, divided, or dissected, and those of the stem forming an involucre either near to or distant from the solitary or umbellate flowers. Sepals 4-20. Petals wanting. Stamens numerous, shorter than the sepals. Pistils numerous, becoming compressed achenes, which are not long-tailed.

Achenes densely woolly.

Stem low, simple, 1-flowered.

From slender rootstocks

From a short erect caudex

Stems generally branching above, $1-3 \mathrm{dm}$. high; flowers mostly more than 1 .

Head of carpels globose

Head of carpels cylindrical

1. A. parviflora.

2. A. lithophila.

3. A. globosa.

4. A. cylindrica. 
Achenes pubescent only or glabrate.

Leaves of the involucre sessile. Achenes appressed-pubescent Achenes wholly glabrous

Leaves of the involucre petioled. Stems from horizontal or ascending rootstocks

Stems from an erect caudex. Styles deciduous

Styles persistent

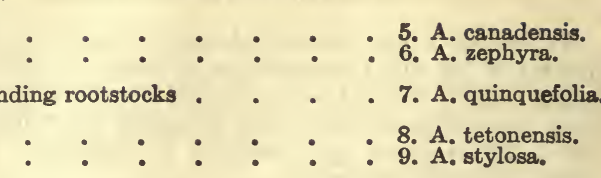

1. Anemone parviflora Michx. Fl. Bor. Am. 1: 319. 1803. Sparingly softly hirsute: the stems low, 4-10 cm. high, the solitary peduncles, in fruit, often longer: rootstock slender: root-leaves 3-parted, their broadly cuneate segments crenately lobed or toothed; involucral leaves nearly sessile, their segments more deeply lobed: sepals 5 or 6 , oval, white: head of fruit globular.Mountains of Colorado, northward to the Arctic sea.

2. Anemone lithophila Rydb. Bull. Torr. Bot. Club 29: 152. 1902. Sparingly pubescent with long silky hairs: stems 1 or more from a short erect rootstock: leaves ternate, the obovate-cuneate segments once or twice 3-cleft or lobed, the lobes oblong: involucral leaves subsessile and similar: sepals silky, ochroleucous, tinged with blue, broadly obovate or oval: achenes densely villous.-Utah and Montana, probably Wyoming and Idaho.

3. Anemone globosa Nutt. ex Pritz. in Linnaea 15: 673. 1841. Silky hairy, 1-3 dm. high: basal leaves long-petioled, 3-5-parted, the segments cleft into linear acute lobes; involucral leaves short-petioled: sepals 5-9, red, rarely yellow, oval or oblong, silky or downy beneath. A. multifida.-Frequent in the central Rocky Mountains.

4. Anemone cylindrica Gray, Ann. Lyc. N. Y. 3: 221. 1836. Tall and clothed with silky hairs: flowers $2-6$, on very long and upright naked peduncles: leaves of the involucre long-petioled, twice or thrice as many as the flower stalks, 3-divided, their divisions wedge-shaped, the lateral 2-parted, the middle one 3-cleft, lobes cut and toothed at the apex: sepals greenishwhite: head of fruit cylindrical.-From Colorado to Bitter Root valley and thence eastward across the continent.

5. Anemone canadensis L. Syst. Ed. 12. 3: App. 231. 1768. Hairy, rather low: involucres sessile; the primary ones 3-leaved, bearing a naked peduncle, and soon a pair of branches or peduncles with a 2-leaved involucre at the middle, which branch similarly in turn; their leaves broadly wedge-shaped, 3-cleft, cut and toothed; radical leaves 5-7-parted or cleft: sepals 5, obovate, white: carpels orbicular. A. dichotoma.-Common along streams; eastern Colorado and Wyoming and eastward.

6. Anemone zephyra A. Nels. Bot. Gaz. 42: 51. 1906. Green but sparsely long-pilose: stems 1 or more from the thick erect caudex, 7-15 dm. high, rather stout: basal leaves petioled, ternate, the broad petiolulate segments mostly deeply 3-cleft, and these segments in turn deeply incised into linearoblong lobes; involucral leaves sessile, with linear-oblong lobes: flowers large, 2-3 cm. broad, lemon-yellow or ochroleucous, usually solitary and rather long pedunculate, sometimes umbellately 2-4-flowered: achenes large, glabrous, obovate, tapering to a stipe-like base, tipped with the short hooked style. A. narcissiflora.-Subalpine or alpine in the central Rocky Mountains.

7. Anemone quinquefolia L. Sp. Pl. 541. 1753. Smooth or somewhat villous: stem perfectly simple from a filiform rootstock, slender, leafless, except for the involucre of 3 long-petioled trifoliolate leaves; their leaflets wedgeshaped or oblong, toothed or cut, or the lateral ones 2-parted; a similar radical leaf in sterile plants solitary from the rootstock: sepals 4-7, oval, white or pinkish: achenes oblong, with a hooked beak. A. nemorosa.-Scarcely within our range; northward and eastward.

8. Anemone tetonensis Porter, Brit. N. Y. Acad. Sci. 6: 224. 1891. Much like A. globosa, but lower and more slender: leaf-segments somewhat broader, obtusish, glabrate: flowers deep purple: achenes dorsally glabrate.-In the high mountains of northwest Wyoming and extending into Idaho and Montana. 
9. Anemone stylosa A. Nels. Bot. Gaz. 42: 52. 1906. Low from a thickened simple or branched caudex, densely covered with the dead sheathing petioles: basal leaves pale green, glabrous, biternate, segments 3-parted, again incised into linear-lanceolate acute lobes; involucral leaves short-petioled, otherwise quite similar: stems and petioles sparsely long-pilose, the hairs spreading or refracted: sepals oval or oblong, purplish-red or greenish-red: achenes pubescent, with rather long straight glabrous persistent styles, hooked at the tip. -Only as yet from type locality, Fish Lake, Utah.

\section{PUlsatilla Adans. Pasque Flower}

Characters nearly the same as for Anemone, except that the styles are always persistent and become greatly elongated and plumose.-Anemone in part.

1. Pulsatilla hirsutissima (Pursh) Brit. Ann. N. Y. Acad. Sci. 6: 1891. Villous with long silky hairs: flower erect, developed before the leaves, which are ternately divided, the lateral divisions 2-parted, the middle one stalked and 3-parted, the segments deeply once or twice cleft into narrowly linear and acute lobes: sepals 5-7, purplish or whitish. Anemone patens Nuttalliana. -From the mountains eastward to Illinois and Wisconsin; the state flower of South Dakota.

\section{Clematis L. Virgin's Bower}

Perennial herbs, either climbing or upright, with opposite leaves, enlarged nodes, and usually showy flowers (large and solitary or smaller and clustered). Sepals 4 or rarely more, valvate, petal-like. Petals none, sometimes the outer stamens sterile, with the filaments broadened and petaloid. Stamens many. Pistils numerous, becoming achenes tailed with feathery or hairy or rarely naked styles.

Petals none; stamens with adnate anthers.

Stems erect; leaves pinnate or pinnatifid.

Leaves pinnate; the leaflets all petiolulate . . . . . 1. C. plattensis.

Leaves twice or thrice pinnatifid.

Petiolules of leaves straight (not contorted). Low and white-villous .

Taller and sparsely villous

Petiolules of some of the leaves contorted as if for climbing

Stems climbing; leaves ternate or pinnately 5 -foliolate .

Petals none; some of the outer stamens petaloid and sterile; stems climbing or sometimes low.

Leaves ternate, entire or merely toothed

Leaves biternate, incisely toothed or lobed

2. C. eriophora.

3. C. Douglasii.

4. C. Scottii.

5. C. ligusticifolia.

1. Clematis plattensis A. Nels. Bot. Gaz. 42: 52. 1906. Stems clustered on the crown of a thick woody root, $12-18 \mathrm{~cm}$. high, terminated by the single stout peduncle of nearly equal length in fruit, sparsely short-villous: basal leaves small, scale-like and entire; foliage proper of about 3 pairs of nearly simple-pinnate short-petioled leaves; pinnae 7-9, the lowest pair sometimes ternate, all distinctly petiolulate (petiolule 3-10 $\mathrm{mm}$. long) and oblonglanceolate, entire, and (in age) merely ciliate-villous: achenes long-tailed, hairy-plumose: flowers not known, presumably much like those of $C$. Douglasii.-Eastern Wyoming, in the cañon of the Platte.

2. Clematis eriophora Rydb. Bull. Torr. Bot. Club 29: 154. 1902. Prominently white-villous: stems 2-4 dm. high, simple: leaves 5-10 cm. long, distinctly petioled, twice pinnately divided; ultimate segments narrowly linear: flowers nodding: calyx villous, campanulate, about $3 \mathrm{~cm}$. long: sepals oblong, obtuse, the upper third spreading, with a dilated margin: achenes silky, their tails long and plumose.-In mountain cañons; Colorado.

3. Clematis Douglasii Hook. Fl. Bor. Am. 1: 1. pl. 1. 1829. Stem simple or branching, more or less villous, woolly at the joints: leaves pinnate to 2or 3-pinnatifid; the leaflets linear or linear-lanceolate: sepals thick, deep purple within, paler externally, woolly at the apex, and spreading: achenes silky, 
the tails 3-4 cm. in length. [C. Bakeri Greene, Pitt. 4: 147. 1900; C. Jonesii (Kuntze) Rydb. 1.c. 153.]-Colorado, northward and westward to Washington.

4. Clematis Scottii Porter, Fl. Col. 1. 1874. Near the two preceding: leaves large, with some or all the divisions 3-5-parted or 3-5-foliolate; lobes or leaflets oblong or ovate-lanceolate; some upper leaves with distinctly tortuous petiolules, as if for clasping a support.- Southern Colorado and New Mexico.

5. Clematis ligusticifolia Nutt. T. \& G. Fl. N. A. 1: 9. 1838. Nearly glabrous: stem more or less woody, often very long, climbing by the tortuous grasping. petiolules: leaves pinnate and ternate, mostly 5-foliolate; the leaflets oblong, acute, often somewhat lanceolate-cuneate, incisely toothed and trifid: flowers white, in paniculate corymbs, dioecious: sepals thin, equaling the stamens.-From New Mexico to the Saskatchewan and Oregon, and also in California; climbing over bushes and producing a great abundance of white flowers.

6. Clematis occidentalis Homem.* Hort. Hafn. 520. 1813. Leaves simply 3 -foliolate, slender-petioled; leaflets slender-petiolulate, ovate mostly acuminate, entire or sparingly dentate: sepals violet, $3-5 \mathrm{~cm}$. long, oblong, acute or acutish: usually some of the outer stamens sterile, with enlarged spatulate petaloid filaments. C. verticillaris.-Colorado to California and north into British America.

7. Clematis pseudoalpina (Kuntze) A. Nels. Stems very short, trailing, hardly if at all climbing: leaves biternate; the divisions lanceolate or ovatelanceolate, acute, pinnately 3-7-toothed, lobed or cleft: sepals lanceolate, acute, thin, purplish-blue or rarely white: petaloid filaments (staminodia) all linear, more or less antheriferous, scarcely exceeding the other stamens: achenes pubescent or glabrous, with long plumose tails. C. alpina occidentalis. (Atragene repens. Rydb. 1. c.)-New Mexico to Utah and Wyoming.

7a. Clematis pseudoalpina tenuiloba (Gray) A. Nels. Differs from the preceding but little: stems even shorter: leaflets more deeply incised and the lobes narrow, often lance-linear. [Atragene tenuiloba (Gray) Brit. in Bull. Herb. Boiss. 3: 206. 1895.]-Colorado and Utah to Dakota and Montana.

\section{MYOSURUS L. MoUSETAIL}

Very small annual herbs, with a tuft of linear or spatulate entire radical leaves, and solitary flowers on simple scapes. Sepals 5 , spurred at base. Petals 5, linear, on a slender claw with a pit at its summit. Stamens 5-20. The long slender spike of achenes and linear radical leaves give the plant the appearance of a diminutive plantain.

1. Myosurus apetalus Gay, Hist. Chil. Bot. 1: 31 . 1845. Scapes 3-5 cm. high, usually spreading, but little surpassing the linear leaves: petals of ten wanting: spike of achenes 6-20 mm. long, ovoid-oblong and more or less squarrose, or cylindrical: achenes oblong, thin-walled, with narrow, prominently carinate back prolonged into a spreading or ascending beak: achene oblong.-Wet saline places; western N. America; also in Chile.

\section{BATRACHIUM S. F. Gray. Water Crowfoot}

Aquatic or subaquatic perennials or winter annuals, with filiform-dissected submersed leaves and sometimes also a few dilated emersed ones; petioles with dilated stipular base. Peduncles solitary, opposite the leaves. Petals white, with a naked nectariferous pit upon the yellow base. Achenes marginless and transversely rugose.-Ranunculus in part.

1. B. longirostre.

* See discussion of this and the following species, under Atragene, by Dr. P. A. Rydberg, Bull. Torr. Bot. Club 29: 155-157. 1902. 
Flowers large (petals 5-8 $\mathrm{mm}$. long); stamens many.

Leaves short and scarcely collapsing when withdrawn from the water

water
Leaves longer and collapsing when withdrawn from the water

Flowers smaller; stamens 5-12

2. B. trichophyllum.

3. B. flaccidum.

4. B. confervoides.

1. Batrachium longirostre (Godr.) F. Schutz. Arch. Fl. Fr. et Allem. 1: 70. 1844. Stem leafy (the internodes short): leaves nearly sessile, all submersed; segments numerous, filiform, 12-15 mm. long, hardly collapsing when withdrawn from the water; the stipules broad and hairy: peduncles moderately stout, 2-3 cm. long: petals ovate, $5-7 \mathrm{~mm}$. long: achenes in a globose head, distinctly beaked.-Ponds and streams; infrequent in our range, but common eastward.

2. Batrachium trichophyllum (Chaix) Bossch. Prod. Fl. Bat. 5. 1850. Wholly submersed; the stems long (3 dm. or more), with rather long internodes: leaves petioled; their segments short $(10-16 \mathrm{~mm}$.), scarcely collapsing when withdrawn from the water; stipules broad, short, hairy: flowers rather large, on stoutish peduncles bringing them just above the surface: achenes apiculate but not beaked, on a hairy receptacle.-Ponds and streams, frequent; across the continent and in Europe.

3. Batrachium flaccidum (Pers.) Rupe. Fl. Cauc. 15. 1869. Scarcely differing from the preceding except in the shorter internodes, more numerous longer-petioled leaves, which have longer more slender segments that collapse on being withdrawn from the water.-Occurring not only in N. America but in Europe and Asia.

4. Batrachium confervoides Fries, Bot. Notiser 121. 1844. Differing from the three preceding in the filiform stem, the very flaccid leaves, the smaller flowers, the few stamens, and the conic (not ovoid) receptacles. - In cold waters; northern Wyoming to Alaska and Lake Winnipeg.

\section{Ranunculus L. Buttercup. Crowfoot}

Mostly low perennial herbs, more rarely annual, with leaves varying from entire to divided, parted or dissected; those of the stem alterncte. Flowers solitary or several in a subcorymbose cluster. Sepals usually 5. Petals 3-15, with a little scale-covered pit at the base inside, yellow (in some degree), often broad and conspicuous. Achenes aggregated in a globular or oblong head, usually compressed; the style often in part (more rarely as a whole) persisting and pointing the achene.

AMPHIBIOUS AQUATICS, the submersed leaves, if any, capillary-multifid.

Leaves orbicular in outline, multifid or many-toothed or lobed

Leaves reniform, 3-lobed

MARSH PLANTS, perennial by creeping stolons

TERRESTRIAL PERENNIALS, often growing in wet places.

All the leaves entire.

Some of the leaves entire

None of the leaves entire.

Some or all of the radical merely crenate-dentate, not divided or parted.

Achenes glabrous, in a globose head.

Sepals densely villous with brown hair . $\quad . \quad$ - $\quad$ 6. R. Macauleyi.
Sepals glabrate or ciliate-pubescent.

Radical leaves reniform-cordate

Radical leaves ovate or suborbicular

Achenes pubescent, in an oblong head.

Petals small, spatulate-oblong.

Petals large, obovate-suborbicular
Most of the radical cleft to the middle or below.

Head of carpels elliptic or oblong.

Achenes pubescent .

Achenes glabrous

Head of achenes globose

All of the leaves deeply cleft or parted.

Plants of alpine or subalpine stations, 3-14 cm. high. Flowers small.

Sepals glabrous

1. R. Purshii.

2. R. natans.

3. R. reptans.

4. R. calthaeflorus.

5. R. glaberrimus.

Sepals villous 
Flowers very large, $2-3 \mathrm{~cm}$. broad.

Leaves 2-3-ternately parted into linear lobes

Leaves digitately 3-7-divided or parted

Plants of middle elevations or lower; mostly $2-\dot{4} \mathrm{dm}$, high.

Wholly, glabrous

More or less pubescent.

Achenes with short hooked beak.

Stems glabrous or nearly 'so; flowers small

Stems hirsute; flowers $15-25 \mathrm{~mm}$. broad.

Pubescence mostly appressed

Pubescence mostly spreading

Achenes with straight stout beak.

Stems stout, very rough hirsute; beak much shorter than the body of the achene.

Head of carpels oblong; petals not longer than the sepals

Head of carpels globose or ovoid; petals longer than the sepals

Stems slenderer; beak as long as the body of the achene

16. $R$. adoneus.

17. R. eximius.

18. R. eremogenes.

19. R. Douglasii.

20. R. acriformis.

21. R. montanensis.

22. R. pennsylvanicus.

23. R. Macounii.

24. R. maximus.

1. Ranunculus Purshii Rich. in Frank. Journ. 751. 1823. Stems floating or immersed, with the divisions of the leaves long and filiform; or rooting in the mud and the leaves round-reniform and more or less deeply lobed and toothed; petioles short, broadly stipulate-dilated at base: flowers large, the petals with conspicuous obovate scales: achenes in a small globose head, beaked by a short straight style. R. multifidus.-Colorado and northward, and across the continent.

2. Ranunculus natans C. A. Meyer, in Ledeb. Ic. t. 114. 1829. Stem filiform, creeping: leaves glabrous, petioled, reniform, 3-cleft; the lobes ovaloblong, divaricate, the lateral ones sometimes somewhat 2-cleft: heads of achenes globose, compact; style wanting.-In swamps at middle elevations; Colorado and northward.

3. Ranunculus reptans L. Sp. Pl. 549. 1753. Glabrous throughout: stems filiform, creeping and rooting at the joints: leaves mostly lanceolate and acute at each end: petals half longer than the sepals: achenes few in a small globular head, plump; beak very short and curved.-Found in Colorado, but most common northward, where it extends across the continent.

4. Ranunculus calthaeflorus Greene, Erythea 3: 45. 1895. Nearly or quite glabrous throughout: roots thickened-fibrous: stems usually solitary, more or less branched, often dichotomously from near the middle, 1-3 dm. high: leaves ovate and oblong-lanceolate, $3-10 \mathrm{~cm}$. long, entire or nearly so; the cauline somewhat narrower and sessile: inflorescence more or less corymbose: petals about 10, oblong-obovate or narrower: achenes in a subglobose head; the beak short, subulate, and nearly straight. $R$. alismaefolius. $(R$. unguiculatus Greene, Pitt. 4: 142. 1900.)-Frequent at high altitudes in the central Rocky Mountains.

5. Ranunculus glaberrimus Hook. Fl. Bor. Am. 1: 13. t. 5. 1829. Glabrous, less than $1 \mathrm{dm}$. high: roots a fascicle of thickened fibers: stems 1-several-flowered: radical leaves elliptic, cuneate at base, 3-cleft to the middle or deeper: flowers $18-25 \mathrm{~mm}$. broad: petals twice as long as the sepals, bright yellow, glossy and shining: achenes with a short beak. $(R$. ellipticus Greene, Pitt. 2: 110. 1890.)-Colorado, northward and west to Washington.

6. Ranunculus Macauleyi Gray, Proc. Am. Acad. 15: 45. 1880. Roots a fascicle of fleshy fibers: stems 10-15 cm. high: leaves petioled, soft-pilose when young, soon glabrate, from oblong to obovate-spatulate, 3-10 toothed: sepals very dark-villous: petals crenulate, about $1 \mathrm{~cm}$. long: carpels glabrous, subglobose, beaked by a short straight style.-Alpine; in southwestern Colorado.

7. Ranunculus abortivus L. Sp. Pl. 551. 1753. Glabrous, 1-5 dm. high: primary root-leaves round heart-shaped or kidney-form, barely crenate, the succeeding ones often 3-lobed or 3-parted; those of the stem and branches 3-5-parted or divided, their divisions oblong or narrowly wedge-form, mostly toothed: petals shorter than the reflexed sepals: achenes with a minute 
curved beak. [R. micropetalus (Greene) Rydb. Bull. Torr. Bot. Club 29: 158. 1902.]-From the mountains eastward across the continent.

8. Ranunculus ovalis Raf. Proc. Dec. 36. 1814 . Dwarf, 7-15 cm. high, hairy: basal leaves petioled, oval to oblong, crenate or slightly lobed; cauline mostly sessile, deeply 3-7-divided into obtuse linear lobes: flowers 10-12 mm. broad; the petals narrow and much exceeding the sepals: head of carpels spherical; achenes ovoid, minutely beaked. $R$. rhomboideus.-From the borders of Wyoming far to the north and east.

9. Ranunculus inamoenus Greene, Pitt. 3: 91. 1896. Green but sparsely hairy, 1-3 dm. high: radical leaves short-petioled, ovate-flabelliform, crenately toothed or 3-lobed at summit; cauline sessile, once or twice ternately divided into oblanceolate segments: peduncles short, slender, sólitary, or several and subumbellate: corolla $6-10 \mathrm{~mm}$. broad; the 5 petals obovateoblong: head of pubescent achenes oblong-cylindrical.-Frequent in moist soil throughout our range.

10. Ranunculus cardiophyllus Hook. Fl. Bor. Am. 1: 14. 1829. More or less pubescent, rather stout and succulent, 1-3 dm. high: some or all of the radical leaves ovate-cordate and coarsely crenate; cauline 3-7-cleft or parted, with broadly linear or oblanceolate divisions: flowers few to several, rather large; the petals obovate-orbicular: achenes pubescent, in an oblong-cylindrical head; the style short.-Occasional; moist valleys in the mountains.

11. Ranunculus pedatifidus J. E. Smith, in Rees. Cycl. No. 72. 1813-16. Similar but smaller and not succulent: radical leaves nearly all more or less lobed or divided, usually pedately multifid with broadly linear lobes: petals pale yellow, $6-8 \mathrm{~mm}$. long: achenes pubescent or glabrate, with short recurved style.-Subalpine; New Mexico, northward to arctic America.

12. Ranunculus alpeophilus A. Nels. Bull. Torr. Bot. Club 26: 350. 1899. Bright green and nearly glabrous throughout, $8-15 \mathrm{~cm}$. high: radical leaves orbicular-flabelliform to nearly reniform, crenately toothed or incisely lobed, the middle lobe lingulate; cauline few, near the top and somewhat involucrate, divided nearly to the base: flowers few: calyx nearly glabrous: achenes in an oblong head, glabrous. $R$. nivalis Eschscholtzii. ( $R$. ocreatus Greene, Pitt. 4: 15. 1899.) -Subalpine, on moist slopes; central Rocky Mountains.

13. Ranunculus pygmaeus Wahl. Fl. Lapp. 157. 1812. Dwarf, 2-5 cm. high: leaves glabrous, 3-5-cleft; the radical petioled: stems usually 1-flowered: sepals glabrous: petals obtuse, about $4 \mathrm{~mm}$. long, not longer than the sepals: achenes subglobose, tipped with a short hooked style, aggregated in an oblong head.-Alpine and rare within our range; extending to arctic America.

14. Ranunculus Jovis A. Nels. Bull. Torr. Bot. Club 27: 261. 1900. Diminutive glabrous perennial, 2-4 dm. high: roots few, fascicled, tuberous, vertical and largest below: radical leaves entire or trifid, long petioled; cauline single, trifid, sessile: stem as long as the petioles, mostly 1-flowered: petals oblong-spatulate, barely exceeding the broader sepals: achenes in a subglobose head, slender beaked. $R$. digitatus Hook.; not $R$. digitatus Willd.Alpine; Utah, northern Wyoming, and westward.

15. Ranunculus Grayi Brit. Bull. Torr. Bot. Club 18: 265. 1891. Low but stouter than the foregoing two: radical leaves biternately or pedately divided and parted; the primary divisions often petiolulate and the lobes linear-oblong or spatulate: stems 1-2-flowered: petals about $5 \mathrm{~mm}$. long, surpassing the villous sepals: achenes subglobose, tipped with a subulate beak and aggregated in a subglobose head.-Rare; on the highest peaks in Colorado, and in British America.

16. Ranunculus adoneus Gray, Proc. Acad. Phila. 56: 1863. Low, sparsely villous, becoming glabrous: stems branching from the base, 1-3-leaved above, sometimes sarmentose-decumbent and 2-3-flowered:' leaves twice pedately parted, segments narrowly linear: petals golden yellow, twice exceeding the subvillous sepals: achenes crowded in an oval head, turgid, with the rather long ensiform beak scarious-winged on each edge.-High altitudes, close to the snow; Colorado.

17. Ranunculus eximius Greene, Erythea 3: 19. 189 Radical leaves 
few, often only 1 , on short stout petioles, cuneate-obovate to flabelliform, deeply about 7-lobed or divided; upper cauline sessile, cleft to the middle or below into broadly linear lobes: corolla $25-30 \mathrm{~mm}$. broad, circular by the overlapping of the several obovate or almost obcordate petals: achenes ovoid, in an ovoid head.-Near snow banks; in the mountains of Northern Wyoming and Montana; probably in Idaho also.

18. Ranunculus eremogenes Greene, Erythea 4: 121. 1896. Annual, erect, 2-5 dm. high, stout and fistulous, sparingly leafy, simple below, loosely corymbose-paniculate above, glabrous, the herbage light green: leaves of rounded general outline, mostly 5-parted and the segments cleft into about 3 lobes, these toothed: flowers $8-10 \mathrm{~mm}$. broad; light yellow petals surpassing the sepals: head of numerous achenes obtusely ovoid-oblong, the oblongovoid receptacle much inflated; achenes nearly beakless. $R$. sceleratus.Margins of pools and springy bogs; plains and valleys of our range, and westward.

19. Ranunculus Douglasii Howell, Fl. N. W. Am. 18. 1897. More or less pubescent or hirsute, 3-6 dm. high: leaves thin, deeply 3-5-cleft; the segments oblanceolate to obovate-cuneate, sharply and irregularly few-toothed: petals spatulate, small, only 2-4 mm. long: receptacle glabrous: achenes glabrous, tipped with a short stout hooked beak.-From Colorado northward (in the mountains) and west to Oregon and Washington.

20. Ranunculus acriformis Gray, Proc. Am. Acad. 21: 374. 1886. Pubescence hirsute, more or less appressed: stems strict and slender, $2-5 \mathrm{dm}$. high: leaves palmately or pedately 3-5-parted into narrow segments which are again 2-3-cleft into lance-linear lobes: flowers several to many: petals orbicular-obovate, $6-8 \mathrm{~mm}$. long, much exceeding the sepals: achenes glabrous, with a curved beak half as long as the body. (R. Earlei Greene, Pitt. 4: 15 . 1900.) -Abundant; moist bottom lands, on the high plains; Colorado into British America.

21. Ranunculus montanensis Rydb. Mem. N. Y. Bot. Gard. 1: 166. 1900. In habit and foliage much like the preceding, but stouter and silky with more spreading hairs: flowers few, large, $20-25 \mathrm{~mm}$. broad: achenes in a globose head, glabrous; the beak long and strongly hooked.-From northern Wyoming into Idaho and Montana.

22. Ranunculus pennsylvanicus L. f. Suppl. 272. 1781. Hirsute with rough spreading bristly hairs: stem stout, erect: divisions of the leaves stalked, somewhat ovate, unequally 3-cleft, sharply cut and toothed, acute: petals pale, not exceeding the sepals: achenes in ovate heads, glabrous, pointed with a sharp beak one third their length.-Within the northeastern part of our range and then eastward to the Atlantic.

23. Ranunculus Macounii Brit. Trans. N. Y. Acad. Sci. 12: 3. 1892. Stout and often diffusely branching from the base, rather rough-hirsute throughout: leaves large, 3-divided; the divisions broadly oblong, acute, cuneate, variously cleft and lobed: flowers $10-12 \mathrm{~mm}$. broad: petals surpassing the spreading or reflexed sepals: achenes with a sharp beak one fourth their length.-Wet soil in the valleys; from the Missouri River to the Pacific.

24. Ranunculus maximus Greene Bull. Torr. Bot. Club 14: 118. 1887. More or less hirsute with spreading hairs, rather stout, 3-6 dm. high: leaves large, 5-10 cm. long, about 5-cleft or divided into oblong or rhomboidal-ovate segments which are laciniately cleft and incised: petals 5-10 $\mathrm{mm}$. long: achenes ovate, strongly margined, tipped with a rigid straight subulate beak as long as the rather large body. $R$. orthorhynchus. (R. orthophyllus A. Nels. Bot. Gaz. 42: 52. 1906.) - In wet places; northern Wyoming and far westward and northward.

\section{HALERPESTES Greene. Trailing Buttercup}

Perennial by long jointed flagelliform stolons which ultimately strike root and produce a new plant at each node. Petals yellow, with a scale at the base as in Ranunculus, deciduous with the sepals. Stamens and carpels numerous. 
Head of fruit oblong-cylindric. Achenes thin-walled and utricular, compressed, the sides striate.-Ranunculus in part; Oxygraphis Prantl.

1. Halerpestes cymbalaria (Pursh) Greene, Pitt. 4: 208. 1900. Low, glabrous perennial with numerous thick fibrous roots: leaves broadly ovate or ovate-cordate, coarsely crenate, clustered at the base of the scapes and at the nodes of the stolons: scapes 5-10 cm. high, 1-7-flowered: petals narrowly oblong or spatulate, exceeding the sepals: achenes apiculate, small and very numerous. Ranunculus cymbalaria.-Moist banks, especially in saline situations; in the Rocky Mountains and on northern seacoasts.

\section{CYRTORHYNCHA Nutt. NutTall's ButTercup}

Perennial, with thick fibrous roots and long-petioled ternately compound leaves. Sepals membranous, deciduous with the pale yellow petals. Stamens about 20. Pistils few, becoming somewhat utricular laterally flattened nerved achenes.-Ranunculus in part.

1. Cyrtorhyncha ranunculina Nutt. T. \& G. Fl. N. A. 1: 26. 1838. Smooth, .7-15 cm. high: radical leaves biternately divided, segments 3-5-parted, lobes oblong or linear, sometimes 2-3-cleft: petals spatulate, a little longer than the broader sepals which are also yellow: achenes rather few, in a globose head, cylindrical-oblong, grooved, many-nerved, tipped with a long slender, incurved style.-Colorado and Wyoming, along the eastern foothills.

2. Cyrtorhyncha neglecta Greene, Pitt. 4: 146. 1900. Similar but taller: flowers few; petals wanting: stamens about 10: achenes ovate.-Rare; cañons near Golden, Colorado.

\section{THalictrum. Meadow Rue}

Erect perennial herbs with radical and cauline leaves ternately decompound. Flowers perfect, polygamous or dioecious, generally small, greenish-white, in panicles or racemes. Sepals 4 or 5, petals none. Pistils few or several, becoming ribbed or nerved achenes, sessile or short-stipulate. Stamens indefinite, exserted.

Flowers hermaphrodite (perfect).

Stem scapose; achenes oblong, few . . . . . . 1. T. alpinum.

Stem leafy; achenes ventrally gibbous, half rhombic, numerous $\quad 2$. T. sparsiflorum.

Flowers dioecious or polygamo-dioecious.

Achenes flattened, 2-edged.

Ovate or ovate-oblong, one edge more gibbous than the other

Lanceolate, acuminate, the two edges nearly alike

Achenes terete or but slightly flattened.

Flowers dioecious; leaves glabrous and glaucous .

Flowers polygamous; leaves obscurely glandular or waxy :

3. T. Fendleri.

4. T. occidentale.

5. T. venulosum.

6. T. dasycarpum.

1. Thalictrum alpinum L. Sp. P1. 545. 1753. Stem simple, scape-like, 5-20 cm. high, slightly pubescent: leaves mostly radical; leaflets roundish, 8-12 mm. long, somewhat lobed and crenately toothed: flowers perfect, in a simple raceme, nodding: stigma thick and pubescent: achenes ovate, sessile.Infrequent, -in the mountains; Colorado and far northward; also in Europe and Asia.

2. Thalictrum sparsiflorum Turcz. in Fisch. \& Mey. Ind. Sem. Hort. Petrop. 1: 40. 1835. Stems striate angled, leafy, 3-8 dm. high: leaves 2 or 3-ternate, the upper sessile; leaflets rather small, sometimes pulverulentglandular beneath: flowers perfect, on long pedicels in a loose panicle: filaments filiform with clavate summit: achenes flat, half rhombic-obovate, the dorsal edge straight, short-stipitate, and tipped with the subulate style:Colorado, northward and west to California.

3. Thalictrum Fendleri Engelm. in Gray, Pl. Fendl. 5. 1848. Stems 3-10 $\mathrm{dm}$. high, 3-5-leaved: leaves 2-4-ternately compound; the leaflets firm, 10-12 mm. long, with rounded or mucronate lobes: flowers dioecious: fila- 
ments capillary; anthers linear, mucronate or apiculate: achenes usually several in the head, ovate or ovate-oblong, flattened and 2-edged, somewhat oblique, the ventral edge more gibbous, 3-nerved on each face, 5-6 mm. long. - Southern Colorado, southward and westward.

4. Thalictrum occidentale Gray, Proc. Am. Acad. 8: 372. 1872. Stem 5-10 $\mathrm{dm}$. high, rather stout, 2-3-leaved: leaves 2-4-ternate; leaflets thin, glaucescent, 15-20 mm. long, the lobes rounded: flowers as in the last: pistils several, usually only a few maturing: achenes scarcely oblique, ovate-lanceolate or narrower, 7-9 mm. long, strongly 3-nerved on the faces.-Colorado, far northward and west to the coast.

5. Thalictrum venulosum Trelease, Proc. Bost. Soc. Nat. Hist. 23: 302. 1886. Glabrous aind glaucous: stem 2-5 dm. high, often purplish: leaves 3-4-ternate, rather long-petioled; leaflets approximate, but primary petiolules rather long, firm, suborbicular and crenate, whitened and veiny below: inflorescence rather narrow: achenes 6-8, but slightly flattened, narrowed to a nearly straight beak, the nerves at maturity becoming enlarged, almost carinate-angled.-From Colorado to British America.

6. Thalictrum dasycarpum F. \& L. Ind. Sem. Hort. Petrop. 8: 72. 1844. Glabrous or glandular-pubescent, 8-15 dm. high, often purplish, branching above: leaves 3-4-ternate; leaflets thick, oblong or obovate, dark green above," often waxy beneath and with revolute margins, coarsely few-toothed around the summit: flowers in lax somewhat pyramidal panicles, polygamo-dioecious: anthers cuspidate: achenes ovoid, glabrous or pubescent, short-stipitate, with 6-8 salient ribs. T. Cornuti.-Moist open woods; from the Rocky Mountains to the Atlantic coast.

\section{BERBERIDACEAE T. \& G. BARBERRY FAMILY}

Our species are shrubs with alternate simple or compound leaves and no stipules. The flower parts are distinct and free, and are opposite to each other instead of alternate; the anthers open by uplifted valves. Sepals and petals imbricated and deciduous. Pistil one, simple; style short or none. Fruit a berry.

\section{BERBERIS L. BARBERRY}

Shrubs with yellow wood, simple or compound often spiny leaves, and yellow racemose flowers. Sepals 6 , yellow, with 3 or 6 closely appressed bracts. Petals six, imbricated in two series, each with 2 basal glands. Stamens 6. Stigma circular and peltate. Fruit a berry with 1-3 seeds.

Stems unarmed.

Prostrate or trailing

Erect, $10-30 \mathrm{dm}$. high

Stems spine-bearing

1. Berberis aquifolium Pursh, Fl. Am. Sept. 219. 1814. A low glabrous shrub, trailing or sometimes suberect; the stems rarely more than 1-3 dm. long: leaves pinnately compound; leaflets $3-7$, ovate to oblong, acute or with rounded apex, spinulose-dentate: racemes few, terminating the stems: berry globose, blue or purple, about $6 \mathrm{~mm}$. in diameter. B. repens. (Odostemon Rydb. Fl. Col. 148.) Commonly known as Oregon Grape.-British Columbia to New Mexico.

2. Berberis Fremontii Torr. Bot. Mex. Bound. 30. 1859. A shrub 15-30 dm. high: leaflets 2-3 pairs, the lowest pair close to the base of the petiole, repand-dentate and spiny: berries somewhat ovate, $5-8 \mathrm{~mm}$. in diameter, dark blue. (Odostemon Rydb. 1. c.)-Infrequent; cañons; southwestern Colorado to Mexico.

3. Berberis Fendleri Gray, Pl. Fendl. 5. 1848. Low but erect shrubs, 5-10 $\mathrm{dm}$. high; stems smooth and shining as if varnished: leaves entire or denticu- 
late, lucid, seemingly simple and fascicled but really compound-unifoliate (the lower leaflets being transformed into rigid spines): raceme crowded, fewflowered, spreading or drooping: berries oval. Southern Colorado and southward.

\section{PapaVeraceae B. Juss. Poppy Family}

Herbs with watery, milky, or heavy yellow sap, the leaves exstipulate, alternate or more rarely the uppermost opposite. Flowers perfect, regular or irregular. Sepals early deciduous, 2 or rarely $3-4$. "Petals imbricated, 4 or more, these also rather early deciduous. Stamens distinct, hypogynous, with filiform filaments and longitudinally dehiscent anthers. Ovary usually 1-celled, with many ovules, becoming a dehiscent 1-celled capsule.-Papaveraceae and Fumariaceae.

Flowers regular; capsule dehiscent at the summit.

Sap milky.

Stemless alpine perennial

Stems stout, hispid, leafy

Sap yellow; stem spinescent
Flowers irregular; capsule dehiscent to the base; sap watery.

The two outer sepals spurred at the base

Only one of the sepals spurred at the base
1. Papaver.
2. Enomegra.
3. Argemone.
4. Dicentra.
5. Corydalis.

\section{PAPAVER L. POPPY}

Ours is a small subcaespitose perennial, with pinnately parted leaves and solitary scapose flowers; sap milky and narcotic. Sepals 2. Petals 4. Ovary 1-celled, with 5-7-placentae which project into the cell partially dividing it; stigmatic lobes or rays as many. Capsule dehiscent by pores which open under the edge of the stigma.

1. Papaver alpinum L. Sp. Pl. 507. 1753. More or less hispid-hirsute: scapes less than $1 \mathrm{dm}$. high: leaves ovate in outline, deeply lobed or parted; the divisions entire or nearly so: petals yellow: capsule hispid. $P$. nudicaule. It seems very probable that P. pygmaeum Rydb. Bull. Torr. Bot. Club 29: 159. 1902, will prove to be the same.-Rare; alpine in our highest mountains.

\section{ENOMEGRA A. Nels.}

Coarse perennial herbs with thick milky sap, and alternate pinnate or bipinnate leaves which are green and sometimes glaucescent but not splotched with white. Pubescence of two kinds: hispid-spinescent on stem and capsules and sparsely so on the toothed lobes of the leaves and on their veins; also a short puberulence which on the stem and capsules tends to become hispid. Flowers crowded in a terminal cluster on the simple stems. Sepals 3. Petals 4-6. Stamens numerous. Capsule 4-valved, with dilated 4-lobed stigma. Seeds numerous, flattened, scarcely pitted.-Argemone in part.

1. Enomegra hispida (Gray) A. Nels. Key Ry. Mt. Fl. 27. 1902. Stems usually several from the deep-set root, 3-6 dm. high: flowers large, 6-9 cm. broad: sepals hispid near the cornuate subcucullate apex, conspicuously reticulate-veiny, and inequilateral by the wing-like membranous margin on one side: petals suborbicular or reniform: filaments and anther both narrow, subequal. Argemone platyceras in part. (Argemone bipinnatifida Greene, Pitt. 3: 346. 1898.) Sandy valleys and slopes; southern Wvoming to New Mexico.

\section{ARgemone L. Prickly Poppy}

Mostly herbaceous annuals with orange-yellow thick acrid sap, and sinuate or pinnatifid spinulose-dentate glaucous leaves, more or less splotched with 
white, and without any setulose hispidity. Sepals usually 3 and petals 6 . Stamens many. Capsule 1-celled, with 4-6 nerviform placentae. Seed pitted.

1. Argemone intermedia Sweet, Hort. Brit. Ed. 2. 585. 1830. Stout, very glaucous, moderately prickly with stramineous spines, otherwise smooth: leaves repand-toothed to sinuate-pinnatifid: petals white or tinged with rose: sepals sparsely spiny, the horns unarmed and not even hispid. A. platyceras in part.- Southern Wyoming to New Mexico.

\section{DICENTRA Bernh.}

Glabrous perennials with the fleshy root surmounted by a bulb-like cluster of fleshy grains and ternately or pinnately compound leaves. Sepals 2 , small and scale-like. Petals 4, in two sets; the outer pair larger, saccate at base, the tips spreading; the inner much narrower, spoon-shaped, the hollowed tips lightly united at the apex, thus forming a cavity which contains the anthers and stigma. Middle anther in each set 2-celled, lateral ones 1-celled. Stigma 2-lobed. Pod 1-celled.-(Bicuculla Adans.)

1. Dicentra uniflora Kellogg, Proc. Calif. Acad. Sci. 4: 141. 1870. The 3 to 7 divisions of the leaves pinnatifid into a few linear-oblong or spatulate lobes: scape 2-3-bracted, 1-flowered: flowers flesh-colored, 10-12 $\mathrm{mm}$. long, the divergent or reflexed tips of the outer petals equaling or exceeding the erect gibbous-saccate base; inner ones not crested, the blade broadly hastate: capsule abruptly beaked with the short style.-Alpine; mountains of Utah and northwest Wyoming to those of Washington.

\section{5. ' CORYDALIS Medik.}

Annual or perennial herbs with watery juice, compound or dissected leaves, and racemose flowers. Sepals 2, small. Corolla irregular; petals 4 , one of the outer pair spurred at the base. Stamens 6 , in 2 sets, opposite the outer petals. Placentae 2. Capsule 2-valved, linear or oblong.-(Capnoides Adans.)

Flowers golden-yellow.

C'apsule incurved-ascending; seeds acute-margined.

Capsule terete or torulose

Capsule thick and somewhat $\dot{4}$-angled

Capsule spreading or pendulous; seeds obtuse-margined Flowers white or cream-color

1. Corydalis montana Engelm. in Gray, Man. Ed. 5. 62. 1867. Light green and glabrous: stems spreading, branched, $1-3 \mathrm{~cm}$. long: leaves pinnately dissected; the divisions oblong or nearly linear: flowers bright yellow, 12-16 mm. long; the spur nearly as long as the body: capsule incurvedascending or somewhat spreading, 15-25 mm. long: seeds lenticular, black, shining, sharp-margined, and obscurely reticulated. Corydalis aurea occidentalis.- In the central Rocky Mountain region, eastward to the plains.

2. Corydalis curvisiliqua Engelm. l. c. Near the last but usually taller, stouter, and more erect: flowers nearly sessile in a spicate raceme: capsule oblong-linear, more or less 4-angled, incurved-ascending: seeds distinctly finely reticulated.- In the eastern part of our range.

3. Corydalis a urea Willd. Enum. 740. 1809. Green and glabrous, usually low and decumbent; the stems branched: raceme many-flowered: tips of the outer petals blunt, carinate but not crested; the spur half as long as the body or often more: capsule usually pendent, more or less constricted and torulose: sceds shining, obtuse-margined, scarcely reticulated.-From Colorado northi.ard and eastward.

4. Corydalis Brandegei Wats. Bot. Calif. 2: 430. 1880. Glabrous and somewhat glaucous; stems stout, mostly erect, $3-10 \mathrm{dm}$. high: leaves twice or thrice pinnately divided; the leaflets $2-3 \mathrm{~cm}$. long, from lanceolate to 
broadly obovate, usually acute: corolla cream-color or white; the spur straight and nearly twice as long as the body: capsule short-oval to oblong, obtuse, reflexed on the ascending pedicels. ( $C$. brachycarpum Rydb. Bull. Torr. Bot. Club 34: 426. 1907.) - Southwest Colorado to Utah.

\section{CRUCIFERAE B. Juss. Mustard Family}

Annual, biennial, or perennial herbs, sometimes with woody base, with watery acrid or pungent sap. Leaves alternate. Flowers perfect, racemose or corymbose. Sepals 4 , deciduous. Petals 4 , or rarely wanting, alternating with the sepals. Stamens 6 , tetradynamous, rarely only 2 or 4 ; the two outer - shorter, opposite the inner sepals. Ovary 2-celled by a septum which stretches across from the placentae, rarely 1-celled; style undivided or wanting; stigma entire or 2-lobed. Fruit a capsule, often greatly elongated, technically called a silique * or, if short, a silicle. The two valves (in most cases) fall away. from the partition or septum, which persists and is often known as the replum. Seeds attached to both sides of the septum.

Silique dehiscent, i. e., the two valves separate from the septum at maturity.

Silique borne on a long stipe .

Silique sessile on the receptacle, or very short-stipitate.

Silique linear or oblong, at least three times longer than broad. Mature silique long-linear (more than $2 \mathrm{~cm}$.).

Silique flattened parallel to the septum.

Pubescence branched or stellate

Pubescence wanting or simple

Silique terete or 4-angled, slightly flattened if at all.

Flowers yellow, large.

Silique 4-angled; plant roughish-pubescent

Silique terete; plant glabrous

Flowers not yellow; silique terete or nearly so.

Petals with crisped margin; stem succulent .

Petals flat; stem not fleshy

Mature silique short-linear or oblong (less than $2 \mathrm{~cm}$.).

Flowers white or purple.

Plants glabrous

Plants pubescent. Leaves entire or toothed

Leaves pinnatifid

Flowers yellow.

Leaves dissected

Leaves lyrately broad-lobed.

Silique distinctly beaked by the persistent style Silique beakless.

Seeds in 2 rows, flat

Seeds in 1 row, globose or oblong

Silique short, rarely more than twice as long as it is broad.

Silique twin, each cell much inflated, subglobose

Silique globose or oblong, not twin.

Scarcely flattened, nearly circular in cross section.

Flowers white; silique pear-shaped

Flowers yellow; silique globose of ellipsoid :

Silique flattened parallel to the septum .

Silique flattened at right angles to the narrow septum.

Silique triangular-obovate or obcordate.

Radical leaves pinnatifid; silique cuneate

Radical leaves entire or merely toothed

Silique elliptic or oval.

Small aquatic annuals

Terrestrial plants.

Seeds several in each cell

Seeds solitary in each cell Seeds solitary in each cell
Silique indehiscent, i. e., the valves not separating from the septum
even at maturity

1. Stanleya.

23. Arabis.

5. Streptanthus.

24. Erysimum.

2. Schoenocrambe.

4. Caulanthus.

3. Thelypodium.

13. Cardamine.

22. Stenophragma.

20. Smelowskia.

21. Sophia.

9. Brassica.

11. Barbarea.

- 12. Roripa.

14. Physaria.

18. Camelina.

15. Lesquerella.

19. Draba.

17. Capsella.

8. Thlaspi.

6. Subularia.

16. Hutchinsia.

7. Lepidium.

10. Raphanus.

* For convenience the term silique has been used to designate the fruit in this family no matter what its shape. 


\section{STANLEYA Nutt.}

Stout herbaceous perennials with entire or pinnatifid leaves, and rather large flowers in greatly elongated spike-like racemes. Buds crowded, each elongated-clavate. Calyx narrow, spreading, yellow. Petals with long connivent claws, yellow. Anthers linear, curved or spirally coiled; filaments elongated, spreading. Capsule subterete, long-stipitate.

Leaves variously pinnatifid.

Plant tomentose or white-villous

Plant glabrous or pubescent, not tomentose.

Flowers pale or cream-color

Flowers bright yellow

Leaves twice-pinnate or dissected

Leaves simply-pinnate or subentire

Leaves entire or nearly so.

Leaves mostly cauline, normal .

Leaves mostly basal; stem leaves reduced :
1. S. tomentosa.

2. S. albescens.

3. S. bipinnata.

4. S. pinnata.

5. S. integrifolia. 6. S. viridiflora.

1. Stanleya tomentosa Parry, Am. Nat. 8: 212. 1874. White-villous or hirsute throughout, stout, 8-15 dm. high: lower leaves lyrate-pinnatifid; the upper entire and hastate: raceme dense, thick, cylindrical, 3-5 dm. long: flowers pale or cream-color: pedicel and stipe subequal.-Dry gypsaceous soil; Big Horn Basin, Wyoming.

2. Stanleya albescens Jones, Zoe 2: 17. 1891. Erect and branching, 3-10 dm. high: leaves thick, pale and glaucous, lyrately pinnatifid or some of the upper entire, more or less petioled, with hastately auricled base: sepals greenish-white: petals cream-color, the blade broad, the narrow claw scarcely woolly-pubescent: anthers tightly coiled: silique curved-ascending.-Western Colorado, Utah, and southward.

3. Stanleya bipinnata Greene Erythea 3: 173. 1896. Closely allied to the preceding but the stems several from the same crown, spreading-assurgent, 3-5 dm. high: leaves sometimes dissected, at least more or less twice-pinnate, usually lightly pubescent above but often glabrous: inflorescence slightly pubescent or glabrous: siliques very slender, torulose and tortuous; the stipe about equaling the pedicel. (S. glauca Rydb. Bull. Torr. Bot. Club 31: 409 . 1904.)-Dry banks and slopes; Wyoming, Colorado, Utah.

4. Stanley apinnata (Pursh) Brit. Trans. N. Y. Acad. Sci. 8: 62. 1888. Glabrous or nearly so, 4-10 dm. high: leaves mostly cauline, from nearly entire to pinnately divided; the lower rather long-petioled; the upper often entire, short-petioled: petals 15-20 mm. long: stamens well exserted: siliques somewhat torulose, twice as long as the stipes. (S. arcuata Rydb. Bull. Torr. Bot. Club 29: 232. 1902.)-Widely distributed; dry plains; Dakota to New Mexico and California.

5. Stanleya integrifolia James, Cat. 185. 1825. Closely allied to S. pinnata, stems less stout but the base indurated-shrubby, erect, 3-6 dm. high: leaves entire, or the lower rarely few-toothed, mostly oblong, all short-petioled: buds cylindric, the raceme relatively short: pedicel shorter than the stipe which is somewhat surpassed by the slender curved spreading silique.-Wyoming and Colorado.

6. Stanleya viridiflora Nutt. T. \& ${ }^{-G}$. Fl. N. A. 1: 98. 1838. Glabrous, 4-12 dm. high: leaves crowded toward the base, mostly entire; the lower cuneate-obovate, sometimes with a few teeth toward the base; becoming smaller upward, clasping, lanceolate and passing into the bracts of the greatly elongated spike-like raceme: sepals and petals greenish-yellow.-From the Mexican border to the upper Missouri, and west to California.

\section{SCHOENOCRambE Greene. Planns Mustard}

Perennial herbs from long horizontal rootstocks which give rise at intervals to slender virgate simple or branched stems, with no root leaves, linear, entire, or pinnate stem leaves, and racemose slender-pediceled rather large yellow flowers. Buds cylindric-oblong. Sepals erect. Petals twice as long 
as the sepals. Stamens not exserted. Ovary sessile; style short. Silique slender, terete.-Sisymbrium in part.

1. Schoenocrambe linifolia (Nutt.) Greene, Pitt. 3: 127. 1896. Glabrous and green: stems from running rootstocks, one or more from each node, erect, simple or at length somewhat branched above: leaves all cauline, linear, entire, or the lower sometimes somewhat incised and oblanceolate: silique $3-6 \mathrm{~cm}$. long, linear, suberect, on short spreading pedicels; style short; seeds oblong. Sisymbrium linifolium. (S. decumbens Rydb. Bull. Torr. Bot. Club 31: 409. 1904.) - Northern Colorado to Montana and westward.

1a. Schoenocrambe linifolia pinnata (Greene) A. Nels. Glabrous and glaucous throughout: stems always simple, nearly leafless above: the lower leaves rather numerous, pinnatifid into 5-8 pairs of obovate-oblong entire segments. (S. pinnata Greene, l. c.)-Range of the species.

\section{THELYPODIUM Endl.*}

Mostly biennial herbs (rarely perennial), with alternate petioled or clasping stem leaves and white, purple, or yellow flowers. Calyx cylindric or clavate in bud, spreading in flower. Petals flat, long and narrow or with claw and blade. Filaments long and slender; anthers linear, sagittate at base, curved or coiled. Stigma small, circular in outline, or very slightly 2 -lobed. Silique slender, terete, or 4-angled, often torulose.

Biennials.

Flowers white or purple.

Stem leaves not clasping.

Sessile; siliques numerous, short . . . . . . 1. T. integrifolium.

Petioled; siliques few, long.

Siliques erect, on spreading pedicels . . 2. T. linearifolium.

Siliques widely spreading, on divaricate or deflexed pedicels 3 . T. Wrightii.

Stem leaves clasping by a cordate or sagittate base.

Lanceolate to linear, acute

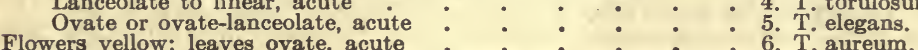

Perennials.

Glabrous or glabrate

More or less stellate-pubescent

1. Thelypodium integrifolium Endl. Walp. Rep. 1: 172. 1842. Glabrous, erect, more or less branched, usually simple at base, 4-12 dm. high: radical leaves petioled, oblong or elliptical; cauline lanceolate, sessile, the uppermost nearly linear: inflorescence usually corymbosely branched; flowers pale rosecolor, very crowded-spicate, on divaricate pedicels: siliques sharp-pointed, somewhat nodulose, suberect or upwardly curved, very uniform, $2-3 \mathrm{~cm}$. long.-From Colorado and Nebraska to the Pacific.

1a. Thelypodium integrifolium gracilipes Robinson Syn. Fl. 1: 176. 1895. Racemes more elongated, becoming $1 \mathrm{dm}$. or more in length: siliques borne upon a slender stipe 2-3 mm. long. (T. lilacinum Greene, Pl. Baker. 3: 9. 1901.) Southwestern Colorado.

2. Thely podium linearifolium Wats. Bot. King's Rep. 5: 25.1871. Glabrous biennial (rarely perennial), more or less branched, sometimes from the base: basal leaves incisely serrate, obovate, early deciduous; cauline leaves linear to linear-oblong, narrowed to the short petiole-like base: flowers somewhat scattering: petals with obovate blade and slender claw, rose-purple: silique suberect, 4-7 cm. long, on very slender spreading pedicels.-Colorado and southward.

3. Thelypodium Wrightii Gray, Pl. Wright. 1: 7. 1852. Glabrous annual or biennial, $5-8 \mathrm{dm}$. high, more or less paniculately branched above: leaves broadly lanceolate or lanceolate-oblong, 5-10 cm. long, all repand toothed or

* This genus has recently been the subject of some discussion, and Rydberg has proposed the following doubtfully distinct segregates: Thellypodiopsis, Pleurophragma, Hesperidanthus, Stanleyella, and Heterothrix. For species included under each, see Bull. Torr. Bot. Club 34: 432. 1904.

ROCKY MT. BOT. -14 
denticulate: flowering raceme short and dense, more open in fruit: siliques very slender, $4-8 \mathrm{~cm}$. long, widely spreading or recurved, on filiform pedicels half as long.- Colorado and Utah and southward.

4. Thelypodium torulosum Heller, Bull. Torr. Bot. Club 25: 265. 1898. Glabrous and somewhat glaucous: stems erect, rather weak, branching above, 4-7 dm. high: leaves from lanceolate below to linear above, auricled-sagittate, clasping: flowers lilac-colored: petals 12-15 mm. long: silique slender, narrowed to a substipitate base, ascending-torulose, 4-7 $\mathrm{cm}$. long: pedicel divaricate, $8-12 \mathrm{~mm}$. long. T. sagittatum.-Western Wyoming, westward and northward.

5. Thelypodium elegans Jones, Zoe 4: 265. 1894. Smooth and glaucous: stems simple or branched from the base, rather closely leafy below: radical leaves early deciduous; cauline leaves cordate-clasping, ovate, or ovatelanceolate, acute, 15-35 $\mathrm{mm}$. long: flowers opening at the summit of the raceme which becomes greatly elongated in fruit: petals pale purple: siliques sessile, on pedicels less than $1 \mathrm{~cm}$. long, straight or curved, ascending, rather thick-linear, 5-7 cm. long.-Western Colorado and adjacent Utah.

6. Thely podium aureum Eastw. Zoe 2: 227. 1891. Glaucous but sparsalretrorsely hairy on the lower part of the stem, branched from the base, 3-4 din. high: radical leaves oblanceolate, dentate, on margined petioles; caulizo ovate, auriculate-clasping, acuminate: sepals and petals bright yellow: siliques very slender, 4-6 cm. long, short-stipitate, nearly erect, on short spreading pedicels.-Mancos, Colorado.

7. Thely podium paniculatum A. Nels. Bull. Torr. Bot. Club 26: 123. 1899. Glabrous and glaucous perennial: stems simple below, paniculately branched above: radical leaves oblong, short-petioled; cauline sagittate clasping, subacute or obtuse, from oblong below to lanceolate above: petals white or purplish, twice as long as the oblong-spatulate sepals, the limb obovate: silique substipitate, pointed at apex, $20-30 \mathrm{~mm}$. long, nearly erect, on short spreading pedicels. T. Nuttallii. -Wyoming and northwestward.

8. Thely podium micranthum (Gray) Wats. Bot. King's Rep. 5: 25. 1871. More or less stellate-pubescent (or even quite glabrous), 3-9 dm. high: lower and stem leaves oblanceolate, sinuately pinnatifid, stellate-pubescent; the upper linear, entire, usually glabrous: flowers small, 2-3 $\mathrm{mm}$. long: calyx glabrous or pubescent: pod slender, subpendulous, about $2.5 \mathrm{~cm}$. long, sessile, with a very short thick style. ( $T$. longifolium of most authors.)-Colorado to Texas and Mexico.

\section{Caulanthus Wats. Wild Cabbage}

Coarse and more or less succulent herbs, with the leaves largely basal, and greenish-yellow flowers in racemes. Sepals large, somewhat saccate at base, usually purplish. Petals undulate-crisped, with a broad claw and narrow or obsolete blade. Anthers linear, sagittate. Silique subterete, sessile; the style nearly wanting; the valves 1 -nerved and often reticulate.

Stem fleshy, hollow; flowers ascending

Stem not hollow; flowers horizontal or deflexed

1. C. crassicaulis.

1. Caulanthus crassicaulis (Torr.) Wats. Bot. King's Rep. 5: 27. 1871. Glabrous or nearly so, except the pubescent sepals: stems simple, erect, thickfleshy, hollow, 3-5 dm. high: leaves mostly basal, lyrately toothed or pinnatifid; cauline much reduced, linear or somewhat hastate: flowers subsessile, rather large: silique ascending, slender, 7-12 cm. long.-Western Wyoming to Idaho and southern California.

2. Caulanthus hastatus Wats. Bot. King's Rep. 5: 28. pl. 3. 1871. Glabrous, simple or somewhat branched. 4-8 dm. high: leaves petioled, very variable; radical lyrate or entire, the terminal leaflet ovate, hastate, or truncate at base, the lateral leaflets very small; cauline ovate-oblong, entire, hastate, rounded or cuneate at base: flowers in a loose virgate raceme, reflexed: sepals narrow, distant: petals (sometimes nearly wanting) equaling the sepals, 
toothed on the sides: siliques spreading, somewhat knotted. (Chlorocrambe hastatus Rydb. Bull. Torr. Bot. Club 34: 435. 1904.)-Eastern Utah (probably adjacent Colorado and Wyoming) to Oregon.

\section{STREPTANTHUS Nutt.}

More or less branching usually glaucous annuals, biennials, or perennials, with leaves generally sagittate and clasping, and racemed white, purple, or yellow flowers. Calyx ovoid or by the spreading of the tips of the sepals flaskshaped. Petals usually narrow, linear, or with a well-developed blade and a channeled claw. Anthers long, sagittate. Silique oblong to linear, flattened. Pubescence, if any, simple.

Annual; leaves not clasping

Perennials; leaves clasping.

Leaves acute: siliques broadly linear

Leaves acute; siliques subterete.

Siliques stipitate

Siliques not stipitate

1. Streptanthus longirostris Wats. Proc. Am. Acad. 25: 127. 1889. Glabrous and glaucous annual, branching above, $2-5 \mathrm{dm}$. high: radical leaves ovate-spatulate, soon deciduous; cauline linear to narrowly oblanceolate, entire or sparingly toothed: flowers spreading or reflexed: petals white, about $5 \mathrm{~mm}$. long: silique linear, attenuate to the slender style that points it, reflexed on short pedicels: seeds elliptical, winged.-Colorado and Wyoming to Washington.

2. Streptanthus cordatus Nutt. T. \& G. Fl. N. A. 1: 77. 1838. Glabrous or glaucous: stem simple, $2-5 \mathrm{dm}$. high, rather stout: leaves thick, usually repandly toothed toward the apex, the teeth often setosely tipped; lower leaves spatulate-ovate or obovate, cauline cordate to oblong or ovate-lanceolate: petals about half longer than the sepals, greenish-yellow to purple: siliques broadly linear, 5-10 cm: long, spreading.-Colorado and Wyoming to the Sierra Nevada.

3. Streptanthus coloradensis A. Nels. Sparsely ciliate-hirsute, especially below: stems several from the crown of a biennial or perennial root, ascending, 1-3 dm. long: radical leaves obovate-spatulate, sharply serrate around the summit, short-petioled, ovate-lanceolate, clasping-auricled, 1-3 cm. long: flowers white, crowded at first, the raceme much lengthened in fruit: sepals linear, acute, half as long as the obovate-spatulate petals: silique linear, 6-9 $\mathrm{cm}$. long, ascending, somewhat torulose, attenuate to a beak $3-5 \mathrm{~mm}$. long; the stipe slender, about $5 \mathrm{~mm}$. long, half as long as the slender pedicel. (Euklisia crassifolia Rydb. Bull. Torr. Bot. Club. 33: 142. 1906; not S. crassifolius Greene, Pitt. 3: 227. 1897.)-Western Colorado.

4. Streptanthus wyomingensis A. Nels. Bull. Torr. Bot. Club 26: 126. 1899. Glabrous or nearly so, branched from the base: stems simple or branched, 3-4 dm. high: radical leaves laciniate-toothed, obovate, short-petioled; cauline clasping-auriculate, from coarsely dentate to entire above: flowers large, numerous: sepals oblong, half as long as the white or pinkish petals; claw of petal long and narrow, the blade oval: silique linear, sessile, not beaked, ascending, 6-10 cm. long, on stout pedicels.-Western Wyoming to Utah.

\section{SUBULARIA L. Awlwort}

A dwarf stemless aquatic, with tufted subulate leaves and few minute white flowers in a loose scapose raceme. Sepals ovate, obtuse. Petals oblong or spatulate. Stigma sessile. Silique slightly flattened, elliptic or oval; the seeds in 2 rows.

1. Subularia aquatica L. Sp. Pl. 642. 1753. Growing in tufts in shallow water of cold lakes or on the muddy shores: leaves glabrous, terete, shorter than the scapes: flowers scattered: sepals and petals subequal: silique some- 
what truncately obtuse.- " In great abundance at the head of the Yellowstone Lake," Parry; infrequent but very widely distributed.

\section{Lepidium L. Peppergrass}

Annual, biennial, or perennial herbs, with entire, toothed, or pinnatifid leaves tapering at base, and with small white or greenish flowers (which are sometimes apetalous) in dense racemes. Stamens often fewer than 6 . Silique strongly flattened at right angles to the septum, oblong to orbicular, frequently wing-margined especially toward the summit which thus becomes more or less notched. Seeds flattened, solitary in each of the flattened keeled valves. Cotyledons (in ours) incumbent.

Style short but evident; biennials or perennials.

Silique not notched at apex

Silique with shallow notch and short style.

Leaves entire or merely toothed at apex.

Leaves, in part at least, pinnately toothed, pinnatifid, or parted.

Linear-entire and linear-parted; perennials. Silique rhombic-ovate

Silique orbicular
Pinnatifid, or the upper entire; biennials. Branched from the crown of the thick root

Branched above, the base usually simple

Style wanting; the stigma sessile in the notch of the silique.

Siliques glabrous.

Annuals.

Petals wanting; root leaves incisely toothed or pinnatifid. Stem simple at base

Stem divergently branched from the base

Petals evident; root leaves entire or merely toothed : Biennials.

Stems several from the crown, widely spreading

Stems single from the crown, branching from the base ip $\cdot 10$. L. ramosissimum.

Siliques pubescent.

Stem hirsute with white hairs .

Stem finely puberulent

1. L. Draba.

2. L. spatulatum.

3. L. alyssoides.

4. L. Fremontii.

5. L. montanum.

6. L. Jonesii.

1. Lepidium Draba L. Sp. Pl. 645. 1753. Pubescent perennial, 2-4 dm. high: leaves elliptic to elliptic-lanceolate, obtuse, denticulate, clasping by a somewhat narrowed auricled base, $3-6 \mathrm{~cm}$. long: petals white, conspicuous: silique broadly ovate, subcordate at base, acutish at apex and tipped with the short slender style.-Adventive; infrequent; waste grounds.

2. Lepidium spatulatum Vasey, Robins. Syn. Fl. 1: 125. 1895. Glabrous perennial, 2-5 dm. high: stems usually several from the woody caudex, each simple below, paniculately branching upward: leaves green, rather thick; the lower oblanceolate, tapering gradually to the slender petiole, 3-toothed at the apex, as are also some of the oblong shorter stem leaves: racemes numerous, dense: petals white, exceeding the sepals: silique glabrous, ovate, minutely notched at apex; style short. (L. crenatum Rydb.; Thelypodium crenatum Greene.)-Western Colorado and in Utah.

3. Lepidium alyssoides Gray, Pl. Fendl. 10. 1848. Probably perennial, usually a few stems from the base which are corymbosely branched above, glabrous or puberulent, about $2 \mathrm{dm}$. high: leaves glabrous, linear, 4-8 cm. long; the lower pinnate with 2-3 pairs of linear lobes: racemes dense: petals white, conspicuous: silique rhombic-ovate, the shallow notch occupied by the short style. (L. Eastwoodiae Wooton, Bull. Torr. Bot. Club 25: 258. 1898, as to Colorado specimens; L. Crandallii Rydb. Bull. Torr. Bot. Club 34: 427. 1897.) - Arid places; western Colorado, Utah. and southward.

4. Lepidium Fremontii Wats. Bot. King's Rep. 5: 30. 1871. Glabrous and glaucous: stems several from the woody caudex, paniculately branched above, $3-4 \mathrm{dm}$. high: leaves linear, acute, 4-8 cm. long; some of the lower pinnate with 1-3 pairs of linear teeth or lobes: flowers white: silique large, suborbicular, very thin, acutish at base, cordately notched above; style very short.Arid areas; Colorado and New Mexico to California.

5. Lepidium montanum Nutt. T. \& G. Fl. 1: 116. 1838. Nearly glabrous: 
stems usually many from the enlarged crown of the biennial (possibly perennial) root, decumbent-spreading, 1-2 dm. long: leaves pinnatifid, sometimes bipinnatifid, with short acute segments; the upper tending to become entire: flowers in dense racemes: sepals oblong-oval, half as long as the white petals: silique elliptic to suborbicular.-Dry saline soils; Montana to New Mexico and far westward.

6. Lepidium Jonesii Rydb. Bull. Torr. Bot. Club 29: 233. 1902. Glabrous biennial or sometimes perennial: stem simple below, branching freely from the base upward, 2-3 dm. high: basal leaves pinnatifid with linear acute divisions; stem leaves similar but becoming linear and entire above: sepals oblanceolate; obtuse, much shorter than the white petals: silique ovate, emarginate; style short, enlarged upward toward the rather large circular stigma. (L. brachybotryum Rydb. 1. c.) - Western Colorado and in Utah.

7. Lepidium a petalum Willd. Sp. Pl. 3: 439. 1801. Glabrous annual, with erect stem, generally simple below and more or less paniculately branched above but sometimes very freely branched throughout, 1-2 dm. high: leaves usually pale green; the lower more or less incisely toothed or pinnatifid: flowers apetalous: stamens only 2: raceme appearing contracted just below its summit: silique orbicular, glabrous, the stigma sessile in the evident notch.-Very widely distributed; across the continent northward; south through the Rocky Mountains to New Mexico.

8. Lepidium divergens Osterh. Bull. Torr. Bot. Club 30: 237. 1903. Biennial, minutely pubescent, divergently branched from the base: radical leaves broadly spatulate, more or less dentate, short-petioled; cauline smaller and mostly entire: racemes long, with horizontal pedicels: petals wanting: capsule elliptic, glabrous, emarginate, $3 \mathrm{~mm}$. long.-In the mountains; northwestern Colorado.

9. Lepidium medium Greene, Erythea 3: 36. 1895. Glabrous annual, the stem simple below, usually sparingly branched upward, $2-4 \mathrm{dm}$. high: leaves narrowly lanceolate, more or less toothed but scarcely pinnatifid; the upper linear and entire: pedicels slender, early divaricate: petals small but evident: stamens 2 or 4 : silique orbicular, retuse, the stigma sessile. L. intermedium.From Texas to Idaho and California.

10. Lepidium ramosissimum A. Nels. Bull. Torr. Bot. Club 26: 124. 1899. Obscurely pruinose-pubescent biennial, profusely branched; the branches either divaricate and crowded the whole length of an excurrent axis, or diffusely spreading from the base, or both: first year's leaves oblanceolate, coarsely toothed; the second year's leaves cauline, oblanceolate, sparsely toothed; the upper entire, linear or oblong: racemes very numerous; the flowers crowded: petals minute: stamens 2 (to 4): silique broadly ovate, nearly smooth, the notch relatively broad and deep. L. virginicum.-Plains of southwestern Wyoming and northern Colorado.

11. Lepidium ramosum A. Nels. 1. c. 125. Obscurely granular-puberulent: a simple erect stem from the rosette of the first year's leaves, corymbosely branched from the base up, 1-2 dm. high: leaves much as in the preceding, some of the lower cauline often pinnately lobed and rather large: racemes contracted just below the summit, the pedicels spreading after flowering: sepals subecute, about as long as the narrow spatulate petals: stamens 2 (to 4): silique orbicular narrowly winged around the summit, the sinus deep and narrow.-Western Wyoming and northward and westward.

12. Lepidium lasiocarpum Nutt. T. \& G. Fl. N. A. 1: 115. 1838. Hirsutely white-pubescent: the stem branching from the near base: lower leaves pinnately parted, the lobes rather broad and obtuse; the cauline spatulate, more or less dentate: pedicels flattened horizontally: petals minute or none: stamens 2: siliques orbicular, hispidulous, emarginate, with a narrow sinus. - Sandy soils; from southwestern Colorado to Texas and California.

13. Lepidium pubecarpum A. Nels. Bot. Gaz. 30: 189. 1900. Annual, freely branched from the base and paniculately upward, not much more than $1 \mathrm{dm}$. high, obscurely puberulent: leaves small, glabrous, linear or somewhat spatulate, acute, sometimes remotely toothed; petals wanting: the sepals 
purplish: silique permanently finely pubescent, oval or orbicular, the sinus narrow and shallow.-From Yellowstone Park to Utah and Nevada.

\section{THLASPI L. Wild Candytuft}

Annual or perennial herbs, with entire leaves, the radical rosulate (entire or toothed), the cauline auriculate-clasping. Stems usualiy simple, terminating in a more or less elongate raceme. Sepals short, equal at base. Petals obovate or oblanceolate, entire. Style slender, or rarely none. Silique orbicular, elliptic-oblong or oblanceolate; the valves very strongly and usually sharply keeled, of ten winged, especially toward the apex.

Capsules orbicular, large

Capsules obovate or oblong-cuneate.

Basal leaves closely rosulate, thick, dark or purplish-green. Oval or orbicular, abruptly contracted to the petiole. Broadly spatulate

Basal leaves openly rosulate, thin, pale green. Petals 5-6 mm. long; style $1.5 \mathrm{~mm}$. long Petals 2-3 mm. long; style $0.5 \mathrm{~mm}$. long
1. T. arvense.

2. T. Fendleri.

3. $\mathrm{T}$. coloradense.

4. T. glaucum.

5. T. parviflorum.

1. Thlaspi arvense L. Sp. Pl. 646. 1753. Glabrous annual, 2-3 dm. high: stems simple or branched above: leaves spatulate below, oblong upwards, obtuse, remotely and irregularly dentate: flowers small, the greenish sepals somewhat exceeded by the white $3 \mathrm{~mm}$. long petals: silique very flat, orbicular, broadly winged, deeply notched at apex.-Adventive and occurring as a weed in waste ground, increasingly so in our range; often called FrencH WEED.

2. Thlaspi Fendleri Gray, Pl. Wright. 2: 14. 1853 . Glabrous perennial, $8-15 \mathrm{~cm}$. high: branches of caudex several, short, slender, covered with the somewhat rosulate leaves: basal leaves small, oval or orbicular, mostly less than $1 \mathrm{~cm}$. long, abruptly contracted to the short slender petiole; stem leaves auriculate-clasping, ovate or oblong, acute or obtuse, 5-15 $\mathrm{mm}$. long: petals spatulate, $5 \mathrm{~mm}$. long: sepals elliptic, with petaloid margin and a purplish spot, half as long as the petals: silique obovate-cuneate, truncate or slightly depressed at summit, 6-7 mm. long; the slender style nearly one half as long. -Subalpine, flowering in summer; southern Colorado and New Mexico.

3. Thlaspi coloradense Rydb. Bull. Torr. Bot. Club 28: 280. 1901. Quite similar; the caudex denser and the stems as well as the leaves inclined to be rosulate-spreading: the early leaves murky green or purplish; the basal broadly spatulate; otherwise like the preceding. T. alpestre. (T. purpurascens Rydb. l. c., at least as to Colorado specimens.) - One of the earliest flowers at middle elevations; Wyoming and Colorado.

4. Thlaspi glaucum A. Nels. Bull. Torr. Bot. Club 25: 275. 1898. Glabrous and glaucous, 1-3 dm. high: caudex open and slender-branched: stems few, erect: leaves all large, thin and pale or glaucous; the basal oblong or obovate, obscurely repand-denticulate, petioled; the cauline elliptic or deltoidovate: petals spatulate, $6 \mathrm{~mm}$. long, much exceeding the thin greenish sepals: silique obovate, obtuse or emarginate, twice as long as the style but exceeded by the divaricate pedicels. - Late summer in the highest mountains; Colorado to Idaho.

5. Thlaspi parviflorum A. Nels. Bull. Torr. Bot. Club 27: 264. 1900. Similar but smaller in every way, less glaucous: the floral parts half as large: silique spatulate, with a thick style only $0.5 \mathrm{~mm}$. in length. (T.Nuttallii Rydb. 1. c. 29: 235.) - Open slopes, middle elevations; Yellowstone Park.

\section{BRASSICA L. MUUSTARD}

Coarse annual, biennial, or perennial herbs with rather large more or less pinnatifid leaves and large yellow flowers in elongated racemes. Siliques elongated, subterete, beaked with an indehiscent prolongation of the convex 
nerved valves. Seeds oblong, in 1 row. An important genus, giving us the cabbage, turnip, mustard, etc.; when running wild becoming unsightly weeds.

Siliques spreading, gradually beaked Siliques appressed, abruptly beaked .
1. B. arvensis.

2. B. nigra.

1. Brassica arvensis (L.) B. S. P. Prel. Cat. N. Y. 1888. Rough with scattered hairs, 3-5 dm. high: lower leaves pinnatifid, long-petioled, the terminal lobe large and toothed; upper smaller and sometimes nearly entire: pedicels stout, short: silique sessile, spreading, tapering to the flattened beak which is often 1-seeded. CHARLOCK, Wild Mustard.-Introduced, and more or less common as a weed.

2. Brassica nigra (L.) Koch, in Roehl, Deutsche Fl. Ed. 3. 4: 713. 1833. Very similar but usually larger: the leaves more pinnatifid, the uppermost reduced to oblong-lanneolate entire sessile blades: silique cylindric or 4-sided, abruptly contracted to we short beak, closely appressed to the rachis. BLACK Mustard.-Infrequent; in waste places.

\section{RAPHANUS L. WILD RADish}

Erect biennial herbs with pinnate or lyrate leaves and large showy flowers in panicled racemes. Sepals oblong, the lateral somewhat saccate. Petals large, long-clawed, yellow or fading to white. Siliques linear-conical, coriaceous, indehiscent, constricted between the seeds or continuous or spongy within, tipped by the slender style. Seeds subglobose.

1. Raphanus raphanistrum L. Sp. Pl. 669. 1753. Stem erect and freely branching, 4-7 dm. high, hispid pubescent below: the lower leaves lyratepinnatifid; the upper reduced, becoming oblong and entire: siliques $3-4 \mathrm{~cm}$. long. WILD RADISH.-An occasional weed in waste places.

\section{BARBAREA R. Br. Winter Cress}

An erect branching biennial, with angled stem, lyrately pinnatifid leaves, and yellowish racemose flowers. Silique linear, somewhat 4-angled, pointed. Seeds in 1 row in each cell.

1. Barbarea americana Rydb. Mem. N. Y. Bot. Gard. 1: 174. 1900. Glabrous erect biennial 2-4 dm. high: basal leaves broadly elliptic, wavy, simple, or with 1 or 2 pairs of small lobes on the petiole; lower stem leaves similar but with the petiole clasping at base; upper stem leaves sinuately toothed or lobed: petals spatulate, about $3 \mathrm{~mm}$. long: silique somewhat 4 -angled, $2-3 \mathrm{~cm}$. long, pointed with the short style, suberect, on short spreading pedicels. -This native species was long mistaken for the European $B$. vulgaris, naturalized in many parts of the United States.

\section{RORIPA Scop. Cress}

Mostly glabrous biennials or perennials, with simple or pinnately lobed or lyrate leaves and yellow or white flowers. Sepals flat, nearly equal at base. Petals short-clawed. Silique sessile, usually short, subterete; style short and rather thick; valves 1 -nerved. Seeds in 2 rows, turgid. Plants growing mostly in wet places, or rarely in the water.-Nasturtium.

Flowers white; aquatic perennial

Flowers yellow.

Perennial by running rootstocks

Annual or biennial.

Stems erect, simple below, 2-10 dm. high.

Hispidly hirsute on stems

Glabrous throughout (or nearly so)

Stems branched from the base, low and spreading.

Fruiting raceme normal.

Silique slender, curved, 8-15 mm, long .

Silique short, straight, 5-7 $\mathrm{mm}$. long :

Fruiting raceme unilateral
1. R. Nasturtium.

2. R. sinuata.

3. R. hispida.

4. R. palustris.

5. R. curvisiliqua,

6. R. lyrata.

7. R. curvipes, 
1. Roripa Nasturtium (L.) Rusby, Mem. Torr. Club 3: 5. 1893. A glabrous aquatic with decumbent stems rooting at the nodes, often 4-5 dm. high: leaves pinnate or pinnately lobed; the leaflets or lobes sinuate, the terminal one larger: racemes crowded, elongating in fruit: petals white, twice as long as the sepals: silique linear, as long as the divaricate pedicels; style very short. Nasturtium officinale. WATER CREss.- Naturalized in many ponds and streams.

2. Roripa sinuata (Nutt.) A. S. Hitch. Spring Fl. Manhattan 18. 1894. Glabrous perennial, spreading by horizontal slender rootstocks: stems numerous, diffuse, branched, 2-3 dm. long: leaves oblong or lanceolate, sinuately pinnatifid; the lobes obtuse or acute, entire or toothed: flowers yellow: siliques linear, tipped with the long style, becoming curved, as also the slender pedicel.-From New Mexico to Montana and west to the Sierras.

3. Roripa hispida (Desv.) Brit. Mem. Torr. Club 5: 169. 1894. Hispidly hirsute with spreading hairs on the stem and on the veins of the leaves below: stem usually simple below, more or less branched above, 3-10 dm. high: leaves lyrate-pinnatifid, the lower petioled: flowers yellow, on slender pedicels: silique globose to narrowly ovate, rarely more than twice as long as broad, and shorter than the spreading pedicel.- - In wet places; not infrequent in our range, and widely distributed throughout the United States.

4. Roripa palustris (L.) Bess. Enum. 27. 1821. Very similar but usually lower, sometimes branched from the base, glabrous or obscurely pubescent, never hirsute or hispid: silique narrowly ovate to nearly linear, 2-4 times as long as broad, about equaling the pedicels. ( $R$. Underwoodii Rydb. Bull. Torr. Bot. Club 29: 235. 1902.) - Approximately the same range as the preceding.

5. Roripa curvisiliqua (Hook.) Bessey, Mem. Torr. Club 5: 169. 1894. More or less minutely pubescent, usually branched from the base but erect, 1-2 dm. high: leaves narrowly oblong or oblanceolate, pinnatifid with oblong usually toothed lobes, rarely only sinuate-toothed: petals pale yellow, surpassing the sepals: silique linear, curved upwardly, about $1 \mathrm{~cm}$. long, on spreading pedicels half as long; stigma sessile or subsessile.-From Colorado and Wyoming to British Columbia.

6. Roripa lyrata (Nutt.) Rydb. Mem. N. Y. Bot. Gård. 1: 176. 1900. Glabrous, branched from the base and spreading: leaves lyrately deeply divided; the lobes broad but variously toothed and incised: flowers small: silique nearly straight, tapering slightly toward the apex which terminates abruptly in the short style, 8-12 mm. long, twice as long as the pedicels. Includes $R$. obtusum alpinum and $R$. sphaerocarpa.-In the mountain districts of our range and northwestward.

7. Roripa curvipes Greene, Pitt. 3: 97. 1896. Low, slender, diffusely branched, the branches in maturity ending in several elongated racemes which are unilateral by the decurved pedicels of the very small pods: herbage nearly glabrous: leaves from lyrate-pinnatifid to ovate-lanceolate and merely dentate: flowers minute, yellow in all parts, the petals slightly surpassing the sepals: stamens not exserted: pods ovate-acuminate or ovate-falcate, scarcely $4 \mathrm{~mm}$. long, tipped by a short style, few-seeded, often torulose by one or more manifest constrictions.- " Rather frequent in the mountains of southern Colorado, at middle elevations, along streamlets chiefly."

\section{CARDamine L. Bitter Cress}

Mostly glabrous herbaceous perennials, growing in wet places, with running rootstocks or small tubers, petioled, simple or pinnate leaves, and white or purple racemed flowers. Sepals equal at base. Petals obovate to spatulate. Siliques linear, straight, with stout replum and nerveless valves. Seeds in 1 row.

Leaves entire, broad, and somewhat cordate. Stem glabrous Stem hirsute

1. C. cordifolia.

2. C. infausta. 
Leaves pinnate.

Leaves and plant small, 1-2 dm. high

Leaves and plant larger, 2-4 dm. high. Leaflets ovate to rotund

Leaflets linear to elliptic

1. Cardamine cordifolia Gray, Pl. Fendl. 8. 1848. Glabrous throughout, 3-8 dm. high, leafy to the top: leaves cordate, sparingly repand-dentate or angular-toothed, 5-8 cm. long; the lowest of ten orbicular and the uppermost triangular-cordate: flowers white, rather large: siliques $3-4 \mathrm{~cm}$. long erect on ascending pedicels.-Along streamlets in the mountains; New Mexico to Idaho.

2. Cardamine infausta Greene, Pitt. 4: 307. 1901. Quite similar to the preceding but the stem, petioles, and pedicels, and to a less degree the leaves, more or less whitened with a shaggy hirsute pubescence: flowers smaller; the petals spatulate. (C. cardiophylla Rydb. Bull. Torr. Bot. Club 28: 280. 1901.) - Utah and southwestern Colorado to Arizona.

3. Cardamine unijuga Rydb. Bull. Torr. Bot. Club 24: 246. 1897. Glabrous: stems from very slender rootstocks, simple or branching, 1-2 dm. high: basal leaves simple, cordate, or reniform; lower stem leaves with 1 or 2 pairs of small oblong leaflets; the upper similar or reduced and entire: raceme slender: sepals obtuse, half as long as the white $2 \mathrm{~mm}$. long petals: siliques linear, 15-20 mm. long, erect, on erect pedicels and with short style.-Wyoming and Montana.

4. Cardamine Breweri Wats. Proc. Am. Acad. 10: 339. 1875. Glabrous, 2-4 dm. high: stems simple or branched from the base: radical leaves simple or with a pair of rounded lateral leaflets, round-cordate, entire or sinuate; cauline pinnate, with 5-7 leaflets; leaflets from oblong or ovate to orbicular, the terminal one much the largest, crenately toothed or lobed: flowers white, 20-25 mm. long, ascending, on ascending pedicels half as long: style short or wanting. (C. vallicola Greene, Pitt. 3: 116. 1896.)-Colorado, southward and westward to Oregon.

5. Cardamine pennsylvanica Muhl. in Willd. Spec. 3: 486. 1800. Glabrous, erect, simple, or branched from the base, leafy up to the racemes of small white flowers: basal leaves pinnate, with 9-17 small oblong-oval entire or toothed leaflets; the leaflets of the upper leaves usually oblong with somewhat narrowed base decurrent upon the rachis: siliques linear, $20-30 \mathrm{~mm}$. long, erect when mature, on somewhat divergent pedicels. C. hirsuta.Colorado to Montana and across the continent.

\section{Physaria Gray. Double Bladder Pod}

Low and stellately canescent perennials with stems simple or branched from the base, simple leaves, and yellow, racemose flowers. Siliques membranous, the two cells inflated-globose and joined by the narrow septum.

Constriction separating the cells equally deep above and below, cells globose

Constriction separating the cells much deeper above.

Leaves lyrate or panduriform

Leaves oblanceolate, sinuately toothed.

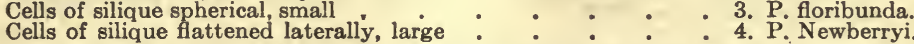

1. Physaria didymocarpa Gray, Wats. Bot. King's Exp. 20. 1871. Densely stellate-canescent: leaves and stems rosulately crowded on the crown of the thick root, 10-20 cm. high: radical leaves ovate to broadly spatulate, entire or sinuately toothed, obtuse or acute, petioled; cauline oblanceolate to linear: sepals lanceolate, surpassed by the large showy pale yellow petals: style slender, persistent, 5-6 mm. long: silique deeply and equally notched above and below; the cells $8-10 \mathrm{~mm}$. in diameter, walls papery.-Colorado to British America and far westward.

1a. Physaria didymocarpa lanata A. Nels. Bull. Torr. Bot. Club 31: 241. 1904. Much like the species but white-tomentose with a copious simple 
pubescence intermingled with the long-rayed stellate canescence: fruits very large, thin, and papery.-Powder river, Wyoming.

2. Physaria vitulifera Rydb. Bull. Torr. Bot. Club 28: 278. 1891. Resembling the foregoing, but leaves less whitened, fiddle-form in outline: petioles somewhat margined and bearing a very few large teeth; stem leaves entire, oblanceolate: silique deeply divided above only, the cells round-obovate, divergent; pedicels more or less curved in fruit.-Dry ravines and cañons; Colorado.

3. Physaria floribunda Rydb. 1. c. Densely tufted, the numerous stems and leaves suberect, $15-25 \mathrm{~cm}$. high: radical leaves oblanceolate or spatulate, sinuately toothed, usually acute, 5-10 cm. long; cauline oblanceolate, entire: petals bright yellow, oblanceolate, with a broad claw, 8-9 $\mathrm{mm}$. long, twice as long as the lanceolate sepals: silique deeply divided above only, the cells globose, 6-8 mm. in diameter. (P. acutifolia Rydb. 1. c.)-Colorado and Utah.

4. Physaria Newberryi Gray, Bot. Ives Rep. 6. 1860. White, with the dense fine stellate pubescence: leaves and stems rosulate spreading: leaves mostly entire, petioled; radical orbicular to spatulate; cauline spatulate to nearly linear: flowers large; petals $12-15 \mathrm{~mm}$. long: silique deeply notched above, scarcely notched at all below; the cells laterally flattened and provided with two keels or ridges separating the convex dorsal surface from the nearly flat sides, the walls folding along the keels in drying.-Colorado and New Mexico to Utah and Arizona.

\section{LesQUeRella Wats. Bladder Pod}

Low densely stellate-canescent herbaceous annuals, biennials, or perennials (sometimes with frutescent base), with more or less rosulate radical leaves, and yellow flowers in elongated or corymbose racemes. Sepals equal at base, oblong. Petals spatulate or oblong-ovate. Siliques turgid, oblongovate, or globose; style slender, rather long, persistent. Seeds flattened. -Vesicaria.

Siliques stellate-pubescent.

Globose or nearly so, not compressed at apex.

All the leaves narrow (linear or oblanceolate)

Some of the radical leaves broad (oval or obovate).

Silique and pedicel subequal; the style shorter

Silique and style subequal; the pedicel longer .

Ovate or oblong, often compressed at apex.

All the leaves narrow (linear or oblanceolate).

Plants low, caespitose (less than $1 \mathrm{dm}$. high).

Raceme' and leaves subequal

Raceme surpassing the leaves

Plants taller, not caespitose, branched from the base (more than $1 \mathrm{dm}$. high)

Some of the radical leaves broad (orbicular to obovate).

Raceme elongated, narrow

Raceme short, subcorymbose

Siliques glabrous.

All leaves narrow (linear or oblanceolate)

Stem leaves linear to oblanceolate

Stem leaves large, thin, elliptic .

1. L. argentea.

2. L. macrocarpa.

3. L. prostrata.

4. L. condensata.

5. L. alpina.

6. L. curvipes.

7. L. montana.

8. I. valida.

9. L. Fendleri.

10. I. Engelmannii. 11. L. aurea.

1. Lesquerella argentea (Pursh) MacM. Met. Minn. 263. 1892. Stellatepubescent throughout but greenish rather than white: stems several from the crown, decumbent spreading, simple or branched: leaves all linear or linearoblanceolate; the basal crowded-rosulate, $3-8 \mathrm{~cm}$. long, entire or remotely toothed: raceme in fruit 10-25 cm. long: silique globose or nearly so, about $5 \mathrm{~mm}$. long, equaling the slender style: pedicel spreading or recurved, $1-2 \mathrm{~cm}$. long. Vesicaria ludoviciana.-Colorado to Montana and Minnesota.

2. Lesquerella macrocarpa A. Nels. Bot. Gaz. 34: 366. 1902. Light green but stellate-pubescent throughout, freely branched from the crown; branches decumbent-prostrate with assurgent tips, mostly simple: radical leaves orbicular to obovate, short-petioled; cauline oblong or oblanceolate, short- 
petioled, 15-30 $\mathrm{mm}$. long: raceme crowded even in fruit: petals obovate, emarginate, 5-7 mm. long: silique subglobose, 6-8 $\mathrm{mm}$. in diameter, twice as long as the style; pedicels stout, recurved, 5-10 mm. long.-Naked clay ridges and flats; Red Desert, Wyoming.

3. Lesquerella prostrata A. Nels. Bull. Torr. Bot. Club 26: 124. 1899. The stellate-pubescence dense and silvery: stems several to many, rosulately spreading, sometimes branched: crown-leaves densely rosulate, rhomboidal, orbicular, oval or oblong, 5-15 $\mathrm{mm}$. long, the petioles often longer; cauline few, oblanceolate to linear: raceme in fruit 6-12 cm. long: silique subglobose or broadly ovate, as long as the style but somewhat surpassed by the curved, spreading or recurved pedicel. $[L$. utahensis Rydb. Bull. Torr. Bot. Club 30: 252. 1903; L. Macounii Greene, Pitt. 4: 310. 1901 (?).]-Wyoming, Utah, and probably Colorado.

4. Lesquerella condensata A. Nels. Bull. Torr. Bot. Club 26: 228. 1899. Depressed-caespitose, the caudex multicipital, not rising above the ground, acaulescent, the linear leaves and small crowded racemes on the crowns and subequal: petals spatulate, about $6 \mathrm{~mm}$. long: silique ovate, compressed at summit, $5 \mathrm{~mm}$. long, two-ovuled in each cell (usually only one maturing). (L. parvula Greene, Pitt. 4: 308. 1901.)-Barren and rocky slopes; one of the earliest plants to bloom; southern Wyoming and in Colorado.

5. Lesquerella alpina (Nutt.) Wats. Proc. Am. Acad. 23: 251. 1888. Caudex few-branched; the branches usually rising a few $\mathrm{cm}$. above the ground, thickly covered with the persistent leaf-bases: leaves all linear, tufted on the several crowns and on the base of the very short stems: raceme slenderpedunculate, often few-flowered; the pedicels slender, erect or recurved, much longer than the silique: silique ovate, somewhat angled but scarcely compressed, 3-4 mm. long, nearly equaled by the slender style. (L. spathulata Rydb. Cont. U. S. Nat. Herb. 3: 486. 1896.) - The upper Missouri region.

6. Lesquerella curvipes A. Nels. Bull. Torr. Bot. Club 25: 205. 1898. Stems numerous on the expanded crown of the woody root, in fruit 1.5-3 dm. long: radical leaves oblanceolate, on margined petioles; cauline oblanceolate to linear, with a narrowed petiole-like base, 3-6 cm. long: siliques ovate, compressed at summit, gibbously convex toward the base, about $8 \mathrm{~mm}$. long; the slender style somewhat shorter; pedicels 1-2 cm. long, "s" -shaped (the proximal part curved upward, the distal downward, with ascending tip): seeds 2 in each cell, rarely 1 or 3 .-Wyoming.

7. Lesquerella montana (Gray) Wats. Proc. Am. Acad. 23: 251. 1888. Caudex usually simple, the leaves and stems rosulate-spreading: stems mostly simple, short: crown-leaves crowded, some of them broad (orbicular, obovate, or rhomboid), passing into the oblanceolate ones of the stems, $1-2 \mathrm{~cm}$. long: siliques oblong, not compressed at summit but sometimes slightly quadrangular, about $6 \mathrm{~mm}$. long, somewhat exceeding the style, usually erect on the upwardly turned tip of the widely divaricate subequal pedicel. ( $L$. Shearis Rydb. Bull. Torr. Bot. Club 29: 237. 1902; L. rosulata A. Nels. Bull. Torr. Bot. Club 25: 205. 1898.)-Colorado and southern Wyoming.

8. Lesquerella valida Greene, Pitt. 4 * 68. 1899. Silvery lepidote-stellate, the leaves and stems crowning a taproot: stems decumbent, 1-2 dm. high: basal leaves entire or toothed, obovate or spatulate, petioled; cauline oblanceolate: raceme short and dense, hardly more than corymbose even in fruit: siliques ovate, somewhat compressed, tipped with a style of half their own length; the cells about 6-ovuled.-Southern Colorado and New Mexico.

9. Lesquerella Fendleri (Gray) Wats. Proc. Am. Acad. 23: 251. 1888. Whitecanescent: caudex multicipital; stems several, slender, erect, 1-2 dm. high: leaves all linear or narrowly oblanceolate: raceme short, dense: siliques glabrous, subglobose, 4-6 $\mathrm{mm}$. in diameter, on slender much longer erect pedicels; the style about equal in length; the cells 10-16-ovuled.-Southern Colorado to Texas.

10. Lesquerella Engelmannii Wats. 1. c. 254. Silvery canescent: stems low and simple or taller and branched, 1-3 dm. long: some of the radical leaves broad (orbicular to oblanceolate), petioled; cauline oblong or oblanceo- 
late: petals broadly spatulate, 8-12 $\mathrm{mm}$. long: siliques in a short raceme, subglobose or oval, substipitate, glabrous, 6-8 $\mathrm{mm}$. long, on ascending pedicels of about the same length; style a little shorter than the silique. $[L$. pruinosa Greene, Pitt. 4: 307. 1901 (?); L. ovata Greene, 1. c.; L. ovalifolia Rydb. in Brit. Ill. Fl. 2: 137. 1897.) - Southern Colorado to Texas.

11. Lesquerella a urea Wooton, Bull. Torr. Bot. Club 25: 260. 1898. Annual, branching from the base, 2-3 dm. high, leafy up to the short racemes of bright yellow flowers: leaves pale green, thin, rather thinly covered with the fine branched pubescence, oblong to broadly oblanceolate-cuneate, 1-3 cm. long: siliques glabrous, subglobose, somewhat longer than the slender style but much exceeded by the finally recurved pedicel.-New Mexico and probably extending into southern Colorado.

\section{HUTCHINSIA R. Br.}

Low spreading annual, only a few $\mathrm{cm}$. high, with entire or pinnately lobed leaves and minute white flowers in crowded racemes which become greatly elongated in fruit. Stigma sessile or nearly so. Silique oval, compressed at right angles to the septum; each valve with a conspicuous mid-nerve.-Capsella in part.

1. Hutchinsia procumbens (L.) Desv. Journ. Bot. 3: 168. 1814. Glabrous or pubescent with forked hairs, very slender and diffusely branched: radical leaves pinnate or pinnatifid with few lobes; the upper oblanceolate to linear, entire: siliques elliptic-oblong, on very slender spreading pedicels. Capsella divaricata.-Colorado, Wyoming, and westward.

\section{CAPSELla Medik. Shepherd's Purse}

An annual herb but often enduring a second year, the leaves mostly rosulate and the minute white flowers in elongated racemes. Silique obcordate or triangular-cuneate, flattened at right angles to the septum; style short but evident. Seeds numerous.-(Bursa Weber.)

1. Capsella bursa-pastoris Medik. Pflanzengat. 1: 85. 1792. More or less hirsute with branched hairs: radical leaves mostly runcinate-pinnatifid; cauline lanceolate and auricled at the base: flowers white in a congested raceme, which becomes greatly elongated in fruit: siliques cuneate-obcordate, 6-8 $\mathrm{mm}$. long.-Naturalized from Europe, but now one of the commonest weeds everywhere.

\section{Camelina Crantz. False Flax}

Erect annuals with sagittate-clasping mostly entire leaves and yellow or white flowers. Sepals short-oblong. Petals unguiculate. Silique obovoid, with a broad, thin, persistent septum; the valves firm and strongly convex. Seeds numerous, wingless.

1. Camelina sativa Crantz, Stirp. Austr. 1: 18. 1762. Pubescent or sometimes nearly glabrous annual, simple or branched, 3-6 dm. high: lower leaves lanceolate, entire or toothed; cauline sessile, sagittate-clasping: flowers numerous, yellowish: silique pear-shaped, 6-9 $\mathrm{mm}$. long, on slender ascending pedicels 1-2 cm. long; style slender, short.-Naturalized from Europe; common, especially where flax has been grown; not infrequent in our range.

\section{DRABA Dill}

Annual, biennial, or perennial herbs, mostly low, the leaves entire or toothed and the white or yellow flowers in crowded racemes which become more or less elongated in fruit. Sepals short, broad, and obtuse. Petals obovate or spatulate, entire or somewhat notched at apex. Style mostly short, or want- 
ing; silique ovate to lanceolate or linear. Seeds in 2 rows, not winged or margined. Pubescence simple or branched.

Annuals or winter annuals.

Silique glabrous; flowers yellow, sometimes turning white in drying.

Style wanting.

Stems scapose, glabrous . _ . 1. D. crassifolia.

Stems scapose, ciliate-hirsute below : $: \quad: \quad: \quad 2$. D. nitida.

Style evident

Flowers white.

Leaves entire; siliques in a terminal cluster Leaves toothed

Pedicels ascending or erect

Pedicels reflexed

Flowers yellow.

Pedicels longer than the silique

Perennials.

Pedicels shorten than the silique

3. D. mongollonica.

4. D. caroliniana.

5. D. cuneifolia.

6. D. reflexa.

7. D. nemorosa.

Low, caespitose, and scapose; leaves imbricated.

Scape pubescent

Scape glabrate; silique ovate.

Flowers white

Flowers yellow.

Silique broadly ovate

Silique ovate-oblong

Taller; stems more or less leafy.

Siliques glabrous or nearly so, not twisted. Flowers yellow.

Pubescence branched; flowers large Pubescence simple; flowers small Flowers white, small .

Siliques pubescent, more or less twisted. Pubescence of herbage long and villous

Pubescence of herbage short and stellate.

Leaves large and thin

Leaves rather small and firm.

Silique with flat valves, glabrate on the face Silique with convex valves, pubescent

8. D. lapilutea.

9. D. densifolia.

10. D. oligosperma.

11. D. andina.

12. D. saximontana.

1. Draba crassifolia Graham, Edinb. New Phil. Journ. 182. 1829. Glabrous throughout or with the leaves sparsely ciliate, annual or biennial: scape naked or with a single leaf, 5-10 cm. high: leaves lanceolate-linear, entire or somewhat serrulate, ciliate with simple hairs: flowers small, white or yellowish; petals a little exceeding the sepals, retuse: siliques oblong-lanceolate, acute, 5-9 mm. long, on spreading pedicels of about the same length. $(D$. Parryi Rydb. Bull. Torr. Bot. Club 29: 241. 1902.)-High mountains; Colorado to British America.

2. Draba nitida Greene, Pl. Baker. 3: 7. 1901. Erect annual 1-3 dm. high, glabrous and somewhat shining: stems 1 or more from the base, ciliate-pubescent below only: leaves mostly in a rosulate tuft at the base, sparsely substellate, the margins loosely bristly-ciliate: raceme long in fruit: petals yellow, longer than the green somewhat pilose sepals: silique oblong-linear, acutish, 10-15 mm. long, on ascending pedicels of about the same length. D. stenoloba. -At middle or higher elevations; Colorado to Montana.

3. Draba mongollonica Greene, Bot. Gaz. 6: 157. 1882. Somewhat scapose annual, $2-4 \mathrm{dm}$. high, villous or loosely stellate-pubescent below: stem simple or branching from the base: leaves oblanceolate, stellate-pubescent, 3-6 cm. long: flowers large, in broad racemes which are elongated in fruit: sepals glabrous: siliques linear or oblong, glabrous, 8-15 mm. long, with a slender style 2-3 $\mathrm{mm}$. long; pedicels slender, variable, longer or shorter than the silique.-Infrequent; New Mexico and probably southern Colorado.

4. Draba caroliniana micrantha Gray, Man. Ed. 5. 72. 1867. Low, usually less than $1 \mathrm{dm}$. high: leaves obovate or oblanceolate, entire, rosulate or crowded near the base, loosely stellate-pubescent, 10-12 $\mathrm{mm}$. long: scapose stems few or several from the crown, glabrous or pubescent: flowers small, white, the pedicels closely approximate even in fruit: siliques minutely hispid, 10-15 $\mathrm{mm}$. long, much exceeding the divergent pedicels. This variety does 
not differ from the species $D$. caroliniana Walt. except in the hispid silique.Throughout our range and eastward to the Missouri.

5. Draba cuneifolia Nutt. T. \& G. Fl. 1: 108. 1838. Low, usually less than $1 \mathrm{dm}$. high: leaves clustered near the base, obovate to oblanceolate, entire or few-toothed, loosely stellate-pubescent, acutish, 1-3 cm. long: scapose stems solitary or few, usually loosely stellate-pubescent: flowers small, white: silique linear-oblong, mostly subacute, minutely hispid, 8-10 $\mathrm{mm}$. long, on divaricate pedicels much shorter. (D. coloradensis Rydb. Bull. Torr. Bot. Club 31: 555. 1904.)-Infrequent; from Missouri to California.

6. Draba reflexa Greene, Pitt. 4: 20. 1899. Stem stout, erect, about $1 \mathrm{dm}$. high, racemose almost from the base: leaves mostly in a dense rosulate basal tuft, oblong-lanceolate, entire or sparingly toothed, nearly glabrous superficially, but the margin hirsute-ciliate: calyx glabrous, the thin sepals tinged with purple: petals white, showy: pedicels widely spreading, in fruit deflected, much exceeding the pods in length, these elliptic-oblong, 6-8 $\mathrm{mm}$. long, glabrous, the stigma small and sessile.-Camp Stambaugh, Wyoming.

7. Draba nemorosa L. Sp. Pl. 643. 1753. Low slender loosely stellatepubescent annual, 5-30 cm. high: stems simple or with a few short slender branches from near the base: leaves mostly toward the base but hardly rosulate, ovate to oblong-lanceolate, entire or toothed, 1-3 cm. long: flowers crowded, but the fruiting raceme long and open: sepals villous: petals yellow, small: siliques narrowly oblong, minutely pubescent, 8-12 $\mathrm{mm}$. long, much shorter than the slender spreading pedicels. D. nemorosa and varieties.Colorado, north to Montana and thence both eastward and westward.

8. Draba lapilutea A. Nels. Stellate-pubescent throughout and villous below, 1-3 dm. high: stems erect, rather stout, simple or with some slenderer branches from near the base: leaves oblanceolate or oblong to nearly linear, mostly radical and on the lower part of the stem, 1-2 cm. long: petals small, spatulate, yellowish or turning white in drying, longer than the elliptic sepals: silique linear-oblong 8-12 $\mathrm{mm}$. long, suberect, on much shorter spreading pedicels; the style wanting or barely discernible. D. montana (name untenable. (D yellowstonensis A. Nels. Bot. Gaz. 30: 189. 1900, a name to be discarded.) - In the mountains; Colorado to Montana.

9. Draba densifolia Nutt. T. \& G. Fl. N. A. 1: 104. 1838. Densely caespitose in somewhat close tufts: scapes only $3-6 \mathrm{~cm}$. high, more or less woollyhirsute: leaves greatly crowded on the crowns of the caudex, oblong-linear, strongly ciliate and woolly-hirsute with nearly simple hairs: flowers small, yellow or turning white: siliques crowded at summit of scape, broadly ovate, pubescent, about $5 \mathrm{~mm}$. long; the style about one fourth as long. D. ventosa.(?) -Wyoming, Idaho, and Montana.

10. Draba oligosperma Hook. Fl. Bor. Am. 1: 51. 1830. Subcaespitose, the leaves mostly rosulate at the base of the few short $(4-8 \mathrm{~cm}$. high) slightly pubescent scapes: leaves suberect, linear or oblong, rigid, ciliate, stellately pubescent on both sides, especially toward the apex: petals white, twice as long as the slightly hairy calyx: siliques quite pubescent, suborbicular; the style one fourth as long.-Northern Wyoming (probably), Montana, and to the north and west.

11. Draba andina (Nutt.) A. Nels. Bull. Torr. Bot. Club 26: 352. 1899. Very densely caespitose, the numerous branches of the caudex closely covered with the persistent imbricated leaf-bases: leaves mostly oblong, rather rigid, ciliate and stellate-pubescent: scapes glabrous, $3-8 \mathrm{~cm}$. high: flowers numerous, yellow or turning white: silique broadly ovate to orbicular, $3-4 \mathrm{~mm}$. long; the cells about 2-seeded; style short, about one fourth as long as the silique. Possibly D. stellata and some of its varieties.-Barren soils, mostly at high elevations; Wyoming and northward.

12. Draba saximontana A. Nels. Bull. Torr. Bot. Club 27: 264. 1900. Much like the last, equally caespitose: leaves linear, ciliate and stellatepubescent: scapes numerous, glabrous, many-flowered: petals spatulate, twice as long as the elliptic glabrate sepals: siliques ovate-oblong, subacute, obscurely pubescent with simple hairs, 4-5 mm. long, 6-8 times as long as 
the style: pedicels usually much longer than the silique. D. alpina possibly or D. glacialis.-Stony slopes, middle elevations; northern Colorado to Montana.

13. Draba spectabilis Greene, Pitt. 4: 19. 1899. Green but more or less pubescent with short branched hairs: stems few to many from the short woody caudex, 2-4 dm. high, equally leafy to the middle: radical leaves obovate to oblanceolate, short-petiolate; the cauline ovate, oblong, or lanceolate, acute, entire or toothed, 1-3 cm. long: sepals subglabrous or hirsute: petals large, yellow: siliques 8-12 mm. long, oblong, glabrous or nearly so, on spreading pedicels of about equal length; the style prominent. (D. oxyloba Greene, Pl. Baker. 3: 6. 1901, seems to be a smaller form of this.)-Southern Colorado and New Mexico.

14. Draba chrysantha Wats. Proc. Am. Acad. 17: 364. 1882. Perennial, with leafy, decumbent or erect stems, $5-15 \mathrm{~cm}$. high, from a branching rootstock, sparingly pubescent with simple hairs: basal leaves narrowly oblanceolate, $3-4 \mathrm{~cm}$. long, entire or few-toothed, subciliate; cauline oblanceolate to lanceolate: raceme open; flowers yellow, on pedicels 4-12 $\mathrm{mm}$. long: silique glabrous, oblong, acute at each end, $8-10 \mathrm{~mm}$. long, beaked by a short slender style. [(?) D. graminea Greene, Pl. Baker. 3: 5. 1901.]-Mostly alpine; New Mexico to Montana.

15. Draba cana Rydb. Bull. Torr. Bot. Club 29: 241. 1902. Perennial with a taproot and short caespitose caudex, whole plant densely grayish stellate: stem 1-2 dm. high, often branched: basal leaves numerous, oblanceolate or spatulate, $1-1.5 \mathrm{~cm}$. long, entire or minutely but sharply toothed, densely stellate; stem leaves lanceolate to ovate, about $1 \mathrm{~cm}$. long: racemes manyflowered; pedicels short, nearly erect, in fruit $2-3 \mathrm{~mm}$. long; flowers small: petals white, about $3 \mathrm{~mm}$. long: silique linear-oblong, 6-8 $\mathrm{mm}$. long, densely pubescent; style about $5 \mathrm{~mm}$. long. D. incana.-Mountains of Colorado, far north into British America.

16. Draba streptocarpa Gray, Am. Journ. Sci. II. 33: 242. 1862. More or less villous with long spreading mostly simple hairs: stems erect, 1 or more from the base, $3-15 \mathrm{~cm}$. high: leaves oblanceolate to lanceolate, mostly acute, somewhat villous, $6-15 \mathrm{~mm}$. long: calyx glabrous or villous: siliques lanceolate, acute, flattened, more or less twisted, nearly glabrous except on the margins, 6-12 mm. long, on pedicels half as long; the short style slender. (D. Bakeri Greene, Pl. Baker. 3: 6. 1901.)-Alpine or subalpine; from New Mexico far into British America.

17. Draba surculifera A. Nels. Bull. Torr. Bot. Club 26: 237. 1899. Perennial: stems few to several, usually with some short leafy stolons at the base, $2-4 \mathrm{dm}$. high, pubescent with some simple hairs and a closer branched puberulence: basal leaves crowded, oblanceolate, subpetioled, $3-5 \mathrm{~cm}$. long, thin, glabrate or stellate-pubescent; cauline similar but ovate or lanceolate, sessile by a broad base, sometimes toothed: petals obovate, narrowed to a claw, twice as long as the sepals: silique lanceolate, finely pubescent, $8-12 \mathrm{~mm}$. long, flat, or sometimes twisted; the style $1 \mathrm{~mm}$. long.-Cliff sides in the mountains; Wyoming.

18. Draba Helleriana Greene, Pitt. 4: 17. 1899. Rather stout, erect, branching, especially above, 2-4 dm. high: pubescence scanty, the hairs subappressed and 2-4-rayed: leaves ovate-oblong, entire or toothed, sessile: racemes few to many, short: sepals yellow, hirsutulous: petals golden-yellow: siliques much longer than the pedicels, flattened, acute, nearly glabrous except on the ciliolate margins. $D$. aurea and var. stylosa. (D. neo-mexicana Greene, 1. c. 20.)-Middle elevations; extending into Colorado from New Mexico.

19. Draba luteola Greene, 1. c. 19. Perennial, 1-3 dm. high, cinereously stellate-pubescent with some villous simple hairs: leaves ovate-lanceolate, subacute, entire or serrulate: racemes few or several, often long: sepals thin, yellowish-green, hirsute: petals yellow, obtuse: silique rough-puberulent, tipped with a short slender style; pedicels shorter than the silique and distinctly villous. D. lutea. (D. uber A. Nels. Bot. Gaz. 34: 366. 1902; D. 
aureiformis Rydb. Bull. Torr. Bot. Club 28: 278. 1901; D. decumbens Rydb. 1. c. 29: 240.)-Subalpine; New Mexico to British America.

20. SMELOWSKIA C. A. Mey.

Low caespitose perennials with pinnatifid leaves and small flowers in terminal racemes; pubescence simple or stellate. Sepals oblong, nearly equal at base. Petals entire, obovate, or spatulate. Siliques lance-oblong, flattened at right angles to the septum; the valves sharply keeled so that the silique presents a 4-angled aspect; stigma sessile, or with short style. Seeds few.

1. Smelowskia americana Rydb. Bull. Torr. Bot. Club 29: 239. 1902. Densely caespitose; caudex closely covered by the bases of the dead leaves: leaves $2-5 \mathrm{~cm}$. long, pinnately divided to the midrib into linear acute divisions, finely stellate and the petioles ciliate: stems about $1 \mathrm{~cm}$. high, fewleaved: inflorescence at first short and corymbiform, in fruit elongated: sepals oblong, pubescent, about $3 \mathrm{~mm}$. long: petals clawed, 5-6 mm. long, white or pink, blades broadly spatulate: silique $11-12 \mathrm{~mm}$. long and about $1 \mathrm{~mm}$. wide, tapering at both ends. S. calycina. (S. linearifolia Rydb. 1. c. 31: 555.) -In the high mountains of our range.

\section{SOPHIA Adans. Tansy Mustard}

Annual or perennial herbs, with pinnatifid or dissected pubescent or canescent leaves, and small yellow flowers in crowded racemes which become greatly elongated in fruit. Siliques linear or linear-oblong, on slender pedicels; the valves 1 -nerved. Seeds minute, in 1 or 2 rows in each cell.-Sisymbrium in part.

Herbage more or less pubescent but not cinereous-tomentulose.

Silique and pedicel erect or appressed, each less than $1 \mathrm{~cm}$. long

Silique and pedicel divergent or divaricate; silique usually $1 \mathrm{~cm}$. or more long.

Siliques ascending.

Seeds in 1 row in each cell.

Pedicels 10-20 mm. long, equaling or longer than the silique Pedicels 4-8 mm. long, shorter than the silique. Seeds in 2 rows

Silique and pedicel widely divaricate :

Herbage densely cinereous-tomentulose

1. S. Hartwegiana.

1. Sophia Hartwegiana (Fourn.) Greene, Pitt. 3: 95. 1896. Slender or often quite stout, erect, 2-5 dm. high, often somewhat branched, glabrate, granular-glandular, or glandular-pubescent: leaves pinnate; the leaflets narrowly oblong or lanceolate, obtuse and obtusely or acutely toothed: siliques short, 5-7 mm. long, crowded, erect; pedicels about as long as the silique, suberect or more usually appressed: seeds uniseriate or more rarely irregularly biseriate. (S. glandulifera Rydb. Bull. Torr. Bot. Club 28: 281. 1901.)From New Mexico to Montana and westward.

2. Sophia filipes (Gray) Heller, Bull. Torr. Bot. Club 24: 311. 1897. Erect, slender or slenderly branched, 2-4 dm. high, usually finely pubescent or glandular-puberulent, light green (not canescent or tomentose): leaves thin, pinnatifid or dissected; the upper less so, with segments nearly entire and becoming elongated-linear: fruiting raceme open: siliques glabrous, linear, acute, ascending, 8-14 mm. long; pedicel filiform, glabrous, widely spreading, usually longer than the silique: seeds in one row.- Colorado to Oregon.

3. Sophia incisa (Engelm.) Greene, Pitt. 3: 95. 1896. Much like the preceding, green but often quite densely pubescent and more or less glandular: leaves bipinnatifid or dissected; the segments oblong and incisely toothed or entire and linear: the small flowers corymbose; the fruiting raceme long: siliques acute, 5-10 mm. long, slightly curved, ascending; pedicels slender, widely spreading, either longer or shorter than the silique. Exceedingly variable. The following have recently been proposed as species, but they seem impossible 
of segregation as they run hopelessly into each other: S. intermedia Rydb. Mem. N. Y. Bot. Gard. 1: 184. 1900; S. purpurascens Rydb. Bull. Torr. Bot. Club 31: 556. 1904; S. ramosa Rydb. 1. c.; S. viscosa Rydb. 1. c. 29: 238. 1902.-Throughout the western half of the United States.

4. Sophia pinnata (Walt.) Brit. Mem. Torr. Club 5: 173. 1894. Canescent with short branching hairs: stems $2-8 \mathrm{dm}$. high, more or less branched: leaves once or twice pinnate; the segments more or less deeply pinnatifid or toothed: siliques acute at each end, and pointed with the very short style, usually shorter than the slender spreading pedicels: seeds in 2 rows. $S$. canescens.-Common throughout our range; nearly across the continent; quite variable.

5. Sophia leptophylla Rydb. Bull. Torr. Bot. Club 29: 239. 1902. Sparingly glandular, $4-7 \mathrm{dm}$. high: leaves very thin, green, only once pinnate; segments of the lowest leaves rounded; those of the middle lanceolate and somewhat incised; the upper segments entire: pedicels slender, in fruit 5-8 mm. long, spreading; silique linear, 8-10 mm. long, much less than $1 \mathrm{~mm}$. wide, torulose, spreading, upwardly curved: seeds uniseriate.-From eastern Wyoming to Montana.

6. Sophia ochroleuca Wooton, Bull. Torr. Bot. Club 25: 455. 1898. Cinereous-tomentulose, with close branching hairs, 5-7 dm. high: leaves pinnatifid or dissected; the segments small, oblong to linear: petals cream-white or purplish: silique terete, $8-10 \mathrm{~mm}$. long, ascending, as is also the subequal pedicel: seeds in 2 rows. (The following seem too near to be clearly distinguished: S. halictorum Ckll. Bull. Torr. Bot. Club 25: 460. 1898; S. andrenarum Ckll. 1. c. 28: 48. 1901.)-Southern Colorado and New Mexico.

\section{STENOPHRAGMA Celak.}

Annual or biennial herbs with the aspect of some species of Arabis; pubescence branched. Stems simple or branched, with entire or dentate leaves. Flowers small, white, in terminal racemes. Silique linear; valves convex, nerveless; style short; stigma entire, 2-lobed. Seeds in one or two rows.Sisymbrium in part.

1. Stenophragma virgata (Nutt.) Greene, Pitt. 3: 138. 1896. Cinereous or tomentose with branched hairs, biennial, 1-4 dm. high: stem simple or freely branched from the base: radical leaves rosulate, oblong, entire, or toothed, petioled, 3-6 cm. long; cauline entire, sagittate-clasping: siliques 20-30 mm. long, erect, on spreading pedicels about one third as long. Sisymbrium virgatum. (Arabis Brebneriana A. Nels. Bull. Torr. Bot. Club 25: 373. 1898.)Frequent, moist banks and slopes; southern Wyoming.

\section{ARABIS L.}

Annual, biennial, or perennial herbs, glabrous or pubescent, with entire, toothed, or pinnatifid leaves, and white, rose-colored, or purple flowers. Siliques long-linear, compressed, with 1-nerved valves, dehiscent at maturity; 'stigma nearly entire or 2 -lobed. Seeds in 1 or 2 rows in each cell, flattened, winged, or wingless; cotyledons accumbent.

Cauline leaves wholly glabrous, at least the uppermost; basal leaves more or less pubescent.

Mature siliques erect or nearly so.

Stems hirsute at base

Stems glabrate at base.

Seeds broadly winged, in 2 rows

Seeds narrowly winged, in 1 row

Mature siliques widely spreading.

Straight and long $(4-6 \mathrm{~cm}$.)

Curved or else short $(2-3 \mathrm{~cm}$.).

Leaves all entire, linear or nearly so.

Plants low $(5-20 \mathrm{~cm}$.); silique short (less than $3 \mathrm{~cm}$.).

Sepals pubescent.

Basal leaves dentate, thin

Basal leaves entire, thick

ROCKY MT. BOT. -15

1. A. glabra.

2. A. Drummondii.

3. A. Lyallii.

4. A. divaricarpa.

5. A, recondita.

6. A. Lemmonii. 
Sepals glabrous or nearly so.

Silique strongly nerved, obtusish

Silique lightly nerved, cuneately pointed

Plants taller (more than $2 \mathrm{dm}$.); silique long (more than $\dot{4}$ cm.)

Leaves more or less dentate; oblong to ovate : : : : Cauline leaves more or less pubescent as well as the basal.

Biennials or perennials, but without woody caudex.

Siliques erect or nearly so.

Leaves more or less hirsute, spatulate or broader.

Mature silique short (less than $3 \mathrm{~cm}$.)

Mature silique long (more than $4 \mathrm{~cm}$.)

Leaves densely stellate-pubescent, oblanceolate.

Seeds in 1 row in each cell

Seeds in 2 rows in each cell

Siliques widely spreading or deflexed.

Pubescence wholly stellate-canescent.

Flowers large (9-12 mm. long).

Leaves linear; flowers pale flesh-color

Leaves oblanceolate; flowers deep purple

Flowers small (4-6 mm. long).

Leaves narrowly linear, crowded at the base

Leaves lanceolate or oblanceolate, equably distributed. Seeds in 2 rows

Seeds in 1 row

Pubescence in part ciliate or branched-hirsute.

Siliques pendent, on divaricate pedicels.

Leaves fascicled on the crown

Leaves equably distributed

Siliques pendent on refracted pedicels

Perennials, with woody caudex.

Stems solitary from the simple crown

Stems several.

Caudex branched, lignescent.

Leaves entire, seeds in 1 row

Leaves toothed; seeds in 2 rows

Caudex simple, but stems several from the base $\quad 25$. A. Selbyi.

1. Arabis glabra (L.) Bernh. Verz. Syst. Erf. 195. 1800. Tall, mostly simple-stemmed biennial, 4-8 dm. high: glabrous and glaucous above, hirsute on stem and leaves below: basal leaves oblanceolate or oblong, petioled, 5-30 cm. long, dentate, or even lyrate; cauline lanceolate, sessile, entire, auriculate: flowers yellowish-white; the petals barely exceeding the sepals: siliques linear, erect, and appressed, 5-8 cm. long: seeds in 2 rows. $A$. perfoliata.-Across the continent.

2. Arabis Drummondii Gray, Proc. Am. Acad. 6: 187. 1866. Biennial or more often perennial, sparingly pubescent below (or glabrous), the hairs horizontal and attached by the middle: stems mostly simple, erect, $3-8 \mathrm{dm}$. high: basal leaves narrowly oblanceolate, short-petioled; cauline auriculate, oblong to linear-lanceolate, $3-5 \mathrm{~cm}$. long, glaucous: petals white or pinkish, twice as long as the narrow sepals: silique erect, rather broadly linear, obtuse, 5-8 cm. long; the valves faintly veined and with a conspicuous mid-nerve: seeds in 2 rows, membranously broad-winged. (A. oxyphylla Greene, Pitt. 4: 196. 1900; A. connexa Greene, 1. c. 197.)-Frequent; throughout the Rocky Mountains.

3. Arabis Lyallii Wats. Proc. Am. Acad. 11: 122. 1876. - Near the preceding but smaller, usually less than $3 \mathrm{dm}$. high, bright green or glaucous, sometimes a little pubescent below, leaves similar: flowers rose-color: siliques erect or ascending, straight, only 3-4 cm. long: seeds narrowly winged, usually in 1 row in each cell.- In the highest mountains; in northwestern Wyoming and far to the northwestward.

4. Arabis divaricarpa A. Nels. Bot. Gaz. 30: 193. 1900. Biennial or sometimes more enduring, glabrous above, somewhat glaucous and tinged with purple, 4-6 dm. high: stems simple, rarely more than one from the base: basal leaves narrowly oblanceolate, petioled, with a minute branched pubescence; cauline sagittate-clasping, linear-oblong, 1-4 cm. long: flowers pale or purple: siliques straight, linear, uniformly divaricate-ascending, 1-nerved, 4-6 cm. long, on pedicels 4-8 $\mathrm{mm}$. long: seeds in 1 irregular row, margined but not winged.-In the mountains; northern Wyoming and probably Montana and Idaho. 
5. Arabis recondita Greene, Pitt. 4: 195. 1900. Perennial, green and glabrous above, minutely stellate-pubescent below: stems few to many, only 1-2 dm. high: basal leaves obovate to oblanceolate, dentate, narrowed to a petiole which is ciliate with simple hairs or hairs forked at summit: calyx stellate-pubescent: petals rose-purple: siliques glabrous, $3-4 \mathrm{~cm}$. long, spreading, slightly curved: seeds imperfectly biserial.-Western Colorado to Arizona.

6. Arabis Lemmonii Wats. Proc. Am. Acad. 22: 467. 1887. Perennial, glabrous and glaucous above, finely hoary stellate-pubescent below: stems few to several from the caudex, 1-2 dm. high: basal leaves obovate or oblongspatulate, entire, rather thick, short-petioled; cauline oblong-lanceolate: sepals pubescent: petals rose-color: siliques ascending or spreading, broadly linear, 2-3 cm. long; the valves faintly nerved to the middle: seeds in $1 \mathrm{row}$, narrowly winged.-From northwestern Wyoming to far northwest.

7. Arabis rugocarpa Osterh. Bull. Torr. Bot. Club 31: 357. 1904. Perennial, more or less purple-tinged throughout, hispid-ciliate and obscurely pubescent with branched hairs: stems few to several, spreading, only 1-2 dm. high: basal leaves oblanceolate, acute or acuminate, $2-3 \mathrm{~cm}$. long; cauline auriculate, small, oblong: petals purple, fully twice as long as the spatulate scarious-margined sepals: siliques rugose, 1-nerved, 2-3 cm. long, reflexed, on pedicels about $5 \mathrm{~mm}$. long: seeds in 1 row, margined but not winged.Western Colorado.

8. Arabis oxylobula Greene, Pitt. 4: 195. 1900. Much like the preceding, nearly glabrous: stems few from the short branched caudex, 1-2 dm. high: basal leaves narrowly oblanceolate, sparingly hispid-ciliate at base; cauline oblong, sessile, not auricled, about $1 \mathrm{~cm}$. long: siliques linear, straight, about $2 \mathrm{~cm}$. long, spreading or a little deflexed on short filiform pedicels; the valves 1-nerved: seeds imperfectly biserial. (A. demissa Greene, Pl. Baker. 3: 8. 1901.) - Western Colorado.

9. Arabis microphylla Nutt. T. \& G. Fl. N. A. 1: 82. 1838. Perennial, softly stellate-pubescent, especially below: stems several to many from the freely and slender-branched caudex, 2-4 dm. high: basal leaves crowded, linear or nearly so, with petioles often ciliate; cauline few, similar: sepals generally glabrous: petals pale rose-color: siliques narrowly linear, somewhat curved and spreading, 4-6 cm. long, on filiform pedicels about $1 \mathrm{~cm}$. long: seeds small, in 1 row. (A. densicaulis A. Nels. Bot. Gaz. 30: 190. 1900.)Utah, northwestern Wyoming to Oregon.

10. Arabis fructicosa A. Nels. Bot. Gaz. 30: 190. 1900. Biennial, glabrous and glaucous, except for a little fine stellate pubescence at base: stems several from the enlarged crown of the taproot, each simple or somewhat branched above, very leafy below, 4-8 dm. high: radical leaves not persisting the second year; cauline short, 1-2.5 cm. long, elliptic-oblong to ovate, more or less toothed, subauricled: petals white or purplish: siliques linear, divaricate, ascending, $4-6 \mathrm{~cm}$. long, on slender pedicels $6-8 \mathrm{~mm}$. long: seeds in 1 row, not margined:- Yellowstone Park.

11. Arabis Nuttallii Robinson, Syn. Fl. 1: 160. 1895. Perennial, with short branching caudex, more or less hirsute, with simple or forked hairs: basal leaves spatulate-oblanceolate, acute or obtuse, petioled, $2-3 \mathrm{~cm}$. long; cauline mostly oblong, sessile (not auricled): flowers white: siliques 1-nerved, obscurely veined, erect, less than $2 \mathrm{~cm}$. long, on ascending pedicels often as long as the silique. A. spathulata.-Wyoming and Montana and far westward.

12. Arabis hirsuta Scop. Fl. Carn. Ed. 2. 2: 30. 1772. Biennial, more or less hispidly hirsute or ciliate: stem erect, solitary or several from the base, leafy, 2-5 dm. high: basal leaves obovate to spatulate, dentate or repand, on margined petioles, 3-5 cm. long; cauline sessile, auriculate, from oblong to linear, suberect, coarsely toothed or entire: flowers white: siliques erect, usually very numerous and fascicled, linear, $3-5 \mathrm{~cm}$. long: seeds narrowly margined, imperfectly biseriate.-Frequent in our range; across the continent; also in Europe and Asia.

13. Arabis Crandallii Robinson, Bot. Gaz. 28: 135. 1899. Caespitose perennial, hoary puberulent throughout, with minute stellate hairs: stems nu- 
merous from the multicipital caudex, 2-3 dm. high: radical leaves oblanceolate spatulate, $15-20 \mathrm{~mm}$. long; the cauline similar but shorter, sessile: petals obovate-cuneate, twice as long as the obtuse stellate-pubescent sepals, white or rose-tinged: siliques linear, $2.5-4 \mathrm{~cm}$. long, erect on ascending or erect pedicels: seeds uniseriate in each cell.-Western Colorado.

14. Arabis oblanceolata Rydb. Bull. Torr. Bot. Club 31: 557. 1904. Resembling the preceding, but less densely stellate and larger: stems several from the base, $3 \mathrm{dm}$. high: basal leaves oblanceolate, $3 \mathrm{~cm}$. or more in length, sagittate-auricled; cauline sessile, lanceolate: petals reddish-purple, twice as long as the acute pubescent sepals: siliques broadly linear, glabrous, about $5 \mathrm{~cm}$. long, ascending on ascending pedicels $1 \mathrm{~cm}$. long: seeds in 2 rows. Southwestern Colorado.

15. Arabis formosa Greene, Pitt. 4: 198. 1900. Perennial, canescent with a fine stellate indument throughout: stems virgate, one or more from the crown, erect, 2-4 dm. high: basal leaves oblanceolate, entire, $3-4 \mathrm{~cm}$. long (including the rigid petiole); cauline as long, sessile by a truncate but not auricled base: raceme long and loose: petals flesh-color, 10-14 $\mathrm{mm}$. long, with oblong-spatulate limb, 2-3 times as long as the stellate-canescent sepals: silique pendulous, somewhat stellate-pubescent.-New Mexico, and probably in southern Colorado.

16. Arabis perelegans A. Nels. Tall biennial, more or less pubescent with branched hairs below, glabrate upward: stems solitary, strict, 6-10 dm. high, very leafy up to the raceme: basal leaves few and early deciduous the second season; cauline entire or remotely denticulate, oblanceolate, and petioled below, passing into lanceolate-linear auriculate forms above: flowers large, from deep purple to almost white: petals twice as long as the pubescent sepals; the buds erect but drooping in anthesis: siliques linear, $5-8 \mathrm{~cm}$. long, divaricate, drooping, or variously twisted, on long ciliate pedicels. (A. elegans A. Nels. Bot. Gaz. 30: 192. 1900.)-Yellowstone Park.

17. Arabis canescens Nutt. T. \& G. Fl. N. A. 1: 83. 1838. Perennial from a multicipital caudex, finely and canescently stellate-pubescent throughout: stems numerous, erect, slender, $2-4 \mathrm{dm}$. high: leaves all linear, crowded on the crowns and the lower part of the stems, $2-4 \mathrm{~cm}$. long: flowers small, pale: siliques linear, glabrous, $3-5 \mathrm{~cm}$. long, pendent on reflexed or sometimes refracted pedicels: seeds small, winged, in 2 rows.- Western Wyoming and Utah to Oregon.

18. Arabis exilis A. Nels. Bull. Torr. Bot. Club 26: 123. 1899. Biennial or sometimes perennial, minutely stellate-pubescent, more glabrate upwards: stems solitary or 2 or 3 from the caudex, $2-5 \mathrm{dm}$. high: basal leaves rosulate, entire or toothed, oblong, acute at both ends, on short petioles; cauline lanceolate or linear, becoming sessile above but not auriculate-clasping: petals linear-spatulate, white or purplish, exceeding the pubescent narrow sepals: silique linear, 4-6 cm. long, pendent on abruptly deflexed somewhat pubescent pedicels: seeds in 2 rows. A. Holboellii in part. (A. consanguinea Greene, Pitt. 4: 190. 1900; A. pendulocarpa A. Nels. Bot. Gaz. 30: 192. 1900.)Southern Colorado to Montana.

19. Arabis rhodantha Greene, Pitt. 3: 155. 1897. Biennial, stellatetomentulose throughout: stem simple, stout, erect, 3-5 dm. high: basal leaves cuneate-oblanceolate, entire or toothed; cauline linear, acutish, sessile by an abruptly dilated auriculate base: raceme elongated, glabrous, subsecund: flowers small, pendulous: petals rose-red, barely longer than the pubescent sepals: siliques linear, straight, long, deflexed: seeds in 1 row, narrowly wing-margined. A. Holboellii in part.-Subalpine; Colorado.

20. Arabis a prica Osterh. Biennial, glabrous above, cinereous below with a subhispid branched (not stellate) pubescence: stems 1-4 from the single crown, ascending, 1.5-2 cm. high: basal leaves a crowded fascicle on the summit of the crown (the few stems arising just below or outside of the clustered leaves), hispid-ciliate, narrowly oblanceolate, tapering to a slender petiole, about $3 \mathrm{~cm}$. long; cauline leaves few, glabrous, merely foliar lanceolate auriculate bracts: flowers few, small: petals light rose, twice as long as the sepals: 
siliques glabrous, linear, somewhat curved, reflexed or pendent, on short widely spreading pedicels: seeds in 1 irregular row.-On naked limestone slopes; southeastern Wyoming to Colorado.

21. Arabis Fendleri (Gray) Greene, Pitt. 3: 156. 1897. Related to the foregoing, with similar pubescence: stem mostly solitary, erect, $3-5 \mathrm{dm}$. high, glabrous above: basal leaves few, oblanceolate, similar to the lower cauline which are equably distributed, with hirsute-ciliate and scattered trifurcate hairs, tapering to a slender petiole, rarely $3 \mathrm{~cm}$. long; the upper cauline reduced, glabrous, auriculate-clasping: siliques as in the preceding but longer: seeds in 2 rows.-Colorado to New Mexico.

22. Arabis caduca A. Nels. Biennial, maturing early the second season and then quickly disintegrating: stems solitary from a taproot, erect, thick but brittle, branched above, hirsute with branched hairs at base only: basal leaves rosulate, early caducous, oblanceolate, petioled, $2-3 \mathrm{~cm}$. long, rough with a branched hirsute pubescence; cauline oblong or broadly linear, sessile by an auricled base, glabrous: flowers small; racemes becoming very long, rather crowded: siliques 1-nerved to the middle, broadly linear, straight, acute, glabrous, 5-7 cm. long, pendent on reflexed pedicels, or more usually on pedicels sharply refracted at their base: seeds in 2 rows. A. Holboellii in part.- Sandy slopes and plains; southern Wyoming, south and west to Utah.

23. Arabis lignipes A. Nels. Bot. Gaz. 30: 191. 1900. Short lived perennial: stem usually solitary, virgate, and simple (rarely 2 or 3 from the crown), 3-5 dm. high, cinereously stellate-pubescent below (often only the raceme glabrous), lignescent at base, a short portion persisting each year (for 2 or 3 years) and this part crowned with a rosulate cluster of leaves, from among which rises, proliferous, the next year's stem: lower leaves oblanceolate-linear, cinereous-stellate, subpetioled, $2-4 \mathrm{~cm}$. long; upper cauline sessile, auriculate, lanceolate, often glabrous: raceme long and narrow: sepals purplish, scariousmargined, exceeded by the white or pale petals: siliques very slender, curved, becoming $6 \mathrm{~cm}$. or more in length, pendent on slender pedicels, usually sharply refracted: seeds in 1 row.-From northern Wyoming to Utah.

24. Arabis lignifera A. Nels. Bull. Torr. Bot. Club 26: 123. 1899. Branched from the base and decidedly woody-persistent, 3-5 dm. high: annual stems several, assurgent or erect, simple or branched, substellate below, glabrous above: leaves finely stellate, mostly basal, on short sterile branchlets, oblongoblanceolate, petioled, $3-5 \mathrm{~cm}$. long; cauline from oblong to lanceolate, shortauriculate: raceme simple or branched, nearly or quite glabrous: petals white or pinkish, twice as long as the obtuse scarious-margined sepals: siliques linear, 3-4 cm. long, from widely divaricate to pendulous; the valves 1-nerved: seeds uniseriate, as broad as the valves, narrowly winged.-Arid cañon-sides; southwestern Wyoming to Colorado and Utah.

25. Arabis Selbyi Rydb. Bull. Torr. Bot. Club 31: 257. 1904. Perennial with a basal rosette of oblanceolate, acute, sinuate-denticulate, short petioled leaves, 5-10 cm. long and green but stellate on both sides: stems branched, 4-5 dm. high: cauline leaves linear-lanceolate, sagittate at the base: raceme long and lax: sepals linear, sparingly stellate: petals red-purple, long-clawed: silique divergent, broadly linear, $3 \mathrm{~cm}$. long, on short divergent pedicels: seeds in 2 rows. - Southwestern Colorado.

26. Arabis eremophila Greene, Pitt. 4: 194. 1900. Perennial, the herbage cinereous with a rather dense branched pubescence: stems several from the base, ascending, 1-3 dm. long: leaves mostly basal, oblong-lanceolate, saliently denticulate, petioled; cauline few, linear, with short and inconspicuous auricles: petals rose-red, small: siliques narrowly linear, $3-4 \mathrm{~cm}$. long, spreading, on slender pedicels nearly half as long: seeds in 1 row.- Southern Colorado to New Mexico and Arizona.

\section{ERYSIMUM L. WESTERN WALLFLOWER}

Biennials or perennials, with short harsh pubescence of branched hairs, alternate, entire or toothed leaves (not clasping at base), and flowers generally 
large and yellow (sometimes orange-red, brownish, or rose-purple). Sepals erect, one pair strongly gibbous at base. Petals long-clawed, with a flat blade. Silique more or less 4-angled, sessile; stigma 2-lobed. Seeds numerous.-Cheiranthus of some Am. authors.

Biennials.

Stems simple or branched from the base only.

Mature silique short ( $2 \mathrm{~cm}$. or less)

Mature silique long ( $3 \mathrm{~cm}$. or more).

Flowers small; petals 6-10 mm. long

Flowers large; petals $12-20 \mathrm{~mm}$. long.

Silique obtusely angled, with convex sides .

Silique sharply angled, with flat sides. Stems usually paniculately branched from the base upward
Perennials.

Low and somewhat caespitose; flowers yellow

Taller, the caudex subsimple; flowers orange, reddish, or rosepurple

1. Erysimum cheiranthoides L. Sp. Pl. 661. 1753. Minutely roughpubescent, rather slender and erect, 3-8 dm. high: stems more or less branched: leaves lanceolate, entire or nearly so: flowers only 5 or $6 \mathrm{~mm}$. long, yellow: silique linear, obtusely 4-angled, $15-25 \mathrm{~mm}$. long, nearly erect on short divergent pedicels; style short $(1 \mathrm{~mm}$.). TREACLE Mustard.-Frequent, on stream banks; across the continent.

2. Erysimum inconspicuum (Wats.) MacM. Met. Minn. 268. 1892. Scabrocanescent, the hairs 2-rayed and appressed (appearing as if affixed by the middle): stems simple or slightly branched, one or more from the crown: leaves linear or lanceolate, usually entire, crowded on the crown and the lower part of the stem: flowers small, the petals about $8 \mathrm{~mm}$. long: silique erect, $3-5 \mathrm{~cm}$. long; the valves convex, strongly nerved; pedicels somewhat spreading. Erysimum parviflorum.-Kansas and Colorado, and far to the north and west.

3. Erysimum asperum DC. Syst. 2: 505. 1821. Greenish-canescent with appressed hairs (2-rayed as in the preceding): stems single and simple or nearly so, 2-5 dm. high: leaves oblanceolate or narrowly spatulate, entire or repandly toothed; the cauline mostly entire and upwardly becoming linearlanceolate: flowers large and very typically cruciform, in a compact raceme, which is short even in fruit: petals yellow or often changing to orange, brownish-red, or rose-purple, $12-20 \mathrm{~mm}$. long: siliques obtusely 4-angled, widely and regularly divaricate, $5-8 \mathrm{~cm}$. long. (Cheiranthws Bakeri Greene, Pitt. 4: 235. 1901; Erysimum oblanceolatum Rydb. Bull. Torr. Bot. Club 31: 557. 1904.)-From beyond the Mississippi to California.

4. Erysimum asperrimum (Greene) Rydb. Bull. Torr. Bot. Club 33: 141. 1906. Much like the preceding but more roughly and densely canescent, usually low, 1-3 dm. high: flowers smaller, 10-14 mm. high: silique long, sharply 4-angled, the sides very flat. (Erysimum pumilum Rydb.; not E. pumilum Nutt.)-On the high plains of northern Colorado and Wyoming.

5. Erysimum aridum A. Nels. Green but appressed-pubescent with minute 2-parted hairs: stem single from the enlarged crown of the taproot, more or less paniculately branched from the base up, 2-3 dm. high: the crown leaves early deciduous; the cauline oblanceolate to lance-linear, entire or nearly so: racemes many, elongated in fruit: petals yellow, $16-20 \mathrm{~mm}$. long: siliques 8-12 cm. long, subterete, but the valves distinctly 1-nerved, curvedascending. (Cheiranthus aridus A. Nels. Bull. Torr. Bot. Club 26: 351. 1899.)-Desert regions of south-central Wyoming and extending southward into Colorado.

6. Erysimum nivale (Greene) Rydb. Bull. Torr. Bot. Club 31: 558. 1904. Low multicipital perennial, bearing separate tufts of leaves and as many short flowering stems, $5-15 \mathrm{~cm}$. high: leaves green but somewhat pubescent with appressed 2-parted hairs, linear to lanceolate, entire or nearly so: petals large, 14-18 mm. long, the blade relatively small: siliques suberect, nearly terete, taper-pointed. ( $E$. radicatum Rydb. 1. c.)-Subalpine heights of the Colorado mountains.

7. Erysimum Wheeleri Wats. Wheeler Rep. 6: 64. 1878. Perennial, with 
a low simple or branched caudex: stems one from each crown, simple, 1-3 dm. high: herbage grayish-strigose; basal leaves narrowly oblanceolate, entire or denticulate; cauline linear: petals with slender claws and obovate-cuneate blade, 12-16 mm. long, varying in color from orange or brown to rose-purple or the older to pale yellow: siliques 4-angled, slender, erect, 5-8 cm. long. [E. amoenum Rydb. 1. c. 33: 142. E. alpestre (Ckll.) Rydb. 1. c. 28: 277. 1901.]-In the Colorado mountains at lower elevations than the preceding, with $E$. amoenum as an alpine state.

\section{CAPPARIDACEAE Lindl. Caper Family}

Ours are erect annual herbs with alternate leaves and regular or irregular perfect hypogynous flowers. Sepals 4 . Petals 4 . Stamens 6 or more, nearly equal in length. Receptacle usually elongated, often forming a stipe under the fruit which is a 1-celled capsule, with 2 parietal placentae. Seeds reniform, the embryo incurved, rather than infolded.

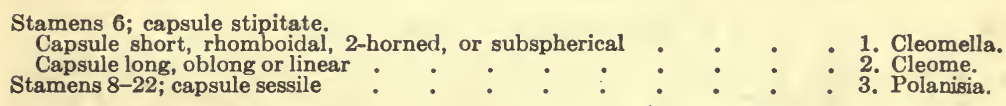

\section{CLEOMELLA DC.}

Erect branching annuals with alternate 3 -foliolate leaves and yellow racemose flowers. Sepals distinct. Petals 4, not clawed. Stamens 6, on the receptacle. Ovary and capsule filiform-stipitate. Capsule short, rhomboidal, 2-horned, or subspherical, of two deltoid or boat-shaped saccate valves. Seeds few, ovoid or rhomboidal, smooth or variously marked.

Stipe not more than twice as long as the capsule .

1. C. angustifolis. Stipe 3 or more times as long as the capsule .

2. C. cornuta.

1. Cleomella ang ustifolia Torr. in Gray, Pl. Wright. 1: 12. 1852. Glabrous, branching above: leaflets oblong-linear: capsule broader than long, several times longer than the style, flattened rhomboid, the valves nearly conical: stipe and pedicels subequal: seeds about 6 , transversely rugulose.-Colorado and southeastward.

2. Cleomella cornuta Rydb. Bull. Torr. Bot. Club 30: 249. 1903. Glabrous, branched from the base: leaflets oblong or narrowly oblanceolate: capsule broadly rhombic, broader than long, the corners somewhat produced into horn-like processes, 2-3 times longer than the beak-like style: stipe 3 or more times as long as the capsule: seeds smooth (?). C. oocarpa.-Utah and probably in southwestern Colorado.

\section{CLEOME L.}

Erect branching annuals with digitate or simple leaves and yellow or pinkpurple regular or irregular flowers, solitary or in racemes. Sepals distinct or slightly united at base. Petals entire, distinct, more or less clawed. Stamens 6 , inserted on the narrow receptacle above the petals. Capsule oblong or linear, many-seeded, stipitate, pendent on spreading pedicels.-Peritoma in Lit.)

Flowers pink-purple or nearly white.

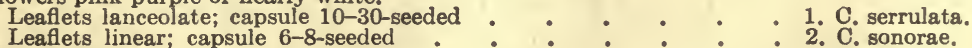

Flowers yellow.

1. Cleome serrulata Pursh, Fl. Am. Sept. 441. 1814. Glabrous and somewhat glaucous: stems erect, at length freely branching, 3-10 dm. high: leaflets 
3, lanceolate or oblong, entire or distantly serrulate, 4-8 cm. long: flowers numerous, reddish-purple, sometimes pinkish or white; the fruiting raceme becoming very long: capsule oblong or narrower, acute, $3-5 \mathrm{~cm}$. long, longer than the stipe which about equals the spreading pedicel. $C$. integrifolia. [C. inornata Greene, Pitt. 4: 16. 1899 (?).] Rocky Mountain Bee-Plant.-From New Mexico to Montana; also eastward to Missouri.

2. Cleome sonorae Gray, Pl. Wright. 2: 16. 1853. Glabrous, erect, 3-6 dm. high: leaves short-petioled and the upper almost sessile: leaflets 3 , very narrowly linear as also the simple similar bracts: raceme loose: petals white and rosecolor, spatulate, $4 \mathrm{~mm}$. long: capsule cylindraceous, torulose, 6-8-seeded, pendulous on a usually shorter stipe from the much longer and spreading filiform pedicel: seeds smooth.-Colorado, New Mexico, and Arizona.

3. Cleome lutea Hook. Fl. Bor. Am. 1: 70. 1830. Glabrous and more or less branched, $2-5 \mathrm{dm}$. high: leaflets digitately 5 -foliolate, petioled, or the upper subsessile and 3-foliolate, linear-oblong, entire: flowers bright yellow, in a corymbose raceme which elongates in fruit: stamens much exserted: capsule linear, on a stipe which becomes longer than the slender pedicel.-From Nebraska to the far west.

\section{POlanisia. Clammy-weed}

More or less branching annual herbs, ill-scented and mostly glandularpubescent (clammy), with trifoliolate petioled leaves. Flowers whitish or purple, in leafy-bracted racemes. Sepals sometimes united at base. Petals somewhat clawed and emarginate. Stamens 8 or more, somewhat unequal. Capsule sessile, elongated, flattened or cylindrical, many-seeded.

Stamens long-exserted; flowers large

Stamens barely longer than the petals

1. P. trachysperma.

1. Polanisia trachysperma T. \& G. Fl. N. A. 1: 669. 1840. Very clammy glandular-pubescent, $2-5 \mathrm{dm}$. high, somewhat branched: leaflets lanceolate or narrowly oblong-ovate: floral bracts foliar, mostly simple: petals 10-12 mm. long, with slender claws as long as the sepals: stamens slender, much exserted; the filaments purple: capsule scssile or nearly so, $3-4 \mathrm{~cm}$. long: seeds pitted and roughened.-From Texas to the Columbia river.

2. Polanisia graveolens Raf. Am. Journ. Sci. 1: 378. 1819. Similar but less glandular-pubescent, equally heavy scented: leaflets oblong: flowers only half so large: stamens scarcely longer than the petals: capsule lanceolateoblong, somewhat compressed, substipitate.-Southern Colorado and eastward across the continent.

\section{CRASSUlaCEAE DC. ORpine Family}

Usually succulent or fleshy plants, ours all herbaceous, with exstipulate leaves and usually cymose flowers. Calyx free and 4-5-parted or cleft. Petals of the same number, distinct or slightly united at base. Stamens as many or twice as many. Carpels 4-5, forming as many follicles which are dehiscent along the ventral suture. Seeds numerous. Receptacle often with a scale at the base of each carpel.

Stamens as many as the calyx-lobes Stamens twice as many as the calyx-lobe
Stamente
1. Tillaeastrum.

2. Sedum.

\section{1. tillaeastrum Brit. Pigmy Weed}

Small glabrous aquatic annuals, with opposite entire leaves and minute solitary axillary flowers. Sepals 4 . Petals 4 , distinct or slightly united. Stamens, styles, and carpels of the same number. Seeds few.

1. Tillaeastrum aquaticum (L.) Brit. Bull. N. Y. Bot. Gard. 3: 1. 1903. 
Stems decumbent, rooting at base, $3-5 \mathrm{~mm}$. long: flowers sessile or nearly so: petals greenish, twice as long as the sepals: follicles ovoid, 8-10-seeded. Tillaea angustifolia.-Wet muddy banks; across the continent; reported from Colorado.

\section{SEDUM L. STONECROP}

Herbs, mostly perennial and glabrous. Leaves fleshy. Flowers rarely dioecious, in cymes, often secund. Sepals 4-5, united at base. Petals as many, distinct or somewhat united at base. Stamens twice as many. Carpels distinct or rarely connate below, few to many-seeded.

Flowers terminal, in unilateral racemes or cymes.

Petals somewhat united below

Petals distinct.

Carpels spreading; flowers yellow. Branched from the base, 10-30 cm. high . Caespitose, 5-15 cm. high

Carpels erect; flowers purple or purplish

Flowers axillary, in equilateral racemes or cymes

1. S. debile.

2. S. Douglasii.

3. S. stenopetalum. 4. S. integrifolium. 5. S. rhodanthum.

1. Sedum debile Wats. Bot. King's Exp. 102. 1871. Stems weak, 5-12 cm. high: leaves elliptic to obovate, obtuse, sessile: flowers perfect, secund upon the branches of a forked cyme: calyx-segments ovate-lanceolate: petals yellow, lanceolate-acuminate; about twice as long as the calyx-lobes: follicles erect, tipped by the subulate style. (Gormania debilis Brit. Bull. N. Y. Bot. Gard. 3: 30. 1903.) -Utah and northwestward.

2. Sedum Douglasii Hook. Fl. Bor. Am. 1: 228. 1839. Much like the following but scarcely caespitose: stems few to several from the base, 1-3 dm. high: leaves flat above, carinate beneath: cyme more open, several forked or sometimes much reduced: petals lanceolate-acuminate, shorter than the stamens but surpassing the ovate-acuminate sepals: follicles widely divergent from the slightly united bases.-Western Wyoming to Oregon and California.

3. Sedum stenopetalum Pursh, Fl. Am. Sept. 324. 1814. Glabrous tufted perennial, usually less than $1 \mathrm{dm}$. high: leaves crowded, and on sterile shoots imbricated, thick-linear, 8-14 mm. long: cyme compact; flowers short-pediceled: petals lanceolate, acute, nearly as long as the stamens and twice as long as the ovate calyx-lobes: follicles erect, tipped by the long divergent styles.Very common on stony slopes and ridges; from Colorado to Oregon and Washington.

4. Sedum integrifolium (Raf.) A. Nels. Rootstock fleshy: stems 5-20 cm. high: leaves obovate to oblong-obovate, sessile, 1-2 cm. long, dentate or entire: flowers dioecious, dark purple, in a dense cyme: petals oblanceolate or oblong, acute, nearly twice as long as the calyx-lobes, exceeded by the purple filaments: follicles more or less divergent. S. Rhodiola. (S. frigidum Rydb. Bull. Torr. Bot. Club 28: 282. 1901; S. polygamum Rydb. 1. c.; Rhodiola integrifolia Raf. Atl. Journ. 1: 146. 1832.)-Alpine; in the Rocky Mountains and westward.

5. Sedum rhodanthum Gray, Am. Journ. Sci. II. 33: 405. 1862. Glabrous: stems usually many, 1-3 dm. high, very leafy: leaves linear-oblong to oblanceolate, entire or toothed, $15-25 \mathrm{~mm}$. long: petals rose-color to white, linearlanceolate, twice as long as the calyx: follicles erect, with spreading tips. (Clementsia rhodantha Rose, Bull. N. Y. Bot. Gard. 3: 3. 1903.)-Along streams in the mountains; throughout our range.

\section{SAXIFRAGACEAE Dumort. SaXifrage Family}

Herbs with alternate or opposite leaves without true stipules and mostly perfect flowers, solitary or in paniculate or capitate racemes or cymes. Sepals 4-5, united or nearly distinct. Petals as many, alternate with them, or wanting. Stamens as many or twice as many, inserted on the throat of the calyx. Ovary either free from the calyx or coherent with its tube, 1-3-celled, 
with either axile or parietal placentae; ovules mostly numerous; styles distinct or more or less united. Fruit capsular; the carpels either distinct or united but their upper portion free, opening along the inner suture of each.

Ovary 1-celled, with 2-4 parietal placentae.

Stamens 5 , alternating with 5 clusters of sterile filaments

Stamens all anther-bearing.

Stamens 5; petals sometimes wanting.

Filaments and styles exserted; petals entire

Stamens 8-10.

Petals wholly wanting; capsule obcordate, flattened

Petals present, conspicuous, 3-7-parted .

Ovary 2-celled, and placentae in the axis or the carpels distinct.
Ovary more or less adnate to the calyx-tube.

Stamens 5, inserted below the throat of the calyx, next to the

Stamens 10, inserted in the throat of the calyx :

Ovary free from the calyx; stamens 10 .

\section{Parnassia.}

2. Heuchera.

3. Mitella.

4. Chrysosplenium.

5. Tellima.

\section{Sullivantia.}

7. Boykinia.

8. Saxifraga.

\section{PaRnassia L. Grass of Parnassus}

Smooth perennial herbs with entire and chiefly radical leaves and large solitary flowers terminating the long naked stems. Calyx 5-parted. Petals 5, white, with greenish or yellowish veins. Stamens 5 , alternating with 5 clusters of sterile filaments (staminodia). Ovary 1-celled, with 3 or 4 parietal placentae directly under as many sessile stigmas. Seeds numerous.

Petals sessile, entire; leaves ovate or cordate.

Scape (stem) with a single leaf.

Staminodia 5-7; leaf near the middle of the scape

Staminodia 7-15; leaf usually below the middle

Scape naked, or with 1 leaf near the base .

Petals with a short claw, fringed

1. P. parviflora.

2. P. palustris.

3. P. kotzebuei.

4. P. fimbriata.

1. Parnassia parviflora DC. Prodr. 1: 320. 1824. Scape 1-2 dm. high, slender, bearing a small ovate or oval leaf near the middle (sometimes lower): leaves ovate or oblong, tapering to the petioles: petals sessile, entire, elliptic, scarcely longer than the oblong or elliptic sepals: sterile filaments (staminodia) about 5.-Lake and stream banks at middle elevations; Colorado, Wyoming, northward and eastward.

2. Parnassia palustris L. Sp. Pl. 273. 1753. Scape 1-2 dm. high, the single ovate clasping leaf usually below the middle: leaves broadly ovate, more or less cordate, rather long slender-petioled: petals sessile, broadly elliptic, somewhat longer than the ovate subacute sepals: sterile filaments slender, 9-15 at the base of each petal.-Extending into the mountains of Wyoming from the north and east.

3. Parnassia kotzebuei C. \& S. Linnaea 1: 549. 1826. Scape usually less than $1 \mathrm{dm}$. high, leafless, or rarely with a single oval leaf near the base: leaves thin, ovate or oval, often subcordate at base, short-petioled: petals sessile, about equaling the oblong calyx-lobes: sterile filaments slender, only $3-5$ at the base of each petal.-Arctic, but extending south along the mountains to northern Wyoming.

4. Parnassia fimbriata Banks, Kon. \& Sims. Ann. Bot. 1: 391. 1805. Scape 1-2 dm. high, the single clasping ovate-cordate leaf at the middle or a a little above: leaves broadly reniform to ovate-cordate, slender-petioled: petals with a short claw, fringed below the middle or toward the base: sterile filaments 5-9 in each set, united below into a fleshy carinate scale, or sometimes a dilated scale destitute of bristle-like filaments. ( $P$. rivularis Osterh. N. A. Fl. 22: 78. 1905.)-Subalpine, wet shady banks; Colorado to California and northward to British America.

\section{HEUCHERA L. ALUMROot}

Caespitose perennials, with mostly basal leaves, those on the scape (if any) alternate. Petioles with dilated margins or adherent stipules at their base. 
Flowers in small clusters disposed in a prolonged and narrow panicle, greenish or purplish. Calyx 5-cleft, bell-shaped. Petals entire, small or minute (sometimes wanting). Stamens 5, commonly slender as are also the 2 styles. Ovary 1-celled; the capsule 2-beaked, fully half adnate to the calyx, with 2 parietal placentae alternate with its 2 beaks.

Inflorescence open-paniculate; stamens well exserted.

Peduncles glabrate; petioles somewhat hirsute

Peduncles and petioles both very hirsute-hispid :

Inflorescence spicate; stamens included or nearly so.

Plants more or less glandular-hirsute

Plants glabrate or glandular-puberulent on scape and inflorescence.

Stamens at length exserted; petals filiform

Stamens never exserted; petals spatulate.

Flowers in a narrow unilateral raceme

Flowers not unilateral.

Scapes g'abrous; inflorescence spicate

Scapes glandular-puberulent.

Inflorescence paniculate

Inflorescence a simple raceme

1. H. rubescens.

2. H. hispida.

3. H. ovalifolia.

4. H. bracteata.

5. H. Hallii.

6. H. grossulariifolia.

7. H. parvifolia.

8. H. Williamsii.

1. Heuchera rubescens Torr. Sitgr. Rep. 160. 1854. Scapes glabrous, naked or with 1 or 2 foliar bracts, $3-5 \mathrm{dm}$. high: petioles more or less villous: root leaves round-cordate or truncate, crenate-dentate, $3-5 \mathrm{~cm}$. broad: inflorescence an open panicle, minutely glandular; the pedicels long and very slender: calyx narrowly campanulate: petals linear-spatulate, about twice as long as the calyx-lobes: stamens early conspicuously exserted. (H. Sitgreavesii Rydb. N. A. Fl. 22: 110. 1905.)-Throughout our range and westward.

2. Heuchera hispida Pursh, F1. Am. Sept. 187. 1814. Scapes and petioles densely hirsute or ciliate-glandular below, glandular-pubescent above; scapes 2-4 dm. high: leaves round-reniform, somewhat 5-7-lobed and crenate, glabrous above, pubescent beneath: inflorescence a narrow panicle, very glandular, the pedicels short and rather stout: calyx broadly campanulate, gibbous at base and very oblique at summit: petals spatulate, slightly glandular, barely longer than the oblong calyx-lobes: stamens finally well exserted. (H. ciliata Rydb. Mem. N. Y. Bot. Card. 1: 196. 1900.)-Sides of rocky cliffs; from the Mississippi valley (Illinois) west to northern Wyoming and Montana and northward.

3. Heuchera ovalifolia Nutt. T. \& G. Fl. N. A. 1: 581. 1840. Villous and viscid-glandular throughout, the leaves sparsely so: scapes stout, $2-3 \mathrm{dm}$. high, foliar bracted near top: leaves $2-4 \mathrm{~cm}$. long, oval to rotund, truncate or subcordate at base, doubly and incisely crenate, with obtusish teeth: inflorescence spicate, sometimes interrupted: calyx campanulate, the lobes as long as the tube, ovate or oval, white or petaloid: petals wanting: stamens included, the filaments only $1 \mathrm{~mm}$. long. H.cylindrica. (H. saxicola E. Nels. Bot. Gaz. 30: 117. 1900.)-Northern Wyoming to Montana and Idaho.

4. Heuchera bracteata (Torr.) Ser. in DC. Prodr. 4: 52. 1830. Glabrous but for the minute glandular-puberulence above: scapes short, usually several from the very leafy crowns of the woody caudex, naked or foliar-bracteate, 1-2 dm. high: leaves roundish, subcordate, incisely lobed and toothed, the teeth usually spinulose: inflorescence short-spicate: calyx campanulate: petals filiform, a little longer than the calyx-lobes: stamens at last a little exserted.Rocky cliffs; southern Wyoming, south through Colorado.

5. Heuchera Hallii Gray, Proc. Acad. Phila. 62. 1863. Herbage glabrate, inflorescence minutely glandular-puberulent: scapes 1-2 dm. high, naked or foliar-bracteate: leaves round-cordate or subcordate, 1-3 cm. broad, slightly 5-lobed; the lobes crenate-dentate, with ciliate-spinulose teeth: inflorescence a short unilateral spike-like raceme: calyx campanulate: petals narrowly spatulate, with a long slender claw, nearly.twice as long as the calyx-lobes: stamens not at any time exserted.-Rocky cliffs; southern Colorado.

6. Heuchera grossulariifolia Rydb. Mem. N. Y. Bot. Gard. 1: 196. 1900. Resembling the preceding, being low-caespitose, with glabrous scapes 1-2 dm. high: leaves suborbicular-cordate, more or less deeply 5-cleft; the lobes crenate, with spinulose-ciliate teeth: inflorescence a spike-like raceme (not 
unilateral), more or less glandular-puberulent: calyx campanulate, slightly oblique: petals spatulate, slightly exceeding the calyx-lobes: stamens not at any time exserted.-From northern Colorado to Idaho and Montana; probably in Utah.

7. Heuchera parvifolia Nutt. T. \& G. Fl. N. A. 1: 581. 1840., Scapes slender, 2-6 dm. high, decidedly glandular-puberulent: leaves crowded on the caespitose crowns of the caudex, orbicular-cordate or subreniform, crenately 5-7-lobed: inflorescence at first crowded and seemingly spicate, at length a long narrow panicle, minutely glandular-puberulent: calyx obconical: petals small, broadly spatulate, barely exceeding the calyx-lobes: stamens not at any time exserted. (H. flabellifolia and $H$. utahensis Rydb. N. A. Fl. 22: 115. 1905.) - Very common on rocky ridges and steep slopes; from New Mexico to British America.

8. Heuchera Williamsii Eaton, Bot. Gaz. 15: 62. 1890. Scape altogether naked, minutely glandular-puberulent, 3-4 dm. high: leaves rather few, closely basal, short-petioled, reniform, $2-3 \mathrm{~cm}$. broad, crenulate and scabrociliate on the margin: inflorescence a simple raceme, the flowers short-pediceled and rather discant: calyx turbinate: petals spatulate, with long slender claw, 3-4 times as long as the calyx-lobes: stamens not exserted. (This is thought by some botanists to be a Tellima and by Rydberg has been made a new genus Conimitella.)-Northern Wyoming and Montana.

\section{Mitella L. Miterwort}

Low and slender perennials, with round-cordate alternate leaves on the crown of the rootstock; those on the scape (if any) opposite. Flowers in a simple slender raceme or spike. Calyx 5-cleft, short, adnate to more or less of the ovary. Petals pinnatifid, 3-cleft, or entire. Stamens 5 , nearly sessile. Styles very short. Capsule depressed.-(Ozomelis and Perctianthia Raf.)

Stamens opposite the greenish pinnatifid petals

Stamens alternate with the white trifid or entire petals.

Leaves pilose; petals trifid.

Petals much longer than the calyx

Petals scarcely longer than the calyx.

Leaves puberulent; petals entire

1. M. pentandra.

1. Mitella pentandra Hook. Bot. Mag. 56 pl. 2933. 1829. Sparingly pubescent with short white hairs; scapes slender, 1-3 dm. high: leaves cordate to round-reniform, obscurely 3-5-lobed, unequally serrate, $2-3 \mathrm{dm}$. in diameter: flowers numerous, in a subpaniculate raceme: calyx short-campanulate, the very short obtuse lobes green: petals pinnate with 7-9 approximate filiform pinnae: filaments very short, inflexed.-In wet places, on the highest mountains; Alaska to Oregon and the Rocky Mountains.

2. Mitella stauropetala Piper, Erythea 7: 161. 1899. Scapes naked, 3-5 $\mathrm{dm}$. high, slender, sparsely pubescent below, minutely glandular-puberulent above: leaves orbicular, indistinctly 5 -lobed, simply or doubly crenate, but not strongly so, reniform with narrow sinus, sparsely pilose on each surface and ciliate with reddish or white hairs: raceme 6-12 cm. long, 10-25-flowered, strictly secund; flowers white, sometimes violet-tinged, 4-5 mm. long: calyxlobes erect, oblong-obovate: petals nearly twice as long as the calyx-lobes, filiform, 3-parted nearly half their length into linear lobes, the lateral lobes divaricate: stamens short and included.-From Colorado to Idaho and Washington.

3. Mitella Parryi (Piper) A. Nels. Smaller in every way, 1.5-3 dm. high: scapes slender: leaves $2 \mathrm{~cm}$. in diameter, doubly and conspicuously crenate, sparsely pilose as are also the petioles: petals mostly 3-parted at the apex, only half as long as in the preceding and scarcely surpassing the calyx: stamens very short. (M. stenopetala Parryi Piper, l. c. 162.)-Colorado and Wyoming and probably westward.

4. Mitella violacea Rydb. Bull. Torr. Bot. Club 24: 248. 1897. Scapes slender, naked, 3-5 dm. high, minutely puberulent: leaves orbicular, obscurely 5 -lobed, reniform with a broad sinus, very minutely puberulent on each side, 
sparsely ciliate, $2-5 \mathrm{~cm}$. in diameter; petioles $2-3$ times as long as the blade, puberulent: raceme secund, bearing 15-20 evenly scattered flowers; flowers white, $2 \mathrm{~mm}$. long, spreading on short petioles: calyx-lobes oblong, obtuse: petals filiform to oblanceolate, 1-nerved, entire, or very rarely parted near the apex into two or three lobes, slightly longer than the calyx: stamens 5, very short. (M. stenopetala Piper, 1. c.)-Colorado to Montana and far westward.

\section{ChRYSOSPLENIUM (Tourn.) L. Golden Saxifrage}

Low and small smooth herbs, with tender succulent leaves, and small corymbose flowers. Calyx-tube adnate to the ovary, the obtuse lobes 4 or 5 , yellow within. Petals wanting. Stamens 4-8, very short, inserted on a conspicuous disk. Styles 2. Capsule obcordate, flattened.

1. Chrysosplenium tetrandrum Th. Fries, Bot. Notiser 193. 1858. Flowering stems erect, branched above: leaves alternate, reniform-cordate, doubly crenate, or somewhat lobed. C. alternifolium.-Arctic in Europe, Asia, and America; said to have been collected in Colorado by Hall and Harbour.

\section{TELLIMA R. Br.}

Low slender perennials with palmately divided or parted leaves, few on the simple stem but more numerous downward. Petioles with stipule-like dilations at base. Flowers in a simple terminal raceme. Calyx campanulate or turbinate, 5-lobed, the base of the tube more or less adnate to the ovary. Petals white or pink, 3-7-parted into narrow lobes. Stamens 10, included. Styles 2-3, very short. Our species frequently bear small grain-like bulblets on the roots, in the axils of the leaves, or in place of flowers in the raceme. -(Lithophragma.)

Calyx obconical or clavate

Calyx campanulate.

Pedicels and fruit subequal; seeds smooth

Pedicels longer than the fruit; seeds muriculate .

1. T. parviflora.

2. T. tenella.

3. T. bulbifera.

1. Tellima parviflora Hook. Fl. Bor. Am. 1: 239. pl. 78. 1833. Roughish hirsute or scabro-pubescent, 1-3 dm. high: stems sparsely leafy: leaves generally 3-lobed or cleft; the divisions cuneate and once or twice 3-cleft: calyx obconical or at length almost clavate: petals deeply 3-cleft into linear or oblong divisions: ovary and capsule adnate to the calyx-tube for at least half their length: bulblets rarely produced.-Colorado and Utah, northward through the Yellowstone region to British America.

2. Tellima tenella (Nutt.) Walp. Repert. 2: 371. 1843. Obscurely puberulent and glandular, or sometimes nearly glabrous: perennial from bulblets which also give origin to numerous fibrous roots: stems very slender, 1-2 dm. high: leaves small, $3-5$-cleft, the divisions again cleft into mostly linear lobes: calyx campanulate, the short lobes often very unequal, sometimes dark purplish-red: petals 3-5-cleft or parted, or even irregularly 7-parted into mostly linear divisions: ovary and capsule free except at the base. [T. glabra (Nutt.) Steud. Nom. Bot. Ed. 2. 2: 665. 1841; Lithophragma australis Rydb. N. A. Fl. 22: 86. 1905.]-Colorado, Wyoming, and westward to the Sierras.

3. Tellima bulbifera (Rydb.) A. Nels. Glandular-puberulent, 1-2 dm. high: leaves divided to the base; the divisions cuneate or obovate, 3-cleft and the lobes often toothed; the stem leaves usually bearing bulblets in the axils; stipules fimbriate: flowers 3-6, sometimes replaced by bulblets: petals $4-7 \mathrm{~mm}$. long, 3-5-cleft. (Lithophragma bulbifera Rydb. N. Am. Fl. 222: 86. 1905.) -From the British boundary to Colorado and California.

6. SULLIVANTIA T. \& G.

Slender perennial herbs, with mostly basal palmately veined leaves and small flowers in paniculate cymules. Calyx campanulate, its base adnate to 
the ovary, 5-cleft. Petals 5, white, entire, withering-persistent. Stamens 5, very short. Ovary 2-celled, with the placentae in the axis. Carpels united to the middle. Seeds numerous.

1. Sullivantia Hapemannii Coult. Bot. Gaz. 17: 421. 1892. Stems 1-3 dm. high, glandular-pubescent especially above: leaves mostly orbicular-reniform, $2-5 \mathrm{~cm}$. in diameter, more or less lobed and the lobes toothed; petioles as long as or longer than the blades: sepals about $2 \mathrm{~mm}$. long, 3-nerved: petals spatulate to obovate, somewhat exceeding the sepals: carpels united to the beak, 4-5 mm. long. (S. halmicola A. Nels. ex Rydb. N. A. Fl. 22: 122. 1905.)Growing in the crevices of dripping cliffs; Big Horn Mountains and Casper Mountain, Wyoming; also in Colorado.

\section{BOYKINIA Nutt.}

Glandular-pubescent perennial herbs, with simple leafy stems, alternate petioled crenate leaves, and paniculate or corymbose cymes of white flowers. Leaves round-reniform, palmately lobed and incised or toothed; the teeth with callous glandular tips, and the petiole with mostly stipule-like dilations at base. Calyx 5-lobed. Petals entire, ours purple or violet, the base contracted into a short claw. Stamens 10. Ovary 2-celled, adnate to the calyxtube.-(Telesonix Raf.)

\section{Petals long-clawed, blade orbicular, well exserted}

Petals short-clawed, blade oblong, scarcely exserted

1. B. Jamesii.

2. B. heucheriformis.

1. Boykinia Jamesii (Torr.) Engler, Nat. Pf. 32: 51. 1890. Glandularpuberulent: stem leafy, assurgent, $10-15 \mathrm{~cm}$. high: radical leaves petioled, reniform-cordate, smoothish, crenately toothed or lobed; the cauline few, bract-like above: inflorescence a crowded paniculate cyme, glandular, purplish: calyx-tube campanulate, adnate to the base of the ovary; calyx-lobes triangular, acute: petals purple, long-clawed, with well exserted orbicular blade: stamens inserted in the throat of the calyx: styles united. Saxifraga Jamesii.

- Colorado.

2. Boykinia heucheriformis (Rydb.) A. Nels. Very near the preceding, caespitose, with a thick scaly caudex: sepals ovate, erect: petals obovateoblanceolate or oblong-spatulate, dark violet, scarcely longer than the sepals: styles free. (Therophon heucheriforme Rydb. Bull. Torr. Bot. Club 24: 247. 1897.)-Wyoming, into Montana and Idaho.

\section{SAXIFRAGA L.* SAXIFRAGE}

Either scapose or short-stemmed perennial herbs, with exstipulate alternate (rarely opposite) leaves and small flowers, in simple, panicled, or glomerate cymes (rarely solitary). Calyx 5-lobed or parted, free or more or less adnate to the base of the ovary. Petals 5 (or rarely wanting), entire. Stamens 10. Ovary 2-celled, the placentae in the axis, or the carpels distinct. Styles and tips of the carpels distinct and soon divergent.

Stems more or less leafy.

Stem leaves opposite; calyx free

Stem leaves alternate; calyx adnate to the base of the ovary.

Petals yellow.

Leaves not rosulate at base

Leaves crowded-rosulate at base.

Stoloniferous .

Without stolonis

Petals white, or nearly so.

Leaves as broad as they are long, reniform, lobed, or entire. Calyx adnate to the ovary, turbinate Calyx adnate below only, campanulate

Leaves longer than broad, entire, cleft, or parted.

Leaves entire, linear or oblong.

Calyx cleft nearly to the base
Calyx-lobes shorter than the tube

1. Ś. oppositifolia.

2. S. Hirculus.

3. S. flagellaris.

4. S. chrysantha.

5. S. debilis.

6. S. cernua.

7. S. austromontana. 8. S. oregonensis.

* For list of old and new segregates of this genus see Small, N. A. Fl. 22: 129.1905. 
Leaves 3-5-cleft or toothed. Petals minute $(2 \mathrm{~mm}$.) Petals evident (5-7 $\mathrm{mm}$.) Stems leafless (scapose).

Leaves reniform-cordate

Leaves ovate to oblong.

Sepals erect.

Scape puberulent

Scape glandular-pubescent

Sepals reflexed, at least in fruit. Inflorescence open-paniculate Inflorescence spiciform
9. S. micropetala.

10. S. caespitosa.

11. S. arguta.

12. S. rhomboidea.

13. S. austrina.

14. S. saximontana.

15. S. subapetala.

1. Saxifraga oppositifolia L. Sp. Pl. 402. 1753. The numerous stems prostrate in a dense tuft: leaves fleshy, ovate, keeled, ciliate, imbricated on the sterile branches: flowers solitary, large: petals purple, obovate, much longer than the 5-cleft calyx which is free from the capsule: seeds rugose.Arctic and northeastern America; also in the Rocky Mountains as far south (it is said) as Wyoming.

2. Saxifraga Hirculus L. Sp. Pl. 402. 1753. Stems single from a slender caudex, erect, glabrous or pubescent, 1-2 dm. high: leaves oblong or linearoblong, the lower short-petioled, somewhat equally distributed the whole length of the stem: flowers solitary (rarely 2-4), terminal: sepals often ciliate, nearly distinct, soon reflexed, much shorter than the large yellow petals: capsule free from the calyx, or nearly so.-From Colorado to the Arctic sea.

3. Saxifraga flagellaris Willd. ex Sternb. Rev. Saxif. 25. t. 6. 1810. Glandular-pubescent: stems erect, usually less than $1 \mathrm{dm}$. high: stolons from the axils of the radical leaves, long and filiform, naked and rooting at the ends: leaves rosulate-crowded at the base, and very numerous the whole length of the stem, ovate-spatulate, ciliate: flowers large, yellow: sepals very glandular: ovary slightly adnate to the calyx.-Alpine in Colorado, and far to the northward.

4. Saxifraga chrysantha Gray, Proc. Am. Acad. 12: 83. 1877. Dwarf, somewhat caespitose, the filiform somewhat glandular-pubescent stem 3-10 $\mathrm{cm}$. high: leaves mostly rosulate at the base, very few on the stem, oblongovate, thick, very smooth: flowers large, 1-3, yellow: calyx-segments reflexed, much shorter than the obovate petals: carpels nearly or quite free from the calyx.-On the highest mountain peaks; Colorado to New Mexico.

5. Saxifraga debilis Engelm. Gray, Proc. Phila. Acad. 1863: 62. Glabrous or very sparingly glandular-pubescent: stems weak, ascending, 2-4-flowered, 5-10 cm. high: radical leaves small, crenately lobed, cauline ones 3-lobed or entire: lobes of the calyx ovate, obtusish, at length shorter than the tube: petals ovate, obtuse, twice longer than the calyx, white or pinkish: tube of the calyx obconical, wholly adherent to the ovary.-High mountains; Colorado, Wyoming, and Utah.

6. Saxifraga cernua L. Sp. Pl. 403. 1753. Glabrate or glandular-pubescent; stems granulate at base, weak, 6-14 cm. high: lower leaves reniform, broadly toothed or lobed; the upper ones bearing little bulbs in their axils: flowers often solitary, terminal, pendulous: petals retuse or rounded, 3-4 times as long as the ovate calyx-lobes. (S. simulata Small N. A. Fl. 22: 128. 1905.)Alpine in the Rocky Mountains and far to the north; also in Europe and Asia.

7. Saxifraga a ustromontana Wiegand, Bull. Torr. Bot. Club 27: 388. 1900. Glabrous, densely caespitose: stems ascending, slender, somewhat purplish, $7-15 \mathrm{~cm}$. high: leaves crowded at the base, firm, linear-oblong, spinuloseciliate; the stem leaves smaller: flowers numerous, in an open somewhat corymbose panicle, sparingly glandular: petals white, spotted with orange and purple dots, longer than the short obtuse sepals. S. bronchialis. (S. cognata E. Nels. Bot. Gaz. 30: 118. 1902.) - Colorado, northward, and west to Washington.

8. Saxifraga oregonensis (Raf.) A. Nels. Bot. Gaz. 33: 52. 1906. Diminutive perennials from a slender caudex: stems simple, $3-8 \mathrm{~cm}$. high, glandular-pubescent: leaves small, mostly basal, oblong-spatulate, minutely 
hispid-ciliate: flowers few, in a crowded glomerule at summit: calyx minutely glandular-pubescent, its whole tube adnate to the carpels: petals broadly obovate-cuneate, truncately rounded at summit, twice as long as the calyxlobes, distinctly divergently 3-nerved: the distended subglobose calyx-tube papillose-rugose from the pressure upon it by the numerous brown seeds within. S. adscendens. (Muscaria delicatula Small, 1. c. 129.)-High mountains, Colorado to Montana.

9. Saxifraga micropetala (Small) A. Nels. Plants $2-6 \mathrm{~cm}$. tall, rather copiously glandular-pubescent: leaves compactly crowded on the caudices, the blades 5-9 mm. long, 3-lobed at the apex, the lobes linear or oblonglinear: flower-stalks relatively stout, 1-3-flowered, each bearing 2 or 3 leaves: hypanthium about $3 \mathrm{~mm}$. long at maturity: sepals broadly ovate, obtuse or acutish, about $2 \mathrm{~mm}$. long: petals oval or oval-obovate, about $1.5 \mathrm{~mm}$. long, clawless: follicles 5-6 mm. long. (Orig. desc. as Muscaria micropetala Small, 1. c.)-Wyoming and Utah.

10. Saxifraga caespitosa L. Sp. Pl. 404. 1753. Dwarf (3-5 cm. high), caespitose:- leaves glandular-pubescent, 3-5-cleft, segments broadly linear and obtuse; the upper leaves linear and entire: flowering stems with a few scattered leaves, glandular, 1-4-flowered: petals obovate, much longer than the ovate-oblong obtuse calyx-lobes: base of the carpels adnate to the calyxtube.-Colorado to Arctic America.

11. Saxifraga arguta Don, Trans. Linn. Soc. 13: 356. 1822. Nearly glabrous: scape slender, naked, $3-5 \mathrm{dm}$. high: leaves all radical, $3-5 \mathrm{~cm}$. broad, reniform-cordate or orbicular, crenate-dentate, with acute teeth; petioles long: panicle open, somewhat glandular, usually many-flowered: petals oval, longer than the ovate-oblong reflexed sepals: filaments often petaloid and abortive. S. punctata.-From New Mexico to the far northwest.

12. Saxifraga rhomboidea Greene, Pitt. 3: 343. 1898. Scape glabrate or pubescent, stout, simple, erect, 1-3 dm. high: leaves rosulate in a depressed radical tuft, rhombic-ovate or oval, $3-6 \mathrm{~cm}$. long (including the short-margined petiole), entire, crenate-dentate, or somewhat repand, glabrous, or often lightly pubescent on the margin: flowers small, white, at first densely capitate, later somewhat branched-thyrsiform: petals spatulate-obovate, often emarginate: ovary adnate to base of calyx. S. nivalis.-Very common on moist slopes; Colorado, north to Montana.

13. Saxifraga austrina A. Nels. Resembling the preceding, the scape slenderer, sometimes 2 or more from the short rootstock, often pedunculately branched upward, rather densely glandular-pubescent: inflorescense interruptedly capitate or paniculately branched-thyrsiform: sepals obtuse, as long as the adnate base: petals clawed, much exceeding the sepals: carpel-tips becoming widely divaricate: seeds numerous, brown, oblong, subacute at both ends. (S. rhomboidea austrina A. Nels. Bot. Gaz. 31: 394. 1901.)-Southern Colorado and New Mexico.

14. Saxifraga saximontana E. Nels. Erythea 7: 168. 1899. Scapes 1 or 2, from a short rootstock, pubescent with short purple-tipped glandular hairs, 1-2 dm. high: leaves ovate or rhombic-ovate, 2-4 cm. long: inflorescence a panicle of ascending few-flowered corymbose cymes: petals rotund to oval, short-clawed, nearly twice as long as the ovate-obtuse 3 -nerved calyx-lobes, which become reflexed: carpels distinct to the base, somewhat adnate to the calyx below: seeds low-tuberculate. S. virginiensis.-Northern Wyoming and northwestward.

15. Saxifraga subapetala E. Nels: Erythea 7: 169. 1899. Scapes solitary from a thick corm-like caudex, somewhat hirsute and glandular, $2-4 \mathrm{dm}$. high: leaves elliptic to oblanceolate, glabrous or short-pubescent, the margins ciliate, 5-10 cm. long: panicle spiciform, the glomerules dense: calyx-tube adnate to the carpels for most of its length, the ovate-obtuse finally reflexed lobes longer than the tube: petals wanting or minute: carpels distinct, adnate to the disk-like base of the calyx: seeds wing-margined, short-tuberculate in lines. S. integrifolia, in part.-Wyoming, northward and westward.

15a. Saxifraga subapetala normalis A. Nels. Bot. Gaz. 42: 53. 1906. 
Very similar to the species but petals evident, elliptic-spatulate, as long as the calyx-lobes: as in the species the carpels are immersed in a crest-margined disk which persists at the middle of the mature carpels as an undulate ridge. (Micranthes arnoglossa Small, l. c. 138.)-At high elevations in the Colorado mountains.

\section{GROSSUlARIACEAE Dumort. Gooseberry Family}

Erect or procumbent branching shrubs with alternate palmately lobed, often resinous-glandular or viscid leaves; stipules when present adnate to the petiole. Flowers racemose, rarely solitary on 1-2-leaved axillary shoots; pedicels subtended by a bract and usually bearing 2 bractlets at about the middle. Calyx-tube adnate to the globose ovary and more or less produced above it. Petals 5 or rarely 4 , erect, mostly smaller than the calyx-lobes. Stamens equaling the petals in number and alternate with them. Ovary 1-celled with 2 parietal placentae; styles 2 , more or less united; stigmas terminal. Fruit a berry, crowned with the withered remains of the flower.

\section{RIBES L. Gooseberries and Currants}

The only genus; characters of the family.

Stems usually armed with spines and often with prickles (setosehispid); leaves plicate in the bud (Gooseberries; Nos. 5 \& 6 transitional).

Racemes 1-4-flowered; calyx-tube cylindrical or campanulate. Spines solitary or wholly wanting, but the stems often setosehispid.

Spines short or unequal; setose-hispid or nearly unarmed. Leaves glabrate or puberulent; fruit smooth Leaves closely pubescent; fruit hispid

Spines long and conspicuous; setae few; leaves glabrate Spines triple, long .

Racemes several-flowered; calyx-tube salverform. Leaves finely pubescent; fruit red

Leaves glabrate; fruit black

Stems unarmed (neither thorns nor prickles present) (Currants.)

Flowers not yellow; leaves plicate in the bud.

Berry glandular-bristly.

Leaves glabrous; fruit spherical. Calyx-tube salverform Calyx-tube campanulate

Leaves pubescent and glandular; fruit ovoid

Berry smooth (rarely glandular in No. 12).

Calyx-tube campanulate.

Racemes erect or ascending

Racemes drooping
Calyx-tube cylindrical, with dilated base

Flowers yellow; leaves convolute in the bud
1. R. saxosum.
2. R. setosum.
3. R. leptanthum.
4. R. saximontanum.
5. R. lentum.
6. R. parvulum.

1. Ribes saxosum Hook. Fl. Bor. Am. 1: 231. 1833. Stems simple or branched, sometimes unarmed but usually more or less prickly and with scattering short spines: leaves from glabrous to finely puberulent, 3-5-lobed; the lobes crenately incised or coarsely toothed; base usually somewhat cordate: peduncles short, deflexed; peduncles and bracts glabrate or minutely glandular and pubescent: calyx-tube usually glabrous; the lobes reflexed and twice as long as the petals: stamens not longer than the calyx-lobes: berry smooth and often quite large, dark purple. $R$. divaricatum irriguum and $R$. oxyacanthoides. (R. Purpusii Koehne, Deutsche Dendr. 187. 1893; R. inerme Rydb. Mem.N. Y. Bot. Gard. 1: 202. 1900; R. vallicola Greene.)-Our commonest gooseberry; throughout our range and extending into the Canadian regions.

2. Ribes setosum Lindl. Trans. Hort. Soc. 7: 243. 1830. A low branched bush: spines usually present, single or paired and spreading; prickles genROCKY MT. BOT.-16 
erally numerous: leaves slender-petioled, rather densely pubescent or puberulent, 2-3 cm. broad, 3-5-lobed, the lobes crenately incised or coarsely toothed: calyx-tube cylindrical, longer than the oblong lobes: stamens not exserted: berry sparingly bristly or rarely glabrous, pleasantly acid.-Wyoming and Montana to the Saskatchewan.

3. Ribes leptanthum Gray, Pl. Fendl. 53. 1848. Freely branched and rigid, only moderately leafy, 4-12 dm. high: spines long, rather slender, usually single (rarely triple): leaves roundish, small, $8-12 \mathrm{~mm}$. broad, crenately incised or toothed: peduncles very short, 1-2-flowered: flowers yellow or yellowish: anthers oblong: berry smooth.-Southern Colorado, southward and westward.

3a. Ribes leptanthum brachyanthum Gray, Bot. Cal. 1: 205. 1876. Very leafy, finely and densely puberulent: calyx shorter: berry densely glandular. (R. brachyanthum Card., Bush Fruits 460. 1898.)-Coming into our range from the westward.

4. Ribes saximontanum E. Nels. Bot. Gaz. 30: 118. 1900. The spreading stems 3-8 dm. long, more or less bristly; spines triple, stout, 8-12 mm. long: leaves suborbicular, finely-pubescent or glabrate, 6-20. $\mathrm{mm}$. broad, deeply 3-lobed and each lobe bilobed: flowers $1-3$, about $1 \mathrm{~cm}$. long, white tinged with violet: calyx-tube cylindrical, villous within, longer than the oblong lobes: stamens included: style villous, divided halfway to the base: berry smooth, reddish-purple.-Colorado to Montana.

5. Ribes lentum (Jones) Coville and Rose, Proc. Biol. Soc. Wash. 15: 26. 1902. Freely branched, 3-6 dm. high, bristly-prickly or almost naked: spines short-triple or multiple: leaves finely-pubescent, suborbicular, $2-3 \mathrm{~cm}$. broad, 5 -parted and the lobes incisely cleft or toothed: racemes 5-9-flowered; flowers greenish-white: calyx-tube short, with short rounded leaves: petals and stamens very short: berry light red, medium size, well-flavored, smooth or more usually lightly glandular-bristly.-Subalpine; in the Rocky Mountains and the Sierras.

6. Ribes parvulum (Gray) Rydb. Mem. N. Y. Bot. Gard. 1: 203. 1900. Stems procumbent, mostly less than $1 \mathrm{~m}$. high; spines weak, slender, sometimes wanting; the branches often very hispid-bristly: leaves suborbicular, 3-5-parted or lobed, cordate at base, nearly glabrous, $2-4 \mathrm{~cm}$. long: flowers in 5-12-flowered racemes: berry small and currant-like, nearly black when ripe, covered with short weak gland-tipped bristles. $R$. lacustre parvulum. Very near to R. lacustre (Pers.) Poir, a species of the cold bogs to the northward and eastward of our range. $R$. echinatum Lindl. is a form of $R$. lacustre with less dissected and somewhat pubescent leaves.-It occurs in dryer situations, mostly on wooded hillsides; in our range northwestward.

7. Ribes coloradense Coville, Proc. Biol. Soc. Wash. 14: 3. 1901. Stems procumbent, unarmed, with brown bark; the twigs pubescent and glandular: leaves cordate-reniform, 4-7 cm. broad, 5-lobed, nearly glabrous but with minute sessile glands; the lobes ovate-triangular: racemes 6-12-flowered, the pedicels and rachis glandular and minutely pubescent: calyx-lobes spreading, ovate, obtuse; the tube short, salverform, glandular-pubescent: petals short, broad, purplish: fruit spherical, sparingly glandular-hairy, black, with bloom. R. prostratum.-Mountains of Colorado.

8. Ribes Wolfii Rothrock, Am. Nat. 8: 358. 1874. Unarmed shrub, 5-12 dm. high, glandular-pubescent on the young branches, petioles, and pedicels: leaves cordate-orbicular, thickish, 4-8 cm. broad, smooth above, paler and sparsely glandular-pubescent beneath: raceme 4-10-flowered; the flowers yellowish-white, varying to red: calyx-lobes spatulate, not reflexed: petals red, half as long as the sepals: young berry glandular-hairy, smoother with age. $R$. sanguineum variegatum.-Wyoming to New Mexico, Utah, and Arizona.

9. Ribes viscosissimum Pursh, Fl. Am. Sept. 1: 163. 1814. A shrub 8-15 dm. high with reddish shreddy bark and stiffish branches; young branches, leaves, and inflorescence viscid-pubescent: leaves round-cordate, shallowly 3-lobed, incisely crenate, $3-5 \mathrm{~cm}$. in diameter: racemes short; bracts spatulate, 12-16 
$\mathrm{mm}$. long, about equaling the glandular pedicels: calyx-tube cylindrical, 10-12 $\mathrm{mm}$. long, abruptly inflated above its union with the ovary, twice as long as the oblong lobes: petals oblong, rounded at the summit, about half as long as the lobes of the calyx:- styles smooth, 2-cleft at the apex about equaling the short included stamens: fruit ovoid, black, viscid-pubescent.In the mountains; from our range to the Pacific States.

10. Ribes Hudsonianum Richards, Frank. Journ. Ed. 2: 6. 1823 . Stems erect, 10-18 dm. high: leaves rounded-cordate in outline, 5-19 cm. in diameter, smooth above, resinous-dotted beneath, 3-5-lobed; the lobes acute, coarsely and doubly serrate: racemes erect, with or without a few small leaves at base, 5-10 cm. long, many-flowered; bracts setaceous, much shorter than the pedicels: calyx campanulate, deeply 5-parted, the oblong obtuse lobes 2-3 mm. long: petals oblong, minute: style glabrous, deeply cleft: fruit globose, resinous-dotted. (R. petiolare Dougl. in Trans. Hort. Soc. 7: 514. 1830 , seems to be mercly the more glabrous form of this species.)-Wyoming and across the continent northward.

11. Ribes americanum Mill. Gard. Dict. Ed. 8. No. 4. 1868. Branches erect: petioles slender; leaves nearly orbicular, glabrous above, somewhat pubescent and resinous-dotted beneath, 3-8 cm. wide, sharply 3-5-lobed; the lobes dentate-serrate, acutish: bractlets linear, much exceeding the pedicels, or shorter; flowers greenish-white, 8-10 mm. long: calyx-lobes short, broad, obtuse: stamens not exserted: fruit globose-ovoid, about $6 \mathrm{~mm}$. in diameter. (R. floridum L'Her. Stirp. Nov. 1: 4. 1785.) -In wet woods; from Nova Scotia to the Rocky Mountains.

12. Ribes cereum Dougl. Trans. Hort. Soc. 7: 512. 1830. A variable rigid intricately branched shrub, 1-2 m. high: petioles more or less glandularpubescent, 6-20 mm. long: leaves reniform-orbicular, cordate at the base, 1-4 cm. wide, sparingly glandular-pubescent, or glabrate on both sides, 3-5-lobed; the lobes obtuse, crenate or crenulate: racemes short, pubescent, pendulous; bractlets persistent; flowers sessile or short-pediceled, pink or greenish-white: calyx dilated at the base: petals minute, nearly orbicular: stamens short: fruit insipid, about $6 \mathrm{~mm}$. in diameter, red, often glandularpubescent. (The species is variable, and the following are other described forms: $R$. pumilum Nutt. T. \& G. F1. 1: 551. 1840; $R$. inebrians Lindl. Bot. Reg. t. 1471.) - Throughout the Rocky Mountains and west to the coast States.

13. Ribes longiflor um Nutt. Ker. Bot. Reg. 2: pl. 125. 1816. A smooth shrub, 1-3 m. high: petioles slender, pubescent, at least when young; leaves pubescent and ciliate, or at length glabrous and shining, often broader than long, thick, 3-lobed or sometimes 5-lobed, broadly cuneate or truncate at the base, the lobes obtuse: racemes leafy-bracted, few-flowered; flowers goldenyellow, spicy-scented, $12-25 \mathrm{~mm}$. long: calyx-tube cylindric, glabrous, 3-4 times as long as the oval spreading lobes: stamens slightly exserted: fruit black, glabrous, 6-10 $\mathrm{mm}$. in diameter. $R$. aureum, which name is now restricted to the plant of the Columbia watershed. In our range, among other forms, there is one which well deserves a horticultural name. Its fruit is large, yellowish-red, juicy, well-flavored, and highly prized. (The Missouri or Golden Currant.)-Throughout the trans-Missouri country.

\section{HYDRANGEACEAE Dumort. Hydrangea Family}

Mostly shrubs with simple opposite exstipulate leaves and usually perfect flowers, solitary or cymose. Sepals and petals 5. Stamens twice as many or numerous, epigynous. Carpels $2-10$, wholly united or the apex free, adnate below (at least) to the inclosing calyx-tube. Seeds numerous.-Saxifragaceae in part.

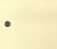

Cymes 1-3-flowered; leaves entire
1. Philadelphus.

2. Jamesia.

3. Fendlera. 


\section{Philadelphus L. Syringa. Mock Orange}

Freely and divaricately branched shrubs with opposite entire leaves. Flowers, white, showy, solitary (rarely 3), terminating the slender branchlets. Calyx 4-5-parted. Petals oblong to obovate. Stamens numerous (20-60). Styles 3-5, free or united; ovary inferior, 4-5-celled, becoming a dry capsule.

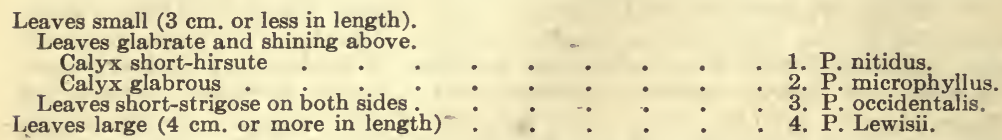

1. Philadelphus nitidus A. Nels. Bot. Gaz. 42: 54. 1906. Slenderly and divaricately branched: leaves rather few, shining and with glaucous hue on both sides, nearly glabrous above, minutely appressed strigose below, mostly narrowly lance-oblong, subacute at both ends, very short-petioled, 1-2 cm. long: flowers generally at the ends of the branchlets: calyx cleft below the middle, hirsute on the outside, soft-pubescent on the inside of the lobes: petals elliptic, entire, $8-10 \mathrm{~mm}$. long, twice as long as the calyx-lobes: stamens 30-40: styles distinct down to the ovary; stigmas short, slightly geniculate at junction with style.-Cañons of western Colorado and into Utah.

2. Philadelphus microphyllus Gray, Pl. Fendl. 54. 1848. Freely branched but the branches ascending, leafy: leaves glabrous and green but somewhat shining above, pale and sparsely short-strigose beneath, lance-ovate, tapering to both ends, subsessile, $2-3 \mathrm{~cm}$. long: flowers solitary or in 3-flowered cymes, large for the plant: calyx glabrous on the exterior; the lobes softly pubescent within and on the margins, elliptic, short-acuminate: petals oval, slightly erose-dentate on the margins, about $15, \mathrm{~mm}$. long: styles united; the relatively long stigmas distinct or slightly coherent.- Southern Colorado and in New Mexico.

3. Philadelphus occidentalis A. Nels. Bull. Torr. Bot. Club 25: 374. 1898. Divaricately and rather rigidly branched: leaves numerous, short-hirsute on both sides, as are also the young twigs, oblong to ovate, subacute, with rounded base: flowers terminal, solitary or in threes: peduncles and receptacles densely white hirsute: the calyx-lobes hirsute on both faces: petals obovate, 10-12 mm. long: stamens 50-60: styles united; the stigmas distinct, fully half as long as the styles.-Dry cañons; southwestern Wyoming and in Utah.

4. Philadelphus Lewisii Pursh, Fl. Am. Sept. 329. 1814. Branching shrub 1-2 m. high: leaves $3-5 \mathrm{~cm}$. long, short-petioled, subacute, rounded at the base, glabrous or nearly so, with short ciliate incurved hairs on the margin: calyx glabrous on the outside, minutely pubescent on the inside of the lobes: petals oval, 12-16 $\mathrm{mm}$. long: stigmas distinct and the upper part of the styles only lightly coherent.-Probably within our range, Montana and westward.

\section{JAMESIA T. \& G.}

A diffusely branching shrub, 1-2 m. high, with opposite exstipulate serrate leaves and cymose flowers in terminal panicles. Calyx-lobes 5 , sometimes bifid. Petals 5, obovate. Stamens 10, the alternate ones shorter; filaments . linear, flattened, acuminate. Ovary conical, 1-celled, with 3-5 parietal manyovuled placentae; styles 3-5. Capsule incompletely 3-5-celled, included. Seeds striate-reticulate.-(Edwinia Heller.)

1. Jamesia americana T. \& G. Fl. N. A. 1: 593. 1840. Leaves ovate, mucronately serrate, green and glabrate above, white-canescent beneath and on the petioles, $2-5 \mathrm{~cm}$. long: flowers in small terminal cymes, the branchlets, peduncles, and calices white-canescent: petals white, slightly hairy within, 7-10 $\mathrm{mm}$. long, longer than the calyx-lobes (the latter enlarged in fruit).Cañon sides at middle elevations; Wyoming to New Mexico and west to Utah. 


\section{FENDLERA Eng. \& Gray}

Erect intricately-branched shrub, with small opposite exstipulate leaves and large flowers terminal on the branchlets. Calyx-tube 8-ribbed. Petals ovate-deltoid, unguiculate, emarginate. Stamens 8; filaments 2 -forked at the apex, the lobes divaricate and extended beyond the cuspidate anther. Capsule crustaceous. Seeds reticulate-winged below.

1. Fendlera rupicola Eng. \& Gray, Smithson. Contrib. 3: 77. pl. 5. 1852. Pubescent or glabrate, branches terete, striate: leaves deciduous, subsessile, oblong, entire, 3-nerved at the base: flowers solitary or in 3-flowered cymes, white, short-peduncled.-Southwestern Colorado and southward.

\section{ROSACEAE Juss. Rose Family}

Herbs or shrubs with alternate stipulate leaves (the stipules often early deciduous) and perfect regular flowers. Calyx free from or adnate to the carpels, usually 5-lobed and often with 5 alternating bractlets. Petals of the same number, or wanting, distinct. Stamens perigynous or rarely hypogynous, usually many, sometimes as few as 5. Carpels 1-many, distinct, or adnate to the calyx; ovary 1-celled, with either terminal or lateral style. Fruit an achene or a few-seeded follicle.

Fruit not inclosed in a hollow receptacle, i. e., the calyx not constricting over the fruit.

Shrubs; pistils few (usually 1 or 2 , rarely $5-8$ ). Carpels becoming dry achenes.

Flowers solitary, or in fascicles of 2-3.

Style becoming elongated and plumose.

Leaves not glandular-dotted; petals wanting . . 1. Cercocarpus.

Leaves glandular-dotted; petals yellow . $\quad . \quad$. 2. Cowania.

Style not elongating.

Leaves fascicled; petals yellow

Leaves opposite; petals wanting

Flowers panieled

Carpels becoming few-seeded follicles.

Leaves simple.

Erect and branching "shrubs.

Flowers in simple corymbs

Flowers in dense panicles

Depressed-caespitose shrubs.

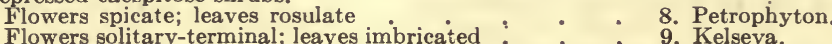

Leaves compound.

Pinnate; the pinnae small, numerous

Biternate; the leaflets large

Shrubs or herbs; pistils numerous.

Woody, at least at base.

Fruit dry tailed achenes; leaves simple.

Flowers solitary; plant caespitose

Flowers subpanicled; plant erect

Fruit of small drupelets crowded on a spongy receptacle.

Leaves simple; stem unarmed

Leaves compound; stem prickly .

Fruit dry achenes, not tailed; leaves compound

Wholly herbaceous; pistils becoming dry achenes.

3. Purshia.

4. Coleogyne.

5. Holodiscus.

Leaves compound or ternately cleft; style deciduous from the achene.

Trifoliolate; style lateral.

Receptacle dry; flowers yellow

Receptacle becoming fleshy: flowers white

Ternately many-cleft into linear divisions.

Pinnately or digitately compound.

Receptacle dry.

Leaflets pinnate.

Style basal; leaflets opposite

Style lateral; leaflets interrupted

Leaflets pinnate or digitate; style terminal or nearly so. Stamens inserted near throat of calyx, distant from the receptacle

6. Physocarpus.

7. Spiraea.

8. Petrophyton.

9. Kelseya.

10. Chamaebatiaria. 11. Aruncus.

12. Dryas.

13. Fallugia.

14. Bossekia.

15. Rubus.

16. Dasiophora.
17. Sibbaldia.

18. Fragaria.

19. Chamaerhodos.

20. Drymocallis.

21. Argentina.

22. Horkelia. 


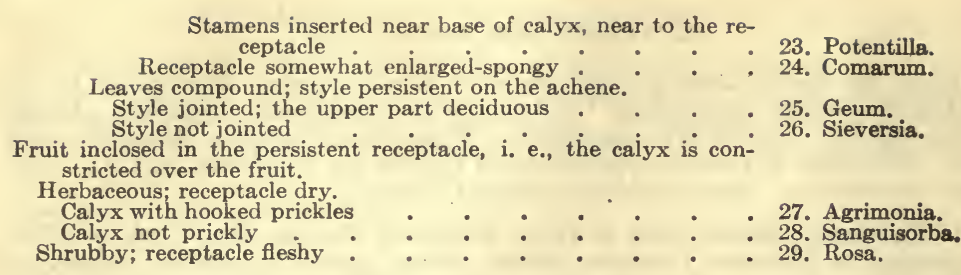

\section{CERCOCARPUS H.B.K. MountanN Mahogany}

Shrubs or small trees, with simple evergreen leaves. Flowers small, axillary, solitary. Calyx without bractlets; its tube long, cylindrical. Corolla wanting. Stamens $15-25$, in 2 or 3 rows on the deciduous limb of the calyx. Fruit coriaceous, linear, terete, villous, included in the enlarged calyx-tube and tailed with the elongated and plumose style.

Leaves not resinous, obovate .

Leaves resinous, narrow.

Oblong-lanceolate, 4-6 $\mathrm{cm}$. long

Linear, $2-4 \mathrm{~cm}$. long
1. C. parvifolius.

2. C. ledifolius.

3. C. intricatus.

1. Cercocarpus parvifolius Nutt. H. \& A. Bot. Beechey Voy. 337. 1841. A shrub 6-30 dm. high (sometimes twice as high): leaves cuneate-obovate, coriaceous, serrate towards the obtuse or rounded summit, more or less silky above, densely hoary-tomentose beneath: flowers on short slender pedicels: limb of calyx with short teeth: tail of achene often $10 \mathrm{~cm}$. long.-Bleak stony slopes; from the plains east of the Rocky Mountains to the Pacific.

2. Cercocarpus ledifolius Nutt. T. \& G. Fl. N. A. 1: 427. 1840. A shrub or small tree, 1-3 m. high: leaves entire, oblong-lanceolate, 4-6 cm. long, thick-coriaceous, margins more or less revolute, nearly glabrous and somewhat resinous above, densely tomentose beneath: flowers sessile, tomentose, solitary or 2-3 in the axils: calyx deeply toothed: tail of the achene at length 4-7 cm. long.- Utah, western Wyoming, and west to California.

3. Cercocarpus intricatus Wats. Proc. Am. Acad. 10: 346. 1875. A low shrub, rarely more than $1 \mathrm{~m}$. high, intricately branched: leaves linear, closely revolute, about $3 \mathrm{~cm}$. long; otherwise as in the preceding except that the flowers and fruits are much smaller.-From northeastern Wyoming and Montana to Utah and Nevada.

\section{COWANIA Don. Cuiff Rose}

Shrubs, with small coriaceous entire or deeply toothed gland-dotted leaves. Flowers showy, terminal, short-peduncled. Calyx-tube turbinate. Petals 5, obovate. Stamens numerous, in 2 rows inserted with the petals at the throat of the calyx-tube. Carpels about 5 , densely villous. Fruit coriaceous, narrowly oblong, striate, partly included in the enlarged calyx-tube, and tailed with the elongated plumose styles.

1. Cowania mexicana Don. in Trans. Linn. Soc. 14: 575. 1825. A much branched shrub, 3-12 dm. high; the trunk with abundant shreddy lightcolored bark: leaves approximate upon the short branchlets, cuneate-obovate in outline, pinnately 3-7-lobed, dark green above, tomentose beneath: flowers yellow, the calyx-tube attenuate into a short glandular-hairy pedicel: tail of the achene at length $5 \mathrm{~cm}$. long or more.-Northern Utah and southern Colorado to central Mexico.

\section{PURSHIA DC.}

A low intricately-branched prostrate shrub, or in the far west taller and erect, with fascicled cuneate leaves, and flowers terminal on the short branch- 
lets. Calyx funnel-shaped. Petals exceeding the calyx-lobes, yellow. Stamens about 25, in one row. Carpels 1, or sometimes 2, narrowly oblong. Fruit pubescent, attenuate at each end, exserted.

1. Purshia tridentata DC. Trans. Linn. Soc. 12: 158. 1817. Prostratespreading, or an erect shrub 1-3 m. high, with brown or grayish bark; the young branches and numerous short branchlets pubescent: leaves cuneateobovate, 3-lobed at the apex, petioled, white-tomentose beneath, greener above: calyx tomentose with some glandular hairs: petals spatulate-obovate: carpels oblong, densely pubescent, striate, attenuate at each end, 8-12 mm. long, exserted. (Kunzia tridentata, in lit.)-Throughout the Rocky Mountains, and west to California and Oregon.

\section{COLEOGYNE Torr.}

A diffusely branched somewhat spinescent desert shrub, with coriaceous leaves and flowers terminal on short branchlets. Flowers yellow, showy, subtended by 1 or 2 pairs of 3 -lobed bractlets. Calyx with a membranaceous margin, colored within. Stamens numerous, inserted upon the base of a tubular torus which includes the ovary. Style lateral, very villous at base, twisted, exserted, persistent. Fruit glabrous, included.

1. Coleogyne ramosissima Torr. Pl. Frem. 8. pl.4. 1850. The short rigid branches opposite and spinescent; bark gray: leaves approximate upon the branchlets, linear-oblanceolate, puberulent with appressed hairs attached by the middle: tube of the torus membranaceous, dilated below and narrowed to the shortly 5 -toothed apex, densely white-villous within: achene somewhat compressed, the obtuse apex incurved.-From southern Colorado to southern California.

\section{HOLODISCUS Maxim.}

Unarmed shrubs with simple toothed or lobed exstipulate deciduous leaves, and terminal panicles of numerous white flowers. Calyx deeply 5-cleft, nearly rotate. Petals 5, rounded. Stamens 20, inserted on an annular perigynous disk. Pistils 5, distinct, becoming 1-seeded hairy carpels, tardily dehiscent by the dorsal suture, or indehiscent.

1. Holodiscus dumosus (Nutt.) Heller, Cat. N. A. Pl. 4. 1898. Low shrub with slender branches, 4-10 dm. high: leaves small, ovate, incisely toothed, glabrate above, white-tomentose beneath, cuneate into a short margined petiole: panicle branched, dense: calyx tomentose; the lobes acute, spreading: carpels 5, compressed, hirsute. (H. microphyllus Rydb. Bull. Torr. Bot. Club 31: 559. 1904.)-Colorado, west to the Sierras.

\section{PHYSOCARPUS Maxim.}

Shrubs with simple toothed or lobed alternate leaves, membranaceous deciduous stipules, and rather large white flowers in simple terminal corymbs. Calyx 5-cleft, persistent. Petals 5, rounded, sessile. Stamens numerous, perigynous. Carpels 1-5, distinct, often stipitate, becoming membranaceous inflated capsules; ovules few to several. Seeds with shining stony testa.(Opulaster of Am. authors.)

Carpels somewhat inflated.

Leaves evidently pubescent

Leaves glabrous or glabrate.

Pedicels conspicuously bracteate

Pedicels ebracteate.

Mature carpels twice as long as the calyx, 2, united below

Mature carpels not surpassing the calyx, 1 or 2, united nearly to the summit
Carpels compressed laterally

1. P. pubescens.
2. P. Ramaleyi.

3. P. intermedius.

4. P. monogynus. 5. P. malvaceus, 
1. Physocarpus pubescens (Rydb.) A. Nels. A shrub about $1 \mathrm{~m}$. high, with strict branches and light colored shreddy bark; pubescent with branched or stellate hairs: leaves orbicular with cordate base, slightly 5-lobed and doubly crenate, about $2 \mathrm{~cm}$. long: sepals densely stellate-tomentose, ovate, obtuse: petals broadly obovate, about one third longer than the sepals: ovaries densely stellate-tomentose, united to above the middle; carpels not much inflated, the apex straight or perhaps somewhat spreading in fruit. (Opulaster pubescens Rydb. Mem. N. Y. Bot. Gard. 1: 208. 1900.)-Montana to Colorado and Utah.

2. Physocarpus Ramaleyi A. Nels. Shrubby, 1-2 m. high; the stems brown with fibrous-shreddy bark; young branchlets green, glabrous: leaves broadly ovate or subcordate, some incisely 3-lobed, the margin more or less doubly crenate-dentate, 2-7 cm. long: corymb many-flowered; the slender pedicels each subtended by a conspicuous bract; bracts spatulate or obovate, sometimes toothed or lobed; pubescence on pedicels soft and rather long, somewhat tufted and substellate: calyx short, hoary-tomentose; sepals ovate, acute, about $3 \mathrm{~mm}$. long: petals slightly exceeding the sepals: anthers dark purple: ovaries four, densely pubescent; carpels elliptic, inflated, more than twice as long as the sepals, about $7 \mathrm{~mm}$. long, nearly distinct, pubescent, usually three maturing (sometimes only two). (Opulaster bracteatus Rydb. Bull. Torr. Bot. Club 31: 558. 1904; O. Ramaleyi A. Nels. Bot. Gaz. 34: 367. 1902.) - Cañons of the Colorado Rocky Mountains.

3. Physocarpus intermedius (Rydb.) A. Nels. Shrub 1-2 m. high: leaves orbicular in outline, with rounded lobes, $2-6 \mathrm{~cm}$. long, obtuse or subcordate at base, crenate: pedicels and calyx finely pubescent: ovaries 3 or 4 , rarely 2 , pubescent, united below: carpels $6-7 \mathrm{~mm}$. long, rounded or obtuse at apex, tipped with a subulate style. Physocarpus opulifolius, in part. (Opulaster intermedius Rydb. Brit. Man. 492. 1901.)-From the Mississippi to central Colorado.

4. Physocarpus monogynus (Torr.) A. Nels. A low shrub, 5-8 dm. high, branching freely: leaves usually glabrate, deltoid-ovate in outline, incisely 3-lobed; the lobes nearly equal, with crenate or incised secondary lobes: corymb few-flowered: petals comparatively large, often rose-tinted: carpels 1 or 2 ; if 2 , adnate nearly to the summit, somewhat inflated, about equaling the calyx, 1-seeded: seed obovoid. Physocarpus Torreyi. (Spiraea monogyna Torr. Ann. Lyc. N. Y. 2: 194. 1827; O. glabratus Rydb. Bull. Torr. Bot. Club 31: 559. 1904.) - In the mountains of Colorado.

5. Physocarpus malvaceus (Greene) A. Nels. Shrub 1-2 m. high: leaves digitately 5-veined, orbicular or oval, sometimes 3-lobed above the middle; the secondary lobes crenate: inflorescence stellate-tomentose, few-flowered: calyx large, broadly campanulate, at maturity the lobes connivent over the fruit: carpels 2 , connate nearly to the summit, compressed, forming a bifid fruit like that of a Lepidium. (Neillia malvacea Greene, Pitt. 2: 30. 1889; Opulaster pauciflorus Heller, Bull. Torr. Bot. Club 25: 581. 1898.)-Western Wyoming to Utah and Oregon.

\section{SPIRAEA L. MeAdowsweet}

Shrubs with simple alternate exstipulate leaves and perfect flowers in compound corymbs, or in panicles or spikes. The persistent calyx 5-cleft; the 5 petals and numerous stamens inserted together upon it. Carpels 5, distinct, alternate with the calyx-lobes, becoming dry cartilaginous severalseeded follicles. Seeds small, with thin membranous testa.

Leaves large (5-8 cm. long); flowers white

Leaves small (2-4 cm. long); flowers rose-color
1. S. lucida.

2. S. densiflora.

1. Spiraea lucida Dougl. Hook. Fl. Bor. Am. Sept. 1: 172. 1833. Glabrous, the stems usually simple and erect, 4-8 dm. high: leaves small below, larger upward, oval or elliptic-oblong, incisely serrate around the obtuse or acute summit, pale and glaucescent beneath: inflorescence a compound corymb, 
the flowers white: calyx-tube campanulate, with short ovate lobes: follicles 5 , 2-3 mm. long, glabrous or puberulent. S. betulaefolia.-Through northern Wyoming, Montana, and westward.

2. Spiraea densiflora Nutt. T. \& G. Fl. N. A. 1: 414. 1840. Lower, rarely more than $4 \mathrm{dm}$. high: stems usually decumbent and branching, especially above: leaves elliptic, sharply serrate around the obtuse summit, glabrous, 2-4 cm. long: corymbs small, terminating the numerous branchlets, compact: flowers rose-color: otherwise much like the preceding. S. betulaefolia rosea.Subalpine; from the Teton Mountains, Wyoming, northwestward.

\section{PETROPHYTON Nutt.}

Stems very short, caespitose, woody. Leaves crowded-rosulate, entire, without stipules. Flowering stems scapose, sparsely leafy-bracted. Flowers perfect, in dense cylindrical simple or compound spikes. Disk free above, nearly entire. Filaments distinct, rather longer than the spatulate-oblong obscurely pubescent petals. Stigma simple; ovules 2-3; the seeds 1-2.

1. Petrophyton caespitosum (Nutt.) Rydb. Mem. N. Y. Bot. Gard. 1: 206. 1900. Densely matted: leaves rosulate, about $1 \mathrm{~cm}$. long, silky-villous: scapes 5-20 cm. high: flowers white: calyx silky-villous, the segments ovate, acute.-On shelving exposed rocks in the mountains; northern Wyoming, Montana, and westward.

\section{KELSEYA Rydb.}

Densely caespitose, the matted tuft consisting of the short freely branched fascicled stems. Leaves closely imbricated the whole length of the branchlets, long-persistent (only the outer ones remaining green). Flowers solitary at the ends of the branchlets, on pedicels so short that they remain concealed by the leaves that surround them. Calyx hirsute, the 5 oblong obtuse lobes longer than its tube. Petals spatulate, twice as long as the calyx. Stamens 10, equaling the petals, inserted on the margin of the entire wholly united disk. Carpels 5, glabrous; the slender styles as long as the stamens; ovules pendulous.-Eriogynia Wats. Bot. Gaz. 15: 241. pl. 14. 1890.

1. Kelseya uniflora (Wats.) Rydb. Mem. N. Y. Bot. Gard. 1: 207. 1900. (Characters as given above.) (Eriogynia uniflora Wats. 1. c:)-Big Horn Mountains, Wyoming; also in Montana.

\section{CHAMAEBATIARIA Maxim.}

A stout diffusely branched glandular pubescent shrub. Leaves coriaceous, small, bipinnately dissected, stipulate. Flowers in a leafy terminal racemose panicle, perfect, white. Follicles coriaceous, 1-valved, connate at base, several-seeded.

1. Chamaebatiaria millefolium (Torr.) Maxim. Act. Hort. Petrop. 6: 225. 1879. More or less tomentose: leaves narrowly lanceolate in outline, scattered or fascicled at the ends of the branches, with very numerous (about 20) pinnae and minute oblong obtuse leaflets (about 6 pairs): the erect acute lobes of the calyx nearly equaling the orbicular petals: carpels 5, pubescent.-Western Wyoming to California.

\section{ARUNCUS Adans. Goat's BeARD}

A large herb, with bi- or tri-ternately divided leaves. Flowers dioectous, small, white, in numerous filiform panicled spikes. Calyx marcescent in fruit. Stamens hypogynous. Carpels cartilaginous, 1-valved, distinct, few-seeded.

1. Aruncus sylvester Kost. Ind. Hort. Prag. 15. 1844. Smooth, branching, 7-15 dm. high: leaves large; leaflets thin, sparingly villous beneath, ovate to 
lanceolate, acuminate, sharply and laciniately doubly toothed, the terminal one broadest: panicle large and compound, pubescent: filaments long-exserted: carpels 3-5, smooth. [A. Aruncus (L.) Karst.]-Across the continent; rare in our range.

\section{DRYAS L. Alpine Avens}

Dwarf and matted slightly shrubby plants, with simple toothed leaves and large solitary flowers on slender scapes. Calyx open, shallow-salverform, 8-9-parted. Petals 8-9, longer than the calyx. Carpels many (indefinite), inserted on the dry receptacle; style terminal, persistent, elongated and plumose in fruit.

1. Dryas octopetala L. Sp. Pl. 501. 1753. Leaves oblong-ovate, coarsely crenate-toothed, obtuse at each end, clothed with a white tomentum beneath, the veins prominent, the margins revolute: sepals linear.-Alpine; high peaks of Colorado and northward throughout British America to Greenland.

\section{FALLUGIA Endlich.}

A low undershrub with pinnately lobed leaves and white showy flowers somewhat panicled on long peduncles. Calyx-tube villous within, the 5 lobes with alternate linear bractlets. Petals 5. Stamens numerous, inserted in a triple row upon the margin of the turbinate calyx-tube. Carpels glabrous, included; the style lateral, very villous at base, twisted, exserted, persistent.

1. Fallugia paradoxa (Don.) Endlich. Gen. Pl. 1246. 1840. Much branched with somewhat virgate slender branchlets; epidermis white, persistent: leaves scattered or fascicled, somewhat villous, cuneate and attenuate into a linear base, pinnately 3-7-cleft above. [F. acuminata (Wooton) Rydb.]-From Colorado to California and southward into Mexico.

\section{BOSSEKIA Necker. FALSE RASPBERRY}

Low unarmed shrubs, with simple alternate petioled ribbed and lobed leaves with cordate bases. Flowers showy, solitary or in small panicles; receptacle flat. Sepals ovate or ovate lanceolate, acuminate or with foliaceous tip. Petals large, oval or obovate, white (or rarely pink). Stamens numerous. Carpels many, on a nearly flat scarcely spongy receptacle, more or less pubescent and fleshy, the carpellary wall developing either a dry cap or a wing; the deciduous styles clavate and nearly terminal.

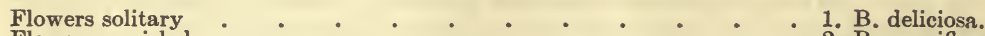

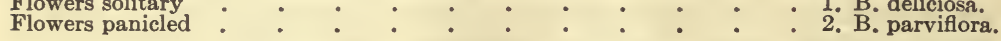

1. Bossekia deliciosa (James) A. Nels. Shrub 7-12 dm. high: branches, young leaves, and calyx tomentose-pubescent or puberulent: leaves reniformorbicular, rugose, more or less 3-5-lobed, finely serrate-toothed: flowers white, about $5 \mathrm{~cm}$. broad: sepals with a dilated acumination: fruit purplish, large, glabrous; the carpels slightly winged; the "flavor not agreeable to the human palate." Rubus deliciosus James. (Oreobatus deliciosus Rydb. Bull. Torr. Bot. Club 30: 275. 1903.)-Cañons in the Colorado mountains.

2. Bossekià parviflora (Nutt.) Greene, Leaflets 1: 211. 1906. Stems 1-2 m. high; dark green and smooth or more or less glandular-pubescent, becoming brown and shreddy: leaves palmately and nearly equally 5-lobed, cordate at base, unequally serrate, $10-25 \mathrm{~cm}$. broad, glabrous or somewhat tomentose, the veins beneath as well as the petioles and peduncles usually more or less hispid with gland-tipped hairs: flowers white, $3-5 \mathrm{~cm}$. broad: calyx densely tomentose: carpels very numerous, tomentose: fruit red, large, and pleasantly flavored. R. Nutkanus Moc. (Rubacer parviflorum Rydb. 1. c. 275.) SAlmon BerRy,-Colorado, northward and westward. 


\section{RUBUS L. RaspberRies and Blackberries}

Mostly prickly shrubs or sometimes almost herbaceous plants, with trifoliolate or pinnately compound leaves, with adnate stipules. Flowers white or purple, in panicles or corymbs or sometimes solitary. Receptacle conical, hemispherical, or nipple-shaped. Sepals and petals 5. Stamens numerous. Styles filiform; carpels numerous, becoming drupelets and forming an aggregate fruit on the fleshy receptacle. Ours are RAsPBERRIEs in which the fruit separates from the receptacle; in the BlackBERRIEs the receptacle and the carpels detach together.

Stems herbaceous; prickles often wanting

1. R. americanus. Stems woody, very prickly .

2. R. strigosus.

1. Rubus americanus (Pers.) Brit. Mem. Torr. Club 5: 185. 1894. Stems short, trailing or ascending, undrmed: leaves few, of 3-5 rhombic-ovate or ovate-lanceolate, doubly-serrate, thin smooth leaflets, $2-4 \mathrm{~cm}$. long: peduncle 1-3-flowered: petals small, white: fruit small, of few red drupelets. $R$. triflorus. - Said to occur in Colorado; from northern Wyoming east to the Atlantic.

2. Rubus strigosus Michx. Fl. Bor. Am. 1: 297. 1803. Stems biennial, woody, erect, prickly with stiff straight bristles, glandular when young, somewhat glaucous: leaflets oblong-ovate, incisely serrate, whitish-pubescent below, the lateral ones sessile: petals as long as the sepals: receptacle oblong: fruit hemispherical, light red, of excellent flavor. The WILD RED RAsPBERRY. - Throughout the Rocky Mountains and eastward.

\section{DASIOPHORA Raf. Shrubby Cinquefoil}

A freely branching shrub; the branchlets often slender. Leaves pinnate, the small leaflets with entire margins; stipules scarious, sheathing. Caly salver-form, with 5 bractlets alternating with the 5 sepals. Petals 5 . Stamens about 20. Style clavate, glandular upward, inserted near the base of the ovary; stigma large, 4-lobed. Achene densely villous, as is also the receptacle.-Potentilla in part.

1. Dasiophora fruticosa (L.) Rydb. Mem. Dept. Bot. Columbia Univ. 2: 188. 1898. A freely branched shrub, 3-10 dm. high, silky-villous: leaves pinnate; leaflets 5-7, linear-lanceolate, entire, rather crowded, usually white beneath and the margins revolute: flowers terminal, cymose or solitary: petals yellow, 15-25 $\mathrm{mm}$. broad, longer than the ovate calyx-lobes and bractlets. Potentilla fruticosa.-Creek banks and boggy ground; throughout the Rocky Mountains and across the continent to the northward; also in Europe and Asia.

\section{SIBBALDIA L.}

Dwarf and caespitose arctic or alpine perennials, with thick trifoliolate stipulate leaves and cymose flowers on scape-like nearly leafless peduncles. Leaflets few-toothed at the truncate summit. Calyx persistent, nearly flat, with 5 sepals and 5 bractlets. Petals 5, yellow, narrow, minute. Carpels 5-10, on a dry receptacle; style lateral.

1. Sibbaldia procumbens L. Sp. Pl. 284. 1753. Densely tufted, the creeping stems $5-20 \mathrm{~cm}$. long, leafy at the extremities: leaflets obovate-cuneate, somewhat villous: peduncles about equaling the leaves: petals shorter than the sepals: achenes on very short hairy stipes.-North in the mountains from Colorado, and then across the continent.

\section{FRAGARIA L. STRAwBERRY}

Acaulescent stoloniferous perennials, with palmately trifoliolate leaves tufted at the base and having membranous stipules, and white cymose 
flowers upon short erect scapes. Leaflets obovate-cuneate, coarsely toothed. Calyx deeply 5-lobed and 5 bracteolate. Petals 5. Stamens numerous. Carpels many, in fruit on a large fleshy scarlet receptacle; styles lateral.

Leaves not glaucous; pubescence of scapes and petioles spreading or reflexed.

Leaflets subsessile; achenes superficial

- Leaflets petiolate; achenes in deep pits

Leaves somewhat glaucous; pubescence of scapes and petioles appressed.

Leaflets moderately thick, obovate; scapes several-flowered

Leaflets thin, oblong-cuneate; scapes few-flowered

1. F. americana.

2. F. platypetala.

3. F. ovalis.

4. F. pauciflora.

1. Fragaria americana (Porter) Brit. Bull. Torr. Bot. Club 19: 222. 1892. Rootstock short: leaves thin, soon glabrate on both sides; petioles slender, 5-10 cm. long, sparingly silky with spreading hairs, often becoming nearly glabrous; leaflets $3-8 \mathrm{~cm}$. long, rhombic-obovate, mostly acute, incisely and deeply serrate: runners very slender and long: scape $8-15 \mathrm{~cm}$. long, seldom much longer than the petioles, sometimes leafy-bracteate: fruit ovoid, 8-15 mm. long, red, achenes superficial. $F$. vesca in part. (F. bracteata Heller, Bull. Torr. Bot. Club 25: 194. 1898.)-Throughout our range and eastward.

2. Fragaria platypetala Rydb. Mem. Dept. Bot. Columbia Univ. 2: 177. 1898. Rootstock very thick and woody: leaves glabrous and glaucous above, appressed-silky beneath; petioles 2-20 cm. long, silky-villous with long spreading or reflexed hairs; leaflets broadly cuneate or obovate, $2-8 \mathrm{~cm}$. long, coarsely serrate or crenate above the middle, more or less petiolate: runners rather thick: scape $8-15 \mathrm{~cm}$. high, rarely exceeding the leaves, several-flowered, often leafy-bracteate: flowers large, $15-25 \mathrm{~mm}$. in diameter: sepals and bractlets lanceolate: petals suborbicular, about twice as long as the sepals: fruit hemispherical; the achenes in rather shallow pits. $F$. virginiana in part.Utah and Wyoming and northwestward.

3. Fragaria ovalis (Lehm.) Rydb: Bull. Torr. Bot. Club 33: 143. 1906. Rootstock short, moderately thick: leaves firm and rather thick, somewhat glaucous, almost glabrous above, appressed-pubescent beneath; petioles and scapes subequal, from densely appressed-pubescent to almost glabrate; leaflets broadly obovate, $3-5 \mathrm{~cm}$. long, evidently petiolate, coarsely toothed, the lateral ones very oblique at base: runners slender, nearly glabrous: sepals and bractlets oblong-lanceolate, acute: petals obovate, one half longer than the sepals: achenes in shallow pits. $(F$. prolifica Baker and Rydb. Mem. Dept. Bot. Columbia Univ. 2: 181. 1898; F. pumila Rydb. 1. c.; F. firma Rydb. 1. c. 184.)-From Canada to New Mexico and Nevada.

3a. Fragaria ovalis glauca (Wats.) A. Nels. Leaves thin, less pubescent as are also the petioles and scapes. [F. glauca (Wats.) Rydb. 1. c. 183.]The commoner form in our range.

4. Fragaria pauciflora Rydb. Mem. Dept. Bot. Columbia Univ. 2: 183. 1898. Rootstock slender: leaves thin and glaucous, almost glabrate above, soon glabrate beneath; petioles and scapes more or less appressed-silky; leaflets cuneate, subsessile, coarsely toothed above the middle, scarcely oblique at base: scape 2-4-flowered, seldom exceeding the leaves: flowers 10-15 $\mathrm{mm}$. in diameter: bractlets and sepals lanceolate: petals obovate: achenes set in deep pits. $F$. vesca Wats. in part.-Same range as the preceding.

\section{CHAMAERHODOS Bunge}

Small erect and branching glandular-pubescent herbs, with leaves many cleft into linear segments and a dichotomously cymose inflorescence. Calyx campanulate, deeply 5-cleft, the base lined with a membranous disk which is densely bearded at the margin. Stamens 5, opposite the white petals, inserted with them in the sinuses of the calyx above the disk; filaments short. Pistils 5-10, on a dry villous receptacle; subulate styles inserted near the base of the ovary. 
1. Chamaerhodos erecta (L.) Bunge, in Ledeb. Fl. Alt. 1: 430. 1829. Stem slender, paniculately branched above, 1-3 dm. high: radical leaves rosulate, ternately or biternately many cleft: sepals lanceolate, nearly equaling the short white obovate-cuneate petals.-From Canada to Wyoming and northwestward.

\section{DRYMOCALLIS Fourr.}

Perennial, usually glandular-viscid herbs, with pinnate leaves and irregularly cymose flowers. Sepals 5 , with 5 alternating bractlets. Petals 5 , white or yellow. Stamens 20-30, in five fascicles on the thickened margin of a disk around the receptacle. Receptacle hemispheric, bearing the numerous pistils. Style inserted near the base of the ovary, thickened and glandular a little below the middle and tapering to both ends; the stigma minute.-Potentilla in part.

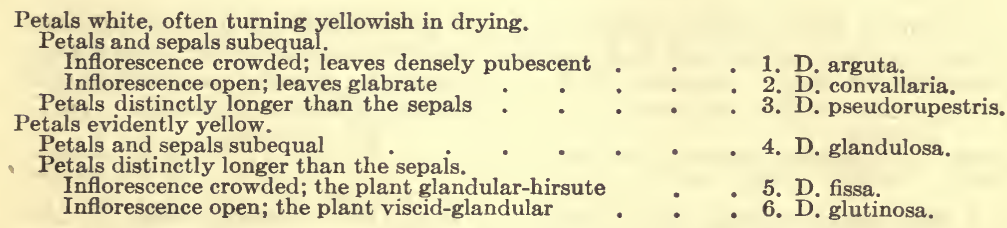

1. Drymocallis arguta (Pursh) Rydb. Mem. Dept. Bot. Columbia Univ. 2: 192. 1898. Erect, stout, glandular and villous pubescent, $3-7 \mathrm{dm}$. high: leaflets of basal leaves 7-11, ovate or rhomboid-ovate; the terminal one cuneate, the others rounded at base and somewhat oblique; all incisely serrate: stem leaves with few leaflets and often subsessile: flowers white, densely cymose: petals obovate, scarcely longer than the acute sepals. Potentilla arguta Pursh.-From Colorado eastward to the New England States.

2. Drymocallis convallaria Rydb. 1. c. 193 . Sparsely long-villous, viscidglandular above, $4-8 \mathrm{~cm}$. high, somewhat branched above: basal leaves with 9-11 glabrate or somewhat pubescent obovate obtuse incisely serrate leaflets, on long petioles, villous at base; the stem leaves smaller, with subacute leaflets: cyme branched; the flowers on short pedicels: calyx villous, glandularviscid: petals obovate; white, drying yellowish, scarcely longer than the sepals which are much longer than the bractlets. Potentilla glandulosa Lindl. in part.-From Wyoming to Washington.

3. Drymocallis pseudorupestris Rydb. 1. c. 194. Sparingly glandularvillous, the slender striate stems with ascending branchlets above, $2-4 \mathrm{dm}$. high: basal leaves short-petioled, with 7-9 sparsely pubescent or glabrate leaflets; the terminal one obovate or cuneate-flabelliform; the lateral ones obliquely elliptic or suborbicular; all incisely serrate, with ovate mucronulate teeth; stem leaves few, with 3-5 leaflets: inflorescence open, the flowers on slender pedicels: calyx viscid-villous, scarcely enlarged in fruit: petals obovate, white, drying yellowish, exceeding the sepals by a third: bractlets much smaller than the sepals.-Through northern Wyoming to Washington.

4. Drymocallis glandulosa (Lindl.) Rydb. 1. c. 198. Viscid and glandularhairy, especially upward, the stem simple below, irregularly branched above: basal leaves petioled, pinnate or interruptedly pinnate; leaflets 7-9, sparingly hairy or glabrate above, obovate, obtuse, 1-3 $\mathrm{cm}$. long, with broad teeth: cyme open, many-flowered: calyx glandular-hirsute, bractlets almost linear, much shorter than the sepals: petals yellow, obovate, not longer than the sepals, which in fruit are 8-10 $\mathrm{mm}$. long. Potentilla glandulosa Lindl. in part.-Dakota to New Mexico, west to California.

5. Drymocallis fissa Nutt. Rydb. 1. c. 197. Glandular-hirsute throughout, rather freely branched, 2-3 dm. high: basal leaves short-petioled, with about 9 suborbicular, subrhombic, and incisely doubly serrate leaflets; stem leaves similar but reduced: flowers yellow, large, $2 \mathrm{~cm}$. in diameter, in a narrow 
cyme extending well down the stem: calyx densely glandular-viscid; bractlets linear to ovate, shorter than the long-acuminate sepals: petals orbicular, much longer than the sepals.-Rocky cañons and slopes; throughout the Rocky Mountains.

6. Drymocallis glutinosa (Nutt.) Rydb.1.c. 196. Viscid with long glandularvillous hairs: stem stout, branched above, $4-8 \mathrm{dm}$. high: leaflets $7-11$, coarsely incised-serrate, pubescent or glabrate, $3-6 \mathrm{~cm}$. long; the terminal one obovate; the lateral obliquely elliptic or suborbicular: cyme broad with divergent branches, in fruit somewhat flat-topped: flowers about $2 \mathrm{~cm}$. broad, yellow: calyx viscid-villous, the acuminate sepals distinctly exceeding the bractlets and much shorter than the elliptic or orbicular petals.-Montana and Wyoming to California.

\section{ARgentina Lam. Silverweed}

Perennial herbs, with interruptedly pinnate leaves and long runners. Flowers yellow, solitary on long peduncles from the axils of the basal leaves. Petals suborbicular. Stamens $20-25$. Style filiform, attached near the middle of the ovary; carpels glabrous; the receptacle very villous.-Potentilla in part.

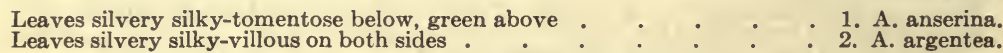

1. Argentina anserina (L.) Rydb. Mem. Dept. Bot. Columbia Univ. 2: 159. 1898. Spreading by slender many-jointed silky-tomentose runners: leaves all radical; stipules many-cleft; leaflets $7-21$, with smaller ones interposed, oblong, sharply serrate, green and glabrate above, white silky-tomentose beneath. Potentilla anserina L.-Common; in the mountain districts from Mexico northward to the aretic seas; also in Europe and Asia.

2. Argentina argentea Rydb. Bull. Torr. Bot. Club 33: 143. 1906. Similar but more robust, the runners shorter and stouter, somewhat enlarged at the nodes, which are sheathed by the large conspicuous many-cleft stipules, silvery-silky as are also the peduncles: leaves suberect, larger, densely silvery silky-villous on both sides, but not tomentose; leaflets 15-29, elliptic to obovate.-Infrequent; in the mountain districts from New Mexico to the far north.

\section{HORKELIA Cham. \& Schlecht.}

Herbaceous perennials, with pinnate leaflets and flowers in cymes or open panicles. Leaflets usually numerous, of ten imbricated. Sepals and bractlets 5. Petals 5, white or yellow. Stamens 5-20, inserted in the throat of the rather deep calyx-tube. Style filiform, inserted near the base of the ovaries; carpels (in ours) few.

1. Horkelia Gordonii Hook. Journ. Bot. \& Kew Gard. Misc. 5: 341. 1853. Caudex thick, resinous, and scaly: stem scapose, 1 or 2 -bracted, minutely glandular-puberulent or glabrous, 1-2 dm. high: leaves puberulent or glabrate; leaflets in 10-20 approximate pairs, divided into 3-5 oblong or linear segments: cyme capitate: calyx glandular-pubescent, yellowish; bractlets linear, half as long as the sepals: petals yellow, spatulate, shorter than the sepals: stamens 5. Ivesia Gordonii T. \& G.-Subalpine; Central Wyoming to California.

\section{Potentilla L. Cinquefoil}

Herbs or shrubs with alternate stipulate digitately or pinnately compound leaves and mostly yellowish cymose (or solitary) flowers. Calyx persistent, with 5 sepals and 5 alternating bractlets. Petals 5 , mostly obovate-emarginate. Stamens 10-30, with small anthers. Carpels usually numerous, mostly in 3 series, inserted on a dry, usually hairy receptacle; style terminal, deciduous. Achenes (in ours) glabrous. 


\section{Key to the Sections*}

Short-lived plants, mostly biennials.

I. SUPINAE.

Perennials.

Leaves digitately 5 -9-foliolate.

Petioles witnout a remote reduced pair of leaflets; terminal leaflet not petiolulate.

Depressed spreading perennials

Erect perennials, 1-several dm, high

Petioles with a remote reduced pair of leaflets or the terminal leaflet petiolulate

Leaves digitately 3 -foliolate.

Leaves pinnate.

Style short, not longer than the mature achene, glandularthickened below

Styles long, exceeding the mature achene, filiform.

Leaflets $3-7$

Leaflets 7-27.

Green or greenish, never tomentose Whitish-silky or tomentose

I. SUPINAE.-Sinort-lived plants, mostly biennials; style short, thickened-glandular below.

Leaves all pinnately 5- or more-foliolate; achenes with a lateral gibbosity

Some or all of the leaves trifoliolate.

Upper leaves trifoliolate; the lower pinnate.

Achenes with a lateral gibbosity; flowers axillary

Achenes not gibbous; flowers in a leafy cyme

All the leaves trifoliolate.

Stamens 10 or fewer; sepals exceeding the petals.

Leaflets cuneate; flowers in a broadly branched cyme Leaflets broadly obovate; flowers in racemose cymules Stamens more than 10; sepals and petals subequal

II. CONCINNAE.-Depressed-spreading perennials, digitately 5foliolate; style short-filiform.

Leaflets more or less deeply toothed all around .

Leaflets truncately 3-5-toothed at apex

III. GRACILES. - More or less erect perennials, digitately 5-9foliolate; style long and filiform.

Leaflets toothed or cleft halfway to the midrib, or less.

Leaves without white-tomentum.

Densely silky-villous at least below

Tall erect plants, 3 or more dm. high.

Cyme glomerate-congested, almost capitate

Cyme corymbosely broad-topped

Low suberect plants, usually less than $3 \mathrm{dm}$. high

Sparsely pubescent or glabrate, green.

Low, subglaucous, sparsely villous plants, usually less than $3 \mathrm{dm}$, high.

Leaflets subpinnate and somewhat decurrent

Leaflets strictly digitate

Tall, dark green, more or less hirsute plants, $3 \mathrm{dm}$. or more high .

Leaves white-tomentose.

Below only, green above

On both sides

Leaflets toothed or cleft more than halfway to the midrib.

Silky-sericeous; cyme crowded

White-tomentose below; cyme open and broad-topped

IV. SUB JUGAE. - Rather low suberect perennials, having digitate leaves with a pinnate tendency; style filiform.

Leaves digitately 5 -foliolate, with a small additional pair on the petiole

Leaves digitately 5 -foliolate, the terminal leaflet petiolulate

V. NIVEAE. - Low tufted perennials, digitately trifoliolate; style usually glandular-thickened near the base.

Stem several-flowered; leaflets oblong-cuneate

Stem 1-3-flowered; leaflets broadly obovate-rhomboid

VI. MULTIFIDAE.-Erect perennials; leaves pinnately ${ }^{\circ}$-15foliolate; style glandular-thickened toward the base.

Leaves silvery-white on both sides

Leaves not silvery-white, at least not above.

Leaves silky-villous or subtomentose

Leaves neither silky-villous nor tomentose.

Somewhat hirsute, dark green on both sides

Obscurely pubescent and granulo-glandular

II. CONCINNAE

III. GRACILES.

IV. SUBJUGAE.

V. NIVEAE.

VI. MULTIFIDAE.

VII. RUBRICAULES.

VIII. MULTIJUGAE. IX. LEUCOPHYLLAE.
1. P. paradoxa.

2. P. Nicollettii.

3. P. rivalis.

4. P. leucocarpa.

5. P. biennis.

6. P. monspeliensis.

7. P. concinna.

8. P. bicrenata.
9. P. glomerata.

10. P. viridescens.

11. $P$. diversifolia.

12. P. decurrens

13. P. glaucophylla.

14. P. Nuttallii.

15. P. gracilis.

16. $P$. candida.

17. P. pectinisecta.

18. P. flabelliformis.

19. P. subjuga.

20. P. quinquefolia.

21. P. nivea.

22. P. uniflora.

23. P. pinnatifida.

24. P. pennsylvanica.

25. P. atrovirens.

26. P. virgulata.

* Adapted from Dr. P. A. Rydberg's Monograph of the genus. Indebtedness to that exhaustive work is gratefully acknowledged.-A. N. 
VII. RUBRICAULES.-Low caespitose perennials; leaves 5-7foliolate; styles filiform.

Calyx bractlets elliptic, obtuse

Calyx bractlets linear-oblong, acute

VIII. MULTIJUGAE. - Low caespitose perennials; leaves pinnately 9-27-foliolate; styles filiform; no tomentum.

Stems from tue crown of a taproot.

Prostrate-spreading; leaflets not cleft to the midrib

Erect; leaflets cleft to the midrib

Stems from a multicipital woody caudex.

Leaflets many, cleft to the base into linear divisions.

Whitish, silky-strigose; petals elliptic, rounded at apex Somewhat hirsute; petals obovate and truncate-retuse Leaflets few, oblong, incisely few-toothed. Green and glabrate on both sides

Silky below, the teeth crenate

IX. LEUCOPHYLLAE. - Stout perennials; leaves pinnately 7-13foliolate; leaflets silvery-silky and usually more or less tomentose; style filiform.

Leaves white-tomentose, especially beneath.

Tomentose on both sides; bractlets shorter than the sepals

Silky above, tomentose-silky beneath; bractlets as long as the sepals

Leaves silvery-silky, scarcely tomentose, greener above

27. P. saximontana.

28. $P$. rubricaulis.

29. P. plattensis.

30. P. pinnatisecta.

31. P. monidensis.

32. P. wyomingensis.

33. P. rupicola.

34. P. crinita.

\section{P. effusa.}

36. P. Hippiana.

37. P. ambigens.

1. Potentilla paradoxa Nutt. T. \& G. Fl. N. A. 1: 437. 1840. At first subsimple, later freely branched and more spreading: leaves pinnately 7-11foliolate, short-petioled, sparingly short-hirsute, becoming glabrate; leaflets obovate-cuneate, with crenately rounded teeth; stipules ovate; acute, more or less toothed and ciliate: sepals and petals subequal: achenes with a thick corky swelling on the inner side. $P$. supina in part.-Throughout our range and across the continent to the northward.

2. Potentilla Nicollettii (Wats.) Sheld. Bull. Nat. Hist. Surv. Minn. 9: 16. 1894. Stems slender, spreading or prostrate and freely branched: leaves thinhirsute; the lower pinnately few-foliolate; the upper trifoliolate and reduced in size; leaflets obovate-cuneate, with acutish teeth; the terminal one much larger than the lateral leaflets; stipules ovate, acute, entire or sinuate: flowers falsely racemose, on slender pedicels in the axils of the uppermost leaves: bracts and sepals subequal, mucronate, as long as the obovate-cuneate petals: achenes with a corky swelling on the inner side. P. supina in part.-Eastern Wyoming to Minnesota.

3. Potentilla rivalis Nutt. T. \& G. Fl. N. A. 1: 437. 1840. Stems erect, simple below, branched above, villous-hirsute: leaves all ternate or the lower pinnately 5 -foliolate, somewhat villous or glabrate; leaflets obovate, incisely serrate; stipules broadly ovate, coarsely toothed: flowers short-pediceled, in a leafy cyme with ascending branches: sepals exceeding the bracts and also the small cuneate petals: stamens 10: achenes numerous, not gibbous.-From Canada to Mexico.

4. Potentilla leucocarpa Rydb. (Monog. Pot.) Mem. Dept. Bot. Columbia Univ. 2: 43. 1898. Stem freely and divaricately branched throughout: all the leaves trifoliolate, finely pubescent, thin and pale; leaflets serrate, oblongcuneate; stipules lanceolate, subentire: flowers in broad spreading leafybracteate cymes: bracts and sepals subequal, exceeding the small light yellow petals: stamens 10: carpels numerous, whitish, and smooth. $P$. rivalis millegrana.-From Illinois to California.

5. Potentilla biennis Greene, Fl. Fran. 1: 65. 1891. Branched from the base, erect, stoutish, 2-3 dm. high: leaves pubescent and granulo-glandular, trifoliolate; leaflets cuneate-flabelliform, incisely lobed or with broad mucronulate teeth; stipules oblong-lanceolate, entire or lobed: flowers in dense cymes: sepals longer than the bracts and the small obovate-cuneate petals: stamens 10: carpels whitish. (P. lateriflora Rydb. 1. c. 44.)-From Canada to Mexico and California.

6. Potentilla monspeliensis L. Sp. Pl. 499. 1753. Stems stout, erect or spreading, leafy, branched above, hirsute: leaves digitately 3 -foliolate, more or less hirsute; leaflets obovate, serrate with broad teeth; stipules broadly ovate, more or less toothed: flowers on short pedicels in a dense leafy cyme: calyx 
hirsute, its sepals equaling the bracts and the light yellow obovate petals: stamens 15-20: achenes numerous, somewhat rugulose when mature. $P$. norvegica.-Across the continent to the northward and south in the Rocky Mountains to New Mexico.

7. Potentilla concinna Rich. Frankl. 1st. Journ. 739. 1823. Stems depressedspreading, somewhat tomentose: leaves densely white-tomentose beneath, greenish but somewhat silky-villous above, 5 -foliolate; leaflets obovate-cuneate, incisely toothed, 1-3 cm. long; stipules ovate-acuminate: flowers solitary, axillary or radical: sepals silky-villous or tomentose, longer than the bractlets but surpassed by the obcordate petals: carpels 15-20. P. humifusa.-Throughout our range and to the northwest.

8. Potentilla bicrenata Rydb. Bull. Torr. Bot. Club 23: 431. 1896. Much like the preceding, the stem short, with spreading branches: leaves greenish but silky above, densely white-tomentose beneath, digitately 5 -foliolate; leaflets oblong-cuneate, entire except at the truncately 3-5-toothed apex; stipules as in the preceding: calyx silky; its sepals ovate-lanceolate; the bractlets similar but smaller, exceeded by the ovate truncate petals.-Wyoming to New Mexico.

9. Potentilla glomerata A. Nels. Bull. Torr. Bot. Club 26: 480. 1899. Stem stout, simple, erect, 4-8 dm. high, sometimes several from the large "woody root: leaves pinnately 5-7-foliolate; the lower long-petioled; the uppermost reduced and nearly sessile; leaflets oblong to narrowly obovate, cleft into long, oblong, mostly obtuse teeth, green but finely pubescent above, densely white-silky below; stipules oblong-ovate, entire or incised: flowers congested-glomerulate: calyx silky; bractlets oblong, acute, shorter than the sepals which equal the nearly orbicular petals.-Western Wyoming, Utah, and Idaho.

10. Potentilla viridescens Rydb. Monog. Pot.1. c. 69. Stems erect, branched above, 4-7 dm. high: leaves about 7-foliolate, green but silky above, silkytomentulose but not white beneath; the lower long petioled; leaflets deeply toothed, the teeth oblong; stipules ovate, incisely cleft: flowers in an open cyme, widely branched, corymbosely broad-topped: calyx and bractlets silky, lanceolate, acuminate, scarcely shorter than the obcordate petals. (P. Bakeri Rydb. Bull. Torr. Bot. Club 31: 560. 1904.) - Colorado to Canada.

11. Potentilla diversifolia Lehm. Stirp. Pug. 2: 9. 1830. Stems erect, often more than one from the crown, branched above, about $2 \mathrm{dm}$. high: leaves 5-7-foliolate; the lower often approximately pinnate rather than digitate; the upper reduced and sometimes trifoliolate; leaflets incisely toothed, silvery silky-hirsute below, green but somewhat hirsute above; stipules lance- or ovate-acuminate: cyme open, several-flowered: sepals softly hirsute, lanceolate, longer than the similar bractlets but well exceeded by the obcordate petals. P. dissecta. [P. dissecta Pursh, Fl. Am. Sept. 355. 1814 (?).]Infrequent; Colorado to California and north to the British boundary.

12. Potentilla decurrens (Wats.) Rydb. Bull. Torr. Bot. Club 23: 396. 1896. Low and somewhat tufted, about $1 \mathrm{dm}$. high: leaves subpinnate, 5 -foliolate, thick, with prominent veins beneath, sparsely villous and somewhat glaucous; leaflets obovate, incisely cleft and more or less decurrent, the lower pair reduced in size; stipules ovate, acute: cyme small, terminal on the scapelike stems, very few-flowered: sepals silky-villous, lance-ovate, exceeding the short obtuse bractlets by as much as they are exceeded by the obcordate petals.-Subalpine; northern Wyoming, westward and northward.

13. Potentilla gla ucophylla Lehm. Del. Sem. Hort. Bot. Hamb. 1836: 7. Stems usually several, from a simple or branched scaly caudex, assurgent, 1-3 dm. high: leaves digitately 5-foliolate, nearly glabrous on both sides, glaucous-green; leaflets silky on the margin, somewhat unequally serrate; stipules ovate, acuminate, somewhat scarious on the margins: cyme open, several-flowered: bractlets small, about half as long as the lance-ovate merely pubescent sepals: petals broadly obovate, truncate or scarcely retuse at apex. $P$. dissecta glaucophylla.-Very common in moist grassy valleys in the mountains; throughout our range. 
14. Potentilla Nuttallii Lehm. Ind. Sem. Hort. Bot. Hamb. 1852: 12. Stems stout and green, sparsely hirsute, 5-8 dm. high: leaves digitately about 7-foliolate, green and sparsely hirsute; the lower on long petioles; stem leaves gradually reduced; leaflets oblanceolate, toothed or divided nearly halfway to the midrib; stipules nearly entire, lanceolate, acute: cyme open, manyflowered, often broad and flat-topped: calyx hirsute; the bractlets linearlanceolate, shorter than the long-acuminate sepals: petals obcordate, scarcely longer than the sepals. $P$. gracilis rigida. ( $P$. etomentosa Rydb. Monog. Pot. probably in so far as our range is concerned; $P$. jucunda A. Nels. Bull. Torr. Bot. Club 27: 32. 1900.)-Colorado to the British boundary.

15. Potentilla gracilis Dougl. Hook. Bot. Mag. pl. 2984. 1829. Stems usually several, decumbent at base, suberect, more or less branched, silkyvillous: leaves 5-7-foliolate, on petioles gradually shorter upward; leaflets oblanceolate or narrowly obovate, green and sparsely pubescent above, densely white-tomentose below, merely toothed or incisely dentate halfway to the midrib; stipules lárge, ovate, more or less toothed: cyme rather narrow, or if many-flowered well-branched and broader: sepals lance-ovate, acuminate, surpassing the bractlets but exceeded by the obovate emarginate petals. (This may be a composite species; as here used it includes the following which are not readily discriminated: $P$. fastigiata Nutt.; $P$. pulcherrima Lehm.; $P$. Blaschkeana Turcz. See descriptions in Rydberg's Monog. Pot. P. filipes Rydb. Bull. Torr. Bot. Club 28: 174. 1901 also is included.)

16. Potentilla candida Rydb. Bull. Torr. Bot. Club 24: 6. 1897. Stems low, densely white silky-strigose, 1-2 dm. high: leaves short-petioled, very white silvery-silky on both sides, no tomentum, digitately 7-9-foliolate; leaflets obovate, deeply incised or cleft into large oblong teeth; stipules ovate, entire: cyme dense: calyx white-silky, the ovate sepals longer than the lanceolate bracts: petals obcordate, a little longer than the sepals.-Rare; northern Wyoming, west to Nevada.

17. Potentilla pectinisecta Rydb. Bull. Torr. Bot. Club 24: 7. 1897. Stem slender, ascending, minutely hirsute, 2-4 dm. high: leaves appressed-silky on both sides, sometimes obscurely tomentulose underneath, slender-petioled, digitately 5-7-foliolate; leaflets obovate, pectinately divided into oblonglinear segments extending well toward the midribs; stipules ovate, often pectinately cleft: flowers in a dense narrow cyme: calyx appressed-silky; the sepals longer than the narrower bractlets and about equaling the obcordate petals. [P. brunnescens Rydb. Bull. Torr. Bot. Club 28: 171. 1901 (?).]Montana and Wyoming to Utah.

18. Potentilla flabelliformis Lehm. Stirp. Pug. 2: 12. 1830. Stems usually several, slender, decumbent at base but erect, 3-8 dm. high: leaves large, digitately about 7-foliolate, densely silky above, white-tomentose beneath; leaflets large, 3-5 cm. long, deeply divided or parted into linear lobes with more or less revolute margins; stipules lanceolate or linear: cyme open, with short strict branches: calyx silky-villous; the sepals triangular-lanceolate, acuminate, much exceeding the small lance-linear bractlets and almost as long as the obcordate petals. $P$. gracilis flabelliformis. ( $P$. ctenophora Rydb. Bull. Torr. Bot. Club 24: 7. 1897.)-Colorado to the British boundary, west to California.

19. Potentilla subjuga Rydb. Bull. Torr. Bot. Club 23: 397. 1896. Stems more or less tufted, 1-3 dm. high, branched above, rough below with the brown, scarious, persistent stipules: leaves crowded at the base, digitately 5 -foliolate, with a small additional pair on the petiole; leaflets obovate, deeply incised, the teeth broad and subobtuse, green but silky-villous above, whitetomentose beneath; stipules green, ovate, entire: calyx silky-hirsute; its bracts much shorter than the ovate-acuminate sepals, and shorter than the broadly obcordate petals. Subalpine; Colorado.

20. Potentilla quinquefolia Rydb. 1. c. 302. Stems several from a short thick rootstock, ascending, usually less than $2 \mathrm{dm}$. high: leaves crowded at the base, mostly 5-foliolate, silky-villous above, white-tomentose beneath; leaflets broadly obovate, cleft halfway to the midrib into oblong segments, 
the terminal one short-petiolulate; stipules large, ovate: flowers few, in a close cyme: sepals and bractlets loosely silky, subequal, somewhat exceeded by the obovate emarginate petals. - Subalpine; Colorado (Rydberg), Montana, and northwestward.

21. Potentilla nivea L. Sp. Pl. 499. 1753. Stems tufted on the branched caudex, which is brown-scaly with persistent petioles and stipules, 1-2 dm. high: leaves coarsely crenate, digitately ternate, glabrate or sparsely villous above, densely white-tomentose beneath; the lower short-petioled; the upper reduced; stipules ovate-lanceolate: cyme 2-6-flowered: calyx white-villous or tomentose; the linear-oblong bractlets shorter than the lanceolate acute sepals: petals obcordate, barely longer than the sepals.-Not rare in alpine stations of the Rocky Mountains.

22. Potentilla uniflora Ledeb. Mem. Acad. Petersb. 5: 543. 1812. Stems caespitose-crowded on the multicipital caudex, a few $\mathrm{cm}$. high: leaves mostly basal, 3-foliolate, silky or glabrate above, densely white-tomentose beneath; leaflets broadly cuneate or rhombic-obovate, incisely cut from the apex, the teeth coarse, oblong-lanceolate; stipules lanceolate: flowers usually solitary on the scapose stems: calyx grayish-villous; the sepals and bracts lanceolate, subequal, only half as long as the obcordate petals.-Rare; in the higher Rocky Mountains, north to the arctic seas.

23. Potentilla pinnatifida Dougl. Hook. Fl. Bor. Am. 1: 188. 1833. Stems several from a thick perennial root, erect, $3-4 \mathrm{dm}$. high, white silky-villous: leaves pinnately 7-9-foliolate, densely and finely silky above, white-tomentose beneath; leaflets obovate, pectinately divided almost to the midrib; the segments linear-oblong, obtuse; stipules ovate-lanceolate, entire or toothed: flowers in a congested cyme: calyx white-silky; the bractlets oblong-lanceolate, shorter than the ovate sepals: petals obovate-truncate, with cuneate base, barely exceeding the sepals. (P. pseudosericea Rydb. Monog. Pot. 1. c.)Frequent; the plains of Colorado to the far northwest.

24. Potentilla pennsylvanica L. Mant. Pl. 76. 1767. Stems single or several from the same crown, erect, subtomentose, $3-5 \mathrm{dm}$. high: leaves pirnately 7-15-foliolate, greenish and minutely pubescent above, grayish-tomentose and veiny beneath; leaflets oblong, pinnately divided halfway to the midrib; the pinnae scarcely revolute; stipules ovate in outline, pectinately divided: flowers short-pediceled, in a dense cyme with erect branches: calyx strigosetomentose; the acute sepals and bractlets subequal, nearly equaling the obovate, emarginate or truncate petals.-Infrequent, the following varieties being far more common in the same range; extending from British America along the high plains to Colorado.

24a. Potentilla pennsylvanica strigosa.Pursh, Fl. Am. Sept. 356. 1814. Usually lower, pubescence mixed with some long strigose hairs: leaflets more deeply divided, the segments narrow and revolute-margined: cyme short and compact.-The most common form in our range and extending eastward to the upper Missouri.

24b. Potentilla pennsylvanica arachnoidea Lehm. Stirp. Pug. 9: 41. 1851. A reduced form with stems arachnoid-pubescent and the segments of the leaflets short, silky-tufted at the apex.-Wyoming to New Mexico and Arizona.

25. Potentilla atrovirens Rydb. Monog. Pot. 1. c. 95. Stems few from the same crown, erect and rather stout, pilose, $2-4 \mathrm{dm}$. high: leaves dark green and densely pilose on both sides, strongly veined, pinnately 7-9-foliolate; leaflets obovate or oblanceolate, incisely and coarsely dentate, the segments oblong: flowers numerous, in a narrow cyme, with erect branchlets: calyx densely pilose; the bractlets and sepals subequal, exceeded by the cuneateobovate bright yellow petals: carpels numerous; the style fusiform.-Infrequent; Wyoming to Minnesota.

26. Potentilla virgulata A. Nels. Bull. Torr. Bot..Club 27: 265. 1900. Stems slenderly virgate, single from the one or two crowns of the thick root, simple, glabrate, obscurely granulo-glandular, as are also the leaves, 3-4 $\mathrm{dm}$. high: leaves few, erect, pinnately only 5-7-foliolate, dark green above, lighter 
beneath, with an obscure pubescence, petioled below, nearly sessile at summit; leaflets obovate, dissected nearly to the midrib into linear segments which are obscurely revolute-thickened; the terminal leaflet petiolulate; stipules ovate-lanceolate: flowers several, congested in a corymbose cyme: sepals lightly pubescent, equaled by the bractlets and fully as long as the suborbicular petals.-Marshy meadows, infrequent; Wyoming to the Dakotas.

27. Potentilla saximontana Rydb. Bull. Torr. Bot. Club 23: 399. 1896. Densely caespitose, with several silky pubescent stems only a few $\mathrm{cm}$. long: leaves numerous, mostly basal, pinnately 5-7-foliolate, silky-pubescent and tomentose beneath; leaflets obovate, deeply incised; the oblong segments obtuse or acute: flowers 1-3 on each scapose stem: calyx densely silky; the bractlets oblong, obtuse, much shorter than the ovate triangular sepals: petals broadly obcordate, much longer than the sepals: the style no longer than the smooth achene.-Alpine; in the mountains of Colorado.

28. Potentilla rubrica ulis Lehm. Stirp. Pug. 2: 11. 1830. Stems somewhat tufted, ascending, about $1 \mathrm{dm}$. long, somewhat branched, silky-strigose: leaves silky above, more or less white-tomentulose beneath, pinnately 5-7foliolate; leaflets small, obovate or oblong, deeply pinnatifid; the segments narrowly oblong; stipules ovate, acute: flowers few, in an open cyme, with erect branches: sepals silky, lanceolate, acute, longer than the oblong-linear bracts and considerably exceeded by the obcordate petals. ( $P$. minutiflora Rydb. Bull. Torr. Bot. Club 23: 399. 1896 may be merely a depauperate alpine form: $P$. tenerrima Rydb. l. c. 398.)-On the higher peaks of the Rocky Mountains; Colorado to Alberta.

29. Potentilla plattensis Nutt. T. \& G. Fl. N. A. 1: 439. 1840. Stems several from the crown of a taproot, prostrate spreading or ascending, 1-2 dm. long: leaves appressed-strigose or glabrate, pinnately 9-17-foliolate; leaflets obovate-oblong, deeply incised; the lobes oblong, obtuse, or narrower and acute; the stem leaves reduced, often merely 3-cleft; stipules broadly ovate, large for the plant: flowers at first crowded, in age in an open paniculate cyme: sepals strigose, twice as long as the similar bractlets but exceeded by the obovate retuse petals.-Frequent in grassy valleys; Colorado to Utah and north to Wyoming and Montana.

30. Potentilla pinnatisecta (Wats.) A. Nels. Wyo. Expt. Sta. Bull. 28: 104. 1896. Stems several, from the one or more scaly crowns of the woody taproot, erect, 10-15 cm. high, sparsely strigose: leaves nearly glabrous, somewhat hoary when young, mostly basal, pinnately many-foliolate; leaflets crowded, deeply cleft into oblong obtuse lobes; stipules ovate-lanceolate, acute: cymes small, 3-6-flowered: bractlets and sepals hirsute, lanceolate, acute, unequal, shorter than the obcordate petals.-Frequent in the alpine regions of the Rocky Mountains; Colorado to British America.

31. Potentilla monidensis A. Nels. Bull. Torr. Bot. Club 27: 266. 1900. Stems numerous, from a multicipital caudex, prostrate-assurgent, slender, silky-strigose, about $1 \mathrm{dm}$. long: leaves crowded on the crowns, petioled, silky-strigose above, white with a dense hirsute silkiness beneath, pinnately 7-15-foliolate; leaflets crowded, pinnately or digitately cleft nearly to the midrib into oblong-linear segments; stem leaves reduced, cleft into linear segments: sepals and bractlets silky-hirsute, lanceolate, unequal: petals broadly elliptic or oval, exceeding the calyx.-Infrequent; open sagebrush slopes; Western Wyoming to Montana.

32. Potentilla wyomingensis A. Nels. Bull. Torr. Bot. Club 27: 32. 1900. Stems crowded on the multicipital caespitose caudex, simple except for tha corymbosely branched open cyme, green, glabrate, less than $2 \mathrm{dm}$. high: leaves mostly basal, 5-7-foliolate, green on both sides, nearly glabrous above, lightly pubescent beneath; leaflets obovate to oblanceolate, coarsely and deeply serrate; stipules lanceolate, entire, acute: sepals hirsute, ovate-lanceolate, twice as long as the oblong-linear bractlets: petals broadly obovate, retusely truncate at summit.- Subalpine; mountains of central Wyoming to Yellowstone Park and Montana.

33. Potentilla rupicola Osterh. Büll. Torr. Bot. Club 26: 256. 1899. Stems 
slender, glabrous, 2-3 dm. high: leaves mostly basal, interruptedly pinnate; leaflets 5-9, oblong-cuneate, incisely few-toothed above, glabrous except for a few ciliolate hairs, dark green, the terminal one petiolulate, the others slightly decurrent on the rachis: cyme paniculately branched: sepals woolly-pubescent at base, sharply acuminate, only $5 \mathrm{~mm}$. long, twice as long as the minute linear bractlets: petals broadly obovate, retuse, barely surpassing the calyx: achenes glabrous but imbedded in the wool of the receptacle.-In cliff crevices; northern Colorado.

34. Potentilla crinita Gray, Mem. Am. Acad. 1849: 41. Stems few from the caudex, ascending, silky-pilose: leaves short-petioled, pinnately 9-15-foliolate, green but silky-villous below, glabrate above; leaflets oblong-cuneate, crowded, toothed at summit, the white silky pubescence of the under side projecting beyond the tip of the teeth in a soft tuft; stipules ovate-lanceolate, acuminate: the acute bractlets a little shorter than the ovate-lanceolate sepals, which are surpassed by the obovate deeply retuse petals.-On the dry plains; southern Colorado to Arizona.

35. Potentilla effusa Dougl. Lehm. Stirp. Pug. 2: 8. 1830. Stems numerous from the same crown, ascending or diffuse, silky-tomentose, becoming glabrate, more or less branched: leaves white-tomentose on both sides, interruptedly and irregularly 5-13-foliolate; leaflets obovate or cuneate-oblong, the upper often confluent, toothed with rather broad teeth; stipules lanceolate, subentire: flowers many in a paniculate cyme: calyx tomentose; the sepals lanceolate acuminate, nearly twice as long as the slender bractlets and nearly equaling the obcordate petals. (P. coloradoensis Rydb. Monog. Pot. l. c. 115.) -On the dry plains; New Mexico to British America.

36. Potentilla Hippiana Lehm. l. c. 2: 7. 1830. Stems many from the crown, ascending or nearly erect, white with appressed hairs, 2-4 dm. high: leaves greenish and appressed-silky above (not tomentose), silky and tomentose beneath, pinnately few-foliolate; leaflets obovate or cuneate-oblong, obtusely toothed, smaller toward the base of the leaf, sometimes a little decurrent upon the rachis; stipules long, ovate-lanceolate, acute, subentire: flowers in a rather short dichotomously branched cyme: calyx silky; the sepals ovate-lanceolate, acute, scarcely longer than the similar but narrower bractlets: petals $6-8 \mathrm{~mm}$. long, obovate, retuse, longer than the calyx. ( $P$. propinqua Rydb. Bull. Torr. Bot. Club 2S: 176. 1901; P. filicaulis Rydb. Bull. Torr. Bot. Club 24: 2. 1897.) - In the moist parks of the mountains; New Mexico to British America.

37. Potentilla ambigens Greene, Erythea 1: 4. 1903. Stems few, assurgent, stout, 4-7 dm. high, silky-villous with spreading hairs: leaves large, irregularly pinnate, $9-15$-foliolate, silky-villous on both sides but more densely so below; leaflets oblong-obovate, coarsely serrate, more or less decurrent on the petiole and the uppermost of ten confluent; stipules large, subentire or toothed: flowers in a long, rather narrow cyme, the branchlets and pedicels often long and slender: bractlets and sepals lanceolate, subequal, exceeded by the obcordate petals.-Infrequent; middle altitudes; New Mexico to Wyoming.

\section{COMARUM L.}

Perennial herbs, resembling Potentilla, with pinnately 5-7-foliolate leaves and cymose flowers. Bractlets, sepals, and petals 5 . Receptacle becoming enlarged and spongy in fruit. Pistils numerous; the style lateral and filiform.

1. Comarum palustre L. Sp. Pl. 502. 1753. Stems stout, ascending from a decumbent base, glandular-pubescent above: leaves green above, lighter beneath and more or less pubescent; the leaflets oblong, the pairs closely approximate; stipules large, the lower amplexicaul and long-adnate: flowers in an open cyme: sepals purplish, in fruit 1-2 cm. long, much exceeding the linear bractlets: petals red, ovate, acute, much shorter than the sepals: stamens with fleshy filaments, inserted on the margin of the thickened disk: 
carpels numerous, sessile on the spongy receptacle.-Marshy ground; northern Wyoming to the arctic circle.

\section{GEUM L. Avens}

Perennial herbs with large, mostly radical, lyrate or pinnate leaves (those of the stem much smaller), and stipules adnate to the sheathing petioles. Flowers corymbosely cymose or solitary. Calyx persistent, 5-lobed, and 5-bracteolate. Petals 5. Stamens numerous, inserted on a disk at the base of the calyx. Pistils numerous; the style persistent, straight or (in ours) jointed, hooked or sometimes plumose in fruit. Achenes small, compressed, on a small conical or clavate receptacle.

\footnotetext{
Sepals reflexed; upper part of style deciduous.

Terminal leaflet cuneate-obovate; receptacle downy-pubescent . 1. G. strictum.

Terminal leaflet broadly cordate; receptacle nearly naked : $\quad 2$. G. macrophyllum. Sepals erect; upper part of style persistent and plumose in fruit . 3 . G. rivale.
}

1. Geum strictum Ait. Hort. Kew 2: 217. 1789. Stems erect, pubescent, 3-8 dm. high: root leaves interruptedly pinnate; the leaflets obovate-cuneate; stem leaves few, 3-5-foliolate; the leaflets rhombic-ovate or oblong, acute: flowers yellow, terminal, short-peduncled: carpels compressed, hairy at summit or on the base of the hooked style: receptacle downy-pubescent. ( $G$. scopulorum Greene, Pitt. 4: 148. 1900.) - From Colorado northward, and eastward to the Atlantic.

2. Geum macrophyllum Willd. Enum. 557. 1809. Bristly-hairy, stouter, $3-5 \mathrm{dm}$. high: root leaves lyrately and interruptedly pinnate, with the terminal leaflet very large and round heart-shaped; the lateral leaflets of the stem leaves minute, $2-4$; the terminal one roundish, 3-cleft, the lobes cuneateobovate: flowers yellow, in a terminal cyme; the petals obovate, longer than the acute calyx-lobes: receptacle nearly glabrous: style hooked, obscurely glandular (the minute glands short-stipitate), pubescent near the base. (G. oregonense Rydb. Bull. Torr. Bot. Club 25: 56. 1898.)-From California to the Atlantic.

3. Geum rivale L. Sp. Pl. 501. 1753. Somewhat pubescent, erect, 3-5 dm. high: stem nearly simple: root leaves lyrate and interruptedly pinnate; those of the stem few, 3-foliolate or 3-lobed: calyx brown-purple: petals dilatedobovate, retuse, contracted into a claw, purplish-orange: head of fruit stalked in the calyx: achenes very pubescent; styles jointed, plumose.-Colorado and northward, and east to Newfoundland.

\section{SIEVERSIA Willd.}

Rather low perennial herbs, with simple stems, mostly radical pinnate leaves, and rather large flowers in terminal cymes. Sepals, bractlets, and petals 5. Sepals erect or spreading. Style not jointed, straight, slender, persistent and often plumose; head of carpels sessile.

Clammy, short-pubescent and hirsute or ciliate; style plumose

Nearly glabrous; style glabrous.

Stem leaves pinnatifid; root leaves mostly suberect

Stem leaves entire; root leaves rosulate-spreading

\section{S. ciliata.}

2. S. turbinata. 3. S. scapoidea.

1. Sieversia ciliata G. Don. Gen. Hist. 2: 528. 1832. Somewhat clammy, short-pubescent and more or less softly hirsute or ciliate: leaves mostly basal, suberect, interruptedly pinnate; the leaflets very numerous and crowded, cuneate-obovate in outline, deeply incised, often nearly to the midrib: stems simple, merely leafy-bracteate, terminating in the mostly 3-flowered cyme: flowers long-pediceled: calyx purple, its linear bractlets longer than the sepals and as long as the purplish erect petals: styles very long, strongly plumose in fruit. Geum triflorum.-Moist slopes in the mountains; common in our whole range.

2. Sieversia turbinata (Rydb.) Greene, Pitt. 4: 50. 1899. Low, 7-15 cm. 
high, glabrate or more or less puberulent, especially above: leaves mostly basal, interruptedly pinnate, spreading or suberect, dark green or tinged with purple; leaflets ovate-cuneate or narrower, incisely toothed; stem leaves pinnately incised: stems surpassing the leaves, rarely nearly twice as long, 1-3-flowered: calyx dark- or purplish-green; the triangular lobes scarcely longer than the lanceolate bractlets, much surpassed by the obovate bright yellow petals: style glabrous, not exserted in fruit; achene villous-hirsute. Geum Rossii.-Alpine; in Colorado, Utah, and Wyoming.

3. Sieversia scapoidea A. Nels. Glabrous (obscurely puberulent under a strong lens): leaves rosulate-spreading from the crowns of a more or less branched woody rootstock, interruptedly pinnate, 5-10 cm. long; leaflets obovate, 3-cleft into oblong, subacute lobes, not crowded: stems scapose, few, erect, strictly 1-flowered, 14-20 cm. high; the bract-like leaves entire, linear, 15-20 $\mathrm{mm}$. long, the rather large stipules long-adnate: flowers large, $2 \mathrm{~cm}$. broad: calyx softly pubescent, its triangular-lanceolate lobes longer than its tube; the bractlets minute, nearly linear: petals obovate-orbicular, pale yellow, twice as long as the calyx: achene tapering gradually into the style, longhirsute as is also the thickened base of the style.-Utah.

\section{AGRIMONIA L. AgRIMONY}

Tall perennial herbs, with interruptedly pinnate leaves, and flowers with 3 -cleft bracts, in long slender spicate racemes. Calyx turbinate, surrounded by a margin of hooked prickles. Petals yellow, small. Stamens 5-12. Carpels 1-3, becoming achenes, inclosed in the dry and firm calyx-tube which is constricted at the throat and its 5 lobes connivent.

1. Agrimonia Brittoniana Bickn. Bull. Torr. Bot. Club 23: 517. 1896. Stout, 4-7 dm. high, virgately branched, hirsute: leaflets 7-11, with smaller leaf-segments interposed, elliptic-oblong, acute, sharply serrate; stipules lanceolate, acuminate: flowers crowded: fruit $8 \mathrm{~mm}$. long, reflexed; the bristles often purplish, inflexed. A. Eupatoria.-Colorado to Montana, east to New York.

\section{SANGUISORBA L.}

Annual or perennial herbs, with alternate, pinnatifid, stipulate leaves and small perfect flowers in 'dense, terminal, peduncled spikes or heads. Calyxlobes 4, imbricated, deciduous, petaloid; calyx-tube 4-angled, naked. Petals wanting. Stamens 2-12, inserted on the throat of the calyx. Carpels usually only 1 , inclosed in the dry, 4-wing-angled calyx.-Poterium.

1. Sanguisorba annua Nutt. T. \& G. Fl. N. A. 1: 429. 1840. Glabrous, slender, 2-4 dm. high: leaflets 4-6 pairs, ovate to oblong, with linear segments: flowers greenish; the heads ovoid or oblong: stamens 2-4: fruits shorter than the bracts. Poterium annuum.-Possibly within our range; said to occur from the upper Missouri to Oklahoma and in California to Washington.

\section{ROSA (Tourn.) L.* RosE}

Shrubby more or less prickly plants, with pinnate leaves and large flowers solitary at the ends of the branchlets or in few-flowered corymbs. Stipules adnate to the petiole. Calyx without bractlets. Stamens numerous on the thick margin of the silky disk which nearly closes the throat of the calyx. Carpels many, hairy, becoming bony achenes inclosed and concealed in the globose or urn-shaped fleshy calyx-tube, which resembles a pome.

* There are few genera in which the species are so difficult of discrimination. The species as given here are no doubt, in some cases at least, "group species," but it does not seem possible in the present state of our knowledge so to characterize the different forms as to make them distinguishable. 
Calyx-tube and fruit not prickly.

Sepals connivent and persistent after flowering.

Infrastipular spines wanting.

Flowers solitary; sepals erect

Flowers corymbed; sepals spreading.

Infrastipular spines commonly present.

Rachis of leaves more or less prickly

Rachis of leaves without prickles.

Outer sepals laterally lobed

Outer sepals entire

Sepals spreading after flowering and deciduous

Calyx-tube and fruit prickly.

Pubescence on young stems lepidote-stellate.

Pubescence wanting; or at least not stellate

\begin{tabular}{|c|c|c|}
\hline & & • \\
\hline$\bullet$ & • & • \\
\hline • & • & - \\
\hline$\bullet$ & 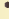 & $\bullet$ \\
\hline & & \\
\hline • & & • \\
\hline
\end{tabular}

1. R. Sayi.

2. R. arkansana.

3. R. Fendleri.

4. R. Woodsii.

5. R. Nutkana.

6. R. gymnocarpa.

7. R. stellata.

8. R. MacDougalii.

1. Rosa Sayi Schwein. Long's Expd. Winnep. 2: 388. 1825. Stems usually low, 3-8 dm. high, thickly covered with prickles: stipules usually dilated, glandular-ciliate and resinous; leaflets 3-7 (usually 5 or 7), glabrous or slightly pubescent above, more or less resinous beneath, broadly elliptical to oblonglanceolate, usually sessile and rounded or subcordate at base, more or less doubly and glandular toothed, the terminal 2-4 dm. long: flowers solitary (very rarely 2 or 3 ): outer sepals with one or more very narrow lateral lobes (very rarely all entire), not hispid, or slightly so on the margin: fruit globose with more or less of a neck below the calyx, 8-12 mm. in diameter (S. Watson, Proc. Am. Acad. 20: 340). (R. Engelmannii Wats. Gard. \& For. 2: 376. 1889; following Watson's view that $R$. acicularis Lindl. is arctic, $R$. Sayi is used as the available name.) - Colorado and northward into British America.

2. Rosa arkansana Porter, Syn. Fl. Colo. 38. 1874. Stem stout, erect, leafy, 3-4 dm. high, glabrous and glaucous, armed with weak, deciduous, bristly prickles: leaflets $9-11$, ovate and oblong-ovate, $2 \mathrm{~cm}$. or more in length, acute or obtuse, glabrous, sharply serrate; midrib and long stipules somewhat prickly and minutely glandular: flowers numerous, terminal, corymbed, on peduncles about $3 \mathrm{~cm}$. long: fruit globose, smooth, glaucous: calyx-segments ovate, reflexed in fruit, with terminal and sometimes lateral appendages, more or less glandular and tomentose-pubescent on the margins: petals broadly obcordate or emarginate, longer than the calyx-segments, rose-color: flowers 4-5 cm. in diameter. (R. pratincola Greene, Pitt. 4: 13. 1899; $R$. manca Greene, 1. c. 11.)-From Colorado northward and eastward into the plains of the upper Missouri region.

3. Rosa Fendleri Crepin, Bull. Soc. Bot. Belg. 15: 91. 1876. Stems often tall (15-20 dm. high, or less), with rather slender, straight or recurved spines, often scattered or wanting: stipules mostly narrow, usually naked, sometimes glandular-ciliate; rachis pubescent or prickly; leaflets 5 or 7 (very rarely 9), oblong or obovate, more or less cuneate at base and often petiolulate, usually glaucous, very finely pubescent beneath or glabrous or somewhat resinous, the teeth usually simple: flowers small, often solitary, the short pedicels, receptacles, and sepals glabrous, or the last subpubescent: fruit globose or broadly ovate, with little or no neck, about $8 \mathrm{~mm}$. broad (Watson, l. c.).-Western Texas, westward to the Sierras and northward in the Rocky Mountains to British America.

4. Rosa Woodsii Lindl. Mon. Ros. 21. 1820. Stems usually low, 2-10 dm. high, with slender, straight or recurved spines, and sometimes with scattered prickles, or unarmed above: stipules narrow or dilated, entire; leaflets 5 or 7 (sometimes 9), obovate to oblong or lanceolate, rounded or acute at the summit, obtuse or usually cuneate at base, glabrous or subpubescent above, villous or finely pubescent or glabrous beneath (with the rachis and stipules), simply toothed, often only above the middle, sometimes resinous and serrulatetoothed, sometimes glaucous, usually small (the terminal 1-4 cm. long): flowers $4-5 \mathrm{~cm}$. broad, corymbose or very often solitary, on very short, naked pedicels: sepals naked or hispid, the lobes more or less conspicuous: fruit globose with a short neck, $8-10 \mathrm{~mm}$. broad (Watson, l. c.). (R. Maximillianii Nees. Pl. Maxım. 8. 1841; R. Macounii Greene, Pitt. 4: 10. 1899.)From the Missouri river to Colorado and north into British America.

5. Rosa Nutkana Presl. Epimel, Bot. 203. 1849. Stems stout, 3-15 dm. 
high, armed with stout, straight or recurved spines, the branches sometimes unarmed, and young shoots sometimes prickly: stipules glandular-ciliate; leaflets 5 or 7 (very rarely 9), broadly elliptic to ovate or oblong or lanceolate, usually rounded at base, obtuse or acute (the terminal $2-5 \mathrm{~cm}$. long), resinous beneath (as well as the rachis and stipules) and the teeth more or less glandular-serrulate, smoother above, sometimes nearly or quite glabrous (and teeth entire), or the pubescence not resinous; rachis more or less prickly or hispid: flowers 5-7 cm. broad, solitary (rarely 2 or 3); pedicel and receptacle very rarely hispid; sepals naked or very rarely hispid: fruit globose, not contracted above into a neck, $12 \mathrm{~mm}$. broad (Watson, 1. c.). (R. melina Greene, Pitt. 4: 10. 1899; $R$. oreophila Rydb. Bull. Torr. Bot. Club 31: 561. 1904; R. grosseserrata E. Nels. Bot. Gaz. 30: 119. 1900.) - From Colorado to the far northwest.

6. Rosa gymnocarpa Nutt. T. \& G. Fl. N. A. 1: 461. 1840. Stem slender and weak, 1-3 m. high, with straight slender spines: stipules narrow, glandular-ciliate; leaflets 5-9, glabrous, doubly glandular-toothed, sessile or nearly so: flowers solitary or few: sepals 6-12 mm. long, entire, spreading after flowering and deciduous (with the distinct styles) from the very contracted top of the naked, oblong-ovate to globose fruit. - Scarcely within our range; western Montana and Idaho to the Pacific States.

7. Rosa stellata Wooton, Bull. Torr. Bot. Club 25: 152. 1898. Stems 4-6 dm. high, with numerous straight or slightly curved yellowish spines; young stems closely covered with stellate trichomes which may be scale-like or have a central gland-bearing axis, or this axis may be a well-developed spine: leaves small, 3-5-foliolate; leaflets triangular-cuneate, with rounded acute teeth; stipules spreading, silky-pubescent, not glandular: flowers solitary, 4-7 cm. broad: calyx-lobes enlarged, glandular on the margin, generally laciniately lobed: fruit spiny, reddish-brown.-New Mexico and probably reaching southern Colorado.

8. Rosa MacDougalii Holz. Bot. Gaz. 21: 36. 1896. Resembling $R$. Nutkana: stems with few epidermal spines, or frequently none, the infrastipular spines wanting: flowers solitary at the ends of short leafy branches: receptacle and calyx conspicuously glandular and hispid: fruits densely spiny. (R. Underwoodii Rydb. Bull. Torr. Bot. Club 31: 560. 1904.)-Colorado to Idaho.

\section{POMACEAE L. Apple Family}

Trees or shrubs with alternate, pinnate, simple or compound leaves; the stipules free from the petiole and early deciduous. Flowers regular, solitary or in cymes or racemes. Calyx 5-lobed or toothed, adnate to the ovary. Stamens usually many, distinct. Ovary 1-5-celled, of as many carpels, more or less united; the ovules one or more in each cell. Fruit a fleshy pome, formed by the calyx-tube becoming thickened-fleshy and inclosing the 1-5 bony, papery, or leathery carpels.-Rosaceae in part.

Leaves simple.

Flowers many, in racemes; pome berry-like . . . . . 1. Amelanchier. Flowers several, in short corymbs; seeds bony $: \vdots \quad \vdots \quad \vdots \quad 2$. Crataegus.

Flowers solitary or $2-3$ in sessile umbel; seeds cartilaginous $: \vdots 3$. Peraphyllum. Leaves pinnately compound .

4. Sorbus.

\section{AMELANCHIER Medic. Service-Berry}

Shrubs with alternate, simple, serrate leaves and white flowers in racemes; not thorny. Calyx-tube adnate to the ovary, its five lobes persistent and reflexed. Petals 5, inserted with the numerous stamens on throat of the calyx. Styles connate, $2-5$; cells of the ovary as many as the styles, becoming in the berry twice as many, with 1 cartilaginous seed in each cell. 
Glabrous throughout, at least at maturity.

Leaves crenately serrate

Leaves incisely serrate

More or less pubescent.

Leaves glabrous above, at least at maturity

Leaves pubescent on both faces.

Incisely serrate around the summit.

Calyx and pedicels lanate-pubescent

Calyx (on the exterior) and pedicels green and glabrate

Entire or crenately toothed

1. A. alnifolia.

2. A. glabra.

3. A. elliptica.-

4. A. Bakeri.

5. A. oreophila.-

6. A. prunifolia.

1. Amelanchier alnifolia Nutt. T. \& G. Fl. N. A. 1: 473. 1840. A shrub or small tree, 2-4 m. high, glabrate throughout (including the calyx-lobes) at least at maturity: leaves thickish, somewhat glaucous, elliptic, oval or obovate, very obtuse or even truncate, the base rounded, truncate, or subcordate, coarsely crenately serrate-dentate above the middle: raceme dense, erect: petals oblanceolate, about $1 \mathrm{~cm}$. long: pome purple, with bloom, 6-8 $\mathrm{mm}$. in diameter, sweet and juicy.-On stream banks; from Colorado to Nebraska and the head waters of the Missouri.

1a. Amelanchier alnifolia pumila (Nutt.) A. Nels. A low shrubby form with small, nearly orbicular leaves, serrate-dentate to the base. A. pumila Nutt. T. \& G. Fl. N. A. 1: 474. 1840.-Infrequent; moist hillsides; eastern Wyoming.

2. Amelanchier glabra Greene, Fl. Fran. 52. 1891. Stout shrub, divaricately branched: leaves thin, deep green, obovate to orbicular, truncate or retuse, deeply and incisely serrate nearly to the base, $15-25 \mathrm{~mm}$. long: calyx as well as the leaves quite glabrous: petals cuneate-oblong: fruit depressedglobose, crowned by the short triangular calyx-lobes. (A. polycarpa Greene, Pitt. 4: 127. 1900.)-From southern Colorado to the Sierra Nevada.

3. Amelanchier elliptica A. Nels. Bot. Gaz. 40:66. 1905. A small slender tree-like shrub, growing as scattered individuals rather than in clumps; twigs slender, gray except at the ends which are purplish-black, with an inconspicuous beady resin: leaves elliptic, $2-4 \mathrm{~cm}$. long, incisely serrate to the middle or lower, nearly glabrous above; softly lanate beneath when young, as are also the slender petioles: flowers few, large: calyx woolly-pubescent; its lobes deltoid-triangular, shorter than the tube, lanate on the inner face: petals narrowly oblanceolate, $12-15 \mathrm{~mm}$. long: fruit spherical.-Wet open places in the mountains; Colorado, Wyoming, and Utah.

4. Amelanchier Bakeri Greene, Pitt. 4: 128. 1900. Shrubs or small trees, growing in clumps; the branches rigid and divaricate, the younger ones puberulent: leaves orbicular, $15-20 \mathrm{~mm}$. long, obtuse or truncate at both ends, evenly serrate above the middle, both faces tomentulose; the stipules villous: raceme short, dense, small-flowered: calyx villous-tomentose, the triangularlanceolate lobes equaling the tube: petals 5-10 mm. long.-Southern Colorado.

5. Amelanchier oreophila A. Nels. Bot. Gaz. 40: 65. 1905. Low, intricately rigid-branched, 1-2 m. high, growing in dense clumps; pubescence short-lanate, some of it persisting till maturity, especially on the lower face of the leaves: leaves elliptic to obovate, $2-4 \mathrm{~cm}$. long, incisely dentate from the middle to the rounded apex; the petioles scarcely half as long as the blade: racemes short, dense: calyx-lobes subulate-triangular, glabrate outside, lanatepubescent on the margins and inside: petals about $8 \mathrm{~mm}$. long: pome globose, purplish-black, developing but little pulp, remaining dry and insipid, maturing late.-Dry stony hills and cañons; Colorado and Wyoming and probably westward.

6. Amelanchier prunifolia Greene, Pitt. 4: 21. 1899. Stems clustered and bushy, 2-3 m. high; the branches rigid, with ashy bark: leaves coriaceous, pale and glaucescent, but permanently obscurely puberulent, from oblong to ovate or obovate, few-toothed around the obtuse summit: cyme few-flowered: calyx-lobes lanceolate, elongated in fruit, hoary-tomentulose: fruit on slender pedicels about $2 \mathrm{~cm}$. long. (Possibly the following from New Mexico are the same: A. crenata Greene, Pitt. 4: 127, and A. rubescens Greene, Pitt. 1. c.) -In the dry mountains; west central Colorado. 


\section{CRATAEgUS L.* HawthorN}

Shrubs or small trees with thorny branches, simple alternate toothed or lobed leaves, and usually white flowers in corymbs. Calyx-tube urn-shaped; its limb 5-parted. Petals 5, spreading. Stamens 5-20. Ovary 2-5-celled, becoming a drupe containing $2-5$ bony 1 -seeded carpels.

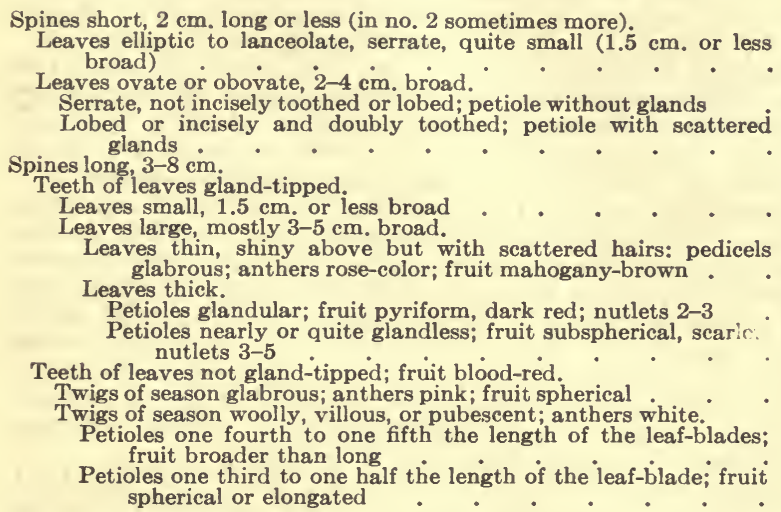

1. C. saligna.

2. C. rivularis.

3. C. Douglasii.

1. C. saligna.

4. C. cerronis.

5. C. Doddsii.

6. C. sheridana.

7. C. coloradensis.

8. C. occidentalis.

9. C. coloradoides.

1. Crataegus saligna Greene, Pitt. 3: 99. 1896. A slender tree 2-6 m. high, with slender willowy branchlets: leaves oblong or oblong-lanceolate, $3-5 \mathrm{~cm}$. long, firm, acute or obtuse at apex, cuneately narrowed to the slender petiole, minutely crenate-serrate above the middle, glabrous below, obscurely appressed-strigulose on the glossy upper surface: spines slender, flexible, glossy black, 2-3 cm. long: corymb glabrous, few-flowered: calyx-lobes triangular: petals suborbicular, about $4 \mathrm{~mm}$. in diameter: stamens 20: styles 5: fruit subglobose, black with bloom, dry, mealy, insipid. $(C$. Wheeleri A. Nels. Bot. Gaz. 34: 369. 1902.)-Cañons of west-central Colorado.

2. Crataegus rivularis Nutt. T. \& G. Fl. N. A. 1: 464. 1840. A small tree, well branched; the branchlets rather slender: leaves $3-6 \mathrm{~cm}$. long, bright green and glossy, glabrous except for some obscure hairs above, ovate or elliptic-ovate, usually acute, serrate, the teeth short: spines moderately stout, glossy, somewhat curved, $2-4 \mathrm{~cm}$. long: corymb glabrous, several-flowered: calyx-lobes with a linear non-glandular acumination: petals orbicular, crenate at summit: stamens 10: styles 5: fruit nearly black, $1 \mathrm{~cm}$. in diameter.Stream banks; western Wyoming to Utah and Idaho; probably in northwestern Colorado.

3. Crataegus Douglasii Lindl. Bot. Reg. pl. 1810. 1835. A stout shrub or small tree, 4-8 m. high, well branched; spines stout, rarely more than $2 \mathrm{~cm}$. long: leaves elliptic to obovate, usually cuneate at base, irregularly serrate, those of the young shoots often incisely lobed, $3-6 \mathrm{~cm}$. long, glabrous or sometimes slightly pubescent on both sides: corymb 10-15-flowered, nearly glabrous or slightly tomentulose, not glandular: calyx-lobes entire, triangularsubulate: petals orbicular, 6-8 mm. in diameter: stamens 10: fruit black, or purplish-black; the carpels 3-4.-NorthernWyoming (apparently), westward through Montana and Idaho to Oregon.

4. Crataegus cerronis A. Nels. Bot. Gaz. 34: 370. 1902. Small tree, widely branched, $2-5 \mathrm{~m}$. high; trunk short, stout, with rough bark; young twigs brown; lenticels small, nearly white: leaves broadly elliptic-ovate, 3-5 cm. long, coarsely serrate; the teeth with finer gland-tipped serrations,

* Nomenclature and synonomy supplied by Prof. Francis Ramaley of the University of Colorado, who has studied critically the Rocky Mountain species of the genus both in field and herbarium. He suggests that with further study it may be found desirable to unite $C$. Doddsii with $C$. sheridana. 
acute or acuminate at apex, glabrous below, sparsely ciliate-pubescent above (especially on the veins); petioles slender, without glands: thorns numerous, stout, 2-3 cm. long, morocco-red, with pale lenticels: corymb 5-10-flowered: calyx-lobes with a broad gland-margined acumination, longer than the calyxtube: petals 6-8 mm. broad, reticulate-veined: stamens 1-8 (generally 5-8); anthers large, purple: styles 5: fruit black or brown; carpels large and somewhat dissimilar, the pulp scanty. (C.erythropoda Ashe and probably C.chrysocarpa Ashe in part.) Stream banks, in cañons; Colorado and Wyoming.

5. Crataegus Doddsii Ramaley, Bot. Gaz. 46: 381. 1908. A small tree or shrub near the following: the leaves smaller and pleated along the veins at anthesis, shining, glabrous except on the veins below, obovate, obscurely lobed and the margin serrate: stamens 10 or fewer; anthers white: fruit hard, dark red: nutlets 2-3. (C. chrysocarpa Ashe in part, probably.)-Colorado.

6. Crataegus sheridana A. Nels. Bot. Gaz. 34: 370. 1902. A small tree 3-5 m. high, with reddish-brown twigs; lenticels few, large; spines slender, curved and deflexed, 4-5 cm. long: leaves oval to almost orbicular, coarsely and incisely toothed, with rather blunt gland-tipped serratures; pubescence sparse and softly strigose on the lower surface of the leaves (mostly on the veins), minute and appressed on the upper, merely ciliate or wanting in the inflorescence: corymb 5-11-flowered: calyx-lobes ovate-lanceolate, glandularfimbriate: stamens 8-10: styles 3-4: fruit nearly spherical, 8-9 mm. in diameter, scarlet-red; the carpels slightly crested-bisulcate dorsally.- Stream banks; through northern Wyoming and westward to Idaho.

7. Crataegus coloradensis A. Nels. Proc. Biol. Soc. Wash. 17: 175. 1904. A low well-branched tree, 3-5 m. high: leaves 4-5 cm. long, oval to suborbicular; the base rounded or somewhat cuneate, either entire or minutely serrate; the upper half incisely coarsely toothed, with finer serrations on the teeth which are slightly calloused but not glandular, ciliate-pubescent above, nearly glabrous beneath except for the ciliate-hirsuteness on the veins: thorns few, stout, variable, $3-5 \mathrm{~cm}$. long: corymb 10-20-flowered, broad; pedicels lanate-pubescent: calyx-tube short, hirsute or lanate, its lobes cut into long gland-tipped teeth: petals $8 \mathrm{~mm}$. broad: stamens 10: styles usually $3(2-4)$ : fruit $10-13 \mathrm{~mm}$. in diameter, dark scarlet-red; the pulp juicy and well flavored; carpels mostly 3, large, slightly ridged on the back.-Cañons of the front range of the Rocky Mountains in Colorado.

8. Crataegus occidentalis Brit. Bull. N. Y. Bot. Gard. 1: 448. 1900. A shrub or small tree, sometimes 6-7 m. high; thorns slender, about $3 \mathrm{~cm}$. long: pedicels and calyx pubescent: leaves oval or slightly obovate, irregularly serrate and sometimes slightly lobed, mostly obtuse at the apex and narrowed or subcuneate at the base, $4-7 \mathrm{~cm}$. long, 3 or $4 \mathrm{~cm}$. wide, slenderpetioled, pubescent beneath, at least on the veins: corymbs several-flowered; flowers about $1.5 \mathrm{~cm}$. wide: fruit oval-globose, about $1 \mathrm{~cm}$. long. (C. colorado Ashe.)-Nebraska and Colorado; also Montana.

9. Crataegus coloradoides Ramaley, 1. c. 383. Small tree or shrub, the young branches pubescent: leaves more or less blue-green and glossy above, somewhat glaucous beneath, obovate, serrate and obscurely lobed, pubescent on the nerves below and on the petiole which is often half as long as the blade: pedicels pubescent: stamens 10 or fewer; anthers white: fruit pulpy, sweet, spherical, red, about $9 \mathrm{~mm}$. in diameter: nutlets 2-3.-Colorado.

\section{PERAPHYLLUM Nutt.}

Low shrubs with grayish bark, intricately branched, the branchlets short and rigid. Leaves fascicled at the ends of the branchlets. Flowers solitary or in sessile 2-3-flowered umbels. Ovary 2-celled, each cell becoming partly divided by a spurious partition.

1. Peraphyllum ramosissimum Nutt. T. \& G. Fl. N. A. 1: 474. 1838. Somewhat silky-pubescent or nearly glabrous, 1-2 m. high: leaves narrowly oblanceolate, attenuate into a very short petiole, serrulate or entire: flowers 
appearing with the leaves, pale rose-color: calyx-tube adnate to the ovary, its lobes pubescent within: petals orbicula:-obovate: styles 2 : fruit globose, crowned with the persistent calyx-lobes.-Colorado and to the far northwest.

\section{SORBUS L. Mountain Ash}

Low shrub with pinnate, serrate, deciduous leaves and white flowers in flattopped compound cymes. Calyx-tube urn-shaped or turbinate, 5-lobed. Petals 5, spreading, short-clawed. Stamens 20. Styles $3-5$, distinct, woolly at base. Ovary 3-5-celled, becoming a berry-like pome with 2-seeded cells. -Pyrus.

1. Sorbus scopulina Greene, Pitt. 4: 130. 1900. Shrub 1-4 m. high, rather stout, the young branches sparsely hirsutulous: leaves 1-2 $\mathrm{dm}$. long, the rachis glabrous or slightly pilose at the joints; leaflets 11-15, glabrous on both sides, 3-4 cm. long, oblong-lanceolate, sharply serrate; the teeth not glandular or callous at tip: cyme large, flat-topped: fruit red, bitter. Pyrus sambucifolia, in part.-Rocky cañons; Colorado, Wyoming, and northwestward.

\section{DRUPACEAE DC. Plum Familì}

Trees or shrubs, with alternate, petioled, serrate leaves and small earlydeciduous stipules. Bark, leaves, and seeds bitter (prussic acid). Flowers regular and perfect. Calyx 5-lobed, free from the ovary, deciduous. Petals 5 , inserted on the calyx as are also the numerous stamens. Stigma small, capitate; ovary 1-celled. Fruit a drupe.-Rosaceae in part.

\section{PRUNUS L. Plum and Cherry}

Trees or shrubs, with simple serrate leaves, the bark exuding gum. Flowers white, fascicled in the axils or in terminal racemes. Calyx 5-cleft. Petals 5, spreading. Stamens 15-25, inserted with the petals. Carpels solitary, entirely free from the calyx, becoming drupes.

Leaves convolute in vernation; fruit large and pit flattened.

Flowers appearing before the leaves; umbels 2-5-flowered.

Sepals entire, not glandular

Sepals glandular-ciliate

Flowers appearing after the leaves; umbel 1 -3-flowered

Leaves conduplicate in vernation; fruit small and pit subglobose.

Flowers in terminal racemes

Flowers axillary.

A small tree; flowers in short corymbs

A low shrub; flowers in sessile umbels

1. P. americana. -

2. $\mathrm{P}$. angustifolia.

3. $\mathbf{P}$. ignota.

4. P. melanocarpa. -

5. P. pennsylvanica. 6. P. Besseyi.

1. Prunus americana Marsh, Arb. Am. 111. 1785. Tree thorny, 2-5 m. high: leaves ovate or somewhat obovate, conspicuously pointed, coarsely or doubly serrate, very veiny, glabrous when mature: fruit nearly destitute of bloom, roundish oval, yellow, orange, or red; the stone turgid, more or less acute on both margins; pleasant-tasted, but with a tough and sour skin. Wild Yellow or Red Plum.-Along streams; Colorado, Wyoming, and eastward.

2. Prunus angustifolia Marsh, Arb. Am. 111. 1785. Stem scarcely thorny: leaves nearly lanceolate, finely serrulate, glabrous: fruit nearly destitute of bloom, globular, red; the stone ovoid, almost as thick as wide, rounded at both sutures, one of them minutely grooved. P. chicasa Michx. CHICKasaw Plum.-Native in the central southwest; widely introduced; Colorado.

3. Prunus ignota A. Nels. Bot. Gaz. 42: 53. 1906. Shrubby or possibly becoming tree-like; branches slender, none of them becoming indurated or thorny: leaves glabrous from the first, simply and sharply serrate: flowers white, anpearing with or after the leaves, solitary or 2-3 in a cluster: calyx 
turbinate; its lobes entire, glabrous within and nearly so without: petals obovate: fruit not known.-On the Cache La Poudre, near Fort Collins, Colorado.

4. Prunus melanocarpa (A. Nels.) Rydb. Bull. Torr. Bot. Club 33: 143. 1906. An erect slender shrub or small tree 1-5 m. high: leaves ovate or oblong-ovate, abruptly acuminate, rounded or somewhat cordate at base, smooth or nearly so on both sides, the teeth of the fine serration incurved or appressed; petioles not glandular: raceme compact, erect or ascending: fruit when fully mature black, always more or less astringent. $P$. demissa, which probably belongs wholly to the northwest of our range.-This is the common CHOKECHERRY in the central Rocky Mountains.

5. Prunus pennsylvanica L. f. Suppl. 252. 1781. Tree 4-8 m. high, with light red-brown bark: leaves oblong-lanceolate, pointed, finely and sharply serrate, shining, green and smooth both sides: fruit globose, light red, very small, with thin and sour flesh; stone globular. Wild Red Cherry.-From Colorado, northward and eastward to Newfoundland.

6. Prunus Besseyi Bailey, Bull. Cornell Expt. Sta. 70: 261. 1894. A low shrub with spreading or prostrate branches, often only a few dm. high: leaves oblong to oval, the teeth appressed, either acute or obtuse at base and apex: flowers in sessile umbels, expanding with the leaves, about $1 \mathrm{~cm}$. broad: fruit large, 12-15 $\mathrm{mm}$. in diameter, yellowish-red, juicy, scarcely astringent, edible. SAND ChERRY.-From the western plains to the foothills of the Rocky Mountains.

\section{Leguminosae Juss. Pea Family}

Herbs, shrubs, or trees with alternate and usually compound leaves, irregular flowers, 5 sepals more or less united, 5 very dissimilar petals (upper petal or standard larger than the others and inclosing them in the bud, turned back or spreading; the two lateral petals or wings oblique; the two lower petals coherent by their edges and forming the keel which usually incloses the stamens and pistil), usually 10 variously united stamens (mostly 9 , united into a tube and the upper one separate, rarely 9 or 5), and a 1-celled ovary becoming a more or less elongated pod. Style generally inflexed or incurved. Seeds mostly with thick cotyledons and without endosperm.

Stamens 10 , wholly distinct.

Leaves digitately 3 -foliolate; flowers yellow

Leaves odd-pinnate; flowers white Stamens (some or all) united by their
monadelphous or diadelphous.

Anthers of 2 forms; stamens monadelphous; leaves digitately 5- or more-foliolate.

Anthers all alike, reniform.

Leaves odd-pinnate, without tendrils.

Pod not a loment, 2-valved or indehiscent.

Eoliage not glandular dotted.

Digitately 3 -foliolate or rarely 5 -foliolate.

Leaflets entire

Leaflets serrulate or denticulate.

Flowers in racemes

Flowers capitate or in short loose spikes.

Pods curved or coiled

Pods straight, membranous

Pinnately 5- or more-foliolate (rarely simple or 3 -foliolate in no. 9).

Shrubs

Herbs, or rarely with ligneous base.

Keel of the corolla blunt

Keel of the corolla acute

Foliage glandular-dotted.

Pod with hooked prickles.

Pod not prickly.

Herbs, or merely with ligneous base.

1. Thermopsis.

2. Sophora.

3. Lupinus. 
Leaves digitately 3-5-foliolate

Leaves pinnately 5-many-foliolate. Stamens 10

Stamens 5

Pod a loment, with reticulated indehiscent joints

Leaves even-pinnate, terminated by a tendril or bristle.

Style slender, with a tuft of hair near the apex

Style flattened, hairy on the inner side
13. Psoralea.

14. Parosela.

15. Petalostemon.

16. Hedysarum.

17. Vicia.

18. Lathyrus.

\section{THERMOPSIS R. Br.}

Stout perennial herbs with erect clustered stems from running rootstocks. Leaves digitately 3 -foliolate; the leaflets entire; stipules conspicuous, free. Flower large, yellow, in racemes. Calyx campanulate, cleft to the middle. Standard shorter than the oblong wings, the sides reflexed; keel nearly straight, as long as the wings. Stamens distinct. Pod linear to oblonglinear, much compressed, shortly stipitate or nearly sessile, straight or incurved.

Mature pods straight or only slightly curved.

Erect and nearly straight

Spreading, somewhat curved, not recurved or deflexed

Mature pods strongly annulately curved and often recurved.

Leaflets silky-pubescent, at least beneath

Leaflets glabrate

1. T. montana.

2. T. divaricarpa.

3. T. rhombifolia. 4. T. arenosa.

1. Thermopsis montana Nutt.* T. \& G. Fl. 1: 388. 1840. Stems erect, simple or with a few strict, leafy, sterile branches, more or less silky-pubescent, becoming glabrate, 3-6 dm. high: leaflets oblong-oblanceolate or obovateoblong, usually acute; sparingly silky-villous beneath, glabrous or nearly so above: flowers alternate or geminate, showy, in a spike 6-12 cm. long: calyx silky-canescent; its teeth narrow, shorter than the tube: pods silky-canescent or somewhat villous, straight, linear, erect, even appressed, or, if very much crowded, somewhat spreading. (T. stricta Greene, Pl. Baker. 3: 34. 1901.)"High valleys in the Rocky Mountains, in bushy places by streams;" west to the Sierras.

2. Thermopsis divaricarpa A. Nels. Bot. Gaz. 25: 275. 1898. Similar in habit and size, the sterile branches very leafy: leaflets elliptic or obovate, nearly glabrous; the large stipules ovate, somewhat inequilateral, longer than the petiole: pods pubescent when young, at length glabrous, $8-10 \mathrm{~cm}$. long, about $7 \mathrm{~mm}$. broad, slightly curved and becoming widely divaricate. ( $T$. pinetorum Greene, Pitt. 4: 138. 1900.) - Often in rather dense patches; stream banks and moist copses; throughout our range.

3. Thermopsis rhombifolia (Nutt.) Rich. Frank. Journ. App. 13.1823. Low, erect or ascending, branched, 2-4 dm. high, appressed silky-pubescent, or the leaves sometimes glabrate above: leaflets oval or obovate or rhombicelliptic, obtuse, sessile; stipules ovate to orbicular: racemes short; flowers 15-20 mm. long: pod broadly linear, silky at first and more or less pubescent at maturity, annulately recurved-spreading, several-seeded. ( $T$. annulocarpa A. Nels. Bull. Torr. Bot. Club 26: 239. 1899.)-In dry washes and on sterile sandy plains; from Manitoba to Kansas along the eastern boundary of our range.

4. Thermopsis arenosa A. Nels. 1. c. 276. 1898. Similar in habit and size: stems from the persistent branched bases numerous: leaflets oblong to oblanceolate or even obovate, mostly subacute, nearly glabrous, $3-4 \mathrm{~cm}$. long, 1-2 cm. broad; stipules longer than the petioles, ovate to suborbicular: raceme short even in fruit: pods softly pubescent but at maturity nearly or quite glabrous, widely spreading from the first or even drooping, somewhat curved or at length annulately recurved, often stipitately narrowed at base and constricted at intervals by the aborting of one or more of the seeds. Open sandy washes in the foothills; Colorado and Wyoming. 


\section{SOPHORA L.}

Ours are herbs with coriaceous odd-pinnate leaves with numerous entire leaflets. Stipules small or obsolete. Flowers white, in terminal racemes. Calyx campanulate; its teeth short. Petals nearly equal; the standard broad. Pod stipitate, large, thick, terete or somewhat compressed, several-seeded, often somewhat transversely constricted.

1. Sophora sericea Nutt. Gen. 1: 280. 1818. Low, 1-3 dm. high, more or less silky-canescent: leaflets about 21 , elliptic or cuneate-oval: racemes short, at first scarcely exserted beyond the leaves: calyx gibbous at base.-High plains of Colorado and northward along the plains of the Platte and the Missouri.

\section{LUPINUS L. LUPINE}

Generally herbaceous, with 5 or more digitately arranged entire leaflets. Stipules adnate to the petioles. Flowers in terminal racemes, verticillate or scattered, bracteate. Calyx 2-lipped. Standard with recurved sides; wings united above, inclosing the falcate keel. Filaments strictly monadelphous; anthers of two forms. Pod large, straight, compressed, 2-valved, coriaceous.

Annuals; ovules only 2.

Coarsely hirsute; stem branched

Softly hirsute; subacaulescent

Perennials; ovules more than 2.

Dwarf and caespitose (5-15 cm. high).

Racemes surpassed by the leaves

Racemes surpassing the leaves

Medium to large, usually $2 \mathrm{dm}$. or more high.

Flowers conspicuously bicolored.

Leaflets green, appressed-pubescent beneath

Leaflets canescent, pubescent on both faces.

- Racemes lax, verticils distant

Racemes dense

Flowers often bi- or tri-colored but not strikingly so.
Herbage conspicuously canescent or rough-hoary.

Pubescence dense and white, spreading or subappressed.

Racemes large and long (1-3 dm.) .

Racemes short, terminating divaricate branches :

Pubescence sericeous, mostly appressed.

Flowers blue

Flowers violet

Herbage green or greenish, at least in part.

Pubescence of stem and petioles appressed.

Leaflets glabrous above or nearly so.

Linear-oblong or oblanceolate, usually folded.

Raceme solitary or several in a terminal fascicle

Racemes terminating the stem and divaricate branches.

Stems usually solitary; pubescence scanty Stems tufted; pubescence silky-appressed

Oblong to oblanceolate or broader, mostly flat.

Stems branched above.

Flowers blue

Flowers violet

Stems mostly simple.

Calyx scarcely gibbous

Calyx conspicuously gibbous

Leaflets pubescent on both sides.

Stems purplish-red

Stems green or greenish.

Tufted and low (2 dm. or less).

Taller, usually 3-6 dm. high.

Basal-leaves abundant and long-petioled

Basal leaves wanting, or small and short-, petioled.

Stems densely tufted

Stems mostly solitary
Pubescence of stem and petioles hirsute (if any), spreading or reflexed.

More or less rough-hirsute.

Raceme as long as the leaf-bearing part of the stem

1. L. pusillus.

2. L. brevicaulis.

3. L. caespitosus.

4. L. Kingii.

5. L. plattensis.

6. L. dichrous.

7. L. ornatus

8. L. leucophyllus.

9. L. ramosus.

10. L. flexuosus.

11. L. Greenei.

12. L. floribundus.

13. L. parviflorus.

14. L. argenteus.

15. L. decumbens.

16. L. alsophilus.

17. L. alpestris.

18. L. pseudoparviflorus.

19. L. rubricaulis.

20. L. monticola.

21. L. humicola.

22. L. laxiflorus.

23. L. Bakeri.

24. L ammophilus. 
Raceme relatively short; stems tall. Flowers ochroleucous Flowers blue or pink

Whole plant glabrous or nearly so
25. L. barbiger.

26. L. Wyethii. 27. L. Burkei.

1. Lupinus pusillus Pursh, Fl. Am. Sept. 468. 1814. A low rather stout diffusely branched annual, 1-2 dm. high, hirsute with spreading hairs: leaflets usually 5 , cuneate-oblong or oblanceolate, $2-3 \mathrm{~cm}$. long, acute or obtuse, nearly glabrous above, about half as long as the petioles: racemes shortpeduncled or sessile; pedicels 4-5 $\mathrm{mm}$. long; the bractlets minute: upper calyx-lip 2-cleft; the lower subentire: pods 10-15 mm. long, 1-2-seeded.Throughout the whole Rocky Mountain region.

2. Lupinus brevicaulis Wats. King's Rep. 53. pl. 7. 1871. Acaulescent and somewhat caespitose, annual or seemingly sometimes perennial with slender rootstocks, 3-10 cm. high: leaflets mostly 7 , cuneate-obovate, $10-15 \mathrm{~mm}$. long, rounded at apex: racemes dense, $3-4 \mathrm{~cm}$. long, the peduncles nearly equaling the leaves; pedicels $2-4 \mathrm{~mm}$. long in fruit; bractlets small: upper calyx-lip very short or truncate, scarious; the lower subentire: petals blue, 6-10 mm. long, equal: pod 6-10 mm. long, 2-3-seeded.-Southern Colorado to Arizona and Oregon.

3. Lupinus caespitosus Nutt. T. \& G. Fl. N. A. 1: 379. 1840. Dwarf caespitose perennial, $5-15 \mathrm{~cm}$. high, silky hirsute: leaflets $5-7$, oblong-lanceolate, attenuate at base, much shorter than the petiole; stipules subulate, adnate: spike sessile, densely flowered, much shorter than the leaves; bracts setaceous, deciduous; flowers small, nearly sessile, pale blue: calyx bracteolate; the upper lip 2-parted; the lower obscurely 3-toothed: pod villous, 3-4-seeded. - Colorado and Utah, north to Montana.

4. Lupinus Kingii Wats. Proc. Am. Acad. 8: 534. 1873. From a perennial rootstock, dwarf, caespitose, $7-15 \mathrm{~cm}$. high; pubescence villous and spreading: leaflets oblong-lanceolate, $2-3 \mathrm{~cm}$. long, acutish or obtuse, half as long as the petioles: raceme on slender peduncles equaling the leaves; bracts short: calyx nearly equaling the petals; the lower lip equally 3-toothed: petals purplish, 7-8 $\mathrm{mm}$. long, the narrow rhomboidal standard shorter than the wings: pod ovate, about $1 \mathrm{~cm}$. long, 1-2-seeded. (L. Sileri Wats. 1. c. 10: 345. 1875; L. aduncus Greene, Pitt. 4: 132. 1900.)-Colorado, Wyoming, and Utah.

5. Lupinus plattensis Wats. Proc. Am. Acad. 17: 369. 1883. Stems erect, from an underground rootstock, appressed silky-villous, branched: leaflets 7-10, oblanceolate or short-spatulate, obtuse or sometimes subacute, usually with a glaucescent hue, appressed-pubescent beneath, glabrous above: raceme elongated, loosely large-flowered: petals pale, blue or purplish; the standard with a conspicuous darker spot.-Western Nebraska and adjacent Wyoming and Dakota.

6. Lupinus dichrous Greene, Pl. Baker. 3: 35. 1901. Tufted, erect, 5-8 dm. high, the stems mostly simple; pubescence short, spreading, silvery: racemes long, very open; flowers, large, subverticillate; pedicels and short gibbous calyx velvety: corolla at first pale or nearly white, the standard soon assuming a dark reddish-purple hue; keel lunate, strongly ciliate throughout: pods oblong-linear, 3-4 cm. long, silky-tomentose, 5-seeded; the seeds white, very flat.--Probably rare; western Colorado.

7. Lupinus ornatus Dougl. Lindl. Bot. Reg. 14. pl. 1316. 1828. Stems often decumbent at base, ascending or erect, 4-8 dm. high; pubescence dense, rather short, somewhat silky, subappressed: leaflets 5-7, oblanceolate or cuneate-oblong, 3-5 cm. long, usually acute: racemes 1-2 dm. long, shortpeduncled; bracts short, subulate or ovate: calyx-lips nearly equal; the upper short-toothed or bifid; the lower subentire: petals subequal, blue; the standard paler especially at the center, subsilky on the back; the keel ciliate: ovules 5-8: pod 4-5-seeded; the seeds small, white and polished.-Western Wyoming, northward and westward to the coast States.

8. Lupinus leuco phyllus Dougl. Lind. Bot. Reg. 13. pl. 1124. 1828. Stems large, leafy, 6-9 dm. high, densely silky-tomentose throughout: stipules ROCKY MT. Вот. -18 
setaceous or subulate; leaflets $7-10$, oblanceolate or cuneate-oblong, 3-6 dm. long, acute; the petioles about equaling the leaves, or the lower twice as long: raceme dense, 1.5-3 dm. long; bracts subulate or linear, about as long as the calyx; flowers nearly sessile, scattered or subverticillate: upper calyx-lip 2-cleft; the lower slightly longer, subentire: petals blue or pink, equal, 8-10 $\mathrm{mm}$. long; the standard densely villous; keel naked or ciliate: ovules 5-6.This northwestern plant may reach our northwestern boundary.

9. Lupinus ramosus E. Nels. Bot. Gaz. 30: 120. 1900. Stems several from a woody caudex, 2-4 dm. high, divaricately simple-branched; pubescence dense, of two kinds, finely lanate-canescent and sparsely villous with spreading hairs: leaflets 5-8, oblanceolate, obtuse to acute, 2-4 cm. long, the lower half the length of the petioles; the upper equaling them: racemes terminating stem and branches, short-peduncled, 3-5 cm. long; bracts ovate-lanceolate; flowers scattered or subverticillate: upper lip of calyx notched, a little shorter than the lower: standard very silky on the back, with yellowish white center, otherwise pale blue or lilac as are also the wings; keel pale, ciliate on the margin below: pod silky, 3-5-seeded.-Northwestern Wyoming.

10. Lupinus flexuosus Lindl. in Agh. Syn. Lup. 34. 1835. Stems ascending or erect, often decumbent at base, 4-6 dm. high, branching; pubescence short, silky, appressed or subvillous on the lower leaves: leaflets 6-8, oblanceolate, $3-4 \mathrm{~cm}$. long, acute, silky on both sides: raceme $7-14 \mathrm{~cm}$. long; bracts equaling or exceeding the calyx; pedicels $4-5 \mathrm{~mm}$. long: calyx-lips subequal, subentire or the upper slightly toothed: petals blue or flesh-color, equal, about $1 \mathrm{~cm}$. long; the standard hairy, the keel ciliate: pods $2-3 \mathrm{~cm}$. long, 4-5-ovuled.-In the northern part of our range and west to Washington.

11. Lupinus Greenei A. Nels. Stems tufted, erect or with decumbent base, $3-5 \mathrm{dm}$. high, usually simple, whitened throughout with a dense silky tomentum: leaflets $7-9,3-5 \mathrm{~cm}$. long, oblanceolate, obtuse, mucronulate, shorter than the petioles: racemes short, the violet flowers in verticils; pedicels equal: the standard and sometimes the wings villous along the midnerve on the outside; keel short but falcate, subtomentose on the margin. L. oreophilus Greene, Pitt. 4: 135. 1900; not L. oreophilus Phil.-Southern Colorado.

12. Lupinus floribundus Greene, Proc. Acad. Phila. 364. (1892) 1893. Stems tufted, simple with a terminal raceme, or branching above and the racemes several, purplish, and sparsely strigulose: raceme long (1-2 dm.) and slender, dense and the flowers very small: petioles slender; leaflets $7-9$, narrowly oblanceolate, acute, glabrous above, densely strigulose beneath and on the margins: flowers violet or blue, in closely contiguous verticils; the early deciduous bracts with attenuate and spreading tips; pedicels and calyx densely villous: petals equal, 5 or $6 \mathrm{~mm}$. long, the broad keel delicately ciliolate. (L. myrianthus Greene, Pitt. 4: 134. 1900; L. leptostachyus Greene, Pl. Baker. 3: 36. 1901.)-Mountain valleys; western and southern Colorado.

13. Lupinus parviflorus Nutt. Hook. \& Arn. Bot. Beech.336. 1839. Stems erect, slender, $4-8 \mathrm{dm}$. high, simple or branched above; pubescence scanty, short and appressed, the calyx and pedicels silky: stipules setaceous; leaves rather distant; leaflets 5-11, broadly linear to oblanceolate, $3-5 \mathrm{~cm}$. long, mostly acute and mucronulate, glabrous above; the lower shorter than the petioles: raceme 1-3 dm. long, slender; bracts linear-subulate, equaling the calyx: flowers scattered or in verticils, on slender pedicels 2-4 $\mathrm{mm}$. long: calyx-lips nearly equal, the upper 2-toothed: petals blue, equal, 6-8 $\mathrm{mm}$. long; the keel ciliate or naked: pod pubescent, 2-4-seeded. (L. ingratus Greene, Pitt. 4: 133. 1900.)-From New Mexico to Montana and west to Washington.

14. Lupinus argenteus Pursh, Fl. Am. Sept. 468. 1814. Stems erect or ascending, slender and branching, 3-5 dm. high; pubescence minute, silvery appressed: stipules small; leaflets 5-8, linear-lanceolate, $3-5 \mathrm{~cm}$. long, acute, smooth above or nearly so, about as long as the petiole: racemes $5-15 \mathrm{~cm}$. long, nearly sessile; flowers in verticils or scattered: calyx campanulate, gibbous at base; the upper lip broad, 2-toothed; the lower subentire, slightly longer: petals blue, cream-color, or even purplish; the standard and keel 
either naked or somewhat pubescent.-Seemingly extending from Dakota and Nebraska to the plains of the Columbia. The more silky-hairy form is known as var. argophyllus.

15. Lupinus decumbens Torr. Ann. Lyc. N. Y. 2: 191. 1828. Closely allied to the preceding, but the stems stouter, freely branched, often 7-10 dm. high, very leafy: leaflets green, glabrous or nearly so above, short-pubescent beneath: racemes several to many, dense and many-flowered.-Abundant throughout our range on the plains, especially adjacent to the streams.

16. Lupinus alsophilus Greene, Pitt. 4: 135. 1900. Tall, branching, green and seemingly glabrous: leaves few and large; leaflets about 8, spatulately oblanceolate, obtuse, mucronate, glaucescent beneath, green and glabrous above, 5-7 $\mathrm{cm}$. long, $12-16 \mathrm{~mm}$. broad above the middle: racemes 5-10 cm. long, on slender peduncles; flowers violet: calyx with very short tube: petals equal, 6-8 mm. long, the keel short, broad and blunt, the margin naked: pods densely villous.-Subalpine; in the mountains of Western Colorado.

17. Lupinus alpestris A. Nels. Bull. Torr. Bot. Club 27: 127. 1899. Stems tufted on a branched persistent caudex, 4-6 dm. high, simple or corymbosely branched above, striate, short-pubescent: leaflets oblong to oblanceolatecuneate, mostly obtuse at apex and with a cusp, minutely appressed-pubescent or nearly glabrous above; the lower petioles much longer than the leaflets; the uppermost shorter: racemes terminal on stem and branches; flowers small to medium, in rather loose verticils: corolla blue with purple spot on standard: pod silky-hirsute, $2-3 \mathrm{~cm}$. long, about 5-ovuled: seeds very flat, oval, $4 \mathrm{~mm}$. long.- In moist woods in mountains of our range, at middle or subalpine stations.

18. Lupinus pseudoparviflorus Rydb. Mem. N. Y. Bot. Gard. 1: 232. 1900. Stems solitary or several from woody caudex, erect, 3-6 dm. high: stipules lanceolate; petioles slender, the lower twice as long as the leaflets; leaflets $8-10$, oblanceolate, $3-5 \mathrm{~cm}$. long, acute or mucronate, finely strigose beneath, glabrate above: raceme loosely flowered, $7-14 \mathrm{~cm}$. long: calyx appressed-silky, very gibbous at base: corolla blue, about $1 \mathrm{~cm}$. long; the standard very broad, a little shorter than the wings: ovules 4-6. (L. Jonesii J. W. Blank. Mont. Agr. Coll. Sc. Stud. 1: 79. 1905.)-Northern Wyoming, Montana, and Idaho:

19. Lupinus rubricaulis Greene, Pl. Baker. 3: 35. 1901. Stems tufted, slender, 3-5 dm. high, mostly simple, rather remotely leafy, dark red-purple as are to some extent the leaves and petioles also: leaflets $7-8$, cuneate-oblong or elliptical, unequal, $3-5 \mathrm{~cm}$. long; the slender petioles much longer; stipules small, subulate: racemes sessile, $7-10 \mathrm{~cm}$. long, rather dense, the middlesized flowers scattered: calyx white-silky, very gibbous at base: corolla bluepurple; the standard shorter than the other petals; keel falcate, glabrous. Very near the preceding; but distinguished by its reddish hue.-Colorado and Wyoming.

20. Lupinus monticola Rydb. Mem. N. Y. Bot. Gard. 1: 232. 1900. Stems numerous from a branched woody caudex, 1-2 dm. high, grayish-strigose: lower petioles often longer than the leaflets; the upper often much shorter; leaflets $7-9$, oblanceolate, $2-4 \mathrm{~cm}$. long, silky, strigose or somewhat hoary on both sides: raceme $3-6 \mathrm{~cm}$. long; pedicels, bracts, and calyx silky-villous: upper calyx-lip 2-cleft, the lower entire: corolla glabrous, 8-10 mm. long; the standard broad, dark blue as are also the wings; keel lighter, strongly curved: ovary silky, with 4-6 ovules.-Alpine; northern Wyoming and in Montana.

21. Lupinus humicola A. Nels. Bull. Torr. Bot. Club 25: 204. 1898. Perennial; rootstock branched, the low crowns covered with the scale-like dead petioles: stems several from each crown, simple, erect or ascending, 3-6 dm. high, finely but not densely appressed-pubescent throughout: leaflets $7-12$, usually 10 or 11 , oblong-oblanceolate, cuspidate-acute, 4-7 cm. long; petioles slender, elongated, radical 1.5-3 dm. long, cauline gradually shortened upward; stipules linear-lanceolate, villous: racemes terminal, dense, 1-2 dm. long, 
elongating in fruit; flowers blue, subverticillate, standard glabrous; bracts minute or wanting; pedicels $5-8 \mathrm{~mm}$. long, stout in fruit: pods villouspubescent, 2.5-4 cm. long, normally 6-seeded.-A vernal species of moist slopes protected by undershrubs; Wyoming and Colorado.

22. Lupinus laxiflor us Dougl. in Lindl. Bot. Reg. pl.1140. 1828. Ascending or erect, 3-6 dm. high, the slender tufted stems simple; pubescence minute, silky, appressed: stipules very small, setaceous; leaflets 6-8, oblanceolate, 3-5 cm. long, pubescent on both sides, at least half as long as the petioles: racemes loose and slender; flowers verticillate or scattered, rather small, on pedicels $4-5 \mathrm{~mm}$. long: calyx narrowed and saccate at base; the upper lip short-toothed, the lower subentire: petals blue, equal, 6-10 $\mathrm{mm}$. long; banner subpubescent, and the keel ciliate: pod silky-hairy: seeds $3-5$. (The following are segregates from $L$. laxiflorus, and may or may not be distinct: $L$. argophyllus, L. argenteus argophyllus Wats. Proc. Am. Acad. 8: 532. 1873; L. argentinus Rydb. Bull. Torr. Bot. Club 30: 257. 1903; L. comatus Rydb. 1. c.; L. pulcherrimus Rydb. 1. c. 258; L. laxus Rydb. 1. c.; L. leucanthus Rydb. 1. c. $259 ;$ L. Helleri Greene, Pitt. 4: 134. 1900.)-New Mexico to Montana and west to the coast States.

23. Lupinus Bakeri Greene, Pitt. 4: 132. 1900. Densely tufted, erect, 5-9 dm. high, silvery or hoary pubescent throughout; stems rather stout, often fistulous below: leaflets 7-9, lance-elliptical, acute, $3-5 \mathrm{~cm}$. long, about equally pubescent on the two faces: raceme solitary, rather short, subsessile; the flowers of middle size and in rather distinct whorls, blue, with a spot on the standard, turning red or purple: standard shorter than the wings or subequal; the keel falcate, densely woolly-ciliate: pods $2-3 \mathrm{~cm}$. long, velvetytomentose. (L. arceuthinus Greene, Pl. Baker. 3: 35. 1901.)-Western Colorado.

24. Lupinus ammophilus Greene, Pitt. 4: 136. 1900. Perennial from horizontal rootstocks; stems not tufted, rather low and stout; the raceme and peduncle usually longer than the stem: petioles and stem coarsely hirsute, with long, spreading or reflexed hairs: leaflets 8-10, cuneate-obovate to oblanceolate, glabrate above, sparsely hirsute beneath, $3-4 \mathrm{~cm}$. long: raceme large and showy; pedicels and gibbous calyx hirtellous: corolla about $1 \mathrm{~cm}$. long, purple; the standard with a light spot in the middle, this changing to red; keel falcate, thinly woolly-ciliate: pods broad, 2-3 cm. long, densely hirsute.-Sandy banks; southern Colorado and New Mexico.

25. Lupinus barbiger Wats. Proc. Am. Acad. 8: 528. 1873. Pubescence of the stem, pedicels, and petioles short stiffish spreading hairs; that of the leaves and calyx silky and subappressed: stems rather stout, 4-7 dm. high: stipules setaceous; leaflets 5-7, narrowly oblanceolate, silky on both sides: raceme rather dense, short-peduncled; pedicels 4-5 $\mathrm{mm}$. long; the setaceous bracts longer than the calyx: lower calyx-lip narrow, subentire, exceeding the broader, deeply toothed upper lip: petals ochroleucous or purplish, equal; the standard rounded, silky; the keel copiously ciliate: ovules about 7 . Western and southern Colorado to Utah and southward.

26. Lupinus Wyethii Wats. 1. c. Sparsely villous with spreading pubescence throughout; stem ascending or erect, stout, often branching, 3-5 dm. high, few-leaved: leaflets 8-12, oblong to oblanceolate, 4-6 cm. long, acute, often glabrous above; the lower petioles much elongated: raceme 1-2.5 dm. long, often long-peduncled; bracts subulate-setaceous, exceeding the calyx; flowers blue or pink, scattered or verticillate; pedicels $6-8 \mathrm{~mm}$. long: calyx villous, with short setaceous bractlets; upper lip 2-toothed; the lower one longer, subentire: petals 10-14 mm. long, equal; the keel naked: ovules 7-8. (L. amplus Greene, Pl. Baker. 3: 36. 1901.)-From Colorado and Wyoming to Oregon.

27. Lupinus Burkei Wats. Proc. Am. Acad. 8: 525. 1873. Stout, nearly glabrous, erect, branching, 5-10 dm. high: lower leaves long-petioled; the stipules lanceolate; leaflets 7-10, 5-10 cm. long, oblanceolate, acute, or the lower ones obtuse, glabrous above, sparsely strigose beneath: raceme short and dense; the pedicels short; flowers blue; bracts ciliate, somewhat persis- 
tent: pubescence of the calyx more or less villous, spreading: pods 8-seeded. -Western Wyoming to Nevada and Washington.

\section{LOTUS L. Trefoil}

Herbaceous. Leaves (in ours) 1-5-foliolate; stipules minute and gland-like. Flowers in axillary umbels, or solitary. Calyx-teeth nearly equal, usually shorter than the tube. Petals free from the stamens, nearly equal, yellow or ochroleucous, or turning reddish; claw of the standard usually remote from the others; keel somewhat incurved. Stamens diadelphous. Pod linear, sessile, partitioned between the seeds.

Annual

Perennial

1. Lotus americanus (Nutt.) Bisch. Litt. Ber. Linnaea 14: 132. 1840. Annual; more or less silky-villous or sometimes glabrous: leâves nearly sessile; leaflets 3 (or 1, rarely 4), varying from ovate to lanceolate: peduncles exceeding the leaves, one-flowered: calyx-teeth linear, much longer than the tube, about equaling the corolla: keel attenuated upward, falcate, mostly acute. Hosackia Purshiana.--Across the continent; infrequent in our range.

2. Lotus Wrightii (Gray) Greene, Pitt. 2: 143. 1890. Perennial; ashypuberulent, bushy-branched, very leafy: leaflets $3-5$, apparently palmate and sessile, the lowest oblong, the rest filiform-linear: peduncles short, rarely equaling the leaf, 1-2-flowered: calyx-teeth setaceous-subulate, about equaling the tube: keel not falcately-attenuate, mostly very obtuse.-S. W. Colorado, New Mexico, and Arizona.

\section{Melilotus Tourn. Melilot. Sweet Clover}

Annual or biennial herbs, with pinnately 3-foliolate leaves, usually serrulate leaflets, small yellow or white flowers in slender axillary pedunculate racemes, and an ovoid coriaceous wrinkled pod which is 1 or 2-seeded and scarcely dehiscent.

1. Melilotus alba Desv. in Lam. Encycl. 4: 63. 1797. Erect, 1-2 m. high, branching: leaflets oblong, truncate, emarginate, or rounded at apex, 1-2 cm. long: flowers white in slender racemes 5-10 cm. long, often 1-sided: pod ovoid, glabrous. White Sweet Clover.-Naturalized from Europe; sparingly grown for forage, and spreading as a weed.

2. Melilotus officinalis (L.) Lam. Fl. Fr. 2: 594. 1778. Resembling the preceding: leaves with rounded serrate apex: flowers yellow: pod subpubescent, reticulate-veined. Yellow SweEt Clover.-Adventive from Europe; in waste grounds.

\section{6. medicago L. Alfalfa. Lucerne. Medic}

Annual or perennial herbs, with pinnately 3-foliolate leaves, toothed leaflets, small flowers in spike-like racemes, and curved or coiled 1-few-seeded pods.

1. Medicago sativa L. Sp. Pl. 778. 1753. Upright and smooth perennial: leaflets obovate-oblong: flowers purple, racemed: pod spirally twisted.-An extensively cultivated forage plant, peculiarly adapted to our range, and of the highest value because of its quality and productiveness.

\section{TRIFOLIUM L. Clover}

Herbs, often tufted or diffuse, with palmately 3 -foliolate leaves, or rarely pinnately 3-5-foliolate. Stipules adnate to the petiole. Flowers usually capitate, the heads sometimes elongated and spike-like. Calyx persistent, with slender bristle-form teeth. Corolla persistent, united with the stamens. Pods small, membranous, indehiscent, often included in the calyx. 
Introduced species grown for forage or pasture; widely naturalized. Stems creeping; flowers white or pinkish Stems tufted, no creeping stems.

Flowers sessile; heads sessile
Flowers pediceled; heads long-peduncled $\quad: \quad: \quad: \quad$ : $\quad$ 3. T. Tratense. Indigenous species.

Heads not involucrate.

Stems slender, erect, 1-3 dm. high.

Peduncles very short

Peduncle much elongated

Stemless or nearly so; often caespitose.

Leaves glabrous.

Head of several flowers, pedunculate.

Leaflets sharply denticulate.

Leaflets entire

Flowers $1-3$, on very short radical peduncles

Leaves pubescent, at least below

Heads subtended by a many-cleft usually monophyllous involucre.

Low or dwarf perennials; acaulescent or nearly so.

Glabrous, with large leaflets and long peduncles

Pubescent.

Distinctly pedunculate.

Corolla bicolored, ochroleucous and purple

Corolla purple or red.

Appressed silvery-pubescent; standard obtuse

Sparsely hairy; standard attenuate
Peduncle nearly wanting; the plants depressed-caespitose

Slender, glabrous, and caulescent.

Perennial, branching from the base

Annual, stems simple

1. Trifolium repens L. Sp. Pl. 767. 1753. Smooth perennial, the slender stems creeping and spreading: leaflets inversely heart-shaped or merely notched, obscurely toothed; stipules scale-like, narrow; petioles and especially the peduncles very long: heads small and loose: calyx much shorter than the white corolla: pods about 4-seeded. The common White Clover.-Widely dispersed and now frequent in our range.

2. Trifolium pratense L. 1. c. 768 . Stems ascending, somewhat hairy: leaflets oval or obovate, often notched at tip and with a pale spot above: rose-purple flowers sessile in dense ovate heads; the corolla elongated-tubular. The common RED Clover.-In cultivation and escaped along roadsides and ditch banks.

3. Trifolium hybridum L. 1. c. 766. Perennial, erect or ascending, 3-6 dm. high, nearly glabrous: leaves long-petioled; the leaflets obovate, sharply serrulate: heads globose, long-pedunculate; the flowers on slender pedicels. Alsike Clover. - Sparingly naturalized.

4. Trifolium latifolium (Hook.) Greene, Pitt. 3: 223. 1897. Stems erect, scarcely tufted, few-leaved, 5-12 cm. high: leaflets oblong to oval, 7-15 $\mathrm{mm}$. long, glabrous as is also the stem and petioles: peduncles very short, pubescent: heads spherical but soon loose; the flowers distinctly pediceled, reflexed in age. T. longipes latifolium. ( $T$. longipes Nutt. and $T$. Kingii Wats. are probably wholly west of our range.)-Occurs sparingly on our northwestern border.

5. Trifolium Rydbergii Greene, 1. c. 222. Nearly glabrous, the erect stems $1-4 \mathrm{dm}$. high, not tufted: leaflets of the lowest leaves short, oval; the others oblong to linear-lanceolate, $2-4 \mathrm{~cm}$. long: heads ovoid, about $2 \mathrm{~cm}$. long: calyx and peduncle somewhat pubescent or even slightly villous; the teeth of the calyx much longer than the tube: corolla ochroleucous or nearly white, sometimes purple-tinged. T. eriocephalum and $T$. longipes in part.-Frequent; moist grassy valleys, in the open or among the undershrub; throughout our range.

6. Trifolium Haydenii Porter, Hayden's Rep. 480. 1872. Glabrous and caespitose, with branching caudex: leaflets obovate, obtuse or abruptly pointed, sharply denticulate, strongly veined: peduncle twice as long as the leaves; the lower stipules obtuse, scarious; the upper acute: flowers purple, large (12-15 mm. long), in 2-3 verticils, reflexed in fruit: teeth of the calyx setaceous-subulate, about as long as the tube: standard obtusely rounded or emarginate.- Northern Utah and adjacent Wyoming and Idaho. 
7. Trifolium Brandegei Wats. Proc. Am. Acad. 11: 130. 1876. Dwarf perennial, caespitose and acaulescent, glabrous, the inflorescence slightly villous: stipules scarious; leaflets elliptic-oblong, thin, acutish, entire, 15-20 $\mathrm{mm}$. long: peduncles about equaling the leaves; flowers spicate, in a loose naked head, purplish, 12-14 mm. long: calyx-teeth lanceolate, acuminate, a little longer than the campanulate tube: ovary stipitate, 7 -ovuled.- Southern Colorado and New Mexico.

8. Trifolium nanum Torr. Ann. Lyc. N. Y. 1: 35. 1824. Depressedcaespitose glabrous perennial, $2-5 \mathrm{~cm}$. high: leaflets small, oblanceolate, serrulate, strongly veined: peduncles very short, radical; flowers large, 1-3, dark purple: calyx-teeth broad, acute, shorter than the tube: ovary 4-5-ovuled.Mountains of Colorado and Utah.

9. Trifolium gymnocarpon Nutt. T. \& G. Fl. N. A. 1: 320. 1838. A small caespitose perennial with short, thick caudex: leaves mostly radical; leaflets oval-oblong, obtuse, serrate, glabrous above; stipules scarious, oval: stems very short, a little leafy at summit: peduncles equaling the leaves; heads 5-6-flowered: calyx-segments subulate, as long as the tube: pod hairy, reticulate, rugose, 1-2-seeded, stipitate.-Dry hills and plains; Colorado, Wyoming, and westward.

9a. Trifolium gymnocarpon subcaulescens (Gray) A. Nels. Leaflets cinereous-pubescent or slightly lanate beneath, quite glabrous above: otherwise like the species. ( $T$. subcaulescens Gray, Ives. Rep. 10. 1860; T. nemorale Greene, Pitt. 4: 136. 1900.)-Southwestern Colorado.

10. Trifolium Parryi Gray, Am. Journ. Sci. II. 33: 409. 1862. Acaulescent or nearly so, glabrous, the scape and petioles rather stout, $7-15 \mathrm{~cm}$. high: leaflets 15-25 mm. long, oblong to oblanceolate, sharply dentate: involucre scarious, 5-7-parted; heads large, many-flowered: calyx-teeth broadly subulate, as long as the tube: corolla purplish-red or rose-purple: pod sessile, 3-4-seeded. (T. montanense Rydb. Mem. N. Y. Bot. Gard. 1: 236. 1900 is a dwarf form from alpine summits in Montana; possibly distinct.) - Frequent in open spruce woods at high elevations throughout our mountains.

11. Trifolium dasyphyllum T. \& G. Fl. N. A. 1: 315. 1838. Densely caespitose: caudex short and thick, branching: peduncles and calyx silky with brownish hairs: leaflets lanceolate or oblong-lanceolate, acute or acuminate, entire; stipules membranaceous: heads globose, many-flowered, on a rather long radical peduncle: calyx-teeth subulate-setaceous, exceeding the tube: corolla bicolored, the standard ochroleucous, the wings and tip of the keel deep purple: pod 3-4-seeded. (T. bracteolatum Rydb. Bull. Torr. Bot. Club 28: 500. 1901.)-Frequent; at subalpine stations in our range.

12. Trifolium anemophilum Greene, Pitt. 4: 137. 1900. Closely allied to the preceding, depressed-caespitose and spreading: foliage and peduncles white with silvery-silky close indument: bracts of the involucre several, unequal, scarious-margined, linear-lanceolate: calyx-teeth often nearly twice as long as the tube: corolla purple; the standard broadly elliptic. (T. scariosum A. Nels. Bull. Torr. Bot. Club 29: 401. 1902; T. stenolobum Rydb. Bull. Torr. Bot. Club 28: 499. 1901.)-Naked limestone slopes, middle elevations; Wyoming and Colorado.

13. Trifolium attenuatum Greene, Pitt. 4: 137. 1900. Allied to the two foregoing, less caespitose, greener and nearly erect, 5-12 cm. high, rather sparsely silky-hairy: leaflets mostly linear, $2-4 \mathrm{~cm}$. long: peduncles and leaves subequal: involucral bracts short and relatively broad: calyx-teeth slender, variable: corolla deep red-purple; the standard acuminate and well surpassing the other petals: pedicels deflexed in age.-Among the rocks, at alpine stations; southern Colorado to New Mexico.

14. Trifolium andinum Nutt. T. \& G. Fl. N. A. 1: 314. 1838. Depressed, caespitose, and densely silky-canescent: caudex short, thick, and branching: leaves mostly radical; leaflets cuneate-oblong, apiculate; stipules broadly ovate, membranaceous: heads on very short scapes with two bract-like sheathing leaves at base: calyx densely villous; its teeth subulate, shorter than the tube: pod usually 1-seeded.-Dry barren hills; central Wyoming, 
15. Trifolium Fendleri Greene, Pitt. 3: 221. 1897. Low glabrous perennial, 8-20 cm. high, usually branched from the base: leaflets from obcordate to obovate-oblong, or sometimes oblong-lanceolate, minutely serrulate: heads slender-pedunculate; involucre many-lobed, somewhat lacerate: flowers from nearly white to rose-purple: calyx-tube 10-nerved, half as long as the slender teeth: pod turgid, stipitate, 2-seeded. T. involucratum.-Colorado to New Mexico.

16. Trifolium Wormsjoldii Lehm. Ind. Sem. Hort. Hamb. 17. 1829. Annual, biennial, or even seemingly perennial by slender rootstocks in some localities: stems simple or sparingly branched, erect or decumbent, $1-4 \mathrm{dm}$. long: leaflets obovate-oblong, obtuse, pectinate-denticulate, $2-3 \mathrm{~cm}$. long: heads hemispherical, $15-25 \mathrm{~mm}$. in diameter; the involucre broad, laciniatearistate: calyx-tube scarious, 10-nerved, much exceeded by the linear lobes: standard emarginate, purple. T. involucratum and T. pauciflorum in part; the former of these is Mexican and the latter is of the range to the northwest of ours.-Our species seems to extend from California (where it is perennial) into Colorado.

\section{ROBINIA L. LOCUST}

Trees or shrubs, often with prickly spines for stipules. Flowers showy, in hanging axillary racemes. Base of the leafstalks covering the buds of the next year. Calyx slightly 2-lipped. Standard large and rounded, turned back. Pod 2-valved, flat and thin, margined on one edge.

1. Robinia neo-mexicana Gray, Mem. Am. Acad. N. S. 5: 314. 1855. Shrub 1-2 m. high: stipular prickles subrecurved, sharp and stout; leaflets elliptical or oblong: peduncles and the short crowded racemes hispid with straight glanduliferous hairs: calyx finely hispid: corolla rose-color: pods glandular-hispid.-Southern Colorado and southward.

\section{ASTRAGALUS L.* Vetch}

Chiefly herbs (ours perennials), with odd pinnate leaves and spiked or racemed flowers. Calyx 5-toothed. Corolla usually long and narrow; standard narrow, equaling or exceeding the wings and blunt keel, its sides reflexed or spreading. Stamens diadelphous. Pod several-many-seeded, various, mostly turgid, one or both sutures usually projecting into the cell, either slightly or so as to divide the cavity lengthwise into two. Mature pods are usually necessary for certainty in determination of those species with which one is not familiar through long association.

Pods 2-celled, the septum perfect

Pods 1-celled, but the cell divided by an incomplete septum formed by the intrusion of the ventral or the dorsal suture, or by both being more or less intruded. (In Phaca septum sometimes wholly wanting.) . Pods 1-celled, no intrusion of either suture .

SERIES I.

* This large and difficult genus is richly represented in the Rocky Mountains. The following are the principal attempts to elaborate the North American species: Torrey and Gray, Fl. N. A. 1: 328-353; Gray, Proc. Am. Acad. 6: 188. 1866; Watson, King's Report, 435. 1871; E. P. Sheldon, Geol. and Nat. Hist. Surv. Minn. 1: 116-176. 1894. Recently Rydberg has given us a very helpful outline and key to the Colorado species (Bull. Torr. Bot. Club 32: 657. 1905), arranging them under seventeen genera. To each of the foregoing scholarly elaborations grateful acknowledgment is made. In the following treatment of the genus the aim has been merely to facilitate the recognition of species, and therefore the keys are largely artificial and the species not necessarily in the sequence of true relationship. In the interest of simplicity for the one who wishes to know plants by their names (if for no other reason), it has seemed wise not to follow the recent tendency to segregate a popularly recognizable genus. The name Astragalus will be retained for the whole rather than replaced by a considerable series of names representing groups that shade into each other so gradually that even with a list of their technical characters before one, there is often doubt as to the disposition to be made of some particular specimen. The proposed names, however, are very useful in the designation of sections, and Rydberg's service in indicating the boundaries of these and in enumerating the species under each is a valuable one. His paper has been heavily drawn upon for the present treatment of the genus. His generic names are given and the main grouping shown. 


\section{SERIES I}

Pods fleshy, somewhat plum-shaped, indehiscent (GEOPRUMNON). Flowers ochroleucous, the keel purple-tipped

Flowers purple, often pale .

Pods not fleshy, dehiscent.

Pod not inflated, membranous or leathery.

Pods ovate or oblong, leathery (ASTRAGALUS).

Plants densely villous-canescent throughout.

Pods glabrous .

Pods woolly

Plants glabrate or appressed strigose-pubescent.

Stems erect, 3-10 dm. high; flowers ochroleucous, spreading or reflexed in the dense spike

Stems ascending, 1-3 dm. high; flowers ascending, in $a^{\circ}$ short spike.

Stems stoutish; spike oblong; pod sessile.

Flowers purplish

Flowers ochroleucous

Stems weak, spikes capitate; porl stipitate

Pods ascending, broadly linear, flattened, membranous (HAMOSA).

Caulescent; greenish, sparsely hirsute

Acaulescent; silvery-silky

Pods conspicuously inflated, papery (ĊYSTIUM).

Nearly glabrous throughout

1. A. succulentus.

2. A. crassicarpus.

Subcinereous or strigillose

\section{SERIES II}

Pods deeply sulcate dorsally, this suture being thus deeply intruded and the pod obcordate in cross section (TIUM).

Stems rather stout, suberect; flowers yellowish; pods $3 \mathrm{~cm}$. or more long, exsert-stipitate, spreading or pencient.

Plant woolly-pubescent .

Plant appressed-pubescent or glabrate.

Leaflets obovate-oblong, glabrous above

Leaflets linear-oblong, glabrate on both faces

Stems slender, flexuous or spreading: flowers not yellow; pods less than $2 \mathrm{~cm}$. long, short-stipitate or subsessile.

Pods black-hairy; stipe as long as the calyx

Pods pale-pubescent; stipe short or wanting.

Pods coriaceous, mottled, incurved

Pods chartaceous, deflexed

Pods slightly if at all sulcate dorsally, one or both of the sutures in:truded but rarely deeply so (the sections $X$ ylophacos and Phaca quite variable).

Pods membranous, coriaceous or woody, not conspicuously inflated.

Pods membranous (ATELOPHRAGMA).

Pods exsert stipitate.

Leaves cinereous-pubescent on both faces

Leaves glabrous or minutely appresse $\mathrm{j}$-pubescent beneat'i.

i Pods glabrous

Pods black-hairy :

Pods sessile or nearly so.

Pods reflexed.

Pods ascending

Pods coriaceous or woody.

Pods stipitate; leaves unifoliolate (JONESIELLA) .

Pods sessile; leaves pinnate.

Tall glabrous perennial; calyx-tube not longer than its lobes (PHACOPSIS)

Low caespitose perennials; the calyx-tube longer than its lobes (XYLOPHACOS).

Pods coriaceous, more or less pubescent but not woolly. Herbage appressed silvery-silky.

Pods obtuse at base.

Pods elliptical, straight

Pods curved or incurved at tip.

Pods not noticeably veined
Pods transversely veined and finely reticulated Pods tapering to both ends

Herbage glabrate or villous with loose spreading hairs.

Leaves glabrous, at least above.

Pods sessile

Pods stipitate

Leaves softly villous.

\section{A. Drummondii.}

14. A. scopulorum.

15. A. racemosus.

16. A. alpinus.

17. A. sparsiflorus.

18. A. desperatus.

19. A. aboriginorum.

20. A. glabriusculus.

21. A. Macounii.

22. A. elegans.

23. A. Brandegei.

24. A. asclepiadoides.

\section{A. Pattersonii.}

26. A. missouriensis.

27. A. Shortianus.

28. A. chamaeluce.

29. A. amphioxus.

30. A. cibarus.

31. A. Beckwithii, 
Flowers ochroleucous

Flowers violet

Pods coriaceous, strikingly woolly-pubescent. Leaflets 9-17.

Leaflets oblong; flowers ochroleucous

Leaflets suborbicular; flowers purple

Leaflets 3-7; flowers ochroleucous

Pods strongly inflated, papery (PHACA).

Stems evident, usually more than $1 \mathrm{dm}$. long (except in No. 40). Leaflets long-linear or filiform; pods mottled

Leaflets short-linear to suborbicular.

Pods quite glabrous, or glabrate.

Pods sessile; stems low.

Leaflets elliptic to orbicular

Pods stipitate.

Stemless or nearly so

Pods pubescent.

Stems glabrous

Stems hirsute.

Plant perennial

Plant annual

Stems wanting or very short, or prostrate-spreading.

Dwarf or prostrate; leaflets short (4-8 mm.).

Pods conspicuously mottled

Pods not mottled.

Peduncles 1-3-flowered

Peduncles 5-12-flowered

More robust, sometimes caulescent.

Leaflets glabrous above

Racemes sessile, often elongating in fruit

Raceme on a peduncle surpassing the leaves
Leaflets oblong to linear.

Stems tall

Leaflets pubescent on both faces.

32. A. Parryi.

33. A. glareosus.

34. A. Purshii.

35. A. utahensis.

36. A. Newberryi.

37. A. ceramicus.

38. A. Eastwoodiae.

39 A. artipes

40. A. megacarpus. 41. A. americanus.

42. A. Wetherillii.

43. A. ceru'ssatus. 44. A. Geyeri.

45. A. jejunus

46. A. humillimus.

47. A. microcystis.

48. A. leptaleus.

49. A. elatiocarpus.

50. A. lotiflorus.

\section{SERIES III}

Leaves pinnate or in No. 60 partly simple.

Pods conspicuously bisulcate ventrally (DIHOLCOS).

Flowers purple or violet

Flowers white or ochroleucous

Pods various but not bisulcate.

Pods with a thickened fleshy epicarp; leaves pectinately lobed rather than pinnate, the leaflets being obscurely articulated (CTENOPHYLLUM).

Divisions of the leaves narrowly linear; pods pendent

Divisions of the leaves broadly linear; pods ascending.

Pods without fleshy epicarp and leaflets with evident articulations.

Pods coriaceous or woody; often flattened dorsally.

Calyx cylindrical; flowers large (refer to group $X$ ylophacos). Calyx campanulate; flowers small.

Corolla yellow; calyx-tube as long as its lobes (CNEMIDOPHACOS)

Corolla purple; calyx-tube longer than its lobes (MICROPHACOS).

Stems virgate; pods concave dorsally

Stems diffuse; pods barely flattened dorsally

Pods membranous, usually flattened laterally and the sutures prominent; in Nos. 69,70 , and 71 nearly terete.

Leaves spinulose-tipped; pods 1-2-seeded (KËNTROPHYTA).

Flowers ochroleucous, or tinged with violet; herbage somewhat hoary-pubescent

Flowers purple; herbage sparsely hirsute :

Leaves not spinulose-tipped; pods several-seeded (HOMALOBUS).

Leaves simple, or rarely 3 -foliolate in part (see also No. 67).

Raceme several-flowered

Raceme 1-3-flowered

Leaves pinnate, usually with many leaflets.

Pods compressed; stipules connate.

Pods stipitate

Pods sessile.

Plants low (7-20 cm.), usually tufted.

Leaflets elliptic to linear, glabrate or minutely pubescent.

Leaves and pods more or less pubescent
51. A. bisulcatus.

52. A. Haydenianus.

53. A. pectinatus.

54. A. Grayi.

55. A. flaviflorus.

56. A. gracilis.

58. A. viridis.

59. A. aculeatus.

60. A. caespitosus.

62. A. tenellus

63. A. campestria,
57. A. microlobus.

61. A. simplicifolius, 
Leaves glabrate; pods glabrous

Leaflets linear to filiform, cinereous or silky; pod broad-linear, hoary or silky pubescent. Leaflets linear

Leaflets lance-oblong

Plants taller $(2-5 \mathrm{dm}$.), scarcely tufted.

Stems rush-like; lateral leaflets linear, often wanting .

Stems leafy; leaflets oblong-linear

Pods subterete; stipules distinct or nearly so.

Calyx gibbous at base; leaflets oblong.

Calyx not gibbous at base.

Stems ascending or spreading.

Green; racemes elongated; pods $15-25 \mathrm{~mm}$. long 70. A. flexuosus.

Cinereous; raceme subcapitate; pods 7-10 $\mathrm{mm}$. long

Stems erect.

Pods sessile

Pods large, exsert-stipitate

Low caespitose plants with palmately 3 -foliolate leaves (OROPHACA)

Flowers ochroleucous

Flowers purple.

Raceme sessile, shorter than the leaves

Raceme short-peduncled, exceeding the leaves

64. A. hylophilus.

65. A. decumbens.

66. A. pauciflorus.

67. A. diversifolius.

68. A. Wingatensis.

69. A. Hallii.

71. A. Bodinii.

72. A. Fendleri.

73. A. lonchocarpus.

74. A. triphyllus.

75. A. tridactylicus.

76. A. sericoleucus.

1. Astragalus succulentus Rich. Frank. Journ. 746. 1823. Stems prostratespreading from the crown of a woody caudex, 1-3 dm. long, finely strigose: leaflets green, 15-25, 10-15 mm. long, elliptic-oblong, obtuse: raceme short, on a peduncle $3-10 \mathrm{~cm}$. long: calyx slightly gibbous, somewhat dark-strigose especially on the teeth: corolla ochroleucous, with purple-tipped keel, 20-35 $\mathrm{mm}$. long; the narrow standard deeply notched at apex: pod 2-celled, fleshy, indehiscent, plum-shaped and about $2 \mathrm{~cm}$. long at maturity. A. caryocarpus in part. (A. prunifer Rydb. Mem. N. Y. Bot. Gard. 1: 239. 1900.)-Plains and foothills; Colorado to Canada.

2. Astragalus crassicarpus Nutt. in Fras. Cat. 1: 1813. Size and habit of the preceding, pale and minutely appressed-pubescent: leaflets narrowly oblong: flowers in a short spike-like raceme: corolla violet-purple: pod glabrous, ovate-globular, more or less abruptly pointed, 20-25 $\mathrm{mm}$. long, very thick-walled, succulent but cellular or corky when dry. A. caryocarpus in part.-Colorado eastward on the plains and thence to Minnesota and Texas.

3. Astragalus mollissimus Torr. Ann. Lyc. N. Y. 2: 178. 1828. Stems rather stout, mostly ascending from a decumbent base, the whole plant densely silky-villous and tomentose: leaflets 17-29, ovate-oblong: spikes dense, on elongated peduncles: calyx tubular: corolla violet, $12-20 \mathrm{~mm}$. long: pod glabrous, dry, coriaceous, dehiscent, narrowly oblong, obcompressed and sulcate at both sutures, at length incurved, $10-18 \mathrm{~mm}$. long. ( $A$. anisus Jones, Zoe 4: 34. 1894.) - Wyoming and Nebraska to Kansas and New Mexico; one of the several Loco weeds.

4. Astragalus Bigelovii Gray, Pl. Wright. 2: 42. 1853. Densely lanatevillous throughout: stems stoutish, ascending, 1-3 dm. high: leaflets 15-25, oval to obovate-oblong, 10-15 mm. long: spike crowded, long-peduncled: calyx-tube cylindrical, villous: corolla purple, $12-16 \mathrm{~mm}$. long: pod turgid, ovate, acute, not sulcate at the sutures, densely lanate.-Colorado to New Mexico and Texas.

5. Astragalus carolinianus L. Sp. Pl. 756. 1853. A glabrate or puberulent perennial: stems erect, 3-10 dm. high, often striate: leaflets 11-29, oval to oblong, usually glabrous above and white-pubescent beneath: flowers 10-15 mm. long, becoming horizontal or reflexed: spikes long and dense, peduncled: calyx cylindrical, with subulate teeth: corolla ochroleucous or greenish: pod oblong or elliptical, nearly erect, 10-15 $\mathrm{mm}$. long, glabrous, 2-celled. (A. oreophilus Rydb. Bull. Torr. Bot. Club 31: 561. 1904, and A. coloradensis Rydb. seem to be merely variations of the widely disseminated $A$. canadensis L., which may or may not be specifically distinct from A. carolinianus L.)

5a. Astragalus carolinianus Mortonii Wats. King's Rep. 68. 1871. Usu- 
ally lower: leaflets 13-17: pod somewhat pubescent and usually evidently sulcate dorsally.- Extending from Colorado to the far northwest.

6. Astragalus nitidus Dougl. Hook. Fl. Bor. Am. 1: 149. 1834. Cinereous with minute appressed pubescence, or glabrate: stems ascending or decumbent, rather stout, 1-4 cm. long: leaflets 15-21, oblong or narrower, 12-18 mm. long: spike dense, oblong or subcapitate; flowers purplish, ascending: calyxtube slightly villous, long-campanulate; the setaceous teeth only half as long as the tube: pod ccriaceous, sessile, pubescent, straight, ascending, ovate-oblong, somewhat triangular-compressed, with a dorsal sulcus, 2-celled. $A$. adsurgens. (A. adsurgens Pall. is Asian; A. terminalis Wats. Proc. Am. Acad. 17: 370. 1882.)-From Colorado to Manitoba and Oregon.

7. Astragalus sulphurescens Rydb. Bull. Torr. Bot. Club 28: 36. 1901. Glabrate, pale green and somewhat caespitose: stems ascending, 2-3 dm. high: leaflets 13-19, elliptic to oblong, mostly obtuse, 15-25 mm. long: 'spike dense, rather long and cylindrical; flowers ascending: calyx white-strigose, with scattered black hairs, its lobes as long as the tube: corolla light-yellow; the banner yellow and longer than the wings: pods with the dorsal suture inflexed (obcordate in cross section), strigose with black hairs.-Not infrequent; Colorado.

8. Astragalus hypoglottis L. Mant. 2: 274. 1771. Loosely pubescent or glabrate, branched from the base: the stems slender, diffusely procumbent or ascending, 1-2 dm. long: stipules rather large, somewhat sheathing; leaflets 13-21, oblong, obtuse or retuse: flowers crowded, capitate: corolla violet or purplish, 10-12 mm. long: pod triangular-compressed, sulcate dorsally, silkyvillous, sometimes profusely so, 6-8-seeded. (A. goniatus Nutt. T. \& G. Fl. N. Am. 1: 330. 1838; A. virgultulus Sheld. Bull. Geol. \& Nat. Hist. Surv. Minn. 9: 23. 1894.) -In grassy places; New Mexico to Washington and Hudson Bay.

8a. Astragalus hy poglottis bracteatus Osterh. Bull. Torr. Bot. Club 24: 256. 1899. Flowers white or ochroleucous; the bracts large and conspicuous, green, spatulate.-Colorado and Wyoming.

9. Astragalus Nuttallianus DC. Prodr. 2: 289. 1825. Stems ascending or erect, 7.5 to $45 \mathrm{~cm}$. high, minutely pubescent: leaflets 11-15, elliptical or oblong, obtuse or retuse: flowers few, subcapitate or sometimes solitary on slender peduncles, light purple, small, $4 \mathrm{~mm}$. long: pod coriaceous, linear, glabrous, subcompressed, incurved near the base, sulcate dorsally, reticulated.- Southern Colorado to Texas and California.

10. Astragalus calycosus Torr. in Wats. King's Rep. 66. 1871. Silverysericeous and nearly acaulescent, with short branched caudex; the leaves and peduncles spreading: leaflets $9-13$, oblong or ovate, $3-10 \mathrm{~mm}$. long, usually subacute: peduncles basal, somewhat surpassing the leaves: calyx campanulate; the tube longer than its triangular teeth: corolla ochroleucous and purplish, or purplish throughout: pod sessile, pubescent, chartaceous, straight, subcompressed, slightly sulcate dorsally, 2-celled, about 10 -seeded. ( $A$ brevicaulis A. Nels. Bull. Torr. Bot. Club 25: 9. 1898.)-Gravelly ridges and slopes; Wyoming to Nevada.

10a. Astragalus calycosus scaposus Jones, Zoe 4: 26. 1894. Stouter and with longer scapes: calyx-lobes very short: the corolla wings scarcely cleft. (A. scaposus Gray; A. candicans Greene.)-Southwestern Colorado to Arizona.

11. Astragalus diphysus Gray, Pl. Fendl. 34. 1849. Stems clustered on the crown of a semifleshy root, spreading-assurgent, 1-3 dm. long, subglabrous: leaflets 15-21, somewhat fleshy, obovate-oblong, slightly retuse: peduncles as long as the leaves: flowers in a dense short spike: calyx shortcylindric: corolla blue or purple or rarely nearly white: pod membranous, inflated, ovate-acuminate, somewhat didymous, $18-25 \mathrm{~mm}$. long, incurved in age: seeds many, shining.-Utah and Colorado to New Mexico.

12. Astragalus ineptus Gray, Proc. Am. Acad. 6: 525. 1868. Cinereouspubescent or glabrate: stems spreading from the crown of the perennial root, branched, 1-4 dm. long: leaflets 11-19, oblong, emarginate, glabrous above, a 
fine lax pubescence beneath: spike short; the flowers subsessile, 10-12 mm. long: corolla white or ochroleucous; the wings and keel often purple-tipped: pod membranous, inflated, ovate, 2-celled, more or less pubescent, about $2 \mathrm{~cm}$. long.-The northern counterpart of A. Fremontii T. \& G. of the southwestern deserts; Wyoming, Utah, and probably northward.

13. Astragalus Drummondii Dougl. Hook. Fl. Bor. Am. 1: 153. 1833. Loosely woolly-pubescent: stems growing in clumps, very leafy, suberect, 3-5 dm. high: leaflets 17-31, oblong to oblanceolate, obtuse, 1-2 cm. long: calyx black-hairy, its teeth shorter than the tube: flowers rather large, white or slightly yellowish, in long crowded racemes: pod long-linear, terete, with a deep narrow sulcus, obcordate in cross section, 1-celled but the dorsal suture intruded.-Frequent on gravelly slopes.

14. Astragalus scopulorum Porter, Fl. Col. 24. 1874. Puberulent with appressed hairs: stems ascending, 2-4 dm. high, branching: leaflets 17-27, obovate or oblong, acute, glabrous above: peduncles longer than the leaves; the racemes loosely many-flowered: calyx gibbous at base, pilose with blackish hairs, the subulate teeth about half as long as the cylindrical tube: corolla yellow or yellowish, 15-20 mm. long: pod stipitate, $2-3 \mathrm{~cm}$. long, pendulous, sharply 3-angled, the dorsal suture salient, with an acute sulcus on each side intruded halfway to the ventral, at length arcuate.-Colorado.

15. Astragalus racemosus Pursh, Fl. Am. Sept. 740. 1814. Appressedpubescent or glabrate: stem 3-6 dm. high, rather stout, very leafy: leaflets 17-23, mostly linear-oblong, mucronate, 12-15 mm. long: peduncles about as long as the leaves, loosely many-flowered; the flowers nodding and somewhat secund: calyx strongly gibbous, puberulent: corolla ochroleucous, 15-18 mm. long: pod lance-oblong, glabrous, 3 -angled, 1-celled, broadly sulcate and with the dorsal suture somewhat intruded.- Kansas to Utah and Northwest Territory.

16. Astragalus alpinus L. Sp. Pl. 760. 1753. Glabrous or subpubescent: stems slender, diffuse, 5-15 cm. long: leaflets 13-25, oval or elliptic, obtuse or retuse: peduncles mostly surpassing the leaves; the flowers few, subcapitate: calyx campanulate: corolla violet-purple, or pale with purple- or blue-tipped keel: pod narrowly oblong, short-acuminate, black-pubescent, triangular-turgid, deeply sulcate dorsally, its stipe as long as or longer than the calyx. [A.giganteus (Pall.) Sheld. is merely the larger specimens.)-From Colorado to Manitoba and thence across the continent; also Europe and Asia.

17. Astragalus sparsiflorus Gray, Proc. Am. Acad. 6: 205. 1866. Glabrate or somewhat appressed-pilose: stems slender, 2-4 dm. long, branched: leaflets 9-13, obovate or suborbicular, 4-5 mm. long: peduncles 3-10-flowered: corolla white or violet-tinged, 5-6 mm. long, the standard and wings much longer than the incurved keel: pod small, incurved, strigillose, very shortstipitate, the dorsal suture intruded, the ventral suture acute and prominent. - Colorado.

18. Astragalus desperatus Jones, Zoe 2: 243. 1891. Strigose-pubescent throughout: caespitose from a woody root: stipules scarious and imbricated; leaflets 13-17, oval to orbicular, 3-7 $\mathrm{mm}$. long: peduncles exceeding the leaves: flowers many, at first subcapitate, later racemose, soon reflexed, purple, 10-12 mm. long: pod sessile, reflexed, thin-chartaceous, falcate, acute, 10-12 mm. long, cordate in cross section by the intrusion of the ventral suture, long-hairy.-Utah and Colorado.

19. Astragalus aboriginorum Rich. Frank. Journ. 736. 1823. Hoarypubescent or subvillous: stems numerous, ascending, rigid, 1-3 dm. high: stipules triangular, mostly free; leaflets $7-13$, linear to oblong-lanceolate, acute: peduncles exceeding the leaves, with small flowers in a compact raceme: the filiform calyx-teeth not equaling the tube: corolla white or tinged with violet: pod long-stipitate, reflexed, somewhat membranous, laterally subcompressed, straight dorsally, the ventral suture arcuate, 10-15-ovuled.-Mountains of Colorado and northward throughout W. British America.

20. Astragalus glabriusculus (Hook.) Gray, Proc. Am. Acad. 6: 204. 1866. Much like the last: green, the leaflets glabrous above and nearly so 
beneath, thinner, linear-lanceolate: pod lanceolate, subfalcate; the stipe 2-3 times longer than the calyx. - Same range as the last.

21. Astragalus Macounii Rydb. Mem. N. Y. Bot. Gard. 1: 243. 1900. Finely puberulent, rather slender, 3-5 dm. high: stipules free, ovate-lanceolate; leaflets thin, 9-17, oblong or oval, obtuse, 15-25 mm. long: peduncle surpassing the leaves; raceme 4-10 cm. long: calyx black-hairy, its linear-subulate lobes very short: corolla ochroleucous, tinged with purple: pod membranous, black-hairy, acute at both ends, neither suture sulcate but the dorsal with a narrow inflexed edge. A. Robbinsii occidentalis.-Colorado to Montana.

22. Astragalus elegans (Hook.) Sheld. Bull. Geol. \& Nat. Hist. Surv. Minn. 9: 154. 1894. Subcinereous-puberulent: stems 3-5 dm. high, slender and somewhat branched: leaflets 9-17, oval, oblong, or narrower; stipules ovate, acute: flowers purple, 5-7 mm. long, in long spike-like secund racemes: pod sessile, ellipsoid, 1-celled, pendent, slightly inflated, obtuse but apiculate, 4-6 mm. long, black-pubescent. A. oroboides americana. (A. Shearis Rydb. Bull. Torr. Bot. Club 31: 562. 1904.)-Frequent near mountain streams; from Wyoming into British America.

23. Astragalus Brandegei Porter, Fl. Colo. 24. 1874. Canescent with appressed hairs: stems several from a woody base, assurgent, 1-2 dm. high: leaflets about 11, the pairs distant, linear, obtuse, involute, glabrous above, 10-15 mm. long: peduncles much longer than the leaves; flowers small, in a loose raceme: calyx turbinate, hairy; the subulate teeth longer than the tube: corolla white or yellowish, tinged with purple; the standard reflexed: pod turgid, obovoid, with a shallow dorsal sulcus, short-stipitate and abruptly short-pointed, 8-14 mm. long, hairy.-Colorado.

24. Astragalus asclepiadoides Jones, Zoe 2: 238. 1891. Glabrous and glaucous throughout: stems single or several from the woody root, $3-5 \mathrm{dm}$. high: leaves simple, sessile, ovate-orbicular, cordate, often retuse, thick, 3-5 cm. long: racemes (spikes) axillary, 6-8-flowered: calyx cylindric, with some scattered black hairs: corolla ochroleucous; the keel purple-tipped: pod 1-celled, coriaceous, oblong-ovate, acute, stipitate.-Sandbars; Utah to western Colorado.

25. Astragalus Pattersonii Gray, Brand. Fl. S. W. Colo. 285. 1876. Glabrous or sparsely appressed-puberulent: stems stout, several from the crown, nearly erect, often branched: leaflets oblong or cuneate-linear, obtuse or retuse: racemes mostly elongated, loose: calyx narrowly campanulate, its linear recurved lobes shorter than the tube: corolla white, the keel sometimes purplish-tipped: pod glabrous, elliptic-oblong, abruptly acute at apex and contracted within the calyx, becoming somewhat stipe-like.-Southwestern Colorado and Utah.

26. Astragalus missouriensis Nutt. Gen. 2: 99. 1818. Short-caulescent, hoary with a closely appressed silky-pubescence: leaflets $5-15$, oblong, elliptic or obovate: flowers few, capitate or spicate, 10-16 $\mathrm{mm}$. long, violet: calyx oblong, the teeth very slender: pod oblong, $2.5 \mathrm{~cm}$. long, acute, obtuse at base, pubescent, nearly straight, obcompressed or obcompressedtriangular, depressed on the back and the ventral suture more or less prominent, transversely rugulose.-Throughout our range, east on the plains and south to Texas.

27. Astragalus Shortianus Nutt. in T. \& G. Fl. N. Am. 1: 331. 1838. Usually subacaulescent, silky-canescent with a very closely appressed pubescence: leaflets obovate or ovate, 12-18 mm. long: peduncles scape-like, commonly shorter than the leaves: calyx $12 \mathrm{~mm}$. long, cylindric, teeth shorter than the tube: corolla violet or blue, rather large and showy: pod 3-5 cm. long, ovate or ovate-lanceolate, thick, coriaceous, obcompressed, dorsal suture intruded, approaching the ventral, transversely rugulose, pointed and strongly arcuate, more or less pubescent. (A. cyaneus Gray, Pl. Fendl. 34. 1854.) -Wyoming to New Mexico.

28. Astragalus chamaeluce Gray, Ives Rep. 10. 1861. Silvery-canescent, with a dense silky-pubescence: stems numerous, short $(2-5 \mathrm{~cm}$.), prostrate or nearly acaulescent: leaflets $5-13$, from oval to oblong, $4-8 \mathrm{~mm}$. long: pe- 
duncles shorter than the leaves, slender, 3-8-flowered: calyx-teeth much shorter than the cylindrical tube: corolla light violet, $14-18 \mathrm{~mm}$. long: pod 1-2 cm. long, thick, ccriaceous, sessile, ovate-oblong, acuminate, somewhat arcuate, sometimes sulcate ventrally, rugosely reticulate and subpubescent, many-seeded. (Phaca pygmaea Nutt.; A. uintensis Jones.)-New Mexico and Arizona to Wyoming and Idaho.

29. Astragalus amphioxus Gray, Proc. Am. Acad. 13: 366. 1878. Resembling both $A$. missouriensis and $A$. Shortianus except in the pods which are acute at both ends, the base so much narrowed that it often seems stipitate in the calyx, texture much thinner, fore-and-aft compression greater, and moderately curved in the shorter pods, but strongly so in the longer ones: leaflets more apt to be oblong and acute.-Colorado to Texas and Arizona.

30. Astragalus cibarus Sheld. Bull. Geol. \& Nat. Hist. Surv. Minn. 9: 149. 1894. Glabrate or sparsely pubescent: stems several from the crown, decumbent-spreading, 1.5-3 dm. long: leaflets 11-17, suborbicular to oblong, obtuse or retuse; stipules subfoliaceous: flowers subcapitate, 12-15 mm. long: calyx oblong-campanulate, black-strigose; the narrow teeth one third as long as the tube: corolla ochroleucous and purple: pod coriaceous, narrowly oblong, pointed at both ends, glabrous and transversely rugose-veined at maturity, the ventral suture strongly introflexed.-Wyoming to Utah and Idaho.

31. Astragalus Beckwithii T. \& G. Pac. R. R. Rep. 2: 120. 1855. Glabrous or nearly so: stems diffusely spreading, 3-6 dm. long: stipules adnate; leaflets 13-25, broadly oval, 10-14 mm. long: flowers ochroleucous, in a short loose raceme: calyx-tube glabrous, campanulate; the subulate teeth subequal: pod 2-3 cm. long, glabrous, transversely rugulose, coriaceous, stipitate, somewhat obcompressed, flattened dorsally with the suture slightly intruded, bisulcate ventrally with the prominent suture acutely margined, manyseeded.-Wyoming and Colorado to Nevada.

32. Astragalus Parryi Gray, Am. Journ. Sci. II. 33: 410. 1862. Stems short and prostrate, villous with loose spreading hairs: leaflets oblong, elliptic, or obovate: flowers few, loosely subcapitate on rather short peduncles, whitish or yellowish, tinged with purple, 12-16 $\mathrm{mm}$. long: calyx-teeth half shorter than the cylindric tube: pod pubescent, oblong-lanceolate, $2.5 \mathrm{~cm}$. long or more, arched or at length circinate, strongly obcompressed and rugulose, both sutures sulcately impressed, contiguous.-Wyoming to Texas.

33. Astragalus glareosus Dougl. Hook. Fl. Bor. Am. 1: 152. 1833. Villous silky with white incumbent hairs: depressed-caespitose, the stems short or nearly wanting: leaflets 11-15, linear-oblong: peduncles not exceeding the leaves, few-flowered: calyx-tube narrowly cylindric, with teeth one third as long: corolla narrow, bright violet: pod oblong-ovate, attenuate above, incurved, silky-pubescent, becoming glabrate. (A. argophyllus Nutt.)-Colorado to Idaho.

34. Astragalus Purshii Dougl. Hook. Fl. Bor. Am. 1: 151. 1833. Canescent with a long and dense woolly pubescence, nearly acaulescent: leaflets 9-17, lanceolate or oblong, 6-10 $\mathrm{mm}$. long: peduncles 5-12 cm. long: flowers rather large, about $2 \mathrm{~cm}$. long, ochroleucous, the keel mostly purple-tipped: pod coriaceous, very densely white-woolly pubescent, somewhat arcuate, about $2 \mathrm{~cm}$. long.-Colorado to Montana and west to Nevada.

35. Astragalus utahensis T. \& G., Gray, Proc. Am. Acad. 6: 213. 1866. Resembling the preceding but subcaulescent, the short stems prostrate: pubescence dense, woolly, appressed: leaves suborbicular, 4-7. mm. long: flowers dark purple: pod moderately sulcate at the sutures, inordinately white-woolly.-Western Wyoming and Colorado to Nevada.

36. Astragalus Newberryi Gray, Proc. Am. Acad. 12: 55. 1877. Nearly acaulescent, silvery-silky; the stems very short, crowded on the crown of a deep-set elongated root: leaflets $3-7$, broadly to narrowly obovate, approximate: peduncles few-flowered: corolla large, ochroleucous: pods sessile, turgid, ovate-oblong, the broad point laterally compressed, villous.-Western Colorado to Utah and Arizona. 
37. Astragalus ceramicus Sheld. 1. c. 19. Sparingly hoary with a loose silky pubescence: roots filiform: stipules subulate, rigid, persistent, connate at base; leaflets 7-15, narrowly linear or filiform, 1-5 cm. long, some or most of them usually abortive: flowers few, rather small; keel with the inflexed apex somewhat produced, pale rose-color: pod 12-30 $\mathrm{mm}$. long, mottled with purple blotches, ovoid, short-stipitate, stipe equaling the calyx, barely pointed, pendent. A. pictus (name untenable). The varieties often listed seem to have no constant characters.-Idaho to New Mexico.

38. Astragalus Eastwoodiae (Jones) Rydb. Bull. Torr. Bot. Club 32: 664 . 1905. Densely branched from the base, $10-15 \mathrm{~cm}$. high, glabrous throughout: leaflets $15-25$, mostly narrowly oblanceolate, 4-8 $\mathrm{mm}$. long: peduncles as long as the leaves, stout, rather few-flowered: calyx-teeth one fourth as long as the tube: corolla purple, $16-20 \mathrm{~mm}$. long: pods oblong-oval, contracted at both ends, very acute, ventrally sulcate, with the suture intruded, chartaceous and inflated, reddish but not spotted, 15-18 mm. long.-Colorado to Utah.

39. Astragalus artipes Gray, Proc. Am. Acad. 13: 370. 1878. Glabrous, from a perennial caudex: stipules adnate; leaflets 11-17, oblong to oval, about $8 \mathrm{~mm}$. long: peduncles shorter than the leaves, its few flowers crowded; the pedicels suberect, shorter than the calyx: calyx campanulate; its longsubulate teeth as long as the tube: corolla white and purple: pod ovate, bladdery-inflated,. mottled with purple, attenuated into a slender stipe which is articulated above the calyx.-Western Wyoming to Colorado and Arizona.

40. Astragalus megacarpus (Nutt.) Gray, Proc. Am. Acad. 6: 215. 1866. Glabrous, somewhat caespitose and nearly stemless: leaflets 9-13, broadly oval or ovate, usually emarginate: scape 3-6-flowered, much shorter than the leaves: flowers ochroleucous or whitish, $20-25 \mathrm{~mm}$. long: calyx cylindrical; its subulate teeth long: pod ovate-oblong, acuminate, very obtuse at base, obscurely and sparsely strigillose, 4-6 cm. long; the stipe very short.-Low saline soils; Wyoming and Colorado to Utah.

41. Astragalus americanus (Hook.) Jones, Contrib. W. Bot. 8: 8. 1898. Nearly or quite glabrous, rather tall and leafy: leaflets 13-19, ovate or ellipticoblong: peduncles equaling the leaves; the racemes many-flowered; flowers white: pod with a stipe equaling or exceeding the calyx, acute at each end, glabrous or shining. [Phaca americana (Hook.) Rydb. Mem. N. Y. Bot. Gard. 1: 245. 1900.]-Colorado to arctic America.

42. Astragalus Wetherillii Jones, Zoe 4: 34. 1903. Glabrous or sparsely pubescent above: stems crowded on the crown of a woody root, $3-5 \mathrm{dm}$. high: leaflets 9-19, oval to obovate, obtuse or retuse: peduncles short, capitately few-flowered: calyx nigrescent, with short hairs: corolla white, with pinktipped standard and keel: pods articulated to a short stipe, inflated, obliquely ovate, the base rounded and the apex short-acuminate, sulcate ventrally only, the suture intruded, 15-25 $\mathrm{mm}$. long, not pendulous or spotted.-Colorado.

43. Astragalus cerussatus Sheld. 1. c. 139. Loosely pubescent throughout; stems erect or spreading, 2-3 dm. high: leaflets 9-17, narrowly oblong, emarginate, 6-12 mm. long: peduncles slender, exceeding the leaves, loosely 3-5-flowered: calyx campanulate, the filiform teeth spreading and longer than the tube: corolla ochroleucous, the keel purple-tipped: pod thin-chartaceous, inflated, ovate-oblong, finely reticulated, often purplish but not mottled, nearly glabrous, the ventral suture intruded nearly to the middle.-Colorado.

44. Astragalus Geyeri Gray, 1. c. 214. A low nearly simple annual, 1-2 dm. high; subcanescent with appressed pubescence: leaflets linear to oblong, obtuse, glabrous above: peduncles shorter than the leaves, 3-5-flowered: calyx-teeth subulate, as long as the campanulate tube: corolla ochroleucous, about $6 \mathrm{~mm}$. long: pod membranous, inflated, ovate-lunate with an incurved acumination, sessile, finely reticulated and not mottled. (A. triflorus Gray, probably, as to the Colorado specimens.) - From Wyoming to Idaho and Nevada. 
45. Astragalus jejunus Wats. King's Rep. 73. 1871. A low, many-stemmed dwarf perennial, with short-branched woody caudex covered with imbricated persistent stipules, usually sparsely and minutely hoary pubescent: leaflets 9-15, linear to oblong, 3-5 mm. long: peduncles shorter than the leaves, 2-3-flowered: calyx-teeth scarcely as long as the campanulate tube: corolla ochroleucous: pod membranous, inflated, globose, sessile, glabrous, wholly 1-celled, 8-10 mm. in diameter.-Dry sterile hills and ridges; Wyoming and Utah.

46. Astragalus humillimus Gray, Proc. Am. Acad. 12: 57. 1877. Habit of the last, but much more dwarf and condensed: stums $2-3 \mathrm{~cm}$. long, with the scarious, coalescent stipules imbricated and petioles persistent and spinescent: leaflets 7-11, oblong, canescent, with revolute margins: peduncles 1-3-flowered: corolla pale: pod ovate, 12-15 mm. long, coriaceous, with a white pubescence.-Often choked in drifting sand; Mesa Verde, southwestern Colorado.

47. Astragalus microcystis Gray, Proc. Am. Acad. 6: 220. 1866. A small diffuse or procumbent ashy-pubescent perennial, with slender stems from a woody root: leaflets $9-13$, oblong-lanceolate, obtuse: racemes 5-12-flowered: calyx pilose, the short teeth as long as the campanulate tube: corolla viclet or varying to white; the banner deeply emarginate: pod thin-membranous, ovate-globose, gray-pubescent, about $6 \mathrm{~mm}$. long.-From Wyoming to Washington.

48. Astragalus leptaleus Gray, 1. c. Nearly glabrous; the slender stems ascending: leaflets 13-23, lanceolate-linear to oblong, acute: peduncles shorter than the leaves, 2-4-flowered: calyx blackish-pilose, campanulate: corolla white; the banner emarginate; the keel purple-tipped: pod chartaceous, ovate or oval, puberulent, 7-9 mm. long. (Phaca pauciflora Nutt.)-Colorado and Wyoming.

49. Astragalus elatiocarpus Sheld. 1. c. 20. Caespitose and acaulescent, more or less depressed, long-pubescent: leaves suberect, $5-13 \mathrm{~cm}$. long; leaflets $9-13$, broadly lanceolate, acute or rarely obtuse, $10-18 \mathrm{~mm}$. long; stipules ovate, acuminate: raceme at first sessile, the peduncle elongating in fruit: calyx campanulate, the tube shorter than the teeth: corolla yellow, the keel inflexed: pod ovate-acuminate, incurved, woody, white with spreading hairs, 18-25 mm. long.-Texas to Wyoming and Minnesota.

50. Astragalus lotililorus Hook. Fl. Bor. Am. 1: 152. 1833. Very similar to the preceding: leaves shorter: peduncles $6-8 \mathrm{~cm}$. long, usually exceeding the leaves, capitately 6-10-flowered: pod oblong-ovate, coriaceous, straight, the dorsal suture impressed.-Texas to Wyoming and Minnesota.

51. Astragalus bisulcatus (Hook.) Gray, Pac. R. R. Rep. 12: 42. 1860. Strigillose-puberulent: stems erect, often densely tufted in large clumps, rather stout, 3-7 dm. high: stipules distinct; leaflets oblong, of ten narrow, the lowest near the stem: flowers violet, in dense spike-like racemes, medium sized, spreading or pendent; the keel nearly straight: calyx-teeth setaceous, nearly as long as the campanulate tube: pod coriaceous, 10-12 mm. long, shortly exsert-stipitate, oblong, semicylindric, the deeply concave ventral surface divided by the salient obtuse suture.-From Colorado to Nebraska and far northward.

52. Astragalus Haydenianus Gray, Proc. Am. Acad. 12: 1876. Smaller than the preceding: pubescence more cinereous: spike elongated, virgate: flowers much smaller: calyx-teeth much shorter than the tube: corolla white, keel tinged with purple at the tip: pod rugulose with transverse veins; stipe not exceeding the calyx.-Wyoming and Colorado.

53. Astragalus pectinatus Dougl. in Don. Gen. Syst. 2: 257. 1832. Pale green and ashy-puberulent: stems ascending or spreading, $2-4 \mathrm{dm}$. high, rather rigid, striate, and branched: leaflets 9-19, nearly filiform, seemingly not articulated to the rachis, persistent; lower stipules connate: flowers white or yellowish, $20-25 \mathrm{~mm}$. long, in a rather short raceme; the keel nearly straight and the banner elongated: pod thick, cartilaginous, oblong, turgid, sessile or short-stipitate, neither suture intruded but both thick and promi- 
nent, 10-15 mm. long, pendulous, glabrous, cuspidate.-Colorado to Nebraska and far northward.

54. Astragalus Grayi Parry, Wats. Am. Nat. 8: 212. 1873. Distinguished from the last by the broader leaflets, quite strongly veined, and by the somewhat thinner ascending pod: flowers light yellow.-Through the western half of Wyoming.

55. Astragalus flaviflor us (OK.) Sheld. 1. c. 158. Canescent with appressed hairs; diffusely branched and decumbent: leaflets 5-11, oblong or lanceolatelinear, subacute, glabrate above: peduncles longer than the leaves; spikes becoming elongated and loose: the subulate calyx-teeth nearly as long as the campanulate tube: corolla yellow: pod short, mostly included in the calyx, strongly obcompressed and with a broad furrow below. A. flavus.-Western Wyoming and Colorado and westward.

56. Astragalus gracilis Nutt. Gen. 2: 100. 1818. Subcinereous; stems slender, virgate, $2-4 \mathrm{dm}$. high: leaflets 11-17, linear or filiform: racemes dense, elongated, long-peduncled; flowers pale purple or whitish: pods spreading, coriaceous, elliptic-ovate, 'strongly concave dorsally, white-hairy or at length glabrous, transversely rugose-veined, wholly 1-celled, the ventral suture thick and prominent, 4-5 $\mathrm{mm}$. long.-Extending from the mountains east to the Missouri.

57. Astragalus microlobus Gray, Proc. Am. Acad. 6: 203. 1866. Closely allied to the foregoing but the stems diffuse: leaflets shorter, linear or oblonglinear: racemes rather short and usually loosely flowered; flowers deep purple: pods reflexed, thick-cartilaginous, puberulent, finely rugulose, a little flattened on the back, the ventral suture very thick. Same range as the preceding.

58. Astragalus viridis (Nutt.) Sheld. 1. c. 118. Caulescent but depressedspreading, intricately branched from a long root, hoary with a short silky pubescence: leaflets $5-7$, linear-subulate, usually rigid and divaricate, pungent: flowers 1-3, sessile in the axils of the leaves, ochroleucous or tinged with violet: pods ovate, sessile, compressed, pubescent, acuminate, somewhat incurved, usually 1-seeded. A. Kentrophyta. (A. viridis impensa Sheld. 1. c.)New Mexico to Canada and west to Nevada.

59. Astragalus aculeatus A. Nels. Bull. Torr. Bot. Club 26: 10. 1899. Very similar to the foregoing, even more caespitose-depressed, greener with merely a sparse hirsutulous pubescence: leaflets 5-7, plane, involute, or somewhat channeled, pungently long-mucronate: flowers purple, 6-8 $\mathrm{mm}$. long: calyx-lobes slender, as long as the campanulate tube, hirsute (a few of the hairs black): pod narrowly ovate, acuminate, scarcely exceeding the calyxlobes. [A. Wolfii Rydb. Bull. Torr. Bot. Club 31: 562. 1904.]-Mostly alpine and subalpine; Colorado to Montana and Idaho.

60. Astragalus caespitosus (Nutt.) Gray, 1. c. 230. Silvery-canescent and densely depressed-caespitose, forming broad mats: leaves crowded on the crowns, simple, or more rarely 3-5-foliolate, linear-lanceolate to linear-spatulaté, tapering to a slender petiole-like base: peduncles slender, $3-8 \mathrm{~cm}$. long, much surpassing the leaves; the raceme several-flowered; flowers small, purple: pod oblong-lanceolate, acuminate, compressed and thin-edged above, pubescent when young. A. spatulatus Sheld. 1. c. 22.-Colorado to Montana.

61. Astragalus simplicifólius (Nutt.) Gray, Proc. Am. Acad. 6: 231. 1866. Appressed silky-pubescent, growing in broad cushioned mats: leaves simple, 6-12 mm. long, spatulate-lanceolate, acute, frequently involute, crowding the extremities of the short branches: scapes 2-3-flowered, scarcely if at all exceeding the leaves; flowers purple: calyx-teeth nearly as long as the tube: pod coriaceous, the ventral suture straight and acute, the dorsal gibbous. (A. lingulatus Sheld. 1. c.; A. exilifolius A. Nels. Bull. Torr. Bot. Club 26: 10. 1899.) -Dry sterile slopes and plains; Colorado and Wyoming.

62. Astragalus tenellus Pursh, Fl. Am. Sept. 2: 473. 1814. Perennial, somewhat glabrous: stems several, branched, 2-4 dm. high: stipules dark, at least the lower sheathing; leaflets 11-21, linear or narrowly cisiong, acute or obtuse, 7-12 mm. long: peduncles not exceeding the leaves, few-flowercd; 
flowers white or ochroleucous, tinged with purple: stipe as long as the campanulate calyx-tube: pod flattened or compressed, straight, margined by the nerve-like sutures, reflexed, 8-12 mm. long, 2-4-seeded. A. multiflorus. (A. grallator Wats. Zoe 3: 52. 1892; A. acerbus Sheld. 1. c. 123.)-Very common throughout our range and far northward and westward.

63. Astragalus campestris (Nutt.) Gray, 1. c. 229. More or less pubescent, somewhat tufted, branched from the base, 1-2 dm. high: stipules triangularacuminate, the lower membranous; leaflets $7-13$, or the uppermost sometimes simple, mostly linear, often somewhat rigid and subulate: peduncles fewflowered, rather long and surpassing the leaves: calyx hirsute, some of the hairs black; its teeth short-subulate: corolla ochroleucous, tinged with purple: pod flat, from linear-elliptic to oblong, pubescent. [A. convallarius Greene; $A$. decurrens (Rydb.), Bull. Torr. Bot. Club 31: 563. 1904; A.tenuifolius (Nutt.).] - Colorado to Montana and Idaho.

64. Astragalus hylophilus (Rydb.) A. Nels. Very similar to the preceding: leaves nearly erect; leaflets 15-23, lance-oblong or narrowly elliptic, 1-2 cm. long, glabrate: calyx-tube dark-strigose: corolla nearly white; keel purplishtipped: pod linear-oblong, glabrous, more reflexed. (Homalobus hylophilus Rydb. Mem. N. Y. Bot. Gard. 1: 247. 1900.)-Colorado to Montana.

65. Astragalus decumbens (Nutt.) Gray, Proc. Am. Acad. 6: 229. 1866. Cinereous or silky-pubescent: stems diffuse or ascending, 1-2 dm. high: petioles sometimes somewhat flattened, mostly with 7-13 linear-lanceolate acute leaflets: racemes 5-10-flowered: calyx-teeth attenuate, a little shorter than the tube: corolla 8-10 mm. long, ochroleucous or purple; keel with a short, inflexed tip: pod broad-linear, straight or falcate, $15-20 \mathrm{~mm}$. long, hoarypuberulent. (A. camporum Rydb. Bull. Torr. Bot. Club 32: 666. 1905.)Colorado to British Columbia.

66. Astragalus pauciflorus Hook. Fl. Bor. Am. 1: 149. 1838. Cinereouspubescent, dwarf, from a woody caudex, matted-decumbent, with crowded leaves: leaflets 7-11, oblong or lanceolate; the stipules all more or less connate: peduncles 2-5-flowered: calyx-teeth very slender, exceeding the tube: corolla violet: pod linear-oblong, silky-puberulent, $8-10 \mathrm{~mm}$. long. (A.vexilliflexus Sheld.)-In the mountains; Wyoming into British America.

67. Astragalus diversifolius Gray, Proc. Am. Acad. 6: 230. 1866. Ashystrigillose; stems diffuse, decumbent, elongated, 2-4 dm. high: petioles short, flattened; leaves 1-5-foliolate; terminal leaflet or simple leaf linear, elongated, 2-5 cm. long, attenuated at each end: peduncle 1-5-flowered: calyx-teeth half shorter than the tube: corolla ochroleucous or lurid, keel falcate-incurved: pod oblong-linear, straight or subfalcate, 15-20 mm. long, canescent-puberulent. A. junceus. (A. junciformis A. Nels. Bull. Torr. Bot. Club 26: 9. 1899.)Arid and sterile slopes; Colorado to Idaho.

68. Astragalus Wingatensis Wats. Proc. Am. Acad. 18: 192. 1883. Somewhat canescent, the pubescence appressed: stems several, 7-15 cm. high: leaflets 9-13, narrow, glabrate: calyx short, with very short teeth: corolla purplish, $6 \mathrm{~mm}$. long: pod flat or compressed, sessile, subacute at apex, obtuse or somewhat narrowed at base, glabrate or black-hairy. [A. Clementis (Rydb.), Bull. Torr. Bot. Club 31: 562. 1894.]-New Mexico into Colorado.

69. Astragalus Hallii Gray, Proc. Am. Acad. 6: 224. 1866. Subcinereous or glabrate; stems rather stout, ascending: stipules subulate; leaflets 17-25, oblong, subcuneate, retuse, 8-15 mm. long: peduncles exceeding the leaves; flowers violet, 20 or more in a dense capitate raceme: calyx dark-pubescent, broadly campanulate, gibbous at base; the broad teeth only one fourth as long as the tube: pod oblong, inflated, glabrous, subcoriaceous, short-stipitate, straight, 12-20 mm. long.-Colorado.

70. Astragalus flexuosus Dougl. Hook. Fl. Bor. Am. 1: 141. 1831. Ashypuberulent; stems ascending, 2-5 dm. high, flexuous: leaflets oblong or cuneate-linear, obtuse or retuse: peduncles exceeding the leaves: racemes mostly elongated, loose; flowers $8-10 \mathrm{~mm}$. long, white or purplish: calyx hoary-pubescent, teeth one third as long as the tube: pod cylindric, 18-25 mm. long, puberulent, thinly coriaceous, straight or subincurved; stipe very short 
but evident. (A. proximus and A. salidae Rydb. Bull. Torr. Bot. Club 32: 667. 1905.) - Common at middle elevations; Colorado and Nebraska to Manitoba.

71. Astragalus Bodinii Sheld. 1. c. 122. Subglabrous slender perennial: stems ascending or prostrate, 3-7 dm. long, branched, striate: leaflets 11-17, narrowly obovate to lanceolate, abruptly acute, 7-12 $\mathrm{mm}$. long; stipules ovate-acuminate: peduncles 6-7 cm. long, dark-strigillose, rather few-flowered: calyx campanulate, purplish, and nigrescent: corolla purple, 8-10 $\mathrm{mm}$. long: pod short-stipitate, chartaceous, oblong, flat, 1-celled and often only 1-seeded. -Wet low meadow lands; Colorado and Wyoming.

72. Astragalus Fendleri Gray, Pl. Wright. 2: 44. 1853. An erect perennial, 2-4 dm. high, glabrous or appressed-pubescent: leaflets oblong or linearoblong: racemes long-peduncled, loosely flowered; flowers purple: pod oblong, inflated, chartaceous-coriaceous, about $20 \mathrm{~mm}$. long, straight, pointed, minutely puberulent, the stipe very short or wholly wanting.-Colorado to New Mexico.

73. Astragalus lonchocarpus Torr. Pac. R. R. Rep. 4: 80. 1857. Ashypuberulent or glabrate perennial: stem fistulous, sulcate, branched, 5-7 dm. long: stipules distinct, small; leaflets 1-5, linear or filiform-linear, remote, the leaf sometimes reduced to the flattened filiform rachis: racemes loosely many-flowered, on long, strict, stoutish peduncles; bracts one half shorter than the pedicels; flowers white, pendent: calyx-teeth broad-subulate, much shorter than the tube: pod membranous, lanceolate-cylindrical, straight, 3-4 cm. long, very sharply acuminate at each end, exsert-stipitate, glabrous, neither suture intruded. (Phaca macrocarpa Gray, Pl. Fendl. 36. 1849.)Colorado.

74. Astragalus triphyllus Pursh, Fl. Am. Sept. 2: 740. 1814. A caespitose perennial, from a much branched woody caudex, with crowded leaves, silvery and glossy silky: stipules glabrous; primary leaves sometimes 5-foliolate with cuneate oblanceolate leaflets, the rest with three longer lanceolate leaflets, long-petioled, exceeding the sessile crowded flowers: calyx-teeth half shorter than the tube: corolla ochroleucous or white: pod villous, included, conicalovate, acuminate, somewhat coriaceous. (A. gilviflorus Sheld.; Phaca caespitosa Nutt.) - From Nebraska and Wyoming to the Saskatchewan.

75. Astragalus tridactylicus Gray, Proc. Am. Acad. 6: 527. 1866. Perennial, caespitose from a short woody caudex, dwarf, $5-8 \mathrm{~cm}$. high, silverysilky: leaves pinnately 3 -foliolate, long-petioled, exceeding the sessile crowded flowers; leaflets oblanceolate, $10-12 \mathrm{~mm}$. long, acute: flowers $1 \mathrm{~cm}$. long, palepurple: calyx-teeth equaling the tube: pod globose, ovoid, 5-8 mm. long, very turgid, puberulent, 12-ovuled, 3-4-seeded: calyx deciduous, exposing the pod.-Colorado and Wyoming.

76. Astragalus sericoleucus Gray, 1. c. 232. Very broadly caespitose, silky-hoary; stems branched, prostrate; branches covered with the villous stipules: leaves all 3-foliolate, not equaling the 2-6-flowered filiform peduncles; leaflets $6 \mathrm{~mm}$. long; oblanceolate or cuneate-oblong: calyx-teeth about equaling the campanulate tube: corolla purple, 6-8 $\mathrm{mm}$. long: pod ovate-oblong, $6 \mathrm{~mm}$. long, hoary, half included in the calyx.-Colorado to Dakota and Nebraska.

\section{ARAGALLUS Neck. Loco}

Like Astragalus, but distinguished by a subulate beak at the tip of the keel. Mostly low perennials, with tufts of numerous very short stems from a hard and thick root or rootstock, covered with scaly adnate stipules. Leaves pinnate, of many leaflets. Scapes naked, bearing a head or short spike of flowers. -Oxytropis.

Stipules free; pod 1-celled

Stipules adnate to the petiole.

Pod included in the calyx.

Calyx bladdery-inflated, not distended by the pod.

Plants dwarf and caespitose; flowers purple.

Plants 1-2 dm. high; flowers ochroleucous :

1. A deflexus.

2. A. multiceps.

3. A. collinus. 
Calyx distended or split by the turgid included pod.

Corolla violet-blue; the wings oblong

Corolla purple; the wings dilated and emarginate

Pod at length evidently exceeding the calyx.

Calyx somewhat bladdery-inflated

Calyx not inflated.

Pod bladdery-inflated, membranous

Pod not bladdery-inflated, often turgid or coriaceous.

Flowers 1-3

Flowers several or many.

Plants somewhat glandular-viscid.

Leaflets 17-31

Leaflets 25-55

Plants neither glandular nor viscid.

Leaves simply pinnate.

Pod nearly 2-celled.

Flowers yellow or yellowish

Flowers purple or ochroleucou

Pod half 2-celled or less.

Flowers purple or violet.

Pod submembranous

Pod coriaceous

Flowers white or yellowish.

Dwarf alpine plants.

Stout and tufted.

Corolla yellowish throughout
Corolla white or yellowish; the keel always
purple-tipped

Leaflets very numerous and subverticillate
4. A. lagopus.
5. A. nanus.
6. A. Blankinshipii.
7. A. podocarpus.
8. A. Parryi.

9. A. viscidulus.

10. A. viscidus.

11. A. gracilis.

12. A. dispar.

13. A. monticola.

14. A. Lambertii.

15. A, alpicola.

16. A. villosus.

17. A. albiflorus.

18. A. Richardsonii.

1. Aragallus deflexus (DC.) Heller, Cat. N. A. Pl. 4. 1898. Loosely silkypubescent; leafy-stemmed or more rarely depauperate and nearly stemless; taller forms over $3 \mathrm{dm}$. high: leaflets crowded in 12-16 pairs, lanceolate to oblong, 6-12 mm. long; stipules free: peduncles much surpassing the leaves; flowers rather small (about $6 \mathrm{~mm}$. long), in a short and close or in fruit lengthened and open spike: pod oblong-lanceolate, not stipitate, 1-celled, much surpassing the calyx.-In the mountains from British America to southern Colorado and westward to Utah. Subalpine forms are often depauperate and almost stemless [A. foliolosus (Hook.) Rydb.].

2. Aragallus multiceps (Nutt.) Heller, l. c. Canescently silky; matted caespitose, subcaulescent, 3-7 $\mathrm{cm}$. high: leaflets 7-9: peduncles weak, 1-2flowered; flowers purple: pod stipitate, wholly inclosed in the bladdery, ovateglobose calyx, turgid, ovate, 1-celled.-Granite soils, middle altitudes; Wyoming and Colorado.

2a. Aragallus multiceps minor (Gray) A. Nels. Erythea 7: 57. 1899. Pulvinate or depressed caespitose: leaflets very small: fruiting calyx much reduced.-Subalpine gravelly barrens.

3. Aragallus collinus A. Nels. Erythea 7: 57. 1899. Canescently appressedpubescent and silky-villous; crown woody, covered with the persistent petioles: leaves and scapes tufted on the crowns: scapes 1-2 dm. long, exceeding the leaves: leaflets $7-13$, oblong to linear-lanceolate, acute, $10-30 \mathrm{~mm}$. long: spike 10-20-flowered; bracts leaf-like, greenish, equaling the calyx, or nearly so: calyx inflated in fruit, globose-urceolate: corolla white or yellowish, the standard streaked with purple, twice as long as the calyx: pod turgid, nearly filling the calyx; style abruptly flexed near its apex and protruding from the narrowed mouth of the calyx.-Northern Wyoming and Montana.

4. Aragallus lagopus (Nutt.) Greene, Pitt. 3: 212. 1897. Canescently silky, with loose villous hairs; nearly stemless and rather dwarf: scapes surpassing the leaves, 5-6-flowered: leaflets 9-13, lanceolate or oblong, 6-8 $\mathrm{mm}$. long: flowers bright violet: calyx cylindrical, silky: pod ovate, thin membranaceous and almost bladdery, obtuse, abruptly tipped with the persistent style, slightly protruding from the calyx which splits down one side.-Mountains of Wyoming and Montana.

5. Aragallus nanus (Nutt.) Greene, 1. c. Silvery with appressed silky pubescence: leaflets 3 or 4 or rarely 6 pairs, narrowly lanceolate: flowers purple or whitish: pod turgid, oblong, somewhat coriaceous, the acuminate 
tip barely projecting out of the undivided lightly villous calyx.-Mountains of Wyoming and Montana.

6. Aragallus Blankinshipii A. Nels. 1. c. 58. Tufted on the crown of a woody taproot, silky-sericeous: leaves lax, half as long as the 1-2 dm. high scapes; leaflets $11-17$, linear-oblong, acute at both ends, 12-16 mm. long: spike dense, 8-12-flowered: calyx loosely lanate-hirsute, inflated in fruit and becoming subglobose: corolla purple, $20 \mathrm{~mm}$. long; the standard deeply 2 lobed: pod elliptic, acuminate, at length slightly protruded from the calyx. (A. Besseyi Rydb. Mem. N. Y. Bot. Gard. 1: 250. 1900.)-Northern Wyoming, Montana, and Idaho.

7. Aragallus podocarpus (Gray) A. Nels. Very low, depressed, tufted plants, villous or in age glabrate: leaflets 11-23, linear-lanceolate, 5-8 mm. long: peduncles 2-flowered, scarcely surpassing the leaves, somewhat deflexed in fruit: flowers violet, $10-15 \mathrm{~mm}$. long: pod large, $15-25 \mathrm{~mm}$. long, bladdery, inflated, broadly ovate, 1-celled, neither suture at all inflexed, puberulentshort-stipitate. (A. inflatus A. Nels. 1. c. 59.)-Alpine and subalpine; Colorado and far northward.

8. Aragallus Parryi (Gray), Greene, 1. c. Silky-canescent; leaves and scapes $10-15 \mathrm{~cm}$. high: leaflets $13-21$, oblong-lanceolate, 4-6 mm. long: calyx short, cinereous-pubescent: pod nearly $12 \mathrm{~mm}$. long, terete with a strong ventral groove, grayish-pubescent, not at all stipitate, oblong or narrower, coriaceous, nearly or quite 2-celled.-Mountains of Colorado near the limit of trees.

9. Aragallus viscidulus Rydb. Mem. N. Y. Bot. Gard. 1: 253. 1900. Tufted, the caudex clothed with old petioles and stipules: leaflets 17-31, somewhat villous-pubescent: scape much exceeding the leaves, $10-15 \mathrm{~cm}$. high, subviscid and somewhat black-hairy: petals yellowish at base, bluishpurple above: pod membranous, oblong-ovate, beaked, black-pubescent or in age glabrate, ventral suture half dividing it, $10-15 \mathrm{~mm}$. long.-Montana to Utah and probably in Wyoming.

10. Aragallus viscidus (Nutt.) Greene, 1. c. More or less glandular-viscid, at least the calyx and commonly the pod: leaflets numerous and small, 5-10 $\mathrm{mm}$. long, thickish, oval or oblong, often pubescent when young, at maturity green and glabrate: flowers in a dense oblong head or at length in a short spike, about $10 \mathrm{~mm}$. long: calyx villous and with sessile glands usually evident: pod small, 7-10 mm. long, puberulent, oblong, thin-chartaceous, half 2-celled, the small beak or point straight. - In the mountains from British America to Colorado; common in Wyoming.

11. Aragallus gracilis A. Nels. 1. c. 60 . Tufted; scapes few-several, 2-5 $\mathrm{dm}$. high, slender, erect, lightly pubescent: leaves about half as long as the fruiting scape; leaflets 21-31, sparsely soft-pubescent: spike long, open in fruit; the bracts conspicuous, often exceeding the short-cylindric calyx: corolla ochroleucous or more deeply yellow, about $15 \mathrm{~mm}$. long: pod pubescent, oblong-ovate, about $20 \mathrm{~mm}$. long, semimembranous, soon splitting the calyx, nearly 2-celled. - Northern Cólorado to Dakota and Manitoba.

12. Aragallus dispar A. Nels. 1. c. 61 . Leaves and scapes rather few, crowded on the crown of a strong taproot; the persistent membranous stipules white strigose-pubescent: scapes rather stout, noticeably tapering, silkypubescent, usually unequal: leaves silky-pubescent, unequal; the primary short, with orbicular to oblong leaflets $5 \mathrm{~mm}$. or less in length; those of the longer leaves oblong to linear and 7-12 $\mathrm{mm}$. long: spikes dense, many-flowered; the bracts from very short to longer than the calyx: calyx short-tubular, silky-lanate, its teeth short: corolla ochroleucous with a purple spot on the keel (or more rarely purple throughout), $15-18 \mathrm{~mm}$. long: pod oblong, beaked with a thick point, pubescent, nearly twice as long as the calyx.-Northern Wyoming, and from the Dakotas to Oregon.

13. Aragallus monticola (Gray) Greene, 1. c. Not glandular-viscid, loosely silky-villous, at least the scapes and calyx, 1-2 dm. high: leaflets somewhat glabrate, oblong or lanceolate, $7-15 \mathrm{~mm}$. long: spike oblong or cylindraceous, dense even in fruit; flower hardly $12 \mathrm{~mm}$. long: pod ovate-oblong, between 
membranaceous and chartaceous, $7-12 \mathrm{~mm}$. long, tipped with a straight point, one-celled with no introflexion of the ventral suture, or nearly half 2-celled, silky-canescent.-Mountains of Wyoming, Dakota, and northward.

14. Aragallus Lambertii (Pursh) Greene, 1. c. Commonly taller as well as larger, the scapes often $3 \mathrm{dm}$. or more high, silky- and most silvery-pubescent, sometimes glabrate in age: leaflets oblong-lanceolate to linear, 8-30 mm. long: spike sometimes short-oblong and densely-flowered at least when young, often elongated and sparsely flowered; flowers mostly large, often $25 \mathrm{~mm}$. long, but sometimes much smaller, mostly purple or purplish: pod either narrowly or broadly oblong, sericeous-pubescent, firm-coriaceous, $12 \mathrm{~mm}$. or more long, imperfectly 2-celled.-Includes Oxytropis campestris of Hook. Fl. Bor. Am. in part. (A. patens, A. angustatus, and A. atropurpureus Rydb. Bull. Torr. Bot. Club 34: 421-4. 1907.) -Common along the Great Plains from the Saskatchewan to New Mexico, and in the foothills.

14a. Aragallus Lambertii sericeus (Nutt.) A. Nels. 1. c. 62. Leaflets broader, more silky: spike robust. [A. sericeus (Nutt.) Greene.]-Same range.

15. Aragallus alpicola Rydb. Mem. N. Y. Bot. Gard. 1: 252. 1900. Depressed-caespitose; the caudex clothed with leaf remnants: leaves numerous, white-silky; leaflets 8-13, oblong, 5-8 $\mathrm{mm}$. long: scape short, depressed or ascending, 3-8-flowered: calyx cylindric, densely black-hairy: corolla 12-15 $\mathrm{mm}$. long, sulphur-yellow; the keel purple-tipped: pod about $15 \mathrm{~mm}$. long, subcoriaceous, ovoid, beaked.-Wyoming and Montana.

16. Aragallus villosus Rydb. Bull. Torr. Bot. Club 28: 36. 1901. Intricately caespitose: leaflets $25-31,10-15 \mathrm{~mm}$. long, lanceolate, acute, loosely silky or hirsute: scapes 10-15 cm. high: spike dense: calyx white, silkyvillous: corolla ochroleucous: pod thin, 2-celled, white-silky, twice as long as the calyx, tipped with a hooked beak.-Replaces the eastern A. campestris in the northern part of our range.

17. Aragallus albiflorus A. Nels. 1. c. 62 . Caudex densely tufted on the crowns of a large root, clothed with hairy stipules and leaf-bases: leaflets 11-21, oblong to lanceolate, 15-25 $\mathrm{mm}$. long, grayish or silvery with appressed pubescence: scapes rather stout, 2-4 dm. high, at length distinctly surpassing the leaves: calyx sericeous, some short black hairs intermingled: corolla white or often ochroleucous; the keel usually purple-tipped: pod pubescent, oblong, with a straight tip, at maturity about twice as long as the calyx; the ventral suture somewhat intruded. (A. saximontanus A. Nels.)-From New Mexico to Montana.

18. Aragallus Richardsonii (Hook.) Greene, Pitt. 4: 69. 1899. Silvery silky-villous, 1-4 dm. high: stipules adnate to the petiole, imbricated on the short branches of the caudex, which bear the leaves and scapes; leaflets numerous, fascicled in threes or fours (or more) or as if verticillate: scape spicately many-flowered; the flowers erect-spreading: calyx very hairy, white: corolla rather large, bright blue: pod ovate, partly 2-celled, erect, acuminate, hairy, much longer than the calyx. Oxytropis splendens.-Mountain valleys; throughout our range.

\section{GLYCYRRHIZA L. LICORICE}

Erect perennial herbs. Flowers in dense axillary pedunculate spikes, with caducous bracts. Root large and sweet. Flowers nearly as in Astragalus. Ovary sessile; style short and rigid. Pod compressed and often curved.

1. Glycyrrhiza lepidota Pursh, Fl. Am. Sept. 480. 1814. Somewhat glandular-puberulent, or the younger leaves slightly silky: stems erect, branching, 3-8 dm. high: leaflets 11-19, oblong-lanceolate, acute or obtuse: spike short, the peduncle shorter than the leaves; flowers ochroleucous: pod thickly beset with hooked prickles, oblong, 1-2 cm. long.-New Mexico to Canada and west to the coast.

\section{2. amorpha. L. False Indigo. Lead Plant}

Shrubs with odd-pinnate leaves, dotted and usually stipellate leaflets, and 
violet or purple flowers crowded in clustered terminal spikes. Corolla of a single petal (the standard) which is wrapped around the stamens and style. Stamens 10, monadelphous at base. Pod oblong, roughened, 1-2-seeded, exceeding the calyx.

Leaflets 2-5 cm. long; pod 2-seeded

Leaflets less than $2 \mathrm{~cm}$. long; pod 1-seeded.

Green and glabrate

White-canescent

1. Amorpha fruticosa L. Sp. Pl. 713. 1753. Shrubby, variable, sometimes tall and tree-like; pubescent or nearly glabrous: leaflets 8-12 pairs, oblong to broadly elliptical, scattered: calyx somewhat pubescent, the lower tooth acuminate and longest, the others commonly obtuse: standard purple, deeply emarginate: pod 2-seeded.-Extending into the eastern part of our range.

2. Amorpha nana Nutt. Fras. Cat. 1813. Very low, nearly glabrous: leaflets somewhat ovate-elliptical, rigid: spikes solitary and aggregated. $A$. microphylla.-Along the Platte to the mountains and northward to the plains of the Red River.

3. Amorpha canescens Pursh, Fl. Am. Sept. 467. 1814. Whitened with hoary down, 3-8 dm. high: leaflets small, crowded, 29-51, elliptical, smoothish above with age: pod slightly exceeding the calyx, 1-seeded.-This and the preceding possibly coming into our range from the east or north.

\section{PSORALEA L.}

Perennial herbs, usually sprinkled all over or roughened (especially the calyx, pods, etc.) with glandular dots or points. Leaves mostly palmately 3-5-foliolate. Flowers blue-purplish or white, in spikes or racemes. Stamens diadelphous, with half the anthers often smaller or less perfect. Pod small, thick, often wrinkled, indehiscent, 1-seeded.

Low or almost stemless; roots tuberous or thickened.

Canescently hirsute

Greenish but rough-hirsute.

Stem short but divaricately branched; pod glabrous

Stemless; pod somewhat hirsute

Taller, the stems leafy and branched.

Roots tuberous.

Roots not tuberous.

Densely silvery-silky throughout. Calyx-lobes subequal Calyx with one elongated lobe

Greenish, glabrate or minutely canescent. Pods subglobose; leaves glabrate

Pods ovoid to ovoid-oblong. Leaves obovate to oblong-cuneate. Leaves narrowly linear

1. P. mephitica. $\rightarrow$

2. P. esculenta.

3. P. hypogaea. -

4. P. cuspidata.

5. P. digitata.

6. P. argophylla.

7. P. lanceolata.

8. P. tenuiflora.

9. P. linearifolia.

1. Psoralea mephitica Wats. Proc. Am. Acad. 14: 291. 1879. Softly silvery silky-villous throughout: stems very short, from a tuberous root: leaflets 4 or 5 , obtuse or retuse: peduncles and petioles subequal: bracts somewhat scarious, shorter than the calyx: the linear calyx-lobes as long as the blue petals: pod small, somewhat chartaceous, moderately villous above. Said to have the odor of the skunk. - Southern Colorado to Arizona.

2. Psoralea esculenta Pursh, Fl. Am. Sept.475. 1814. Roughish hairy all over: stem stout, 1-3 dm. high, erect from a tuberous or turnip-shaped farinaceous root: leaflets obovate or lanceolate-oblong: spike oblong, longpeduncled: calyx-lobes and bracts lanceolate, nearly equaling the corolla which is $12 \mathrm{~mm}$. long.-Extending from the northern prairie States to western Texas, and into our range.

3. Psoralea hypogaea Nutt. T. \& G. Fl. N. A. 1: 302. 1838. Acaulescent; hirsute with whitish appressed hairs: leaflets linear-lanceolate or linearoblong, nearly glabrous above: spikes capitate, on peduncles much shorter than the petioles: lobes of the calyx linear, acuminate, the lowest lanceolate, elongated.-Nebraska to Colorado and New Mexico, 
4. Psoralea cuspidata Pursh, F1. Am. Sept. 741. 1814. Canescent with appressed pubescence: stipules subulate; leaflets obovate or elliptical-oblong, pubescent: peduncles much longer than the leaves: calyx large, somewhat inflated, gibbous at the base, conspicuously dotted, teeth triangular-lanceolate, acuminate, the lower one produced: pod hid in the large calyx.-From southeastern Colorado to Texas and Arkansas.

5. Psoralea digitata Nutt. T. \& G. Fl. N. A. 1: 300. 1838. Canescent, diffusely branched: stipules lanceolate, reflexed; leaflets cuneate-oblong and oblong-linear with an abrupt rigid point, smooth and minutely dotted above, hirsute beneath: bracts obcordate or reniform: lobes of the calyx ovate: pod hirsute, not wrinkled.- Southeastern Colorado and southeastward along the Red River into Arkansas.

6. Psoralea argophylla Pursh, 1. c. 475. Silvery silky-white all over, divergently branched: leaflets elliptical-lanceolate: lobes of the calyx and bracts lanceolate: flowers in interrupted spikes: peduncles and lower tooth of the calyx elongated. (P. campestris Nutt.)-Colorado, far northward and eastward.

7. Psoralea lanceolata Pursh, 1. c. Glabrous, or with a few scattered hairs: stipules linear-lanceolate; leaflets linear to oblong-obovate, acute: pedunçles about equaling the leaves: calyx very small, its teeth short, obtuse, nearly equal: ovary very silky: pod very glandular.-Washington to northern Arizona and eastward to the Saskatchewan and Nebraska.

8. Psoralea tenuiflora Pursh, 1. c. Slender, much branched and bushy, minutely hoary-pubescent when young: leaflets varying from linear to obovate-oblong: flowers in panicled racemes: lobes of the calyx and bracts ovate, acute: pod glandular. ( $P$. floribunda Nutt.)-From Colorado to Montana and east to Illinois.

9. Psoralea linearifolia T. \& G. Fl. N. A. 1: 300. 1838. Tall and slender, divaricately branched, slightly pubescent with appressed hairs: leaflets 3 , narrowly linear, elongated, mucronate, the upper surface dotted with black glands, lower surface scarcely dotted, $5-7.5 \mathrm{~cm}$. long and $2-4 \mathrm{~mm}$. wide; stipules minute, subulate, deciduous: racemes few-flowered, much longer than the leaves: calyx-lobes and bracts lanceolate.-From Wyoming to Texas.

\section{PAROSELA Cav.}

Glandular-punctate herbs or shrubs, with odd-pinnate (rarely palmate) leaves, small entire leaflets, and flowers in terminal pedunculate spikes. Stamens 9 or 10 , monadelphous, the cleft tube of filaments bearing four of the petals about its middle (the cordate standard being free). Pod ovate, flat, usually indehiscent, 1- or 2-seeded, included in the calyx.-Dalea.

Glabrous; flowers not yellow.

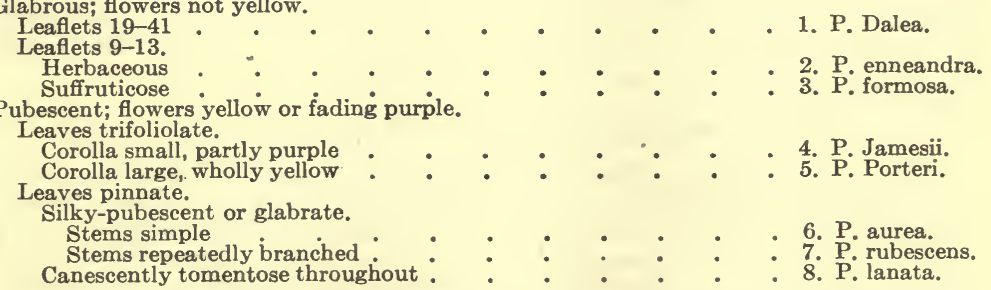

1. Parosela Dalea (L.) Brit. Mem. Torr. Club 5: 196. 1894. An erect glabrous annual, 2-5 dm. high: leaflets 13-40: flowers light rose-color, in cylindrical spikes; bracts conspicuous, ovate, pubescent, deciduous: calyx very villous, with long slender teeth.-From Colorado to southern Arizona and eastward to Illinois.

2. Parosela enneandra (Nutt.) Brit. 1. c. Glabrous, 4-10 dm. high: branches. slender and spreading: leaflets 9-13, linear-oblong, 5-8 mm. long, 
strongly dotted: spikes panicled, few-flowered; flowers distant; bracts very broad, almost orbicular, glandular, coriaceous, glabrous, slightly cuspidate, embracing the flower: calyx deeply cleft, teeth long, setaceous, beautifully plumose: corolla white, keel twice as long as the wings; standard cordate, very small, sometimes with 4 approximated glands near the middle.-Texas to Colorado and the upper Missouri.

3. Parosela formosa (Gray) Vail, Bull. Torr. Bot. Club 24: 16. 1897. Suffruticose, much branched: leaflets very small, about 5 pairs, cuneateoblong, retuse, dotted with black glands beneath: spikes loose, few-flowered, on short peduncles; flowers large and showy, bright purple; bracts ovate, silky-villous on the margin.-On the Platte and southward.

4. Parosela Jamesii (Torr.) Vail, l. c. Whole plant silky; stems several, 8-15 cm. high: leaves trifoliolate, glandless; the leaflets obovate, very obtuse; stipules spiny: spikes oblong, dense, $2-3 \mathrm{~cm}$. long: calyx deeply cleft, the segments setaceous-plumose: keel and wings oblong, purple, the standard yellowish: bracts rhombic-ovate, as long as the calyx.-Colorado and southeastward.

5. Parosela Porteri A. Nels. Bot. Gaz. 31: 395. 1901. Stems several or many, prostrate-spreading from the crown of a woody root, $10-25 \mathrm{~cm}$. long: leaves trifoliolate, strigose-silky; the leaflets cuneately obovate; stipules setaceous: spike dense, $2-5 \mathrm{~cm}$. long, with purple bracts: calyx-tube campanulate, with 10 greenish nerves; the triangular lobes attenuate into filiform plumose setae twice as long as the tube: flowers lemon-yellow: keel and wings oval or broader; the standard shorter than the wings, broader than it is long.Berwind, southern Colorado.

6. Parosela a urea (Nutt.) Brit. 1. c. Stems pubescent, simple, erect, 4-8 dm. high: leaflets 3-4 pairs, oblong-obovate and linear-oblong, more or less silky-pubescent: spikes ovate, very compact, on long peduncles; bracts rhombic-ovate, as long as the calyx: corolla yellow, $8-10 \mathrm{~mm}$. long; the standard much shorter than the wings and keel.-From the eastern border of our range to Missouri and Texas.

7. Parosela rubescens Wats. Proc. Am. Acad. 17: 369. 1882. Stems 2-4 dm. high, canescent with appressed pubescence, branching; branches leafy to the top: leaves remote; leaflets $2-3$ pairs, oblong and obovate, slightly apiculate, clothed with silky, canescent hairs, not dotted, 3-8 mm. long: spikes ovate, loosely flowered, elongated and cylindrical in fruit, $2 \mathrm{~mm}$. long; bracts obovate, apiculate, about the length of the yellow flowers (purplish in drying): calyx deeply cleft, teeth setaceous, plumose.- Southeastern Colorado and southward.

8. Parosela lanata (Spreng.) Brit. 1. c. Decumbent, the whole plant clothed with a soft almost woolly pubescence: leaflets 4-6 pairs, obovatecuneate, emarginate, 10-12 mm. long: spikes elongated, rather loose, manyflowered, on rather long peduncles; bracts ovate, with a long acumination: calyx-teeth subulate, plumose, dilated at base, as long as the tube: petals deep purple.-Southern part of our range and southward.

\section{Petalostemon. Prairie Clover}

Herbaceous, mostly perennial plants, dotted with glands. Leaves unequally pinnate; stipules minute, setaceous. Flowers in pedunculate, dense, terminal spikes or heads. Calyx often glandular, 5-toothed; the teeth connivent, nearly equal. Petals 5, on filiform claws; four of them nearly similar, their claws united to the stamen-tube quite to the summit and deciduous by an articulation; the standard free, inserted at the bottom of the calyx; the limb cordate or oblong, conduplicate. Stamens 5, monadelphous; the tube cleft. Ovary with 2 collateral ovules. Pod membranaceous, inclosed in the calyx, indehiscent, 1-seeded.

Flowers white.

Calyx and spike glabrate.

Leaves lanceolate or oblong .

Leaves linear or nearly so :

Pod membranaceous, inclosed in the calyx, 
Calyx and spike densely silky-villous

Flowers not white.

Leaflets 5-9.

Glands evident

Glands wanting or obscure

Leaflets 13-17.
3. P. compactus.

4. P. purpureus.

5. P. pubescens.

6. P. villosus.

1. Petalostemon candidus Michx. Fl. Bor. Am. 2: 49. 1803. Glabrous; stems firm and erect, sparingly branched: leaflets 7 or 9 , lanceolate or linearoblong, sparingly dotted beneath: spikes oblong, in age long-cylindrical: calyx glabrate: corolla white; wing and keel petals ovate; the standard broadly cordate: ovary pubescent.-Coming into our range from the prairie states.

2. Petalostemon oligophyllus (Torr.) Rydb. Mem. N. Y. Bot. Gard. 1: 237. 1900. Very similar but the stems slender, ascending, freely branched: leaflets 5-9, linear-oblong: spike short, ovate-oblong, becoming cylindric, loosely flowered.-Very common; from Montana to Texas.

3. Petalostemon compactus (Spreng.) Swezey, Nebr. Fl. Pl. 6. 1891. Glabrous; stem sparingly branched, 3-6 dm. high, dotted: leaflets 5-7, lanceolate-oblong, obtuse, dotted beneath: spikes cylindrical, very dense and much elongated; bracts lanceolate, as long as the flower: calyx silky-villous; the teeth lanceolate: standard cordate; the other petals linear-oblong, all white or nearly so. P. macrostachyus.-Throughout the eastern part of our range.

4. Petalostemon purpureus (Vent.) Rydb. 1. c. Smooth or nearly so: leaflets 5, narrowly linear: spikes globose-ovate, or oblong-cylindrical when old; bracts pointed, not longer than the silky-hoary calyx: corolla rose-purple. $P$. violaceus.-Prairies from the Saskatchewan to Texas, and from Colorado to Indiana.

4a. Petalostemon purpureus mollis (Rydb.) A. Nels. Stems and leaves more or less villous-pubeseent: leaflets linear, usually obtusish: corolla rosecolor. (P. mollis Rydb. Mem. N. Y. Bot. Gard. 1: 238. 1900.) Probably $P$. tenuifolius Gray as to our range.-Montana to Colorado.

5. Petalostemon pubescens A. Nels. Bot. Gaz. 31: 395. 1901. Pale with a sublanate pubescence throughout: stems several-many from a large woody crown, from suberect to prostrate-assurgent, 1-3 dm. long: leaves neither glandular nor dotted, 5-foliolate; the leaflets spatulate-linear, obtuse, 10-14 $\mathrm{mm}$. long: spike oblong, dense, silvery-lanate; bracts about as long as the calyx, obovate, abruptly acuminate, the purple tip concealed by the copious pubescence: corolla light purple.-Southern Colorado.

6. Petalostemon villosus Nutt. Gen. 2: 85. 1818. Soft-downy or silky all over: leaflets 13-17, linear or oblong, 8-10 mm. long: spikes cylindrical, 3-10 cm. long, short-peduncled, soft-villous; bracts lanceolate, acuminate, exceeding the calyx: corolla rose-purple, of ten pale; standard oblong; the wings and keel oblong-obovate.-Northeastern part of our range to Wisconsin and Missouri.

\section{HEDYSARUM L.}

Perennial herbs. Leaves odd-pinnate. Calyx 5-cleft, the lobes awl-shaped and nearly equal. Keel nearly straight, obliquely truncate, not appendaged, longer than the wings. Stamens diadelphous (9 and 1). Pod flattened, composed of several equal-sided, separable, roundish joints connected in the middle.

Flowers rose-color, lilac, or purple.

Stems and leaves canescent ${ }_{\text {Stems and leaves green, glabrate or obscurely pubescent. }}$

Stems and leaves green, glabrate

Joints of loment not wing-margined.

Flowers tardily if at all reflexed

Flowers reflexed from the first

Flowers white or yellow.

Leaflets 11-13

Leaflets 15-23

1. Hedysarum cinerascens Rydb. Mem. N. Y. Bot. Gard. 1: 257. 1900. Cinereous-canescent: stems several, erect or decumbent, 3-6 dm. high: leaflets 
9-13, oblong or cuneate-oblong; stipules small, sheathing, subulate: peduncles longer than the leaves: raceme elongated in fruit; flowers spreading and at length reflexed: joints of the loment oval-orbicular, nearly glabrous, transversely rugose-reticulated. (H. canescens Nutt.) - From central Wyoming northward and westward.

2. Hedysarum marginatum Greene, Pitt. 4: 138. 1900. Stems tufted, 5-8 dm. high, minutely appressed-pubescent: leaflets 11-15, oblong, obtuse, mucronulate, thin, pinnately veined beneath and pubescent, glabrous above: raceme large and showy, elongating in fruit: corolla rose-purple, 16-20 $\mathrm{mm}$. long: joints of the loment 2-4, obovoid, $10-12 \mathrm{~mm}$. long, at maturity with a thin scarious margin, the surface strigillose and irregularly reticulate.Pagosa Springs, Colorado.

3. Hedysarum pabulare A. Nels. Proc. Biol. Soc. Wash. 15: 185. 1902. Stems several, slender, decumbent, 4-7 dm. long, subcinereous: leaflets 9-15, from narrowly to broadly oblong, 1-2 cm. long: racemes long, on axillary peduncles surpassing the leaves; flowers lilac or pale purple, tardily or not at all reflexed: calyx-tube only about $2 \mathrm{~mm}$. long, its slender teeth twice as long: standard 12-14 mm. long, broadly obovate, emarginate: joints of the loment $3-5$, suborbicular, 5-7 mm. broad, pale green and nearly glabrous. H. Mackenzii.-Throughout our range.

4. Hedysarum uintahense A. Nels. 1. c. 186 . Green but obscurely pubescent; stems stoutish, striate, erect or nearly so: leaflets $11-23$, from oval to lanceolate, mostly obtuse, $2-3 \mathrm{~cm}$. long; stipules large, membranous: racemes axillary in the uppermost approximated nodes (appearing clustered); flowers purple or lavender, reflexed from earliest anthesis: calyx-tube about $4 \mathrm{~mm}$. long, its unequal teeth much shorter: keel longer than the narrow wings and the standard: loment stipitate, its $2-5$ joints canescent on the connective, lightly reticulated, oval to oblong, 10-15 $\mathrm{mm}$. Jong. H. boreale.-In the mountains; from Colorado to Washington.

5. Hedysarum sulphurescens Rydb. Bull. Torr. Bot. Club 24: 251. 1897. Erect, 3-4 dm. high, minutely pubescent: stipules connate, opposite the petiole; leaflets 11-13, oblong-elliptical, 1.5-2 cm. long, slightly pubescent beneath: racemes 15-30-flowered, short, rather dense, elongated in fruit; flowers bright yellow, $15 \mathrm{~mm}$. long, the wings exceeding the standard but shorter than the keel: calyx-teeth triangular-subulate, shorter than the tube: pod 2-3-jointed, smooth. (H. flavescens Coult. \& Fish. Bot. Gaz. 18: 300. 1893, name untenable.)-Wyoming, Montana, and Idaho.

6. Hedysarum philoscia A. Nels. 1. c. 185. Bright green and nearly glabrous throughout; stems slender, few-several, from thickened roots: leaflets 15-23, mostly oblong, $15-30 \mathrm{~mm}$. long, peduncles overtopping the leaves: raceme slender: calyx-tube campanulate, exceeding its triangular teeth: corolla white, the wings linear: loment glabrate, the joints oval to orbicular, 6-8 $\mathrm{mm}$. long, lightly reticulated from a somewhat large, marginal nerve.Shaded stream banks; eastern Wyoming.

Hedysarum carnosulum Greene, Pitt. 3: 212. 1897. Said to be distinguishable from all other species of this country by its succulent herbage, veinless leaflets, and the close transverse lineation of the loment.-Cañon of the Arkansas; no specimen or type cited.

\section{VICIA L. Vetch}

Herbs, mostly climbing more or less by the tendril at the end of the pinnate leaves. Stipules half-sagittate. Flowers or peduncles axillary. Calyx 5-cleft or 5 -toothed, the 2 upper teeth often shorter, or the lowest one longer. Wings of the corolla adhering to the middle of the keel. Stamens more or less diadelphous $(9$ and 1$)$, the orifice of the tube oblique. Style filiform, hairy all round or only on the back at the apex. Pod flat, 2-valved,-2-several-seeded. Seeds globular.

J.eaves lance-ovate to broadly oval Leaves narrowly linear to oblong.

Peduncle not produced beyond the terminal flower

Peduncle produced beyond the terminal flower .

1. V. americana.

2. V. linearis.

3. V. producta. 
1. Vicia americana Muhl. Willd. Sp. Pl. 3: 1906. 1803. -Glabrous; stems climbing or scrambling, 5-10 dm. long: leaflets 10-14, elliptical-lanceolate or ovate-oblong, obtuse or retuse, mucronate, 20-30 $\mathrm{mm}$. long; stipules deeply toothed: peduncles shorter than the leaves, 4-8-flowered; flowers purplishblue, $18-20 \mathrm{~mm}$. long: pods linear-oblong, reticulated.-Frequent; across the continent especially northward.

1a. Vicia americana oregana (Nutt.) A. Nels. Somewhat pubescent; stems weak: leaves mostly lance-oblong, usually some of them truncate or serrate at apex. (V.oregana Nutt. and V.truncata Nutt. T. \& G. Fl. 270.)

2. Vicia linearis (Nutt.) Greene, Fl. Francis. 3. 1891. Nearly glabrous; stems decumbent or scrambling: leaflets 8-14, linear, often obtuse, apiculate; tendrils short, simple or bifid; stipules laciniate-toothed or incised below: peduncles 3-4-flowered, shorter than the leaves; flowers large (18-25 mm. long), pale purple: style nearly filiform, villous around the summit.-Very common throughout our range and westward.

2a. Vicia linearis caespitosa A. Nels. A reduced form, the stems branched and matted.-With the species.

3. Vicia producta Rydb. Bull. Torr. Club 28: 500. 1901. Sparsely pubescent perennial; stems slender, branched, angled and leafy: leaflets 6-10, oblong to linear: peduncles 2-3-flowered, distinctly produced beyond the small lateral flowers: calyx-tube about $2 \mathrm{~mm}$. long, exceeding its lance-subulate teeth: corolla ochroleucous with purplish tip.- Southern Colorado.

\section{LATHyRUS L. Pea or Vetch}

Our species are perennial and mostly smooth plants, the rachis of the leaves in some not produced into a tendril. Style flattish, dilated (not grooved) above, hairy along the inner side (next the free stamen). Sheath of the filaments scarcely oblique at the apex. Otherwise nearly as in Vicia.

\section{Flowers purple.}

Leaves not tendril-bearing.

Leaves linear. Glabrous .

Villous-canescent

Leaves lance-oblong

Leaves tendril-bearing

Flowers white or yellowish.

Leaves linear to oblong.

Stipules semisagittate.

Stipules foliaceous :
Leaves ovate, conspicurously veiny :

1. Lathyrus ornatus Nutt. T. \& G. Fl. N. A. 1: 277. 1838. Erect, glabrous, often glaucous; stem 1-2 dm. high, sometimes branched, quadrangular: leaflets 3-4 pairs, lanceolate-linear, acute, mucronate, rigid and strongly veined, tendrils scarcely any; stipules linear-lanceolate and slender, semisagittate, entire: peduncles about 4-flowered, longer than the leaves; flowers large, purple, 2-3 cm. long, very showy: calyx-teeth subulate, slightly unequal, rather shorter than the tube: pod smooth, flat, acuminate at each end.-Plains at the eastern base of the Rocky Mountains.

2. Lathyrus incanus Rydb. Size and habit of the preceding, densely villous-canescent throughout, otherwise quite similar.-Sandy banks and washes; Wyoming and Nebraska.

3. Lathyrus decaphyllus Pursh, Fl. Am. Sept. 471. 1814. Mostly glabrous; stem erect, slightly woody at the base, much branched, a little quadrangular, about $3 \mathrm{dm}$. high: leaflets $2-5$ pairs, elliptical-lanceolate, somewhat glaucous, rigid, strongly veined; stipules lanceolate, subfalcate, semisagittate at base: peduncles 3-5-flowered, rather shorter than the leaves; flowers large, purple: segments of the calyx broadly or narrowly subulate, somewhat unequal, shorter than the tube: pod large, glabrous. L. polymorpius.-Throughout the Rocky Mountains of the United States.

4. Lathyrus arizonicus Brit. Trans. N. Y' Acad. Sci. 8: 65. 1889. Perennial, glabrous or somewhat pubescent; stem often winged: leaflets 4-8, 
narrowly oblong to linear, acute, $2.5-5 \mathrm{~cm}$. long; stipules mostly narrow, often small: peduncles 2-6-flowered; flowers purple, $12 \mathrm{~mm}$. long.-Colorado and southward.

5. Lathyrus leucanthus Rydb. Bull. Torr. Bot. Club 28: 37. 1901. Nearly glabrous, 2-3 dm. high; stem angled: stipules very narrow, semisagittate; leaflets 2-4 pairs, elliptic or narrower, veiny; tendrils of the lower leaves short or wanting; of the upper elongated and 2-3-divided: racemes 2-4-flowered: calyx glabrous, cleft to the middle: corolla white or yellowish, about $15 \mathrm{~mm}$. long; the banner broad. L. palustris and L. myrtillifolius as to the plants of our range.-Colorado to Utah and Nevada.

6. Lathyrus ochroleucus Hook. Fl. Bor. Am. 1: 159. 1833. Glabrous or subglaucous; stems slender, climbing or scrambling: stipules broad, foliaceous, semicordate, half as large as the thin ovate leaflets: peduncles 7-10-flowered; flowers 12-20 mm. long, yellowish-white: pod sessile, glabrous, $3-4 \mathrm{~cm}$. long.Coming into the northeastern part of our range; extending far northward and eastward.

7. Lathyrus utahensis Jones, Proc. Cal. Acad. 5: 678. 1895. Leaflets 4-6 pairs, oval or ovate, 2-4 cm. long, obtuse at both ends, apiculate at apex, prominently veined: stipules large, reniform, variously cut: peduncles about equaling the leaves, 4-6-flowered; flowers 15-20 mm. long, white or ochroleucous, sometimes tinged with purple: calyx-lobes subulate-triangular: pod 4-5 cm. long, smooth as is the rest of the plant.-Colorado and Utah.

\section{GERANIACEAE St. Hil. Geranium Family}

Herbs, with alternate or opposite lobed or dissected leaves, and complete, regular, symmetrical 5-merous flowers. Sepals persistent. Petals deciduous. Stamens same number as petals or 2-3 times as many; filaments distinct; anthers versatile. Pistil of 5 united carpels, the styles united into a column. Fruit a 5-celled capsule.

Stamens 10; carpel-tails naked on the inner side . Stamens 5; carpel-tails hairy on the inner side :

\section{geranium L. Geranium or Cranesbill}

Annual or perennial herbs, often glandular-pubescent, usually with deeply lobed or dissected leaves with conspicuous stipules. Petals imbricated, alternating with 5 glands. Stamens usually 10,5 of them longer and alternating with the 5 shorter ones. Capsule 5 -lobed, each lobe separating elastically at the base at maturity, curling upward and back upon the united styles; the cavities 1-seeded.

Annual or biennial; adventive.

Stamens 5; seeds smooth $\quad$. . . . . . . 1. G. pusillum.

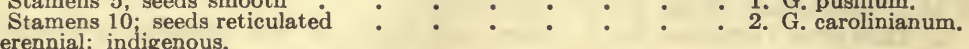

Perennial; indigenous.

No glandular pubescence

More or less glandular-pubescent.

Leaves and flowers large; petals (within) and filaments more or less long-villous.

Plants single or scarcely tufted.

Pubescence tipped with purple glands . . . . 4. G. Richardsonii.

Pubescence viscid-glandular $\quad \cdot \quad: \quad: \quad: \quad$ : $\quad$ 5. G. viscosissimum.

Plants caespitose-tufted.

Pubescence short-glandular, mostly above only . . 6. G. Fremontii.

Pubescence viscid-villous as well as short-glandular ${ }^{*} \quad$ 7. G. Parryi.

Leaves and flowers small; petals and filaments not long-

8. G. longipes.

1. Geranium pusillum L. Sp. Pl. Ed. 2, 957. 1763. Slender, spreading, soft-pubescent on the calyx, etc., somewhat glandular-villous or with short 
glands: leaves small, round-reniform or the cauline truncate at base, equally cleft into about 7 cuneate-oblong lobes, each more or less regularly 3 -toothed at apex: peduncles distributed along the stem: petals pale to deep violet, somewhat notched: antheriferous stamens only 5 (exceptional in the genus): fruit very small, with puberulent beak, the carpels $2 \mathrm{~mm}$. long, finely canescent, not wrinkled.-Adventive in a few places in our range.

2. Geranium carolinianum L. Sp. Pl. 1: 682. 1753. Erect, diffusely much branched from the base, or nearly simple, 1-5 dm. high, pubescent: leaves $2-5 \mathrm{~cm}$. in diameter, palmately 5-7-lobed or parted, the divisions cleft into oblong-linear lobes: pedicels short, crowded at the end of branchlets: petals obcordate, pale flesh-color, equaling the awned sepals: carpels pubescent: seeds obscurely reticulated. (G. Bicknellii Brit. as to plants of our range.)Across the continent, but rare in our range.

3. Geranium caespitosum James, in Long's Exped. Am. Ed. 2. 3. 1825. Caespitose-tufted, lightly grayish-pubescent throughout, not glandular: leaves orbicular-reniform, deeply 5-7-cleft: sepals oblong, scarious-margined, aristate: petals generally rose-purple, obovate, scarcely longer than the calyx, bearded near the base within with straight white hairs: filaments pilose: capsule sof tly pubescent. [G. atropurpureum Heller, Bull. Torr. Bot. Club 25: 195. 1898; G. Cowenii Rydb. (?).] - Central Colorado but occasionally north to Wyoming and south to New Mexico.

4. Geranium Richardsonii F. \& M. Ind. Sem. Hort. Petrop. 4: 37. 1835. Slender, erect, inconspicuously retrorsely-pubescent below, the peduncles and pedicels and often the upper part of the stem villous with long white hairs tipped with purple glands: leaves thin, 5-7-cleft, the uppermost with the terminal lobe longer than the often greatly reduced lateral ones: petals white with roseate veins, or seemingly sometimes purple: capsule puberulent or glandular-pubescent on the beak. (G. strigosum Rydb. Bull. Torr. Bot. Club 29: 243. 1902.)-Along streams in the mountains; from Canada to New Mexico.

5. Geranium viscosissimum F. \& M. Ind. Sem. Hort. Petrop. 9: Suppl. 18. 1835. Coarser and leafy branched, dingy-viscid and glandular-pubescent, at least above, often throughout, 3-8 dm. high: leaves large, thick, long-petioled, nearly orbicular, with cordate or reniform base, deeply 3-parted, the lateral lobes deeply 2-lobed: petals purple, broadly obcordate, 12-15 mm. long, densely bearded at base: styles minutely hispid: beak of fruit very glandular. G. incisum.-From Wyoming to the far northwest.

6. Geranium Fremontii Torr. in Gray, Pl. Fendl. 26. 1848. More or less caespitose-tufted, rather stout, 2-4 dm. high; pubescence sparse, short, and appressed, and viscid-glandular above: upper leaves deeply 3-5-cleft; the radical ones 7 -cleft, the segments 3-lobed or incised: petals mostly light purple, twice as long as the sepals, villous at base: beak of fruit dirty-glandular. [G. nervosum Rydb. 1. c. 28: 34. (?).]-Dry open hillsides; Colorado to Idaho.

7. Geranium Parryi (Engelm.) Heller, Muhl. 1: 7. 1900. Quite similar but stouter and often taller, with dense viscid pubescence throughout, of two kinds, loosely villous-viscid and short-glandular: leaves 5-7-cleft; the lobes obovate-cuneate, with ovate teeth: petals obovate, light purple or rose, with darker veins: seeds reticulated. (G. Pattersonii Rydb. Bull. Torr. Bot. Club 29: 242. 1902.) G. Fremontii Parry $i$ Engelm.-Mountains of central Colorado and probably extending into Wyoming and Utah.

8. Geranium longipes (Wats.) L. N. Good. Bot. Gaz. 37: 56. 1904. Perennial (?), at least biennial: stems simple below, branching above into 3-6 slender equal branches, each of which gives rise to 2-flowered elongated slender peduncles: pedicels almost filiform, long: pubescence sparse-strigose, reflexed below, glandular-pubescent above: leaves reniform, 5-7-cleft nearly to the base, the radical on long slender petioles: sepals oblong, long-awned: petals narrowly obcordate, shorter that the sepals: ovary strigose-pubescent: seeds oblong, pitted. G. carolinianum longipes.-Indigenous in the mountains of western Colorado and Wyoming and in Utah. 


\section{ERODIUM L'Her. STORKsBILL}

Like Geranium but with only 5 stamens. The carpel-tails long bearded on the inner side and becoming spirally twisted. Peduncles 2-several-flowered, with a 4-bracted involucre, either terminal or lateral.

1. Erodium cicutarium L'Her. Ait. Hort. Kew 2: 414. 1789. Hairy, much branched from the base: leaves pinnate; the leaflets laciniately pinnatifid, with narrow acute lobes: peduncles exceeding the leaves, bearing a 4-8flowered umbel: sepals 2-6 $\mathrm{mm}$. long, acute: petals bright rose-color, a little longer: tails of the carpels $2.5-5 \mathrm{~cm}$. long: pedicels slender, at length reflexed, the fruit still erect. Known as Alfilaria or Pin-ClOver.-From the Rocky Mountains to the far west.

\section{OXALIDACEAE Lindl. Wood Sorrel Family}

Annual or perennial, leafy stemmed or acaulescent herbs, often with rootstocks or scaly bulbs, with sour sap (oxalic acid), and mostly palmately 3foliolate leaves. Stipules commonly present as scarious margins to the bases of the petioles; leaflets mostly obcordate. Flowers perfect, in umbel-like or forking cymes or rarely solitary, or mostly on rather long peduncles. Sepals 5, often unequal. Petals 5, white, purple or yellow. Stamens 10-15. Ovary 5-lobed, 5-celled; styles united or distinct; ovules 2-many in each cell. Fruit a loculicidal, globose or columnar capsule.

\section{OXALIS L. WOOD SORREL}

Low, often acaulescent herbs with a sour sap, alternate 1-3-foliolate leaves, few-many-flowered peduncles, 10 stamens, and a 5 -celled columnar or ovoid loculicidal capsule, with 2-several seeds in each cell.

Acaulescent; flowers not yellow _ . . . . . . . . 1. O. violacea.

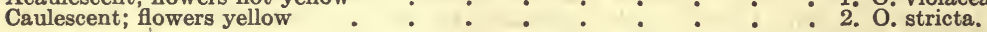

1. Oxalis violacea L. Sp. Pl. 434. 1753. Acaulescent glabrous perennial, 5-10 cm. high; the petioles and scapes from a short scaly bulb-like rhizome: leaflets about $10 \mathrm{~mm}$. long, broadly obcordate, with an open sinus: scapes several, longer than the leaves, umbellately 3-12-flowered: sepals ovate, obtuse: petals rose-violet, three times as long as the sepals: capsule ovoid: seeds 2-3 in each cell, rugose-tuberculate. An exceedingly acid plant.-Common eastward and said to extend into Colorado.

2. Oxalis stricta L. Sp. Pl. 435. 1753. Glabrate or more or less strigillose, especially on the stems and pedicels, perennial; stem more or less branched, 10-25 cm. high: leaves bright green, without stipules; the leaflets obcordate, sensitive: sepals oblong, somewhat ciliate and pubescent on the back: petals pale yellow, longer than the sepals: capsule columnar, $15-25 \mathrm{~mm}$. long. (O. coloradensis Rydb. Bull. Torr. Bot. Club 29: 243. 1903. More nearly glabrous.)-Open woods along streams; from the mountains eastward.

\section{LiNaCeae Dumort. Flax Family}

Herbs or shrubs, with alternate or opposite leaves and perfect, regular, symmetrical, 5-merous flowers. Calyx imbricated. Petals convolute. Stamens united at the base. Capsule with twice as many cells as there are styles, 8-10-seeded. 


\section{LINUM L. FLAX}

Herbs, with tough fibrous bark, alternate (sometimes opposite) leaves without stipules or with glands in their place, persistent sepals and ephemeral petals, and a 5-celled pod with 2 seeds hanging from the summit of each cell, which is partly or completely divided into two by a false partition projecting from the back of the carpel, the pod thus becoming 10-celled.

Petals blue

Petals yellow or yellowish.

Glabrous on leaves and stems. Leaves imbricated

Leaves small and sparse.

Flowers orange; styles united to summit. Flowers yellow; styles distinct at summit

Puberulent on leaves and stems.

Filaments dilated below; styles united to summit

Filaments linear; styles distinct at summit .
1. L. Lewisii.

\section{L. Kingii.}

3. L. arkansanum.

4. L. rigidum.

5. L. puberulum.

6. L. compactum.

1. Linum Lewisii Pursh, Fl. Am. Sept. 210. 1814. Branching above, leafy: leaves linear to linear-lanceolate, acute: flowers large, in few-flowered corymbs or scattered on the leafy branches: capsule exceeding the sepals, the prominent false partitions long-ciliate. L. perenne.-Common on dry soils throughout our whole range, thence northward and westward.

2. Linum Kingii Wats. Bot. King's Exp. 49. 1871. Low glabrous perennial with woody base, $10-25 \mathrm{~cm}$. high: stems numerous, ascending, panicled above: leaves alternate, crowded or imbricated below, linear to oblong, obtuse: flowers yellow, crowded: sepals ovate, acute, glandular-margined: filaments dilated at base: styles free, as long as the stamens: capsule globose, cuspidate, exceeding the calyx.-Wyoming and westward.

3. Linum arkansanum Osterh. Bull. Torr. Bot. Club 28: 645. 1901. Glabrous or obscurely scabro-puberulent, perennial (?), 1-2 dm. high, paniculately branched from near the base: leaves linear, 1-2 cm. long; the upper broader at base and ciliate-glandular: sepals aristate-pointed, $1 \mathrm{~cm}$. Ilong: petals cuneate, $15 \mathrm{~mm}$. long, $10 \mathrm{~mm}$. broad, orange-colored with rose-tinted base: styles united to the summit: capsule half the length of the sepals.Colorado and southeastern Wyoming to Kansas.

4. Linum rigidum Pursh, Fl. Am. Sept. 210. 1814. Glabrous or nearly so and glaucous, branched, 2-5 dm. high; the branches stiff and more or less angular: leaves linear or linear-lanceolate; the upper glandular-serrulate: sepals lanceolate, acute or awn-pointed: petals sulphur-yellow, cuneateobovate, twice as long as the sepals: styles united nearly to the summit: filaments subulate from a triangular base: capsule ovoid, a little shorter than the sepals. (L. australe Heller, Bull. Torr. Bot. Club 25: 627. 1898.)-From British America to New Mexico.

5. Linum puberulum (Engelm.) 'Heller, Bull. Torr. Bot. Club 23: 627. 1896. Puberulent but glaucous, 1-2 dm. high: stems branched from the base; the branches paniculately branched above: leaves erect, linear, '1-nerved, mucronate, a pair of stipular glands at the base: pedicels equaling or exceeding the calyx: sepals glandulose-ciliate, the exterior 3-nerved: filaments with an ovate-triangular base: styles united to the summit: capsule ovate, scarcely shorter than the sepals.-Utah and Colorado to Texas.

6. Linum compactum A. Nels. Bull. Torr. Bot. Club 31: 241. 1904. Perennial from slender rhizomes, murky-green, with a scabrous. puberulence throughout, seemingly also subglutinous: stems crowded on the somewhat enlarged crowns, about $1 \mathrm{dm}$. long, each freely branched, striate but not wingangled: leaves linear, about $1 \mathrm{~cm}$. long, mucronate, no stipular glands: sepals lanceolate, obscurely 1-3-nerved, short-cuspidate, glandular-ciliate on the scarious margin, 5-6 mm. long, scarcely surpassing the mature fruit: petals yellowish, wholly glabrous, nearly twice as long as the sepals: filaments linear: styles free for one third their length.-On the Platte river in eastern Wyoming.

ROCKY MT. BOT.-20 


\section{ZYGOPhyllaceae Lindl. Bean Caper Family}

Herbs, shrubs, or trees, with opposite, pinnately compound, dotless, stipulate leaves, symmetrical 4 - or 5-merous flowers solitary on lateral or terminal naked peduncles, stamens as many or twice as many as the petals, and a single style terminating a 2-12-carpeled ovary which ripens dry.

Herb; leaves with 6-10 leaflets

Shrub; leaves with two leaflets

1. Kallstroemia.

2. Covillea.

\section{KALLSTROEMIA Scop. Caltrop}

Pubescent branching herbs, with opposite, evenly pinnate leaves and solitary, axillary, peduncled flowers. Sepals 5 (in ours), tardily deciduous. Petals 5, early deciduous. Stamens 10. Ovary sessile, with 10-12 1-ovuled cells; the style thick, striate. Fruit broad, crenately lobed, splitting into 10-12 1-seeded segments which are tubercled on the back.

1. Kallstroemia brachystylis Vail, Bull. Torr. Bot. Club 24: 208. 1897. Sparsely pubescent, diffusely branched from the base; the stems brittle, striate, 1-4 dm. long: leaflets 3-4 pairs, 6-15 mm. long, oval to oblong, oblique at the base: sepals linear-lanceolate, falling before the fruit matures: petals obovate, obtuse or retuse: fruit finely pubescent, on a peduncle 1-2 cm. long. Tribulus maximus in part.-Southern Colorado and New Mexico.

\section{Covillea Vail. Creosote Bush}

Evergreen heavy-scented shrubs, with nodose branches, opposite 2-foliolate leaves, and solitary yellow flowers. Sepals 5, deciduous. Petals 5, clawed. Disk 10-lobed. Stamens 10; the filaments winged below and with a bifid scale on the inner side. Ovary 5-celled. Fruit globose, short-stipitate, separating into 5 hairy 1-seeded carpels.-Larrea.

1. Covillea tridentata (DC.) Vail, Bull. Torr. Bot. Club 22: 229. 1895. Diffusely branched, 12-30 dm. high, densely leafy, of a yellowish hue: leaves nearly sessile, the thick resinous leaflets inequilateral, oblong, 6-12 $\mathrm{mm}$. long, with a broad attachment to the rachis, somewhat curved: sepals ovate, obtuse, silky: petals bright yellow, 6-8 $\mathrm{mm}$. long: fruit $5 \mathrm{~mm}$. in diameter, beaked by the slender style. Larrea mexicana.-A shrub of the dry mesas; southern Colorado to Texas and west to California.

\section{RUTACEAE Juss. Rue Family}

Shrubs or small trees, with pellucid or glandular-dotted aromatic leaves, definite hypogynous stamens, and few seeds. Sepals and petals 4 or 5 , imbricated in the bud. Stamens as many or twice as many as the petals, inserted outside of a hypogynous disk. Stipules none.

Leaves 3 -foliolate

Leaves simple

\section{Ptelea L. Hop Tree. Shrubby Trefoil}

Shrubs or small trees, with trifoliolate leaves, and small, polygamous, greenish-white flowers in terminal cymes or compound umbels. Stamens 4 or 5 . Ovary with a short thick stipe, 2-celled; the cells 2 -ovuled, the lower ovule abortive. Fruit orbicular, broadly winged.

1. Ptelea crenulata Greene, Pitt. 1: 216. 1888. A shrub or small tree 2-7 m. high, glabrous except the tomentulose flowers: leaflets ovate-lanceolate 
to obovate, somewhat cuneate at base and either obtuse or acute at apex, 3-7 cm. long, crenulate or crenate-serrate or almost entire: filaments villous near the base: samara, including the broad wing, 12-18 $\mathrm{mm}$. broad, either truncate or emarginate at both ends. P. trifoliata. ( $P$. angustifolia Benth., a Mexican species, has been reported from our range, but such specimens may prove to be $P$. crenulata.) - Colorado to New Mexico and west to California.

\section{THAMNOSMA Torr.}

Low glandular desert shrubs. Strongly scented leaves simple and linear. Alternate flowers purple or yellow, solitary. Sepals 4 . Petals 4, erect. Stamens 8 , at the base of a cup-shaped crenate or lobed disk. Ovary stipitate, 2-lobed and 2-celled, with 5 or 6 ovules in each cell; style elongated. Capsule didymous; coriaceous, dehiscent down the inner edge of each lobe. Seeds 4-6 in each cell, reniform.

1. Thamnosma texanum Torr. Bot. Mex. Bound. Surv.42. 1858. Woödy only at base, the slender stems 1-4 dm. high: flowers on short naked pedicels: petals yellow tinged with purple.-Southwestern Colorado and southward.

\section{POLYGalacEAE Reichenb. Milkwort Family}

Herbs with simple entire leaves and no stipules, remarkable for the seemingly papilionaceous flowers, monadelphous stamens coherent with the petals, and 1-celled anthers opening at the top.

\section{POLYGALA L. Milkwort}

Herbaceous or somewhat shrubby, with racemose or spicate flowers. Sepals 5 , very unequal, the 2 lateral large and petal-like. Petals 3 , united to each other and to the stamen-tube, the middle one hooded above and often crested or beaked. Stamens 6 or 8 . Ovary 2-celled; style long, curved, dilated above. Capsule membranaceous, flattened at right angles to the narrow partition, often notched above. Seed carunculate at the hilum.

Shrubby and spinescent.

Subcinereous-pubescent.

Herbaceous or nearly so; spines wanting.

Annual; leaves verticillate

Perennial; leaves alternate

1. Polygala acanthocarpa Gray, Proc. Am. Acad. 11: 73. 1876. Somewhat shrubby, 4-7 dm. high, subcinereous-pubescent, armed with slender spines: leaves linear-spatulate: flowers subaxillary, scattered, white; pedicels bibracteolate at base: keel short, boat-shaped, with a boss on the back.Probably coming into our range at the southwest.

2. Polygala subspinosa Wats. Am. Nat. 7: 299. 1873. Perennial, herbaceous, glabrous or more or less pubescent; stems $5-20 \mathrm{~cm}$. high, branched above, the branches often spinose: leaves scattered, 1-3 cm. long, oblong or oblanceolate, acute or obtuse, attenuate to the base: raceme loose, fewflowered; bracts small and scarious; pedicels becoming reflexed, shorter than the flowers: sepals naked or ciliate, the wings oblong, 8-10 $\mathrm{mm}$. long and equaling the petals; keel hooded, crested with a broad saccate process: style linear; capsule orbicular, emarginate, short-stipitate.-From Colorado to the Pacific southwest.

3. Polygala verticillata L. Sp. Pl. 706. 1753. Slender, 2-3 dm. high: stem leaves whorled in fours, sometimes in fives; those of the branches scattered, linear: spikes peduncled, dense, slender; the bracts falling with the flowers, which are small, greenish-white or barely tinged with purple, the crest of the 
keel conspicuous: the 2-lobed caruncle half the length of the seed.-Colorado and eastward across the plains.

4. Polygala alba Nutt. Gen. 2: 87. 1818. Smoothish, about $3 \mathrm{dm}$. high, leafy half-way to the summit: leaves linear to oblanceolate, margins slightly revolute: flowers deciduous, leaving the rachis roughened after their fall, white: seed with caruncle extended into 2 ear-like lobes nearly as long as the seed.-Plains of the upper Missouri.

64. EUPHORBIACEAE St. Hil. Spurge FAmily

Herbs, shrubs, or trees, usually with milky or purplish acrid sap and monoecious or dioecious flowers. Leaves either opposite, alternate, or whorled, with or without stipules. Flowers with or without floral envelopes; if the calyx is wanting then a calyx-like involucre is present. Ovary 3-celled, with a pendulous ovule in each cell, maturing into a 3-celled elastically dehiscent capsule with crustaceous seeds. Stamens few or numerous, the filaments free or united. Styles and stigmas as many as the cells of the ovary.

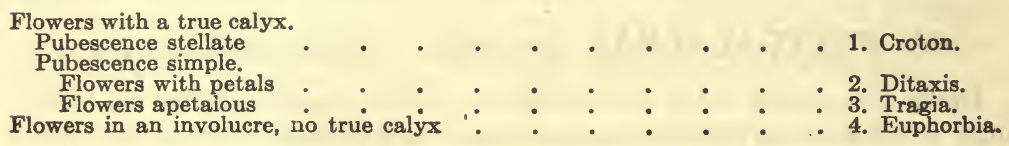

\section{CROTON L.}

Herbs or shrubs, scurfy or stellately hairy or sometimes glandular: leaves alternate, entire or repand. Staminate calyx 4-6-parted. Petals often present but small or rudimentary, alternating with the glands of a central disk. Stamens 5-many, on a hairy receptacle. Pistillate calyx usually 5-parted, but the petals mostly obsolete. Seeds smooth and shining, carunculate.

1. Croton texensis (Klotzsch.) Muell. Arg. in DC. Prodr. 15: 692. 1862. Covered with a close, canescent, stellate pubescence, dichotomously branched or spreading, 3-6 dm. high: leaves lanceolate, oblong, or linear-lanceolate: dioecious; racemes of staminate flowers short: ovary stellate-tomentose; styles twice or thrice dichotomously 2-parted.-From Wyoming to Colorado and southward.

\section{DITAXIS Vahl.}

Erect herbs or shrubs with purplish sap. Leaves (in ours) entire, alternate, usually stipulate. Calyx valvate in the staminate flowers, imbricate in the pistillate. Petals 4 or 5 , alternate with the calyx-lobes and with the lobes of the glandular disk. Filaments united into a central column. Seeds subglobose, roughened or reticulated, not carunculate.

1. Ditaxis humilis (Eng. \& Gray) Pax, in Engl. \& Prantl, Nat. Pfl. Fam. $3^{5}: 45$. 1890. Stem about $3 \mathrm{dm}$. high, much branched, silky or strigosepubescent, branches spreading: leaves narrowed at the base, spatulate or obovate, lanceolate or linear-lanceolate, acute, sparingly pubescent: raceme much shorter than the leaves, on very short peduncles. Argythamnia humilis. -Colorado, southward and eastward.

\section{TRAGIA L.}

Erect or climbing plants, pubescent or hispid, sometimes stinging, with mostly alternate, stipulate leaves. The sterile flowers above, the few fertile at the base, all with small bracts. Staminate calyx 3-5-parted; filaments 
short; anther-cells united. Pistillate calyx 3-8-parted, persistent. Capsule 3 -lobed, bristly, separating into three 2-valved carpels.

1. Tragia ramosa Torr. Ann. Lyc. N. Y. 2: 245. 1826. Perennial, light green, bristly with stinging hairs: stem erect, slender, often freely branched, 2-4 dm. high: leaves ovate-lanceolate to narrowly oblong, 1-4 cm. long, serrate, cordate at base: calyx in pistillate flowers 5-lobed, 3-bracted; in staminate 4-5-lobed, with 4-6 stamens: capsule depressed, bristly: seeds globose orange, variegated. T. nepetaefolia ramosa.-Colorado, eastward and southward.

\section{EUPHORBIA L. SPURge}

Monoecious herbs (ours), with alternate, opposite, or verticillate leaves and cymose inflorescence. Flowers included in the 4-5-lobed involucres which are terminal or in the axils; the involucral-lobes alternating with as many fleshy glands, which are rounded and naked or bear petal-like or lunate appendages. Sterile flowers lining the base of the involucre, each of a single pediceled (or filament-bearing) stamen, joined to a minute bract (the supposed rudimentary calyx). Fertile flowers solitary in the middle of the involucre, soon protruded on a long pedicel. Capsule erect or nodding, 3-lobed, splitting into three 2 -valved carpels.

Glands of the involucre with petal-like appendages (Chamaesyce).

Leaves inequilateral and oblique at base.

Quite entire.

Seeds smooth.

Appendages conspicuous; seeds terete

Appendages small; seeds obtusely 4-angled •

Seeds somewhat roughened.

Glands broader than long, with fan-shaped appendages

Glands longer than broad, with crescent-shaped append-

Serrate or dentate.

Glabrous.

Seeds pitted, faintly if at all rugose .

Seeds rugose, not pitted .

Pubescent

Leaves with the two sides at the base similar.

Appendages very large and conspicuous; leaves alternate Appendages small; leaves opposite

Glands of the involucre naked (without petal-like appendages).

Leaves opposite (Poinsettia).

Ovate or orbicular-oblong, coarsely dentate

Oblong-linear or linear, nearly entire.

Branched from the base, spreading

Stem simple (at least below), erect

Leaves alternate or scattered (Tithymalus).

Entire; glands semilunate.

Stems tufted, low and stout

Stems few, taller and more slender

Serrate or dentate.

Annuals.

Stems simple below

Stems branched from the decumbent base

Biennial; stem branched from the base

1. E. Eetaloidea.

3. E. albomarginata.

4. E. Fendleri.

5. E. serpyllifolia.

6. E. glyptosperma.

7. E. stictospora.

8. E. marginata.

9. E. hexagona.
10. E. dentata.

11. E. Aliceae.

- 12. E. cuphosperma.

13. E. robusta.

- 14. E. montana.

15. E. arkansana.

16. E. manca.

17. E. commutata.

1. Euphorbia petaloidea Engelm. Bot. Mex. Bound. Surv. 185.1859. Glabrous annual, low, freely branched, procumbent: leaves all similar, oblonglinear, obtuse or retuse, attenuate to the scarcely oblique base: involucres solitary, campanulate, lobes hairy beneath the glands which are about as long as the lobes; appendages conspicuous, white, ovate or orbicular, entire or crenulate: capsules globose-depressed: seeds cinereous, nearly smooth, oblongovoid.-Sandy plains; from the Rocky Mountains to the Mississippi river.

2. Euphorbia serpens H. B. K. Nov. Gen. 2: 52. 1817 . Glabrous or glaucescent annual, with filiform prostrate stems, often rooting: leaves roundovate, obtuse or cordate at base; stipules membranaceous, triangular: peduncles longer than the petioles, solitary in the axils: glands salverform, shorter than the lobes of the involucre; appendages minute, crenulate: cap- 
sules nodding, depressed-globose: seeds obtusely quadrangular, $1 \mathrm{~mm}$. long or less.-Plains; Colorado, east to the Mississippi, south to Mexico.

3. Euphorbia albomarginata T. \& G. Pac. R. R. Rep. 2: 174. 1857. Perennial, slender, much branched, smooth: leaves stipulate, opposite, suborbicular or subcordate, entire, distinctly petiolate: involucre solitary, shorter than the peduncles; glands transversely oval, with an entire or slightly crenate petaloid border, which is twice as broad as the gland itself: seeds obovate, somewhat rugose transversely, dull, gelatinous when moistened.-Colorado to Utah and southward.

4. Euphorbia Fendleri T. \& G. Pac. R. R. Rep. 2: 175. 1855. Glabrous perennial, from a slender rootstock: stems delicately filiform, erect or decumbent, dichotomous, much branched, $5-10 \mathrm{~cm}$. high: leaves ovate, obtuse, obliquely rounded or truncate at base; stipules subulate: involucres terminal, solitary, turbinate, slightly bearded in the throat, lobes short and fimbriate; glands transversely oblong, with a very narrow obscure appendage: capsule deflexed, somewhat 3-lobed: seeds ovoid, transversely rugose.-Throughout our range and southward and eastward.

5. Euphorbia serpyllifolia Pers. Syn. 2: 14. 1807. A prostrate spreading glabrous annual with obovate-oblong leaves, narrowed at the very oblique base and serrulate towards the obtuse apex (6-12 $\mathrm{mm}$. long); stipules lanceolate, at length fimbriate at tip: peduncles as long as the petioles or longer, solitary in the axils or clustered towards the ends of the branches: glands of the small involucre with narrow somewhat toothed appendages: capsules sharply angled, slightly drooping: seeds transversely wrinkled and pitted.From California to Iowa and Texas.

5a. Euphorbia serpyllifolia rugulosa (Engelm.) Millsp. Pitt. 2: 85. 1890. More matted: leaf toothed on the longer side: seeds turgid, finely rugulose.Southwestern Colorado, Mexico, and California.

6. Euphorbia gly ptosperma Engelm. Bot. Mex. Bound. Surv. 187. 1859. Glabrous annual, erect and spreading: leaves linear-oblong, mostly falcate, * very unequal at base, slightly serrulate towards the obtuse apex (4-10 mm. long); stipules lanceolate, setaceously divided: peduncles as long as the petioles, solitary or in dense foliaceous lateral clusters: glands of the very small involucre with narrow crenulate appendages: capsules nodding, sharply angled: seeds quadrangular and with 5 or 6 sharp transverse wrinkles.-From Canada to Mexico.

7. Euphorbia stictospora Engelm. Bot. Mex. Bound. Surv. 187. 1859. A yellowish-green pubescent annual: stem 1-1.5 $\mathrm{dm}$. long: leaves rounded, subcordate, sharply serrate, $4-8 \mathrm{~mm}$. long: racemes crowded with very small and slender long-peduncled involucres; glands narrowly appendaged: capsule pubescent, sharply angled: seeds slender, sharply quadrangular, rugose, pitted.-Wyoming to Mexico.

8. Euphorbia marginata Pursh, Fl. Am. Sept. 607. 1814. A stout erect annual, bright green, glabrous or pubescent, 3-7 dm. high: leaves entire, ovate or oblong; the uppermost or floral leaves with conspicuous white or petal-like margins, whorled or opposite: involucres 5-lobed, collected in an umbel-like inflorescence with 3 dichotomous rays; glands with broad white appendages: capsule depressed-globose, about $6 \mathrm{~mm}$. in diameter: seeds reticulate-tuberculate.-From Minnesota to Colorado and Texas.

9. Euphorbia hexagona Nutt. Spreng. Syst. 3: 791. 1826. Erect annual, somewhat hairy with scattered appressed hairs: stem slender, 3-6 dm. high; branches opposite and dichotomous, striate-angled: leaves all opposite, short-petioled, linear-lanceolate, alternate at each end, acute, mucronulate, entire; floral ones very narrowly linear: involucre hairy without and in the throat, short, many-cleft; glands 5 , transversely ovate, with a green ovatetriangular acute appendage, twice their length: styles very short, capitate and somewhat 2-lobed at the apex; carpels of the smooth capsule obtusely carinate: seeds ovate, finely papillose.-From the upper Missouri to 'New Mexico.

10. Euphorbia dentata Michx. Fl. Bor. Am. 2: 211. 1803. A dull green pubescent annual with ovate, or ovate-lanceolate, coarsely dentate, opposite, 
petioled leaves: involucres in terminal clusters, oblong-campanulate, about $3 \mathrm{~mm}$. long, 3-5-lobed, with 1-4 short-pediceled glands without appendages: capsules glabrous: seeds ovoid or subglobose, slightly tuberculate.-Extending into Colorado from the east.

11. Euphorbia Aliceae A. Nels. Bot. Gaz. 42: 50. 1906. Perennial from slender horizontal rootstocks, glabrous or slightly pubescent, 10-15 cm. high: stem branching from the base, the branches spreading-decumbent: leaves narrowly oblanceolate, short-petioled, sharply serrate, opposite, more crowded toward the terminal clustered involucres: involucres nearly sessile, small, turbinate, somewhat fimbriate-margined; the glands about 4, small, shortstipitate, sometimes minutely cornuate or even obscurely appendaged: capsules glabrous: seeds cubical, with a caruncle, slightly tuberculate, ashy.Known as yet only from Hartville, Wyoming.

12. Euphorbia cuphosperma (Engelm.) Boiss. in DC. Prodr. 152: 73. 1862. Annual, sparingly rough-pubescent: stem simple or somewhat branched upward with erect slender branchlets, 2-5 dm. high: leaves opposite or alternate, narrowly linear-lanceolate, acute, subentire: involucres $3-5$, corymbose, subsessile, campanulate, with ovate lobes; glands 4, long-stipitate, unappendaged: seeds irregularly 4-angled and slightly tuberculate.-From Dakota to Mexico.

13. Euphorbia robusta (Engelm.) Small, in Brit. Fl. 2: 381. 1897. Glabrous: stems short, stout, tufted on the crown of a perpendicular rootstock, 1-2 dm. high: leaves scattered, oblong-ovate, 10-14 mm. long, entire, obtuse, sessile: involucres terminal in a 3-5-rayed umbel, campanulate, bearing 4 unappendaged crescent-shaped glands: capsule of 3 ovate rounded lobes: seeds terete, gray, minutely pitted. E. montana in part.-Montana to Colorado.

14. Euphorbia montana Engelm. Bot. Mex. Bound. Surv. 192. 1859. Resembling the preceding but the stems few, slender and taller, somewhat branched below the umbel: usually somewhat pubescent on the involucre and the floral leaves: glands short-stipitate and bearing 2 short horn-like protuberances: seeds ovoid-oblong, ash-colored, deeply and irregularly pitted. Southern Colorado and to the southwestward.

15. Euphorbia arkansana Engelm. \& Gray, Bost. Journ. Nat. Hist. 5: 53. 1845. Annual, glabrous, erect, branching above, 2-5 dm. high: stem leaves few, cuneate-spatulate or oblanceolate, 1-5 cm. long; upper leaves oblong to triangular-ovate: involucre small, its lobes short; glands yellow, transversely elliptical: capsule depressed-globose, more or less warty: seeds ovoid-lenticular, with sharp reticulations. E. dictyosperma. Quite variable. Several varieties have been characterized by J. B. S. Norton in the Eleventh Rep. Mo. Bot. Gard.-From Wyoming to Mexico.

16. Euphorbia manca A. Nels. 1. c. 47: 437. 1909. Annual, the decumbent base giving rise to few-several simple erect branches 1-2 dm. high: leaves obovate-cuneate, broadly obtuse, numerous, lower reduced: primary floral bracts ovate-reniform; secondary broadly reniform, sometimes connate: inflorescence once or twice trichotomous: capsule about $4 \mathrm{~mm}$. long: seeds short, cylindrical-oblong, gray but not ashy, nearly smooth.-Colorado.

17. Euphorbia commutata Engelm. in Gray Man. Ed. 2. 389. 1856. Biennial, branched from the base, glabrous, 1-3 dm. high: leaves scattered, thin and membranaceous, petioled, round-obovate or the upper ovate: umbels terminal, 3-rayed and again forking or 3-rayed: involucres campanulate, sessile; glands 3-4, unappendaged, prolonged into slender horns: capsule obtusely angled, glabrous: seeds terete, irregularly pitted.-Extending into our range from the eastward.

\section{CALLITRICHACEAE Lindl. Water Starwort Family}

Small, slender, aquatic herbs, with opposite entire leaves, no stipules, and monoecious, axillary flowers without perianth, but sometimes with 2 bracts. Stamen 1, with slender filament and heart-shaped 4-celled anther. Ovary 
4-celled, with 2 styles. Fruit 4-lobed, flattened, and emarginate. Flowers mostly solitary, sometimes a stamen and a pistil in the same axil.

\section{CALLITRICHE L.}

Characters given under the family.

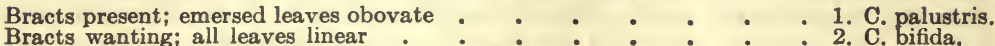

1. Callitriche palustris L. Sp. Pl. 969. 1753. Aquatic or growing in the mud, with elongated stems, and floating, rosulate, obovate often emarginate leaves; the submerged ones linear or nearly so: bracts often exceeding the fruit: styles erect or spreading, deciduous: fruit orbicular or obcordate, of connate carpels, more or less winged. C. verna.-Across the continent.

2. Callitriche bifida (L.) Morong, Mem. Torr. Club 5: 215. 1894. Entirely submerged: leaves linear or linear-lanceolate, clasping at the base: flowers without bracts: styles reflexed, deciduous: fruit round, deeply notched, sessile, broadly winged on the margins. C. autumnalis. - Across the continent in the northern part of our range.

\section{Limnanthaceae Lindl. False Mermaid Family}

Glabrous annual herbs, with pungent juice, dissected alternate leaves without stipules, and pale, regular, symmetrical flowers. Sepals valvate, persistent, and accrescent. Petals withering-persistent. Stamens twice as many as the petals, those opposite the petals having a gland at the base outside.

\section{FLOERKIA Willd.}

Flowers solitary at the ends of bractless axillary peduncles, $3-5$-merous. Carpels 1-ovuled, distinct, the 5-lobed style rising from the center, in fruit becoming semi-drupaceous, rugose-tuberculate nutlets.

1. Floerkia occidentalis Rydb. Mem. N. Y. Bot. Gard. 1: 268. 1900. Very slender, less than $1 \mathrm{dm}$. high, glabrous: leaves pinnate, with 1-2 pairs of oblong leaflets: sepals ovate, acute: petals oblanceolate, about half as long as the sepals: carpels two, sharply rugose-tuberculate.-In wet places; western Wyoming, Utah and northwestward.

\section{ANACARDIACEAE Lindl. Sumac FAMILY}

Shrubs or trees with acrid, resinous, or milky sap, alternate leaves without stipules, and small, regular, commonly polygamous or dioecious flowers. Calyx 3-7-cleft. Petals the same number, imbricated in the bud. Stamens as many or twice as many, inserted at the base of the disk. The free ovary 1-celled and 1-ovuled but the styles often 3 . Fruit generally a small drupe.

\section{RHUS L. SUMAC}

Leaves trifoliolate or pinnately compound. Sepals and petals usually 5 . Stamens inserted under the edge of a disk lining the calyx.

Leaflets 11-31

Leaflets 3 .

Large, rhombic ovate

Small, crenately lobed 
1. Rhus cismontana Greene, Wash. Acad. Sci. 8: 189. 1906. Shrub 8-20 $\mathrm{dm}$. high, with smooth, glabrous or glaucous branches: leaflets 9-17, sessile or petiolulate, from broadly to narrowly lance-oblong, acute or acuminate, serrate, pale green above, lighter beneath and often glaucous, moderately firm: panicle dense, generally pyramidal: drupelets spherical to ovate, pubescent with acid reddish hairs; stone smooth. $R$. glabra. ( $R$. nitens, $R$. tessellata, $R$. albida, and $R$. asplenifolia Greene, and possibly others of the species proposed in the paper cited above.) - From Dakota and Utah to New Mexico and Arizona.

2. Rhus Rydbergii Small, Mem. N. Y. Bot. Gard. 1: 268. 1900. A singlestemmed shrub, less than $1 \mathrm{~m}$. high: petioles 6-12 cm. long; leaflets 3-10 $\mathrm{cm}$. long, broadly ovate, often somewhat rhomboid, glabrous except on the prominent veins beneath, sinuately toothed: flowers in small, conical, axillary panicles: petals ovate, $3 \mathrm{~mm}$. long, yellowish streaked with green: fruit globular, about $6 \mathrm{~mm}$. in diameter, white and shining when ripe. $R$. Toxicodendron in part. Western Poison Ivy. Poisonous to the touch-Open woods; in the mountains and extending eastward to the plains.

3. Rhus trilobata Nutt. T. \& G. Fl. N. A. 1: 219. 1838. A diffusely branched shrub, 6-16 dm. high, ill-scented: leaflets cuneate-obovate or rhomboidal, crenately toothed or lobed above the middle, sometimes 3-lobed: flowers in scaly-bracted, spike-like catkins, yellowish, preceding the leaves: fruits globose, red, viscid-pubescent. $R$. aromatica trilobata. SKUNK-BUSH. Not poisonous.-Common on bleak hillsides; throughout our range.

\section{Celastraceae Lindl. Staff Tree Family}

Shrubs with simple leaves, no stipules, und small, dull-colored, perfect, regular flowers. Sepals and petals imbricated. Stamens as many as the petals, alternate with them and inserted on the margin of a broad disk which lines the calyx-tube. Seeds arillate.

\section{PACHYSTIMA Raf.}

Low evergreen shrubs, with smooth, opposite, short-petioled, serrulate leaves. Flowers solitary or in few-flowered axillary cymes. Calyx with a short tube and 4 rounded lobes. Petals 4 . Ovary free, 2-celled; style very short. Capsule small, coriaceous, 1-2-seeded. Seeds inclosed in a white many-cleft membranaceous aril.

1. Pachystima myrsinites Raf. Am. Month. Mag. 1818. Leaves ovate to oblong or oblanceolate, cuneate at base: fruit smooth.-In the mountains; from New Mexico to British America and west to California.

\section{ACERACEAE St. Hil. Maple Family}

Trees or shrubs, with watery saccharine sap and opposite palmately lobed or more rarely compound leaves. Flowers polygamous or dioecious, in lateral or terminal umbel-like corymbs or fascicles. Calyx imbricate, 5-parted. Petals 5 or wanting, inserted around the hypogynous disk. Ovary 2-lobed, its 2 styles inserted between the lobes. Fruit of 2 long-winged samaras joined at the base.

\section{ACER L. Maple}

Flowers in umbel-like corymbs. Calyx colored, usually 5-lobed. Petals 5 or none. Stamens usually 8 . Fruit divaricately 2 -winged above, separable at maturity, each 1-seeded, 
Leaves simple.

Corymbs peduncled; fruit wings broad

Corymbs nearly sessile; fruit wings narrow

Leaves compound

1. Acer glabrum Torr. Ann. Lyc. N. Y. 2: 172. 1826. A shrub usually, rarely a small tree: leaves orbicular in outline, 3-lobed or often 3-parted, sometimes truncate or subcordate at base; segments short and broad, acutely incised and toothed, somewhat 3-lobed, the middle one cuneate: flowers polygamous, the umbel-like corymb pedunculate: sepals about 8. Rocky Mountarn Maple. - New Mexico to Montana and west to the coast.

2. Acer grandidentat um Nutt. T. \& G. Fl. N. A. 1: 247. 1838. Becoming a tree, sometimes 10-12 m. high: leaves slightly cordate or subcordate at base, rather deeply 3-lobed, the sinuses broad and rounded; the lobes subacute with a few sinuous indentations: corymbs nearly sessile, few-flowered; the pedicels long and nodding: fruit glabrous, with small diverging wings.-Infrequent; near streams; from western Wyoming into Utah and northward.

3. Acer Negundo L. Sp. Pl. 1056. 1753. A low and freely branched tree, with light green twigs and delicate drooping clusters of greenish flowers, a little earlier than the leaves: leaves trifoliolate or pinnately 5 -foliolate; the leaflets ovate, acute, dentate: flowers dioecious: petals and disk wanting: fruit glabrous, the broad wings somewhat incurved and finely veined. Negundo aceroides. (Rulac Negundo and R. texanum Rydb. Fl. Col. 227. 1906.) Box Elder.-From New Mexico and Arizona northward to Canada and eastward.

\section{RHAMNACEAE Dumort. BuckThorN FAMILY}

Shrubs or small trees, with simple undivided leaves, small and often caducous stipules, and.small regular flowers. Sepals valvate in the bud; a conspicuous disk lining the short tube of the calyx. Petals clawed, mostly involute, each around a stamen in the bud, sometimes wanting. Stamens perigynous and alternate with the sepals. In ours the fruit is berry-like or dry, containing 2-4 separating seed-like nutlets, and the leaves are alternate.

Petals short-clawed or wanting; fruit fleshy

1. Rhamnus.

Petals long-clawed; fruit dry, with three dehiscent nutlets .

2. Ceanothus.

\section{RHAMNUS L. BUCKTHORN}

Shrubs or small trees (ours unarmed), with alternate or somewhat opposite pinnately veined leaves and small greenish flowers in sessile or short-peduncled axillary umbels. Calyx 4-5-cleft, with erect or spreading lobes, the campanulate tube persistent and lined with the disk. Petals on the margin of the disk which is free from the ovary. Fruit berry-like, with 2-4 indehiscent nutlets.

Petals wanting; nutlets grooved Petals present; nutlets smooth

1. Rhamnus alnifolia L'Her. Sert. Angl. 5. 1788. Shrub 6-12 dm. high: leaves deciduous, ovate-oblong, acute at each end, 5-8 cm. long, crenately serrate, slightly puberulent on the slender petioles: calyx-lobes and stamens 5: fruit black, 3-lobed, $6 \mathrm{~mm}$. long, as long as the pedicels.-Northern Wyoming and westward.

2. Rhamnus Smithii Greene, Pitt. 3: 17. 1896. Deciduous shrub, with short, stout, glabrous, rather densely leafy and fructiferous branchlets: budscales obtuse, densely woolly-ciliate: flowers appearing with the undeveloped leaves and mostly solitary in their axils: mature leaves $3-5 \mathrm{~cm}$. long, lanceolate, scarcely acute, finely serrulate: flowers 4-merous: berries on very short pedicels, black when ripe, 2-seeded.- Southern Colorado. 


\section{CEANOTHUS L.}

Unarmed or spinescent shrubs, with alternate or opposite leaves, and small but showy white, blue, or purple usually fragrant flowers, often in longpeduncled dense axillary or terminal clusters. Calyx 5-lobed. Petals 5, hooded, long-clawed. Ovary immersed in the disk and adnate to it at the base, 3-lobed; disk adnate to the calyx; style short, 3-cleft. Fruit somewhat 3lobed, separating at maturity into 3 nutlets.

Shrubs without spines.

Leaves large, leathery, shining

Leaves small, thin, softly pubescent .

Shrubs with spines

1. C. velutinus.

2. C. mollissimus.

3. C. Fendleri.

1. Ceanothus velutinus Dougl. Hook. Fl, Bor. Am. 1: 125. pl. 45. 1830. A smooth shrub 7-14 dm. high, growing in dense clumps or patches: leaves orbicular-elliptic or elliptical-ovate, obtuse at both ends, coriaceous, shining above (as if varnished), balsamic fragrant, lighter beneath and slightly pubescent, strongly 3-ribbed, 5-10 cm. long, on short stout petioles, persistent: panicles axillary, compound, long-peduncled: flowers white: styles as long as the stamens. Mountain Balm.-Common on mountain sides; Colorado, northward and westward.

2. Ceanothus mollissimus Torr. Robins. Syn. Fl. 1: 409. 1897. A low shrub, persistently dingy villous-tomentose: the dull leaves usually broadly elliptical, crenate-serrulate, obtuse or subacute at both ends: inflorescence of two to several terminal and axillary crowded corymbs on slender branchlets: flowers white: capsule nearly globose, somewhat lobed at top, smooth and crestless. C. ovatus. (C. pubescens Rydb.)-Colorado and Wyoming.

3. Ceanothus Fendleri Gray, Pl. Fendl. 29. 1848. A thorny or spinose low bushy shrub, rarely nearly unarmed, 4-8 dm. high: leaves entire, silkypubescent beneath, narrowly oblong to elliptic, 10-25 $\mathrm{mm}$. long, somewhat narrowed and cuneate at base, obtuse or acute at apex: flowers in simple terminal racemes, white. C. subsericeus Rydb. Bull. Torr. Bot. Club 31: 564 . 1904.-Southern Wyoming and southward to New Mexico.

\section{VITACEAE Lindl. Vine Family}

Woody plants, mostly climbing by tendrils. Branchlets articulated and often thickened at the nodes. Leaves alternate, palmately veined or lobed or compound. Flowers small, greenish or whitish, in a panicled cymosethyrsoid inflorescence, very commonly polygamous or dioecious. Calyx minute, truncate or 4-5-toothed, caducous or early deciduous. Petals 4 or 5, valvate. Stamens the same number and opposite. Ovules in pairs or solitary in the cells of the ovary. Fruit a berry.

Leaves simple Leaves compound

\section{VITIS Tourn. Grape}

Plants climbing by the coiling of forked naked-tipped tendrils, with simple cordate palmately veined lobed leaves and a compound thyrsus of very fragrant 5-merous flowers. Calyx minute, filled with a glanduliferous fleshy disk which surrounds the ovary and bears the small green petals and the stamens. Petals coherent, falling together without opening. Fruit an edible herry with pear-shaped seeds.

1. Vitis vulpina L. Sp. P1. 203. 1753. Glabrous or somewhat pubescent on the veins on the lower face of the leaves: leaves thin, shining, incisely $\therefore$ or more-lobed, the middle one long, all sharply serrate: berries bluish-black, 
with bloom, about $8 \mathrm{~mm}$. in diameter: seeds 2-4. Vitis riparia. RIverBANK GRAPE.-On stream banks; eastern Wyoming, Colorado, and eastward.

\section{Parthenocissus Planch. Virginia Creeper}

Climbing or trailing by tendrils which are often tipped with adhering disks but in ours with naked tips. Leaves palmately 5-7-compound. Flowers in compound cymes or panicles. Calyx slightly 5-toothed. Petals concave, thick and expanding before they fall. Berry 2-3-seeded, not edible.

1. Parthenocissus vitacea A. S. Hitch. Spring Fl. Man. 26. 1894. Tendrils without terminal adhering disks, climbing by the coiling of the naked tips: leaflets oblong-lanceolate to ovate, rather sharply and deeply serrate, dark green above, only slightly lighter below: berries nearly black. Ampelopsis quinquefolia in part. Also called AMERICAN IvY.-Eastern Wyoming, Colorado, and southward.

\section{MalVaceae Neck. Mallow Family}

Mostly herbs, with mucilaginous juice. Leaves stipulate, alternate, generally palmately ribbed. Peduncles axillary, the flowers usually showy. Calyx 5-parted, obovate, often involucellate. Petals 5, convolute, their bases or short claws united with each other and to the base of a column of numerous monadelphous stamens. Anthers reniform, 1-celled, borne at the top (in ours) of the stamen column. Ovary several-celled; the styles united below but free above, usually projecting from the stamen-column. Fruit capsular; the carpels around a common axis, each 1-many-seeded, falling away entire, or loculicidally dehiscent.

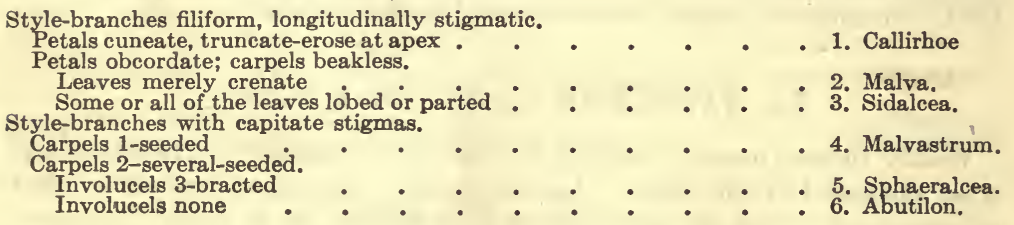

\section{CALliRHOE Nutt.}

Herbs, generally with lobed or divided leaves. Flowers showy, axillary or in racemes. Calyx either naked or 3-bracted. Petals cuneate, truncate at apex. Styles stigmatic down the inner side. Carpels 10-20, with nearly straight beaks.

1. Callirhoe involucrata (T. \& G.) Gray, Pl. Fendl. 16. 1848. Hirsute: stem branching, procumbent: leaves deeply 3-5-parted, covered with stellate hairs; the segments linear-lanceolate, laciniately 3-5-toothed: peduncles erect, 1-flowered, longer than the leaves: sepals nearly twice as long as the linear-lanceolate bracts of the involucel: petals scarlet or purplish-red, $2 \mathrm{~cm}$. long or more: carpels about 20, hairy, somewhat rugose-reticulated.-Colorado and southward.

\section{Malva L. Mallow}

Herbs with rounded and mostly lobed leaves and axillary fascicled flowers. Calyx 3-bracted. Petals obcordate. Styles numerous, stigmatic down the inner side. Fruit depressed, separating at maturity into 1-seeded, blunt reniform carpels. 
1. Malva rotundifolia L. Sp. Pl. 688. 1753. Stems procumbent from a biennial root: leaves round-cordate, on very long petioles, crenate, obscurely lobed: flowers clustered in the axils, pale blue or whitish, $10-12 \mathrm{~mm}$. broad, on pedicels 2-4 cm. long: carpels about 15, rounded on the back, pubescent. Common Mallow or Chenses.-Introduced in some localities in this range.

\section{SIDALCEA Gray}

Perennial herbs with rounded and mostly lobed or parted leaves. Flowers showy, purple, rose-colored, or white. Bractlets none. Calyx 5-cleft. Stamentube double. Styles united below, stigmatic on the inner face; carpels 5-9, indehiscent, 1-seeded, beakless.

Flowers white

Flowers rose-color.

Stems glabrous below

Stems hirsute-pubescent

1. Sidalcea candida Gray, Pl. Fendl. 20. 1848. Glabrous or nearly so, 5-8 dm. high, from creeping rootstocks, leafy below: lower leaves orbicular, 5-10 cm. in diameter, about 7-lobed, somewhat ciliate, the segments coarsely toothed; the upper leaves lobed or parted, with entire lanceolate segments: flowers spicate: calyx-lobes deltoid: petals white or shading to cream-color, 10-14 mm. long: carpels 9 or 10, nearly smooth and glabrous.-Along streams; from Wyoming and Utah to New Mexico.

2. Sidalcea nervata A. Nels. Proc. Biol. Soc. Wash. 17: 94. 1904. Glabrous below, minutely stellate-pubescent above, $4-7 \mathrm{~cm}$. high: stems usually somewhat branched above: leaves strongly veined below; the basal longpetioled, orbicular, 6-8-lobed, the lobes with 2-3 broad teeth; the upper deeply divided or cleft to the base into linear divisions: inflorescence densely stellatepubescent, rather few-flowered: calyx-lobes triangular-lanceolate: petals broadly obovate, emarginate, about $2 \mathrm{~cm}$. long: fruit slightly depressed, the carpels glabrous, rugose-reticulated on the dorsal angles.-Western Wyoming and westward.

3. Sidalcea neo-mexicana Gray, Pl. Fendl. 23. 1848. Hirsute-pubescent on the slender stems, 3-9 dm. high, more or less branched: radical leaves orbicular, 5-9-lobed or incisely crenate; stem leaves parted, the segments 3-lobed or those of the uppermost entire: raceme many-flowered, the pedicels sometimes longer than the hirsute calyx: petals about $12 \mathrm{~mm}$. long: carpels smooth and glabrous.-Southern Wyoming to New Mexico.

\section{MALVASTRUM Gray. . False Mallow}

Herbaceous perennials, often tufted, with stellate-pubescent, entire, cordate or divided leaves. Flowers in a narrow naked or leafy raceme, the pedicels short. Calyx 5-cleft, 3-bracted or naked. . Petals entire or emarginate. Stamentube single. Stigmas capitate. Carpels 5 or more, each completely filled by the solitary seed.

Leaves greenish, with cuneate or oblong segments.

Stems tall, subsimple, erect
Stems low, bushy-branched, spreading

Leaves hoary-white, with linear segments.

Herbaceous; pubescence stellate

1. Malvastrum elatum (E. G. B.) A. Nels. Bot. Gaz. 34: 25. 1902. Sparsely stellate-pubescent: stems several from a woody root, subsimple, erect, $3-5 \mathrm{dm}$. high: leaves broadly cuneate in outline, 3-5-cleft, the cuneate divisions again lobed or cleft: the paniculate raceme crowded, silvery-canescent: floral and fruit characters much as in the next.-Probably only to the southwest of our range, Utah, etc.

2. Malvastrum coccine um (Pursh) Gray, Pl. Fendl. 21. 1848. Somewhat 
silvery-canescent: the stems tufted, branched, and spreading, 1-2 dm. high: leaves pedately $3-5$-parted, 2-4 cm. in diameter, the cuneate divisions 2-3cleft: flowers short-pediceled, at first crowded but later in a loose raceme: calyx-lobes lanceolate, in age incurved over the fruit: petals copper-scarlet or brick-red: carpels round-reniform, reticulate-rugose, tardily and incompletely dehiscent.-The Trans-Missouri region to the mountains.

3. Malvastrum dissectum (Nutt.) A. Nels. Bot. Gaz. 34: 25. 1902. Perennial; many-stemmed from a multicipital caudex, $2 \mathrm{dm}$. high or less, densely cinereously stellate-pubescent, the stems whitened with the closely appressed hairs, the calyx obscurely glandular beneath the pubescence: leaves small, 1-3 cm. broad, pedately 3-5-parted, the divisions incisely lobed, the lobes narrowly oblong to linear: racemes several-flowered, pedicels $2-5 \mathrm{~mm}$. long; flowers scarlet: the petals obovate, nearly truncate and merely emarginate.Desert areas of Wyoming and Colorado.

3a. Malvastrum dissectum Cockerellii A. Nels. Less hoary, the leaf segments broader: calyx-lobes abruptly contracted to a linear tip: ovules two in each cell, but one of them abortive. M. Cockerellii A. Nels. 1. c.-New Mexico.

4. Malvastrum leptophyllum Gray, Pl. Wright. 1: 17. 1852. Three dm. or less high from lignescent base and stock: stems very numerous, erect or ascending, slender: lower leaves short-petioled and 3-parted or -divided into narrow linear divisions; upper simple and sessile, mostly filiform: flowers few and racemose at summit: petals copper-red, less than $12 \mathrm{~mm}$. long: fruit depressed-globular, slightly surpassing the triangular calyx-lobes; carpels 9 or 10 , tomentulose, thickish and rounded on the back, sides coarsely and strongly reticulated.-Colorado to Texas and New Mexico.

\section{SPHAERAlCEA St. Hil. Globe Mallow}

Differing from Malvastrum only in the carpels being 2- or 3-seeded, or when 1-seeded with an empty terminal portion.

Leaves linear-oblong to lanceolate Leaves crenate, ovate-cordate

Leaves cordate and deeply 5-7-lobed

1. Sphaeralcea cuspidata (Gray) Brit. Fl. 3: 519. 1898. Densely stellatepubescent, 4-8 dm. high: leaves oblong-linear to lanceolate, usually rounded or subcordate at base, crenately serrate; the lower with petioles as long as the blade, the petioles shorter upward: peduncles axillary, shorter than the petioles, 2-several-flowered: corolla purple or red, $12-15 \mathrm{~mm}$. broad: carpels 1-3-seeded. S. angustifolia Spach. - Southern Colorado and southward.

2. Sphaeralcea Munroana (Dougl.) Spach. Hist. Veg. 3: 353. 1834. Grayish with a dense stellate-pubescence, branching, 3-6 dm. high: leaves ovatecordate, somewhat lobed and the lobes crenate, 3-4 cm. long, on slender petioles about as long: calyx-lobes acute or acuminate: petals scarlet, obovate, 12-20 mm. long: carpels pubescent on the back. Malvastrum Munroanum Gray.- - Western Wyoming and westward.

3. Sphaeralcea rivularis (Dougl.) Torr. in Gray, Pl. Fendl. 23. 1848. Scabrous with stellate pubescence: stems stout, much branched, 6-12 dm. high: leaves cordate, deeply 5-7-lobed, lobes acute, coarsely toothed: racemes leafy below, naked above, the flowers clustered on short peduncles: lobes of the calyx broadly triangular, acute or acuminate: petals $2-3 \mathrm{~cm}$. long, white or pale purple: carpels hirsute on the back. (S. Crandallii and S. grandiflora Rydb. Bull. Torr. Bot. Club 31: 564. 1904.)-Wyoming, northward, and westward.

\section{6. abUtilon (Tourn.) Mill. Indian Mallow}

Herbs or shrubs, often tomentose or velvety, and with leaves generally cordate. Calyx naked, 5-cleft. Stigmas capitate; carpels 5 or more, 3-9-ovuled. Seeds more or less reniform. 
1. Abutilon Theophrastii Medic. Malv. 28. 1787. Velvety pubescent annual, 8-15 dm. tall, freely branched: leaves roundish-cordate, acuminate, 8-20 cm. broad: flowers solitary in the axils, yellow, 1-2 cm. broad, on short stout peduncles: fruit about $2 \mathrm{~cm}$. broad; the carpels 12-15, pubescent, each valve beaked by a slender awn. [A. Abutilon (L.) Rusby; A. Avicennae Gaertn.]-Only sparingly introduced but gradually spreading as a weed here as it has elsewhere.

2. Abutilon parvulum Gray, Pl. Wright. 1: 21. 1852. Cinereous-tomentose with a lax minute pubescence: stems slender, spreading, from a perennial woody root, paniculate above; branchlets pilose with spreading hairs: leaves small, 2-3 cm. broad, cordate, dentate, sometimes 3-lobed, usually obtuse, canescent, tomentose beneath: peduncles axillary, 1-flowered, longer than the leaf: flowers small, yellow: capsule ovoid, somewhat tomentose, 5-lobed at the apex, much longer than the short calyx; carpels erect, 5 , rather obtuse, awnless, 2-3-seeded.- Southern Colorado and southward.

\section{ElATINACEAE Lindl. Waterwort Family}

Ours are low annuals, with membranous stipules between the opposite dotless leaves, and with regular and mostly symmetrical flowers (2-5-merous). Sepals free. Petals and stamens on the receptacle. Pistil with distinct styles, capitate stigmas, and a 2-5-celled ovary. Fruit capsular, with axillary placenta.

\section{Elatine L. Waterwort}

Small, prostrate, glabrous plants, growing in water or wet places, with entire leaves and usually solitary flowers. Parts of the flower in twos or threes. Sepals membranous, obtuse. Capsules membranous, globose. Seeds numerous, transversely and longitudinally striate.

1. Elatine americana (Pursh) Arn. Edinb. Journ. Sci. 1: 430. 1830. Leaves obovate, very obtuse: flowers with their parts in twos or sometimes in threes: seeds cylindraceous, somewhat curved, the membranous coat manylatticed in 9-10 lines;-Across the continent; infrequent.

\section{FRANKENIACEAE A. St. Hil.}

Low perennial herbs or shrubs, freely branched, with opposite leaves having a membranous sheathing base and no stipules. Flowers sessile in the axils and in terminal leafy buds. Sepals 5, united into a furrowed tube, persistent, equal. Petals 5. Stamens as many or sometimes more; anthers versatile. Ovary 1-celled, with 2-3 parietal placentae; styles filiform, 2-4, united for a part of their length.

\section{FRANKENIA L.}

Leaves small, mostly crowded and also fascicled in the axils. Flowers small, solitary, and sessile in the forks of the stem or becoming cymose-clustered on the branches. Petals clawed, bearing a crown. Capsule included in the persistent calyx.

1. Frankenia Jamesii Torr. Gray in Proc. Am. Acad. 8: 622. 1873. Shrubby, with scabro-puberulent fascicled branches: leaves linear, 5-6 mm. long, with revolute margins: petals white, cuneate, the apex erose-denticulate, 
the blade 5-6 mm. long, equaling the claw: stamens 6 : ovules 1 to each of the 3 placentae.-Southern Colorado and southward.

\section{HYPERICACEAE Lindl. ST. JoHn's-wort FAMILY}

Herbs (in ours), with opposite, entire leaves, punctate with translucent or dark-colored glandular dots, no stipules, and perfect flowers with 5 petals and numerous stamens, the fruit a many-seeded capsule. Sepals 5, imbricate. Petals convolute, glandular-punctate. Stamens very numerous, in 3 bundles. Styles 2-5.

\section{HYPERICUM L. ST. JoHN's-WORT}

In our species the capsule is 3-celled by the union of the placenta with the axis, septicidal. The flowers yellow, with black dots.

1. Hypericum formosum H.B.K. Nov. Gen. and Sp. 5: 196. 1815-25. Perennial, herbaceous, branched above, 2-6 dm. high: leaves oblong-obovate, closely sessile or clasping, usually obtuse, $1-3 \mathrm{~cm}$. long, glandular-dotted near margin on the underside: flowers in panicled cymes: sepals oval to oblong, obtuse or acute, about $4 \mathrm{~mm}$. long: petals obovate, $10-14 \mathrm{~mm}$. long: stamens. numerous, in 3 bundles; the anthers black-dotted as are the petals and sepals: styles 3 , long and distinct. H. Scouleri Hook.-Stream banks and wet meadows; Mexico to Wyoming and westward.

\section{Violaceae DC. Violet Family}

Herbs with simple, alternate, stipulate leaves and complete flowers, which are more or less irregular. Sepals 5. Petals 5, imbricated in the bud. Stamens 5 , the filaments short and broad and bearing the connivent anthers on their inner face. Style more or less club-shaped and abruptly bent at apex. Ovary becoming a 3-valved capsule with parietal placentae. After opening the valves fold together lengthwise, forcibly dislodging the rather large, hardcoated seeds.

Sepals auricled at base; lower petal spurred Sepals not auricled at base

\section{VIOLA L. VIOLET}

Perennial or rarely annual herbs, with alternate, stipulate leaves. The flowers scapose or on axillary peduncles, often of two kinds; the early ones with showy petals and sometimes sterile; the later ones cleistogamous and more usually fertile. Sepals 5, often auricled at base. Petals 5, unequal, the lower one produced into a nectariferous spur at base. Filaments short or wanting; the anthers distinct but more or less connivent and the two upper with spur-like appendages produced into the spur of the lower petal. Style usually enlarged upward. Capsule oval to oblong, usually crustaceous, 3-valved.

Perennials; stipules never leaf-like, small and often scarious.

Leaves deeply parted or divided .

Leaves entire, crenate, or dentate.

Flowers evidently yellow.

Leaves cordate-reniform

Leaves ovate to lance-linear.

Coarsely toothed or angularly lobed

Entire or remotely denticulate.

Plants small and prostrate or spreading. Leaves linear-lanceolate
Leaves ovate to subcordate

1. V. pedatifida.

2. V. biflora.

3. V. atriplicifolia.

4. V. Nuttallii.

5. V. vallicola. 
Plants larger, erect or suberect.

Leaves, petioles, and peduncles green and glabrate

Leaves, petioles, and peduncles somewhat white-hirsute

Flowers not yellow.

Acaulescent; flowers scapose.

Flowers white

Flowers blue, lilac, or violet.

Stoloniferous

Producing no stolons.

All the leaves obtuse

The later leaves trigonous-acute

Caulescent; flowers axillary.

Stipules entire, mostly scarious

Stipules fimbriate or incised.

Leaves glabrous.

Dwarf, alpine plants.

Larger, plants of the mountain valleys

Leaves puberulent.

Stipules more or less fimbriate. Petioles glabrous

Petioles retrorse-pubescent

Stipules more or less laciniate

Annual or short-lived perennial; stipules leaf-like
6. V. erectifolia.
7. V. linguaefolia.

8. V. blanda.

9. V. palustris.

10. V. nephrophylla.

11. V. retusa.

12. V. canadensis.

13. V. bellidifolia.

14. V. adunca.

15. V. odontophora. 16. V. montanensis.

17. V. subvestita.

18. V. Rafinesquii.

1. Viola pedatifida Don, Gard. Dict. 1: 320. 1831. Acaulescent, the leaves and scapes from short, thick, vertical rootstocks: leaves pedately dissected or flabellately palmate or ternate, the segments ternately or pinnately divided into broadly linear segments, minutely pubescent or glabrate: scapes and leaves subequal, 1-2 dm. high: flowers blue or shading toward white; the lateral petals bearded: capsules about $10 \mathrm{~mm}$. long, those from the abundant cleistogamous flowers short-peduncled. $V$. delphinifolia. (V. biternata Greene, Pl. Baker. 3: 12. 1901; V. Sheltonii Rydb. Fl. Col., not Torr.)-From the Rocky Mountains to the Mississippi.

2. Viola biflora L. Sp. Pl. 936. 1753. Stems 2 or more from a short vertical rootstock, 1-2 dm. long, weak, ascending, about 2-leaved, and 1- or 2-flowered at summit: leaves nearly glabrous, round-reniform, with narrow sinus, $2-3 \mathrm{~cm}$. broad; stipules green and entire: flowers small: sepals linear-oblong: petals yellow with dark purple-brown striae, spur short.-Colorado; seemingly the same as the old-world form.

3. Viola atriplicifolia Greene, Pitt. 3: 38. 1896. Dwarf, the whole stem including the petioles and longer peduncles about $5 \mathrm{~cm}$. high: herbage cinereously puberulent, leaf-margins not ciliate; petioles $3-4 \mathrm{~cm}$. long; the lamina mostly less than $12 \mathrm{~mm}$. long, that of the lowest leaf broader than long, all truncate at base and angularly but not deeply 5-7-lobed, or the uppermost 3-lobed and hastate: flowers small, yellow, the upper pair of petals red-purple externally.-Dry hills, Yellowstone National Park.

$3 a$. Viola atriplicifolia Thorii A. Nels. Nearly glabrous and the leaves merely coarsely dentate. (V. Thorii A. Nels. Bull. Torr. Bot. Club 27: 193. 1900.) - Mountains of Yellowstone Park, Montana, and probably westward.

4. Viola Nuttallii Pursh, Fl. Am. Sept. 1: 174. 1814. Roots semifleshy, often branched or fascicled: stems several, short, spreading: leaves oblonglanceolate to nearly linear, 3-6 $\mathrm{cm}$. long, tapering to the margined petiole which usually exceeds the blade, more or less puberulent, entire or obscurely repand-denticulate: peduncles mostly shorter than the leaves: sepals lanceolate, acuminate: petals yellow, 8-12 mm. long, glabrous or slightly bearded: stigma bearded: capsule subglobose.-From the Rocky Mountain plains into Nebraska and Kansas.

5. Viola vallicola A. Nels. Bull. Torr. Bot. Club 26: 128. 1899. Low, caulescent, glabrous or puberulent, from a short rootstock with fascicled fleshy roots: stems few, short or at length $10-15 \mathrm{~cm}$. long: leaves entire, ovate, mostly obtuse, the base rounded or (in the broadest) subcordate, $2-5 \mathrm{~cm}$. long, on petioles as long or longer: peduncles mostly shorter than the leaves: sepals lanceolate: petals yellow, streaked with purple, 10-14 mm. long: capsules oval with many large ovoid seeds. ( $V$. physalodes Greene, Pl. Baker. 3: 12. 1901.)-Moist mountain valleys; Dakota and Colorado. 
6. Viola erectifolia A. Nels. Bot. Gaz. 29: 143. 1900. Stems short, from a single taproot: leaves usually erect, elliptic to lance-oblong, entire or repanddenticulate, sparsely pubescent especially on margins and veins, or glabrate, $3-8 \mathrm{~cm}$. long on somewhat longer petioles: peduncles $6-12 \mathrm{~cm}$. long, rarely surpassing the leaves: flowers large: sepals linear, $7 \mathrm{~mm}$. long: petals yellow, tinged or streaked with purple, the laterals short-hirsute below the middle. (V.gomphopetala Greene. Pl. Baker. 3: 11. 1901.)-In the higher mountains; from Colorado to Montana.

7. Viola linguaefolia Nutt. ex T. \& G. Fl. 1:-41. 1838. Mature plant 2-3 $\mathrm{dm}$. high, subcaulescent, from a slender rootstock; leaves long-petioled, oblanceolate, obtuse, decurrent upon the petiole; margins ciliate and obscurely denticulate; surfaces more or less white-hirsute: flowers surpassing the leaves, bright yellow, faintly veined with purple, the lateral petals slightly bearded: sepals narrowly linear, finely ciliate. ( $V$. flavovirens Pollard, Bull. Torr. Bot. Club 24: 405. 1897).-Utah and Idaho to Oregon.

8. Viola blanda Willd. Hort. Berol. Pl. 24. 1806. Acaulescent from slender running rootstocks, and more or less stoloniferous: leaf-blades ovate, orbicular, or reniform, crenate, glabrous or nearly so, 1-3 cm. long, on longer petioles: peduncles $3-10 \mathrm{~cm}$. long, usually surpassing the leaves; flowers white, fragrant: the sepals lanceolate: the 3 lower petals purple-veined and nearly beardless: capsule oval. White Sweet-violet. (V. LeConteana Rydb. Fl. Col., not Don; V. Macloskeyi Rydb. Fl. Col., not Lloyd).-Wet stream banks in the mountains.

9. Viola palustris L. Sp. Pl. 934. 1753. Glabrous and acaulescent, from slender creeping rootstocks, stoloniferous: leaves ovate to reniform, crenate, $3-4 \mathrm{~cm}$. long, on longer petioles: scapes $5-15 \mathrm{~cm}$. high, generally surpassing the leaves: flowers lilac to white, streaked with darker veins; sepals ovate, mostly obtuse; spur short and saccate.-Marshy meadows; Colorado, northward and eastward.

10. Viola nephrophylla Greene, Pitt. 3: 44. 1896. Closely allied to the preceding, but larger and not stoloniferous, and from a short, thickened, vertical rootstock: leaves firm, glabrous, reniform to orbicular, crenate, $2-3 \mathrm{~cm}$. broad, on somewhat longer petioles; the later ones much larger, often tending to ovate-cordate in outline, on lengthened petioles: scapes slender, from shorter than to somewhat surpassing the leaves: sepals oblong, obtuse, 3-nerved, scarious-margined: petals purple or violet but white at base, with dark veins, more or less villous: cleistogamous flowers on short, slender, ascending peduncles: seeds large, exactly obovate.-Common in open woods on moist bottom lands throughout our range.

11. Viola retusa Greene, Pitt. 4: 6. 1899. Low, stout, glabrous, and acaulescent; the erect rootstock short and thick: the early leaves small, subreniform; the later successively cordate-ovate and deltoid-ovate with an abrupt acumination, all with broad, open sinus and with the blade tapering more or less to the petiole, crenate-serrate: peduncle stout, $5-15 \mathrm{~cm}$. high, about as long as the leaves, with triangular-subulate bracteoles above the middle: sepals lanceolate, scarious-margined, nerveless: petals spatulate or oblong, retuse or obtuse at apex, purple or violet (blue ?), three of them somewhat bearded at base.-Colorado and Wyoming.

12. Viola canadensis L. Sp. Pl. 936. 1753. Nearly glabrous, 1-3 dm. high, from an ascending rootstock: leaves thin, cordate or broader, either abruptly or gradually acuminate; stipules entire, lanceolate, acuminate, scarious: peduncles shorter than the leaves, slender, axillary: sepals linearlanceolate, scarcely auricled: petals from pale violet to nearly white, purpleveined, with yellowish base: capsules pubescent.- Seemingly within our range; common eastward.

12a. Viola canadensis Rydbergii (Greene) House. Scabro-puberulent on the veins and leaf-margins. (V.Rydbergii Greene, Pitt. 5: 27. 1902.)-The more usual Rocky Mountain form.

12b. Viola canadensis scopulorum Gray, Bot. Gaz. 11: 291. 1886. A small, depressed, nearly glabrous form.-Cañons and cliffs; central Colorado. 
13. Viola bellidifolia Greene, Pitt. 4: 292. 1901. Dwarf and tufted, appearing as if acaulescent, only $4-7 \mathrm{~cm}$. high, glabrous: leaves more or less succulent, ovate to subcordate, $5-10 \mathrm{~mm}$. long, on rather long petioles, entire or crenate: peduncles numerous, from shorter than the leaves to much surpassing them: sepals oblong-lanceolate, acute: corolla less than $1 \mathrm{~cm}$. long, the spur relatively long, violet-purple above, lighter below with purple veins. ( $V$. demissa Greene, Pl. Baker. 3: 10. 1901.)-Subalpine; Colorado and Wyoming.

14. Viola adunca Smith, in Rees Cycl. 37: pl. 63. 1802-20. Glabrous or nearly so, 1-3 dm. high, tardily stoloniferous with cleistogamous flowers: leaves ovate, more or less cordate at base, obscurely crenate, $1-4 \mathrm{~cm}$. long: peduncles usually surpassing the leaves: flowers violet to purple, or almost white: petals $10-15 \mathrm{~mm}$. long, the lateral ones bearded; spur as long as the sepals, rather slender, somewhat curved or hooked.-Probably coming into our range from the northwest.

14a. Viola adunca longipes (Nutt.) Rydb. Mem. N. Y. Bot. Gard. 1: 163. 1900. Quite glabrous, the long-peduncled, dark purple flowers with a short, straight, thick spur.- In mountains from northwestern Colorado through Utah and Wyoming to Montana.

15. Viola odontophora Rydb. Mem. N. Y. Bot. Gard. 1: 164. 1900. The slender woody branches of the caudex from a woody taproot: stems several, slender, with a fine puberulence or nearly glabrous, $5-15 \mathrm{~cm}$. long, quite leafy: leaves crenate, ovate or ovate-trigonous, obtuse or acute, truncate or subcordate at base, sparsely puberulent on both faces or glabrate, 15-25 mm. long; petioles glabrous, slender, $2-5 \mathrm{~cm}$. long: peduncles about equaling or sometime surpassing the leaves: sepals lanceolate, glabrous: petals purple or violet, the lateral ones bearded; the spur half as long as the petals, often somewhat inflated at the tip, occasionally with an inconspicuous lateral tooth.-Moist loamy banks; Colorado to Montana.

16. Viola montanensis Rydb. Mem. N. Y. Bot. Gard. 1: 263. 1900. Rootstock slender, woody: stems slender, 1-2 dm. high, subscabrous with sparse, short, reflexed hairs: stipules linear-lanceolate: petals blue or violet, with yellowish-white base and spur: capsule ovoid. (V. retroscabra Greene, Pitt. 4: 290. 1901; V. inamoena Greene, Pl. Baker. 3: 11. 1901.)-From Montana to Colorado.

17. Viola subvestita Greene, Erythea 5: 39. 1897. Finely puberulent throughout, subcaespitose, 4-7 cm. high: leaves broadly ovate, usually subcordate, 1-2 cm. long: peduncles scarcely longer than the leaves: flowers small, light blue; spur half as long as the petals. ( $V$. monticola Rydb. Mem. N. Y. Bot. Gard. 1: 264. 1900.)-Across the continent through northern Wyoming and Montana.

18. Viola Rafinesquii Greene, Pitt. 4: 9. 1899. Stems slender, glabrous, 6-15 cm. long: leaves oblong-lanceolate to ovate, entire or crenate-dentate, 1-2 cm. long; stipules leaf-like, pinnatifid or laciniate: sepals linear, nearly as long as the small, bluish or yellowish-white, sometimes purple-spotted petals. Wild Pansy.-Colorado and eastward.

\section{HYBANTHUS Jacq.}

Low herbs or suffruticose plants, with alternate or opposite leaves and solitary, axillary peduncles. Sepals more or less unequal, not auricled. Petals very unequal; the two upper shorter; the lower one very large, with dilated, more or less gibbous or concave claw. Stamens approximate, the anterior ones each furnished with a nectariferous gland at the base. Capsules and seeds much as in Viola.-Ionidium Vent.

1. Hybanthus verticillata (Ort.) A. Nels. Somewhat pubescent, stem branched: leaves opposite or more rarely alternate, entire or remotely serrulate; the lower from lanceolate to oblong or obovate; the upper linear, obtuse or acute, usually 3-4 times as long as the linear stipules: peduncles slender, 
4-12 mm. long, articulated, bibracteolate: flowers small: capsules glabrous: seeds turning black. Ionidium lineare Torr.: Calceolaria verticillata (Ort.) Kuntz, Rev. Gen. Pl. 41. 1891.

\section{LOASACEAE Reichenb. LOASA F'amily}

Herbaceous plants with either stinging or jointed and rough-barbed hairs, no stipules, calyx-tube adnate to a 1-celled ovary, parietal placentae, and a single style. Stamens usually very numerous, some of the outer occasionally petaloid. Flowers perfect, often showy.

\section{MENTZELIA L*}

Erect, the stems becoming white and shining. Leaves alternate, mostly coarsely toothed or pinnatifid. Flowers cymose or solitary, orange or goldenyellow to white. Calyx-tube cylindrical or turbinate; the limb 5-lobed. Petals 5 or 10. Stamens inserted below the petals on the throat of the calyx. Ovary truncate at the summit; style 3-cleft, the lobes often twisted. Capsule opening usually irregularly at the apex.

Petals 5, small; filaments all filiform; seeds not winged.

Leaves petioled

Leaves sessile.

Seeds tuberculate.

Leaves broad, merely toothed

Leaves narrow, entire to sinuate-pinnatifid : $\quad$ - $\quad$ - $\quad$ - 3. M. latifolia. albicaulis.

Seeds smooth or striate.

Stems slender and sparsely branched . . . . . 4. M. dispersa.

Petals 5 or 10, large; filaments often dilated-petaloid.

Flowers white or merely yellowish.

Seeds margined but not winged

Seeds conspicuously winged

Flowers yellow.

Seeds margined but not winged.

Stems smooth

Stems puberulent

Seeds evidently winged.

Petals 10, large; filaments filiform. Seeds tuberculate

Seeds smooth
Petals 5 , smaller; some of the filaments dilated and antheriferous

1. Mentzelia oligosperma Nutt. T. \& G. Fl. N. A. 1: 533. 1840. Rough with multibarbate hairs, dichotomously branched, brittle, 2-8 dm. high: leaves ovate-lanceolate, cuneate at the base, incisely toothed or somewhat lobed and angled, 3-7 cm. long, short-petioled: petals 5, cuneate-oblong, cuspidate, entire, a little longer than the 20 or more stamens, golden-yellow, expanding in sunshine, evanescent: filaments all linear: capsule narrow, 6-12-seeded: seeds oblong, irregular, not winged. (M. Nelsonii Greene, Erythea 3: 70. 1895.) -Extending into our range from the Mississippi valley.

2. Mentzelia latifolia (Rydb.) A. Nels. Stout annual, 3-5 dm. high, branched: leaves sessile, ovate or ovate-lanceolate, coarsely toothed or entire, $5-10 \mathrm{~cm}$. long, $2-3 \mathrm{~cm}$. wide: sepals lanceolate, $2.5-3 \mathrm{~mm}$. long: petals obovatespatulate, about $5 \mathrm{~mm}$. long: capsule linear, cylindric, $2.5-3 \mathrm{~cm}$. long, about $2.5 \mathrm{~mm}$. thick, sessile: seeds prismatic, muriculate. (Acrolasia latifolia Rydb. Bull. Torr. Bot. Club 31: 567. 1904.)-Mountains of Colorado.

3. Mentzelia albicaulis Dougl. Hook. Fl. Bor. Am. 1: 222. 1833. Low, nearly simple or branching from the base, 1-3 dm. high: stem very pale, be-

* This genus has been the subject of much discussion in recent years. Naturally readily separated into two sections, the large-flowered forms were erected into a genus under the name Hasperaster. This group has since been successively referred to Touterea and to Nuttallia, while the other or small-flowered group has been called Acrolasia. 
coming white and polished, nearly glabrous: leaves lanceolate to linear, from nearly entire to deeply sinuate-pinnatifid, sessile or nearly so, scabrous: flowers small, solitary or in loose clusters, not bracteolate: petals 5, yellow, obovate, about $4 \mathrm{~mm}$. long, scarcely longer than the subulate-lanceolate calyx-segments: filaments 20-40, subulate-filiform: capsule linear-clavate: seeds numerous, irregularly angled with obtuse margins, rather strongly tuberculate. (M. Tweedyi and M. tenerrima Rydb. Mem.' N. Y. Bot. Gard. 1: 271. 1900; M. ctenophora Rydb. Bull. Torr. Bot. Club 28: 33. 1901; M. gracilis Rydb. l. c. 566. 1904.)-Frequent; on slopes and dry banks, often in partial shade; throughout our range and far westward.

4. Mentzelia dispersa (Wats.) Proc. Am. Acad. 11: 137. 1876. A slender annual, usually about $3 \mathrm{dm}$. high: leaves narrowly lanceolate, sinuate-toothed or sometimes entire, rarely pinnatifid, the uppermost often ovate: flowers small, mostly approximate near the ends of the branches: calyx-lobes $2 \mathrm{~mm}$. long, little shorter than the five spatulate or obovate petals: filaments not dilated: capsule narrowly linear-clavate, $15-25 \mathrm{~mm}$. long: seeds very often in a single row, angular and somewhat rhombohedral, more or less grooved upon the angles, very nearly smooth, $1 \mathrm{~mm}$. long.-Colorado to Montana and west to Washington.

5. Mentzelia compacta A. Nels. Bull. Torr. Bot. Club 25: 275. 1898. Annual, 2-2.5 dm. high, numerously and compactly branched: stems whitish, pubescent, somewhat brittle: leaves numerous, sessile, entire, obtuse, from broadly linear at base to almost oval at summit, generally ovate-oblong, 2-3 cm. long, rough-hirsute, more coarsely and sparsely so above: flowers yellow, small, numerous, in compact cymes at the ends of the branches, sessile, about $3 \mathrm{~mm}$. broad: calyx-lobes lanceolate-ovate, shorter than the corolla: petals obovate, about $4 \mathrm{~mm}$. long: stamens 15, anthers small, subspherical: capsule linear-clavate, 10-13 mm. long, 10-12-seeded: seeds in one compact row, smooth, longitudinally groove-angled, in form from frustra of triangular prisms to rhomboidal cuboids, faces about $1 \mathrm{~mm}$. long.-Wyoming and northward.

6. Mentzelia decapetala (Pursh) Urban and Gilg. in Engl. \& Prantl Nat. Pfl. Fam. 3: 111. 1894. Roughish-pubescent, stout, seldom over $6 \mathrm{dm}$. high: leaves oval, lanceolate or oblong, acute or acuminate, sinuate-pinnatifid, 5-15 cm. long, the upper sessile, the lower petioled: flowers mostly solitary, terminal: petals 10, about twice as long as the lanceolate calyx-lobes: filaments all filiform, very numerous $(200-300)$ : capsule oblong, $3-5 \mathrm{~cm}$. long: seeds numerous, margined, not winged. M. ornata.-From Montana to New Mexico and Texas.

7. Mentzelia nuda (Pursh) T. \& G. Fl. N. A. 1: 535. 1840. Rough with minute pubescence, slender, $3-15 \mathrm{dm}$. high, the stems light-colored: leaves lanceolate or oblong-lanceolate, acute, usually sharply and deeply dentate, or the upper pinnatifid, 2-8 cm. long: petals 10, about twice as long as the lanceolate calyx-lobes: calyx-tube usually not bracteolate: stamens 100 or more, the outer ones somewhat petaloid: capsule oblong, $1.5-2.5 \mathrm{~cm}$. long, about $6 \mathrm{~mm}$. thick: seeds numerous, wing-margined. ( $M$. stricta Osterh. Bull. Torr. Bot. Club 29: 174. 1902; M. Rusbyi Wooton, Bull. Torr. Bot. Club 25: 261. 1898.)-Plains; Montana to New Mexico.

8. Mentzelia chrysantha Engelm. Brand. Bull. U. S. Surv. Terr. 2: 237. 1876. Stems 3-6 dm. high, branching: leaves ovate-lanceolate, the lower narrowed towards the base: flowers subsessile: petals $12-18 \mathrm{~mm}$ : long, acute, often fewer than 10, the innermost smaller and antheriferous: seeds narrowly margined but not winged.- Southern Wyoming to Colorado and Utah.

9. Mentzelia multiflora (Nutt.) Gray, Pl. Fendl. 48. 1848. Stems scabrous, branching freely, 2-4 dm. high: leaves generally deeply sinuate-pinnatifid, attenuate below: petals yellow, abruptly pointed, $12-20 \mathrm{~mm}$. long, exceeding the subulate calyx-segments: outer filaments noticeably dilated: capsule short, obconic with broad summit: seeds few, broadly winged. (M. laciniata Rydb. 1. c. 31: 566.)-Colorado to New Mexico.

9a. Mentzelia multiflora densa (Greene) A. Nels. Freely branched, short- 
lived perennial; scarcely different from the species. ( $M$. densa Greene, Pitt. 3: 99. 1900.) - Southern Colorado.

10. Mentzelia laevicaulis (Dougl.) T. \& G. Fl. N. A. 1: 533. 1840. Stout, 6-9 dm. high, branching: leaves lanceolate, $5-20 \mathrm{~cm}$. long: flowers sessile on short branchlets, very large, light yellow, opening in sunshine: calyx-tube naked, the lobes $24-30 \mathrm{~mm}$. long: petals acute at each end, 5-7 cm. long, the filaments and slender style a little shorter: capsule $30 \mathrm{~mm}$. long, 6-8 $\mathrm{mm}$. in diameter: seeds very minutely tuberculate.-Wyoming and Montana to the Pacific States.

11. Mentzelia speciosa Osterh. Bull. Torr. Bot. Club 28: 689. 1901. Perennial, finely pubescent, glandular on the pedicels and ovary, corymbosely branched from near the base: the leaves linear to oblong, sinuate-dentate to sinuate-pinnatifid, the lower, including the narrowly winged petiole, $10-15 \mathrm{~cm}$. long, hispid on both sides: flowers yellow, numerous, vespertine, the earlier ones sessile, the others on pedicels 1-2 $\mathrm{cm}$. long: petals 10 , the 5 outer ones whitish on the outside, $2 \mathrm{~cm}$. long and $8 \mathrm{~mm}$. wide at the widest portion, narrowed to a claw which is nearly half the length of the whole petal; the 5 inner ones narrow and not more than half the size of the outer, a number of the outer filaments also petaloid: the capsule a little more than $2 \mathrm{~cm}$. long, striate: the seeds round, winged, mature ones smooth, i. e., not punctate. (M. sinuata Rydb. 1. c. 566.) - Colorado.

12. Mentzelia pumila Nutt. T. \& G. 1. c. Stems $2-3 \mathrm{dm}$. high, rough with a minute barbed pubescence, whitish, branching towards the summit: leaves lanceolate, sinuate, toothed, or pinnatifid, the lower ones petioled, the upper sessile: flowers solitary or three together, terminating the loose flowering branches, slightly pedicellate, with one or two linear-setaceous bracts at the base: petals 10 , lanceolate, acute, spreading, longer than the lanceolatesubulate calyx-lobes, the inner ones smaller: stamens very numerous, the outer filaments flat and somewhat dilated: capsule clavate-cylindrical, 3valved: seeds numerous, winged.-Colorado.

12a. Mentzelia pumila multicaulis (Osterh.) A. Nels. Leaves all narrow, the upper entire: stem glabrate below: seeds scarcely winged. (Touterea multicaulis Osterh. Bull. Torr. Bot. Club 30: 236. 1903.)-Wolcott, Colorado.

\section{CACTACEAE Lindl. Cactus Family}

Green, fleshy, and thickened, persistent, mostly leafless plants, of peculiar aspect. Globular or columnar, tuberculated or ribbed, or jointed and often flattened, usually armed with bundles of spines from areolae. Flowers with numerous sepals, petals, and stamens, usually in many rows, the cohering bases of all of which coat the inferior, 1-celled, many-ovuled ovary, and above it form a tube or cup nectariferous at base. Style 1, with several or numerous stigmas. Fruit a pulpy or rarely dry 1-celled berry.

Stems globose, oval or ovoid, usually not jointed; leaves wanting; spines not barbed.

Flowers from between the tubercles; ovary naked

Flowers from the tubercles or the ribs; ovary scaly (the imbricated sepals).

Flowers nearly terminal, arising near the young or just forming

areolae
Flowers lateral, arising near the older spine-bearing areolae
.

Stems flat or cylindrical and conspicuously jointed; leaves small, early deciduous; bristles barbed

1. Mamillaria.

2. Echinocactus.

3. Echinocereus.

4. Opuntia.

\section{Mamillaria Haw. Ball Cactus}

Small, more or less globose or oval, simple or caespitose plants, the spinebearing areolae borne on cylindric, oval, conical, or angular tubercles which cover the body of the plant. Flowers about as long as wide, the tube cam- 
panulate or funnel-shaped, from the axils of the tubercles, fully open in sunlight and only for a few hours. Ovary often hidden between the bases of the tubercles and naked, as is also the exserted succulent berry.

Flowers yellowish-green; central spine mostly solitary, or wanting. Plants simple (single)

Plants caespitose

Flowers red or purple; central spines $\dot{3}-12$. Central spines about 4 , brown

Central spines 3-12, purple

1. M. missouriensis. 2. M. similis.

3. M. vivipara.

4. M. neomexicana.

1. Mamillaria missouriensis Sweet, Hort. Brit. 171. 1827. Globose, 3.5 $\mathrm{cm}$. in diameter, simple or nearly so: tubercles ovate-cylindrical, 12-14 mm. long, slightly grooved: radial spines 13-17, straight, whitish, setaceous, somewhat unequal, $8-10 \mathrm{~mm}$. long; central spine more robust, straight and porrect, puberulent, $10-12 \mathrm{~mm}$. long, often wanting: flowers about $2.5 \mathrm{~cm}$. long, yellow or reddish: stigmas 2-5: fruit globose, scarlet, $6-8 \mathrm{~mm}$. in diameter: seeds globose, black and pitted, 0.8-1.1 mm. in diameter.-On the plains; Montana to Kansas and Colorado.

2. Mamillaria similis Engelm. Bost. Journ. Nat. Hist. 5: 246. 1845. Closely related to the preceding but caespitose, with $12-15$ puberulent radial spines, the central very often wanting, larger flowers $(2.5-5 \mathrm{~cm}$. long), fruit and seeds (1.6-2.2 mm. in diameter), and 5 stigmas.-Colorado (?) to Oklahoma and Texas.

3. Mamillaria vivipara (Nutt.) Syn. Succ. Suppl. 72. 1819. Low and depressed-globose, usually proliferous and caespitose (forming large masses), but sometimes simple: tubercles terete and loose, lightly grooved: radial spines 12-20, stiff and white, often dark-tipped, 6-8 mm. long; central spines usually 4, brownish, 8-12 mm. long, 3 spreading upwards, the lowest stouter and shorter and deflexed: flowers about $3.5 \mathrm{~cm}$. long and even broader when expanded, bright purple: stigmas pointed with a short mucro: fruit oval, pale green, juicy, 12-18 mm. long: seeds yellowish-brown.-On the foothills and eastern plains of the Rocky Mountains, from the Canadian border to Colorado.

4. Mamillaria neomexicana (Engelm.) A. Nels. Globose to short-cylindrical, simple or branched from the base, only a few $\mathrm{cm}$. high: radial spines 12-40, white with dusky apex; centrals 3-12, purplish: flowers $3-5 \mathrm{~cm}$. long and about as broad, violet to dark purple: seeds obovate, pitted, less than $2 \mathrm{~mm}$. long. [Cactus radiosus neomexicanus (Engelm.) Coult. Rev. N. A. Sp. Cactus, etc., 120. 1894.]-Utah and Colorado, southward and eastward to Mexico.

\section{ECHINOCACTUS Link \& Otto}

Mostly larger plants, globose or depressed, or ovate, or rarely subcylindric, simple or very rarely caespitose. The spines on the more or less vertical ribs. Flowers contiguous to and above the spines (on the new growth of the plant, often from the nascent woolly areolae and therefore more or less vertical). Ovary covered with sepaloid scales which are naked or woolly in their axils. Fruit succulent (edible), or sometimes dry, covered with the persistent scales, sometimes enveloped in copious wool, and usually crowned with the persistent remnants of the flower.

Stems with tubercles, mostly in spiral rows.

Radiating spines fewer than 10 ; centrals fewer than 5 .

Radiating spines more than 10; centrals more than 5 . Stems with vertical and definite ridges.

1. Echinocactus glaucus K. Sch. Gesamth. Kakteen 438. 1899. Simple, sometimes proliferous, depressed-globose or ellipsoidal: ribs entirely broken up into glaucous tubercles arranged in about $8-13$ rows: radial spines 8 or 9 , centrals 1-3: flowers rose-color: ovary scaly, glabrous.-Colorado.

2. Echinocactus Simpsonii Engelm. Trans. St. Louis Acad. 2: 197. 1863. Subglobose or depressed, turbinate at base, simple, often clustered, 7.5-12.5 $\mathrm{cm}$. in diameter; ribs $8-13$, only indicated by the spiral arrangement of the 
prominent tubercles, which are 12-16 $\mathrm{mm}$. long, somewhat quadrangular at base and cylindric above: radial spines 20-30, slender, rigid, straight, whitish, 8-12 mm. long, with 2-5 additional short setaceous ones above; central spines 8-10, stouter, yellowish and reddish brown or black above, erectspreading, 10-14 mm. long: flowers 16-20 mm. long and nearly as broad, yellowish-green to pale purple: fruit green and dry, 6-7 $\mathrm{mm}$. long and almost as broad: seeds black, obliquely obovate, tuberculate, $3 \mathrm{~mm}$. long.-Utah to Nevada.

3. Echinocactus Whipplei spinosior Engelm. Globose, $7.5 \mathrm{~cm}$. in diameter: ribs 13: radial spines 9-11,12-36 mm. long, the lower ones often dusky, the 2 upper ones often elongated, flattened, and curved; the 4 centrals $3.5-5 \mathrm{~cm}$. long, the uppermost one flexuous and white, the other 3 a little shorter, dusky, all or only the lower one hooked: flowers about $2.5 \mathrm{~cm}$. long: fruit oval, $12 \mathrm{~mm}$. long.-Southwestern Colorado.

\section{ECHINOCEREUS Engelm.}

Globose to cylindrical, simple or caespitose, sometimes very large, with spine-bearing ribs. Flower-bearing areolae close above fully developed, spinebearing areolae. Ovary bearing bracts which are naked or woolly and always spiny in the axils; stigmas always green. Fruit succulent. Seeds almost without endosperm. Embryo mostly hooked, with short or foliaceous cotyledons.-Cereus.

Flowers yellowish-green; ribs 12 or more

Flowers not yellowish-green; ribs 5-12.

Flowers violet-purple; central spine dark, terete

Flowers scarlet.

Central spine angled.

Ribs 5-7

Ribs 9-11

Central spine terete
1. E. viridiflorus.

2. E. Fendleri.

3. E. gonacanthus.

4. E. Roemeri.

5. E. aggregatus.

1. Echinocereus viridiflorus Engelm. Wisliz. Mem. 91. 1848. Subglobose, simple or sparingly branched, $2.5-7.5 \mathrm{~cm}$. high: ribs 13 , acute, scarcely interrupted: radial spines 12-18 (with 2-6 setaceous upper ones), straight and strictly radiant, $2-6 \mathrm{~mm}$. long, laterals longest and reddish-brown, the rest white (rarely purple); central none or a single stout, straight or curved spine (rarely a second more slender one) 12-14 mm. long, variegated purple and white: flowers $2.5 \mathrm{~cm}$. long and wide, greenish-brown outside, yellowishgreen within; petals obtuse: fruit elliptical and greenish, 10-12 $\mathrm{mm}$. long: seeds 1-1.2 mm. long, tuberculate.-Wyoming to New Mexico.

2. Echinocereus Fendleri Engelm. Pl. Fendl. 50. 1849. Ovate or ovatecylindrical, $7.5-20 \mathrm{~cm}$. high, 5-7.5 cm. in diameter, simple or branching at base, caespitose, dark green: ribs $9-12$, straight or oblique, tuberculate, with areolae 8-14 $\mathrm{mm}$. apart: spines stout, very variable in length and color; radials 5-10 (mostly 7), straight or curved, lowest stoutest, white, and angular, 12-25 mm. long, next 2 almost as long (or longer), more terete, blackish above and white beneath or all blackish, then 2 white or dark or variegated, then 2 weaker, whiter, and shorter $(6-14 \mathrm{~mm}$.), often 2 more upper spines and sometimes a slender or stout dark spine (24-30 $\mathrm{mm}$. long) on upper edge of areola; central 1, stout and very bulbous at base, curved upward, reddishblack, teretish, $2.5-5 \mathrm{~cm}$. long, rarely wanting: flowers deep violet-purple, 6-8.5 cm. broad: fruit ovate-globose, $2.5-3 \mathrm{~cm}$. long, purplish-green, edible: seed curved, deeply and irregularly pitted, $1.4 \mathrm{~mm}$. long.-Utah and Arizona.

3. Echinocereus gonacanthus Engelm. \& Bigel. Rumph. in Forst. Hand. Cact. Ed. 2. 806. 1886. Ovate, 7.5-12.5 cm. high, simple or sparingly branched at base: ribs 7 (sometimes 9), tuberculate, with large areolae $12-20 \mathrm{~mm}$. apart: spines stout, angular, straight or variously curved and flexuous; radials 8, lower 16-24 mm. long, the rest 20-30 mm. long, lower and laterals quadrangular, yellow at base and of ten dark-tipped, uppermost one much larger than 
the rest, about size and character of the central, which is solitary, very stout, 6 or 7 -angled and deeply furrowed, of ten flexuous, $3-6 \mathrm{~cm}$. long, $2 \mathrm{~mm}$. broad: flower scarlet, about $6 \mathrm{~cm}$. long: fruit and seed unknown.-Colorado to New Mexico.

4. Echinocereus Roemeri (Muhlenpf.) Engelm. \& Bigel. 1. c 792. Ovate, conoid-acutish at apex, 7.5-10 cm. high, sparingly branched at base: ribs 9-11, obtuse, tuberculate, with areolae 8-12 mm. apart: spines whitish or strawcolor, translucent with bulbous base; radials 8-12, slender and rigid, straightish, upper 4-10 mm. long, lateral $12-30 \mathrm{~mm}$.; centrals 3-5 (usually 4), very bulbous, upper hardly longer than lateral radials, lowest quadrangular, of ten dusky when young, $2.5-7.5 \mathrm{~cm}$. long, porrect or deflexed: flower crimson, 8$10 \mathrm{~cm}$. long, $3.5-5 \mathrm{~cm}$. broad: fruit and seed unknown. Cereus conoideus.Colorado, southward, and westward.

5. Echinocereus aggregatus (Engelm.) Rydb. Bull. Torr. Bot. Club 33: 146. 1906. Ovate or subglobose, obtuse, $3.5-7.5 \mathrm{~cm}$. in height, $3-5 \mathrm{~cm}$. in diameter, caespitose (mostly in dense hemispherical masses $30-100 \mathrm{~cm}$. in diameter): ribs $8-11$, tuberculate, with areolae $6-8 \mathrm{~mm}$. apart: spines slender, almost setaceous, straight, terete; radials 8-12, white, 6-12 $\mathrm{mm}$. long, upper much the shorter; centrals 1-3, a little stouter, white or horny, 10-20 mm. long: flower deep crimson, $3.5-6 \mathrm{~cm}$. long, $2.5-3.5 \mathrm{~cm}$. broad: fruit and seed unknown. Cereus phoeniceus.-Colorado to New Mexico and Arizona.

\section{OPUNTIA Mill.}

Articulated, much branched plants of various shapes, low and prostrate or erect and shrub-like, with young branches bearing small, terete, subulate, early deciduous leaves and in their axils an areola with numerous short, easily detached barbed bristles and (usually) stouter spines. Flowers mostly large, diurnal, with very short cup-shaped tubes on joints of the previous year and on the same areolae with the spines. Petals widely spreading. Ovary with bristle-bearing areolae in the axils of small, terete, deciduous leaves. Fruit a succulent or dry berry marked with bristly or spiny areolae.

Joints short and flat (except in Nos. 8 and 9).

Internodes oval or orbicular.

Fruit pulpy, unarmed or nearly so.

Spines dissimilar in size, 1-3, or wanting . . . . 1. O. humifusa.

Spines similar, 1-8.

Spines not twisted.

Spines 1-3; internodes suborbicular

Spines 5-7; internodes oblong

Spines twisted; internodes suborbicular

Fruit dry and more or less spiny.

Corolla yellow

Corolla red.

Fruit nearly unarmed; filaments yellow.

Fruit very prickly; filaments red

Internodes flattened or subterete, the stem readily disjointing. Flowers yellowish

Flowers pink or reddish

Joints long, subcylindric.

An erect tree-like shrub Spreading or procumbent, freely branched

1. Opuntia humifusa Raf. Med. Bot. 2: 247. 1830. Diffuse, from a fibrous root, with obovate or suborbicular, very green joints $7.5-12.5 \mathrm{~cm}$. long, bearing elongated. subulate, spreading leaves 6-8 mm. long: pulvini $1.8-2.5 \mathrm{~cm}$. apart, with slender, reddish-brown bristles, mostly unarmed: spines (when present) few, mostly only marginal, stout, terete, straight, erect or spreading, whitish (often reddish at base and apex), 1.8-2.5 cm. long, single, or 1 or 2 smaller deflexed ones in addition: flowers sulphur-yellow (often with red center), 6-8.5 cm. broad: fruit clavate, naked, with funnel-shaped umbilicus, $3.5-5 \mathrm{~cm}$. long (less than half that in diameter), with acid or sweetish purplish pulp: seeds almost regular, compressed, with rather narrow and thick but acutish margins, $5 \mathrm{~mm}$. broad. $O$. Rafinesquii.-In the Mississippi valley, and on the eastern base of the Rocky Mountains, 
2. Opuntia camanchica Engelm. \& Bigel. Proc. Amer. Acad. 3: 293. 1856. Prostrate and extensively spreading, with ascending, obovate-orbicular joints $15-17.5 \mathrm{~cm}$. long by $13.5-17.5 \mathrm{~cm}$. broad: pulvini about $3 \mathrm{~cm}$. apart, with few greenish or yellowish-brown bristles, mostly armed: spines 1-3 (or marginal ones 3-6), compressed, reddish-brown to blackish-brown, paler at tip, $3.5-7.5 \mathrm{~cm}$. long, the upper one elongated and suberect, the rest deflexed: fruit oval, with broad umbilicus, deep red, sweet and juicy, $3.5-5 \mathrm{~cm}$. long: seeds angular, with broad, thick, acute or obtuse margins and deeply notched at the hilum, 4-6 m. broad.-Colorado to Texas.

3. Opuntia Schweriniana K. Sch. Monatsschr. Kakt. 9: 148. 1899. Joints oblong, tuberculate: spines 5-7, white: flower yellow.-Reported from our range.

4. Opuntia tortispina Engelm. 1. c. 293. Prostrate, with ascending, orbicular-obovate joints $15-20 \mathrm{~cm}$. long: pulvini $2.5-3.5 \mathrm{~cm}$. apart, with yellowish bristles: spines 3-5, white, angular and channeled, often spirally twisted, 3.5-6 cm. long, with 2-4 more slender ones (1-2.5 cm. long) added below: flowers sulphur-yellow, 6-7.5 cm. broad: fruit ovate, with broad umbilicus, $4.5-5 \mathrm{~cm}$. long: seeds orbicular, regular, and but slightly notched at hilum, 4-6 mm. broad.-Nebraska and Colorado to Oklahoma.

5. Opuntia polyacantha Haw. Suppl. Pl. Succ. 82. 1819. Prostrate, forming large spreading masses: joints light green, orbicular, tuberculate, $5-10 \mathrm{~cm}$. (rarely 10-15 cm.) long: leaves minute, 3-4 mm. long: pulvini 8-12 mm. apart, with reddish-brown bristles (fewer but longer and darker than in other forms), all armed: spines $8-15$; the 5-10 (generally 6-8) exterior ones radiant, setiform, whitish or reddish-variegated; the $3-5$ interior ones stout, reddishbrown (paler-tipped), 3-5 cm. long, 2-4 of them deflexed, the other one spreading or suberect and very stout: flowers yellow (orange within) or sometimes purple: stigmas 5-8: fruit ovate, dry, and spiny, with shallow, flat umbilicus, $2.5 \mathrm{~cm}$. long: seeds irregular, large $(5-6 \mathrm{~mm}$. broad). Very variable; some of the forms have been described. See Coulter's treatment in Contrib. U. S. Nat. Herb. 3: 435.- Plains on the eastern base of the Rocky Mountains.

6. Opuntia xanthostemma K. Sch. Gesamtb. Kakteen 735. 1899. Very branching, erect, low, obscurely green and sometimes purplish: joints obovate, tuberculate, subareolate: spines $2-4$, with some accessory ones: flower red, stamens yellow: ovary unarmed.-Colorado.

7. Opuntia rhodantha K. Sch. Gesamtb. Kakteen 735. 1899. Branching, erect, low, green: joints obovate or oblong, subtuberculate: spines 2-4, sometimes with accessory ones: flowers and stamens red: ovary very spiny.Colorado.

8. Opuntia fragilis (Nutt.) Haw. 1. c. Subdecumbent, with small, ovate, subcompressed or subglobose (even terete), scarcely tuberculate, shining green joints, variable in size and shape (fruit-bearing ones compressed, $3.5-5 \mathrm{~cm}$. long by $2.5-3 \mathrm{~cm}$. broad, the others smaller and more tumid): pulvini large, 8-12 mm. apart, with white wool, and very few, short, whitish bristles (on old joints a little more abundant, coarser, and straw-colored): spines 1-4 (mostly 4 and cruciate), the uppermost one stout, angular, suberect or porrect, yellowish-brown, 12-20 mm. long, the others weaker (6-16 mm.), paler, spreading or radiant, and 2-6 additional slender, white radiant ones below, 4-8 $\mathrm{mm}$. long: flowers pale yellow, about $5 \mathrm{~cm}$. broad: fruit ovate, almost naked, with funnelform umbilicus, about $2.5 \mathrm{~cm}$. long: seeds few, large $(6 \mathrm{~mm}$.), with broad and thick, obtuse, corky margin.-From British Columbia to Utah and Kansas.

9. Opuntia rutila Nutt. T. \& G. F1. 1: 555. 1840. Ascending and diffuse: joints swollen, ovate or teretish, $5-10 \mathrm{~cm}$. long by $2.5-7.5 \mathrm{~cm}$. broad (sometimes elongated and almost cylindrical): pulvini very crowded $(4-6 \mathrm{~mm}$. apart), with white wool, and at length straw-colored bristles, all armed: spines $3-5$, slender, reddish-gray, 1-4 cm. long (1-3 upper shorter and erect, central one longer, spreading or declined, the rest deflexed, sometimes larger ones flattened and often twisted), 2-4 smaller ones added below: flowers rose-red or paler: fruit ovate, dry, and spinulose, with a deep funnelform um- 
bilicus, $2.5-3 \mathrm{~cm}$. long: seeds large $(6 \mathrm{~mm}$. broad), much compressed, with broad, acute margins.- Southwestern Wyoming to Nevada.

10. Opuntia arborescens Engelm. Wisliz. Mem.90. 1848. Arborescent and erect, 15-50 dm. high, $12.5-25 \mathrm{~cm}$. in diameter, with verticillate, horizontally divaricate or pendulous, very spiny branches: joints verticillate (mostly in threes or fours), cylindrical and very green, $5-15 \mathrm{~cm}$. long, less than $2.5 \mathrm{~cm}$. in diameter, with prominent, elongated, compressed-cristate tubercles 14-18 $\mathrm{mm}$. long, and terete, elongated, spreading leaves $12-20 \mathrm{~mm}$. long: pulvini with short wool, but scarcely bristly: spines 8-30, terete, horny or reddishbrown, in straw-colored sheaths, porrect in every direction, 1-8 interior ones longer (16-28 mm.), more loosely sheathed, the central subdeflexed, the exterior ones weaker, closely sheathed, $8-16 \mathrm{~mm}$. long, all sometimes very short: flower purple, 6-7.5 cm. broad: fruit globose or hemispherical, $2.5 \mathrm{~cm}$. in diameter, prominently cristate-tuberculate, unarmed, dry or nearly so, yellow: seeds regular, smooth, $3-4 \mathrm{~mm}$. broad, with narrow commissure.Colorado to New Mexico and Texas.

11. Opuntia Davisii Engelm. \& Bigel. Proc. Amer. Acad. 3: 305. 1856. Stem spreading and somewhat procumbent, with dense woody and divaricate branches, 4-5 dm. high: joints attenuate at base, rather slender, 10-15 cm. long (younger ones erect), with oblong-linear tubercles 14-16 mm. long: inner spines 4-7, subtriangular, divergent, reddish-brown, in a loose straw-colored sheath, $2.5-3.5 \mathrm{~cm}$. long; lower ones 5 or 6 , slender, $6-12 \mathrm{~mm}$. long: flower yellowish (?): fruit ovate, spiny, $2.5 \mathrm{~cm}$. long or more.-Texas, extending north into Colorado.

\section{ELAEAGNACEAE Lindl. Oleaster Family}

Shrubs or small trees with the entire leaves scurfy throughout, with scarioussilvery or brown scales or with silvery stellate-pubescence. Flowers regular, perfect or dioecious, clustered in the axils or solitary. Perianth of fertile flowers with a deciduous 4-lobed limb and a persistent base inclosing the ovary. Perianth of sterile flowers 4-parted, bearing the 4 or 8 stamens on the throat. Pistil simple, with slender style, the solitary ovule becoming a nut-like achene inclosed in the finally fleshy, drupe-like fruit (the perianth base).

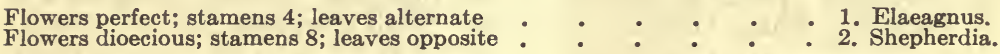

1. Elaeagnus.

\section{ELAEAGNUS L.}

Shrubs with silvery-scaly alternate leaves and brownish or silvery branchlets. Perianth tubular, its 4-lobed limb deciduous, its tube contracted over the ovary. Stamens 4 , borne on the throat of the perianth and alternate with its lobes. Fruit drupe-like with an 8-striate stone.

1. Elaeagnus argentea Pursh, Fl. Am. Sept. 114. 1814. A stoloniferous shrub 1-3 m. high, the younger branches brownish with scurfy scales, becoming silvery: leaves from broadly to narrowly elliptic, silvery-scurfy: flowers numerous, 12-15 mm. long, 1-3 in the axils, deflexed, silvery without, pale yellow within, fragrant, the lobes ovate: fruit globose-ovoid, silvery, 8-10 $\mathrm{mm}$. long. SilverberRy.-Moist sandy swales and banks; from Utah through Wyoming northward and eastward.

\section{SHEPHERDIA Nutt.}

Shrubs or small trees with opposite petioled leaves with silvery-stellate or scurfy-brownish scales. Flowers small, dioecious, axillary or nodal, fascicled, 
few or solitary, short-pediceled. The staminate flowers larger, 4-parted, the lobes spreading; stamens alternate with as many lobes of a thick disk. The pistillate flowers with oblong, tubular perianth, with 4-cleft limb and the throat nearly closed by the 8-lobed disk. Fruit berry-like, with a smooth, shining compressed seed.-(Lepargyrea Raf.)

Tree-like shrub, thorny; leaves silvery .

Low shrub, thornless; leaves green

1. Shepherdia argentea Nutt. Gen. 2: 241. 1818. A stout tree-like shrub, 2-5 mm. high: leaves silvery on both sides, mostly oblong, obtuse, cuneate at base: flowers fascicled at the nodes: fruit a smooth, ovoid, scarlet berry, about $5 \mathrm{~mm}$. long, nearly sessile, acid, and edible. BuFfalo BERRY.-Stream banks; from the Saskatchewan south through the mountains to New Mexico.

2. Shepherdia canadensis (L.) Nutt. Gen. 2: 240. 1818. A more or less tufted shrub, 1-2 m. high, brownish-scurfy on the branchlets, leaves, and flowers: leaves elliptical or ovate, nearly naked and dark green above, silverydowny beneath: flowers yellowish: fruit oval, red or yellowish, 5-7 mm. long, the flesh very juicy and exceedingly bitter.-Moist, partly wooded mountain slopes; throughout the Rocky Mountains.

\section{LYTHRACEAE Lindl. LoOSestrife FAMily}

Herbs (ours) with simple and entire leaves, calyx tubular or campanulate and free from the ovary and capsule but inclosing it, the petals and definite stamens borne in its throat, a single style, and numerous small seeds on a central placenta. Distinguished from Haloragidaceae and Onagraceae by the free ovary, and from the former also by the numerous seeds.

Annual; leaves opposite; calyx 4-angled

Perennial; upper leaves alternate; calyx striate

\section{AMMANNIA L.}

Low and smooth annuals, with 4-angled stems, sessile leaves, and small axillary flowers. Calyx 4-toothed, with as many intermediate, small, toothlike processes. Petals as many, small and fugacious, or none. Stamens 4 or 8. Capsule globular, bursting irregularly. Seeds numerous.

1. Ammannia coccinea Rottb. Pl. Hort. Havn. 7: 1773. Stems erect: leaves linear-lanceolate, with a broad auricled base: flowers $1-5$ in each axil, mostly closely sessile: petals purple, fugacious: style slender, elongated. A. latifolia.-From the Alleghanies west; infrequent; possibly within our range.

\section{LYTHRUM L. LOOSESTRIFE}

Erect slender herbs, with angled stems, and axillary, mostly solitary, dimorphous flowers. Calyx 4-7-toothed, with intermediate tooth-like processes. Petals oblong-obovate, often conspicuous. Ovary 2-celled, with filiform style; stigma capitate. Capsule membranous, inclosed by the calyx. Seeds flat or angular.

1. Lythrum alatum Pursh, Fl. Am. Sept. 334. 1814. Tall and wand-like perennial, smooth; branches with margined angles: leaves oblong-ovate to lanceolate, the upper scattered, not longer than the flowers, which are small and nearly sessile in the axils: proper calyx-teeth often shorter than the intermediate processes: petals purple: stamens of the short-styled flowers exserted.-Colorado and Wyoming, east to the Atlantic States. 


\section{ONAGRACEAE Dumort. Evening Primrose Family}

Annual or perennial herbs, rarely shrubs, with alternate or opposite leaves, no stipules or mere glands in their place, and axillary, spicate or racemose, generally perfect, regular or sometimes irregular flowers. Calyx-tube adnate to the ovary, often prolonged beyond it, the limb 2-6-lobed, usually 4-lobed. Petals $2-9$, mostly 4 , convolute in the bud, rarely none. Stamens commonly as many or twice as many as the petals and inserted with them on the summit of the calyx-tube, or on the epigynous or perigynous disk. Ovary 1-6-celled, usually 4-celled; styles united; stigma capitate, discoid or 4-lobed. Fruit usually a capsule; ovules many in each cell. Seeds mostly small, sometimes with a coma.

Flowers 4-merous.

Fruit a many-seeded capsule opening by valves.

Calyx-tube not prolonged beyond the ovary.

Annuals; seeds not comose

Perennials; seeds comose

Calyx-tube prolonged beyond the ovary. Seeds comose.

Flowers showy, scarlet

Flowers small, not scarlet

Seeds naked or sometimes tuberculate.

Stigma deeply cleft into 4 linear lobes.

Stamens equal in length.

Flowers yellow; seeds in 2 rows

Flowers yellow; seeds in 2 rows
Flowers white or pink; seeds in 1 row $\quad \cdot \quad \cdot \quad$ 5. Onagra.

Stamens unequal, the alternate ones longer.

Capsule not winged, but the rounded angles often more

or less double crested
Capsule winged or merely sharply angled.

Plants stemless Plants with diffuse wiry stems: : :

Stigma entire (discoid or capitate) or barely 4 -toothed.

Stigma discoid; stamens equal; calyx-tube funnelform above.

Calyx-tube longer than the ovary

Calyx-tube shorter than the ovary

Stigma capitate.

Calyx-tube cylindrical, longer than the ovary; capsule 4-winged widened above, shorter than the ovary;

Calyx-tube widened ab
capsule not winged.

Capsule linear, sessile

Fruit indehiscent, nut-like.

Flowers 2-merous; fruit indehiscent and bristly with hooked hairs
1. Gayophytum.
2. Chamaenerion.
3. Zauschneria.
4. Epilobium.

\section{Anogra.}

7. Pachylophus.

8. Lavauxia.

9. Gaurella.

10. Galpinsia.

11. Meriolix.

12. Taraxia.

13. Sphaerostigma.

14. Chylisma.

15. Gaura.

16. Circaea.

\section{GAYOPHYTUM Juss.}

Very slender branching annuals, with linear entire leaves and very small axillary flowers. Calyx-lobes reflexed. Petals white or rose-colored.

Subsimple or paniculately branched; capsule nearly sessile

Usually freely branched above; capsules on elongated pedicels.

Flowers large, 5-10 $\mathrm{mm}$. broad

Flowers small, 2-4 mm. broad

1. G. caesium.

2. G. diffusum.

3. G. ramosissimum.

1. Gayophytum caesium T. \& G. Fl. 1: 514. 1840. Glabrous, or more or less canescent with short appressed pubescence, the elongated branches mostly simple: flowers $1 \mathrm{~mm}$. long, axillary the whole length of the branches: capsules linear, sessile or very shortly pediceled, $15-20 \mathrm{~mm}$. long, usually many-seeded: stamens in two sets; the anthers of the shorter set smaller. G. racemosum. (G. Nuttallii T. \& G. 1. c.)-The western half of the United States.

2. Gayophytum diffusum T.\& G. I.c.513. Loosely dichotomously branched, 2-5 dm. high, somewhat canescent above or with spreading hairs through- 
out: flowers large, 5-10 mm. broad: stamens all with similar and perfect anthers: capsules thick, subclavate, torulose, erect or refracted: seeds few, low-papillate.-In the western part of our range to the Pacific States.

3. Gayophytum ramosissimum T. \& G. 1. c. Glabrous, or the inflorescence puberulent, diffusely much branched: flowers $1-2 \mathrm{~mm}$. long, mostly near the ends of the branches: capsule oblong, 5-8 $\mathrm{mm}$. long, on pedicels of about the same length or shorter, often deflexed, 3-5-seeded: stamens in two sets; the anthers of the shorter set often abortive. (G. intermedium Rydb. Bull. Torr. Bot. Club 31: 569. 1904.) - Throughout the western United States.

\section{CHAMAENERION Adans. Frreweed}

Perennials from a stout caudex, bearing sessile, scaly, winter buds with terete stems and ample leaves. Calyx cleft almost to the ovary. Corolla slightly irregular; petals widely expanded. Stamens inserted in a single series; the filaments dilated below. Style at first recurved; stigma with four ultimately divergent lobes. Capsule mostly linear-fusiform, many-seeded. Seeds fusiform, beakless, comose.

Stems tall; bracts small; style pubescent at base Stems low (2-5 dm.); bracts leaf-like; style glabrous .

1. C. angustifolium.

1. Chamaenerion angustifolium (L.) Scop. Fl. Carn. Ed. 2. 1: 271. 1772. Stems erect, 5-15 dm. high, subsimple, glabrate below: leaves lanceolate, acute, nearly entire, 1-2 mm. long, on very short petioles, thin, pinnately veined, with the evident lateral veins confluent in submarginal loops: inflorescence elongated; racemes with small bracts; young flower buds soon reflexed, but again spreading or ascending before expansion: petals 9-15 mm. long: style exceeding the stamens, hairy at base: capsule 5-7 $\mathrm{cm}$. long: seeds less than $2 \mathrm{~mm}$. long, with very long dingy coma. Epilobium spicatum.Frequent in our mountains; across the continent northward and in Europe and Asia.

2. Chamaenerion latifolium L. Sweet, Hort. Brit. Ed.2. 198. 1830. Stems 2-4 dm. high, frequently branched, mostly glabrate below: leaves $3-5 \mathrm{~cm}$. long, usually opposite and connected below on the branches and rarely on the main stem, lanceolate to ovate, acute at both ends, entire or sparingly and minutely denticulate, scarcely petioled, rather coriaceous, the mostly free lateral veins inconspicuous: inflorescence usually short and few-flowered, leafy throughout, the buds not reflexed: petals $1-2 \mathrm{~cm}$. long, rather narrow: styles shorter than the stamens, glabrous. Epilobium latifolium.-Northern America and extending south to Colorado in the mountains.

\section{ZAUSCHNERIA Presl.}

Perennial herbs or somewhat suffrutescent. Leaves opposite, except those of the floral branches. Flowers racemose, large, scarlet. Calyx-tube globose, inflated just above the ovary, then becoming funnelform, 4-lobed, bearing 8 small scales within at the upper end of the short proper tube, 4 erect and 4 reflexed. Petals 4, little exceeding the calyx-lobes, obcordate or deeply cleft. Stamens 8 , the 4 alternate with the petals inserted lower down and appearing shorter; anthers linear-oblong. Style long, exserted; stigma peltate or capitate, 4-lobed. Capsule slender-fusiform, obtusely 4-angled, 4-valved, manyseeded.

1. Zauschneria Garrettii A. Nels. Proc. Biol. Soc. Wash. 20: 36. 1907. Caudex woody; stems simple, slender, suberect, $1.5-3 \mathrm{dm}$. high, hirsute, the hairs long and widely spreading: leaves oval or ovate, $2-3 \mathrm{~cm}$. long, with small, rather remote and irregular teeth, green but sparsely soft-hirsute: calyx puberulent, its tube deep red, 12-16 mm. long: petals thick, deep red, obovate-cordate, slightly exceeding the calyx-lobes: stigma tardily well ex- 
serted; ovary and capsule minutely glandular-pubescent.-Utah, and probably in northwestern Colorado.

\section{EPILOBIUM L. Willow Herb}

Herbs or sometimes shrubby plants, with alternate or opposite leaves, and axillary or terminal, solitary or racemose flowers. Calyx linear, produced beyond the ovary, the limb 4-parted, deciduous. Petals 4, mostly obovate or obcordate. Stamens 8; anthers oblong or linear, short. Ovary 4-celled; united styles slender or filiform; stigma club-shaped or 4-lobed. Capsule elongated, 4-sided, 4-celled, loculicidally dehiscent by 4 valves. Seeds small, numerous, with a tuft of hairs (coma) at the summit.

Annual

Perennials.

Stigma deeply 4-lobed or 4-cleft; flowers cream-colored

Stigma entire or only notched; flowers never yellow.

Seeds smooth or nearly so under the microscope.

Leaves medium size, more or less toothed.

Flowers violet

Flowers white

Leaves small, entire or nearly so; plants $\dot{3}-10 \mathrm{~cm}$, high

See $\mathrm{ts}$ papillate-roughened under the microscope.

Plants not glandular; leaves linear.

Foliage and lower part of the stem glabrous . Foliage and stem crisped-hairy

1. E. paniculatum.

Plants glandular above at least.

Plants usually less than $3 \mathrm{dm}$. high.

Leaves numerous and approximate; plants low, less than $2 \mathrm{dm}$. high.

Plants erect, not caespitose

Plants assurgent; densely caespitose

Leaves fewer, remote, suberect; plants $2-3 \mathrm{dm}$. high, with turions (if any) not sessile.

Leaves narrow, somewhat petioled

Leaves oblong to ovate, sessile

2. E. suffruticosum.

nts tall, 4-10 dm. high.

Usually freely branched, leafy, very glandular;

petioles short, winged
Usually subsimple, less leafy and less glandular; petiole slender

3. E. Hornemannii.

4. E. alpinum.

5. E. anagallidifolium.

6. E. wyomingense.

7. E. lineare.

1. Epilobium paniculatum Nutt. T. \& G. Fl. 1: 490.1840. Annual,
ender, $3-6 \mathrm{dm}$. tall, loosely branched, glandular-pubescent above: leaves slender, 3-6 dm. tall, loosely branched, glandular-pubescent above: leaves
alternate, linear to linear-lanceolate, $2.5-7.5 \mathrm{~cm}$. long, denticulate or nearly entire, attenuate into slender-winged petioles: calyx often purple, its tube funnelform, 2-3 mm. long, shorter than the lanceolate segments: petals cuneate, notched, 6-8 mm. long, violet: capsules ascending, linear-fusiform, 2-3 cm. long, curved: seeds obovoid, $2 \mathrm{~mm}$. long, black, slightly papillose.-Apparently in most parts of the western United States.

2. Epilobium suffruticosum Nutt. 1. c. 488 . Stems woody ard freely branched at base, $10-16 \mathrm{~cm}$. high, minutely canescent throughout or at length glabrate below: leaves numerous, less than $2 \mathrm{~cm}$. long, mainly opposite, broadly lanceolate, acutish, entire, narrowed below but hardly petioled, thick, with inconspicuous veins: flowers rather few, in the axils of the scarcely reduced upper leaves: calyx-tube broadly funnelform: petals $6-8 \mathrm{~mm}$. long: capsule 20-25 mm. long, short-stalked: seeds $1 \mathrm{~mm}$. or more long, coma long and very dingy.-Western Wyoming to Montana and Oregon.

3. Epilobium Hornemannii Reichenb. Icon. Crit. 2: 73. 1824. Mostly 2-3 dm. high, ascending, unbranched, somewhat crisp-hairy in the inflorescence, or slightly glandular at top, otherwise glabrate: leaves about $25 \mathrm{~mm}$. long, subascending, elliptical-ovate, mostly very obtuse, nearly entire to remotely serrulate, the lower cuneately narrowed, the upper usually abruptly rounded to the short petioles: flowers rather few, nearly erect: petals $5-8 \mathrm{~mm}$. long, dilac to deep violet: capsules as much as $5 \mathrm{~cm}$. long, slender, erect, on slender peduncles about equaling the gradually reduced subtending leaves: seeds rather abruptly short-appendaged, from nearly smooth to very rough.Throughout our range to California and British Columbia. 
4. Epilobium alpinum L. Sp. Pl. 1: 348. 1753. Size and habit of $E$. Hornemannii but the inflorescence more nearly glabrous: leaves uniformly distributed, thin and delicate, pale green, $4 \mathrm{~cm}$. long, subelliptical, rather obtuse, subentire to somewhat sharply serrulate, gradually narrowed to slender petioles: flowers few, suberect in the upper axils: petals about $3 \mathrm{~mm}$. long, white or rosy-tipped: capsules very slender, erect or ascending, about $50 \mathrm{~mm}$. long, their peduncles rather slender and about equaling the subtending leaves, or stouter and is long as the capsules: seeds smooth, gradually attenuated at apex, with very evident beak.-Widely distributed through the northern part of the continent and in the high mountains.

5. Epilobium anagallidifolium Lam. Dict. 2: 376. 1786. About $1 \mathrm{dm}$. high, rather densely caespitose, the very slender stems curved and nodding at apex, somewhat crisp-hairy at least in lines and occasionally very slightly glandular in the inflorescence: leaves $10-20 \mathrm{~mm}$. long, ascending, rather uniformly distributed, all but the lowermost very narrowly ovate or oblong, rather obtuse, entire or remotely very low-denticulate, cuneately narrowed, the lowest mostly wing-petioled, rather firm and inconspicuously veined: flowers few, crowded at apex, somewhat nodding: petals lilac to violet, about $5 \mathrm{~mm}$. long: capsules $25 \mathrm{~mm}$. long, slender, their rather slender peduncles shorter than the leaves or, when only one or two are present, equaling the capsules: seeds somewhat obovoid-fusiform, short-beaked, coma rather dingy. - Circumpolar and extending south in our mountains to Colorado.

6. Epilobium wyomingense A. Nels. Bot. Gaz. 30: 194. 1900. Stems 2-4 dm. high, strictly erect, simple or with erect opposite branches, glabrous or obscurely pubescent above: leaves thin, narrow, tapering to both ends, 3-5 or more cm. long, in 4-7 equidistant pairs, often shorter than the internodes: flowers small, white: capsule linear, 4-7 cm. long, minutely cinereouspuberulent; the pedicels variable, from much shorter to even exceeding the capsule: seeds numerous, smooth, fusiform, scarcely beaked; the coma white, persistent.-Wyoming and Colorado.

7. Epilobium lineare Muhl. Cat. 39. 1813. Slender, canescent throughout with incurved hairs, 3-6 dm. high, at length much branched: leaves linear or linear-lanceolate, mostly short-petioled, opposite or alternate, acute at both ends, 2.5-5 cm. long, the veins obscure: flowers erect, pink or whitish, 4-8 mm. broad; pedicels mostly slender: stigma entire or slightly notched: capsules about $5 \mathrm{~cm}$. long: seeds less than $2 \mathrm{~mm}$. long, slightly papillose.-Colorado and Wyoming, and far northward and eastward.

8. Epilobium saximontanum Hausskn. Oesterr. Bot. Zeitschr. 29: 119. 1879. Somewhat crisp-hairy, at least along the elevated lines, and glandular above: leaves about $20 \mathrm{~mm}$. long, mostly crowded and ascending or suberect, oblong to elliptical, the upper rather acute, very minutely denticulate or subentire, cuneately narrowed to the sessile base, or the lowest $3 \mathrm{~cm}$. long, more lanceolate, and with somewhat elongated winged base: flowers few, pale to deep violet: capsules short-stalked: seeds slightly larger and often less papillate.-Said to occur in the mountains of Colorado and Nevada.

9. Epilobium clavatum Trelease, Rep. Mo. Bot. Gard. 2: 111. 1891.' One $\mathrm{dm}$. or more high, mostly densely caespitose, the slender stems ascending, glabrate to sparingly glandular throughout: leaves 15-20 $\mathrm{mm}$. long, divergent, broadly ovate, very obtuse, subentire to remotely serrulate, mostly rounded to evident petioles, firm: flowers rather few, suberect: petals rosecolored, about $5 \mathrm{~mm}$. long: capsules $25 \mathrm{~mm}$. long, subclavate, arcuately divergent, their slender peduncles equaling the subtending leaves: seeds fusiform, tapering into a pale beak, nearly smooth to coarsely papillate.-Utah and Colorado, northward and westward to Washington.

10. Epilobium Drummondii Haussk. Monog. 271. 1884. Plant 2-3 dm. high, glandular above, the decurrent lines subglabrate: leaves $2.5-4 \mathrm{~cm}$. long, typically remote and erect, lanceolate to almost linear-lanceolate, rather acute, the upper, especially, denticulate, mostly rounded to the subsessile base: flowers erect: petals $3-4 \mathrm{~mm}$. long, usually pale: capsules $3-5$ 
cm. long, slender-stalked.-Frequent in the mountains from Montana to Colorado.

11. Epilobium ovatifolium Rydb. Bull. Torr. Bot. Club 31: 567. 1904. Plant 2-6 dm. high, propagating by turions: stem glabrous except the decurrent lines which are more or less crisp-hairy, especially above: leaves sessile or nearly so, ovate or ovate-lanceolate and acute, or the lowest oval and obtuse, 3-4 cm. long, entire or denticulate, glabrous: petals purple or rarely rose, 5-7 $\mathrm{mm}$. long: pods $5-6 \mathrm{~cm}$. long, $1.5-2 \mathrm{~mm}$. in diameter, sessile, more or less crisp and glandular-hairy: seed a little over $1 \mathrm{~mm}$. long, abruptly contracted above, but without neck; coma white, about $6 \mathrm{~mm}$. long. ( $E$. Drummondii latiusculum Rydb. Mem. N. Y. Bot. Gard. 1: 276. 1900; E. brevistylum; E. Halleanum; and E. glandulosum probably, but only as to plants of our range.) - Colorado to Montana.

12. Epilobium adenocaulon Hausskn. Oesterr. Bot. Zeitschr. 29: 119. 1877. With upcurving branches throughout, the inflorescence, capsules, etc., very glandular-pubescent and with few if any incurved hairs: leaves $5 \mathrm{~cm}$. or, exceptionally, $7 \mathrm{~cm}$. long, frequently erect, elliptical to mostly ovatelanceolate, obtuse, only slightly serrulate or denticulate, abruptly rounded to short-winged petioles, rather pale green and glossy, glabrous except the uppermost, which are gradually reduced and but slightly rugose: flowers very numerous, nodding at first: petals $3-5 \mathrm{~mm}$. long, rosy: fruiting peduncles slender, mostly short: seeds obovoid, abruptly short-beaked; coma white. E. coloratum. (E. rubescens Rydb. 1. c. 568.) - The commonest of our species, variable; wet banks everywhere.

13. Epilobium perplexans Trel. in Herb. ex Tweedy (1900), Greene (1902). Slender, subsimple or with few ascending remotely leafy branches, less glandular, the inflorescence sometimes canescent with incurved hairs: leaves scarcely $5 \mathrm{~cm}$. long, divergent, lanceolate, rather obtuse and sparingly undulateserrulate, thin and light green, the upper acutely tapering to slender sometimes elongated petioles. (E. adenocaulon perplexans Trelease, Rep. Mo. Bot. Gard. 2: 96. 1891; E. stramineum Rydb. l. c., in part; E. Palmeri Rydb. 1. c. 569.) - Frequent in our range.

\section{ONAgRA Adans. Evening Primrose}

Annual or biennial herbs, with mostly erect stems. Leaves alternate, undulate or toothed. Buds erect. Flowers yellow, nocturnal, in terminal spikes. Calyx-tube elongated. Ovary 4-celled; ovules in 2 or more rows, horizontal. Capsule 4-angled, more or less tapering, opening loculicidally. Seeds prismatic-angled.-Oenothera in part.

Calyx-tube slender, 2.5-5 cm. long.

Plant somewhat strigose; petals yellow, 1-2 cm. long

Plant somewhat hirsute; petals yellow or pinkish, $2.5-4 \mathrm{~cm}$. long

Calyx-tube stout, 5-10 cm. long

1. O. strigosa.

2. O. Hookeri.

3. O. Jamesii.

1. Onagra strigosa Rydb. Mem. N. Y. Bot. Gard. 1: 278. 1900. Strigose and somewhat villous above with grayish hairs, 4-10 dm. high: leaves various, the basal obovate or spatulate, obtuse; stem leaves oblanceolate to lanceolate, 5-10 cm. long or the upper shorter, acute, undulate: spike leafy-bracted, many-flowered: calyx-segments with short free tips: corollas pure yellow, 3-4.5 cm. broad: capsules 2.5-3 cm. long. Oenothera biennis.-Along the eastern base of the mountains to Montana, S. Dakota, and Nebraska.

2. Onagra Hookeri (T. \& G.) Small, Bull. Torr. Bot. Club 23: 171. 1896. Stems erect, usually stout and mostly simple, canescently pubescent and more or less hirsute: leaves lanceolate to ovate-lanceolate, acute or acuminate, repandly denticulate, the lowest petioled: flowers sessile, in a leafy spike: calyx villous, the tube twice the length of the ovary, rather shorter than the slightly acuminate segments: petals obcordate, about $3 \mathrm{~cm}$. long: stigma linear, somewhat thickened: capsule more or less pubescent.-From the Rocky Mountains to the Pacific coast.

ROCKY MT. BOT.-22 
3. Onagra Jamesii (T. \& G.) Small, 1. c. 840 . Stems stout, canescently strigillose, decumbent, 1-4 m. long, more or less branched: leaf-blades narrowly oblong or lanceolate, 5-20 cm. long, often curved, acute, repandly denticulate, the lower ones narrowed into short petiole-like bases, the upper sessile or nearly so: calyx-tube stout, $5-11 \mathrm{~cm}$. long: calyx-lobes nearly linear, about half as long as the tube: corolla showy, yellow, turning to rose: capsules tapering upward, 35-40 mm. long.-Southern Colorado and southward.

\section{ANOGRA Spach. White Evening Primrose}

Caulescent annual or perennial herbs, often with a papery bark. Stems sometimes somewhat woody. Leaves alternate; blades usually pinnatifid. Buds drooping. Flowers usually axillary, diurnal. Calyx-tube elongated; sepals narrow. Corolla white or pink. Ovary slender; ovules numerous, in 1 row in each cavity, ascending. Capsules elongated, spreading or ascending, loculicidal. Seeds terete.-Oenothera in part.

Calyx in bud merely acutish, the tips of its lobes not free.

Capsule erect or ascending; seeds pitted

Capsule divaricate; seeds smooth

Calyx in bud acuminate or acute, the tips of its lobes free.

Capsule linear-cylindric; throat of the calyx glabrous.

Calyx glabrate, or sparsely hairy, or glandular-puberulent.

Leaves deeply pinnatifid

Leaves subentire or toothed or some of them short-lobed.

Capsule straight, ascending; leaves pubescent beneath

Capsules divaricate, usually some of them contorted or twisted; leaves glabrous

Calyx villous or densely strigose.

Leaves, at least some of them, deeply pinnatifid

Leaves subentire or sinuately toothed.

Silvery-canescent

Dark green and hispid-villous
Capsule oblong; throat of the calyx hairy; leaves rather finely pinnatifid

1. A. albicaulis.

2. A. violacea.

3. A. rhizomata.

4. A. Nuttallii.

5. A. pallida.

6. A. trichocalyx.

7. A. cinerea.

8. A. neo-mexicana.

9. A. coronopifolia.

1. Anogra albicaulis (Pursh) Brit. Mem. Torr. Club 5: 234. 1894. Stems diffusely branched, the branches decumbent or ascending, 1-3 dm. long, more or less hirsute or puberulent, with whitish and often shreddy bark: leaves alternate; blades oblanceolate or lanceolate, deeply pinnatifid or the lower ones repand-dentate (rarely entire), $2.5-10 \mathrm{~cm}$. long: sepals lanceolate, acuminate, hirsute, the tips not free in the bud: corolla $3.5-7.5 \mathrm{~cm}$. broad, white, becoming rose-color: capsules linear-cylindric, $2.5-3.5 \mathrm{~cm}$. long: seeds finely pitted. Oenothera pinnatifida. (A. Buffumii A. Nels. Bull. Torr. Bot. Club 27: 267. 1900.)-On the plains east of the mountains, Dakota to New Mexico.

2. Anogra violacea A. Nels. Bull. Torr. Bot. Club 31: 242. 1904. Stems several to many, decumbent at base, $2-3 \mathrm{dm}$. high, usually violet or purplish (broadly splotched), appearing smooth but puberulent under a lens: crown leaves rather small, linear-oblanceolate, entire or toothed; stem leaves puberulent, dark green, numerous, 4-8 $\mathrm{cm}$. long, linear-oblong or narrowly oblanceolate, coarsely sinuate-dentate and some of them deeply pinnatifid; the lobes acute, triangular to oblong: buds drooping, oblong or slightly enlarged towards the obtusish tip, pubescent with flat, crinkled hairs: calyx-lobes a little more than half as long as the tube: petals triangular-obcordate, sinus broad and shallow, 15-20 mm. long, scarcely longer than the calyx-lobes, white, drying pink: capsule subangulate, sinuate-tubercled on the margins.Sandy slopes and washes; Wyoming and Colorado.

3. Anogra rhizomata A. Nels. 1. c. 26: 240. 1899. Perennial: rhizome horizontal, long, thick, giving rise at intervals to short, obliquely ascending stems: stems several, 1-2 dm. high, from pinkish to light violet, puberulent: leaves from nearly entire to deeply pinnatifid, linear-oblong, $3-5 \mathrm{~cm}$. long, more or less hispid-ciliate and puberulent: buds acute at apex, sometimes glabrate: calyx-tips free, lobes shorter than the petals, usually much shorter than the tube: petals white or pink, suborbicular: capsule linear, somewhat 
angled, 2-3 cm. long, divergent or becoming deflexed.-Habitat and range of the last.

4. Anogra Nuttallii (Sweet) A. Nels. Bot. Gaz. 34: 368. 1902. Stems one to several from the crown, erect, 5-10 dm. high: leaves very numerous, somewhat fascicled in the axils, softly and minutely puberulent on the lower surface, broadly linear, margin entire or merely denticulate: flowers drooping in bud: calyx glandular-puberulent on the tube; calyx-lobes narrowly lanceolate, $2-3 \mathrm{~cm}$. long, about as long as the tube, the tips free: petals white, broadly obovate, nearly as long as the reflexed calyx-lobes: stigmas exserted, linear, about $10 \mathrm{~mm}$. long: mature capsule cylindrical, about $3 \mathrm{~cm}$. long, pale, minutely puberulent except on the rather broad, whitish sutures, not contorted: seeds narrowly ovate, light green, copiously speckled with purple, indistinctly striate under a lens, about $2 \mathrm{~mm}$. long.-Throughout our range and westward and northward.

5. Anogra pallida (Lindl.) Brit. 1. c. Much resembling the preceding but the leaves usually narrow, nearly entire and wholly glabrous, more rarely broader, minutely pubescent (especially on the margins) and runcinately toothed or pinnatifid toward the base: calyx glabrous or with scattered hairs; the tube much longer than the ovary and often twice or thrice the length of the segments: style not exserted: capsules spreading, at least some of them more or less contorted. (A. Vreelandii Rydb. Bull. Torr. Bot. Club 31: 570 . 1904.)-Less frequent; Wyoming and western Nebraska and northward and westward.

6. Anogra trichocalyx (Nutt.) Small, Bull. Torr. Bot. Club 23: 174. 1896. Stems usually several from the crown, 1-3 dm. long: leaves pinnatifid, somewhat canescent and sprinkled with rather long flattish hairs; the terminal lobe of the basal leaves oblong and entire: calyx rather densely villous with long crisped hairs; the segments shorter than the tube and the roundish petals which exceed the stamens and the short style: capsule cylindrical: seeds lanceolate, acute, smooth, with minute purple spots.-Frequent in sandy soil; Nebraska to Nevada.

7. Anogra cinerea Rydb.1. c. 31: 570. 1904. Branched perennial; the stem 3-4 dm. high, whitish cinereous, strigose when young: leaves lanceolate to ovate-lanceolate, mostly subsessile, 3-5 cm. long, sinuate-dentate or denticulate, cinereous: calyx glabrous or sparingly long-hairy, acuminate; tips free and rather long: petals 15-18 mm. long: pods divergent at right angles to the stem, 3-3.5 cm. long, almost straight. (A. latifolia Rydb. 1. c. 33: 146.)Nebraska, Colorado, and Wyoming.

8. Anogra neo-mexicana Small, 1. c. 176. Stout, hispid-villous, dark green: stem 6-7 dm. tall, flexuous, clothed with a pale papery bark: leaves oblong or lanceolate, 4-8 cm. long, sinuate-toothed, puberulent, with some hispid-villous hairs on the midrib and lateral nerves: calyx hispid-villous, the tube stoutish, 4-4.5 cm. long, nearly thrice longer than the ovary; the segments nearly linear, one half as long as the tube, the tips free in the bud: petals broadly deltoid, $1.8 \mathrm{~cm}$. long, $2 \mathrm{~cm}$. broad: style slender, longer than the petals: capsule nearly cylindric, $2-2.5 \mathrm{~cm}$. long, somewhat narrowed at the base and the apex, hispid-villous: seeds "oblong and perfectly smooth."New Mexico and probably southern Colorado.

9. Anogra coronopifolia (T. \& G.) Brit. 1. c. Stems erect or nearly so, branched, 1.5-3 dm. tall, more or less hispid or canescent: leaf-blades lanceolate or oblanceolate in outline, $1.5-5 \mathrm{~cm}$. long, usually finely and deeply pinnatifid into linear-oblong lobes: sepals linear: corolla white, turning pink, 2-3 cm. broad: capsules oblong, abruptly constricted at the top, straight, 8-20 mm. long, about $4 \mathrm{~mm}$. thick: seeds tuberculate.-Plains and prairies; from Montana to Texas.

\section{PACHYLophuS Spach, Fragrant Primrose}

Perennial, acaulescent or somewhat caulescent herbs. Leaves basal, pinnatifid or pinnately-toothed. Calyx-tube linear-funnelform, the segments shorter 
than the tube. Petals white or pink. Capsules basal, woody, pyramidal, their angles retuse or obtuse, transversely wrinkled, and sometimes tuberculatecrested. Seeds sessile, in 1 or 2 rows, deeply furrowed along the raphe. This has been considered a monotypic genus, and it must be said that the following species are far from sharply distinct.-Oenothera in part.

Wholly glabrous throughout; calyx-tube several times longer than its lobes.

Capsule tuberculate-crested on the angles; flowers large, surpassing the leaves

Capsule with smooth rounded angles; flowers small, surpassed by the leaves

More or less pubescent or hirsute.

Strictly acaulescent; calyx-tube only twice as long as its lobes

Acaulescent or caulescent; calyx-tube three to several times as long as its lobes.

Capsule sessile.

Acaulescent or nearly so, sparingly pubescent

Acaulescent and conspicuously pubescent or villous :

Capsule stipitate; caulescent

1. P. caespitosus.

2. P. glaber.

3. P. montanus.

4. P. macroglottis.

5. P. eximius.

6. P. marginatus.

1. Pachylophus caespitosus (Nutt.) Raimann, Eng. \& Prantl. Nat. Pfl. Fam. 37: 215. 1893. Wholly glabrous, stemless or subcaulescent: leaves lanceolate, acute, repandly toothed or nearly entire, attenuate into a long margined petiole: tube of the calyx 4 times as long as the carinate, acuminate segments: corolla very large, $6-8 \mathrm{~cm}$. broad; petals obcordate, white, with yellowish veins, reddish in withering, longer than the declined stamens and style: capsules nearly sessile, oblong-conical, conspicuously doubly tuberculate-cristate along the sutures. Oenothera caespitosa. "The typical form only on the upper Missouri in Dakota and Nebraska."-Reported doubtfully from Wyoming and Colorado.

2. Pachylophus glaber A. Nels. Bull. Torr. Bot. Club 31: 242. 1904. Acaulescent and completely glabrous throughout: root thick, semifleshy, caespitosely branched at summit: leaves crowded, nearly linear, 7-12 cm. long, remotely and irregularly toothed, tapering to both ends, acute; slender petiole about half as long as the blade: flowers not equaling the leaves: the calyx-tube slender, $1 \mathrm{dm}$. or less long; calyx-lobes about $2 \mathrm{~cm}$. long: petals somewhat inequilateral, broad, deeply cleft-cordate, about $2 \mathrm{~cm}$. long: fruits small, 12-15 mm. long, strictly basal, not tubercled and but slightly angled. -The region of the Platte, in Wyoming.

3. Pachylophus montanus (Nutt.) A. Nels. 1. c. 26: 128. 1899. Root large, woody with fleshy cortex, crowns one or more, strictly acaulescent: leaves $3-8 \mathrm{~cm}$. long, oblong or oblanceolate, irregularly pinnately toothed, from sparsely hirsute to green and glabrous on the faces, canescently hirsute on the margins and midrib: flowers few: calyx-tube equaling or shorter than the leaves, hirsute-pubescent; segments pinkish, lanceolate, glabrous but for a pubescent line down the middle: petals white (drying pink), broadly obcordate, $2-3 \mathrm{~cm}$. long: capsule sessile, oblong or narrowly ovate, obscurely tubercled on the obtuse sutures, $15-20 \mathrm{~mm}$. long: seeds in two rows, brown or nearly black, irregularly obovate.-On otherwise naked red clay soils; Colorado to Montana.

4. Pachylophus macroglottis Rydb. Bull. Torr. Bot. Club 30: 259. 1903. Acaulescent or nearly so: leaves 8-15 cm. long, tapering into a margined petiole; blades broadly oblanceolate, acute, sinuate-dentate, more or less pubescent, and villous-ciliate on the margins and the veins: calyx-tube long and slender, $14 \mathrm{~cm}$. long, sparingly villous or nearly glabrous, gradually widening into a funnelform throat, more than twice as long as the lanceolate lobes: petals obcordate, about $3.5 \mathrm{~cm}$. long, at first white but turning pink in age: capsule with rather strong, sinuately lobed ridges. The species as here described comprises most of the forms long known in literature and in herbaria as Oenothera caespitosa. (P. hirsutus Rydb. 1. c. 31: 571. 1904.)-Frequent throughout our range.

5. Pachylophus eximius Gray, Pl. Fendl. 45. 1848. More or less caulescent, the stem rather fleshy and leafy: leaves 1-2 dm. long, pinnatifid-sinuate, 
pubescent or villous, especially on the margins and midrib: calyx-tube very long (12-20 cm.), villous as are also its lobes $(5-7 \mathrm{~cm}$. long): corolla large and showy: capsule glabrate or villous, sessile, oblong-cylindrical or lance-ovoid, 3-4 cm. long, sinuately ridged or low-tuberculate on the sutures. ( $P$. caulescens Rydb. 1. c.) - Colorado and Utah to New Mexico.

6. Pachylophus marginatus (Nutt.) Rydb. 1. c. $33 . \quad 1906$. Subcaulescent or stem sometimes 1 or $2 \mathrm{dm}$. high, from hirsute to villous throughout (including the capsule): leaves pinnatifid, toothed, or runcinate: calyx-tube about twice as long as its long lobes: petals broad, 4-5 cm. long: capsule lance-ovate, about $3 \mathrm{~cm}$. long, usually conspicuously pediceled, somewhat tuberculate-cristate on the obtuse angles.-Probably extending into our range from the northwest.

\section{LAVAUXIA Spach.}

Perennial or annual, usually low acaulescent herbs. Leaves mostly basal; blades pinnatifid. Flowers few. Calyx-lobes narrow. Corolla white, pink or pale yellow. Ovary short, 4-angled; ovules few. Capsule stout, the acute angles sometimes winged above. Seeds few.-Oenothera in part.

Capsule beaked; flowers $3-4 \mathrm{~cm}$. broad Capsule obtuse; flowers $8-10 \mathrm{~cm}$. broad

1. L. flava.

2. L. brachycarpa.

1. Lavauxia flava A. Nels. Bull. Torr. Bot. Club 31: 243. 1904. Stemless perennial (?), nearly glabrous: leaves crowded, oblong-lanceolate, deeply and irregularly runcinate-pinnatifid, $10-25 \mathrm{~cm}$. long: flowers shorter than the leaves: calyx-tube 4-7 cm. long, the lobes about $2 \mathrm{~cm}$. long: petals yellow, invariably turning pink with age and in drying, obovate: stamens shorter than the petals: capsule oblong, narrowly wing-angled, $2-3 \mathrm{~cm}$. long, one third as broad: seeds numerous, cuneate-obovate. Oenothera triloba.-Colorado and Wyoming and probably of wider range.

2. Lavauxia brachycarpa (Gray) Brit. Mem. Torr. Club 5: 235. 1904. Perennial, caespitose, acaulescent or subcaulescent, at first canescent throughout, glabrate with age: leaves ovate to oblong-linear, from nearly entire to lyrate-pinnatifid: calyx-tube 7-14 cm. long, the lobes nearly half as long, reflexed: petals golden-yellow, $3-5 \mathrm{~cm}$. long, somewhat broader: capsule ovate, $2.5-3.5 \mathrm{~cm}$. long, wing-angled. [L. Howardii (Jones) A. Nels. Bot. Gaz. 34: 368. 1902.] - Nebraska to Nevada and to Texas and New Mexico.

\section{GAURELLA Small}

Low perennial herbs, with wiry, diffusely branched stems. Leaves alternate; blades nearly entire or distantly toothed. Flowers axillary, sessile. Calyx-tube slightly dilated at the throat, scarcely as long as its lobes. Petals white or pink, spotted or striped with red. Ovary short; style stout, enlarged above. Capsule sessile, with a curved beak, the faces swollen. Seeds angled, delicately striate.-Oenothera in part.

1. Ga urella canescens (Torr.) A. Nels. Stems 1-5 dm. long, canescent with appressed hairs, the branches decumbent or ascending: leaf-blades lanceolate or linear-lanceolate, $8-16 \mathrm{~mm}$. long, repand-denticulate or entire: corolla white or pink, 18-25 mm. wide; petals obovate, entire: capsules canescent, 8-10 $\mathrm{mm}$. long, angled, not wirged: seeds angled, slipper-shaped. Oenothera canescens Torr. in Frem. Rept. 315. 1845. [G. guttulata (Geyer) Small, Fl. 844. 1903.] -Prairies and plains; Colorado, Nebraska, and New Mexico.

\section{GALPINSIA Britton}

Perennial herbs or shrubby plants with much-branched stems. Leaves alternate. Flowers yellow, axillary. Calyx-tube slender, longer than the ovary. Ovary 4-celled, elongated; stigma disk-like, entire. Capsules elon- 
gated, narrowed at the, base, more or less curved. Seeds sometimes tubercu late.-Oenothera in part.

1. Galpinsia lavandulaefolia (T. \& G.) Small, Fl. S. E. U. S. 845.1903. Stems copiously tufted, radially spreading and seldom rising more than $1 \mathrm{dm}$., the internodes very short: leaves very numerous and crowded; blades linear or linear-spatulate, on the lower part of the stem entire or essentially so, finely but closely pale-pubescent: flowers few: calyx-tube elongated, rather gradually dilated, lobes $10-16 \mathrm{~mm}$. long: petals $12-18 \mathrm{~mm}$. long: capsules narrow, 2-2.5 cm. long. Oenothera Hartwegii lavandulaefolia.-Wyoming to New Mexico.

\section{MERIOLIX Raf.}

Biennial or perennial herbs with branched stems, or sometimes shrubby. Leaves alternate, narrow, entire or sharply serrate. Flowers regular, axillary, yellow. Calyx-tube funnelform, shorter than the ovary. Calyx-segments keeled on the back. Petals often blotched at the base. Stigma disk-like, 4-toothed. Capsules linear, 4-angled, sessile. Seeds longitudinally grooved. -Oenothera in part.

1. Meriolix serrulata (Nutt.) Walp. Repert. 2: 79. 1843. Stems often copiously branched at the base, the branches canescent, 1-5 dm. high: leafblades spatulate to linear-oblong or linear, $2-5 \mathrm{~cm}$. long, serrate: calyx-tube $3-4 \mathrm{~mm}$. broad at the mouth, the free portion yellow within: sepals $5-7 \mathrm{~mm}$. long: petals obovate, $8-12 \mathrm{~mm}$. long, crenulate: anthers $2.5-3 \mathrm{~mm}$. long: capsules linear-cylindric, $1.5-2 \mathrm{~cm}$. long, about $1.5 \mathrm{~mm}$. thick.-From Manitoba to New Mexico and Texas.

\section{TARAXIA Nutt.}

Acaulescent plants with pinnatifid or entire leaves and yellow or white axillary flowers. Calyx 4-parted, the tube filiform, longer than the ovary, marcescent or tardily deciduous. Petals 4, deciduous. Stamens 8, erect; anthers oval or oblong and fixed near the base, or linear and fixed near the middle. Style usually adherent, to the calyx-tube; stigma capitate, entire or rarely 4-toothed. Capsule sessile.-Oenothera in part.

Leaves pinnatifid.

Leaves subentire or repand-denticulate:

1. Taraxia breviflora Nutt. in T. \& G. Fl. 1: 506. 1840. Stemless, minutely pubescent or somewhat canescent: leaves lanceolate, interruptedly pinnatifid, somewhat petioled; the segments short, 1-2-toothed or entire: flowers (small) scarcely longer than the petioles: tube of the calyx subulate, rather longer than the linear-lanceolate segments: style shorter than the calyxsegments: capsules ovoid-oblong, deeply 4-grooved, subulate with the persistent calyx-tube.-Utah and Wyoming to Northwest Territory.

2. Taraxia subacaulis (Pursh) Rydb. Mem. N. Y. Bot. Gard. 1: 281. 1900. Glabrous perennial: leaves oblong-lanceolate, tapering into a slender petiole, entire or repand, 5-10 cm. long: tube of the calyx much shorter than the leaves, the segments linear-lanceolate: petals broadly obovate, retuse: capsule 15-20 mm. long, obovoid-oblong, tetragonal, attenuate above into the persistent calyx-tube, the sides nearly flat, ribbed, subreticulated: seeds numerous, minutely pitted.-From Colorado and Wyoming to Oregon.

\section{SPHAEROSTIGMA Nutt.}

Annual or perennial herbs with erect branching or spreading stems, the bark often exfoliating and shiny. Leaves alternate, entire or dentate, petioled or sessile. Flowers solitary in the axils or in terminal spikes, usually yellow, rarely white or rose-color, often with a brownish spot at the base, 
turning green or reddish in age. Stamens 8; anthers versatile, oblong. Style filiform; stigma capitate. Capsule 4-celled, usually linear, 4-angled, often contorted, sessile, dehiscent loculicidally. Seeds in 1 row in each cell.

Flowers yellow, sometimes turning red or green.

Capsules straight

Capsules more or less curved or contorted.

Capsules merely curved, less than $2 \mathrm{~cm}$. long .

Capsules contorted, 2-3 cm. long . .

Flowers white or rose-color.

Foliage glabrous

Foliage tomentose

1. Sphaerostigma andinum (Nutt.) Walp. Repert. 2: 70. 1843. Only 3-7 cm. high, becoming diffusely branched, canescently puberulent throughout: leaves linear-spatulate, 1-2 cm. long, attenuate into slender petioles: spikes mostly dense, many-flowered, erect; flowers $2 \mathrm{~mm}$. long, yellow: capsules 6-12 mm. long, attenuate upward from near the base: seeds linearoblong, $1 \mathrm{~mm}$. long, nearly smooth.-From Western Wyoming to Washington and California.

2. Sphaerostigma Nelsonii Heller, Muhl. 1: 1. 1900. Stems simple or two or more from the base, erect, $3-10 \mathrm{~cm}$. high, minutely puberulent or at length glabrous: leaves linear to oblong or broader, entire, $12-25 \mathrm{~mm}$. long, mostly short-petioled: flowers yellowish, minute, axillary, mostly crowded near the end of the stems: calyx-tube very short, about as long as the narrowly ovate, obtusish segments: petals oval with acutish ends, scarcely exceeding the sepals and equaled by the pistil and the longer stamens, about $1.5 \mathrm{~mm}$. long: capsule nearly straight, spreading or erect, linear, striate at maturity, obscurely puberulent.-Shale cliffs, Green River, Wyoming.

3. Sphaerostigma contortum flexuosum A. Nels. Bot. Gaz. 40: 58. 1905. Small, about $1 \mathrm{dm}$. high; branches few, divaricate, ascending, usually a pair near the base: leaves linear: flowers yellow; calyx-tube obconic: capsule cylindrical, sessile, linear, 2-3 cm. long, variously curved, usually deflexed and again upturned, producing S-shaped forms: seeds smooth. [S. pubens (Wats.) Rydb. as to Fl. Colo.; not S. contortum pubens (Wats.) Small.]-Western Colorado and Wyoming and Utah.

4. Sphaerostigma tortum (Levl.) A. Nels. 1. c. 60. Branched from the base and spreading, becoming at length nearly prostrate: leaves glabrous, mostly basal, oblanceolate and tapering into slender petioles: capsules about $2 \mathrm{~cm}$. long, cinereous, variously contorted. [S. minutiflora (Wats.) Rydb. Bull. Torr. Bot. Club 33: 146. 1906.]-Western Wyoming, through Utah and Wyoming to Idaho.

4a. Sphaerostigma tortum Eastwoodae A. Nels. 1. c. 61. Leafy throughout, the leaves oblong-linear: flowers very small: capsule tapering into a slender beak, spirally coiled at base.-Glenwood, Colorado.

5. Sphaerostigma utahense Small, Bull. Torr. Bot. Club 23: 191. 1896. Whitened with a tomentose pubescence, branching from the base upward, $15 \mathrm{~cm}$. or more high: leaves ovate, obovate, or oblanceolate, $2-4 \mathrm{~cm}$. long, generally tapering to a short petiole: flowers crowded in terminal somewhat corymbose racemes, white: calyx-tube longer than the lanceolate lobes: petals obovate, $5 \mathrm{~mm}$. long, longer than the stamens but surpassed by the pistil: capsule linear, less than $2 \mathrm{~cm}$. long, more or less contorted.-Utah and probably in western Colorado.

\section{CHYLISMA Nutt.}

Caulescent annuals with pinnate or simple leaves and yellow flowers in terminal racemes. Calyx-tube funnelform or obconic, the limb 4-parted. Petals 4, entire. Stamens 8, unequal; anthers oblong, attached near the middle. Stigma capitate, entire. Capsule linear, subcylindrical or subclavate, obtuse, membranaceous, not sessile.-Oenothera in part.

1. Chylisma scapoidea (Nutt.) Small, Bull. Torr. Bot. Club 23: 193. 
1896. Puberulent or nearly glabrous: leaves low on the stem, usually lyratelypinnatifid: calyx-tips not free: capsule 10-25 mm. long.-Wyoming and Colorado and far northwestward.

\section{GAURA L.}

Annual, biennial, or perennial herbs, with alternate narrow leaves, and white, pink, or red flowers in terminal spikes or racemes. Calyx-tube narrow, prolonged beyond the ovary, the limb 4-lobed. Petals clawed, unequal. Stamens usually 8 , declined, each with a small scale at the base. Ovary 4-celled; united styles declined; stigma 4-lobed, surrounded by a cup-like border; ovules usually 4 , pendulous. Fruit nut-like, ribbed or angled, indehiscent or nearly so, 1-4-seeded.

Anthers oval; fruits fusiform, 8-ribbed ${ }_{\text {Anthers linear or nearly so; fruit strongly 4-angled, at least above. }}$

Plants tall, erect, herbaceous.

Fruit sessile

Fruit with a slender stipe-like base

Plants low, with assurgent stems from a subligneous base : $\quad$. 4. G. coccinea.

1. Gaura parviflora Dougl. Hook. Fl. Bor. Am. 1: 208. 1832. Perennial herbs or shrubby plants with much-branched stems: leaves alternate: flowers yellow, axillary: calyx-tube slender, longer than the ovary: ovary 4-celled, elongated; stigma disk-like, entire: capsules elongated, narrowed at the base, more or less curved; seeds sometimes tuberculate.-In dry soil; rather infrequent; from the Missouri to Oregon.

2. Gaura neo-mexicana Wooton, Bull. Torr. Bot. Club 25: 307. 1898. Stems virgately branched above: leaves lanceolate, subsessile, entire or sinuate: pubescence subvillous and viscid glandular above: calyx-segments oblong-spatulate, barely longer than the tube: petals obovate, $1 \mathrm{~cm}$. long, rose-pink: style villous below the middle: fruit obovate-pyramidal, sessile.New Mexico and also reported from Colorado.

3. Gaura coloradensis Rydb. Bull. Torr. Bot. Club 31: 572. 1904. Herbaceous biennial with fusiform root: stem 5-7 dm. high, finely strigose: leafblades narrowly oblanceolate, $5-10 \mathrm{~cm}$. long, callous-denticulate, finely strigose: inflorescence slender and rather lax, 1.5-2 dm. long: calyx-tube about $2 \mathrm{~cm}$. long, finely strigose; segments about $1 \mathrm{~cm}$. long, linear-lanceolate, reflexed: petals about $8 \mathrm{~mm}$. long, spatulate, pink, short-clawed: fruit 8-10 mm. long, fusiform, 4-angled, tapering below into a short and rather slender stipelike base.-Northern Colorado.

4. Gaura coccinea Pursh, Fl. Am. Sept. 733. 1814. Erect or ascending, much branched, canescent or glabrate, 1.5-4 dm. high: leaves oblong, lanceolate, or linear-oblong, denticulate, repand, or entire, acute or obtuse at the apex, 1.5-3.5 cm. long: flowers red, turning scarlet: fruit terete below, 4-sided and narrowed above, canescent, 6-8 mm. long. (G. glabra Lehm., a nearly glabrous form; $G$. parvifolia Torr., glabrate and with numerous small linear leaves; G. marginata Lehm., puberulent, and the leaves and calyx-lobes rather narrower than in the typical species.)-Manitoba and Minnesota to Arizona and Texas.

\section{CIRCAEA L.}

Low, slender, perennial herbs, with opposite petioled leaves and small white flowers in racemes. Calyx-tube slightly prolonged beyond the ovary, its limb 2-parted. Petals 2, notched. Stamens 2, alternate with the petals. Ovary 1-2-celled; ovules usually 1 in each cavity. Fruit obovoid, indehiscent, bristly with hooked hairs.

Leaves undulate-denticulate; raceme bractless . Leaves sharply dentate; bracts present

1. G. pacifica. 2. C. alpina.

1. Circaea pacifica Ach. \& Mag. Bot. Zeit. 29: 392. 1871. Mostly glabrous; 
stems usually simple, 1.5-3 dm. high, from a small tuber: leaves ovate, rounded or cordate at base, acute or acuminate, repandly denticulate, 3-7 cm. long; the slender petiole about as long: racemes without bracts: calyx white, with a very short tube: fruit rather loosely covered with soft hairs, 1-celled, 1-seeded.- In close damp woods; Wyoming to California and Washington.

2. Circaea alpina L. Sp. Pl. 9. 1753. Glabrous, stems weak, 1-2 dm. high, often branching above: leaves cordate, shining, rather coarsely toothed, 2-4 cm. long, on slender petioles nearly as long as the blade: pedicels subtended by minute setaceous bracts; flowers reddish, especially before opening: fruit pubescent but scarcely hispid.-Colorado to Northeastern America.

\section{HALORAGIDACEAE Kl. \& Garcke. WATER Milfoil FAMILY}

Perennial aquatic herbs, with alternate or verticillate leaves, which if immersed are usually dissected. Flowers inconspicuous, sessile in the axils of the leaves or bracts, perfect, monoecious, or dioecious. Calyx-tube entire or 4-lobed. Corolla small or wanting. Stamens 1-8. Ovary 1-4-celled, adnate to the calyx-tube. Fruit indehiscent, nut-like, of 2-4 one-seeded carpels.

Leaves entire, in whorls of 6-12

Leaves dissected, in whorls of 3-5

\section{Hippuris L. Mare's-tail. Bottle Brush}

Smooth erect herbs from running rootstocks, growing in shallow ponds and on muddy banks. Leaves simple, entire, linear, in whorls of 8-12. Flowers solitary, perfect. Calyx-tube entire. Petals wanting. Stamen one. Ovary 1-celled, 1-seeded, indehiscent and drupe-like.

1. Hippuris vulgaris L. Sp. Pl. 4. 1753. Glabrous, slender, $2-5 \mathrm{dm}$. high: leaves $1-3 \mathrm{~cm}$. long, or the submerged ones often longer: the stamen with a short, thick filament: style filiform, stigmatic throughout.-Across the northern part of the continent and south in the mountains to New Mexico.

\section{MYRIOPHYLLUM L. WATER MILFOIL}

Smooth, leafy herbs. Leaves whorled in threes or fours. Upper flowers usually staminate, the lower pistillate, and the intermediate ones perfect. Limb of the calyx 4-lobed in the sterile flowers, wanting or minutely toothed in the others. Petals 2-4, minute or wanting in the pistillate flowers. Stamens 8 (in ours). Ovary 4-celled; stigmas recurved and plumose.

Floral leaves (bracts) shorter than the flowers.

1. M. spicatum.

Floral leaves (bracts) longer than the flowers:

- 2. M. verticillatum.

1. Myriophyllum spicatum L. Sp. Pl. 992. 1753. Leaves in whorls of 4-5, all pinnately parted into capillary divisions, except the floral ones or bracts; these ovate, entive or toothed and mostly shorter than the flowers, which thus form an interrupted spike: petals deciduous: stamens 8: carpels rounded on the back, with a deep groove between them.-Common in our range, and across the continent; also in the Old World.

2. Myriophyllum verticillatum L. 1. c. Very similar but the whorls mostly of 3-4 leaves; the floral also pinnately parted into linear segments and very many times longer than the flowers: petals of the staminate flowers 4, purplish: otherwise much like the preceding.-Rare in our range; across the continent; also in Europe and Asia. 


\section{ARALIACEAE Vent. Ginseng Family}

Herbs, shrubs, or trees, with alternate or verticillate rarely opposite leaves, and perfect or polygamous, variously clustered flowers. Calyx-tube adnate to the ovary, its limb truncate or toothed. Petals usually 5 , valvate or slightly imbricate, inserted on the margin of the calyx. Stamens as many as the petals and alternate with them, rarely none, inserted on the epigynous disk; filaments filiform or short; anthers introrse. Ovary inferior, 1-several-celled; styles as many; ovules 1 in each cell. Fruit a berry or drupe. Seeds flattened or somewhat 3 -angled.

Stem very prickly; flowers in racemosely disposed umbels . . . . 1. Fatsia. Stem not prickly; flowers in one or more simple umbels . : $\quad$ : $\quad$ : $\quad$ : 2. Aralia.

\section{FATSIA. Decaisne \& Planch.}

Densely prickly shrubs with large palmately lobed leaves and greenishwhite flowers in dense paniculate umbels. Calyx-teeth obsolete. Petals 5, valvate in the bud. Stamens 5, alternate with the petals; filaments filiform; anthers ovate to oblong. Ovary 2-3-celled; styles 2, filiform; stigma terminal. Fruit laterally compressed, drupaceous, the endocarp indurated.

1. Fatsia horrida (Sm.) B. \& H. Gen. 1: 939. 1867. Stem stout and woody, 1-3 m. long, creeping at base, leafy at the summit, and very prickly throughout, making the forests in places almost impassable.-Cascade and Coast Ranges, from the Columbia northward, and extending into the Bitter-Root Mountains.

\section{ARAlia L. Wild Sarsaparilla}

Perennial herbs or shrubs. Leaves alternate, digitate or compound, with serrate leaflets. Umbels mostly simple, solitary, racemed or panicled. Calyx 5-toothed or entire. Petals 5, ovate. Stamens 5. Disk depressed or rarely conical. Ovary 2-5-celled; styles free or connate at base, at length divaricate. Fruit laterally compressed, becoming 3-5-angled.

1. Aralia nudicaulis L. Sp. Pl. 274. 1753. Stem somewhat woody, short, scarcely rising out of the ground, bearing a single long-stalked compound leaf and a shorter naked scape with 2-7 umbels: leaflets oblong-ovate or oval, serrate, 5 on each of the 3 divisions. - In the Rocky Mountains, and from Canada to the southern States.

\section{UMBELLIFERAE * B. Juss. Parsnip Family}

Herbs, commonly with hollow stems. Leaves mainly alternate, mostly compound, often decompound, the petiole expanded or sheathing at base. Flowers small, mostly in umbels (rarely in heads); umbels usually compound, forming umbellets; the bracts under the general umbel form an involucre, under an umbellet an involucel. Calyx-tube adnate to the 2-celled ovary, its margin truncate or 5-toothed. Petals 5, inserted on the margin of the calyx. Stamens 5, epigynous, on slender filaments with versatile anthers. Ovary inferior; the two filiform styles often borne on a depressed or a conical stylopodium; ovules 1 in each cavity, pendulous. Fruit either flattened laterally (at right angles to the commissure), or dorsally (parallel to the commissure), or nearly terete (not flattened). Carpels after parting from

* Adapted from Coulter and Rose's Monograph of the Umbelliferae, Contrib, Nat, Herb. 7: 1900, and Supplement, 1. c. 12: 1909. 
each other supported on the summit of a slender axis (the carpophore), each with 5 primary ribs in their pericarps (rarely ribless), and in some genera with 4 additional secondary ones, the ribs or some of them often winged. Pericarp membranous or corky-thickened, usually containing oil-tubes between the ribs or under the ribs, and on the commissural side; oil-tubes sometimes irregularly scattered, sometimes none.

Leaves palmately divided; the fruit covered with hooked bristles

Leaves various; fruit not bristly (except in No. 2).

Leaves simple and perfoliate

Leaves, or some of them, not simple; oil-tubes present.

Fruit more or less bristly on the margins

Fruit smooth.

Fruit strongly flattened dorsally.

Oil-tubes solitary in the intervals.

Stylopodium conical.

Plants with small glabrous pinnate or ternate leaves or some of the leaves simple.

Plants stout, with large rough ternately compound leaves

Stylopodium flat or wanting.

Plants tall and often branching. Flowers white Flowers yellow: $:$

Plants acaulescent or nearly so. Calyx-teeth and stylopodium wanting Calyx-teeth and stylopodium evident

Oil-tubes more than one in the intervals.

Plants caulescent and branching.

Leaves ternately or pinnately compound

Leaves decompound

Plants acaulescent or nearly so.

Lateral wings thin.

Calyx-teeth and stylopodium wanting

Calyx-teeth and stylopodium evident

Lateral wings thick.

Dorsal ribs very prominent or slightly winged

Dorsal ribs filiform.

Leaves small, pinnate or lobed

Leaves large, decompound

Fruit not strongly flattened dorsally, usually more or less

flattened laterally.

Oil-tubes solitary in the intervals.

Flowers white; stylopodium conical.

Leaflets linear or nearly so; involucre present

Leaflets broader; involucre wanting

Flowers yellow; stylopodium flat or wanting.

Ribs equal, broad and corky.

Low caespitose plants; alpine or subalpine .

Taller (2-4 dm.); middle elevations .

Ribs winged or filiform.

Wings conspicuous

Ribs filiform.

Tall and branching, with broad leaflets .

Acaulescent and caespitose

1. Sanicula.

5. Bupleurum.

2. Washingtonia.

\section{Oxypolis.}

28. Heracleum.

17. Angelica.

29. Pastinaca.

26. Cogswellia.

27. Cynomarathrum.

17. Angelica.

16. Conioselinum.

26. Cogswellia.

27. Cynomarathrum.

23. Pseudocymopterus.

22. Cymopterus.

25. Leptotaenia. 


\section{SANICULA L.}

Smooth perennials, with nearly naked stems. Leaves palmately divided; the lobes more or less pinnatifid or incised. Umbels involucrate with sessile, leafy, usually toothed bracts; the bractlets of the involucels small and entire. Calyx-teeth foliaceous, persistent. Fruit subglobose or obovoid; ribs obsolete; oil-tubes numerous. Seed hemispherical.

1. Sanicula marylandica L. Sp. Pl. 1: 235. 1753. Stem 3-5 dm. high: leaves all 5-7-parted: sterile flowers numerous, on slender pedicels: styles elongated and conspicuous, recurved: fruit subglobose, covered with hooked bristles or tubercles.- In the eastern part of our range and extending to the Atlantic States.

\section{WASHINGTONIA Raf.}

Glabrous to hirsute perennials, from thick aromatic roots, 3-9 dm. high, with ternately decompound leaves, broad-ovate to lanceolate variously toothed leaflets, involucre and involucels few-leaved or wanting, and white or purple flowers in few-rayed and few-fruited umbels. Calyx-teeth obsolete. Fruit linear-oblong, more or less attenuate at base, obtuse, acute, or beaked at apex, glabrous or bristly on ribs. Carpel slightly flattened dorsally or not at all, often tapering into a long caudate attenuation at base.-Osmorhiza.

Fruit with bristly ribs and carpel with long caudate attenuation.

Involucel present; style evident

Involucel wanting.

Fruit obtuse at apex

Fruit with a sharp beak

Fruit glabrous, the carpel without caudate attenuation :

1. W. longistylis.

2. W. obtusa.

3. W. divaricata.

4. W. occidentalis.

1. Washingtonia longistylis (Torr.) Brit. Ill. Fl. 2: 530. 1897. Stout, from sweet aromatic roots, glabrous or glabrate (sometimes quite pubescent when young): leaves 2-3-ternate; leaflets acuminate, much cleft and toothed: umbel 4-6-rayed, with involucre and involucels of few bracts; rays stout and spreading, 3-5 cm. long: fruit (not including the attenuation) $12 \mathrm{~mm}$. long, bristly on the ribs; stylopodium slender, conical, terminated by a style $2 \mathrm{~mm}$. long.- In the eastern part of our range to the Atlantic States.

2. Washingtonia obtusa C. \& R. Contr. Nat. Herb. 7: 64. 1900. Slender, $3-5 \mathrm{dm}$. high, nearly glabrous: leaflets ovate to lanceolate, acute or acuminate, sharply toothed: umbel with very wide-spreading rays (lateral ones even deflexed); the 2-4 pedicels 12-25 mm. long: fruit about $16 \mathrm{~mm}$. long, obtuse (often slightly pointed just at the tip), somewhat hispid-pubescent; stylopodium very short. Osmorhiza nuda.-Throughout the Rocky Mountains and far westward.

3. Washingtonia divaricata Brit. 1. c. 531. Resembles the preceding, but 3-7 dm. high, nearly glabrous: leaflets thin and larger, becoming $6 \mathrm{~cm}$. long, lanceolate to ovate, acute to acuminate, coarsely toothed and usually incised: umbels with 2-9 spreading rays, and pedicels $10-18 \mathrm{~mm}$. long, usually about as long as the fruit, sometimes longer or shorter: fruit $16-20 \mathrm{~mm}$. long, with a distinct beak $2 \mathrm{~mm}$. long; stylopodium and style $1 \mathrm{~mm}$. long, the former not so broad as high and longer than the very short style.-Wyoming and Utah to Alaska.

4. Washingtonia occidentalis (Nutt.) C. \& R. 1. c. 67 . Rather stout, puberulent: leaves 2- or 3-ternate; leaflets lanceolate-oblong, 3.5-10 cm. long, acute, coarsely serrate, rarely incised: umbel 5-12-rayed, naked or with 1 or 2 involucral bracts; fruiting rays $2.5-12.5 \mathrm{~cm}$. long, usually erect and forming a somewhat compact cluster of fruits; pedicels 2-8 $\mathrm{mm}$. long: fruit 12-16 $\mathrm{mm}$. long, obtuse at base, glabrous, distinctly beaked, and with prominent acute ribs; stylopodium and style 1-2 mm. long, the former mostly conical: seed face strongly concave.-Throughout our range, westward and northward. 


\section{OROGENIA Wats.}

Dwarf, glabrous, nearly acaulescent plants, from tuberous or fusiform roots, with ternate leaves and linear segments, no involucre, involucels of few linear bractlets, and white flowers in subcompound umbels with very unequal rays. Calyx-teeth minute. Fruit oblong, very slightly flattened laterally, glabrous. Carpel much flattened dorsally, with filiform dorsal and intermediate ribs; laterals excessively corky-thickened, involute (that is, extended toward the other carpel, leaving between the commissural faces a cavity, which is divided longitudinally by a thick corky projection from the middle of each face).

1. Orogenia linearifolia Wats. Bot. King's Rep. 120. 1871. Stem (or scape) slender, rising 2-12 cm. above ground from a deep-seated round tuber: leaves 2 or 3 , once. or twice ternate upon slender petioles; leaflets entire, 2.5-5 cm. long, 2-6 mm. wide, obtuse: umbels 2-10-rayed, with nearly sessile flowers: fruit $3-4 \mathrm{~mm}$. long, lateral ribs and commissural projection rather strongly developed.- Southwestern Colorado and to the far northwest.

\section{MUSINEON Raf.}

Glabrous or scabrous, dwarf, resiniferous, dry-ground perennials, from thick elongated roots, acaulescent or dichotomously branching at base, with pinnately decompound leaves, no involucre, involucels of a few narrow bractlets, and yellow flowers. Calyx-teeth prominent (in ours). Fruit ovate or ovateoblong, flattened laterally. Carpel flattened dorsally, with equal filiform ribs and thin pericarp with no distinct strengthening cells; carpophore entire; stylopodium depressed; oil-tubes usually 3 in the intervals, very unequal in size (middle one largest), 2-4 on the commissural side. Seed face broadly concave.-Musenium.

\section{Stems usually dichotomously branching from the base; leaf-segments} toothed.

Fruit smooth; stems glabrous.

Peduncles slender, scarcely longer than the leaves. Peduncles stout, 2-3 times as long as the leaves

Fruit scabrous.

Stem scabrous

Acaulescent, the simple peduncles exceeding the leaves; flowers yel-

low or sometimes white.

1. M. divaricatum.

2. M. pedunculatum.

3. M. Hookeri.

4. M. vaginatum.

5. M. tenuifolium.

1. Musineon divaricatum (Pursh) C. \& R. Bot. Gaz. 20: 259. 1895. Decumbent, glabrous: leaves bipinnatifid, with winged rachis; segments $3-5$ toothed: peduncles 5-12.5 cm. long; umbel 10-25-rayed; rays 6-18 mm. long; pedicels short: fruit smooth, about $4 \mathrm{~mm}$. long; oil-tubes 3 in the intervals, with accessory ones beneath the ribs, 4 on the commissural side: seed terete, with rather deeply concave face.-From Colorado and Nebraska to Alberta and Assiniboia.

2. Musineon pedunculatum A. Nels. Bull. Torr. Bot. Club 25: 225. 1901. Root large, fleshy: stems nearly acaulescent: leaves thick, usually ternate; the segments pinnate or bipinnate, ovate in outline, the alternate segments broad and short, variously cut and toothed: peduncles prostrate, stout, $12-20 \mathrm{~cm}$. long, 2-3 times as long as the leaves; umbel 12-20-rayed; rays $15-25 \mathrm{~mm}$. long; pedicels 1-4 mm. long: fruit smooth; oil-tubes 3 in the intervals and 4 on the commissural side: seed slightly flattened dorsally, with plane face.Naked clay soils; central Wyoming.

3. Musineon Hookeri (T. \& G.) Nutt. T. \& G. Fl. 1: 642. 1840. Resembling $M$. divaricatum, but more or less scabrous throughout: fruit scabrous, smaller, 2-3 mm. long, with more prominent ribs; oil-tubes mostly solitary in the intervals, often with smaller accessory ones i, the intervals or beneath the ribs, 2 on the commissural side: seed sulcate beneath the oil-tubes, with more shallow concavity. (Includes both $M$. trachyspermum and $M$. anjustrfolium Nutt. T. \& G. Fl. 1: 642. 1840.)-From Colorado to Canada. 
4. Musineon vaginatum Rydb. Mem. N. Y. Bot. Gard. 1: 288. 1900. Stems becoming slender, glabrous, more or less purple tinged: basal leaves twice or thrice ternate; stem leaves two or three: involucre none; involucels of linear bractlets: petals white, sometimes tinged with yellow: fruit slightly scabrous.-Montana.

5. Musineon tenuifolium Nutt. 1. c. Acaulescent, somewhat caespitose, glaucous: leaves tripinnatifid, with narrowly linear segments: peduncles much longer than the leaves, 1-2 dm. long; umbel 12-20-rayed: fruit nearly glabrous, 3-4 mm. long; oil-tubes large, 2-3 in the intervals; flowers apparently sometimes white.-Eastern Wyoming and adjacent Nebraska and Dakota.

\section{BUPLEURUM L.}

Annuals or perennials, with simple, entire, clasping or perfoliate stem leaves, with or without an involucre, and involucels of 5 or more ovate bractlets. Calyx-teeth obsolete. Fruit oblong, flattened laterally, with rather broad commissure. Carpel with equal very slender or prominent ribs; stylopodium prominent and flat; oil-tubes wanting or continuous about the seed cavity.

Flowers yellow

Flowers purple.

1. Bupleurum americanum C. \& R. Rev. N. Am. Umbell. 115.1888. Basal leaves linear-lanceolate; cauline ones very variable, oblong to linear, more or less clasping: rays unequal, $1.5-5 \mathrm{~cm}$. long; pedicels short. B. ranunculoides.-Wyoming to Alaska.

2. Bupleurum purpureum Blankinship, Mont. Agric. Coll. Sci. Studies 1: 89. 1905. Differs from $B$. americanum in its low subacaulescent habit, shorter leaves, wider obtuse bractlets of the involucels, smaller dark purple flowers, shorter fruit with fewer oil-tubes in the intervals, and in its alpine situation.-High mountains of Montana.

\section{ZIZIA Koch}

Smooth perennials of open prairies and upland meadows, with simple to ternately compound leaves, no involucre, involucels of small bractlets, yellow flowers, and the central fruit of each umbellet sessile. Calyx-teeth prominent. Fruit flattened laterally, ovate to oblong, glabrous. Carpel with filiform ribs; stylopodium wanting; styles long; oil-tubes large and solitary in the broad intervals, 2 on the commissural side, and a small one in each rib. Seed terete, sulcate beneath the oil-tubes.

1. Zizia cordata (Walt.) Koch, DC. Prodr. 4: 100. 1830. Basal leaves mostly long-petioled, cordate or even rounder, crenately toothed, very rarely lobed or divided; stem leaves simply ternate or quinate; the leaflets ovate to lanceolate, serrate, incised, or even parted: fruit ovate, $3 \mathrm{~mm}$. long. Thaspium trifoliatum in part.-Throughout our range and across the continent.

\section{HARBOURIA C. \& R.}

Glabrous perennials, with 1-3 leaves which are ternately decompound and with narrowly linear or filiform segments, involucre and involucels of few subulate bracts, and long-peduncled umbels (mostly in pairs) of yellow flowers. Calyx-teeth evident. Fruit flattened laterally, ovate, with narrow commissure, tuberculate-roughened. Carpel with equal, obtuse, broad, very prominent ribs, a small group of strengthening cells in each; the narrow commissure prominently corky-thickened, partly divided by a groove; stylopodium depressed or wanting; oil-tubes large, solitary in the intervals, 2 on the commissural side. Seed section nearly round.

1. Harbouria trachypleura (Gray) C. \& R. Rev. N. A. Umbell. 125. 1888. 
Plant 3-6 dm. high: leaf-segments mucronulate: umbels (mostly 2 longpeduncled ones) 15-25-rayed; rays $1-2.5 \mathrm{~cm}$. long; pedicels $4-6 \mathrm{~mm}$. long: fruit $4 \mathrm{~mm}$. long. Cicuta (?) trachypleura.-Throughout our range.

\section{CICUTA L.}

Smooth, poisonous, marsh perennials, with pinnately compound leaves and serrate leaflets, involucre of few bracts or none, involucels of several slender bractlets, and white flowers. Calyx-teeth rather prominent. Fruit flattened laterally, oblong to orbicular, glabrous. Carpel with strong flattish corky ribs, the laterals largest (at least in section), without strengthening cells; stylopodium low, sometimes low-conical; oil-tubes solitary in the intervals, 2 on the commissural side. Seed nearly terete or somewhat dorsally flattened, with face plane to slightly concave.

1. Cicuta occidentalis Greene, Pitt. 2: 7. 1889. Stout, 9-18 dm. high: rootstock short, giving rise to slender roots above, and a fascicle of thick and elongated ones below: leaves twice pinnate; leaflets linear-lanceolate to lanceolate, 5-8 cm. long, sharply serrate and conspicuously reticulate beneath: fruit oblong, $3 \mathrm{~mm}$. long, constricted at the commissure, the ribs approximately equal in surface display (laterals largest in section), the intervals broad; oil-tubes large. C. maculata.-Throughout our range.

\section{CARUM L.}

Smooth, erect, slender herbs, with tuberous or fusiform-fascicled roots, pinnate leaves with few linear leaflets, involucels of few to many bracts, and white flowers. Calyx-teeth prominent for the size of the fruit. Fruit flattened laterally, orbicular to oblong, glabrous. Carpel with filiform or inconspicuous ribs, with or without strengthening cells; stylopodium conical; oiltubes large and solitary in the intervals, $2-6$ on the commissural side. Seed dorsally flattened, more or less sulcate beneath the oil-tubes; the face plane or slightly concave.

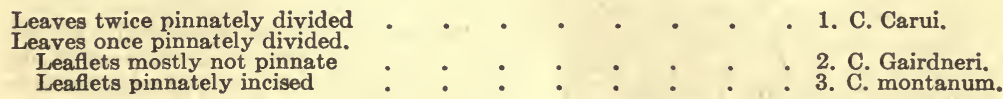

1. Carum Carui L. Sp. Pl. 1: 263. 1753. Leaves pinnately compound, with very narrow and often filiform entire or toothed divisions.-The common garden caraway, naturalized from Europe.

2. Carum Gairdneri (H. \& A.) Gray, Proc. Am. Acad. 7: 344. 1867. Stem 3-12 dm. high, from fascicled, tuberous or fusiform roots: leaves few, usually simply pinnate, with 3-7 linear leaflets $5-15 \mathrm{~cm}$. long (the lower rarely pinnate); upper leaves usually simple: umbels 6-15-rayed, with involucre of several bracts or none, and involucels of linear-acuminate bractlets; rays 2.5-4 cm. long: fruit broadly ovate or nearly orbicular, small, 1-2 mm. long, with small ovate calyx-teeth, low conical stylopodium, and long slender styles: seed terete.-From the Rocky Mountains to the Pacific States.

3. Carum montanum Blankinship, Mont. Agric. Coll. Sci. 1: 89. 1905. Differs from $C$. Gairdneri in its larger size, larger leaves, pinnately incised leaflets, large fruit, and longer styles.-Montana.

\section{ALETES C. \& R.}

Acaulescent glabrous mountain perennials, with pinnate leaves, broad sharply toothed or cut rather distant leaflets, mostly no involucre, involucels of linear to lanceolate bractlets, and yellow flowers. Calyx-teeth prominent. Fruit flattened laterally, oblong, glabrous. Carpel with equal and prominent ribs; stylopodium wanting; oil-tubes large and solitary in the broad intervals, 
2 on the commissural side and a small one in each rib. Seed sulcate beneath the oil-tubes, with face plane or slightly concave.

Peduncles longer than the leaves

Leaflets rhombic, deeply cut into lanceolate lobes.

Leaflets broadly obovate, more or less cleft

Peduncles much shorter than the leaves.

1. A. acaulis.

2. A. obovata.

1. Aletes acaulis (Torr.) C. \& R. Contrib. U. S. Nat. Herb. 7: 106. 1900. Caespitose, with peduncles $10-30 \mathrm{~cm}$. high, often much longer than the leaves: leaflets rhombic, deeply cut into lanceolate acuminate lobes: umbels 8-15rayed; rays stiff, 19-20 $\mathrm{mm}$. long: fruit almost sessile, narrowly oblong, $4 \mathrm{~mm}$. long. Carum Hallii.--Rocky foothills of Colorado and New Mexico.

2. Aletes obovata Rydb. Bull. Torr. Bot. Club 31: 573. 1904. Caespitose, with peduncles 10-30 cm. high: leaflets broadly obovate, 1-2 cm. long, more or less cleft, with short ovate teeth, strongly veined beneath: fruiting rays $2-2.5 \mathrm{~cm}$. long; pedicels very short or none: fruit 5-6 mm. long.-Colorado.

3. Aletes humilis C. \& R. 1. c. 107 . Caespitose, with peduncles much shorter than the leaves, $2-5 \mathrm{~cm}$. long: petioles slender, longer than the blade; leaflets generally 5 , entire to few-toothed, slightly scabrous on the margin, linear to obovate: rays $4-6$, rather weak and spreading, $2.5-3 \mathrm{~cm}$. long; pedicels very short; involucels of linear, distinct bractlets: fruit ovate, $3 \mathrm{~mm}$. long.-Type locality only; Dale Creek, Colorado, near the Wyoming line.

\section{SIUM L.}

Smooth perennials growing in water or wet places, with pinnate leaves and serrate or pinnatifid leaflets, involucre and involucels of numerous narrow bracts, and white flowers. Calyx-teeth minute. Fruit flattened laterally, ovate to oblong, glabrous. Carpel with prominent, corky, nearly equal ribs, each with a prominent group of strengthening cells at tip; stylopodium depressed; styles short; oil-tubes $1-3$ in the intervals (never solitary in all the intervals), 2-6 on the commissural side. Seed subangular, with plane face.

1. Sium cicutaefolium Gmelin, Syst. 2: 482. 1791. Stout, 6-8 dm. high; leaflets 3-8 pairs, linear to lanceolate, sharply serrate and mostly acuminate, 5-13 cm. long (lower leaves sometimes submersed and finely dissected): umbel many-rayed; rays $2.5-4 \mathrm{~cm}$. long; pedicels $2-6 \mathrm{~mm}$. long: fruit $3 \mathrm{~mm}$. long, with prominent ribs; oil-tubes 2-6 on the commissural side.-Throughout our range and across the northern half of the United States.

\section{BERULA Hoffm.}

Smooth aquatic perennial, with simply pinnate leaves and variously cut leaflets, usually conspicuous involucre and involucels of narrow bractlets, and white flowers. Calyx-teeth minute. Fruit flattened laterally, nearly round, emarginate at base, glabrous. Carpel nearly globose, with very slender, inconspicuous ribs, thick corky pericarp, and no strengthening cells; stylopodium conical; oil-tubes numerous and contiguous, closely surrounding the seed cavity. Seed terete.

1. Berula erecta (Huds.) Coville, Contrib. Nat. Herb. 4: 115. 1893. Erect, 1.5-9 dm. high or even smaller: leaflets 5-9 pairs, linear to oblong or ovate, serrate to cut-toothed, often laciniately lobed, sometimes crenate, $1-7.5 \mathrm{~cm}$. long: umbel many-rayed; rays $5 \mathrm{~cm}$. long or less; pedicels 4-6 mm. long: fruit scarcely $2 \mathrm{~mm}$. long.-Very widely distributed.

\section{LIGUSTICUM L.}

Smooth perennials from large aromatic roots, with usually large, ternately or pinnately compound leaves mostly no involucre, usually involucels of narrow bractlets, and white or pinkish flowers in large, many-rayed umbels. 
Calyx-teeth small or obsolete. Fruit oblong or ovate, flattened laterally if at all, glabrous. Carpel with all the ribs prominent and equal (intervals broad), acute or sometimes slightly winged, a group of strengthening cells beneath each rib; stylopodium conical; oil-tubes 2-6 (mostly $3-5$ ) in the intervals, 6-10 on the commissural side. Seed with round or angled back; face from plane to deeply concave, with or without a central longitudinal ridge.

Stems more or less leafy; fruit more or less winged.

Fruit 4-5 mm. long.

Foliage dark green; oil-tubes mostly 3 in the intervals and 6-8 on the commissure

Foliage light green; oil-tubes mostly $5^{\circ}$ in the intervals and about 10 on the commissure .

Fruit 6-7 mm. long.

Ultimate leaf-segments narrowly linear

Ultimate leaf-segments not linear
Stems naked or nearly so, giving an acaulescent appearance

1. L. simulans.

2. L. affine.

3. L. filicinum.

4. L. Porteri.

5. L. tenuifolium.

1. Ligusticum simulans C. \& R. Contrib. Nat. Herb. 7: 135. 1900. Glabrous except some slight roughness in the inflorescence; rather stout, 6-9 dm. high: leaves nearly all basal, varying greatly in size, ternate, then once or twice pinnate; segments narrowly oblong to ovate, variously toothed or lobed: -umbel many-rayed, with involucels of linear bractlets; rays (fruiting) 2.5-7.5 cm. long; pedicels 6-10 mm. long; flowers white: fruit oblong, 4-5 mm. long, the ribs with narrow and very thin wings; stylopodium low-conical.- Southern Wyoming.

2. Ligusticum affine A. Nels. Bull. Torr. Bot. Club 25: 223. 1901. Similar but larger, pale green: root leaves large, biternate and then once or twice pinnate; the ultimate segments linear-oblong to lanceolate, entire or fewtoothed; stem leaves 1-3, much smaller: peduncles long, much surpassing the foliage; involucels of few linear-subulate, early deciduous bractlets: fruit elliptic, about $5 \mathrm{~mm}$. long, the ribs distinctly winged; oil-tubes usually 5 in the intervals, and 10 on the commissural side; stylopodium flattened, hemispherical.-In the mountains; southern Wyoming and adjacent Colorado.

3. Ligusticum filicinum Wats. Proc. Am. Acad. 11: 140. 1876. Stem 4-9 dm. high, more or less leafy, with glabrous inflorescence: lower leaves often very large, once or twice ternate, then bipinnate; the segments or their pinnatifid divisions narrowly linear: umbel of numerous rays, with involucels of one or few small linear bractlets; rays (fruiting) $2.5-5 \mathrm{~cm}$. long; pedicels 6-10 $\mathrm{mm}$. long: fruit narrowly oblong, 6-7 $\mathrm{mm}$. long, with somewhat prominent conical stylopodia, and prominent somewhat winged ribs; oil-tubes $3-5$ in the intervals, $6-8$ on the commissural side.-Mountains of Utah and extending into Wyoming and Montana.

4. Ligusticum Porteri C. \& R. Rev. N. Am. Umbel. 86. 1888. Rather stout, 6-9 dm. high, leafy, with glabrous or puberulent inflorescence: leaves large, biternate then bipinnate; the numerous, rather crowded segments lanceolate to lanceolate-ovate, laciniately pinnatifid, toothed to entire, varying greatly in the degree and character of cutting, the lobes ranging from very narrow and sharp to broad and obtuse: umbel of numerous rays, mostly with neither involucre nor involucels; rays (fruiting) $2.5-5 \mathrm{~cm}$. long; pedicels 6-8 mm. long; flowers white or pinkish: fruit oblong-ovate, 6-7 mm. long, with rather prominent winged ribs; stylopodium broad and low; oiltubes 4-6 in the intervals, 8-10 on the commissural side.-Throughout our range.

5. Ligusticum tenuifolium Wats. Proc. Am. Acad. 14: 293. 1879. Stem slender, $3-6 \mathrm{dm}$. high, naked above the base or with a single leaf, bearing 1-3 glabrous umbels: leaves small, ternate, then pinnately decompound, finely dissected with laciniately divided leaflets, the ultimate segments narrowly linear to filiform: umbel few-rayed (6-12), with involucels of 1 or 2 narrowly linear bractlets; rays about $2.5 \mathrm{~cm}$. long; pedicels $4-6 \mathrm{~mm}$. long: fruit oblong, with narrow ribs; oil-tubes $3-5$ in the intervals, $6-8$ on the commissural side. Colorado to Idaho and Oregon.

$$
\text { ROCKY мT. Вот. - } 23
$$




\section{LIGUSTICELLA C. \& R.}

Low, glabrous, acaulescent perennials, with small simply pinnate leaves, no involucre (rarely 1 or 2 caducous bracts), involucels of broad toothed bractlets, and yellowish green flowers in few-rayed compact umbels. Calyxteeth evident. Fruit ovate, flattened laterally, glabrous. Carpel with filiform ribs, the laterals no more prominent than the dorsals; stylopodium conical; oil-tubes 2 or 3 in the intervals, 4 on the commissural side. Seed considerably broader than thick, with nearly plane face.

1. Ligusticella Eastwoodae C. \& R. Contr. Nat. Herb. 12: 445. 1909. Low, acaulescent, $10-30 \mathrm{~cm}$. high, glabrous: leaves pinnate, $10-15 \mathrm{~cm}$. long; leaflets 7-13, opposite, oval, 2-3-lobed, and lobes 2-3-cleft into linear-acute segments: umbel few-rayed, compact, with involucre of 1 or 2 bracts or none, and conspicuous involucels of bractlets longer than the fruit; rays 4-6 $\mathrm{mm}$. long; pedicels about $2 \mathrm{~mm}$. long: fruit ovate, glabrous, $3 \mathrm{~mm}$. long, with small ribs. Ligusticum Eastwoodae C. \& R. 1. c. 3: 320. 1895.- In the high mountains of southwestern Colorado.

\section{OREOXIS Raf.}

Alpine caespitose perennials, with pinnate leaves usually shorter than the peduncles, no involucre, and involucels of narrow bractlets equaling the yellow flowers. Calyx-teeth prominent. Fruit globose, slightly flattened laterally if at all, glabrous or puberulent. Carpel with very thick and prominent equal corky ribs, each with a large group of strengthening cells; carpophore none; stylopodium wanting; oil-tubes 1-3 in the very narrow intervals, 2 on the commissural side, and a small one in each dorsal rib. Seed sulcate beneath the oil-tubes, with flat or somewhat concave face.

Glabrous or nearly so; oil-tubes more than 1 . in the intervals.

Involucels linear.

Involucels conspicuous and toothed

Puberulent; oil-tubes solitary in the intervals :

1. Oreoxis humilis Raf. Ser. Bull. Bot. 217. 1830. Glabrous (sometimes slightly puberulent just below umbel), caespitose, from a somewhat slender elongated root: leaves pinnate, the leaflets cut into 3-7 linear-lanceolate segments: peduncles $2-7.5 \mathrm{~cm}$. high; umbels few-rayed, with involucels of linear, distinct bractlets; flowers bright yellow: fruit 3-4 $\mathrm{mm}$. long; oil-tubes 2-3 (rarely 1) in the intervals.- High mountains of Central Colorado.

2. Oreoxis Bakeri C. \& R. Contrib. Nat. Herb. 7: 144. 1900. Glabrous throughout except some puberulence at the top of peduncle and on rays, caespitose, from thickish elongated roots: leaflets opposite, 3-5 pairs, somewhat distant, 3-5-cleft into linear or linear-lanceolate entire lobes: peduncles longer than the leaves, $3-8 \mathrm{~cm}$. long, erect, or more or less inclined; flowering umbel very compact, almost head-like; fruiting rays nearly equal, $3-5 \mathrm{~mm}$. long; pedicels $2 \mathrm{~mm}$. or less long; involucel of numerous distinct obovate bractlets strongly 3-toothed at apex: fruit 3-4 $\mathrm{mm}$. long, usually purplish; oil-tubes $2-5$ in the intervals. - High mountains of Colorado.

3. Oreoxis alpina (Gray) C. \& R. 1. c. Puberulent (rarely glabrous), with paler, more dissected leaves and shorter, more crowded leaflets: involucels of somewhat broader bractlets more or less united at base; flowers paler: fruit 4-5 mm. long, puberulent (at least when young); oil-tubes solitary in the intervals. Cymopterus alpinus.-Colorado and Utah to Wyoming.

\section{CONIOSELINUM Hoffm.}

Glabrous perennials (or inflorescence sometimes puberulent), with ternate then pinnately decompound leaves, ovate-acute, laciniately toothed or lobed leaflets, involucre more or less conspicuous or none, involucels of numerous more or less elongated narrow bractlets, and white flowers. Calyx-teeth ob- 
solete. Fruit oblong, dorsally flattened, glabrous. Carpel with prominent dorsal and intermediate ribs (sometimes narrowly winged), and the laterals broadly winged and thickish; stylopodium slightly conical; oil-tubes usually solitary in the dorsal intervals, 1 to several in the lateral, 2-8 on the commissural side. Seed with plane or slightly concave face.

1. Conioselinum scopulorum (Gray) C. \& R. Contrib. Nat. Herb. 7: 151. 1900. Nearly simple, 6-9 dm. high, more or less leafy, with puberulent inflorescence: lower leaves often very large, twice to thrice ternate, then once or twice pinnate; leaflets (sometimes small) laciniately pinnatifid; upper leaves often ternate-pinnate or simply pinnately compound: umbel of numerous rays, with involucels of several narrowly linear elongated bractlets; rays (fruiting) 5-7.5 cm. long; pedicels $12 \mathrm{~mm}$. long: fruit about $6 \mathrm{~mm}$. long; oiltubes usually 1 in the dorsal intervals and 2 in the lateral, 2-4 on the commissural side. Ligusticum scopulorum.-From New Mexico through our range to Oregon.

\section{ANGELICA L.}

Stout perennials, with ternate-pinnate (rarely simply pinnate) compound leaves, scanty involucre or none, involucels of small bractlets or none, and large umbels of white flowers (greenish-yellow or purplish in two or three species). Calyx-teeth mostly obsolete. Fruit flattened dorsally, ovate or oblong, glabrous or pubescent, with prominent crenulate disk. Carpel with strong ribs, each with a group of strengthening cells; laterals usually broadly winged, distinct from those of the other carpel, forming a double-winged margin to the fruit; stylopodium conical; oil-tubes 1-several in the intervals or indefinite, 2-10 on the commissural side. Seed face plane or somewhat concave.

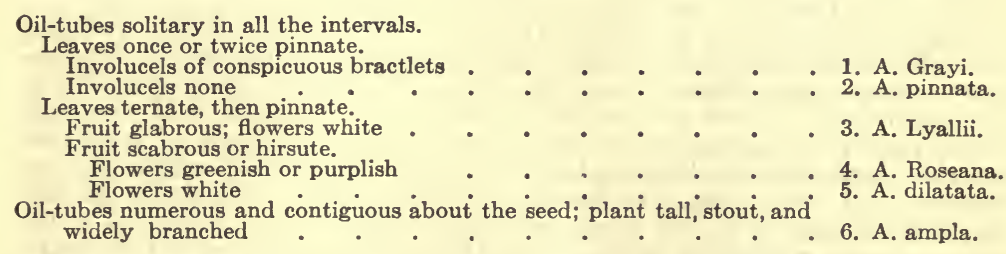

1. Angelica Grayi C. \& R. Contrib. Nat. Herb. 7: 154. 1900. Usually very stout, 3-6 dm. high, glabrous except the more or less scabrous inflorescence, leaf-margins, and veinlets (beneath): leaves once or twice pinnate, with muchdilated petioles; leaflets oblong to ovate, $2.5 \mathrm{~cm}$. long, acute, toothed (sometimes laciniately toothed or lobed): umbel with involucels of conspicuous, lanceolate-ovate, long-acuminate bractlets; rays $2.5-3.5 \mathrm{~cm}$. long; pedicels 2-4 mm. long: fruit oblong, smooth, 4-5 mm. long, with prominent thin wings, the laterals decidedly broadest: seed face dorsally sulcate.-High mountains of Colorado and southern Wyoming.

2. Angelica pinnata Wats. Bot. King's Rep. 126. 1871. Glabrous, 6-9 dm. high: leaves simply pinnate, with $2-4$ pairs of ovate to narrowly lanceolate, sharply serrate to entire leaflets (lowest pair sometimes pinnate): umbels 10-20-rayed, with neither involucre nor involucels; rays $5-10 \mathrm{~cm}$. long; pedicels $4 \mathrm{~mm}$. long; flowers greenish-yellow or dull purple: stylopodium slightly conical; fruit oblong, glabrous (at maturity), 4-6 mm. long; dorsal and intermediate ribs thick and prominent; laterals with wings hardly as broad as body.-Extending from New Mexico to Utah and Montana.

3. Angelica Lyallii Wats. Proc. Am. Acad. 17: 374. 1882. Glabrous except the sometimes puberulent inflorescence, stout, 6-15 dm. high: leaves ternate then once or twice pinnate, the uppermost reduced to large inflated petioles; leaflets extremely variable in size, ovate to lanceolate, rather acute, serrate or dentate: umbel many-rayed, with neither involucre nor involucels; rays 
2.5-25 cm. long; pedicels 2-10 $\mathrm{mm}$. long, coalescent at base (giving a "webfooted " appearance): fruit oblong to obovate, glabrous, 4-6 $\mathrm{mm}$. long; dorsal and intermediate ribs thick and slightly elevated; lateral wings as broad as the of ten much flattened body or broader.-Northwestern Wyoming to Oregon and northward.

4. Angelica Roseana Henderson, Contrib. Nat. Herb. 5: 201. 1899. Low and very stout, 5-6 dm. high, with glabrous and usually purplish stems, and more or less scabrous inflorescence: leaves twice or thrice ternate then pinnate; upper stem leaves reduced, with large inflated petioles; leaflets broadly ovate to lanceolate, thick, with prominent veins, laciniately mucronate-toothed, 2.5-3.5 cm. long, obtuse or acute, glabrous or more or less scabrous: umbels with very unequal rays, no involucre (or sometimes 1 or 2 bracts), and involucels of few filiform and very scabrous bractlets: flowers greenish or tinged with purple: ovaries glabrous or puberulent: fruit broadly oblong-elliptic, more or less scabrous, $4-5 \mathrm{~mm}$. long; dorsal and intermediate ribs often nearly as prominent as the lateral, thick and corky; stylopodium conical; oil-tubes mostly solitary in the intervals.-Subalpine or alpine, among the broken rocks of the cliffs; throughout our range.

5. Angelica dilatata A. Nels. Contrib. U. S. Nat. Herb. 12: 446. 1909. Glabrous, 5-10 dm. high: lower leaves ternate, then pinnate; the upper simply pinnate or reduced to the greatly dilated petiole which is sometimes tipped with a diminutive biternate leaf; leaflets obovate or ovate, nearly or quite sessile, obscurely and somewhat irregularly serrate, or sometimes with a basal lobe on one side; dilated petioles $10-20 \mathrm{~cm}$. long: umbel about 30-rayed, the involucre wanting or of 1-2 bracts; involucels none; rays 5-8 cm. long: fruit oblong-elliptic, obscurely and sparsely hirsute, less than $5 \mathrm{~mm}$. long; lateral wings broader than the dorsal and intermediate ones; oil-tubes solitary in all the intervals; pedicels unequal, usually much longer than the fruits.-Type locality, City Creek Cañon, Utah.

6. Angelica ampla A. Nels. Bull. Torr. Bot. Club 25: 375. 1898. Tall and stout, 15-25 dm. high, with purplish, glabrous stems and puberulent inflorescence: leaves large, ternate then twice pinnate; leaflets ovate to obovate, short-acuminate, serrate or toothed, 5-20 cm. long: umbels with very numerous, nearly equal rays, no involucre, and usually involucels of setaceous bractlets; rays 5-10 cm. long; pedicels 10-12 $\mathrm{mm}$. long: fruit broadly oblong, glabrous, 5-7 mm. long, the dorsal and intermediate ribs sharp (hardly winged), narrower than the thin, very' narrow lateral wings; oil-tubes small and numerous, contiguous about the seed and adhering to it with the breaking down of the pericarp.-On stream banks; from southern Wyoming to central Colorado.

\section{PHELlOPTERUS Nutt.}

Acaulescent or short caulescent plants, with pale once or thrice pinnate leaves (segments usually short, broad, crowded, and more or less confluent), mostly conspicuous and similar more or less hyaline involucre and involucels, and purple flowers (except in $P$. montanus). Calyx-teeth evident. Fruit oblong to orbicular in outline, glabrous. Carpel with 3-5 broad wings, thin throughout or slightly thickened at insertion, the laterals distinct from those of the carpel; stylopodium wanting; oil-tubes usually more than one in the intervals, 4-8 on the commissural side. Seed more or less dorsally flattened, the face with a shallow and broad concavity.-Cymopterus in part.

Flowers white

Flowers pinkish or purple.

Involucels with 1-3-nerved bractlets. Fruit oblong, $8 \mathrm{~mm}$. long . Fruit orbicular, 10-12 mm. long

Involucels with many-nerved bractlets
1. P. montanus.

2. P. bulbosus.

3. P. purpurascens.

4. P. multinervatus.

1. Phellopterus montanus Nutt. T. \& G. Fl. 1: 624. 1840. Flowering umbels compactly clustered at the base of the rosette of much longer leaves, 
often appearing sessile, somewhat elongated in fruit: involucre inconspicuous, hyaline, and lobed, sometimes reduced to a cup; involucels conspicuous, the bractlets distinct, obovate, entire, with very broad, white, and hyaline margins, with more or less distinct green central region: pedicels shorter than the bractlets: flowers white, sometimes purplish: fruit broadly oblong to nearly orbicular, 6-8 $\mathrm{mm}$. long, with broad, thin wings somewhat thickened at insertion; oil-tubes 1-3 in the intervals, 4-8 on the commissural side: seed somewhat flattened, with broadly concave face. Cymopterus montanus.-Kansas to Dakota and west to Colorado and Wyoming.

2. Phellopterus bulbosus (A. Nels.) C. \& R. Contrib. Nat. Herb. 7: 168. 1900. Leaf-segments more crowded than in $P$. montanus: flowering umbel more elongated, in fruit equaling or exceeding the leaves; involucre conspicuous, of broad hyaline bracts united at base; involucels more conspicuous, the broad hyaline bracts sometimes with a greenish central region; pedicels longer than in $P$. montanus; flowers purplish: fruit oblong, much narrower than in $P$. montanus, $8 \mathrm{~mm}$. long, with broad thin wings not thickened at insertion; oil-tubes $3-5$ in the intervals, 6-10 on the commissural side: seed face with rather deep and broad concavity.-Green river region of Wyoming.

3. Phellopterus purpurascens (Gray) C. \& R. 1. c. Peduncles longer than in $P$. montanus, in fruit equaling or exceeding the leaves; umbels more or less compacted; involucre conspicuous, composed of white or purplish hyaline bracts which have 1-3 green or purplish nerves and are united at base, or sometimes reduced to a hyaline sheath; involucels resembling the involucres: flowers purple: fruit orbicular, with broad wings and oblong body 10-12 $\mathrm{mm}$. long: carpels somewhat flattened, with 5 broad, thin wings scarcely thickened at insertion; oil-tubes 2 or 3 in the intervals, 4 on the commissural side: seed somewhat flattened, with broadly concave face.-Mostly west of our range.

3a. Phellopterus purpurascens Eastwoodae (Jones) C. \& R. l. c. 169. More robust, 2-3 dm. high, with usually long peduncles: umbels and umbellets more open, with prominent rays and pedicels: wings of fruit much narrower, resulting in a narrow fruit.-More eastern in range; central and western Colorado.

4. Phellopterus multinervatus C. \& R. 1. c. Peduncles as in P. purpurascens; involucre a low, hyaline more or less lobed sheath, or developing one or more conspicuous bracts resembling those of the involucel; involucels conspicuous, composed of broad purplish bractlets united at base, which are rounded at apex, many-nerved, and with narrow hyaline margins; flowers purple: fruit orbicular, with very broad wings and oblong body, 12-15 $\mathrm{mm}$. long: carpels somewhat flattened, with 5 broad thin wings more or less thickened at insertion; oil-tubes $2-4$ in the intervals, 8 on the commissural side: seed somewhat flattened, with broadly concave face. (P. camporum Rydb. Bull. Torr. Bot. Club 31: 574. 1904.) - Colorado and New Mexico and west to Utah and Arizona.

\section{PTERYXIA Nutt.}

Plants of acaulescent habit or nearly so, and clothed at base with persistent leaf-sheaths, leaves clustered at base with main divisions ternate then pinnately finely dissected into short-linear more or less pungent segments, mostly no involucre, involucels of narrow bractlets (not at all hyaline), and yellow flowers. Calyx-teeth evident. Fruit oblong to orbicular in outline, glabrous. Carpel usually strongly flattened dorsally, with wings thin throughout, lateral ribs with broad wings, dorsal and intermediates from strongly ribbed to broadly winged; stylopodium wanting; oil-tubes several in the intervals. Seed face plane or with a shallow and broad concavity.-Cymopterus in part.

Flowers yellow; fruit oblong Flowers white; fruit orbicular

1. Pteryxia calcarea (Jones) C. \& R. 1. c. 173. Short caulescent, giving 
rise to a tuft of leaves and longer peduncles (occasionally bearing a small leaf): leaves with the ultimate divisions linear: peduncles reaching a height of 2-3 dm.; umbel of unequal rays, no involucre, and involucels of small linear bractlets; rays 1-3.5 $\mathrm{cm}$. long; pedicels $2-4 \mathrm{~mm}$. long; flowers yellow: fruit oblong, 6-7 $\mathrm{mm}$. long, the dorsal and intermediate wings sometimes reduced in breadth; oil-tubes $3-5$ in the intervals, 6 or more on the commissural side: seed face with broad and shallow concavity, but in immature specimens sometimes appearing plane.-Interior Wyoming to Nevada and Oregon.

2. Pteryxia albiflora Nutt. T. \& G. Fl. 1: 625. 1840. Low, very leafy at base: leaves pale, the ultimate, segments divaricate and often 3-cleft, short, acute: peduncles slender, more or less spreading, 1-1.5 dm. high, considerably longer than the leaves; umbels with unequal rays, no involucre, and involucels of several linear bractlets; rays $4-12 \mathrm{~mm}$. long; fruiting pedicels $3 \mathrm{~mm}$. long; flowers white: fruit nearly orbicular, $4 \mathrm{~mm}$. long, each carpel with usually 5 more or less undulate wings. - Northern Wyoming, Idaho, and Montana.

\section{THASPIUM Nutt.}

Perennials, with ternately compound leaves and broad serrate or toothed leaflets (or lower leaves simple), mostly no involucre, involucels of small bractlets, mostly yellow flowers, and all the fruits pediceled. Calyx-teeth conspicuous. Fruit ovoid to oblong, mostly glabrous. Carpel with 3 or 4 or all the ribs strongly winged; stylopodium wanting; style long; oil-tubes solitary in the intervals, 2 on the commissural side. Seed face plane.

1. Thaspium trifoliatum aureum (Nutt.) Brit. Mem. Torr. Club 5: 240. 1894. Glabrous, $6-15 \mathrm{dm}$. high: basal leaves mostly cordate, serrate; stem leaves simply ternate (rarely biternate); leaflets ovate to lanceolate, rounded or tapering at, base, serrate: umbels 8-12-rayed; rays 1-2.5 cm. long; pedicels about $2 \mathrm{~mm}$. long; flowers yellow: fruit globose-ovoid, about $4 \mathrm{~mm}$. long, all the ribs equally winged. $T$. trifoliatum in part.-Wyoming and eastward.

\section{AULOSPERMUM C. \& R.}

Caulescent or acaulescent plants, with more or less pinnately dissected leaves (or primary division ternate), mostly no involucre, involucels of small narrow bractlets, which are not at all hyaline, and white, yellow, or purple flowers. Calyx-teeth evident. Fruit oblong to orbicular in outline, glabrous. Carpel with 3-5 usually broad wings which are sometimes thickened at insertion, and with narrow or broad intervals; stylopodium wanting; oil-tubes several in the intervals, 2 or more on the commissural side. Seed not dorsally flattened or but slightly so, the face usually with a narrow and deep sulcus.-Cymopterus in part.

Stems becoming caulescent, crowned with a cluster of leaves and peduncles.

Flowers yellow.

Leaves coarsely dissected Leaves more finely dissected

Flowers white or purplish. Flowers white Flowers purple

Stems acaulescent

1. Aulospermum longipes (Wats.) C. \& R. Contrib. Nat. Herb. 7: 175. 1900. Glabrous and glaucous: leaves pinnate to bipinnate, the ultimate segments oval and mucronulate: fruiting peduncles longer than the leaves, 10-25 cm. long; umbels 5-10-rayed, with no involucre, and involucels of subulate acuminate bractlets; raýs 12-40 $\mathrm{mm}$. long; pedicels 4-6 $\mathrm{mm}$. long; flowers yellow: fruit 6-8 $\mathrm{mm}$. long, the 5 carpel wings broad and thin, somewhat unequal; oil-tubes 3-4 in the intervals, 6 on the commissural side: seed face with deep and narrow sulcus, which broadens into a central cavity.Naked clay soils in the desert areas; Colorado, Utah, and Wyoming. 
2. Aulospermum angustum Osterh. Bull. Torr. Bot. Club 31: 358. 1904. Glabrous and glaucous, $20 \mathrm{~cm}$. or more high: leaves glaucous throughout, bipinnate, with crowded small segments: fruiting peduncles $10-20 \mathrm{~cm}$. long; umbels 5-rayed or more, with no involucre and involucels of few subulate bractlets; rays about $1 \mathrm{~cm}$. long; pedicels $3-4 \mathrm{~mm}$. long; flowers yellow: fruit 6-7 $\mathrm{mm}$. long, the 5 carpel wings narrow and subequal; oil-tubes $4-5$ in the intervals, 6 on the commissural side.-Habitat and range of last.

3. Aulospermum ibapense (Jones) C. \& R. Contrib. U. S. Nat. Herb. 7: 176. 1900. Glabrous and glaucous: leaves tripinnate, the ultimate divisions crowded, oblong, obtuse, with revolute margins: fruiting peduncles longer than the leaves; umbels 6-8-rayed, with no involucre and involucels of linear acute bractlets; rays about $1 \mathrm{~cm}$. long; pedicels $4 \mathrm{~mm}$. long; flowers white: fruit 4-5 mm. long, the 5 carpel wings broad and thin; oil-tubes 3 in the intervals, 6 on the commissural side. (Cymopterus ibapensis Jones, Zoe 3: 302. 1893.) - Habitat and range of last.

4. Aulospermum planosum Osterh. Bull. Torr. Bot. Club 30: 236. 1903. Shortly caulescent, crowned by the numerous widely spreading leaves and peduncles longer than the leaves: flowers purplish: fruit oblong, $6 \mathrm{~mm}$. long.Colorado.

5. Aulospermum purpureum (Wats.) C. \& R. 1. c. 178. Whole plant purplish, nearly acaulescent, glabrous: leaves broadly triangular in outline, twice or thrice pinnate, the segments coarsely mucronate-dentate: peduncles stout, exceeding the leaves; umbel unequally 8-12-rayed, with more or less elongated rays and pedicels, mostly no involucre, and involucels of lanceolate bractlets united near the base and nearly equaling the yellowish-purple flowers: fruit $8-10 \mathrm{~mm}$. long, each carpel with $3-5$ broad wings scarcely thickened at insertion; oil-tubes 4 or 5 in the intervals, 8 on the commissural side: seed somewhat flattened, with broadly concave face.-New Mexico to Colorado and west to Utah and Arizona.

\section{CYMOPTERUS Raf.}

Dwarf, acaulescent, xerophytic plants, with small pinnate or bipinnate leaves, of ten no involucre, usually foliaceous and conspicuous involucels, and white or yellow flowers. Calyx-teeth obsolete or evident. Fruit flattened dorsally, ovate, glabrous. Carpel with dorsal and intermediate ribs filiform or winged and approximate; lateral wings broad, very thick and corky, with neither nerves nor strengthening cells, coherent till maturity with those of the other carpel, forming a broad corky margin to the fruit usually thicker than the much-flattened fruit body and in cross section showing a neck-like connection; stylopodium wanting; oil-tubes very small, 4-8 in the intervals, 8-14 on the commissural side. Seed very flat, with plane face.

Umbels globose, flowers white.

Fruit with $3-5$ broad wings on each carpel. Ultimate leaf-segments narrow and acute Ultimate leaf-segment short-oblong, obtuse

Fruit with only the lateral nerves broadly winged

Umbels open, flowers yellow.

Leaf-segments narrow

Leaf-segments broad

1. Cymopterus acaulis (Pursh) Rydb. Bot. Surv. Nebr. 3: 38. 1894. Low (7-20 cm.) and glabrous, with a short caudex bearing a cluster of leaves and peduncles: leaves merging from pinnate to bipinnate; ultimate segments mostly small and narrow: peduncles mostly shorter than the leaves; rays and pedicels very short, making a rather compact cluster; involucel of linear and entire more or less united foliose bractlets; flowers white: fruit 6-8 $\mathrm{mm}$. in diameter, with 3-5 broad wings on each carpel; oil-tubes small, 4-8 in the intervals (or double the number where a rib has been suppressed), 8-14 on the commissural side.-From Colorado to Assiniboia.

2. Cymopterus Parryi (C. \& R.) Jones, Zoe 4: 48. 1893, Resembling $C$. 
acaulis, but the leaf-segments shorter and more obtuse: involucre small, hyaline: fruit somewhat larger, the lateral wings moderately thickened.Gravelly bench lands; western Wyoming and adjacent Montana.

3. Cymopterus lapidosus Jones, Contrib. Western Bot. No. 8: 31.1898. Glabrous: leaves and peduncles borne in a cluster at the summit of a more or less elongated subterranean stem arising from a long branching root: leaves 5-10 cm. long, pinnate to bipinnate, the pinnae rather crowded, ovate, lower ones incised, upper ones entire: peduncles sometimes shorter than the leaves, or becoming $1.5-2 \mathrm{~cm}$. high, bearing a nearly equally rayed umbel, with involucels of several linear bractlets; rays 1-2 cm. long; pedicels $4 \mathrm{~mm}$. long; flowers white: fruit oblong, glabrous, 6-7 mm. long, 2-2.5 mm. broad, with wings half as broad as body or less, and prominent dorsal and intermediate ribs (more or less winged); oil-tubes several in the intervals. - Southern Wyoming and adjacent Utah.

4. Cymopterus Fendleri Gray, Pl. Fendl. 56. 1849. Low $(5-10 \mathrm{~cm}$.) and glabrous, the cluster of leaves and peduncles springing from a slender subterranean stem which arises from an elongated thick root: leaves usually exceeding the peduncles, 2-3-pinnate; pinnae and segments 5 or 7, oblong and incised: umbels with few and unequal rays and yellow flowers, sterile flowers with longer pedicels than the fertile; involucre represented by a short sheath whose teeth are occasionally prolonged into small linear bracts, and involucels of bractlets united at base and exceeding the flowers: fruit oblong, 6-10 $\mathrm{mm}$. long; each carpel with 3 or 4 wings which are thin at the margin and also next to the body; oil-tubes several in the intervals, 4-8 on the commissural side.-Gravelly soil; New Mexico, Colorado, and Utah.

5. Cymopterus Newberryi (Wats.) Jones, Zoe 4: 47. 1893., Often more robust than the other species $(5-18 \mathrm{~cm}$. high), but with the same habit: leaves shorter than the peduncles, pinnately $3-5$-foliolate or simply lobed, lobes and leaflets broad; terminal leaflet 3-lobed, the lower mostly 2-lobed, all the lobes sparingly incised: umbel unequally 4-13-rayed, with yellow flowers, and conspicuous involucels of more or less unequal oblong to ovate foliaceous bractlets: fruit sessile or nearly so, 6-8 $\mathrm{mm}$. long, with very thick lateral wings and dorsal and intermediate ribs filiform or winged; oil-tubes 4-8 in the intervals, $8-10$ on the commissural side.-Colorado and New Mexico and west to Utah and Arizona.

\section{PSEUDOCYMOPTERUS C. \& R.}

Caulescent or acaulescent plants, with bipinnate leaves, no involucre (very rarely a bract or two), involucels of mostly linear bractlets, and variously colored flowers. Calyx-teeth evident. Fruit oblong, glabrous. Carpel with very prominent and acute (sometimes narrowly winged) dorsal and intermediate ribs, and rather broad and thickish lateral wings (sometimes not much more prominent than the dorsals and intermediates), which are distinct from those of the other carpel; stylopodium wanting; oil-tubes 1-4 in the intervals, 2-8 on the commissural side. Seed more or less flattened, with plane face (except in $P$. bipinnatus).

More or less caulescent.

Flowers yellow.

Ultimate divisions of leaves short, ovate to lanceolate

Ultimate divisions of leaves elongated, linear

Leaves (at least basal ones) ovate

Leaves (at least basal ones) broadly rhombic.

Plant slender; leaves mostly compound, with very long and

few divisions low; leaves thrice pinnate, with shorter, crowded, nuFlowers purple merous divisions

Acaulescent.

Leaves on long petioles, green.

Segments linear

Segments obovate to rhombic-cuneate

Leaves on short petioles, very pale or glaucous

1. P. montanus.

2. P. sylvaticus.

3. P. tenuifolius.

4. P. multifidus. 5. P. purpureus.

6. $P$. anisatus.

7. P. aletifolius.

8. P. bipinnatus. 
1. Pseudocymopterus montanus (Gray) C. \& R. Rev. N. Am. Umbell. 74. 1888. Stem erect, slender, 3-6 dm. high, more or less leafy, glabrous except at the base of the umbel or on the rays: the bipinnate leaves mostly with broad outline; leaflets exceedingly variable, variously cut or entire: umbel 6-12rayed, with involucels of linear or setaceous bractlets longer than the yellow flowers; rays 12-30 $\mathrm{mm}$. long; pedicels about $2 \mathrm{~mm}$. long: fruit broadly oblong, 4-5 mm. long, with lateral wings almost as broad as body, the dorsal and intermediates very variable (either ribbed or narrowly winged); oil-tubes 1-4 in the intervals, 4-6 on the commissural side: seed much flattened.Open mountain sides; Colorado to New Mexico and Arizona.

2. Pseudocymopterus sylvaticus A. Nels. Bull. Torr. Bot. Club 28: 224. 1901. Similar but the stems more slender, the leaf-segments long-linear, the fruiting peduncle elongated and naked: fruit broader and with thin, conspicuous, lateral wings as broad as the body; oil-tubes mostly 1 in the intervals and $2-4$ on the commissural sides.-Wet woods and thickets; Wyoming and Colorado.

3. Pseudocymopterus tenuifolius (Gray) Rydb. Bull. Torr. Bot. Club 33: 147. 1906. Resembling $P$. montanus, but often larger and more branching, and the bipinnate leaves with very few and narrowly linear leaflets 1-4 cm. long. (P. montanus tenuifolius C. \& R. Rev. N. Am. Umbell. 74. 1888.)In mountain woods; Colorado to New Mexico.

4. Pseudocymopterus multifidus Rydb. 1. c. Resembling P. montanus, but low, about $2 \mathrm{dm}$. high: lower leaves broadly rhombic in outline, thrice pinnate; the upper twice pinnate; ultimate divisions linear: fruit smaller and more rounded.- High mountains; Colorado and New Mexico.

5. Pseudocymopterus purpureus (C. \& R.) Rydb. 1. c. Resembling $P$. montanus, but short caulescent, with rather weak ascending peduncles 7.5-15 $\mathrm{cm}$. long, and purple flowers. (P. montanus purpureus C. \& R. 1. c.)-Moist places in the mountains; Colorado to New Mexico and Utah.

6. Pseudocymopterus anisatus (Gray) C. \& R. 1. c. Acaulescent, caespitose from a much branched caudex, which is more or less covered with the remains of old leaves: leaves on long petioles, narrow, somewhat rigid, pinnate, and the leaflets pinnately parted into linear (sometimes broader) pungently acute segments: peduncles 1-3 dm. high, exceeding the leaves; umbel unequally 5-12-rayed, with involucels of linear-subulate (sometimes lobed) bractlets exceeding the white or yellow flowers; rays $1-7.5 \mathrm{~cm}$. long; pedicels $2-6 \mathrm{~mm}$. long: fruit about $4 \mathrm{~mm}$. long, the carpel irregularly 2-5-winged; oil-tubes 1-3 in the intervals, 2-4 on the commissural side: seed face plane.-Dry hills and mountains; throughout our range and to the northwestward.

7. Pseudocymopterus aletifolius Rydb. Bull. Torr. Bot. Club 31: 574. 1904. Densely caespitose, with the habit of $P$. anisatus: leaves once or twice pinnate, stiff and shining, with petioles about as long as the blades; segments obovate to rhombic-cuneate, deeply cleft into usually 3-toothed lobes: peduncles 1-1.5 dm. high, about equaling the leaves; rays of the umbel very unequal, in fruit 1-5 cm. long; pedicels also very unequal, $1-8 \mathrm{~mm}$. long in fruit; flowers yellow: fruit 5-6 mm. long; lateral wings evident but rather narrow; dorsal ribs acute or slightly winged; oil-tubes usually solitary in the intervals.- In the mountains of Colorado, among rocks.

8. Pseudocymopterus bipinnatus (Wats.) C. \& R. 1. c. 75. Caespitose, the short branches of the rootstock covered with the crowded remains of dead leaves, glaucous, puberulent: leaves pinnate with few pairs of short segments, which are pinnately divided into short linear lobes: peduncles 1-2 dm. high, much exceeding the leaves; rays 2-8 $\mathrm{mm}$. long; involucels of conspicuous linear-lanceolate or broader bractlets; with hyaline margins, and more or less united at base ; flowers white: fruit nearly sessile, ovoid, 3-4 mm. long, moderately flattened dorsally, the 5 thickish carpel wings equal and narrow (often being but very prominent acute ribs); oil-tubes 3-4 in the intervals, 6-8 on the commissural side: seed face slightly concave.-Western Wyoming to Montana and Oregon. 


\section{OXYPOLIS Raf.}

Smooth, erect, swamp herbs, with fascicled tubers, leaves simply pinnate or ternate or reduced to petioles, involucre of few bracts or none, involucels of numerous small bractlets or none, and white flowers. Calyx-teeth evident. Fruit flattened laterally, ovate to obovate, glabrous. Carpel with dorsal and intermediate ribs filiform; lateral wings closely contiguous to those of the other carpel and nerved dorsally at the inner margin (giving the appearance of 5 filiform ribs on the back of each carpel); strengthening cells beneath the dorsal ribs and nerves of the lateral wings; stylopodium thick, short-conical; oil-tubes solitary in the intervals, 2-6 on the commissural side. Seed face plane.-Archemora.

1. Oxypolis Fendleri (Gray) Heller, Bull. Torr. Bot. Club 24: 478. 1897. Stem slender, simple, 3-6 dm. high, from a large fascicle of tubers $(2.5 \mathrm{~cm}$. long): leaves pinnate, 5-9-foliolate; leaflets ovate or oblong (or lanceolate in upper leaves), obtuse, $2.5-5 \mathrm{~cm}$. long, incisely serrate: umbel unequally 5-12-rayed, with neither involuore nor involucels; rays 1-3.5 cm. long; pedicels 4-8 $\mathrm{mm}$. long: fruit ovate, scarcely $4 \mathrm{~mm}$. long, with rather prominent dorsal and intermediate ribs and narrower lateral wings; oil-tubes 2-4 on the commissural side.-In the mountains of our range.

\section{LEPTOTAENIA Nutt.}

Usually tall and stout, glabrous, nearly acaulescent perennials, with thick often very large fusiform roots, usually large pinnately decompound leaves, involucre of few bracts or none, involucels of numerous small bractlets, and yellow or purple flowers. Calyx-teeth obsolete or sometimes evident. Fruit flattened dorsally, oblong-elliptical, glabrous. Carpel with dorsal and intermediate ribs, filiform or obscure; lateral wings very thick and corky, with large groups of thick-walled strengthening cells; commissural face with a prominent central longitudinal ridge left after separation from the carpophore; stylopodium wanting; oil-tubes 3-6 in the intervals, $4-6$ on the commissural side, mostly small, sometimes obsolete. Seed very flat, with plane or slightly concave face.

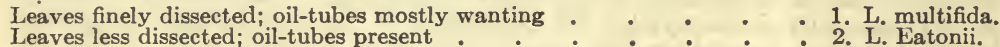

1. Leptotaenia multifida Nutt. T. \& G. Fl. 1: 630. 1840. Leaves finely dissected: umbels mostly without involucre; pedicels of the fruit 6-24 $\mathrm{mm}$. long; flowers purple or yellow: fruit 8-12 mm. long, and with no strengthening cells in the almost obsolete dorsal and intermediate ribs: seed face concave, the carpel section being crescentic.-Montana to New Mexico.

2. Leptotaenia Eatonii C. \& R. Rev. N. Am. Umbell. 52. 1888. Like L. multifida, but with less dissected leaves: umbels few-rayed; pedicels of fruit 8-12 mm. long: fruit 16-18 $\mathrm{nm}$. long, 8-10 $\mathrm{mm}$. broad, flatter and thinner than in any other species; oil-tubes $4-6$ in the intervals, 4 on the commissural side, a prominent corky nerve on the commissural face of the lateral wing near the inner margin: seed face plane.-Western Wyoming, Utah, and Idaho.

\section{COGSWELLIA Raf.}

Acaulescent or short caulescent, dry ground perennials, with fusiform or tuberous roots, ternate (sometimes pinnate) to dissected leaves, no involucre, involucels mostly present, and yellow, white, or purple flowers. Calyx-teeth obsolete (very rarely evident). Fruit strongly flattened dorsally, oblong to orbicular. Carpel with filiform and approximate dorsal and intermediate ribs, and winged laterals coherent till maturity with those of the other carpel; pericarp thin, with strengthening cells beneath each rib and nerve; stylopodium wanting; oil-tubes one to several in the intervals (rarely obsolete), 2-10 on the commissural side. Seed dorsally flattened, with plane face (rarely slightly concave).-Peucedanum. 
Flowers yellow.

Roots tuberous or moniliform.

Umbellets open; pedicels slender

Umbellets compact; fruit nearly sessile

Roots more or less thickened.

Plant glabrous or nearly so; fruit glabrous.

Oil-tubes several in the intervals

Oil-tubes large and solitary.

Glabrous throughout

Slightly puberulent on the herbage

Plant pubescent, at least when young.

Leaves finely dissected, ternate then pinnate.

Bractlets or involucels lanceolate, conspicuous and united at buse

Bractlets linear, smaller, distinct
Leaves ternate or biternate, with long linear segments

Flowers white.

Bractlets not scarious

Bractlets scarious-margined

1. Cogswellia ambigua (Nutt.) Jones, Contrib. West. Bot. 12: 32. 19908. Glabrous, from low acaulescent to $3 \mathrm{dm}$. high and caulescent, with tuberous sometimes moniliform roots: petioles much dilated at base; leaves once to twice pinnate, with more or less elongated linear leaflets, the upper often more dissected: umbel unequally 8-18-rayed, with no involucels; rays 2.5-8.5 cm. long; pedicels 4-8 $\mathrm{mm}$. long; flowers yellow: fruit narrowly oblong, glabrous, 6-8 mm. long, $2 \mathrm{~mm}$. broad, very narrowly winged; oil-tubes solitary in the intervals, 2 (broad and thin) on the commissural side.-Wyoming and Montana to Oregon.

2. Cogswellia leptocarpa (Nutt.) Jones 1. c. 33. Acaulescent, becoming $3 \mathrm{dm}$. high, from deep-seated tuberous roots, glabrous: leaves ternate then pinnate, the ultimate segments linear and usually much elongated: umbels with few very unequal rays, and involucels of small linear bractlets; rays from almost wanting to $7.5 \mathrm{~cm}$. long; flowers yellow: fruit nearly sessile, forming a dense cluster, linear, 9-10 $\mathrm{mm}$. long, $2 \mathrm{~mm}$. broad, with very narrow wings; oil-tubes solitary in the intervals.-Reported from Steamboat Springs, Colorado; mostly to the northwest of our range.

3. Cogswellia montana Jones 1. c. 34. Acaulescent, from a slender or somewhat enlarged and elongated rootstock, glabrous except the slightly puberulent inflorescence, 5-20 $\mathrm{cm}$. high: leaves usually twice pinnate, the leaflets short-oblong, obtuse, much crowded: umbel unequally 3-8-rayed, with involucels of distinct, obovate, more or less purplish bractlets; rays 4-30 $\mathrm{mm}$. long; pedicels 2-4 mm. long; flowers yellow: fruit oblong, glabrous, 5-6 mm. long, 2-3 mm. broad, with wings about half as broad as body; oiltubes several in the intervals. (Lomatium purpureum A. Nels. Bull. Torr. Bot. Club 28: 226. 1931.)-The western Dakotas to Wyoming and Oregon.

4. Cogswellia Grayi C. \& R. Contrib. U. S. Nat. Herb. 12: 450. 1909. Glabrous throughout, with peduncles $7.5-22.5 \mathrm{~cm}$. lorg: leaves ternate then pinnately decompound, the ultimate segments linear-filiform, elongated or shortcuspidate, exceedingly numerous: umbel rather equally 6-16-rayed, with involucels of distinct linear subulate bractlets; rays $2.5-7.5 \mathrm{~cm}$. long; pedicels 10-16 mm. long; flowers yellow: fruit oblong, 8-16 mm. long, 5-9 mm. broad, with wings usually more than half as broad as body, and filiform dorsal and intermediate ribs: oil-tubes usually solitary in the intervals (sometimes 2 in the lateral intervals), 2-4 on the commissural side.-Frequent in our range and westward to Oregon and Washington.

5. Cogswellia bicolor (Wats.) Jones 1. c. 38. Caulescent or scarcely so, 1-4.5 dm. high, glabrous or slightly puberulent: petioles wholly dilated; leaves ternate then pinnately decompound, the ultimate segments very numerous and filiform: umbel very unequally 2-10-rayed, with involucels of 1-8 linear-subulate bractlets; rays 2.5-12.5 cm. long; pedicels short; flowers yellow: fruit linear-oblong, glabrous, 10-12 $\mathrm{mm}$. long, 2-5 mm. broad, with very narrow wings and nearly obsolete dorsal and intermediate ribs; oiltubes large and solitary in the intervals, 2 on the commissural side.-Western Wyoming and in Utah and Idaho. 
6. Cogswellia foeniculacea (Nutt.) C. \& R. 1. c. 449 . Acaulescent, at first densely villous but becoming more or less glabrate, 1-3 dm. high: leaves finely dissected, ternate then pinnately decompound, with very numerous narrow crowded segments: umbel somewhat equally 5-15-rayed, with involucels of conspicuous, lanceolate, more or less united and usually very tomentose bractlets; rays $2-4 \mathrm{~cm}$. long; pedicels 2-6 $\mathrm{mm}$. long; flowers yellow, the ovaries densely pubescent: fruit orbicular to oblong, somewhat pubescent, 5-8 mm. long, 4-5 $\mathrm{mm}$. broad, with wings half as broad as body; oil-tubes 3 or 4 in the intervals, 4 on the commissural side: seed face plane.-From the plains of Assiniboia to Texas.

7. Cogswellia Jonesii (C. \& R.) Jones 1. c. 34. Resembling C. foeniculacea, but lower, more inclined to branch at base, at least the foliage persistently villous: leaves smaller, with more crowded segments: involucels of less conspicuous linear, usually distinct and villous bractlets; rays $1-3 \mathrm{~cm}$. long; pedicels 3-12 $\mathrm{mm}$. long; flowers yellow or tinged with purple: fruit elliptical or broadly oblong, pubescent, $8 \mathrm{~mm}$. long, 6-7 $\mathrm{mm}$. broad, with broader wings (more than half as broad as body).-From Utah and Wyoming to the Northwest Territory.

8. Cogswellia platycarpa (Torr.) Jones 1. c. 32. Caulescent or acaulescent, puberulent, often tall and stout: leaves ternate or biternate; leaflets very narrowly linear (almost filiform) to linear-lanceolate, 5-10 cm. long: umbel unequally 3-15-rayed, with involucels of lanceolate or setaceous bractlets; rays $1-7.5 \mathrm{~cm}$. long; pedicels $2-6 \mathrm{~mm}$. long; flowers yellow: fruit broadly oblong to nearly orbicular, sometimes emarginate at each end, 6-12 $\mathrm{mm}$. long, 4-10 $\mathrm{mm}$. broad, with wings broader than body (also extending below body), and prominent dorsal and intermediate ribs; oil-tubes large and solitary in the intervals, 2 on the commissural side: seed face slightly concave. Peucedanum simplex.-In the western part of our range to Montana and Washington.

9. Cogswellia macrocarpa (Nutt.) Jones 1. c. 33. Somewhat caulescent or nearly acaulescent, 1-6 dm. high, more or less pubescent, much branched at base, from a more or less elongated thick root: leaves pinnately (or first division ternate) compound; segments pinnately incised, ultimate divisions ovate or short-linear: umbel somewhat equally 3-10-rayed, with involucels of conspicuous, somewhat foliaceous, lanceolate or linear bractlets often united and unilateral; rays $2-10 \mathrm{~cm}$. long; pedicels 2-10 $\mathrm{mm}$. long; flowers white: calyx-teeth evident: fruit linear-oblong to broadly oblong, elliptical or ovate, glabrous, 6-20 mm. long, 3-7 mm. broad, with wings from very narrow to as broad as body, and filiform dorsal and intermediate ribs; oil-tubes solitary in the intervals (often obscure, rarely $2-3$ ), 2 or 4 on the commissural side: seed face with a slight central longitudinal ridge.-Throughout the western part of our range and west to the Pacific States.

10. Cogswellia orientalis Jones 1. c. 33. Acaulescent or shortly caulescent, with short and soft pubescence: peduncles 1-3 cm. high, and a thick elongated root (often swollen in places): leaves bipinnate, the small oblong segments entire or toothed: umbel unequally 5-8-rayed, with involucels of scarious-margined (often purplish) lanceolate, distinct bractlets; rays $1-3.5 \mathrm{~cm}$. long; pedicels glabrous, 5-7 mm. long; flowers white or pinkish, with glabrous ovaries: fruit almost round, emarginate at base, glabrous, $5 \mathrm{~mm}$. long, $4 \mathrm{~mm}$. broad, with wings not as broad as body, and indistinct or obsolete dorsal and intermediate ribs; oil-tubes solitary in the intervals (rarely 2 in the lateral intervals), 4 on the commissural side: seed face plane. Peucedanum nudicaule.-On the plains and foothills; N. Dakota to Kansas and far westward.

\section{CYNOMARATHRUM Nutt.}

Acaulescent plants or nearly so, from a stout caudex becoming multicipital and densely clothed with old leaf-sheaths, with leaves narrow in outline (the first division pinnate), and yellow flowers. Calyx-teeth evident. Fruit strongly flattened dorsally, oblong. Carpel with sharp or winged dorsal and 
intermediate ribs and broader winged laterals; stylopodium flat but evident, in dry specimens appearing spongy; oil-tubes mostly several in the intervals or obscure. Seed dorsally flattened, with plane face.

Foliage glabrous

Foliage scabrous

1. Cynomarathrum Nuttallii (Gray) C. \& R. Contrib. Nat. Herb. 7: 245. 1900. Acaulescent, glabrous: scape 1.5-4.5 dm. high, a little exceeding the leaves, arising from a stout caudex becoming multicipital: leaves pinnate or bipinnate; leaflets linear, elongated, cuspidate, sometimes $5 \mathrm{~cm}$.. long: umbel somewhat equally 4-20-rayed, with involucels of linear-lanceolate bractlets; rays $3-3.5 \mathrm{~cm}$. long; pedicels $2-6 \mathrm{~mm}$. long; flowers yellow: calyx-teeth evident: fruit oblong, $8-10 \mathrm{~mm}$. long, $4 \mathrm{~mm}$. broad, narrowly winged, the dorsal and intermediate ribs also sometimes irregularly winged; oil-tubes $3-5$ in the intervals, 6-10 on the commissural side: seed somewhat sulcate on the back with slightly concave face. Peucedanum graveolens.-From Nebraska through Wyoming to Utah.

2. Cynomarathrum Eastwoodae C. \& R. 1. c. 247. Stems low, much tufted at base: leaves shorter than the peduncles, very narrow in outline, once to twice pinnate, very scabrous; segments short and narrow, apiculate: rays few, nearly equal, 2-2.5 $\mathrm{cm}$. long; pedicels $12-18 \mathrm{~mm}$. long, usually longer than the fruit; involucels of several linear, entire bractlets: fruit glabrous, oblong, 8-10 mm. long, with wings nearly as broad as body: calyx-teeth evident.-Colorado.

\section{HERACLEUM L.}

Tall, stout perennials, with large, ternately compound leaves, deciduous involucres, involucels of numerous bractlets, large many-rayed umbel of white flowers, and obcordate petals (the outer ones often dilated and 2-cleft). Calyxteeth small or obsolete. Fruit broadly obovate, very much flattened dorsally, somewhat pubescent. Carpel with dorsal and intermediate ribs filiform; the broad lateral wings contiguous to those of the other carpel, strongly nerved toward the outer margin; strengthening cells continuous about seed cavity and under the nerves; stylopodium thick-conical; oil-tubes solitary in the intervals, conspicuous, about half as long as the carpel, 2-4 on the commissural side. Seed very much flattened dorsally.

1. Heracleum lanatum Michx. Fl. Bor. Am. 1: 166. 1803. Very stout, 12-24 dm. high, pubescent or woolly above: petioles much dilated; leaflets petiolulate, round-cordate, $10-25 \mathrm{~cm}$. broad, irregularly cut-toothed: rays 5-15 cm. long: fruit 8-12 mm. long, somewhat pubescent.-On wet banks; in most parts of the northern United States.

\section{PASTINACA L.}

A genus of stout plants resembling Heracleum, with thick roots, pinnate leaves, and compound umbels of yellow flowers. Seeds very flat. Oil-tubes solitary in the intervals, and 2-4 on the commissural side.

1. Pastinaca sativa L. Sp. PI. 1: 262. 1753. The common parsnip, a native of Europe. It has become widely dispersed as a weed in North America.

\section{CORNACEAE Link. Dogwood Family}

Trees or shrubs, rarely herbs, with simple and entire, mainly opposite leaves, no stipules, and flowers in cymes or involucrate heads. Petals and stamens 4 and epigynous. Calyx adherent to the 1-2-celled ovary, which becomes a 1-2-seeded drupe or berry. 


\section{CORNUS L. DogwOod}

Shrubs or perennial herbs, with opposite entire leaves and small flowers in open naked cymes or in close heads surrounded by a corolla-like involucre. Flowers perfect. Calyx minutely 4-toothed. Petals 4, oblong, spreading. Stamens 4, with slender filaments. Style slender, with terminal stigma. Fruit a small drupe with a 2-celled and 2-seeded stone.

A low herb, from a creeping rootstock . . . . . . . 1. C. canadensis. Shrubs.

Pubescence straight; stone irregular and scarcely flattened

Pubescence partly woolly; stone flattened .

2. C. stolonifera.

1. Cornus canadensis L.Sp.Pl. 117. 1753. Stems low and simple, 1-2 dm. high, from a slender creeping trunk: leaves scarcely petioled, the upper crowded into an apparent whorl of six or four, ovate or oval: flowers greenish, in a head or close cluster, which is surrounded by a large and showy, 4-leaved, corolla-like, white or rarely pinkish involucre: fruit bright red. (Cornella Rydb.) - Colorado and northward, thence eastward across the continent.

2. Cornus stolonifera Michx. Fl. Bor. Am. 1: 92. 1803. Shrub 1-2 m. high; branches, especially the osier-like annual shoots, bright red-purple, smooth: leaves ovate, rounded at the base, abruptly short-pointed, roughish with a minute close straight pubescence on both sides, whitish underneath: flowers white, in open and flat, spreading cymes; involucre none: fruit white or leadcolor. - Same range as the last.

3. Cornus Baileyi Coult. \& Evans. Bot. Gaz. 15: 37. 1890. Erect shrub, with reddish-brown mostly smooth branches; branchlets and inflorescence pubescent to woolly: leaves from lanceolate to ovate, acute or short-acuminate, appressed-pubescent to glabrate above, white beneath and with woolly hairs variously intermingled with appressed ones: flowers in small, rather compact cymes: calyx-teeth from small to prominent: fruit white; stone decidedly compressed, flat-topped, rarely oblique, with a very prominently furrowed edge, much broader than high. (Suida interior Rydb. Bull. Torr. Bot. Club 31: 572. 1904.) - Colorado to northeastern Wyoming and the Great Lakes.

\section{PYROLACEAE Agardh. Wintergreen Family}

Mostly low perennials, with simple, petioled, dark green leaves. Flowers perfect, solitary, racemose, or corymbose, nearly regular, white or purple. Calyx 4-5-lobed. Corolla of 5 distinct or but slightly united petals. Stamens twice as many as the corolla lobes; the anthers opening introrsely by pores or short slits, inverted in anthesis so that the real base with its pores becomes apical. Ovary superior; the style often declined. Fruit a loculicidal capsule with numerous seeds.

Flowers racemose; leaves basal

Flowers solitary-terminal; leaves whorled near the base - • • . 1. Pyrola.

3. Chimaphila.

\section{Pyrola L. Wintergreen}

Acaulescent evergreens, with a cluster of round or roundish leaves, and some scarious scales on the ascending summit of slender subterranean rootstocks. Scape more or less scaly-bracted, bearing a raceme of white, greenish, or purplish nodding flowers, in summer. Stamens 10; anthers emarginate or 2-beaked at the base. Disk usually obsolete. Ovary 5-valved from the base, the valves with cobwebby margins.

Style and stamens declined.

Flowers white or greenish; plants of dry ground.

Leaf-blades shorter than the petioles, leathery. Orbicular, not mottled

1. P. chloranthe. 
Ovate to oblong, usually mottled or blotched Leaf-blades oval or elliptic, membranous Flowers pink or purple; bog plant

Style straight; anthers connivent.

Raceme regular; style short

Raceme 1-sided; style elongated
2. P. picta.

3. P. elliptica.

4. P. uliginosa.

5. P. minor.

6. P. secunda.

1. Pyrola chlorantha Sw. Act. Holm. 190, Pl. 5. 1810. Leaves small, 1-3 cm. in diameter, orbicular or nearly so, coriaceous, not shining, shorter than the petiole: scape 1-2 dm. high, 3-10-flowered: calyx-lobes very short and obtuse or rounded, appressed to the greenish-white corolla: anther-cells with distinctly beaked tips: style strongly declined or decurved and toward the apex more or less curved upward, longer than the concave, somewhat campanulate-connivent or partly spreading petals; stigma much narrower than the truncate and usually excavated apex of the style, which forms a ring or collar.-Mountains of Colorado, northward and eastward.

2. Pyrola picta Smith, Rees, Cycl. 29: No. 8. Leaves firm-coriaceous, dull, commonly veined or blotched with white above, pale or sometimes purplish beneath, 3-5 cm. long, broadly ovate to spatulate or narrowly oblong, all longer than the petiole, the margins quite entire or rarely remotely denticulate: scapes 1-2 dm. high, 7-15-flowered; bracts few and short: calyx-lobes ovate, not half the length of the greenish-white petals: style as in the preceding.-Western Wyoming to Utah and California and thence northward.

3. Pyrola elliptica Nutt. Gen. 1: 273. 1818. Leaves oval or broadly oblong, 4-6 cm. long, membranaceous, acute or merely roundish at base, longer than their petioles, plicately serrulate: scape 1-2 dm. high, loosely several to many-flowered: calyx-lobes ovate and acute, short: corolla greenish-white: anther-tips hardly at all beaked: style as in the preceding.-Mountains of New Mexico to British Columbia, the northern Atlantic States, and Canada.

4. Pyrola uliginosa Torr. Fl. N. Y. 1: 453. pl. 60. 1843. Scape 1.5-4 dm. high, 7-15-flowered: blades broadly oval or orbicular, dull, rather thick, obscurely crenulate, obtuse at both ends: flowers $10-16 \mathrm{~mm}$. broad: calyxlobes oblong or ovate-lanceolate, one fourth to one third the length of the petals: anther-sacs beaked: capsule about $5 \mathrm{~mm}$. in diameter; style slightly exserted. ( $P$. asarifolia Michx. is very similar and scarcely distinguishable except by the somewhat smaller subcordate leaves.)-In bogs; across the continent northward and south in the mountains to Colorado.

5. Pyrola minor L. Sp. Pl. 396. 1753. Leaves orbicular, thinnish, obscurely serrulate or crenulate, about $2 \mathrm{~cm}$. long: scape 10-15 cm. high, 7-15flowered: petals white or flesh-colored, orbicular, naked at the base, globose connivent: stigma peltate, large, obscurely 5-lobed; hypogynous disk none; style straight, much narrower than the expanded, depressed, 5-rayed stigma: anthers not narrowed below the openings.-Mountains; from New Mexico to Oregon and northward, thence eastward across the continent.

6. Pyrola secunda L. l. c. Inclined to be caulescent from a branching base: leaves thin, ovate, serrulate or crenate, $3-5 \mathrm{~cm}$. long: scape $10-15 \mathrm{~cm}$. long, bearing numerous flowers in a secund, spike-like raceme: petals greenish-white, oblong, each with a pair of tubercles on the base, equally connivent: stigma peltate, large, 5-lobed; hypogynous disk 10-lobed.-Mountains of Colorado, California, and far northward and eastward.

\section{MONESES Salisb.}

Petals 5, widely spreading, orbicular. Filaments awl-shaped, naked; anthers as in Purola, but conspicuously 2-horned. Style straight, exserted; stigma large, peltate, with 5 narrow and conspicuous radiating lobes. Valves of the capsule naked. (Flowers occasionally tetramerous). Scape 1-flowered. Otherwise as Pyrola; intermediate between it and Chimaphila.

1. Moneses uniflora (L.) Gray, Man. 273. 1848. Herb with 1-flowered scape $5-10 \mathrm{~cm}$. high, a cluster of roundish and serrulate thin leaves at base on a short stem or the ascending summit of a filiform rootstock: corolla white 
or tinged with rose-color, $15-18 \mathrm{~mm}$. in diameter.-Deep moist woods; Colorado and Utah to Oregon, Pennsylvania, and northward.

\section{Chimaphila Pursh. Pipsissewa}

Low, nearly herbaceous plants, with long running underground shoots, and evergreen thick and shining leaves somewhat whorled or scattered along the short ascending stems. The fragrant (white or purplish) flowers corymbed or umbelled on a terminal peduncle. Petals 5, concave, orbicular, widely spreading. Stamens 10; filaments enlarged and hairy in the middle; anthers as in Pyrola, but more or less conspicuously 2-horned. Style very short, inversely conical, nearly immersed in the depressed summit of the globular ovary; stigma broad and orbicular, disk-shaped, the border 5-crenate. Capsule, etc., as in Pyrola, but splitting from the apex downward, the edges of the valves not woolly.

1. Chimaphila umbellata Nutt. Gen. 1: 274. 1818. Stem stout, 1-3 dm. high, very leafy, often branched: leaves cuneate-oblanceolate with tapering base, sharply serrate, not spotted, bright green and shining, 2-7 cm. long: flowers several, umbellate or subcorymbose, white or pinkish; bracts narrow, deciduous: filaments hairy on the margins only.-In dry woods; across the continent; also in Europe and Asia.

\section{MONOTROPACEAE Lindl. Indian Pipe Family}

Fleshy herbs, parasitic or more often saprophytic, usually pale (tawny or flesh-color), the leaves reduced to mere scales upon the scapes. Flowers much as in Pyrolaceae.

Petals united (sympetalous), persistent

Petals distinct, deciduous.

Flowers solitary, inodorous

Flowers racemose, odorous

\section{PTEROSPORA Nutt. Pinedrops}

Scape tall, scaly-bracted, from a thick base with matted fibrous roots. Calyx deeply 5-parted. Corolla globular urn-shaped. Stamens 10, included. Disk none. Stigma 5-lobed. Capsule depressed-globular, 5-lobed. Seeds innumerable, broadly winged from the apex.

1. Pterospora Andromeda Nutt. Gen. 1: 269. 1818. Stems simple, stout, purplish-brown, 3-8 dm. high or more, glandular and viscid-pubescent throughout, bearing numerous lanceolate or linear scales and many flowers in a long raceme: pedicels slender, spreading, soon recurved, 7-20 mm. long: sepals oblong, 2-4 mm. long: corolla white, $6 \mathrm{~mm}$. long, viscid.-In rich woods; probably parasitic on the roots of conifers; the Rocky Mountains and across the continent northward.

\section{MONOTROPA L. Indian Pipe}

Low fleshy plants with many scattered scale-like bracts and a solitary nodding white flower. Calyx of 2-4 irregular sepals, or perhaps bracts, the lower ones rather distant from the flower, deciduous. Petals 5 , rarely 6 , erect, not saccate at base, tardily deciduous. Stamens twice as many as petals; filaments filiform-subulate; anthers somewhat reniform, opening at first by two transverse chinks, at length 2 -valved, the valves almost equal and equally spreading. Style short and thick; stigma funnelform with naked edge. Capsule ovoid, erect in fruit. Seeds small, very numerous, with loose cellular coat. 
1. Monotropa uniflora I.Sp. Pl. 387. 1753. Smooth, waxy-white (turning blackish in drying), 1-flowered inodorous plant, 7.5-20 cm. high: calyx of 2-4 irregular scales or bracts: anthers transverse, opening equally by 2 chinks: style short and thick; stigma naked.-Damp woods throughout the continent.

\section{HYPOPITYS Dill. PinesaP}

Plant often scented, commonly pubescent, at least above, racemosely 3several-flowered. Terminal flower earliest and usually 5-merous and the lateral 3-4-merous. Sepals less bract-like, as many as the petals; the latter saccate at base. Anthers more reniform; the cells completely confluent into one, which opens by very unequal valves, the larger broad and spreading, the other remaining erect and contracted. Stigma glandular or hairy on the margin.

1. Hypopitys multiflora Scop. Fl. Carn. Ed. II. 1: 285. 1772. Somewhat pubescent or downy, tawny, whitish, or reddish, commonly fragrant plants, 10-30 cm. high: flowers several in a scaly raceme; the terminal one usually 5-merous, the rest 3-or 4-merous: bract-like sepals mostly as many as the petals: anthers opening by a continuous line into 2 very unequal valves: styles longer than the ovary, hollow; stigma ciliate: pod globular or oval. Monotropa Hypopitys.-Under coniferous trees in temperate regions.

\section{ERICACEAE DC. Heath Family}

Shrubs, perennial herbs, or trees, with simple exstipulate leaves and mostly perfect sympetalous or rarely choripetalous flowers. Calyx free from the ovary, 4-5-parted or 4-5-cleft, mostly persistent. Corolla regular or rarely somewhat 2-lipped and irregular, usually 4-5-toothed, lobed, or divided. Stamens hypogynous, usually as many or twice as many as the corolla-lobes; filaments mostly separate; anthers 2-celled, attached to the filament by the back or base, the sacs often prolonged above into tubes, dehiscent by terminal pores or chinks, often awned. Disk crenate-lobed or often none. Ovary 2-5-celled; style elongated or short: stigma peltate or capitate; ovules usually numerous. Fruit a capsule, berry or drupe. Seeds numerous or sometimes only 1 in each cavity.

Fruit a dry capsule.

Anther-cells each tipped with a recurved awn; leaves opposite

Anther-cells not appendaged; leaves alternate.

Corolla sympetalous.

Leaves heath-like (linear, obtuse)

Leaves lanceolate to elliptic. Corolla urn-shaped Corolla saucer-shaped Corolla of separate petals

Fruit more or less fleshy.

Fruit a capsule inclosed in the fleshy calyx

Fruit a berry or drupe, not inclosed in the calyx

- 1. Cassiope.

2. Phyllodoce.

3. Menziesia.

4. Kalmia.

5. Ledum.

6. Gaultheria.

7. Arctostaphylos.

\section{CASSIOPE D. Don.}

Low, tufted, heath-like, evergreen shrubs, with small, sessile, imbricated, entire leaves, and solitary peduncled white or pink nodding flowers. Sepals 4 or 5. Corolla campanulate, 4-5-lobed. Stamens 8-10, included; anthers attached to the filaments near the apex, the sacs opening by large terminal pores and tipped with a recurved awn. Capsule globose or ovoid, 4-5-valved. Seeds minute, numerous.

ROCKY MT. BOT. - 24 
1. Cassiope Mertensiana (Bong.) Don. Hirt. Dichl. Pl. 3: 829. 1834. A low Lycopodium-like plant with small imbricate.4-ranked carinate glabrous leaves (2-4 mm. long), lateral peduncles, and pinkish bell-shaped corolla.Mountain sides; Montana to the Pacific States and northward.

\section{PHYLlODOCE Salisb. Mountain Heath}

Low branching shrubs, with small, crowded, linear, obtuse, evergreen leaves. Flowers long-pediceled, nodding, mostly pink, blue, or purple, in terminal umbels. Calyx 5-parted, persistent. Corolla contracted at the throat, 5toothed. Stamens 10, included; anthers oblong, obtuse, the sacs dehiscent by oblique chinks. Ovary 5-celled; ovules numerous; stigma obscurely 5-lobed, or capitate. Capsule subglobose or globose-oblong.-Bryanthus.

Corolla campanulate, red; sepals obtuse

Corolla ovoid, yellowish; sepals usually acute

1. P. empetriformis. 2. P. glanduliflora.

1. Phyllodoce empetriformis (Smith) Don, Edinb. New Phil. Journ. 17: 160. 1834. Densely branched from the base, $2-5 \mathrm{dm}$. high, often forming clumps $1 \mathrm{~m}$. in diameter: leaves 6-14 mm. long, with strongly revolute, thickened, and rough margins: pedicels several, somewhat umbellate, minutely glandular, subtended by foliaceous and rfgid bracts: corolla rose-color, 5-8 $\mathrm{mm}$. long, campanulate, barely 5-lobed, the lobes much shorter than the tube: stamens included.- In the mountains from Wyoming and Colorado to California and Alaska.

2. Phyllodoce glanduliflora (Hook.) Coville, Mazama 1: 196. 1897. Stems rather rigid, fastigiately branched, 1-3 dm. high: leaves numerous and crowded but somewhat spreading, linear-oblong, obtuse, 6-12 $\mathrm{mm}$. long, thick, with a white line through the center below and a deep furrow above, narrowed at base to a short petiole, the margins thick and scabrous: pedicels $15-25 \mathrm{~mm}$. long, glandular-hirsute: sepals lanceolate, acutish to acuminate, $4 \mathrm{~mm}$. long, glandular-hirsute: corolla yellowish, ovoid, 3-4 lines long; the short lobes glabrous.-On rocky banks and cliffs near perpetual snow; Oregon to Alaska and the Rocky Mountains.

2a. Phyllodoce glanduliflora intermedia (Hook.) A. Nels. . Probably a hybrid between the two foregoing and hence variable, but usually with yellowish or pale red corolla, moderately glandular, and sepals either obtuse or acute. [P. intermedia (Hook.) Rydb. Mem. N. Y. Bot. Gard. 1: 298. 1900; P. hybrida Rydb. 1. c. 299.] -The two species and the hybrid frequently occur near each other.

\section{MENZIESIA Smith}

Shrubs with alternate deciduous leaves and small mostly dull-colored flowers on nodding pedicels. Calyx bristly-hirsute, usually 4-lobed. Corolla globular-urceolate to cylindraceous, 4-toothed or lobed. Stamens not exserted, usually 8 ; filaments subulate; anthers mostly linear-sagittate, the cells opening by an oblique pore or short chink. Style not exserted; stigma truncate. Capsule short.

1. Menziesia ferruginea Smith Ic. Pl. 3: pl. 56. 1791. Erect or straggling shrub, 1-2 m. high: leaves oblong or elliptic, acute at both ends, often with strigose-chaffy, ferruginous scales, more or less rusty strigose above, paler beneath, usually mucronate and ciliate with glandular bristles: filaments glabrous or ciliate below: capsule ovate: seeds apiculate or appendaged at each end. (M. urceolaria Salisb.; M. glabella Gray.)-Yellowstone Park to Oregon and Alaska.

\section{KALMia L. American Laurel}

Leaves evergreen and entire. The showy flowers umbellate-clustered, rosecolored, purple, or white. Limb of the corolla in bud strongly 10-keeled from 
the pouches upward, the salient keels running to the apex of the lobes and to the sinuses.

1. Kalmia polifolia Wang. Ges. Naturf. Fr. Berl.Sohr. 2: 130. 1788. Shrub 2-5 dm. high, glabrous, mostly glaucous, branchlets 2-edged: leaves all opposite or rarely in threes, almost sessile, oblong or linear-oblong, or appearing narrower by the usually strong revolution of the edges, glaucous-white beneath: flowers in spring in a simple terminal umbel or corymb, lilac-purple, 12-15 mm. in diameter. K.glauca. [Var. microphylla Hook.; K. microphylla (Hook.) Heller, Bull. Torr. Bot. Club 25: 581. 1898.]-Bogs; Colorado and northward, thence eastward across the continent. The forms extending southward into the Colorado mountains are depauperate alpine forms, 1-2 dm. high, and with leaves about $12 \mathrm{~mm}$. long.

\section{LEDUM L. Labrador Tea}

Low shrubs, with alternate, persistent leaves, which are entire and more or less resinous-dotted, slightly fragrant when bruised. Flowers white, developed in early summer from terminal or sometimes lateral buds; pedicels recurved in fruit.

1. Ledum glandulosum Nutt. Trans. Am. Phil. Soc. 8: 270. 1843. Shrub 5-15 dm. high, stout: leaves oblong or oval, or approaching lanceolate, $3-5 \mathrm{~cm}$. long, glabrous both sides, pale or whitish and minutely resinous-atomiferous beneath: inflorescence often compound and crowded: capsules oval, retuse.From California northward and eastward into British America; occurring in the northwestern border of our range.

\section{GaUltheria L. Creeping Wintergreen}

Shrubs, with alternate evergreen leaves, and small axillary white, red, or pink flowers. Calyx 5-parted or 5-cleft, persistent. Corolla urn-shaped or campanulate, 5-toothed or 5-lobed. Stamens 10, included; anther-sacs opening by a terminal pore, commonly awned. Stigma obtuse, entire; ovary 5-celled, 5-lobed. Calyx becoming fleshy and at length surrounding the capsule, forming a berry-like fruit.

1. Gaultheria humifusa (Graham) Rydb. Mem. N. Y. Bot. Gard. 1: 300 . 1900. Caespitose-procumbent or depressed, glabrous, the flowering branches $3-10 \mathrm{~cm}$. long: leaves oval or rounded, mostly only $12-14 \mathrm{~mm}$. long: pedicels solitary in the axils, very short, 3-5-bracteolate: corolla depressed-campanulate, little surpassing the calyx: fruit scarlet, $5-6 \mathrm{~mm}$. in diameter. $G$ myrsinites.-In the woods in the mountains; our range and northwestward.

\section{ARCTOSTAPHYLOS Adans. BearberRy}

Shrubs. Leaves alternate, petioled, firm or coriaceous, evergreen. Flowers small, nodding, pediceled, white or pink. Calyx 4-5-parted, persistent. Corolla 4-5-lobed, the lobes recurved. Stamens 10, rarely 8, included; anthers short, with 2 recurved awns on the back, the sacs opening by a terminal pore. Ovary 4-10-celled; ovules solitary in the cavities; style slender. Fruit a berry-like drupe, with 4-10 seed-like nutlets coherent into a solid stone.

1. Arctostaphylos uva-ursi (L.) Spreng. Syst. 2: 287. 1825. Depressedtrailing or creeping, green: leaves coriaceous and evergreen, oblong-spatulate, retuse, $1-2 \mathrm{~cm}$. long, tapering into a petiole: flowers rather few in simple small clusters, 4-5 mm. long: ovary and reddish fruit glabrous: nutlets 1nerved on the back.-From New Mexico to Pennsylvania, California, and northward. Often called KinNikINNICK as well as BEARBERRY. 


\section{VACCINIACEAE Lindl. Huckleberry Family}

Shrubs with alternate leaves, and small white, pink, or red flowers in racemes or clusters, or solitary in the axils. Calyx-tube globose, hemispheric, or turbinate, not angled, adnate to the ovary, the limb 4-5-toothed or 4-5-lobed, persistent. Corolla sympetalous, urn-shaped or cylindric, rarely subglobose, its limb 4-5-toothed or 4-5-lobed. Stamens twice as many as the lobes of the corolla; anthers upwardly prolonged into tubes, opening by terminal pores or chinks. Ovary 4-5-celled, or 8-10-celled by false partitions; ovules several or numerous; stigma small. Fruit a many-seeded berry.

\section{VACCINIUM L. BLUEBERRIES}

Characters of the family.

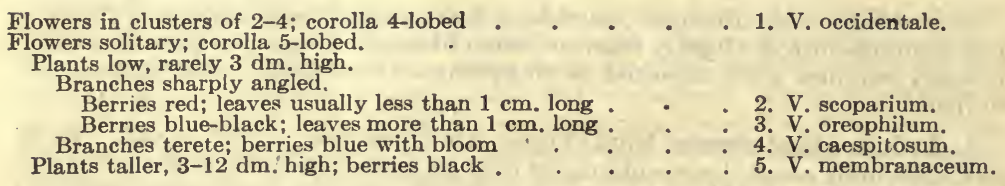

1. Vaccinium occidentale Gray, Bot. Cal. 1: 451. 1876. Glabrous shrub, 3-8 dm. high: leaves rather thin, glaucescent, obscurely veiny, oval to obovate-oblong or oblanceolate, obtuse or acutish, 12-20 $\mathrm{mm}$. long: flowers $2-4$, or rarely solitary: corolla oblong-ovate: berries small, 5-6 $\mathrm{mm}$. in diameter.-Extending to Wyoming from California and Washington.

2. Vaccinium scoparium Leiberg, Mazama 1: 196. 1897. Low, branches sharply angled and green: leaves small, glabrous, ovate or oval, thin, shining, serrate, conspicuously reticulated-veiny, and with a prominent narrow midrib (7-15 mm. long): limb of calyx almost entire: corolla globular-ovate: berries black, nodding. V. Myrtillus microphyllum. (V. erythrococcum Rydb. Mem. N. Y. Bot. Gard. 1: 301. 1900.)-Common throughout our range, and far northwestward.

3. Vaccinium oreophilum Rydb. Bull. Torr. Bot. Club 33: 148. 1906. Slender-branched, 2-6 dm. high, glabrous throughout; branchlets more or less angled: leaves ovate or oval, 1-3 cm. long, minutely serrate, reticulate-veiny, with prominent narrow midrib: limb of calyx nearly obsolete: corolla globular: berry blue-black or black. V. Myrtillus.-Colorado to Montana and westward.

4. Vaccinium caespitosum Michx. Fl. 1: 234. 1803. Nearly glabrous throughout: leaves 12-25 mm. long, green and shining both sides, nearly sessile, serrulate: flowers longer than their pedicels: corolla obovoid or obovoidoblong, pink or white, rarely 4-toothed: stamens rarely 8: berry blue with a bloom, sweet, about $6 \mathrm{~mm}$. in diameter.-Across the continent northward; extending south in the mountains to Colorado.

5. Vaccinium membranaceum Dougl. Hook. Fl. Bor. Am. 2: 32.1834. Nearly or quite glabrous, 3-12 dm. high, the branchlets more or less angled: leaves thin, 1-3 cm. long, oblong or ovate, obtuse or acute, paler beneath, reticulate, finely serrate: calyx-teeth nearly obsolete: corolla subglobose, yellowish-green or purplish: berry purplish-black or black, 6-7 $\mathrm{mm}$. in diameter, rather acid. [V.globulare Rydb. Mem. N. Y. Bot. Gard. 1: 300. 1900; V. macrophyllum (Hook.) Piper, Contrib. Nat. Herb. 11: 443. 1906.]-Northern Wyoming and Montana and far westward.

\section{PRIMUlaceae Vent. Primrose Family}

Herbs with simple leaves and symmetrical flowers. Calyx usually 5-parted, free, or rarely adnate to the base of the ovary, imbricated in the bud, usually 
persistent. Corolla hypogynous, except in Samolus in which it coheres below with the base of the ovary, usually 5-parted, wanting in Glaux. Stamens as many as the lobes of the corolla and opposite to them, inserted on the tube or base of the corolla, rarely perigynous; anthers introrse. Ovary 1-celled, with a free central placenta. Fruit capsular.

Ovary wholly superior.

Corolla present.

Scapose plants with basal leaves.

Corolla-lobes erect or spreading; stamens included, distinct.

Corolla-tube equaling or exceeding the calyx.

Corolla-lobes obcordate or emarginate; capsule many-seeded 1. Primula.

Corolla-lobes entire; capsule few-seeded $\left.(1-2) \cdot{ }^{2}\right)$
Corolla-tube shorter than the calyx.

Perennials; umbel subcapitate; capsule few-seeded . . 3. Drosace.

Annuals; umbel open; capsules many-seeded $\quad \dot{0}$ 4. Androsace.

Corolla-lobes reflexed; stamens exserted, connivent in a cone and somewhat monadelphous

Leafy-stemmed plants.

Flowers solitary in the axils

Flowers in short axillary spikes

Corolla wanting; calyx petaloid; leaves opposite

Ovary adnate to the calyx

\section{PRIMUla L. Primrose}

Perennial scapose herbs with leaves all radical and flowers umbellate or in involucrate or bracted racemose. whorls at the summit of a scape. Calyx tubular, funnelform, or campanulate; persistent, often angled, 5-lobed, the lobes imbricated. Corolla funnelform or salverform, the tube longer than or at least equaling the calyx. Stamens 5, distinct, inserted on the tube or at the throat of the corolla. Style filiform; stigma capitate. Capsule 5-valved at the summit, many-seeded.

Leaves white-mealy beneath

Leaves green.

Plants small, 3-10 cm. high

Plants with large leaves; scapes $1.5-4 \mathrm{dm}$. high
1. P. americana.

2. P. angustifolia. 3. P. Parryi.

1. Primula americana Rydb. Bull. Torr. Bot. Club 28: 500. 1901. Perennial: leaves oblong or oblong-oblanceolate or spatulate, $2-8 \mathrm{~cm}$. long, obtuse, gradually contracted at the base, sinuate-dentate or subentire, thin, more or less mealy: scape 1-2 dm. high, mealy when young; bracts $6-10 \mathrm{~mm}$. long, linear-lanceolate; pedicels in flower little if any exceeding the bracts, in fruit sometimes $2 \mathrm{~cm}$. long: calyx 6-8 $\mathrm{mm}$. long; lobes oblong-obtuse: corolla lilac; tube $8-9 \mathrm{~mm}$. long, only slightly exceeding the calyx; the lobes obcordate, 2-3 mm. long. P. farinosa.-Wet meadows; Colorado to Montana.

2. Primula angustifolia Torr. Ann. Lyc. N. Y. 1: 34. 1824. Small: scape 1-flowered, $3-10 \mathrm{~cm}$. high, equaling or surpassing the lanceolate-spatulate obtuse entire short-petioled leaves: involucre of 1 or 2 minute bracts: lobes of the lilac-purple corolla obovate, emarginate $6-8 \mathrm{~mm}$. long; the tube hardly exceeding the narrow teeth of the oblong calyx.-Alpine in Colorado and Wyoming.

3. Primula Parryi Gray, Am. Journ. Sci. II. 34: 257. 1862. Large: leaves rather succulent, spatulate-oblong or oblanceolate, 1-3 dm. long, often denticulate: scape 1.5-4 dm. high, 3-12-flowered; bracts of the involucre subulate: calyx ovoid-campanulate, glandular, commonly reddish; the lanceolatesubulate lobes as long as the tube: corolla crimson-purple with yellow eye; the round, obovate lobes about $10 \mathrm{~mm}$. long, emarginate or obcordate.-A handsome plant but very rank smelling; along subalpine brooks; Colorado to Montana.

\section{DOUGLASIA Lindl.}

Depressed and tufted small herbs with suffrutescent or at least persistent stems, imbricated or crowded leaves, and solitary or somewhat umbellate 
small flowers. Calyx campanulate, 5 -lobed, persistent. Corolla-tube equaling or surpassing the calyx, somewhat inflated above; the throat more or less contracted and 5-crested beneath the sinuses. Stamens included, distinct, with short filaments and blunt anthers. Ovary 5-ovuled; style filiform. Capsule turbinate; 1 or 2 -seeded.

Flowers solitary; leaves dark green, subulate, imbricated on the shoots from the slender branches of the caudex

Flowers 2-3 (sometimes solitary); leaves pale, closely rosulate on the - crowns of the low-caespitose caudex

1. D. montana.

2. D. biflora.

1. Douglasia montana Gray, Proc. Am. Acad. 7: 371. 1868. Caespitose, the caudex slender-branched and terminating in short leafy shoots: leaves subulate, somewhat interruptedly imbricate-clustered, sparsely and minutely ciliate, about $4 \mathrm{~mm}$. long: peduncles short, slender, 1-flowered, with 1-2 minute bractlets: corolla-tube equaling the calyx; corolla-lobes obovatecuneate, about $4 . \mathrm{mm}$. long.- In the mountains of northern Wyoming and in Montana.

2. Douglasia biflora A. Nels. Bull. Tor. Bot. Club 25: 277. 1898. Broadly caespitose, the numerous suffrutescent branches of the depressed caudex crowned with a rosulate cluster of leaves: leaves lanceolate-linear, blunt, 9-12 $\mathrm{mm}$. long: peduncles pubescent, fascicled, 3-5 from the terminal rosette of leaves, 1-3 cm. long, bearing usually a terminal, nearly sessile flower and 1 or 2 lateral, slender-pediceled ones (sometimes only the terminal one): calyxtube subscarious, turbinate; calyx-lobes about as long as the tube: corollatube as long or longer than the calyx, equaled by the obovate, truncate, emarginate or denticulate lobes: capsule subspherical (turbinate at base).Northern Wyoming and in Montana.

\section{DROSACE A. Nels.}

Perennials with depressed-caespitose branched caudex. Leaves rosulateimbricated on the crowns of the caudex. Scapes (peduncles) solitary from each of the several crowns, few to several-flowered. Flowers in a subcapitate umbel. Corolla white or yellowish. Capsule few-seeded.

1. Drosace carinata (Torr.) A. Nels. A depressed perennial, the short branches of the caudex terminating in a close rosulate cluster of leaves: leaves small, usually less than $1 \mathrm{~cm}$. long, mostly oblong, subacute, white-ciliate, somewhat keeled: scape and umbel moderately ciliate-hirsute: calyx-tube campanulate, as long as the lanceolate lobes: corolla-lobes obovate, as long as the tube: stamens near the middle of the tube: capsule globose. $A n$ drosace Chamaejasme. (Probably not A. Chamaejasme Willd. Sp. Pl. 1: 799; Douglasia Johnstonii A. Nels. Proc. Biol. Soc. Wash. 20: 57. 1907.)-Colorado and far northward in the Rocky Mountains.

\section{ANDROSACE L.}

Small annual herbs with tufted leaves and small white or pink flowers. Calyx persistent, 5-lobed to 5-parted. Corolla salverform or funnelform; the tube short, not longer than the calyx; the limb 5-lobed, imbricated in bud. Stamens 5, included, distinct, with short filaments and short blunt anthers. Style mostly short; stigma capitellate. Capsule short, 5-valved from the apex, few to many-seeded.

Corolla shorter than or barely equaling the calyx.

Bracts of the involucre ovate or oblong

Bracts of the involucre lance-subulate.

Calyx-lobes densely-puberulent, exceeding the capsule
Calyx-lobes glabrous, shorter than the capsule $\quad: \quad 2$. A. puberulenta.

Corolla longer than the calyx.

Capsule exceeded by the calyx-lobes.

Scape long $(9-20 \mathrm{~cm}$.), usually much longer than the pedicels

Scape short $(2-5 \mathrm{~cm})$, often equaled or exceeded by the pedicels

Capsule much exceeding the calyx-lobes

4. A. septentrionalis،

5. A. subumbellata.

6. A. filiformis. 
1. Androsace occidentalis Pursh, Fl. Am. Sept. 137. 1814. Minutely pubescent, not over $1 \mathrm{dm}$. high: radical leaves and those of the conspicuous involucre oblong-ovate or spatulate, entire, sessile: scapes diffuse: lobes of the calyx as long as the tube: lobes of the corolla oblong, shorter than the calyx: calyx-tube obpyramidal in fruit, whitish with conspicuous green teeth which surpass the capsule.-From Illinois to the eastern base of the Rocky Mountains.

2. Androsace puberulenta Rydb. Bull. Torr. Bot. Club 30: 260. 1903. A puberulent, rosulate annual: leaves oblanceolate, $1-3 \mathrm{~cm}$. long, acute, entire or sinuately denticulate, densely puberulent: peduncles several, $3-10 \mathrm{~cm}$. long; bracts narrowly lanceolate, $3-4 \mathrm{~mm}$. long; pedicels $1-5 \mathrm{~cm}$. long, spreading, densely puberulent: calyx $3-4 \mathrm{~mm}$. long, cleft to the middle; tube glabrous, turbinate; lobes lanceolate, strongly keeled, densely puberulent, in fruit much exceeding the short capsule: corolla white, about equaling the calyx.-From New Mexico to Manitoba.

3. Androsace diffusa Small, Bull. Torr. Bot. Club 25: 318. 1898. Leaves oblanceolate to spatulate or nearly linear, 1-4 cm. long, obtuse or acute, sharply serrate or sparingly toothed: scapes erect and spreading, 5-10 cm. long or shorter; pedicels filiform, very variable in length, 'often $1-8 \mathrm{~cm}$. long in the same cluster: corolla white or pink, included; segments oblong, obtuse or retuse at apex: capsules subglobose, about $3 \mathrm{~mm}$. in diameter.-In rocky soil; western arctic America to the Dakotas, New Mexico, and Arizona.

4. Androsace septentrionalis L. Sp. Pl. 142. 1753. Almost glabrous: leaves lanceolate or oblong-lanceolate, narrowed at base, from irregularly denticulate to laciniate-toothed: scapes erect, $8-20 \mathrm{~cm}$. high; bracts of the small involucre subulate: lobes of the calyx mostly shorter than the tube: lobes of the corolla obovate, longer than the calyx. (A. pinetorum Greene, Pitt. 4: 149. 1900.)-From New Mexico far northward and westward; also in Europe.

- 5. Androsace subumbellata (A. Nels.) Small, 1. c. 319. Similar to the preceding but greatly reduced in size, only a few $\mathrm{cm}$. high: leaves $5-10 \mathrm{~mm}$. long, oblong, rather thick, mostly entire: scapes few-flowered, short, sometimes shorter than the pedicels. - In the alpine regions of our range.

6. Androsace filiformis Retz. Obs. 2: 10. 1779-91. Annual: leaves ovate, obtuse, narrowed at base to a winged petiole, entire, 5-10 $\mathrm{mm}$. long: scapes filiform, 5-20 cm. high; bracts of the involucre minute, subulate; pedicels filiform: calyx-tube hemispherical, green, with short triangular lobes: tube of the corolla at length much longer than the calyx, the short ovate lobes closely reflexed: capsule ovoid, much longer than the calyx: seeds globular, minutely tuberculate. (A. capillaris Greene, 1. c. 148.)-Cold wet banks, in the mountains and in the arctic regions.

\section{Dodecatheon L. Shooting Star. American Cowslip}

Low acaulescent perennial herbs, with entire leaves and few or numerous flowers in an umbel terminating a naked scape. Calyx deeply 5-lobed, the lobes reflexed in flower, erect in fruit. Corolla 5-parted, with very short tube and dilated thickened throat, the long and narrow divisions reflexed. Stamens inserted on the throat of the corolla; filaments short and flat, monadelphous, but separable in age. Style filiform, exserted; stigma small. Placenta columnar, many-ovuled.

Capsule dehiscing by valves from the apex; filaments united and yellow, or wanting.

Filaments short or wanting, the stamineal tube, if any, rarely more than $1 \mathrm{~mm}$. long.

Scape stout; leaves thickish; flowers many; bracts acute

Scape slender; leaves thin; flowers few; bracts obtuse or acute

Filaments evident, the stamineal tube from one half to as long as the anthers.

Anthers and stamineal tube subequal.

Plant more or less puberulent; bracts lanceolate, acute Plant wholly glabrous: bracts oblong, mostly obtuse

1. D. radicatum.

2. D. philoscia.

3. D. Cusickii.

4. D. salinum. 
Anthers at least twice as long as the stamineal tube Capsule circumscissile; filaments short, free or nearly so

5. D. pauciflorum.

6. D. conjugens.

1. Dodecatheon radicatum Greene, Erythea 3: 37. 1895. Glabrous: corm short, fibrous-rooted or with a semblance of a taproot: leaves few, rather large and thin, 8-20 cm. long, mostly oblanceolate or spatulate, obtuse: scape moderately stout, $2-4 \mathrm{dm}$. high; bracts lanceolate; flowers several to many: calyx-lobes lanceolate, about equaling the tube: corolla pinkish or bluishviolet; the lobes oblong, obtuse: stamineal tube very short, or wanting; anthers acute, 6-8 mm. long: capsule narrowly ovate, but slightly surpassing the calyxlobes. (D. multiflorum Rydb. Bull. Torr. Bot. Club 31: 631. 1904.)-Wet copses and shaded banks; New Mexico to Wyoming.

2. Dodecatheon philoscia A. Nels. Bull. Torr. Bot. Club 28: 227. 1901. Glabrous throughout: scape $1.5-3 \mathrm{dm}$. high, very slender, few-flowered: leaves few, elliptic to oblong, mostly obtuse: bracts oblong: calyx-lobes lanceolate, 2-3 mm. long, longer than the tube: united part of the corolla with a purple wavy line; lobes deep sky-blue, narrowly oblong: united filaments $1 \mathrm{~mm}$. or less long, yellow; anthers broadly subulate; connective linearacuminate: capsules on slender erect pedicels (which are 2-4 cm. long), subcylindric, about $4 \mathrm{~mm}$. in diameter and $1 \mathrm{~cm}$. long, twice as long as the calyx, splitting only at the summit. (D. sinuatum Rydb. 1.c.33: 148.)-Borders of shaded mountain streams; Wyoming and Colorado.

3. Dodecatheon Cusickii Greene, Pitt. 2: 73. 1890. More or less pubescent and glandular: leaves broadly to narrowly lanceolate, entire, or dentate toward the apex, usually obtuse, $3-9 \mathrm{~cm}$. long, narrowed below to a winged petiole: scapes 7-15 cm. high, few-flowered; bracts lanceolate: lobes of the calyx lanceolate, acute, but little longer than the tube: corolla-lobes dark purple with yellow base and a dark purple line at the mouth of the tube: stamen-tube less than $2 \mathrm{~mm}$. long; anthers yellow with a black stripe through the center: capsule ovoid, acute, scarcely surpassing the calyx, 5-valved from the apex. [D. puberulenta Heller, Bull. Torr. Bot. Club 24: 311. 1897; $D$. puberulum (Nutt.) Piper, Contrib. Nat. Herb. 11: 445. 1906.]-Extending into Wyoming and Montana from Oregon and Washington.

4. Dodecatheon salinum A. Nels. 1. c. 26: 131. 1899. Crown short; roots numerous, fascicled, slender but somewhat fleshy: leaves widely spreading or ascending, glabrous, elliptic, sometimes obovate or oblanceolate, obtuse, 2-4 cm. long, on slender petioles: scape slender, $10-20 \mathrm{~cm}$. high, glabrous as is also the inflorescence; bracts few, oblong or spatulate, mostly obtusish; flowers few to several: segments of the corolla lilac-purple, the undivided part yellowish-white with an indistinct purplish ring near the base: anthers purple with whitish margins: capsule elliptic, somewhat exceeding the calyx, splitting from the obtuse summit into two equal valves.-Wet alkali soils; western Wyoming and in Utah and Idaho.

5. Dodecatheon pauciflorum (Durand) Greene, 1. c. 72. 1890. The short, perpendicular crown solitary, simple, producing neither bulbets nor offsets; herbage glabrous, glandless: leaves deep green, entire, suberect, one fourth or one third as long as the scape: bracts of the few-flowered umbel lanceolate: segments of corolla rich lilac-purple, the undivided part yellow, with a narrow scalloped ring of deep purple midway between the base of the segments and the stamen-tube: stamen-tube about half as long as the anthers, yellow; anthers purple: capsule crustaceous, 10-14 mm. long, slender, nearly cylindrical, acute, opening by 5 short teeth. [D. cylindrocarpum Rydb. Mem. N. Y. Bot. Gard. 1: 305. 1900; D. vulgare (Hook.) Piper, l. c.]-The commonest species of our range and extending far to the northwestward.

6. Dodecatheon conjugens Greene, Erythea 3: 40. 1895. Short crown with a dense fascicle of fleshy fibrous roots that are deciduous from it after the flowering; whole plant glabrous: leaves obovoid and elliptic, 5-14 cm. long including the distinct petiole, obtuse, entire: scape stoutish, 1-2 dm. high; umbel few-flowered; flowers large: corolla deep purple, varying to rosered and to white: anthers distinct, obtuse, the connective lanceolate, acumi- 
nate, of ten delicately rugulose: capsule cylindric, circumscissile. (D. pulchrum Rydb. 1. c.)-Montana and western Wyoming to Oregon and Washington.

\section{STEIRONEMA Raf. Fringed Loosestrife}

Leafy-stemmed perennial herbs, with opposite or verticillate simple leaves and axillary yellow flowers nodding on slender pedicels. Flowers 5-merous. Corolla rotate, with no proper tube, deeply 5-parted, the sinuses rounded; the divisions ovate, cuspidate-pointed, each separately involute or convolute around its stamen. Stamens 5 , alternating with 5 sterile filaments, distinct or nearly so, inserted on a ring at the base of the corolla. Capsule 10-20seeded.

1. Steironema ciliatum (L.) Raf. Ann. Gen. Phys. 7: 192. 1820. Glabrous throughout except the petioles: stems erect, 4-10 dm. high, mostly simple: leaves ovate-lanceolate to oblong-ovate, gradually acuminate, 5-12 cm. long, mostly with rounded or subcordate base, minutely ciliate, membranaceous, pinnately veined; the long petioles hirsutely ciliate: calyx-lobes linearlanceolate, acuminate: lobes of the corolla obovate, obtuse, nearly twice as long as the calyx, erose-denticulate, 8-12 mm. long: capsule longer than the calyx.-Low moist grounds; Colorado and Wyoming and thence across the continent.

\section{NAUMBERGIA Moench.}

Erect perennial herbs, with opposite entire leaves, the lower reduced to scales, and small yellow flowers in short axillary spikes. Calyx 5-7-divided, the sepals linear, slightly imbricated. Corolla deeply 5-7-parted, with very short tube and narrow segments. Stamens 5-7, exserted; filaments slender, glabrous, slightly united at base, alternating with as many small tooth-like staminodia at each sinus of the corolla. Style slender, equaling the stamens; stigma capitate. Capsule 5-7-valved, few-seeded.

1. Na umbergia thyrsiflora (L.) Duby, in DC. Prodr. 8: 60. 1844. Glabrous or becoming so: stem 3-6 dm. high, from a slender rootstock: leaves lanceolate, sessile, $3-6 \mathrm{~cm}$. long, the lower smaller and the lowest reduced to ovate scales: peduncles from only 2 or 3 pairs of leaves near the middle of the stem, axillary, shorter than the subtending leaf, bearing several or numerous small flowers in a dense head or oblong spike: lobes of the calyx linear-lanceolate, acute, half as long as the narrow purple-dotted lobes of the corolla: capsule globose, glandular-dotted, few-seeded.-In boggy ground; across the continent; also in Europe and Asia.

\section{GLAUX L.}

Small leafy-stemmed herbs, with opposite entire leaves and small, axillary, white or pink apetalous flowers. Calyx 5-parted, the lobes petaloid, about as long as the campanulate tube. Stamens 5, inserted at the base of the calyx and alternate with its lobes; filaments subulate-filiform; anthers cordate. Capsule 5-valved at the top, few-seeded.

1. Glaux maritima L. Sp. Pl. 237. 1753. Glabrous and glaucous or pale perennial by slender running rootstocks: stems $5-10 \mathrm{~cm}$. high, erect or spreading: leaves oval to oblong-linear, 6-12 $\mathrm{mm}$. long, entire, sessile: calyxlobes oval, purplish or white. - Salt marshes along both seacoasts; also in subsaline soil in the interior west of the Mississippi.

\section{SAMOLUS L. BROOKWEED}

Low glabrous annuals, with alternate entire leaves and small white flowers in simple or panicled racemes. Calyx persistent, its tube adnate to the ovary below. Corolla perigynous, nearly campanulate; the rounded lobes imbri- 
cated in the bud. Fertile stamens 5 ; staminodia 5, in the sinuses of the corolla, or wanting. Style short; stigma obtuse or capitate. Capsule ovate or globular, 5-valved at the top, many-seeded. Seeds minute.

1. Samolus floribundus H.B.K. Nov. Gen. 2: 224. 1817. Stem erect, slender, leafy, becoming diffusely branched: leaves obovate: racemes of ten panicled; bracts none; bractlets on the middle of the slender, spreading pedicels. S. Valerandi americanus.-In wet places; across the continent.

\section{Oleaceae Lindl. Olive Family}

Trees or shrubs with opposite or rarely alternate simple or pinnate exstipulate leaves and regular 2-4-parted flowers in panicles, cymes, or fascicles. Calyx inferior, usually small, sometimes none. Stamens 2-4; filaments separate; anthers ovate, oblong or linear, 2-celled, the sacs longitudinally dehiscent. Ovary superior, 2-celled; ovules few in each cavity; style usually short or none. Fruit a capsule, samara, berry, or drupe.

Leaves pinnate; fruit a samara . . . . . . . . . 1. Fraxinus.

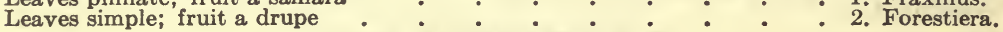

\section{FRAXINUS L. Ash}

Trees, with rather light tough wood, petioled odd-pinnate leaves of 3-15toothed or entire leaflets, and small flowers in crowded panicles, which in ours are from the axils of last year's leaves. The oblong seed fills the cell of the samara or key-fruit. Ours are apetalous and dioecious, with a minute calyx or none, and the fruit winged only from the summit or upper part of the terete body, which tapers gradually from summit to base and is more or less margined upward by the decurrent wing.

Leaves lanceolate.

Leaves broadly ovate or cordate

1. F. lanceolata.

1. Fraxinus lanceolata Borck. Handb. Forst. Bot. 1: 826. 1800. A tree sometimes $20 \mathrm{~m}$. tall, with glabrous foliage: leaves 1-3 dm. long; leaflets firm, $5-7$, the blades of the lateral ones lanceolate or elliptic-lanceolate and sometimes elliptic, 5-20 cm. long, pale or light green, usually acuminate at both ends, entire or serrate, especially near the apex: samaras $3.5-6 \mathrm{~cm}$. long, each with a slender linear body and a linear or linear-oblong wing which is much longer than the body or rarely about equal in length and decurrent to the middle or near it. $F$. viridis. Green AsH.-Wyoming (on the Platte) to N. W. Territory and to Vermont.

2. Fraxinus anomala Torr. ex. Wats. King's Rep. 283. 1871. A small tree 3-6 dm. high; branchlets and petioles pubescent: leaves simple, broadly cordate or ovate, abruptly acute or emarginate, $3-4 \mathrm{~cm}$. in diameter, longer than the petiole, entire, more or less pubescent beneath: fruit wing-margined the entire length, 12-20 mm. long, oblong, cuneate at base and acutish or emarginate above: calyx 1-2 mm. long, persistent at the base of the fruit: seeds 1 or 2, 6-8 mm. long. - Southern Colorado through Utah to Nevada.

\section{FORESTIERA Poir.}

Shrubs, with inconspicuous flowers, in early spring, from imbricated-scaly axillary buds, and small dark-colored drupes. Fascicles or panicles very short, few-flowered; the staminate sessile and in a sessile, globular, scaly glomerule. Branches minutely warty.

1. Forestiera neo-mexicana Gray, Proc. Am. Acad. 12: 63. 1877. Shrub 
1-3 m. high, glabrous: leaves spatulate-oblong, obtuse or obtusely acuminate, short-petioled, obtusely or obsoletely serrulate, $2-3 \mathrm{~cm}$. long: fertile flowers in sessile fascicles: drupe obtuse, short-oblong or ovoid.-Southern Colorado to New Mexico and Texas.

\section{Gentianaceae Dumort. Gentian Family}

Smooth herbs with bitisr, colorless juice. Leaves opposite, rarely alternate or verticillate, without stipules. Flowers perfect, regular. Calyx mostly 4-12-lobed or -toothed, often marcescent. Corolla sympetalous, 4-12-lobed or -toothed, convolute or imbricated and usually twisted in the bud, often marcescent. Stamens as many as the lobes of the corolla, alternate with them, inserted on its tube; the 2-celled anthers opening longitudinally. Ovary free, 1-celled, rarely 2-celled, with 2 parietal placentae, or the whole wall ovuliferous; style single, with usually 2-lobed or 2-lamellate stigma. Capsule dehiscent through the placentae. Seeds indefinitely numerous, rarely few, commonly small.

Style filiform, deciduous; anthers recurved or twisted in age.

Corolla-tube exceeding the calyx

Corolla-tube shorter than the calyx : ${ }^{\circ} \cdot{ }^{\circ}$ Corolla-tube shorter than the calyx
Style short and persistent or wanting; the stamens remaining
straight.

Corolla without nectariferous pits or large glands. Corolla rotate, with the stamens on its base Corolla not rotate, the stamens on its tube. Flowers solitary-terminal; anthers versatile Flowers cymose; anthers not versatile

Corolla with 1 or 2 nectariferous pits or scales at the base of each lobe. Leaves not verticillate; style wanting Leaves verticillate; style evident.

1. Erythraea. 2. Eustoma.

\section{ERYThraEA Neck. Centaury}

Low and small branching annuals, chiefly with rose-purple or reddish flowers. Calyx 4-5-parted, the divisions slender. Corolla funnalform or salverform, with slender tube and 4-5-parted limb. Anthers exserted, erect, twisting spirally. Style slender, single; stigma capitate or 2-lipped.

1. Erythraea arizonica (Gray) Rydb. Bull. Torr. Bot. Club 33: 148. 1906. Paniculately or somewhat racemosely branched, 2-3 dm. high: leaves narrowly oblong to lanceolate or linear: pedicels as long as or longer than the calyx: corolla-tube longer than the calyx, its lobes obtuse and somewhat shorter than its tube: seeds globular. E. Douglasii.-Colorado to Uteah and Arizona.

\section{EUSTOMA Salisb.}

Glaucous, large-flowered annuals or perennials, with more or less clasping and connate leaves, and slender terminal and more or less paniculate 1-flowered peduncles. Calyx 5 (rarely 6)-parted; its lobes long-acuminate, with carinate midrib. Corolla campanulate-funnelform, deeply 5-6-lobed. Anthers oblong, versatile, straight or recurving in age. Stye filiform, nearly persistent; stigma of 2 broad lamellae.

1. Eustoma Andrewsii A. Nels. Proc. Biol. Soc. Wash. 17: 177. 1904. Perennial from short, vertical, semifleshy roots, with a somewhat enlarged crown or caudex; the old stems occasionally persisting; stems simple below, more or less fasciculately branched above, 2-4 dm. high: leaves ellipticoblong below to lanceolate and acute above, mostly 3 -nerved, $2-4 \mathrm{~cm}$. long; the next year's crown leaves appearing in the autumn as rosettes which are persistent and evergreen: peduncles ebracteate, $3-8 \mathrm{~cm}$. long: calyx deeply 
cleft, less than half as long as the corolla: corolla deep purple, $3-4 \mathrm{~cm}$. long, the lobes elliptic-obovate: stamens short; anthers sagittate, erect: style stoutish, scarcely longer than the ovary and shorter than the mature capsule.Colorado.

\section{PLEUROGYNE Eschsch.}

Small annuals of cold regions, with blue or whitish flowers, and distinguished by the remarkable decurrent stigmas.

1. Pleurogyne fontana A. Nels. Proc. Biol. Soc. Wash. 17: 177. 1904. Glabrous throughout; stems slender, simple or with a few narrower erect branches, 1-4 dm. high: leaves linear, mostly narrowly so, thin, with distinct midrib and two faint lateral nerves, $20-25 \mathrm{~mm}$. long: flowers in a narrow somewhat panicled raceme, having long, very slender pedicels, pentamerous: sepals green, linear, resembling the bracts but shorter, usually 3-nerved as are also the bracts: corolla often surpassed by the sepals, its lobes ellipticoblong, subacute, about 5-nerved: stamens half as long as the corolla-lobes; the anthers oblong: mature capsule translucent, with numerous ovules, ultimately as long as the sepals. P. rotata.-Colorado and Wyoming.

\section{CHONDROPHYLLA A. Nels.}

Small annuals or biennials, from a few $\mathrm{cm}$. to $1 \mathrm{dm}$. high, the stems single or several from the slender root. Leaves numerous, small, opposite, seemingly imbricated below because of the short internodes, the margins white and scarious or cartilaginous. Flowers solitary and terminal. Calyx narrow, 4 or 5-toothed. Corolla salverform when expanded, plicate at the sinuses with broad emarginate lobes or plates, without crown or glands. Anthers cordate, versatile. Seeds oblong, with a close coat.

Leaves broadly scarious-margined; capsule at maturity exsert-stipitate 1. C. Fremontii. Leaves narrowly margined; capsule short-stipitate . . • . 2. C. americana.

1. Chondrophylla Fremontii (Torr.) A. Nels. Bull. Torr. Bot. Club 31: 245. 1904. Stems few-many, erect or ascending, 5-10 cm. high, somewhat succulent: leaves with a broad white margin, pale, cuspidate or mucronate; the lower rosulate, orbicular or ovate; the cauline linear-oblong, connate-sheathing: flowers rotate, short-pediceled, white or dull-colored: capsule clavate-obovate, at length exserted beyond the flower on a stout stipe. Gentiana humilis.Grassy banks in the mountains of Colorado and Wyoming.

2. Chondrophylla americana (Engelm.) A. Nels. 1. c. Stems weaker than in the preceding, and when elongated the lateral ones often procumbent: leaves ovate, less erect, greener, and less white-margined: flower 4-merous: corolla azure-blue, in fruit inclosing the linear-oblong, rather short-stipitate capsule. Gentiana prostrata.-Alpine in our range.

\section{GENTIANA L. Gentian}

Bitter herbs with conspicuous cymose or rarely solitary flowers of various colors, in summer or autumn. Calyx 4-5-cleft. Corolla 4-5-lobed, regular, often with intermediate plaited folds, which bear appendages or teeth at the sinuses. Style short or none; stigmas 2, persistent. Capsule oblong, 2valved; the innummerable seeds either borne on placentae at or near the sutures, or in most of our species covering nearly the whole inner face of the pod.

Annuals (except no. 2); corolla without extended plaits or lobes or teeth at the sinuses.

Flowers large (3-6 cm. long), 4-merous; corolla-lobes more or less fringed.

Annual

Perennial :

1. G. elegans.

2. G. barbellata. 
Flowers smaller (less than $3 \mathrm{~cm}$. long); corolla-lobes never fringed.

Flowers solitary on a long terminal peduncle

Flowers few-many.

Sepals very unequal, two of them foliaceous and overlapping the others

Sepals somewhat unequal but none foliaceous.

Flowers very numerous, in a spike-like thyrse, shortpediceled; leaves generally as long as the internodes

Flowers fewer, of ten long-pediceled; some of the internodes much exceeding the leaves

Perennials; corolla plicate at the sinuses, the folds more or less extended into thin teeth or lobes.

Anthers distinct.

Corolla open-campanulate or funnelform, the lobes spreading; the subtending leaves broad.

Flowers always yellowish but freely spattered with purplishbrown spots; the basal leaves persistent .

Flowers blue or blue-purple, or rarely ochroleucous, the basal leaves deciduous.

Flowers solitary

Flowers 1-5

Corolla funnelform, its lobes but slightly divergent; the subtending leaves narrow.

Leaves oblong-lanceolate to ovate.

Calyx-lobes present

Calyx-lobes wanting or minute and irregular

Upper leaves linear to lance-linear

Anthers cohering in a ring

3. G. monantha.

4. G. heterosepala.

5. G. strictiflora.

6. G. plebeja.

7. G. Romanzovii.

8. G. calycosa.

9. G. Parryi.

10. G. affinis.

11. G. Forwoodii.

12. G. Bigelovii.

13. G. Andrewsii.

1. Gentiana elegans A. Nels. Bull. Torr. Bot. Club 25: 276. 1898. Annual, 2-3 dm. high, branched from the base, the 2-20 stems simple or nearly so, each stem or branch terminated by a single flower: leaves 3-6 pairs on each stem, mostly obtuse; the lower petioled, obovate to broadly spatulate; the upper sessile, oblong or narrower: calyx-lobes nearly equal and similar, equaling the tube: corolla $4-5 \mathrm{~cm}$. long, deep blue with lighter patches or streaks downward; the lobes obovate-oblong, dentate around the summit, fimbriate on the sides: capsule stipitate: style nearly as long as the capsule proper, the stigma suborbicular, dentate. G. serrata. Rocky Mountain Fringed GenTIAN.-Frequent in moist subalpine parks; throughout our range.

1a. Gentiana elegans unicaulis A. Nels. 1. c. Reduced, simple-stemmed alpine form.- Same range.

2. Gentiana barbellata Engelm. Trans. Acad. St. Louis 2: 216. 1863. Perennial from slender fleshy rootstocks, about $1 \mathrm{dm}$. high, glabrous throughout, 1-2-flowered: leaves about 4 pairs, narrowly oblanceolate to broadly linear, 2-3 cm. long: calyx green with purple streaks, about $15 \mathrm{~mm}$. long; the lobes triangular-lanceolate, equaling or exceeding the tube: corolla dark blue, about $25 \mathrm{~mm}$. long; the lobes oblong, obtuse, exceeding the tube, conspicuously long setaceous-lacerate on the sides and often nearly to the summit which is obscurely dentate; the tube arachnoid woolly within especially toward the base: filaments stout, flattened, equaling the tube: stipe half as long as the elliptic-oblong capsule: style almost wanting. (G. Moseleyi A. Nels. Bot. Gaz. 31: 396. 1901.) Perennial Fringed Gentian.-Rare; in the Colorado mountains.

3. Gentiana monantha A. Nels. Bull. Torr. Bot. Club 31: 244. 1904. An alpine annual, mostly much less than $1 \mathrm{dm}$. high; stem simple or with one or two branchlets from the base, only 1-3 cm. high, terminated by a slender, naked, 1-flowered peduncle very much longer than the stem: leaves oblong to spatulate, 5-10 mm. long: calyx one fourth shorter than the corolla and somewhat exceeding the tube; sepals 4 , equal, oblong-lanceolate, subacute, distinct nearly to the base: corolla about $12 \mathrm{~mm}$. long; the tube twice as long as the 4 lance-ovate, subacute lobes; the fimbriae of the crown rather coarse and short: stamens shorter than the corolla-tube. G. tenella.--In the high mountains of Colorado.

4. Gentiana heterosepala Engelm. 1. c. 115. Annual, 1-3 dm. high, mostly simple, with few pairs of leaves and long internodes: flowers terminal and axillary, either solitary and long-peduncled or else in threes with shorter pedicels, 15-20 mm. long: calyx with two greatly enlarged, foliaceous, ovate 
sepals; these more or less enfolding the three small linear-lanceolate ones: corolla blue or purplish, the tube equaling the calyx, a crown of setaceous filaments at the base of its lobes. (G. distegia Greene, Pitt. 4: 182. 1900.)-Rare; mountains of Colorado, Utah, and Wyoming.

5. Gentiana strictiflora (Rydb.) A. Nels. Bot. Gaz. 34: 26. 1902. Stem simple or branched, very strict, 1-4 dm. high: leaves often rather remote, thickish, mostly lanceolate-linear, light green: flowers numerous, spicatethyrsiform on stem and branches, 4-merous: calyx-lobes unequal, mostly shorter than the tube: corolla ochroleucous, sometimes tinged with blue, but little longer than the calyx, 8-12 mm. long; the setae of the crown often few or even wanting. G. A marella stricta.-Frequent; throughout our range.

6. Gentiana plebeja Cham. Linnaea 1: 181. 1826. Stem simple or branched from the base, slightly angular, 1-3 dm. high, the internodes often much longer than the leaves: basal leaves oval-spatulate; middle stem leaves oblong or oblong-lanceolate, obtuse, 2-4 cm. long; the uppermost oblong-linear, acute: flowers several in each axil, often on a short branch, more numerous at summit: calyx deeply cleft, its longer linear lobes almost equaling the corolla tube: corolla 12-18 mm. long, pale blue, the lobes fringed at base. $G$. Amarella acuta. (Amarella scopulorum Greene, Leaflets 1: 55. 1904; Gentianella Clementis Rydb. Bull. Torr. Bot. Club 31: 631. 1904.)-Throughout our range.

6a. Gentiana plebeja Holmii Wettst. Oester. Bot. Zeitsch. 50: 195. 1900. Slender and low; simple or nearly so, few-flowered.-A reduced alpine state of the species.

7. Gentiana Romanzovii Ledeb, Nouv. Mem. Soc. Nat. Mosc. 1: 215. 1829. Stems 5-15 cm. high, often tufted, each 1-3-flowered: leaves linear, varying to lanceolate or spatulate, thickish; the cauline $2-4$ pairs, connatesheathing at base: calyx-tube obconical, the lobes somewhat unequal, about half as long as the corolla: corolla funnelform, 3-4 cm. long, yellowish, often streaked with blue, liberally spattered with purplish dots; the lobes short and broad, the plaits entire and broad, only slightly extended at summit: seeds with a loose cellular coat having crested longitudinal ridges. G. frigida. -Alpine regions in the Rocky Mountains.

8. Gentiana calycosa Griseb. Gent. 292. 1839. Stems erect, 1-3 dm. high: leaves ovate, $15-30 \mathrm{~mm}$. long, commonly equaling or exceeding the internodes, the lowest pairs smaller and with connate-sheathing base, the upper hardly so; the uppermost involucrate and somewhat exceeding the calyx of the commonly solitary flower: lobes of the calyx ovate or oblong, or even subcordate, about as long as the turbinate tube: corolla blue, oblong-funnelform, the appendages in the sinuses triangular-subulate, laciniate or 2-cleft at tip, shorter than the broadly ovate lobes: seeds lanceolate, acuminate, wingless. On the highest mountains; western Wyoming to California and Oregon.

$8 a$. Gentiana calycosa xantha A. Nels. 1. c. Leaves about 5 pairs, longer than the internodes: flowers yellow or yellowish-white with numerous green dots.-Teton Mountains, Wyoming.

9. Gentiana Parryi Engelm. 1. c. 218. Stems numerous from the crown of a somewhat woody root, 1-3 dm. high: leaves glaucescent, thickish, ovate, varying to oblong-lanceolate, $18-36 \mathrm{~mm}$. long, most of the pairs with somewhat sheathing base; the upper two or three pairs involucrate around the 1-5 flowers, concealing the calyx and sometimes almost equaling the bright blue corolla: lobes of the calyx small, moderately or much shorter than the campanulate tube: appendages in the sinuses of the corolla narrow, deeply 2-cleft, but little shorter than the obovate lobes: seeds lanceolate, wingless, with obtuse or acutish edge.-Alpine and subalpine in the Cascade and Rocky Mountains.

9a. Gentiana Parryi bracteosa (Greene) A. Nels. Leaves narrower, the floral ones thin and somewhat scarious: calyx-lobes small and inserted at the base of the membranous summit of the tube. (G. bracteosa Greene, Pitt. 4: 180. 1900.)-Colorado.

10. Gentiana affinis Griseb. 1. c. 289 . Stems clustered, 1-3 dm. high: 
leaves 6-16 pairs, ovate or oblong-lanceolate: flowers from numerous and thyrsoid-racemose to few or rarely almost solitary; bracts lanceolate or linear: calyx-lobes linear or subulate, unequal and variable, the longest rarely equaling the tube, the shorter sometimes minute: corolla 2-3 cm. long, rather narrowly funnelform; the lobes ovate, acutish or mucronulate-pointed, spreading; the laciniate-toothed or cleft appendages at the sinuses sometimes almost equaling the lobes. (G. interrupta Greene, l. c. 182.)-Very frequent at middle elevations in our range.

11. Gentiana Forwoodii Gray, Proc. Am. Acad. 19: 86. 1883. Resembling G. affinis, but the corolla decidedly smaller, about $18 \mathrm{~mm}$. long, narrow, and with shorter and rounder lobes, these little surpassing the plicate appendages: stems equably leafy to the very top: calyx subcampanulate, with no vestige of lobes or teeth.- Rare in Colorado and Utah but frequent in northwestern Wyoming.

12. Gentiana Bigelovii Gray, 1. c. 87. Near G. affinis, very leafy: leaves thick; the lower lanceolate-oblong; the upper linear and the floral often much exceeding the flowers: stems 1-3 dm. high, somewhat scabrous: flowers densely spicate: calyx-teeth very slender, as long as the tube: corolla $20-25 \mathrm{~mm}$. long, slightly scabrous on the outside; the lobes short, broadly ovate, twice as long as the bifid appendages: stipe of the capsule short and fistulous.Colorado to New Mexico and Arizona.

13. Gentiana Andrewsii Griseb. in Hook. Fl. Bor. Am. 2: 55. 1834. Stems upright, smooth: leaves ovate-lanceolate: calyx-lobes lanceolate, half as long as the tube: corolla blue, with pale streaks, somewhat cylindric-clavate, nearly closed at the mouth, twice as long as the calyx, nearly truncate at the summit with the lacerate appendages as long as the lobes.-Infrequent; stream banks of northern Colorado. Apparently our plants are not identical with the eastern form of this species.

\section{SWERTIA L.}

Simple-stemmed perennials, occasionally with alternate leaves, the lower at least tapering into margined petioles. Inflorescence thyrsoid; flowers blue or purple, varying to white. Corolla rotate, 4- or 5-lobed. Style very short or none; stigma 2-lobed or 2-lamellate. Capsule ovate.

Flowers 4-merous

Flowers 5-merous.

Inflorescence elongated; corolla-lobes oblong or narrower

Inflorescence capitate-congested; corolla-lobes elliptic to oval

1. S. scopulina.

2. S. palustris.

3. S. congesta.

1. Swertia scopulina Greene, Pitt. 4: 184. 1900. Plant 1-4 dm. high: inflorescence very strict: leaves broadly oblanceolate or spatulate-oblanceolate; radical leaves very large, often more than half the length of the subscapiform stem, usually all, even the lowest and largest cauline ones, alternate, with broad-winged petioles and half-clasping: flowers 4-merous: sepals lanceolatesubulate, often 3-nerved, and three fourths as long as the corolla-lobes; these 10-14 mm. long, dark blue-purple: glands subulate-fringed: seeds roundobovate varying to somewhat quadrangular, very distinctly winged on one, two, or three sides, the testa wrinkled.-Colorado and New Mexico.

2. Swertia palustris A. Nels. Bull. Torr. Bot. Club 28: 227. 1901. Stems simple, erect, glabrous, 2-3 dm. high: leaves glabrous, thin, entire or rarely denticulate; radical leaves oblong to elliptic, obtuse, $5-10 \mathrm{~cm}$. long; stem leaves several, generally in pairs but not rarely alternate, spatulately oblanceolate or broader: inflorescence very strict; peduncles erect, axillary to the bracts and uppermost leaves, 1-3-flowered; flowers 5-merous: sepals subulatelanceolate, delicately nerved, about half as long as the petals: corolla-lobes dark blue shading to purple, oblong, obtuse, about $10 \mathrm{~mm}$. long, 3-4 $\mathrm{mm}$. broad; glands orbicular, the appendages few (10 or less), short-subulate: seeds lenticular, wing-margined.-Shaded mountain bogs; Wyoming and Colorado. 
3. Swertia congesta A. Nels. 1. c. Commonly less than $2 \mathrm{dm}$. high: leaves alternate, rarely more than 3 or 4 , usually on the basal half of the stem, elliptic to oblanceolate, obtuse or subacute, 3-6 cm. long: inflorescence congested, usually subtended by a pair of foliar bracts; flowers 5-merous, 3-7, dark bluish-purple: sepals as in the preceding: corolla-lobes elliptic, obtuse, usually emarginate, 8-10 mm. long, nearly half as broad; glands cup-shaped, the setaceous appendages as long as the cup: filaments flat and thin, their bases involved in a ring of very short, sparse, subulate setae in the base of the corolla: seeds small, very numerous, narrowly wing-margined on the angles.Open subalpine swales; Wyoming and Colorado.

\section{FRASERA Walt.}

Smooth herbs with erect stems, opposite or verticillate leaves, and numerous flowers in thyrsoid or paniculate cymes. Corolla rotate, 4-parted, the lobes bearing a single or double fringed gland, and sometimes a fimbriate crown at base. Stamens inserted on the very base of the corolla; filaments subulate, often united at base, occasionally with some interposed small bristles or scales. Ovary ovate, tapering into a distinct and often slender, persistent style; stigma small, 2-lobed or nearty entire. Capsule coriaceous.

1. Frasera speciosa Griseb. Gent. 329. 1839. Stems 6-14 dm. high, very leafy: leaves in fours and sixes; the radical and lowest cauline obovate or oblong, 2-3 dm. long; the upper lanceolate and at length linear: flowers very numerous in a long leafy thyrsus: lobes of the greenish-white or barely bluish and dark-spotted corolla oval-oblong, bearing a pair of contiguous and densely long-fringed glands about the middle, and a distant, transversely inserted and setaceously multifid scale-like crown near the base. ( $F$. macrophylla Greene, Pitt. 4: 186. 1900.) - In the mountains from Wyoming to Oregon and southward to New Mexico and Arizona.

1a. Frasera speciosa scabra Jones, Zoe 4: 277. 1893. More or less puberulent or scabro-puberulent on stem and leaves. ( $F$. scabra, $F$. stenopetala, $F$. angustifolia Rydb. Bull. Torr. Bot. Club 33: 149. 1906.) Seemingly the more usual state in our range, and may therefore be recognized as a variety.

\section{3. menyanthaceae G. Don. Buckbean Family}

Perennial aquatic or marsh herbs, with basal or alternate leaves, and clustered, regular, perfect flowers. Calyx deeply 5-parted, persistent. Corolla 5-lobed or 5-cleft, the lobes induplicate-valvate, at least in the bud. Stamens 5, borne on the corolla, and alternate with its lobes; anther-sacs longitudinally dehiscent; pollen-grains 3-angled. ' Ovary 1-celled, the 2 placentae sometimes intruded. Fruit a capsule, or indehiscent.

\section{MENYANTHES L.}

Leaves trifoliolate; other characters as given under the single species of the genus.

1. Menyanthes trifoliata L. Sp. Pl. 145. 1753. Rootstocks thick, scaly, sometimes $3 \mathrm{dm}$. long: petioles sheathing at the base; leaflets oblong or obovate, entire, obtuse, narrowed to the sessile base, $3-8 \mathrm{~cm}$. long: raceme 10-20flowered; pedicels 6-25 mm. long, bracteolate at the base; flowers 10-12 $\mathrm{mm}$. long: calyx shorter than the white or purplish corolla: capsule ovoid, obtuse, about $8 \mathrm{~mm}$. long.-In bogs; circumpolar; south in our mountains to Colorado. 


\section{APOCYNACEAE Lindl. Dogbane Family}

Perennial herbs (ours), mostly with acrid, milky juice, simple, opposite or alternate leaves, and perfect, regular, cymose, solitary, or paniculate flowers. Calyx 5-parted, persistent, the lobes imbricated in the bud. Corolla 5-parted, the lobes convolute in the bud. Stamens as many as the lobes of the corolla and alternate with them, inserted in the tube or throat; anthers linear-oblong, sagittate, 2-celled. Ovary superior or its base adherent to the calyx, of 2 distinct carpels; ovules few or numerous; style simple or 2-divided; stigma simple. Fruit of 2 follicles. Seeds often appendaged by a coma.

Leaves alternate; anthers free from the stigma

Leaves opposite; anthers converging around the stigma and slightly ad-

1. Amsonia. herent to it

2. Apocynum.

\section{AMSONIA Walt.}

Herbs. Leaves alternate; blades entire. Flowers in terminal thyrsoid or corymbose cymes. Calyx-lobes 5, acuminate; disk wanting. Corolla mainly salverform; tube slightly dilated upward, villous within; lobes narrow. Stamens included; anthers unappendaged. Carpels 2, connected by the slender styles; stigma appendaged by a reflexed membrane. Follicles 2 together, erect, several-seeded. Seeds unappendaged.

1. Amsonia texana (Gray) Heller, Muhl. 1: 2. 1900. Stems 1.5-7 dm. tall, often sparingly branched, glabrous: leaves numerous; blades oblong to narrowly elliptic or linear, conspicuously narrower on the upper part of the plant, 2.5-6 cm. long, acute or blunt, of ten somewhat lustrous above, glabrous at least at maturity: calyx-lobes acuminate, the longer about $2 \mathrm{~mm}$. long: corolla glabrous; tube $9-11 \mathrm{~mm}$. long; lobes usually about as long as the tube: follicles 6-10 cm. long, glabrous.-Colorado to Texas.

\section{APOCYNUM L. DogBane. Indian Hemp}

Pale perennial herbs, with very tough-fibrous bark and opposite mucronatetipped leaves. Flowers small, in terminal cymes, white or rose-color. Calyx small, deeply 5-cleft, the tube by means of a thickish disk adnate to the back of the ovaries below. Corolla campanulate, 5-lobed, toward the base bearing 5 small, triangular-subulate appendages alternate with the stamens. Filaments very short and broad; anthers sagittate. Follicles slender, 5-15 cm. long, terete. Seeds numerous, with a long coma at apex.

Corolla pink, its lobes spreading or revolute

Corolla greenish-white, its lobes mostly erect.

Leaves petioled, cuneate or cuneately rounded at base

Leaves sessile or nearly so, subcordate or broadly rounded at base

1. Apocynum androsaemifolium L. Sp. 213. 1753. Stems 3-15 dm. tall, with widely-spreading branches, mostly glabrous: leaf-blades ovate, oblong or oval, 4-11 cm. long, deep green and glabrous above, pale and more or less pubescent beneath, short-petioled: cymes rather lax: calyx-lobes ovate to ovate-lanceolate, $2-2.5 \mathrm{~mm}$. long: corolla pink, 5-7 $\mathrm{mm}$. long; lobes revolute: follicles 10-15 cm. long. (A. scopulorum Greene; A. ambigens Greene, Pl. Baker. 16. 1901, the glabrate form.)-Throughout our range, and very widely distributed in the United States.

2. A pocynum cannabinum L. 1. c. Stems 8-18 dm. tall, the branches erect or ascending, glabrous at maturity: leaf-blades oblong to ovate-oblong or oblong-lanceolate, 5-12 cm. long, glabrous, or slightly pubescent beneath, short-petioled: cymes rather dense: calyx-lobes lanceolate, $2.5-3 \mathrm{~mm}$. long: 
corolla greenish-white, 3-3.5 mm. long; lobes erect or nearly so: follicles 12-15 cm. long.-Throughout the United States.

2a. Apocynum cannabinum lividum (Greene) A. Nels. Habit, size, and leaf characters the same, glabrous: calyx-lobes only half as long as the narrowly campanulate corolla. (A. lividum Greene, Pl. Baker. 16. 1901.)Wyoming and Colorado.

3. Apocynum hypericifolium Ait. Hort. Kew 1: 304. 1789. Not strongly differentiated from $A$. cannabinum: leaves usually broader, with rounded or subcordate base, subsessile, often abruptly apiculate.-New Mexico to Montana and the Great Lakes.

\section{ASCLEPIADACEAE Lindl. Milkweed Family}

Mostly herbs with milky juice, usually opposite leaves without stipules, and regular perfect flowers in terminal or pseudo-axillary or sometimes axillary cymes (often umbelliform). Calyx free from the ovary or nearly so, imbricated in the bud. Corolla 5-merous, convolute, or often nearly valvate in the bud. Stamens 5, borne on the tube of the corolla and alternate, with its lobes; anthers surrounding the stigma; pollen in 1 or 2 waxy masses, in ours all the pollen in each cell in one mass and attached to the stigmatic disk by the glands that alternate with the anthers. A crown of 5 parts or lobes usually present between the corolla and the mostly monadelphous stamens, and adnate either to the one or the other. Ovary of 2 cells that become several to many-seeded follicles. Seeds almost always bearing a long and soft coma.

\footnotetext{
Lobes of the corolla reflexed at anthesis.

Leaves alternate or opposite; hoods of the crown crestless .

Leaves mostly opposite; hoods of the crown each with an incurved horn Lobes of the corolla erect at anthesis; leaves alternate; hoods of the crown prominently crested

1. Acerates.

2. Asclepias.

3. Asclepiodora.
}

\section{ACERATES Ell. Green Milkweed}

Perennial herbs, with thick leaves and green or purplish flowers in shortpeduncled or sessile umbels. Calyx 5-parted or 5-divided, the segments acute, glandular within. Corolla deeply 5-cleft, the segments valvate, reflexed in anthesis. Crown-column very short; crown of 5 involute-concave or somewhat pitcher-shaped hoods, neither horned nor crested within, or in one species having a small interior crest and usually a few small processes at the base of the anther-wings, forming an obscure inner crown. Stigma 5-lobed.

Leaves numerous, alternate-scattered; auricles of the hoods conspicuous 1. A. auriculata.

Leaves in part opposite; auricles of the hoods concealed or wanting.

Hoods entire

Hoods trilobed

2. A. viridiflora.

3. A. angustifolia.

1. Acerates a uriculata Engelm. Bot. Mex. Bound. 160. 1859. Glabrous up to the inflorescence; stem 5-8 dm. high, slender: leaves linear-filiform, with scabrous margins: umbels several, lateral: column below the hoods very short; hoods oval or quadrate, emarginately or sometimes 3-crenately truncate, the involute margins at base appendaged with a pair of remarkably large and broad auricles: anther-wings narrow and of equal breadth from top to bottom.-Colorado and Kansas to Texas and New Mexico.

2. Acerates viridiflora (Raf.) Eaton, Man. Ed. 5.90. 1829. Tomentosepuberulent; stem 2-5 dm. high: leaves oval or oblong and obtuse or retuse, or sometimes narrower and acute: umbels $2-5$ or sometimes solitary, dense, mostly lateral and subsessile; pedicels little over twice the length of the reflexed narrowly oblong lobes of the greenish corolla: hoods somewhat fleshy, 
with small auricles at base much involute and concealed, alternated by as many short and roundish or gland-like, small internal teeth: anther-wings semi-rhomboid above, with a much longer tapering base.-From Colorado to the Saskatchewan and eastward across the continent.

2a. Acerates viridiflora Ivesia Brit. Mem. Torr. Club 5: 265. 1894. Leaves lanceolate or oblong-lanceolate, 5-12 cm. long.- Same range and often with the species.

2b. Acerates viridiflora linearis Gray, Syn. Fl. 2: 90. 1878. Leaves elongated-linear, stems low, and umbels usually solitary.-New Mexico to Canada.

3. Acerates angustifolia (Nutt.) Dec. in DC. Prodr. 8: 522. 1844. Stem puberulent but foliage glabrous, slender, 3-5 dm. high, simple: leaves long and narrowly linear, with scabrous and more or less revolute margins and a strong midrib; the upper alternate and the lower opposite: umbels several, 10-15-flowered; flowers greenish: hoods whitish, erect, equaling the anthers, conduplicate-concave, the base of each inner margin appendaged by a cuneate, erosely truncate lobe, the apex 2-lobed and the narrow internal crest exserted in the sinus in the form of an intermediate tooth; interior crown of 5 very small 2-lobed processes between the bases of the anthers: follicles longacuminate, erect on the ascending pedicel. Acerates stenophylla Decaisne.From Colorado and Nebraska to Texas.

\section{ASCLEPIAS L. MILKWEED}

Herbs with erect or merely spreading stems, opposite or sometimes verticillate or alternate leaves, and terminal and lateral umbellate inflorescence. Calyx 5-parted, commonly bearing some minute processes at the base within. Corolla rotate, 5-parted, dextrorsely valvate-convolute in the bud; crown consisting of 5 distinct cucullate or hollowed, nectariferous appendages, opposite the anthers, that are involute or complicate and bearing a horn or crestlike process from the back or toward the base within, either sessile or elevated on a column which is shorter than the anthers. Anthers tipped with an inflexed or sometimes erect membrane; the polliniferous cells lower than the stigma; pollen masses suspended, attached in pairs to the glands of the stigmatic ring.

Corolla and crown orange or bright red.

Leaves nearly all alternate; corolla orange

Leaves opposite; corolla red

Corolla greenish, purplish, yellowish, or white.

Leaves lanceolate or broader (not linear).

Leaves sessile, very broad (suborbicular), soon glabrous.

Horns concealed; leaves obtuse

Horns exserted; leaves retuse

Leaves petioled, lanceolate or broader, canescent or tomentose, or in No. 7 nearly glabrous.

Leaves obtuse; follicle with soft spinose processes
Leaves lanceolate or obovate; follicle without spinoseprocesses.

Leaves obovate-retuse, densely tomentose-canescent Leaves lanceolate, glabrate.

Leaves linear.

Leaves opposite

Leaves verticillate or scattered.

Plant tall, 4-6 dm. high; leaves verticillate. Hoods entire

Hoods dorsally hastate-sagittate

Plant low, 1-2 dm. high; leaves crowded, filiform-linear

1. A. tuberosa.

2. A. incarnata.

3. A. cryptoceras.

4. A. latifolia.

5. A. speciosa.

6. A. arenaria.

7. A. Hallii.

8. A. brachystephana.

9. A. verticillata

10. A. galioides.

11. A. pumila.

1. Asclepias tuberosa L.Sp. Pl.217. 1753. Hirsute or roughish-pubescent, 4-8 dm. high, very leafy to the top: leaves lanceolate-oblong to linearlanceolate, sessile or slightly petioled: umbels several and mostly cymose at the summit of the stem: hoods narrowly oblong, erect, deep bright orange, much surpassing the anthers, almost as long as the purplish- or slightly greenish-orange, oblong corolla-lobes, nearly equaled by the filiform-subulate 
horn: follicles cinereous-pubescent.-From southern Colorado and Arizona to Texas, thence eastward to Florida and Canada. Known commonly as ButrerFly-Weed or Pleurisy Root.

2. Asclepias incarnata L. 1. c. 215. Stem slender, 6-12 dm. high, leafy to the top: leaves acuminate, $8-15 \mathrm{~cm}$. long, the primary nerves not widespreading: umbels usually numerous, many-flowered; pedicels pubescent: corolla red or rose-purple, rarely white, its lobes oblong, about $4 \mathrm{~mm}$. long; horns incurved, longer than the hoods, obtuse, pink or purplish: anther-wings entire, or obscurely notched at the base: fruiting pedicels erect or incurved; follicles erect, 5-9 cm. long, sparingly puberulent.-Within our range and thence far eastward and southward.

3. Asclepias cryptoceras Wats. King's Rep. 283. 1871. Glabrous; stems decumbent, 2-3 dm. long, simple: leaves 3-4 pairs, rounded-ovate, $3-5 \mathrm{~cm}$. long, on very short petioles: umbels axillary and terminal, sessile, few-flowered: corolla-lobes ovate-lanceolate, spreading, greenish-yellow, $10 \mathrm{~mm}$. long; hoods of the crown $6 \mathrm{~mm}$. long, equaling the disk, purple, ovate, abruptly pointed with two short recurved beaks; horn short, incurved, not at all exserted: follicles 3-5 cm. long.-Western Wyoming to Nevada and Oregon.

4. Asclepias latifolia (Torr.) Raf. Atl. Journ. 146. 1832. Puberulent when young, soon green and glabrous: leaves about 5 pairs, approximate, very thick and large, orbicular or broadly oval, often emarginate and with a mucro, subcordate at base, nearly sessile, copiously transversely veined: umbels 2 or 3, all or mostly lateral, densely many-flowered; flowers greenish: column very short but distinct; hoods barely equaling the anthers, broad, with a truncate entire summit, which is equaled by the upper margin of the falciform triangular crest, the apex of which extends into a short subulate horn partly over the top of the stigmatic disk. A. Jamesii.-Plains of Colorado to Arizona and Texas.

5. Asclepias speciosa Torr. Ann. Lyc. N. Y. 2: 218. 1826. Finely canescenttomentose: leaves subcordate-oval to oblong, thickish: pedicels of the manyflowered dense umbel and the calyx densely tomentose; flowers purplish, large: corolla-lobes ovate-oblong; hoods spreading, the dilated body and its short inflexed horn not surpassing the anthers, but the center of its truncate summit abruptly produced into a lanceolate-ligulate, thrice longer termination; column hardly any: wings of the anthers notched and obscurely corniculate at base.-From Nebraska and Arkansas westwald across the continent.

6. Asclepias arenaria Torr. Bot. Mex. Bound. 162. 1859. Lanuginoustomentose, in age glabrate; stems thickly leaved: leaves smaller, coriaceous when old, obovate or oval and retuse or the lower ovate, with rounded or subcordate base, somewhat undulate, distinctly petioled: umbels all lateral, rather densely many-flowered: corolla greenish-white; column nearly half the length of the anthers; hoods about as broad as high, surpassing the anthers, truncate at base and summit, the latter oblique and notched on each side near the inner angle, which forms an obtuse tooth; horn with included ascending portion or crest broadly semilunate, as high as the hood; the abruptly incurved apex subulate-beaked, horizontally exserted, or the slender termination ascending.- On sandbanks; southeastern Colorado to New Mexico.

7. Asclepias Hallii Gray, Proc. Am. Acad. 12: 69. 1876. Puberulentglabrate; stem stout: leaves thickish, ovate-lanceolate or oblong-lanceolate, with rounded base and rather acute apex, short-petioled, the stout midrib and straight veins prominent underneath: umbels few and corymbose, manyflowered, on peduncles somewhat longer than the pedicels: corolla greenishwhite and purplish; hoods elongated-oblong in outline, entire, hastately 2gibbous above the narrower base, a little surpassing the sickle-shaped horn: anther-wings unappendaged at base. (A. curvipes A. Nels. Bull. Torr. Bot. Club 28: 229. 1901.)-Southern Wyoming and Colorado.

8. Asclepias brachystephana Engelm. Torr. Bot. Mex. Bound. 163. 1859. Stems 2-3 dm. high, very leafy, cinereous-puberulent or tomentose when young, the inflorescence more floccose-tomentose: leaves lanceolate with a broader rounded base to linear, short-petioled, very much surpassing the 
(3-8) few-flowered umbels: flowers lurid-purplish: hoods only half the length of the anthers, erect, strongly angulate-toothed at the front; the tip of the erect subulate horn exserted.-Dry sandy soil; from Wyoming and Colorado to Arizona and Texas.

9. Asclepias verticillata L. 1. c. 217. Stems 3-6 dm. high, slender, very leafy: leaves mostly in whorls of $3-6$, or some scattered, filiform-linear, with revolute margins: umbels numerous, small, many-flowered, on peduncles longer than the pedicels: corolla greenish-white; hoods white, broadly ovate and entire, with somewhat auriculate involute base, barely equaling the anthers, much shorter than their elongated-subulate, falcate-incurved horn.In dry soil; from New Mexico and Colorado to Nebraska, and eastward across the continent.

10. Asclepias galioides H.B.K. Nov. Gen. \& Sp. 3: 148. 1815. Glabrous, except the minutely pubescent stems and pedicels; stems erect, $3-5 \mathrm{dm}$. high from a horizontal rootstock: leaves erect or spreading, in whorls of $2-6$, narrowly linear, 5-8 cm. long, the margins revolute: peduncles longer than the pedicels and shorter than the leaves; umbels $19-26 \mathrm{~mm}$. in diameter; flowers greenish-white: corolla-segments $4 \mathrm{~mm}$. long; hoods as high as the anthers, broadly rounded at the summit, dorsally hastate-sagittate, the ventral margins slightly involute, entire; horn arising from the base of the hood, longexserted over the anthers: anther-wings minutely notched at the base: follicles erect on erect fruiting pedicels, attenuated, 5-7 cm. long, glabrous or nearly so.-Kansas to Colorado, Arizona, and Mexico.

11. Asclepias pumila (Gray) Vail, in Brit. and Br. Fl. 3: 12. 1898. Stems 4-25 cm. high, tufted, from a woody root: leaves numerous, crowded, sometimes obscurely whorled, filiform-linear, $2.5-5 \mathrm{~cm}$. long, smooth or minutely roughened, the margins revolute: umbels 2-several, short-peduncled, fewflowered; pedicels filiform, puberulent, 6-9 $\mathrm{mm}$. long: corolla greenish-white, its segments oblong, 3-4 mm. long; hoods white, erect, oblong, entire, equaling the anthers, shorter than the slender incurved horn: follicles erect, on erect fruiting pedicels, narrowly spindle-shaped, $3-5 \mathrm{~cm}$. long, finely puberulent.-Dry plains; South Dakota and Wyoming to Arkansas and New Mexico.

\section{ASCLEPIODORA Gray}

Low and stout perennial herb, often decumbent. Flowers large. Corollalobes ovate, greenish. Follicles usually bearing some scattered, soft-spinulose projections, on recurved or sigmoid pedicels. Distinguished from Asclepias by the hood bearing a crest instead of a horn.

1. Asclepiodora decumbens (Nutt.) Gray, Proc. Am. Acad. 12: 66. 1876. Scabrous-puberulent: leaves lanceolate to linear, tapering to the apex: umbels solitary: corolla depressed-globular in bud, hardly twice the length of the yellowish or dark purplish hoods, which overtop the somewhat depressed anther-column: anther-wings salient, especially at the broader and strongly angulate upper portion; pollinia pear-shaped, short-caudicled.-From Utah through Colorado and New Mexico to Texas and Arkansas.

\section{CUSCUTACEAE Dumort. Dodder Family}

Parasitic plants with slender, thread-like, yellowish or reddish stems which twine dextrorsely about the vegetative organs of the host plant and invade its tissues by means of suckers. Leaves and bracts reduced to small scales of the same color as the stems. Flowers small, cymose-clustered, mostly white, 5 (rarely 4)-merous. Calyx cleft or parted. Corolla globular, urn-shaped, bell-shaped, or somewhat tubular. Stamens inserted in the throat of the corolla above as many scale-like crenulate or lacerate appendages. Ovary 
globular, 2-celled, 4-ovuled; styles distinct or rarely united; the stigmas globose or filiform. Embryo thread-shaped, spirally coiled, destitute of cotyledons.

\section{CUSCUTA L. DODder}

Characters of the family. Seeds large, globular or angular by mutual pressure. Germinating in the soil but scarcely rooting; the root and basal portion perishing as soon as the parasite has attached itself to the host.

Corolla scales crenate; stigmas filiform; capsule circumscissile.

Corolla surpassing the calyx

Corolla scarcely equaling the calyx

Corolla scales fringed; stigmas peltate-capitate; capsule indehiscent.

Calyx of 5 distinct sepals, subtended by sepal-like bracts.

Bracts few, appressed, entire

Bracts many (8-15), recurved, serrulate

Calyx gamosepalous.

Ovary and capsule depressed-globose.

Corolla persistent at base of capsule.

Flowers sessile, in globular clusters.

Scales large, deeply fringed

Scales small and bifid, or even abortive

Flowers pediceled, in cymose panicles

Corolla persistent, capping the capsule .

Ovary and capsule pointed.

Corolla persistent, inclosing the capsule

Corolla persistent, capping the capsule.

Scales obsolete or nearly so

Scales 2-lobed, fringed in the sinus

Corolla scales fringed, exceeding the tube; capsule circumscissile

1. C. gracilis.

2. C. Anthemi.

3. C. cuspidata.

4. C. paradoxa.

1. Cuscuta gracilis Rydb. Bull. Torr. Bot. Club 28: 501. 1902. Stems filiform: flowers in dense globular clusters: calyx gamosepalous but cleft to near the base, lobes ovate: corolla urceolate, less than $2 \mathrm{~mm}$. high; lobes ovate, widely spreading, acute, delicate, about $1 \mathrm{~mm}$. long; scales ovate, crenate, almost half as long as the corolla-tube: filaments subulate, about twice as long as the anthers: styles distinct, equal, about as long as and somewhat thicker than the red, filiform, curved stigmas: capsule about $2 \mathrm{~mm}$. high, acute-globose, circumscissile near the base: seeds about $1 \mathrm{~mm}$. long. -On Compositae, Medicago, etc.; Wyoming.

2. Cuscuta Anthemi A. Nels. Stems delicately slender-filamentous, only 2 or $3 \mathrm{dm}$. long: flowers sessile in capitate, few-flowered clusters about $5 \mathrm{~mm}$. in diameter: calyx-lobes broadly ovate, acute, united below the middle, somewhat imbricated, equaling or at first surpassing the corolla: corolla less than $2 \mathrm{~mm}$. long; the lobes ovate, acute, equaling or longer than the broadly campanulate tube; scales oval, fringed around the summit with short processes: filaments about as long as the anthers: capsule globose, about $1 \mathrm{~mm}$. in diameter: stigmas linear, purple, as long as the distinct equal styles; stigma and style together $1 \mathrm{~mm}$. long: ovules 4, usually but one maturing.-On Artemisia gnaphalodes; Wyoming.

3. Cuscuta cuspidata Engelm. Bost. Journ. Nat. Hist. 5: 224. 1845. Stems slender: flowers in loose panicles, $3-5 \mathrm{~mm}$. long, thin, membranous when dry: sepals 5, ovate-orbicular, subtended by some similar bracts: corolla-lobes shorter than the tube, cuspidate or mucronate, spreading; scales narrow, about half as long as the tube, deeply and irregularly fringed: styles many times longer than the ovary, at length exserted: capsule topped by the withered corolla.- On various coarse herbs, as Ambrosia, Iva, many Leguminosae, etc.; eastern part of our range.

4. Cuscuta paradoxa Raf. Ann. Nat. 13. 1820. Stems coarse, orangecolored, soon withering away, leaving dense flower-clusters encircling in ropelike masses the stems of the host: sepals recurved-spreading, nearly equaling the upwardly widening corolla-tube; the subtending bracts $8-15$, serrulatetipped as are also the sepals: scales copiously long-fringed at the summit, sparingly on the sides. $C$. glomerata Choisy.-Scarcely within our range; eastward, on tall herbs, as Compositae, etc. 
5. Cuscuta arvensis Beyrich, Hook: Fl. Bor. Am. 2: 77. 1834. Stems pale and slender, low; flowers sessile or nearly so, small, about $2 \mathrm{~mm}$. long: calyx-lobes obtuse, broad: corolla-lobes acuminate, longer than the tube, the tips inflexed; scales large, deeply fringed all around with irregular filaments: ovary and capsule depressed-globose, its base encircled by the withering corolla: styles not longer than the capsule.-Not frequent; various low plants as hosts; from our range to the Atlantic States.

6. Cuscuta Polygonorum Engelm. Am. Journ. Sci. 43: 342. 1842. Stems coarse, orange-yellow: flowers crowded, sessile: calyx 4-5-lobed; its lobes ovate-acute: corolla-lobes triangular-ovate, as long or longer than the tube; scales reduced, 2-cleft, or of ten nearly wanting: capsule depressed-globose, the withering corolla persistent at its base.-On Polygonum and other herbs.

7. Cuscuta plattensis A. Nels. Bull. Torr. Bot. Club 26: 131. 1899. Stems yellowish-green, moderately slender: flowers in either loose or dense paniculate cymes, short-pediceled: calyx-lobes obtuse, suborbicular, somewhat exceeding $1 \mathrm{~mm}$. in length, the tube very short: corolla marcescent at the base of the capsule; the lobes short-ovate, obtuse, about half the length of the broadly campanulate tube; tube about $2 \mathrm{~mm}$. long; scales shorter than the tube, broadest at the truncate fringed summit: styles distinct, but slightly unequal, scarcely more than $1 \mathrm{~mm}$. in length and not more than one fourth the length of the mature capsule: capsule subglobose, $5 \mathrm{~mm}$. in diameter. -On Grindelia, Solidago, and Helianthus; Wyoming.

8. Cuscuta Cephalanthi Engelm. Am. Journ. Sci. 43: 336. 1842. Stems coarse and yellow, mostly high-climbing: flowers in paniculate, often compound cymes, very small, about $1.5 \mathrm{~mm}$. long, on short thick pedicels, often 4-merous: calyx-lobes obtuse: corolla cylindric-campanulate; the lobes obtuse, half as long as the tube; scales shorter than the tube, irregularly fringed around the summit: capsule depressed-globose; styles slender, as long as the ovary, the marcescent corolla capping the large capsule.-On tall herbs and shrubs.

9. Cuscuta indecora Choisy, Mem. Soc. Gen. 9: 278. 1842. Stems coarse: flowers $3 \mathrm{~mm}$. long, cymose, rather long-pediceled: calyx-lobes 5, ovatelanceolate, acute: corolla campanulate; the lobes subcrenate, triangular, as long as the tube, spreading but with inflexed tips; scales ovate, irregularly fringed all around: capsule oblong, acute.-On low herbs and shrubs; frequent on alfalfa.

10. Cuscuta Coryli Engelm. Am. Journ. Sci. 43: 337. 1842. Stems coarse: flowers about $2 \mathrm{~mm}$. long, in cymes, on pedicels of variable length: calyx 4-5-lobed; the lobes triangular-acute, as long as the corolla-tube: corolla campanulate; the lobes crenulate, acute, about as long as the tube, the tips inflexed; scales small, oval, fringed on the sides sparingly or not at all: capsule pointed, longer than the styles, covered or capped by the withered corolla. -On hazels and other shrubs.

11. Cuscuta megalocarpa Rydb. Bull. Torr. Bot. Club 28: 501. 1901. Stem stout, usually over $1 \mathrm{~mm}$. in diameter: flowers in dense globular clusters; pedicels very short, at most $2 \mathrm{~mm}$. long: calyx gamosepalous, lobes rounded, scarcely $1 \mathrm{~mm}$. long: corolla about $3 \mathrm{~mm}$. high and broad; lobes broadly triangular, acutish, about $1 \mathrm{~mm}$. long, with incurved tip; fringed scales attached near the bottom, deeply 2-lobed, and fringed only in the open sinuses: stamens about as long as the lobes of the corolla; filaments subulate, about twice as long as the rounded anthers: style distinct, short; stigmas capitate: capsule 5-6 mm. in diameter, acute-globose, about 4-seeded.-On willows and other shrubs; Colorado and Wyoming.

12. Cuscuta umbellata H.B.K. Nov. Gen. \& Sp. 3: 121. 1815. Stems low and capillary: flowers $3-4 \mathrm{~mm}$. long, few together in umbel-like clusters, usually shorter than their pedicels: acute calyx-lobes and lanceolate-subulate lobes of the corolla longer than its shallow tube: scales deeply fringed and exceeding the tube: capsule more or less regularly circumscissile, usually capped by the remains of the corolla.-Dry places, on low herbs (Portulaca, etc.); Colorado and southward. 


\section{Convolvulaceae Vent. Morning-glory Family}

Herbs, chiefly trailing or twining vines, with alternate, exstipulate leaves and regular 5-androus flowers. Calyx-lobes or sepals imbricated. Corolla sympetalous, the limb angled or plaited, 5-lobed or nearly entire, convolute in bud. Stamens inserted on corolla-tube. Ovary 2-3-celled with 2 ovules in each cell, the cells sometimes doubled by a false partition, entire, with terminal style, or 2-3-divided with 1-3 styles from between the lobes. Fruit a capsule.

Styles 2 and 2-cleft.

Style 1.

Stigmas 1-3, small, capitate

Stigmas 2, linear to oblong .

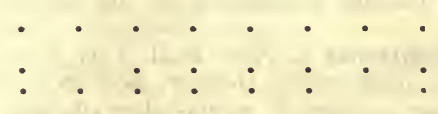

1. Evolvulus.

2. Ipomoea.

3. Convolvulus.

\section{EVOLVULUS L.}

Hairy or silky-pubescent herbs, with erect or diffuse or prostrate (never twining) stems, small leaves, and small axillary flowers. Calyx of nearly equal segments. Corolla small, purple or blue, rotate, campanulate, or funnelform, solitary or on few-flowered peduncles. Styles 2, distinct or sometimes united below, each 2-cleft; stigmas linear-filiform or somewhat clavate. Capsule 2-4-valved, 1-4-seeded.

1. Evolvulus pilosus Nutt. Gen. 1: 174. 1818. Whole plant densely silky-villous, silvery or becoming fulvous; stems numerous from a lignescentbase, erect or ascending, 1-2 dm. high, very leafy: leaves spatulate and obtuse to linear-lanceolate and acute, $7-15 \mathrm{~mm}$. long: flowers solitary on short, 2-bracted peduncles: sepals acute: corolla short, funnelform-campanulate. E. argenteus Pursh.

\section{IPOMOEA L. MORNING-GLORY}

Twining, trailing, or erect annual or perennial herbs, mostly with large showy flowers. Sepals usually unequal. Corolla funnelform to trumpetshaped, plicate and generally convolute; the limb from entire to lobed. Stamens included. Style slender, with capitate stigma. Capsule globular, 2-4celled, 4-6-ovuled.

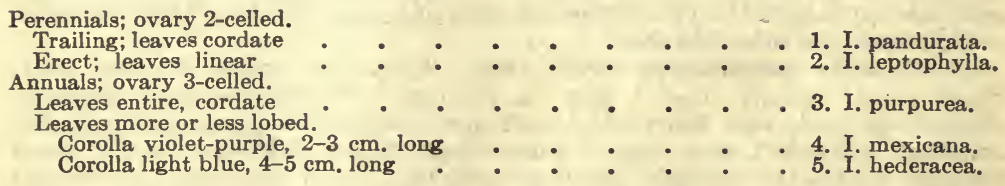

1. Ipomoea pandurata (L.) Meyer, Prin. Fl. Esseq. 100. 1818. Nearly glabrous; stems trailing or scrambling, $1 \mathrm{~m}$. or more long; root very long and large: leaves mostly entire, cordate or some of them angulate or lobed, 4-8 cm. long: sepals oblong: corolla funnelform, with broad limb, 5-7 cm. long, white with purple throat: seeds woolly on the angles. Wild Potato Vine.Scarcely within our range; southeastward.

2. Ipomoea leptophylla Torr. Frem. Rep. 95. 1845; Emory Rep. 148. pl. 11. 1848. Wholly glabrous; stems erect or diffuse, 6-12 dm. high, several from an enormous root: leaves linear, 5-10 cm. long, 4-6 mm. broad, shortpetioled, acute: sepals ovate, obtuse, the outer ones shorter: corolla funnelform, pink to purple, 6-8 $\mathrm{cm}$. long, the limb nearly entire: capsule ovoid, acute: 
seeds rusty-pubescent. BUsh MorNING-GLORY.--On dry banks; through eastern Wyoming and Colorado.

3. Ipomoea purpurea (L.) Roth. Bot. Abh. 27. 1787. An annual with long, slender, twining stems: leaves cordate, entire: peduncles $5-15 \mathrm{~cm}$. long, bearing 1-5 umbellately clustered flowers; the pedicels thickened and refracted in fruit: sepals lanceolate, somewhat hirsute, $10-12 \mathrm{~mm}$. long: corolla about $5 \mathrm{~cm}$. long, purple to white and of ten variegated: capsule depressed-globose. The common MorNING-GLORY. - Sparingly escaped from cultivation.

4. Ipomoea mexicana Gray, Syn. Fl. 2: 210. 1878. A slender annual with angulate, 3-lobed leaves or some entire; the later ones deeply-lobed, the lobes ovate-lanceolate, often cordate at base: peduncles slender, 1-3-flowered; the pedicels as long as the lanceolate sepals: sepals hispid or lightly hirsute, about $12 \mathrm{~mm}$. long: corolla violet-purple, rarely $3 \mathrm{~cm}$. long.-Probably within our range on the south.

5. Ipomoea hederacea Jacq. Ic. Rar. pl. 36. 1781. Stem slender, 6-15 dm. long, retrorsely hairy: leaves deeply 3-lobed; the lobes ovate to ovatelanceolate, and the middle one narrowed at base, the lateral ones often repandlobed: peduncles short, 1-3-flowered, pedicels wanting or nearly so: sepals linear-attenuate from a dilated and densely long-villous-hirsute base, $2-3 \mathrm{~cm}$. long, at length recurved: corolla sky-blue, with whitish tube, $4-5 \mathrm{~cm}$. long: capsule depressed-globose. IVY-LEAVED MORNING-GLORY.-Introduced from tropical America.

\section{CONVOLVULUS L. Bindweed}

Ours slender twining or trailing perennial herbs, generally with cordate or sagittate-petioled leaves and large axillary flowers. Sepals equal or unequal, of ten a pair of bracts at their base. Corolla campanulate to funnelform, plicate; the limb entire or lobed. Stamens inserted on the tube, included. Stigmas 2, filiform or oblong. Capsule globose, 2-4-valved, usually 2-celled.

Calyx subtended and inclosed by 2 bracts. Leaves hastate, glabrate

Leaves oblong-cordate, pubescent

Calyx not subtended by bracts.

Leaves broad, entire, glabrous
Leaves narrow, lobed at base, canescent

1. Convolvulus sepium L.Sp. Pl. 153. 1753. Glabrous or slightly pubescent, freely twining: leaves slender-petioled, deltoid-hastate, $5-12 \mathrm{~cm}$. long, acute or acuminate, the basal-lobes acute, divergent, entire or angulate toothed: peduncles elongated, 1-flowered; bracts cordate-ovate: corolla broadly funnelform, pink or white: stigmas oblong. HedGe Bindweed.-Introduced in many localities.

2. Convolvulus repens L. Sp. Pl. 153. 1753. Pubescent or tomentose; stems prostrate-trailing: leaves oblong, with sagittate or cordate base, the lobes entire, obtuse or rounded: flowers much as in the preceding; corolla usually white. Trailing Bindweed.-Frequent in fields.

3. Convolvulus arvenis L.Sp. Pl. 153. 1753. Nearly glabrous, the twining stems very slender, $4 \mathrm{dm}$. or more long: leaves oblong-sagittate or somewhat hastate, $3-5 \mathrm{~cm}$. long, the basal-lobes short, acute: bracts at base of pedicel small and subulate: corolla white or tinged with rose, $2-3 \mathrm{~cm}$. long: stigmas filiform.-Sparingly as an introduced weed.

4. Convolvulus incanus Vahl. Symb. 3: 23. 1794. Canescent with a short and close silky-pubescence; stems filiform, 3-10 dm. long, mainly procumbent: leaves short-petioled, polymorphous; some simply lanceolate- or linear-sagittate or hastate, obtuse and mucronate, entire, and with the narrow elongated basal lobes entire or 2-3-toothed; usually variously cleft or parted at base, the lobes divergent or reflexed: peduncles equaling the leaf, 1-2-flowered: corolla white or tinged with rose, the angles salient-acuminate, 10-14 mm. long.-Throughout the eastern part of our range to Texas. 


\section{POlemoniaceae Vent. Phlox Family}

Herbs with alternate or opposite leaves and regular 5-merous flowers. Calyx persistent, imbricated. Corolla convolute in the bud. Stamens either equally or unequally inserted. Ovary 3-celled, with 3-lobed style. Pod 3celled, 3-ovuled, loculicidal, few-many-seeded. Seed coat frequently mucilaginous when moistened and emitting spiral threads.

Leaves simple and entire, often crowded or imbricated.

Perennials with alternate leaves, or if annuals the leaves either opposite or alternate.

Stem leafless except for the pair of cotyledons; plants very small Stems leafy.

Calyx not ruptured by the maturing capsule; stamens unequally inserted; ovules solitary

Calyx at length ruptured by the maturing capsule; stamens equally inserted; ovules more than 1 in each cell . . .

Leaves pinnate or pinnatifid.

Leaves and calyx-teeth spinulose-tipped

1. Phlox.

2. Gymnosteris.

3. Collomia.

4. Gilia.

5. Navarretia.

Leaves and calyx-teeth herbaceous

6. Polemonium.

\section{PHLOX L. PhLOX *}

Perennials (except a few southern species, such as $P$. Drummondii of the gardens), with opposite and sessile, perfectly entire leaves, the floral often alternate. Flowers cymose, mostly bracted; the open clusters terminal or crowded in the upper axils. Calyx narrow, somewhat prismatic, or plaited and angled. Corolla salverform, with a long tube. Stamens very unequally inserted in the tube of the corolla, included. Capsule ovoid, with sometimes 2 ovules, but ripening only a single seed in each cell. Our Rocky Mountain forms are somewhat suffrutescent, chiefly with narrow or minute and thickishmargined leaves, and branches or peduncles mostly 1-flowered.

Pulvinate or caespitose.

Flowers solitary, the annual growth 1-flowered.

Leaves beset with woolly, cobwebby hairs.

Densely arachnoid-lanate; leaves scale-like, imbricated.

Leaves 4-ranked; corolla-tube much longer than the calyx

Leaves not 4-ranked; corolla-tube not longer than the calyx

Sparsely arachnoid-lanate or glabrate; leaves subulate, often bisulcate.

Corolla-tube much longer than the calyx

Corolla-tube but little if any longer than the calyx. Leaves sparsely lanate

Leaves not beset with woolly cobwebby hairs.

Leaves hispid-ciliate and often glandular-pubescent.

Leaves not thickened-cartilaginous on the margins. Leaves bisulcate, oblong-linear

Leaves plane, lance-linear

Leaves thickened-cartilaginous on the margins

Leaves glabrous, only the inflorescense pubescent, or the whole plant glabrate.

Leaves plane; flowers pedunculate

Leaves involute; flowers subsessile

Flowers not solitary, the annual stems 2-several-flowered.

Stems from a rhizome, erect; leaves bisulcate

Stems caespitose-spreading; leaves plane

Scarcely tufted, suffrutescent or nearly herbaceous.

Glabrate or puberulent, not glandular.

Stems few, slender, 1-3 dm. high

Stems numerous, less than $1 \mathrm{dm}$. high

Pubescent and glandular.

Corolla-tube more than twice as long as the calyx.

Pubescence minute.

Pubescence coarse

Corolla-tube less than twice as long as the calyx :

1. P. bryoides.

2. P. muscoides.

3. P. canescens.

4. P. Hoodii.

5. P. glabrata.

6. $P$. condensata

7. P. caespitosa.

8. P. alyssifolia.

9. P. multiflora.

10. P. depressa.

11. P. andicola.

12. P. Kelseyi.

13. P. longifolia.

14. P. cernua.

15. P. puberula.

16. P. Stansburyi.

17. P. nana.

* The treatment of this genus is adapted from Elias Nelson's excellent "Revision of Western North American Phloxes," Ninth Rep. Wyo. Agr'l College, 1899. 
1. Phlox bryoides Nutt. $\mathrm{Pl}$ Gamb. 153. 1848. Copiously lanate, densely caespitose and depressed, forming cushion-like mats: leaves short, imbricated in 4 strict ranks, crowded up to the mostly solitary flowers, ovate or triangularlanceolate, about 3-4 mm. long, the margins usually inflexed: tube of the corolla exceeding the calyx, the cuneate lobes about $3 \mathrm{~mm}$. long.-Stony slopes and ridges at middle elevations; Colorado to Montana and west to Utah.

2. Phlox muscoides Nutt. Journ. Acad. Phila. 8: 42. 1834. Like the preceding, more resembling some canescent moss: the branches much tufted, very short: leaves less strictly 4-ranked and less lanate, ovate-lanceolate: tube of the corolla not surpassing the calyx.-Rare; Montana.

3. Phlox canescens T. \& G. Pacif. R. R. Rep. 2: 122. 1855. Densely caespitose, lanate and somewhat canescent, at least when young: leaves subulate, pungent, somewhat granular-roughened, at length recurved-spreading, 6-10 $\mathrm{mm}$. long: corolla white (tube "yellow "), somewhat hairy at base within, twice the length of the calyx or nearly so, the lobes broadly obovate to rotund, usually entire, about $5 \mathrm{~mm}$. long: style less than half the length of the corolla-tube.Western Colorado to California.

4. Phlox Hoodii Rich. Frankl. Journ. App. pl. 28. 1823. Densely tufted and much branched from a somewhat woody root, sparsely lanate: leaves subulate, apiculate, with broader clasping bases, 4-10 $\mathrm{mm}$. long: calyx 5-7 mm. long, the teeth like the leaves, the thickened central portion of the teeth produced into strong ribs on the tube below: corolla white, the tube equaling or somewhat exceeding the calyx, the lobes obovate, entire or mucronate, about $5 \mathrm{~mm}$. long.-Flowering early in the spring on the plains and foothills; from Saskatchewan to Montana and Wyoming.

5. Phlox glabrata (E. Nels.) Brand, Pflanzenreich, Polem. 86. 1907. Depressed-caespitose; stems very numerous from the small, ligneous, branched, rhizomatous caudex, ascending, the internodes very short: leaves glabrate, densely imbricated-appressed, nearly linear, 5-6 mm. long: flowers solitary, sessile: calyx subglabrous, the lobes shorter than the tube: corolla 8-10 $\mathrm{mm}$. long, the tube scarcely longer than the calyx, the lobes broadly ovate, not much shorter than the tube: stamens inserted in the throat: style as long as the calyx. (P. Hoodii glabrata E. Nels. Rev. W. N. A. Phloxes 11.)-On the high plains of southern Wyoming.

6. Phlox condensata (Gray) E. Nels. Rev. W. N. A. Phloxes 13. 1899. Densely pulvinate-tufted: leaves much imbricated, rigid, oblong-linear, apiculate, distinctly bisulcate, hispid-ciliate on the margins and slightly glandular, 5-6 mm. long: calyx as long as the leaves, the teeth oblong-linear, apiculate: corolla white, the tube twice the length of the calyx or less, somewhat hairy at the base within, the lobes rotund, $4.5 \mathrm{~mm}$. long: style shorter than the calyx. (P. scleranthifolia Rydb. Mem. N. Y. Bot. Gard. 1: 313. 1900, at least as to Colorado specimens.)-At high altitudes in Colorado.

7. Phlox caespitosa Nutt. 1. c. 41. Densely or somewhat loosely caespitose, often with long, prostrate stems: leaves oblong-linear or lanceolate, apiculate, 8-14 mm. long, 1-2 $\mathrm{mm}$. wide, usually plane, the somewhat cartilaginous margins hispid-ciliate or naked, surface glabrous or with short, scattered, gland-tipped hairs: flowers sessile or subsessile (peduncles rarely $2 \mathrm{~mm}$. long): calyx more or less hispid-ciliate and usually with some short gland-tipped hairs, the teeth as long as the tube, lanceolate or narrowly so, pungent: corolla white or light blue, the tube slightly hairy at base within, about three times the length of the calyx-teeth, the lobes broadly obovate, 5-7 mm. long.-In the mountains from New Mexico to Montana; type locality, "Flat-Head River, on the sides of dry hills."

8. Phlox alyssifolia Greene, Pitt. 3: 27. 1896. Stems nearly prostrate, herbaceous, short, stout, from a subligneous branching caudex, the short internodes hispidulous with white hairs: leaves 10-18 mm. long, oblonglinear, cuspidately acute, plane, rather thick, with callous, white, entire margins, and a similar midvein very prominent beneath, though obsolete above, both faces glabrous, only the margins loosely ciliate toward the base of the leaf: flowers very few, large, pale purple or white, short-pediceled at the 
ends of the branches: calyx-tube glandular-pubescent, the scarious line below the sinuses very narrow; teeth oblong-lanceolate, aristate-pointed: corolla-tube well exserted; segments narrow, obtuse, entire: style about equaling the tube of the corolla.-Gravelly or stony hills; eastern Wyoming to Assiniboia.

9. Phlox multiflora A. Nels. Bull. Torr. Bot. Club 25: 278. 1898. Suffrutescent as to the caespitose much branched prostrate base, the numerous herbaceous stems nearly erect, 6-10 cm. high, the branches simple, 1-flowered: leaves broadly linear, glabrous, apiculate, $1-2 \mathrm{~cm}$. long, opposite or fascicled: peduncles finely pubescent, 1-3 cm. long: calyx angled by the prominent midrib of the lobes, membranous in the sinus only; lobes linear-apiculate, equaling the tube: tube of the corolla exceeding the calyx; lobes obovate, entire, $1 \mathrm{~cm}$. long: style as long as the calyx.-In the foothills of the mountains; from Colorado to Montana.

10. Phlox depressa (E. Nels.) Rydb. Bull. Torr. Bot. Club 33: 149. 1906. Depressed-caespitose, rising but little above the ground: leaves $1 \mathrm{~cm}$. long, rarely $2 \mathrm{~cm}$.: flowers mostly subsessile, the corolla-lobes $6-7 \mathrm{~mm}$. long: otherwise much like the preceding. ( $P$. densa Brand, 1. c. 83 , seems to be merely a still more compact form with some traces of lanate pubescence.) - In moist swales on the plains; Colorado, Wyoming, and Idaho.

11. Phlox andicola (Brit.) E. Nels. 1. c. 11. Stems from a rhizome, usually erect, often branched at the surface of the ground and with opposite branches at the nodes, white, the bark exfoliating with age in thin shreds, $5-10 \mathrm{~cm}$. high; sparsely lanate on the calyx and bases of the leaves, the stems granularpubescent and somewhat glandular: leaves acerose or subulate, often somewhat bisulcate, pungent, 1-2 cm. long: flowers sessile or on peduncles $2 \mathrm{~mm}$. long: calyx-teeth as long as the tube, pungent: corolla white, the tube somewhat hairy near the base within, one and a half times the length of the calyx, the lobes broadly obovate, $5-7 \mathrm{~mm}$. long: style about as long as the calyx.On the plains east of the Rocky Mountains, from Montana to western Nebraska and eastern Wyoming.

12. Phlox Kelseyi Brit. Bull. Torr. Bot. Club 19: 225. 1892. Manystemmed from a woody root, the stems spreading, creeping or ascending, sometimes $20 \mathrm{~cm}$. long, glabrous or slightly pubescent above, very leafy: leaves sessile, oblong or linear-oblong, glabrous or nearly so on both sides, 5-15 mm. long, 2-4 mm. wide, thick, rigid, the apex mucronately tipped with a short spine, the margins revolute, ciliate; upper leaves narrower and longer than the lower: flowers sessile or short-peduncled, the peduncles and calyx somewhat glandular-pubescent or glabrous: calyx-teeth subulate, as long as or longer than the tube: corolla-tube somewhat exceeding the calyx-lobes; limb about $1.5 \mathrm{~cm}$. broad, bright blue or lilac, the lobes obovatc-cuneate, rounded. [Brand in his monograph of this family (Pflanzenreich) reduces the following to varietal rank, which is probably quite justifiable: $P$. albomarginata Jones, Zoe 4: 367. 1894; $P$. costata Rydb. Mem. N. Y. Bot. Gard. 1: 315. 1900; P. collina Rydb. 1. c.; P. diapensioides Rydb. 1. c.]-Wyoming and Montana.

13. Phlox longifolia Nutt. 1. c. Usually erect in habit, 10-25 cm. high, finely pubescent or glabrous: leaves linear, with prominent midvcins and somewhat thickened cartilaginous margins, $3-6 \mathrm{~cm}$. long, 2-3 mm. wide: flowers on pedicels $1-3 \mathrm{~cm}$. long: calyx with slightly replicate sinuses: corolla white, the tube somewhat exceeding the calyx, the lobes obovate or cuneateobovate, entire, emarginate, or erose, $8-10 \mathrm{~mm}$. long: oviles generally solitary in each cell.-Along the western side of the Rocky Mountains from Montana to Colorado and Utah; also in Oregon and Washington.

14. Phlox cernua E. Nels. 1.c. 22. Suffrutescent at base and many-stemmed, 6-12 cm. high, the lower part of the stems purple; glabrous throughout or the stems puberulent below: leaves linear, spreading, 2-3 cm. long, less than $2 \mathrm{~mm}$. wide: flowers on slender pedicels (about $1 \mathrm{~cm}$. long), inclined to be nodding: calyx with somewhat replicate sinuses, the teeth half the length of the tube: corolla white or tinged with purple, the tube twice the length of 
the calyx, the lobes obovate, entire or somewhat erose, 7-8 mm. long: ovules solitary in each cell.-Cimarron, Montrose county, Colorado.

15. Phlox puberula (E. Nels.) A. Nels. Low, $1 \mathrm{dm}$. high or less, stems erect or ascending; more or less glandular-puberulent, very densely so on the pedicels and calyx, nearly destitute of roughish hairs: leaves usually spreading, linear, bluntish at tip or apiculate, 2-4 cm. long, 1-2.5 mm. wide: replication of the calyx sinuses very slight and inconspicuous: corolla light blue or lilac, the lobes obovate or cuneate-obovate, retuse or blunt, 7-12 $\mathrm{mm}$. long: ovules solitary in each cell. ( $P$. longifolia puberula E. Nels. l. c. 26.)-Frequent in western Wyoming and adjacent Utah and Idaho. Flowering much earlier than $P$. longifolia.

16. Phlox Stansburyi (Torr.) Heller, Bull. Torr. Bot. Club 24: 478. 1897. Stems several from a ligneous base, rather stout, usually simple below, cymosely branched above into leafy-bracted corymbs, about $1 \mathrm{dm}$. high; pubescent throughout, roughly so above, the pedicels and calyx usually glandular: leaves thick, usually recurved-spreading, linear or linear-lanceolate, apiculate, 20-35 mm. long, 2-3 mm. wide: flowers on pedicels $5-15 \mathrm{~mm}$. long: calyx $1 \mathrm{~cm}$. long, the sinuses more or less replicate, the teeth apiculate or somewhat cuspidate-attenuate, as long as the tube: corolla pink or rose-color, the tube fully twice the length of the calyx, the lobes cuneate-obovate, erose, emarginate or retuse, 7-8 mm. long: ovules usually one in each cell. ( $P$. dasyphylla Brand, 1. c. 80 . The type, Baker's No. 620, seems to be merely an over-mature, hence glabrous, specimen of this species.)-Colorado and New Mexico and thence far westward.

17. Phlox nana Nutt. Pl. Gamb. 153. 1848. Herbaceous to the ground or somewhat ligneous at base, 1-2 dm. high, stems freely branched; roughishpubescent throughout and more or less glandular: leaves spreading, opposite below, alternate above, lance-linear, on the main stems 20-35 mm. long, 3-4 $\mathrm{mm}$. wide, on the lateral branches shorter and narrower: flowers scattered or somewhat corymbose, on pedicels 5-35 mm. long: calyx-teeth slightly longer than the tube, green and apiculate: corolla "red " or "white," the tube pubescent, somewhat exceeding the calyx, the lobes broadly cuneateobovate, entire or with wavy margins, often mucronate, about $15 \mathrm{~mm}$. long: ovules 2 or 3 in each cell.-Common in New Mexico, also in Arizona.

\section{GYMNOSTERIS Greene}

Diminutive annuals devoid of proper foliage, the cotyledons persisting on the otherwise naked stem. The capitate-congested inflorescence subtended by an involucre of 4 or 5 leaves which are distinct and herbaceous above, but scarious and united at base. Calyx vesicular and urceolate, thin-scarious, only the unequal teeth herbaceous. Corolla salverform, with long and slender tube; the somewhat dilated throat bearing the stamens, the whole marcescentpersistent, the dilated base of the tube still investing the thin, apparently indehiscent capsule with its ripe seeds. Seeds many, obliquely somewhat cubical, the angles membranaceously margined or winged; testa thin, mucilaginous when wetted, but not developing spiracles.

1. Gymnosteris nudicaulis (H. \& A.) Greene, Pitt. 3: 304. 1898. Very glabrous, $3-10 \mathrm{~cm}$. high, at length branching from the base: stem leafless from the cotyledons up to the inflorescence, which is a close head or glomerule subtended by an involucre of several entire, ovate-lanceolate or lanceolate, foliaceous bracts: corolla salverform, white, pink, or yellow; the tube 5-7 mm. long and thrice the length of the calyx: ovules 10-16 in each cell.- Sandy stream banks.

\section{COLLOMIA Nutt.}

Herbs with alternate, mostly entire leaves. Calyx scarious below between the angles, accrescent, obpyramidal or nearly cyathiform, not distended by the capsule. Corolla tubular-funnelform, with open throat and a spreading 
limb of short obtuse lobes. Stamens unequal and unequally inserted on the tube of the corolla. Capsule narrowed at base. Seeds usually 1 in each cell, mucilaginous when wetted, and emitting spiracles.

Flowers in terminal clusters

Flowers solitary in the uppermost axils

1. C. linearis.

1. Collomia linearis Nutt. Gen. 1: 126. 1818. Stems simple or branching above, sometimes in age widely so, 1-3 dm. high: flowers capitate-crowded and leafy-bracted: calyx obconical; the lobes triangular-lanceolate: corolla from lilac-purple to nearly white, very slender, tubular-funnelform, the tube minutely pubescent: capsule triangular-obcordate.-Very common in moist sandy soils in our range.

2. Collomia tenella Gray, Proc. Am. Acad. 8: 259. 1870. Viscid-puberulent, very slender, 5-12 $\mathrm{cm}$. high, simple or laxly branched above: leaves entire, linear, obtuse, attenuate at base, the lowest opposite: flowers solitary in the axils, remote, nearly sessile: calyx obconic, about $4 \mathrm{~mm}$. long, the lobes short-triangular, shorter than the broadly turbinate tube: corolla purplish, about $8 \mathrm{~mm}$. long, narrow, salverform: ovules solitary.-Mountains of Utah and Nevada.

\section{GILIA Ruiz \& Pav.}

Annual, biennial, or perennial herbs, with alternate or opposite, entire or divided leaves. Flowers scattered or congested in heads or thyrsiform panicles. Calyx tubular or campanulate, at length split by the enlarging capsule. Corolla tubular or funnelform, with an open funnelform throat. Stamens unequally or equally inserted. Seeds usually developing spirally-twisted threads when wetted.

\section{Key to the Sections}

Leaves alternate, the lowest sometimes opposite.

Flowers scattering-solitary, in corymbs, or in corymbosepanicles.

Annuals, with straight embryo (see also nos. 7 and 8); the seed-coats often developing mucilage and emitting spiral threads if wetted.

Ovules solitary in each cell

Ovules 2-several in each cell

Biennials or perennials (except nos. 7 and 8 ), with straight embryo; the seedcoats developing mucilage and emitting spiral threads if wetted

Flowers congested in capitate or spicate inflorescences: embryo broadly curved; calyx and bracts viscid pubescent; seed-coats developing mucilage and emitting spiral threads if wetted

Leaves opposite or rarely alternate and then palmately $3-7^{\circ}-$ cleft or parted.

Perennials

Annuals, with funnelform corolla

I. PHLOGASTRUM.

II. EUGILIA.

III. IPOMOPSIS.

\section{ELAPHOCERA.}

V. LEPTODACTYLON.

VI. DACTYLOPHYLLUM.

I. PHLOGASTRUM.-Leaves entire or divided; flowers solitary or loosely corymbed.

Corolla scarcely longer than the calyx, salverform.

Stamens unequally inserted Stamens equally inserted

Corolla twice as long as the calyx

II. EUGILIA. - Leaves pinnatifid or bipinnatifid, rarely nearly entire; flowers scattered-paniculate.

Seeds unchanged if wetted.

Seeds emitting spiral threads if wetted

III. IPOMOP IIS. - Biennials, perennials, or rarely annuals; stems usually tall; corolla usually well exserted from the calyx.

Leafy throughout.

Corolla 10-12 mm. long

Corolla 20-50 mm. long.

Annuals; capsule much longer than the calyx. Corolla more than $3 \mathrm{~cm}$. long . Corolla less than $3 \mathrm{~cm}$. long

Biennials; capsule not longer than the calyx. Flowers red or roseate Flowers white

1. G. micrantha.

2. G. Tweedyi.

3. G. tenerrima.

4. G. leptomeria.

5. G. inconspicua.
6. G. polyantha.

7. G. longifiora.

8. G. laxiflora.

9. G. aggregata.

10. G. attenuata. 
Leaves mostly in a basal rosette.

Stems leafy; filaments conspicuously exserted

Stems nearly naked; filaments wanting or very short

IV. ELAPHOCERA.-Biennials or annuals; flowers congested.

Biennials; leaves more or less divided, or entire; ovules 1-4 in each cell.

Flowers spicate

Flowers capitate.

Style pilose above

Style glabrous, at least above

Annuals, with pinnatifid leaves.

Style glabrous

Style pilose below

V. LEPTODACTYLON.-Perennials; leaves alternate or opposite, of ten pungent.

Shrubby

Woody at base only.

Leaves opposite

Leaves alternate.

Depressed-caespitose Erect and branching

VI. DACTYLOPHYLLUM. - Annuals with opposite leaves palmately parted or rarely entire; corolla funnelform; seeds mucilaginous or emitting spiral threads when wetted.

Stamens glabrous

Stamens pilose

11. G. pinnatifida.

12. G. subnuda.

1. Gilia micrantha (Kell.) A. Nels. Annual, puberulent or pubescent with gland-tipped hairs, at length freely branched from the base, $5-15 \mathrm{~cm}$. high, as broad as high: leaves alternate, usually at the base of the branches, lanceolate or linear, 1-3 cm. long: flowers mostly geminate on short subequal pedicels: calyx-teeth acute, about half the length of the tube: corolla white or pale pink or violet, the tube usually subsurpassing the calyx: capsule elongatedoval. G. gracilis. (Collomia micrantha Kell. Proc. Cal. Acad. 3: 18, 1863; Microsteris micrantha Greene, Pitt. 3: 303. 1898; under various other names.) - Throughout our range and westward.

2. Gilia Tweedyi Rydb. Bull. Torr. Bot. Club 31: 634. 1904. Annual, branched, 1-4 dm. high; stem and branches glandular-puberulent, especially above: leaves 1-3 cm. long, pinnatifid with lanceolate-cuspidate lobes, or the uppermost entire: flowers paniculate; pedicels 1-8 $\mathrm{mm}$. long: calyx about $3 \mathrm{~mm}$. long, scarious between the green ribs, the lobes lanceolate: corolla funnelform, barely exceeding the calyx, bluish: capsule ovoid, about $4 \mathrm{~mm}$. long. G. minutiflora.-Colorado to Montana and Idaho.

3. Gilia tenerrima Gray, Proc. Am. Acad. 8: 277. 1870. Slender annual, 1-3 dm. high, diffusely branched from the base with numerous, scattered, divaricate, almost filiform branchlets, minutely glandular-pubescent: leaves alternate, linear or the radical lanceolate, the upper much reduced, entire: flowers small, solitary, terminal on the branchlets: corolla salverform, twice as long as the calyx, white: capsule compressed-globose: seed-coats mucilaginous.-Western Wyoming, Utah, and Idaho.

4. Gilia leptomeria Gray, l.c. More or less glandular-pubescent; stem erect, divaricately branched from base to summit, 6-15 $\mathrm{cm}$. high: radical leaves rosulate, oblong-linear, dentate to pinnatifid, teeth usually short-mucronate; cauline leaves reduced and bract-like: flowers numerous, corymbose-paniculate: calyx-teeth shorter than the tube: corolla white or rose-color, salverform, 4-6 $\mathrm{mm}$. long, the tube nearly twice the length of the lobes and of the calyx: stamens inserted in the throat: style as long as the corolla: ovules and seeds 2-3 in each cell of the globose capsule.-Colorado to California.

5. Gilia inconspicua (Smith) Dougl. Hook. Mag. 56: pl. 2883. 1829. One to three or more dm. high, usually with slight woolly pubescence when young, and viscid-glandular, often branching from the base: leaves mostly pinnatifid or pinnately-parted, or the lowest bipinnatifid, with short, mucronate-cuspidate lobes; the uppermost becoming small, subulate and entire: flowers either somewhat crowded and subsessile or at length loosely panicled and some of them slender-pediceled: corolla violet or purplish, 5-10 $\mathrm{mm}$. long, narrowly funnelform, the lobes oval, half as long as the tube which much exceeds the calyx: ovules 2-several in each cell. Very variable, and a number of segregates have 
been proposed, only the following of which need to be mentioned.-Widely distributed in the western half of America.

5a. Gilia inconspicua sinuata Gray, Proc. Am. Acad. 8: 278. 1870. Nearly glabrous, the leaves sinuate: the corolla tubular to salverform.-Western part of our range, and westward.

5b. Gilia inconspicua subacaulis (Rydb.) Brand, Polem. (Pflanzenreich) 105. 1907. Stem low, very slender, usually branched above. (G. subacaulis Rydb. 1. c. 30: 261. 1903.) - Southern Wyoming.

6. Gilia polyantha Rydb. 1. c. 31: 634. 1904. Stem single at base but branched from near the base upward; branches mostly simple and moderately divaricate, almost equaling the main stem, minutely pruinose-viscid: leaves $2-5 \mathrm{~cm}$. long, somewhat pungent, linear, entire or simple-pinnatifid, with few to several linear lobes: flowers in small bracteate cymes forming narrow panicles: calyx membranous, narrowly campanulate, about $4 \mathrm{~mm}$. long, merely pruinose; its teeth very short, green, triangular-subulate, and minutely pungent: corolla white, purple-dotted, 10-12 mm. long, somewhat trumpet-shaped; the tube surpassing the calyx; the lobes elliptic-oblong, acute, almost as long as the tube: stamens noticeably exserted; style scarcely so: ovules about 2 in each cell. (G. exserta A. Nels. Bot. Gaz. 40: 65. 1905.)-Southern Colorado.

7. Gilia longiflora (Torr.) G. Don, Gen. Syst. Gard.4: 245. 1837. Glabrous, loosely paniculate-branched: divisions of the leaves long and slender: flowers somewhat corymbose on slender peduncles: corolla white, strictly salverform, showy; the tube often 3-5 cm. long, with narrow orifice; lobes orbicular or ovate, many times shorter than the tube: stamens unequally inserted near the top of the tube, included: capsule obovate-oblong, twice as long as the calyx, many-seeded: seeds angled.-Texas and Mexico to Nebraska and Colorado.

8. Gilia laxiflora (Coult.) Osterh. Bull. Torr. Bot. Club 24: 51. 1897. Annual, about $3 \mathrm{dm}$. high, erect, branching, glabrous except the calyx, pedicels, and growing stem, which are minutely glandular: leaves pinnate with slender divisions, mucronate-tipped, the upper few-lobed or entire: inflorescence scattering, with flowers on slender pedicels 1-2 cm. long: corolla white or bluish-tinted, slender, $10-15 \mathrm{~mm}$. long; the lobes ovate, pointed, 4-5 $\mathrm{mm}$. long: filaments included, unequally inserted: tube of the calyx $5 \mathrm{~mm}$. long, with subulate teeth 1.5-2 mm. long: capsule $10 \mathrm{~mm}$. long, having 6 seeds in each cell, which develop mucilage and spiracles when wetted.-Colorado to New Mexico and Texas.

9. Gilia aggregata (Pursh) Spreng. Syst. 1: 626. 1825. Somewhat pubescent; stems 3-10 dm. high, leafy, sometimes loosely branching: leaves thickish, with narrowly linear mucronulate divisions: panicle loose or interrupted; the flowers sessile in small mostly short-pedunculate clusters: calyx commonly glandular: corolla scarlet to pink-red, with narrow tube; the lobes ovate or lanceolate, acute or acuminate, widely spreading, soon recurved: stamens and style exserted. (Greene, in Leaflets 159 and 160, offers the following segregates, under the proposed new generic name Callisteris: $C$. collina, C. formosissima, 'C. flavida, C. pulchella. Gilia scariosa Rydb. 1. c. 31: 632. 1904 is also to be referred to this species.)-Texas to western Nebraska and west to Oregon.

10. Gilia attenuata (Gray) A. Nels. Bull. Torr. Bot. Club 25: 278. 1898. Nearly related to the preceding: basal leaves green and glabrate; the upper pubescent and more or less glandular, the inflorescence decidedly so: inflorescence more narrowly thyrsiform: calyx-lobes narrowly attenuate: corolla white, the tube often pinkish, 3-4 cm. long, the lobes long and gradually acuminated: style and stamens included. (G. candida Rydb. 1. c. 28: 29. 1904; Callisteris leucantha Greene, 1. c.)-Wyoming and Colorado.

11. Gilia pinnatifida Nutt. Gray in Proc. Am. Acad. 8: 276. 1870. Stem simple or loosely branching, 1-5 dm. high: inflorescence open-paniculate, often compound: leaves pinnately parted into linear or narrowly oblong lobes; these sometimes again 1 or 2-lobed: stamens conspicuously exserted: corolla strictly salverform, 4-5 $\mathrm{mm}$. long, pale blue or violet, or the narrow tube 
white: style as long as the corolla; the exserted stamens inserted in the sinuses: capsule ovoid: seeds small, narrowly winged.-Wyoming to New Mexico.

12. Gilia subnuda Gray, 1. c. 276. Biennial; stems erect, simple or branched, 3-5 dm. high: radical leaves rosulate, oblong-spatulate, lobed or somewhat pinnatifid, attenuate to the base; cauline small, bract-like, and nearly or quite entire: flowers subcorymbose, terminating the branchlets, pediceled: calyx glandular, as are also the pedicels, the teeth subulate, as long as the narrowly campanulate tube: corolla yellow or rose-color, tubular-funnelform, 15-20 mm. long, minutely glandular; the lobes oval, less than half as long as the tube: stamens included, nearly sessile: style glabrous: capsule ovoid: seeds angled, narrowly winged, unchanged if wetted. (G. Crandallii Rydb. I. c. 634 ; G. Bakeri Greene, Brand, Polem.) - Southern Colorado to New Mexico and thence westward to Nevada.

12a. Gilia subnuda Haydenii (Gray) Brand, 1. c. 119. Glabrate: leaves deeply incised, rarely pinnatifid: corolla rose-color. (G. Haydenii Gray, l. c. 11: 85.) - Colorado to New Mexico.

12b. Gilia subnuda superba (Eastwood) Brand, 1. c. Viscid-glandular throughout: leaves irregularly lobed or dentate: corolla orange or red. ( $G$. superba Eastwood, Zoe 4: 122. 1893.) - Utah to Nevada.

13. Gilia spicata Nutt. Journ. Acad. Nat. Sci. 2: 156. 1848. Stems rather stout, erect, simple, or several from the fusiform root, 2-3 dm. high: capitate flower-clusters crowded in an elongated, virgate, and spike-like thyrsus: leaves thickish, almost filiform, some about 3-cleft, occasionally all entire, barely mucronate: corolla salverform, purplish, 10-12 mm. long; the lobes shorter than the tube: anthers subsessile in the throat: ovules 4-6 in each cell.Mountains of Colorado to Utah and Wyoming.

13a. Gilia spicata deserta A. Nels. Bull. Torr. Bot. Club 26: 132. 1899. Habit of the species, but usually shorter-stemmed; stems one or more from a woody root with one or more swollen crowns, lanate: basal leaves crowded on the crowns, mostly simple, linear; the cauline pinnatifid, the divisions few (3-5), linear, shorter than in the species: inflorescence crowded-spicate, in dwarf plants approaching capitate: calyx closely and minutely glandular.Desert areas in Colorado and Wyoming.

14. Gilia cephaloidea Rydb. 1. c. 24:293. 1897. Lanate-pubescent; stems simple, solitary or several from the crown, 1-3 dm. high; root somewhat woody: radical leaves crowded, linear, or 3-cleft at the apex, $5 \mathrm{~cm}$. long; cauline few, 3-5-cleft, the segments short, linear: corolla white: stamens equally inserted in the throat, exserted, the filament and anther subequal: style as long as the corolla, pilose at the apex.- South Dakota to Montana and Wyoming.

15. Gilia congesta Hook. Fl. Bor. Am. 2: 75. 1838. Stems erect or spreading, 1-3 dm. high, from a tufted base, bearing single terminal or few and corymbose capituliform cymes: leaves with 2-7 mucronate divisions, or some of them entire: corolla white, salverform; lobes of the corolla nearly as long as the tube, which does not exceed the usually aristulate-tipped calyx-lobes: exserted filaments at length as long as the anthers: ovules 1-2 in each cell: capsule globose, 1-3-seeded.-From the Rocky Mountains to the Pacific States.

15a. Gilia congesta iberidifolia (Benth.) Brand, 1. c. 121. Leaves more rigid and the lobes cuspidate-tipped, as are also the bracts: capitate cymes corymbose: filaments shorter: ovules solitary in each cell. Not readily distinguished from depauperate specimens of the species. (G. spergulifolia Rydb. 1. c. 633 ; G. roseata Rydb. 1. c.)-Nebraska to Colorado and Wyoming.

15b. Gilia congesta crebrifolia (Nutt.) Gray, 1. c. Low, often depressed: leaves crowded, all entire, linear, rigid: stems usually terminated by a single capitate cluster. (G. Merrillii A. Nels. Bot. Gaz., 34: 27. 1902.)-In the Rocky Mountain States.

16. Gilia polycladon Torr. Bot. Mex. Bound. 2: 146. 1859. Stems 1-2 $\mathrm{dm}$. high, puberulent or sparsely pubescent, diffuse, very few-leaved: leaves pinnatifid or incised; the lobes short, oblong, abruptly spinulose-mucronate,

ROCKY мт. Вот.-26 
those subtending the cymose cluster longer than the flowers: flowers cymuloseglomerate and leafy-bracted: tube of the corolla hardly exceeding the aristulatemucronate calyx-lobes: anthers in the throat, on very short filaments: ovules 2 in each cell.- Texas to Colorado and west to Nevada.

17. Gilia pumila Nutt. 1. c. Stems 1-2 dm. high, loosely woolly, at least when young, leafy: leaves narrowly linear, entire or most of them 2 to 4-parted into diverging linear lobes, mucronate: flowers cymulose-glomerate and leafy-bracted: tube of the corolla slender, about twice the length of the aristulate-tipped calyx-lobes: filaments slender, inserted in the sinuses, exserted, shorter than the lobes of the corolla: ovules about 6 in each cell.From western Nebraska and Texas to the Sierra Nevada.

18. Gilia pungens (Torr.) Benth. in DC. Prodr. 9: 316. 1845. Stems woody, tufted, branched, very leafy, 1-3 dm. high: leaves alternate except the lowest, much fascicled in the axils, or rather 3-7-palmately parted with acerose segments: flowers sessile and solitary in the upper leaf-axils: calyx tubular, with subulate teeth, glandular-ciliate: corolla roseate, white or yellowish, tubular: stamens unequally affixed, scarcely exserted: ovules many (6-10 in each cell): capsule oblong, shorter than the calyx.-From New Mexico to the Canadian provinces.

18a. Gilia pungens Hookeri. (Dougl.) Gray, Proc. Am. Acad. 8: 268. 1870. More or less glandular above: leaves strict: bracts shorter than the calyx.Throughout our range.

19. Gilia Watsonii Gray, 1. c. 267. Roughish-puberulent and glandular, or at length smoothish; slender branches 1-2 dm. high from the woody caudex: leaves not much fascicled, widely spreading; the slender acerose divisions 10-15 mm. long, often shorter than the internodes: calyx-lobes barely half the length of the tube: corolla nearly white with purplish throat; the tube and lobes each about $12 \mathrm{~mm}$. long: anthers at the orifice: ovules 10 or more in each cell.-Utah and probably in western Colorado and Wyoming.

20. Gilia caespitosa (Gray) A. Nels. 1. c. 25: 546. Densely caespitose, the much-branched woody base hardly emergent from the soil; stems numerous and very short, clothed with the persistent crowded leaves: leaves alternate, palmately 3-parted (rarely 5-parted), densely fascicled, rigid, subulatepungent, $5-7 \mathrm{~mm}$. long, nearly glabrous or somewhat ciliate on the margins, green as to the new leaves, the short stems gray with the persistent dead ones: flowers numerous: calyx one half the length of the corolla-tube, the lobes 4 (rarely 5), acerose: corolla white to yellowish, salverform, the tube very slender and but little dilated at the throat, about $12 \mathrm{~mm}$. long; lobes 4, narrowly obovate, about $4 \mathrm{~mm}$. long: stamens 4 ; filaments short, anthers in the throat: pistil less than half the length of the corolla-tube; styles 2 or rarely 3.-Dry bluffs; western Nebraska to the interior desert areas of Wyoming; rare.

21. Gilia Nuttallii Gray, 1. c. Cinereous-puberulent or the leaves gtabrate, more or less woody at base; stems or branches 1-4 dm. high, terminated by a dense leafy cluster of flowers: leaves 3-7-parted; the divisions narrowly linear, mucronate: corolla white with yellow funnelform throat; the tube not longer than the calyx: ovules a pair in each cell. G. floribunda Gray, 1. c.-Mountains of Colorado and Utah to Arizona and the Sierras of California.

22. Gilia Harknessii Curran, Bull. Cal. Acad. 1: 12. 1884. Stem erect, diffusely branched, $8-20 \mathrm{~cm}$. high: leaves divided to the base into filiform segments, $5-20 \mathrm{~mm}$. long: flowers paniculate, on filiform pedicels $12-25 \mathrm{~mm}$. long: calyx minutely pubescent; the lanceolate lobes as long as the tube: corolla white, 2-4 mm. long; the tube but little longer than the calyx and about as long as the lobes: capsule oval, exceeding the calyx; seeds solitary in the cells, smooth, turgid, oblong, about $2 \mathrm{~mm}$. long.-Western Wyoming to the Pacific States.

23. Gilia pharnaceoides Benth. Bot. Reg. 19: pl. 1622. 1833. Stem slender, with diffuse filiform branches, $1-2 \mathrm{dm}$. high: leaves palmately $2-5$-parted into acerose-pubescent segments, 4-12 $\mathrm{mm}$. long: flowers paniculate, on filiform pedicels: calyx campanulate, 4-5 $\mathrm{mm}$. long; the triangular acute lobes not as long as the tube: corolla almost rotate, the broad tube hardly as long as the 
calyx; the broad lobes obovate, rounded at the apex, 4-6 $\mathrm{mm}$. long: ovules 6-8 in each cell: capsule shorter than the calyx.-Wyoming to California and Washington.

\section{NAVARRETIA Ruiz and Pavon}

Glabrous or viscid-pubescent annuals. Leaves all alternate, pinnatifid, setaceous or spinose. Flowers in crowded bracteate clusters terminating the branches. Calyx-tube scarious between the five prominent green ribs prolonged into the unequal pungent lobes. Corolla tubular, funnelform, or salverform. Stamens and style either included or exserted. Capsule 1-3-celled, 1-many-seeded.-Under Gilia.

Glandular-viscid

Glabrous.

Stems erect, simple or branched; corolla about $5 \mathrm{~mm}$. long.

Stems low, mostly divaricately branched at the base; corolla small, less than $2 \mathrm{~mm}$. long

1. N. Breweri.

2. N. intertexta.

3. N. minima.

1. Navarretia Breweri (Gray) Greene, Pitt. 1: 137. 1887. Erect or at length much branched and diffusely spreading, 3-12 cm. high, very minutely glandular-puberulent all over: flowers somewhat glomerate: leaves with mostly simple acicular-subulate divisions: calyx-lobes similar to these, narrowly subulate, about equaling the yellow corolla, 6-8 mm. long, 3 or 4 times the length of the tube: ovules 1 or 2 in each cell.-From Wyoming to Utah, Nevada, and California.

2. Navarretia intertexta (Benth.) Hook. Fl. Bor. Am. 2: 75. 1838. Erect or widely branched, low and rather stout, neither viscid nor glandular; stem retrorsely pubescent: leaves mainly glabrous, with divaricate, acerosespinescent divisions sparingly divided or simple: flowers densely glomerate: tube of the calyx and base of the bracts strongly villous with white spreading hairs; the lobes equaling the white corolla, 6-8 mm. long: ovules and seeds 3 or 4 in each cell.-From the Rocky Mountains westward to California and Oregon.

3. Navarretia minima Nutt. Journ. Acad. Phila. 1: 160. 1848. Depressed, often forming broad tufts, $2-6 \mathrm{~cm}$. high, glabrate: leaves acicular and with simpler and fewer divisions than the preceding: tube of the calyx white-hairy in the broad sinuses, as long as the unequal lobes, which equal or exceed the white corolla, $3 \mathrm{~mm}$. long: ovules $1-3$ in each cell.-In very dry regions from Dakota to Colorado and Oregon.

\section{POLEMONIUM L.}

Mostly perennial herbs, with alternate pinnate or pinnately parted leaves, and blue or white or rarely purplish flowers, which are mostly terminal, either solitary, 2-3 together, or aggregated in capitate or paniculate cymes. Calyx rotate-campanulate to tubular. Corolla funnelform to nearly rotate. Stamens equally inserted; the filaments more or less declined and usually piloseappendaged at base. Capsule oblong to globose. Seeds black or brown, oblong, often angled or even winged.

Corolla campanulate; filaments pilose-appendaged at base; leaflets not verticillate.

Stems tall, leafy, solitary.

Inflorescence narrow, usually densely thyrsoid.

Plants from a slender rootstock; seed-coats unchanged if

wetted
Plants from a lignescent caudex; seed-coats becoming mucilaginous if wetted

Inflorescence broad and open.

Stems and herbage pubescent

Stems and herbage glabrate
Stems low, several to many in tufts, sparsely leafy or only bracteate.

Seeds angled but not winged.

Stems from a rootstock with a single or nearly simple crown Stems from a lignescent freely branched caudex

Seeds narrowly winged

1. P. occidentale.

2. P. foliosissimum.

2. P. foliosissimum.

3. P. filicinum.

4. P. pulcherrimum.

5. P. Haydenii.

6. P. pterospermum. 
Corolla funnelform or narrower; filaments not pilose-appendaged at base; leaflets more or less verticillate.

Corolla purple; flowers capitate.

Corolla broadly funnelform, less than $2 \mathrm{~cm}$. long .

Corolla narrower, more than $2 \mathrm{~cm}$. long

Corolla whit
spikes.

Corolla with broad tube, white or bluish

Corolla with very slender tube, yellow

7. $\mathbf{P}$. viscosum.

8. $\mathbf{P}$. confertum.

1. Polemonium occidentale Greene, Pitt. 2: 75. 1890. Either glabrous or viscid-pubescent; stem strict and virgate, 5-10 dm. high, from running rootstocks, 5-10-leaved: leaflets 15-23, linear-lanceolate to oblong-ovate, 10$20 \mathrm{~mm}$. long: flowers numerous, in a naked and narrow thyrsus or panicle: calyx cleft to or below the middle, with short lanceolate lobes: corolla blue, 15-20 $\mathrm{mm}$. in diameter, the obovate lobes much longer than the tube: filaments densely bearded at base, often equaling the corolla-lobes: style exserted. $P$. caeruleum.-Boggy or springy places in the mountains; throughout our range and west to the Pacific States.

2. Polemonium foliosissimum Gray, Syn. F1. 21: 151. 1878. Rootstock lignescent; stems solitary, pilose at base, glandular upward, simple or branched, leafy throughout: leaflets lanceolate to ovate-lanceolate: flowers corymbosecymose, smaller: corolla commonly white or cream-color, sometimes violet, 10-12 mm. long, twice the length of the calyx: style and stamens not protruding: capsule subglobose: seeds oblong, becoming mucilaginous if wetted.In the mountains throughout our range.

2a. Polemonium foliosissimum robustum (Rydb.) Brand, Polem. 34. 1907. Leaves short-petioled: flowers smaller, blue. (P. molle Greene, Leaflets 1: 153. 1905; P. robustum Rydb. Bull. Torr. Bot. Club 31: 635. 1904.)Mountains of Colorado and Utah.

3. Polemonium filicinum Greene, Pitt. 1: 124. 1887. Slender, 5-10 dm. high, glabrous up to the inflorescence which is rather densely glandularviscid: leaves ovate-oblong in outline, the segments lanceolate, acute, somewhat closely ranged and decurrent upon the rachis: inflorescence corymbosecongested: segments of the calyx erect, lanceolate, longer than the tube: corolla deep purple, campanulate, $10-12 \mathrm{~mm}$. broad, the segments ovate, acute: stamens declined and incurved, reaching little beyond midway of the corolla: style exserted: seeds very dark brown, sharply angled.-New Mexico.

3a. Polemonium filicinum Archibaldae (A. Nels.) Brand, 1. c. 37. Usually smaller but with relatively larger and more open inflorescence: corolla-lobes very obtuse: stamens usually declined. (P. Archibaldae A. Nels. Bot. Gaz. 31: 397. 1901; $P$. grande Greene, Leaflets 1. c.)-Southern Colorado.

4. Polemonium pulcherrimum Hook. Bot. Mag. 57: pl. 2979. 1830. Minutely puberulent and viscid-glandular; stems rather slender, sparingly branched, 1-3 dm. high: leaflets 9-21, oblong to lanceolate: flowers in clusters of small cymes, mostly slender-pediceled: calyx narrowly campanulate, cleft to below the middle, 4-5 mm. long: corolla blue with white tube, 10-15 $\mathrm{mm}$. long, the ample oblong lobes much longer than the short tube: filaments pilose but not dilated at base: capsule obovoid, much shorter than the calyx: ovules $2-4$, and seeds usually 1 in each cell. $P$. humile pulchellum. - In the high mountains of our range.

4a. Polemonium pulcherrimum parvifolium (Nutt.) A. Nels. Reduced or depauperate forms, usually with fewer leaflets, the flowers on slender pedicels. [P. parvifolium (Nutt.) Rydb. 1. c. $24: 253$. 1897; $P$. delicatum Rydb. 1 . c. 28: 29. 1901.]

5. Polemonium Haydenii A. Nels. Bull. Torr. Bot. Club 26: 353. 1899. Root large, woody, surmounted by a short, woody, branched caudex; stems several, one or more from each crown, 1-3 dm. high, the minute puberulence becoming glandular above: leaves crowded on the crowns, more than half as long as the stems; leaflets 15-25, oval, oblong, or oblanceolate, mostly very small, rarely exceeding $1 \mathrm{~cm}$. in length, glabrous or nearly so: flowers numerous and rather crowded, drooping or suberect, on slender pedicels: calyx 
narrowly campanulate, about as long as the corolla-tube: corolla blue, tubularcampanulate, 12-16 mm. long, the broadly elliptic lobes a little longer than the calyx: filaments very slender, the base slightly dilated and sparsely pilose: seeds 2-3 in each cell.-Yellowstone Park and probably Idaho and Montana.

6. Polemonium pterospermum Nels. \& Ckll. Proc. Biol. Soc. Wash. 16: 45. 1903. Low, 1-2 dm. high, glabrate below, glandular-puberulent above; stems several, spreading or decumbent at base, very leafy, especially above: leaves 4-6 cm. long; the segments oblong, acute, 8-12 $\mathrm{mm}$. long, the lower distinct and subpetiolate, the terminal crowded and slightly confluent: flowers in congested corymbs: calyx-lobes about equaling the campanulate tube: corolla purple, campanulate, 10-12 mm. long, quite as broad; the tube short, the lobes broadly ovate, moderately obtuse: filaments shorter than the corolla, somewhat incurved, glabrous, but involved in dense fine pubescence at the insertion: style filiform; the stigmas narrowly linear, exserted: ovules few, apparently only 2 or 3 maturing: the seeds narrowly wing-margined and subconcave ventrally.- Northern New Mexico, probably extending into Colorado.

7. Polemonium viscosum Nutt. Pl. Gamb. 154. 1848. Somewhat viscid throughout; rhizome somewhat fleshy; stems erect, $5-12 \mathrm{~cm}$. high: leaflets 30-40, small, oblong to suborbicular, crowded or subimbricate: flowers in capitate clusters: calyx campanulate, very glandular and often pilose: corolla blue, twice as long as the calyx, broadly funnelform, 14-18 $\mathrm{mm}$. long, the lobes rounded-obtuse: stamens and style about as long as the corolla. (P.Grayanum Rydb. 1.c. 31: 635. 1904 $4^{\prime}$-Rare; on the highest of the Rocky Mountain peaks.

8. Polemonium confertum Gray, Proc. Am. Acad. Sci. Phila. 73. 1863. Perennial, 1-2 dm. high, glandular-viscid and musk-scented, pubescent above: leaflets very numerous, small, 3-8 $\mathrm{mm}$. long, mostly as if whorled or fascicled, being 2-5-divided and sessile, segments either broadly oval or linear-oblong: flowers capitate-crowded, at length racemose-spicate, somewhat nodding, honey-scented: lobes of the calyx narrow, half as long as the cylindrical or oblong tube: corolla 2-3 cm. long, blue, the narrow funnelform tube longer than the calyx and 2-3 times longer than the rounded lobes: filaments barely hairy and scarcely dilated at base.-In the higher mountains; from Colorado to Montana.

9. Polemonium mellitum (Gray) A. Nels. Bull. Torr. Bot. Club 26: 354. 1899. Viscid-pilose, tufted, the stems erect or spreading: radical leaves long; the leaflets in verticils of 3-4 or merely paired, oval to broadly linear, thin: inflorescence loosely spicate to racemose, bracteose: the lanceolate calyx-lobes scarcely shorter than the tube: corolla white or ochroleucous, tubular, more than twice as long as the calyx (20 $\mathrm{mm}$. or more), the lobes one third as long as the tube. Herbage heavy musk-scented, but the flowers "honey-sweet."In the mountains of our range to Nevada.

9a. Polemonium mellitum speciosum (Rydb.) A. Nels. Similar in all respects except that the leaves are often merely paired and the flowers tinged with blue. (P. speciosum Rydb. 1. c. 28: 29.)-Mount Garfield in Colorado.

10. Polemonium Brandegeei (Gray) Greene, Pitt. 1: 126. 1887. Very viscid with glandular pubescence, pleasantly odoriferous, caespitose; stems 1-3 dm. high, simple: leaves all pinnate, elongated-linear in outline, the radical crowded, the cauline scattered; leaflets very small and numerous, oval to oblong-linear, some simple, others 2-parted and so appearing verticillate: flowers several in a short and racemiform leafy thyrsus: corolla golden-yellow, trumpet-shaped, with very narrow tube, 20-25 mm. long. Gilia Brandegeei. - Colorado.

\section{HYDROPHYLLACEAE L. Waterleaf Family}

Herbs or shrubs with opposite or alternate leaves. Flowers regular, 5merous in racemes or spikes (often scorpioid), or capitate, or solitary. Stamens near the base of the corolla, alternate with its lobes. Styles 2, distinct 
or more or less completely united even to the stigmas. Fruit a 1-celled capsule or partly or quite 2-celled by the intrusion of the placentae or their union in the axis; valves 2 , rarely 4 . Seed-coat pitted, the cavities regular and honeycomb-like.

\section{Leaves all basal; peduncles 1-flowered}

Leaves not all basal.

Corolla convolute in bud; placentae broad.

Perennials; stamens exserted
Calyx enlarged in fruit, naked at the sinuses
Calyx not much enlarged in fruit, with a reflexed appendage at Corolla imbricated in bud; placentae narrow.

Flowers in a scorpioid cyme.

Corolla deciduous, not yellow

Corolla persistent, yellow or yellowish

Flowers solitary in the leafy forks of the stem

\section{Capnorea.}

2. Hydrophyllum.

3. Macrocalyx.

4. Nemophila.

5. Phacelia.

6. Emmenanthe. 7. Nama.

\section{CAPNOREA Raf.}

Low stemless perennials, with entire spatulate or oblong leaves on elongated petioles crowning the caudex, and from their axils sending up 1-flowered peduncles. Calyx 5-parted; rarely 6 or 7-parted; the lobes linear-lanceolate, occasionally unequal. Corolla campanulate or rotate, the stamens inserted on the base of its tube. Style 2-cleft at the apex. Capsule loculicidal.

1. Capnorea pumila Greene, Erythea 2: 193. 1894. Leaves several from the crown of a short, usually branching rootstock, lanceolate to spatulate, tapering below to a slender petiole, minutely ciliate, otherwise glabrous: peduncles slender, 3-7 $\mathrm{cm}$. long, about equaling the leaves, glabrous: sepals lanceolate, about $12 \mathrm{~mm}$. long, minutely ciliate: corolla white to purple, rotate, often $2 \mathrm{~cm}$. broad; the broad ovate lobes longer than the tube; the tube within and base of the filaments pubescent.-In wet places; Wyoming to California and Washington.

\section{HYDROPHYLLUM L. WATERLEAF}

Perennial herbs with horizontal rootstocks. Leaves alternate or mainly radical, pinnate or pinnately parted, long-petioled. Flowers in capitate cymes. Corolla campanulate, 5-lobed, the tube with a nectar-bearing grooved appendage opposite each lobe. Stamens exserted, the filaments hairy at the middle. Style filiform, exserted; ovary hispid. Capsule 2-valved, 1-4-seeded.

Flowers crowded-capitate; peduncle shorter than the petiole .

1. H. capitatum. Flowers loosely-capitate; peduncle longer than the petiole :

2. H. Fendleri.

1. Hydrophyllum capitatum Dougl. Benth. in Linn. Trans. 17: 273. 1836. Retrorsely hispid with minute white hairs; stems often tufted, 1-2 dm. high, from a small fascicle of thickened perennial roots, 1-several-leaved, erect in flower, recurving and often prostrate in fruit: leaves pinnately 5-7-parted or at base divided; the lanceolate divisions entire or of ten 2-3-lobed, mucronatetipped: flowers in a dense capitate cluster: calyx very hispid, parted nearly to the base: corolla blue, but little longer than the calyx: filaments twice as long as the corolla: style equaling the stamens, 2-lobed.-Colorado to Montana and far westward.

2. Hydrophyllum Fendleri (Gray) Heller, Cat. N. A. Pl. 40. 1898. Pubescent, hirsute, or sparingly hispid, 2-4 dm. high: leaves elongated-oblong, pinnately parted or divided into 7-15 divisions; divisions inclined to ovatelanceolate, acute or acuminate, incisely serrate: cyme rather open: corolla white or nearly so: calyx deeply parted, the lobes lanceolate. $H$. occidentale Fendleri. -Wet copses and bottom lands; New Mexico to Montana and westward. 


\section{MACROCALYX Trew.}

Leaves pinnately parted or bi- or tripinnately dissected and the bractless flowers in axillary peduncled racemes. Calyx without appendages at the sinuses, and usually much enlarged under the fruit. Corolla white, campanulate, shorter or little longer than the calyx, the internal appendages minute or none. Ovules 4-8.-Ellisia.

1. Macrocalyx Nyctelea (L.) Kuntze, Rev. Gen. Pl. 434. 1891. Annual, 1-2 dm. high, at length very diffuse: leaves on naked or barely margined petioles; the divisions 7-13, lanceolate, acute, mostly 1-3-toothed or lobed: peduncles solitary in the forks or opposite the leaves, or some of the later ones racemose and secund: calyx-lobes acuminate, longer than the capsule: corolla rather shorter than the calyx.-Colorado to the Saskatchewan, and eastward across the continent.

\section{NEMOPHILA Nutt.}

Delicate low annuals. Leaves opposite, or the uppermost alternate, more or less pinnate. Flowers solitary or inclined to be racemose. Calyx with a reflexed appendage in each sinus, accrescent. Corolla rotate to broadly campanulate, in all our species longer than the calyx, with 10 internal appendages at base. Stamens shorter than the corolla, inserted near its base. Styles more or less 2-cleft; ovules 4-20.

1. Nemophila parviflora Dougl. Hook. Fl. 2: 79. 1840. Stems slender and weak, trailing or procumbent: leaves pinnately lobed, parted, or divided into 3-5 lobes: calyx-appendages rather conspicuous, or sometimes almost none: corolla white or whitish, $5-8 \mathrm{~mm}$. in diameter, narrowly campanulate to almost rotate, the lobes longer than the tube; appendages adherent by one edge: filaments inserted on the very base of the corolla: seeds 1-4, often deeply pitted. -From Western Wyoming to California and Washington.

\section{PHACELIA}

Annual, biennial, or rarely perennial mostly hirsute or hispid herbs, often glandular, with entire or variously lobed or dissected leaves, and often showy flowers in scorpioid spikes or racemes. Calyx deeply 5-parted. Corolla from nearly rotate to campanulate, tubular or funnelform, deciduous, the tube commonly with internal lamellate projections or appendages. Style 2-cleft. Capsule 1-celled, 2-valved, the thin septa-like placentae adherent.

Leaves simple and entire, or the lower more or less pinnate with entire divisions.

Annuals.

Vernal and evanescent, diminutive; leaves ovate

Aestival; leaves or their lobes linear-oblong .

Rather large and coarse perennials or biennials.

White-canescent; stems clustered, assurgent .

Hispidly hirsute; stems mostly single, erect :

Leaves sinuate or crenate to bipinnatifid.

Annuals or biennials.

Leaves pinnately divided quite to the midrib.

Terminal divisions of the leaves distinctly larger than the

lateral
Terminal divisions of the leaves not larger than the lateral.

Ovules and seeds 4 or by abortion fewer.

Canescent biennial, scarcely glandular

Sordid-green glandular annuals.

Corolla-lobes crenulate to erose-denticulate Corolla-lobes entire.

Ovules and seeds several to numerous $(8-\dot{4} 0)$.

Plants simple, or branched above, $2-3 \mathrm{dm}$. high
Plants diffusely slender-branched from the base, low $\quad$ 9. P. Franklinii.

Leaves merely sinuately or crenately lobed.

Leaves coarsely and sinuately lobed halfway to the midrib

Leaves finely and shallowly crenate

11. P. corrugata.

12. P. integrifolia,

1. P. Knightii.

2. P. linearis.

3. P. leucophylla.

4. P. heterophylla.

5. P. splendens.

6. P. deserta.

7. P. glandulosa.

8. P. neo-mexicana. 
Perennials; leaves more or less silky. Caespitose; sericeous throughout

Scarcely caespitose; merely pubescent or finely hirsute :

13. P. sericea.

14. $P$. idahoensis.

1. Phacelia Knightii A. Nels. Bull. Torr. Bot. Club 28: 229. 1901. A diminutive annual $2-5 \mathrm{~cm}$. high, minutely puberulent, simple or branched: leaves few, semifleshy, orbicular to ovate, entire or nearly so, 5-10 mm. long: flowers few, subspicate and nearly sessile in the uppermost axils: corolla narrowly campanulate, about $5 \mathrm{~mm}$. long, longer than the linear-spatulate calyx-lobes, the limb purple, the tube yellowish: seeds about 14, oblong, large for the plant, conspicuously alveolate-hexagonal-reticulate, slightly wingmargined by the cellular coat.- In the crevices of the naked Wasatch clays, western Wyoming.

2. Phacelia linearis (Pursh) Holz. Contrib. Nat. Herb. 3: 242: 1895. Stems 1-3 dm. high, at length paniculate-branched, hispid or roughish-hirsute, usually also minutely cinereous-pubescent: leaves mostly sessile, linear or lanceolate and entire or some of them deeply cleft; the lobes few or single, linear or lanceolate, entire: spikes or spike-like racemes thyrsoid-paniculate, at length elongated and erect: corolla bright violet or sometimes white: ovules 12-16: capsule shorter than the calyx; seeds oblong, coarsely favose-reticulated. $P$. Menziesii.-Wyoming to California and British Columbia.

3. Phacelia leucophylla Torr. Frem. Rep. 93. 1845. Perennial by a stout rootstock, pale, densely silky-pubescent; stems 3-5 dm. high: leaves lanceolate to oblong, 5-10 cm. long, the lower long-petioled: spike-like branches of the scorpioid cymes dense, $2-8 \mathrm{~cm}$. long; flowers sessile, numerous, about $8 \mathrm{~mm}$. high: calyx-lobes hispid, oblong-lanceolate or linear, somewhat shorter than the white or bluish, 5-lobed corolla: corolla-appendages in pairs between the filaments: filaments exserted, glabrous or sparingly hairy: ovules 2 on each placenta. P. circinata.-In dry soil; Colorado to North Dakota and to Idaho.

4. Phacelia heterophylla Pursh, Fl. 140. 1814. Much like the preceding but probably only biennial, the stems single, or rarely more, from the semifleshy root, erect, 3-5 dm. high; pubescence of two kinds, a fine canescence and more or less hirsute-hispid hairs: leaves simple, or some of them with divergent, lanceolate or linear lobes near the base: inflorescence hispid; the dense spikes thyrsoid-congested: corolla bluish, longer than the oblonglanceolate or linear calyx-lobes: filaments much exserted, sparingly bearded. $P$. circinata in part. (P. biennis A. Nels. 1. c. 26: 132.)-Colorado and Wyoming and west to the Pacific States.

4a. Phacelia heterophylla alpina (Rydb.) A. Nels. Scarcely more than a reduced form of alpine stations, tending to become perennial. ( $P$. alpina Rydb. Mem. N. Y. Bot. Gard. 1: 324. 1900.)-In the high mountains.

5. Phacelia splendens Eastw. Zoe 4: 9. 1893. Annual, erect, 2-3 dm. high, usually simple-stemmed; stems glandular or glabrous: leaves pinnately parted into three or four pairs of alternate divisions, crenate or bluntly lobed and oblique at base, nearly glabrous, glandular on the rachis: scorpioid cyme on a naked peduncle; flowers on short pedicels: calyx white-hirsute and slightly glandular, the lobes linear-lanceolate, 4-6 mm. long, slightly surpassing the ripe capsule: corolla bright blue, rarely white, about $1 \mathrm{~cm}$. in diameter, divisions obtúse: stamens and style conspicuously exserted: capsule glandular and hirsute; seeds with the central ridge very prominent, cymbiform, favose over the whole surface, but not corrugated.-In adobe soil; western Colorado and Utah.

6. Phacelia deserta A. Nels. 1. c. 25: 278. 1908. Stem erect, simple or branched from the base, 1-2 dm. high, densely leafy at base, sparsely so upward, the whole plant canescent with a short close pubescence, obscurely glandular: leaves pinnate, the pinnae opposite, nearly oval and crenately toothed, 5-9 pairs which are nearly equal in size: inflorescence dense, paniculate, of scorpioid cymes: sepals equal, lanceolate-oblong: corolla bright blue, turbinate-campanulate, $7 \mathrm{~mm}$. long, lobes equaling or surpassing the tube, rounded, entire; the obliquely vertical lamellae broad and conspicuous, 
loosely united over the filament: filaments and style conspicuously exserted.In the Green river shales, Wyoming.

7. Phacelia glandulosa Nutt. Journ. Acad. Sci. Phila. II. 1: 160. 1847. Plants 2-7 dm. high, rather stout, often widely branched, viscidly pubescent or in the inflorescence hirsute: primary segments of the leaves few-lobed or incised, or some entire: flowers comparatively large: corolla violet or blue, 8-12 mm. high, with ample rounded lobes .quite entire: stamens and style much exserted: capsule short-oval.-Montana to Texas and Arizona.

8. Phacelia neo-mexicana Thurb. Torr. Bot. Mex. Bound. 143. 1859. Plants 2-6 dm. high, erect and strict, very leafy, viscid-pubescent, sometimes also hirsute: leaves interruptedly twice pinnately parted into small and short lobes: corolla comparatively small, 4-6 mm. long, bluish, purplish, or white, the short lobes minutely crenulate to erose-denticulate: stamens and style often no longer than the corolla-lobes, sometimes rather conspicuously exserted. (P. alba Rydb. Bull. Torr. Bot. Club 28: 30. 1901.)-Southern Colorado and New Mexico.

9. Phacelia Franklinii (R. Br.) Gray, Man. Ed. 2. 329. 1856. Erect, simple, or corymbose at summit, 2-4 dm. high, soft-hirsute or pubescent: lower leaves petioled and pinnately or somewhat bipinnately divided or parted into numerous and short linear-oblong divisions or lobes, the upper sessile and less divided: spikes cymose-glomerate or crowded, little elongated in age: corolla pale blue or almost white: ovules 40 or more: capsule about the length of the calyx eeds oval, minutely alveolate in vertical lines.-Wyoming and far northward and westward.

10. Phacelia Ivesiana'Torr. Ives Colorado Exp. 21. 1860. Diffusely much branched from the base, 10-15 cm. high, hirsute-pubescent and glandular: leaves pinnately parted into 7-15 linear or oblong and entire or incisely fewtoothed lobes, rarely bipinnatifid: racemes loose, 6-20-flowered: narrow appendages of the corolla adnate to the filament only at base: capsule oblong, 16-24-seeded. (P. campestris A. Nels. 1. c. 26: 242.)-From western Wyoming to southern California.

11. Phacelia corrugata A. Nels. Bot. Gaz. 34: 26. 1902. Slightly glutinous and more glandular-pubescent; stem branched or simple, moderately leafy, terminating in elongated naked peduncles: leaves narrowly oblong, somewhat alternately 11-15-lobed, the broad sinuses extending about halfway to the midrib, each lobe with 2 or 4 rounded unequal lobes; petioles short or wanting: spikes very dense even in fruit: sepals linear-oblanceolate, sparsely hirsute, nearly as long as the corolla: corolla blue, campanulate-funnelform, $1 \mathrm{~cm}$. or more long: stamens and styles nearly twice the length of the corolla; the undivided base of the style pubescent: capsule elliptical, about $5 \mathrm{~mm}$. long; seeds oblong, obtuse at both ends.-Utah, through Colorado to western Texas.

12. Phacelia integrifolia Torr. Ann. Lyc. N. Y. 2: 222. 1827. Annual or biennial; stem very leafy, 1.5-5 dm. high: leaves finely strigose-pubescent, ovate-oblong or oblong-lanceolate, irregularly crenate-dentate, obtuse at the apex, rounded or cordate at the base, $2-6 \mathrm{~cm}$. long, petioled or the uppermost sessile: spike-like branches of the scorpioid cymes dense, 5-10 cm. long when expanded; flowers sessile, about $8 \mathrm{~mm}$. long: calyx-segments acute: corolla tubular-campanulate, white or blue, the tube longer than the calyx: filaments glabrous, exserted: ovules 2 on each placenta.-In saline soil; Kansas and Colorado to Utah and Arizona.

13. Phacelia sericea (Graham) Gray, Proc. Am. Acad. 10: 323. 1875. Stems 1-3 dm. high from a branching caudex, silky-pubescent or canescent, or the simple virgate stems and inflorescence villous-hirsute, rather leafy to the top: leaves pinnately parted into numerous linear or narrowly oblong lobes, these often again few-cleft or pinnatifid, silky-canescent or sometimes greenish; the lower petioled; the uppermost simpler and nearly sessile: short spikes crowded in a naked spike-like thyrsus: corolla violet-blue or whitish: stamens long-exserted: capsule a little longer than the calyx.-Mountains of Colorado, Nevada, and northward.

14. Phacelia idahoensis Henderson, Bull. Torr. Bot. Club 22: 48. 1895. 
Much resembling the preceding, less strongly caespitose, the stems usually taller; pubescence less dense and often merely villous-hirsute: thyrsus rather long and narrow: stamens and style sometimes but little longer than the corolla: seeds 12-22, angled by pressure, rather deeply alveolate. ( $P$. ciliosa Rydb. 1. c. 33: 149.)-Colorado to Montana and Washington.

\section{EMMENANTHE Benth.}

Annuals. Corolla yellow or yellowish, campanulate, persistent. Seeds several. Otherwise like Phacelia.

Corolla equaling or exceeding the calyx-lobes .

Corolla distinctly shorter than the calyx-lobes

1. E. scopulina.

1. Emmenanthe scopulina A. Nels. Bull. Torr. Bot. Club 25: 380. 1898. Small, pubescent but scarcely glandular, branched from the base; branches short, ascending, 1-8 cm. long: leaves ovate, elliptic, or oblong, crenately lobed to nearly entire, 5-12 $\mathrm{mm}$. long: flowers in short racemes; pedicels short, rarely exceeding the calyx in length: sepals linear, obtuse, at maturity about $4 \mathrm{~mm}$. long: corolla equaling the calyx-lobes: capsule exceeding the calyx at maturity: ovules usually 10 ; seeds brown, irregularly ovate, obliquely rugose, $2 \mathrm{~mm}$. long.--In the Green river cliffs, Wyoming.

2. Emmenanthe salina A. Nels. 1. c. 45. Similar but even smaller, somewhat viscid-pubescent: leaves oval to oblong, entire to pirately lobed: corolla minute, narrow, distinctly shorter than the $3 \mathrm{~mm}$. long linear sepals: capsule shorter than the sepals; seeds pale, oblong-flattened, transversely rugose and obscurely reticulated.-On the naked, ashy, alkali flats of Bitter Creek, Wyoming.

\section{NAMA L.}

Low herbs, with purple, bluish, or white corolla. In ours the corolla is short-funnelform and hardly exceeding the calyx, the flowers are in the forks of the stem, and the leaves are entire. Ovary imperfectly 2-celled; styles 2, distinct.

1. Nama angustifolium (Gray) A. Nels. Erect, 1-2 dm. high, minutely pubescent, glándular; stem repeatedly forked and with a nearly sessile flower in each fork: leaves narrow, linear or nearly so: sepals narrowly linear: seeds marked with about 5 longitudinal rows of large pits, from 4-6 in each row. $N$. dichotomum angustifolium. Gray, Proc. Am. Acad. 8: 284. 1870. (Marilaunidium angustifolium Kuntze.)-Colorado and New Mexico.

\section{BORAgINACEAE A. Gray. Borage Family}

Chiefly rough-hairy herbs, with alternate or rarely opposite entire leaves and symmetrical flowers mostly on one side of the branches of a reduced cyme. Calyx 5-parted. Corolla regular, 5-lobed. Stamens 5, inserted on the corollatube. Style single; ovary deeply 4-lobed (occasionally undivided), forming in fruit 4 (or by abortion fewer) seed-like nutlets, each with a single seed.

Ovary undivided or only 4-grooved, with terminal style.

Style 2-cleft or 2-parted.

Style entire or none; stigma annuli

Ovary 4-lobed or 4-divided, with central style.

Nutlets armed with barbed prickles; fruit bur-like

Nutlets unarmed or the prickles (if any) not barbed.

Nutlets widely divaricate, bordered with uncinate prickles receptacle.

Annuals.

Leaves opposite below .

Leaves all alternate

1. Coldenia.

2. Heliotropium.

3. Lappula.

4. Pectocarya.

6. Allocarya.

7. Cryptanthe. 
Biennials or perennials.

Nutlets prickly on the margin

Nutlets not prickly on the margin.

Flowers white or yellow

Flowers blue (rarely white)

Nutlets attached by their bases.

Nutlets small, smooth and membranous; flowers blue, in bractless racemes

Nutlets bony and polished; flowers yellow, in leafy or bracteate racemes; corolla-lobes rounded, spreading .

Nutlets smooth, subglobose; flowers greenish or yellowish, in leafy-bracteate racemes; corolla-lobes acute, erect

\section{Eritrichium:}

8. Oreocarya.

9. Mertensia.

\section{Myosotis.}

11. Lithospermum.

12. Onosmodium.

\section{COLDENIA L.}

Low herbaceous or suffrutescent plants, with canescent or hispid entire leaves, and small, white, clustered, sessile flowers. Calyx 5-parted. Corolla funnelform or salverform and convolute. Fruit separating at maturity into four 1-seeded nutlets.

1. Coldenia Nuttallii Hook. Kew Journ. Bot. 3: 296. 1851. Prostrate annual, repeatedly and divergently dichotomous: leaves ovate or rhomboidrotund, 4-10 $\mathrm{mm}$. long, on longer petioles, with 2 or 3 pairs of strong and somewhat curving veins, and margins somewhat revolute: flowers densely clustered in the forks and at the ends of the naked branches: filaments inserted nearly in the throat of the pink or whitish corolla, the tube of which bears 5 short obtuse scales near the base: nutlets marked with a linear and raphe-like ventral scar--Dry plains; from Wyoming to New Mexico and westward.

\section{HELiOTROPIUM L. Heliotrope}

Annuals or perennials; ours herbaceous and with alternate, entire leaves, white flowers, deeply 5-parted persistent calyx, salverform or funnelform corolla, sinuses more or less plaited in bud, connivent anthers, and a 4-celled ovary becoming a 2 or 4 -lobed fruit splitting into 1 -seeded nutlets.

Glabrous and glaucous; fruit 4-lobed .

Strigose-canescent; fruit 2-lobed.
1. H. spathulatum.

2. H. convolvulaceum.

1. Heliotropium spathulatum Rydb. Bull. Torr. Bot. Club 30: 262. 1903. Diffusely spreading perennial, 1-3 dm. high: leaves succulent, oblanceolate or narrower: spikes unilateral, scorpioid, mostly in pairs or twice forked, densely flowered: corolla 6-8 $\mathrm{mm}$. broad, white, with a yellow eye: stigma sessile, disk-shaped, as broad as the glabrous ovary: nutlets scarcely rugose. $H$. curassavicum L. in part.-In moist strongly saline soils; throughout our range.

2. Heliotropium convolvulaceum (Nutt.) Gray, Mem. Am. Acad. 6: 403. 1857. A low, spreading, freely branched annual, 1-3 dm. high: leaves ovate to nearly linear, short-petioled: flowers solitary, opposite the leaves and terminal, short-peduncled: calyx-segments acuminate: corolla large, strigose on the tube, which exceeds the sepals and the angulate-lobed ample limb: anthers cohering slightly by their minutely bearded tips: style long and filiform; stigma conical, with a truncate, penicillate tip.-Sandy plains; Colorado and westward.

\section{LAPPULA Moench. Stickseed}

Hispid-pubescent or canescent herbs, with alternate entire leaves, and small white or blue flowers in spikes or racemes. Calyx 5-cleft. Corolla salverform or funnel-form, with short tube and the lobes imbricated in bud. Stamens included. Ovary 4-lobed, becoming a bur-like fruit of 4 nutlets armed with barbed prickles.-Echinospermum $\mathrm{Sw}$.

Racemes ebracteate above; fruiting pedicels deflexed.

Annual; flowers small; racemes open.

Biennial; flowers medium; raceme dense

1. L. americana.

Perennial.

2. L. floribunda. 


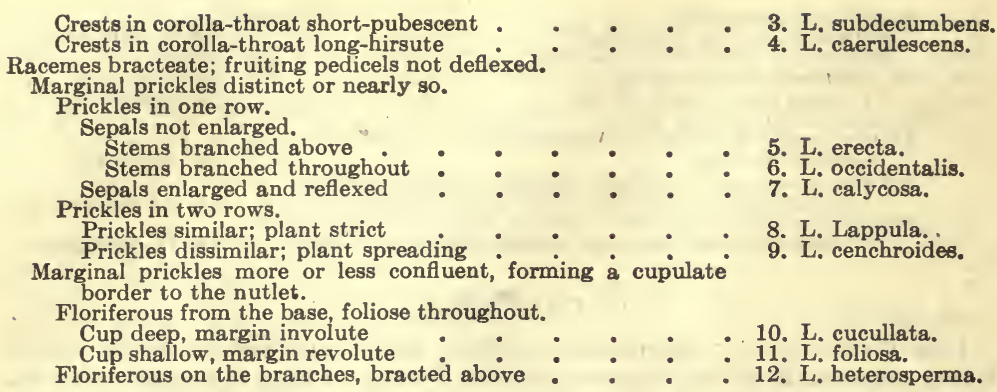

1. Lappula americana (Gray) Rydb. Bull. Torr. Bot. Club 24: 294. 1897. Roughly short-pubescent, 3-7 dm. high; stem simple below, slenderly and divaricately branched above: leaves oblong-lanceolate, $4-8 \mathrm{~cm}$. long: racemes slender and sparsely flowered; the slender pedicels deflexed in fruit, 5-6 mm. long: corolla minute: nutlets roughened-papillose on the back, a row of flat prickles on the margin.-Wyoming and northward.

2. Lappula floribunda (Lehm.) Greene, Pitt. 2: 182. 1891. Hirsutepubescent; stems stout, erect, 5-8 dm. high: leaves oblong to linear-lanceolate, the lowest tapering into margined petioles: racemes numerous, crowded, commonly geminate and in fruit rather strict: corolla rotate, blue, 7-8 mm. broad: fruit pyramidal, on recurved pedicels about $6 \mathrm{~mm}$. long; nutlets with a flat, elongated-triangular scabrous back, the margin armed with a close row of flat subulate prickles, the bases often confluent.Echinospermum floribundum Lehm.-Rich moist ground; Western United States.

3. Lappula subdecumbens (Parry) A. Nels. Mostly soft-hirsute, some of the hairs with papillose base; stems several or many from large roots, diffusely spreading, 3-7 dm. long: leaves ample; lower oblanceolate, tapering into a margined petiole, 7-15 cm. long; upper oblong, sessile, gradually smaller and bract-like: inflorescence paniculate, at length open: corolla rotate, blue varying to white, 8-12 $\mathrm{mm}$. broad: pedicels at length deflexed, about $5 \mathrm{~mm}$. long, equaling the fruit: marginal prickles of nutlets subulate and very flat, nearly as long as the width of the dorsal disk, this beset with a few small glochidiate processes. (Echinospermum subdecumbens Parry, Proc. Davenport Acad. 1: 148. 1876.) -Northwestern part of our range and westward.

4. Lappula caerulescens Rydb. Mem. N. Y. Bot. Gard. 1: 328. 1900. Stems several, ascending, 4-6 dm. high, grayish-strigose, simple up to the inflorescence: basal leaves 5-10 cm. long, numerous; blade oblanceolate, obtuse, grayish-strigose and ciliate-margined, tapering into a winged petiole; stem leaves oblong, $2-5 \mathrm{~cm}$. long, sessile or the upper somewhat clasping: inflorescence open and rather loosely flowered: calyx strigose, $2 \mathrm{~mm}$. long: corolla 6-10 mm. in diameter, from nearly white to sky-blue, the crests with some long white hairs upon them: nutlets $3 \mathrm{~mm}$. long; marginal prickles of two lengths, free to the base, all glochidiate; back finely muriculate and usually with a central ridge bearing about 10 glochidiate prickles; ventral surface finely rugose.-Northwestern Wyoming, Yellowstone Park, and northwestward.

5. Lappula erecta A. Nels. Bull. Torr. Bot. Club 27: 268. 1900. Annual or biennial, cinereously strigose-pubescent; stems 1-5 from the crown of a taproot, simple, erect, paniculately branched above, 2-4 dm. high: crown leaves rosulate, small, oblanceolate, petioled; stem leaves broadly linear, sessile or nearly so, 1-4 cm. long: flowers small, blue varying to white, crowded on the panicled branches, more open in fruit: nutlets minutely and densely muricate-tuberculate on all sides, with the murications in the median line of the back a little more prominent than the others, a single series of about 10 
prickles which are distinct to an obscure marginal ridge.-Frequent in Wyoming; probably southward.

6. Lappula occidentalis (Wats.) Greene, Pitt. 4: 97. 1899. Pubescence short, pustulate at base; stems one or more, freely branched from near the base, 1-4 dm. high: leaves linear-oblong, mostly small, passing into small bracts: flowers minute, crowded; fruiting racemes elongated and slender: nutlets with 7-11 distinct triangular-subulate prickles generally grooved down the whole inner face, the surface of the nutlet covered with low tuberculations (not muricate). Echinospermum Redowskii occidentale Wats.-Frequent in our range and extending both eastward and westward.

7. Lappula calycosa Rydb. Bull. Torr. Bot. Club 28: 30.1901. A hirsute annual, simple below, virgately branched above, $3-\mathrm{dm}$. high: leaves oblong, obtuse, 3-4 cm. long, smaller and bract-like on the branches: flowers and fruit on short pedicels: the calyx-lobes enlarged, in fruit subfoliaceous and reflexed: the minute corolla blue: nutlets as in the preceding but the prickles not grooved; backs of nutlets muricate.-Colorado (Rydberg and Vreeland, 1900).

8. Lappula Lappula (L.) Karst. Deutsch. Fl. 979. 1880-83. A pale, leafy, hispid-pubescent annual, 3-6 dm. high, erect with a few erect or divaricate branches above: leaves from spatulate below to linear above, mostly obtusish: racemes crowded, sometimes 1-sided: corolla blue: fruit ovate-globular, 2-3 $\mathrm{mm}$. in diameter, on short stout pedicels: nutlets roughened-papillose on the back, with 2 rows of small slender prickles on the margins.- Naturalized from Europe and to be expected within our range as a weed.

9. Lappula cenchroides A. Nels. Bull. Torr. Bot. Club 28: 2. 1899. Annual or biennial, rather harshly pubescent, mostly intricately bushy-branched, 2-4 cm. high: leaves numerous, oblong to ovate, 1-2 cm. long, the pubescence on the underside with large pustulate bases: flowers minute, in leafy-bracted spikes: fruits large, nearly sessile; nutlets ovate-acute, armed on the margins with a double row of numerous large distinct unequal aculei, scabroustuberculate on the back with a noticeable median row.-Dry cañons; southern Wyoming.

10. Lappula cucullata A. Nels. Bot. Gaz. 34: 29. 1902. Pubescence short, subcinereous, scarcely hispid, more or less branched from the crown of the slender taproot, 1 (rarely 2) dm. high: leaves numerous, narrowly oblong, 1-3 cm. long, passing into the smaller foliar bracts: flowers inconspicuous: fruits large for the plant; nutlets similar, all deeply cupulate or hooded, the border thin but strongly involute, the rounded margin bearing a few short, glochidiate prickles; the tip of the nutlet with nearly an equal number of slender prickles not involved in the border of the hood (these characters not fully developed till maturity); the body of the nutlet with a dorsal, slightly muriculate ridge, ventrally orbicular with an abrupt acumination, strongly keeled, the sides closely muriculate.-Sandy barrens; Wyoming and southward.

11. Lappula foliosa A. Nels. Diffusely and profusely branched from the base, the slender branches very leafy throughout, 10-20 cm. long, floriferous nearly to the base but more remotely so downward: leaves broadly linear, 1-3 cm. long: flowers blue: fruits on short pedicels which tend to recurve; nutlets all alike, the prickles widely dilated and connected at base, forming a narrow wing-like revolute margin, minutely papillose-scabrous on all sides with a noticeable dorsal ridge. L. desertorum foliosa A. Nels. Bull. Torr. Bot. Club 27: 267. 1900.-Red Desert of Wyoming; probably southward.

12. Lappula heterosperma Greene, Pitt. 4: 94. 1899. Diffusely branched, often nearly to the base; the branches $10-15 \mathrm{~cm}$. long, loosely floriferous, each flower subtended by a leafy bract which surpasses even the mature fruit: leaves linear to oblong-linear, subcinereous: flowers pale blue: nutlets dissimilar, 3 with an elevated, coroniform, thickened, aculeate border, the fourth with about 6 prickles almost distinct, but each dilated and slightly inflated at base, a line of sharp murication forming a dorsal ridge and the whole surface of nutlets minutely muricate, even on the cupulate crown.-Southwestern Colorado and southward as to the species. The following variety occurs farther northward. 
12a. Lappula heterosperma homosperma A. Nels. Bot. Gaz. 34: 29. 1902. Larger than the species, paniculately and somewhat rigidly branched from near the base upward: nutlets all similat and with the character of the cupulate ones of the species.-Northern Colorado.

\section{PECTOCARYA DC.}

Small annuals with narrow subopposite leaves and minute flowers. Calyx cleft to the base or nearly so and open in fruit. Corolla with crests nearly closing its throat, the 5 short stamens included. Style minute with capitate stigma. Nutlets thin and flat, widely divergent, winged by a thin pectinate or bristly border.

1. Pectocarya miser A. Nels. Bot. Gaz. 37: 310. 1904. Minutely appressedstrigose, branched from the base, the several stems filiform, spreading, 5-20 $\mathrm{cm}$. long: leaves linear, imperfectly opposite, mostly less than $1 \mathrm{~cm}$. long; the floral one of the pair reduced or wanting: flowers single at the nodes: nutlets geminate, very flat, irregularly and narrowly winged at the sides, sides and apex bordered with hooked bristles, the dorsal disk slightly keeled and glandular-hairy.-Known only from type locality, Point of Rocks, Wyoming.

\section{ERITRICHIUM Schrad.}

Dwarf, caespitose, mountain perennials with narrow leaves and small white or blue flowers. Corolla rotate, with short tube, 5 crests in the throat, and 5 included stamens. Nutlets divergent, with sharp margin or winged by an acute pectinate-toothed border.-Omphalodes.

Pubescence long and villous

1. Eritrichium argenteum Wight, Bull. Torr. Bot. Club 29: 411. 1902. Densely caespitose, only $2-4 \mathrm{~cm}$. high, closely villous with long soft white hairs: leaves narrowly ovate to narrowly lanceolate: flowers terminating very short leafy shoots, becoming more or less racemose: nutlets with a pectinate-toothed or spinulose dorsal border. Omphalodes nana aretiodes. - Alpine; in Colorado, Utah, Wyoming, and northwestward.

2. Eritrichium Howardii (Gray) Rydb. Mem. N. Y. Bot. Gard. 1: 327. 1900. Densely caespitose, sericeous-canescent with appressed pubescence: leaves spatulate-linear, 7-15 mm. long, crowded on the tufted branches of the caudex: stems short, with a few linear leaves, simple or dichotomous, fewflowered: corolla larger $(7-10 \mathrm{~mm}$. broad): nutlets flattened dorsally, the disk smooth or minutely papillose, the margin acutely angled. Omphalodes Howardii. (Eritrichium elongatum Wight, Bull. Torr. Bot. Club 29: 408. 1902). Wyoming, Montana, and westward in the mountains.

\section{ALLOCARYA Greene}

Small semisucculent somewhat hirsute annuals, with opposite (at least the lower) linear leaves, and several to many slender usually depressed branches from the base. Flowers, small, white, racemose, on turbinate-thickened pedicels. Calyx 5-parted. Corolla salverform, yellow-throated. Nutlets 4, variable (from smooth to rugose or even glochidiate), ovate or lanceolate.-Krynitzkia Fisch. \& Mey. in part.

Fruiting racemes lax .

Fruiting racemes dense

1. Allocarya scopulorum Greene, Pitt. 1: 16. 1887. Minutely strigillosehispid or the leaves glabrate above, branched from the base; the slender, prostrate-spreading stems at length branched, 7-15 cm. long: leaves linear, the floral somewhat elongated: calyx-segments not accrescent, linear-lanceolate: nutlets with ovate nearly basal scar, slightly carinate ventrally and also 
dorsally toward the apex, rugulose or obscurely pericillate-roughened or muriculate. Krynitzkia californica subglochidiata Gray.-Frequent on moist saline soil throughout our range.

2. Allocarya Nelsonii Greene, Erythea 3: 48. 1895. Similai in size and habit, the pubescence denser and the hairs with pustulate base; very profusely branched from the crown: inflorescence dense in fruit as well as in flower: calyx open, the segments short: corolla inconspicuous: nutlets with nearly basal scar, sharply keeled ventrally, a few sharp transverse or oblique rugulae on the dorsal side, beset with minute hooked or forked hairs on the ridges and obscurely papillose in the intervals.-Known only from the type locality, Silver Creek, Fremont county, Wyoming.

\section{CRYPTANTHE Lehm.*}

Slender, hirsute or hispid annuals, with narrow entire alternate leaves and bractless (sometimes leafy-bracteate below). flowers in slender spikes or racemes. Calyx more or less hispid, closely embracing the fruit and deciduous with it. Corolla small, often inconspicuous. Nutlets 4 , or by abortion fewer, attached from the base upward usually nearly to the apex, smooth, muriculate or tuberculate, sometimes with a slight dorsal ridge, the margin sometimes acute or even winged.-Krynitzkia Fisch. \& Mey. in part.

Nutlets smooth, light gray or mottled.

Sepals with a thickened rigid midrib.

Branched from the base:

One nutlet more persistent

Nutlets all alike
Simple below, paniculately branched above

Sepals setose-hispid, midrib not noticeably thickened.

Sepals long-attenuate, the tips open-divaricate. Nutlets usually all maturing

Nutlets solitary

Sepals short, tips closed

Nutlets roughened or muricate, at least some of them.

Nutlets dissimilar, one larger and smooth

Nutlets alike, one sometimes aborted.

1. C. Pattersonii. 2. C. ramulosissima.

4. C. flexuosa.

5. C. gracilis.

6. C. Watsonii.

7. C. crassisepala. 8. C. multicaulis.

1. Cryptanthe Pattersonii (Gray) Greene, Pitt. 1: 120.1897. Rough-hispid, 15-25 cm. high; the several stems from the base simple or sparingly branched: leaves narrowly spatulate or linear: calyx hispid with pungent bristles, the lobes linear-lanceolate and with noticeably thickened midrib: nutlets ovateacuminate, smooth, one of them disposed to be more persistent than the rest, sometimes but one maturing, attached from the base to the middle or above. Krynitzkia Pattersonii Gray.-Plains and foothills of the eastern side of the Rocky Mountains.

2. Cryptanthe ramulosissima A. Nels. Erythea 7:68. 1899. Densely hispid throughout, closely and intricately branched from the base up, the whole forming a subspherical mass $2-4 \mathrm{dm}$. in diameter: leaves small, numerous, linear, the hairs with pustulate base: spikes uniserial, crowded, the flowers in pairs: sepals linear, setose-hispid, midrib thickened at base, 5-6 $\mathrm{mm}$. long: nutlets all alike, smooth, subconical, $2 \mathrm{~mm}$. long, ventral groove widening slightly into an open basal areola.-Southern Wyoming.

3. Cryptanthe Fendleri (Gray) Greene, Pitt. 1: 120. 1887. Erect, paniculately branched from near the base, rather rigid, 2-3 dm. high: leaves linear, 2-4 cm. long: spikes slender, bracteate at base: sepals narrowly linear, in fruit: nutlets narrowly ovate-acuminate, attached nearly to the apex, all maturing and alike, brown, less than $2 \mathrm{~mm}$. long. Kryntzkia Fendleri Gray.Sandy plains in the Rocky Mountains and westward.

* Besides the species described, several others are occasionally reported from our range among which may be named $C$. affinis, $C$. Torreyana, $C$. ambigua, etc. It seems doubtful whether these species occur in our range. Fully developed material with mature nutlets is likely to show that those so reported belong to one or the other of the species here described, or else that they are new and yet undescribed. 
4. Cryptanthe flexuosa A. Nels. Pale, hispid-pubescent; stems simple or several from the base, loosely branched upward, erect, or (if long) flexuousspreading, $15-30 \mathrm{~cm}$. long: leaves narrowly oblong, 2-3 cm. long: fruiting spike open, below with foliar bracts: sepals lanceolate-acuminate, hispid at base, the tips mostly spreading, $5-8 \mathrm{~mm}$. long: nutlets mottled, smooth and shining, about $2 \mathrm{~mm}$. long, the ventral groove nearly closed, forked at the base but without areola, all maturing.-C. affinis flexuosa A. Nels. Bot. Gaz. 30: 183. 1900.-Northwestern Wyoming, Utah, and Idaho.

5. Cryptanthe gracilis Osterh. Bull. Torr. Bot. Club 30: 236. 1903. Slender, erect, 10-15 cm. high, sparsely hispid: leaves rather few, oblanceolate, obtuse, about $1 \mathrm{~cm}$. long, sparsely hispid: inflorescence pedunculate, open in fruit; the flowers small: calyx densely hispid, the lobes narrow and not thickened, $3 \mathrm{~mm}$. long in fruit: nutlet solitary, ovate-acuminate, smooth, somewhat triangular in cross section, about $2 \mathrm{~mm}$. long, a little longer than the large gynobase to which it is attached for about half its length.-Known only from the type locality, Glenwood Springs, Colorado.

6. Cryptanthe Watsonii (Gray) Greene, Pitt. 1: 120. 1887. Erect, dark green, slightly hispid, 12-25 cm. high; stem simple or branched from the base, slender and somewhat weak: leaves narrowly oblong or spatulate, $2-4 \mathrm{~cm}$. long: flowers minute, relatively few, the fruiting spikes open, naked except at base: sepals short, only 3-4 mm. long, the tips mostly closed; midrib not thickened: nutlets narrow, subtriquetrous, about $2 \mathrm{~mm}$. long, attached from the base nearly to the apex, smooth and shining. Krynitzkia Watsonii Gray.Northwestern Colorado and through western Wyoming.

7. Cryptanthe crassisepala (T. \& G.) Greene, Pitt. 1: 112. 1887. Very rough-hispid, freely and diffusely branched from the base upward, rather stout, 15-25 cm. high: leaves oblanceolate and linear-spatulate: calyx very hispid with yellowish or fulvous bristles, the sepals greatly thickened at base in fruit, $5-8 \mathrm{~mm}$. long, inclined to disarticulate at maturity, forming a sort of bur inclosing the nutlets: nutlets ovate, acute, dissimilar, 3 of them muricategranulate, and 1 larger and smooth or nearly so, attached for half its length. Krynitzkia crassisepala Gray.-From the Rocky Mountains eastward to Kansas and Nebraska.

8. Cryptanthe multicaulis A. Nels. Bot. Gaz. 30: 183. 1900. Few to many-stemmed from the crown of the vertical taproot; stems slender, erect or decumbent at base, sparingly branched, 12-24 cm. high: leaves broadly linear, 2-3 cm. long; pubescence from hispid to hirsute-ciliate: spikes slender, rather dense even in fruit: sepals setose-hispid, narrowly lanceolate-acuminate, about $5 \mathrm{~mm}$. long, the midrib not thickened: nutlets obscurely roughened, ovate, subacute, $2 \mathrm{~mm}$. long, the ventral groove forked at base but without conspicuous open areola, usually only 3 maturing.-Wyoming and probably southward into Colorado.

\section{OREOCARYA Greene}

Coarse biennial herbs, with rough or hispid pubescence, alternate leaves, and white or yellow flowers in crowded paniculate or thyrsoid clusters. Calyx 5-parted, open in fruit. Corolla salverform, 5-lobed, crested in throat and bearing 5 included often dimorphic stamens. Ovary deeply 4-lobed, becoming a fruit of 4 sharp-angled or wing-margined nutlets which are attached laterally to the pyramidal receptacle.-Krynitzkia Fisch \& Mey. in part.

Flowers yellow or with yellow throat.

Flowers yellow, in a spicate thyrsus i - . - . 1. O. Hava.

. . . 2. O. glata.

Flowers white with yellow throat . . . . . . 3. O. flavoculata.

Tufted or caespitose perennials.

Inflorescence racemose-paniculate; nutlets smooth:

Fruiting raceme uniserial; nutlets gray

Fruiting raceme biserial; nutlets brown
Inflorescence thyrsoid or thyrsoid-glomerate; nutlets rough.

4. O. multicaulis.

5. O. suffruticosa. 
Calyx-lobes equaling or exceeding the corolla-tube.

Hirsute, fulvous above.

Nutlets nearly smooth

Nutlets conspicuously roughened $\quad . \quad+\quad 6$ O. caespitosa.

Silvery-canescent; nutlets muricate - • • - 7. O. nana.

White-sericeous, tawny above; nutlets rugulosetuberculate.

Floriferous above only

Floriferous from the base
Calyx-lobes shorter than the corolla-tube.

Inflorescence terminal.

Contracted capitate

Compound spicate

Floriferous throughout; nutlets rugose - • . . - 12. O. cristata.

Biennials or scarcely more enduring, mostly from a taproot.

Corolla-tube not surpassing the calyx-lobes.

Stem simple, or with smaller branches from the base; lower leaves oblanceolate

Stem simple or several from the base; lower leaves obovate

Stems two or more from the crown, equal.

Nutlets sharply rugose

Nutlets roughly white-papillose

Stem strict, stout; inflorescence spicate, leafy-bracteate

Corolla-tube surpassing the elongated calyx-lobes'.

9. Q. sericea.

10. O. elata.

11. O. fulvocanescens

13. O, Bakeri.

14. O. affinis.

15. O. glomerata.

16. O. thyrsiflora.

17. O. aperta.

18. O. virgata.

19. O. longiflora.

1. Oreocarya flava A. Nels., Bull. Torr. Bot. Club 25: 202. 1898. Whitepubescent below, fulvous or yellow-hirsute upward; stems numerous, tufted on a branched lignescent caudex, $10-25 \mathrm{~cm}$. high: leaves numerous; basal ones scale-like and white-hairy; stem leaves linear to oblanceolate, $3-5 \mathrm{~cm}$. long: inflorescence crowded, glomerate-spicate: calyx yellow-hirsute, lobes linear, half the length of the corolla-tube: corolla a decided yellow, tube about $12 \mathrm{~mm}$. long; crests conspicuous, emarginate: stamens and pistils dimorphic; stamens inserted just below the throat or just below the middle of the tube; style the length of the tube or half the length: nutlets smooth, ovate, narrowly winged, not all maturing.- Southern desert region of Wyoming.

2. Oreocarya alata (Jones) A. Nels. Pubescence short, soft and appressed, longer but scarcely hispid in the inflorescence; caudex woody, branched; stems single from the crowns, erect, 2-5 cm. high: basal leaves crowded, linear-oblanceolate, 3-6 cm. long; those of the stem oblong-linear: inflorescence subcapitate, with one or more small clusters in the axils of the uppermost leaves: calyx-lobes linear, shorter than the corolla-tube, fulvous-hirsute: corolla yellowish, tube about $10 \mathrm{~mm}$. long, at least twice as long as the lobes: nutlets smooth, obtusely and narrowly wing-margined.-Krynitzkia leucophaea alata Jones, Cal. Acad. Sci. II. 5: 710. 1895.-Sandstone cliffs and barrens; Utah and probably western Colorado.

3. Oreocarya flavoculata A. Nels. Erythea 7: 66. 1899. Hispid-ciliate, loosely tufted on a branched caudex the branches of which are clothed with dead leaf-bases, 1-2 dm. high: leaves linear-spatulate to narrowly obovate, canescent: inflorescence crowded, becoming a thyrsus of short racemes, fulvous and somewhat strigose: sepals lanceolate, about $7 \mathrm{~mm}$. long: corolla white or ochroleucous, the throat and conspicuous oblong crests bright yellow; tube slightly exceeding the calyx and nearly twice the length of the oval lobes: nutlets ovate, roughened-papillate on the back. (O. eulophus Rydb. Bull. Torr. Bot. Club 31: 637, 1904.)-Southwestern Wyoming and southward.

4. Oreocarya multicaulis (Torr.) Greene, Pitt. 3: 114. 1896. Perennial, tufted, densely pubescent and somewhat tomentose; stems numerous, rather rigid, 3-5 dm. high, moderately leafy, bearing a thyrsus of numerous elongated spikes at and near the summit: leaves mostly oblanceolate, becoming broadly linear upward: spikes appearing uniserial and unilateral: nutlets ovatetrigonous, smooth and shining. Krynitzkia Jamesii Gray in part.-Southern Colorado and southward.

5. Oreocarya suffruticosa (Torr.) Greene, Pitt. 1: 57. 1887. Stems tufted, freely branched, canescently pubescent or white-hirsute, about $2 \mathrm{dm}$. high, rather rigid and brittle: leaves linear-lanceolate or oblanceolate, cinROCKY MT. BOT. -27 
ereous with appressed pubescence: fruiting spikes geminate and biserial: sepals ovate-lanceolate: nutlets ovate-trigonous (a quarter of a sphere), polished, red-brown, dotted with white. Krynitzkia Jamesii Gray in part.Southeastern Wyoming and southward in Colorado.

6. Oreocarya caespitosa A. Nels. Erythea 7: 65. 1899. The multicipital caudex densely tufted, often forming broad mats, the branches clothed with dead leaves; stems 5-10 cm. high, single from the crowns, simple: leaves numerous, linear to spatulate, 5-30 $\mathrm{mm}$. long, silky-canescent: inflorescence at first capitate, in fruit thyrsoid-spicate, fulvous-pubescent: corolla white, tube scarcely equaling the sepals, crests conspicuous: nutlets narrowly ovate, scarcely roughened on the back, attached by nearly the whole inner margin. -Wyoming and southward.

7. Oreocarya nana Eastw. Bull. Torr. Bot. Club 30: 243. 1903. Caespitose, 5-20 cm. high, hispid throughout, floriferous nearly from the base: radical leaves crowded, oblanceolate, petiolate, $1-2 \mathrm{~cm}$. long; cauline leaves few, similar but shorter than the radical: inflorescence spicate-glomerate: calyx-lobes linear-subulate, longer than the corolla-tube, enlarging in fruit and conniving over the nutlets: corolla white, with prominent crests: nutlets ovate, keeled on the dorsal side and rough with sharp, transverse, interrupted muriculations, with fine papillae intervening.-Mesa lands; Grand Junction, Colorado.

8. Oreocarya cana A. Nels. Bot. Gaz. 34: 30. 1902. Caudex multicipital, clothed with densely pubescent leaf-bases; stems 1-2 dm. high, simple, softly pubescent: leaves silvery-white with a short, close, soft pubescence, linearoblanceolate, 3-7 $\mathrm{cm}$. long: the short, dense, thyrsoid spike closely fulvoushairy (scarcely hispid): sepals linear, 5-7 $\mathrm{mm}$. long: tube of the white corolla equaling the calyx: nutlets narrowly ovate, sharply angled, closely muriculate on back and sides, ridged on the back by a double row of minute tubercles, scar open, lanceolate, seldom all maturing.-Barren hills on the North Platte.

9. Oreocarya sericea (Gray) Greene, Pitt. 1: 58. 1887. Canescent below, more hirsute upward and becoming a tawny yellow; stems tufted on a branched caudex, 1-2 dm. high: leaves spatulate, 2-4 cm. long: inflorescence short, at first capitate, at length open thyrsoid: corolla white, the short tube equaled by the oval lobes and much surpassed by the hispid linear fruiting sepals: nutlets ovate, subacute, closely muricate-tuberculate on the back, the ventral groove terminating in a broader basal scar. Krynitzkia sericea Gray.Western part of our range (probably) and westward to the Sierra Nevada.

10. Oreocarya elata Eastw. Bull. Torr. Bot. Club 30: 241. 1903. Stems 1-several from a woody taproot, 2-4 dm. high, floriferous from the base, the axillary clusters becoming spicate and the summit of the stem branching into a panicle of bracteate spikes: basal leaves spatulate, white with a fine, dense, interlaced pubescence; cauline distant, similar but sessile or clasping: calyxlobes ovate, with strong midvein, densely hispid, surpassing the corolla-tube: corolla white, the tube longer than the lobes: nutlets ovate, acute but not winged on the margin, tuberculate with glossy-white tubercles which are separate or confluent in irregularly transverse ridges.-Type locality, clay hills, near Grand Junction, Colorado.

11. Oreocarya fulvocanescens (Gray) Greene, Pitt. 1: 58. 1887. Silkytomentose and the inflorescence yellow hispid-hirsute; caudex caespitose; stems $1 \mathrm{dm}$. or more high: leaves linear-spatulate, acute: inflorescence contracted and subcapitate: tube of the white corolla much longer than the lobes and surpassing the calyx, the crests elongated and exserted. Krynitzkia fulvocanescens Gray.-Southern Colorado and New Mexico.

12. Oreocarya cristata Eastw. Bull. Torr. Bot. Club 30: 244. 1903. Caudex branched from a slender woody taproot; stems slender, $2 \mathrm{dm}$. high: leaves oblanceolate-spatulate, on broad petioles; pubescence from cinereous to tawny (above): inflorescence short, glomerate-spicate: calyx-segments about $6 \mathrm{~mm}$. long, very bristly, shorter than the tube of the corolla: corolla with broad orbicular divisions, the throat-crests prominent: nutlets globose, incurved, acutely margined to the scar, rough with transverse ridges and minute 
papillae intervening; scar broad and open, and forked at base.-Type locality, Grand Junction, Colorado.

13. Oreocarya Bakeri Greene, Pitt. 4: 92. 1899. Densely appressedpubescent, becoming hispid above; perennial with stout stems, usually decumbent at base, more or less branched and floriferous almost throughout: leaves petioled, oblanceolate to elliptic-lanceolate: flowers crowded in the few, solitary, or geminate racemes, bracted: sepals ovate-lanceolate, short, only a little longer than the fruit: nutlets narrowly margined, sinuately and sharply rugose on the back, pitted on the ventral face.-Southern Colorado.

14. Oreocarya affinis Greene, Pitt. 3: 110. 1896. Biennial, 15-25 cm. high, with 1 stoutish, erect, hispid stem and usually 2 or more small, ascending, accessory ones from the base: leaves mostly oblanceolate, obtuse, canescent with a minute pubescence in termixed with hispid hairs from a canescent base: flowers in short axillary racemes, forming a long narrow thyrsus: corolla 6-8 mm. across, the tube equaling the calyx: nutlets narrowly ovate, subacuminate, tuberculate-rugose on the back. Krynitzkia glomerata Gray, in part.- Southern Wyoming, westward and southward.

14a. Oreocarya affinis perennis A. Nels. Erythea 7: 67. 1899. Very similar but the root becoming indurated and perennial: nutlets nearly smooth, obscurely wing-margined.-Desert areas; Wyoming, and Colorado to Nevada.

15. Oreócarya glomerata (Nutt.) Greene, Pitt. 1: 58. 1887. Pubescence subtomentose, strigose hairs with pustulate bases intermingled, upwardly becoming densely hispid; stems simple, one or sometimes more: basal leaves crowded, short, obovate-spatulate, very obtuse or sometimes retuse; stem leaves spatulate, becoming acute upward: inflorescence and flowers as in the preceding: nutlets narrowly ovate, with dorsal ridge, transverse bars, and numerous tubercles. Krynitzkia glomerata Gray in part.-Coming into the northeastern part of our range.

16. Oreocarya thyrsiflora Greene, Pitt. 3: 111. 1896. Strigose-hispid throughout, usually with 3 or more equal stoutish stems from the crown, 2-4 dm. high: leaves oblanceolate: thyrsus large, its forked branches panicled: corolla-tube short, scarcely equaling the short sepals: nutlets about $3 \mathrm{~mm}$. long, ovate, obtuse, sharply but interruptedly rugose.-Frequent on dry hills; eastern Rocky Mountains.

17. Oreocarya a perta Eastw. Bull. Torr. Bot. Club 30: 241. 1903. Probably perennial, the caudex branched; stems several, 1-2 dm. high, branched from the base but the whole forming a close thyrsus of 2-forked spikes; pubescence gray, setose-hispid, and a finer indument of appressed hairs: ealyx-lobes subulate-acuminate, elongating and spreading in fruit: corolla white, tube and limb subequal; crests conspicuous: nutlets ovate, obtuse, with prominent dorsal ridge and acutely margined all around, rough with glossy-white papillae, the larger merging into small papillae and forming somewhat star-shaped figures.-Type locality, Grand Junction, Colorado.

18. Oreocarya virgata (Porter) Greene, Pitt. 1: 58. 1887. Very hispid, not at all canescent; stem strict, 3-6 dm. high, flowering for most of its length in short and dense, nearly sessile clusters, which are generally much shorter than the linear, subtending leaves, and forming a long, virgate, leafy spike: corolla-tube short, equaled by the lobes and by the sepals: fruit pyramidal; nutlets broadly ovate, sparingly papillose. Krynitzkia virgata Gray.-Eastern slopes of the Rocky Mountains in Colorado and Wyoming.

19. Oreocarya longiflora A. Nels. Erythea 7: 67. 1899. Canescently hispid, with a denser underlying fine puberulence, setose-hispid in the thyrsus; stems 1 or more from the crown of the biennial (possibly more enduring) root, 1-2 dm. high (including the thyrsus): leaves mostly basal, spatulate, 3-7 cm. long: inflorescence occupying nearly the whole length of the stem, the numerous racemes in the axils of the leaf-like bracts (reduced above): sepals linear, 8-10 mm. long, longer in fruit: corolla-tube much exceeding the sepals: stamens dimorphic: nutlets ovate, obtuse, $3-4 \mathrm{~mm}$. long, acute-angled, slightly keeled on back, obscurely rugose and low-papillate towards the margin.Southwestern Colorado. 


\section{MERTENSIA Roth.}

Perennial herbs, with glabrous or minutely hispid or softly pubescent alternate leaves and handsome blue, purple, or white flowers clustered in paniculate racemes or in cymes. Calyx-lobes linear to lanceolate, usually somewhat enlarged in fruit. Corolla tubular to funnelform-campanulate; the limb 5-lobed; crests in throat small. Stamens inserted on the corolla-tube; anthers included, or at least not surpassing the limb. Ovary 4-divided; style slender. Nutlets attached laterally, but near the base only, to a slightly elevated receptacle, erect, leathery, and wrinkled when mature.

Leaves glabrous or nearly so, sometimes papillose or otherwise roughened.

Corolla-tube equaling the calyx

Corolla-tube about twice as long as the calyx. Tube glabrous within

Tube with a villous ring within

Corolla-tube more than twice as long as the calyx. Leaves crowded, usually glaucescent

Leaves sparse, vivid green

Leaves strigillose above, sometimes papillose as well.

Calyx and corolla-tube subequal.

Stamens included in corolla-tube

Stamens exserted from the tube

Calyx shorter than the corolla-tube.

Low and tufted (8-15 cm: high).

Leaves ovate or elliptic

Leaves oblong or oblance-spatulate

Taller and loosely tufted ( $20 \mathrm{~cm}$. or more high). Smaller upward, bright green . Equably leafy, dark green

Leaves open on stem, few or wanting below. Glaucescent, rather thick Bright green, thin and large

Leaves pubescent on both sides
1. M. alpina.
2. M. foliosa.
3. M. coriacea.
4. M. ciliata.
5. M. cynoglossoides.

6. M. brevistyla.

7. M. papillosa.

8. M. ovata.

9. M. Tweedyi.

10. M. viridis.

11. M. coronata.

12. M. lanceolata.

13. M. pratensis.

14. M. Bakeri.

1. Mertensia alpina (Torr.) Don, Gen. Syst. 4: 372. 1838. Smooth and somewhat glaucous, $10-15 \mathrm{~cm}$. high: leaves broadly oblong to narrowly lanceolate, obtuse or subacute, $3-5 \mathrm{~cm}$. long; the lower numerous and on slender petioles as long as or longer than the blade: flowers crowded, more open in fruit: calyx-lobes scarcely equaling the tube of the blue corolla: the limb of the corolla mostly shorter than the tube: filaments inserted either on the margin of the throat or about the middle of the tube, very short, narrower than the anther: style included.-Open subalpine plains and foothills.

2. Mertensia foliosa A. Nels. Bull. Torr. Bot. Club 26: 243. 1899. Glabrous, dark green, 2-3 dm. high; rootstock thick, shreddy, branched at summit; stems numerous, 1 or more from each crown, striate, ascending or erect: leaves thick, ample, scabrous on the margins; radical numerous, elliptic to oblong, 4-7 cm. long, on slender petioles of ten twice as long; cauline crowded, sessile, oblanceolate or (upwardly) lanceolate and acute: panicle crowded: corolla $15 \mathrm{~mm}$. long, the tube slightly exceeding the limb, about twice the length of the lanceolate calyx-lobes, a 10-toothed ring inside at the base of the glabrous tube: filaments as broad as the anthers, which are protruded from the conspicuously crested throat.-Moist slopes; western Wyoming.

3. Mertensia coriacea A. Nels. Bull. Torr. Bot. Club 29: 402. 1902. Glabrous, tufted, assurgent, $2-3 \mathrm{dm}$. high: leaves crowded, thick and coriaceous, with some flat-topped papillae on the upper surface; radical oblong or elliptic, 4-6 cm. long, on petioles mostly shorter than the blade; lower stem leaves oblanceolate, passing into sessile ovate leaves upward: flower-clusters terminal and in the axils of the upper leaves, crowded even in fruit: calyxlobes triangular-lanceolate, subciliate: corolla nearly tubular, limb and throat exceeding the tube, the latter with a villous ring below the middle: filaments spatulate, broader and shorter than the anthers: nutlets ovate, coarsely rugose. (M. perplexa Rydb. Bull. Torr. Bot. Club 31: 639. 1904.) -Alpine; southern Wyoming and southward.

3a. Mertensia coriacea dilatata A. Nels. 1. c. Less leafy: inflorescence more 
open: sepals lance-linear: filaments broadly and spatulately dilated.-Range of the species.

4. Mertensia ciliata (Torr.) Don, Gen. Syst. 4: 322. 1838. Pale and glaucescent, glabrous and smooth, very leafy, 3-12 dm. high: leaves ample, veiny; cauline oblong or lanceolate-ovate, ciliate-margined, mostly acute, the upper becoming acuminate; basal leaves ovate or subcordate, $5-10 \mathrm{~cm}$. long, petioled: short racemes panicled: corolla bright blue; the tube exceeding the limb and 3-5 times as long as the ovate or oblong-obtuse, ciliate calyx-lobes: filaments as broad as the anthers, inserted in the throat: style long and capillary. $M$. sibirica Don. (M. picta Rydb. l. c. 638.)-Throughout our range.

4a. Mertensia ciliata polyphylla (Greene) A. Nels. Stem strict, closely and equably leafy. M. polyphylla Greene, Pitt. 4: 87. 1899.-Colorado.

4b. Mertensia ciliata punctata (Greene) A. Nels. Foliage green, nearly devoid of bloom, the leaves and pedicels roughened-puncticulate. M. punctata Greene, Pitt. 4: 88. 1899.-Colorado.

4c. Mertensia ciliata longipedunculata A. Nels. Bull. Torr. Bot. Club 29: 402. 1902. Size of the species; stems more freely branched; stem and branches few-leaved, terminating in long naked peduncles: calyx-lobes ovate, subacute.-Eastern Wyoming and southward.

5. Mertensia cynoglossoides Greene, Pl. Baker. 3: 19. 1901. Stems depressed, 3-5 dm. long: leaves large, glabrous below, sparsely papillosescabrous above, ciliate-scabrous on the margins; basal leaves oblong, obtuse, 6-10 cm. long, petioled; cauline ovate to lanceolate, subacute: racemes few, sparse, often long-peduncled: sepals small, lanceolate or broader, obtusish, hispid-ciliolate as are also the pedicels: corolla-tube broad, as long as the limb, 3-4 times as long as the calyx. M. muriculata Greene, 1.c.-Western Colorado.

6. Mertensia brevistyla Wats. Bot. King's Expd. 239. 1871. Low, 1-2 dm. high, pubescent with short, appressed, rigid hairs, the lower surface of the leaves excepted: leaves oblong or oblong-lanceolate, very obtuse: flowers in a loose panicle: calyx deeply 5-cleft or 5-parted, very hirsute; lobes oblong or ovatelanceolate, usually acute: corolla-tube short, equaling or but little exceeding the calyx, and rarely as long as the deep blue limb: anthers inserted near the base of the tube, and included within it: style very short.-Western central Rocky Mountains.

6a. Mertensia brevistyla obtusiloba (Rydb.) A. Nels. Calyx-lobes obtuse, noticeably shorter than the corolla-tube, merely ciliate on the margins. $M$. obtusiloba Rydb. Bull. Torr. Bot. Club 28: 32. 1901. - Southern Colorado.

7. Mertensia papillosa Greene, Pitt. 3: 361. 1898. Sparingly leafy, 1-3 dm. high: leaves oblong, revolute, densely papillose above, the low papillae bearing a minute, short, setose hair at summit; lower face of leaf smooth and glabrous, margin scabrous: flowers panicled: fruiting calyx short and campanulate, cleft to the middle, the lobes triangular, their margins pubescent, each lobe traversed by a strong carinate midnerve: corolla small and almost tubular, the narrow limb with its shallow lobes apparently erect.-Mountains of Colorado.

7a. Mertensia papillosa fusiformis (Greene) A. Nels. Root large and fusiform: calyx parted to the base, the segments crinite-hirsute: corolla more campanulate. $M$. fusiformis Greene, Pitt. 4: 89. 1899; $M$. congesta Greene, Pl. Baker. 2: 17. 1901.-Southern Colorado.

7b. Mertensia pa pillosa lineariloba (Rydb.) A. Nels. Smaller, the stem leaves nearly linear, very closely short-strigose above: pedicels strigose: calyx-lobes narrow, merely hispid-ciliate on the margins. $M$. lineariloba Rydb. Bull. Torr. Bot. Club 29: 32. 1901.-Mountains of Colorado.

8. Mertensia ovata Rydb. Bull. Torr. Bot. Club 28: 32. 1901. The low stems numerous and tufted, 1-2 dm. high: leaves minutely strigose above, broadly ovate, $20-25 \mathrm{~mm}$. long, all but the lowest sessile: flowers crowded, on short pedicels: sepals ciliate, shorter than the corolla-tube: corolla 10-12 mm. long, the tube longer than the limb and throat: stamens nearly as long as the corolla, the filaments broader than the anthers. (M. Parryi Rydb. 1. c. 34: 639.)-Nearly alpine, among rocks; Colorado. 
9. Mertiensia Tweedyi Rydb. Mem. N. Y. Bot. Gard. 1: 336. 1900. Stems low, loosely tufted, decumbent at base, $8-15 \mathrm{~cm}$. long: leaves minutely strigillose and papillose above, dark green, oblong to spatulate, subacute: calyxlobes lance-linear, ciliate, about half as long as the corolla-tube: corolla dark blue, $8-10 \mathrm{~mm}$. long, limb and tube subequal: stamens included in the throat, filaments very short: style short.-High mountains; Wyoming and northward.

10. Mertensia viridis A. Nels. Bull. Torr. Bot. Club 26: 244. 1899. Rootstocks woody, creeping in the crevices among the rocks; stems slender, rather weak, decumbent at base, 2-4 dm. long, glabrous or sparsely hispidulous: leaves bright green, minutely hispidulous above; radical oblong to elliptic, 4-6 cm. long, on longer slender petioles; cauline oblong, smaller and acutish upward: panicle leafy-bracteate; peduncle and pedicels slender; corolla about $1 \mathrm{~cm}$. long, the tube exceeding the limb and about twice the length of the sepals: filaments narrower than the anthers.-High rocky summits; Wyoming and Colorado.

11. Mertensia coronata A. Nels. Bull. Torr. Bot. Club 29: 403. 1902. Tufted, from large friable roots; stems shining, assurgent, 2-4 dm. long: leaves numerous, large for the plant, minutely scabrous above (the hairs short, curved, and sometimes early deciduous from the small pustulate base); radical oblong, 5-10 cm. long, on petioles 2-3 times as long; cauline smaller, and becoming sessile and ovate-lanceolate above: flower clusters terminal and axillary, at length open-paniculate among the floral leaves: calyx-lobes triangular-lanceolate, sparingly ciliate: corolla-tube rather broad, $5 \mathrm{~mm}$. long, exceeding the calyx; limb shorter than the tube, the lobes suborbicular, abruptly dilated from the rounded sinus: stamens inserted below the conspicuous crown of crests in the throat; the filaments broader than the anthers.- Western Wyoming to Idaho and Montana.

12. Mertensia lanceolata (Pursh) DC. Prod. 10: 88. 1846. Minutely pubescent on upper face of leaves, otherwise glabrous and glaucescent; stems simple or at length paniculately branched, 2-4 dm. high: leaves spatulateoblong to lanceolate-linear, 3-5 cm. long, obtuse to acute, semifleshy: raceme becoming loosely panicled: calyx-lobes lanceolate, ciliate, one half to nearly as long as the corolla-tube, which usually exceeds the subcampanulate throat and limb: corolla-tube hairy at the base within: filaments inserted in the throat, longer than the anther: style capillary, nearly as long as the corolla.Plains and open hills; Colorado and Wyoming.

12a. Mertensia lanceolata brachyloba (Greene) A. Nels. Calyx turbinate, the broad lobes shorter than the tube: corolla-tube scarcely equaling the limb. $M$. brachyloba Greene, Pitt. 4: 90. 1899.-In the mountains of Colorado.

13. Mertensia pratensis Heller, Bull. Torr. Bot. Club 26: 550. 1899. Stems erect, several from a thick rootstock, 3-5 dm. high, rather equably leafy: leaves thin, bright green, lanceolate, mostly acute; lower petioled, 5-10 cm. long; upper merely foliar bracts: inflorescence pubescent with short appressed hairs, especially the margins of the linear-lanceolate acute calyx-lobes: corolla blue or pink, $15-18 \mathrm{~mm}$. long; the tube much surpassing the calyx and about equaling the campanulate limb, which has short, broad rounded lobes. ( $M$. alba Rydb. is an albino form.)-Southern Colorado and New Mexico.

14. Mertensia Bakeri Greene, Pitt. 4: 91. 1899. Softly ciliate or villouspubescent throughout, with appressed or spreading hairs, tufted on a branched semiwoody caudex, $15-25 \mathrm{~cm}$. high: basal leaves oblong, subacute, $3-5 \mathrm{~cm}$. long, on longer petioles; stem leaves linear-lanceolate or oblanceolate, smaller, sessile upward: inflorescence crowded, terminal: corolla about $15 \mathrm{~mm}$. long, the tube scarcely longer than the limb and twice as long as the lanceolate, villous-ciliate calyx-lobes: style filiform, about equaling the corolla.-Mountains of Colorado.

14a. Mertensia Bakeri amoena A. Nels. Less densely pubescent, the calyxlobes merely ciliate on margins: crests in corolla-throat inconspicuous. $M$. amoena A. Nels. Bot. Gaz. 30: 95. 1900.-Yellowstone Park and adjacent regions. 
14b. Mertensia Bakeri lateriflora (Greene) A. Nels. Pubescence close and canescent: leaves numerous, all linear-oblong: flowers smaller, in a narrow secund cluster. (M. lateriflora Greene, Pl. Baker. 3: 18. 1901; M. canescens Rydb. Bull. Torr. Bot. Club 31: 640. 1904.)-Western Colorado.

\section{MYOSOTIS L. FORGET-ME-NOT}

Low and often spreading herbs, with mostly soft hairy leaves, those of the stem sessile. Flowers small, blue, in slender bractless racemes. In ours the calyx is beset with hairs, some of them bristly and having minutely hooked tips. Stamens and style included.

1. Myosotis alpestris Schmidt, Fl. Boem. 3: 26. 1793. A green, softly hirsute perennial, with slender, tufted, nearly erect stems 1-2 dm. high: leaves oblong-linear to lanceolate: racemes densely flowered, bractless when fully developed; pedicels mostly shorter than the calyx: calyx-lobes erect: corolla blue, the limb 6-9 mm. broad: nutlets more or less margined and carinate ventrally at the apex. $M$. sylvatica alpestris Koch.-Moist open woods in the mountains; Colorado and Wyoming.

ti:

\section{Lithospermum L. Gromwell. Puccoon}

Softly hirsute or hispid herbs, with alternate entire sessile leaves and flowers axillary in leafy bracted spikes. Corolla mostly salverform or funnelform, yellow or greenish-yellow, naked or pubescent or crested in the throat. Stamens 5, short, included. Nutlets (in ours) bony, ovoid, smooth and polished, attached by their base to the nearly flat receptacle. Roots yielding a violet or red dye.

Corolla-tube not exceeding the calyx

Corolla-tube about twice as long as the calyx.

Bracts (of the later flowers) scarcely exceeding the calyx .

Bracts foliar, much longer than the calyx. Oblong-lanceolate Narrowly linear

Corolla-tube more than twice as long as the calyx.

Pubescence appressed; nutlets pitted ventrally

Pubescence hispid, spreading; nutlets not pitted .
1. L. pilosum.

2. L. multiflorum.

3. L. Gmelinii.

4. L. albicans.

5. L. angustifolium.

6. L. asperum.

1. Lithospermum pilosum Nutt. Journ. Phil. Acad. 7: 43. 1834. Softly hirsute-canescent, with numerous tufted, simple, leafy stems, from a stout root, about $3 \mathrm{dm}$. high: leaves linear to narrowly lanceolate: flowers crowded in a terminal leafy thyrsus: corolla greenish-yellow, campanulate-funnelform, silky-pubescent on the outside, nearly naked in the throat, the tube and the calyx subequal: nutlets acute, white and shining.-From Utah to Montana; extending into British Columbia and California.

2. Lithospermum multiflorum Torr. Wats. in Bot. King's Exped. 238. 1871. Minutely strigose-hispid; stems more or less tufted, virgate and often paniculate at summit, $3-5 \mathrm{dm}$. high: leaves linear to lanceolate, often small for the plant: flowers numerous, short-pediceled; the later ones spicate: corolla light yellow, tubular-funnelform, 10-12 mm. long; lobes short and rounded; crests inconspicuous; tube about twice as long as the calyx and the bract, somewhat bearded at the base within.-Wyoming, Colorado, and southward.

3. Lithospermum Gmelinii (Michx.) Hitch. Spring Fl. Manh. 30. 1894. Hispid or hirsute and at length rough; stems stoutish, $3-5 \mathrm{dm}$. high: leaves lanceolate or the lower linear; the floral oblong-lanceolate or broader: flowers in short, terminal, leafy racemes: corolla orange-yellow, the throat crested, the ring at the base within bearing 10 very hirsute lobes or teeth: stamens and pistils dimorphic: nutlets white and shining, much exceeded by the narrow calyx-lobes. $L$. hirtum Lehm.-Mostly eastward of our range.

4. Lithospermum albicans Greene, Pitt. 4: 91. 1899, Related to the next, 
but stems only $2-3$ from the root, erect, $2-3 \mathrm{dm}$. high when beginning to blossom, slender and simple but for the somewhat branched inflorescence; pubescence silvery-hoary or -strigose: leaves linear, beset with setose hairs: corolla only $2-3 \mathrm{~cm}$. long, deep yellow, the lobes crenulate: nutlets ovate, smooth, white and shining. - Southern Colorado and probably extending into New Mexico.

5. Lithospermum angustifolium Michx. Fl. 1: 130. 1803. Minutely scabrous-strigose and somewhat cinereous; stems numerous from a stout root, at first blossoming low and simple but becoming 2-3 dm. high and freely branched: leaves linear: flowers pediceled, leafy bracted, of two sorts; the earlier large, bright yellow, salverform, with corolla-tube 3-4 times as long as the calyx and with conspicuous arched crests in the throat; the later cleistogamous, pale yellow and smaller, on pedicels which are recurved in fruit: nutlets ovoid, white, shining, keeled and pitted on the inner side. ( $L$. linearifolium Goldie.)-Dry soil; throughout our range and eastward.

6. Lithospermum asperum A. Nels. Bull. Torr. Bot. Club 26: 244. 1899. Rough, the short spreading hairs often from pustulate bases; root stout and woody, with dark exfoliating bark; stems numerous, simple or at length sparingly branched, $15-25 \mathrm{~cm}$. high, brittle: leaves oblong to linear: corolla yellow, the lobes crenulate-erose; crests small; tube $2-3 \mathrm{~cm}$. long; $3-5$ times as long as the linear sepals (flowers not known to be cleistogamous): stamens and pistils probably dimorphic: nutlets smooth (obscurely if at all keeled or punctate). (L. ciliolatum Greene, Pitt. 4: 92. 1899.) - Sandstone ledges; south-central Wyoming and Colorado.

\section{ONOSMODIUM Michx.}

Rather stout and coarse rough-hispid or hirsute herbs, with leafy-bracteate flowers crowded in scorpioid spikes and racemes. Calyx 5-parted. Corolla small, rarely twice the length of the calyx, greenish-white or yellowish-green, tubular or tubular-funnelform, a glandular 10-lobed ring at the base of the tube within. Style filiform, exserted. Nutlets 4 (sometimes not all maturing), smooth, attached by the base.

1. Onosmodium occidentale MacKenzie, Bull. Torr. Bot. Club. 32: 502. 1905. Somewhat canescent when young, becoming appressed-hirsute; stems tufted, somewhat diffuse, 4-8 dm. long: leaves ovate-lanceolate, 5-9-ribbed: corolla-lobes hairy on the outside: nutlets large, ovoid, sparingly pitted. $O$. carolinianum and var. molle. - From the Rocky Mountains eastward.

\section{VERBENACEAE J. St. Hil. Vervain Family}

Herbs or shrubs, chiefly with opposite or verticillate simple leaves and no stipules. Flowers (in ours) generally spicate or capitate, with persistent, 4-5-lobed calyx and 2-lipped or nearly regular corolla. Stamens didynamous, inserted on the corolla and alternate with its lobes. Style single, with 1 or 2 stigmas; ovary undivided, 2-4-celled. Fruit dry, separating at maturity into 2-4 nutlets.

Corolla 5-lobed; nutlets 4 Corolla 4-lobed; nutlets 2

\section{Verbena L: Verbena. Vervain}

Herbs with bracted flowers sessile in single or often panicled spikes, tubular 5-toothed calyx, and tubular (often curved) salverform corolla with somewhat unequally 5-cleft border. Stamens 4, included; the anthers sometimes wanting on the upper pair, the connective with or without a gland- 
like appendage. Style short, stigmatic on only one of its lobes. Spontaneous hybrids are known to be common.

Flowers small, spicate; anthers unappendaged.

Spike slender; bracts inconspicuous.

Plants glabrate or sparsely rough-hirsute .

Plants densely soft-pubescent

Spike thick; bracts surpassing the flowers

Flowers large, capitate, becoming spicate; anthers of the longer stamens appendaged.

Bracts surpassing the calyx

Bracts shorter than the calyx

1. Verbena hastata L. Sp. Pl. 20. 1753. Tall perennial 9-15 dm. high, glabrate or sparsely rough-hirsute or scabrous: leaves lanceolate or oblonglanceolate, acuminate, cut-serrate, petioled, the lower sometimes hastately lobed at base: spikes linear, panicled, peduncled, 5-12 cm. long; flowers blue; bracts ovate-acuminate, not surpassing the flowers: fruits crowded or overlapping, 2-3 mm. high. Blue Vervain.-Common from the Atlantic region to eastern Wyoming and south to New Mexico and Texas.

2. Verbena stricta Vent. Descr. Pl. Jard. Cels. pl. 53. 1800. Lower, 3-7 dm. high, softly cinereous or hoary-pubescent, simple or branched: leaves ovate or oblong, nearly sessile, sharply often doubly serrate, rarely incised, thickish and rugose-veiny, 3-7 cm. long: spikes dense, thicker, canescent, 1-2 dm. long; flowers blue or purplish; bracts lanceolate-subulate, about as long as the calyx: fruit larger. HOARY VervaIn.-Extending eastward from our range.

3. Verbena bracteosa Michx. Fl. Bor. Am. 3: 13. 1803. Perennial, branched from the base, diffuse or decumbent, hirsute: leaves cuneate-oblong or cuneateobovate, narrowed into a short-margined petiole, pinnately incised or 3-cleft and coarsely dentate: spikes terminating the branches; bracts rigid and somewhat foliaceous, surpassing the flowers, the lowest often pinnatifid or incised: corolla purplish-blue.-Plains and waste grounds; across the continent.

4. Verbena bipinnatifida Nutt. Journ. Acad. Phila. 2: 123. 1821. Hispidhirsute, 1-3 dm. high: leaves usually 4-10 dm. long, bipinnately parted or 3-parted into more or less bipinnatifid divisions, the lobes linear or broader: spikes elongated in age; bracts mostly surpassing the calyx: limb of bluishpurple corolla $8-10 \mathrm{~mm}$. broad: fruit $3-4 \mathrm{~mm}$. high, the nutlets usually retrorsely scabrous on the commissure.-Dry plains east of the Rocky Mountains from Dakota to Mexico. This and the next frequently found in cultivation, though mostly the hybrid forms.

5. Verbena canadensis (L.) Brit. Mem. Torr. Club 5: 276. 1894. Slender, $3 \mathrm{dm}$. high or less, soft-pubescent or glabrate: leaves $3-5 \mathrm{~cm}$. long, ovate or ovate-oblong in outline, cuneate at base, incisely lobed and toothed, often more deeply 3-cleft: spikes pedunculate, elongated in fruit; bracts shorter than or equaling the calyx: limb of reddish-purple or lilac corolla 14-18 mm. broad: fruit 5-6 mm. high; the nutlets minutely white-dotted or nearly smooth on the commissure. V. Aubletia Jacq.-Southern Colorado, southward and eastward.

\section{LIPPIA L.}

Herbs or shrubs, with spikes or heads of small flowers and short often flattened 2-4-toothed or 2-lipped calyx inclosing the dry fruit which separates into 2 nutlets. Corolla 2-lipped, the upper lip notched, the lower 3-lobed. Stamens 4, didynamous. Style short, slender; the stigma oblique.

Peduncles scarcely longer than the leaves

Peduncles much longer than the leaves.

1. L. cuneifolia. 2. L. lanceolata.

1. Lippia cuneifolia (Torr.) Steud. Torr. in Marcy Rep. 293. pl. 17. 1853. Diffusely branched, procumbent, minutely canescent throughout: leaves rigid, cuneate-linear, sessile, incisely 2-6-toothed above the middle: peduncles mostly shorter than the leaves; bracts rigid, broadly cuneate, abruptly acumi- 
nate: calyx-lobes emarginate: corolla-tube longer than the calyx: fruit oblong. - Throughout our range and southward.

2. Lippia lanceolata Michx. Fl. Bor. Am. 2: 15. 1803. Creeping extensively or the branches ascending, often rooting at the nodes, green and glabrate or strigillose with forked hairs: leaves thin, oblong-obovate to lanceolate, narrowed at base, sharply serrate above: peduncles much exceeding the leaves; heads at first globose, becoming short-cylindric; bracts mucronate or pointless: calyx-lobes linear-lanceolate: corolla pale blue, scarcely longer than the calyx: fruit globose.-From Colorado eastward and westward to the coasts.

\section{LABIATAE B. Juss. Mint Family}

Chiefly herbs, with aromatic punctate foliage, square stems, and opposite leaves. Flowers axillary, mostly in cymose clusters which are often aggregated in terminal spikes or racemes. Corolla more or less bilabiate, the upper lip 2-lobed or entire, the lower 3-lobed. Stamens didynamous or diandrous, inserted on the tube of the corolla. Ovary 4-lobed or 4-parted, forming in fruit 4 little seed-like nutlets or achenes, surrounding the base of the single style which is bifid at apex.

Ovary only 4-lobed, the style not basal; the small lobes of the upper lip united to the lateral lobes of the lower

Ovary deeply 4-parted, the style basal.

Calyx with a crest-like gibbosity on the upper side

Calyx not crested.

Anther-bearing stamens 4.

Upper (posterior) pair as long as the lower (anterior) . . 3. Mentha.

Upper pair longer than the lower.

Anther sacs parallel or nearly so

Anther sacs divergent.

Coarse erect herbs.

Perennial; corolla well exserted . $\quad$ 5. Nepeta.

Annual or biennial; corolla scarcely longer than the Trailing herbs

Upper pair shorter than the lower.

Calyx 2-lipped, closed in fruit.

Calyx subequally 5 -toothed.

Membranous and inflated in fruit Not membranous, unchanged in fruit. $^{\text {Not }}$.

Corolla-tube hairy within

Corolla-tube glabrous within.

Leaves small (about 1 cm. long)

Anther-bearing stamens 2.

Corolla 2-lipped.

Connective of anther laterally elongated, one end bearing a perfect cell, the other a modified abortive one or none Connective short.

Flowers large, in one or few dense capitate clusters . . 14. Monarda.

Flowers small, in many axillary clusters . $\quad . \quad$ : 15. Hedeoma.

Corolla nearly regular
1. Teucrium.

2. Scutellaria.

4. Agastache.

6. Dracocephalum.

7. Glecoma.

8. Prunella.

9. Physostegia.

10. Leonurus

11. Monardella.

12. Stachys.

\section{TEUCRIUM L. Germander}

Herbs (ours) with 10-nerved, 5-toothed calyx and tubular corolla with irregular limb, the upper and lateral lobes subequal and declined, the lower lobe much larger. Stamens 4, didynamous, exserted from the deep cleft between the two upper lobes of the corolla, the anterior pair the longer; the confluent anther cells divergent. Nutlets rugose-reticulate.

Leaves undivided

Leaves multifid or incised

1. T. occidentale.

1. Teucrium occidentale Gray, Syn. Fl. $2^{1}: 349$. 1878. Loosely pubescent, branched, 3-5 dm, high; leaves $3-5 \mathrm{~cm}$, long, ovate-oblong to broadly lanceo- 
late, sharply serrate: calyx villous with viscid hairs, the upper lobes acute: corolla 7-12 mm. long, purple, rose, or cream-color.-From Colorado and Nebraska southward to New Mexico.

2. Teucrium laciniatum Torr. Ann. Lyc. N. Y. 2: 231. 1828. Glabrous or hirsute-pubescent, much branched from a woody perennial root: leaves pinnately 3-7-parted into narrow, linear, entire or 2 or 3-lobed or toothed divisions, rather rigid; the floral much crowded, 3-parted; the upper equaling the flowers: corolla pale blue or lilac, $12-20 \mathrm{~mm}$. long, with spatulate lower lobe much surpassing the calyx.-From Wyoming to Arizona and Texas.

\section{SCUTELlaria L. Skullcap}

Bitter perennial herbs with blue or violet flowèrs in simple racemes or solitary in the axils. Calyx campanulate, 2-lipped, the lips entire and closed in fruit, the upper with a helmet-like appendage on the back (which at length becomes enlarged and concave). Corolla 2-lipped, the tube curved and dilated at throat; the upper lip arched, entire or nearly so; the lower lip spreading or deflexed, the middle lobe broad, the lateral lobes small and somewhat united to the upper lip. Stamens didynamous, ascending under the upper lip, the upper pair the shorter; anthers ciliate, those of the upper pair of stamens 2-celled, of the lower 1-celled. Nutlets papillose or tuberculate.

Flowers in racemes, axillary or terminal

1. S. lateriflora.

Flowers solitary in the axils.

Plant more or less glandular.

Leaves longer than the internodes

Leaves shorter than the internodes

Plant not glandular.

1. Scutellaria lateriflora L. Sp. Pl. 598. 1753. Glabrous, 3-5 dm. high, leafy: leaves thin, oblong-ovate and ovate-lanceolate, acuminate, coarsely serrate, rounded at base, slender-petioled; the lower floral ones of the terminal racemes similar: flowers small, about $6 \mathrm{~mm}$. long, mostly in lateral racemes: lips of the corolla short, equal.-Widely distributed, but rare in our range.

2. Scutellaria Brittonii Porter, Bull. Torr. Bot. Club 21: 177. 1894. Glandular or viscid-pubescent, branching from the base, 1-2 dm. high: leaves oblong or oval, sessile and entire or the lowest short-petioled and slightly crenulate, obtuse, rather prominently veined on the lower surface, 1-2 cm. long, mostly longer than the internodes: flowers solitary in the axils; the pedicels mostly shorter than the calyx: corolla pubescent, blue, $20-25 \mathrm{~mm}$. long. $S$. resinosa Torr. in part.-Wyoming and Colorado and probably western Nebraska.

3. Scutellaria virgulata A. Nels. Bull. Torr. Bot. Club 25: 283. 1898. Similar but merely puberulent, taller; stems slender, generally simple: leaves nervose, green, obscurely puberulent; the lower much shorter than the internodes: calyx green (even the crest): corolla blue, gradually dilated upward, glabrous in the throat and glandular-puberulent outside: nutlets minutely tuberculate.-From Wyoming to Colcrado.

4. Scutellaria galericulata L. Sp. Pl. 599. 1753. Nearly glabrous or slightly pubescent, slender, 3-7 dm. high, simple or paniculately branched above: leaves ovate-lanceolate, broadest next the subsessile subcordate base, $3-5 \mathrm{~cm}$. long, all but the upper appressed-serrate: corolla puberulent, $12-18 \mathrm{~mm}$. long; lower lip nearly erect and surpassing the upper.-Stream banks; across the continent.

\section{MENTHA Tourn. MrNT}

Odorous herbs, with simple mostly punctate leaves and small flowers usually in close clusters forming axillary capitate whorls or interrupted spikes. Calyx 5-toothed, tubular or bell-shaped. Corolla campanulate, with subequal lobes and included tube. Stamens 4, equal, with glabrous filaments bearing anthers with parallel cells. Nutlets ovoid and smooth. 
Flowers in terminal spikes. Flowers in axillary whorls

1. Mentha spicata L. Sp. Pl. 576. 1753. Glabrous perennial with erect stem, 2-4 dm. high: leaves lanceolate, sharply and unequally serrate, acute or acuminate: flowers in narrow spikes, with subulate-lanceolate bracts: calyx campanulate: corolla glabrous. SPEARMint.-Native from Europe and now common eastward; sparingly introduced in our range.

2. Mentha canadensis L. Sp. Pl. 577. 1753. More or less pubescent or villous-hairy, perennial by running rootstocks, 1-3 dm. high: leaves oblongovate to oblong-lanceolate, sharply serrate, acute, generally tapering into a slender petiole: flowers in sessile, axillary whorls (the uppermost axils flowerless): calyx hairy, with triangular-subulate teeth about one third as long as the tube. Common WiLd MinT.-Frequent on ditch and stream banks; across the continent.

\section{AGastache Clayt. Giant Hyssop}

Tall perennial herbs, with serrate-petioled leaves and small flowers crowded in interrupted spikes. Calyx tubular-campanulate, 15-nerved and obliquely 5-toothed. Corolla bilabiate; the upper lip nearly erect, 2-lobed; tl e lower somewhat spreading, 3-cleft, with the middle lobe crenate. Stamens 4, exserted, the inner pair declined and the outer shorter pair ascending (so that the pairs cross); anther cells nearly parallel. Nutlets ovoid, smooth.

Leaves pale beneath; flowers blue . . . 1. A. anethiodora. Leaves green on both sides; flowers light violet or purple : : : 2. A. urticifolia.

1. Agastache anethiodora (Nutt.) Brit. Ill. Fl. 3: 85. 1898. Glabrous or very minutely puberulent, 5-10 dm. high: leaves pale beneath, ovate, often subcordate, acute at apex, anise-scented: spike short and narrow, sometimes leafy below and paniculate: calyx-teeth ovate-lanceolate, acute, tinged with purple or violet: corolla blue, 8-10 $\mathrm{mm}$. long, slightly surpassing the calyx. Lophanthus anisatus Benth.-From the plains of the Missouri westward to the mountains.

2. Agastache urticifolia (Benth.) Rydb. Mem. N. Y. Bot. Gard. 1: 339. 1900. Glabrous; stems erect and simple, 5-10 dm. high: leaves glabrous, triangular-ovate, obtuse or acute, truncate or cordate at base, coarsely and irregularly dentate, $3-8 \mathrm{~cm}$. long, on short petioles: spikes dense, $3-7 \mathrm{~cm}$. long; bracts linear-lanceolate, entire or some of the lower ones broader and toothed: calyx campanulate, 7-10 mm. long, the teeth subequal, nearly as long as the tube: corolla violet, purple, or nearly white, 12-14 mm. long. Lophanthus urticifolius Benth. - In the mountains; from Wyoming far to the northwestward.

\section{Nepeta L. Catmint or Catnip}

A perennial herb with crenate-dentate leaves. Calyx tubular and obliquely 5-toothed. Corolla dilated in throat; the upper lip erect, concave, emarginate or cleft, with the middle lobe largest, either entire or notched. Stamens 4, ascending under the upper lip, the lower pair shorter; anther cells divergent.

1. Nepeta Cataria L. Sp. Pl. 570. 1753. Erect, branched, and densely canescent-tomentulose' throughout: leaves ovate-cordate, coarsely crenatedentate: flowers in spikes: the corolla white or purplish, dark-dotted, about $12 \mathrm{~mm}$. long, the middle lobe of the lower lip crenulate.-Native in Europe; common in many parts of the United States as a weed about dwellings; not yet extensively introduced in our range.

\section{DRACOCEPHALUM L. DRagon-head}

Coarse herbs with small blue flowers in bracteate terminal clusters. Calyx tubular, 15-nerved. Corolla 2-lipped, the upper lip erect, emarginate, the lower 3-lobed. Stamens 4; anther cells divaricate. Nutlets ovoid, smooth. 
1. Dracocephalum parviflorum Nutt. Gen. 2: 35. 1818. Rather stout, 2-7 dm. high, somewhat pubescent: leaves lanceolate or oblong, petioled, incisely dentate or the lower pinnatifid-incised; the lower floral similar: flowers numerous, in sessile glomerules crowded in a thick, terminal, leafy-bracted head or spike interrupted at base; bracts pectinate-laciniate and the teeth aristate: corolla bluish, slender, scarcely exceeding the calvx.--Throughout our range and extending eastward to the Atlantic States.

\section{GLECOMA L. GROUND IVY}

Low creeping herbs, with crenate orbicular or reniform leaves on long petioles and flowers in small verticillate axillary clusters. Calyx 15-nerved, oblique and unequally toothed. Corolla 2-lipped, the tube dilated above and exserted. Anther-sacs divergent. Nutlets ovoid and smooth.

1. Glecoma hederacea L. Sp. Pl. 578. 1753. A pubescent perennial, with creeping stems 2-4 dm. long: leaves 1-3 cm. in diameter, the petioles often equaling or exceeding the leaves: flowers few in the clusters: corolla 2-3 times as long as the calyx; the upper lip 2-lobed or emarginate; the broad middle lobe of the lower lip emarginate: upper stamens much surpassing the lower. [Nepeta hederacea (L.) Trev.]-Sparingly introduced in our range, though quite common in other states.

\section{PRUnella L. Self-heal}

Perennial herbs with petioled leaves and the small purple flowers in crowded leafy-bracteate heads or spikes. Calyx 10-nerved, 2-lipped; the upper lip dilated and truncately 3 -toothed; the lower 2-cleft. Corolla strongly 2-lipped and with dilated tube. Filaments forked, one point of the fork bearing a 2-celled anther with divaricate cells.

1. Prunella vulgaris L. Sp. Pl. 600. 1753. Stems slender, decumbentascending, 1-3 dm. long: leaves oblong-ovate, toothed, petioled below, sessile above: flowers in dense, bracteate, capitate spikes; bracts broadly ovateorbicular, strongly ciliate, 2 under each verticil of the spike: corolla blue, purple, or violet (rarely white), about twice as long as the calyx.-Adventive from Europe and widely distributed, but seemingly native on moist slopes in the mountains.

\section{Physostegia Benth. False Dragon-Head}

Almost glabrous herhs, with lanceolate and callous denticulate or serrate leaves; the upper ones sessile, the lowest tapering into a petiole, floral reduced to bracts of the simple or panicled spikes. Corolla much longer than the calyx, showy rose or flesh-color, often variegated. Anthers 4, on villous filaments, the cells parallel.

1. Physostegia parviflora Nutt. Benth. in DC. Prodr. 12: 434. 1848. Stems rather slender, leafy, 3-6 dm. high: leaves lanceolate or ovatelanceolate, denticulate: spikes short, 3-10 cm. long: calyx short-campanulate, inflated-globular in fruit and with short, mostly obtuse teeth: corolla about $12 \mathrm{~mm}$. long.-From Wyoming northward and westward.

\section{LEONURUS L. MOTHERWORT}

Tall herbs with dentate or incised leaves and small flowers in axillary verticils. Calyx turbinate, 5 -nerved, and with 5 equal teeth which are at length spiny-pointed and spreading. Corolla 2-lipped; the upper lip oblong and entire; the lower 3-lobed, with the middle lobe obcordate. Stamens 4, ascending under the upper lip; anther cells parallel. Nutlets truncate and 3-angled. 
1. Leonurus cardiaca L. Sp. Pl. 584. 1753. A puberulent perennial 5-10 $\mathrm{dm}$. high: leaves long-petioled; the lower suborbicular, dentate, 5-10 $\mathrm{cm}$. broad; the upper oblong-lanceolate, from incisely 3-lobed or cleft to nearly entire: corolla varying from purple to white, densely white-woolly on the outside of the upper lip and mottled or spotted on the lower, an oblique ring of hairs on the tube within.-Naturalized from Europe; waste grounds; infrequent in our range but a common weed in the older states.

\section{MONARDELLA Benth.}

Perennials (ours) with the aspect of Monarda, but not with the same floral characters, with entire leaves and small purple or white flowers in terminal heads which are subtended by broad, thin bracts. Calyx tubular, 5-toothed and 10-13-nerved. Corolla somewhat bilabiate; the upper lip cleft; the lower 3 -cleft into narrow similar lobes. Stamens 4, somewhat unequal, the lower pair the longer; anther-cells at length divergent. Style 2-cleft at summit.

1. Monardella parviflora Greene, Pl. Baker. 3: 22. 1901. Suffrutescent at base, the many slender tufted stems $3 \mathrm{dm}$. long, more or less decumbent at base, or more depressed, subcinereous-puberulent: leaves mostly ovatelanceolate, some oblong-lanceolate, all entire, obtusish, nerveless except as to the quite distinct midvein, obscurely puberulent, chosely glandular-punctate, small, half as long as the internodes, the largest seldom $12 \mathrm{~mm}$. long including the short petiole: heads about $18 \mathrm{~mm}$. broad; bracts scarcely colored, somewhat strigosely pubescent along the veins and densely white-ciliate all around the margin: nerves of the calyx strigose-hairy, the short teeth densely but shortly setose-hirsute: corolla lilac-purple.-Cañon of the Gunnison and probably extending into Utah.

\section{STACHYS .L. WOUNDWORT}

Herbs with verticillate-capitate or loosely clustered spicate flowers. In the following species the calyx is equally 5 -toothed and the tubular corolla purple or purple-spotted. Stamens 4 , ascending under the concave upper lip of the bilabiate corolla; anthers approximate in pairs.

1. Stachys palustris L. Sp. Pl. 580. 1753. From densely soft-pubescent to roughish-hirsute; stems $3-10 \mathrm{dm}$. high, hirsute or hispid: leaves ovatelanceolate, crenate-serrate, $4-8 \mathrm{~cm}$. long, sessile or nearly so by a broad or subcordate base, sometimes almost velvety-tomentose beneath: clusters of the spike mostly approximate, 6-10-flowered: corolla about $14 \mathrm{~mm}$. long, the tube not longer than the calyx-teeth, the upper lip pubescent.-Moist banks; across the continent.

\section{SALVIA L. SAGE}

Herbs (ours) with flowers in terminal spikes or narrow racemes. Calyx 2 -lipped, naked in the throat. Corolla blue or purple, varying to white, strongly 2-lipped; the upper lip emarginate or 2-lobed; the lower 3-lobed or 3 -cleft. Stamens 2 ; the anterior portion of the connective deflexed, linear or gradually somewhat dilated downward, closely approximate or connate, and destitute of an anther-cell. Nutlets smooth, often developing mucilage and spiral tubes when wetted.

Perennial; pubescent or downy . + . . . . . . . 1. S. Pitcheri. Annual; glabrous or nearly so $\vdots \vdots \vdots \vdots \vdots \vdots \vdots \vdots 2$. S. lanceolata.

1. Salvia Pitcheri Torr. in Benth. Lab. \& DC. 12: 302. 1848. Tomentosepubescent or canescent; stem herbaceous, $4-6 \mathrm{dm}$. high, erect, simple or branched above: leaves oblong-lanceolate to linear, acute, subserrate, narrowed to a subsessile base: raceme simple, elongated, the whorls distant; bracts often equaling the calyx: calyx tomentulose-sericeous; the upper lip 
obtuse, undivided; the lower of 2 obtuse lobes: corolla twice or more longer than the calyx: style bearded.-Eastern Colorado, eastward and southward.

2. Salvia lanceolata Willd. Enum. 37. 1809. Puberulent or nearly glabrous, branched from the base, 1-3 dm. high: leaves lanceolate or linear-oblong, obtuse, irregularly serrate with obtuse appressed teeth or nearly entire: inflorescence virgate-spiciform, interrupted; bracts very small: "calyx deeply bilabiate: corolla small, about $8 \mathrm{~mm}$. long, hardly at all exserted; the lower lip nearly twice as long as the upper: lower ends of the connective dilated.Eastern Wyoming to Arizona and Texas.

\section{MONARDA L. HoRsemint}

Odorous erect herbs with entire or toothed leaves and rather large flowers in a few whorled heads closely surrounded with bracts. Calyx elongated, tubular, 15-nerved, subequally 5-toothed, usually hairy in the throat. Corolla strongly 2-lipped; the upper lip oblong, erect, entire or notched; the lower oblong, spreading, 3-lobed at the apex, middle lobe narrowest and slightly notched. Stamens 2, inserted in the throat of the corolla, on elongated ascending filaments; the divaricate anthers confluent at their junction. Nutlets ovoid, smooth.

Stamens and style surpassing the upper lip of corolla.

Stems nearly glabrous
Stems short-lanate, especially at the nodes : :

Stamens not surpassing the falcate upper lip

1. Monarda menthaefolia Graham, Edinb. N. Phil. Journ. 1829: 347. Minutely appressed-pubescent, the leaves canescent beneath; stems simple or branched above, 3-7 dm. high, tinged with red or purple: leaves ovate to triangular-lanceolate, 4-9 cm. long, remotely serrate-dentate, petioled: involucral bracts leaf-like, more or less colored above; heads terminal, purple to bluish: calyx white or purple bearded in throat, about $10 \mathrm{~mm}$. long: corolla strongly bilabiate, villous on the outside: stamens exserted with the pistil. $M$. fistulosa L. in part; M. stricta Wooton, Bull. Torr. Bot. Club 25: 263. 1898. - From Manitoba to New Mexico.

2. Monarda Ramaleyi A. Nels. Bot. Gaz. 31: 398. 1901. Very similar to the preceding, but softly and lanately white-pubescent, densely so at the nodes; the stems nearly or quite simple, erect or somewhat flexuous, monocephalous, 3-6 dm. high: leaves lanceolate to narrowly ovate, subcordate or truncate at base; petioles short, lanately pubescent as are also the midribs of the leaves: involucral leaves ovate, scarcely purple-tinged: calyx-teeth subulate, with a pubescent ring at base: corolla lavender; lower lip oblongelliptic, as long as the upper, obtuse and broadly emarginate at apex, with a short, broadly linear, cucullate pubescent bidentate appendage from the notch: the exserted stamens surpassed by the pistil. (M. comata Rydb. Bull. Torr. Bot. Club 28: 502. 1901.) - Central Colorado.

3. Monarda Nuttallii A. Nels. Bot. Gaz. 31: 397. 1901. Perennial from short, slender, often nearly vertical rootstocks; stems slender, single or several from the crowns, usually simple, $2-3 \mathrm{dm}$. high, closely puberulent: leaves oblong, short-petioled, remotely serrulate, glabrous, $2-4 \mathrm{~cm}$. long, usually some similar but much smaller leaves fascicled in the axils: involucral leaves similar in outline, green, with thickened midrib, entire but noticeably ciliate on the margin, tapering gradually into the slender awn; verticils 2-5: calyxlobes aristate and strikingly ciliate-bearded: corolla white or barely pinkish. Monarda citriodora Cerv. in part.-From southeastern Wyoming through Colorado.

\section{5. hedeoma Pers. Pennyroyal}

Odorous annuals or perennials, with small leaves and loose axillary clusters of flowers often forming terminal leafy racemes. Calyx 13-nerved, ovoid or tubular, gibbous on the lower side near the base, bearded in the throat. Corolla 2-lipped; the upper lip erect, entire or emarginate; the lower spread- 
ing, 3-cleft. Stamens 2 and sometimes 2 sterile rudiments (staminodia); the anther-cells divergent. Pungently sweet-aromatic.

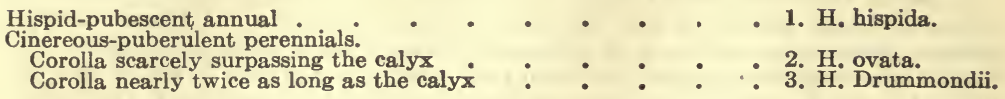

1. Hedeoma hispida Pursh, Fl. Am. Sept. 414. 1814. Stems 8-15 cm. high: leaves linear, entire, thickish, nearly sessile, crowded, almost glabrous but the margins hispid-ciliate: bracts rigid, about equaling the calyx: calyx bilabiate, the teeth subequal, those of the lower lip narrower and more hispid than those of the upper, about half the length of the oblong, gibbous, hispid tube: corolla blue or purplish, about $6 \mathrm{~mm}$. long: staminodia small or wanting.-From Colorado northward to Northwest Territory.

2. Hedeoma ovata A. Nels. Bull. Torr. Bot. Club 31: 245. 1904. Perennial, the slender branches of the caudex widely divaricate from the summit of the taproot; stems slender, branched, 12-20 cm. high, puberulent with recurved hairs: leaves entire, from broadly to narrowly oval, 7-15 mm. long, glabrous above, nearly so below, crowded and more bract-like upward: flowers small, cymulose in the axils, short-pediceled and bracteolate: calyx about $5 \mathrm{~mm}$. long, the lower teeth surpassing the upper, somewhat hispidpubescent on the tube and teeth: corolla inconspicuous, barely surpassing the calyx, the upper lip 2-lobed: staminodia wanting.-Type locality, Pole Creek, Albany county, Wyoming.

3. Hedeoma Drummondii Benth. Lab. Gen. \& Sp. 368. 1834. Cinereouspuberulent, 1-2 dm. high, copiously branched: leaves oblong to linear, obtuse, subsessile or narrowed into a very short petiole: the subulate bracts not longer than the pedicels: calyx hirsute or hispid, in age more or less curved, not plainly bilabiate; the subulate setaceous teeth at length all connivent, the lower nearly twice the length of the upper: corolla purple, 8-12 mm. long, often nearly twice as long as the calyx.-Dry slopes and cañons; Wyoming and southward to Texas and Mexico.

\section{LYCOPUS L. WATER HoARHOUND}

Low perennial herbs, glabrous or puberulent. Leaves sharply toothed or pinnatifid; the floral ones similar and much longer than the dense, axillary whorls of small white flowers. Calyx campanulate, naked in the throat, 4-5-toothed. Corolla campanulate, equally 4-lobed, scarcely longer than the calyx. Perfect stamens 2, with parallel anther sacs; the upper pair sterile or rudimentary.

Some or all of the leaves incised . Leaves serrate or dentate

1. Lycopus americanus Muhl. Bart. Fl. Phil. Prodr. 15. 1815. Green and glabrous or puberulent, with angled stems $2-4 \mathrm{dm}$. high: leaves from broadly to narrowly lanceolate, some or all of them incisely pinnatifid, 3-6 cm. long: calyx with rigid triangular-subulate or cuspidate teeth: corolla small, scarcely surpassing the calyx: the upper stamens sterile and thickened at their tips: nutlets small, included in the calyx. L. sinuatus Ell.-Throughout our range and widely distributed elsewhere, nearly across the continent.

2. Lycopus asper Greene, Pitt. 3: 339. 1898. Glabrate, puberulent or even hirsute on the stoutish erect stem, 4-8 dm. high, acutely angled above: leaves oblong-lanceolate, acute or acuminate, $5-10 \mathrm{~cm}$. long, very sharply and coarsely serrate with triangular-subulate ascending teeth, sessile or nearly so, coarsely punctate: calyx-teeth lanceolate-subulate, about as long as the calyx-tube: corolla but little longer than the calyx: rudimentary stamens with thickened tips. L. lucidus americanus Gray.-From the Missouri west to the sea. 


\section{Solanaceae Pers. Potato Family}

Ours all herbs of various habit, with alternate or more rarely opposite leaves without stipules. Flowers regular and perfect. Calyx 5-lobed. Corolla sympetalous, more or less 5-lobed, variously arranged in bud but mostly plicate. Stamens 5, inserted on the tube and alternate with the corollalobes. Style and stigma single; the ovary mostly 2-celled and many-ovuled on a central placenta. Fruit a berry or capsule.

Fruit a berry.

Fruiting calyx bladdery-inflated; anthers distinct. Corolla yellow or lighter, often with darker center . . . 1. Physalis. Corolla purple

Fruiting calyx closely investing the fruit

Fruiting calyx not enlarged; anthers connivent
Fruit a capsule.

Capsule prickly

Capsule not prickly

\section{PHYSALIS L. GRound Cherry}

2. Quincula.

3. Chamaesaracha.

4. Solanum.

5. Datura.

6. Nicotiana.

Herbaceous annuals or perennials, with entire or sinuate-toothed leaves and solitary, axillary, pedunculate flowers. Calyx becoming much enlarged and membranaceous-inflated, completely and loosely inclosing the fruit, reticulateveiny and 5-angled or 10-costate. Corolla white or yellow, often with a dark center, rotate or rotate-campanulate, 5-angulate or obscurely 5-lobed. Stamens inserted near the base of the corolla; the anthers longitudinally dehiscent. Style slender, somewhat bent. Berries juicy, greenish, red, or yellow, with numerous flattened seeds.

Annuals.

Densely pubescent; corolla and berry yellow

Glabrous or nearly so; corolla yellow with purple center; berry purple
Perennials.
2. P. ixocarpa.

Pubescence simple or wanting (branched in no. 7).

Leaves glabrous.

Corolla yellow with purplish throat; berry red or purple

Corolla yellow with brownish center; berry yellow .

Leaves sparsely pubescent with flat hairs.

Corolla yellow with brownish center

Corolla greenish-yellow with dark green spots
Leaves pubescent, the hairs branched on the lower surface

Pubescence branched.

Pubescence dense and viscid-glandular.

Leaves large ( $5 \mathrm{~cm}$. or more long), cordate-ovate; pubescence

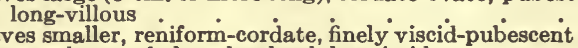

Leaves smaller, reniform-cordate, finely viscid-
Leaves subrotund, densely glandular-viscid

Pubescence stellate.

1. P. neo-mexicana.

3. P. philadelphica.

4. P. longifolia.

5. P. lanceolata.

6. P. polyphylla.

7. P. pumila.

1. Physalis neo-mexicana Rydb. Mem. Torr. Bot. Club 4: 325. 1896. Stem stout and strict, obtusely angled; pubescence fine, dense, short, scarcely viscid: leaves $3-5 \mathrm{~cm}$. long, rather thick, broadly ovate or orbicular, very obtuse, often subcordate, sinuately crenate: peduncles less than $2 \mathrm{~cm}$. long: calyx-lobes finely pubescent, lanceolate; calyx in fruit rather firm, sharply angled, sunken at the base. $P$. pubescens in part.- Southern Colorado and southward.

2. Physalis ixocarpa Brot. Horneman, Hort. Hafn. Suppl. 26. 1819. In age much branched and widely spreading; stem angled, glabrous, sparingly hairy on the branchlets: leaves cordate to ovate, base cuneate and oblique, entire or sinuate, $3-6 \mathrm{~cm}$. long: calyx slightly hairy; the lobes broadly triangular, shorter than the tube: corolla bright yellow with purple throat: fruiting calyx rounded-ovate, obscurely 10-angled, often purple-veined, at last nearly filled by the purple berry.-Probably reaching our range from the southwest.

3. Physalis philadelphica Lam. Enc. Meth. 2: 101. 1786. The dichotomously branched stem angled, erect, 5-10 dm. high: leaves ovate or narROCKY MT. ВOT. -28 
rower, narrowed and oblique at base, margins entire or repand-denticulate, alternate or paired, 6-10 $\mathrm{cm}$. long: peduncles slender, 1-2 cm. long: calyx glabrous or nearly so; the lobes ovate to lanceolate-triangular, about equaling the tube: corolla with purplish throat, rather large: anthers tinged with purple: fruiting calyx somewhat 10-angled, sunken at the base, becoming filled with the red berry.- Scarcely in our range; extending eastward to the Atlantic.

4. Physalis longifolia Nutt. Trans. Am. Phil. Soc. II. 5: 193. 1834. Perennial from a thick rootstock; stem usually stout and tall, 4-8 dm. high, branched mostly above, the branches strict, glabrous: leaves broadly linear to lanceolate or broader, subentire or repand, short-petioled: peduncles 1-2 $\mathrm{cm}$. long, in fruit often recurved: calyx generally glabrous, with triangularlanceolate lobes as long as the tube: corolla large, yellow with dark center: anthers yellow, tinged with purple: fruiting calyx ovoid, about $3 \mathrm{~cm}$. long, not sunken at the base: berry yellow, the lower portion and the stipe glutinous. P. lanceolata laevigata Gray.-From Wyoming to Mexico, and eastward.

5. Physalis lanceolata Michx. Fl. Bor. Am. 1: 149. 1803. Perennial from slender creeping rootstock, 2-5 dm. high, at length branched or even spreading, more or less hirsute with flat hairs: leaves oblong-ovate to narrowly lanceolate, tapering to the petiole, undulate or entire: corolla ochroleucous, with brownish center: calyx commonly strigose or villous, the lobes triangularlanceolate; in fruit ovoid, not sunken at base, slightly 10-angled: berry greenish-yellow.-Common in our range; widely distributed eastward.

6. Physalis polyphylla Greene, Pitt. 4: 150. 1900. A nearly glabrous perennial 1-3 dm. high; stem angular, scabrous, puberulent: leaves $2-4 \mathrm{~cm}$. long, very numerous, notably feather-veined with white fine veins, lanceolate to linear, glabrous except for the strigillose margins and veins: peduncles 1 $\mathrm{cm}$. long, deflexed in fruit: corolla greenish-yellow, with dark green spots: fruiting calyx broadly and acutely ovate, reticulate, the teeth whitishpuberulent. Southern Colorado.

7. Physalis pumila Nutt. Trans. Am. Phil. Soc. II. 5: 193. 1834. Near the two preceding: leaves thicker, generally broadly ovate and acute at both ends, often somewhat rhomboid, entire or nearly so, rather larger, on petioles 15-25 mm. long, strigose with many-branched hairs, especially on the lower surface: calyx hirsute, in fruit oblong-ovoid, somewhat sunken at the base.From Colorado eastward to the Missouri.

8. Physalis heterophylla Nees. Linnaea 6: 463. 1831. Perennial from creeping rootstocks, diffusely much branched, or at first erect, villous-subviscid with flat jointed hairs, 3-8 dm. high: leaves oblong to cordate, moderately thick, 4-6 cm. long, sinuate-toothed to subentire: corolla $15-20 \mathrm{~mm}$. broad, yellow: calyx long-villous, the lobes lanceolate, usually shorter than the tube: anthers yellow: berry yellow. $P$. virginiana.-Common in our range and extending far eastward.

9. Physalis hederaefolia Gray, Proc. Am. Acad. 10: 65. 1874. Erect or at length diffuse, densely viscid-pubescent or on young parts more or less villous: leaves roundish-cordate or almost reniform, or sometimes ovate, coarsely and obtusely angulate-toothed, 18-36 mm. in diameter: corolla about $12 \mathrm{~mm}$. broad, on pedicels 4-8 $\mathrm{mm}$. long: calyx finely viscid-pubescent; in fruit angled, ovoid, 20-30 mm. long.- Southern Colorado and southward to Mexico.

10. Physalis rotundata Rydb. Mem. Torr. Bot. Club 4: 352. 1896. Perennial, freely and horizontally long-branched from the base up, about 2-3 dm. high, broader than high, closely and finely granular-glandular or glandularpubescent, very leafy: leaves broadly ovate or subrotund, coarsely and irregularly dentate, obtuse or acute, $2-4 \mathrm{~cm}$. long, on petioles usually less than one fourth as long: peduncles slender, shorter than the fruiting calyx, divaricate to deflexed: calyx-lobes triangular-lanceolate, in blossom longer than the tube; fruiting calyx dilated, globose, $25-30 \mathrm{~mm}$. in diameter, distinctly angled, finely reticulate-veined, sunken at base: berry yellowish, 12-15 mm. in diameter.-Wyoming, Colorado, and southward. 
11. Physalis Fendleri Gray, Proc. Am. Acad. 10: 66. 1874. Perennial from a fleshy rootstock, 2-5 dm. high; pruinose-puberulent, the pubescence minute, partly simple, partly branched or stellate, sometimes a little glandular: leaves small, deltoid-ovate or slightly cordate to ovate-lanceolate, with abrupt base, the margins repand-undulate to coarsely sinuate-toothed: corolla about $12 \mathrm{~mm}$. broad: fruiting calyx rounded-ovate: berry yellow.-Dry rocky plains; Colorado to Mexico.

\section{QUINCULA Raf.}

A low perennial herb, with subfleshy' sinuate or pinnatifid leaves and mostly paired, pedunculate, axillary flowers. The angulate, reticulate calyx inflated and with connivent lobes, inclosing the fruit. Floral characters much as in Physalis, but the veiny corolla rotate, violet or purplish. The kidney-shaped seeds rugose-reticulate.

1. Quincula lobata (Torr.) Raf. Atl. Journ. 145. 1832. Low, small and diffusely branched, young parts (or on stalks and calyx densely) scurfygranuliferous, otherwise quite glabrous: leaves oblong-spatulate or obovate, repand to sinuate-pinnatifid, the base cuneately tapering into a margined petiole: corolla violet, the center with a 5 or 6-rayed white woolly star: globular-inflated fruiting calyx strongly 5-angled. Physalis lobata Torr.From Kansas through Colorado to California.

\section{CHAMAESARACHA Gray}

Perennials, with mostly narrow entire or pinnatifid leaves tapering into margined petioles and filiform naked pedicels solitary in the axils and refracted or recurved in fruit. Calyx herbaceous, open at the mouth but closely investing the berry and not ribbed or angled. Corolla rotate, 5-angulate. Filaments filiform, with separate oblong anthers.

1. Chamaesaracha coronopus (Dunal) Gray, Bot. Cal. 1: 540. 1876. Green, almost glabrous, or beset with some short and roughish hairs, diffusely very much branched: leaves lanceolate or linear with cuneate-attenuate base, varying from nearly entire to laciniate-pinnatifid: peduncles elongated: calyx more or less hirsute (hairs often 2-forked at tip), the lobes triangular, acute: corolla yellowish: berry 5-8 mm. in diameter, nearly white.-From Utah through Colorado to Texas.

2. Chamaesaracha conioides (Moricand) Brit. Mem. Torr. Bot. Club 5: 287. 1895. Cinereous with short-viscid pubescence: leaves obovate-spatulate or cuneately oblong to oblanceolate, repand to incisely pinnatifid: calyx when young villous-viscid: corolla pale yellow or sometimes violet-purple. C. sordida Gray.-Rare in our range; Colorado and southward.

\section{SOlanum L. Nightshade and Potato}

Ours are herbs with simple or rarely pinnate alternate leaves. Peduncles usually solitary, axillary or extra-axillary, few-flowered. Calyx 5-parted or cleft, unchanged but often enlarged in fruit. Corolla rotate, with plicate 5 -lobed limb and very short tube. Stamens inserted on the throat by short filaments; the anthers connate, forming a cone, usually dehiscent by a terminal pore. Fruit a 2-celled berry.

Pinnate-leaved perennial

Simple-leaved; annuals except No. $\dot{6}$.

Plant not prickly.

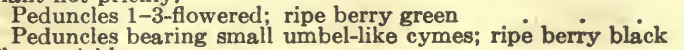

Plant prickly.

Fruit inclosed in the prickly calyx.

Plant stellate-pubescent; flowers yellow

Plant glandular-pubescent; flowers violet

Fruit naked; flowers violet, blue, or whito
1. S. Jamesii.

2. S. triflorum.

3. S. nigrum.

4. S. rostratum.

5. S. heterodoxum.

6. B. elaeagnifolium. 
1. Solanum Jamesii Torr. Ann. Lyc. N. Y. 2: 227. 1828. Perennial from small tubers, 2-3 dm. high: leaves pinnate; the leaflets 7-9, lanceolate to ovate-oblong, smoothish, the lowest often smaller but with no small ones interposed: peduncles cymosely few-several-flowered: corolla white, deeply 5-cleft: fruit not inclosed in the somewhat enlarged calyx. A relative of the potato ( $S$. tuberosum), which is native in South America.-Mountains of Colorado to New Mexico and Arizona.

2. Solanum triflorum Nutt. Gen. 1: 128. 1818. Green, slightly hairy or nearly glabrous, low and much spreading: leaves oblong, deeply pinnatifid, with wide-rounded sinuses; the lobes 7-9, lanceolate, entire or dentate: peduncles 1-3-flowered: corolla small, white, a little longer than the 5-parted persistent calyx: berries green, 10-12 mm. in diameter, on nodding pedicels. Wild Tomato.-Abundant and prolific; throughout our range on the plains, mostly in waste and cultivated ground.

3. Solanum nigrum L. Sp. Pl. 186. 1753. Low annual, much branched and often spreading, nearly glabrous, rough on the angles: leaves ovate, repand-dentate: flowers white, in small umbel-like lateral clusters, drooping: calyx spreading, shorter than the corolla: filaments hairy: berries black when ripe, 7-8 mm. in diameter. (S. interius Rydb. Bull. Torr. Bot. Club 31: 641. 1904.) Common Nightshade.- In our range an introduced weed in waste ground.

3a. Solanum nigrum villosum Mill. Low, somewhat viscid-pubescent: leaves angulate-dentate: berries varying from yellow to black. [S. villosum (Mill.) Lam.]-Adventive and infrequent.

4. Solanum rostratum Dunal, Sol. 234. pl. 24. 1813. Densely hoary or yellowish with stellate pubescence and armed with yellow prickles: leaves ovate or oval in outline, deeply and irregularly pinnately lobed or often 1-2-pinnatifid: corolla yellow, about $25 \mathrm{~mm}$. broad, the lobes ovate: stamens and style declined, the lowest stamen larger and longer and with an incurved beak: fruit inclosed by the close-fitting and horridly prickly calyx. Bufralo Bur.--Indigenous in our range on sandy plains; eastward becoming a weed.

5. Solanum heterodoxum Dunal, Sol. 235. pl. 25. 1813. Pubescent with gland-tipped simple hairs, with a few 5-rayed ones on the upper face of the irregularly or interruptedly bipinnatifid leaves, which are armed with yellow subulate prickles; stems branched, 3-8 dm. high: corolla violet, $3-4 \mathrm{~cm}$. broad, 5-cleft and somewhat irregular; the lobes ovate-acuminate: stamens unequal, the larger one violet, the others yellow: fruit as in the preceding.-From Colorado to Texas.

6. Solanum elaeagnifolium Cav. Icon. 3: 22. 1794. Silvery-canescent with dense, scurf-like stellate pubescence; stem branched, armed with sharp prickles which are rarely wanting: leaves oblong-lanceolate to linear, 4-10 cm. long: flowers on short stout peduncles: the corolla angulate, 5-lobed: calyx-lobes slender: berry at first green, then yellow, finally black, on reflexed pedicels, about $10 \mathrm{~mm}$. in diameter.-Frequent in Colorado; extending to Kansas and Texas.

\section{DATURA L. Thorn Apple}

Rank narcotic-poisonous weeds, with ovate leaves and large showy flowers on short peduncles in the forks of the branching stem. Calyx prismatic or tubular, 5-toothed, separating transversely above the base in fruit. Corolla funnelform with a large and spreading 5 or 10 -toothed plaited border. Fruit a globular or ovate prickly capsule, 4-valved, 2-celled, with 2 thick placentae projected from the axis into the middle of the cells. Seeds large and flat.

Stem purple; flowers violet or lavender

Stem green; flowers white.

Leaves irregularly sinuate-lobed

Leaves unequally ovate, repand-entire
1. D. Tatula.

2. D. Stramonium. 3. D. meteloides.

1. Datura Tatula L. Sp. Pl. Ed. 2. 256. 1762. Sparingly pubescent, moderately stout, 3-12 dm. high; stem purple: leaves sinuate-lobed, 1-2 dm. long; the lobes acute: flowers about $1 \mathrm{dm}$. long, violet or lavender: calyx 
prismatic: capsule ovoid, spinose-prickly, 4-5 $\mathrm{cm}$. high.-An introduced weed in fields and waste places.

2. Datura Stramonium L. Sp. Pl. 179. 1753. Quite similar but less pubescent; stem stouter, green: leaves ovate, acute or acuminate, narrowed at base, sinuate or angulate toothed: flowers white: calyx half as long as the corolla: capsule as in the preceding. JAMESTOWN or Jimson WEED.-Frequent as an introduction about old buildings and in barn lots.

3. Datura meteloides DC. Prodr. 13: 544. 1852. Pruinose-glaucescent with minute puberulence or pubescence: leaves unequally ovate, repand to entire: calyx cylindrical, about $7.5 \mathrm{~cm}$. long: corolla white or suffused with violet, sweet-scented, 1.5-2 dm. long: pod thickly armed with short equal prickles, nodding on the short peduncle.-Extending through Colorado; probably indigenous in the southern portion, as it is in the Texas-Arizona belt.

\section{NICOTIANA L. TOBACCO}

Acrid-narcotic mostly clammy-pubescent herbs, with ample leaves and racemed or panicled flowers. Calyx tubular-campanulate, 5-cleft. Corolla funnelform or salverform, usually with a long tube and 5-lobed plaited border. Stigma capitate. Capsule 2-celled, 2-4-valved from the apex. Seeds numerous, minute.

Stem leaves petioled

Stem leaves sessile

1. N. attenuata.

2. N. trigonophylla.

1. Nicotiana attenuata Torr. in Wats. Bot. King's Exped. 276. 1871. Stem 3-5 dm. high: leaves all on naked and mostly slender petioles, acute or subobtuse at base; the lower ovate or oblong; the-upper oblong-lanceolate and attenuate-acuminate to linear-lanceolate or linear: corolla dull white or greenish, slender salverform, not enlarged at the throat; the tube $3-4 \mathrm{~cm}$. long; the limb 8-10 mm. broad: filaments equally inserted low down on the tube.-In dry ground; from Colorado to Idaho and California.

2. Nicotiana trigonophylla Dunal, in DC. Prodr. 13: 562. 1852. . Viscidpubescent, 4-6 dm. high: leaves sessile or the lower tapering to a winged petiole, obovate-oblong to oblong-lanceolate, sometimes with a cordate or auricled base, 3-10 cm. long: inflorescence at length loosely paniculateracemose: corolla greenish-white or yellowish, about $18 \mathrm{~mm}$. long, somewhat pubescent, the sinuately-lobed limb about $8 \mathrm{~mm}$. broad.-Probably extending into southern Colorado from Texas and New Mexico.

\section{SCROPHULARIACEAE Lindl. Figwort FAMILY}

Herbs, shrubs, or rarely trees (ours herbs or rarely shrubs) with exstipulate leaves. Calyx variously toothed, cleft, or parted. Corolla sympetalous (rarely wanting), more or less irregular, the limb 2-lipped or nearly entire and the lobes imbricated in the bud. Stamens didynamous (or perfect stamens only 2, rarely 5), inserted on the corolla-tube and alternate with the lobes; the anther sacs sometimes unequal, or confluent, or reduced to one. Pistil 1; the ovary 2-celled, becoming a 2-celled many-seeded capsule with central placentae.

Anther-bearing stamens 5; leaves alternate

Anther bearing stamens 4 or 2 .

Corolla spurred or saccate at base on the lower side

Corolla not spurred, but sometimes somewhat ventricose or gibbous.

Stamens 5, four anther bearing, the fifth often rudimentary.

Sterile stamen reduced to a scale or gland on the upper side of the corolla-tube

Small annuals; peduncles 1-flowered; corolla gibbous at base; seeds solitary or few

Coarse perennials; peduncles several-flowered; corolla somewhat ventricose; seeds numerous
1. Verbascum,

2. Linaria.

3. Collinsia.

4 Scrophularia 
Sterile stamen conspicuous, elongated.

Calyx deeply 5-parted or divided

Calyx obtusely 5-lobed

Stamens all anther-bearing.

Stamens 2 (in No. 7 also a pair of sterile rudiments).

Calyx of 5 nearly distinct lobes

Calyx 4-parted.

Leaves alternate, mostly basal

Stamens 4.

Corolla regular or nearly so.

Stemless, small, mud-loving or aquatic plants . . . 10. Limosella.

Stems erect, usually branched . . . . . . 11. Gerardia.

Corolla distinctly bilabiate.

Stamens not inclosed in the upper lip

Stamens ascending under or inclosed in the upper lip. Anther-cells equal, parallel.

Calyx inflated and veiny in fruit; leaves opposite Calyx not inflated; leaves alternate or verticillate Anther-cells unequal, one pendulous by its apex. Lips of the corolla very unequal

Lips of the corolla equal or nearly so.

Calyx nearly equally 4-lobed, i. e., the lips deeply

cleft
Calyx-lips not cleft, the lower sometimes wanting :

5. Pentstemon.
6. Chionophila.

7. Gratiola.

8. Synthyris.

9. Veronica.

\section{Mimulus.}

13. Rhinanthus.

14. Pedicularis.

15. Castilleja.

16. Orthocarpus.

17. Cordylanthus.

\section{VERBASCUM L. MULlein}

Tall and usually woolly biennial herbs, with alternate leaves (those of the stem sessile or decurrent) and flowers in large terminal spikes or racemes. Calyx 5-parted. Corolla rotate, 5-lobed, the lobes broad and rounded and but little unequal. Stamens 5, all (or only the upper 3) filaments woolly. Capsule globular, many-seeded.

Plant stout, densely woolly

Plant slender, glabrate

1. V. Thapsus.

1. Verbascum Thapsus L. Sp. Pl. 177. 1753. Densely woolly throughout with branched hairs, 5-15 dm. high; stem stout, simple, winged by the decurrent bases of the large, oblong, acute leaves: flowers yellow, in a prolonged and very dense cylindrical spike: stamens unequal, the 3 upper hairy: capsule 5-6 mm. in diameter, with numerous rugose seeds. Common Mullein.-A very widely introduced weed, now found in many places within our range.

2. Verbascum Blattaria L. 1. c. 178. Green and smoothish, slender, 3-6 dm. high: lower leaves petioled, oblong, doubly serrate, sometimes lyre-shaped, the upper partly clasping: raceme loose; flowers yellow or white with a tinge of purple: filaments all bearded with violet wool.-A native of Europe; rare in our range; roadsides and waste places.

\section{Linaria L. Toadflax. Butter and Eggs}

Herbs with alternate leaves or the lower opposite and flowers in slender spikes or racemes. Calyx 5-parted. Corolla personate, the prominent palate often nearly closing the throat, spurred at the base on the lower side. Stamens didynamous. Capsule thin, opening below the summit by one or two pores or chinks.

Flowers blue

Flowers yellow

1. Linaria canadensis (L.) Dumont, Bot. Cult. 2: 96.1802 . Slender and glabrous, 1-8 dm. high: leaves flat, oblong to linear, alternate on the erect flowering stems, opposite or whorled on the procumbent sterile shoots from the base: flowers small, blue, in a naked terminal raceme; pedicels erect, not longer than the filiform-curved spur of the corolla.-Rather infrequent; sandy gravelly soil; southern part of our range.

2. Linaria vulgaris Mill. Gard. Dict. Ed. 8: 1768. Perennial, erect, 2-5 dm. high: leaves alternate, very numerous, pale, linear or nearly so: flowers in a 
terminal raceme, yellow, $2-3 \mathrm{~cm}$. long; the spur slender-subulate: seeds winged. -Fields and roadsides; rare in our range.

\section{COLLINSIA Nutt.}

Ours a low winter annual, with simple opposite sessile leaves or the upper verticillate and flowers solitary or verticillate in the axils. Corolla deeply bilabiate; the upper lip 2-cleft; the lower 3-lobed with the middle lobe conduplicate into a keel-shaped sac which incloses the 4 declined stamens and style. Upper pair of filaments inserted higher than the other; anther cells confluent; a gland near the base of the corolla represents the fifth stamen. Capsule ovoid or globose.

1. Collinsia tenella (Pursh) Piper, Contrib. Nat. Herb. 11: 496. 1906. Diffuse or spreading, 7-15 $\mathrm{cm}$. high: leaves oblong to lanceolate, mostly obtuse, 1-2 cm. long; the lower opposite and petioled; the upper sessile; the floral often whorled: flowers pediceled, solitary or 2-5 in the upper verticils: corolla 5-7 mm. long, exceeding the lanceolate calyx-lobes, blue or bicolored (blue and white): gland small, capitate, short-stipitate. C. parviflora.Widely distributed; throughout our range and eastward and westward.

\section{SCROPHULARIA L. FIgWORT}

Rather coarse perennial herbs with opposite leaves and small yellowishgreen or purplish flowers in terminal paniculate cymes. Calyx 5-parted. Corolla irregular; the tube ventricose-globular; the lobes unequal (4 erect and the fifth reflexed or spreading). Anther-bearing stamens 4, declined; the fifth reduced to a sterile scale on the roof of the corolla-tube. Capsule ovoid; seeds rugose.

1. Scrophularia occidentalis (Rydb.) Bickn. Bull. Torr. Bot. Club 23: 315. 1896. More or less soft-pubescent and glandular; stems stout, 5-12 dm. high: leaves ovate or slightly cordate at base, acute or acuminate, $5-15 \mathrm{~cm}$. long, doubly and sharply serrate or incised, often with fascicles of smaller leaves in their axils: thyrsus with short branches; flowers numerous: calyx-segments rounded-elliptical, obtuse, slightly margined: sterile filament very broad, reniform, stipitate. S. nodosa marylandica.-Alluvial soils; Dakota to Colorado and far westward.

\section{PENTSTEMON Soland. Beard-TONGUE}

Perennial herbs or more rarely low shrubs with opposite leaves (upper sessile and mostly clasping) and generally showy thyrsoid or racemosepanicled flowers. Calyx 5-parted, the tube narrow or more or less campanulateinflated. Corolla irregular, with elongated and often ventricose tube; the limb 2-lipped. Stamens 5, four of them didynamous and normal, the fifth sterile, equaling or surpassing the others, usually flattened, either naked or bearded; anther cells often divergent and becoming confluent at apex. Style filiform and tipped with the small capitate stigma. Capsule ovoid-acute to globose; seeds numerous.

Anther-cells not confluent, but dehiscent from the base nearly or quite to the apex.

Corolla red; anthers glabrous (except in No. 3 ).

Corolla strongly bilabiate.

Sterile filament glabrous. Corolla bearded in throat Corolla-throat glabrous or nearly so : Sterile filament hairy Corolla but slightly bilabiate

Corolla blue or violet.

Plant mostly glabrous or glaucous.

1. P. barbatus.

- 2. P. Torreyi.

3. P. trichander.

4. P. Eatonii. 
Leaves oblong to narrowly lanceolate.

Stems strict and slender. Anthers comose

Anthers short-hirsute

Stems ascending-erect, stout. Few-flowered; mostly low and dwarf Many-flowered; taller

Leaves oblong to ovate or subcordate

Plant pruinose-puberulent.

Conspicuously so
Obscurely so.

Stems slender, strict

Stems stout, decumbent

Anther-cells confluent, being dehiscent from the base through their junction at the apex.

Plant glabrous throughout.

Distinctly suffrutescent at base.

Anthers comose

Anthers glabrous

Herbaceous to the ground (or nearly so).

Upper stem leaves oblong to linear.

Plant tall, 3-12 dm. high

Plant low, mostly less than $3 \mathrm{dm}$. high.

Floral leaves enlarged

Floral leaves reduced.

Leaves nearly or quite linear.

Corolla naked in the throat.

Lilac or purple (high mountains)

Blue (plains and hills)

Corolla bearded in the throat.

Stems tufted, simple.

Flowers purple

Flowers white

Stems branched

Leaves narrowly oblong or oblanceolate

Upper stem leaves ovate or broader.

The uppermost narrowly ovate, acuminate

The uppermost suborbicular.

Stems 4-10 dm. high; corolla 4-6 cm. long

Stems 1-4 dm. high; corolla 2-3. cm. long

Plant more or less pubescent or glandular (at least in the inflorescence).

Stems and leaves glabrous.

Inflorescence distinctly verticillate-capitate.

Sepals green or purplish, at most scarious-margined.

Flowers small, crowded in the verticils

Flowers larger, verticils few-flowered

Sepals lacerate-scarious, with green midrib

Inflorescence thyrsoid, either paniculate or glomerate in the axils.

Thyrsus open

Basal leaves mostly oblanceolate

Basal leaves oval or rotund

Thyrsus of crowded axillary glomerules, flowers large

Stems (at least) and the inflorescence puberulent or more pubescent.

Low ( $2 \mathrm{dm}$. or less), the persistent base caespitosely and slenderly many-branched.

Leaves linear or nearly so.

Caudex depressed-caespitose

Caudex woody, more open

Leaves narrowly oblong to orbicular.

Densely pruinose-pubescent

Glabrate.

Sepals glabrate

Sepals glandular-villous

Taller, rarely tufted (No. 39).

Leaves glabrous.

Corolla blue (about $12 \mathrm{~mm}$. long)

Corolla lilac-purple or white, longer

5. P. strictus.

6. P. utahensis

7. P. alpinus.

8. P. glaber.

9. P. cyananthus.

10. P. Fremontii.

11. $P$. comarrhenus,

7. P. alpinus.

12. $P$. fruticosus

13. $P$. deustus.

14. P. unilateralis.

15. P. Haydenii.

16. P. Hallii.

17. $P$. angustifolius.

18. P. laricifolius.

19. P. exilifolius.

20. $P$. ambiguus

21. $P$. arenicola.

22. P. secundiflorus.

23. P. grandiflorus.

24. $P$. acuminatus.

25. P. procerus.

26. P. Owenii.

27. P. Rydbergii.

28. P. Watsonii.

29. P. humilis.

30. P. brevifolius

31. P. glaucus.

Leaves not glabrous.

Pruinose-puberulent, obscurely if at all glandular.

Corolla nearly tubular

Corolla abruptly and widely dilated. Leaves ovate to narrowly oblong

Leaves oblong to linear

Puberulent and (above) glandular-hirsute. Sterile filament comose-bearded.

Leaves strongly serrate

Leaves nearly entire

32. P. caespitosus.

33. P. linarioides.

34. P. suffrutescens

35. P. Crandallii.

36. P. Harbourii.

37. P. collinus,

38. P. gracilis.

39. P. radicosus.

40. P. Jamesii.

41. P. similis.

42. P. montanus.

43. $P$ erianthers. 
Sterile filament moderately hirsute.

Corolla white.

Corolla-purplish-blue

Anther-cells with closed saccate base, being dehiscent from the middle only, through their junction at the apex.

Corolla scarlet-red

Corolla violet-blue or purple.

Sepals long, lanceolate, acuminate

Sepals very short, ovate, mucronate

44. $P$. albidus.

45. P. Moffattii.

46. P. Bridgesii.

47. P. Kingii.

48. P. sepalulus.

1. Pentstemon barbatus Nutt. Gen. 2: 53. 1818. Herbaceous, glabrous, usually tall, 6-18 dm. high: leaves lanceolate or the upper linear-lanceolate; the lowest and radical oblong or ovate: corolla strongly bilabiate, $2.5 \mathrm{~cm}$. long, from light pink-red to carmine; base of the lower lip or throat usually bearded with long and loose or sparse yellowish hairs: sterile filament glabrous; anthers glabrous, not explanate after dehiscence.-Texas to Mexico and northward possibly to Colorado.

2. Pentstemon Torreyi Benth. in DC. Prodr. 10: 324. 1846. Very similar to the preceding: stems slender, tall: corolla scarlet-red, nearly or quite glabrous in the throat.- Hillsides; central Colorado to Texas and Mexico.

3. Pentstemon trichander (Gray) Rydb. Bull. Torr. Bot. Club 33: 151. 1906. Closely allied to the two foregoing but lower, the stems from a woody caudex: corolla shorter, scarlet-red: anthers beset with long woolly hairs.In southwestern Colorado.

4. Pentstemon Eatonii Gray, Proc. Am. Acad. 8: 395. 1873. Stem-leaves partly clasping: thyrsus virgate and strict, the peduncles very short: corolla obscurely bilabiate, $2.5 \mathrm{~cm}$. long, bright carmine-red, tubular, hardly enlarged at the naked throat: sterile filament sometimes minutely bearded at apex; anther-cells not confluent but often more or less divergent.- In the Wasatch mountains and thence to Nevada and Arizona.

5. Pentstemon strictus Benth. 1. c. Erect, rather rigid, glabrous or subglaucous, 2-5 dm. high: lowest leaves oblong-spatulate, petioled; the cauline linear-lanceolate: the thyrsus elongated, narrowly virgate, often somewhat secund; pedicels short, several-flowered: sepals oblong-ovate, from obtuse to acute or acuminate, with membranous margin: corolla about $2.5 \mathrm{~cm}$. long, with short narrow tube, abruptly dilated into a campanulate throat of about the same length as the widely spreading lips: anthers sparsely woolly-pilose; the sterile filament dilated and nearly or quite naked. ( $P$. strictiformis Rydb. 1. c. 31: 642.)-Frequent in the foothills; Wyoming to Colorado and Utah.

6. Pentstemon utahensis (Gray) A. Nels. Bull. Torr. Bot. Club 26: 242. 1899. Stems strict, moderately slender, often $10 \mathrm{dm}$. high: basal leaves crowded, long-petioled, narrowly oblong or lanceolate; cauline leaves remote, narrower upward and becoming sessile and nearly linear: thyrsus elongated: sepals ovate-acuminate: corolla blue or violet-purple, $3-4 \mathrm{~cm}$. long, ventricoseampliate above: anthers and sterile filament more or less hirsute; anther cells not confluent.-Wyoming and Colorado and westward.

7. Pentstemon alpinus Torr. Ann. Lyc. N. Y. 1: 35. 1827. The numerous stems (5-25) from a woody rootstock, stout, assurgent, 2-4 dm. long, glabrate or puberulent: leaves glaucous or puberulent; root leaves small or none; lower stem leaves spatulate-oblong, 4-7 cm. long, mostly obtuse; upper stem leaves lanceolate, 7-10 cm. long; the leaf-like bracts long-acuminate: inflorescence leafy-bracteate, crowded, 10-15 cm. long; cymes short-peduncled, 3-7-flowered: sepals broadly lanceolate or abruptly long-acuminate from a broad base, margins scarious: corolla moderately ventricose-ampliate, hardly bilabiate, sparsely white-bearded in the throat, about $3 \mathrm{~cm}$. long, tube proper about one third the total length, lobes rounded, spreading: sterile filament flattened at apex, moderately yellow-comose or even glabrous; stamens from sparsely short-hirsute to glabrous. $[P$. riparius A. Nels. 1. c. 25. 1898; $P$. oreophilus Rydb.1.c. 643; P. Bakeri Greene, Pitt.4: 318. 1901 (?).]-Gravelly or sandy banks; on the high plains and in the mountains of our range.

8. Pentstemon glaber Pursh, Fl. Am. Sept. 2: 738. 1814. Somewhat glaucous, leafy, 3-6 dm. high: leaves entire, firm, the basal and lower ones 
narrowed into petioles, the upper oblong or oblong-lanceolate, acuminate: thyrsus narrow, elongated; pedicels $6-14 \mathrm{~mm}$. long in fruit: calyx-segments ovate-lanceolate, scarious-margined, abruptly acuminate, $6-8 \mathrm{~mm}$. long: corolla blue or purple, rather abruptly expanded above the calyx, the limb somewhat 2-lipped, the lobes rounded: sterile filament bearded at the slightly enlarged summit: capsule narrowly ovoid, acute, about twice as long as the calyx.-Moist sandy soils; from Dakota and Nebraska through our range and far westward.

8a. Pentstemon glaber speciosus (Dougl.) Rydb. Mem. N. Y. Bot. Gard. 1: 344. 1900. Taller and more slender than the species, the inflorescence more lax, and the upper leaves much diminished. (P. speciosus Dougl.) Mountain sides; from northwestern Wyoming to Washington.

9. Pentstemon cyananthus Hook. Bot. Mag. pl. 4464 . Closely allied to the foregoing but usually taller and the stems more slender: leaves all broad; the cauline ovate, or subcordate and ovate-lanceolate: thyrsus dense: sepals narrow or long-acuminate: corolla bright blue: anthers and sterile filament from hirsute to nearly glabrous.- In the foothills of the high plains of Colorado, Wyoming, and Utah.

9a. Pentstemon cyananthus Brandegei Porter, Fl. Col. 91. 1874. Leaves thick, coriaceous; the upper cordate-ovate, clasping, ciliate on the margins: cymes 6-8-flowered: corolla abruptly ventricose-campanulate, azure blue or paler: sterile filament scantily bearded.-Reported from Colorado by Brandegee only.

10. Pentstemon Fremontii T. \& G. Proc. Am. Acad. 6: 60. 1866. Stems 1-2 dm. high, minutely and densely pruinose-pubescent: cauline leaves lanceolate or the lowest and radical spatulate: thyrsus spiciform, virgate, rather densely flowered: sepals oblong-ovate, acute, with irregular scarious margins: corolla very obscurely bilabiate, funnelform, 15-18 mm. long, with throat but little dilated: anthers hirsute; sterile filament with dilated bearded apex.-Flowering in June on the Red Desert of Wyoming and the Uintah plains, Utah.

11. Pentstemon comarrhenus Gray, Proc. Am. Acad. 12: 81. 1877. Slender, glaucescent or minutely pruinose-puberulent at least above: basal leaves oblong to oval; the uppermost linear: thyrsus laxly virgate; peduncles and pedicels moderately long: sepals small, oval, rarely more than $3-4 \mathrm{~mm}$. long: corolla about $2.5 \mathrm{~cm}$. long, purplish-blue; the tube proper rather long and narrow: anthers long-woolly.--In western Colorado and in Utah.

12. Pentstemon fruticosus (Pursh) Greene, Pitt. 2: 239. 1892. Stem woody and much branched at base, 2-5 dm. high: leaves oblong, lanceolate, or narrower, entire or toothed, often rather thick, 3-7 cm. long: inflorescence racemose, glandular-pubescent; pedicels usually 1-flowered: sepals ovatelanceolate, acuminate: corolla $2.5-3.5 \mathrm{~cm}$. long, of various shades of pink, violet, or purple, tubular-funnelform and moderately bilabiate: sterile filament short and slender; anthers comose. ( $P$. crassifolius Benth.)-Western Wyoming and Montana and far westward.

13. Pentstemon deustus Dougl. Lindl. Bot. Reg. 16: pl. 1318. 1830. Completely glabrous, the calyx at most obscurely granular-pruinose or glandular; stems 1-3 dm. high, in tufts from a woody base, rigid: leaves coriaceous, ovate to oblong-linear or lanceolate, irregularly and rigidly dentate or acutely serrate, or some of them entire; upper cauline closely sessile: thyrsus virgate or more paniculate, mostly many-flowered; peduncles and pedicels short: sepals ovate to lanceolate, nearly marginless: corolla ochroleucous or dull white, rarely with a tinge of purple, $10-12 \mathrm{~mm}$. long, either narrowly or rather broadly funnelform; the short lobes widely spreading.-Range of the preceding.

14. Pentstemon unilateralis Rydb. Bull. Torr. Bot. Club 33: 150. 1906. Plants 4-8 dm. high, including the elongated and racemiform, strict, manyflowered, 1-sided thyrsus: cauline leaves narrowly lanceolate, 5-10 cm. long; radical spatulate: peduncles 1-3-flowered: sepals ovate or oblong, acute or obtuse, with somewhat scarious but entire margins: corolla with narrow 
proper tube of nearly twice the length of the calyx, abruptly dilated into the broadly campanulate throat of about $8 \mathrm{~mm}$. in height and width; this nearly equaled by the widely spreading lips; the lobes round-oval: sterile filament glabrous or minutely bearded at the dilated tip. $P$. secundiflorus.-In the mountains of Colorado and Wyoming.

15. Pentstemon Haydenii Wats. Bot. Gaz. 16: 311. 1891. More or less glaucous; stem decumbent, leafy, 3-6 dm. high: leaves Knear or elongatedlanceolate, entire, sessile and slightly clasping, acute, acuminate, or the lowest obtusish, 5-13 cm. long, 2-10 mm. wide: thyrsus narrow, dense; bracts ovate or ovate-lanceolate, large, cordate-clasping, acute or acuminate: calyxsegments lanceolate, striate-nerved, acuminate, 6-10 $\mathrm{mm}$. long: corolla blue, the tube broadly dilated above the calyx, the limb nearly equally 5-lobed: capsule acute, twice as long as the calyx.-In Kansas and Nebraska and the eastern part of our range.

16. Pentstemon Hallii Gray, Proc. Am. Acad. 6: 71. 1866. Stems 1-2 dm. high: leaves thickish, linear and linear-spatulate, or the lowest rather broader, obtuse: thyrsus short and spiciform, 5-15-flowered, obscurely viscid: sepals broadly ovate and with widely scarious, erose margins: corolla $15-20 \mathrm{~mm}$. long, broadly campanulate-inflated from a thickish and inconspicuous proper tube which is shorter than the calyx; bilabiate limb rather short: sterile filament short-bearded from the apex downward.-In the Colorado mountains at high elevations.

17. Pentstemon angustifolius Pursh, Fl. Am. Sept. 738. 1814. Glaucous; stem slender, leafy, 1.5-2 dm. high: leaves linear or linear-lanceolate, entire, the lower narrowed into petioles, obtusish, the upper sessile acute, $3-6.5 \mathrm{~cm}$. long, 3-4 mm. wide: thyrsus narrow, spike-like, mostly dense; bracts lanceolate, acuminate; pedicels very short: calyx-segments linear-lanceolate, acuminate, 4-6 mm. long: corolla blue or nearly white, the tube gradually enlarged, the limb somewhat 2-lipped: sterile filament bearded at the summit. $P$. caeruleus.-In dry soil; from the base of the mountains to Nebraska and Dakota.

18. Pentstemon laricifolius H. \& A. Bot. Beech. 376. 1841. Glabrous; stems tufted, 5-18 cm. high; lignescent caudex not rising above the soil: leaves slender, when dry filiform and with the margins revolute, the larger 1-2 mm. wide, 2-4 cm. long, much crowded in subradical tufts and scattered on the slender flowering stems: flowers few, loosely racemose, slender-pediceled: sepals ovate-lanceolate: corolla tubular-funnelform, 12-18 mm. long, purple, the small limb obscurely bilabiate: sterile filament bearded on the upper side. ( $P$. exilifolius desertus A. Nels. 1. c. $28: 231 ; P$. aridus Rydb. Mem. N. Y. Bot. Gard. 1: 348. 1900 much resembles this but has a glandular-pubescent inflorescence with "blue" flowers. It occurs in the arid plains of Montana.)$P$. laricifolius was described from Oregon plants, but aside from the greater size in every way ours from Wyoming and Colorado do not seem to differ essentially.

19. Pentstemon exilifolius A. Nels. 1. c. 28: 230. Stems several to numerous, from a tufted branched caudex, glabrous, as are also the leaves and inflorescence, 1 (rarely 2) dm. high: leaves very numerous, crowded on the crowns, narrowly linear, channeled or involute, subulate-pointed, 15-25 mm. long; stem leaves similar, passing into the smaller bracts: thyrsus narrow, crowded, few to many-flowered; pedicels slender: sepals lanceolate and longacuminate, erose, scarious-margined: corolla white, tubular-funnelform, 12-15 mm. long, obscurely pubescent in the throat, scarcely bilabiate, the nearly orbicular lobes widely spreading, 6-7 $\mathrm{mm}$. long: anthers glabrous, the sterile filament scarcely dilated, very stiffly and densely short-pubescent.Dry stony plains and hills; Wyoming and northern Colorado.

20. Pentstemon ambiguus Torr. 1. c. 2: 228. 1828. Glabrous, 2-5 dm. high, diffuse and often much branched: leaves filiform, or the lowest linear and the floral slender-subulate: inflorescence loosely paniculate: sepals ovate, acuminate: corolla rose-color and flesh-color turning to white, narrow and somewhat curved, about $12 \mathrm{~mm}$. long, the scarcely expanded limb oblique but 
obscurely bilabiate; lobes orbicular-oval; throat or its lower side somewhat hairy: sterile filament sometimes imperfectly antheriferous, glabrous.-On the plains; eastern Colorado to New Mexico and westward.

21. Pentstemon arenicola A. Nels. 1. c. 25: 280. 1898. Simple stems 2-3 dm. high; entire plant glabrous and stem leaves somewhat glaucous: lower leaves petioled, oblanceolate to broadly spatulate; middle stem leaves 4-5 cm. long; upper leaves sessile, oblong to lanceolate, abruptly acute or apiculate: inflorescence short, spiciform, leafy below, the upper bracts short, ovate-lanceolate: sepals broadly lanceolate, slightly scarious, one fourth the length of the corolla-tube: corolla tubular or but slightly inflated upwards, blue, $12-15 \mathrm{~mm}$. long; the lobes oval, spreading, $3 \mathrm{~mm}$. long, naked in the throat: sterile filament equaling the tube, the hooked flattened apex comose, more sparsely hairy down one side for half its length; anthers dehiscent through the junction of the two cells but the cells hardly confluent, not explanate.-Sandy deserts of central Wyoming.

22. Pentstemon secundiflorus Benth. 1. c. 325 . Glaucous, strict, $1.5-6 \mathrm{dm}$. high, leafy: leaves firm, entire, the lower and basal ones oblong or spatulate, narrowed into petioles; the upper sessile or clasping, lanceolate or ovatelanceolate, 5-8 cm. long: thyrsus narrow, sometimes 1-sided: calyx-segments lanceolate, acute, 4-6 cm. long: corolla blue, the tube rather gradually dilated, the limb 2-lipped: sterile filament bearded along the dilated summit: capsule acute, twice as long as the calyx. P. acuminatus. See Rydberg in Bull. Torr. Club 33: 150 on this name and $P$. secundiflorus. ( $P$. Fendleri Gray, Pac. R. R. Rep. 2: 168.) - Sandy plains; Wyoming to New Mexico.

22a. Pentstemon secundiflorus caudatus (Heller) A. Nels. Leaves all sessile, rather fleshy, oblong-lanceolate below, becoming longer upward and ovate-lanceolate, long-attenuate: flowers pale violet or pinkish. (P. caudatus Heller, Minn. Bot. Studies 2: 34. 1898.) - Colorado and New Mexico.

23. Pentstemon grandiflorus Nutt. in Fras. Cat. 1813. Somewhat glaucous, stout, 6-12 dm. high: leaves entire, obtuse; the basal obovate, narrowed into broad petioles; those of the lower part of the stem sessile, oblong or oval, $2.5-6 \mathrm{~cm}$. long; the upper nearly orbicular, cordate-clasping, shorter: thyrsus open, leafy-bracted, the bracts orbicular-cordate: calyx-segments lanceolate, acute, 6-8 $\mathrm{mm}$. long: corolla lavender-blue, the tube dilated above the calyx, the limb somewhat 2-lipped: sterile filament incurved; villous and capitate at the summit: capsule acute, 1.5-2 cm. high, three times as long as the calyx.-On the prairies of the eastern part of our range and thence eastward and northward to the Mississippi.

24. Pentstemon acuminatus Dougl. Lindl. Bot. Reg. 15: pl. 1285. 1829. Glabrous throughout or the basal leaves minutely puberulent; stem strict, 3-4 dm. high: basal leaves spatulate, petioled, 3-6 cm. long; lower stem leaves also spatulate; the others ovate or orbicular, of ten abruptly acuminate or mucronate: bracts ovate or orbicular, abruptly short-acuminate: calyx 6-8 mm. long; lobes lanceolate, scarious-margined and more or less erosedentate: corolla pink-purple, $12-18 \mathrm{~mm}$. long, more or less open-funnelform from a narrow tube: anthers glabrous; sterile stamen spatulate at the apex and with a yellow beard. $P$. acuminatus in part. See note under No. 22 above. (P. cyathophorus Rydb. 1. c. 31: 643. 1904, from which the description here used is drawn.) - Sandy plains; Colorado and far northwestward.

25. Pentstemon procerus Dougl. Edinb. New Phil. Journ. 7: 348. 1829. Glabrous throughout; stems slender, 1-4 dm. high: leaves lanceolate, the lower ones petioled, $3-5 \mathrm{~cm}$. long, those of the middle of the stem largest, all usually entire: flowers in 2-5 dense verticillate clusters: sepals oblong or spatulate, with broad, scarious, erose margins, abruptly acuminate or 3toothed at the apex, about $\dot{\mathrm{mm}}$. long: corolla bright blue and violet, 10-12 $\mathrm{mm}$. long, tubular-funnelform, the lower lip bearded within: sterile filament as long as the others and bearded at the apex.-Moist parks and meadows in the mountains; throughout our range and northwestward.

25a. Pentstemon procerus pseudoprocerus (Rydb.) A. Nels. Sepals not 
acuminate, abruptly acute or obtuse: corolla longer, with more dilated, lessbearded throat. (P. pseudoprocerus Rydb. Mem. N. Y. Bot. Gard. 1: 346. 1900.) - Northern Wyoming and Montana.

26. Pentstemon Owenii A. Nels. Bot. Gaz. 34: 32. 1902. Allied to the foregoing but the stems lower, obscurely puberulent, 1-2 dm. high: basal leaves crowded, petioled, oblong-elliptic or spatulate; cauline similar but becoming smaller and narrower: thyrsus glandular-pubescent, crowded, capituliform to short-spicate and somewhat interrupted-verticillate: sepals lanceolate, scarious-margined, with acuminate green tip: corolla violet-blue, tubular, 12-15 mm. long: sterile filament stiffly bearded at tip.-In the high mountains; northwestern Wyoming.

27. Pentstemon Rydbergii A. Nels. Bull. Torr. Bot. Club 25: 281. 1898. Perennial from horizontal rootstocks which give rise at somewhat regular intervals to vertical branches; from the crowns of these spring long, slender, floriferous stems or very short leafy shoots; glabrous throughout, $3-5 \mathrm{dm}$. high: radical leaves and those on the sterile shoots oblong, obtuse, on slender petioles as long as the blade or longer; cauline leaves few, sessile by a broad base, narrowly oblong; the lowest pair of bracts leaf-like, broadly linear: the two or more verticils of the interrupted spike many-flowered, the lower one usually distant: sepals scarious, somewhat lacerate-margined: corolla pale blue to purple, 12-16 $\mathrm{mm}$. long, the rounded lobes of the lower lip reflexed, bearded in the throat: sterile filament short-bearded. ( $P$. erosus Rydb. Bull. Torr. Bot. Club 28: 28. 1901.)-Moist copses; Colorado and Wyoming.

28. Pentstemon Watsonii Gray, Syn. Fl. 2: 267. 1886. Glaucescent and glabrous throughout, or inflorescence and calyx minutely puberulent, but neither glandular nor viscid; stems $3 \mathrm{dm}$. or more high, ascending or weak: cauline leaves oblong-lanceolate, acute or acuminate, $3-5 \mathrm{~cm}$. long: contracted thyrsus rather loose; peduncles several-flowered, the lower slender; pedicels longer than the calyx: sepals broadly ovate or orbicular, with a small acumination, somewhat scarious-margined, $2-3 \mathrm{~mm}$. long, barely half the length of the mature capsule: corolla narrowly funnelform, 12-16 $\mathrm{mm}$. long, violetpurple or partly white; lower lip almost glabrous within.-Mountains of western Colorado to Nevada.

29. Pentstemon humilis Nutt. Gray, Proc. Am. Acad. 6: 69. 1866. Stems 1-3 dm. high, glabrous or above with the inflorescence and flowers viscid-pubescent: leaves dark green or rarely glaucescent, oblong to lanceolate, $2-5 \mathrm{~cm}$. long; the cauline commonly denticulate: thyrsus strict and virgate, 5-10 cm. long; peduncles (2-5-flowered) and pedicels short: sepals ovate or lanceolate and acuminate, lax: corolla rather narrowly funnelform, 10-14 mm. long, deep blue or partly white; lower lip somewhat hairy within. (P.'pseudohumilis Rydb. Mem. N. Y. Bot. Gard. 1: 347. 1900.)In the mountains, rocky cañons and stony slopes; throughout our range and westward.

30. Pentstemon brevifolius (Gray) A. Nels. Caudex subterranean, woody, freely branched, the branches slender, assurgent; stems slender, weak, somewhat diffuse, 1-3 dm. long: basal leaves numerous on the crowns and short sterile branchlets, suborbicular, oval, or oblong, entire, thin, 5-25 mm. long; petioles very slender, as long as the leaves; cauline leaves mostly sessile and oblong spatulate: inflorescence obscurely glandular-pubescent: corolla blue, $1 \mathrm{~cm}$. or less long. (P. humilis brevifolius Gray, 1. c.)-In the mountains of Utah.

31. Pentstemon glaucus Graham, Edinb. Phil. Journ. 348. 1829. Glabrous up to the inflorescence, more or less glaucous; stems dwarf or ascending, 1-4 dm. high: leaves thickish, oblong-lanceolate or the radical oblong-ovate, 3-5 cm. long, entire or denticulate: thyrsus short and compact, either simple or compound, villous-pubescent and viscid or glandular: corolla dull lilac or violet-purple, $20-25 \mathrm{~mm}$. long, campanulate-ventricose above the very short proper tube, gibbous, not at all plicate-sulcate; the orifice widely ringent; the broad lower lip sparsely villous-bearded within: sterile filament bearded 
mostly at and near the apex only.-In the northern Rocky Mountains and extending into our range.

31a. Pentstemon glaucus stenosepalus Gray, 1. c. Taller, 3-5 dm. high: inflorescence glomerate: sepals attenuate-lanceolate: corolla dull whitish or purplish.-More common than the species; near timber line.

32. Pentstemon caespitosus Nutt. Gray, Proc. Am. Acad. 6: 66. 1866. Minutely cinereous-puberulent, spreading, forming depressed broad tufts 5-10 $\mathrm{cm}$. high: leaves narrowly spatulate to almost linear, 8-20 mm. long, including the tapering base or margined petiole: peduncles mostly secund and horizontal, but with the flower upturned: sepals more acuminate, and the margins below obscurely scarious: corolla tubular-funnelform, and the lower side biplicate, the narrow folds sparsely villous within: sterile filament strongly and densely bearded.-Middle elevations; Wyoming, western Colorado, and Utah.

33. Pentstemon linarioides Gray, Bot. Mex. Bound. 112. 1859. Tufted, with woody, multicipital caudex, minutely cinereous-pubescent throughout; stems slender, numerous, and somewhat fascicled, erect or nearly so, many merely small leafy shoots, the longer ones $2-4 \mathrm{dm}$. high: leaves crowded below, linear, acute, tapering slightly to the base, $10-25 \mathrm{~mm}$. long; the cauline gradually reduced, the uppermost subulate bracts: inflorescence secund, the lower peduncles about 4-flowered, shorter and fewer flowered upward: sepals ovate, acuminate, scarious-margined, about as long as the corolla-tube proper: corolla blue, tubular-funnelform, about $15 \mathrm{~mm}$. long, sparsely bearded on the lower lip: sterile filament short, with a close, short, yellow pubescence; anther-cells dehiscent through the junction of the two cells. ( $P$. coloradensis A. Nels. 1. c. 26: 355. 1899.)-Arid grounds; Colorado to New Mexico and Arizona.

33a. Pentstemon linarioides Sileri Gray, Syn. Fl. 2: 270.1886. Adwarf and suffruticulose form, with smaller and fewer flowers, mostly 1-flowered peduncles subtended by proportionally longer floral leaves, and the lower lip less bearded. $P$. teucrioides Greene, Pl. Baker. 3: 23. 1901. - Southern Colorado.

34. Pentstemon suffrutescens Rydb. l. c. 28: 503. 1901. Suffrutescent, low and rather slender, the older and more woody parts of the branches prostrate and rooting, the leafy and floriferous parts assurgent, the whole 1.5-3 dm. long; branchlets retrorsely puberulent, as are also the pedicels and calyx: leaves green and almost glabrous, often only 10-12 $\mathrm{mm}$. long but rather exceeding the internodes, spatulate-obovate, obtuse or some of the earliest obcordate-notched, entire, those below the inflorescence with some fascicled smaller ones in their axils, the upper with 1-3 flowers in their axils: calyx parted deeply into linear-linguliform, abruptly acutish and minutely ciliolate lobes: corolla elongated and narrow: anthers glabrous. (P. caespitosus suffruticosus Gray; $P$. procumbens Greene, Pl. Baker. 3: 23. 1901.)Arid districts; Colorado.

35. Pentstemon Crandallii A. Nels. Bull. Torr. Bot. Club 26: 354. 1899. Caudex woody, branched-caespitose; the annual herbaceous stems slender, erect, from moderately to very leafy, finely puberulent, 1-2 dm. high: leaves linear-oblanceolate to spatulate, acute or obtuse at apex, 1-2 cm. long, nearly or quite glabrous: inflorescence open; the short peduncles with 1-3 shortpediceled flowers: sepals nearly linear, sparsely glandular-pubescent, about $4 \mathrm{~mm}$. long: corolla moderately ventricose, with subequal lips, obscurely and sparsely glandular-pubescent, a few long hairs in the throat: sterile filament moderately bearded for half of its length or more. ( $P$. xylus A. Nels. Bot. Gaz. 34: 32. 1902.) - In the Colorado mountains.

36. Pentstemon Harbourii Gray, 1. c. 271. Low-caespitose, with suffrutescent caudex; tufted, nearly simple stems $5-10 \mathrm{~cm}$. high, puberulent: leaves green and glabrous, about 3 pairs, thickish, obovate, oval, or the uppermost sometimes ovate and sessile by a broad base: thyrsus reduced to 2 or 3 crowded, short-pediceled flowers: sepals ovate-oblong, villous and somewhat viscid: corolla little bilabiate, with rather broad cylindraceous throat and tube, barely twice the length of the round-oval lobes; lower lip bearded within: 
sterile filament bearded down one side.-High alpine region of the Colorado Rocky Mountains.

37. Pentstemon collinus A. Nels. 1. c. 25: 279. Caespitose, the rootstocks much branched and closely matted; stems numerous, erect, $2-4 \mathrm{dm}$. high, puberulent their whole length, glandular upward: root leaves numerous, entire, glabrous, elliptic-oblong, acute at both ends, $2-3 \mathrm{~cm}$. long, on slender petioles as long; stem leaves narrow-oblong or spatulate, $2-4 \mathrm{~cm}$. long, passing into the shorter lanceolate bracts: thyrsus strict, interrupted, 5-9 cm. long, the whole inflorescence minutely glandular-puberulent; peduncles $3-5$-flowered: sepals broadly lanceolate, scarious-margined, one third as long as the corolla: corolla deep blue, slender-tubular, the lobes short, spreading, sparsely hairy in the throat: sterile filament comose on the flattened apex; anthers dehiscent through the junction of the two cells.-Gravelly hills; from Colorado to Montana and Oregon.

38. Pentstemon gracilis Nutt. Gen. 2: 52. 1818. Glabrous or nearly so up to the glandular-pubescent inflorescence; stem slender, 1.5-4.5 dm. high: basal and lower leaves linear-oblong or spatulate, denticulate or entire, $2-8 \mathrm{~cm}$. long, narrowed into margined petioles; upper leaves sessile, linear-lanceolate or the uppermost lanceolate, acuminate, denticulate: thyrsus open, severalmany-flowered; pedicels 4-8 $\mathrm{mm}$. long: calyx-segments lanceolate, acute or acuminate: corolla purple, $1.8-2.5 \mathrm{~cm}$. long, the tube gradually enlarged above, the throat wide open: sterile filament bearded for about one half its length.Moist prairies; Colorado to Manitoba and eastward to Minnesota.

39. Pentstemon radicosus A. Nels. 1. c. 280 . Caespitose, the short rootstocks producing an inordinate number of coarsely fibrous roots which form an almost unbreakable tufted mat; stems numerous, slender, fascicled, strict and erect, 2-4 dm. high; stems and leaves puberulent, obscurely glandular upward including the inflorescence: root leaves minute and oblanceolate, or none; stem leaves numerous, oblong-linear, short-petioled or sessile, $2-4 \mathrm{~cm}$. long, narrower upward and passing into the linear bracts: thyrsus compact, 4-8 cm. long; peduncles about 3-flowered: sepals broadly lanceolate, somewhat scarious, about one third the length of the corolla: corolla tubular, dark blue, 14-18 mm. long, the lower lip longer, very sparsely white-bearded; lobes 3-4 mm. long: sterile filament flattened, the short yellow beard straight, stiff, dense at apex, more sparse downward past the middle; anthers purple, dehiscent through the junction of the cells.-In moist swales in desert areas; south-central Wyoming and adjacent Colorado and Utah.

40. Pentstemon Jamesii Benth. in DC. Prodr. 10: 325. 1846. Finely but very densely pruinose-pubescent throughout, obscurely glandular upwards; stems 1-several, ascending or erect, 1-2 dm. high: radical leaves entire or rarely denticulate, numerous, ovate to oblong, obtuse to subacute, $2-4 \mathrm{~cm}$. long, tapering into stout, somewhat shorter petioles; cauline entire, narrowly oblong, 2-5 cm. long: thyrsus leafy-bracteate, dense; bracts narrowly oblong to linear, often longer than the flowers: sepals lanceolate, minutely glandularpubescent, about as long as the corolla-tube; which is gradually inflated into the ventricose-campanulate throat: corolla about $2 \mathrm{~cm}$. long, tube shorter than the throat, the rounded lobes subequal, about $5 \mathrm{~mm}$. long, copiously but finely villous on the lower lip: sterile filament bearing a dense tuft of yellow hair at apex (which is slightly exserted) and somewhat similar pubescence for most of its length: capsule short, ovoid, acute, at maturity longer than the sepals. (Not P.Jamesii Gray.)-Blossoming in spring on the desert bad land areas of Wyoming and South Dakota.

41. Pentstemon similis A. Nels. 1. c. 548. Stems few to many, slender, leafy, 2-3 dm. high, glabrate to finely and somewhat sparsely pruinosepubescent: radical leaves mostly short-petioled, narrowly oblanceolate, 3-7 $\mathrm{cm}$. long (including the petiole), mostly entire; stem leaves sparsely denticulate, narrowly oblong to linear, $2-5 \mathrm{~cm}$. long, passing into the small entire bracts: thyrsus narrow, somewhat glandular-pubescent, inclined to be secund: sepals broadly lanceolate, shorter than the corolla-tube: corolla about $2.5 \mathrm{~cm}$. long, sparsely long-hairy within; the tube 8-10 $\mathrm{mm}$. long, abruptly dilated 
into a broadly cyathiform-campanulate throat: anthers glabrous, confluently 1-celled, not explanate; sterile filament bearing some sparse, very long, yellowish-white hairs at the tip, and barbate laterally near the middle with close, somewhat reflexed, yellow bristles. P. Jamesii. (See Bull. Torr. Bot. Club 25: 548. 1898 for distinctions between $P$. Jamesii Benth. and P. Jamesii Gray.) - Central and southern Colorado and New Mexico.

42. Pentstemon montanus Greene, Pitt. 2: 240. 1892. Stems 1-2 dm. high, herbaceous and of annual growth from a slender subterranean caudex or rootstock and with the leaves cinereously puberulent, almost equably leafy up to the inflorescence: leaves oblong- to ovate-lanceolate, the lower obtuse, the upper acute or acuminate, $2-3 \mathrm{~cm}$. long or less, saliently dentate: flowers in 1-3 pairs: corolla about $2.5 \mathrm{~cm}$. long, the tube scarcely ventricose, the color "pink-purple": sterile filament naked.-Northwestern Wyoming and in the high mountains of adjacent Idaho and Montana.

43. Pentstemon erianthera Pursh, Fl. 737. 1814. Puberulent below, glandular-villous and viscid above; stem leafy, 1-3 dm. high: leaves firm, entire or repand; the lower and basal ones oblong or spatulate, 5-10 cm. long, narrowed into margined petioles; the upper sessile or somewhat clasping, acute or acuminate: thyrsus dense, narrow, leafy-bracted; flowers almost sessile: calyx-segments linear-lanceolate, acuminate: corolla about $2.5 \mathrm{~cm}$. long, red or purple, the lower lip villous within: sterile filament densely yellow-woolly. $P$. cristatus.-Plains and foothills; Wyoming and the Dakotas to Washington.

44. Pentstemon albidus Nutt. Gen. 2: 53. 1818. Stem puberulent below, densely glandular-pubescent above, 1.5-2.5 dm. high: basal and lower leaves spatulate or oblong, obtusish, mostly entire; the upper lanceolate or oblong, sessile, denticulate, acute or acuminate, 3-7 $\mathrm{cm}$. long: thyrsus narrow, racemelike, leafy-bracted, interrupted: calyx-segments lanceolate, acuminate, viscid, one half as long as the corolla-tube: corolla white or nearly so, $1.5-2 \mathrm{~cm}$. long, the limb nearly 5-lobed, the lobes spreading.-On dry plains; South Dakota to Colorado, Nebraska, and Texas.

45. Pentstemon Moffattii Eastwood, Zoe 4: 9. 1903. Stems several, 2-5 dm. high, erect, scabrous below, glandular-hirsute above: radical leaves crowded, ovate-spatulate, entire, decurrent on the petioles which are as long or longer than the blade; lower cauline spatulate; upper ovate-lanceolate, closely sessile by a cordate base, obscurely dentate at the apex or entire: thyrsus interrupted, the many-flowered clusters $2-3 \mathrm{~cm}$. apart: sepals linearlanceolate, hirsute, glandular, and ciliate with crimped hairs: corolla purplishblue, hardly bilabiate, the spreading lobes orbicular: two of the stamens inserted at the base, the other two halfway up the limb, nearly on a line with the sterile filament which is moderately bearded down the side with hairs pointing downwards.-Dry plateaus; western Colorado.

46. Pentstemon Bridgesii Gray, Proc. Am. Acad. 7: 379. 1867. Stems 2-5 dm. high from a lignescent base, glabrous up to the virgate secund thyrsus, or pruinose-puberulent: leaves spatulate-lanceolate to linear; the floral reduced to small subulate bracts: peduncles (1-5-flowered) and pedicels short; these and the ovate or oblong sepals glandular-viscid: lips of the narrow corolla fully one third the length of the tubular portion; the upper erect and 2-lobed; the lower 3-parted and its lobes recurved: anthers deeply sagittate, the cells confluent at the apex and opening only to the middle, the base remaining closed and saccate.-Southwestern Colorado and in Nevada and California.

47. Pentstemon Kingii Wats. Bot. King's Exp. 222. 1871. Pruinose- or glandular-pubescent, at least below; stems numerous, from a shrubby base, ascending, 1-2 dm. high: leaves oblanceolate, mostly acute, entire, sessile, with a narrowed base, the lowermost somewhat spatulate and short-petioled, 3-5 cm. long: secund racemes short and rather leafy at base, with 1-4flowered peduncles: sepals ovate or oblong-lanceolate, more or less acuminate, sometimes slightly scarious and erose upon the margin: corolla 14-16 mm. in length, purple, dilated upward, somewhat bilabiate: anthers with confluent cells, dehisoent to the middle, glabrous but hirsute-ciliate upon the margins; 
sterile filament flattened toward the apex, glabrous.-In the Uintah mountains of Wyoming, the Wasatch of Utah, and the Humboldt of Nevada.

48. Pentstemon sepalulus A. Nels. Erect, slender, and paniculately slender branched above, $3-8 \mathrm{dm}$. high, very pale and glaucous throughout: leaves lanceolate to linear, narrowed toward the base, entire: peduncles 1-2-flowered: sepals remarkably small, ovate, mucronate: corolla violet-blue, $3-4 \mathrm{~cm}$. long, the expanded limb broad: anthers as in the preceding; sterile filament glabrous. (P. azureus ambiguus Gray, Syn. Fl. 2: 272. 1886; $P$. heterophyllus Wats. Bot. King's Exp. 222. 1871.)-In the mountains of northwestern Colorado, in adjacent Utah and Wyoming.

\section{CHIONOPHILA Benth.}

A high-alpine dwarf perennial with entire leaves mostly in a radical tuft and a dense spike of cream-colored flowers. Calyx funnelform. Corolla tubular, with slightly dilated throat and bilabiate limb; upper lip erect, barely 2-lobed; lower with convex densely bearded base forming a palate, 3-lobed. Anther cells divaricate and confluent.

1. Chionophila Jamesii Benth. in DC. Prodr. 10: 331. 1846. Glabrous or nearly so, 8-15 cm. high: leaves thickish, spatulate or lanceolate, tapering into a scarious sheathing base; those on the scape-like flowering stems few, paired or alternate, linear: spike few to many-flowered, mostly secund, bracteate: corolla about $1 \mathrm{~cm}$. long, pale cream-color or greenish-white: sterile filament small and short.-Alpine regions of the mountains of Colorado and southern Wyoming.

\section{7. gratiola L. Hedge Hyssop}

Soft-herbaceous and diffusely branching plants, from a creeping base. Pedicels solitary and axillary, a pair of bractlets close to the calyx and equaling it. Corolla-tube cylindraceous, with subequal lips; the upper entire or lobed; the lower 3-cleft. Anther-bearing stamens 2; the anterior pair sterilerudimentary; anther cells distinct.

1. Gratiola virginiana L. Sp. Pl. 17. 1753. Viscid-puberulent or pubescent, often nearly glabrous below, divergently branched from the base, 1-2 dm. high: leaves commonly glabrate, oblong-lanceolate, acute, entire to denticulate-serrate, mostly narrow at base: corolla 7-10 $\mathrm{mm}$. long, with yellowish tube and white limb, about twice as long as the calyx: anther-cells separated by a broad connective: capsule ovoid.-Wet soil; across the continent.

\section{SYNTHYRIS Benth.}

Perennial herbs with simple stems, mainly radical leaves, and rather small purple, blue, or pink flowers in terminal spikes or racemes. Calyx 4-parted, the segments oblong. Corolla oblong to short-campanulate, 4-cleft, more or less irregular, rarely wanting. Stamens 2, exserted; filaments slender; anther-cells parallel or somewhat divergent below, not confluent at the apex. Style filiform, with small capitate stigma. Capsule compressed, obtuse or emarginate.-(Besseya Rydb.)

Corolla wanting

Corolla present.

Leaves more or less divided.

Leaves pinnatifid
Leaves laciniately cleft to the middle or less

Leaves undivided.

Flowers erect.

Corolla violet or purple.

Leaves oval or subcordate

Leaves oblong

Corolla yellowish or white

Flowers reflexed

ROCKY MT. BOT. -29

1. S. wyomingensis.-

2. S. pinnatifida. -

3. S. laciniata.

4. S. alpins. -

5. S. plantaginea. -

6. S. Ritteriana. -

7. S. reflexa. 
1. Synthyris wyomingensis (A. Nels.) Heller, Muhl. 1: 5. 1900. Stems puberulent or softly pubescent, $1-2.5 \mathrm{dm}$. high: radical leaves petioled, broadly ovate to oblong, crenate-dentate, rounded or subcordate at base, mostly obtuse at apex; cauline leaves sessile, small, mostly acute: bracts broadly lanceolate to nearly linear: calyx anteriorly cleft to the base, posteriorly into 2 or 3 lobes to about the middle, the lobes either entire or (if only 2) with 2 tooth-like lobes: corolla wanting: stamens conspicuous, filaments twice the length of the calyx: capsule emarginate, large, turgid, puberulent, protruding from the cleft side of the calyx. S. rubra.-Wyoming and probably in Colorado and Utah.

1a. Synthyris wyomingensis gymnocarpa A. Nels. Similar but smaller, with shorter spike: sepals mostly reduced to the 2 dorsal ones, these distinct or somewhat united: capsule orbicular, much flattened at maturity, naked except for the bract and sepals closely approximated on the posterior angle. (Wulfenia gymnocarpa A. Nels. Bull. Torr. Bot. Club 25: 282. 1898.)-Western Wyoming and Colorado.

2. Synthyris pinnatifida Wats. Bot. King's Exp. 227. pl. 22. 1871. Somewhat villous: radical leaves long-petioled, broadly ovate in outline, pinnately divided, the lowest of the 3 or 4 pairs of lobes nearly distinct, the upper confluent, all laciniately pinnatifid and the segments laciniately toothed: flowering stems 8-16 cm. high, usually exceeding the leaves, naked below: raceme 2-5 cm. long, densely flowered above; pedicels shorter than the subtending ovate or oblong, toothed or entire bracts: calyx-lobes oblong, mostly obtuse: corolla whitish, nearly twice longer than the calyx, the lower lip deeply 3lobed, the upper one entire: capsule elliptical, turgid.-On rocky ridges in the high mountains; Idaho to Utah, Wyoming, and Montana.

3. Synthyris laciniata (Gray) Rydb. Mem. N. Y. Bot. Gard. 1: 353. 1900. Size and habit of the preceding: leaves orbicular or reniform, never pinnatifid, but laciniately cleft to the middle or less.- Same range.

4. Synthyris alpina Gray, Am. Journ. Sci. II. 34: 251. 1862. Somewhat woolly, becoming smooth: radical leaves elliptic or oval, sometimes subcordate, closely crenate, $3-5 \mathrm{~cm}$. long, on slender petioles: scape $5-15 \mathrm{~cm}$. high, leafy-bracted: spike short, dense, in flower 2-6 cm. long: sepals lanceolate, villous on the outside toward the edge with long hairs, also the bracts: corolla 2-parted, upper lip very broad, erose; the lower much smaller, 2-3-parted; lobes narrow, purplish-blue: stigma capitate: stamens exserted.-High alpine in Colorado and southern Wyoming.

5. Synthyris plantaginea Denth. in DC. Prodr. 10: 455. 1846. Woollypubescent, becoming smooth: radical leaves oblong, crenate, thick, coriaceous, 7-15 cm. long, abruptly nariowed at base and somewhat decurrent on the petiole, somewhat pilose on the veins and ribs; petioles $5-8 \mathrm{~cm}$. long: scape 2-3 dm. high, furnished with numerous oblong or orbicular, nearly sessile bracts: flowers in a long, dense spike, in fruit 10-15 cm. in length: fruit scarcely exceeding the round-ovate persistent bracts. - Subalpine woods; Colorado to New Mexico.

6. Synthyris Ritteriana Eastw. Proc. Cal. Acad. Sci. III. 1: 23. 1898. Sparingly pubescent; scape stout, nearly $3 \mathrm{dm}$. high, foliaceous: leaves radical, 8-10 cm. long, oblong-elliptical, obtuse, crenate; petioles stout, 8-12 cm. long; bracts of the scape alternate, ovate-acuminate, sessile by a subcordate base: floral bracts rhomboidal, acuminate, tapering at base to a short petiole; flowers white, in a spike $5 \mathrm{~cm}$. long: calyx of 3 divisions $4 \mathrm{~mm}$. long, each orbicular to obovate, entire, toothed, or cleft, obtuse or acute, fringed with white hairs: corolla of 2 divisions, surpassing the calyx by $2 \mathrm{~mm}$; ; upper part broadly obovate, acute, ciliate; lower variously cleft with 2-3-laciniate, ciliate divisions: filaments inserted at the base of the corolla, surpassing it by $2 \mathrm{~mm}$. (S. flavescens A. Nels. Bot. Gaz. 34: 33. 1902.)-Mountains of Colorado.

6a. Synthyris Ritteriana obtusa A. Nels. 1. c. Leaves broad and obtuse: bracts of scape orbicular, cuspidate; bracts of spike narrowed but not petioled: calyx 2-lobed to the base, one or both lobes sometimes cleft into very unequal 
lobes: corolla yellowish: stamens long-exserted.-La Plata Mountains, Colorado.

7. Synthyris reflexa Eastw. 1. c. 124. Glaucous and somewhat viscid; scape erect, 1-2 dm. high, with broad, foliaceous bracts: leaves radical, $7 \mathrm{~cm}$. long, elliptical-oblong, obtuse, truncate or cuneate at base, finely crenate, thin in texture; petioles $3-5 \mathrm{~cm}$. long: bracts of the scape sessile, broadly ovate, acute, entire, or serrulate near the apex: floral bracts ovate to linear, fringed with long white hairs; flowers greenish-white, reflexed on pedicels $1 \mathrm{~mm}$. long: calyx of 2 divisions $5 \mathrm{~mm}$. in diameter, orbicular, fringed like the bracts: corolla of 2 parts united at base, the upper broad, somewhat hood-shaped, $5 \mathrm{~mm}$. broad, $8 \mathrm{~mm}$. long, sparingly fringed; the lower 2-cleft, divisions laciniate, $2 \mathrm{~mm}$. long: stamens 2 ; filaments inserted at the base of the corolla, surpassing it by $4 \mathrm{~mm}$.-San Juan Mountains, Colorado.

\section{VERONICA L.}

Annual or perennial herbs with mostly opposite leaves and usually small blue, pink, or white flowers in terminal or axillary racemes or spikes. Calyx mostly 4-parted, the segments oblong or ovate. Corolla rotate, the tube very short, the limb deeply and more or less unequally 4-lobed. Stamens 2; anthers obtuse, their cells confluent at the apex. Ovary 2-celled; style slender; stigma capitate; ovules few or many in each cell. Capsule more or less compressed, sometimes very flat, emarginate, obcordate, or 2-lobed. Seeds smooth or rough, flat, plano-convex or excavated on the inner face.

Small annua

Perennials.

Flowers in terminal spikes. Capsule oblong, emarginate Capsule orbicular. obcordate

Flowers racemose in the axils. Leaves oblong to oval. Stem leaves sessile : All the leaves petioled Leaves linear or nearly so
1. V. peregrina.

2. V. alpina.

3. V. serpyllifolia.

4. V. anagallis-aquatica. 5. V. americana.

6. V. scutellata.

1. Veronica peregrina L. Sp. Pl. 14. 1753. Low annuals, glabrous, or above minutely pubescent or glandular; stem and branches erect, $1.5-3 \mathrm{dm}$. high: leaves thickish; the lowest petioled and oblong or oval, dentate; the middle sessile, oblong to linear-spatulate; the uppermost more bract-like and entire: flowers in the axils of ordinary or bract-like, commonly alternate leaves, very short-pediceled: capsule orbicular and slightly obcordate.Throughout the continent.

2. Veronica alpina L. l. c. 11. Hirsute-pubescent or glabrate; stems slender, simple, $8-16 \mathrm{~cm}$. high, from slender creeping rootstocks: leaves mostly shorter than the internodes, ovate to oblong, obscurely crenulate, $15-20 \mathrm{~mm}$. long, rounded, truncate or subcordate at base, sessile or nearly so: raceme spiciform or subspicate, dense or interrupted below; pedicels erect, shorter tLan the calyx, much shorter than the lanceolate bracts: corolla violet, the limb 4-6 $\mathrm{mm}$. in diameter, surpassing the stamens and short style: capsule elliptical-obovate, emarginate. ( $V$. Wormsjoldii R. \& S.)-In the high altitudes and latitudes of northern America and Europe.

3. Veronica serpyllifolia L. 1. c. 12. Pubescent or glabrous; stems creeping and branching at base, the branches at length ascending, 5-25 cm. long: leavcs all opposite and petioled, or the upper ones sessile, oblong to oval or ovate, $8-20 \mathrm{~mm}$. long, crenulate to entire: flowers in short spicate racemes at the cnds of the stems or branches; pedicels equaling or longer than the calyx: corolla pale blue with darker stripes, to almost white: stamens and style exserted: capsule broader than high, obcordate, about $2 \mathrm{~mm}$. high, equaling the calyx; seeds flat.-Wet places; in this and other continents.

4. Veronica anagallis-aquatica L. 1. c. Perennial, glandular-pubescent above; stems 2-9 dm. long, often somewhat branched: leaf-blades lanceolatc to oblong, 2-12 cm. long, acute, finely serrate or nearly entire, sessile and 
partly clasping: racemes spreading, many-flowered; pedicels $3-7 \mathrm{~mm}$. long: sepals glandular, lanceolate to ovate-lanceolate, $3-3.5 \mathrm{~mm}$. long: corolla blue, of ten purple-striped, $4-5 \mathrm{~mm}$. broad: capsules suborbicular or rhombicorbicular, $2.5 \mathrm{~mm}$. broad, minutely notched.-In brooks or wet places; widely distributed in America, Europe, and Asia.

5. Veronica americana Schwein, in DC. Prodr. 10: 468. 1846. Perennial, glabrous; stems erect or decumbent, 1-6 dm. high, sometimes branched: leafblades ovate to oblong or oblong-lanceolate, bluntly or sharply serrate, abruptly contracted or truncate at the base: racemes loosely flowered; pedicels very slender, $4-15 \mathrm{~mm}$. long: sepals glabrous, oblong to oblong-lanceolate, 2.5-3 mm. long, acute: corolla blue or nearly white, usually purple-striped, 4-5 $\mathrm{mm}$. broad: capsules 3-3.5 mm. broad, broader than high, 2-lobed.Frequent in brooks throughout northern North America.

5a. Veronica americana crassula Rydb. Mem. N. Y. Bot. Gard. 1: 353. 1900. Low, with fleshy entire leaves. - Colorado to Montana.

6. Veronica scutellata L. 1. c. 12. Glabrous or very sparingly hairy; stems slender, ascending from a stoloniferous base, 3-5 dm. long: leaves sessile, linear or linear-lanceolate, acute, remotely denticulate, $5-7 \mathrm{~cm}$. long: flowers scattered on filiform, elongated, and widely spreading pedicels: corolla blue or purple, $4-6 \mathrm{~mm}$. broad: capsule broader than high, very flat, deeply emarginate at the summit, slightly so at base; seeds flat.-Wyoming, northward, and thence across the continent.

\section{LIMOSELLA L. MUDWORT}

Small glabrous plants, with fibrous roots, a cluster of entire fleshy leaves at the nodes of the stolons, and short scape-like naked pedicels from the axils each bearing a small white or purplish flower. Calyx campanulate. Corolla rotate-campanulate, 5-lobed, and nearly regular. Stamens 4, no sterile filament; anther-cells confluent.

1. Limosella aquatica L. Sp. Pl. 631.1753 . Tufts $3-6 \mathrm{~cm}$. high: clustered leaves exceeding the pedicels, when scattered on sterile shoots alternate, in the typical form with a spatulate or oblong blade on a distinct petiole, which in mud remains short but in water elongates to 5-12 cm.: corolla pink or white, scarcely surpassing the calyx: capsule obtuse, surpassing the calyx.-Muddy flats and shores, margins of brooks; widely distributed in America and Europe.

\section{GERARDIA L.}

Erect branching herbs with stem leaves opposite (or the upper alternate) and uppermost reduced to bracts subtending 1-flowered peduncles which often form a raceme or spike of showy purple or yellow flowers. Calyx campanulate, 5-toothed or 5-cleft. Corolla campanulate, funnelform, or somewhat tubular, enlarged above. Stamens strongly didynamous, hairy, included; the 2-celled anthers approximated by pairs, and the cells parallel and of ten pointed at base. Style elongated, mostly flattened and enlarged at apex. Capsule globular or ovate-pointed.

Capsule oblong; corolla pubescent on the outside Capsule globose; corolla glabrous

1. Gerardia aspera Dougl., Benth. in DC. Prodr. 10: 517. 1846. Stems and branches strict, 3-5 dm. high: leaves rather erect, strongly hispidulousscabrous, all filiform-linear: pedicels mostly equaling and sometimes moderately exceeding the calyx, erect: calyx-lobes triangular-ovate or triangularlanceolate, acute, mostly less than half as long as the tube: corolla purple, $25 \mathrm{~mm}$. long, pubescent externally: anthers obtuse at base; filaments villous: capsule surpassing the calyx.-From Colorado eastward and southward.

2. Gerardia Besseyana Brit. Mem. Torr. Club 5: 295. 1894. A strict annual 3-6 dm. high: leaves linear, about $25 \mathrm{~mm}$. long, acute, scabrous, 
ascending: pedicels $2-3$ times as long as the calyx: calyx campanulate; the lobes triangular-subulate, half as long as the tube or less: corolla purple, about $12 \mathrm{~mm}$. long: capsule globose, 4-6 mm. in diameter. G. tenuifolia macrophylla Benth.-From the Rocky Mountains to the Mississippi.

\section{MIMULUS L. MONKey Flower}

Herbs with opposite leaves and mostly showy yellow or red flowers solitary and axillary or in a terminal raceme. Calyx prismatic, 5-angled and 5-toothed. Corolla tubular to funnelform, with strongly bilabiate limb or the lobes nearly equal, a pair of bearded ridges extending down the lower side of the throat. Stamens 4 , the fifth entirely wanting. Stigma mostly of 2 flat lobes closing together when irritated. Capsule dehiscent by both sutures or on one side only, or cartilaginous and indehiscent. Seeds many.
Flowers reddish or purple.
Stigmas funnelform
Stigmas 2-lipped.
Flowers small, less than $1 \mathrm{~cm}$. long
Flowers large, $3 \mathrm{~cm}$. or more long
Flowers yellow; stigmas 2-lipped.
Perennials.
Calyx oblique, inflated in fruit, the upper tooth largest. Calyx-teeth acute; stem not rooting at the nodes Calyx-teeth obtuse; stem rooting at the nodes Calyx neither oblique nor inflated, the teeth subequal : Annuals.
Calyx oblique, inflated in fruit
Calyx neither oblique nor inflated
1. M. nanus.
2. M. rubellus.
3. M. Lewisii,
4. M. Langsdorfii.
5. M. Geyeri.
6. M. moschatus.
7. M. Hallii.
8. M. floribundus.

1. Mimulus nanus Hook. \& Arn. Bot. Beech. 378. 1840. Glandular or viscid; stem stoutish, 2-10 $\mathrm{cm}$. high, simple, or branched from the base: leaves oblong or ovate to lanceolate, entire or obscurely toothed, contracted at base; the lower ones petioled, including the petiole $8-25 \mathrm{~mm}$. long: calyxteeth broadly lanceolate, acute: corolla rose-purple with yellow and dark purple in the throat; the limb 8-12 mm. broad, obviously bilabiate: capsule acuminate, surpassing the calyx; the valves chartaceous. [M.Tolmiei (Benth.) Rydb.]-Gravelly hills; western Wyoming to California and Washington.

2. Mimulus rubellus Gray, Torr. Bot. Mex. Bound. 116. 1859. Simple or branched from the base, 5-20 cm. high: leaves spatulate-oblong to linear, 9-18 mm. long, commonly equaling the pedicels; the lower sometimes obovate or ovate: calyx-teeth short and obtuse: corolla 6-8 $\mathrm{mm}$. long, a third longer to twice the length of the calyx, rose-color, sometimes yellow varying or changing to crimson-purple; the throat broad and open: stigma bilamellar. (M. gratioloides Rydb. Bull. Torr. Bot. Club 28: 27. 1901.)-New Mexico to Montana.

3. Mimulus Lewisii Pursh, Fl. Am. Sept. 427. 1814. Pubescent and more or less viscid; stems numerous from a perennial root, 3-6 dm. high, simple: leaves oblong-ovate to lanceolate, denticulate, mostly acute or acuminate, 3-7 cm. long: peduncles longer than the leaves: calyx prismatic-campanulate, 15-20 $\mathrm{mm}$. long, the triangular teeth short-acuminate and very acute: corolla rose-red or purplish, about $3 \mathrm{~cm}$. long, with broad throat and bilabiate limb, sparingly bearded in the throat: stamens not exserted: stigmas oblong: capsule oblong; seeds with a dull and loose coat, longitudinally wrinkled.Along mountain streams in our range and far westward.

3a. Mimulus Lewisii tetonensis A. Nels. Bot. Gaz. 34: 31. 1902. Smaller, more granular-glandular: calyx-lobes narrowly linear-acuminate: corolla smaller, white or ochroleucous.-Teton Mountains.

4. Mimulus Langsdorfii Sims, Bot. Mag. pl. 1501. 1812. Erect perennial with light-green herbage, glabrous or minutely pubescent; stems terete, 2-8 $\mathrm{dm}$. high, usually paniculately branched: leaves orbicular or ovate, the blade 2-5 cm. long, dentate or denticulate, often sublyrate, petioled: floral bracts 4-12 mm. long, connate-clasping: pedicels slender, 2-3 cm. long: calyx cam- 
panulate, in flower about $8 \mathrm{~mm}$. long, often mottled with dark purple, at length much inflated, the 4 lower teeth incurved and closing the orifice: corolla yellow, 2-3 cm. long, funnelform; lobes of the upper lip erect, oblong, the middle lobe of the lower lip broadly cordate, pendulous; the throat usually spotted with dark red, the pubescent lines running to the base: capsule oblong; seeds oblong. (M. puberulus Greene.)-In wet places in the mountains; New Mexico to Montana and far westward.

5. Mimulus Geyeri Torr. Nicol. Rep. Hydrog. Upper Mississippi 157. 1843. Perennial by stolons, glabrous or nearly so; stems slender, creeping, rooting at the nodes, $1.5-5 \mathrm{dm}$. long: leaves broadly ovate, orbicular, or broader, very obtuse, denticulate or entire, membranous, truncate, subcordate, or rarely narrowed at the base, palmately veined, short-petioled or the upper sessile, 6-25 mm. broad: peduncles slender, longer than the calyx in fruit: calyx oblique, scarcely toothed, 6-8 $\mathrm{mm}$. long at maturity: corolla 8-12 $\mathrm{mm}$. long, the lower lip bearded at the base within, the throat broad: seeds nearly smooth. M. Jamesii.-From Mexico to Montana.

6. Mimulus moschatus Dougl. in Lindl. Bot. Reg. 13: pl. 1118. 1827. Villous and slimy-viscid, strongly musk-scented; stems creeping and ascending, 1.5-3 dm. long: leaves ovate or oblong, short-petioled, denticulate, rounded or subcordate at the base, $2-5 \mathrm{~cm}$. long: peduncles slender, longer than the calyx; flowers $2-5 \mathrm{~cm}$. long: calyx-teeth lanceolate, acuminate: corolla 2-3 times as long as the calyx.-The MUSK PLANT of gardens and greenhouses; also indigenous in wet places from Colorado and Wyoming to the Pacific States.

7. Mimulus Hallii Greene, Bull. Cal. Acad. Sci. 1: 113. 1886. Puberulent or glabrous, more or less branched, usually suberect, rather slender, the stems somewhat angled: leaves and bracts oblong or ovate, obtuse, entire or sparingly dentate: calyx subglobose-inflated, with rather broad abruptly acute teeth, the upper one twice as large as the others: corolla light yellow, small, $6-10 \mathrm{~mm}$. long, the slender tube scarcely exserted. (M. thermalis A. Nels. Bull. Torr. Bot. Club 27: 269. 1900; $M$. nasutus Greene, as to our range.)Wet, springy places; eastern slope of the Rocky Mountains.

8. Mimulus floribundus Dougl. 1. c. pl. 1125. Villous annual with spreading white hairs and viscid; stem rather slender, $5-40 \mathrm{~cm}$. long, at first erect, but soon decumbent and diffusely spreading, flowering from the lowest axils: leaves ovate, or the lower subcordate, the blade 12-25 $\mathrm{mm}$. long, rather coarsely toothed, all petioled: peduncles spreading, 1-3 cm. long, exceeding the leaves: calyx campanulate, about $6 \mathrm{~mm}$. long, the short, triangular, acute teeth nearly equal: corolla about $12 \mathrm{~mm}$. long, light yellow, funnelform: capsule globose-ovoid, obtuse, sessile: seeds almost globular, light-colored. (M. membranacea A. Nels. Bot. Gaz. 34: 30. 1902.) - From the mountains of Colorado and Wyoming to the Pacific States.

\section{RHinanthus L. Yellow Rattle}

Herbs, with erect stem, opposite leaves, and mostly yellow subsessile flowers in the axils, the upper ones crowded and secund in a leafy-bracted spike. Calyx ventim cose-compressed, 4 -toothed, inflated in fruit. Corolla-tube cylindraceous; the upper lip galeate, ovate, obtuse-compressed, entire at apex but with a minute tooth on each side; lower lip shorter, with 3 spreading lobes. Capsule orbicular, compressed. The seeds, when ripe rattle in the inflated dry calyx.

1. Rhinanthus Crista-galli L. Sp. Pl. 603. 1753. Glabrous or nearly so, 2-4 dm. high: leaves narrowly oblong to lanceolate, coarsely serrate: bracts incised and the acuminate teeth setaceous-tipped: corolla $10-12 \mathrm{~mm}$. long, only the tip exserted, commonly with a purple spot on one or both of the lips: stamens ascending under the galea; anthers pilose, the cells transverse: seeds suborbicular, winged.-From the Rocky Mountains eastward to the Atlantic. 


\section{PEDICULARIS L. LOUSEWORT}

Herbs with alternate or opposite leaves and yellow, purple, red, or white flowers in terminal spikes or racemes. Calyx tubular, cleft on the lower side or sometimes also on the upper side, or 2-5-toothed. Corolla strongly bilabiate, the tube cylindric; the galea laterally compressed, concave or conduplicate, sometimes beaked; lower lip erect or ascending, 3-lobed, the lobes spreading or reflexed, the middle one smallest. Stamens 4 , didynamous, ascending within the upper lip of the corolla; anthers transverse, approximate in pairs, the cells equal, parallel, obtuse or rarely mucronate at base. Capsule compressed, oblique or curved, beaked, many-seeded, loculicidally dehiscent. Seeds reticulated, pitted, striate, or ribbed.

Calyx cleft below, sometimes above but less deeply.

Leaves more or less pubescent.

Deeply pinnatifid

Crenate

Leaves wholly glabrous.

Corolla white, the beak hooked

Corolla purplish, the beak subcircinate ${ }^{\circ}$

Calyx subequally 5 -toothed or 5 -lobed.

The lobes and the tube subequal.

Flowers purple

Flowers yellow

The lobes or teeth much shorter than the tube.

Corolla yellow or yellowish.

Galea scarcely surpassing the lip

Galea falcate with decurved beak

Corolla purple or purplish.

Beak of galea short and straight

Beak of galea long and lunately curved.

Reak short, rather thick, incurved-lunate

Beak long, slender, recurved or upturned

1. P. canadensis.

2. P. crenulata.

3. P. racemosa.

4. P. ctenophora.

5. P. cystopteridifolia.

6. P. bracteosa.

7. P. Grayi.

8. P. Parryi.

9. P. scopulorum.

10. P. lunata.

11. P. groenlandica.

1. Pedicularis canadensis L. Mant. 86. 1767. Pubescent, or glabrate below; stems commonly tufted, simple: leaves alternate or some of them opposite, oblong-lanceolate, $7-13 \mathrm{~cm}$. long, pinnately parted into obtuse, incised or dentate lobes: spike 1-2 dm. long in fruit: calyx cleft on the lower side, 2-3-crenate on the upper, oblique: corolla yellow or reddish, the galea arched, incurved, minutely 2-toothed below the apex: capsule oblique, $14-16 \mathrm{~mm}$. long. - Scarcely in our range; eastward to the Atlantic States.

2. Pedicularis crenulata Benth. in DC. Prodr. 10: 568. 1846. Pubescent; stems clustered, simple, erect from a decumbent base, 1-3 dm. high: leaves undivided, oblong-linear or narrower, obtuse, 3-6 cm. long, closely crenate and the broad crenatures minutely crenulate: spike short and dense: corolla whitish or purplish, about $20 \mathrm{~mm}$. long, like that of the last, but the teeth at the apex of galea less conspicuous.-Colorado and Wyoming in grassy mountain meadows; spreading rapidly in irrigated meadows, and becoming a pest.

3. Pedicularis racemosa Dougl. Hook. Fl. Bor. Am. 2: 108. 1838. Glabrous, 2-4 dm. high; stems simple or branched, leafy to the top: leaves lanceolate, undivided, minutely and doubly crenulate, $5-10 \mathrm{~cm}$. long: flowers shortpediceled, in a short leafy raceme or spike, or the lower in remote axils and uppermost with bracts hardly surpassing the 2-toothed calyx: slender beak of the galea hamate-deflexed, produccd into a slender, elongated-subulate, circinate-incurved beak, nearly reaching the apex of the broad lower lip.Subalpine throughout our range and far westward.

4. Pedicularis ctenophora Rydb. Bull. Torr. Bot. Club 24: 293. 1897. Stem from a thickened caudex, about $3 \mathrm{dm}$. high, glabrous, strict, striate: leaves numerous, especially at the base, glabrous, rather thickish, pinnately divided into linear-lanceolate serrate segments: spike about $1 \mathrm{dm}$. long, rather loose; bracts broadly ovate in outline, pectinately divided: calyx gibbous above, purple-striate, more or less villous-ciliate at the base: corolla purplish; galea arcuate, produced into an elongated incurved beak; lip very broad, especially the lateral lobes. Very near. the more western $P$. contorta Benth.Wyoming and Montana. 
5. Pedicularis cystopteridifolia Rydb. Mem. N. Y. Bot. Gard. 1: 365. 1900. Perennial, glabrous up to the villous spike; stem 1-3 dm. high, strict, more or less purple-tinged, rather few-leaved: leaves pinnately divided into triangular-lanceolate segments, these again sharply incised and serrate: bracts lanceolate, long-acuminate, about $2 \mathrm{~cm}$. long: calyx densely villous: corolla very dark reddish-purple, over $20 \mathrm{~mm}$. long; galea falcate, arcuate, with a truncate apex and this with a pair of teeth on the lower side, the crenulate lobes of the lip protruding and reaching near to the apex of the galea.-Montana and Wyoming.

6. Pedicularis bracteosa Benth. 1. c. 574. Glabrous or scantily pilose upon the spike; stem erect, $2-5 \mathrm{dm}$. high, leafy: leaves pinnately parted, segments lanceolate, incisely-dentate or pinnatifid: spike pedunculate, elongated, 5-20 cm. long, densely flowered; the bracts ovate, acuminate, and somewhat membranous: calyx-lobes lanceolate, setaceous: galea of the yellow corolla slightly incurved, not beaked, hooded at the apex, and ferminating in an obtuse, somewhat 2-toothed projection; lip much shorter. ( $P$. montanensis Rydb. Bull. Torr. Bot. Club 24: 292. 1897.) - Colorado to the Saskatchewan and westward.

7. Pedicularis Grayi A. Nels. Proc. Biol. Soc. Wash. 17: 100. 1904. Stem 4-10 dm. high, stout, leafy, bearing above a dense-flowered, softly pubescent spike 2-5 dm. long: leaves glabrous, pinnately parted; segments lanceolate, lanciniate-pinnatifid ; lobes serrate or incised; radical leaves 3-4 dm. long • bracts elongated, linear from an ovate-lanceolate base, lower ones pectinate-pinnatifid, exceeding the flowers: calyx about equally 5-cleft, lobes lanceolate, entire, about half shorter than the tube: corolla $25 \mathrm{~mm}$. or more long, striate, dirty green; galea hooded at the apex, not beaked, truncate, 2-toothed, scarcely equaling the shortly 3-lobed, somewhat spreading lip. P. procera.-Wyoming and Colorado.

8. Pedicularis Parryi Gray, Am. Journ. Sci. II. 34: 250. 1860. Very smooth except the ciliated bracts; stem $15-30 \mathrm{~cm}$. high, more or less bracted: leaves linear-lanceolate, pectinate-pinnatifid, petioled, cauline ones small; segments linear, acute, about $6 \mathrm{~mm}$. long, cartilaginous-serrate: bracts small, trifid; flowers numerous, short-pediceled, somewhat crowded in a narrow spike 3-6 cm. long, a dirty or faded yellow: calyx membranaceous, marked with 5 striae, at length subinflated, teeth 5 , short, lanceolate, very entire, lanulose within: galea narrow, apex incurved, gradually produced into a long, emarginate beak which is somewhat decurved, much surpassing the lower lip: filaments very smooth.-In the high mountains of Colorado, Utah, and Wyoming.

9. Pedicularis scopulorum Gray, Syn. Fl.2: 308. 1878. Low alpine perennial 1-2 dm. high, glabrous except the arachnoid-lanate, dense, oblong spike: calyx-teeth triangular-subulate, entire, membranaceous, very much shorter than the tube: galea of the reddish-purple $(18-20 \mathrm{~mm}$. long) corolla with its somewhat produced apex obliquely truncate, edentulate or produced on each side into an obscure triangular tooth. (P. Hallii Rydb. Mem. N. Y. Bot. Gard. 1: 364. 1900.) - Colorado to Montana.

10. Pedicularis lunata Rydb. Bull. Torr. Bot. Club 28: 27. 1901. Perfectly glabrous up to the inflorescence, about $4 \mathrm{dm}$. high: leaves alternate, dark green, 5-12 cm. long, pinnately divided to near the midrib; segments linear or linear-oblong, crenate: spike 15-20 cm. long, rather lax; bracts pectinately divided with prolonged end-lobes, slightly arachnoid, villous: calyx about $9 \mathrm{~mm}$. long; the teeth broadly lanceolate, about $3 \mathrm{~mm}$. long: corolla pinkish, over $20 \mathrm{~m}$. long; the tube about twice as long as the calyx, strongly curved; galea strongly arcuate, produced into a rather long beak and almost crescent-shaped; lower lip almost meeting the beak of the upper, very broad, indistinctly 3-lobed with large rounded lateral lobes.-Wyoming and probably Montana.

11. Pedicularis groenlandica Retz. DC. Prodr. 10: 566. 1846. A simplestemmed nearly glabrous perennial: leaves lanceolate-acuminate in outline, $5-12 \mathrm{~cm}$. long, the upper sessile, the lower slender-petioled; the lanceolate 
segments crenulate or incised: spike dense, 1-2 dm. long: calyx 5-toothed, nearly equaling the corolla-tube: corolla red or purple; galea decurved against the lower lip and upwardly recurved beyond it: capsule obliquely ovate. (Elephantella groenlandica Rydb. Mem. N. Y. Bot. Gard. 1: 360. 1900.)In swamps and wet meadows; throughout northern America.

\section{CASTILLEJA * Mutis}

Herbs with alternate leaves and red, yellow, purple, or white flowers in dense, terminal, leafy-bracted spikes, the bracts often brightly colored and much larger than the flowers. Calyx tubular, laterally flattened, more or less cleft above or below, or both, the lobes entire or 2-cleft. Corolla tubular, very irregular, the tube not longer than the calyx, the limb bilabiate; upper lip (galea) arched, elongated, concave or keeled, laterally compressed, entire, inclosing the didynamous stamens; lower lip short, often very small, 3-toothed, 3 carinate or somewhat saccate below the short teeth.

Annual

Calyx less deeply cleft above than below.

Corolla long (4-5 cm.).

Galea as long as the tube of the corolla

Galea shorter than the tube of the corolla

Corolla short (2-3 cm.).

Inflorescence bright red or scarlet

Inflorescence greenish or yellow.

Lip of corolla half as long as the galea

Lip of corolla very short

Calyx equally or subequally cleft above and below.

Inflorescence conspicuously red, scarlet, or purple.

Galea longer than the tube of the corolla or the two subequal.

Leaves glabrate; galea exserted

Leaves pubescent; galea partly exserted

Galea shorter than the tube of the corolla.

Stems low, mostly less than $3 \mathrm{dm}$. high.

Floral bracts laciniately 3-5-cleft.

Leaves entire or pinnately lobed . Leaves mostly equally 3-cleft

Floral bracts entire or nearly so

Stems taller, 3-5 dm. or more.

Calyx with 4 subequal lobes

Calyx with 2 primary lobes which are more or less cleft.

Floral bracts bright purple

Floral bracts bright scarlet.

Stems in clumps, from a woody caudex

Stems single, spreading by creeping rootstocks

Inflorescence pale, greenish, or yellow.

Galea equaling the tube of the corolla, or nearly so
Galea shorter than the tube of the corolla.

Galea short, or not more than twice as long as the lip.

Calyx cleft into 4 subequal lobes
Calyx 2-cleft, the lobes bidentate or cleft.

Inflorescence more or less pilose.

Primary calyx-lobes merely bidentate

Primary calyx-lobes 2-cleft

Inflorescence cinereous-puberulent, not pilose

Galea more than twice as long as the lip.

Corolla and calyx subequal

Corolla distinctly surpassing the calyx.

Low $(1-2 \mathrm{dm}$.)

Taller (3-5 dm.)

1. Castilleja exilis A. Nels. Proc. Biol. Soc. Wash. 17: 100. 1904. Villouspubescent; stem slender, strict, simple or with 1 or 2 erect branches, 3-7 $\mathrm{dm}$. high: leaves all linear-lanceolate and entire, sessile, acuminate, 4-8 cm. long: bracts similar to the leaves but smaller, red or red-tipped, very narrow, equaling or longer than the short-pediceled flowers: calyx green, cleft on both sides to about the middle, the lobes lanceolate, acute, entire or 2-toothed: corolla yellow, 12-20 mm. long, the upper lip much longer than the small

* For other closely allied species coming into the borders of our range, see Bull. Torr. Bot. Club 34: 35-41. 1907, where Rydberg characterizes thirteen additional species. 
lower one: capsule oblong, acute, 12-16 mm. long. C. minor.-From New Mexico to Nebraska, thence through our range to Oregon.

2. Castilleja linariaefolia Benth. in DC. Prodr. 10: 532. 1846. Glabrous below, the inflorescence somewhat pubescent or villous; stems strict, 5-10 dm. high: leaves linear, entire or some of the upper sparingly laciniate, and the uppermost and bracts 3-parted, 3-nerved: calyx narrowly cylindrical, $2-3 \mathrm{~cm}$. long, mostly red or crimson, sometimes pale, the anterior fissure very much deeper than the posterior; the long upper lip acutely 4-toothed or 2-cleft and the lobes 2-toothed: corolla 4-5 cm. long; the narrow, falcate, and much exserted galea as long as the tube. (C. cognata Greene, Pl. Baker. 3: 22. 1901; C. crista-galli Rydb. Mem. N. Y. Bot. Gard. 1: 355. 1900.)-Throughout our range and west to the Pacific States.

3. Castilleja sessiliflora Pursh, Fl. Am. Sept. 738. 1816. Perennial, cinereous-puberulent; stems stout, 1.5-4 dm. high, densely leafy: leaves sessile, $2-5 \mathrm{~cm}$. long; the lowest commonly linear, obtuse, and entire; the others laciniate into narrow segments: bracts green, similar to the upper leaves, shorter than the sessile flowers: calyx deeper cleft on the lower side than on the upper, the lobes linear-lanceolate, acute: corolla yellowish, $4 \mathrm{~cm}$. long, the upper lip about twice as long as the lower, the lobes of the latter linear: capsule oblong-lanceolate.-Texas to Canada through the eastern part of our range.

4. Castille ja collina A. Nels. Bull. Torr. Bot. Club 28: 231. 1901. Manystemmed, 15-25 cm. high; pubescence a fine puberulence with some soft, white, woolly hairs at the base of the leaves, on their margins, and in the inflorescence; stems simple, the exterior ones in the cluster decumbent: leaves 2-4 cm. long, dark green, variously cleft, the lower mostly pinnately, the divaricate lobes linear or broader, sometimes again 1-3-cleft, on either side: bracts bright red, more freely cleft than the leaves: calyx cleft nearly to the middle before, less deeply behind, the lobes again cleft half their length into lanceolate segments: corolla yellowish, about $3 \mathrm{~cm}$. long; galea distinctly exceeding the tube, slender, truncate or with a short tooth at apex, obscurely pubescent on the exserted tip; lip very short, 3-toothed, the central one short, the lateral longer, acute, divaricate.-In spring, on gravelly sagebrush slopes; Wyoming and Colorado.

5. Castilleja brachyantha Rydb. 1. c. 360 . Pubescent, 1-2 dm. high, erect, rather slender: lower leaves of ten entire, and upper only 3-5-parted, $2-4 \mathrm{~cm}$. long: bracts of the dense spike more dilated; inflorescence yellow or greenish: lobes of the ovoid-oblong calyx lanceolate: corolla scarcely exserted, about $2 \mathrm{~cm}$. long; lip with somewhat callous or saccate keels about the length of the oblong-obtuse lobes. C. breviflora.-Rare; alpine regions; Colorado to Montana.

6. Castilleja flava Wats. Bot. King's Exp. 5: 230. 1871. Plant 2-4 dm. high, with numerous slender stems, cinereous-puberulent, at least above, and the elongated spike more pubescent: leaves entire or the upper with 1 or 2 lobes: bracts 3-cleft and with dilated base; the upper and calyx yellowish: corolla about 2-2.5 cm. long; narrow galea little shorter than the tube; lip very short, globular-saccate and callous, and with very short ovate lobes.From Utah and Colorado to the Canadian border.

7. Castilleja miniata Dougl. Hook. Fl. Bor. Am. 2: 106. 1838. Glabrous or nearly so except the inflorescence; stems numerous and tufted on a short rootstock, mostly simple and strict, 2-6 dm. high: leaves lanceolate or linear, or the upper ovate-lanceolate, acute, entire or rarely laciniately 3-cleft: bracts lanceolate to oval, mostly bright.red, rarely whitish, seldom lobed; spikes short and dense: calyx-lobes lanceolate, acutely 2-cleft: corolla 2.5-3.5 $\mathrm{cm}$. long; the galea exserted, linear, longer than the tube; the very short lower lip protuberant and callous, as deep as long, with short, ovate, involute teeth.-Wet bottom lands; from our range to California and Alaska.

8. Castille ja chromosa A. Nels. 1. c. 26: 245. 1899. Stems numerous, simple or sparingly branched, 2-4 dm. long; pubescence a fine puberulence and more or less of whitish, crisped hairs: leaves variable; the lower entire or 
nearly so, lanceolate to linear, 3-7 $\mathrm{cm}$. long; the upper pinnatifid, consisting of a lanceolate blade proper, 3-5 cm. long, and 2-4 linear to lanceolate, widely divaricate or ascending lobes: inflorescence at first short and dense, 10-15 cm. long, more densely crisped-hairy than the rest of the plant; bracts from scarlet to yellowish-red: calyx about $20 \mathrm{~mm}$. long, about equally cleft before and behind, the tube about twice as long as the bifid lobes: corolla more or less exserted; the galea a little longer than the tube; the lip very short and almost truncate, 3 narrow plicae extending one third the length of the tube.-Dry denuded hills; Colorado and Wyoming.

9. Castille ja Haydenii (Gray) Greene, Pitt. 4: 1. 1899. Low, tufted, 1-2 $\mathrm{dm}$. high, glabrate below or more or less cinereous, the inflorescence often ciliate-pubescent: leaves narrow, mostly entire: bracts broader, 3-5-cleft into linear lobes, "rose-red or else paler and with an admixture of lilac"; spike at first dense but becoming rather long and lax: galea shorter than the tube; the lip not half the length of the galea. C. pallida Haydenii.-High alpine in Colorado.

10. Castilleja Buffumii A. Nels. Cinereous and barely viscid; stems leafy, several to numerous, assurgent from the crowns of a woody tap-root which produces from its base many horizontal yellow roots: leaves mostly 3-cleft, the lobes nearly linear, about as long as or longer than the rather broad base: bracts similar, thinner and subscarious, light wine-color shading to brick-red or maroon: calyx as long as the bracts and the corolla-tube, equally cleft above and below; the lobes half as long as the tube and each cleft halfway into obtuse teeth: corolla yellowish-green; galea half as long as the tube, the free thin edges the same color as the bract; lip short, one fourth as long as the galea and one half as long as the shallow plicae: capsule ovate, 10-12 mm. long.Type locality, the Slick Creek Bad Lands, Big Horn Basin, Wyoming (B. C. Buffum).

11. Castilleja integra-Gray, Bot. Mex. Bound. 119. 1859. Plant 1-3 dm. high; stem rather stout, tomentose: leaves cinereous-tomentulose, linear, 3-7 cm. long, 3-7 mm. wide, entire: bracts of the short spike red or rose-color, entire or sometimes incised: corolla about $3 \mathrm{~cm}$. long; galea rather broad; lip strongly tri-callous, the lobes very short. (Includes C. gloriosa Brit. and C. Lindheimeri Gray, as to our range.) - In dry ground; from Colorado to Arizona and Texas.

12. Castilleja confusa Greene 1. c. Perennial, the tufted stems $3-6 \mathrm{dm}$. high; green and glabrous below, more or less villous above, the inflorescence strongly villous with long, slightly deflexed, somewhat viscid but not glandular hairs: lower leaves all lanceolate, acuminate, entire, 5-8 cm. long; those under the inflorescence broader and with a pair of narrow, falcately divergent lobes; bracts of the spike still shorter and broader, mainly scarlet, and with 2 pairs of lobes: calyx with 4 subequal, lanceolate, acute lobes: corolla well exserted; galea notably villous along the back, twice the length of the lip, the prominent teeth of which are incurved. C. miniata in part. (C.trinervis Rydb. Bull. Torr. Bot. Club 28: 26. 1901.)-From Colorado and Wyoming to Utah.

13. Castilleja lauta A. Nels. 1. c. 27: 269. 1900. Stems several or numerous, simple, erect, yellowish-green to purplish, smooth and shining to striate and granular-puberulent, 1-3 dm. high: leaves 2-5 cm. long or the lower much reduced, linear-lanceolate, acuminate, and entire to more broadly lanceolate and obtusish; upwardly becoming broadened at the apex and toothed or cleft or with short lateral lobes; from glabrate-puberulent below tolanateciliate above: inflorescence short and dense, gay or almost gaudy, the purple bracts large, lanate-ciliate, dilated upward, entire or 3-cleft, nearly equaling the flowers: calyx equally cleft to about the middle, the 2 lobes again cleft to about the middle into oblong-lanceolate lobes: corolla yellow and more or less streaked with purple, 18-22 $\mathrm{mm}$. long; galea half as long as the tube, truncate and obscurely toothed at the apex; the lip short, the 3 teeth acuminate and inflexed. C. brunnescens Rydb. 1. c. 31: 436. 1904.-Mountain slopes; Colorado to Montana. 
14. Castilleja rhexifolia Rydb. Mem. N. Y. Bot. Gard. 1: 356. 1900. Perennial, with a woody caudex, $3-5 \mathrm{dm}$. high, glabrous below, more or less villous above: leaves linear-lanceolate to ovate, $3-5$-nerved, about $5 \mathrm{~cm}$. long, the upper often 3-5-cleft, but not deeply so, with lanceolate lobes: bracts scarlet or red: calyx about $2.5 \mathrm{~cm}$. long, green at the base, otherwise coccineous or scarlet, about equally. cleft above and below, the clefts on the sides about $5 \mathrm{~mm}$. deep: corolla $2.5-3 \mathrm{~cm}$. long, with a galea about $1 \mathrm{~cm}$. in length. (C. Tweedyi Rydb. 1. c. 358; C. obtusiloba Rydb. Bull. Torr. Bot. Club 31: 644. 1904.)-Open woods in the mountains; throughout our range.

15. Castilleja lancifolia Rydb. 1. c. 357. Perennial, with a long creeping rootstock, not growing in clumps, $4-6 \mathrm{~cm}$. high, sparingly villous or glabrate, comparatively very leafy: leaves lanceolate, of ten acuminate, $3-5 \mathrm{~cm}$. long, rather firm, 3ᄀnerved, the upper seldom if ever cleft: calyx and corolla as in the preceding species: corolla about $3 \mathrm{~cm}$. long, with a galea slightly over $1 \mathrm{~cm}$, in length. (Very near to C. Suksdorfi Gray, Proc. Am. Acad. 22: 311. 1877, which has a longer corolla with galea as long as the tube.)-Rich soil among shrubs, mountain sides; Colorado to Montana.

16. Castilleja dubia A. Nels. The woody caudex short, giving rise to few or several slender, simple, ascending or erect stems, 2-3 dm. high; pubescence sparse, cinereous, consisting of fine puberulence and some white, soft hairs: the body or axis of the leaf linear, 3-5 cm. long, 3-5 mm. broad, usually with 1 or 2 pairs of widely divergent linear lobes which are one third to one half as long as the leaf: bracts shorter, the blade and lobes relatively broader and tending to become scarious, decidedly yellowish or at the summit bright yellow: calyx about $2 \mathrm{~cm}$. long, equally cleft to nearly one third its length: corolla scarcely longer than the calyx; galea and tube subequal; lip almost wanting, not noticeably saccate, truncate and short-toothed. (C. angustifolia dubia A. Nels. 1. c. 29: 404. 1902.)-Denuded slopes of the desert areas; Wyoming.

17. Castilleja longispica A. Nels. 1. c. 26: 480. 1899. Stems few to many, 2-3 dm. high, branched, the branches slender, erect (fascicled); pubescence a short-hirsuteness with a fine puberulence: leaves $2-5 \mathrm{~cm}$. long, 3-cleft to the middle or thereabouts into linear lobes: bracts with dilated base, 3-cleft to the middle or beyond, the middle lobe oblong, obtuse, the lateral linear; spikes dense, slender, often half the whole length of the plant, yellowish: calyx-lobes equal, linear-lanceolate, acuminate, a little shorter than the ovoid tube: corolla 12-15 mm. long, one third longer than the calyx and slightly exceeding the bracts; lip triply saccate and conspicuously 3 -toothed, the sacs shallow; galea obtuse or subacute, scarcely longer than the lip.-Wyoming to Montana and Idaho.

18. Castilleja pilifera A. Nels. 1. c. 31: 246. 1904. Perennial, more or less finely pilose throughout; stems several from the crown of a caudex, slender and erect from a somewhat decumbent base, 15-25 cm. high: leaves numerous, flaccid, nearly linear, entire or with one or more linear-divergent lobes, 3-6 cm. long: calyx a little shorter than the bracts, equally cleft above and below to the middle; the lobes linear and rarely more than bidentate at apex: corolla about $2 \mathrm{~cm}$. long (shorter than the calyx), tubular; the lip as long as the galea and about one fourth as long as the tube, the linear teeth as long as the obscurely saccate base. [C. pilosa (Wats.) Rydb. 1. c. 361 has been reported from the northwest portion of our range, as has also the very similar C. villosa Rydb. l. c. Both have the calyx deeply cleft on the back (anteriorly) and the short galea twice as long as the lip.]-Wyoming to Montana and Idaho.

19. Castilleja fasciculata A. Nels. 1. c. 26: 133. 1899. Caudex very short; stems few to several, simple or nearly so, slender, strict and fascicled above, cinereous-pubescent as are also the leaves and inflorescence, 2-3 dm. high: leaves $3-6 \mathrm{~cm}$. long, linear and entire to much divided: inflorescence early elongating into a close, rather slender spike, 8-18 cm. long; bracts light green or indistinctly reddish or yellowish, 14-18 $\mathrm{mm}$. long, 3-cleft below the middle from a broad base, the lateral lobes linear, divergent: calyx equally cleft be- 
fore and behind, the lobes short-bifid: corolla barely exceeding calyx and bracts; galea short, not more than half as long as the tube, twice as long as the lip; lip slightly ventricose but not callous, the 3 teeth short-oblong, obtuse, as long as the ventricose portion.--Northwestern Wyoming and adjacent Idaho and Montana.

20. Castilleja pallescens (Gray) Greenman, Bot. Gaz. 25: 266. 1898. Cinereous-puberulent; stems 2-3 dm. high, usually several from a woody perennial base, simple or sparingly branched above: leaves 3-parted into linear lobes, or the lower entire: bracts similar to the leaves, with dilated base or the upper with shorter, obscurely whitish or yellowish lobes: calyx deeply 2-cleft, the broad lobes merely 2-cleft at the summit: corolla over $12 \mathrm{~mm}$. long; galea broadish, obtuse; the lower lip nearly half as long as the galea, obscurely saccate.-Northwestern Wyoming to Oregon and Washington.

21. Castilleja lineata Greene, Pitt. 4: 151. 1900. Tufted stems rigid and brittle, but not suffrutescent, about $2-4 \mathrm{dm}$. high from a perennial root, narrowly and not densely spicate; herbage hoary-tomentose: leaves ascending, linear, 3-6 cm. long, entire, or in more robust plants with one or more pairs of linear segments, all strongly 3-nerved and channeled and appearing striate: bracts similar to the leaves, more commonly palmately cleft to the middle into 3 linear lobes: corollas greenish and inconspicuous, little exceeding the calyx and bracts, 2-3 dm. long; galea shorter than the tube and the lower lip very short. (C. linearis Rydb. Bull. Torr. Bot. Club 28: 25. 1901.)-Mountains of Colorado.

22. Castilleja occidentalis Torr. Ann. Lyc. N. Y. 2: 230. 1828. Commonly villous with weak cobwebby hairs at least in the dense and short, leafy-bracted spike, often glabrous below; stems short. 8-20 cm. high: bracts comparatively broad, mostly incised or cleft, the tips whitish or yellowish and more or less streaked with red toward the base: calyx equally cleft to or below the middle and again more or less 2-cleft: lip about half the length of the rather broad galea. (C. puberula Rydb. 1. c. $31 ; 644$.) - In the alpine regions of our range.

23. Castilleja sulphurea Rydb. Mem. N. Y. Bot. Gard. 1: 359. 1900. Stems 3-5 dm. high, striate, finely puberulent or the upper portion slightly villous, simple: leaves linear to lanceolate or the upper ovate, 4-5 cm. long, entire or the upper cleft or lobed, acute, finely puberulent, 3-5-ribbed, light green: bracts $2-3 \mathrm{~cm}$. long, broadly ovate, obtuse, entire, or with a few small teeth, 3-5-ribbed, puberulent, yellow or yellowish-green: calyx about $1.5 \mathrm{~cm}$. long, about equally cleft before and behind and cleft about $2-3 \mathrm{~mm}$. at the sides: corolla greenish, $2.2-2.5 \mathrm{~cm}$. long; galea about three times as long as the lip which is 3-cleft or lobed. [C. luteovirens Rydb. Bull. Torr. Bot. Club 28: 26. 1901; C. wyomingensis Rydb. (?).]-Very common in moist places in the mountains; throughout our range.

\section{ORTHOCARPUS Nutt.}

Annual herbs with alternate leaves and yellow, white, or purple flowers in bracted spikes, the bracts often bright-colored. Calyx tubular or tubularcampanulate, 4-cleft. Corolla very irregular, the tube slender, the limb bilabiate; upper lip little if any longer than the 3-lobed, 1-3-saccate lower one. Stamens 4, ascending under the upper lip; anther-cells dissimilar, the outer one affixed by its middle, the other pendulous from its upper end, commonly small, sometimes wanting. Style filiform, with entire stigma. Capsule oblong, many-seeded.

Corolla yellow; spike dense.

Pubescent and hirsute; stem usually strict

Merely puberulent; stem usually divaricately branched above Corolla white, turning rose-purple

1. O. luteus.

2. O. Tolmiei.

3. O. purpureo-albus.

1. Orthocarpus luteus Nutt. Gen. 2: 57. 1818. Pubescent and hirsute, sometimes viscid; stem strict, 1-3 dm. high: leaves linear to lanceolate, occasionally 3-cleft, about equaling the flowers: corolla golden-yellow, about $1 \mathrm{~cm}$. 
long, 2 or 3 times the length of the calyx; tip of galea obtuse and straight.Plains; from northern Minnesota to Colorado and westward.

2. Orthocarpus Tolmiei H. \& A. Bot. Beech. 379. 1840. Puberulent, 1.5-3 dm. high, loosely branched: leaves narrowly lanceolate-linear, chiefly entire: bracts of the small and short spikes little dilated, often 3-cleft, the upper shorter than the flowers: corolla bright. yellow, 12-14 mm. long, 3 or 4 times longer than the calyx; minute tip of galea inflexed.-Western Wyoming, Utah, and Idaho.

3. Orthocarpus purpureo-albus Gray, in Wats. Bot. King's Exp. 458. 1871. Minutely pubescent, somewhat viscid, simple or branched, 1-2 dm. high: leaves entire or mostly 3-cleft, filiform: bracts similar or somewhat dilated at base: corolla about $18 \mathrm{~mm}$. long, white, turning rose-purple, with tube twice or thrice the length of the calyx; tip of galea mucroniform, inflexed.-From Colorado and New Mexico to Utah and Arizona.

\section{CORDYLANTHUS Nutt.}

Branching annuals, with alternate, narrow, entire or parted leaves, and dull-colored flowers in small terminal clusters or sometimes scattered. Calyx spathaceous, 1 or 2-leaved, uncolored as are also the bracts. Corolla tubular, the lips subequal. Stamens 4; anther-cells dissimilar, ciliate or bearded at base and apex; the outer one affixed by its middle; the pendulous one from its upper end smaller or sometimes wanting. Style hooked at tip.

\section{Calyx diphyllous.}

Corolla dull yellow; plant glabrate or subscabrous

Corolla purplish; plant cinereous-puberulent Calyx monophyllous

1. Cordylanthus Wrightii Gray, Bot. Mex. Bound. 120. 1859. Loosely branched, almost glabrous or puberulent-scabrous, 3-6 dm. high: leaves setaceous-filiform, 3-5-parted; floral similar, the tips not dilated: flowers several in the mostly dense terminal heads: corolla purplish, $25 \mathrm{~mm}$. long, with rather long lips: anthers villous.-Probably reaching southern Colorado from New Mexico and Texas.

2. Cordylanthus ramosus Nutt. Benth. in DC. Prodr. 10:597 1846. Cinereous-puberulent, 1-2 dm. high, diffusely much branched: leaves filiform, all but the lower usually 3-7-parted: flowers few in the small terminal heads, or in the upper axils: corolla dull yellow, about $12 \mathrm{~mm}$. long.-Desert areas; Wyoming to Nevada and Oregon.

3. Cordylanthus Kingii Wats. Bot. King's Exp. 233. 1871. Viscid-pubescent or villous, diffusely branched, $2-3 \mathrm{dm}$. high: leaves $3-5 \mathrm{~cm}$. long, mostly 3-5-parted into linear-filiform divisions: flowers glomerate, sessile in the axil of a clasping leaf or bract, or scattered at the summits of the slender branchlets: corolla purplish, about $2 \mathrm{~cm}$. long.-Southwestern Colorado to Nevada.

\section{PINGUiCUlaceaE Dumort. Bladderwort Family}

Small herbs (growing in water or wet places), with a 2-lipped calyx, a 2-lipped corolla, 2 stamens with (confluently) 1-celled anthers, and a 1-celled ovary with a free central placenta bearing several seeds. Corolla deeply 2-lipped, the lower lip larger, 3-lobed and with a prominent palate, spurred at the base in front; the palate usually bearded. Ovary free; style very short or none; stigma 1-2-lipped. Capsule often bursting irregularly. Scapes 1few-flowered.

\section{UTRICULARIA L. Bladderwort}

Aquatic and immersed, with capillary-dissected leaves bearing little bladders, which float the plant at the time of flowering; or rooting in the mud, 
and sometimes with few or no leaves or bladders. Bladders furnished with a valvular lid and usually with a few bristles at the orifice. Lips of the 2parted calyx entire, or nearly so.

Leaves pinnately divided; corolla broarl (12 mm.), with permanent spur . 1. U. vulgaris. Leaves dichotomously divided; corolla half as broad.

2. U. minor.

1. Utricularia vulgaris L. Sp. Pl. 18. 1753. Stems submersed, leafy, 3-12 dm. long: leaves numerous, alternate; blades 2-3-pinnately dissected into filiform segments, usually bearing numerous bladders; bladders when fully developed 3-5 mm. long: scapes erect, 1-3 dm. high: racemes 5-10flowered; pedicels 5-15 mm. long, recurving at maturity: calyx becoming 3-3.5 mm. long: corolla yellow, $12-15 \mathrm{~mm}$. broad; the upper lip erect, nearly entire; the lower lip spreading, slightly 3-lobed; spur not appressed, hornlike, slightly curved, shorter than the lower lip: capsules many-seeded.-In brooks and ponds throughout most of the northern hemisphere.

2. Utricularia minor L. 1. c. Scapes slender, 0.5-1.8 dm. high; branches floating, short: leaf-divisions few and setaceous; bladders borne along the leaves, few, often none, the largest not over $2 \mathrm{~mm}$. long: flowers $1-10$, pale yellow, racemose: corolla $4-6 \mathrm{~mm}$. broad, ringent, the upper lip smaller than the lower; spur usually reduced to a blunt, broad protuberance, shorter than the lips: pedicels reflexed in fruit.-Shallow ponds and bogs; like the preceding widely distributed.

\section{OROBANCHACEAE Lindl. Broom Rape Family}

Commonly perennial herbs, destitute of green foliage and parasitic on the roots of other plants. Stems sometimes almost wanting. Leaves scale-like. Flowers perfect, or rarely dioecious. Calyx of 4 or 5 more or less united sepals, persistent; tube campanulate or tubular. Corolla persistent on withering; limb more or less bilabiate and irregular. Stamens 4, didynamous, adnate to the corolla, mostly included; anthers 2-celled or rarely 1-celled, leathery. Styles united, terminal; stigma capitate. or 2-lobed; ovules mostly numerous, anatropous. Fruit a capsule, inclosed in the persistent corolla, with 1 or apparently 2 cavities.

Flowers spicate, sessile or subsessile, bracteate . Flowers pedunculate and bractless

1. Orobanche. 2. Thalesia.

\section{OROBANCHE L. BRoom RAPE}

Parasitic herbs, on roots of various plants, commonly with yellowish or brownish pubescent foliage. Leaves scale-like. Flowers spicate, with bractlets. Calyx with a deep sinus above and below, the lateral lobes often 2-cleft. Corolla irregular; tube slightly curved; limb 2-lipped, the upper lip erect or incurved, the lower lip spreading. Ovary 1-celled. Capsule 2-valved.-A phyllon in part.

Corolla $2 \mathrm{~cm}$. or more long; anthers woolly Corolla less than $2 \mathrm{~cm}$. long; anthers glabrous

1. O. multiflora. 2. O. ludoviciana.

1. Orobanche multiflora Nutt. Pl. Gamb. 179. 1847. Whole plant viscidly pruinose-puberulent, 1-3 dm. high: flowers nearly sessile or the lower ones short-pediceled: calyx bibracteolate, almost 5-parted into linear-lanceolate lobes, fully half the length of the ample purplish corolla: anthers very woolly. - Gravelly plains and pine woods; western Texas to Arizona, extending into Southern Colorado.

2. Orobanche ludoviciana Nutt. Gen. 2: 58. 1818. Rather less pubescent: spikes more frequently compound: calyx less deeply and somewhat unequally 5-cleft: corolla about half smaller; upper lip sometimes almost entire: anthers 
(before dehiscence) glabrous or nearly so.-From the Saskatchewan to Texas and westward.

\section{THALESIA Raf.}

Glandular or viscid-pubescent simple-stemmed herbs, with scattered scales and long-peduncled flowers. Calyx campanulate or hemispheric, the lobes acute or acuminate. Corolla-tube elongated, curved, the limb slightly 2lipped, the upper lip erect-spreading, 2-lobed, the lower spreading, 3-lobed, the lobes all nearly equal. Stamens included; anther-sacs mucronate at the base. Ovary ovoid; style slender, deciduous; stigma peltate, or transversely 2-lamellate.-A phyllon in part.

Flowers few or solitary

Flowers several or many

1. Thalesia uniflora (L.) Brit. Mem. Torr. Club 5: 298. 1894. Scaly stem short and nearly subterranean, bearing few scapes 1-2 dm. high: calyxlobes mostly much longer than the tube, subulate, usually attenuate: corolla violet-tinged, about $2.5 \mathrm{~cm}$. long; the lobes obovate and rather large.Damp woods; from Newfoundland to Texas and westward across the continent.

2. Thalesia fasciculata (Nutt.) Brit. 1. c. More pubescent and glandular; stem often emergent and mostly as long as the numerous fascicled peduncles, not rarely shorter: calyx-lobes broadly- or triangular-subulate, not longer than the tube, very much shorter than the dull yellow or purplish corolla: lobes of the latter oblong and smaller.-From Lake Michigan to Arizona and westward across the continent; on Artemisia, Eriogonum, etc.

\section{MARTYNIACEAE Link. Martynia Family}

Annual or perennial herbs, with thick branching stems. Leaves opposite; blades expanded, simple, mostly contracted into petioles. Flowers perfect, irregular. Calyx inferior, sessile or stalked; lobes 4 or 5. Corolla showy; tube oblique, often decurved; limb 2-lipped; lobes 5, spreading, the 2 upper exterior in the bud. Stamens didynamous; anthers with spreading saes. Ovary 1-celled; style slender; stigmas 2. Fruit a beaked capsule.

\section{MARTYNia L. Unicorn Plant}

Characters of the family.

1. Martynia louisiana Mill. Gard. Dict. Ed. 8. No. 3. 1768 . Leaves heartshaped, oblique, entire or undulate, the upper alternate: corolla dull white or purplish, or spotted with yellow and purple: endocarp of the fruit crested on one side, long-beaked.-In waste places; rare in our range as an escape from cultivation; native in the Mississippi valley.

\section{Plantaginaceae Lindl. Plantain Family}

Chiefly acaulescent, with 1-several-ribbed or nerved radical leaves, simple spicate inflorescence, and regular 4-merous flowers. Corolla scarious and veinless, usually marcescent. Stamens 4 or 2 , with filiform filaments and versatile anthers. Fruit a capsule (pyxis).

\section{Plantago L. Plantain}

Acaulescent or short-caulescent herbs, with mostly radical parallel-veined leaves and small white or greenish flowers in terminal spikes or heads. Calyx- 
segments equal, or 2 of them larger. Corolla salverform; the tube cylindric, or constricted at the throat; the limb 4-lobed or 4-parted, spreading in flower, in fruit spreading, erect, or reflexed. Stamens 4 or 2 . Ovary 2-celled or falsely 3-4-celled. Fruit a membranaceous capsule. Seed-coat developing copious mucilage when wetted.

Stamens 4; flowers perfect; corolla not closing over the capsule.

Leaves 3-8-nerved, glabrous or pubescent but not silky-lanate; spikes not woolly.

Capsule circumscissile near the middle.

Leaves broad, mostly oval

Leaves lanceolate

Capsule circumscissile near the base.

Crown not woolly.

In saline soil; leaves oval, 5-9-nerved; capsule 5-20-seeded

Subalpine; leaves 3-7-nerved; capsule usually 4-seeded

Crown with brown or red wool involving the base of the petioles

Leaves linear, silky-lanate; spikes woolly

Stamens 2; flowers subdioecious or polygamo-dioecious; ' corolla-lobes

closing over the capsule .

1. Plantago major L. Sp. Pl. 113. 1753. Smooth or sometimes pubescent or even roughish: leaves strongly ribbed, broad, ovate, oblong, oval, or subcordate, often toothed, abruptly narrowed into a channeled petiole: spike dense, obtuse: sepals round-ovate or obovate: corolla glabrous: style exserted from the unopened corolla: stamens exserted when the corolla has opened: pod ovoid, circumscissile near the middle, 8-18-seeded; seeds angled, reticulated.-Cosmopolitan; waste places about towns.

2. Plantago lanceolata L. 1. c. More or less pubescent; rootstock short, with tufts of brown hair at the base of the leaves, perennial or biennial: leaves narrowly lanceolate, mostly erect, entire, acute or acuminate, gradually narrowed into petioles, 3-5-ribbed: scapes slender, channeled, 2-5 dm. high: spikes very dense, at first short and ovoid, becoming cylindric, blunt, $2-8 \mathrm{~cm}$. long in fruit; flowers perfect: sepals ovate, with a narrow green midrib and broad, scarious margins, the 2 lower ones commonly united: corolla glabrous, the tube very short: stamens exserted: capsule oblong, very obtuse, 2-seeded, slightly longer than the calyx, circumscissile at about the middle: seeds deeply excavated on the face.-Infrequent in our range; widely dispersed from Europe.

3. Plantago nitrophila A. Nels. Bull. Torr. Bot. Club 29: 405. 1902. Rootstock short, with a great number of thick, fibrous roots: leaves $1 \mathrm{dm}$. or more in length, mostly oval, sometimes nearly orbicular, obtuse or obtusish, entire or crenately dentate, the 5-7 nerves extending into the pubescent petiole which generally equals or exceeds the thick blade: scape proper about equaling the leaves, whitish with soft crinkly hairs: spike equaling the scape, simple or with 2 or more short spikes from the lowest foliar bracts, moderately thick, crowded; bracts proper ovate, subacute, scarious-margined, keeled and closely appressed, shorter than the mature fruit: sepals nearly orbicular, overlapping each other, scarious with a green midrib, but little more than half as long as the bracts: capsule ovate, $3-4 \mathrm{~mm}$. long, circumscissile near the base: seeds 7-10 in each cell, oblong-elliptic, obscurely wingangled and delicately reticulated, dark brown. ( $P$. asiatica as to our range, and probably also $P$. Rugellii.) -Wet alkaline banks; Colorado and Wyoming.

4. Plantago Tweedyi Gray, Syn. Fl. 21: 390. 1886. Plant 1-2 dm. high from a slender root or rootstock, destitute of wool at the crown: leaves membranaceous, lanceolate-spatulate, entire or obsoletely denticulate, obscurely 3-5-nerved, 3-7 cm. long, attenuate into a shorter margined petiole: spike slender but densely flowered, $2-5 \mathrm{~cm}$. long: bracts and sepals short, about $2 \mathrm{~mm}$. long, pale with greenish midrib, little over half the length of the oblong capsule.-Subalpine; from Colorado to Idaho and Montana.

5. Plantago eriopoda Torr. Ann. Lyc. N. Y. 2: 237. 1827. Usually a mass of yellowish-brown or red wool at the crown: leaves oblanceolate to ovalobovate, fleshy-coriaceous, 3-7-nerved, 1-1.5 dm. long, with a short or stout petiole: spike cylindrical, dense or sometimes sparsely flowered: sepals roundish-

ROCKY MT. BOT.-30 
obovate, scarious except the midrib: capsule ovoid, slightly exceeding the calyx, 2-4-seeded, circumscissile below the middle; seeds nearly flat. ( $P$. retrorsa Greene, Pl. Baker. 3: 32. 1901.)-Abundant in saline or alkaline meadows in our range and far westward.

6. Plantago Purshii Roem. \& Schult. Syst. 3: 120. 1818. White-woolly or silky pale-green annual: leaves ascending, linear, acute or acuminate, narrowed into margined petioles, 1-3-nerved, 5-25 cm. long, entire or with a few small teeth: scapes $0.5-3 \mathrm{dm}$. high: spikes very dense, hoary, cylindrical, obtuse, very woolly; bracts rigid, linear-subulate: sepals oblong, obtuse, scarious-margined: corolla-lobes broadly ovate, spreading: stamens 4 , just exserted from the tube or with long capillary filaments: capsule oblong, obtuse; seeds 2, light brown, oblong, convex on the back, deeply concave on the face.-Dry slopes and plains; the western half of the United States.

7. Plantago elongata Pursh, Fl. 729. 1814. Somewhat cinereous-puberulent annual: leaves linear-spatulate, $3-5 \mathrm{~cm}$. long, entire: scapes $3-10 \mathrm{~cm}$. high: spikes 1-3 cm. long, loosely flowered; flowers imperfectly dioecious or polygamous; bracts ovate, keeled, about $1 \mathrm{~mm}$. long: sepals oblong, obtuse, about equaling the bracts, with broad scarious margins: corolla-lobes triangularovate, acute, becoming erect and closed over the capsule: stamens 2: capsule short-ovoid, a little longer than the calyx, circumscissile below the middle, 4-seeded; seeds elongated-oblong, dark brown. P. pusilla. (P. myosuroides Rydb. Mem. N. Y. Bot. Gard. 1: 369. 1900.)-Wet places; transcontinental; rare in our range.

\section{RUBIACEAE B. Juss. Madder Family}

Shrubs or (ours) herbs, with opposite entire leaves connected by interposed stipules, or verticillate without apparent stipules. Calyx adnate to the 2-4-celled ovary. Stamens as many as the lobes of the regular corolla, and inserted on its tube. Ovary 1-10-celled; style simple or lobed. Fruit (in ours) dry, separating into 2 indehiscent carpels.

Leaves opposite, with entire, interpetiolar stipules Leaves verticillate, without stipules

1. Kelloggia 2. Galium.

\section{KELLOGGIA Torr.}

Small herbs with opposite leaves and small loosely cymose-panicled flowers. Flowers generally 4-merous. Calyx with obovate tube and minute teeth. Corolla between funnelform and salverform. Stamens and style more or less exserted. Ovary 2-celled. Fruit small, dry, and coriaceous, beset with hooked bristles, separating at maturity into 2-closed carpels.

1. Kelloggia galioides Torr. Bot. Wilkes. Exp. 332. 1874. Slender and glabrous or puberulent perennial, 1-3 dm. high: leaves opposite, lanceolate, sessile, with small and entire or 2-dentate interposed stipules: flowers small, in a loose dichotomous cyme, the long pedicels thickened above and articulated with the flower: corolla funnelform, white or pinkish, 5-10 mm. long, pubescent on the outside: fruit small, oblong, coriaceous, uncinate-hispid.From Wyoming to Washington and California.

\section{Galium L. Bedstraw. Cleavers}

Slender herbs, with small cymose flowers (produced in summer), square stems, and whorled leaves, the roots often containing a red coloring matter. Calyx-teeth obsolete. Corolla 4-parted, rarely 3-parted, wheel-shaped, valvate in the bud. Stamens 4, rarely 3, short. Styles 2. Fruit dry or fleshy, globular, twin, separating when ripe into the 2 seed-like, indehiscent, 1seeded carpels. 
Annuals; fruit hispid or hirsute.

Stems rough on the angles; leaves $6-8$ in each whorl. Stems erect or ascending; fruit $2-3 \mathrm{~mm}$, broad .

Stems reclining; fruit $4-6 \mathrm{~mm}$. broad .

Stems erect, smooth; 'leaves mostly in fours :

Perennials.

Stems wholly herbaceous; flowers perfect.

Leaves 3-nerved; fruit canescent, becoming glabrous

Leaves 1-nerved; fruit smooth or hispid.

Leaves cuspidate-pointed

Leaves not cuspidate-pointed.

Fruit hispid with hooked hairs.

Stems and pedicels more or less scabrous

Stems and pedicels glabrous

Fruit merely granulate-scalrot:s.

Stems somewhat woody at base; flowers dioecious

1. G. Vaillantii.

2. G. Aparine.

3. G. bifolium.

4. G. boreale.

5. G. triflorum.

6. G. trifidum.

7. G. Brandegei.

8. G. asperrimum.

9. G. coloradoense.

1. Galium Vaillantii DC. Fl. Fr. 4: 263. 1805. Stems slender, branching from the base, diffuse, 3-5 dm. long, retrorsely hispid on the angles: leaves 6-8 in the whorl, linear-oblanceolate, cuspidate, $1-2.5 \mathrm{~cm}$. long, retrorsely scabrous on the veins and margin, the axillary umbellate cymes 3-9-flowered: corolla about $2 \mathrm{~mm}$. in diameter, white or greenish: fruit large, more or less fine-tuberculate and uncinate-hispid.-Throughout our range and westward.

2. Galium Aparine L. Sp. Pl. 108. 1753. Stems coarse, reclining, 3-15 $\mathrm{dm}$. long, introrsely hispid on the angles: leaves 6-8 in the whorls, oblanceolate to almost linear, 3-5 cm. long, cuspidate-acuminate, retrorsely hispid on the margin and midrib: peduncles rather long, 1-3 in the upper axils or terminal, bearing 1-3 pedicellate flowers: corolla $2-4 \mathrm{~mm}$. in diameter, whitish: fruit not pendulous, rather large, granulate-tuberculate, the tubercles tipped with uncinate bristles.-In rich lands along streams, etc.; California to Alaska and across the continent.

3. Galium bifolium Wats. Bot. King's Exp. 134. 1871. Smooth and glabrous; stems slender, 1-3 dm. high, mostly erect, sparingly branched: leaves 2-4 in the whorl, lanceolate, $8-15 \mathrm{~mm}$. long, when 4 the alternate pair much smaller: peduncles solitary, lateral and terminal, naked, 1-flowered, when in fruit about equaling the leaves, spreading: corolla minute, white: fruit small, minutely hispid, recurved at the end of the pedunele.-Colorado and Wyoming to California and Washington.

4. Galium boreale L. 1. c. Erect, 3-6 dm. high, mostly smooth and glabrous, very leafy: leaves in fours, 3-nerved, blunt, linear to broadly lanceolate, often with fascicles of smaller ones in the axils: flowers very numerous and collected in a terminal and ample thyrsiform panicle, the uppermost leaves being reduced to pairs of small oblong or oval bracts: fruit small, hispidulous, or at first canescent and soon glabrous and smooth.-From New Mexico and California north to the arctic regions.

5. Galium triflorum Michx. Fl. 1: 80. 1803. Diffusely procumbent, smoothish; herbage sweet-scented in drying; stems 3-10 dm. long: leaves in sixes, elliptical-lanceolate to narrowly oblong, 3-5 cm. long, scabrous or not on the margins and midrib beneath: cymes once or twice 3 -rayed; pedicels soon divaricate: corolla yellowish-white to greenish, the lobes hardly surpassing the bristles of the ovary. ( $G$. flaviflorum Heller.)-Across the continent.

6. Galium trifidum L. 1. c. 105 . Weakly erect, branching, 1-5 dm. high, smooth and glabrous, except for the retrorsely scabrous angles of the stem and the usually more hispidulous and sparse roughness of the midrib and margins of the leaves: leaves in sixes, fives, or not rarely fours, linear, oblanceolate, or lanceolate-oblong, obtuse, 1-2 cm. long: peduncles slender, scattered, 1-several-flowered; flowers often 3-merous, as commonly 4-merous: fruit smooth and glabrous.-From Texas to California, northward and eastward.

6a. Galium trifidum subbiflorum Wiegand, Bull. Torr. Bot. Club 24: 399. 1897. Stems less scabrous than in the type, somewhat stouter: leaves larger, very unequal, $8-10 \mathrm{~mm}$. by $2 \mathrm{~mm}$., flaccid and nearly smooth: pedicels capillary and as long as the leaves, or sometimes rather stout: rarely 2 or even 3flowered, nearly glabrous.-From our range to the Pacific. 
7. Galium Brandegei Gray, Proc. Am. Acad. 12: 58. 1877. Perennial and caespitose, forming dense mats; stems low and prostrate or ascending, 5-12 cm. long, slender and rather densely leafy, smooth or nearly so; branches when present solitary: leaves in fours, unequal, obovate-spatulate, small, $10 \mathrm{~mm}$. or less, rounded at the apex, cuneate at the base, somewhat fleshy, dull on both surfaces, veins indistinct, margins and midrib glabrous: flowers lateral, commonly geminate, on glabrous arcuate pedicels which are as long as or longer than the leaves: corolla of medium size, white, 3-parted, lobes broadly oval, obtuse: fruit glabrous.-Colorado to New Mexico and far westward.

8. Galium asperrimum Gray, Mem. Am. Acad. 4: 60. 1840. Stems erect or diffusely ascending but weak, 1-2 dm. long: leaves lanceolate, $1-2 \mathrm{~cm}$. long: cymes twice or thrice dichotomous, with filiform peduncles and pedicels: corolla white or turning purplish: ovary merely puberulent or scabrous: fruit granulate-scabrous and sometimes minutely hispidulous.-Throughout the western United States.

9. Galium coloradoense Wight, Zoe 5: 54. 1900. Glabrous and smooth, paniculately branched, slightly woody at base: leaves 4 in the whorls, smooth, linear, with prominent midrib, 1-3 $\mathrm{cm}$. long, cuspidate-acute: flowers dioecious, the fertile naked-paniculate: corolla about $2 \mathrm{~mm}$. in diameter: bristles of the mature fruit as long as the body or longer, somewhat crumpled but not hooked. G. Mathewsii in part. Arid areas; southern Colorado.

\section{CAPRIFOLIACEAE Vent. Honeysuckle Family}

Shrubs or rarely herbs with opposite exstipulate leaves and perfect mostly cymose flowers. Calyx-tube adnate to the ovary. Corolla sympetalous, 5 -lobed or rarely bilabiate. Stamens 5 ( 4 in Linnaea), inserted on the tube of the corolla and alternate with its lobes. Fruit a berry, drupe, or capsule, 2-5-celled.

Corolla short, rotate or urceolate; stigma nearly sessile; fruit drupaceous.

Leaves pinnately compound

Leaves simple
Corolla tubular or campanulate; style elongated; fruit dry or berrylike.

Slightly woody herb with twin flowers

Shrubs.

Corolla regular; fruit 2-seeded

Corolla irregular; fruit few-several-seeded

1. Sambucus.

2. Viburnum.

3. Linnaea.

4. Symphoricarpos.

5. Lonicera.

\section{SAMBUCUS L. Elder}

Shrubby plants, with a rank smell when bruised, pinnate leaves, serrate pointed leaflets, and numerous small white flowers in compound cymes. Calyx-lobes minute or obsolete. Corolla open, urn-shaped, with a broadly spreading 5-cleft limb. Stamens 5. Stigmas 3. Fruit a berry-like juicy drupe, containing 3 small seed-like nutlets.

Cyme flat-topped; pith in year-old stems white.

Stem tree-like and long enduring; fruit black beneath a copious

Stem short-lived; fruit purple-black, almost devoid of bloom

Cyme not flat-topped; pith in year-old stems yellowish-brown.

Leaves blackening in drying; fruit black
Leaves not blackening in drying; fruit bright red

1. S. glauca.

2. S. canadensis.

3. S. melanocarpa.

4. S. microbotrys

1. Sambucus glauca Nutt. T. \& G. Fl. 2: 13. 1841. Arborescent, 2-4 m. high, the larger with trunks 1-2 dm. in diameter, glabrous throughout: leaflets 5-9, thickish, ovate to narrowly oblong, the lower rarely 3-parted; stipels rare and small, subulate or oblong: fruit nearly black but strongly whitened 
with a glaucous mealy bloom, rather large.-Idaho to Washington, and possibly in Utah and Wyoming.

1a. Sambucus glauca neo-mexicana (Wooton) A. Nels. Habit of the species but with narrower leaves and a tendency to puberulence upon foliage and inflorescence. (S. neo-mexicana Wooton, Bull. Torr. Bot. Club 25: 309. 1898.) - Mountains of southern Colorado and New Mexico.

2. Sambucus canadensis L. Sp. Pl. 269. 1753. Plants 1-3 m. high, glabrous except some fine pubescence on midrib and veins of leaves beneath: leaflets (5-11) mostly 7, ovate-oval to oblong-lanceolate, acuminate, the lower not rarely bifid or with a lateral lobe; stipules not uncommon, narrowly linear, and tipped with a callous gland: compound cymes depressed, 5-rayed; external rays once to thrice 5-rayed: fruit dark purple, becoming black, with very little bloom.-From the Rocky Mountains eastward to Canada and Florida.

3. Sambucus melanocarpa Gray, Proc. Am. Acad. 19: 76. 1883. Stems 1-2 m. high; glabrous or the young leaves slightly pubescent: leaflets 5-7, rarely 9: cyme convex, as broad as high; flowers white: fruit black, without bloom.-New Mexico to Montana and westward to the Pacific.

4. Sambucus microbotrys Rydb. Bull. Torr. Bot. Club 28: 503. 1901. A low shrub 5-20 dm. high, glabrous throughout and with pale green foliage: leaflets ovate or rarely ovate-lanceolate, acute or short-acuminate, 3-9 cm. long, mostly rounded and oblique at the base, coarsely serrate: cyme thyrsoidpaniculate, small, about as long as broad, about $3 \mathrm{~cm}$. in diameter and of the same height; flowers whitish: fruit bright red, 4-5 mm. in diameter; seeds finely punctate-rugose. S. racemosa.-Throughout our range.

\section{VIBURNUM L.}

Shrubs, with simple leaves and white flowers in flat compound cymes. Petioles sometimes bearing little appendages which are evidently stipules; leaf-buds naked or with a pair of scales. Calyx 5-toothed. Corolla spreading, deeply 5-lobed. Stamens 5. Stigmas 1-3. Fruit a 1-celled, 1-seeded drupe, with soft pulp and a thin-crustaceous (flattened or tumid) stone.

Leaves pinnately veined; fruit blue or black

Leaves palmately veined; fruit red.

Cyme with the exterior flowers ray-like.

Cyme with no radiant flowers

1. Viburnum Lentago L. Sp. Pl. 268. 1753. A shrub or small tree; glabrous or nearly so throughout: leaves ovate, rounded at the base, acuminate; 5-10 cm. long, sharply serrulate: cyme sessile, several-rayed, 6-12 cm. broad: drupes oval, black with a bluish bloom, the stone nearly circular and very flat.-Along streams; across the continent northward.

2. Viburnum Opulus L. 1. c. A shrub 1-3 m. high, the branches smooth and nearly erect: leaves broadly ovate, glabrous or sparsely pubescent above and on the veins beneath, 3-ribbed and 3-lobed, the lobes acuminate and coarsely dentate; petioles glandular above: cymes $6-10 \mathrm{~cm}$. broad, with the outer ray-flowers neutral: drupes edible, $8-10 \mathrm{~mm}$. in diameter, red, acid, translucent; the stone flat, orbicular. High Bush Cranberry. The European cultivated form with nearly all the flowers neutral is the common SNowball. - Coming into the northeastern part of our range.

3. Viburnum pauciflorum Pylaie, T. \& G. Fl. N. A. 2: 17. 1841. Glabrous or pubescent, 8-15 dm. high, straggling: leaves roundish or broadly oval, unequally dentate, many of them either obsoletely or distinctly 3-lobed, about 5-nerved at base: cymes small, terminating short and merely 2-leaved lateral branches, involucrate with slender, subulate, caducous bracts, destitute of neutral radiant flowers: fruit much as in the preceding.-Mountains of Colorado, northward and eastward in cold or mountainous regions.

\section{LINNAEA Gronov. TwIN Flower}

A slender creeping and trailing little evergreen, somewhat hairy, with rounded-oval sparingly crenate leaves contracted at the base into short pet- 
ioles and thread-like upright peduncles forking into 2 pedicels at the top, each bearing a delicate and fragrant nodding flower. Calyx-teeth 5, awlshaped, deciduous. Corolla purple and whitish, hairy inside, narrow bellshaped, almost equally 5-lobed. Stamens 4,2 of them shorter, inserted toward the base of the corolla. Ovary and the small dry pod 3-celled, but only 1-seeded, 2 of the cells having only abortive ovules.

1. Linnaea americana Forbes, Hort. Woburn 135. 1833. Somewhat pubescent: leaves obovate and rotund, 1-2 cm. long, crenately few-toothed, somewhat rugose-veiny: peduncles filiform, terminating ascending, short, leafy branches, bearing at summit a pair of small bracts, and from the axil of each a filiform 1-flowered pedicel; pedicels similarly 2-bracteolate at summit, and a pair of larger, ovate, glandular-hairy inner bractlets subtending the ovary: flowers nodding. L. borealis.-From the-mountains of California, Colorado, and Maryland, northward to the arctic regions.

\section{SYMPHORICARPOS * L.' BUCKBRUSH}

Low and branching upright shrubs with short-petioled leaves, which are entire, wavy-toothed, or lobed on the young shoots. Flowers white, tinged with rose-color; in close short spikes or clusters. Calyx-teeth short, persistent. Corolla regularly 4-5-lobed, with as many short stamens inserted into its throat. Ovary 4-celled, only 2 of the cells with a fertile ovule; the berry therefore 4-celled but only 2 -seeded. Seeds bony.

Corolla short-campanulate, 3-4 mm. long.

Leaves thick; stamens and style exserted

Leaves rather thin; stamens and style included

Corolla longer (6-12 mm.), long-campanulate to tubular-funnelform

Leaves tomentulose or finely pubescent

Leaves glabrous or nearly so

1. S. occidentalis.

2. S. racemosus.

1. Symphoricarpos occidentalis Hook. Fl. Bor. Am. 1: 285. 1833. Robust, glabrous or slightly pubescent: leaves oval or oblong, thickish (larger $5 \mathrm{~cm}$. long): axillary flower-clusters not rarely pedunculate, sometimes becoming spicate and 2-3 cm. long: corolla 3-5 mm. high, 5-cleft to beyond the middle, within densely villous-hirsute with long beard-like hairs: stamens and style more or less exserted. WOLFBERRY.-Mountains of Colorado and Montana, northward and eastward.

1a. Symphoricarpos occidentalis quercifolia A. Nels. Stems short, simple, erect: leaves large, coarsely and deeply undulate-toothed.-Infrequent; on the plains in northern Wyoming.

2. Symphoricarpos racemosus Michx. Fl. 1: 107. 1803. More slender and glabrous: leaves round-oval to oblong, smaller: axillary clusters mostly fewflowered, or lowest 1-flowered: corolla $4 \mathrm{~mm}$. high, 5 -lobed above the middle, moderately villous-bearded within, narrowed at base: stamens and style not exserted. SNowberRY.-Across the continent.

2a. Symphoricarpos racemosus pauciflorus Robbins, Gray, Man. Ed. 5. 203. 1867. Low, more spreading: leaves commonly only $2-3 \mathrm{~cm}$. long, strongly whitened underneath: flowers solitary in the axils of the upper leaves, few and loosely spicate in the terminal cluster.-Mountains of Colorado to those of Oregon, Vermont, and northward.

3. Symphoricarpos rotundifolius Gray, Pl. Wright. 2: 66. 1853. Tomentulose or glabrate; stems rigid, much-branched, 4-10 dm. high: leaves orbicular to oblong-elliptical, thickish, 1-2 cm. long, entire or coarsely lobed: corolla elongated-campanulate, $6-8 \mathrm{~mm}$. long, the tube pubescent within below the stamens, twice or thrice the length of the broad lobes: stamens and style included: fruit white, globular or oblong: nutlets oval, equally broad and obtuse at both ends. - Throughout our range and west to the Pacific.

* The familiar coral-berry, Symphoricarpas orbiculatus Moench, has been reported from Colorado. It is easily recognized by the clustered coral-red berries which persist through the winter. 
3a. Symphoricarpos rotundifolius vaccinioides (Rydb.) A. Nels. Leaves soft-pubescent or tomentulose, elliptic, oblong, or oblong-lanceolate, from obtuse to acute at both ends, entire or somewhat dentate: flowers oblongcampanulate, shorter than in the species. (S. mollis acutus Gray, Syn. Fl. 1: 14. 1878; S. vaccinoides Rydb. Mem. N. Y. Bot. Gard. 1: 371. 1900.)-Colorado to Montana.

4. Symphoricarpos oreophilus Gray, Journ. Linn. Soc. 14: 12. 1873. Glabrous or nearly so: leaves oblong to broadly oval, entire or dentate, 10-15 $\mathrm{mm}$. long: corolla tubular or narrowly funnelform, 8-12 $\mathrm{mm}$. long, the tube 4-5-times as long as the lobes and glabrous within: nutlets of the drupe oblong, flattened, pointed at the base. (S.tetonensis A. Nels. Bull. Torr. Bot. Club 31: 249. 1904.)-Montana to New Mexico and far westward.

$4 a$. Symphoricarpos oreophilus utahensis (Rydb.) A. Nels. Leaves larger and the flowers often more numerous, but otherwise as in the species. ( $S$. utahensis Rydb. Bull. Torr. Bot. Club 26: 544. 1899.)-Colorado to Utah and southward.

\section{LONICERA L. HONEYSUCKLE}

Erect or climbing shrubs, with mostly entire leaves and the inflorescence various. Flowers often showy and fragrant. Calyx-teeth very short. Corolla tubular or funnelform, of ten gibbous at the base, irregularly or almost regularly 5-lobed. Stamens 5. Ovary 2-3-celled. Berry several-seeded.-Includes Distegia Raf.

Climbing or scrambling; flowers in capitate clusters Erect shrubs; flowers in pairs.

Bracts small or wanting.

Leaves pale; fruit blue-black

Leaves green, thin; fruit red

Bracts broad, foliaceous

1. Lonicera glaucescens Rydb. Bull. Torr. Bot. Club 24: 90. 1897. Leaves glabrous above, pubescent, at least on the veins beneath, $3-9 \mathrm{~cm}$. long, chartaceous-margined, not ciliate, usually only the upper pair connateperfoliate: flowers verticillate in a short interrupted spike: corolla yellow, changing to reddish, pubescent or puberulent without, pubescent within, $2.5 \mathrm{~cm}$. long or less, the 2-lipped limb shorter than the tube: stamens nearly glabrous, or somewhat pubescent; style hirsute; both exserted.-Wyoming, northward and eastward.

2. Lonicera caerulea L. Sp. Pl. 174. 1753. Stems branched, 3-6 dm. high: leaves $2-3 \mathrm{~cm}$. long, oblong-elliptical, obtuse, short-petioled, conspicuously veined, villous-pubescent or glabrate: peduncles shorter than the flowers: corolla somewhat gibbous at base, moderately bilabiate: bracts subulate or linear: ovaries united and forming a blue-black sweetish berry.-Transcontinental northward; also in Europe and Asia.

3. Lonicera utahensis Wats. Bot. King's Exp. 133. 1871. Leaves oval or elliptical-oblong, rounded at both ends, very short-petioled, glabrous or nearly so from the first, or soon glabrate, reticulate-venulose at maturity, $2-4 \mathrm{~cm}$. long: peduncles seldom over $1 \mathrm{~cm}$. long; bractlets minute, rounded: corolla honey-yellow or ochroleucous, occasionally tinged with purple, 12-18 mm. long; the tube gibbous at base, pilose-pubescent within: berry red. ( $L$. ebractulata Rydb. Mem. N. Y. Bot. Gard. 372. 1900.)-Wyoming to Montana and far westward.

4. Lonicera involucrata Banks, Rich. Bot. App. Frank. Journ. 733. 1823. Pubescent or sometimes glabrate, freely branched, 6-20 dm. high: leaves ovate to oblong-lanceolate, 5-12 cm. long: peduncles $2-5 \mathrm{~cm}$. long; bracts oblong to ovate or cordate and foliaceous; in fruit enlarging and inclosing or surrounding the 2 globose, dark purple or black berries: flowers paired, rarely in threes: corolla yellowish, viscid pubescent, $12-15 \mathrm{~mm}$. long; bractlets 4 or united into 2, viscid-pubescent.-Colorado to Montana and thence across the continent, 


\section{ADOXACEAE Fritsch. Moschatel Family}

Glabrous slender herbs, with scaly or tuberiferous rootstocks, basal and opposite ternately compound leaves, and small green flowers in terminal capitate clusters. Calyx-tube hemispheric, adnate to the ovary, the limb 2-3toothed. Corolla rotate, regular, 4-6-lobed. Stamens twice as many as the lobes of the corolla, inserted in pairs on its tube; filaments short; anthers peltate, 1-celled. Ovary 3-5-celled; style 3-5-parted; ovules 1 in each cavity, pendulous. Fruit a small drupe with 3-5 nutlets.

\section{ADOXA L.}

Characters of the family.

1. Adoxa Moschatellina L. Sp. Pl. 367. 1753. Glabrous and smooth: radical leaves once to thrice ternately compound; cauline pair of leaves 3-parted or of 3 obovate and 3-cleft or parted leaflets: flowers small, greenish-white or yellowish, 4 or 5 in a slender-pedunculate glomerule: corolla of the terminal one 4-5-cleft, of the others 5-6-cleft.-Subalpine; arctic America to Colorado and eastward in the northern States.

\section{CUCURBITACEAE B. Juss. Gourd Family}

Herbs, mostly tendril-bearing and climbing, rather succulent, with alternate and palmately veined or lobed leaves and no proper stipules, and monoecious or dioecious flowers with petals more commonly united into a cup or tube and also blended with the calyx. Sterile flowers with two 2-celled anthers and one 1-celled; the cells usually long and contorted. Fertile flowers with the calyx-tube adnate to a 1-3-celled ovary.

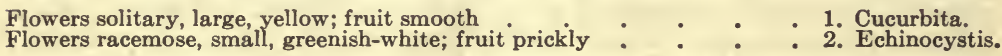

\section{CUCURbita L. Pumpkin, Squash, etc.}

Mostly prostrate and rooting at the joints. Leaves cordate; tendrils compound. Flowers monoecious. Calyx-tube and corolla campanulate. Sterile flowers with the stamens at the base. Fertile flowers with 3 rudimentary stamens. Ovary oblong, with 3 placentae. Fruit fleshy, often with a hard rind. Seed ovate or oblong, flattened.

1. Cucurbita foetidissima H. B. K. Nov. Gen. 2: 123. 1817. Root fleshy, . very large, 1-10 dm. thick, yellow inside: leaves cordate-ovate or triangular, undivided or subsinuate-repand, margin denticulate: fruit globose, yellow, 5-8 cm. in diameter. C. perennis. - Colorado to Texas and Mexico and westward to California.

\section{2. eChinocystis T. \& G. Wild Balsam Apple}

Tall climbing plants, nearly smooth, with 3 -forked tendrils and thin leaves. Flowers monoecious; fertile flowers in small clusters or solitary, from the same axils as the sterile. Petals united at the base into an open spreading corolla. Fruit fleshy, at length dry.-(Micrampelis.)

1. Echinocystis lobata (Michx.) T. \& G. Fl. N. A. 1: 542. 1840. Stem nearly glabrous, angular and grooved, climbing to a height of $4.5-7.5 \mathrm{~m}$., sometimes villous-pubescent at the nodes: leaves thin, roughish on both 
sides, deeply cordate, 3-7-lobed to about the middle, the lobes triangularlanceolate, acute or acuminate, remotely serrulate: staminate flowers very numerous, in narrow compound racemes: pistillate flowers solitary, or rarely 2 together: fruit ovoid, green, about $5 \mathrm{~cm}$. long, armed with slender spines.Along rivers and in waste places; from the eastern part of our range to the Atlantic States.

\section{Campanulaceae Juss. Bluebell Family}

Herbs with alternate exstipulate leaves. Flowers racemose or solitary, generally blue and showy. Calyx-tube adnate to the ovary. Corolla sympetalous, campanulate or rotate. Stamens usually 5 , free from the corolla and distinct." Style single but mostly with 2-5 stigmas. Capsule prismatic or elongated-oblong, 2-4-celled, opening by small lateral valves. Seeds minute and numerous.

Corolla campanulate

Corolla rotate

\section{Campanula L. Bluebell. Harebell}

Herbs with terminal or axillary (usually blue) flowers. Calyx 5-cleft. Corolla generally bell-shaped, 5-lobed. Stamens 5, separate, with filaments broad and membranaceous at base. Stigmas 3 , and as many cells of the ovary. Pod short, opening on the sides by as many valves or pores.

Low and mostly 1-flowered; capsule opening near the summit.

Alpine; with woody caudex

Subalpine; with filiform rootstock

Taller and several to many-flowered.

Stem smooth; capsule nodding
Stem hispid on the angles; capsule erect

1. Campanula unifiora L. Sp. Pl. 163. 1753. Chiefly glabrous, 4-10 cm. high, from a stout, several-headed rootstock: leaves small, 1-3 cm. long, thickish, entire or nearly so; the lowest spatulate or oblong, obtuse; the uppermost linear: flowers 8-12 mm. in length, mostly horizontal: calyx-tube nearly as long as the lobes which are from half to fully as long as the deeply campanulate bluish corolla: capsule cylindraceous or clavate, about $1 \mathrm{~cm}$. long.On bare alpine slopes in the Rocky Mountains, and extending into the arctic regions.

2. Campanula Parryi Gray, Syn. Fl. N. A. 2: 395. 1886. From elongated and creeping filiform rootstocks, $8-25 \mathrm{~cm}$. high, mainly smooth and glabrous; stem slender, erect, simple and with slender-peduncled flower, or with some lateral leafy branches: leaves thinnish, entire or sparingly callous-denticulate, somewhat veiny; radical and lower spatulate or lanceolate with tapering base, hirsute-ciliate; upper linear-lanceolate, from a sessile base, attenuate-acute: flower erect in anthesis: corolla almost crateriform, 5-lobed to middle, spreading, $2-3 \mathrm{~cm}$. in diameter, violet-blue or even purplish, little surpassing the linear-subulate often callous-denticulate calyx-lobes: ovary turbinate: capsule nearly obovate, opening close under the base of the erect calyx-lobes. $C$. planiflora.-In the mountains of our range.

3. Campanula rotundifolia L. Sp. Pl. 163. 1753. Slender, branching, 10-30 cm. high, 1-10-flowered: root leaves round-cordate or ovate, mostly toothed or crenate, long-petioled, early withering away; stem leaves numerous, linear or narrowly lanceolate, entire, smooth: calyx-lobes awl-shaped: capsule nodding, opening at or near the base. ( $C$. petiolata Rydb. Fl. Col. 326. 1906.) Subarctic and extending southward in the mountains to Mexico.

4. Campanula a parinoides Pursh, Fl. 1: 150. 1816. Stem almost filiform, 3-6 dm. high, equably leafy to the top, the sharp angles rough with short re- 
trose bristles; so also the midrib beneath and the margins of the lanceolate or linear sessile leaves: flower-buds drooping:,calyx-lobes triangular: corolla pale blue or whitish, deeply cleft, the lobes $4 \mathrm{~mm}$. long or less: capsule erect.Wet grassy grounds; from Colorado to the Saskatchewan and eastward.

\section{SPECULARIA Heist. Venus's Looking-glass}

Annuals with leafy slender stems and sessile flowers. Corolla blue or purplish. Flowers dimorphous; the earlier ones smaller, with undeveloped corolla, and a 3 or 4-lobed calyx. Calyx-lobes of the later corolliferous flowers 5. Capsule with valvular openings either near the summit or near the middle.-(Legouzia Brit.)

Leaves linear

Leaves ovate or broader

1. Specularia leptocarpa (Nutt.) Gray, Proc. Am. Acad. 11: 82. 1876. Minutely hirsute or nearly glabrous; stems 1-2 dm. high, virgate, mostly simple, or branched from the base: leaves lanceolate: capsule nearly cylindrical, $10-15 \mathrm{~mm}$. long, inclined to curve and rarely to twist, opening by 1 or 2 uplifted valves near the summit; the lower also of ten splitting longitudinally from the summit; seeds oblong.-Arkansas to western Texas and Colorado.

2. Specularia perfoliata L. Sp. Pl. 169. 1753. Stems 1-4 dm. high, very leafy throughout, hirsute or hispid on the angles: leaves round-cordate and clasping, mostly crenate, veiny: flowers single or clustered in the axils: capsule oblong or somewhat obconical; the 2 or 3 valvular openings at or below the middle; the capsule not disposed to split; seeds lenticular.-From Colorado to Utah and Oregon, also throughout the states eastward.

\section{LOBELIACEAE Dumort. Lobelia Family}

Herbs with milky juice, alternate leaves, scattered flowers, irregular 5lobed corolla, and the 5 stamens free from the corolla and united into a tube commonly by their filaments and always by their anthers. Calyx-tube adherent to the 2-celled, many-seeded capsule. Style 1.

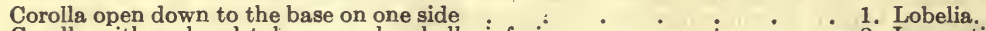

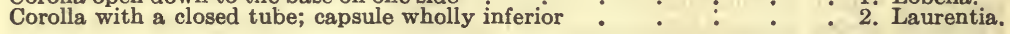

\section{LOBELIA L.}

Flowers axillary or chiefly in bracted racemes. Calyx-tube 5-cleft, with a short tube. Corolla with a straight tube and somewhat 2-lipped; the upper lip of 2 rather erect lobes, the lower lip spreading and 3-cleft. Capsule 2celled, opening at the top.

Flowers red

Flowers blue

1. Lobelia splendens Willd. Hort. Berol. pl. 86. 1809. Perennial, minutely pubescent or glabrate, erect, 3-10 dm. high: leaves linear-lanceolate to linear, more or less glandular-toothed; the upper sessile; the lower tapering to a short petiole: raceme 1-3 dm. long: sepals narrow: corolla deep red; the tube longer than the lobes: capsule subglobose, with a conical beak; seeds tuberculate. L. cardinalis.-Utah to Colorado and Texas.

2. Lobelia syphilitica L. Sp. Pl. 931. 1753. Stems simple, 5-10 dm. high, leafy to the top, somewhat hairy: leaves thin, oblong or ovate-lanceolate, acute at both ends, irregularly serrate: flowers in a long spike-like raceme, light blue, rarely white: sinuses of the calyx with deflexed auricles: capsule 
globose; seeds longitudinally wrinkled.-From our range eastward to the Atlantic.

\section{LAURENTIA Micheli.}

Low herbs, resembling small species of Lobelia excepting the closed tube of the corolla. Flowers blue. Calyx-tube turbinate or oblong. Corolla with its tube as long as the limb. Capsule short, 2-valved at the summit.

1. Laurentia eximia A. Nels. Perennial, the simple stems about $1 \mathrm{dm}$. high, internodes short: lower leaves narrow, tapering from the dilated base, 15-25 mm. long; the floral somewhat broader: flowers few, from the axils of the crowded uppermost leaves, on short peduncles: sepals foliaceous, $6-8 \mathrm{~mm}$. long: corolla deep blue; the upper lip of 2 oblong-erect lobes about as long as the tube; the lower of 3 ovate lobes longer than the tube, somewhat depressed, and with 2 narrow yellow plicae in the throat: capsule obconical, manyseeded. L. carnosula. (Porterella eximia A. Nels. Bull. Torr. Bot. Club 27: 270. 1900.)-Banks of ponds; northwestern Wyoming; probably throughout our range.

\section{VALERIANACEAE Batsch. Valerian Family}

Herbs with opposite leaves and no stipules, and usually small perfect or polygamous flowers in corymbed or capitate cymes. Calyx-tube adnate to the ovary. Corolla tubular or funnelform, mostly 5-lobed. Stamens 1-4, inserted on the corolla-tube. Ovary inferior, 1-3-celled, one of the cells containing a single suspended ovule, the others empty.

\section{VALERIANA L. VALERIAN}

Roots of peculiar scent. Leaves various. Flowers white or rose-colored. Calyx-limb of 5-15 setiform lobes, which are inrolled and inconspicuous until fruiting. Stamens 3.

Leaves nerve-veined, usually thick, entire or with entire linear divisions.

Ovaries and fruits pubescent

Ovaries and fruits glabrous

Leaves pinnately veined, usually thin, and of ten pinnate.

Ovaries and fruits pubescent

Ovaries and fruits glabrous

1. V. ceratophylla.

2. V. furfurescens.

3. V. micrantha.

4. V. acutiloba.

1. Valeriana ceratophylla (Hook.) Piper, Contrib. U. S. Nat. Herb. 11: 532. 1906. Erect from a large, fusiform, perpendicular stock branching below into deep and thickened roots; stem 7-20 dm. or more high: leaves thickish, nervosely veined, not serrate, slightly pubescent; radical leaves oblanceolate to spatulate, tapering into a margined petiole, entire or some sparingly laciniate-pinnatifid; cauline rarely none, commonly 1 or 3 pairs, sessile, and pinnately parted into 3-7 linear or lanceolate divisions, or terminal one spatulate: flowers polygamo-dioecious, yellowish-white, sessile in the cymules, which form an elongated, thyrsiform, naked panicle. V.edulis.-New Mexico and Arizona, northward and eastward.

2. Valeriana furfurescens A. Nels. Bull. Torr. Bot. Club 28: 232. 1901. Similar, the root slender, only 1-3 cm. in diameter: leaves entire or nearly so: inflorescence usually much elongated, often half the height of the plant; flowers very numerous, minute: corolla $1-1.5 \mathrm{~mm}$. long, greenish-yellow: fruit 3-4 mm. long, ovate, compressed, glabrous but often slightly scurfy rugulose. ( $V$. trachycarpa Rydb. Bull. Torr. Bot. Club 31: 645. 1904.)-Moist saline meadows; Colorado and Wyoming.

3. Valeriana micrantha E. Nels. Erythea 7: 166. 1899. Glabrous, erect from creeping rootstocks, $3-8 \mathrm{dm}$. high: radical leaves entire or with 1 or 2 
pairs of oblong or lanceolate leaflets: inflorescence few to many-flowered, rather open even in anthesis and quite so in fruit: corolla white, campanulate, hairy in throat: achenes ovate to lanceolate, pubescent. V. sylvatica in part. -Mountains of Colorado and Wyoming.

3a. Valeriana micrantha wyomingensis (E. Nels.) A. Nels. Usually smaller, the inflorescence few-flowered and very open, the achenes glabrous. (V.wyomingensis E. Nels. 1. c. 167.)-Northwestern Wyoming and contiguous territory.

4. Valeriana acutiloba Rydb. Bull. Torr. Bot. Club 28: 24. 1901, Green and glabrous, 3-5 dm. high: basal leaves entire, spatulate or obovate, acute, the short petiole wing-margined; stem leaves 2 or 3 pairs, pinnately divided: cyme dense and contracted, glandular-puberulent or nearly glabrous: corolla funnelform, with very short tube: ovary and fruit glabrous. $V$. sylvatica in part. ( $V$. oreophila Greene, acc. to Rydb.; V. occidentalis, $V$. septentrioralis, $V$. sitchensis Scouleri, as to our range.)-Partly wooded hillsides, appearing as the snowdrifts recede; in the Rocky Mountains of our range.

4a. Valeriana acutiloba ovata (Rydb.), A. Nels. Reduced alpine state, with simple, ovate, subcordate, petioled basal leaves: fruit ovate. (V.ovata Rydb. 1. c. 31: 645.)-High mountains of Colorado.

\section{COMPOSITAE Adans. Composite Family}

Flowers in a close head, on a common receptacle, surrounded by an involucre, with 5 (rarely 4 ) stamens inserted on the epigynous corolla, the anthers united in a tube (syngenesious). Calyx-tube epigynous upon the 1-celled ovary, the limb (pappus) crowning its summit in the form of bristles, awns, scales, teeth, etc., or cup-shaped, or else entirely absent. Corolla either strap-shaped or tubular; in the latter chiefly 5-lobed, valvate in the bud, the veins bordering the margins of the lobes. Style 2-cleft at the apex (in sterile flowers usually entire). Fruit seed-like (achenes), dry, containing a single, erect, anatropous seed, with no endosperm.-An immense family, in temperate regions chiefly herbs, without stipules, with perfect, polygamous, monoecious, or dioecious flowers. The flowers with a strap-shaped (ligulate) corolla are called rays or ray-flowers; the head which presents such flowers, either throughout or at the margin, is radiate. The tubular flowers compose the disk; and a head which has no ray-flowers is said to be discoid. When the head contains 2 sorts of flowers it is said to be heterogamous; when only 1 sort, homogamous. The leaves of the involucre, of whatever form or texture, are termed bracts. The bracts or scales, which often grow on the receptacle among the flowers, are called the chaff; when these are wanting, the receptacle is said to be naked. The largest family of seed plants. The genera are divided by the corolla into 3 series, only 2 of which are represented in our region, the first being much the larger.

\section{Key to the Tribes}

\section{Series A. TUBULIFLORAE}

COROLLÁS ALL TUBULAR AND REGULAR, OR ONLY THE MARGINAL ONES LIGULATE (IRREGULAR)

Anthers not caudate at base; style branches either truncate or tipped with an appendage.

Heads rayless; flowers all perfect, never yellow. Style branches terete-filiform
Style branches thickened upward (clavate) 
Heads radiate (rarely rayless).

Style branches of perfect flowers flat, or tipped with a distinct

appendage; leaves mostly alternate
Style branches of perfect flowers truncate or appendaged, not flattened; leaves often opposite.

Involucre not scarious.

Pappus never capillary.

Receptacle chaffy

Pappus capillary
Involucre scarious; pappus not capillary : $:$ :

Anthers caudate at base; style-branches neither truncate nor appendaged; heads not radiate.

Receptacle not bristly; corollas not deeply cleft

Receptacle long-bristly; corollas deeply cleft

III. ASTEREAE.

Series B. LIGULIFLORAE

V. HELIANTHEAE.

VI. HELENIEAE.

VIII. SENECIONEAE.

VII. ANTHEMIDEAE.

IV. INULEAE.

IX. CYNAREAE.

COROLLAS ALL LIGULATE AND PERFECT

Ligule 5-toothed at the truncate apex + . + . . . . X. CICHORIEAE.

\section{Abbreviated Key to the Genera}

\section{Tribe I. VERNONIEAE}

Only genus

\section{Tribe II. EUPATORIEAE}

Achenes 5-angled

Achenes 8-10-ribbed or -striate.

Involucral bracts strongly striate-nerved.

Bracts few

Bracts numerous

Involucral bracts faintly nerved, spirally imbricated

\section{Tribe III. ASTEREAE}

Ray-flowers yellow, or wanting.

Pappus of scales

Heads numerous, $4 \mathrm{~mm}$. or less high

Heads large and showy

Pappus, in part at least, of capillary bristles.

Pappus double, the outer series of small scales . . .

Pappus wholly of capillary bristles.

Rays wanting.

Involucral bracts in vertical rows ${ }^{-}$involucral bracts imbricated but not in distinct vertical

Involucral bracts imbricated but not in distinct vertical

Rays present (sometimes wanting in Nos. $13^{\circ}$ and $\dot{1}^{\circ}$ ).

Leaves with spinulose-tipped teeth.

Involucral bracts chartaceous, with green tips

Involucral bracts more or less foliaceous :

Leaves without spinulose-tipped teeth.

Involucral bracts foliaceous, at least in part. Plant 1 dm. or more high.

Low shrubs

Herbaceous
Plant only a few $\mathrm{cm}$. high

Involucral bracts not foliaceous.

Head not corymbose.

Stems leafy.

Involucral bracts cuspidate

Involucral bracts not cuspidate

Stems scapose, or at least naked above , :

Heads corymbose.

Plant woody at least at base

Plant herbaceous.

Outer inv lucral bracts foliaceous

None of the bracts foliaceous

Ray-flowers present, not yellow (in No. 27, rarely yellow or wanting).

Pappus a mere crown, or of a few scales or bristles

6. Gutierrezia.

7. Grindelia.

8. Chrysopsis.

9. Chrysothamnus.

10. Isocoma.

11. Sideranthus.

12. Pyrrocoma.

14. Macronema.

18. Oreochrysum.

16. Tonestus.

13. Oonopsis.

19. Solidago.

15. Stenotus.

17. Petradoria.

18. Oreochrysum.

19. Solidago.

20. Townsendia. 
Involucral bracts in more than two rows.

Involucral bracts herbaceous or at least green-tipped.

Lobes or teeth of the leaves mucronate or bristletipped.

Involucral bracts in several series, usually recurved or reflexed

Involucral bracts in 2-3 series, loose but not reflexed

Lobes or teeth of the leaves not mucronate or bristletipped; involucral bracts often spreading, but not recurved or reflexed.

Disk-flowers turning brown or reddish.

Stems usually branching, and the heads severalmany
Stems low, monocephalous; dwarf alpines.

Stems scapose

Stems leafy

Disk-flowers permanently 'white

Bracts not foliaceous or noticeably green-tipped

Involucral bracts in 1 or 2 rows

Rays inconspicuous or wanting.

Annuals, with numerous small heads and rays not longer than the pappus

Perennials (shrubs); rays wanting : : : : :

23. Machaeranthera.

21. Xylorhiza.

22. Aster.

24. Oreastrum.

25. Ionactis.

26. Leucelene.

28. Wyomingia.

27. Erigeron.

29. Leptilon.

30. Baccharis.

Receptacle chaffy; stigmas of hermaphrodite flowers not truncate .

Receptacle not chaffy; stigmas of hermaphrodite flowers truncate.

Plants dioecious or polygamo-dioecious.

Pappus of staminate flowers clavate

Pappus alike in all the flowers
Plants not dioecious; all the flowers fertile.

All the flowers hermaphrodite

Only the inner flowers hermaphrodite

Tribe V. HELIANTHEAE

Involucral bracts not inclosing the ray achenes; herbage not glandular viscid.

Ray-flowers fertile and ligulate; disk-flowers sterile.

Ligules conspicuous

Ligules reduced to 2 or 3 teeth or wholly wanting.

Caulescent annual

Acaulescent perennial

Disk-flowers fertile; rays, if present, fertile or sterile.

Stamens distinct.

Heads with both staminate and pistillate flowers.

Involucral bracts acuminat

Involucral bracts obtuse.

Fertile flowers more than one

Fertile flower solitary

Heads unisexual; pistillate heads usually spiny.

Bracts of the staminate heads separate; pistillate head forming an oblong bur

Bracts of the staminate heads united.

Pistillate flowers solitary in each head; spines in a single series

Pistillate flowers $1-4$ in each head; spines in several series

Stamens syngenesious.

Ligules persistent and becoming papery.

Achenes compressed; leaves entire

Achenes 4-sided; leaves toothed

Ligules deciduous or wanting.

Receptacle high-conical or cylindrical.

Rays pistillate, sterile.

Ligules rose-colored

Ligules yellow

Rays neutral.

Achenes 4-sided, marginless

Achenes flattened laterally and margined ${ }^{\circ}$ :

Receptacle flat to convex.

Achenes not winged or very flat.

Pappus wanting

Pappus present (a laciniate crown or distinct scales). Pappus coroniform and persistent Pappus of 2-pointed very deciduous scales

Achenes flat, winged or wingless (terete in No. 58), usually 2-3-awned. 
Awns not retrorsely barbed or hispid, often at length deciduous.

Ray-flowers fertile; achenes winged

Ray-flowers neutral.

Involucral bracts distinct, somewhat foliaceous

Involucral bracts all more or less united at base

Awns retrorsely barbed or hispid.

Involucral bracts united only at base

Involucral bracts united into a cup

Involucral bracts partly or wholly inclosing the ray achenes.

Rays 1-5, inconspicuous, yellow

Rays 8-12, conspicuous, white or rose

55. Ximenesia.

54. Helianthella

56. Coreopsis.

57. Bidens.

58. Thelesperma.

69. Madia.

60. Layia.

\section{Tribe VI. HELENIEAE}

Herbage without oil-glands; not rank-scented but often aromatic.

Ligules persistent and becoming papery; plants more or less woolly

Ligules deciduous or wanting.

Achenes flat, with only marginal nerves.

Achenes angled (not flat), nerved or striate.

Receptacle not chaffy.

At least the tips of the involucral bracts petaloid or scarious.

Heads rayless

Heads radiate.

Ligules white or yellowish

Ligules purple

Involucral bracts not petaloid or scarious.

Achenes 4-angled.

Leaves all entire

Leaves not all entire.

Bracts of the involucre in 2 series, more or less united

Bracts of the involucre distinct.

Plants not glutinous or viscid. Flowers yellow

Flowers white or flesh-color

Plants glutinous or viscid

Achenes 5-10-ribbed; herbage commonly impressedpunctate and resiniferous.

Pappus present.

Involucral bracts erect.

Leaves entire, usually linear

Leaves not entire.

Herbage glabrous or becoming glabrate

Low woolly alpine perennial, with enormous heads

Involucral bracts spreading or reflexed.

Leaves not decurrent on the stem, usually some of them parted

Leaves decurrent on the stem, entire

Pappus wanting

Receptacle with bristle-like chaff

Herbage with oil-glands, heavy or rank scented.

Leaves pinnately divided.

Leaves entire, narrow

\section{Tribe VII. ANTHEMIDEAE}

Receptacle chaffy, at least in part.

Heads broad; rays conspicuous

Heads narrow; rays short

Receptacle naked.

Heads solitary or corymbose.

Receptacle conical, at least in age

Receptacle flattish or only moderately convex.

Heads radiate

Heads rayless

Tribe VIII. SENECIONEAE

Flowers white or purple; rays wanting

Flowers yellow.

Leaves opposite.

Involucral bracts spreading

Involucral bracts erect or connivent

Leaves alternate.

Shrubs; heads rayless, 4-9-flowered

Herbs; rays usually present, flowers many
61. Psilostrophe.

62. Pericome.

63. Hymenopappus.

64. Leucampyx.

65. Polypteris.

67. Platyschkuhria.

66. Eriophyllun.

68. Bahia.

69. Chaenactis.

70. Hulsea.

71. Actinella.

72. Hymenoxys.

73. Rydbergia.

74. Dugaldea.

75. Helenium.

76. Flaveria.

77. Gaillardia.

79. Pectis.

80. Anthemis.

81. Achillea.

82. Matricaria.

83. Chrysanthemum.

84. Tanacetum.

85. Artemisia.

86. Petasites.

87. Haploesthes.

88. Arnica.

89. Tetradymia.

90. Senecio.
78. Dysódia. 
Tribe IX. CYNAREAE

Leaves and usually the involucral bracts prickly

91. Carduus.

Tribe X. CICHORIEAE

Pappus plumose or scale-like.

Flowers not yellow.

Achenes beakless

Pappus of bristle-form scales

Pappus plumose

Achenes beaked

Flowers yellow.

Involucral bracts in 1 row

Involucral bracts in 2 or more rows.

Pappus scales unequal; achenes fusiform

Pappus of capillary bristles, never plumose.

Pappus deciduous, all the bristles falling away together, except

1-8 stouter ones which may persist

Pappus persistent or the bristles falling separately.

Flowers rose or purplish.

Annuals

Perennials.

Stems nearly leafless

Stems with ample leaves

Flowers yellow, blue, or white.

Stems more or less leafy; heads several to many (rarely solitary).

Achenes not flattened.

Pappus white

Pappus sordid or fulvous

Achenes flattened.

Involucre cylindraceous

Involucre campanulate

Stems scapose, with solitary heads.

Achenes not spinulose at apex

Achenes spinulose at apex

\section{Synoptical Key to the Genera}

\section{Series A. TUBULIFLORAE}

Corolla tubular in all the perfect flowers, regularly 5 (rarely 3-4) -lobed, ligulate only in the marginal or ray-flowers, which when present are either pistillate only, or neutral (with neither stamens nor pistil).

Tribe I. VERNONIEAE. Heads discoid; the flowers all alike, perfect and tubular, never yellow. Branches of the style long and slender, terete, thread-shaped, minutely bristly-hairy all over. Leaves alternate or scattered.

1. Vernonia. Heads several-many-flowered, separate. Involucre of many bracts. Pappus double, the inner capillary, the outer of minute chaffy bristles.

Tribe II. EUPATORIEAE. Heads discoid; the flowers all alike, perfect and tubular, never yellow. Branches of the style thickened upward or club-shaped, obtuse, very minutely and uniformly pubescent; the stigmatic lines indistinct.

* Pappus of slender bristles.

+ Achene 5-angled; bristles of the pappus roughish.

2. Eupatorium. Involucre of more than 4 bracts and the flowers few or many.

++ Achene 10-ribbed; involucral bracts striate-nerved.

3. Kuhnia. Pappus very strongly plumose. Bracts of the involucre few.

4. Brickellia. Pappus merely scabrous. Involucral bracts in several series.

5. Liatris. Pappus plumose or only barbellate. Corolla red-purple, strongly 5-lobed. Heads spicate or racemose, the involucre well imbricated.

Tribe III. ASTEREAE. Heads discoid, the flowers all alike and tubular; or else radiate, the outer ones ligulate and pistillate. Anthers not caudate at base. Branches of the style in the perfect flowers flat, smooth up to where the conspicuous, marginal, stigmatic lines abruptly terminate, and prolonged above this into a flattened lance-shaped or triangular appendage which is evenly hairy all around or pubescent outside. Leaves alternate. Receptacle naked (destitute of chaff) in all our species.

* Ray-flowers yellow, or sometimes none at all.

- Pappus of not numerous slender bristles; heads radiate; involucre of firm bracts with greenish tips, commonly coated with resin.

6. Gutierrezia. Heads small, numerous; ray-and disk-flowers 1-10 each, all fertile. Pappus of several short chaffy scales. Suffrutescent; leaves very narrow.

7. Grindelia. Heads large, many-flowered; flowers all fertile. Pappus of $2-8$ rigid caducous awns. Coarse herbs with toothed leaves.

++ Pappus (at least of the disk) of copious slender or capillary bristles. 
++ Pappus double.

8. Chrysopsis. Heads many-flowered; rays numerous. The outer pappus of very small chafiy bristles, much shorter than the inner of copious capillary bristles. +++ Pappus simple.

a. Pappus a single row of capilary bristles.

9. Chrysothamnus. Involucre narrowly turbinate; the bracts chartaceous, usually in 5 vertical ranks. Rays none. Pappus a single row of capillary bristles.

10. Isocoma. Involucre broadly turbinate; the bracts imbricated but not in vertical ranks. Rays none. Pappus as in the preceding.

aa. Pappus of many unequal bristles.

11. Sideranthus. Involucre hemispherical; the bracts chartaceous, with green tips. Rays usually present. Leaves with spinulose-tipped teeth.

12. Pyrrocoma. Involucre hemispherical; the bracts more or less foliaceous, Rays conspicuous. Leaves with spinulose-tipped teeth, the basal large, the cauline reduced.

13. Oonopsis. Involucre from hemispherical to turbinate; the bracts more or less greentipped and cuspidate-acuminate. Stems leafy up to the sessile heads.

14. Macronema. Involucre turbinate; the outer bractsfoliaceous. Rays often wanting. Stems leafy throughout.

15. Stenotus. Involucre hemispherical; the bracts not green-tipped, mucronately acute. Rays few-several. Stems scapose or at least naked above.

16. Tonestus. Involucre broadly hemispherical; the bracts herbaceous, very obtuse. Rays conspicuous. Stems low, equably leafy.

17. Petradoria. Involucre turbinate to ovoid; the bracts in more or less distinct vertical rows. Achenes cylindric, 10-striate.

18. Oreochrysum. Involucre campanulate; the bracts chartaceous or the outer foliaceous. Rays 12-20. Achenes angled.

aaa. Pappus of numerous capillary bristles.

19. Solidago. Heads few-many-flowered, numerous, in racemes, panicles, or corymbs; rays $1-16$.

** Ray-flowers white, blue, pink, or purple, rarely yellow in no. 27.

+ Pappus very short, a mere crown or a few scales or awn-like bristles.

20. Townsendia. Involucre broad, many-flowered; the bracts more or less scarious. margined.

$$
++ \text { Pappus of numerous, long, and capillary bristles. }
$$

+ Rays conspicuous.

21. Xylorhiza. Involucral bracts in about 2 series, mucronulate, carinate below, herbaceous with scarious margins.

22. Aster. Involucral bracts in several series, usually herbaceous at tip, not reflexed or recurved.

23. Machaeranthera. Involucral bracts herbaceous and spreading, or recurved or reflexed, in several series.

24. Oreastrum. Involucre hemispherical; the bracts narrow and subequal. Stems scapiform, monocephalous.

25. Ionactis. Involucre hemispherical; the bracts imbricated, coriaceous, and wholly appressed. Stems equably leafy.

26. Leucelene. Involucre turbinate; the bracts narrow, herbaceous but scarious-margined. Leaves narrow, subulate, numerous, and mostly appressed.

27. Erigeron. Heads many-flowered, on naked peduncles. Involucres of narrow equal bracts in two rows. Pappus simple or with some outer minute scales.

28. Wyomingia. Heads large; the involucral bracts in 3-4 series, rigid with a thickened midrib. Pappus in 2 series, the outer short, multisquamellate. +++ Rays iniconspicuous or none.

29. Leptilon. Heads small, radiate or discoid; involucres campanulate; bracts narrow, in 2-3 series. Annúals.

30. Baccharis. Heads rayless, many-flowered, dioecious (all pistillate or all staminate). Smooth glutinous shrubs.

Tribe IV. INULEAE. Heads discoid (radiate only in Inula), the pistillate flowers mostly filiform and truncate. Anthers sagittate, the basal lobes attenuate into tails. Stylebranches with unappendaged, obtuse or truncate naked tips. Pappus capillary or none.

* Receptacle chaffy.

31. Filago. Receptacle hemispherical or conical; fertile flowers in 2 sets separated from each other by a ring of chaffy bracts. Low woolly annuals.

* * Receptacle naked; involucral bracts many, scarious; floccose-woolly herbs. + Heads dioecious or nearly so.

32. Antennaria. Heads dioecious. Pappus of sterile flowers club-shaped or barbellate; of the fertile capillary, united at base and deciduous together.

33. Anaphalis. Heads dioecious or nearly so. Pappus not thickened above or at all united at base.

++ Heads all fertile throughout.

34. Nacrea. Flowers all hermaphrodite; pappus clavate-thickened upward.

35. Gnaphalium. Flowers all fertile but only the inner hermaphrodite; pappus capillary.

Tribe V. HELIANTHEAE. Heads radiate or discoid; involucre not scarious (nut-like in fruit in nos. 42, 43 and 44). Receptacle chaffy. Pappus never capillary, sometimes none. Anthers not caudate. Style-branches truncate or hairy-appendaged.

* Ray-flowers fertile and ligulate (sometimes obscurely so); disk-flowers sterile. + Rav flowers with conspicuous ligules.

36. Melampodium. Involucral bracts in 2 very dissimilar sets.

ROCKY MT. BOT. -31 
++ Ray-flowers with ligule wanting or reduced to $2-3$ teeth.

37. Parthenice. Involucral bracts mostly in 1 series, the inner minute or wanting. A caulescent annual.

38. Bolophyta. A caespitose, acaulescent perennial.

* * None of the flowers ligulate, the fertile few $(1-5)$, with minute tubular corolla or none. + Heads alike.

39. Oxytenia. Acheues with a terminal areola surrounded by a disk. Involucres of 5 dilated, ovate, rigidly acuminate bracts.

40. Iva. Achenes short, thick. Involucre of a few roundish bracts.

41. Dicoria. Achenes flattened, wing-margined. Involucres of 5 ovate-oblong herbaceous bracts and 1 or 2 scarious ones subtending the pistillate flowers.

$+\div$ Heads of two kinds, the fertile with a tuberculate or bur-like involucre.

42. Ambrosia. Bracts of staminate involucre united; fertile involucre with a single row of tubercles near the summit. Fruiting head 1-seeded.

43. Franseria. Staminate involucre as in no. 42; sterile involucre with more than 1 row of tubercles or prickles. Fruiting head 2-4-seeded.

44. Xanthium. Bracts of the staminate involucre distinct. Fruiting head 1-4-celled, 1-4-beaked.

* * * Disk-flowers fertile, the corollas funnel-form; anthers blackish; pappus none, or a crown or cup, or of 1-2 chaffy awns, neither capillary nor of several uniform chaffy scales; leaves more commonly opposite.

+ Rays persistent upon the mature achenes.

45. Crassina. Achenes of the disk compressed. Leaves entire.

46. Heliopsis. Achenes 4-sided. Leaves toothed.

+ + Rays deciduous or wanting. Chaff scale-like, embracing or subtending the achenes; the involucre of two or more rows of separate bracts.

++ Receptacle high conical or columnar in fruit; pappus none or a short crown or awn. $=$ Rays pistillate, sterile.

47. Brauneria. Rays rose-colored (rarely yellow). Achenes short, 4-sided. Chaff spinescent.

48. Gymnolomia. Rays yellow. Achenes compressed-quadrangular.

$==$ Rays neutral.

49. Rudbeckia. Achenes 4-sided or terete, flat at the top, marginless.

50. Ratibida. Achene flattened laterally and margined.

+++ Receptacle flat to convex.

$=$ Achenes not winged or very flat.

51. Balsamorrhiza. Achenes 3-4-angled. Pappus none. Chaff linear-lanceolate.

52. Wyethia. Achenes elongated, 4-5-winged. Pappus a laciniate crown, one of the teeth usually elongated and persistent, or all distinct.

53. Helianthus. Achenes flattened, bearing 2 very deciduous, chaffy pointed scales and rarely minute intermediate ones.

$==$ Achenes thin-edged, margined or winged, often awned.

54. Helianthella. Rays neutral. Achenes merely margined.

55. Ximenesia. Rays fertile. Achenes winged.

**** Rays few and neutral, or wanting; achenes obcompressed, i. e., flattened parallel with the scales of the involucre (rarely terete); involucre double, the outer spreading and often foliaceous; receptacle flat; leaves opposite. + Plants not glandular-viscid.

56. Coreopsis. Involucral bracts distinct or united only at base. Pappus of 2 (or rarely more) scales, teeth, or awns, which are naked, not barbed, sometimes obsolete or a mere crown.

57. Bidens. Involucral bracts distinct or united merely at base. Pappus of 2 or more rigid and persistent barbed awns or teeth.

58. Thelesperma. Inner involucre connate to the middle. Achenes terete. Awns 2, retrorsely hispid.

+ - Plants more or less glandular viscid.

59. Madia. Bracts of involucre uniserial, more or less inclosing the achenes of the fertile rays.

60. Layia. Bracts of the involucre flattened on the back below, with abruptly dilated thin margins abruptly infolded so as to inclose the ray achene.

Tribe VI. HELENIEAE. Nearly as Tribe V, but receptacle not chaffy (somewhat so in nos. 75 and 76 ). In our genera, the disk-flowers perfect and fertile; the pappus a row of several chaffy scales (bristly-dissected in no. 78); the involucre hardly at all imbricated (partly scarious in nos. 64, 65 and 66 ).

* Herbage without oil-glands.

+ Ligules persistent on the striate achenes and becoming papery.

61. Psilostrophe. Plants more or less woolly.

++ Ligules deciduous or wanting.
+ + Achenes flat, with only marginal nerves.

62. Pericome. Involucral bracts lightly connate by their edges into a campanulate cup. ++ Achenes angled (not flat), nerved or striate. $=$ Receptacle not chaffy.

a. At least the tips of the involucral bracts petaloid or scarious.

$b$. Heads rayless.

63. Hymenopappus. Involucre broadly campanulate; the bracts 6-12. Lobes of the disk corollas spreading or reflexed.

$b b$. Heads radiate.

64. Leucampyx. Ligules ochroleucous or white, merely toothed.

65. Polypteris. Ligules purple, deeply cleft. $a a$. Involucral bracts not petaloid or scarious. 
b. Achenes 4-angled.

66. Eriophyllum. Bracts of the involucre in 1 or 2 series and more or less united; ligules broad.

67. Platyschkuhria. Perennial with entire leaves mostly radical and subscapose stem. Bracts about 10 , distinct.

68. Bahia. Annuals or perennials, the leaves cleft, divided, or dissected. Bracts distinct.

69. Chaenactis. Annuals or perennials, the leaves pinnate or bipinnate. Heads of white flesh-colored flowers, rayıess.

70. Hulsea. Low viscid perennial. Pappus of about 4 erose truncate scales.

$b$. Achenes 5-10-ribbed; herbage commonly impressed-punctate and resiniferous. c. Pappus present.

d. Involucral bracts erect.

71. Actinella. Leaves entire. Stems scapose or with a few linear leaves low.

72. Hymenoxys. Leaves 1-3-ternately parted, if wholly only in the axils of the radical leaves. Heads medium.

73. Rydbergia. Low woolly alpine perennial with enormous heads.

dd. Involucral bracts spreading or reflexed.

74. Dugaldea. Leaves entire or parted, not decurrent on the stem.

75. Helenium. Leaves entire, decurrent on the stem.

76. Flaveria. Heads small; the involucre of $2-5$ concave carinate bracts. $==$ Receptacle with bristle-like chaff.

77. Gaillardia. The large ligules 3-toothed or 3-cleft. * * Herbage with oil-glands, heavy scented; pappus a row of chaffy bristles dissected into

78. Dysodia. Bracts of the involucre united at the base.

79. Pectis. Bracts of the involucre distinct.

Tribe VII. ANTHEMIDEAE. Distinguished from the last two tribes by the more or less dry and scarious-imbricated bracts of the involucre. Heads radiate (rays mostly white) or discoid, the perfect flowers sometimes sterile and the pistillate rarely tubular. Achenes small; pappus a short crown or none. Mostly strong-scented; leaves alternate. * Receptacle chaffy, at least in part; heads radiate, many-flowered.

80. Anthemis. Achenes subterete, angled or ribbed. Heads hemispherical, rather large.

81. Achillea. Receptacle flattish. Achenes obcompressed. Heads small, campanulate or obovoid.

$$
\text { ** Receptacle naked. }
$$

+ Heads solitary or corymbose.

+ Receptacle conical at least in age.

82. Matricaria. Heads pedunculate. Rays pistillate or none. Pappus crown-like or

none. Leaves finely dissected.
+++ Receptacle flattish or moderately convex. Corollas of the perfect flowers 5-toothed. Achenes sessile.

83. Chrysanthemum. Heads radiate; rays pistillate. Achenes 5-10-nerved; pappus none.

84. Tanacetum. Heads discoid. Pistillate flowers few, marginal, the corollas inconspicuous, 2-3-toothed. Achenes 3-5-angled; pappus none or a short crown. ++ Inflorescence from spike-like to chiefy racemose-paniculate.

85. Artemisia. Heads small, usually drooping, discoid. Pappus none.

Tribe VIII. SENECIONEAE. Heads radiate or discoid, the involucre little or not at all imbricated or scarious. Receptacle naked. Anthers tailless. Pappus capillary.

* Heads monoecious or subdioecious, the perfect flowers mostly sterile, and the small

(ligulate or tubular) ray-flowers in more than one row (at least in the fertile heads); style-branches obtuse, not appendaged or hispid; leaves chiefly radical.

86. Petasites. Heads corymbed, subdioecious. Flowers white or purplish.

87. Haploesthes. Heads few, cymose. Flowers yellow.

** Flowers all fertile; style-branches truncate or capitellate, often appendaged; involucral bracts connivent-erect.

+ Leaves opposite.

88. Arnica. Heads showy. Pappus rather rigid, scabrous or barbellate.

89. Tetradymia. Heads discoid; the bracts 4-6, firm, erect, concave, and overlapping.

90. Senecio. Heads usually radiate; the bracts several to many, and usually with 1 or 2 rows of erect bracteoles.

Tribe IX. CYNAREAE. Flowers all tubular and perfect. Involucre much imbricated. Anthers caudate, long-appendaged at tip. Style-branches short or united, obtuse, unappendaged, smooth, with often a pubescent ring below. Pappus mostly bristly. Leaves alternate.

91. Carduus. Heads many-flowered. Pappus usually plumose, more rarely merely roughened.

\section{Series B. LIGULIFLORAE}

Corolla ligulate in all the flowers of the head, and all the flowers perfect. Herbs with milky juice. Leaves alternate.

Tribe X. CICHORIEAE. Characters of the series.

* Pappirs plumose or scale-like.

+ Flowers not yellow.

\# Achenes beakless.

92. Cichorium. Involucre double. Pappus a small crown of bristle-form scales. 
93. Stephanomeria. Involucre double but the outer bracts small-calyculate. Pappus plumose.

++ ++ Achenes beaked.

94. Tragopogon. Involucre simple, not calyculate. Pappus plumose.

++ Flowers yellow.

95. Krigia. Involucre simple. Achenes short-cylindric, with broad truncate summit; pappus of both scales and bristles.

96. Nothocalais. Involucral bracts in 2 series, nearly equal. Achenes fusiform; pappus of 10-30 unequal scales (sometimes also some capillary bristles).

97. Ptilocalais. Involucral bracts imbricated in several series. Achenes linear or turbin ate; pappus mostly of scales terminating in a plumose bristle.

* * Pappus of capillary bristles, never plumose.

+ Pappus bristles deciduous together, or 1-8 stouter ones persistent.

98. Malacothrix. Achenes columnar, 5-15-striate.

++ Pappus persistent or the bristles falling separately.

++ Flowers rose or purplish.

99. Lygodesmia. Stems nearly leafless. Achenes tapering at summit; pappus white.

100. Prenanthella. Leaves ample. Achenes ribbed, tapering to the base. Annuals.

101. Prenanthes. Leaves ample, the cauline in part clasping. Achenes terete or 4-5angled. Perennials.

+++ Flowers yellow, blue, or white.

$=$ Leaves not all basal; heads several to many, or rarely solitary.

$a$. Achenes not flattened.

102. Crepis. Achenes tapering upward. Bracts more or less thickened at the base or on the midrib at maturity. Pappus white.

103. Hieracium. Achenes not tapering upward. Bracts not thickened. Pappus sordid or fulvous.

aa. Achenes flattened.

104. Lactuca. Achenes narrowed upward and often beaked. Involucre cylindraceous.

105. Sonchus. Achenes truncate at summit. Involucre campanulate. $==$ Leaves all basal; heads solitary on the scapose stems.

106. Troximon. Achenes smooth at apex, from beakless to long-beaked.

107. Taraxacum. Achenes spinulose at apex, long-beaked.

\section{VERNONIA Schreb. IRONWEED}

Perennial herbs, with leafy stems and alternate and acuminate or very acute leaves. Flowers perfect, mostly purple, discoid; the heads in corymbose cymes, 15-many-flowered. Involucre much imbricated. Receptacle naked. Achenes cylindrical, ribbed, with double pappus (the outer of minute scalelike bristles, the inner of copious capillary bristles).

Leaves conspicuously spinulose-denticulate .

Leaves entire or nearly so

1. V. fasciculata.

1. Vernonia fasciculata Michx. Fl. Bor. Am. 2: 94. 1803. Glabrous or nearly so, 6-12 dm. high: leaves thickish, linear to oblong-lanceolate, conspicuously spinulose-denticulate: heads numerous and crowded on the branches of the compound cyme; involucre $(6-8 \mathrm{~mm}$. high) $20-30$-flowered; the bracts all obtuse, or some of the uppermost abruptly mucronate-acute.-From Dakota to Texas within the eastern limits of our range, and eastward to the Mississippi States.

2. Vernonia Jamesii T. \& G. Fl. 2: 58. 1842. Glabrous or nearly so, $3-5 \mathrm{dm}$. high: leaves linear-lanceolate or linear, like those of narrowest forms of the last, but smaller and less or obsoletely denticulate: heads few or numerous in a loose and open corymbiform cyme, all pedunculate; involucre (8-10 $\mathrm{mm}$. high) 15-25-flowered; the bracts all or mostly obtuse.-Plains of Nebraska and Arkansas to Colorado and Texas.

\section{EUPATORIUM L. THOROUGHWORT}

Erect perennial herbs or sometimes shrubby, often sprinkled with bitter resinous dots, and commonly with opposite (sometimes verticillate) leaves. Heads generally corymbose, discoid, 3 -many-flowered; flowers perfect, white, bluish or purple. Involucre cylindrical or campanulate, few-many-flowered. Receptacle naked, flat or conical. Corolla 5-toothed. Achenes, 5-angled, with a single row of slender, capillary, barely roughish bristles. 
Leaves large (6-10 cm, or more long), usually in verticils of 3

Leaves small ( $2-5 \mathrm{~cm}$. long), opposite.

Involucral bracts striate

Involucral bracts not striate

1. E. maculatum.

2. E. Fendleri.

3. E. texense.

1. Eupatorium maculatum L. Amoen. Acad. 4: 288. 1755. Stems 5-15 $\mathrm{dm}$. high, more or less spotted with purple: leaves in whorls of $3-5$, ovate to ovate-lanceolate, $5-15 \mathrm{~cm}$. long, more or less pubescent and often scabrous, rather coarsely toothed: corymbs flat-topped or ovate: involucres $7-8 \mathrm{~mm}$. high, the outer bracts obtuse, pubescent: corollas white, pink, or purple. ( $E$. Bruneri Gray, Syn. Fl. 1: 96. 1886; E. Rydbergii Brit.; E. atromontanum A. Nels. Bot. Gaz. 31: 400. 1901.) Known as Joe Pye Weed.-From New Mexico, through our eastern border and thence both eastward and westward.

2. Eupatorium Fendleri Gray, Proc. Am. Acad. 17: 205. 1882. Stem 3-6 $\mathrm{dm}$. high, leafy, obscurely puberulent: leaves dentate, opposite or the upper alternate, deltoid-subcordate, tapering gradually to an acute or acuminate point: heads comparatively small and numerous, paniculate, all peduncled; bracts of the involucre all obtuse, the outer oblong: flowers white: achenes minutely pubescent. [E. arizonicum Greene, Pitt. 4: 280. 1901 (?).]-New Mexico and possibly in Colorado and Utah.

3. Eupatorium texense (T. \& G.) Rydb. Fl. Col. 335. 1906. Herbaceous or nearly so, 5-10 dm. high; branches slender, spreading: leaves more or less cinereous-puberulent, deltoid-ovate, obtuse or acute, more or less dentate, slender-petioled: heads $8-10 \mathrm{~mm}$. high, about 12-flowered; involucral bracts nearly or quite nerveless, almost linear. E. ageratifolium.--Infrequent; Colorado and southward.

\section{KUHNIA L. FAlse Boneset}

Perennial caulescent herbs with puberulent or pubescent foliage. Leaves alternate; blades resinous-dotted. Heads discoid, in open or crowded clusters; involucres narrow, several-many-flowered; bracts narrow, in few series, striate, the inner successively longer. Receptacle naked. Corollas white or purplish. Anthers obtuse and entire at the base. Stigmas slender, rather obtuse. Achenes 10-20-striate, columnar. Pappus of one series of very plumose hair-like bristles.

Achenes 10-striate, shorter than the pappus.

Flowers 20-30; stems branched from the base up . . . . 1. K. Hitchcockii.

Flowers 15-20; stems simple below . . . . . 2. K. glutinosa.

Achenes 20-striate, nearly or quite as long as the pappus.

Leaves narrowly lanceolate to linear; stems erect or spreading, usuälly freely branched above

Leaves ovate to lanceolate; stems assurgent, nearly simple .

3. K. Gooddingii. 4. K. reticulata.

1. Kuhnia Hitchcockii A. Nels. Bot. Gaz. 31: 403. 1961. Tuftedsuffrutescent, the lignescent stems decumbent-spreading, each divaricately branched from the base up, dark, minutely puberulent as are also the leaves: stem leaves nearly linear, with a few sharp teeth, 3-4 cm. long; those of the rigid branches numerous, small, linear, 2-3 cm. long: involucre usually subtended by a few linear bractlets, the bracts in about 5 series, the short outer ones broadly lanceolate, the inner broadly linear with thin, scarious margins and cuspidate apex: flowers 20-30, the tube nearly uniform: achenes small, about 10-striate, shorter than the dull white to tawny, distinctly plumose pappus.- On the dry plains east of the mountains.

2. Kuhnia glutinosa Ell. Bot. S. C. \& Ga. 2: 292. 1824. Rather densely rough pubescent; stems 5-12 dm. tall, branching above: leaf-blades lanceolate to linear-lanceolate below, 1-4 cm. long, acute or acuminate, shallowly serrate, sessile by the broad bases or partly clasping: involucres $8-10 \mathrm{~mm}$. high; bracts subulate without, lanceolate to linear within and cuspidateacuminate: achenes $5 \mathrm{~mm}$. long; pappus tawny or brownish. $K$. eupatorioides corymbosa.-From South Dakota to Alabama and Texas and in the eastern part of our range.

3. Kuhnia Gooddingii A. Nels. 1. c. 402. In dense clumps from a tufted 
woody caudex; stems numerous, erect or spreading, 5-8 dm. high: leaves numerous, sparsely and minutely puberulent especially on the margins and veins, linear to narrowly lanceolate, $2-4 \mathrm{~cm}$. long, entire or nearly so, more or less revolute-margined: inflorescence loosely and widely paniculate; the pedicels and involucre finely pubescent: involucres turbinate; the bracts in about 5 series; the outer bracts lanceolate; the inner broadly linear, with villous-pubescent setaceous tip, about 4-striate, sparsely sprinkled with shining resinous particles as are also the corolla-teeth: disk 10-12 $\mathrm{mm}$. high, 15-25-flowered; corolla ochroleucous or shading to brown, slender-tubular: achene linear, finely about 20 -striate, only a little shorter than the white, finely plumose pappus. [K. rosmarinifolia Vent. (K. leptophylla) probably, as to our range.]-From northern Colorado to New Mexico and Utah.

4. Kuhnia reticulata A. Nels. 1. c. 403. Stems several or many, ascending, 3-4 dm. high, simple, light green, finely puberulent: leaves light green, glabrate, closely impressed-punctate, ovate or oblong-lanceolate, $2-4 \mathrm{~cm}$. long, subacute, entire to irregularly few-toothed: cymes congested-corymbose or becoming paniculate: involucre turbinate-campanulate; the bracts in 4 or 5 series, softly pubescent, strongly nervose, resin-sprinkled, shorter than the 12-15 mm. high disk; the outer lanceolate; the inner broadly linear, acute: flowers about 25: style-tips compressed, linear: achenes 20-striate, linear, about $5 \mathrm{~mm}$. long, exceeded by the white, softly plumose pappus.-Eastern Wyoming.

\section{BRICKELLIA Ell.}

Herbs or undershrubs with opposite or alternate leaves and variously disposed heads of white or flesh-colored flowers in late summer. Scales of the campanulate involucre imbricated, lanceolate or linear, the exterior shorter, none herbaceous. Receptacle flat, naked. Corolla slender, 5-toothed at summit, the teeth mostly glandular externally. Pappus a single series of barbellate or subplumose or merely scabrous bristles. Achenes 10-costate or 10-striate.-(Coleosanthus Cass.)

Leaves ovate or cordate-triangular.

Leaves petioled, teeth not spine-tipped.

Heads 30-50-flowered.

Heads more or less umbellately crowded, drooping . $\quad$. 1. B. grandiflora.

Heads cymosely paniculate, erect .

Heads 10-25-flowered.

Leaves 20-40 mm. long; involucral bracts erect

Leaves 5-10 mm. long; involucral bracts squarrose .

Leaves subsessile; teeth spine-tipped

Leaves oblong to linear, sessile.

3. B. Wrightii.

4. B. microphylla.

5. B. atractyloides.

6. B. linifolia.

1. Brickellia grandiflora Nutt. Trans. Am. Phil. Soc. 7: 287. 1841. Puberulent or almost glabrous; stem 3-8 dm. high, paniculately branched, the numerous heads paniculate-cymose and drooping: leaves broadly or narrowly deltoid-cordate, or the upper deltoid-lanceolate, coarsely dentate-serrate and with an entire, gradually acuminate apex (the larger 6-10 cm. long): involucre about 40 -flowered; the bracts papery and scarious-margined when dried; the short outer ones ovate; the inner linear, obtuse or acutish, or some exterior ones with loose subulate acumination: pappus white, inclined to be deciduous. (Includes var. petiolaris Gray; Coleosanthus petiolaris Greene, Bull. Torr. Bot. Club 25: 117. 1898.)-New Mexico to Montana and to Arizona and Washington.

1a. Brickellia grandiflora minor Gray, Proc. Acad. Phila. 67. 1863. Plant usually smaller: the leaves thickish and rugulose-veiny, from puberulent to scabro-pubescent: pedicels mostly shorter than the heads, hence the latter appearing crowded-congested. [Brickellia (Coleosanthus) umbellatus (Greene), Pitt. 4: 238. 1901; C. congestus A. Nels. Bot. Gaz. 31: 401. 1901.]-The more frequent form in our range.

2. Brickellia ambigens (Greene) A. Nels. Herbaceous, 4-7 dm. high, simple up to the rather strict and thyrsiform panicle of middle-sized heads; foliage green and seemingly glabrous, but sparsely scabro-puberulent under 
a lens: lowest leaves opposite, the pairs remote, very thin, deltoid-ovate, 5-8 cm. long, acute, coarsely serrate-toothed; the upper and those subtending the branches of the panicle alternate, all with slender and rather long petioles: involucres $6-7 \mathrm{~mm}$. high, strongly imbricated; the bracts ovate to oblong-linear, obtuse; strongly nerved and tomentose-ciliate: flowers ochroleucous: achenes with 5 prominent angles and as many intervening ribs, not glandular, the angles and ribs scabro-serrulate. (Coleosanthus ambigens Greene, Bull. Torr. Bot. Club 25: 118. 1898; C. Garrettii A. Nels. Proc. Biol. Soc. Wash. 20: 38. 1907.)-New Mexico, Colorado, and Utah.

3. Brickellia Wrightii Gray, Pl. Wright. 2: 72. 1853. Usually much branched from a woody base, $3-10 \mathrm{dm}$. high, puberulent, sometimes a little scabrous: leaves broadly deltoid-ovate, or rounded-cordate and obtuse, or at most acute (but not prolonged upward), more or less crenate-dentate (larger cauline 3-4 cm. long, smaller only $1 \mathrm{~cm}$.): heads glomerate-paniculate, the clusters shorter than or little surpassing the subtending leaves: involucre often purple, turbinate, 10-20-flowered; bracts either obtuse or acute, the outer short-ovate, the inner linear: corolla ochroleucous: pappus white. [Brickellia (Coleosanthus) albicaulis (Rydb.), Bull. Torr. Bot. Club 31: 646. 1904.]-Colorado and Utah to Texas and Arizona.

4. Brickellia microphylla Gray, Pl. Wright. 1: 85. 1852. Glandularpuberulent or pubescent and viscid, 3-5 dm. high, from a partly woody base, paniculately much branched; the short leafy branchlets terminated by 1-3 heads: leaves'subcordate or ovate to oblong, when old somewhat scabrous, obtuse or apiculate, sparingly denticulate or nearly entire, the larger 10-14 $\mathrm{mm}$. long, those of flowering branchlets $2-5 \mathrm{~mm}$. long: heads $10-12 \mathrm{~mm}$. long, about 15-flowered; involucral bracts firm, the outer with green and spreading tips, the lowest herbaceous and passing into the leaves of the branchlets. [Brickellia (Coleosanthus) scaber (Greene), Pitt. 3: 100. 1906.]-From Colorado and Wyoming to Oregon.

5. Brickellia atractyloides Gray, Proc. Am. Acad. 8: 290. 1870. Stems 1-3 dm. high, woody except the new shoots, much branched: leaves ovate-acuminate, green, minutely scabrous-atomiferous, 3-nerved and reticulate-veined, 1-3 cm. long: branchlets terminating in a solitary and slender-pedunculate head: involucre campanulate; the bracts firm-chartaceous; outer ovate, acuminate, little shorter than the linear-lanceolate innermost, 10-13 mm. high, 35-50flowered. (Coleosanthus venulosus A. Nels. Bot. Gaz. 37: 262. 1904.)-Arid areas; Colorado to California.

6. Brickellia linifolia Eaton, Bot. King's Exp. 137. 1871. Minutely glandularpuberulent; stems 1-several, 2-4 dm. high from a woody rootstock, simple or corymbose at the summit: leaves numerous, alternate, sessile, ellipticallanceolate to linear, entire, obscurely 3-nerved, 2-3 cm. long: heads large, 1 or more on elongated somewhat leafy branches: involucre 40-50-flowered, the scales in several series, outer ones ovate, inner ones linear, acute: branches of the style club-shaped, exserted: achenes with a double row of minute bristles along the striae; pappus obscurely plumose. [Brickellia (Coleosanthus) humilis (Greene), Pitt. 4: 124. 1900.].-Sandy banks; Colorado to the Sierra Nevada.

\section{LIATRIS Schreb. Blazing Star}

Erect perennial herbs, usually from a globular tuber, simple or little branched, with alternate, entire, 1-5-nerved leaves, and spicate or racemose discoid heads of rose-purple flowers. Involucre oblong, ovoid, or subhemispheric, the bracts imbricated in several series, the outer shorter. Receptacle flat or slightly convex, naked. Corolla regular, the tube slender, the limb 5-lobed or 5-cleft. Style branches elongated, obtuse or flattened at the apex. Achenes 10-ribbed, slender, tapering to the base. Pappus of 1 or 2 series of slender, barbellate or plumose bristles.-(Laciniaria Hill.) 
1. Liatris punctata Hook. Fl. Bor. Am. 1: 306. 1833. Stems 1-7 dm. high from a thick and branching or sometimes globular stock, stout: leaves all narrowly linear, commonly punctate, rigid: heads oblong or cylindraceous, thickish, 12-18 mm. long, mostly numerous and crowded in a dense spike: bracts of the involucre punctate, oblong, abruptly or sometimes more gradually cuspidate-acuminate, often lanuginous-ciliate.- On the plains; from the Saskatchewan to Montana and southward to Texas and New Mexico.

2. Liatris ligulistylis A. Nels. From an enlarged woody, tuberous root; stems single, 4-5 dm. high, leafy: leaves bright green, rather obscurely punctate, glabrous; the lower lance-oblong, 8-12 cm. long, tapering into a shorter margined petiole; upwardly becoming more lanceolate, gradually smaller, passing into the lance-linear bracts: heads few to several, in a short raceme; peduncles 1-3 cm. long: involucre broadly campanulate, often $20-25 \mathrm{~mm}$. broad; bracts in about 6 series, foliar-green, with dark purple, scarious, laciniate-erose margins; the outer shorter, nearly orbicular to oval; the middle rows broadly obovate; the inner elliptic or oblong and 15-18 mm.long: flowers 50-70, purple: exserted style branches conspicuous, flattened, as long as the corolla, light purple. L. scariosa. (Laciniaria ligulistylis A. Nels. Bot. Gaz. 31: 405. 1901.) - Bottom lands; Colorado, through Wyoming to the Dakotas.

\section{GUTIERREZIA Lag.}

Low suffrutescent or herbaceous plants with nearly glabrous but resinous herbage. Leaves narrowly linear, entire, alternate. Heads radiate, very small, numerous, cymose or paniculate at the summit of the stems; flowers yellow. Involucre imbricated; the bracts coriaceous, with green tips. Receptacle in our species flat. Achenes angled or striate, pubescent. Pappus of 4-15 oblong or narrower commonly erose scales.

Disk- and ray-flowers each 3-10 in each head.

Resinous dots large, bordered by a hyaline scale .

Resinous dots small, not bordered.

Shrubby, at least a part of the main branches persisting .

Only the base woody and persisting.

Involucres turbinate; rays 5-6, disk-flowers 8-10

Involucres clavate-oblong; rays 3-5, disk-flowers 4-7 .

Disk- and ray-flowers each only 1-2 in each head

1. G. lepidota.

2. G. longifolia.

3. G. diversifolia.

4. G. Sarothrae.

5. G. microcephala.

1. Gutierrezia lepidota Greene, Pitt. 4: 57. 1899. Loosely tufted on a woody base, the leafy and floriferous stems $3-5 \mathrm{dm}$. high, smooth and glabrous, the rather large heads loosely cymose-panicled: lower leaves narrowly oblanceolate, obtuse, the upper successively narrower and those under the panicle linear, all ascending, only their margins scabrous, the surface marked with large dots each bordered with a hyaline scale, otherwise glabrous: the very distinctly turbinate involucres about $6 \mathrm{~mm}$. high; the bracts in about 4 series, all with thick, blunt, green tips: flowers of ray and disk each 6 or 7 , light yellow: scales of the pappus all lanceolate, acute.-Known only from type number, Grand Junction, Colorado.

2. Gutierrezia longifolia Greene, 1. c. 54. The leafy and floriferous branches 3-6 dm. high; older stems terete, the newer striate and somewhat angled, devoid of even a scabrous pubescence, or nearly so: leaves glabrous or puberulent, linear, $5 \mathrm{~cm}$. long or more, 1-nerved: heads sessile and glomerate at the ends of fastigiate branchlets and forming a broad, nearly flat-topped inflorescence: involucres elongated, obovate-turbinate, $5 \mathrm{~mm}$. high; the bracts long, with thick, short, green tips: flowers of ray and disk each 4 or 5 : pappus scales of about the same number, mostly lanceolate, those of the ray shorter. (G. linearis Rydb. Bull. Torr. Bot. Club 31: 647. 1904.)-Colorado and Utah to New Mexico.

3. Gutierrezia diversifolia Greene, 1. c. 53. Stems 1-2 dm. high, tufted on a short, stout, ligneous crown, angled and often scabrous but hardly glutinous: lowest leaves somewhat oblanceolate, the short blade tapering to a longwinged and hispid-ciliolate petiole; only the uppermost truly linear; inflo- 
rescence of large and rather broadly turbinate involucres formed into an open more or less dichotomous cyme: bracts of the involucre in only about 3 series, with thick, obtuse, green tips: rays 5 or 6 , disk-flowers 8 or 10 : pappus-scales in the disk-flowers 8-12, very narrow and acute, those of the disk (as is usual in the genus) less than half as long. (G. scoparia Rydb. l. c.)-Common on the plains and in the foothills; Montana to New Mexico and westward.

4. Gutierrezia Sarothrae (Pursh) B. \& R. Trans. N. Y. Acad. 7: 10. 1887. Bushy plant with numerous erect stems from a woody base, $3-6 \mathrm{dm}$. high: inflorescence cymose-paniculate; heads short-peduncled or sometimes in terminal glomerules of 3-5: involucre clavate-oblong, 3 or $4 \mathrm{~mm}$. high; bracts with minute green tips: disk- and ray-flowers each 3-7: achenes sericeous-pubescent. G. Euthamiae. (G. juncea Greene, 1. c. 56; G. divaricata Nutt.; G. myriacephala A. Nels. Bot. Gaz. 37: 264. 1904. Numbers 2 and 3 above are closely allied to this and are distinguished from it with difficulty. It were better perhaps to consider them forms of this as did Dr. Gray.) Almost throughout the western United States.

5. Gutierrezia microcephala Gray, Pl. Fendl. 74: 1848. Tufted stems 3-6 dm. high, slender, fastigiately corymbose, the branches of the season striate, glabrous or hirtellous: leaves narrowly linear, ascending, scaberulous, punctate, the ultimate twigs of the inflorescence and the involucres glutinous; the latter mostly sessile in glomerules of $3-5$, nearly cylindric, usually with only 1-2 each of ray- and disk-flowers; the bracts few, obtuse or acute, scarcely green-tipped.' (G. glomerella and G. filifolia Greene, 1. c. $54 \& 55$.)-Colorado to Texas and westward.

\section{GRINdelia Willd. Gum Plant}

Coarse biennials or perennials. Basal leaves commonly petioled; the cauline mostly sessile, either narrowed petiole-like or clasping by a broad base. Herbage glabrous or scabro-puberulent, balsamic-viscid and often punctate. Heads gummy, medium to large, in panicles or cymes, or rarely solitary; disk and rays yellow, or rarely the latter wanting. Involucre campanulate or hemispheric; the bracts many-ranked, firm-herbaceous, often with attenuate, squarrose points. Style-appendages lanceolate or linear. Achenes short, truncate, compressed or turgid, glabrous. Pappus of 2-8 awns or small scales, very readily deciduous.

Biennials strictly.

Cauline leaves mostly oblanceolate and narrowed to a petiole-like base; pappus bristles distinctly barbellate.

Stems usually' 2 or more from the crown, low (2-4 dm.) .

Stems usually solitary, tall (4-8 dm.)
Cauline leaves mostly oblong and sessile by a broad somewhat clasping base; pappus-awns apparently smooth.

Involucral bracts broad with flattened tips

Perennials.

Involucral bracts narrow, with terete tips

Rays wanting

Rays present.

Stems and leaves glabrous.

None of the involucral bracts reflexed; pappus-awns barbellate above

Some of the outer (at least) involucral bracts reflexed; pappusawns apparently smooth.

Leaves evenly serrate or dentate

Leaves irregularly toothed or lacerate

Stems and leaves crisped-hairy or subscabrous

1. G. subalpina.

2. G. erecta.

3. G. texana.

4. G. squarrosa.

5. G. fastigiata.

6. G. decumbens.

7. G. perennis.

8. G. subincisa.

9. G. scabra.

1. Grindelia subalpina Greene, Pitt. 3: 297. 1898. Biennial, usually 2several unequal stems from the crown, 2-4 dm. high, corymbose-panicled: leaves mostly oblanceolate, those of the crown slender-petioled, more or less toothed and incised, the teeth mucronate: heads depressed-globose; bracts of the involucre numerous, with filiform, squarrose-spreading and more or less reflexed tips, the whole very glutinous (before opening often filled with the white gummy exudation): rays numerous, the expanded head $3-5 \mathrm{~cm}$. broad. 
(G. platylepis Greene, 1. c. Probably based on an abnormal specimen.)-On the high plains; Montana to Colorado.

2. Grindelia erecta A. Nels. Bull. Torr. Bot. Club 26: 356. 1899. Biennial, stem single from the enlarged crown of a strong taproot, erect, simple below, corymbose-paniculate above, $4-8 \mathrm{dm}$. high: leaves ample, serrate, the teeth short, acute; radical leaves early deciduous the second season, oblanceolate, on slender petioles, gradually expanded to a broadish base; the lower cauline similar and also petioled but becoming sessile upward, 6-10 $\mathrm{cm}$. long; the uppermost smaller, oblong, sessile by a clasping base: heads large, subglobose, usually leafy-bracteate; involucral bracts numerous, moderately glutinous, appressed, with slender recurved tips: rays slender, numerous, $14-18 \mathrm{~mm}$. long: pappus bristles 2-6, mostly 4, slender, closely barbelluate.-In the cañons of the foothills and mountains; Wyoming and Colorado.

3. Grindelia texana Scheele, in Linn. 21: 60. 1848. Stems stout, erect, simple below, 6-12 dm. high: leaves dark or bluish-green, with slender spinulose teeth, only the crown leaves petioled; the cauline oval above to ovate-oblong below, sessile by a broad clasping base: heads large, the rays 20-25 mm. long; the bracts broad, even the squarrose tips flat. (Not the G. grandiflora Hook. of Texas.) - Central Colorado to New Mexico.

4. Grindelia squarrosa (Pursh) Dunal, DC. Prodr. 5: 315. 1836. Glabrous, commonly freely branched from the base up, 3-6 dm. high: leaves oblong or oblong-spatulate, obtuse, more or less clasping at the base, sharply dentate, sometimes laciniate, $1-3.5 \mathrm{~cm}$. long, 6-12 $\mathrm{mm}$. wide: heads very glutinous; bracts of the involucre linear-lanceolate, subulate-tipped, strongly squarrose: achenes truncate, those of the outer flowers usually thicker than those of the inner; pappus of 2 or 3 awns.-From Minnesota and Manitoba to Nevada, Texas, and Mexico.

5. Grindelia fastigiata Greene, Pitt. 3: 102. 1896. Stems few to several from the woody root, decumbent at base or if few mostly erect, simple or freely branched, 2-4 dm. high: leaves more or less serrate or toothed; the crown leaves petioled, lanceolate or oblanceolate; the cauline mostly sessile, ovate to narrowly oblong, often clasping by the broadish base: heads medium size, subspherical; involucral bracts numerous, glutinous, slender, with squarrose, reflexed or recurved tips: rays wanting: pappus awns 2 or 3 . [G. nuda Wood (?); G. inornata Greene, l. c.; G. aphanactis Rydb. Bull. Torr. Bot. Club 31: 647. 1904; the latter seemingly founded upon an abnormal specimen of G. perennis.] - Colorado and New Mexico.

6. Grindelia dec umbens Greene, Pitt. 3: 102. 1896. Stems several, 2-4 dm. high, decumbent at base, encircling a tuft of radical leaves: radical leaves thinnish, oblanceolate, obtuse, $3-5$-toothed, tapering very gradually to the narrowly winged petiole; cauline leaves few and small, oblong, acute, entire: heads many, rather small, in a corymbose panicle; bracts of the subglobose involucre rather few, only the outermost short ones conspicuously squarrose: rays ample but few and remote, 10 or 12 to the head: ray-achenes trigonous, those of the disk thin and flat, striate; the 2 pappus-awns stout, flat, barbellate above.-Colorado to New Mexico.

7. Grindelia perennis A. Nels. l. c. 110. Root woody, usually with numerous slender secondary ones; stems 1 or more from the crown, paniculately corymbose branched above, $3-5 \mathrm{dm}$. high, rather leafy above, the basal early deciduous: leaves denticulate, the basal and lowest cauline short-petioled, oblanceolate; the middle cauline sessile, oblong or oblanceolate, 4-7 cm. long; the uppermost oblong or reduced to mere bracts: heads rather numerous, the rays numerous (20-30), about $1 \mathrm{~cm}$. long; involucral bracts glutinous, strongly recurved in undeveloped heads, only slightly squarrose at maturity: pappus bristles 2-6.-From Montana to New Mexico, especially on saline flats.

8. Grindelia subincisa Greene, Pitt. 4: 154. 1900. Stems 2 or more, decumbent, 2-3 dm. high, rather loosely branched, the branches slender, sparingly leafy, and mostly monocephalous: lowest leaves oblanceolate, rather thin, the margin variously but usually remotely incisely serrate; those of the branches oblong-lanceolate and sessile, incisely serrate: involucres hemi- 
spherical or subglobose, 12-16 $\mathrm{mm}$. broad, the numerous bracts with long. slender, more or less squarrose green tips: rays numerous, long, goldenyellow: achenes all turgid, those of the ray trigonous, of the disk somewhat compressed and 2-edged; bristles of the pappus 3 in the ray, 2 in the disk, all short, slender for the genus, glabrous.-Dry hills; Colorado and New Mexico.

9. Grindelia scabra Greene, Bull. Torr. Bot. Club 25: 120. 1898. Perennial, crisped-pubescent or subscabrous; stems 1-several from the woody root, 2-4 dm. high: lowest leaves oblanceolate, petiolate; those of the branches oblong, ses le by a somewhat clasping base; all sharply but not deeply spinulose-serrate: hemispherical involucre of very numerous bracts, all with long, linear-subulate, scarcely glutinous, suberect herbaceous tips: rays golden-yellow: achenes very small, somewhat compressed-pyriform; bristles of pappus 2 or 3, scabrous-serrulate on the margins below.-New Mexico and probably in Colorado.

\section{CHRYSOPSIS Nutt. GOLDEN AsTer}

Perennial herbs, with alternate sessile leaves and large many-flowered heads of both disk and radiate yellow flowers corymbose or solitary at the ends of the branches. Involucre campanulate to hemispheric, the bracts narrow, imbricated in several series, the outer shorter. Receptacle usually flat, foveolate. Ray-flowers pistillate; disk-flowers mostly all perfect. Pappus double in both the disk- and ray-flowers, the inner of numerous rough capillary bristles, the outer of smaller or minute scales or bristles. Achenes flattened, oblong-linear or obovate. Style branches narrow, somewhat flattened, their appendages linear or subulate.

Decidedly viscid or glandular, this character more noticeable than the scanty hispid or hirsute pubescence.

Uppermost leaves scarcely reduced, ovate to oblong

Uppermost leaves greatly reduced, lanceolate to linear

Scarcely viscid or glandular, this character less noticeable than the pubescence.

Pubescence mostly short, hispid and more or less spreading; stems ciliate-hirsute; leaves oblanceolate, petioled except the uppermost.

Stems tufted, simple below, corymbose-paniculate at summit.

Plant green but sometimes pale

Plant canescent, often densely so

Stems branched from the base upwara

Pubescence appressed, at least on the leaves; that of the stems of ten hirsute-ciliate.

Leaves all narrowed to a slender petiole, except the uppermost; lower leaves early deciduous.

Pubescence short, fine and appressed; stems branched above; heads solitary or few

Pubescence coarser, villous and more or less spreading. Stems freely branched, with numerous heads
Stems simple; heads solitary or few at the summit

Leaves sessile or subsessile except the lower which are early deciduous.

Stems short (3-15 cm.), depressed-spreading; leaves $1-2 \mathrm{~cm}$.

Stems longer (20-30 cm.), assurgent or suberect; leaves $3-\dot{7}$ $\mathrm{cm}$. long.

Heads few, sessile, subtended by foliar bracts and crowded into a dense terminal cluster

Heads more numerous, sessile or peduncled, usually in an ample fastigiate corymb.

Plant green, often pale, more or less soft-hirsute or even

Plant canescent, often silky-villous or appressed long-

1. C. resinolens.

2. C. viscida.

3. C. arida.

4. C. hirsutissima.

5. C. hispida.

6. C. Bakeri.

7. C. villosa.

8. C. pumila.

9. C. depressa.

10. C. fulcrata.

11. C. foliosa.

12. C. mollis.

1. Chrysopsis resinolens A. Nels. Bull. Torr. Bot. Club 28: 232. 1901. Green, resin-scented; root woody, the crown bearing few to many ascending or suberect stems; stems $2-4 \mathrm{dm}$. high, very leafy, sparsely hispid-ciliate and minutely glandular or resinous: leaves with minute gland-tipped hairs or dotted with resinous particles, hispid-ciliate especially on the margins; the 
lower dead and falling away at anthesis, narrowly oblanceolate, on short, hispid-ciliate petioles; the upper sessile, oblong or subspatulate, $3-5 \mathrm{~cm}$. long, obtuse or subacute, apiculate: inflorescence crowded, very leafy, densely but finely glandular, the leafy bracts hispid-ciliate on the margins; heads few (3-10), rather large, paniculately corymbose; involucre broadly campanulate, $1 \mathrm{~cm}$. high, green, granular-resinous, ciliate-pubescent: rays 20 (more or less), deep yellow or orange-colored, 8-12 mm. long: pappus dingy, the outer series distinct, of short, narrow scabrous-margined scales.-Frequent in sandy soil; Wyoming and Colorado to Utah.

1a. Chrysopsis resinolens ciliata A. Nels. 1. c. Leaves lanceolate, acute, nearly glabrous, closely glandular-dotted, conspicuously ciliate-margined as are also the leaf-like bracts.-Southern Wyoming.

1b. Chrysopsis resinolens obtusata A. Nels. Rydb. Fl. Col. 340. 1906. Leaves all very obtuse; the upper narrowly obovate and sessile; the lower with narrow margined base: heads large and with oblong or elliptic-ciliate leaf-like bracts.-Wyoming and Colorado.

2. Chrysopsis viscida (Gray) Greene, Erythea 2: 105. 1894. Low, rigid, strongly decumbent, 1-2 dm. high: leaves green, rather obscurely strigosepubescent but viscid-hirtellous or with viscid points, oblong, obtusish: involucre viscidulous: outer pappus distinct, of linear or subulate short scales. -Western Wyoming and Colorado through Utah to Arizona.

3. Chrysopsis arida A. Nels. Rydb. Fl. Col. 340. 1906. From a branched woody caudex, the exposed crowns covered by the persistent stem bases; pubescence a rather short, uniform, scarcely appressed cinereous hirsuteness, partly concealing the minute resinous atoms with which the plant is sprinkled; stems numerous, ascending, 2-3 dm. long, rather slender and brittle, branching only in the inflorescence: leaves numerous, rather small; the lower narrow, tapering into a slender margined petiole, falling away early; the upper sessile, oblanceolate, oblong or even broader, $1-3 \mathrm{~cm}$. long: inflorescence rather leafy but the uppermost leaves becoming small and bract-like: heads several, corymbosely disposed, moderately large; involucral bracts linear, acute, in 3-4 rows, shorter than the disk rays 9-20: outer pappus of short linear scales.-On dry plains and hills; Wyoming and Colorado and probably farther westward.

4. Chrysopsis hirsutissima Greene, Pitt. 4: 153. 1900. Stems 1-2 dm. high, erect and densely leafy, from a ligneous and branched caudex crowning a strong, deep-seated, woody root; whole plant of a silvery whiteness; the stem clothed with a long and rather stiffly hirsute or hispid white-hairiness: the leaves as white with a dense strigose pubescence, their outline oblanceolate, tapering to short slender petioles, or subsessile: heads solitary in the smaller plants, fastigiate-corymbose in the larger; involucre very regularly imbricated, broadly turbinate: rays rather light yellow: achenes densely appressed-silky; outer pappus obvious, indistinctly paleaceous. (C. horrida Rydb. Bull. Torr. Bot. Club 31: 648. 1904; C. asprella Greene, Leaflets 1: 150. 1905.)-Dry rocky slopes; Colorado.

5. Chrysopsis hispida (Hook.) Nutt. Trans. Am. Phil. Soc. 7: 316.1841. Hispid throughout with uniform spreading hairs; stems erect or if several decumbent at base, branching freely, 2-3 dm. long: leaves oblong-spatulate or oblanceolate, subacute or obtusish at apex; the radical long-petioled: corymb ample: involucral bracts linear, acute: achene obovate-oblong, hairy; outer pappus distinctly paleaceous. (C. floribunda Greene, Pitt. 3: 101. 1896.) Said to be widely distributed in the intermountain region.

6. Chrysopsis Bakeri Greene, 1. c. 4: 153. 1900. Densely tufted, stems slender, $2-3 \mathrm{dm}$. high, dark red or purplish, equably though somewhat sparsely leafy and the leaves ascending, frequently monocephalous, otherwise with a few leafy and monocephalous branches toward the summit: leaves $2-3 \mathrm{~cm}$. long, cuneately oblanceolate, acute, entire, strigillose-pubescent on both faces and with minute, sessile, resinous atoms underneath the pubescence: heads broad and short for the genus, subcampanulate; involucral bracts mostly dark reddish like the stem, more villous than the stem, in several series but not very 
regularly imbricated: rays deep golden-yellow approaching orange: achenes silky; outer pappus obvious, whiter than the inner but setaceous rather than paleaceous. (C. pedunculata Greene, l. c. $154 ; C$. incana Greene; $C$. compacta Greene, Leaflets 1: 151. 1905.)-Colorado; probably more widely distributed.

7. Chrysopsis villosa Nutt. Hook. Fl. Bor. Am. 2: 22. 1834. Appressedstrigose pubescent; stem erect or ascending, simple or corymbose: leaves canescently strigose, ascending, usually cuneately narrowed below, entire or nearly so, mucronate; the upper linear-oblong or lanceolate; the lower oblongspatulate: heads solitary to corymbose at the ends of the branches, on short peduncles; bracts of the campanulate involucre linear-subulate, strigosepubescent: achene villous; outer pappus setose-squamellate.-From Colorado to the Canadian provinces.

8. Chrysopsis pumila Greene, Erythea 2: 95. 1894. Whitened with soft, loose, villous pubescence throughout; stems low, spreading, more or less decumbent at base, $10-15 \mathrm{~cm}$. high: leaves narrowly oblanceolate, tapering into a margined petiole-like base, 2-5 cm. long, middle and upper stem leaves usually longer than the basal which are early deciduous: heads solitary or terminal and axillary; terminal head large, $12-14 \mathrm{~mm}$. high and considerably broader, subtended by some foliar bracts which are long-ciliate on the margins; axillary heads reduced, rarely more than the 2 or 3 uppermost developing: rays 15-25, orange-yellow; ligule $12-15 \mathrm{~mm}$. long; disk-corollas numerous, with very slender tube which is shorter than the narrowly tubular throat: pappus dingy, equaling the corolla; achene short-linear, minutely silkypubescent. (C. alpicola Rydb. l. c. 649. 1904; C. Cooperi A. Nels. Bot. Gaz. 40: 63. 1905.)-Alpine in the high mountains of Colorado.

9. Chrysopsis depressa Rydb. Mem. N. Y. Bot. Gard. 1: 381. 1900. Intricately branched, from a woody caudex; stems 7-15 cm. high, densely shortpilose, very leafy: leaves 7-14 $\mathrm{mm}$. long, obovate-elliptic or spatulate, on very short petioles, divaricate, densely grayish-strigose: heads on naked peduncles about $1 \mathrm{~cm}$. long, small, 7-10 mm. high; bracts linear, acute, puberulent, in about 3 rows, one third shorter than the disk: achenes silky-strigose. -Frequent on the Geyser formations in Yellowstone Park.

10. Chrysopsis fulcrata Greene, Bull. Torr. Bot. Club 25: 119. 1898. Tufted, the stoutish erect stems 4-8 dm. high, the herbage green, papilloseglandular and perhaps somewhat viscid beneath a minute strigose pubescence, some rather stiffly hirsute, longer hairs clothing the stems and leaf-margins: leaves oblong, obtuse, sessile, ascending, about $3-4 \mathrm{~cm}$. long, venulose: heads rather large, short-peduncled, subcorymbose at summit of stem and branches; the involucres subtended and partly concealed by one or more leafy bracts; proper involucral bracts in few series: rays numerous and large, goldenyellow: achenes silky; outer pappus very conspicuous, of 20-25. linearacuminate scales. (C. caudata Rydb. Bull. Torr. Bot. Club 31: 648. 1904.)In the mountains of New Mexico and Colorado.

11. Chrysopsis foliosa Nutt. Trans. Am. Phil. Soc. 7: 316. 1840. Stoutish, usually freely branched, 3-5 dm. high; pubescence canescently silky and with a thinner coat of long villous hairs: lower leaves spatulate, obtuse or slightly mucronate, middle and upper leaves broadly oblong or elliptic; the upper cordate or truncate at the base, $3-4 \mathrm{~cm}$. long: inflorescence corymbiform; heads usually subtended by oblong leaves; bracts hirsute-strigose, linearlanceolate, acute: disk $15 \mathrm{~mm}$. or more wide; rays golden-yellow, about $12 \mathrm{~mm}$. long: achenes denisely strigose-canescent.-Common at middle elevations in the central Rocky Mountains.

11a. Chrysopsis foliosa amplifolia (Rydb.) A. Nels. Leaves numerous and large, the upper cordate or truncate at base. (C. amplifolia Rydb. l. c.)Colorado.

11b. Chrysopsis foliosa imbricata A. Nels. Leaves short and crowded on the nearly simple stems, canescent or grayish with a dense appressed pubescence. (C. imbricata A. Nels. Bot. Gaz. 37: 263. 1904.)-Central Colorado on the mountain slopes.

12. Chrysopsis mollis Nutt. 1. c. Resembling the preceding but the pu- 
bescence softly silky-canescent throughout: leaves spatulate-oblong or oblong and sessile: heads few to many, corymbose; bracts of the villous-canescent involucre narrowly linear-lanceolate: outer pappus minute.-Plains of the upper Platte.

\section{ChRYSOThaminus Nutt. Rabitt Brush. Rayless or False GOLDENROD}

Shrubby or suffrutescent plants with narrow or terete entire leaves. Herbage white-tomentose or glabrous, often viscidulous or resinous. Inflorescence paniculate, cymose, or rarely racemose. Heads homogamous. Involucre narrow; the bracts well imbricated usually in more or less distinct vertical ranks, chartaceous or coriaceous, mostly destitute of herbaceous tips. Ray-flowers uniformly wanting; disk-flowers 5-30. Style-branches subulate or filiform, usually long-exserted. Achenes narrow, terete or slightly angled, pubescent. Pappus copious, soft, commonly dull white.-Bigelovia.

The entire plant wholly devoid of tomentum.

Tall (5-10 dm.); branchlets slender-virgate or stouter and fastigiate; leaves scabrous-margined.

Growing on the wet banks of alkali creeks (strikingly halophytic) .

Growing on dry hills, in soil free from alkali : : : : Low (5 dm. or less); usually freely branched.

Leaves glabrous but sometimes scabrous on the margins. Leaves 3-nerved, often involute and twisted Leaves 1-nerved, flat, ciliate on the margin

Leaves puberulent or scabrous, but often very minutely or sparingly so.

Bracts not acuminate, but often subacute. Achenes pubescent

Achenes glabrous

Bracts firm and sharply acuminate

Tomentose, in some species densely so and in the others at least traces upon stems or leaves.

Branchlets permanently white-tomentose.

Plant widely bushy-branched

Plant strict with erect branches

Branchlets either glabrate from the first or shedding more or less of their tomentum.

Involucral bracts acuminate or at least sharply acute, arachnoidciliate.

Achenes glabrous

Achenes pubescent.

Leaves linear, 1-nerved (in no. 12 sometimes surpassing the flowers).

Involucral bracts long-acuminate, somewhat divaricate, the upper usually exceeding the corolla.

Flowers yellow; bracts arachnoid-ciliate on the margins; leaves green, not surpassing the flowers

Flowers pale or dirty yellow; bracts lanate; leaves pale or yellowish-green, the upper often longer than the flowers

Involucral bracts merely acute, erect, shorter than the corolla, arachnoid-ciliate; leaves canaliculate, 3-6

Leaves broadly linear, 3-nerved, green, the upper surpass-

Inv the flowers .
rowly oblong and blunt.

Bracts quite glabrous, not glutinous; leaves glabrous at maturity; stems slender, erect, 4-6 dm. high

Bracts erose-ciliate on the margin, or tomentose, or both, and sometimes glutinous; some tomentum persisting on the leaves.

Plant 5-12 dm. high, with branched trunk-like base, the season's stems slender-virgate, erect the

Plant 2-5 dm. high, freely branched from the bas
Leaves almost filiform and widely divaricate

Leaves linear, mostly erect

1. C. linifolius.

2. C. glaucus.

3. C. pumilus.

4. C. Greenei.

5. C. lanceolatus.

6. C. Vaseyi.

7. C. depressus.

8. C. graveolens.

9. C. nauseosus.

10. C. Bigelovii.

11. C. affinis.

12. C. Howardii.

13. C. wyomingensis

14. C. Parryi.

15. C. oreophilus.

16. C. pulcherrimus.

17. C. plattensis.

18. C. frigidus.

1. Chrysothamnus linifolius Greene, Pitt. 3: 24. 1896. Tufted, woody stems erect, slender and flexible, 6-10 dm. high, fastigiately branching above, 
the leafy flowering branches white, glabrous and striate: leaves suberect, narrowly lanceolate, flat, very acute, 3-nerved, 3-4 cm. long, slightly fleshy, glabrous, the margins minutely scabrous-serrulate: heads many, in a terminal cymose corymb; involucre only $6-8 \mathrm{~mm}$. high; the bracts few, unequal, not in vertical ranks, the inner thin, obtuse, the outer ones with acute herbaceous tips: corollas deeply cleft: style-tips linear-subulate, only tardily exserted: achenes linear, villous-hirsute.-Wet banks of alkali creeks; more tolerant of alkali and water than any other species of this range; Wyoming and Colorado.

2. Chrysothamnus glaucus A. Nels. Bull. Torr. Bot. Club 25: 377. 1898. A slender, sparingly branched shrub, 5-10 dm. high; the older branches gray with a shreddy bark; the season's twigs somewhat fastigiate, leafy, glabrous with whitish shiny bark: leaves suberect, narrowly lanceolate, acute, obscurely 3-nerved, $2.5-4 \mathrm{~cm}$. long, often twisted, margins obscurely scabrociliate: heads about $8 \mathrm{~mm}$. high, numerous, in short, compact, terminal, rounded, cymose corymbs; bracts subcarinate, 5-ranked, 3-4 in each rank, lanceolate, acute, the outer greenish, the inner thin, membranous, glabrous: corollas 4, lobes linear-lanceolate, about half the length of the tube: styletips linear-subulate, tardily exserted: achenes silky, short-linear or slightly enlarged upward.-In dry cañons and on the slopes in alkali-free soil; Colorado and Wyoming.

3. Chrysothamnus pumilus Nutt. Trans. Am. Phil. Soc. 7: 323. 1841. Numerous erect branches slender, 1-3 dm. high, glabrous, very leafy, the bark whitish: leaves 2-4 cm. long, glabrous, slightly glutinous, narrowly linear, very acute, 3-nerved, often involute or occasionally somewhat twisted: involucre 4-6 mm. high; the bracts not very distinctly 4 -ranked, the outer short, ovate-lanceolate, the inner oblong-linear, not acute, faintly carinate. [C. leucocladus Greene, Pitt. 5: 59. 1902 (?).]-A very abundant species on dry hills and plains; Colorado to Utah and Montana.

3a. Chrysothamnus pumilus acuminatus A. Nels. Bot. Gaz. 25: 375. 1899. A very narrow-leaved form, the leaves scarcely twisted, and the bracts more acute or even acuminate. (C. filifolius Rydb. Bull. Torr. Bot. Club 28: 503. 1901.)-Rare; Colorado.

3b. Chry sothamnus pumilus varus A. Nels. 1. c. Low and freely branched: leaves numerous, mostly 1-3-nerved, narrowly to broadly linear, strongly twisted throughout. (C. elegans Greene, Erythea 3: 93. 1894.)-On the driest slopes; Colorado and Wyoming.

4. Chrysothamnus Greenei (Gray) Greene, Erythea 3: 94. 1894. Plant 2-3 dm. high, green and glabrous, more or less balsamic-viscid: leaves very numerous on the branches, filiform-acerose but flat and margins minutely ciliolate-scabrous: heads numerous and fastigiate-cymose, 6-8 $\mathrm{mm}$. high; bracts of the subclavate involucre oblong, abruptly subulate-tipped or short outermost mucronate, only about 3 in each vertical rank, these ranks comparatively indistinct. (C. scoparius Rydb. Bull. Torr. Bot. Club 28: 503. 1901.) Scarcely distinct from the preceding; Colorado and Utah.

5. Chrysothamnus lanceolatus Nutt. 1. c. 324 . Cinereous-puberulent, 2-4 $\mathrm{dm}$. high; branches terete: leaves linear-lanceolate, $3-4 \mathrm{~cm}$. long, mucronate, 3-nerved, with scabrous margins: heads 6-8-flowered, in clusters, forming a compound fastigiate corymb; bracts of the involucre oval, obtuse, or abruptly somewhat acute, loosely imbricated in 3-4 series, the innermost glabrous, nearly the length of the disk: lobes of the corolla about half the length of the tubular portion: branches of the style elongated; the appendages lanceolate, acute. [C. puberulus (Eat.) Greene, l. c.]-Exceedingly abundant throughout our range.

6. Chrysothamnus Vaseyi (Gray) Greene, 1. c. 96. Only 1-2 dm. high, somewhat balsamic-viscid but wholly glabrous, leafy up to the fastigiatecymose cluster of heads: leaves linear or spatulate-linear, obtuse, plane, 2-3 $\mathrm{cm}$. long, with obscure midrib: involucre cylindraceous; the bracts narrowly oblong, firm-chartaceous, and all but the innermost with a thickened greenish spot at the very obtuse apex: lobes of the corolla short-linear: style-appendages 
narrowly subulate, rather obtuse, half the length of the stigmatic portion: pappus fine and soft, rather short; achenes glabrous, 10-striate. (C. Bakeri Greene, Pitt. 4: 152. 1900.)-Dry plains; Wyoming to New Mexico and Utah.

7. Chrysothamnus depressus Nutt. Pl. Gamb. 171. 1848. Obscurely scabro-puberulent and pale, 1-2 dm. high from a decumbent woody base; branches leafy up to the glomerule or fasciculate cyme of few heads: leaves short, 1-2 cm. long, lanceolate, or the lowest rather spatulate, rigid, mucronateacute, with carinate midrib and no veins: heads 10-13 mm. long; involucral bracts lanceolate, gradually acuminate into an almost setaceous tip: achenes glabrous, 4-6-angled and with broad epigynous disk.-Plains of southwestern Colorado to those of New Mexico and Texas.

8. Chrysothamnus graveolens (Nutt.) Greene, Erythea 3: 108. 1894. Stout, very leafy, almost glabrous shrub, usually $7-15 \mathrm{dm}$. high, the numerous long branches ending in an ample rounded cymose corymb, the branches of which are more or less tomentulose: leaves ascending, broadly to narrowly linear, very acute, 5-8 $\mathrm{cm}$. long, obscurely 3-nerved, glabrous: involucral bracts about 4 in each vertical rank, acute, glabrous even to the margin: corolla with slender tube, glabrous or with a few short hairs, the nearly cylindric throat cleft a fourth to a third the way down: pubescence of the achenes abundant, long, appressed: style-appendages at least twice the length of the stigmatic portion. (C. patens Rydb. Bull. Torr. Bot. Club 31: 652. 1904; C. confinis Greene, Pitt. 5: 62. 1902.)-In "denudated soils" along the whole eastern base of the Rocky Mountains, from New Mexico to Dakota and Montana.

8a. Chrysothamnus graveolens glabrata (Gray) A. Nels. Leaves very slender and even the branchlets glabrate. (Bigelovia graveolens glabrata Gray, Proc. Am. Acad. 8: 645. 1873.) - Not infrequent in Colorado and New Mexico.

9. Chrysothamnus nauseosus (Pall.) Brit. Ill. Fl. 3: 326. 1898. Stems and branches lanate-tomentose, 4-8 dm. high, rather slender, terminated by an ample cymose corymb: leaves narrowly linear and, with the branchlets, minutely white-tomentose: involucral bracts firm, acutish, not ciliate, tomentose on the back, or the inner ones glabrous except near the tip, all in vertical ranks of 3 or 4 : corolla with slender pubescent tube rather longer than the subcylindric throat, this cleft a third of the way down: pappus copious, fine, only delicately scabrous, fuscous at least in age. (C. speciosus Nutt. 1. c.; includes the var. albicaulis.) - From the northern part of our range to Washington.

10. Chrysothamnus Bigelovii (Gray) Greene, Erythea 3: 102. 1904. Canescent with fine close tomentum when young, becoming glabrate, shrubby, 3-7 $\mathrm{dm}$. high, fastigiately much branched, rigid; branches less leafy, bearing a few fastigiate-clustered heads: leaves nearly filiform, short, involute: involucral bracts lanceolate, acute, thinnish, all pale, short, in distinct ranks of 4-5.Dry plains of southern Colorado and adjacent New Mexico.

11. Chrysothamnus affinis A. Nels. Bot. Gaz. 28: 374. 1899. The woody base low and branched; the season's stems numerous, simple, 1-2 dm. high, yellowish, glabrate: leaves crowded, linear, acute, erect or spreading, dark green, nearly glabrous, $3-4 \mathrm{~cm}$. long: inflorescence a crowded spicate thyrsus which at maturity distinctly surpasses the leaves: bracts glabrate, arachnoidciliate on the margins; the outer with an ovate base, contracted in a usually spreading acumination; the inner linear-oblong, abruptly acuminate: corollatube slender, bearing only a few, minute, scattering clavellate hairs, shorter than the expanded tubular throat which is cleft aboux one fourth its length. (C. Newberryi Rydb. 1. c.) - Colorado and New Mexico.

11a. Chrysothamnus affinis attenuatus (Jones) A. Nels. 1. c. An erect form with very slender stems and branchlets and very narrowly acuminate bracts.-Known only from type locality, Marysvale, Utah.

12. Chrysothamnus Howardii (Parry) Greene, 1. c. 113. Tufted, canescently tomentulose when young: leaves linear, rigid, $2-4 \mathrm{~cm}$. long, obscurely 1-nerved; upper mostly overtopping the glomerate narrow heads: involucre 5 -flowered; the bracts thinnish, lanceolate, apiculate-acuminate, or some loose outer ones with prolonged subulate-filiform appendages, all more or less 
arachnoid-ciliate or -lanate. (C. collinus Greene, Pitt. 3: 24. 1896.)-Northern New Mexico to Wyoming, and Utah.

13. Chrysothamnus wyomingensis A. Nels. 1. c. 374 . Tufted, 2-4 dm. high, bushy-branched from the base, the branches with ascending or erect, yellowish-green branchlets, with a thin inconspicuous tomentum throughout: leaves 4-6 cm. long, narrowly linear, viscidulous as are also the branchlets: inflorescence a narrow thyrsiform panicle, at maturity barely surpassing the uppermost leaves: heads about $12 \mathrm{~mm}$. high; bracts few, mostly acute or acutish, glandular on the greenish keel: corolla obscurely short-pubescent below: style branches exserted, the appendages longer than the stigmatic portion.-Frequent in Wyoming and extending into Colorado and probably Utah, on saline soils.

14. Chrysothamnus Parryi (Gray) Greene, Erythea 3: 113. 1904. Stems rather strict, leafy to the summit: leaves linear to broadly linear, 5-8 cm. long, obscurely 3-nerved, glabrous; the upper ones hardly diminished in size and overtopping all the heads of the strict and narrow thyrsiform-virgate panicle: heads 12-15 mm. long, 10-15-flowered; bracts of the involucre about 12, lanceolate and gradually acuminate, rather prominently 1-nerved, thinchartaceous, a few exterior ones tapering into a prolonged subulate-linear herbaceous appendage.-Mountain parks; southern Wyoming and in Colorado.

15. Chrysothamnus oreophilus A. Nels. 1. c. 375. Green and nearly glabrous, 2-4 dm. high; stems several to many, strictly erect and somewhat fascicled, grayish with a thin tomentum, the annual twigs also fascicled-erect, slender and yellowish-green: leaves erect, linear-filiform, very acute, canaliculate, green and glabrate, 3-5 cm. long: heads small (about $1 \mathrm{~cm}$. high), in small fastigiate cymes; bracts oblong, abruptly subacute, only 2 or 3 in each vertical row, the scarious margins ciliate-pubescent: corolla sparsely shorthairy; lobes distinctly glandular-thickened at apex: style appendages longer than the stigmatic portion: the short achene finely pubescent. ( $C$. pinifolius Greene, Pitt. 5: 60. 1902.)-Mountain slopes; Wyoming, Colorado, and Utah.

16. Chry sothamnus pulcherrimus A. Nels. 1. c. 370 . Shrub 5-12 dm. high, main stem and branches with grayish bark, the season's stems yellow but under the lens minutely lanate-puberulent, rather slender-virgate, terminating in an ample, compact, paniculate cluster: leaves narrowly linear, rather lax and spreading, 5-8 cm. long, from white-tomentose to greenish-glabrate: involucral bracts only 2 or 3 in each row, oblong, acute, nearly glabrous, ciliate on the margins: corolla-tube longer than the throat into which it gradually expands, rather closely short-hairy: anthers well exserted, the appendages of the style exceeding these: achene softly pubescent.-Near streams; from Colorado to Montana.

17. Chrysothamnus plattensis Greene, Pitt. 4: 42. 1899. Low and merely suffrutescent, 15-30 cm. high, very leafy, the long, narrowly linear, whitetomentose leaves spreading or recurved: involucral bracts about 3 in each vertical rank, acute, glabrous except that the margins are rather densely woolly-ciliate: tube of corolla somewhat pubescent; throat elongated, rather deeply cleft.-Abundant on alkali plains adjacent to the Platte and its tributaries in Colorado and Wyoming.

18. Chrysothamnus frigidus Greene, Erythea 3: 112. 1894. In dense clumps, freely branched, $2-4 \mathrm{dm}$. high; branches of the season erect, numerous, whitish-tomentose: leaves narrowly linear, 3-5 cm. long, acute, erect or ascending, distinctly white-tomentose, seldom glabrate: heads mostly thyrsoidpanicled, 8-10 $\mathrm{mm}$. high; bracts in not very distinct vertical ranks, the outer acute, the inner obtusish, all more or less tomentulose and glandular, the margins delicately ciliate at least near the summit: corolla-tube sparingly short-hairy, rather deeply cleft.-Very abundant on the high plains of Colorado and Wyoming.

The relationship of $C$.leucocladus, C. laetevirens, $C$. falcatus, and $C$. virens, published by Dr. E. L. Greene in Pitt. 5: 59-62, is not known. They seem to have been collected only by the author of the species, the first three at Grand Junction and the last at Cañon City, Colorado.

ROCKY MT. BOT.-32 


\section{ISOCOMA Nutt.}

Herbaceous or suffruticose, commonly more or less balsamic-viscid. Leaves not punctate, sometimes dentate or pinnatifid. Heads several-many-flowered; bracts of the involucre either coriaceous or firm-chartaceous and usually somewhat herbaceous or thickened at the obtuse or barely acute apex, all strictly appressed and well imbricated, but the vertical ranks inconspicuous. Styleappendages subulate-lanceolate or broader, shorter than the stigmatic portion. Achenes short, sericeous-pubescent. Pappus of numerous sordid bristles, the innermost longest and of ten distinctly flattened.

1. Isocoma Wrightii (Gray) Rydb. Bull. Torr. Bot. Club 33: 152. 1906. Commonly glabrous or nearly so; stems rather strict and slender, $3-5 \mathrm{dm}$. high from a lignescent base: leaves thickish, narrowly linear, entire, sometimes lower ones sparingly laciniate-dentate, margins either smooth or sparingly hirtello-scabrous: heads $8-10 \mathrm{~mm}$. high, 7-15-flowered, usually numerous and crowded in a corymbiform cyme; bracts of the involucre oval-oblong to broadly lanceolate, obtuse; the back at or near the apex usually greenish, but no definite tip.-Banks of streams and in saline soil; western Texas to Arizona and in (?) Colorado.

\section{SIDERANTHUS Fraser}

Annual or perennial herbs or shrubs. Leaves alternate; blades flat, spinulose-toothed or lobed or pinnatifid, commonly sessile. Heads radiate and showy or rarely discoid. Involucres hemispheric or campanulate, manyflowered; bracts in several series, the inner successively larger. Receptacle flat or nearly so, naked, generally pitted. Ray-flowers pistillate; diskflowers mostly perfect. Corollas yellow; tube scarcely dilated into a throat. Anthers obtuse at the base. Stigmas flattened, with lanceolate appendages. Achenes obtuse, pubescent, mostly 8-10-nerved. Pappus of 1-3 series of many unequal hair-like bristles, persistent.-(Eriocarpum Nutt.) This and the following seven genera were all included in the A plopappus of the Manual.

\section{Annuals.}

Leaves spinescently toothed; stem stout, simple

Leaves pinnatifid; stem slender, branched Perennials.

Leaves spinescently toothed; stems numerous from a woody caudex

Leaves pinnatifid; stems from a woody caudex; canescently tomentose, cinereous, or glabrate.

Involucres somewhat glandular; leaves pinnatifid to sub-entire Involucres not glandular; all the leaves pinnatifid

1. S. annuus.

2. S. gracilis.

3. S. grindelioides.

4. S. australis.

5. S. spinulosus.

1. Sideranthus annuus Rydb. Bull. Torr. Bot. Club 31: 653. 1904. Annual, 3-7 dm. high, viscid-glandular and pubescent or puberulent: leaves lanceolate or narrowly oblong, incisely pinnatifid or dentate with salient narrow teeth: heads somewhat cymosely paniculate, 10-14 $\mathrm{mm}$. high, usually naked-pedunculate; bracts of the involucre linear-subulate and with slender spreading green tips: stronger bristles of the fulvous or at length rufous pappus numerous: rays golden-yellow. A plopappus rubiginosus.-On the plains; Kansas and Nebraska to Colorado.

2. Sideranthus gracilis (Nutt.) Rydb. Fl. Col. 344. 1906. Annual or becoming lignescent at base and more enduring, canescently pubescent, occasionally glabrate and glandular-scabrous; stems 1-3 dm. high, much branched: leaves linear or the lowest spatulate, pinnatifid, or the upper fewtoothed or entire, tipped or also sparsely fringed with long and slender bristles: heads 8-12 mm. high; bracts of the involucre mostly setaceous-tipped: pappus rigid; the larger bristles manifestly dilated below.-New Mexico and Colorado to Utah and Arizona.

3. Sideranthus grindelioides (Nutt.) Brit. Man. 932. 1901. Perennial by a deep woody root, finely pubescent; stems tufted, simple, erect, 1-3 dm. high: leaves oblong-lanceolate to spatulate, sessile, or the lower petioled, 
1-2.5 cm. long, firm, spinulose-dentate: heads terminating the stem or branches; involucre campanulate, the bracts linear, acute, puberulent, the tips somewhat spreading, the outer shorter than the inner: achenes densely silky-tomentose. A plopappus Nuttallii.-Dry soil; from New Mexico and Arizona to the Canadian border.

4. Sideranthus australis (Greene) Rydb. Bull. Torr. Bot. Club 27: 621 . 1900. Perennial, the clustered stems erect or ascending, 1-4 dm. high, not tomentose but cinereous with a short spreading somewhat glandular indument: radical leaves pinnatifid, the lobes with few coarse teeth; the cauline narrow, pinnately toothed: heads few, solitary at the ends of leafy pedunculiform branches: rays pale yellow: achenes compressed; pappus-bristles not coarse, extremely unequal. (S. puberulus Rydb. 1. c. In this and the next species there are all degrees of pubescence.) - Colorado and New Mexico.

5. Sideranthus spinulosus (Pursh) Sweet. Hort. Brit. 227. 1826. From lanate or tomentose to glabrate, much branched at the base, perennial from thick woody roots, 1-4 dm. high: leaves pinnatifid, linear to ovate in outline, 1-3.5 cm. long, the lobes with bristle-pointed teeth: heads several or numerous, $12-25 \mathrm{~mm}$. broad; involucre hemispheric, the bracts linear, acute, appressed: achenes pubescent, narrowed below; pappus soft and capillary.On the plains; from the base of the mountains to the Dakotas, Nebraska, and Texas.

5a. Sideranthus spinulosus glaberrimus (Rydb.) A. Nels. Wholly glabrous; not otherwise distinguishable. (S. glaberrimus Rydb. 1. c.)-Same range as the species.

\section{PYRROCOMA Nutt.}

Perennial herbs with mostly simple stems, alternate leaves, and showy heads of yellow flowers terminal or in the axils of the upper leaves. Heads many-flowered, radiate. Bracts of the hemispherical or campanulate involucre rigid, somewhat foliaceous, nerveless, oblong with more or less squarrose or herbaceous tips. Receptacle flat, alveolate-toothed. Ray-flowers numerous, pistillate; disk-flowers cylindrical, slightly dilated upward with short, erect teeth. Style-branches of the disk-flowers subulate-linear, elongated, the hispid appendages much longer than the stigmatic portion. Achenes linear, elongated, somewhat 3-angled and striate, glabrous or rarely hairy. Pappus reddish-brown or fulvous, of copious and uniform, slender, rigid bristles.-A plopappus in part.

Involucral bracts with broad obtuse tips .

1. P. crocea.

Involucral bracts acute or acuminate.

Heads mostly solitary, terminal, rarely 1-2 smaller ones in the upper axils.

Heads large, the disk more than $2 \mathrm{~cm}$. in diameter. Stem and involucre villous Stem and involucre glabrate

Heads smaller; the disk less than $2 \mathrm{~cm}$. in diameter

Heads several to many, paniculately corymbose or racemiform

2. P. Clementis.

3. $P$. integrifolia.

4. P. uniflora.

5. P. lanceolata.

1. Pyrrocoma crocea (Gray) Greene, Erythea 2: 69. 1894. Stems stout and erect, commonly 3-5 dm. high, and with radical leaves (including the petiole) 1-2 dm. long: cauline leaves ovate-oblong to lanceolate, partly clasping: heads mostly solitary; involucre about $3 \mathrm{~cm}$. in diameter; the bracts ovate to spatulate-oblong, very obtuse, lax, inner with scarious, erose-denticulate margins: rays saffron-yellow, sometimes $25 \mathrm{~mm}$. long: achenes narrowly oblong, nearly as long as the pappus. Aplopappus crocea.-In the Colorado mountains.

2. Pyrrocoma Clementis Rydb. Bull. Torr. Bot. Club 27: 625. 1900. Stems 1 or more, ascending, 1-2 dm. high, more or less villous as is also the involucre: lower stem leaves linear-oblong, about $1 \mathrm{dm}$. long, glabrous except the ciliate margin, saliently dentate; the upper lanceolate or ovate-lanceolate, dentate or entire-margined: heads solitary; disk about $2.5 \mathrm{~cm}$. broad; bracts all foliaceous, imbricated in 3-4 series, but the outer almost equaling the 
inner, oblanceolate, abruptly acute, villous: rays 10-12 $\mathrm{mm}$. long, bright yellow: achenes sparingly strigose-hirsute.-Colorado.

3. Pyrrocoma integrifolia (Porter) Greene, 1. c. Stems several from the caudex, ascending, 1.5-2.5 dm. high: radical leaves (including short petiole or tapering base) 7-15 cm. long; the cauline lanceolate, or the small uppermost linear: heads solitary or 2 or 3 in the upper axils; involucral bracts narrowly oblong to linear-lanceolate, some loose outer ones usually equaling the disk and more foliaceous: rays bright yellow, 9-12 $\mathrm{mm}$. long: achenes oblong.Mountain meadows of Wyoming and Montana.

4. Pyrrocoma uniflora (Hook.) Greene, l. c. 60. Stems 1-2 dm. high, ascending or erect, sometimes 5-6-leaved, sometimes rather scapiform or upper leaves reduced and bract-like, bearing a solitary head, rarely 1 or 2 axillary: leaves lanceolate or sometimes broader; radical $5-8 \mathrm{~cm}$. long and usually petioled: involucre commonly $10-12 \mathrm{~mm}$. high, and the linear or oblong-linear bracts all of same length, rather loose, outer all foliaceous. $[P$. inuloides (Hook.) Greene, 1. c.; $P$. villosa Rydb. 1. c. $625 ; P$. acuminata Rydb. 1. c.]-Frequent in moist saline soils; Montana to Colorado and Utah.

5. Pyrrocoma lanceolata (Hook.) Greene, 1. c. 69. Habit of the preceding; stems generally more leafy and bearing 3-15 heads; these when few subcorymbose, when more numerous racemosely or paniculately disposed: involucre 10-15 mm. high (the heads varying much in size); the bracts rather closely imbricated in 3 or 4 unequal series, lanceolate, acutish, with short green tips and whitish coriaceous base; outer successively shorter, occasionally some of them longer and more herbaceous. $[P$. Vaseyi (Parry) Rydb. l. c.; P. lagopus Rydb. Bull. Torr. Bot. Club 32: 136. 1905.] Saline soils; Saskatchewan to northern Colorado and west to Nevada.

\section{OONOPSIS Greene}

Plants with equably leafy upright stems, usually tufted, upon a ligneous caudex or crown. Leaves entire; herbage lanate-tomentulose or glabrous. Heads in a terminal fastigiate cyme or solitary, discoid or radiate. Involucres ovate or broader; bracts not carinate, but flat and often 3-nerved, imbricated, subcoriaceous and with green-herbaceous tips ending in a cusp. Disk-corollas subcylindric, with 5 rather short teeth. Stamens and styles scarcely exserted; tips of the latter ovate to subulate, shorter than the stigmatic part. Achenes mostly glabrous, and pappus coarse, rigid, and rather scanty. - This genus is unique in that each of its species is seemingly confined to restricted areas and is singularly limited as to habitat. Aplopappus in part.

Dwarf and somewhat caespitose, less than $1 \mathrm{dm}$. high.

Rays 6-10.

Leaves short $(2-3 \mathrm{~cm}$.)

Leaves long $(4-8 \mathrm{~cm}$.)

Rayless

Taller, 1-3 dm. high; stems few to many.

Rayless.

Stems numerous, fascicled, branched; heads in terminal glomerules.

Leaves short $(3-6 \mathrm{~cm}$.)

Leaves long $(6-12 \mathrm{~cm}$.)

Stems solitary or few; heads solitary

Rays numerous

1. Oonopsis multicaulis (Nutt.) Greene, Pitt. 3: 45. 1906. Very dwarf, tufted, tomentulose, but early glabrate and smooth; stems $3-7 \mathrm{~cm}$. high, from a ligneous caudex, simple or forked, bearing 3 or 4 leaves and few heads: leaves narrowly linear, or the lowest obscurely spatulate, $2-3 \mathrm{~cm}$. long: bracts of the involucre large and rather few (9-14), ovate to oblong-lanceolate, cuspidate-acuminate, marked with a green spot below the slender cusp, or the outermost with a larger foliaceous tip.- "On rocks, mountains of northwestern Wyoming." 
2. Oonopsis argillacea A. Nels. Bull. Torr. Bot. Club 26: 481. 1899. Tufted, caespitose, the crowns more or less covered with the bases of dead leaves; stems numerous, $3-8 \mathrm{~cm}$. long, terminating in a leafy corymbose inflorescence of few heads, sparsely lanate-pubescent as are also the leaves: leaves entire, narrowly to broadly linear, pungently acute, $4-8 \mathrm{~cm}$. long, often overtopping the heads: involucre tomentose, about $1 \mathrm{~cm}$. high; the bracts oblong-ovate, acuminate, not conspicuously green-tipped: rays showy, about 10, the disk-flowers twice as many: achene softly pubescent, oblong, 3-4 mm. long.- On barren clayey slopes and flats; interior Wyoming.

3. Oonopsis Engelmannii (Gray) Greene, 1. c. Stems 1-2 dm. high, in tufts from a subterranean branching caudex, simple, very leafy up to the cymose-glomerate heads: leaves all narrowly linear, $3-5 \mathrm{~cm}$. long, only $2-3$ $\mathrm{mm}$. wide, rigid: bracts of the involucre regularly imbricated and appressed, outer similar but short, all abruptly mucronate or short-cuspidate, slightly greenish below the tip.-Plains of Colorado at Hugo.

4. Oonopsis Wardii (Gray) Greene, 1. c. 46. Dwarf; fascicled stems 10-15 $\mathrm{cm}$. high: leaves $3-6 \mathrm{~cm}$. long, linear-lanceolate, destitute of lateral nerves: heads $10 \mathrm{~mm}$. or less long, 2 or 3 in a terminal glomerule: achenes double the length of the scanty pappus.-Wyoming, "probably in the southwestern part."

5. Oonopsis condensata A. Nels. 1. c. 25: 376. 1898. Stems spreading. mostly simple below, freely and fasciculately branched upward, 1.5-2.5 dm, long, very leafy, especially above: leaves glabrous, broadly linear to narrowly oblanceolate, 1-nerved or often 3-nerved at base, acute, 6-12 cm. long: inflorescence of the tufted plant as a whole dense, from rounded to almost flat-topped; inflorescence of the branchlets a close glomerule of about 3 heads, often overtopped by the upper leaves: heads rayless, 15-25-fiowered, 10-15 mm. high; involucral bracts lanceolate-acuminate, nearly equaling the flowers: achenes striate, flattened-clavate, glabrous, when mature $6 \mathrm{~mm}$. long; pappus scanty, about equaling the achene.-In gravelly clay soils in a few restricted localities; Laramie Plains, Wyoming.

6. Oonopsis monocephala A. Nels. Bot. Gaz. 31: 399. 1891. Caudex woody, the branches slender; stems 1 or more from each branch of the caudex, erect or ascending, 1-2 dm. high, simple, uniformly leafy from base to summit, monocephalous: leaves glabrous as are also the stems, linear-oblong, sessile, acute, quite uniform in size and shape, $5-8 \mathrm{~cm}$. long, about $1 \mathrm{~cm}$. broad, the uppermost involucrating the large head: involucre hemispherical, about $15 \mathrm{~mm}$. high; the bracts oblong, rather abruptly short, acuminate-cuspidate, glabrous but for some ciliate pubescence on the margins: heads rayless; diskflowers very numerous: pappus nearly as long as the corolla-tube, the bristles widely spreading at maturity; achene oblong, about $3 \mathrm{~mm}$. long, sparsely and obscurely glandular.-Known only from the type locality, Berwind, Colorado.

7. Oonopsis foliosa (Gray) Greene, 1. c. Glabrous; stems erect or ascending from a woody base, $1.5-3 \mathrm{dm}$. high, corymbosely branched above, leafy: leaves oblong or linear-oblong, sessile, partly clasping at the base, acute with a mucronate tip, entire or occasionally somewhat denticulate; lower ones 5-7 cm. long, tapering to the base; upper ones clasping by a broad base: heads terminating the leafy branches, globose, $2-3 \mathrm{~cm}$. in diameter; bracts in 3-4 series, lance-ovate, with acuminate, spiny tips, somewhat villouspubescent, with narrow, scarious margins: rays $12-15 \mathrm{~mm}$. long, lance-ovate, yellow: pappus a little shorter than the corolla and rather longer than the very smooth achene. Aplopappus Fremontii.-On clayey plains and hills; upper Arkansas in Colorado.

\section{MACRONEMA Nutt.}

Low and viscidly pubescent, much branched shrubby plants, the fastigiate leafy branches terminated by solitary or fastigiately clustered rather large heads, with entire sessile leaves and yellow flowers. Heads many-flowered, discoid or radiate; disk-flowers tubular, perfect. Bracts of the involucre 
few, loose, somewhat in 2 series, nearly equal, linear-lanceolate, 1-nerved; the exterior mostly with foliaceous spreading tips, commonly with 1 or more foliaceous bracts at the base resembling the upper leaves. Receptacle flat, alveolate. Branches of the style much exserted, the appendages elongated, subulate, hirsute, much longer than the flat stigmatic portion. Achenes large, much compressed. Pappus of copious somewhat unequal scabrous capillary bristles.-A plopappus in part.

\section{Heads radiate.}

Leaves obovate; heads several

Leaves spatulate; heads solitary

Heads discoid.

Leaves oblanceolate; heads solitary

Leaves linear; heads several

1. Macronema obovatum Rydb. Bull. Torr. Bot. Club 27: 618. 1900. Glandular-puberulent, 2-3 dm. high, with light yellow bark on the branches: leaves broadly obovate, 1-2 $\mathrm{cm}$. long, 7-10 $\mathrm{mm}$. wide, mucronate-cuspidate: heads usually 2-3 together, about $10 \mathrm{~mm}$. high, and $8 \mathrm{~mm}$. broad; the bracts rather firm, oblong-linear, abruptly obcuneate-acute at the apex, unequal, imbricated in about 4 series: rays short, 4-5 $\mathrm{mm}$. long, about 10 in number.Known only from type locality, City Creek Cañon, Utah.

2. Macronema grindelioides Rydb. Mem. N. Y. Bot. Gard. 1: 384. 1900. A much-branched undershrub, 1-2 dm. high; young branches glandularpuberulent: leaves oblong or spatulate, more or less fleshy, 1-2 cm. long, obtuse or mucronate, finely glandular-puberulent, and with a more or less crisped margin: heads $1-5 \mathrm{~cm}$. high; the bracts rather few, the outer ones foliaceous, oblanceolate, acute, mostly longer than the disk: rays 6-12, rather conspicuous, often $1 \mathrm{~cm}$. long.- High mountain peaks; northern Wyoming to Montana and Idaho.

3. Macronema discoideum Nutt. Trans. Am. Phil. Soc. II. 7: 322. 1841. Branches erect from a woody base, 1.5-2.5 dm. high, terete, white-tomentose: leaves spatulate-oblong, obtuse, apiculate, 15-25 $\mathrm{mm}$. long, obscurely 3nerved, minutely glandular and scabrous: heads single or few in a corymb, turbinate; bracts of the involucre few, subequal, broadly lanceolate, glandular, the outer ones more or less herbaceous: heads about 25-flowered: rays none: branches of the style very long, filiform, much exserted, the hispid portion twice as long as the stigmatic: achenes pubescent.-Mountains of Colorado,

- Wyoming (?), and westward.

4. Macronema lineare Rydb. 1. c. With the habit and appearance of some Chrysothamni; stem erect, about $1.5 \mathrm{dm}$. high, finely white-tomentose: leaves numerous, linear, acute, glandular-puberulent, bright green: heads $1-1.5 \mathrm{~cm}$. high; the bracts rather few, linear, somewhat foliaceous, but seldom equaling the disk: rays none.-Yellowstone Park and adjacent Wyoming.

4a. Macronema lineare canescens A. Nels. Leaves $2-3 \mathrm{~cm}$. long, acute, lightly canescent and nearly or quite destitute of resinous atoms: involucral bracts very finely lanate.-Same range.

\section{STENOTUS Nutt.}

Dwarf herbaceous plants with linear or lanceolate, 1-3-nerved, rigid, entire, alternate or crowded leaves and middle-sized heads of yellow flowers. Involucre hemispherical; the bracts oblong-ovate to orbicular, 1-nerved, membranaceous with scarious margins, of equal or moderately unequal length, closely appressed and imbricated. Heads many-flowered, radiate. Rays 8-12, pistillate; disk-corollas perfect, dilated toward the summit, deeply 5-toothed. Style branches broad and flat. Achenes oblong-turbinate, densely silky-villous. Pappus commonly bright white, of numerous soft, unequal, densely scabrous capillary bristles.-A plopappus in part.

Caespitose; leaves linear, crowded on the crowns; stems scapose.

Scabrous-pubescent

Glabrous . 
Loosely caespitose; leaves narrowly to broadly oblanceolate; stems leafy.

Caudex branches with enlarged crowns sheathed with the dead petioles

Caudex open with slender naked branches

3. S. armerioides.

4. S. latifolius.

1. Stenotus acaulis Nutt. Trans. Am. Phil. Soc. II. 7: 334. 1841. Depressedcaespitose from a multicipital lignescent caudex: leaves rigid and persistent, crowded on the crown of the caudex and a few on the scapiform flowering stems, spatulate to linear, 2-4 cm. long, mucronate, more or less 3-nerved, commonly scabrous: scapiform flowering stems $3-12 \mathrm{~cm}$. high: heads mostly solitary, many-flowered, radiate; bracts of the involucre ovate to ovatelanceolate, mucronately acute or acuminate, destitute of greenish tips.Shale and clay slopes and cliffs; Saskatchewan to Colorado and westward.

2. Stenotus caespitosus Nutt. 1. c. Habit of the foregoing; glabrous or nearly so: leaves crowded on the crowns of the woody caudex, narrowly lanceolate or linear, acute, 3-nerved; those of the simple or branching scapes $3-4$ : bracts of the involucre broadly ovate, acute, membranaceous, eroseciliate, imbricated in 3 series: appendages of the style subulate-linear, minutely pubescent. Aplopappus acaulis glabratus.-Wyoming to Montana and Nevada.

3. Stenotus armerioides Nutt. 1. c. Caespitose and rigid, 10-15 cm. high, glabrous: leaves crowded on the crowns of the thick woody caudex and on the lower part of the stem, elongated spatulate-linear, obscurely 3-nerved; those of the peduncle 1-2: bracts of the involucre roundish-oval, very obtuse, coriaceous, with abrupt scarious margins and greenish tips, closely imbricated, somewhat in 3 series: style with short and thick lanceolate appendages. [S. falcatus Rydb. Bull. Torr. Bot. Club 27: 616. 1900 (?).]-Dry cliffs and shale slopes.

4. Stenotus latifolius A. Nels. Bot. Gaz. 37: 266. 1904. Caudex woody, with numerous slender, naked branches; herbaceous stems slender, leafy, monocephalous, 10-15 cm. high, naked pedunculate above, glabrous but obscurely glutinous: leaves glabrous, slightly glutinous, acute or apiculate, 3-nerved; the crown leaves not persistent, small, spatulate, 7-12 mm. long; stem leaves longer, several (5-7), the lowest broadly spatulate-cuneate, the upper broadly oblong to lanceolate, 2-3 cm. long: heads 10-12 mm. high; the bracts in 3-4 series, oblong, abruptly acute, light green with narrow scarious margin: rays several, rather short: pappus-bristles slender, white, about as long as the somewhat angled canescent achene.-In the mountains of Utah.

\section{TONESTUS A. Nels.}

Low, herbaceous perennials from woody roots, having a short more or less branched subligneous caudex. Stems simple, a few to several centimeters high, leafy throughout, monocephalous. Leaves herbaceous, obscurely 3nerved, spatulately tapering to a short margined petiole. Heads relatively large (15-25 mm. broad); the involucral bracts herbaceous, in about 2 loosely imbricated rows, usually with 1-several outer foliaceous ones. Rays conspicuous, 10 or more; the disk-flowers more numerous. Pappus soft and white, equaling the corolla. Style tips slender, subulate-elongated. Achenes glabrous or pubescent.-A plopappus in part.

Stems very short (1-5 cm.); involucral bracts obtuse Stems slender, 5-15 cm. long; involucral bracts acute

1. T. pygmaeus. 2. T. Lyallii.

1. Tonestus pygmaeus (T. \& G.) A. Nels. Bot. Gaz. 37: 262. 1904. Softpubescent or glabrate, not viscid or glandular: leaves linear-spatulate to spatulate-oblong: involucral bracts oblong, outer ones foliaceous and loose, very obtuse, equaling the thinner innermost: achenes pubescent.-Alpine region of the Colorado and the Wyoming Mountains.

2. Tonestus Lyallii (Gray) A. Nels. 1. c. Rather taller, larger-leaved, viscid-puberulent: leaves obovate-spatulate to oblanceolate: involucre glandular; the bracts lanceolate, acute, sometimes 2 or 3 outermost oblong and 
more foliaceous: achenes and ovaries glabrous or nearly so.-Alpine; Colorado to Montana and Oregon.

\section{PETRADORIA Greene}

Stems low, rigid, tufted on a low-branched caudex. Leaves linear or narrowly lanceolate, rigid, tapering to both ends, 3-nerved. Heads few-several, 3-4 together and disposed in a rather flat-topped corymb. Involucral bracts in more or less distinct vertical rows. Achenes cylindric, glabrous, distinctly 10-striate.-Aplopappus in part.

1. Petradoria pumila (Nutt.) Greene, Erythea 3: 13. 1895. Dwarf, 1-2 dm. high, many-stemmed from a woody caespitose caudex, glabrous throughout, punctate, somewhat resinous: radical leaves petioled, 5-10 $\mathrm{cm}$. long: cyme glomerate-fastigiate: heads narrowly oblong; involucral bracts rigid, somewhat carinate, and with small green tips.-Stony ridges and hills; from Texas through our range to Oregon.

\section{OREOCHRYSUM Rydb.}

Plants with slender horizontal rootstock, leafy, viscid-puberulent above. Involucral bracts oblong, pale, rather obscurely 1-ribbed, chartaceous or the. outer foliaceous, in about 3 moderately unequal ranks. Rays several, short. Disk-corollas narrowly trumpet-shaped, deeply 5-toothed. Style-appendages lanceolate, longer than the stigmatic portion. Achenes angled. Pappus white or slightly tawny, of soft scabrous bristles.-A plopappus in part.

1. Oreochrysum Parryi (Gray) Rydb. Bull. Torr. Bot. Club 33: 152. 1906. Green and almost glabrous, puberulent, and somewhat viscid above; stems 2-4 dm. high: leaves oblong-obovate and spatulate, or the upper oblonglanceolate, thinnish, 5-10 $\mathrm{cm}$. long: heads about $12 \mathrm{~mm}$. high, rather numerous; involucral bracts oblong, obtuse, pale, and in about 3 moderately unequal ranks: flowers pale yellow. Aplopappus Parryi. - In the mountains of Colorado, Wyoming, and Utah.

\section{SOLIDAGO L. GoldenRoD}

Perennial herbs with alternate leaves. Heads small, the raceme-like clusters aggregated in a pyramidal or spike-like panicle or thyrsus, or in some of our species the heads corymbose. Bracts of the involucre usually thin or chartaceous, imbricated in 2 or more, series. Both ray and disk-flowers yellow. Pappus a single series of scabrous and mostly equal capillary bristles, usually dull white. Achenes terete or angular, 5-10-nerved.

Involucral bracts not longitudinally striate.

Rays usually fewer than the disk-flowers; receptacle aleveolate; inflorescence racemose or paniculate.

Glabrous, or pubescent along the veins and on the margins of the leaves, or often somewhat puherulent but not cinereous, scabrous, or hirsute.

Leaf-blades not triple-veined.

Stems tall (4-8 dm.); leaves pale

Stems rather low (1-4 dm.); leaves usually dark green.

Involucral bracts acute or acuminate linear-oblong, obtuse.

Leaves merely scabrous on the margin

Leaves ciliate on the margin especially towards the base

Leaf-blades triple-veined.

Stem leaves oblanceolate, often narrowly so, the uppermost usually linear; plant mostly less than $4 \mathrm{dm}$. high (1-4 dm.).

Heads 4-6 mm. high; plants not tufted.

1. S. pallida.

2. S. corymbosa.

3. S. decumbens.

4. S. dilatata.

Heads 5-7 mm. high; plants tufted

5. S. missouriensis,

6. S. concinna. 
Stem leaves lanceolate; plants usually more than $4 \mathrm{dm}$. high (4-10 dm.).

Nearly or quite glabrous; the leaves ample, usually broadly lanceolate and sharply serrate.

Glabrate or puberulent; the leaves numerous, usually narrowly lanceolate, subentire or serrate above the middle

Pubescent at léast above, usually on both stem and leaves.

Stem and leaves more or less hirsute, of ten scabrous and then somewhat canescent

Stem and leaves densely canescent.

Plants rather tall (3-6 dm.); inflorescence usually foliarbracted.

Panicle usually long and narrow; involucral bracts obtuse

Panicle usually short and broad; involucral bracts acute. Floral bracts ovate to lanceolate

Floral bracts lanceolate to linear

Floral bracts lanceolate to linear
Plants mostly low $(1-3 \mathrm{dm}$. ), finely cinereous : $: \quad$ : 12. S. trinervata.

Rays more numerous than the disk-flowers; receptacle fimbriolate; inflorescence corymbose.

Leaves linear, dark green

Leaves narrowly oblong-lanceolate, paile green

Involucral bracts longitudinally striate; the heads in $\dot{a}^{*}$ congested corymb

7. S. serotina.

8. S. elongata.

9. S. canadensis.

10. S. pulcherrima.

11. S. mollis.

14. S. occidentalis.

15. S. camporum.

16. S. rigida.

1. Solidago pallida (Porter) Rydb. Bull. Torr. Bot. Club 33: 153. 1906. Stout, erect, 3-8 dm. high: leaves ovate to lanceolate, thick and coriaceous, with prominent veins, pale or whitish: thyrsus narrow, of numerous narrow spike-like clusters, rather showy: heads 5-8 $\mathrm{mm}$. high; the bracts firm, narrowly oblong, very obtuse. (S. speciosa pallida Porter, Bull. Torr. Bot. Club 19: 130. 1892.)-Infrequent; Colorado.

2. Solidago corymbosa Nutt. Trans. Am. Phil. Soc. 7: 328. 1840. Nearly or quite glabrous, $1-3 \mathrm{dm}$. high: leaves firm and finely veined, entire or sparingly serrate; stem leaves ciliate at base, oblong-lanceolate; the radical obovate and narrowed into a petiole: heads rather large, 7-9 dm. high, generally few, in 1 or more rounded or corymbiform clusters; bracts of the involucre about as long as the flowers, acute: rays numerous and conspicuous. S: multiradiata scopulorum. [S. scopulorum (Gray) A. Nels. Bot. Gaz. 37: 264. 1904; S. ciliosa Greene, Pitt. 3: 22. 1896; S. rubra and S. laevicaulis Rydb. 1. c. 33: 649. 1904.]-In the mountains of our range.

3. Solidago decumbens Greene, Pitt. 3: 161. 1897. Stems clustered about the summit of a strong perpendicular root, stout, decumbent, 1-4 dm. high, usually dark red, sparsely puberulent, as is also the foliage: lowest leaves spatulate-obovate to oblanceolate, obtuse or acutish, more or less distinctly serrate toward the summit; upper cauline leaves similar, but few and reduced, all scabrous on the margin: inflorescence interruptedly thyrsoid: heads large; bracts of involucre linear, obtusish, of firm texture and carinate-nerved, forming about 3 series, the outer and shorter subulate-linear rather than linear: achenes subcylindric, strigose-hispidulous; pappus very strongly barbellatescabrous. S. humilis nana. (S. oreophila Rydb. Mem. N. Y. Bot. Gard. 1: 387. 1900, is merely the larger form from the lower stations.)-Frequent in alpine and subalpine stations throughout our range.

4. Solidago dilatata A. Nels. Bot. Gaz. 30: 196. 1900. Stems simple, or branched above, rather stout, glabrous, 4-6 dm. high: leaves glabrous, conspicuously reticulate-veiny below, minutely scabro-ciliate on the margins; basal leaves oblong-spatulate to elliptic, tapering into a broad margined petiole which is sometimes as long as the blade, either closely or remotely serrate, mostly obtuse at apex, $10-15 \mathrm{~cm}$. long; the stem leaves numerous, sessile, mostly small $(2-3 \mathrm{~cm}$.): inflorescence nearly glabrous, the lower pedunculate branches leafy-bracteate: heads about $6 \mathrm{~mm}$. high; involucral bracts in about 3 rows, the 2 inner rows subequal, minutely ciliate on the margins, linear, most of them obtusish and slightly dilated upwards: rays 8-10, conspicuous: achenes short and lightly pubescent.-Authentic specimens from type locality only, Yellowstone Park.

5. Solidago missouriensis Nutt. Journ. Acad. Phila. 7: 32. 1834. Stem rather slender, 2-4 dm. or more high: leaves firm or thick; those of the stem 
sessile, acuminate at apex, narrowed at base, 5-10 cm. long, very roughmargined, entire, or sparingly serrate with low, sharp teeth; the basal and lowest ones larger, spatulate, petioled: heads 5-6 $\mathrm{mm}$. high; bracts of the involucre oblong, greenish-tipped, obtuse, or the inner acute, thick: rays 6-13, short. (S. glaberrima Rydb. in Fl. Col. 348. 1896.)-Coming into our range from the prairie States to the eastward.

6. Solidago concinna A. Nels. Bull. Torr. Bot. Club 25: 377. 1898. Stems tufted, often numerous, glabrous, $1.5-4 \mathrm{dm}$. high: root leaves narrowly oblanceolate, $8-15 \mathrm{~cm}$. long; stem leaves narrowly oblong or oblanceolate, those of the inflorescence small and linear; all the leaves obscurely scabro-ciliate on the margins, usually a few of them showing slight serrations, triple-nerved, but the lateral ones often incomplete or obscure: heads about $5 \mathrm{~mm}$. high, very numerous, closely fastigiate-glomerate; bracts of the involucre oblong, subacute or obtuse, thin-margined, greenish down the middle: rays small, 5-9; disk-flowers 10-15. S. missouriensis extraria.-Frequent in the foothills and mountains; New Mexico to the Canadian Rocky Mountains.

7. Solidago serotina Ait. Hort. Kew 3: 211. 1789. Stem stout, 6-18 dm. high, very smooth and glabrous up to or near the ample panicle, sometimes glaucous: leaves commonly ample, lanceolate or broader, $8-15 \mathrm{~cm}$. long, sharply and saliently serrate, in the typical plant glabrous both sides: heads crowded, rather large, 6-7 mm. long; bracts of the involucre broadly linear or linear-oblong: rays 7-14, moderately large and conspicuous. [S. Pitcheri (Nutt.) Rydb. in Fl. Col.1. c.] Colorado to Montana and thence across the continent.

8. Solidago elongata Nutt. Trans. Am. Phil. Soc. 7: 327. 1841. Stems rather slender, 3-8 dm. high, smooth or minutely pubescent, strict: leaves lanceolate, acute or acuminate at both ends, sparingly serrate, nearly glabrous, obscurely 3-nerved: panicle elongated, virgate or narrowly pyramidal, 1-2 dm. long, the racemes at length somewhat spreading: bracts of the involucre linear-subulate: rays small and slender: achenes pubescent. (S. polyphylla and S. serra Rydb. Bull. Torr. Bot. Club 31: 650. 1904.)-Mostly in dry ground; throughout our range and far northwestward.

9. Solidago canadensis L. Sp. Pl. 878. 1753. Stems 4-12 dm. high, from scabrous- or cinereous-puberulent to hirsute: leaves mostly lanceolate, puberulent, pubescent, or nearly glabrous, sharply serrate or the upper entire, veiny, and with lateral ribs prolonged parallel to the midrib: heads small, ordinarily only 4-5 mm. long; bracts of the involucre small and pale, narrowly linear, acutish or obtuse: rays $9-16$, more numerous than the disk-flowers.Common and very variable; from New Mexico to Montana and to the Atlantic States.

9a. Solidago canadensis procera (Ait.) T. \& G. Fl. 2: 224. 1841. Leaves less serrate, sometimes all entire, cinereous-pubescent with short-appressed hairs.-Range of the species.

9b. Solidago canadensis scabriuscula Porter, Mem. Torr. Club 5: 318. 1894. Leaves shorter, sparingly serrate or entire, rough above, rugose beneath: heads usually larger. [S. scabriuscula (Porter) Rydb. 1. c: 33: 153. 1906.]-Range about the same as the species.

9c. Solidago canadensis gilvocanescens Rydb. Contrib. Nat. Herb. 3: 162. 1895. Only 2-4 dm. high, leafy, canescent, pale or yellowish: leaves remotely serrate or entire: inflorescence crowded. (S. gilvocanescens Rydb. Bull. Torr. Bot. Club 33: 153. 1906.) - On the dry plains; Colorado and Wyoming to Nebraska.

10. Solidago pulcherrima A. Nels. 1. c. 42. Closely cinereous-puberulent throughout; stems tufted, diffusely spreading, 6-8 dm. long: lower stem leaves very narrowly oblanceolate, obscurely 3-nerved, entire, 6-12 cm. long; upper leaves oblong; those of the long, virgate, secund inflorescence regularly reduced but leaf-like except at the summit where they become mere bracts: panicle narrow, racemose, 2-4 dm. long, the short crowded branches scorpioid: heads about $6 \mathrm{~mm}$. high; bracts of the involucre oblong-elliptic, obtuse, glabrous, greenish with thin colorless margins: rays usually 5, small, spatulate; 
disk-flowers 10 or fewer: achene closely puberulent, cylindrical. S. nemoralis as to our range. (S. radulina Rydb. l. c. 31: 650. 1904.)-Frequent; Colorado to Montana.

11. Solidago mollis Bartl. Ind. Sem. Goett. 5. 1836. Stems rigid, stout, low, canescent or slightly scabrous, $1.5-3 \mathrm{dm}$. high: leaves pale, canescent or rough, entire or dentate, strongly 3-nerved, oblong, ovate, or oblanceolate; the lower petioled, 5-7 $\mathrm{cm}$. long, 6-25 $\mathrm{mm}$. wide, obtuse; the upper sessile, smaller: heads 4-6 mm. high, somewhat or scarcely secund on the short branches of the erect, dense panicle: bracts of the involucre oblong: rays 5-9: achenes pubescent. S. nemoralis incana.-In the eastern part of our range to the Dakotas, Nebraska, and Texas.

12. Solidago trinervata Greene, Pitt. 3: 100. 1896. Stems decumbent and ascending, from branching and widely spreading horizontal rootstocks; herbage cinereous-scabrous: leaves widely spreading, linear-lanceolate, entire, very acute, many of them distinctly triple-nerved, mostly $5-8 \mathrm{~cm}$. long: panicle of unilateral racemes rather lax: bracts of the involucre in few series and acutish, glabrous and conspicuously green-tipped: achenes hispidulous. - Frequent in the dry cañons of the foothills throughout our range.

13. Solidago nana Nutt. 1. c. Stems 1-3 dm. high, canescent with minute, dense puberulence, not scabrous in age: leaves mostly obovate or spatulate and entire, small: heads 5-6 mm. long, rather broad, few or numerous in an oblong or corymbiform panicle, not at all secund; bracts of the involucre oval or oblong, very obtuse: rays $5-9$, often more numerous than the disk-flowers. - In the mountains and on the high dry plateaus; New Mexico to Montana and to Arizona and Nevada.

14. Solidago occidentalis Nutt. T. \& G. Fl. 2: 226. 1842. Stems 4-10 dm. high, paniculately branched above: leaves very numerous, linear, 1-3-nerved, more or less finely punctate, glabrous, the margins obscurely scabrous: heads in corymbose clusters, 4-5 $\mathrm{mm}$. high; bracts of the involucre chartaceous, linear-lanceolate: rays 16-20; disk-flowers 8-12. (Euthamia occidentalis Nutt.) - Wet ground; New Mexico to Montana and to the Pacific States.

15. Solidago camporum (Greene) A. Nels. Stems simple or paniculately branched above, 3-6 dm. high, whitish, striate, glabrous: leaves light green, narrowly oblong to lance-linear, 1-nerved, or the lateral nerves faint, marginally serrulate-scabrous, so also the midvein above, but the lower face of the leaf wholly glabrous, strongly and closely punctate on both faces: inflorescence somewhat fastigiate, branchlets and pedicels with remotely scabrous angles: heads not densely glomerate; bracts of involucre thinnish, yellowish throughout, obtuse or acute. S. lanceolata. (Euthamia camporum Greene, Pitt. 5: 74. 1902.)-Eastern Colorado and Wyoming to Minnesota and the Dakotas.

16. Solidago rigida L. Sp. Pl. 880. 1753. Stem stout, simple, or branched above, densely rough-pubescent or hoary, 3-15 dm. high: leaves thick, rigid, often obtuse, rough on both sides; the upper sessile, clasping and rounded or sometimes narrowed at the base, $3-5 \mathrm{~cm}$. long, mostly entire; lower and basal leaves long-petioled, sometimes $3 \mathrm{dm}$. long and $7 \mathrm{~cm}$. wide, entire or serrulate: heads 8-10 mm. high, many-flowered, in a terminal dense corymbose cyme; involucre broadly campanulate, the bracts oblong, obtuse, the outer pubescent: rays 6-10, large: achenes glabrous, 10-15-nerved. (Oligoneuron rigidum Small, Fl. S. E. U. S. 1188. 1903; O. canescens Rydb. Bull. Torr. Bot. Club 31: 652. 1904; S. rigida humilis Porter.)-The eastern part of our range and far eastward and southward.

\section{TOWNSENDIA Hook.}

Annual, biennial, or perennial herbs, often tufted, acaulescent or caulescent (simple or branched from the base). Heads large; the pink, purple, or whitish rays in 1 series, rather long, pistillate, sometimes infertile; disk-flowers perfect, with tubular-obconic 5-toothed corollas. Branches of the style lanceolate, acutish, hairy towards the ends. Involucres hemispherical or subglobose, 
of numerous rather large, imbricated and appressed, scarious-margined, lacerate-fringed and often tinted scales. Achenes flattened, pubescent or glabrous, 2-3-nerved. Pappus of numerous stout barbellate bristles, that of the ray commonly shorter, or reduced in part or wholly to short-subulate bristles or little scales.

Bracts of the involucre acuminate; heads large, when expanded 4-5 cm. or more broad.

Stems evident, 0.5-4 dm. high.

Erect, simple at least below.

Perennial; stems glabrate, monocephalous

Biennials; stems cinereous-canescent.

Pappus of two subulate awns and a circle of short squamellae

Pappus of both ray-and disk-flowers plurisetose

Divaricately branched from the base

Stemless, or stems less than $5 \mathrm{~cm}$. long.

Cinereous-pubescent

Woolly-canescent
Bracts of the involucre acute (not acuminate) or obtuse; heads smaller, when expanded usually only $2-3 \mathrm{~cm}$. broad.

Leafy stems evident, at maturity a few $\mathrm{cm}$. to $1 \mathrm{dm}$. or more long; the whole plant more or less canescent.

Winter annuals or biennials, branched from the crown of the taproot.

Involucral bracts cinereous-canescent on the back

Involucral bracts green but often strigillose on the back.

Diminutive plants with almost filiform stems and roots; heads few

Stouter stems and roots; heads several to many

Perennial with compact branched caudex

Stemless, or the stems very short $(1-3 \mathrm{~cm}$.) even at maturity.

Pale-pubescent; the leaves often surpassing the sessile heads.

Cinereous with appressed pubescence or glabrescent .

White with long fine wool

Green but of ten more or less strigillose, especially when young.

Achenes pubescent (glochidiate-capitellate).

Caudex branched (heads several); involucral bracts acute

Caudex simple (heads usually solitary); involucral bracts obtuse

Achenes glabrous

1. Townsendia formosa Greene, Leaflets 1: 213. 1906. Perennial, from a branched caudex, the sterile branches ending in a rosette of leaves, the others in a stout, upright, leafy, monocephalous stem: basal leaves cuneately to spatulately obovate, very obtuse, entire, $2-4 \mathrm{~cm}$. long, of thin texture, glabrous, except as to the ciliolate margins; those of the stem numerous, spatulateoblong: heads large, $4-5 \mathrm{~cm}$. broad from tip to tip of the broad purple rays; bracts of involucre oblong to lanceolate, thin, broadly scarious-margined. ( $T$. pinetorum Greene, in herb.)-Mountains of New Mexico, and probably in Colorado.

2. Townsendia eximia Gray, Pl. Fendl. 70. 1848. Stems erect, simple or sparingly branching, 1-3 dm. high: leaves spatulate or the upper lanceolate: head sparingly leafy-bracted or naked at base; involucral bracts ovatelanceolate and somewhat rigidly cuspidate-acuminate, whitish-scarious with green center: rays blue or purplish: achenes broadly obovate, almost cartilaginous, glabrate (sprinkled with a few short and obscure glochidiate-tipped hairs); pappus wholly persistent, of 2 subulate at length corneous stout awns which are rather shorter than the achene (sometimes wanting in the ray), and a circle of rigid squamellae which are mostly coroniform-concreted at base and rigid in age. (T. Vreelandii Rydb. Bull. Torr. Bot. Club 28: 22. 1901.)Mountain sides; Colorado and New Mexico.

3. Townsendia Parryi Eaton, Am. Nat. 8: 212. 1874. Perennial or biennial, canescently pubescent; the caudex very short: leaves rosulate, obovatespatulate, often apiculate, tapering into a petiole: peduncles stout, $5-15 \mathrm{~cm}$. long, solitary or several, somewhat leafy below, naked above and bearing single large heads: bracts of the involucre in 3 or 4 series, lanceolate, acute, herbaceous, with scarious lacerate-ciliate margins, the inner ones acuminate: rays bright blue, double the length of the involucre: pappus the same in rays and disk, persistent, of stout and unequal barbellate bristles, a little longer 
than the achenes.-Mountains of northwestern Wyoming and in those of Idaho and Montana.

4. Townsendia grandiflora Nutt. Trans. Am. Phil. Soc. 7: 306. 1841. Perennial from a long woody root, branching at the base and sometimes also above, pubescent, or at length glabrate, 5-20 $\mathrm{cm}$. high: leaves linear or linear-spatulate, 3-7 cm. long, canescent: heads $3-4 \mathrm{~cm}$. broad, solitary at the ends of the branches; involucre hemispheric, the bracts scarious-margined, lanceolate, conspicuously acuminate: rays violet or purple: pappus of the rayflowers a crown of short scales, that of the disk-flowers of rigid bristles longer than the achene.-Wyoming to Nebraska and New Mexico.

5. Townsendia alpina (Gray) Rydb. Mem. N. Y. Bot. Gard. 1: 390. 1900. Allied to the foregoing but nearly or quite stemless and more pubescent and cinereous: leaves small, only 10-15 mm. long: bracts of the involucre shortacuminate: rays rose-purple or pink.--Probably very rare; high mountains, in northwestern Wyoming and adjacent Idaho and Montana.

6. Townsendia condensata Parry, 1. c. 213. Very lanuginous with long and soft arachnoid hairs, the spatulate-obovate leaves rosulate-crowded around the large and broad sessile heads, the whole forming a globular or hemispherical woolly tuft $3-4 \mathrm{~cm}$. high and surmounting a slender stoloniform caudex: bracts of the involucre linear and soft, with a weak attenuate apex, all nearly equal in length: rays 100 or more, narrow: pappus of ray and disk plurisetose and long.-Wyoming, on a high alpine peak of the Owl Creek range.

7. Townsendia Watsonii Gray, Proc. Am. Acad. 16: 84. 1881. Winter annual or biennial, canescent with a fine appressed pubescence; stems many, branching, 7-15 cm. long: leaves linear-spatulate, 2-4 cm. long: heads showy, very many, sometimes leafy-bracted, but mostly on naked peduncles $2-3 \mathrm{~cm}$. long; involucre hemispherical, 10-12 $\mathrm{mm}$. wide, the bracts in about 3 series, the broad white scarious margins deeply fringed: rays pink: pappus of the ray composed of minute lacerate scales; that of the disk of stout bristles $3 \mathrm{~mm}$. long, with a few shorter ones intermixed; achenes minutely pubescent. T. strigosa.-Western Wyoming to Utah and Idaho.

8. Townsendia Fendleri Gray, Pl. Fendl. 70. 1848. Winter annual or biennial, the root very slender; stems few from the crown, spreading, unequal, slender, flowering when very short, strigose: leaves linear, slightly dilated upward; the cauline rather few, the uppermost near the head: involucre 6-8 $\mathrm{mm}$. broad, the bracts in about 3 ranks: rays blue or white: pappus subulatesetiform, scabrous; that of the ray reduced to a crown of short squamellae.Extending into southern Colorado from New Mexico.

9. Townsendia strigosa Nutt. 1. c. Winter annual or more probably biennial, branching from the crown of a moderately slender taproot; stems spreading, beginning to flower when very short, cinereous with fine, close, strigillose pubescence as are also the leaves: early leaves spatulate; the later ones linear: involucres $8-12 \mathrm{~mm}$. broad, the bracts in about 2 ranks, abruptly acute: pappus as in the preceding.-Gravelly plains; Wyoming to New Mexico and Arizona.

10. Townsendia incana Nutt. 1. c. Perennial from a branched woody caudex from the crowns of which spring simple or branched spreading stems 5-12 cm. long; stems densely white-strigose: leaves silky-canescent, oblongspatulate, tapering into a short petiole, numerous and usually involucrating the rather small heads: involucral bracts silky-pubescent, with broad scarious and conspicuously fimbriate-ciliate margins: rays white to lilac: pappus of the ray similar to that of the disk but shorter.-In arid gravelly and sandy soils of the high plains; Wyoming to Utah and Nevada.

11. Townsendia exscapa (Rich.) Porter, Mem. Torr. Club 5: 321. 1894. Depressed-acaulescent perennial, with closely sessile solitary or few heads on the crown next the ground, surrounded and surpassed or equaled by the linear or linear-spatulate leaves, at length multicipital and pulvinate-tufted, 2-5 cm. high: head 15-25 mm. long; involucral bracts narrowly lanceolate, mostly acute: rays white or purplish-tinged: pappus of the ray plurisetose 
like that of the disk (forma papposa Gray, Pl. Fendl.), or of fewer but similar bristles, or (in the northern part of its range) with most of the bristles short and aristiform, and even reduced to squamellae little longer than the width of the achene. T. sericea.-One of the earliest flowers in our range; throughout our range to the Canadian Rocky Mountains.

11a. Townsendia exscapa Wilcoxiana (Wood) A. Nels. Leaves spatulatelinear, in age tending to become glabrate: heads slightly larger. (T. Wilcoxiana Wood, Bull. Torr. Bot. Club 6: 163. 1875; T. intermedia Rydb. Brit. Man. 944. 1901.) - This is the more robust form of the plains; from Oklahoma and Kansas to Colorado.

12. Townsendia spathulata Nutt. 1. c. Depressed and multicipital from a slender perennial root, forming a tuft 3-4 cm. high: leaves crowded, spatulate, densely villous-lanate; the upper about equaling the heads: bracts of the involucre oblong-lanceolate, acute: rays rather short, pinkish: pappus of ray and disk similar and of the same length, of slender bristles.- Hills and mountains of interior Wyoming.

13. Townsendia glabella Gray, Proc. Am. Acad. 16: 84. 1881. Perennial, the caudex simple or with short slender branches, sparsely pilose-pubescent when young: leaves rosulate on the crowns or crowded on the very short branches, rather thick, soon glabrous, spatulate, $2-8 \mathrm{~cm}$. long (including the petiole): heads on naked peduncles, often surpassing the leaves; involucre glabrous, the bracts oblong, acute, in about 3 series: pappus plurisetose, that of the ray very short. (T. Bakeri Greene, Pitt. 4: 157. 1900.)-New Mexico and southern Colorado.

14. Townsendia Rothrockii Gray, in Wheeler Rept. 6: 148. pl. 7. 1878. Leaves spatulate, $15-25 \mathrm{~mm}$. long, rosulate around the solitary head which is closely sessile at the surface of the ground, or at length with 1 or 2 additional heads and tufts from the same crown: involucre short and broad; the bracts oblong, mostly obtuse: ray-pappus of squamellate bristles not longer than the breadth of the achene, or with 1 or 2 more elongated.-Mountains of South Park, Colorado, in the alpine district, at 13,500 feet.

15. Townsendia dejecta A. Nels. Bot. Gaz. 37: 267. 1894. Depressedacaulescent, the caudex bearing a few heads in a small rosulate tuft: leaves linear-spatulate or oblanceolate, somewhat petioled, 1-2 cm. long, surpassing the heads, green and apparently glabrous but strigose on both faces: heads sessile, about $1 \mathrm{~cm}$. high; involucral bracts in 2-3 series, oblong-ovate, mostly subacute, purple or some with green centers, ciliate-margined, otherwise nearly glabrous: rays white or purplish; disk-flowers numerous, the corolla lobes purple: pappus similar in disk and ray-flowers: achenes brown, flattened, spatulate-cuneate, about $4 \mathrm{~mm}$. long, glabrous. (T. scapigera as to our range.) -In the mountains; Utah to western Wyoming and Montana.

\section{XYLORHIZA Nutt.}

Perennial, from deep-set woody roots surmounted by a short more or less branched caudex. Stems solitary or several from the crowns, erect, leafy, monocephalous or with monocephalous branches. Leaves entire or spinulosetoothed, usually narrow (linear to oblanceolate), mucronulate. Heads large, with conspicuous white or pinkish-red rays. Involucral bracts mostly in 2 series, oblong or lanceolate, carinate below, herbaceous with scarious margins, acute or acuminate, the inner as long as the disk, the outer but little shorter. Appendages of the style lanceolate, acute. Achenes oblong, compressed, densely silky. Pappus fulvous.-Aster in part.

Peduncles barely exceeding the leaves.

Herbage glabrate

Herbage softly short-villous
Peduncles about as long as the leafy part of the stem

1. Xylorhiza glabriuscula Nutt. Trans. Am. Phil. Soc. 7: 297. 1841. Glabrate or rarely obscurely short-villous or lanate; stems leafy, 1-2 dm. high, terminating in a single (sometimes 3-5) short peduncle: leaves 3-6 dm. 
long, narrowly oblong-lanceolate or linear: involucre $10-14 \mathrm{~mm}$. broad, the bracts acute, somewhat ciliate: rays white, about $12 \mathrm{~mm}$. long. Aster Xylorhiza. -Naked clayey saline soils; south-central Wyoming.

1a. Xylorhiza glabriuscula villosa (Nutt.) A. Nels. Intermediate between the preceding and the following species: softly villous or tomentose. ( $X$. villosa Nutt. 1. c. 298.)-Habitat and range of the species.

2. Xylorhiza Parryi Gray, Am. Nat. 8: 212. 1874. Somewhat hoary with a thin, loose, villous tomentum; stems several from the woody crowns, $1-2 \mathrm{dm}$. high: leaves spatulate-linear, cuspidate, $3-5 \mathrm{~cm}$. long: peduncles solitary: involucral bracts oblong-lanceolate, long-acuminate, cinereous-pubescent: rays numerous, white, 10-14 mm. long: achenes white-villous. Aster Parryi.In denuded or saline soils; western Wyoming, Colorado, and adjacent Utah.

3. Xylorhiza venusta (Jones) Heller, Cat. N. A. Plants 8. 1900. Softly villous-tomentose up to the canescent involucre; stems many, erect, stout, simple, shrubby at base: leaves all entire, oblanceolate or lowest spatulate, scarcely petioled, 5-8 cm. long, generally apiculate, larger ones indistinctly 3-nerved: peduncles monocephalous, 1-2 dm. long: involucral bracts oblongovate and abruptly long-acuminate, in about 3 series: rays white or light purple, linear-oblanceolate, 20-25 mm. long: pappus of unequal, stiff bristles; achene silky.-Western Colorado to Utah.

\section{ASTER L. Aster}

Perennial or rarely annual herbs, with alternate entire or serrate leaves and racemose, paniculate, or corymbose (rarely solitary) heads of flowers with white, purple, or blue ray; and yellow (often changing to purple) disk corollas. Heads many-flowered; the ray-flowers in a single series, not very numerous, pistillate; those of the disk tubular, perfect. Bracts of the involucre more or less imbricated, usually with herbaceous or foliaceous tips. Receptacle flat or convex, naked. Appendages of the style (in the disk-flowers) lanceolate or subulate, acute. Pappus simple; of numerous, often unequal, scabrous capillary bristles. Achenes usually compressed.-(Includes Brachyactis Ledeb., Eucephalus Nutt., and Unamia Greene.)

\section{ANNUALS (Brachyactis Ledeb.)}

Involucral bracts linear, acute

Involucral bracts oblong, obtuse
1. A. angustus.

2. A. frondosus.

\section{PERENNIALS (Eucephalus Nutt.)}

INVOLUCRAL BRACTS WITH PROMINENT OR KEELED MIDRIB, DRY AND CHARTACEOUS, USUALLY PURPLE-TIPPED

Stems mostly simple below; the involucral bracts acute.

Stout, usually 6-15 dm. high; heads large (12-15 mm. high)

Slender, 3-6 dm. high; heads smaller, with conspicuously

purple-tipped bracts
Stems mostly branched throughout; at least the outer involucral bracts obtuse

\section{A. Engelmannii.}

4. A elegans.

5. A. glaucus.

\section{PERENNIALS}

INVOLUCRAL BRACTS NEITHER KEELED NOR WITH PROMINENT MIDRIB, AT LEAST THE TIPS GREEN

Stems low, usually less than $1 \mathrm{dm}$. high, monocephalous; high alpine.

From a low woody crown or caudex.

Stems and involucre lanate-pubescent

Stems and involucre minutely glandular

From filiform creeping rootstocks.

Stems taller, usually more than $1 \mathrm{dm}$. high, bearing solitary, few, or many heads, mostly from rootstocks which are of ten branching and matted or tufted.

Peduncles and involucres glandular.

Stems simple, rarely branching at summit. Heads solitary or racemed

6. A. culminis.

7. A. Kingii.

8. A. andinus.

$$
\text { Heads not in racemes. }
$$


Heads few to several, corymbed.

Heads small; leaves linear, or the lower spatulate to lanceolate

Heads large; leaves ample, ovate or oblong, $8-1 \dot{2}$

Heads in a narrow crowded panicle; leaves large, oblanceolate to lanceolate

Stems branched.

More or less scabrous-hispid or-ciliate.

Tall and coarse, 6-15 dm. high

Low and rigid, 1-4 dm. high.

Leaves hispidulous-scabrous, spreading or deflexed .

Leaves ciliate-hispid on the margins, ascending

Leaves glabrate, granular-glandular

Peduncles and involucres not glandular.

Leaves not glabrous on their faces, cinereous, scabrous, or hirsutulous.

Stems subsimple, erect, with a few erect or ascending branches bearing solitary or few rather large heads (1 cm. high)

Leaves cinereous; rays violet

Leaves obscurely scabrous; rays white

Stems divaricately branched; heads many to very numerous, small (less than $1 \mathrm{~cm}$. high).

Bracts unequal, usually hispidulous; heads small, very numerous.

All the bracts acute

Some of the bracts obtuse.

Bracts subequal; heads larger and fewer.

Heads paniculate

Heads strictly axillary-racemose

Leaves glabrous on their faces (pubescence, if any, not harsh), often ciliate or hispid on the margins.

Outer involucral bracts shorter than the inner (not foliaceous).

Stems and peduncles wholly glabrous.

Leaves linear, none auriculate-clasping.

Leaves 1-nerved; heads paniculate

Leaves 3-nerved; heads in a flat-topped corymb :

Leaves broadly oblanceolate, oblong, or lanceolate, the upper auriculate-clasping.

Leaves abruptly reduced in size on the branches

Leaves gradually reduced in size on the branches

Stems and peduncles pubescent at least in longitudinal lines.

Lower leaves ovate-cordate, often serrate, longpetioled oblanceolate, lanceolate, or linear.

Lower leaves oblanceolate, lanceolate, or linear. All the bracts narrowly linear ... . . Outer bracts broader than the inner.

Pubescence of branchlets more or less uniform, not characteristically in lines.

Bracts ascending or erect, not refracted.

Bracts oblanceolate, usually some of the outer obtuse.

Stems slender, erect, 4-7 dm, high

Stems stouter, ascending, 2-4 dm. high :

Bracts broadly oblong to linear-lanceolate or linear, all acute.

Stem leaves oblanceolate to linear.

Heads several to many, paniculate

Heads few (rarely solitary), in a flattopped corymb

Stem leaves ovate, elliptic, or ovatelanceolate.

Stems simple below

Stems branched from the base - .

Bracts refracted (at least some of them)

Outer involucral bracts as long as or longer than the inner, more or less foliaceous.

Bracts refracted (at least some of them)

Bracts ascending or erect.

Plants low (1-3 dm.).

Outer bracts little, if any, longer than the inner

Outer bracts foliaceous, much longer than the inner

Plants tall ( $4-8^{\circ} \mathrm{dm}$.).

Bracts mostly linear

Bracts oblong or oblanceolate

9. A. pauciflorus.

10. A. conspicuus.

11. A. integrifólius.

12. A. novae-angliae.

13. A. oblongifolius.

14. A. Fendleri.

15. A. campestris.

16. A. griseus.

17. A. ptarmicoides.

18. A. multiflorus.

19. A. hebecladus.

20. A. commutatus. 21. A. Cordineri.

22. A. Pórteri.

17. A. ptarmicoides.

23. A. laevis.

24. A. Geyeri.

25. A. Lindleyanus.

26. A. caerulescens.

27. A. laetevirens.

28. A. Nelsonii.

29. A. adscendens.

30. A. longifolius.

31. A. Fremontii.

32. A. Canbyi.

33. A. meritus,

34. A. proximus.

34. A. proximus.

35. A. apricus.

36. A fulcratus.

37. A. frondeus.

32. A. Canbyi. 
1. Aster angustus T. \& G. Fl. N. A. 2: 162. 1842. Stems 1-3 dm. high, branching, leafy, nearly glabrous, except that the linear chiefly entire leaves are somewhat ciliate: numerous rather small heads disposed to be racemosepaniculate; bracts of the involucre acute: corolla of the ray-flowers reduced to the tube and much shorter than the elongated style.-Wet saline soil; from Colorado and Utah to the Saskatchewan and Minnesota.

2. Aster frondosus T. \& G. 1. c. 165. Stems 1-3 dm. high, branching from the base, when low usually spreading, when taller the branches bearing numerous spicately paniculate heads (of $8 \mathrm{~mm}$. in height): outer bracts of the involucre linear-oblong, obtuse, wholly foliaceous and loose, numerous: rays in anthesis exserted, $2 \mathrm{~mm}$. long, linear, pinkish-purple, always longer than the style, but equaled or surpassed by the mature copious pappus. Springy places and borders of pools; Wyoming and Colorado to the Sierras.

3. Aster Engelmannii Gray, Am. Journ. Sci. II. 33: 23S. 1862. Rather tall and robust, green, puberulent to glabrous: leaves thin, ovate-oblong to broadly lanceolate, 5-10 cm. long, the larger sometimes with a few small teeth, upper acuminate: heads $12-15 \mathrm{~mm}$. high; involucral bracts acute or acuminate; some outer ones partly herbaceous, or with loose pointed tips; inner purplish: rays $12-14 \mathrm{~mm}$. long.-Mountains of Colorado, Utah, and Wyoming, to the Cascades.

4. Aster elegans T. \& G. 1. c. 159. Slender, 3-6 dm. high, mostly scabropuberulent: leaves thickish, pale, lanceolate, 3-5 cm. long, erect, the upper apiculate-mucronate: heads several at summit of simple stem or branches, comparatively small and few-flowered, 8-10 mm. high; involucral bracts all close and conspicuously woolly-ciliate, barely acute, outer ovate, none with pointed tips: rays rather few, about $8 \mathrm{~mm}$. long.-Mountains of Wyoming and Montana to Nevada and Oregon.

5. Aster glaucus T. \& G. 1. c. 150. Throughout smooth and glabrous, glaucescent or pale; stems 3-7 dm. high from extensively creeping filiform rootstocks, branching, bearing several or numerous paniculate heads: leaves thickish, lanceolate, 3-7 cm. long, 6-12 mm. broad, rather obtuse: involucre imbricated in about 3 ranks: rays bright violet, $8-12 \mathrm{~mm}$. long.-Mountains of Wyoming to Colorado and Utah.

$5 a$. Aster glaucus formosus A. Nels. Involucral bracts very broad and obtuse (suborbicular), sometimes with a mucro. . (Eucephalus formosus Greene, Pitt. 4: 156. 1900.)-Pagosa Peak, Colorado.

6. Aster culminis A. Nels. Caudex low, woody; stems solitary from the enlarged crown, rather stout, short-lanate, pubescent, $1 \mathrm{dm}$. or less high, bearing a large solitary head: leaves linear, spatulate, 1-3 cm. long, mostly basal, cinereous-hirsute to silky: involucral bracts loosely erect, broadly linear, silky, short-lanate, all nearly equaling the disk: rays white, shading to violet: achenes with short pubescence; pappus simple. (A. alpinus $\mathrm{L}$. as to our range.)-Berthoud Pass, Colorado.

7. Aster Kingii Eaton, Wats. Bot. King's Exp. 141.pl. 16. 1871. Caespitose, 5-12 cm. high: leaves mainly radical, spatulate, entire, or with few sharp teeth, mucronate, thinnish, glabrous or nearly so, 3-6 cm. long: flowering stems pubescent and above glandular, bearing solitary or 3-5 middle-sized heads: involucre $8-10 \mathrm{~mm}$. high, merely puberulent-glandular, hardly at all viscid; the bracts linear-lanceolate with attenuate and squarrose-spreading green tips: rays white.-Utah, in the Wasatch Mountains.

8. Aster andinus Nutt. Trans. Am. Phil. Soc. 7: 290. 1841. Dwarf, with decumbent stems 5-8 cm. long, from filiform creeping rootstocks, bearing a solitary comparatively large head: leaves $12 \mathrm{~mm}$. long; radical and lower cauline spatulate; cauline (2 or 3 ) linear-lanceolate: heads $8 \mathrm{~mm}$. high: rays (35-40) violet.- " In the mountains of Wyoming, near perpetual snow" (Nuttall).-It is a question whether this species has since been found, although some specimens from the alpine regions of Colorado have been referred to it.

9. Aster pauciflorus Nutt. Gen. 2: 154. 1818. Stems 2-5 dm. high from a slender creeping rootstock, simple and bearing few heads, or branching above: leaves moderately fleshy, linear, or the radical subspatulate or elongatedROCKY MT. BOT.-33 
lanceolate; uppermost reduced to bracts: bracts of the short hemispherical in. volucre rather fleshy and green, moderately uncqual and rather loose, in only 2 or 3 ranks: achenes narrow, compressed, striate-nerved, appressed-pubescent. -In saline soil; from New Mexico and Arizona to Utah; infrequent.

10. Aster conspicuus Lindl. Hook. Fl. Bor. Am. 2: 7. 1834. Scabrous; stems $3-10 \mathrm{dm}$. high, stout, rigid, bearing several or numerous corymbosely cymose heads: leaves rigid, ovate, oblong, or the lower obovate, acute, ample, often 9-12 cm. long, 3-8 cm. broad, acutely serrate, reticulate-venulose as well as veiny: involucre broadly campanulate, about equaling the disk, 10-12 $\mathrm{mm}$. high; the bracts in several series, minutely glandular-puberulent or viscidulous, lanceolate, acute, the greenish tips a little spreading: rays $12 \mathrm{~mm}$ : long, violet: achenes minutely pubescent.-In the mountains; Wyoming and Montana to Washington.

11. Aster integrifolius Nutt. 1. c. Stems stout, simple, 2-4 dm. high or more, villous-pubescent, the summit and the simple corymb glandular and viscid: leaves of firm texture, oblong or spatulate, or the upper ones lanceolate, the larger ones 10-15 cm. long, sometimes obsoletely repand-serrulate, apiculate, traversed by a strong midrib, glabrate, half-clasping; lowest tapering into a long, stout, wing-margined petiole with clasping base: heads fully 12-15 $\mathrm{mm}$. broad, hemispherical; involucre and branchlets viscid-glandular; the bracts few-ranked, linear, ascending; the outer commonly larger and more foliaceous, nearly equaling the inner: rays 15-25, bluish-purple, $12 \mathrm{~mm}$. long: achenes compressed-fusiform, 5-nerved, and sometimes with intermediate nerves, sparsely pubescent; pappus decidedly rigid.-Moist open subalpine woods; Colorado to Montana and to the Pacific States.

12. Aster novae-angliae L. Sp. Pl. 875. 1753. Stems stout and strict, 6-15 dm. high, very leafy to the top, coarsely hirsute or hispid with manyjointed hairs, also with glandular pubescence: leaves lanceolate or broadly linear, pubescent, 5-12 cm. long, entire, slightly if at all narrowed below, half-clasping by a strongly auriculate-cordate base: heads crowded: rays 50-60 or more, $10-12 \mathrm{~mm}$. long, purple: involucre of middle-sized heads well imbricated; the unequal bracts with loose squarrose-spreading tips.-Colorado to the Saskatchewan and eastward.

13. Aster oblongifolius Nutt. 1. c. 156. Stems 2-5 dm. high, hirsutepubescent, very leafy, corymbosely branched: leaves narrowly oblong to broadly linear; the larger cauline $5 \mathrm{~cm}$. long, somewhat puberulent: involucre aromatic-scented; the linear bracts granulose-glandular and viscidulous: rays $25-30$, bright violet, $10-12 \mathrm{~mm}$. long.-Hardly within our range, but represented in Colorado by

13a. Aster oblongifolius rigidulus Gray, Syn. Fl. 1: 179. 1884. Low, more fastigiate, with more rigid and hispidulous scabrous leaves. (Aster Kumleinii Fries.) - Colorado to Kansas and Texas.

14. Aster Fendleri Gray, Pl. Fendl. 66. 1849. Rigid, 1-3 dm. high, sparsely hispidulous: the linear, 1-nerved, firm leaves hispid-ciliate, otherwise usually smooth and glabrous: involucre somewhat campanulate, 5-7 $\mathrm{mm}$. high; outer bracts shorter, linear-oblong, obtuse, pruinose-glandular: rays violet, $8 \mathrm{~mm}^{\prime}$. long.-Plains and sandhills; from western Kansas to southern Colorado and northern New Mexico.

15. Aster campestris Nutt. Trans. Am. Phil. Soc. 7: 293. 1841. From creeping underground rootstocks; stems erect, rather slender, nearly simple, minutely granular-glandular, becoming glandular or viscid-pubescent above, brownish and more or less tinged with purple, especially above, $2-4 \mathrm{dm}$. high: leaves broadly linear, acute at apex, 3-5 dm. long, about $5 \mathrm{~mm}$. broad, indistinctly 3-nerved, ciliate on the margins, both faces sprinkled with minute nearlysessile glands: heads solitary-terminal, or several and racemosepaniculate; involucre low-hemispherical, about $15 \mathrm{~mm}$. broad, half as high; bracts in about 3 only moderately unequal rows, linear-lanceolate, somewhat acuminate, with glandulosity like that of the stem: rays $20-30$, a beautiful dark azure blue, linear-oblong, about $15 \mathrm{~mm}$. long and $2 \mathrm{~mm}$. wide: pappus a sordid white; the short achenes pubescent. (A. Andrewsii A. Nels. Proc. Biol. 
Soc. Wash. 17: 179. 1904. It is possible that this name should be retained for the plants of our range and $A$. campestris restricted to the north Pacific States.) - Colorado to Montana and westward.

16. Aster griseus Greene, Leaflets 1: 147. 1905. Stems decumbent or ascending, 2-4 dm. high, branching, sparingly villous-hairy; foliage and bracts pale as if glaucous, but finely strigose-pubescent: lowest leaves oblanceolate, $5 \mathrm{~cm}$. long; the cauline oblong-linear to linear; all obtuse, entire, 1-nerved, ciliate or ciliolate: heads of middle size; involucres broadly campanulate or nearly hemispherical; the bracts imbricated in 3 series, erect, appressed even to the tips, the outer obovate, obtuse, the inner more elongated, acutish, all pubescent and more or less ciliate: rays many, showy, pale violet. -Mountains of Colorado.

17. Aster ptarmicoides T. \& G. Fl. 2: 160. 1842. Rather rigid, 2-5 dm. high, in a tuft, from smooth to puberulent, bearing a corymbiform cyme of several or numerous heads: leaves firm, linear or the lower spatulate-lanceolate: bracts of the involucre oblong-lanceolate, obtuse, thickish, rather rigid: rays 4-8 mm. long, broadish: pappus white, of rather rigid bristles, longer ones manifestly clavellate at tip. (Unamia ptarmicoides Greene, Leaflets 1: 6. 1903.)-From Colorado to the Saskatchewan and New England.

18. Aster multiflorus Ait. Hort. Kew. 3: 203. 1789. Stem much branched and bushy, grayish-strigose, 3-20 dm. high, the branches ascending or spreading: leaves rigid, linear or linear-oblong, entire, mostly obtuse, sessile or slightly clasping at the base, strigose or glabrate, those of the stem $1-2.5 \mathrm{~cm}$. long, those of the branches very small and crowded: heads $6-8 \mathrm{~mm}$. broad, densely crowded, nearly sessile; involucre turbinate, $4-6 \mathrm{~mm}$. high; the bracts coriaceous, pubescent, in 3 or 4 series, the short green tips obtuse or mucronate, spreading: rays $10-20$, white, $3-4 \mathrm{~mm}$. long: pappus brownish-white; achenes puberulent.- In the northeastern part of our range to the New England States.

19. Aster hebecladus DC. Prodr. 5: 242. 1836. Stems erect, ascending or decumbent, usually simple below, branched above, 4-7 dm. high, densely hirsute with short divaricate hairs: stem leaves linear or oblong-linear, 3-6 cm. long, 2-3 mm. wide, rather firm, hirsute, with short spreading hairs, acute with a short spinulose tip; those of the branchlets merging into the bracts of the involucres: heads numerous; involucre, $5-8 \mathrm{~mm}$. high; bracts in 3-4 series, minutely spinulose-mucronate, very thick, hirsute especially on the margin, with oval herbaceous tip: rays white, $5-7 \mathrm{~mm}$. long: achenes strigose. [A. crassulus Rydb. Bull. Torr. Bot. Club 28: 504. 1901; A. exiguus (Fern.) Rydb. 1. c. 505; A. polycephalus Rydb. 1. c. 33: 153. 1906.]-From the Dakotas to Texas and New Mexico.

20. Aster commutatus Gray, Syn. Fl. 1: 185. 1884. Similar to the preceding species, except in the inflorescence; the stem rough-pubescent or sometimes nearly glabrous, $4-7 \mathrm{dm}$. high, with ascending or divergent branches: leaves linear or linear-oblong, obtuse, entire, sessile or slightly clasping at the base; those of the stem 2-7 cm. long: heads larger than those of $A$. multiflorus, $12-16 \mathrm{~mm}$. broad; involucre $6-8 \mathrm{~mm}$. high, the bracts squarrose-tipped and sometimes foliaceous: rays $20-30$, about $6 \mathrm{~mm}$. long. (A. adsurgens Greene, Pitt. 4: 216. 1900; A. incanopilosus Sheld. Bull. Torr. Bot. Club 20: 286. 1893; A.falcatus Lindl. T. \& G. Fl. 2: 126. 1842, as to our range.)Northwest territory to Texas and New Mexico.

21. Aster Cordineri A. Nels. Bot. Gaz. 40: 64. 1905. Dark green and seemingly glabrous but sparsely scabrous on the margins of leaves and involucral bracts; stems 3-6 dm. long, generally simple below, racemosely short-branched above, decumbent at base and either widely spreading or nearly erect, often puberulent especially upward, very leafy: leaves broadly linear, crowded, spinulose-tipped; primary ones 4-7 cm. long, 4-6 mm. broad; secondary ones similar but smaller, more or less fascicled in the axils: heads solitary at the ends of the short, leafy, axillary, racemosely disposed branchlets, rather large; involucre nearly $1 \mathrm{~cm}$. high and somewhat broader; bracts erect, glabrate, dark green on the spatulate-linear blade, lighter at base, 
spinulose-tipped: rays 20-30, bluish shading to white: pappus rather coarse and dingy; achene short-pubescent.-Sandy plains; Colorado and Wyoming.

22. Aster Porteri Gray, Proc. Am. Acad. 16: 99. 1881. Stems 1-3 dm. high, glabrous and smooth (except ciliolation of lowest leaves), either simple or branching above: leaves linear or the lower spatulate-linear, 5-10 cm. long, 2-5 $\mathrm{mm}$. wide; radical narrowly spatulate: heads broad, rather small $(6-8 \mathrm{~mm}$. high), thyrsoidly or corymbosely arranged; bracts rigid, narrow, with subulate, green, nearly erect tips: rays numerous, bright white, $8 \mathrm{~mm}$. long: achenes minutely pubescent.-Common in the Colorado mountains.

23. Aster laevis L. Sp. Pl. 876. 1753. Rather stout, 5-12 dm. high, rigid: leaves ovate or oblong to lanceolate, 9-12 cm. long, decreasing upward; the radical and lowest cauline contracted below into a winged petiole; the upper all with auriculate or subcordate partly clasping base: heads sparsely thyrsoidpaniculate, on short and rigid branchlets; involucre campanulate or obscurely turbinate; the whitish coriaceous bracts bearing abrupt rhomboid or deltoid short green tips: rays 20 or 30 , broadish, sky-blue verging to violet.-Eastern slopes of the Rocky Mountains and eastward across the continent.

24. Aster Geyeri (Gray) Howell, Fl. 308. 1897. Whole plant very smooth and glabrous; stem stout, 3-7 dm. high, rigid: leaves ovate or oblong to lanceolate, 9-12 cm. long, decreasing upward to subulate bracts; the radical and lowest cauline contracted below into a winged petiole; the upper all with auriculate or subcordate partly clasping base: heads sparsely thyrsoid-paniculate, on short and rigid branchlets; involucre campanulate, the whitish subcoriaceous bracts mostly attenuate-acute, with obscurely green tips: rays 20-30, broadish, sky-blue to violet: achenes glabrous or nearly so, 4-5-ribbed.Wyoming to Idaho and Montana.

25. Aster Lindleyanus T. \& G. Fl. 2: 122. 1842. Glabrous or sparingly pubescent, 3-10 dm. high, branched above: leaves rather thick, glabrous or slightly pubescent, especially on the veins; the lower and basal ones cordate at the base, sharply serrate, ovate, acute or acuminate, 5-10 cm. long, with slender naked petioles; upper leaves ovate or lanceolate, less serrate or entire, sessile or with margined petioles, those of the branches lanceolate or linear-lanceolate, smaller: heads few, 8-10 mm. high; bracts imbricated, glabrous or nearly so, the tips green: rays 10-20, blue or violet, 6-10 mm. long pappus nearly white.-The form in our range is not typical of this species; Colorado to Montana and thence nearly across the continent.

26. Aster caerulescens DC. 1. c. 235. Tall, 5-15 dm. high, paniculately polycephalous, from nearly glabrous and smooth to scabrous-pubescent: leaves lanceolate to linear, entire or the larger with a few denticulations, 5-12 cm. long: heads rather crowded, 7-10 mm. high; involucre of narrowly linear or more attenuate erect bracts, either unequal and imbricated, or with some loose and slender exterior ones which equal the inner: rays purple, white or violet, 6-10 mm. long. (A. Aluvialis Osterh. Bull. Torr. Bot. Club 32: 611. 1905; A. Osterhoutii Rydb. 1. c. $31: 654 ;$ A. Wootoni Greene, Leaflets 1: 146. 1905; Brachyactis hybrida Greene, Leaflets 1: 147. 1905; A. salicifolius Lam. in part, as to our range.)-Wyoming to New Mexico and westward.

27. Aster laetevirens Greene, Pitt. 4: 219. 1900. Stems very erect, 3-6 dm. high, glabrous except as marked by lines of pubescence decurrent from the leaves, commonly red or purple, otherwise pale and glaucescent, leafy, and somewhat equably so, even to the narrow and fastigiate or broader and subcorymbose panicle: leaves lanceolate or oblong-lanceolate, sessile by a broad and almost auriculate-clasping base, thinnish, light green or glaucescent, entire or obscurely and remotely serrate-toothed, marked by a white midvein and some fine less obvious reticulation: involucres turbinate or subcampanulate; bracts narrowly lance-linear, very acute, the narrow light green herbaceous tips with a fine but distinct white midnerve, the margins remotely serrulate-ciliolate: rays many, usually long and showy, pinkish to rose-purplish. (Many specimens of this species have been variously referred to $A$. salicifolius Lam. and $A$. paniculatus Lam., species which are scarcely within our range.) - Near streams; in Colorado and Wyoming. 
28. Aster Nelsonii Greene, 1. c. Stems slender, wiry, 4-8 dm. high, from branching and only superficially seated subligneous rootstocks, simple, leafy throughout and racemosely or subcorymbosely floriferous above the middle: cauline leaves $5-8 \mathrm{~cm}$. long, firm, narrowly linear, entire, acute, sessile and half-clasping, 1-nerved, glabrous on both faces, the margin scabrellous: involucres broadly turbinate, $6-8 \mathrm{~mm}$. high; bracts imbricated in about 3 series, the short outermost often wholly herbaceous, oblong and obtuse, the others successively narrower and lanceolate or linear, acute, pubescent on the back and marginally ciliate, mostly well differentiated into lanceolate green tip and marginally colorless linear base: rays about 20, violet or paler, rather narrow and inconspicuous.-Frequent on moist banks; Wyoming and Colorado.

29. Aster adscendens Lindl. Hook. Fl. Bor. Am. 2: 8. 1834. Stem slender, rigid, glabrous or sparingly hirsute-pubescent, branched or simple, 2-5 dm. high: leaves firm, entire, rough-margined, sometimes ciliolate; those of the stem linear-lanceolate or linear-oblong, acute or obtusish, 2-7 cm. long, 4-10 mm. wide, sessile by a more or less clasping base; basal leaves spatulate, narrowed into short petioles: heads not numerous, about $25 \mathrm{~mm}$. broad; involucre hemispheric; the bracts imbricated in 3-5 series, oblong-linear or spatulate, the tips usually obtuse or obtusish, slightly spreading, the inner often mucronulate: pappus nearly white; achenes pubescent. (A. Nuttallii T. \& G.; A. denudatus Nutt.; A. orthophyllus Greene, Leaflets 1: 146. 1905; A. pratincola Greene, Pitt. 4: 215. 1900; A. vallicola Greene, 1. c. 213; A. Underwoodii, A. Tweedyi, A. griseolus, A. corymbiformis Rydb. Bull. Torr. Bot. Club 31: 653-5. 1904; A. subracemosus Rydb. Mem. N. Y. Bot. Gard. 1: 394. 1900.)-Quite variable; throughout our range and northwestward.

29a. Aster adscendens armeriaefolius (Greene) A. Nels. Resembling the species but the heads usually few; the branches and branchlets slender above and with greatly reduced leaves. (A. armeriaefolius Greene, Pitt. 4: 214. 1900.) - In the mountains of Colorado.

30. Aster longifolius Lam. Encycl. 1: 306. 1783. Stems glabrous or somewhat pubescent, leafy, paniculately branched, $3-9 \mathrm{dm}$. high: leaves lanceolate to linear-lanceolate, entire or nearly so, acuminate, narrowed into a sessile, clasping, usually slightly cordate base, 7-20 $\mathrm{cm}$. long, 4-12 $\mathrm{mm}$. wide: heads rather numerous, about $25 \mathrm{~mm}$. broad; involucre hemispheric, $8-10 \mathrm{~mm}$. high; the bracts glabrous, narrow, green, acute, imbricated in only 1 or 2 series, nearly equal: rays numerous, about $8 \mathrm{~mm}$. long, violet or pale purple: pappus pale. (A. lonchophyllus Greene, Leaflets 1: 146. 1905.)-Colorado to Montana and thence to New England.

31. Aster Fremontii T. \& G. Gray, Syn. Fl. 1: 191. 1884. Stems slender, erect, 2-5 dm. high, glabrous or the upper parts soft-pubescent: leaves thinnish, the margins either quite naked and smooth or obscurely ciliolatescabrous; the radical and lowest cauline oblong or oblanceolate, or somewhat obovate, 3-7 cm. long, tapering into a slender-margined petiole; the cauline oblong-lanceolate to linear, commonly half-clasping at base: heads solitary in the smaller specimens, several in the larger, 8-12 $\mathrm{mm}$. high, somewhat naked-pedunculate; bracts of the involucre narrowly linear, obtuse, or the inner acute, some of the outer shorter, all loose and similar: rays numerous, 8-12 mm. long.-Wet mountain meadows; in our range and to the northwestward.

32. Aster Canbyi Vasey, Gray, Syn. Fl. 1: 185. 1884. Stems rather stout, simple or branched above, leafy to the top, 2-6 dm. high: leaves thickish, ample; the upper cauline mostly oblong, and with broadly, half-clasping, usually auriculate insertion: heads solitary, several or many, large or smaller as the number increases; bracts oblong or spatulate, acute or obtuse, the outer usually shorter, or sometimes more foliaceous and then equaling the disk. [A. Burkei (Gray) Howell, Fl. 310. 1897; A. majusculus Greene, Pitt. 4: 215. 1900; A. spathulatus Lindl. (A. subspathulatus Rydb. Mem. N. Y. Bot. Gard. 1: 395. 1900); A. ciliomarginatus Rydb. 1. c. 392; A. Cusickii Gray, as to our range.]-In the mountains; New Mexico to Montana, Utah, and Washington. 
33. Aster meritus A. Nels. Bot. Gaz. 37: 268. 1904. Stems 1-several from each of the many crowns of the woody rootstocks, the tufted stems suberect or more usually widely spreading and forming a mat 5-10 dm. across, 2-4 dm. long, green but under a lens sparsely pubescent, simple or branched, leafy throughout: leaves oblong or sometimes elliptic, 3-7 cm. long, subacute, entire or obscurely crenulate-serrate, glabrous above, often sparingly and minutely ciliolate-scabrous below and on the margins: heads several to numerous, usually in a crowded corymbose leafy cyme, turbinate-campanulate; involucral bracts broadly linear, in 3-4 rows, subacute or obtuse, erect, purple-tipped and margined, delicately ciliate, sometimes puberulent (as are the peduncles and pedicels): rays mostly fewer than 15, purple or violet: pappus brownish. (A. Richardsonii Spreng. as to our range.)-Northern Wyoming to Idaho and Montana.

34. Aster proxim us Greene, Pitt. 4: 220. 1900. With vegetative characteristics of $A$. laetevirens (See no. 27) but of a deeper green, the foliage more ampliate and spreading, all the leaves quite entire: inflorescence more truly paniculate and open: involucres campanulate; the outer bracts wholly herbaceous and spreading, the green tips of even the innermost also spreading, all cuspidately acute: rays 35 or more, large and showy, flesh-color to rose-purple.Northern Wyoming; probably in Montana and Idaho.

35. Aster a pricus (Gray) Rydb. Mem. N. Y. Bot. Gard. 1: 396.1900. Low, usually less than $2 \mathrm{dm}$. high, the stems clustered, from tufted rootstocks; the flowering branches mostly few, suberect, sparsely leaved: lower stem leaves comparatively ample, thickish, oblong, broadly lanceolate or spatulate, tapering into winged petioles with clasping base: heads from solitary to several; the bracts all alike, somewhat spatulate-linear, obtuse or acutish: rays "deep blue-violet and reddish-purple intermixed." ( $A$. incertus A. Nels. 1. c. 269.) - In the higher mountains; Colorado to Montana.

36. Aster fulcratus Greene, Pitt. 4: 217. 1900. Stems low, slender, decumbent, numerous, from a loose but extensive system of slender horizontal rootstocks and partly subterranean stolons: the leaves terminating the latter small and obovate to spatulate-oblong; those of the red-purple, whitepuberulent proper stems linear and lance-linear, 5-10 cm. long, 1-nerved, all entire and glabrous: heads large, solitary at the ends of the smaller stems, few and racemose or subcorymbose on the taller stems, but these only $3 \mathrm{dm}$. high; involucres turbinate but broadly so; the bracts few and little imbricated, almost wholly herbaceous, the outer 12-25 $\mathrm{mm}$. long, linear, entire, acute, wholly glabrous as are also the short, spatulate-linear inner ones: rays 15-20, 16-18 $\mathrm{mm}$. long, rich rose-purple or paler and roseate-lilac.-In the mountains; southern Colorado.

37. Aster frondeus (Gray) Greene, Proc. Acad. Sci. Phila. 551. 1895. Stems simple or with sparing erect flowering branches, sparsely leaved: leaves comparatively ample, 8-12 $\mathrm{cm}$. long; the lower tapering into winged petioles; the upper often with clasping base: heads solitary or few, naked-pedunculate, broad; involucral bracts linear-lanceolate, loose and not imbricate, all equaling the disk, occasionally the outermost broader and leaf-like. A. foliaceus principally; typical $A$. foliaceus Lindl. does not occur in this range. ( $A$. glastifolius Greene, 1. c. 218.)-Subalpine in the Rocky Mountains, and westward.

The relationship and validity of the following are not yet clear: A. distichophyllus, A. spithamaeus, A. violaceus Greene, Pitt. 4: 213,217, and 218, respectively.

\section{MACHAERANTHERA Nees.}

Annual, biennial, or perennial branched herbs, with leafy stems, alternate, entire, serrate, or pinnatifid leaves, the teeth or lobes usually bristle-tipped, and large heads of both tubular and radiate flowers. Involucre of numerous series of imbricated canescent or glandular bracts with herbaceous or foliaceous spreading or reflexed tips. Receptacle alveolate, the alveoli usually 
toothed or lacerate. Ray-flowers numerous, violet to red or purple, pistillate; disk-flowers perfect, the corollas tubular, 5-lobed, yellow, changing to red or brown; anthers exserted, appendaged at the tip, rounded at the base; style-appendages subulate to lanceolate. Achenes turbinate, narrowed below, pubescent. Pappus of numerous stiff, rough, unequal bristles.-Aster in part.

Annuals.

Leaves bipinnatifid, pale green; stems usually simple below

Leaves pinnatifid, dark green; stems branching throughout .

1. M. tanacetifolia.

Biennials or rarely perennials.

Involucral bracts for the most part recurved or reflexed

Stems hirsute or hispid throughout, glandular-viscid at least above

Stems glabrate or puberulent, not hispid

Densely glandular-viscid on the branchlets and involucre. Involucral bracts very viscid

Involucral bracts hispid as well as glandular

Moderately glandular-viscid on the involucre but obscurely or not at all on the branchlets.

Stem leaves mostly spatulate-oblanceolate, 3-nerved. Involucral bracts lance-linear, the tips sharply deflexed Involucral bracts almost filiform, squarrose-spreading.

Stem leaves mostly broadly linear or oblong, 1-nerved. Heads large, few; stems reddish Heads many; stems green

Involucral bracts, for the most part, erect.

Leaves and' stems canescently puberulent (rarely nearly glabrous).

Involucres obscurely or not at all glandular.

Stems generally simple below and paniculately branched

above
Stems low, branched from the base

Involucres evidently glandular.

Fastigiately branched from the base, with suberect stems

Divaricately branched throughout, with widely spreading stems

Leaves and stems glabrate

2. M. coronopifolia.

3. M. aspera.

4. M. varians.

5. M. Pattersonii.

6. M. latifolia.

7. M. Bigelovii.

8. M. rubricaulis.

9. M. viscosa.

10. M. canescens.

11. M. shastensis.

12. M. pulverulenta.

13. M. ramosa.

14. M. glabella.

1. Machaeranthera tanacetifolia Nees. Ast. 224. 1832. Pubescent, often rather viscid, very leafy, commonly $2-5 \mathrm{dm}$. high: lowest leaves $2-3-$ pinnately parted; uppermost simply pinnatifid or on the flowering branchlets entire; lobes short, setulose-mucronate: heads $12 \mathrm{~mm}$. high; bracts of the involucre narrowly linear, with slender, mostly linear-subulate, spreading, foliaceous tips, or the outermost almost wholly foliaceous: rays numerous, bright violet: achenes rather broad, villous.- Southern Colorado to Texas and Arizona.

2. Machaeranthera corono pifolia (Nutt.) A. Nels. Bot. Gaz. 37: 268. 1904. Annual, or possibly biennial, divaricate-branched from the base upward, 1-2 dm. high, green but puberulent and minutely glandular: leaves moderately to very deeply pinnatifid, oblanceolate in outline, 1-4 cm. long; the segments very variable, linear to oblong or merely with broad teeth upon the margins of the blade, setulose-mucronate: heads large; the involucral bracts in about 5 series, the slender, green, reflexed portion of the bract about as long as the scarious-imbricated base: rays often nearly $2 \mathrm{~cm}$. long, bluishpurple: achenes sparingly appressed-pubescent. Aster tanacetifolius in part.Wyoming to Nebraska and Northern Colorado.

3. Machaeranthera aspera Greene, Pitt. 3: 62. 1896. Biennial, stoutish, freely branching, 5-8 dm. high, rough throughout, with a gland-tipped indument which is short and scabrous on the leaves, longer and hispidulous on the stem and branches: cauline leaves oblong-lanceolate, sessile by a broad, half-clasping base, spinulosely serrate-toothed: heads large, somewhat racemosely disposed at the ends of the branches; involucres hemispherical; the bracts with long lanceolate spreading herbaceous tips, these glandularscabrous: achenes compressed, cuneate-oblong, striate, strigose-pubescent. (M. Fremontii Rydb. Bull. Torr. Bot. Club 32: 123. 1905; M. cichoriacea Greene, Leaflets 1: 148. 1905.) - Frequent at middle elevations; central Colorado.

4, Machaeranthera varians Greene, Pitt. 4: 98. 1899. Biennial or short- 
lived perennial, the solitary or few stems erect from the base, 2-8 dm. high, simple and leafy up to the corymbose or somewhat panicled summit, from nearly glabrous below to glandular-puberulent above, the upper portion and the branches glandular-hispidulous or hispid: leaves linear-lanceolate, 3-7 cm. long, sessile, entire to more or less regularly spinulose-toothed, mostly glabrous on both faces but marginally glandular-pubescent or ciliate: heads numerous, large and showy with many purple rays; bracts of the hemispherical or subcampanulate involucre in 4 or 5 series, all with long, linear-subulate, spreading, glandular-viscid herbaceous tips: oblong-linear achenes nearly glabrous, hardly striate. (M. viscosula Rydb. 1. c. 124.)-New Mexico to Wyoming.

5. Machaeranthera Pattersonii (Gray) Greene, Pitt. 3: 63. 1896. Branched from the summit of the taproot, 1-3 dm. high; stems and branches with soft or cottony pubescence, or glabrate: leaves thickish, spatulate or lingulate, entire or coarsely few-toothed, conspicuously hirsute-ciliate at base: heads solitary or few; involucral bracts lanceolate, hispidulous as well as viscid, very squarrose: rays about $30,12-15 \mathrm{~mm}$. long, bright violet: achenes glabrate. (M. commixta Greene, Pitt. 4: 71. 1899.)-In the high mountains; Colorado and Utah.

6. Machaeranthera latifolia A. Nels. Proc. Biol. Soc. Wash. 20: 38. 1907. Perennial from short-branched caudex; stems few-several, slender, erect, 2-7 dm. high, minutely puberulent: leaves minutely puberulent (the upper face nearly glabrous), mostly entire, rarely with a few small spinulose teeth, generally 3 -veined from the base and somewhat reticulate above; the basal and lower stem leaves broadly oblanceolate to obovate, $2-3 \mathrm{~cm}$. long, tapering into a short, narrowly margined petiole; the upper stem leaves sessile or nearly so, those of the inflorescence reduced and becoming bractlike: heads few, corymbose, relatively large, 8-14 $\mathrm{mm}$. high; involucre campanulate; the bracts in 5-6 series, oblanceolate or oblong-lanceolate, the dark green acute or acuminate tips ultimately reflexed, minutely glandular-puberulent: rays blue with a slight violet tinge: achenes sparsely and obscurely pubescent, shorter than the pappus. (M. paniculata A. Nels. 1. c.)-In the cañons of Utah (Garrett).

7. Machaeranthera Bigelovii (Gray) Greene, 1. c. Stems 3-7 dm. high, leafy, branching above, roughish-hirsute to glabrate; the flowering branches or peduncles glandular-hirsute, terminated by large showy heads: leaves oblong or lanceolate, irregularly and sometimes incisely dentate, sometimes entire; the radical lanceolate-spatulate; the cauline oblong to lanceolate, usually with broadish partly clasping base: involucral bracts very numerous, linearattenuate or the prolonged and much recurved tips almost filiform: rays very many, 15-20 mm. long.-Southern Colorado to Mexico.

8. Machaeranthera rubricaulis Rydb. 1. c. 28: 506. 1901. Biennial or perhaps perennial; stems solitary or few, erect or nearly so, simple below, branched above, 2-6 dm. high, terete, striate, usually tinged with red or purple, finely strigose-puberulent, not viscid: leaves linear or linear-oblanceolate, sessile, acute, entire or dentate, scabrous-ciliolate on the margins: heads corymbose-cymose; involucre 10-12 mm. high, 12-15 mm. in diameter; bracts numerous, linear-lanceolate with attenuate, almost terete, squarrose tips, viscidpuberulent: rays numerous, dark blue, about $12 \mathrm{~mm}$. long: achenes flat, sparingly and minutely strigose. (M. spectabilis Greene, Leaflets 1: 148. 1905; M. Selbyi Rydb. 1. c. 32: 123. 1905.) - Colorado.

9. Machaeranthera viscosa (Nutt.) Greene, Pitt. 4; 22. 1899. Biennial; the stems solitary or several, erect, $3-5 \mathrm{dm}$. high, usually spicate or racemose in the middle, but more corymbose at summit, or not rarely wholly corymbose; herbage green and seemingly glabrous, but under a lens puberulent, the inflorescence and especially the involucres glandular and viscid: lower cauline leaves narrowly oblanceolate, rather remotely but sharply serrate: bracts of the large and nearly turbinate involucre in 5 or 6 series and closely imbricated, the green herbaceous tips long and narrow, closely reflexed and very viscid: rays purple or violet, 18 or 20.-Montana to Colorado and westward.

10. Machaeranthera canescens (Nutt.) Gray, Pl. Wright. 1: 89. 1852. 
Biennial, erect, 2-4 dm. high, fastigiately or more corymbosély branching, the herbage canescently puberulent: early cauline leaves (fallen before the flowering) spatulate, commonly with a few serrations; those of the branches linear or at least narrowly oblanceolate, entire: bracts of the involucre in about 3 series, the lanceolate green tips ascending or slightly spreading: rays rather deep blue or purplish.-From Assiniboia and the Dakotas to Colorado.

11. Machaeranthera shastensis Gray, Proc. Am. Acad. 6: 539. 1865. Stems several from the crown of the biennial or perennial root, paniculately branched, canescently puberulent as are also the leaves, somewhat purplish: leaves mostly entire, $2-4 \mathrm{~cm}$. long; the lower spatulate or oblanceolate as are the narrower stem leaves: heads rather numerous; the involucre subturbinate to campanulate, $12 \mathrm{~mm}$. high; the bracts rather thin, purplish and canescent, mostly erect: rays few (8-16), rather broad, blue varying to purple. ( $M$ : linearis Rydb. Mem. 'N. Y. Bot. Gard. 1: 398. 1900; M. superba A. Nels. Bot. Gaz. 30: 197. 1900.)-Northwestern Wyoming to California and Washington.

12. Machaeranthera pulverulenta (Nutt.) Greene, 1. c. 23. Biennial, erect, 1-3 dm. high, somewhat fastigiately panicled, more or less canescent with a fine pubescence, this on the peduncular branchlets and involucres mixed with sessile or subsessile very minute resiniferous glands: rather small and scattered leaves oblanceolate, entire or serrate-toothed: heads small, subturbinate; involucral bracts in about 3 series, rigid, the short green tips suberect: rays few (8-16). ( $M$. divaricata and $M$. subalpina Greene, l. c.)Northern Colorado to Montana.

13. Machaeranthera ramosa A. Nels. Bull. Torr. Bot. Club 28: 233. 1901. Stems several to numerous, prostrate-spreading or somewhat assurgent, each freely branched (often intricately so) throughout, $3-4 \mathrm{dm}$. long, the whole plant forming a conspicuous mat from $0.5 \mathrm{~m}$. to nearly $1 \mathrm{~m}$. across; stems and slender branchlets green with a fine puberulence: leaves green, nearly glabrous; the radical and cauline entire or irregularly denticulate, broadly linear or linear-spatulate, 3-5 cm. long, often wanting at anthesis; the rameal numerous, small, linear, entire or nearly so, often somewhat fascicled: heads numerous, terminating the branchlets; involucres broad, subhemispherical; the lanceolate bracts in 5 or 6 series and rather loosely imbricated, the green, acuminate tips at length reflexed, distinctly glandularviscid: rays 20 (more or less), purple.-Sandy gravelly plains; southern Wyoming.

14. Machaeranthera glabella Greene, Rydb. in Fl. Col. 358. 1906. Nearly or quite glabrous throughout, $2-3 \mathrm{dm}$. high; stems few to several from the somewhat branched crown of the taproot, mostly erect, simple below: leaves linear to narrowly oblanceolate, somewhat rosulate on the crowns, $2-4 \mathrm{~cm}$. long: heads rather small, in an open corymbose panicle; involucres campanuloturbinate; the bracts pale except the short-lanceolate dark green tips, erect or some of them tardily recurved: rays 10-15, 10-12 mm. long.-Mountains of Colorado.

\section{OREASTRUM Greene}

Acaulescent perennials, with narrow subcoriaceous entire leaves and scapiform monocephalous branches from a stout somewhat fusiform and not freely branching taproot. Bracts of the involucre narrow, subequal, in about 2 series. Rays rather numerous, elongated, purple; disk-corollas tubularfunnelform, 5-toothed and the teeth erect. Style-branches filiform to subulatelinear, strongly hirsutulous. Achenes subterete, distinctly 5-8-costate. Pappus a single series of brownish barbellate-scabrous and rather fragile or deciduous bristles.

1. Oreastrum alpigineum (T. \& G.) Greene, Pitt. 3: 147. 1896. Scapiform stems spreading and assurgent, 6-12 cm. long, tomentose at the summit: radical leaves lingulate-spatulate to narrowly linear, glabrous, obtuse, nerve- 
less, 3-7 $\mathrm{cm}$. long: heads fully $12 \mathrm{~mm}$. high and broad; bracts of the involucre not very unequal, usually pubescent, linear, acute: rays purple, $12-16 \mathrm{~mm}$. long: style-appendages linear-subulate: achenes linear, striate, glabrate below, hirsute near the top. (Aster pulchellus Eaton, Bot. King's Exp. 143. 1871.)In the higher mountains; Wyoming and Montana to Washington.

\section{IONACTIS Greene}

Low tufted perennials, often lignescent at base, never stoloniferous or with radical leaves. Stems clothed equably with narrow, entire, rigid, 1-nerved and veinless leaves and terminating in 1 or more showy heads with violet rays. Involucre of well imbricated bracts of coriaceous texture, without herbaceous tips, appressed even to the tips. Achenes narrow, villous. Pappus double, the more copious inner series bristly, the outer short and setulose.

1. Ionactis alpina (Nutt.) Greene, Pitt. 3: 245. 1897. Puberulent and somewhat cinereous; stems tufted, rigid, only $9-15 \mathrm{~cm}$. high, terminated by a solitary pedunculate head: leaves short, $6-12 \mathrm{~mm}$. long, rigid, oblong to linear or the lowest spatulate, the broader obtuse with an abrupt mucro, callous-margined: involucre broadly campanulate; the bracts imbricated in about 3 series, scabro-puberulent, lanceolate: rays 10-12 mm. long, light violet: outer pappus sometimes distinctly chaffy. Aster scopulorum.-In the mountains of Montana and Wyoming and thence far westward.

\section{LEUCELENE* Greene}

Low perennials with diffusely branching leafy stems from a slender ligneous base. Leaves numerous, subulate and appressed, or more spreading and nearly linear. Heads small, solitary, and terminal upon the nearly filiform ultimate branchlets. Involucres turbinate, imbricated; the bracts - narrow, nearly plane, herbaceous but with narrow, scarious margins. Rays and disk both white or the former reddish or at least often turning red in drying. Disk-corollas tubular-funnelform, 5-toothed but not deeply so; styletips ovate, acutish. Achenes long and slender, manifestly compressed, hirsutulous. Pappus a single series of long and slender, scabrous, bright-white bristles.

1. Leucelene ericoides (Torr.) Greene, Pitt. 3: 148. 1896. Usually only 8-14 cm. high, canescent and glandular-scabrous, much branched; branches erect or diffuse, terminated by somewhat pedunculate heads: leaves commonly hispid-ciliate, erect or little spreading, 6-12 $\mathrm{mm}$. long; the lowest spatulate and tapering into a petiole; the upper linear to nearly filiform: bracts of the involucre in about 3 series, lanceolate, acute or apiculate, thinnish, scariousmargined: rays white or sometimes rose-color. Aster ericaefolius.-Dry hills; Wyoming and Utah to Kansas and Texas.

\section{ERIgeron L. Fleabane. Erigeron}

Branching or scapose herbs, with alternate or basal leaves, and corymbose, paniculate, or solitary pedunculate heads of both tubular and radiate (rarely all tubular) flowers. Involucre hemispheric or campanulate; the bracts narrow, nearly equal, imbricated in but 1 or 2 series in our species. Receptacle nearly flat, usually naked. Ray-flowers, in our species, white, violet, or purple, or rarely yellow, pistillate; disk-flowers yellow, tubular, perfect, the corollas mostly 5-lobed. Anthers obtuse and entire at the base. Style-branches more or less flattened, the appendages short, mostly rounded or obtuse. Achenes flattened, usually nerved. Pappus-bristles fragile, slender, scabrous or denticulate, in 1 series, or often an additional outer shorter series.

* This genus is essentially monotypic. Several species have been proposed but they rest on characters shading imperceptibly into each other. These species are $L$. arenosa Heller, Cat. N. A. Plants 8. 1900 (Aster ericaefolius tenuis Gray); L. alsinoides Greene, Pitt. 4: 99. 1899; L. hirtella Rydb. (Diplopappus ericaefolius hirtella Gray); and L. serotina Rydb, (L. ericoides serotina Greene), Bull, Torr. Bot. Club 33: 153. 1906. 


\section{RAYS CONSPICUOUS (much surpassing the disk)}

\section{PERENNIALS}

Leaves entire or merely toothed.

Stems usually more than $3 \mathrm{dm}$. high, simple below, solitary from the ends of distinct (sometimes branched) root-stocks.

Involucre with spreading or reflexed bracts; rays rather broad; pappus simple.

Involucre glabrous or glandular

Involucre woolly, or hirsute and viscidulous. Involucre very woolly

Involucre viscidulous and moderately hirsute

Involucre with mostly appressed bracts; rays numerous and narrow; pappus double.

Rather equably leafy, the upper stem leavès not greatly reduced.

Leaves few, short, and distant, broadly obovate to

ovate or broadly oblong .
Leaves more numerous, oblanceolate to ovate and oblong. Bracts glabrate, obscurely glandular

Bracts more or less hirsute.

Herbage nearly or quite glabrous.

Herbage clearly pubescent

Quite inequably leafy, the upper stem leaves greatly reduced in size.

Pale green and apparently glabrate, but under a lens minutely rough-hirsute

Dark green and distinctly pubescent, often viscidulous,

Stems usually"less than $3 \mathrm{dm}$. high (mostly i-2 dm.), either branched near the base or somewhat caespitose.

Stems mostly simple and monocephalous.

Stems leafy below, either scapiform or with greatly reduced leaves above; heads mostly solitary on the bracted or naked peduncle.

Leaves spatulate or oblanceolate to linear.

Involucre woolly.

Wool of involucre blue-black; rays white

Wool of involucre mostly white; rays violet or whitish

Involucre hispid or minutely hirsute.

Rays not yellow.

Rays white.

Bracts hispid-ciliate

Bracts appressed-hirsute

Rays blue, violet, or purple.

Hispid-ciliate throughout

Pubescence not hispid, mostly short and appressed.

Rays violet
Rays pale purple:

Rays yellow.

Leaves obovate to short-oblong.

Plant green and glabrate.

Plant pale-canescent.

Stems leafy throughout.

Leaves all broad, obovate to short-oblong

Leaves narrowly lanceolate to linear.

Involucre glabrous but pruinose-glandular; foliage glabrous or nearly so.

Involucre hirsute or pubescent.

Leaves glandular-scabrous and hirsute.

Leaves not glandular.

Rays not yellow.

Rays purple or violet.

Leaves subglabrous.

Plants low (4-10 cm.); pubescence spread-

Plants taller (8-16 cm.); pubescence appressed hispid-hirsute:

Leaves hispid-hirsute :

Rays white.

Bracts hispid-ciliate

Bracts appressed-hirsute

Rays yellow

Stems more or less branched and with few-several heads.

Rays white.

Leaves 1-nerved.

Herbage minutely hirsute.

Bracts hispid-ciliate

1. E. salsuginosus

2. E. elatior.

3. E. Coulteri

4. E.'superbus.

5. E. macranthus.

6. E. speciosus.

7. E. subtrinervis.

8. E. asper.

9. E. formosissimus.

10. E. melanocephalus.

11. E. uniflorus.

19. E. Engelmannii.

20. E. Eatonii.

21. E. poliospermus.

18. E. ursinus.

17. E. radicatus.

22. E. luteus.

12. E. Garrettii.

13. E. tener.

14. E. nauseosus.

15. E. leiomeris.

16. E. glandulosus.

17. E. radicatus.

18. E. ursinus.

21. E. poliospermus.

19. E. Engelmannii. 20. E. Eatonii.

22. E. luteus. 
Bracts appressed-hirsute Leaves 3-nerved, at least at base.

Rays not white.

Pubescence very short.

Leaves 3-nerved

Leaves 1-nerved

Pubescence hispid, long and spreading

Leaves dissected or deeply cleft.

Leaves ternately divided.

Twice to thrice ternate

Once ternate or quinate

Leaves pinnately divided
Herbage conspicuously hispid or hirsute-ciliate.

20. E Eatonii.

24. E. pumilus.

23. E. microlonchus.

25. E. corymbosus.

26. E. caespitosus.

27. E. concinnus.

28. E. compositus.

29. E. trifidus.

30. E. pinnatisectus.

ANNUALS OR BIENNIALS

Leaves not cordate-clasping.

Stems simple at least below; the heads few, large.

Involucre hirsute or strigose

Involucre more or less glandular or viscid :

Stems branched; the heads small, several to many.

Stems simple at base but branching upward

Stems branching from the base and in no. 32 also above.

Leafy throughout

Leafy below and terminating in a scape-like peduncle.

The few stems erect, but sometimes with a few short stolons from the base

The earlier stems erect, the later slender-stoloniferous, leafy and often rooting

Leaves cordate-clasping

RAYS INCONSPICUOUS (short or wanting)

Inflorescence corymbiform or paniculate.

Plant 3-6 dm. high; stem mostly solitary .

Plant 1-3 dm. high; stems often several

Inflorescence mostly racemose; the stem or stems slender : $\quad$ : 38 . E. lonchophyllus.

1. Erigeron salsuginosus Gray, Proc. Am. Acad. 16: 93. 1880. Rootstocks short and thickish; stems $2-5 \mathrm{dm}$. high, the summit of peduncles lanate-pubescent or puberulent, no bristly or hirsute hairs: leaves very smooth and glabrous or glabrate, thickish; radical and lower cauline leaves spatulate to nearly obovate, with base attenuate into a margined petiole, $3-7 \mathrm{~cm}$. long; upper cauline ovate-oblong to lanceolate, sessile, mucronate or apiculateacuminate; uppermost small and bract-like: bracts of the involucre loose or even spreading, linear-subulate or attenuate, viscidulous or puberulous: disk 12-14 mm. in diameter: rays broad, giving an Aster-like effect, 50-70, purple or violet, 12-15 mm. long.-On wet ground; in the mountains of our range and far northwestward.

1a. Erigeron salsuginosus glacialis Gray, Syn. Fl. 1: 209. 1886. 'Lower, few-leaved, often monocephalous. This and var. angustifolius grade into the species. (E. glacialis A. Nels. Bot. Gaz. 37: 207. 1904.)-Alpine stations.

2. Erigeron elatior (Gray) Greene, Pitt. 3: 163. 1897. Stems somewhat clustered, stout, erect, 4-7 dm. high, leafy up to the monocephalous or usually distinctly corymbose summit, hirsute-pubescent, the foliage scabrous: leaves ovate-lanceolate, acute, entire: heads 1-8, on bracted peduncles; involucres very large, often more than $12 \mathrm{~mm}$. high and 15-18 $\mathrm{mm}$. broad; the linear, attenuate-acuminate bracts squarrose-spreading, imbedded in dense, soft wool: rays showy, numerous and narrow: achenes pubescent; pappus of rather firm bristles and a conspicuous outer circle of white squamellae. $E$. grandiflorus elatior.-Along streams; in the mountains of our range.

3. Erigeron Coulteri Porter, Fl. Col. 61. 1874. Stems 2-5 dm. high, equably leafy, bearing solitary or rarely 2 or 3 slender-pedunculate heads: leaves membranaceous, obovate to oblong, either entire or serrate with several sharp teeth, pilose-pubescent to glabrous; the cauline hardly mucronate: disk about 12-14 dm. wide: involucral bracts less attenuate and spreading, obscurely viscidulous but hirsute with spreading hairs: rays rather narrowly linear, $12 \mathrm{~mm}$. or more long, white, varying to purplish.- In the mountains of our range.

4. Erigeron superbus Greene, ex Rydb. Fl. Col. 364. 1906. Nearly glabrous throughout, 3-6 $\mathrm{dm}$. high, nearly simple and strict: leaves relatively few and distant, rather large, sparsely ciliate; the basal and lower 
cauline tapering into a petiole from an elliptic or oblanceolate blade; the upper sessile and becoming ovate, acute: heads few, corymbose, large: the involucre 12-16 mm. broad, slightly hirsute at base only, obscurely glandular as are also the pedicels: rays numerous, $12-16 \mathrm{~mm}$. long. Formerly referred in part to $E$. salsuginosus and in part to $E$. macranthus.-Colorado and Wyoming to Utah.

5. Erigeron macranthus Nutt. Trans. Am. Phil. Soc. 7: 310. 1841. Glabrous or sparingly strigillose above, the stem leafy, 4-8 dm. high: leaves from oblanceolate below to elliptic-oblong and oval above, $8 \mathrm{~cm}$. to less than $3 \mathrm{~cm}$. in length, more or less hispid-ciliolate on the margins: inflorescence corymbiform, leafy: heads 7-8 mm. high; bracts linear-subulate, acuminate, glandularpuberulent, not at all hirsute, in 2 series but almost equal and crowded: disk $12-15 \mathrm{~mm}$. wide: rays very numerous, fully $1 \mathrm{~cm}$. long. (E. salicinus Rydb. Bull. Torr. Bot. Club 32: 125. 1905; E. platyphyllus Greene, Leaflets 1: 145. 1905.) - In the mountains of our range.

6. Erigeron speciosus DC. Prodr. 5: 284. 1836. Stem from a woody base, 3-5 dm. high, strict, glabrate or sparsely hirsute with rather long white hairs, leafy to the top: lower leaves oblanceolate, 5-10 cm. long, acute, tapering into a winged petiole, which is, as well as the leaves, ciliate-margined; upper leaves lanceolate, sessile, more or less clasping: heads corymbose, 7-10 mm. high and 1.5-2 cm. in diameter; bracts linear-acuminate, minutely glandular and somewhat hirsute: rays blue or violet, very numerous, rather narrow, 12-18 mm. long: achenes strigose; pappus double, the outer of few short setose-squamellate hairs. (E. conspicuus Rydb. Mem. N. Y. Bot. Gard. 1: 400. 1900.)-In the mountains; Colorado to Montana and Washington.

7. Erigeron subtrinervis Rydb. Mem. Torr. Club 5: 328. 1894. Similar to the preceding species, finely pubescent; stems leafy to the inflorescence: leaves entire, thin; the basal and lower ones oblanceolate to oblong, obtuse or acute, petioled; the upper lanceolate or ovate-lanceolate, sessile or somewhat clasping, acute, rather distinctly 3-nerved: heads $25-35 \mathrm{~mm}$. broad, corymbose, or rarely solitary: rays numerous, blue to pink: pappus double, the outer bristles very short. (E. striatus Greene, as to our range; $E$. Vreelandii Rydb. Bull. Torr. Bot. Club 32: 125. 1905.)-From Colorado and South Dakota to Utah and Idaho.

8. Erigeron asper Nutt. Gen. 2: 147. 1818. Stem simple, or branched above, more or less pubescent, sometimes hirsute, $1.5-6 \mathrm{dm}$. high: leaves glabrous, pubescent, or ciliate, entire; the basal ones spatulate, obtuse, $5-10 \mathrm{~cm}$. long, 6-25 mm. wide, narrowed into margined petioles; stem leaves oblonglanceolate or linear-lanceolate, obtuse or acute, the upper smaller: heads several or solitary, slender-peduncled, $2-5 \mathrm{~cm}$. broad; bracts linear, acute, hirsute or pubescent: rays 100-150, very narrow, violet, purple, or white, 8-14 mm. long: pappus double, the outer row of bristles much shorter than the inner. (E. glabellus Nutt. l. c.; E. consobrinus Greene, Pitt. 3: 186. 1897; E. oblanceolatus Rydb. 1. c. 24: 294; E. Earlii Rydb. 1. c. 32: 126.)-Coloradó to Montana and extending far eastward.

9. Erigeron formosissimus Greene, Bull. Torr. Bot. Club 25: 121. 1898. Perennial, somewhat tufted, $3-5 \mathrm{dm}$. high, the stems erect or at base slightly decumbent: basal leaves oblanceolate, obtuse, entire, 1-nerved, 6-12 cm. long, including the long, winged petiole, green and glabrous or cinereous-pubescent, ciliolate-margined; those of the stem 2-4 cm. long or more, oblong-lanceolate, acute, sessile: stem somewhat hirsute-pubescent, ending in few to several large heads: involucre low-hemispherical, $16-20 \mathrm{~mm}$. broad; the biserial equal bracts with spreading green tips and with little pubescence: rays 100 or more, narrow, almost $18 \mathrm{~mm}$. long, light rose-color to deep purple. ( $E$. glabellus mollis. E. eximius Greene; E. incanescens and E. viscidus Rydb. 1. c. 28: 23 \& 24. 1901.)-Throughout our range.

10. Erigeron melanocephalus A. Nels. Bull. Torr. Bot. Club 26: 246. 1900. Caudex thick and nearly simple or more or less branched, the branches short; stems few to several (often 10 or more), slender, erect, $5-15 \mathrm{~cm}$. high, monocephalous, pubescent with purplish hairs: leaves numerous on the crowns, 
nearly sessile to long-petioled, blade elliptic to narrowly oblong, $2-5 \mathrm{~cm}$. long (including the petiole), almost glabrous; stem leaves several, broadly linear, acuminate, 2-3 cm. long; pubescence similar to that of the stem: heads large, when fully expanded $3 \mathrm{~cm}$. broad; involucral bracts involved in a dense, dark purple wool. (E. oreocharis Greene.) - Subalpine in moist parks; Colorado and Wyoming.

11. Erigeron uniflorus L. Sp. Pl. 864. 1753. Stems 3-8 cm. high or more, strictly monocephalous, few-leaved, often naked and pedunculiform at summit: radical leaves spatulate or oblanceolate, $2-4 \mathrm{~cm}$. long; cauline lanceolate to linear: involucre usually hirsute as well as lanate, occasionally becoming naked; the linear-acute bracts rather close, or merely the short tips spreading: rays purple or paler, 4-8 mm. long. (E. simplex Greene, Fl. Fr. 387. 1897; E. leucotrichus Rydb. 1. c. 28: 23. 1901; E. grandiflorus Hook., as to our range.)-Alpine; from Colorado to the arctic regions.

12. Erigeron Garrettii A. Nels. Perennial from a short woody somewhat branched and tufted crown: leaves all basal, nearly or quite glabrous, $2-4 \mathrm{~cm}$. long, oblanceolate, obtuse or subacute, tapering to a short petiole: scape 7-12 $\mathrm{cm}$. long; the solitary heads large, $2-3 \mathrm{~cm}$. broad; involucre dark green, 7-8 mm. high, obscurely hirsutulous as is also the scape; the bracts linearsubulate: rays $40-50$, white, linear-spatulate, the ligule $8-10 \mathrm{~mm}$. long: outer pappus minute or wanting.-Reported only from Cottonwood Cañon, Utah.

13. Erigeron tener Gray, Proc. Am. Acad. 16: 91. 1880. Whole plant canescent (almost silvery) with minute rather soft pubescence; caudex branching, bearing many rigid, erect, slender stems $8-12 \mathrm{~cm}$. high, sparingly branched near the summit, the branches monocephalous: radical leaves thickish and firm, broadly obovate-spatulate, abruptly acuminate, rather indistinctly callous-tipped, $12-18 \mathrm{~mm}$. long by 7-10 $\mathrm{mm}$. wide, on slender petioles twice their length; stem leaves few and small, spatulate-lanceolate: heads rather small; bracts of the involucre narrow-lanceolate, greenish with somewhat scarious margins: achenes compressed, hirsute: pappus simple. (E. Tweedyi Canby, Bot. Gaz. 13: 17. 1888.) - Rocky dry hills; from Montana and Wyoming to Nevada.

14. Erigeron nauseosus (Jones) A. Nels. Bot. Gaz. 37: 270. 1904. Tufted perennial, 1-2 dm. high, leafy throughout, the whole plant minutely scabrous and the leaves hispid-ciliate: basal leaves spatulate to obovate, 4-8 cm. long; the upper similar but gradually smaller, sessile or almost clasping: heads mostly solitary on the leafy ascending stems; the peduncle proper only $2-3 \mathrm{~cm}$. long, glutinous or viscid, as is also the involucre, and with a nauseating odor; the bracts somewhat scabrous, abruptly acuminate: rays white or nearly so. - Hot sandy benches at the base of cliffs; mountains of Utah.

15. Erigeron leiomeris Gray, Syn. Fl. 1: 211. 1884. Stems 8-15 cm. high from the somewhat surculose branches of the caudex, smooth and very glabrous (or some minute hairiness at least on the petioles): leaves bright green, mainly radical and spatulate, very obtuse (larger $3-4 \mathrm{~cm}$. long, with tapering base or petiole of at least equal length), 3-10 mm. wide; cauline only 2 or 3 and smaller: involucre $6-7 \mathrm{~mm}$. high; the bracts lanceolate and not attenuate, glabrous but pruinose-glandular, brownish-purple: rays about 40, linear, violet, 6-8 mm. long. (E. spathulifolius Rydb. 1. c. 26: 545. 1899.) -In the alpine regions; Wyoming and Colorado to Utah and Nevada.

16. Erigeron glandulosus Porter, Fl. Col. 60. 1874. Caespitose from a stout caudex, 1-2 dm. high, rigid, granulose-glandular or glandular-scabrous and with sparse or hispid hairs, especially on the margins of the leaves: leaves thickish, spatulate to linear-oblanceolate, $3-8 \mathrm{~cm}$. long: head 8-10 $\mathrm{mm}$. high; involucre glandular or viscid as well as pubescent: rays 40 or 50, violet or purple, 8-12 mm. long.-Middle elevations in the foothills; Wyoming and Colorado.

17. Erigeron radicatus Hook. Fl. Bor. Am. 2: 17. 1834. Stems slender, ascending, 5-10 cm. high, more or less tufted on the woody caudex: leaves all spatulate-linear or wider, the broadest only $2-4 \mathrm{~mm}$. wide, hirsute or hir- 
sutely ciliate or sometimes nearly glabrous, no glandular roughness: involucre more or less villous-pubescent, only $5-6 \mathrm{~mm}$. high: rays mostly pale purple. (E. Parryi Canby \& Rose, Bot. Gaz. 15: 65. 1890; E. Scribneri Canby, 1. c.; E. vetensis Rydb. Bull. Torr. Bot. Club 32: 126. 1905.)-In the highest mountains of our range and extending far northward.

18. Erigeron ursinus Eat. Bot. King's Exp. 148. 1871. Stems 1-2 dm. high, loosely caespitose: leaves green, mostly smooth and glabrous, but their margins more or less hirsute-ciliate, spatulate to narrowly oblanceolate; cauline ones lanceolate or linear and acute: involucre $(6 \mathrm{~mm}$. high) and naked summit of flowering stem hirsute-pubescent: rays 40 or 50, purple, narrowly linear, $6 \mathrm{~mm}$. long.-Alpine and lower in our range and westward to California.

18a. Erigeron ursinus gracilis (Rydb.) A. Nels. More leafy and the whole plant more or less strigose-pubescent. (E. gracilis Rydb. Mem. N. Y. Bot. Gard. 1: 404. 1900.) Subalpine in open grassy places; Yellowstone Park.

19. Erigeron Engelmannii A. Ncl3. Bull. Torr. Bot. Club 26: 247. 1899. Crown woody, from nearly simple to numerously but very short-branched: leaves numerous, crowded on the crowns, linear, on very slender petioles which about equal the blade, closely subcinereous, somewhat ciliolate on the petioles, 2-6 cm. long (including the petioles): stems weak, decumbent or prostrate, moderately leafy, 3-6 $\mathrm{cm}$. long, monocephalous or with 2 or 3 heads: peduncles short, ascending, 1 or more-bracted; heads rather small; involucre about $5 \mathrm{~mm}$. high; the bracts equal, narrowly linear, acuminate, dark green with light margins, ciliolate: rays white, broadly linear, 40 (more or less), the ligules about $5 \mathrm{~mm}$. long, equal ( $E$. simulans Greene, PI. Baker. 3: 31. 1901). Stony slopes and foothills at middle elevations; Wyoming, Colorado, and Utah.

20. Erigeron Eatonii Gray, Proc. Am. Acad. 16: 91. 1880. Stems several from the crown of a strong taproot, slender and weak, diffuse, 1-2 dm. long, simple or with 2 or 3 monocephalous branches: leaves all linear, thickish, minutely pubescent; the radical about $5 \mathrm{~cm}$. long and the broadest $4 \mathrm{~mm}$. wide: heads only $6 \mathrm{~mm}$. high; bracts of the sparsely hirsute involucre little unequal: rays seldom over 20 , at most $6 \mathrm{~mm}$. long, white or purplish. (E. nematophyllus Rydb. Bull. Torr. Bot. Club 32: 124. 1905.)-On the lower slopes of the mountains; Wyoming to Colorado and Utah.

21. Erigeron poliospermus Gray, Syn. Fl. 1: 210. 1884. Caudex multicipital, the branches short and crowded; stems simple, numerous, rather closely pubescent with spreading unequal hairs, leafy below, naked-pedunculate above, $7-15 \mathrm{~cm}$. long: leaves crowded on the crowns, short-hirsute all over, the margins strongly hirsute-ciliate especially on the petioles, linear-spatulate, 3-5 $\mathrm{cm}$. long (including petiole); stem leaves several, similar but becoming smaller upward: peduncles naked or with a filiform bract, monocephalous; heads large, including the spreading rays $20-25 \mathrm{~mm}$. broad; involucral bracts narrow, in 2 rows; hirsute, long-acuminate, with a dark green midrib: rays 2050 , purple or violet. (E. wyomingensis and E. inamoenus A. Nels. Bull. Torr. Bot. Club 26: 248. 1899.)-Gravelly hills; Wyoming to Montana and Oregon.

22. Erigeron luteus A. Nels. 1. c. 27:33. 1900. Densely tufted on a multicipital caudex: leaves closely crowded on the crowns, all narrowly linear with slightly tapering, petiole-like base, subcinereous, $3-5 \mathrm{~cm}$. long: stems monocephalous, simple, scape-like but bearing 2 or more short leaves below, the peduncular portion usually with 1 small bract, from barely exceeding the leaves to about twice as long: heads $6-8 \mathrm{~mm}$. high; the involucral bracts linear, acutish, somewhat unequal and in 2 rows, rather shorter than the disk: rays $30-40$, a pure yellow, rather broad and short, the ligules only $3-4 \mathrm{~mm}$. long: pappus in 2 series, the outer of very short, inconspicuous bristles; the inner bristles rather sparse and coarse, nearly as long as the tube of the disk-corollas; achenes minutely pubescent. (C'hrysopsis hirtella DC. 5: 327. 1836; E. curvifolius Piper, Bull. Torr. Bot. Club 27: 396. 1900.) -Sandy stream banks; Yellowstone Park to the plains of the Columbia.

23. Erigeron microlonchus Greene, Pitt. 3: 293. 1898. Slenderly fusiform perennial root bearing at the crown a central tuft of leaves encircled by several 
slender decumbent flowering stems 10-15 cm. high; herbage subcinereous with a fine appressed pubescence of straight hairs: basal leaves 7-12 cm. long including the short petiole, linear-lanceolate, acute at both ends, entire, 3nerved; stems with few and rather remote, sessile, linear-lanceolate leaves: heads commonly solitary, rarely 2 or 3 , on slender naked peduncles; bracts of the rather small involucre subequal, hispid at the very base: rays 30 or more, rather narrow, purplish: achenes sparsely strigose-hispid; bristles of the pappus fine and fragile, subtended by an obscure, short-setiform outer series. - Common in the foothills of our mountains.

24. Erigeron pumilus Nutt. Gen, 2: 147. 1818. Stems tufted, slender, simple or branched; 1-2.5 dm. high: leaves entire, hirsute, the lower and basal ones narrowly spatulate or linear, petioled, $2-10 \mathrm{~cm}$. long, 2-4 mm. wide; stem leaves linear: heads 12-20 mm. broad, short-peduncled; bracts linear, acute, hirsute: rays 50-80, white, 6-8 mm. long, at length deflexed: pappus double, the outer row of bristles short and more or less intermixed with the inner; achenes pubescent.-Dry sandy plains; South Dakota to Kansas and west to Utah and Idaho.

25. Erigeron corymbosus Nutt. Trans. Am. Phil. Soc. 7: 308. 1841. Stems erect from a creeping rootstock, often 3-4 dm. high, soft-cinereous or sometimes hispidulous with mostly spreading short pubescence: radical leaves narrow-lanceolate or spatulate-lanceolate, largest 8-12 cm. long, 6-8 mm. wide, 3-nerved; the cauline linear and narrow: heads sometimes solitary, usually several and corymbosely disposed on short slender peduncles; involucre $6 \mathrm{~mm}$. high, canescently pubescent: rays $30-50$, mostly narrow and $6-10 \mathrm{~mm}$. long, blue or violet, apparently sometimes white. (E. Nelsonii Greene, 1. c. 294.) - Colorado to Montana and far northwestward.

26. Erigeron caespitosus Nutt. 1. c. 307. Stems tufted, canescent, simple or branched above, 1.5-3 dm. high: leaves canescent or pubescent, entire, the lower and basal ones petioled, narrowly oblanceolate or spatulate, $2-7 \mathrm{~cm}$. long: heads solitary or several, short-peduncled, $25-35 \mathrm{~mm}$. broad; bracts lanceolate or linear-oblong, acute, canescent: rays 40-60, 6-12 mm. long, white or pinkish: pappus doublc, the outer series of very short bristles. ( $E$, subcanescens Rydb. Bull. Torr. Bot. Club 24: 294. 1897.)-Dry flats and ridges; throughcut our range and west to the Pacific States.

27. Erigeron concinnus (H. \& A.) T. \& G. Fl. 2: 174. 1842. Very hirsute throughout with long, spreading, white hairs; stems several from the same root or caudex, 1-2 dm. high, slender, leafy, branching above, the branches terminated by single heads: leaves narrowly linear, elongated, entire, attenuate at the base, the lowermost tapering into a slender petiole: heads 10-12 mm. in diameter; bracts of the involucre linear, very acute, densely hirsute: rays numerous, $12 \mathrm{~mm}$. long, white to blue. The variety aphanactis $[E$. aphanactis (Gray) Greene Fl. Fr. 389. 1907] is a rayless form which may occur in the western part of our range.-Infrequent; in the arid areas of the western parts of our range to the Pacific States.

28. Erigeron compositus Pursh, Fl. Am. Sept. 2: 538. 1814. Herbage hirsute to glabrate and more or less viscidulous; stems very short, from a somewhat woody creeping base, densely leafy: leaves fan-shaped in outline, usually 2-3-ternately parted into linear or shotanand narrow spatulate lobes, 4-12 mm. long, on lon's; slender, hispid-ciliate petioles; the few on the erect flowering stems 3-lobed, or entire and linear: involucre 6-8 $\mathrm{mm}$. high, sparsely hirsute: rays $40-60$, not very narrow, white (purple or violet), mostly 6-8 $\mathrm{mm}$. long. (E. multifidus Rydb. Mem. N. Y. Bot. Gard. 1: 402. 1900.)-Dry, stony slopes, middle elevations; throughout our range and to the Pacific States.

28a. Erigeron compositus discoideus Gray, Am. Journ. Sci. 33: 237. 1862. Rays wanting or abortive: heads commonly smaller.-Same range as the species and often growing with it. Two other varieties, nudus Rydb. and incertus A. Nels., are merely glabrate forms of the species and the variety, respectively.

29. Erigeron trifidus Hook. Fl. Bor. Am. 2: 17. pl. 120. 1834. Very near to the preceding, hirsute: leaves slightly fleshy, on long petioles, 3-cleft; the 
segments short, entire, or the lateral often 2-lobed; scapes nearly naked: rays twice the length of the very hirsute involucre: achenes minutely hairy; pappus hispid-scabrous, as long as the corolla of the disk. (E. flabellifolius Rydb. Bull. Torr. Bot. Club 26: 545. 1899.) -Colorado and Utah to Montana and Idaho.

$29 a$. Erigeron trifidus discoideus A. Nels. Rayless form of the species, and sometimes glabrate.-Same range.

30. Erigeron pinnatisectus (Gray) A. Nels. 1. c. 26: 246. 1899. From cinereous-hirsute to glabrate, somewhat tufted, the rather few stems mostly erect, 1-2 dm. high: leaves petioled, the blade pinnately divided into 9-11 linear and entire or more or less cleft lobes: heads rather large (8-10 mm. high) or in depauperate specimens small: the rays purple or violet-purple, numerous, 8-14 mm. long. E. compositus pinnatisectus.-Mostly high alpine; in the mountains of our range.

31. Erigeron ramosus (Walt.) B. S. P. Prel. Cat. N. Y. 27. 1788. Annual, with somewhat appressed pubescence; the stem erect, 3-6 dm. high, corymbosely branched: stem leaves linear-oblong or linear-lanceolate, most of them entire; basal and lowest cauline spatulate or oblong, usually serrate: bracts of the involucre glabrous or nearly so: pappus double; the inner a series of slender, fragile, deciduous bristles (often wanting in the ray-flowers); the outer a persistent series of short, partly united, slender scales: rays white, rarely purplish, occasionally minute or wanting. $E$. strigosus. $E$. annuus L. is quite similar but taller and with more spreading pubescence and smaller heads.- Neither are indigenous to our range, but the former occurs in many fields and the latter will no doubt be found sooner or later. Both are known as Daisy Fleabane.

32. Erigeron divergens T. \& G. Fl. 2: 175. 1841. Stems several or numerous, ascending, from a stout taproot, sometimes decumbent at base; herbage roughened with a short hispid pubescence: leaves linear, 1-2 cm. long, or the lower somewhat longer and linear-spatulate, the uppermost reduced: heads solitary, terminating slender peduncles: rays numerous, filiform, $6 \mathrm{~mm}$. long, violet or purplish [or white (?)]: inner pappus of scanty slender bristles, the outer of much shorter subulate squamellae.-From Texas to Montana and west to the Pacific.

32a. Erigeron divergens arenarius (Greene) A. Nels. Freely, slenderly, and diffusely branched: leaves small and numerous: rays pale (lavender): the pappus apparently simple. ( $E$. arenarius Greene, Bull. Torr. Bot. Club 25: 121. 1898.) - Through the southern part of our range to Arizona.

32b. Erigeron divergens nudiflorus (Buckley) A. Nels. Branches rather few and suberect, densely leafy for two thirds of their length and terminating in a rather stout naked peduncle: leaves linear-spatulate, densely cinereoushirsute. (E. nudiflorus Buckley, Proc. Acad. Sci. Phila. 456. 1862; E. pedunculata Heller.)-Colorado to Arizona. The varieties as well as the species are probably biennial. Intermediate forms are common.

33. Erigeron colo-mexicanus A. Nels. Stems few to several from a slender annual taproot, ascending, naked-pedunculiform above the middle, very leafy, flowering when very short, the later heads on stems $7-15 \mathrm{~cm}$. long: leaves mostly linear-spatulate to linear, the basal sometimes oblanceolate and 3-lobed at apex, all softly cinereous-pubescent: heads much as in $E$. divergens. ( $E$. cinereus Gray, Pl. Fendl. 68. 1848; not $E$. cinereus H. \& A. Comp. Bot. Mag. 2: 50. 1836.)-Southern Colorado and New Mexico.

34. Erigeron flagellaris Gray, Mem. Am. Acad. 4: 68. 1849. More or less cinereous with appressed pubescence; stems slender, diffusely decumbent and flagelliform but leafy, some prostrate, some at length rooting at the apex and proliferous: leaves small, entire; radical spatulate and petioled; those of the branches becoming linear: solitary peduncles $4-10 \mathrm{~cm}$. long: rays white or purplish: pappus double, the outer of subulate bristles. (E. MacDougallii Heller, Bull. Torr. Bot. Club 26: 599. 1899.)-Moist soil; from Montana to New Mexico and Texas.

35. Erigeron philadelphicus L. Sp. Pl. 863. 1753. Perennial by stolons ROCKY MT. ВOT. -34 
and offsets, soft-pubescent or sometimes nearly glabrous; stems slender, mostly branched above, 3-9 dm. high: basal and lower leaves spatulate or obovate, obtuse, dentate, $2-7 \mathrm{~cm}$. long, narrowed into short petioles; upper stem leaves clasping and often cordate at the base: heads several or numerous, corymbose-paniculate, $10-25 \mathrm{~mm}$. broad, slender-peduncled; bracts linear, usually scarious-margined: achenes puberulent.-Through much of North America; in fields and woods; rather rare in our range.

36. Erigeron lapiluteus A. Nels. Biennial, with a strong vertical taproot; generally only one stem from the enlarged crown, simple, stout, striate, erect, paniculately branched as to the inflorescence, 3-6 dm. high, purplish, glabrate, the whitish hairs very straggling, obscurely granular: leaves numerous, glabrate; crown leaves oblanceolate, petioles $3-6 \mathrm{~cm}$. long; lower stem leaves similar but with short-winged petioles; upper leaves sessile, narrowly lanceolate, not much reduced; bracts small, linear: heads numerous, on rather slender peduncles; involucral bracts dark green, in 2 rows, subequal, very narrow, acuminate, shorter than the $1 \mathrm{~cm}$. high disk: flowers very numerous; rays filiform, purplish, largely concealed by copious pappus: achenes linear, less than $2 \mathrm{~mm}$. long; the soft, dirty-white pappus nearly 3 times as long. $(E$. yellowstonensis A. Nels. Bot. Gaz. 30: 198.1900, a name to be rejected.)-At middle elevations, in open woods or burned over timber lands; Colorado to Montana.

37. Erigeron acris L. Sp. Pl. 863. 1753. More or less hirsute-pubescent; stems 1-2 dm. high from a biennial or perennial root, the larger plants branching and bearing several or numerous somewhat paniculately disposed heads: leaves pubescent or glabrate, entire; the radical and lower cauline spatulate, mostly obtuse, 3-8 cm. long, petioled; the upper cauline mostly oblong or oblanceolate, obtuse or acutish, sessile: involucre hemispheric, the bracts linear, hirsute: rays numerous, purple, equaling or exceeding the brownish pappus: tubular pistillate flowers filiform, numerous: pappus simple or nearly so, copious.-Across the continent northward, and south in our mountains to Colorado.

37a. Erigeron acris debilis Gray, Syn. Fl. 1: 220. 1884. Sparsely pilose; stems $7-15 \mathrm{~cm}$. high from an apparently perennial root, slender: leaves bright green; the radical obovate or oblong; the cauline spatulate to lanceolate, short: heads 1-3 in a terminal cluster, $8-10 \mathrm{~mm}$. high; bracts of the involucre sparsely hirsute below, the smooth attenuate tips spreading: rays in flower rather conspicuously surpassing the disk. (E. jucundus Greene, Pitt. 3: 165. 1897.) -In the mountains of our range and northward. The variety Droebachensis probably does not occur in our range.

38. Erigeron lonchophyllus Hook. Fl. Bor. Am. 1: 18. 1834. Sparsely more or less hirsute with spreading bristly hairs; stems clustered on the small rootstock, 1-3 dm. high, leafy: leaves hirsutely ciliate below the middle, otherwise glabrous or glabrate, entire; the cauline linear or linear-lanceolate (4-10 cm. long, 2-6 mm. wide), the lowest linear-spatulate or oblanceolate and usually tapering into slender petioles: heads peduncled and simpleracemose, or rarely panicled; involucre $6-8 \mathrm{~mm}$. long: rays more numerous than the disk-flowers, the purplish or whitish nearly filiform ligules when fully developed projecting only 1-2 mm. beyond the pappus: disk-flowers filiform. (E. armeriaefolius Turcz. in DC. Prodr. 5: 291. 1836; $E$. racemosus Nutt. Trans. Am. Phil. Soc. 7: 312. 1841.)-Moist saline meadows in the mountains of our range and in the Sierra Nevada, and far northward.

\section{WYOMINGIA A. Nels. Wyoming DaIsy}

Perennials with woody more or less branched roots and short, woody, caespitose, multicipital caudices whose branches are roughened or sheathed by the bases of the leaves of the previous years. Stems simple, monocephalous, 1 or more from each crown, becoming naked and pedunculiform above. Leaves crowded on the crowns and on the bases of the stems. Heads large; involucral bracts in 3-4 successively shorter rows, rigid with a thickened midrib. Flowers 
Aster-like; rays broad, comparatively few; disk-flowers numerous. Styleappendages short, triangular-cuspidate. Achenes short, densely pubescent, subterete.-Erigeron in part.

Caudex merely an enlarged crown, or the branches, if any, very short.

Glistening silvery-white, the pubescence microscopically fine, appressed

Greenish but more or less cinereous-lanate.

Leaves short, mostly $1-3 \mathrm{~cm}$. long

Leaves long, mostly 4-8 cm. long

Caudex freely branched, forming a dense tuft, with one or more stems from each crown.

Leaves 1-2 mm. wide; stems slender, curved-ascending .

Leaves 2-5 mm. wide; stems stoutish, strict .

1. W. argentata.

2. W. cana.

3. W. Tweedyana.

4. W. pulcherrima. 5. W. cinerea.

1. Wyomingia argentata (Gray) A. Nels. Silvery white pubescence throughout very close and fine, the separate hairs indistinguishable; stems 1-3 dm. high: radical leaves very densely clustered, linear-spatulate or broader, $2-5 \mathrm{~cm}$. long; the cauline scattered and much smaller: heads broad, 12-15 $\mathrm{mm}$. high: rays rather broad and large, $12-14 \mathrm{~mm}$. long: achenes sericeous-pubescent or villous, 5-8-nerved. (Erigeron argentatus Gray, Proc. Am. Acad. 8: 649. 1873.)-Desert regions of western Colorado to Utah and Nevada.

2. Wyomingia cana (Gray) A. Nels. Silvery appressed pubescence obviously strigillose under a lens, that of the involucre loose and spreading: stems 1-2 dm. high, leafy: the linear cauline leaves gradually diminishing upward; the radical spatulate-lanceolate or narrower: head about $8 \mathrm{~mm}$. high: rays narrow, 6 mm. long: achenes glabrous. (Erigeron canus Gray, Pl. Fendl. 67. 1848.) - Arid areas; western Nebraska to Wyoming and New Mexico.

3. Wyomingia Tweedyana (Canby \& Rose) A. Nels. Perennial, from a multicipital caudex, 1-2 dm. high, simple or somewhat branched, soft-pubescent below, becoming lanate above (apparently densely white, lanate when young): leaves narrowly linear, 4-8 cm. long, crowded at base, reduced and scattered above, somewhat pubescent: heads 6-10 mm. high, a little broader, terminating the simple stems or the branches: the peduncles long and naked or with few bract-like leaves: involucre of numerous narrow acuminate bracts, so crowded as to seem but 1-2 series, with tips a little spreading, densely lanate: rays numerous, conspicuous, white: pappus double, the outer multisquamellate; achenes pubescent. (Erigeron Tweedyana Canby \& Rose, Bot. Gaz. 15: 65. 1890; E. montanensis Rydb. Bull. Torr. Bot. Club 24: 296. 1898.)-Arid districts; Montana.

4. Wyomingia pulcherrima (Heller) A. Nels. Bull. Torr. Bot. Club 26: 249. 1899. Stems about $20 \mathrm{~cm}$. high, tufted at the base, simple, slender, leafy, with prominent yellowish lines, pubescent with short, appressed, white hairs: leaves all very narrow, about $1 \mathrm{~mm}$. wide; the basal ones linear-spatulate, about $1.5 \mathrm{~cm}$. long; those of the stems 2-4 cm. long, linear, acute, whitepubescent: peduncles a prolongation of the stems, 2-5 $\mathrm{cm}$. long: heads large, $3.5 \mathrm{~cm}$. in diameter, $7 \mathrm{~mm}$. high; involucral bracts in about 4 rows, slightly spreading, linear-lanceolate, with spreading pubescence: rays $20-30$, either white, pinkish, or violet blue, $1.5 \mathrm{~cm}$. long, $2 \mathrm{~mm}$. wide, emarginate. Sandy hills; New Mexico and probably southern Colorado.

5. Wyomingia cinerea A. Nels. 1. c. 250 . Stems erect, fascicled, somewhat striate with yellowish-green lines, about $2 \mathrm{dm}$. high, the upper part nakedpedunculate, usually with a single bract: leaves linear or some of the crown leaves spatulate, acute, cinereous (as are also the stems) with a short, close, appressed pubescence: heads large, when fully open $3 \mathrm{~cm}$. or more across; involucre broadly hemispherical, about $1 \mathrm{~cm}$. high; the bracts acute, cinereous with a spreading, crinkled pubescence: rays 30. (more or less), 5-7-nerved, white or pinkish, the tube finely pubescent as are also the disk florets, $3 \mathrm{~mm}$. broad, 3-toothed at the rounded apex: pappus tawny, in a single series, about as long as the disk-corollas, the bristles mostly abruptly flexed one third their length below the apex: achene short, striately marked with 2-4 greenishyellow lines: receptacle flat, alveolate.-Desert hillsides; south central Wyoming. 


\section{Leptilon Raf. Canada Fleabane}

Annual or biennial caulescent herbs. Leaves alternate; blades narrow, entire, or sparingly toothed. Heads small, radiate or discoid. Involucres usually campanulate; bracts several, in 2-3 series. Receptacle naked. Rayflowers few, pistillate, with short white or purplish ligules; disk-flowers several, perfect, the corollas usually with 4 lobes. Stigmas flattened, with short appendages. Achenes flattened, often pubescent. Pappus of many brittle hair-like bristles in 1 series.

1. Leptilon canadense (L.) Brit. Ill. Fl. 3: 391. 1898. From sparsely hispid to almost glabrous; stem strict, 2-12 dm. high, with numerous narrowly paniculate heads, or in depauperate plants only a few scattered heads: leaves linear, entire, or the lowest spatulate and incised or few-toothed: rays white, usually a little exserted and surpassing the style-branches. (Erigeron canadense.) - A weed in waste grounds throughout the continent.

2. Leptilon divaricatum Raf. Fl. Tell. 2: 265. 1818. Low, 1-2 dm. high, diffusely much branched, somewhat fastigiate: leaves all narrowly linear or subulate, entire: rays purplish, rarely surpassing the style-branches or the pappus. $E$. divaricatum.-Possibly coming into our southeastern border.

\section{BACCHARIS L.}

More or less shrubby, with alternate, simple leaves, and the branches striate, bearing small heads of white or yellowish flowers. Heads completely dioecious, many-flowered. Involucre regularly imbricated. Receptacle mostly flat and naked, rarely chaffy. Flowers of the staminate heads with tubularfunnelform, 5-cleft corolla; the pistillate with corolla reduced to a slender truncate or minutely toothed tube. Achenes 5-10-costate. Pappus of the staminate flowers a series of scabrous and often tortuous bristles; those of the fertile flowers usually more numerous, finer, and often elongated in fruit.

Herbaceous except at base.

Pappus copious, elongating in fruit and surpassing the style-branches; leaves linear, entire

Pappus scanty, scarcely elongating in fruit; leaves elongated-lanceolate, somewhat serrate

Shrubs, 1-4 m. high.

Involucral bracts all acute

Involucral bracts obtuse (at least most of them)

1. Baccharis Wrightii Gray, Pl. Wright. 1: 101. 1852. Herbaceous from a woody base, very smooth and glabrous, 3-6 dm. high, diffusely branching, sparsely leaved; slender branches terminated by solitary heads: leaves linear, small; the uppermost linear-subulate: involucre campanulate, 7-10 mm. high; the bracts lanceolate, gradually acuminate, conspicuously scarious-margined, with a green back: pappus very copious and pluriserial, soft, elongating in fruit, fulvous or purplish, 4 times the length of the scabrous-glandular 8-10nerved achene.-Western Texas to southern Colorado and Arizona.

2. Baccharis glutinosa Pers. Syn. 2: 425. 1807. Stems herbaceous above but woody toward the base, 1-3 m. high; branches somewhat striate-angled: leaves elongated-lanceolate, serrate with few or several scattered teeth on each side, more or less distinctly 3-nerved from near the base, 7-15 cm. long: heads mostly $6 \mathrm{~mm}$. long, numerous and corymbosely cymose at the summit of comparatively simple stems or branches; involucre stramineous: pappus not very copious or flaccid, and elongated hardly at all in fruit; achene 5-nerved.-From southern California to southern Colorado and Texas.

3. Baccharis salicina T. \& G. F1. 2: 258. 1842. Branching shrubs, 1-4 m. high, glabrous or nearly so, usually viscous, with a resinous exudation: leaves mostly subsessile, oblong to linear-lanceolate, sparingly toothed, rarely entire: heads or glomerules pedunculate; involucre campanulate, about $6 \mathrm{~mm}$. high; the bracts ovate and acutish: pappus more or less copious, but mostly uniserial, conspicuously elongating in fruit, white, soft and flaccid; achenes 10-nerved.-Southern Colorado to Texas and far westward. 
4. Baccharis Emoryi Gray, Bot. Mex. Bound. 83. 1859. Erect, with slender branches, 1-4 m. high: cauline leaves mostly oblong or the lower broader, with attenuate or cuneate base and the larger somewhat petioled, more or less triple-nerved, often with 2-4 short lobes or teeth; those of the branches oblanceolate to linear, mostly entire, 1-nerved: heads somewhat nakedly paniculate on the branchlets, short-pedunculate or the glomerules more or less pedunculate; involucre campanulate or oblong, 5-7 mm. long, mostly of firm coriaceous and obtuse bracts; the outermost oval, the inner oblong, the innermost thin, linear, and acutish.-Southern California to Nevada and Arizona, and reported from southwestern Colorado.

\section{FILAGO L.}

Low woolly annuals with small more or less glomerate heads. Receptacle hemispherical or conical. Fertile pistillate flowers in 2 sets, the outer set separated from the inner by a circle of open, scarious or chaff-like nearly glabrous bracts; flowers of the outer set, which is borne on the margin of the receptacle, commonly destitute of pappus, each loosely infolded by a concave or boat-shaped long-woolly bract; flowers of the inner set provided with a pappus of copious capillary bristles, not infolded by bracts. Hermaphrodite flowers in the center of the head few, often fertile, their pappus abundant. Achenes terete or nearly so, either smooth or minutely granular.-Evax Gaertn.

1. Filago prolifera (Nutt.) Brit. Mem. Torr. Bot. Club 5: 329. 1894. Rather stout; stem 7-12 cm. high, simple and erect, or with ascending branches from the base, bearing numerous small spatulate leaves and a capituliform glomerule, $10-12 \mathrm{~mm}$. in diameter, whence proceed 1-3 nearly leafless branches similarly terminated; sometimes again proliferous: fructiferous bracts scarious, oval or oblong, mainly naked; those embracing staminate flowers more herbaceous and woolly-tipped, of firmer or more herbaceous texture: staminate flowers each on a filiform stipe representing an abortive ovary. Evax prolifera.-Dakota, Colorado, and southward.

\section{ANTENNARIA* Gaertn.}

Dioecious or polygamo-dioecious perennial herbs with alternate leaves and many-flowered heads of inconspicuous flowers. Heads discoid; the pistillate flowers with filiform truncate corolla shorter than the 2-cleft style; the staminate with tubular 5-lobed corolla and style with undivided truncate apex. Involucre of imbricated, scarious, persistent bracts, at least their tips white or colored. Receptacle flat or convex, naked. Achenes small, nearly terete or flattish, mostly glabrous. Pappus a single series of capillary bristles, those of the fertile flowers very slender, connate at base, and so falling from the achene in a body; those of the sterile often crisped, mostly thickened at the apex.

\section{PLANTS SURCULOSE-PROLIFEROUS WITH LEAFY STOLONS}

Leaves comparatively small, 5-25 $\mathrm{mm}$. long.

Tips of involucral bracts green or brown.

Stems very slender, 2-7 cm. high .

Stems medium, 8-15 cm, high.

Leaves broadly spatulate; involucres $6-7 \mathrm{~mm}$. high
Leaves spatulate-oblanceolate; involucres about $5 \mathrm{~mm}$. high.

Leaves spatulate-oblanceolate;
Leaves obtuse, tomentose

Leaves acute, canescent

Tips of involucral bracts not brown or green.

Heads comparatively small, involucres $5(4-6) \mathrm{mm}$. high.

Tips of involucral bracts rose-color or rarely whitish.

Leaves narrowly oblanceolate, acute

Leaves spatulate, obtuse

1. A. media.

2. A. fusca.

3. A. reflexa.

4. A. umbrinella.

5. A. rosea.

6. A. concinna.

* The treatment of this genus is largely an adaptation from Prof. Elias Nelson's clear and discriminating revision of a large part of the genus, in Proc. U. S. Nat. Museum 23: 697-713. 1901 . 
Tips of involucral bracts white.

Stems evident.

Stems generally more than $1 \mathrm{dm}$. high (1-4 dm.); tomentum fine, silky, appressed.

Leaves of the stolons narrowly oblanceolate, acute

Leaves of the stolons spatulate, obtuse or acute

Stems rarely more than $1 \mathrm{dm}$. high (3-15 cm.); hoarytomentose.

Leaves conduplicate for the most part

Leaves not conduplicate

Stems wanting, the heads sessile in the rosulate leaves

Heads comparatively large, involucres $8(7-9) \mathrm{mm}$. high.

Leaves permanently tomentose on both surfaces.

Pistillate bracts acute

Pistillate bracts generally obtuse

Leaves glabrous above or nearly so

Leaves comparatively large, 3-5 $\mathrm{cm}$. long.

Leaves green and glabrate above.

Leaves oblanceolate to linear

Leaves broadly oval to oblong

Leaves tomentose above also

7. A. corymbosa

8. A. parvifolia.

9. A. arida.

10. A. scariosa.

11. A. rosulata.

12. A. oxyphylla.

13. A. aprica.

14. A. marginata.

15. A. oblancifolia.

16. A. racemosa.

17. A. obovata.

PLANTS NOT SURCULOSE-PROLIFEROUS

Plants more than $1 \mathrm{dm}$. high; pappus-bristles of the staminate heads clavate.

Plants tall (3-6 dm.); bracts tomentose except the scarious tips.

Leaves linear or narrowly oblanceolate

Leaves lanceolate or spatulate-lanceolate

Plants lower (less than $3 \mathrm{dm}$.); bracts nearly glabrous

Plants less than $1 \mathrm{dm}$. high; pappus-bristles not clavate

18. A. luzuloides.

19. A. pulcherrima.

20. A. oblanceolata. 21. A. dimorpha.

1. Antennaria media Greene, Pitt. 3: 286. 1898. Rarely more than $6 \mathrm{~cm}$. high; stolons 1-3 cm. long: leaves spatulate-oblanceolate, often narrowly so, abruptly acute or acutish, $15 \mathrm{~mm}$. or less long, white or grayish-tomentose on both surfaces: involucres (pistillate) about $4 \mathrm{~mm}$. high; tips of the pistillate bracts oblong to oblong-linear, obtuse, rarely acutish, green or greenishbrown, rarely light brown and whitish at the very tips; tips of the staminate bracts oval, obtuse, of same color as the pistillate ones.-From the mountains of California to British Columbia and in the Rocky Mountains from Colorado to Alberta.

2. Antennaria fusca E. Nels. Bot. Gaz. 30: 120. 1900. About $1 \mathrm{dm}$. high: leaves spatulate, obtuse and more or less truncate at apex, indistinctly mucronate, about $2 \mathrm{~cm}$. long, 5-7 mm. broad, canescently tomentulose or striatewoolly on both surfaces: involucres $6-7 \mathrm{~mm}$. high, the tips of the bracts (pistillate) oblong or oblong-linear, obtuse, greenish-brown to buff-color: staminate plant unknown.--In the mountains; Wyoming.

3. Antennaria reflexa E. Nels. Bot. Gaz. 27: 208. 1899. Slightly suffrutescent, $5-15 \mathrm{~cm}$. high: leaves spatulate or spatulate-obovate, obtuse, 6-15 $\mathrm{mm}$. long (usually $10 \mathrm{~mm}$.), dull grayish-white, tomentose on both surfaces: involucres 4-5 mm. high; the bracts few, in less than 3 series; the tips of the pistillate usually from oval in the outer to oblong-linear in the inner, all obtuse, less frequently ovate or lanceolate in the outer to linear in the inner, and acute or acuminate, greenish-brown to yellowish-white, rarely rose-color; the tips of the staminate oval, obovate or oblong, obtuse or truncate, usually of firm texture, like the pistillate ones as to color. ' $(A$. flavescens Rydb. Mem. N. Y. Bot. Gard. 1: 411. 1900.) - Colorado to Montana.

4. Antennaria umbrinella Rydb. Bull. Torr. Bot. Club 24: 302. 1897. Stems 10-15 cm. high; stolons $4 \mathrm{~cm}$. long or less: leaves narrowly spatulateoblanceolate, acute or abruptly acute and mucronate, $15-25 \mathrm{~mm}$. long, canescent on both surfaces, rarely tomentose: involucres 5-6 $\mathrm{mm}$. high; tips of the bracts (pistillate) oblong or oblong-lanceolate, obtuse, rarely acutish, greenish-brown, the very tips often whitish: typical staminate plants unknown. (A. mucronata E. Nels. 1. c. 209.)-Colorado to Montana and Oregon.

5. Antennaria rosea (Eat.) Greene, Pitt. 3: 281. 1898. Slender, 2-4 dm. high; sterile basal branches ascending to erect, rarely prostrate; the canescent tomentum of the leaves and the striate wool of the stems slightly viscid: leaves very narrowly oblanceolate or elongated-spatulate, acute, $15-20 \mathrm{~mm}$. 
long, less than $5 \mathrm{~mm}$. wide: heads in close and rounded or often rather open clusters: involucres 5-6 mm. high; bracts (pistillate) in about 3 series, nearly equal or somewhat imbricated, the tips oval to linear, usually all obtuse, rosecolor to dull white: staminate plant unknown.-From Colorado to Alberta and the Pacific States.

5a. Antennaria rosea imbricata E. Nels. Proc. U. S. Nat. Museum 23: 707. 1901. Leaves obovate or oblanceolate, obtusish, 20-25 mm. long, about 5 $\mathrm{mm}$. wide, thin in texture, the indument appressed, whitish: involucral bracts (pistillate) broader than in the species, in about 4 series, imbricated, rosecolor to nearly white.-Wyoming and Montana to California and Oregon.

6. Antennaria concinna E. Nels. Proc. U. S. Nat. Museum 23: 705. 1901. Caespitose, with leafy offsets or procumbent stolons, the latter at most $5 \mathrm{~cm}$. long; stems slender, leafy, $10-15 \mathrm{~cm}$. high: leaves spatulate, with no distinction of blade or petiole, scarcely abruptly acute, about $1 \mathrm{~cm}$. long and 2-4 $\mathrm{mm}$. broad, white-tomentose on both surfaces; the cauline linear-oblong to linear, acute, shorter than the internodes: heads 6-8 and glomerate, or often as many as 15, and the cluster then rather open; involucres 6-7 $\mathrm{mm}$. high; bracts (pistillate) in about 3 series, all obtuse and about $1 \mathrm{~mm}$. wide, the herbaceous portion livid green, the outer bracts with a brown middle portion and their tips light brown, the tips of the others rose-color or yellowish-white: staminate plant unknown.-Colorado and Wyoming to Washington.

7. Antennaria corymbosa E. Nels. Bot. Gaz. 27: 212. March 1899. Stem slender, $12-25 \mathrm{~cm}$. high; stolons flexible: leaves from almost linear to narrowly oblanceolate, rarely oblanceolate, acute, cuspidately mucronate, 25-35 mm. long, canescent or lightly tomentose, rarely green and glabrate: heads more or less pediceled and corymbosely disposed; involucres $4-5 \mathrm{~mm}$. high; bracts with a brownish spot at the middle, the tips dull white or milky white, the pistillate ones ovate to oblong, obtuse, the staminate rotund to oblong, obtuse or truncate. [A. nardina Greene, Pitt. 4: 82. Dec. 1899.]In the mountains; Colorado to Montana.

8. Antennaria parvifolia Nutt. Trans. Am. Phil. Soc. 7: 406. 1842. Slender, 1-3 dm. high; stolons short, procumbent: leaves rhomboidally spatulate and acute or rarely with the terminal dilated portion obovate and obtuse, 5-15 mm. long, silvery-tomentose on both surfaces or only canescent above: heads in a rounded cluster or in an open corymb; involucres 5-6 $\mathrm{mm}$. high; tips of the pistillate bracts usually narrow, obtuse or acute, dull white or somewhat yellowish; those of the staminate bracts rotund to oblong, obtuse or truncate, dull white or yellowish-white. (A. microphylla Rydb. Bull. Torr. Bot. Club 24: 303. 1897.)-Colorado to Nevada and northward to Alberta.

8a. Antennaria parvifolia bracteosa (Rydb.) A. Nels. About $3 \mathrm{dm}$. high: leaves broadly spatulate, thin in texture, canescent or tomentose, $15-20 \mathrm{~mm}$. long; the cauline about $3 \mathrm{~cm}$. long: involucral bracts (pistillate) narrow, the tips white, acutish to acuminate. (A. bracteosa Rydb. Mem. N. Y. Bot. Gard. 1: 413. 1900.)-Colorado to Montana.

9. Antennaria arida E. Nels. Bot. Gaz. 27: 210. 1900. Stems 7-15 cm. high: leaves small (8-12 mm. long) and inclined to be conduplicate, spatulate, acute, hoary-tomentose: involucres about $6 \mathrm{~mm}$. high; the bracts (pistillate) nearly all equal, obtuse, or somewhat imbricated and acutish, the tips dull white, very rarely pinkish: staminate plant unknown.--In the arid desert areas; Colorado, Wyoming, and Utah.

9a. Antennaria arida viscidula E. Nels. Proc. U. S. Nat. Museum 23: 710. 1901. Size, habit, and leaves of the species, but glandular about the inflorescence, stem, and usually on the leaves below: middle portions of outer bracts (pistillate) greenish-yellow or brown, the tips dirty white or pale brown.Wyoming and Colorado.

9b. Antennaria arida humilis (Rydb.) E. Nels. 1. c. General aspect of the species but taller, $15-20 \mathrm{~cm}$. high, rarely more: the leaves somewhat larger: the involucral bracts more unequal. (A. foliacea humilis Rydb. Mem. N. Y. Bot. Gard. 1: 414. 1900.)-Montana and Wyoming. 
10. Antennaria scariosa E. Nels. Bot. Gaz. 27: 211. 1899. Caespitose, lightly hoary-tomentose throughout; stems 3-6 $\mathrm{cm}$. high; stolons short, at most $4 \mathrm{~cm}$. long: leaves $1.4 \mathrm{~cm}$. long or less, spatulate, obtuse or acutish, inclined to be conduplicate; cauline leaves rather ample, oblanceolate to narrowly oblong, occasionally the lowest spatulate: heads $6 \mathrm{~mm}$. high, sessile, $6-8$ in a subcapitate, leafy-bracted cluster; bracts (pistillate) rather conspicuously scarious, all obtuse, the scarious portion milk-white, elliptic to obovate.Southwestern Wyoming.

11. Antennaria rosulata Rydb. Bull. Torr. Bot. Club 24: 300. 1897. Densely matted and depressed, the heads scarcely rising above the leaves: these spatulate, obtuse or acutish, 6-10 $\mathrm{mm}$. long: involucres about $7 \mathrm{~mm}$. high. (A. Sierrae-blancae Rydb. Bull. Torr. Bot. Club 31: 127. 1905, "leaves glabrate above.")-Arizona to southern Colorado.

12. Antennaria oxyphylla Greene, Pitt. 4: 284. 1901. Stems 15-25 cm. high: leaves spatulate-obovate, permanently tomentose on both surfaces, 2 $\mathrm{cm}$. long or less: heads $6-15$; involucres $7-8 \mathrm{~mm}$. high; bracts in about 4 series, imbricated, "all acute and of a rather dull white," rarely pinkish: staminate plant unknown.-Southern Wyoming to South Dakota and British Columbia.

13. Antennaria a prica Greene, Pitt. 3: 282. 1898. Low and usually densely matted, less than $17 \mathrm{~cm}$. high: leaves cuneate-obovate to narrowly oblanceolate, permanently tomentose on both surfaces, acute to obtuse: heads large for the plant, the pistillate involucres $6-8 \mathrm{~mm}$. high; bracts numerous and imbricated; the tips in the pistillate plant.acute or obtuse, dull white or pink, often with a brown spot at the base of the scarious portion; in the staminate plant broad and obtuse, white. (A. Holmii Greene, Pitt. 4: 81. 1899.)Dry ground, foothills and plains; New Mexico to Nebraska and northward to Assiniboia and Manitoba.

14. Antennaria marginata Greene, Pitt. 3: 290. 1898. Like A. aprica, but leaves glabrous above, or nearly so, and prominently mucronate: staminate involucral bracts with rhomboid-ovate and obtuse or acute tips.- New Mexico and southern Colorado.

15. Antennaria oblancifolia E. Nels. Bot. Gaz. 30: 121. 1900. Caespitose; stolons very short; stems slender, $15 \mathrm{~cm}$. high or less: radical leaves oblanceolate, those of the stolons narrowly so, acute, mucronate, about $2 \mathrm{~cm}$. long, sparsely canescent to glabrous above, canescently tomentose below; cauline leaves linear or oblong-linear, the lower acute, the upper acuminate: heads $4-13$, in close racemose or paniculate clusters; involucres (staminate) $4 \mathrm{~mm}$. high, the herbaceous portion of the bracts sparsely woolly, the scarious portion oval, obtuse, brownish or white.-Yellowstone Park.

16. Antennaria racemosa Hook. Fl. Bor. Am. 1: 329. 1834. Freely surculose by long and slender, sparsely leafy stolons, lightly woolly, becoming glabrate; flowering stems 1-4 dm. high, slender, sparsely leafy, bearing few or numerous racemosely or paniculately disposed heads, nearly all slenderpeduncled: leaves thin, the radical broadly oval, acute at each end, slenderpetioled, obscurely 3-nerved at base, rather veiny, densely tomentose beneath, green and glabrate above; cauline leaves similar but smaller and sessile, lanceolate: involucre campanulate, $6 \mathrm{~mm}$. high; the bracts green or brownish; those of the staminate heads obtuse, the inner obscurely white-tipped; those of the pistillate heads narrow and mostly acute, with scarious white tips.Moist woods and rocky banks; Oregon to British Columbia and the Rocky Mountains.

17. Antennaria obovata E. Nels. Bot. Gaz. 27: 213. 1899. Stems $30 \mathrm{~cm}$. high; stolons 5-8 cm. long: leaves tomentose on both sides; the basal $3 \mathrm{~cm}$. long, 3-ribbed, the midrib continuous to the apex, obovate-cuneate, about 13 mm. broad; cauline leaves small, oblong-linear: heads $3-7$, corymbosely disposed on pedicels 5-20 mm. long; involucres sparingly long, woolly; bracts (pistillate) in several series; the outer short and obtusish; the inner twice as long, narrow, acute to acuminate; nearly all with a purplish spot at the middle. (A. Howellii Greene, as to our range.)-Along the eastern base of the mountains; Colorado to the Black Hills. 
18. Antennaria luzuloides T. \& G. Fl. 2: 430. 1842. "Closely silky-woolly; stems slender, 2-3 dm. high: leaves all narrowly linear or some of the lowest narrowly lanceolate-spatulate; the small uppermost linear-subulate: heads small, 4-5 mm. long, several or numerous; involucre glabrous nearly or quite to the base; the inner bracts in the pistillate heads obtuse: achenes glandular; the spatulate and as it were petaloid tips of the staminate pappus obtuse." British Columbia to Oregon and Wyoming.

19. Antennaria pulcherrima (Hook.) Greene, Pitt. 3: 176. 1898. Stems simple, not surculose, $3-4 \mathrm{dm}$. high, stout: basal leaves oblanceolate, $10-15 \mathrm{~cm}$. long, acute, more or less distinctly 3 -nerved, loosely tomentose; stem leaves lance-linear, acute, the upper ones small: heads 6-8 $\mathrm{mm}$. high, almost hemispheric, tomentose at the base; the bracts in 3-4 series, brown or with scarious tips, in the sterile head obtuse or truncate, in the fertile obtuse or acutish: pappus (staminate) moderately dilated above. (A. anaphaloides Rydb. Mem. N. Y. Bot. Gard. 1: 409. 1900.) - Colorado to Montana and far northward.

20. Antennaria oblanceolata Rydb. Mem. N. Y. Bot. Gard. 1: 409. 1900. Stems simple, from a branching caudex, $10-25 \mathrm{~cm}$. high, slender: basal leaves oblanceolate or spatulate, white silky-tomentose, mucronate, 3 -nerved, $3-5 \mathrm{~cm}$. long; stem leaves similar, narrower, reduced: heads in a small corymb, small, 4-5 mm. high; involucre tomentose only at the base; the bracts otherwise gläbrous, brownish, only the inner ones with a white tip, in the sterile obtuse, in the fertile acutish: pappus (staminate) much dilated at the end.-Colorado to Montana, British Columbia, and California.

21. Antennaria dimorpha (Nutt.) T. \& G. 1. c. 430. Depressed, caespitose, forming dense matted tufts $2-5 \mathrm{~cm}$. high; the thickish rootstocks creeping; stems very leafy: leaves spatulate, attenuate below to a petiole, $10-20 \mathrm{~mm}$. long, whitish-tomentose both sides: heads solitary, 6-8 mm. high; bracts of the involucre well imbricated, the outer successively shorter and obtuse, the inner acute or acuminate; those of the fertile heads narrow, with hyaline acuminate tips: achenes oblong, pubescent; pappus of the fertile flowers copious, of soft and very slender bristles that are not at all thickened upward. -Dry plains; Colorado, far northward and westward.

\section{ANAPhalis DC. Pearly Everlasting}

White-tomentose, woolly perennial herbs with leafy erect stems, entire leaves, and numerous small discoid heads of yellow disk-flowers. Heads dioecious but usually with a few hermaphrodite flowers in the center of the pistillate heads. Bristles of the pappus of the staminate flowers but little if at all thickened at the apex; those of the pistillate flowers not united at base but falling separately.

1. Anaphalis subalpina (Gray) Rydb. Mem. N. Y. Bot. Gard. 1: 415. 1900. Commonly $3-5 \mathrm{dm}$. high, in tufts, very leafy, the white floccose wool rarely becoming tawny: leaves 5-10 $\mathrm{cm}$. long, rather broadly to linearlanceolate, green above, the broader ones indistinctly 3-nerved: heads numerous, corymbosely cymose; bracts of the involucre very numerous, almost wholly pearly white, radiating in age. Anaphalis margaritacea, as to our range. -In the mountains of our range and westward."

\section{NACREA A. Nels.}

Perennial from horizontal rootstocks. Stems stoutish, erect, permanently lanate as are also the leaves. Heads discoid, congested in a cymose corymb; involucral bracts thin, pearly white, pluriserially imbricated. Flowers all hermaphrodite. Corolla inserted below the summit of the achene which projects into the tube of the corolla as a short, eylindrical base supporting the style. Receptacle plane, alveolate. Pappus-bristles capillary, thickened at the apex. Achene constricted at the point where the corolla is inserted, basal portion obconical. 
1. Nacrea lanata A. Nels. Bull. Torr. Bot. Club 26: 357. 1899. Stems single, very strict, leafy, $2-4 \mathrm{dm}$. high: leaves (like the stem) densely white lanate, thick, rather rigid, erect or somewhat appressed to the stem, sessile or clasping, all nearly similar, narrowly oblong, the rounded-tapering apex subacute, $4-8 \mathrm{~cm}$. long, the floral much reduced: heads about $6 \mathrm{~mm}$. high, bracts wanting except for a few foliar ones at the lower pedicels; involucral bracts ovate to narrowly obovate, the inner ones with a narrowed base: corolla-tube slender, the limb slightly expanded, yellow: pappus-bristles barbellulate, the unicellular barbules becoming large and obtuse toward the thickened apex of the bristle; achenes roughened with upwardly pointed papillae.-Known as yet only from Goose Creek Cañon, northern Wyoming.

\section{GNAPHalium L. Cudweed. Everlasting}

Floccose-woolly herbs with sessile and sometimes decurrent leaves and commonly numerous heads of small flowers in cymose clusters or glomerules. Heads heterogamous, discoid, fertile throughout, of few or many series of pistillate flowers surrounding a smaller number of hermaphrodite ones. Involucre pluriserial, imbricated, the scarious and commonly partly woolly bracts with or without colored papery tips or appendages. Style of hermaphrodite flowers 2-cleft. Pappus of numerous merely scabrous capillary bristles in a single series. Achenes terete or flattish, mostly nearly nerveless.

Heads not leafy-bracted; involucre woolly only at base; achenes glabrous.

Leaves tomentose on both faces.

Narrowed at the base and not at all decurrent

Narrowed at the base and more or less decurrent

Leaves green on the upper face and glandular-viscid

Heads leafy-bracted; involucres more involved in wool.

Freely and divaricately branched from the base.

Tomentum dense and floccose; leaves oblong to spatulate

Tomenturn sparse (especially on the leaves) and appressed; leaves all linear

Simple and erect or with a few erect basal branches

1. G. Wrightii.

2. G. chilense.

3. G. decurrens.

4. G. palustre.

5. G. angustifolium. 6. G. strictum.

1. Gnaphalium Wrightii Gray, Pl. Wright. 1: 124. 1850. Low, 1-2 dm. high, branched from the base, the stems more or less branched throughout or simple to near the summit; stems and leaves grayish-woolly: radical leaves oblanceolate, about $35 \mathrm{~mm}$. long; the cauline narrowly oblanceolate to linear, 1-3 cm. long: heads sessile in small glomerules terminating the branches; involucres 4-5 mm. high; bracts dull white, from ovate in the outer to linear in the inner, obtuse or acutish, nearly all apiculate. (G. sulphurescens Rydb. Mem. N. Y. Bot. Gard. 1: 415. 1900; G. thermale E. Nels. Bot. Gaz. 30: 121. 1900, the description of which is here used.)-Colorado to Texas and New Mexico and on the Hot Springs formations, Yellowstone Park.

2. Gnaphalium chilense Spreng. Syst. 3: 480. 1826. Stems usually stout, 2-7 dm. high: leaves lanceolate or linear, or the lowest spatulate, densely white-woolly or sometimes thinly floccose, the short decurrent bases or adnate auricles rather broad, slightly if at all glandular or heavy-scented: heads in single or few close glomerules terminating the stem or branches; involucre hemispherical, white or yellowish, becoming rusty-tinged. G. Sprengelii.Texas to southern California and to Montana and Oregon.

3. Gnaphalium decurrens Ives, Am. Journ. Sci. 1: 380. pl. 1. 1819. Stem stout, 5-8 dm. high, corymbosely branched above and bearing cymosely crowded glomerules of broad heads: leaves very numerous, lanceolate or the upper linear, obviously adnate-decurrent, the upper face becoming naked and green in age and with the stem glandular-pubescent or viscid, white-woolly beneath, strongly balsamic-scented: involucre campanulate, white, becoming rusty-tinged.-From Texas and New Mexico to Washington and British Columbia, and eastward to New England.

4. Gnaphalium palustre Nutt. Trans. Am. Phil. Soc. 7: 403. 1841. Loosely floccose with long wool; stems erect or diffusely branching from the base, 5-15 cm. high: leaves spatulate to oblong or lanceolate-linear, 15-20 mm. 
long: heads very numerous, in small glomerules terminating the stem or branches; involucre campanulate, the bracts linear, with glabrous, white, acute tips.-Borders of ponds and damp places; British Columbia to California and the Rocky Mountains.

5. Gnaphalium angustifolium A. Nels. Bull. Torr. Bot. Club 26: 357. 1899. Low annual, branching from the base; stems decumbent-spreading or assurgent, 8-12 cm. long, loosely floccose on the stems and involucres, appressed-pubescent on the leaves: leaves narrowly to broadly linear, $2-4 \mathrm{~cm}$. long: the small heads glomerate in the axils, the upper internodes very short forming a congested leafy cluster: heads moderately involved in wool, about $3 \mathrm{~mm}$. high; involucral bracts lanceolate, acutish, the scarious tips white, brownish below: achene roughened with short, cylindrical papillae.-Moist places; Wyoming and Colorado.

-6. Gnaphalium strictum Gray, Pac. R. Rep. 4: 110. 1858. Appressedwoolly; stem strict and simple, 1-2 dm. high, sometimes branching or with ascending stems from the base: leaves all linear, seldom $2 \mathrm{~mm}$. wide: heads in spicately disposed glomerules in the axils or on short lateral branches; involucral bracts with brownish or somewhat whitish tips, obtuse.-Rocky Mountain region, from Wyoming to New Mexico and Arizona.

\section{MELAMPODIUM L.}

Annual or perennial small caulescent herbs or shrubby plants. Leaves opposite; blades often narrow, thickish, entire, toothed, or pinnatifid. Heads radiate, sometimes conspicuous. Involucre double, the outer of 4-5 partially united flat bracts, the inner a series of bracts each embracing an achene and deciduous with it, but unarmed. Receptacle convex or conic. Rayflowers in 1 series, pistillate; ligules white or yellow; disk-flowers perfect but not fruit-producing. Anthers entire at the base. Achenes broadened upward, somewhat incurved. Pappus wanting.

1. Melampodium cinereum DC. Prodr. 5: 518. 1836. Branched from the base, 1.5-3 dm. high, cinereous or even silvery-canescent with a close pubescence, or greener: leaves linear or the lower lanceolate or spatulate, entire or undulate, or even sinuate-pinnatifid: ligules 5-9, cuneate-oblong, 2-3-lobed at apex, 6-12 mm. long; bracts of the involucre ovate, appressed, slightly united at base; fructiferous bracts nearly terete, somewhat incurved, muricate with sharp tubercles; the hood about the length of the body and very much wider, nearly smooth, the truncate and usually even margin commonly incurved. (M. leucanthum T. \& G.) - Southern Colorado to Arkansas, Texas, and Arizona.

\section{PARTHENICE Gray}

Tall branched annual. Fertile flowers 6-8, with ligule obsolete or reduced to 2 or 3 small teeth; sterile flowers 40 or 50, with funnelform corolla. Involucre of 5 somewhat herbaceous oval exterior bracts, and of 6 or 8 somewhat larger orbicular-obovate and more scarious interior ones, these subtending the fertile flowers. Receptacle convex, with linear-oblong or spatulate chaffy bracts subtending the outer series of sterile flowers, but mostly minute or wanting to the inner flowers. Achenes oblong-obovate, glabrous, wingless but acute-margined, with an incurved apiculation, inserted by a very small base, falling away at maturity with the involucral and 2 receptacular bracts, but these readily separating. Pappus none, and corolla deciduous.

1. Parthenice mollis Gray, Pl. Wright. 2: 85. 1853. Annual, with odor of Artemisia, 1-2 m. high, paniculately branched, minutely cinereous throughout, wholly destitute of any coarser pubescence: leaves all alternate, ovate, some of the larger (2-3 dm. long) subcordate, acuminate, irregularly or doubly dentate, long-petioled: heads small, $4 \mathrm{~mm}$. broad, numerous, in loose axillary and terminal somewhat leafy panicles: flowers greenish-white.-Southern Colorado to Arizona. 
38. BOLOPHYTA Nutt.

An acaulescent caespitose perennial, with the ligule wanting, the corolla reduced to a truncate tube which is obscurely notched at the front and back. -Parthenium.

1. Bolophyta alpina Nutt. Trans. Am. Phil. Soc. 7: 347. 1841. Densely tufted on a thick branching caudex, depressed, rising only $3-5 \mathrm{~cm}$. high: leaves crowded, silvery-canescent with a fine appressed pubescence, and villous in the axils, spatulate-linear, $2-3 \mathrm{~cm}$. long, entire: heads solitary and nearly sessile among the leaves: pappus a pair of oblong-lanceolate membranaceous scales. Parthenium alpinum.- "On rocks near the Three Buttes," Rocky Mountains in Wyoming (at 7,000 feet). (Nuttall.)

\section{OXYTENIA Nutt.}

Shrubby perennial with erect branches. Leaves alternate, 3-5-parted into filiform divisions, or the upper ones often sparse and entire. Involucral bracts about 5, somewhat coriaceous, the tips rigidly acuminate. Bracts of the receptacle slender, chaffy, with cuneate-dilated tips. Pistillate flowers about 5 , destitute of corolla; staminate flowers 10-20. Young achenes obovate, very villous with long soft hairs, terminated by a large areola. Pappus none or a mere vestige.

1. Oxytenia acerosa Nutt. Pl. Gamb. 172. 1848. Stems canescent, halfwoody, 1-2 m. high, sometimes leafless and rush-like, sometimes covered with leaves $1.5 \mathrm{dm}$. or less long: heads $4 \mathrm{~mm}$. high, numerous, in dense panicles.Dry alkaline plains; southern Colorado to California.

\section{IVA L.}

Ours coarse herbs with thickish alternate or opposite leaves and small nodding heads of greenish-white flowers. Involucre hemispherical, the bracts few and rounded. Receptacle with chaff-like, linear or spatulate bracts. Marginal flowers of the head pistillate, 1-5 in number, the corollas tubular or none; disk-flowers perfect, with 5-lobed funnelform corolla and undivided style. Anthers almost distinct. Achenes flattened, glabrous. Pappus none.

Tall coarse plants; the heads in panicled crowded spikes . . . . 1. I. xanthifolia. Low and often clustered stems; the heads solitary axillary $: \bullet^{-} \quad$. $_{\text {. }}$. I. axillaris.

1. Iva xanthifolia Nutt. Gen. 2: 185. 1818. Tall and coarse, 7-18 dm. high, pubescent, at least when young: leaves mainly opposite, broadly ovate, ample, coarsely or incisely serrate, acuminate, 3-4-ribbed at base, puberulently scabrous above: panicles axillary and terminal: outer involucral bracts 5 , broadly ovate and herbaceous; the inner of as many membranaceous, dilated-obovate or truncate ones, which are strongly concave at maturity and half embrace the obovate-pyriform and glabrate achenes.-From New Mexico to Idaho and the Saskatchewan.

2. Iva axillaris Pursh, Fl. 743. 1814. Stems or branches nearly simple, ascending, 1-4 dm. high: leaves obovate or oblong to nearly linear, obtuse, entire, sessile, 1-3 cm. long, even the uppermost usually much surpassing the mostly solitary heads in their axils: bracts of the involucre connate into a 4 or 5-lobed or sometimes parted or merely crenate cup.-From New Mexico to Dakota and the Saskatchewan, and westward.

\section{DICORIA T. \& G.}

Diffusely branched annuals of the desert area. Upper leaves alternate. Inflorescence loosely paniculate. Involucral bracts 6 or 7 , distinct; the 5 outer ones herbaceous; 1 or 2 of the inner ones much larger, scarious and sub- 
tending the fertile flowers, or these wanting in staminate heads. Receptacular bracts few, narrow. Pistillate flowers 1 or 2 , destitute of corolla; staminate flowers 6-12, the filaments almost free from the corolla and monadelphous up to the lightly connected anthers. Achenes surpassing the outer involucre, convex on the dorsal side, flat on the anterior face, conspicuously margined with a scarious pectinate border. Pappus of several small squamellae.

1. Dicoria Brandegei Gray, Proc. Am. Acad. 11: 76. 1875. Strigillosecanescent, diffusely and alternately branched: leaves of the branches oblonglanceolate or partly spatulate, obtuse, mostly entire, $2-3 \mathrm{~cm}$. long, and with slender petiole: heads sparse, racemose-paniculate: fertile flower solitary; the dilated-cuneate hyaline subtending bract hardly surpassing the outer involucre: achene naked and exserted, bordered with pectinate callous teeth connected by an indistinct scarious margin.-Sandy bottoms of the San Juan, Colorado.

\section{AMBROSIA L. RAGWEED}

Coarse herbs with mostly lobed or dissected opposite and alternate leaves and dull inconspicuous flowers. Sterile heads racemose or spicate and with no bracts; fertile flowers usually glomerate in axils below. Involucre of the staminate flowers depressed-hemispherical to turbinate, 5-12-lobed or truncate, herbaceous. Receptacle flat or flattish, usually with some filiform chaff among the outer flowers. Involucre of the solitary fertile flower nutlike, apiculate or beaked at the apex, and usually armed with 4-8 tubercles or short spines in a single series below the beak.

Leaves entire or palmately 3-cleft; involucre of staminate heads

Leaves once to thrice pinnatifid; involucres of staminate flowers not
ribbed.

Annual; fruit with acute teeth .

Perennial from rootstocks; fruit unarmed or with blunt teeth

1. A. trifida.

2. A. artemisiaefolia. 3. A. psilostachya.

1. Ambrosia trifida L. Sp. Pl. 987. 1753. Tall and stout, 1-3 m. high, roughish-hispid or almost glabrous: leaves all opposite, very deeply 3-lobed or the lower 5-lobed; the lobes acuminate, serrate: sterile racemes long and dense; fertile heads clustered and as if involucrate by short bracts: fruit very thick, with 5-7 strong ribs or angles terminating above in spinous tubercles around the base of the conical beak. Var. integrifolia T.\& G. with entire leaves. Great Ragweed.-Moist banks and draws; Colorado and far northward and eastward.

2. Ambrosia artemisiaefolia L. 1. c. Variously pubescent or hirsute, paniculately branched, 3-6 dm. high, or taller: leaves thinnish, bipinnatifid or pinnately parted, with the divisions irregularly pinnatifid or sometimes nearly entire, on the flowering branches often undivided: sterile heads pediceled: fruit short-beaked, armed with 4-6 short acute teeth or spines.- A weed in waste and cultivated grounds across the continent, known variously as Roman Wormwood, Ragweed, and Bitterweed.

3. Ambrosia psilostachya DC. Prodr. 5: 526. 1836. Stems simple, erect, commonly 5-10 (2-15) dm. high from slender running rootstocks; herbage scabrous or short-hirsute, somewhat strigose: leaves once or the lower twice pinnatifid, with acute lobes: fruit an obovoid turgid bur, about $3 \mathrm{~mm}$. long, mostly solitary in the axils, pubescent, rugose-reticulated, bearing 4 protuberances or sometimes unarmed. WESTERN RAGWEeD.-A common weed along roadsides and in waste places throughout western North America.

\section{FRANSERIA Cav.}

Ours are herbaceous, with chiefly alternate leaves, and the spines of the fruiting and 1-2-flowered involucre comparatively few. Heads of staminate flowers as in A mbrosia, or sometimes intermixed with the pistillate. Fertile involucre 1-4-flowered, 1-4-celled, a single pistil to each cell, 1-4-rostrate, 
more or less bur-like, being armed over the surface with several or numerous prickles or spines (the spiny free tips of the component bracts) in more than 1 series. Leaves mostly alternate.

Leaves twice or thrice pinnately dissected.

Annuals

Perennials.

Leaves regularly pinnate, the lobes linear or narrowly oblong Leaves interruptedly pinnate, the lobes ovate or triangular . Leaves simple or simply pinnate

1. F. acanthicarpa.

2. F. tenuifolia.

3. F. tomentosa.

4. F. Grayi.

1. Franseria acanthicarpa (Hook.) Coville, Contr. U. S. Nat. Herb. 4: 129. 1903. Diffusely spreading or sometimes rather strict, 3-6 dm. or more high, from an annual or more enduring (?) root; in age scabrous or short-hirsute and somewhat canescent: leaves on long petioles, broadly ovate in outline, once or twice pinnatifid into short, rounded, often toothed lobes: staminate racemes solitary or in small panicles, the heads nodding on short slender peduncles; fruiting involucres in the axils below, either solitary or 2 or 3 together, 1flowered, glabrous; spines flat, thin, lanceolate-subulate, with straight or slightly curved but not uncinate tips.- $F$. Hookeriana.-Common on sandy plains; throughout our range and westward to the coast.

2. Franseria tenuifolia Gray, Pl. Fendl. 80. 1848. Erect, 3-10 dm. high, leafy to the top, hispid, variously pubescent, or glabrate: leaves mostly 2-3pinnately parted or dissected into narrowly oblong or linear lobes, the terminal elongated: sterile racemes commonly elongated and paniculate; fertile heads in numerous glomerules below, in fruit minutely glandular, usually 2-flowered, armed with 6-18 short and stout incurving spines, their tips almost always hooked, and an excavated cartilaginously bordered areola above each. (Gaertneria linearis Rydb. Bull. Torr. Bot. Club 32: 133. 1905.) -Kansas and Colorado to Texas and California.

3. Franseria tomentosa (Nutt.) A. Nels. Erect from perennial slender creeping rootstocks, 1-3 dm. high: leaves canescently tomentose beneath, green and glabrate above, interruptedly pinnatifid, oblong in outline, comparatively large, the lowest, often $8-12 \mathrm{~cm}$. long; the lobes usually short and broad: sterile racemes commonly solitary; fruiting involucre 2-flowered, canescent, armed with rather short, conical-subulate, very acute, and straight spines. (Ambrosia tomentosa Nutt.; $F$. discolor Nutt.; Gaertneria tomentosa A. Nels. Bot. Gaz. 34: 34.'1902.) -A most ineradicable weed in cultivated ground; Montana to New Mexico.

4. Franseria Grayi A. Nels. Stems about $3 \mathrm{dm}$. high, rather stout, erect, from an apparently perennial base, canescent with a dense sericeous tomentum: leaves very white beneath, cinereous above, pinnately $3-5$-cleft or parted; the terminal division large, oblong or broadly lanceolate, serrate; upper lateral similar but smaller; the lowest commonly very small and entire: fruiting involucre $6 \mathrm{~mm}$. long, 2-flowered, nearly glabrous; the short spines conical-subulate, very acute, and the very tip usually uncinate-incurved. (F. tomentosa Gray, Pl. Fendl. 80. 1848; Gaertneria Grayi A. Nels. 1. c. 35.)Along streams; Kansas, Nebraska, and eastern Colorado.

\section{XANTHIUM L. CocklebuR}

Coarse annual weeds with widely branching and very stout stems. Leaves alternate, toothed or lobed, petioled. Heads unisexual, the flowers greenish. Staminate heads subglobose, in a terminal cluster; involucre of several distinct narrow bracts in 1 or 2 series; receptacle cylindrical; flowers many, separated by the bracts of the receptacle; corolla tubular. Pistillate heads axillary, below the staminate; involucre closed, forming in fruit an ovoid or oblong indurated bur covered with hooked prickles, 1 or 2-beaked, 2-celled, each cell containing 1 seed; corolla none; pappus none; style 2-cleft, the branches exserted through the beaks.

1. Xanthium echinatum Murr. Comm. Goett. 6: 32. 1783. Stem often punctate with brown spots: leaves cordate or ovate, 3-ribbed from the base, 
with dentate margins and often incised or lobed, on long petioles: fruiting involucre about $20-25 \mathrm{~mm}$. long, densely beset with rather long prickles, the 2 stout beaks at maturity usually hooked or incurved, the surface and base of the prickles more or less hispid. X. canadense. (X. commune Brit. Man. 912. 1901.)-A troublesome weed in waste and cultivated ground.

\section{CRASSINA Scepin}

With opposite and mostly entire sessile leaves and single showy heads terminating the branches; in ours the leaves are narrow and rigid, connate-sessile and crowded, and the achenes 2-4-aristate. Involucre campanulate or cylindraceous; the closely appressed-imbricated bracts dry and firm, broad, with rounded summit often margined. Receptacle becoming conical or eylindraceous; the chaffy bracts conduplicate around the disk-flowers. Lobes of the disk-corolla mostly velvety-villous. Pappus when present of erect awns or chaffy teeth.-Zinnia.

1. Crassina grandiflora (Nutt.) Kuntze, Rev. Gen. Pl. 331. 1891.. Scabrous; stems or branches $15 \mathrm{~cm}$. or more high from a stout woody base: leaves linear, 3-nerved at base: involucre narrow, $8 \mathrm{~mm}$. long: ligules 4 or 5, at maturity 10-16 mm. long, dilated-obovate or roundish, light yellow or sulphurcolor, becoming white.-Plains and bluffs; Eastern Colorado to Texas and Arizona.

\section{HELIOPSIS Pers.}

With loosely branching stems, veiny and mostly serrate 3-ribbed leaves on naked petioles, and pedunculate showy heads with numerous yellow rays. Involucre short, of nearly equal oblong or lanceolate bracts. Receptacle from high-convex to conical; the pointless chaffy bracts partly embracing the diskflowers. 'Ligules large; disk-corollas glabrous. Achenes obtusely 4-angular, with broad truncate summit, wholly destitute of pappus or of $2-4$ teeth or a coroniform border.

1. Heliopsis scabra Dunal, Mem. Mus. Par. 5: 54. 1819. Hispidulousscabrous, especially the leaves, $5-10 \mathrm{dm}$. high; leaves broadly ovate and subcordate to ovate-lanceolate, the upper occasionally entire: rays oblong, 2-3 cm. in length: achenes smooth, but the angles above pubescent when young, the summit usually bearing an obscure or evident and irregular coroniform chaffy pappus, or sometimes 2 or 3 conspicuous and rigid teeth. $H$. laevis.-Frequent eastward; rare in the eastern part of our range.

\section{BRAUNERIA Necker}

Perennial herbs, with rather stout erect stems, undivided leaves, the lower long-petioled, and solitary large heads on long peduncles terminating the stem and few branches. Rays flesh-color to rose-purple, elongating with age. Involucre imbricated in 2 or 3 or more series; the bracts lanceolate. Disk at first only convex, becoming ovoid and the receptacle acutely conical; chaffy bracts of the latter persistent, carinate-concave, acuminate into a rigid and spinescent cusp. Disk-corollas cylindraceous, with 5 erect teeth and almost no proper tube. Achenes acutely quadrangular, somewhat obpyramidal, with a thick coroniform pappus more or less extended into triangular teeth at the angles.-Echinacea.

1. Brauneria angustifolia (DC.) Heller, Muhl. 1: 5. 1900. Hispid, 3-5 $\mathrm{dm}$. high, mostly simple: leaves broadly lanceolate to nearly linear, entire, 3-nerved, all attenuate at base, the lower into slender petioles: bracts of the involucre in onily.about 2 series.-Within the eastern limit of our range and extending eastward. 
48. GYMNOLOMIA H.B.K.

Annual or perennial caulescent herbs or shrubby plants, with pubescent foliage. Leaves alternate or opposite, narrow, entire or toothed. Heads radiate, rather conspicuous. Involucres hemispheric or campanulate; bracts narrow, in 2 or 3 series, the inner ones somewhat longer than the outer. Receptacle more or less conic, chaffy. Ray-flowers pistillate, yellow; diskflowers perfect, with yellow or brownish corollas. Stigmas of the disk-flowers obtuse or with acute appendages. Achenes 4-angled, either somewhat flattened or turgid, truncate. Pappus a denticulate crown, or wanting.

1. Gymnolomia multiflora (Nutt.) B. \& H., Rothrock in Wheeler's Rep. 6: 160. 1878. Perennial, 3-10 dm. high, pubescent or scabrous, sometimes also hispid, often much branched: leaves narrowly linear to lanceolate, either alternate or mainly opposite, entire or obscurely denticulate: rays 10-15, golden-yellow: disk hemispherical, in age little more elevated and receptacle obtusely conical; the bracts linear, obtuse or the inner acute: achenes smooth.-Very polymorphous; from Arizona to Wyoming and western Texas.

\section{RUdBeckia L. Cone-flower. Black-eyed Susan}

Mostly perennial herbs with alternate leaves and rather large showy heads terminating the stem or branches. Heads many-flowered; the ray-flowers neutral, in a single series; those of the disk tubular and perfect. Bracts of the involucre foliaceous, in about 2 series, spreading. Receptacle conical or often more or less elongated and spiciform. Disk-corollas with a short but usually manifest proper tube and erect or spreading teeth. Style-branches tipped with an acute or obtuse hispid appendage. Achenes 4-angled, prismatic, in some species quadrangular-compressed. Pappus a coriaceous or firm-scarious and often 4-toothed crown, sometimes deep and cupuliform, sometimes obsolete.

Rays present and conspicuous.

Leaves entire or sparingly serrate

Leaves deeply 3-7-cleft or -divided (at least some of them) Rays wanting.

Leaves entire or sparingly toothed

Leaves pinnately parted

1. R. hirta.

2. R. laciniata.

3. R. occidentalis. 4. R. montana.

1. Rudbeckia hirta L. Sp. Pl. 907. 1753. Rather stout, 3-8 dm. high, rough-hispid and hirsute: leaves oblong to lanceolate, sparingly serrate or nearly entire, 5-12 cm. long, the lower narrowed into margined petioles: rays when well developed $3-5 \mathrm{~cm}$. long, golden-yellow, sometimes deeper colored toward the base: disk at first nearly black, in age dull brown, becoming ovoid in fruit: achenes small, quadrangular, wholly destitute of pappus. (R. flava Moore, in Greene, Pitt. 4: 179. 1900.)-In the eastern part of our range and eastward to the Atlantic States.

2. Rudbeckia laciniata L. 1. c. 906. Glabrous and smooth, sometimes minutely scabrous, at least on the margins and upper face of the leaves; stem 1-2 $\mathrm{m}$. high, branching above: leaves veiny, broad, incisely and sparsely serrate; the radical commonly pinnately 5-7-foliolate or nearly so, and divisions often laciniately 2-3-cleft; the lower cauline 3-5-parted, upper 3-cleft, and those of the branches few-toothed or entire: rays few or several, $3-5 \mathrm{~cm}$. long, drooping, pure yellow: disk dull yellowish: the tip of the chaffy bracts canescent: pappus a short 4-toothed or nearly entire crown. (R. ampla A. Nels. Bull. Torr. Bot. Club 28: 234. 1901.)-Moist banks; Arizona to Montana and eastward across the continent.

3. Rudbeckia occidentalis Nutt. Trans. Am. Phil. Soc. 7: 355. 1841. Nearly glabrous and smooth, or somewhat scabrous-puberulent; stems stout, 6-20 dm. high, nearly simple: leaves ovate or ovate-lanceolate, acuminate, entire or irregularly and sparingly dentate, 1-2 dm. long; upper ones sessile by a rounded or subcordate base, lower ones abruptly contracted into a short, 
winged petiole: heads few, on long peduncles: rays wholly wanting: disk brownish, ovoid to oblong, becoming $3-5 \mathrm{~cm}$. long; the chaffy bracts puberulent at tip: achenes 3-4 mm. long, with conspicuous, coroniform, scarious pappus.-Moist shaded banks; Wyoming and Montana to the Pacific States.

4. Rudbeckia montana Gray, Proc. Am. Acad. 17: 217. 1882. Smoother, somewhat glaucous, tall and very stout: leaves $2-3 \mathrm{dm}$. long, pinnately parted into 3-9 oblong-lanceolate divisions, or the lanceolate uppermost cauline with 2-4 narrow lateral lobes: disk cylindrical, at length often $6-7 \mathrm{~cm}$. long and in diameter: achenes with the deep coroniform pappus $6-8 \mathrm{~mm}$. long.Mountains of Colorado.

\section{RATIBIDA Raf. CONE-FLOWER}

Herbs, with pinnately parted leaves, and terminal, long-peduncled, showy heads, the drooping rays yellow or partly brown-purple. Truncate inflexed tips of the chaff pubescent. Disk yellowish, becoming darker. Achenes short and broad, compressed, acutely margined or sometimes.winged at one or both edges, on a slender-subulate receptacle. Pappus a chaffy tooth over one or both edges, or none. Chaffy bracts of the receptacle conduplicate, with thickened and truncate summit, embracing and hardly surpassing the achenes, at length deciduous with them. Corollas of the disk with hardly any proper tube. Ligules, involucre, etc., of Rudbeckia.-Lepachys.

Disk in fruit cylindrical, $2-4 \mathrm{~cm}$. long

Disk in fruit oblong, about $1 \mathrm{~cm}$. long

1. R. columnaris. 2. R. Tagetes.

1. Ratibida columnaris (Sims) D. Don. in Sweet, Brit. Flow. Gard. II. pl. 361. 1838. Strigose-scabrous, $3-5 \mathrm{dm}$. high, branching from the base, terminated by long peduncles bearing a showy head: divisions of the cauline leaves 5-9, oblong to narrowly linear, sometimes $2-3$-cleft: rays commonly 3 $\mathrm{cm}$. long or more, normally all yellow: disk at length columnar, $2-4 \mathrm{~cm}$. long: pappus of 1 or sometimes 2 awn-like deciduous teeth and usually a series of minute and delicate squamellae around the broad flat summit.-Plains along the eastern base of the mountains to Texas.

1a. Ratibida columnaris pulcherrima (DC.) D. Don. 1. c. Differs only in having a part or even the whole upper face of the ray brown-purple.

2. Ratibida Tagetes (James) Barnhart, Bull. Torr. Bot. Club 24: 410. 1897. Perennial, $1-4 \mathrm{dm}$. tall, gray-strigose; stems commonly much branched: leaves numerous; blades $2-6 \mathrm{~cm}$. long, pinnately parted into $3-7$ narrowly linear thickish segments: peduncles $2-5 \mathrm{~cm}$. long: disk subglobose or oval, about $1 \mathrm{~cm}$. long: ligules of the ray-flowers soon reflexed, 5-9 $\mathrm{mm}$. long, mainly brown-purple.-Colorado and New Mexico to Arkansas and Texas.

\section{BALSAMORRHIZA Hook. BALSAM-ROot}

Low, with thick, deep, and balsamic roots, a tuft of radical leaves mostly on long petioles, and short, simple, few-leaved flowering stems or naked scapes bearing large and mostly solitary heads of yellow flowers. Involucre broad; the outer bracts foliaceous, sometimes enlarged. Receptacle flat or merely convex. Achenes destitute of pappus, all fertile; those of the ray triquetrous or obcompressed; those of the disk quadrangular. Chaff linear-lanceolate.

Leaves entire or somewhat toothed Leaves entire or somewhat toothed
Green, glabrous or sparingly hirsute

Canescent or lanate.

The sericeous pubescence appressed or spreading

The white tomentum of ten floccose
1. B. sagittata.

2. B. macrophylla.

3. B. Hookeri.

4. B. incana.

1. Balsamorrhiza sagittata (Pursh) Nutt. Trans. Am. Phil. Soc. 7: 350. 1841. Silvery-canescent or tomentose and the involucre white-woolly: radROCKY MT. BOT.-35 
ical leaves cordate-oblong to hastate, 1-3 dm. long, the base 5-15 cm. wide, on petioles of greater length; the few and inconspicuous cauline linear to spatulate: scape at length $3 \mathrm{dm}$. or more high: rays $3-5 \mathrm{~cm}$. long. (B.tomentosa Rydb. Bull. Torr. Bot. Club 27: 628. 1900.) - "Used by the Indians for food "; mountains of Colorado to Montana and British Columbia.

2. Balsamorrhiza macrophylla Nutt. 1. c. Green, not at all canescent, glabrate, except the ciliate margins of the leaves, usually minutely glandularviscidulous: leaves ample, ovate or oblong in outline, $1.5-3 \mathrm{dm}$. long, some with only 1 or 2 lobes or coarse teeth, most of them pinnately parted into broadly lanceolate and commonly entire lobes: scapes $3-5 \mathrm{dm}$. high: bracts of the involucre narrowly lanceolate to spatulate and foliaceous, $3-5 \mathrm{~cm}$. long, nearly equal, either half or fully the length of the rays.-Rocky and Wasatch Mountains in Wyoming and Utah.

2a. Balsamorrhiza macrophylla terebinthacea (Nutt.) A. Nels. Differs from the species in being somewhat hispidulous-scabrous or hirsutulous on the leaf-margins, and lanate-tomentose on the involucre. (B. terebinthacea Nutt. 1. c.)-Stony ground; Wyoming to Oregon.

3. Balsamorrhiza Hookeri Nutt. 1. c. Canescent with fine sericeous or more tomentose pubescence, but not at all hirsute: scapes and leaves $1.5-3 \mathrm{dm}$. high; the latter lanceolate or elongated-oblong in outline, pinnately or bipinnately parted into lanceolate or linear divisions or lobes, or some of them only pinnatifid or incised: involucre canescently puberulent to lanate; the bracts linear to oblong-lanceolate, either unequal and well imbricated or sometimes the outermost foliaceous and enlarged.-West of our range, but represented by

3a. Balsamorrhiza Hookeri hirsuta (Nutt.) A. Nels. The pubescence roughish-hirsute and spreading, not canescent or tomentose. (B. hirsuta Nutt. l. c.)-Wyoming to Utah and northwestward.

4. Balsamorrhiza incana Nutt. 1. c. Densely white-tomentose throughout; stems 1-2 dm. high: leaves oblong- or deltoid-lanceolate in outline, pinnately or bipinnately parted or lobed, the divisions oval or oblong: bracts of the involucre lanceolate to linear, $15-20 \mathrm{~mm}$. long, imbricated in 2 or 3 series: rays 12-14, 3-4 cm. long: chaff of the receptacle much shorter than the flowers. (B. floccosa Rydb. 1. c. 629.)-Wyoming to Montana and to the Pacific States.

\section{WYETHIA Nutt.}

Coarse perennial herbs with usually simple stems, alternate mostly entire leaves, and large heads of yellow flowers. Heads many-flowered. Bracts of the campanulate involucre loosely imbricated in 2 or 3 series, nearly equal, foliaceous, the innermost smaller and resembling the chaff. Receptacle slightly convex; the chaff lanceolate, carinate, acute, as long as the flowers and embracing them. Rays large, pistillate, sometimes with sterile filaments; disk-corollas cylindrical, elongated, with a short proper tube, 5-toothed. Style-branches in the ray-flowers glabrous; in the disk elongated, filiform, revolute, strongly hispid on the inner faces. Achenes stout, elongated, 4-5angled, terminated with a coroniform 5-10-toothed or laciniate pappus, 1 or more of the teeth usually prolonged into a rigid persistent awn.

Rays pale, yellowish to white.

Rays bright yellow.

Plant glabrous and smooth throughout

Plant hirsutely pubescent or scabrous.

Leaves oblong-lanceolate, tapering to both ends Leaves broadly linear
1. W. helianthoides.

2. W. amplexicaulis.

3. W. arizonica.

4. W. scabra.

1. Wyethia helianthoides Nutt. Trans. Am. Phil. Soc. 7: 351. 1841. Stems 2-4 dm. high, simple and with a single large head, or rarely 3 or 4 , hirsute: leaves oval to broadly lanceolate, denticulate or entire, $1-2 \mathrm{dm}$. long, mostly narrowed at base into a short-margined petiole: heads $2-3 \mathrm{~cm}$. high; bracts of the involucre narrowly lanceolate, numerous: rays $4-5 \mathrm{~cm}$. 
long: achenes 7-8 $\mathrm{mm}$. long, either prismatic-quadrangular or flattish, 12nerved: pappus sometimes minute, chaffy coroniform and cleft into few or several teeth.-Yellowstone Park and Montana to Oregon.

2. Wyethia amplexicaulis Nutt. 1 . c. Stems $3-5 \mathrm{~cm}$. high, robust: leaves mostly lanceolate-oblong, entire or denticulate; the radical of ten $3-4 \mathrm{dm}$. long; the upper cauline partly clasping by a rounded or somewhat narrowed base: heads solitary or several, short-peduncled; involucral bracts broadly lanceolate, 1 or 2 outer ones occasionally foliaceous and larger: rays about $4 \mathrm{~cm}$. long: achenes with a conspicuous crown cleft into acute teeth, and sometimes a small awn.-Called "PE-IK" by the Indians; from Colorado to Montana and British Columbia.

3. Wyethia arizonica Gray, Proc. Am. Acad. 8: 655. 1873. Hirsutely pubescent, $3 \mathrm{dm}$. high, bearing a single or few heads: leaves oblong-lanceolate, tapering to both ends, or the upper and sessile cauline broader: involucre of rather foliaceous and erect bracts: rays 8-12: pappus a very narrow crown, extended into 3 or 4 stout subulate teeth, or into 1 or 2 short awns.-Colorado to Utah and Arizona.

4. Wyethia scabra Hook. Lond. Journ. Bot. 6: 245. 1847. Very scabrous, 3-5 dm. high, rigid: cauline leaves linear, thick, $10-15 \mathrm{~cm}$. wide, sessile, attenuate-acute: involucral bracts imbricated in 3 or 4 series, all the outer with an appressed base, which is acuminate into a longer, subulate, filiform, spreading, very hispid-scabrous appendage: rays several, 10-14 mm. long: achenes acutely angled, the 3 or 4 angles extended into a pappus of as many short blunt teeth, which are barely confluent at base.-New Mexico and Colorado to Utah and Wyoming.

\section{HELIANTHUS L. SUNFLOWER}

Annual or perennial caulescent herbs. Leaves alternate or opposite; blades simple, entire or toothed. Heads conspicuous. Involucres flat or hemispheric; bracts in several series, fleshy or leathery. Receptacle flat, convex or conic, chaffy. Ray-flowers neutral; ligules yellow; disk-flowers perfect; corollas brownish or purple. Stigmas with pubescent appendages. Achenes flattened or somewhat 4-angled. Pappus of 2 awns or scales, and these sometimes accompanied by $2-4$ shorter ones, all early deciduous.

Plants annual; receptacle flat or nearly so.

At least the lower leaves broadly ovate, and more or less cordate

Leaves ovate-lanceolate to narrowly oblong-lanceolate

1. H. annuus.

Plants perennial; receptacle more or less convex.

Disk-flowers purple or brown.

Leaves linear.

Leaves ovate to lanceolate

Disk-flowers yellow or yellowish.

All the leaves opposite (except the few foliar bracts); roots not thickened-tuberiform

Some or many of the upper leaves alternate; the roots more or less fasciculate-thickened.

Stem and leaves scabrous

Stem smooth or nearly so, of ten glaucous. Leaves usually coarsely toothed, more or less pubescent

(not scabrous) beneath
Leaves entire or denticulate, glabrate or scabrous beneath

2. H. petiolaris.

3. H. orgyalis.

4. H. scaberrimus.

5. H. pumilus.

6. H. Maximilianus.

7. H. grosse-serratus.

8. H. Nuttallii.

1. Helianthus annuus L. Sp. Pl..904. 1753. Annual, markedly pubescent; stem hispid or hirsute, 1-2 m. high, branched above: leaves mainly alternate; blades broadly ovate, $7-30 \mathrm{~cm}$. long, or smaller above, usually slightly acuminate at the apex, decidedly toothed, those of the lower leaves cordate at the base, those of the upper cuneate: bracts of the involucre ovate to oblong or oblong-lanceolate, long-acuminate, hirsute: ligules of the ray-flowers 2-4 cm. long: disk flat, $3-5 \mathrm{~cm}$. broad. (H. lenticularis Dougl.) - From the mountains to the Mississippi; many forms (often very large) in cultivation.

2. Helianthus petiolaris Nutt. Journ. Acad. Phila. 2: 115. 1812. Stem 2-6 dm. high, branching, strigose-hispidulous, rarely hirsute: leaves oblong- 
lanceolate or ovate-lanceolate, entire or sparingly denticulate, $3-8 \mathrm{~cm}$. long, cuneately attenuate or the lower abruptly contracted into a long and slender petiole: bracts of the involucre lanceolate or oblong-lanceolate, with acute and mucronate or sometimes more attenuate tips, canescent or sometimes ciliate: disk 12-15 mm. in diameter. (H. aridus Rydb. Bull. Torr. Bòt. Club 32: 127. 1895.)-Range about the same as the last.

3. Helianthus orgyalis DC. Prodr. 5: 586. 1836. Stem smooth and glabrous, $4-15 \mathrm{dm}$. high, very leafy to the top: leaves mostly alternate, from long-linear, 1-3 dm. long, 4-8 mm. wide (or the lowest lanceolate), to almost filiform, slightly papillose-scabrous, the lower narrowed into a petiole and sometimes serrulate: bracts of the involucre filiform-attenuate; those of the receptacle entire: achenes oblong-obovate with a rounded summit, 5-6 mm. long.-Dry plains; Nebraska to Texas, west to southeast Colorado.

4. Helianthus scaberrimus Ell. Bot. S. C. \& Ga. 2: 423. 1824. Stem 3-12 $\mathrm{dm}$. high, rigid, sparingly branched: leaves very firm-coriaceous and thick, both sides hispidulous-scabrous, shagreen-like, entire or serrate; the lower ovate and ovate-lanceolate, attenuate at base into short-winged petioles; the upper mostly lanceolate: heads comparatively large, showy: disk 15-18 mm. high, dark purple or brownish; involucre pluriserially imbricated; the bracts mainly ovate, obtuse or acutish, rigid, appressed, densely and minutely ciliate. H. rigidus. (H. subrhomboideus Rydb. Mem. N. Y. Bot. Gard. 1: 419. 1900.) - Plains and prairies; Montana to Colorado and Georgia.

5. Helianthus pumilus Nutt. Trans. Am. Phil. Soc. 7: 366. 1841. Hispid and scabrous throughout; stems simple, 3-6 dm. high, bearing 5-7 pairs of leaves and a few rather short-peduncled heads: leaves mostly broadly ovatelanceolate, acute, entire or nearly so, 4-10 cm. long, rigid, abruptly contracted at base into a short-margined petiole: involucre about $12 \mathrm{~mm}$. high, whitehirsute or scabro-hispidulous; the bracts imbricated in about 3 series, oblonglanceolate, acutish: disk yellow.-Eastern Rocky Mountains and adjacent plains, from Wyoming and Colorado to Nebraska and Kansas.

6. Helianthus Maximilianus Schrad. Ind. Sem. Hort. Goett. 1835. Hispidulous-scabrous; stem stout, $4-20 \mathrm{dm}$. high, below mostly rough-hispid: leaves almost all alternate, thickish, becoming rigid, very scabrous above, lanceolate, acute or acuminate at both ends, mostly subsessile, all entire or sparingly denticulate: involucre of more rigid bracts: rays numerous, often 3-4 cm. long, golden-yellow.-Prairies and plains west of the Mississippi, and from the Saskatchewan to Texas.

7. Helianthus grosse-serratus Martens Sel. Sem. Hort. Loven. 1839. Stem very smooth and glabrous, commonly glaucous, 1-2 m. high, bearing numerous rather cymosely disposed and short-peduncled heads: leaves slenderpetioled, thinnish, oblong-lanceolate or narrower, or some of the cauline almost deltoid-lanceolate, gradually acuminate, sharply serrate, or upper merely denticulate, slightly scabrous above, whitish and soft-puberulent beneath; the larger cauline commonly $1-2 \mathrm{dm}$. and the petiole $3-5 \mathrm{~cm}$. long: the deep yellow oblong rays $2-3 \mathrm{~cm}$. long.-Dry plains; from Texas to Dakota and as far east as Ohio.

8. Helianthus Nuttallii T. \& G. Fl. 2: 324. 1842. Roots fleshy, fascicled or variously branched, mostly fusiform, often nearly $1 \mathrm{dm}$. long; stems generally solitary, simple below, branched above, $1 \mathrm{~m}$. (more or less) high, glabrous, striate: lower leaves opposite, $7-15 \mathrm{~cm}$. long, all lanceolate, the uppermost narrowly so, with short, sparse, incurved, hispid hairs: peduncles pubescent, slender, those from the lower axils often much elongated: involucre hemispherical; the bracts linear-lanceolate, white-ciliate-pubescent on the margins, $10-15 \mathrm{~mm}$. long, the loose acuminate tips often reflexed: rays usually 14-18, 25-30 mm. long, narrpwly oblong: disk yellowish-brown, $1 \mathrm{~cm}$. high and fully as broad: chaff oblong, acute, pubescent on the brownish tip: achenes oblong, brown, $4 \mathrm{~mm}$. long, nearly as long as the corollas; pappus of 2 linearlanceolate awns as long as the achenes. ( $H$. fascicularis Greene, Pl. Baker. 3: 28. 1901; H. utahensis A. Nels. Bull. Torr. Bot. Club 29: 405. 1902.)Throughout our range to Oregon and British Columbia. 
54. HELIANTHELLA T. \& G.

Perennial herbs with mostly simple stems, entire, scattered, and sessile leaves, and solitary heads with yellow ray and yellow or purplish-brown diskflowers. Heads many-flowered, the ray-flowers neutral; those of the disk perfect. Bracts of the involucre in about 2 series, loose, somewhat foliaceous. Chaff of the receptacle persistent, embracing the achenes. Corolla of the disk cylindrical, elongated, 5-toothed, with a very short proper tube. Branches of the style very hispid, more or less obtuse. Achenes compressed, with one or both margins slightly winged and produced at the summit into short auriculate and lacerate-persistent appendages or into an awn, sometimes with intermediate squamellae.

Disk yellowish; the anthers dark.

Heads large; disk $2-3 \mathrm{~cm}$. broad; rays $3-4 \mathrm{~cm}$. long

Heads half as large

Disk purple.

Heads several, small; rays 5-6 mm. long

Heads solitary or few, larger; rays 20-25 mm.long

1. H. quinquenervis. 2. H. Parryi.

3. H. microcephala. 4. H. uniflora.

1. Helianthella quinquenervis (Hook.) Gray, Proc. Am. Acad. 19: 10. 1883. Somewhat hirsutely pubescent or almost glabrous; stems solitary or scattered, 6-12 dm. high: leaves mostly opposite, oblong- or ovate-lanceolate, acuminate, 1-2, dm. long, uppermost sessile; the lower ones tapering into margined petioles, and the lowest $(2-3 \mathrm{dm}$. long) into longer petioles: head mostly long-peduncled, ample, the disk $2-3 \mathrm{~cm}$. in diameter: rays $15-20$, pale yellow, commonly 3-4 cm. long: pappus of 2 slender awns, half the length of the achene, and nearly thrice the length of the squamellae, which form a conspicuous, finely dissected fringe.-Mountains; from Dakota and Montana to southern Colorado.

2. Helianthella Parryi Gray, Proc. Acad. Phila. 68. 1863. Hispiduloushirsute; stems numerous from a thickened root, $3-4 \mathrm{dm}$. high, rather slender: leaves mostly alternate, more rigid, lanceolate and $3-6 \mathrm{~cm}$. long, or the lowest and radical oblong-spatulate and double the size: heads and rays barely half the size of the preceding: pappus of fimbriately dissected squamellae only, or with a pair of slender awns not surpassing them.-Mountains of Colorado and New Mexico.

3. Helianthella microcephala Gray, Proc. Am. Acad. 19: 10. 1883. Hispidulous-scabrous; stems numerous from a greatly thickened root, 2-3 dm. high, slender, somewhat paniculately or corymbosely branched at summit and bearing several heads: leaves rigid, all but the lower alternate; the radical lanceolate-spatulate: the upper cauline nearly linear and sessile, $2-3 \mathrm{~cm}$. long: involucral bracts linear-oblong, mostly obtuse: rays not over $6 \mathrm{~mm}$. long: pappus of several slender squamellae intermixed with the long hairs, 2 marginal ones often extended and awn-like.-Borders of Colorado and adjacent New Mexico and Utah.

4. Helianthella uniflora (Nutt.) T. \& G. ex Gray, 1. c. Minutely pubescent or glabrate; stems 3-6 dm. high: leaves more commonly opposite, sometimes all alternate, oblong-lanceolate, 5-12 cm. long; the lower short-petioled: involucre pubescent or slightly hirsute: rays $25-30 \mathrm{~mm}$. long: chaffy bracts of the receptacle firm-chartaceous: achenes more or less ciliate; pappus a pair of long awns and rather conspicuous squamellae. (H. multicaulis Eat. Bot. King's Exp.)-Mountains of Montana and eastern Idaho to southern Utah.

\section{XIMENESIA Cav.}

Annual caulescent herbs, with pubescent foliage. Leaves alternate or sometimes opposite, simple, toothed or somewhat laciniate. Heads solitary or few, radiate, showy, peduncled. Receptacle convex, chaffy. Ray-flowers pistillate, numerous, yellow; disk-flowers numerous, perfect. Stigmas with slender pubescent appendages. Achenes flat, winged. Pappus of short and straight awns. 
1. Ximenesia encelioides Cav. Ic. 2: 60. pl. 178. 1793 (?). Stems 3-6 dm. high, freely branching, pale and cinereous or sometimes canescent: leaves mostly alternate, and the upper face green, ovate or cordate to deltoidlanceolate, variously serrate or laciniate-dentate, most with winged petioles, and commonly with auriculate-dilated appendage at base: disk $16-20 \mathrm{~mm}$. in diameter: rays 12, 15-25 mm. long, deeply 3-cleft at summit: achenes obovate, mostly broadly winged and with short awns. Verbesina encelioides.-From Montana to Texas and Arizona.

\section{COREOPSIS L. TICKSEED}

Annual or perennial herbs. Heads terminating the peduncle-like branches, the ray-flowers neutral, yellow or parti-colored. Disk-flowers perfect. Involucres campanulate or hemispheric, the bracts in 2 series, all more or less united at the base, those of the outer series usually narrow and herbaceous, the inner series broad, variously colored, either thin and scarious or with scarious margins. Receptacle flat or slightly convex, chaffy. Achenes flat or more or less convex on the back, oblong to orbicular, winged or wingless. Pappus in ours wanting or minute.

Leaves once or twice pinnately divided Leaves simple

1. Coreopsis tinctoria Nutt. Journ. Acad. Phila. 2: 114. 1821. Glabrous, 5-8 dm. high: leaves opposite, and all 1-2-pinnately divided into lanceolate or linear divisions: outer involucre short and close: rays $12-16 \mathrm{~mm}$. long, either yellow with crimson-brown base or nearly all crimson-brown: diskflowers dark purple or brown: achenes moderately incurved; pappus none or an obscure border.-From Colorado and Arizona to the Saskatchewan and Texas.

2. Coreopsis lanceolata L. Sp. Pl. 908. 1753. Low, only 3-5 dm. high, including the long and simple naked peduncles: leaves ordinarily a few pairs, oblong-spatulate to lanceolate or nearly linear, obtuse, thickish, all entire, or rarely 1 or 2 small lateral lobes: rays commonly $25 \mathrm{~mm}$. long and $12 \mathrm{~mm}$. broad, sometimes smaller: pappus very small or obsolete.-Mostly to the eastward of our range.

\section{Bidens L. Bur Marigold. Spanish Needles. Beggar's Ticks}

Leaves opposite, simple or compound. Heads of mostly yellow flowers solitary or paniculate. Bracts of the involucre distinct, or united only at the common base. Rays neutral, yellow or white, sometimes wanting. Achenes neither winged nor beaked, 2-5-awned; the awns retrorsely hispid.

Leaves simple.

Heads radiate

Heaves pinnately parted or divided

Achenes flat, obovate or cuneate.

Leaves narrowly acuminate; heads many, small, the outer bracts 4-8

Leaves acute; heads few, large, the outer bracts 8-16 : :

Achenes linear-tetragonal; leaf-segments small.

Leaf-segments linear

Leaf-segments deltoid or oblong

1. Bidens gla ucescens Greene, Pitt. 4: 258. 1901. Stout, often freely and widely branched, 3-8 dm. high, glabrous, the terete stem glaucescent, the internodes short and foliage ample: leaves elliptic-lanceolate, the largest 10-15 $\mathrm{cm}$. long, closely striate-nerved between midnerve and margin and as closely serrate: heads large, hemispherical; outer involucre surpassing the rays; these many (occasionally wanting): disk-corollas exceeding the awns, the tube longer than the short cylindric limb: achenes mostly 4-angled and 4-awned, 
the angles more or less corky. B. chrysanthemoides; it has passed also as $B$. cernua L.-Common in wet ground throughout our range.

2. Bidens comosa (Gray) Wieg. Bull. Torr. Bot. Club 24: 436. 1897. Stem stout, 3-8 dm. high: leaves elliptic-lanceolate, serrate, acute, attenuate into a margined petiole, or the upper sessile: peduncles short and stout: outer bracts $\emptyset \mathrm{f}$ the involucre $6-8$, often $2-5$ times the length of the disk, erect: rays wanting: disk-corollas funnelform, pale yellow, 4-lobed: achenes large and flat, 8-10 mm. long, $3 \mathrm{~mm}$. wide, brown or olive, the 3 long awns retrosely barbed.-In damp soil; Maine to Colorado and Louisiana.

3. Bidens frondosa L. Sp. 832. 1753. Stem slender, bushy-branched, nearly glabrous, 3-8 dm. high: leaf-blades pinnately 3-divided or rarely 5divided, the segments lanceolate, serrate, with sharp spreading teeth, acuminate: heads not large; outer bracts of the involucre 6-8, subequal, spatulate, sparsely ciliate, usually exceeding the disk: rays usually present, goldenyellow, the ligules equaling the disk, the ovaries hairy and with 2 short retrorsely barbed awns: disk-corollas orange, 5-lobed: achenes black, about 6 $\mathrm{mm}$. long and $3 \mathrm{~mm}$. wide, cuneate, flattish; barbs on the 2 awns either erect or reflexed.-Common eastward and extending into our range.

4. Bidens vulgata Greene, 1. c. 72 . Stem tall, branched, nearly glabrous: leaf-blades commonly 5-divided, the segments lanceolate, acute, serrate: heads large, 15-25 mm. wide; outer bracts of the involucre 8-16, unequal, usually longer' than the disk, ciliate, with narrowed tips: rays pale yellow, the ligules equaling the disk, the ovaries awnless; disk-corollas funnelform, pale, 4-5-lobed: achenes 7-9 $\mathrm{mm}$. long, very flat, brown or olive, the 2 long awns and the upper part of the achene-margins retrorsely barbed:- Closely allied to the preceding, more frequent as a weed and the more common form in our range.

5. Bidens tenuisecta Gray, Pl. Fendl. 86. 1848. Stems 3-6 dm. high, branched from the base, sparsely hirsute or glabrous: leaves 2-3-ternately or pinnately dissected into narrow linear lobes: heads on naked rather long and stout peduncles, many-flowered, 8-12 mm. high in flower: achenes glabrous, 2-awned; inner $10 \mathrm{~mm}$. long, with tapering summit; outermost $6 \mathrm{~mm}$. long, stouter and with broad summit and usually short awns: rays yellow, mostly surpassing the disk.-Along water courses; Colorado, New Mexico, and Arizona.

6. Bidens bipinnata L. Sp. Pl. 832. 1753. Stem glabrous, 4-angled, branched, slender, 3-10 dm. high: primary leaf-segments thin, deltoid, the ultimate one lanceolate, incised or lobed: outer involucral bracts $7-10$, linear, shorter than the acute inner ones: rays few, the ligules yellowish-white, about equaling the disk, mostly entire: achenes spindle-shaped, in fruit much longer than the involucre, the outer slightly shorter; awns 3-4, yellow, retrorsely barbed. (B. Bigelovii Gray, as to our range at least.)-Damp scil and waste grounds; a common and disagreeable weed, widely dispersed; usually known as Spanish NeEdles.

\section{THELESPERMA LesS.}

Smooth and glabrous perennials, with opposite usually finely dissected leaves, pedunculate heads, and the rays golden-yellow (if present). Bracts of the inner involucre united into a cup; outer of shorter and narrow bracts, connate at base with the inner. Chaff of the flat receptacle white-scarious. Rays about 8, cuneate-obovate. Disk-corollas with long and slender tube, and abrupt campanulate or cylindrical throat. Anthers wholly exserted. Achenes slightly obcompressed or terete, narrowly oblong to linear, marginless, beakless; the abrupt summit crowned with a pair of persistent and stout awns or scales, or sometimes pappus wanting.

Heads rayless (discoid) .

1. T. gracile.

Heads radiate.

Leaves linear; plant perennial.

Leafy throughout; pappus evident

2. T. ambiguum. 
Leaves largely basal; pappus nearly or quite obsolete

Leaves filiform-linear; plant annual, biennial, or short-lived perennial

3. T. subnudum 4. T. trifidum.

1. Thelesperma gracile (Torr.) Gray, Kew Journ. Bot. 1: 253. 1849. Rather rigid, 3-6 dm. high, from a deep root, branched, naked above: leaves once or twice ternately or quinately divided or parted into filiform-linear or broader lobes, or some upper ones filiform and entire: bracts of the outer involucre 4-6, very short, ovate or oblong; those of the inner one connate to above the middle, the edges of their lobes slightly scarious: disk mostly yellow, barely brownish after anthesis: achenes slightly papillose or roughened, the breadth of the summit exceeded by the subulate awns: rays usually none, rarely present and 4-5 mm. long.-On the plains; Montana to Arizona and Texas.

2. Thelesperma ambiguum Gray, Proc. Am. Acad. 19: 16. 1883. Stems 3-5 dm. high, rather rigid: leaves bipinnately divided into narrowly linear or filiform lobes: bracts of the outer involucre 8, subulate-linear, almost equaling or half the length of the inner, which are connate to or above the middle: rays broad, $10-15 \mathrm{~mm}$. long, rarely wanting: disk usually purple, turning brownish: outer achenes becoming coarsely papillose; the stout pappusscales not longer than the width of the achene. ( $T$. intermedium Rydb. Bull. Torr. Bot. Club 27: 631. 1900.)-Montana to New Mexico and Texas.

3. Thelesperma subnudum Gray, 1. c. 10: 72. 1874. Rather stout: leaves thickish and rigid, once or twice ternately parted into linear or lanceolate lobes: peduncles 1-2 dm. long; head $12 \mathrm{~mm}$. high: rays sometimes none, sometimes ample: pappus a minute, $4-5$-toothed naked crown, or obsolete. Wyoming to New Mexico and Arizona.

4. Thelesperma trifidum (Poir.) Brit. Trans. N. Y. Acad. Sci. 9: 182. 1890. Stems 3-5 dm. high, loosely branching, leafy: leaves not rigid, bipinnately divided into filiform lobes no wider than the rachis: bracts of the outer involucre 8, subulate-linear, almost equaling or more than half the length of the inner, which are connate only to the middle: rays broad, $12-15 \mathrm{~mm}$. long: disk usually purple, turning brownish: outer achenes becoming coarsely papiliose on the back; the stout triangular-subulate pappus-scales not longer than the width of the achenes. (T. tenue Rydb. 1. c.)-Dry plains; Colorado to Arkansas and Texas.

\section{MAdIA Molina. TARWEed}

Glandular and viscid herbs, mostly heavy-scented, with entire or merely toothed leaves, some or all of them alternate. Heads axillary and terminal, many-several-flowered. Involucre ovoid or oblong, few to many-angled by the salient narrow backs of the involucral bracts. Receptacle flat or convex, bearing a single series of bracts inclosing the disk-flowers as a kind of inner involucre, either separate or connate into a cup. Ray flowers 1-20, with cuneate or oblong 3-lobed ligules; the achenes laterally compressed, and inclosed in conduplicate-infolded involucral bracts.-Ours belongs to the section Eumadia, in which the rays are few and inconspicuous or none and the pappus mostly wanting.

1. Madia glomerata Hook. Fl. 2: 24. 1834. Stems 2-5 dm. high, rigid, very leafy, hirsute, glandular only toward the inflorescence: leaves narrowly linear: heads glomerate: rays $2-5$ or sometimes none, not surpassing the about equal number of disk-flowers: achenes narrow; those of the disk 4-5-angled; those of the ray somewhat curved and.1-nerved on each face.-Mountains of Colorado, to the Saskatchewan, the Sierras of California, Oregon, and Washington.

\section{LAYIA H. \& A.}

Branches terminated by showy heads of (in ours) white flowers. Herbage hispid or hirsute, somewhat viscid above, beset with scattered, stipitate, blackish glands. Heads many-flowered, broad. Ray-flowers 8-20, with 3-lobed or 
-toothed ligules. Bracts of the involucre flattened on the back below, with abruptly dilated thin margins infolded so as to inclose the ray-achene. Receptacle broad and flat, bearing a series of thin chaffy bracts between the rayand disk-flowers. Achenes of the ray obcompressed, almost always smooth, destitute of pappus; those of the disk similar or more linear-cuneate, mostly pubescent, bearing a pappus of 10-20 bristles or scales, or rarely none.

1. Layia glandulosa H. \& A. Bot. Beech. 350. 1833. Stems 2-4 dm. high, diffusely branched: lower leaves lanceolate or linear, laciniate-pinnatifid or incised; the upper narrow and entire: rays 8-13, large and conspicuous (bright white or tinged with rose), 8-14 mm. long, 3-lobed: villous hairs of the pappus bristles copious, the outer straight and erect, the inner soon crisped and interlaced into a woolly mass. (Blepharipappus glandulosus Hook.) - In barren ground; chiefly west of our range.

\section{PSILOSTROPHE DC.}

Low and corymbosely branched woolly herbs, with alternate and spatulate or linear leaves, the cauline entire, and small heads of yellow flowers. Bracts of the involucre distinct, but connected by the intricate wool so as to seem connate. Heads with 3 or 4 ray and 5-12 disk-flowers, all fertile. Involucre of 4-10 linear coriaceous woolly bracts, and a few smaller scarious ones within, with sometimes an additional narrow outer one. Receptacle small, flat. Ligules broad, abruptly contracted at base into a short tube, truncate and 2-3-lobed; disk-corollas with short externally glandular-bearded teeth. Pappus of 4-6 hyaline seales.-Riddellia.

\section{Pappus-scales oval, obtuse}

Pappus-scales lanceolate, acute

1. Psilostrophe Bakeri Greene, Pl. Baker. 3: 29. 1901. Herbaceous, perennial, much-branched, 1-2 dm. high, the branches short, almost divaricate, at earliest flowering not much exceeding the large, spatulate- obovate or -oblong green but thinly villous-lanate basal leaves, which are obtuse, entire, some of the cauline coarsely toothed or 3-lobed at or near the apex, all obviously 1-3-nerved: heads large, apparently always 5-rayed and the rays 10-14 $\mathrm{mm}$. long, deeply 3-lobed; bracts of involucre green-herbaceous, distinct, the tips spreading: achenes glabrous, closely and strongly striate; scales of the pappus obtuse, more or less toothed, little longer than broad, not half as long as the achene. (P. pumila A. Nels. Proc. Biol. Soc. Wash. 16: 22. 1903.)Western Colorado and Utah.

2. Psilostrophe tagetina (Nutt.) Greene, Pitt. 2: 176. 1891. Loosely or somewhat villosely lanate, sometimes glabrate in age, rather widely branched: radical and even lower cauline leaves often laciniate-pinnatifid: heads numerous, mostly cymosely clustered and short-peduncled: scales of the pappus oblong-lanceolate, entire, usually more than half as long as the disk-corollas. Riddellia tagetina.-Southern Colorado (?) to Arizona and western Texas.

\section{PERICOME Gray}

Strong-scented yellow-flowered branching perennials, with long-acuminate leaves. Head many-flowered, homogamous. Involucral bracts lightly connate by their edges into a campanulate cup. Disk-corollas with viscousglandular tube and much exserted anthers. Achenes strongly villous-ciliate. Pappus a lacerate-ciliate crown, and sometimes a pair of short awns, one from each angle of the achene.

1. Pericome caudata Gray, Pl. Wright. 2: 82. 1852. Leaves opposite, long-petioled, green and minutely somewhat resinous-atomiferous, triangularhastate, 5-10 cm. long, with sparingly crenate-dentate or entire margins, caudately long-acuminate, as also in less degree are the basal angles: heads numerous in terminal corymbiform cymes, 9-12 mm. high; flowers golden- 
yellow, conspicuously longer than the glabrous involucre: pappus a crown of hyaline scales which are more or less connate and fimbriate-lacerate at summit, the fringe dissected into bristles or hairs somewhat simulating those of the margin of the achene.-Rocky cañons, etc.; southern Colorado, New Mexico, and Arizona.

\section{HYMENOPAPPUS L'Her.}

Perennial or biennial herbs with sulcate-angled erect stems, alternate mostly once or twice pinnatifid or parted leaves, and corymbosely cymose or solitary pedunculate heads of yellow or white flowers. Involucre campanulate, many-flowered, of 6-12 mostly appressed bracts with scariousmembranaceous usually colored tips. Rays none; disk-corollas numerous, all alike, with narrow tube, abruptly dilated throat, and reflexed or widely spreading lobes. Style-branches with short and thick conical appendages. Achenes obpyramidal, 4-5-angled, with attenuate base, the faces 1-3-nerved. Pappus of 10-20 thin-scarious and mostly hyaline obtuse scales; sometimes very short or obsolete.

Stems leafy throughout, mostly corymbosely branched and with numerous heads.

Pappus evident and nearly as long as the corolla-tube

Pappus either wanting or hidden by the hairs of the achenes

Stems leafy below, upward the leaves reduced, few or wanting; heads not numerous.

Stems somewhat branched, 2-5 dm. high.

Pappus hidden by the hairs of the achene

Pappus evident, nearly as long as the corolla-tube:

Stems scapose, less than $2 \mathrm{dm}$. high

1. H. tenuifolius.

2. H. luteus.

1. Hymenopappus tenuifolius Pursh, Fl. 2: 742. 1814. Lightly tomentose, or soon glabrate and green, leafy: leaves rather rigid, once or twice pinnately parted into very narrowly linear or filiform divisions, the margins soon revolute: heads only $6-10 \mathrm{~mm}$. high, numerous and cymose; involucre rather erect and close; the bracts oblong-obovate, greenish with whitish apex and margins: corolla dull white: achenes long-villous.-Eastern Wyoming and southward through Nebraska and Kansas.

2. Hymenopappus luteus Nutt. Trans. Am. Phil. Soc. 7: 374. 1841. Stems 1 or more from each crown; crowns densely lanate; stems spreading, 1-3 dm. long: leaves white-tomentose; basal leaves numerous, petioled, pinnately parted; the pinnae irregularly pinnatifid into 3-9 short-linear divisions; cauline leaves similar but smaller and narrower: heads loosely corymbose-paniculate, when fully developed, about $1 \mathrm{~cm}$. high; bracts of the involucre oblong, obtuse, truncate or even retuse, greenish and sparsely lanate, margins and tip membranous: flowers numerous (40-60); corolla yellowishwhite, tube glandular, about half the length of the campanulate throat; lobes much shorter than the throat: pappus wanting or obscure and short: achene softly pubescent.-Desert areas; Wyoming, Colorado, and Utah.

3. Hymenopappus filifolius Hook. Fl. Bor. Am. 1: 317. 1833. Tomentosecanescent, or somewhat denudate and glabrate, leafless above; stems $1.5-3$ $\mathrm{dm}$. high, sometimes scapiform: leaves nearly as in the last, or of more filiform rigid divisions: heads $8-12 \mathrm{~mm}$. high, few; bracts of the involucre oblong or obovate-oblong, largely green or else white-woolly, the tips whitish or purplish-tinged: corolla yellowish-white or sometimes clear yellow: achenes very long-villous.-From Nebraska and Montana to New Mexico and southern California.

4. Hymenopappus arenosus Heller, Bull. Torr. Bot. Club 25: 200. 1898. Stems clustered, leafy below, branching, floccose-tomentose: leaves thrice or the upper ones only twice pinnately divided, the divisions all linear, from $0.5-2 \mathrm{~cm}$. long, petioled: heads corymbosely cymose, on stoutish peduncles, $1 \mathrm{~cm}$. high; flowers yellow; bracts of the involucre obovate-oblong, the margins thin, whitish, floccose-tomentose at base: corollas $5 \mathrm{~mm}$. long, the tube nearly half the length, the triangular-lanceolate lobes little more than one 
fourth the length of the throat: achenes villous with rather long hairs; scales of the pappus oblong, a little longer than the corolla-tube. (H. cinereus Rydb. Bull. Torr. Bot. Club 27: 634. 1900; H. ochroleucus Greene, Pl. Baker. 3: 30. 1901.) - Colorado and New Mexico.

5. Hymenopappus scaposus Rydb. 1. c. An almost scapose perennial with a caespitose caudex; stem with 1-2 reduced leaves: basal leaves 5-7 cm. long, bipinnately divided into linear segments, $3-15 \mathrm{~mm}$. long, more or less densely tomentose, especially at the base: heads few, corymbose, hemispherical, about $1 \mathrm{~cm}$. high and broad; bracts obovate, with yellowish or purplish-scarious margins: corollas yellow; tube and throat each nearly $2 \mathrm{~mm}$. long; the latter campanulate and longer than the lobes: achenes densely silky; scales of the pappus fully $2 \mathrm{~mm}$. long, longer than the tube of the corolla. (H. parvulus Greene, 1. c.) - Colorado to New Mexico and Nevada.

\section{LEUCAMPYX Gray}

Perennial herb with the aspect of Hymenopappus. Heads heterogamous, radiate; those of the disk perfect; both fertile. Involucre broadly hemispherical; bracts in 2-3 series, imbricated, broadly scarious at the apex. Receptacle somewhat convex, covered with broad membranaceous-hyaline chaffy scales half inclosing the achenes. Branches of the style in the perfect flowers with short penicillate appendages. Achenes cuneate, incurved, dorsally compressed, subtriquetrous, attenuate at base, obtuse at apex. Pappus none.

1. Leucampyx Newberryi Gray, Porter \& Coulter, Fl. Col. 77. 1874. Herbaceous, at first woolly, at length nearly glabrous; stems stout, 3-6 dm. high, corymbosely branched: leaves 2-3 pinnately parted, segments short, linear, revolute on the margins; the radical ones lanceolate in outline, $8-15 \mathrm{~cm}$. long including the petioles: heads many, rather large, long-peduncled; bracts of the involucre obovate, obtuse, with broad scarious tips: corolla of the disk yellow, of the ray white or cream-colored with a spreading cuneate limb 10-12 mm. long: achenes glabrous, angled, black.-In cañons; Colorado and New Mexico.

\section{POLYPTERIS Nutt.}

Herbs more or less scabrous-pubescent, with undivided and mostly entire petiolate leaves, all or the upper alternate and loosely cymose or paniculate and pedunculate heads of rose-purple flowers. Involucre broadly campanulate to turbinate; the bracts spatulate to linear-lanceolate, commonly in 2 series and equal. Rays in our species evolute into a palmate, 3-cleft ligule, fertile; corolla of the disk-flowers with long lobes; stamens wholly exserted. Achenes from linear and downwardly attenuate to clavate-obpyramidal, 4-sided, minutely pubescent. Pappus of 6-12 equal hyaline scarious scales.

1. Polypteris Hookeriana Gray, Proc. Am. Acad. 19: 30. 1883. Stout, 2-6 dm. high, above glandular-pubescent and somewhat viscid: leaves narrowly to broadly lanceolate: involucre many-flowered, broad, 10-14 $\mathrm{mm}$. high, of 12-16 lanceolate bracts in 2 series, the outer looser and often wholly herbaceous, inner with purplish tips: ray-flowers 8-10, the rose-red rays 10-12 mm. long, but sometimes reduced or abortive: pappus of the disk of thin scales attenuate at apex into a slender point or short awn, nearly the length of the achene.-Sandy plains; from Nebraska to Texas, and extending within the eastern limits of our range.

\section{ERIOPHYLLUM Lag.}

Mostly floccose-woolly herbs, with alternate or partly opposite leaves and peduncled heads of golden-yellow flowers; in ours the heads are solitary or scattered. Involucre of 1 or sometimes 2 series of oblong, permanently erect bracts, either distinct or sometimes partially united into a cup, at least in fruit concave at center, partially receiving the achenes. Receptacle from convex or rarely conical to plane. Ray-flowers usually with broad ligules, 
very rarely none. Achenes narrow, from clavate-linear to cuneate-oblong, mostly 4-angled. Pappus of nerveless and mostly pointless scales.

Plants small, $1 \mathrm{dm}$. or less high; heads sessile or nearly so .

1. E. Wallacei.

Plants 1-3 dm. high; heads pedunculate

2. E. integrifolium.

1. Eriophyllum Wallacei Gray, Proc. Am. Acad. 19: 25. 1883. Stem freely branching from the base; the branches ascending, 2-10 cm. high; the copious matted wool tardily or not at all deciduous: leaves spatulate or obovate, obtuse, mostly entire, $1 \mathrm{~cm}$. or less long: heads short-pedunculate; involucre $5 \mathrm{~mm}$. high, the overlapping bracts not united: receptacle low-conical, obtuse: rays about 10, yellow, $4 \mathrm{~mm}$. long and nearly as broad: anther-tips subulate: style-branches conical, acutish: scales of the pappus 6-10, oblong or obovate, obtuse, erose, one half to one fourth as long as the corolla.-Desert soils; southern Wyoming to Arizona and California.

2. Eriophyllum integrifolium (Hook.) Greene, Fl. Fran. 444. 1891. Low, often dwarf, caespitose, 1-3 dm. high: leaves narrowly spatulate and entire to more dilated and 3-lobed, floccosely hoary: heads rather long-peduncled; involucre cylindrical, of 6-8 narrowly oblong bracts: achenes glabrous, rarely somewhat glandular-atomiferous near the summit; scales of the pappus mostly of the same length, about equaling the very glandular but not hirsute corollatube. (E. multiflorum Nutt.)-In the mountains; Wyoming to California and Washington.

\section{PLATYSCHKUHRIA (Gray) Rydb.}

Herbaceous from a perennial caudex. Leaves all alternate and entire, coriaceous. Scales of the pappus about 10 , linear-lanceolate, with a distinct excurrent or percurrent costa.-Section Platyschkuhria Gray, under Bahia.

1. Platyschkuhria integrifolia (Gray) Rydb. Bull. Torr. Bot. Club 33: 155. 1906. Cinereous-puberulent and glabrate, upper part of the scapiform stem and involucre minutely glandular, 1-3 dm. high: leaves nearly all radical, oval or spatulate-oblong, tapering into a slender petiole: heads solitary or few and somewhat corymbosely paniculate, $10-12 \mathrm{~mm}$. high; involucre of about 10 oblong bracts: rays 6-9, oblong: pappus fully half the length of the cuneate-linear, sparsely hairy achene; the thin margins of the scales of the pappus erose. Bahia nudicaulis.-Arid areas; Wyoming and Colorado.

68. BAHIA Lag.

Ours are herbaceous plants, sometimes canescent but not woolly, with opposite or sometimes alternate leaves and rather small pedunculate heads of yellow flowers terminating the branches. Involucre hemispherical or obovate and lax or open in fruit; the plane bracts distinct to and commonly narrower at the base, not embracing achenes. Receptacle mostly flat. Pistillate flowers with exserted ligules, or rarely none. Achenes narrow, quadrangular. Pappus of several scarious scales.-Includes Picradeniopsis Rydb. and Achryopappus H. B. K.

Perennial from a lignescent root Annuals.

Rays none; leaves mainly opposite

Rays conspicuous; leaves mainly alternate:
1. B. oppositifolia.

2. B. neo-mexicana. 3. B. dissecta.

1. Bahia oppositifolia Nutt. T. \& G. Fl. 2: 376. 1842. Tufted, 1-2 dm. high, fastigiately branched and many-stemmed, very leafy up to the shortpeduncled heads, cinereous with fine close pubescence: leaves petioled, palmately or pedately 3-5-parted into linear divisions little broader than the margined petiole: bracts of the involucre oblong or oval, comparatively close: rays 5 or 6 , oval, hardly surpassing the disk-flowers: achenes slender, glandular; pappus half the length of the corolla-tube.-Sterile hills and plains: Nebraska to Wyoming and New Mexico. 
2. Bahia neo-mexicana Gray, Proc. Am. Acad. 19: 27. 1883. Stems 1-2.5 dm. high, minutely puberulent: leaves 3-7-parted into narrow linear divisions; the uppermost little shorter than the slender peduncles: involucre of about 10 sparingly pubescent spatulate bracts: disk-corollas small, with glandular tube, almost equaled by the obovate scales of the pappus, which are much thickened at and near the base.-New Mexico and southern Colorado.

3. Bahia dissecta (Gray) Brit. Trans. N. Y. Acad. Sci. 8: 68. 1889. Stems stoutish, 3-10 dm. high, puberulent or glabrous below, above with the flowering branches and short peduncles glandular-pubescent and viscid: leaves 1-3-ternately divided or parted; the lobes from oblong and obtuse to nearly linear: heads 10-14 mm. high and broad; bracts of the involucre 16-20, crowded, oblong-lanceolate to obovate-oblong, most of them conspicuously acuminate. B. chrysanthemoides.-Along water courses; Wyoming to New Mexico and Arizona.

\section{CHAENACTIS DC.}

Herbs with alternate mostly pinnately dissected leaves, pedunculate solitary or cymose heads of yellow or (in ours) white or flesh-colored flowers, and pappus mostly of entire or merely erose persistent scales (in ours 4-14). Receptacle flat. Heads rayless but the marginal flowers enlarged. Achenes slender, linear-tetragonal or more compressed, pubescent.

Annual.

Heads corymbose, short-peduncled; pappus-scales 8-14

Heads solitary; pappus-scales 4-6

1. C. stevioides.

2. C. Douglasii. 3. C. alpina.

1. Chaenactis stevioides H.\& A. Bot. Beech. 353. 1840. Floccose-tomentose, glabrate in age, 2-3 dm. high, freely and loosely branched, bearing numerous somewhat cymosely disposed heads on short, slender peduncles: leaves 1-2pinnately parted into short, linear lobes, uppermost rarely entire: bracts of involucre narrowly linear, obtuse, with obscure midrib: marginal corollas with moderately ampliate unequally 5-lobed limb, not surpassing the disk: scales of the pappus scarcely thickened at base, those of the inner flowers oblong-lanceolate and shorter than the corolla, of the outer one ovate or oblong, often unequal, sometimes much shorter.-Arid areas of our range, and westward.

2. Chaenactis Douglasii H. \& A. 1. c. Canescent with a fine, somewhat floccose tomentum, or sometimes glabrate, 1-4 dm. or more high: leaves mostly of broad outline and bipinnately parted into crowded, short, and very obtuse divisions and lobes: heads 12-18 mm. long, in larger plants several or numerous and corymbosely cymose: scales of the pappus from linear-ligulate to narrowly oblong and one half to three fourths the length of the corolla.From Montana to New Mexico and westward.

2a. Chaenactis Douglasii achilleaefolia (H. \& A.) A. Nels. Dwarf, the leaves more rosulate-tufted and their divisions crowded-approximate. $\left(C^{\top}\right.$. achilleaefolia H. \& A. 1. c.).-In arid sterile soils; Wyoming to Montana and Washington.

3. Chaenactis alpina (Gray) Jones, Proc. Cal. Acad. II. 5: 699. 1895. Dwarf, 6-16 cm. high, consisting of a rosette or thick tuft of leaves with very approximate divisions, and naked or scapiform stems, bearing mostly solitary heads, surmounting the subterranean branches of a multicipital perennial caudex or rootstock: heads large, with broadly linear, rough, greenish bracts: pappus scales narrowly oblong, usually 6,2 of which are somewhat shorter and narrower. C. Douglasii alpina. (C. pedicularia Greene, Pitt. 4: 98. 1899).- - In the mountains of Colorado.

70. HULSEA T. \& G.

Herbs, viscid-pubescent and balsamic-scented, most of the species when young floccose-woolly, with alternate, mostly sessile, entire or dentate or 
pinnatifid leaves, and solitary or scattered large heads of yellow flowers, or rays sometimes purple. Bracts of the involucre linear or lanceolate. Rayflowers numerous and ligulate, but sometimes short and inconspicuous; disk-corollas with proper tube slender or narrow, but shorter than the cylindraceous throat. Achenes linear-cuneate, compressed or somewhat tetragonal, soft-villous, especially the margins. Pappus mostly of 4 truncate scales, erose or lacerate at summit or nearly entire.

1. Hulsea carnosa Rydb. Mem. N. Y. Bot. Gard. 1: 423. 1900. Very fleshy; stems from creeping rootstocks and a deep thick root, in big clumps, $1.5-3 \mathrm{dm}$. high, very leafy throughout, pubescent, more or less viscid: leaves very fleshy, linear, sinuately lobed, $5-8 \mathrm{~cm}$. long: heads solitary, $1.5-2 \mathrm{~cm}$. high, hemispheric; the bracts linear-lanceolate, viscid-pubescent and more or less villous: rays light yellow, less than $1 \mathrm{~cm}$. long: achenes tapering downward, densely silky-strigose: pappus of fimbriate scales about $2 \mathrm{~mm}$. long.Wet rocky ravines; Montana and Yellowstone Park.

\section{ACTINELLA Nutt.}

Mostly scapose, villous-pubescent or glabrous, bitter and aromatic herbs, with alternate or basal often punctate entire leaves, and equally peduncled heads of both tubular and radiate yellow (rarely flesh-colored) flowers, or rays rarely wanting. Involucre hemispheric, campanulate or depressed, the bracts imbricated in 2-3 series, appressed. Receptacle convex or conic, naked. Ray-flowers pistillate and fertile, the rays 3-toothed; disk-flowers perfect, fertile, the corollas with 4-5-toothed limbs. Style-branches truncate and penicillate at the summit. Achenes turbinate, 5-10-ribbed or angled, villous or pubescent. Pappus of 5-12 thin, aristate, acuminate, or truncate scales.-(Tetraneuris Greene.)

Leaves borne wholly on the crowns of the caudex.

Leaves densely pubescent (silky, villous, or canescent).

Plants broadly low-caespitose, the numerous crowns bearing a

solitary head on a scape 1-10 cm. long
Plants simple or tufted, the crowns few, the scapes slender, 10-30

1. A. acaulis. cm. high.

Rays present.

Pubescence silky-sericeous . . . . . . 2. A. simplex.

Pubescence short, dense and silvery-white : : : : 3. A. incana.

Rays wanting. Disk yellow.

Disk flesh-color

Leaves loosely villous or glabrate.
Crowns of the caudex short.

The leaf-bases involved in long white or brown hairs. Sparsely long-villous throughout forbans

The leaf-bases naked or nearly so.

Leaves green, broadly linear

Leaves pale, narrowly linear

Crowns of the caudex fastigiate and elongated $\left(1-2 \mathrm{dm} \cdot \dot{\mathrm{h}}^{\circ} \mathrm{hig}\right)$

Leaves borne on the crowns of the caudex and 1-4 on the lower portion

of the slender scape

7. A. Torreyana.

8. A. epunctata.

9. A. linearis.

10. A. fastigiata.

11. A. leptoclada.

1. Actinella acaulis (Pursh) Nutt. Gen. 2: 173. 1818. Densely caespitose, the branches of the caudex short, thick, and crowded, canescently villous or sericeous, sometimes more naked: scape 1-10 cm. high: leaves thickish, all entire, spatulate to nearly linear, commonly short, $2-5 \mathrm{~cm}$. long, densely crowded on the caudex: rays long.-Mountains and the bordering plains and hills; Dakota to Montana, and south to Colorado.

1a. Actinella acaulis caespitosa A. Nels. Densely silky or sericeouscanescent: heads sessile or subsessile among the crown leaves. ( $A$. depressa Gray; A. depressa pygmaea Gray; Tetraneuris brevifolia Greene, Pitt. 3: 266. 1898; T. acaulis caespitosa A. Nels. Bot. Gaz. 28: 127. 1899.)-Same range as the species.

2. Actinella simplex A. Nels. Caudex short, consisting of one or more thick 
crowns which are densely covered with brown dead leaf-bases: leaves appressed pubescent, nearly naked in the axils or sparsely long-hairy, glabrate in age when the fine punctation becomes evident, crowded on the crowns, ascending or erect, linear-spatulate, tapering only slightly to the margined base, subacute, 4-7 cm. long: scapes simple, single from the crowns, $15-25 \mathrm{~cm}$. high, slender, erect, lightly pubescent below, becoming silky or lanate above and on the involucre: heads large, $2.5-4 \mathrm{~cm}$. across: rays with a broad ligule (5-8 mm.): achene pubescent. (Tetraneuris simplex A. Nels. 1. c.) Southern Wyoming to New Mexico and Arizona.

3. Actinella incana A. Nels. Root rather slender, simple or branched; caudex simple or few branched, the crowns enlarged by a dense covering of the broadly expanded bases of the petioles which are more or less involved in white, hirsute wool: leaves crowded on the crowns, silvery-white with an appressed pubescence, linear-oblanceolate, $2-4 \mathrm{~cm}$. long: scapes naked, slender, curved-ascending, 1-2 dm. high: involucre silvery-silky; bracts few, shorter than the $1 \mathrm{~cm}$. high disk, the outer oblong, obtuse, the inner spatulate, scariousmargined: rays few, the ligule as long as the disk: pappus-scales oblong, aristate; achene slender, nearly as long as the corolla, pubescent. (Tetraneuris incana A. Nels. l. c.) - White barren clay hills and ridges; east-central Wyoming.

4. Actinella eradiata A. Nels. Densely silky throughout; caudex short, of one or more crowns, slightly lanate and covered with the expanded bases of the petioles: leaves crowded on the crowns, linear or narrowly oblanceolate, 5-8 $\mathrm{cm}$. long, the short petiole margined and expanding at its scarious base: scapes slender, $12-25 \mathrm{~cm}$. high: heads wholly eradiate, $1 \mathrm{~cm}$. or more high, the disk almost orange or tinged with brown: pappus-scales obovate, glisteningwhite, tipped with a slender awn, including the awn almost as long as the silvery achene and scarcely shorter than the corolla. (Tetraneuris eradiata A. Nels. Bot. Gaz. 37: 275. 1904.)-Eastern base of the Big Horn Mountains, Wyoming.

5. Actinella carnosa A. Nels. Caespitose, caudex $6-8 \mathrm{~cm}$. high, branching underground from a perennial, woody root; whole plant hirsute-canescent: leaves all radical, simple, from oblong to orbicular, 8-12 $\mathrm{mm}$. long on petioles equaling them or twice as long; blade coriaceous, acute or obtuse, entire or crenate, margins revolute; lower surface densely covered with appressed white hairs; upper surface impressed-punctate and sparingly hirsute: heads $15 \mathrm{~mm}$. high and broad; involucral scales linear-oblong, obtuse, about 12, arranged in 2 series, densely pubescent externally, glabrous and marked by prominent nerves within; the inner series longer, with reddish scarious-margined tips: lobes of flesh-colored corolla equal: stamens included: style-tips broad: achenes clavate, densely villous; pappus of 8 nearly equal, hyaline scales one half the length of the achenes, with prominent midrib and erose tips. (Chaenactis scaposa Eastw. Zoe 2: 231. 1891; Chamaechaenactis scaposa Rydb. Bull. Torr. Bot. Club 33: 156. 1906.)-From type locality only, Grand Junction, Colorado.

6. Actinella lanata Nutt. Trans. Am. Phil. Soc. 7: 379. 1881. Caudex caespitose, the crowns short and densely hairy or woolly: leaves linearoblanceolate, loosely silky-villous but often glabrate in age, nearly impunctate: scape 7-12 cm. long: bracts of the involucre oblong lanceolate, in about 3 series, the inner with scarious margins: pappus-scales 5-6, ovate, tipped with short awns. (Tetraneuris lanata Greene, Pitt. 1. c. 265.)-Wyoming to New Mexico and Arizona.

7. Actinella Torreyana Nutt. 1. c. Caudex very stout, depressed, the crowns greatly thickened by the copious brown hair or wool which involves the old leaf-stalks: leaves green and becoming almost glabrous, linearoblanceolate, subglutinous and strongly impressed glandular-punctate: scapes 6-12 cm. high, silky-pubescent as is also the involucre: inner involucral bracts scarious-margined: heads large, with conspicuous yellow rays which have a greenish tinge: pappus-scales nearly awnless. (Tetraneuris Torreyana Greene 1. c.)-On rocky hills of Colorado, Wyoming, and Utah. 
8. Actinella epunctata A. Nels. Caudex simple or with 2-several crowns: leaves crowded on the crowns, glabrate and bright green, obscurely punctate, narrowly spatulate or oblanceolate, $2-4 \mathrm{~cm}$. long, the margined petiolar bases imbricated on the crowns but not involved in the usual wool: scapes $1 \mathrm{dm}$. or less high, sparsely silky-canescent: heads large, $25-30 \mathrm{~mm}$. broad when fully expanded; involucre silky-lanate; the green tips of the oblong-acute bracts mostly free from the wool: the bright yellow rays about $12 \mathrm{~mm}$. long: pappus scales nearly as long as the disk-corollas, obovate, abruptly long-acuminate. (Tetraneuris epunctata A. Nels. 1. c.; T. glabra Greene, 1. c. 268, not T. glabra Nutt.; T. glabriuscula Rydb. Bull. Torr. Bot. Club 33: 155. 1906.)-Colorado and Utah to Nevada and New Mexico.

9. Actinella linearis (Nutt.) A. Nels. Caespitose, but the short caudex slender: leaves very narrow and almost linear, pubescent but not villous, the punctation manifest but superficial rather than impressed: scapes tall and slender: scales of the pappus obovate, obtuse, tipped with a rather long awn. (A. scaposa linearis Nutt. 1. c.; Tetraneuris linearis Greene, 1. c. 267; T. angustifolia Rydb. 1. c. 32: 128. 1905.)-Texas and New Mexico and rarely in southern Colorado.

10. Actinella fastigiata (Greene) A. Nels. Subligneous stem 1-2 dm. high, parted into many fastigiate densely leafy branches and forming a compact tufted undershrub-like plant: leaves spatulate-linear, acute, glabrous or somewhat scabrous, superficially punctate, the basal part much dilated, with strong midvein and no lateral nerves, the margin hirsute with long deflexed hairs: scapes slender, shorter than the leafy branches, 7-12 cm. long: involucre narrow and small, the bracts oblong, obtuse, pubescent. (Tetraneuris fastigiata Greene, 1. c. 268; T. stenophylla Rydb. 1. c. 33: 155.)-Dry hills in Kansas; reported also from Colorado.

11. Actinella leptoclada Gray, Pacif. R. R. Rept. 4: 107. 1857. Tufted, with woody root and multicipital caudex, the short thickened crowns clothed with the expanded, membranous, lanate leaf-bases: leaves glabrous, 4-8 cm. long, crowded on the crowns, linear-oblanceolate, acute or cuspidate, rather minutely punctate: stems few to several, 1-2 dm. long, bearing a few (usually 2) leaves: heads large; disk about $1 \mathrm{~cm}$. high; involucre silky-lanate; the bracts in two or three rows, the inner oblong or somewhat expanded upward by the scarious margins: scales of the pappus oblong-elliptic with an acumination as long as the body proper, equaling the disk-corollas: ligules of the rays 15-18 $\mathrm{mm}$. long, 6-8 $\mathrm{mm}$. broad. [The fact that the stem leaves are often concealed among the others has probably contributed in part to the making of the following synonyms: T. mancosensis A. Nels. l. c. 28. 1898; T. intermedia Greene, Pl. Baker. 3: 29. 1901; T. Crandallii Rydb. 1. c. 32: 127. 1905; T. arizonica Greene, Pitt. 3: 266. 1898; T. pilosa Greene (?)].-Colorado to New Mexico and Arizona.

\section{HYMENOXYS Cass.}

Herbaceous plants with aromatic herbage, alternate leaves, and pedunculate heads. Ray-flowers pistillate or the heads homogamous. Bracts of the involucre in two series, in our species the narrow and rigid outer bracts united at base into a shallow cup inclosing the broadly oblong obtuse inner ones. Flowers yellow. Achenes turbinate, hairy. Pappus of 5-12 conspicuous hyaline paleae.-Actinella in part.

Perennial, the stems from a low branched caudex, simple below.

Heads solitary or few at the ends of the stems

Heads several to many, in a corymbose inflorescence

Annual or biennial, branched throughout, with a taproot

1. H. Richardsonii.

2. H. floribunda.

3. H. multiflora.

1. Hymenoxys Richardsonii (Hook.) Ckll. Bull. Torr. Bot. Club 31: 471. 1904. Stems 1-2 dm. high, in tufts from a multicipital caudex, puberulent or nearly glabrous, woolly in the axils of radical leaves, polycephalous: upper leaves mostly once, and the lower twice, ternately parted into long and simple filiform-linear lobes, rather rigid: involucre 4-6 mm. high, 6-9-angled; the 
6-9 bracts of the outer series strongly carinate, united for the lower quarter or third: rays broadly or sometimes narrowly cuneate, 4-8 $\mathrm{mm}$. long. Actinella Richardsonii. (Hymenopappus ligulaeflorus A. Nels. Bull. Wyo. Exp. Sta. 28: 135. 1896; Picradenia pumila Greene, Pitt. 3: 271. 1898; P. macrantha A. Nels. Bot. Gaz. 28: 130. 1899. These are reduced to varieties and some other varieties added by Cockerell in his revision, cited above.)-Plains; Saskatchewan and eastern Oregon to Utah and New Mexico.

2. Hymenoxys floribunda (Gray) Ckll. 1. c. Taller and more slender than $H$. Richardsonii, the wool at base of stem more silky; stems repeatedly branched: heads many times more numerous, less than half the size, forming a broad, flat-topped inflorescence: scales of the pappus lanceolate, some slenderly acuminate, others not so. This species received some notice a few years since as a possible source of rubber and became known as the Colorado RuBber Plant.-In dry or gravelly soil; Colorado to Texas, New Mexico, and Arizona.

3. Hymenoxys multiflora (Buckley) Rydb. Bull. Torr. Bot. Club 33: 157. 1906. Diffuse and at length much branched, from an annual or biennial root, 1-3 dm. high, with scattered small heads terminating leafy branches: leaves once to thrice ternately parted into filiform lobes, not rigid: involucre campanulate, rigid; the outer of 7 or 8 oblong bracts, united at base: scales of the pappus aristately attenuate. (Picradenia multiflora Greene, 1. c.; H. chrysanthemoides multiflora Ckll. 1. c.; H. Osterhoutii Ckll. 1. c.)-Dry plains; Kansas and Colorado to Texas and Arizona.

\section{RYDBERGIA Greene}

Stout but low, upright, sparingly branched alpine woolly perennials, with very large heads with long and narrow spreading yellow rays. Bracts of the low-hemispherical involucre all alike, distinct, herbaceous, in several series, loose, woolly. Receptacle broad and hemispherical. Rays 15-30, 2-3 cm. long, linear-cuneiform, broadest and deeply 3-toothed at apex. Scales of the pappus white, elongated-lanceolate, and slenderly acuminate.

Leaves glabrate; involucre short-villous

Leaves floccose-woolly; involucre woolly

1. R. Brandegei.

1. Rydbergia Brandegei (Gray) Rydb. Bull. Torr. Bot. Club 33: 156. 1906. Leaves glabrate, with 2 or 3 lobes toward the upper part, or some entire, narrowly linear, only 2 or 3 on the somewhat scapiform simple flowering stem (1-2 dm. high): head therefore conspicuously pedunculate, 10-12 $\mathrm{mm}$. high and wide; involucral bracts lanceolate: rays $12-16,6-8 \mathrm{~mm}$. long.- In the high mountains; southern Colorado and New Mexico.

2. Rydbergia grandiflora (Pursh) Greene, Pitt. 3: 270. 1898. Stem 1-3 $\mathrm{dm}$. high, very stout, floccose-woolly, somewhat glabrate in age; stem simple or branching below, leafy: leaves with petiole scarious-dilated at base, lower ones 2-3-ternately or quinately parted, upper with 3-5 simple lobes: involucre about $20-25 \mathrm{~mm}$. broad, very woolly, the bracts linear: rays 30 or more, 12-16 mm. long. Actinella grandiflora.-Alpine regions from Montana to Colorado.

\section{DUGALDIA Cass.}

Tall, erect, rather stout perennials or possibly biennials, with entire or parted alternate leaves which are more or less resinous-atomiferous and impressed-punctate. Heads usually several and rather long-pedunculate. Bracts of the involucre numerous, in 2 series, tardily reflexed. Rays fertile, numerous, long, and narrow; disk-corollas with moderately long proper tube. Pappus of elongated scales.-Helenium in part.

All the leaves entire

Some of the leaves parted or divided :

1. D. Hoopesii.

1. Dugaldia Hoopesii (Gray) Rydb. Mem. N. Y. Bot. Gard. 1: 425.1900. Slightly tomentose or pubescent when young, soon glabrate; stem stout, 3-8

ROCKY MT. BOT.-36 
$\mathrm{dm}$. high, leafy, bearing several or sometimes only a solitary large head: leaves thickish, oblong-lanceolate, or the lower spatulate with long tapering base: rays becoming $2-3 \mathrm{~cm}$. long, tardily reflexed: disk $12-16 \mathrm{~mm}$. high, hemispherical: scales of the pappus ovate-lanceolate, long-attenuate-acuminate, a little shorter than the corolla. Helenium Hoopesii.-In the mountains; Wyoming to New Mexico and Arizona.

2. Dugaldia helenioides (Rydb.) A. Nels. A comparatively tall, finely pubescent plant with apparently only biennial root; stem leafy, about $5 \mathrm{dm}$. high, with several to many erect branches: leaves rather firm, distinctly ribbed, finely pubescent; the lower petioled, entire, very narrowly linearoblanceolate; middle stem leaves erect, fully $1 \mathrm{dm}$. long, parted into 3-5 linear divisions; upper stem leaves linear, entire: heads corymbose; involucre somewhat tomentose, $8-10 \mathrm{~mm}$. high and often $15 \mathrm{~mm}$. broad; outer bracts lanceolate, longer than the inner, 14-18: rays orange, about $1 \mathrm{~cm}$. long: achenes silky; scales of the pappus broadly lanceolate, acuminate. (Picradenia helenioides Rydb. Bull. Torr. Bot. Club 28: 21. 1901.)-Type locality only, Sangre de Cristo Creek, Colorado.

\section{HeleniUM L. SNeEzeweed}

Herbs, with alternate simple leaves, commonly decurrent, resinousatomiferous and punctate, and pedunculate heads of yellow flowers. Bracts of the involucre spreading, subulate or linear. - Rays fertile or sterile, rarely none; disk-corollas with 4-5-toothed limb; the teeth obtuse, glandularpubescent. Pappus usually of 5 or 6 thin scarious scales.

1. Helenium autumnale L. Sp. Pl. 866. 1753. Perennial; stem puberulent or glabrous, rather stout, narrowly winged by the decurrent bases of the leaves, corymbosely branched above, $3-10 \mathrm{dm}$. high: leaves firm, acuminate or acute at apex, narrowed to the sessile base, pinnately few-veined, $5-12 \mathrm{~cm}$. long, $0.5-5 \mathrm{~cm}$. wide, green: heads numerous, $3-5 \mathrm{~cm}$. broad, borne on long puberulent peduncles; bracts of the flattish involucre densely canescent, linear-lanceolate: rays 10-18, drooping, bright yellow, 3-cleft: achenes pubescent on the angles; pappus-scales ovate, acuminate or aristate, often lacerate or toothed. (H. montanum Nutt. differs only in being lower, somewhat puberulent, paler, and the heads more crowded-corymbose.)-Wet lands; from Arizona to British Columbia and eastward across the continent.

\section{FLAVERIA Juss.}

Glabrous herbs with small and fascicled or glomerate heads of yellowish or yellow flowers and opposite sessile leaves. Heads 1-several-flowered; the flowers all fertile, homogamous and tubular, or 1 pistillate and short-ligulate. Disk-corollas 5-toothed. Involucre of $2-5$ mostly carinate-concave bracts. Pappus none. Achenes mostly smooth and glabrous.

1. Flaveria angustifolia (Cav.) Pers. Syn. 2: 489. 1807. Erect, 2-5 dm. high: leaves linear to lanceolate, serrulate or entire, sessile by broadish or little contracted base: heads in subsessile or short-pedunculate or leafyinvolucrate, chiefly terminal glomerules; involucre mostly of 3 bracts, 3-5flowered or some only 2-flowered.-Alkaline soil; eastern Colorado and New Mexico to western Texas.

\section{GAILLARDIA Foug.}

Herbs with alternate leaves and ample showy heads on terminal peduncles. Ours are more or less pubescent or hirsute and leafy-stemmed, with yellow rays and disk-flowers apt to turn brown, villous achenes, and scales of the pappus slender-awned. Involucre broad; the bracts in 2 or 3 series, hirsute; receptacle with setiform or subulate-setaceous fimbrillae throughout. 
Ligules 3-toothed or 3-cleft; disk-corollas with 5 ovate-triangular to subulate teeth, which are beset with jointed hairs. Achenes turbinate, 5-costate, covered with long villous hairs. Pappus conspicuous, longer than the achenes, of 5-10 hyaline-scarious scales with a costa mostly excurrent into an awn.

Lobes of the disk-corollas acute, tipped with a seta beset with beaded hairs

Lobes of the disk-corollas short and obtuse

1. G. aristata.

2. G. pinnatifida.

1. Gaillardia aristata Pursh Fl. 2: 573. 1814. More or less hirsute, often 5-8 dm. high: leaves lanceolate or broader, or lower spatulate, entire to laciniate-dentate or sinuate-pinnatifid: rays in the largest heads $3-4 \mathrm{~cm}$. long: lobes of disk-corollas subulate-acute and tipped with a cusp: pappus aristate.-From New Mexico and southern Colorado to Oregon, British Columbia, and the Saskatchewan.

2. Gaillardia pinnatifida Torr. Ann. Lyc. N. Y. 2: 214. 1828. Cinereouspubescent; peduncles scapiform or from short leafy stems, 1-3 dm. long: some or even all the leaves pinnatifid, sometimes linear or with linear lobes, sometimes spatulate and sinuate or even entire: teeth of the disk-corollas short and broad, obtuse, pointless: pappus-scales lanceolate.-On the plains; Colorado and Arizona to western Texas.

\section{DYSODIA Cav.}

Herbs, mostly strong-scented, with alternate or opposite leaves and solitary or somewhat paniculate heads of yellow flowers. Involucre hemispherical or campanulate, the bracts more or less united below, often with some loose accessory bracts. Pappus of 6-10 scales, which are erose-truncate or more usually resolved into numerous rather stiff bristles. Achenes mostly terete, striate, and pubescent.-(Includes Hymenatherum.)

Leaves mostly opposite; ill-scented

Leaves mostly alternate; not ill-scented

1. D. papposa. 2. D. aurea.

1. Frsodia papposa (Vent.) Hitch. Trans. St. Louis Acad. 5: 503. 1891. Much-iuranched and ill-scented annual, leafy up to the subsessile or shortpedunculate small heads: leaves 1-2-pinnately parted into linear lobes: involucre purplish-tinged or greenish, of 8 or 10 scarious-tipped oblong bracts, and some linear, loose, accessory ones: rays few and inconspicuous, not surpassing the disk. D. chrysanthemoides.-From Arizona and Colorado to Minnesota and Louisiana, and now spreading eastward to the Atlantic States.

2. Dysodia a urea (Gray) A. Nels. Erect or diffuse, 1-2 dm. high, muchbranched, bearing numerous short-peduncled heads: leaves mostly alternate, pinnately parted into 7-9 linear-filiform pointless divisions: involucre 5-6 $\mathrm{mm}$. high: rays about 12, oblong, $6 \mathrm{~mm}$. long: pappus of 6 or 8 quadrate or oblong and erose-truncate scales, in length little exceeding the breadth of the achene. Hymenatherum aureum. (Lowellia aureum Gray, Pl. Fendl. 91. 1848.)Colorado to Texas.

\section{PECTIS L.}

Mostly low and spreading herbs, usually glabrous and scented, with narrow, opposite leaves conspicuously dotted with round oil-glands, small heads of yellow flowers, and slender, rigid bristles fringing at least the base of the leaves. Heads radiate, several-many-flowered. Involucre naked at base, or nearly so, cylindrical or campanulate, of few or several equal carinate bracts in a single series. Disk-corollas 5-lobed, 1 or 2 sinuses often deeper, thus becoming bilabiate. Achenes linear, terete or angled. Pappus of few or numerous bristles or awns, sometimes chaffy-dilated at base, or of scales.

1. Pectis angustifolia Torr. Ann. Lyc. N. Y. 2: 214. 1828. Smooth, 1-3 dm. high: leaves narrow-linear: heads subsessile or short-peduncled, fastigiate or cymose at the end of the branches; bracts of the involucre about 8 , 
linear, at length with involute margins: pappus a crown of 4 or 5 mostly connate scales, and not rarely 1 or 2 slender usually short awns.-Dry ground; Colorado and Arizona to Texas.

\section{0. anthemis L. Mayweed. Dog Fennel}

Annual or perennial herbs, with pinnatifid or dissected alternate leaves and peduncled heads terminating the branches. Involucre hemispheric, the bracts imbricated in several series, scarious-margined, appressed, the outer shorter. Receptacle convex, conic or oblong, chaffy at least toward the summit, the chaff subtending the disk-flowers. Ray-flowers pistillate and fertile, or neutral, the tube terete or 2-winged, the ray white or yellow, entire or 2-3-toothed; disk-flowers perfect, fertile, yellow, the corollas with 5-cleft limbs. Achenes oblong, angled, ribbed or striate. Pappus none, or a short coroniform border.

1. Anthemis Cotula L. Sp. Pl. 894. 1753. Stems rather low; herbage unpleasantly strong-scented: leaves finely 3-pinnately dissected: receptacle conical: rays mostly white, neutral or abortive: achenes 10-ribbed, rugose or tuberculate.-An excessively common weed eastward, now not infrequent in waste ground in our range.

\section{ACHILlea L. YarRow. Milfoil}

Ours an erect strongly scented perennial herb with finely dissected alternate leaves. Heads radiate, cymose at the ends of the stem and branches. Rayflowers few, pistillate, fertile. Involucral bracts appressed, imbricated in few series, the outer shorter. Receptacle nearly flat, the chaff membranous and subtending fertile disk-flowers. Achenes linear or oblong to obovate, obcompressed. Pappus none.

1. Achillea millefolium L. Sp.: Pl. 899. 1753. From villous-lanate to glabrate; stems simple, 2-6 dm. high: leaves elongated and narrow in outline, sessile, bipinnately dissected into numerous small and linear to setaceoussubulate divisions: heads numerous, crowded in a fastigiate cyme; involucre oblong; the bracts pale or sometimes fuscous-margined, or even wholly brownish: rays $4-5$, about the length of the involucre, white, occasionally rosecolor. A. lanulosa Nutt. and A. alpicola Rydb. are merely forms of a somewhat variable species, though there is more homogeneity in this species than in many which no one has yet thought to disintegrate.-Common throughout the northern hemisphere.

\section{MATRICARIA L.}

Ours glabrous annuals with alternate leaves pinnately dissected into narrowly linear segments. Heads solitary or somewhat cymose, with many greenishyellow or white flowers. Receptacle mostly slender-conical, naked. Bracts of the involucre imbricated in few series, the outer ones a little shorter than the inner, persistent, scarious-margined. Corollas tubular and without limb in our species. Pappus reduced to a coroniform border, or none. Achenes glabrous, irregularly nerved.

1. Matricaria matricarioides (Less.) Porter, Mem. Torr. Club 5: 341. 1894. Annual, somewhat aromatic, glabrous, 1-2 dm. high, very leafy: leaves 2-3-pinnately dissected into short and narrow linear lobes: heads all short-peduncled; bracts of the involucre broadly oval, white-scarious with greenish center, hardly half the length of the well-developed greenish-yellow ovoid disk: achenes oblong, somewhat angled, with an obscure coroniform margin at summit, which is occasionally produced into 1 or 2 conspicuous oblique auricles of coriaceous texture. M. discoidea.-California and far northward and east to Wyoming and Montana; becoming naturalized farther eastward. 


\section{CHRYSANTHEMUM L. OXEYE DAISY}

Perennial herbs, with toothed, pinnatifid, or divided leaves, and single or corymbed heads. Heads many-flowered; rays white, numerous, fertile. Bracts of the broad and flat involucre imbricated, with scarious margins. Receptacle flat or convex, naked. Disk-corollas with a flattened tube. Achene of disk and ray similar, striate, without pappus.

1. Chrysanthemum Leucanthemum L. Sp. Pl. 888. 1753. Glabrous, 3-6 $\mathrm{dm}$. high, simple or sparingly branched: cauline leaves spatulate, and the upper gradually narrower, becoming small and linear, pinnately dentate or incised, partly clasping at base; the radical broader, petioled: head broad and flat: rays about $2.5 \mathrm{~cm}$. long.-Becoming naturalized about Denver, and probably elsewhere in our range; of European origin but common in the eastern United States.

\section{TANACETUM L.}

Herbs or suffruticose plants with alternate variously dissected leaves and solitary or corymbose heads of yellow flowers. Heads many-flowered, discoid; the flowers all tubular and perfect, with 3-5-toothed corolla, or the marginal ones pistillate with more or less oblique or imperfectly ligulate corolla. Bracts of the involucre imbricated, in few or several ranks. Styles deciduous. Achenes 5-ribbed or 3-5-angled, with broad truncate summit bearing a coroniform pappus or none.-Sphaeromeria Nutt. as to our species. The common garden TANSY may occur as an escape from gardens.

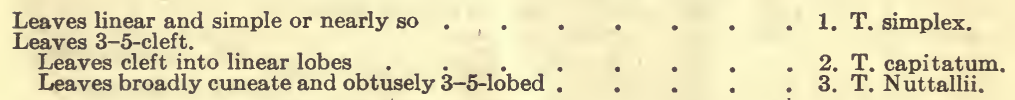

1. Tanacetum simplex A. Nels. Bull. Tor. Bot. Club 26: 484. 1899. Caudex of few short crowded branches, the crowns scarcely above the surface of the ground: leaves crowded on the crowns, closely and finely appressed-silverycanescent, erect, mostly simple and linear, a few bifid or trifid at the apex, only 2-3 cm. long: stems few, rising singly from the crowns, slender, 6-12 cm. high, bearing 2-3 small linear leaves and a single head: head 6-8 $\mathrm{mm}$. high, manyflowered; involucral bracts oval to obovate, in two rows, with slightly thickened greenish midrib and scarious margins: corolla-tubes thin and somewhat transparent: the pistillate flowers in one series: achenes oblong, or slightly enlarged upward, obtuse.-On stony hillsides; southern Wyoming.

2. Tanacetum capitatum (Nutt.) T. \& G. Fl. 2: 415. 1842. Silverycanescent, densely caespitose: leaves simple or pedately 3-5-parted into linear lobes: flowering stems scapiform or 2-4-leaved: heads 10 or more, sessile in a globose glomerule.-Frequent on barren arid hills; Wyoming and in adjacent Utah, Idaho, and Montana.

3. Tanacetum Nuttallii T. \& G. 1. c. Silvery-canescent, loosely caespitose, 10-15 cm. high: leaves short, mostly broad-cuneate with tapering base, obtusely 3-5-lobed at the broad summit; those of the flowering stems usually oblong or linear and entire: heads few, somewhat paniculate or loosely clustered, some of them slender-pedunculate: involucre very scarious.-Dry hills; same range as the preceding.

\section{ARTEMisia L. SAgebrUSh. Wormwood.}

Bitter aromatic herbs or shrubs with alternate leaves and small, paniculately disposed, commonly nodding heads of yellow or whitish flowers. Heads few to many-flowered, small, wholly discoid; heterogamous, the pistillate flowers with small and slender tubular corolla, and the hermaphrodite either sterile or fertile; or homogamous, with the flowers all hermaphrodite and fertile. Involucre imbricated in few or several rows. Anthers commonly tipped with 
subulate-acuminate appendages. Achenes obovate or oblong, mostly with small epigynous disk and no pappus.

Plants spiny; achenes with long cobwebby hairs

Plants not spiny; achenes not cobwebby, sometimes pubescent.

Flowers of two kinds, the marginal ones pistillate and fertile, the inner hermaphrodite but sometimes sterile.

Inner flowers sterile, the style mostly entire and the ovary aborting.

Plants herbaceous, or woody at the base only.

Herbage green and glabrous, and sweet-aromatic

Herbage grayish-pubescent or canescent.

Heads 2-3 mm, wide; flowers yellow.

Plants tall, 3-7 dm. high

Plants very dwarf, $5-15 \mathrm{~cm}$. high

Heads 4-5 mm. wide; flowers brown

Plants shrubby, with filiform leaves; heads numerous, narrow, few-flowered.

Inner flowers also fertile, the style 2-cleft.

Receptacle beset with long woolly hairs.

Heads small (4-5 mm. broad) and numerous

Heads large (6-12 mm. broad) and few or solitary.

Heads several in a spike-like raceme

Heads solitary or few in a close terminal cluster

Receptacle naked (no woolly hairs among the flowers). A tall biennial. Perennials.

Plants herbaceous or woody at the base only.

Silky-pubescent or glabrous, never tomentose. Leaves pinnate, wholly glabrous

Leaves twice 3-7-parted

Tomentose at least on the lower face of the leaves. Involucres densely tomentose.

Leaves permanently tomentose on both faces. Leaves with revolute margins.

Leaves entire, long-linear

Leaves pinnatifid, with narrowly linear or filiform lobes

Leaves entire, toothed or pinnatifid, oblong to short-linear, margins not revolute.

Heads small, numerous, in dense thyrse-like

panicles
Heads large $(6-8 \mathrm{~mm}$. in diameter), few in spike-like racemes

Leaves usually glabrate above in age.

Stems and involucres usually tomentose

Stems and involucres greenish and only lightly pubescent

Involucres glabrous or glabrate, at least in age.

Divisions of the leaves broadly linear or lanceolate

Divisions of the leaves mostly narrowly linear. Leaves 1-2-pinnately parted

Leaves 3-7-parted (southern)

Shrubby, with tridentate cuneate leaves

Flowers all alike, hermaphrodite, fertile; plants shrubby.

Leaves 3-toothed or 3-parted at apex.

Leaf-segments long-linear or filiform

Leaves toothed or lobed at apex or entire.

Heads few, rather large, in a narrow subsimple panicle; leaves lobed

Heads many, small; leaves 3 -toothed.

Shrubs $4 \mathrm{dm}$. to $5 \mathrm{~m}$. high; involucres tomentose

Shrubs less than $4 \mathrm{dm}$. high; involucres glabrate

Leaves all linear and entire or nearly so

1. A. spinescens.

2. A. aromatica.

3. A. canadensis.

4. A. pedatifida.

5. A. borealis.

6. A. filifolia.

7. A. frigida.

8. A. scopulorum.

9. A. Pattersonii.

10. A. biennis.

11. A. subglabra.

12. A. saxicola.

13. A. natronensis.

14. A. Wrightii.

15. A. gnaphalodes.

18. A. paucicephala.

16. A. ludoviciana.

17. A. mexicana.

19. A. franserioides.

20. A. discolor.

14. A. Wrightii.

21. A. Bigelovii.

22. A. trifida.

23. A. arbuscula.

24. A. tridentata.

25. A. nova.

26. A. cana.

1. Artemisia spinescens Eat. Bot. King's Exp. 180. pl. 19. 1871. Stems stout and densely branched, rigid, 1-4 dm. high, white-tomentose: leaves 4-8 $\mathrm{mm}$. long, pedately 3-5-parted, the divisions 3-lobed: heads globose, racemosely glomerate on short and leafy branchlets which become slender, persistent spines; bracts of the involucre 5-6, broadly obovate, obtuse: pistillate flowers 1-4, with truncate corolla; the hermaphrodite sterile flowers $4-8$, the corollas ventricose-campanulate from a narrow base, 5-toothed: achenes oblong-obovate. (Picrothamnus desertorum Nutt. Trans. Am. Phil. Soc. 7: 417. 1841.) Bud-BRUsh is the sheepmen's name.-Alkali desert areas; Colorado to Montana and far westward. 
2. Artemisia aromatica A. Nels. Bull. Torr. Bot. Club 27: 273. 1900. Dark green and nearly or quite glabrous, heavily but rather pleasantly aromatic scented; stems tufted, mostly simple, sometimes sparingly branched from the base, more or less branched in the inflorescence, striate, 4-8 dm. high: leaves nearly all entire, some of the lower 3-cleft, narrowly to broadly linear, 1-several cm. long, numerous: inflorescence leafy; the heads numerous, nodding on short slender pedicels, $3-4 \mathrm{~mm}$. in diameter; involucre glabrous, the bracts oblong-elliptic, obtuse, dark green with scarious margins: flowers numerous, the fertile 10-20, the sterile hermaphrodite about twice as many. A. dracunculoides.*-Mountain valleys and on the plains; frequent throughout our range and westward.

3. Artemisia canadensis Michx. Fl. Bor. Am. Sept. 2: 129. 1803. Glabrous, or mostly with at least the radical and sometimes all the leaves either sparsely or canescently silky-pubescent; stems 3-6 dm. high from a perennial root: leaves mostly bipinnately divided into linear or almost filiform divisions: heads very numerous, $2-4 \mathrm{~mm}$. long, in a compound, oblong or pyramidal, virgate panicle; involucre greenish, glabrous, or rarely pubescent. $[A$. Scouleriana (Besser) Rydb. Bull. Torr. Bot. Club 33: 157. 1906; A. Forwoodii Wats. Proc. Am. Acad. 25: 133. 1890.]-Throughout the northern part of the United States and in the Canadian provinces, and southward in the Rocky Mountains.

4. Artemisia pedatifida Nutt. 1. c. 399. Caespitose, with a stout lignescent caudex, very dwarf, canescent throughout with a fine and close pubescence: leaves chiefly crowded in radical tufts and on the base of the $(3-6 \mathrm{~cm}$. high) rather naked flowering stems, once or twice 3-parted into narrowly spatulate or nearly linear-obtuse entire divisions: heads (about $3 \mathrm{~mm}$. broad) few, loosely spicately or racemosely disposed, canescently pubescent.-Dry ground; on the plains of Wyoming, Montana, and Idaho.

5. Artemisia borealis Pall. Iter. 3: 129. 1871. Stems 1-3 dm. high, from a stout caudex; stems simple: leaves silky-pubescent or silky-villous; radical and lower 1-2-ternately or pinnately divided into linear lobes; the uppermost linear and entire or 3-parted: heads $4 \mathrm{~mm}$. broad, comparatively few, crowded in a narrow (rarely compound) spiciform thyrsus with leaves interspersed; involucre pilose or glabrate, pale fuscous to brownish. (A. spithamaea Pursh, Fl. 2: 522. 1814.) - In the alpine region of Colorado, and far northward across the continent.

6. Artemisia filifolia Torr. Ann. Lyc. N. Y. 2: 211. 1828. Stem branched, 3-6 dm. high, the rigid branches nearly erect: leaves $2-5 \mathrm{~cm}$. long, nearly all 3-parted into filiform entire segments less than $1 \mathrm{~mm}$. wide, or the uppermost undivided: heads exceedingly numerous, about $1 \mathrm{~mm}$. broad, racemosepaniculate, very short-peduncled, 3-5-flowered; involucre oblong, the bracts densely canescent: receptacle small, naked or slightly fimbrillate: central 1-3 flowers sterile.-Dry plains; eastern Wyoming and adjacent Nebraska to Texas, Utah, and Mexico.

7. Artemisia frigida Willd. Sp. Pl. 3: 1838. 1804. Herbaceous from a suffrutescent base, silky-canescent and silvery, 2-3 dm. high; stems simple or branching, bearing numerous racemosely disposed heads in an open panicle: leaves mainly twice ternately or quinately divided or parted into linear, crowded lobes, and usually a pair of simple or 3-parted stipuliform divisions at base of the petiole: heads globular, 3-4 $\mathrm{mm}$. in diameter; involucre pale, canescent, the outer bracts narrow and herbaceous: corollas glabrous.-From Minnesota to Texas and westward to New Mexico, Nevada, and Idaho.

8. Artemisia scopulorum Gray, Proc. Acad. Phila.66.1863. Herbaceous, 1-2 dm. high, from a multicipital caudex, silky-canescent; stems simple, bearing 3-12 spicately or racemosely disposed hemispherical (rarely solitary) heads: radical and few lower cauline leaves pinnately 5-7-divided, and the

* Artemisia dracunculoides Pursh is often reported from our range. That species is paler green, much taller, with numerous drooping branches and smaller heads of only 15-20 flowers; inodorous or at least not sweet-aromatic. Doubtfully in our range, the typical form of it in the central and lower Mississippi valley. 
divisions 3-parted into spatulate-linear lobes; the uppermost simply 3-5-parted or entire: involucre $4 \mathrm{~mm}$. broad, villous, the bracts brown-margined: corollas hirsute at summit.-Alpine region; mountains of Colorado, Utah, and Wyoming.

9. Artemisia Pattersonii Gray, Syn. Fl. 1: 453. 1886. More dwarf and white-tomentose, but sometimes glabrate in age: leaves 3-5-parted or cleft, or the uppermost entire: heads much larger and broader, solitary or 2-5, 40-50flowered: corollas glabrous: receptacle extremely loose-woolly.-Lower alpine region of the Rocky Mountains in Colorado.

10. Artemisia biennis Willd. 1. c. 1842 . Wholly glabrous, inodorous and nearly insipid; stem strict, 3-12 dm. high, leafy to the top, bearing close glomerules of small heads in the axils from toward the base of the stem to the somewhat naked and spiciform summit: leaves 1-2-pinnately parted into lanceolate or broadly linear-laciniate or incisely toothed lobes; or the uppermost small, sparingly pinnatifid and less toothed.-Open grounds from California and Oregon to Hudson's Bay; also now spreading to the eastern seaboard farther south.

11. Artemisia subglabra A. Nels. 1. c. 27: 36. Stems rather few, erect, ascending, slender, more or less branched above, very obscurely glandularpruinose, otherwise green and glabrous as are also the leaves, $3-5 \mathrm{dm}$. high: leaves pinnate or bipinnate; the segments linear or sometimes broader, widely divaricate, the margins more or less revolute: inflorescence racemiform or narrowly paniculate; heads medium size (3-5 mm.), shortly pediceled, spreading or deflexed; involucral bracts green, oblong, with ciliate-lanate margins: flowers 12-20, all fertile, the pistillate with flattened or grooved spatulate styles.-On the stony banks of the Yellowstone river in the National Park.

12. Artemisia saxicola Rydb. Bull. Torr. Bot. Club 32: 128. 1905. Rather stout, 1-5 dm. high, from villous or pubescent to glabrate: leaves twice 3-7parted into linear or lanceolate or more dilated segments: heads 8-10 mm. broad, many-flowered, loosely racemose or racemose-paniculate, most of them long-peduncled; bracts of the involucre broadly brown-margined: corollas loosely pilose, rarely almost glabrous. $A$. norvegica; true $A$. norvegica does not occur on this continent.- High mountains of our range and northward.

12a. Artemisia saxicola Parryi A. Nels. Smaller than the species in all of its parts, with a tendency to become glabrate. (A. Parryi Gray, Proc. Am. Acad. 7: 361. 1868.)-Type locality only, Sangre de Cristo Pass, Colorado.

13. Artemisia natronensis A. Nels. Bull. Torr. Bot. Club 26: 485. 1899. Stems herbaceous, from a woody, persistent crown, suberect, simple, virgate, silvery-white-tomentose as are also the leaves, floriferous for nearly half their length, 3-6 dm. high: leaves long-linear to narrowly lanceolate, in age the margins revolute, the midrib becoming conspicuous below: panicle narrow, the raceme-like clusters in the axils of the leaves which become gradually smaller and bract-like upward or wholly wanting; heads rather large, campanulate, about $5 \mathrm{~mm}$. high, erect or nearly so even at maturity, about 20flowered; the bracts ovate to oval.- On the strongly saline shores of alkali lakes; Wyoming and Colorado.

14. Artemisia Wrightii Gray, Proc. Am. Acad. 19: 48. 1883. . Cinereous, canescent, or glabrate, the radical shoots sometimes white-tomentose, $2-5 \mathrm{dm}$. high, very leafy up to the rather narrow dense panicle: leaves pinnately 5-7parted into narrow, linear and by revolution filiform, entire divisions: involucre cinereous-canescent (sometimes woolly), becoming glabrate; heads small, sessile or short-peduncled, often spreading. (A. kansana Brit. in Brit. \& Brown, Ill. Fl. 3: 466. 1898, more white-woolly than the type; A. stenoloba Rydb.) - From Kansas to Colorado and southward.

14a. Artemisia Wrightii coloradensis (Osterh.) A. Nels. To be distinguished mainly by the coarser leaves and their broader segments. (A. coloradensis Osterh. Bull. Torr. Bot. Club 27: 506. 1900.)-Represents the northern extension of the species in Colorado.

15. Artemisia gnaphalodes Nutt. Gen. 2: 143. 1818. Stems white- 
tomentose, usually much branched, 3-12 dm. high: leaves lanceolate or oblong, 3-7 cm. long, 4-12 $\mathrm{mm}$. wide, entire or the lower somewhat toothed, whitetomentose on both sides, acute or acuminate, sessile or the lower narrowed into short petioles: heads numerous, erect, spicate-paniculate, above $3 \mathrm{~mm}$. broad; involucre oblong, tomentose. (A. rhizomata A. Nels. Bull. Torr. Bot. Club 27: 34. 1900; A. pudica Rydb. 1. c. 32 : 130; A. pabularis Rydb. 1. c. 33: 157; probably $A$. candicans and $A$. floccosa Rydb. l. c. 24: 296; A. Purshiana Bess.)-From the Missouri river to the Pacific. This as well as A. ludoviciana includes a multitude of forms impossible of discrimination. Some of the more important ones that have received specific names are indicated and a few are given varietal rank. Leaf outline and incision are wholly valueless as diagnostic characters, since all possible gradations occur in both groups.

15a. Artemisia gnaphalodes diversifolia A. Nels. Many or most of the leaves deeply pinnately cleft into narrow lobes. (A. diversifolia Rydb. l. c. 28: 20. 1901.)-Colorado to Montana.

16. Artemisia ludoviciana Nutt. 1. c. Perennial, ascending or erect, lower than the preceding, 3-5 dm. high, branched; stem somewhat tomentose: leaves oblanceolate or somewhat cuneate in outline, 2-5 cm. long, densely whitetomentose beneath, floccose but greener above, deeply 3-7-lobed with lanceolate lobes, or the upper entire: heads very small and numerous, somewhat nodding; involucre oblong-campanulate, tomentose, but less so than in the preceding. (A. Underwoodii and A. Brittonii Rydb. l. c. 32: 129; A. latiloba Rydb. Mem. N. Y. Bot. Gard. 1: 429. 1900.) - In the western half of North America.

17. Artemisia mexicana Willd. Spreng. Syst. 3: 490. 1825. Paniculately branched, 4-10 dm. high, less tomentose: leaves narrow-lanceolate to linear, commonly attenuate, some 3-5-cleft or parted; radical cuneate, incisely pinnatifid or trifid: heads very numerous in an ample loose panicle, manypedicellate, 3-4 mm. long; involucre arachnoid-canescent or glabrate, largely scarious.-From Nevada through the southern part of our range to Texas.

17a. Artemisia mexicana silvicola (Osterh.) A. Nels. "Distinguished by its fewer and larger leaves, the more lax inflorescence, and larger heads." These differences probably due to the moisture and shade of its habitat. (A. silvicola Osterh. 1. c. 28: 645.) - Northern Colorado, on shaded stream banks.

17b. Artemisia mexicana Bakeri (Greene) A. Nels. A slender form with short, linear, entire leaves on the branchlets and the lower with remote pinnate segments: the whole plant greenish but lightly arachnoid-canescent. ( $A$. Bakeri Greene, Pl. Baker. 3: 31. 1901.) - Cañon of the Gunnison, Colorado.

18. Artemisia paucicephala A. Nels. 1. c. 35. Tufted on woody rhizomes, thinly but permanently silvery-tomentose throughout; stems numerous, leafy to the summit, erect, simple or sparingly branched, 2-4 dm. high: leaves 4-8 $\mathrm{cm}$. long, entire or deeply pinnatifid, linear to lanceolate, some with a broad, 3-5-cleft apex, nearly all with a narrowed, petiole-like base: heads few, racemosely disposed on the main stem and its slender branches (if any), rather large, sessile or short-pediceled, broadly campanulate, about $5 \mathrm{~mm}$. in diameter (40-60-flowered); involucral bracts oval or ovate, scarious-margined: the pistillate flowers few, very slender, with linear-clavate styles. (A. gracilenta A. Nels. 1. c.) Sandy banks near Yellowstone Lake.

19. Artemisia franserioides Greene, Bull. Torr. Bot. Club 10: 42. 1883. Glabrous except on the lower face of the leaves, or minutely and obscurely puberulent; stem rather stout, 4-8 dm. high: leaves comparatively ample, green above, pale and cinereous beneath; the lower bipinnately and the upper simply pinnately parted into lanceolate-oblong obtuse, entire or 2-3-cleft divisions and lobes: heads numerous, loosely racemose on the branches of the leafy elongated panicle, 4-6 mm. broad.-Mountains of Colorado, New Mexico, and Arizona.

20. Artemisia discolor Dougl. in Herb. Hook.; DC. Prodr. 6: 109. 1837. Stems mostly slender, $2-3 \mathrm{dm}$. high, from a slender lignescent caudex: leaves 1-2-pinnately parted into narrow linear or lanceolate-entire or sparingly 
laciniate divisions and lobes, white beneath with close cottony tomentum, glabrate above: heads glomerate in an interrupted spiciform or virgate panicle, $3-4 \mathrm{~mm}$. high; involucre hemispherical-campanulate, greenish and scarious, glabrous or soon becoming so, 20-30-flowered. [A. elatior (T. \& G.) Rydb. as to our range.] - In the mountains; Colorado to Montana and Washington.

20a. Artemisia discolor incompta (Nutt.) Gray, Syn. Fl. 1: 373.1886. Stouter, with coarser or less dissected leaves, having mostly broader lobes, or the upper entire.-Mountains; Wyoming and Montana to California and Washington.

21. Artemisia Bigelovii Gray, Pacif. R. R. Rept. 4: 110. 1856. Silverycanescent throughout, $2-4 \mathrm{dm}$. high: leaves oblong- to linear - cuneate, mostly 3-toothed at the truncate apex, 10-14 $\mathrm{mm}$. long: heads very numerous and crowded in the oblong or virgate thyrsiform panicle, tomentose-canescent, containing only 1 or 2 hermaphrodite and as many pistillate flowers, all fertile.-Rocky banks; Colorado, on the Upper Canadian and Arkansas.

22. Artemisia trifida Nutt. Trans. Am. Phil. Soc. 7: 398. 1841. Silkycanescent; stems 2-6 dm. high, much-branched: leaves 3-cleft toward the apex or 3-parted, the lobes and entire upper leaves narrowly linear or slightly spatulate-dilated: heads numerous in the contracted leafy panicle, or spicately disposed on its branches; involucre 3-9-flowered, the outer or accessory bracts oblong to short-linear or lanceolate. (A. tripartita Rydb. Mem. N. Y. Bot. Gard. 1: 432. 1900.) -Elevated plains in our range and west to the coast States.

23. Artemisia arbuscula Nutt. 1. c. Dwarf, 1-3 dm. high, with a stout base and slender flowering branches: leaves short, cuneate or flabelliform, 3 -lobed or parted, with the lobes obovate to spatulate-linear, sometimes again 2-lobed; those subtending the heads usually entire and narrow: panicle strict and comparatively simple and naked, often spiciform and reduced to few rather scattered sessile heads: involucre 5-9-flowered. (A. spiciformis Osterh. Bull. Torr. Bot. Club 27: 507. 1900.) - High mountains and elevated plains; Colorado and Wyoming to the northwest.

24. Artemisia tridentata Nutt. l. c. A shrub or small tree $0.5-5 \mathrm{~m}$. high, much-branched: leaves cuneate, 15-30 mm. long, 3-7-toothed or lobed at the truncate summit, uppermost cuneate-linear: heads very numerous, in large dense panicles; involucre 5-8-flowered, oblong, the outer or accessory bracts short, ovate-obtuse, tomentose-canescent. The common SAGEBRUSH; also called BLACK SAGE.-Dry plains and mountains; west of the Missouri.

25. Artemisia nova A. Nels. 1. c. 27: 274. The shrubby base low, scraggybranched, the herbaceous stems numerous, fascicled, slender, simple, 1-2 dm. high including the narrow spike-like panicle, grayish with a thin tomentum or merely pubescent, as also are the leaves: leaves very narrowly cuneate, 1-2 cm. long, 3-toothed at apex, the middle tooth usually longest: panicle leafy at base, naked above, strict and nearly simple; heads small, very numerous, only $3-4 \mathrm{~mm}$. long, usually 3 -flowered but often only 1 or 2 ; involucral bracts closely imbricated, greenish, only slightly puberulent.- Hillsides and ridges in the foothills and on the plains; Colorado and Wyoming.

26. Artemisia cana Pursh, Fl. 2: 521. 1814. Shrubby, densely whitecanescent; stem much-branched, 3-7 dm. high: leaves linear, linear-oblong, or narrowly lanceolate, sessile, acute at both ends, 3-5 cm. long, 3-6 mm. wide, usually quite entire, rarely with 2 or 3 acute teeth or lobes: heads numerous, about $3 \mathrm{~mm}$. broad, glomerate or sometimes solitary in the axils of the leaves, or crowded into a naked thyrsus at the summit, 5-9-flowered; involucre oblong, canescent, the inner bracts oblong or lanceolate, obtuse, usually with 1-3 shorter outer ones.-Plains and mountain valleys; throughout our range and to the northwest.

26a. Artemisia cana viscidula Osterh. 1. c. The herbage tending to become glabrate and obscurely viscidulous. (A. viscidula Rydb. Bull. Torr. Bot. Club 33: 157. 1906.)-Colorado and Wyoming. 


\section{Petasites L. Butterbur. Sweet Coltsfoot}

Perennial herbs, with thickish and creeping rootstocks sending up scapiform simple flowering stems and ample radical leaves on strong petioles, cottony-tomentose or glabrate. Flowers whitish or purplish. Involucre a series of soft herbaceous bracts. Heads subdioecious, racemosely or corymbosely disposed. Achenes narrow, 5-10-costate, with elongating soft and white pappus.

1. Petasites sagittata Gray, Bot. Cal. 1: 407. 1880. Leaves deltoid-oblong to reniform-hastate, acute to rounded-obtuse, repand-dentate, very whitetomentose beneath, when full grown 1.5-2 dm. long: heads short-racemose becoming corymbose.-Wet ground; in the mountains of Colorado and northward; across the continent in northern latitudes.

\section{HAPLOESTHES Gray}

Herbs with opposite leaves. Heads radiate; flowers all fertile. Involucre short-campanulate, of 4-5 similar, rather fleshy, orbicular or broadly oval bracts, the outer strongly overlapping the inner. Ligules of the rather few and short ray-flowers oval. Achenes linear, terete, striate-costate, glabrous. Pappus a single series of rather rigid and scabrous whitish bristles.

1. Haploesthes Greggii Gray, Pl. Fendl. 109. 1859. Somewhat fleshy, herbaceous or suffrutescent, 3-6 dm. high, fastigiately branched, glabrous, leafy up to the loose cymes of a few slender-pedunculate naked heads: leaves all opposite, very narrowly linear or filiform, entire; the lower connate at base: heads 4-6 mm. high: flowers yellow: ligules 2-4 mm. long.-Saline soil; southeast Colorado to western Texas.

\section{ARNICA L.}

Perennial herbs with erect stems, mostly opposite leaves, and comparatively large heads of yellow flowers. Heads many-flowered, conspicuously radiate, or the rays rarely wanting. Involucre campanulate, of several thin-herbaceous oblong-lanceolate to linear equal bracts in a single or somewhat double series. Receptacle flat, sometimes fimbrillate or villous. Corollas of the disk-flowers with a commonly elongated hirsute tube and funnelform or cylindraceous 5-lobed limb. Achenes linear, more or less 5-10-costate or angled. Pappus a single series of numerous rather rigid capillary bristles, scabrous to barbellate, or subplumose.

Heads radiate.

Radical or rhizome leaves in fascicles, long-petioled, and with broad and more or less cordate blade.

Stem leaves evidently cordate, at least the lower.

Heads mostly solitary and long-pedunculate .

Heads corymbose or paniculate

Stem leaves suborbicular to ovate-lanceolate.

Plants tall, 4-8 dm. high, with large thin subsessile leaves

Plants rarely $3 \mathrm{dm}$. high.

Leaves glabrate; heads one or more, usually several, the involucres turbinate.

Leaves sparsely but evidently pubescent; heads one or more but usually solitary, the involucres hemispherical . .

No cordate leaves.

Fascicles of oblong or obovate radical or rhizome leaves present.

Involucre turbinate-campanulate, nearly glabrous.

Stem leaves large, broadly ovate or elliptic, thin .

Stem leaves small, ovate or ovate-lanceolate, acute or acuminate

Involucre broadly hemispherical, hirsute

Fascicles of radical or rhizome leaves usually wanting, if present lanceolate or oblanceolate.

Stems leafy throughout.

Not growing in tufts, the plants mostly single.

1. A. cordifolia.

2. A. paniculata.

3. A. ventorum.

4. A. gracilis.

5. A. pumila.

3. A. ventorum.

4. A. gracilis.

6. A. subplumosa. 
Heads large, solitary, or of ten 3, rarely 5, stout-peduncled. Leaf-blades not decurrent

Leaf-blades decurrent on the petioles .

Heads smaller, few to several, on rather short, slender pedicels, often crowded.

Leaves merely grayish, or densely villous or tomentulose. Leaves broadly oblong to lanceolate. Leaves mostly narrowly lanceolate:

Leaves grayish-green with a fine pubescence and often granular-glandular

Growing in clumps or broad caespitose mats.

Leaves long (7-15 cm.), often tapering to a slender acumination

Leaves shorter $\left(3-7^{\circ} \mathrm{cm}\right.$.), oblong-lanceolate.

Rays orange; achenes sparsely hispidulous

Stems more or less naked-pedunculate upward.

Leaves lanceolate to linear.

Heads large, long-pedunculate, usually solitary but often $3-5$; involucral bracts green

Heads smaller, mostly 5 on short-clustered slender peduncles; involucral bracts purple-tipped .

Heads eradiate.

Lower stem leaves broad, very obtuse, decurrent on the petiole.

6. A. subplumosa.

7. A. mollis.

8. A. rhizomata.

9. A. foliosa.

10. A. celsa.

11. A. longifolia.

12. A. arcana.

13. A. Rydbergii.

14. A. fulgens.

15. A. stricta.

7. A. mollis.

16. A. Parryi.

1. Arnica cordifolia Hook. Fl. Bor. Am. 1: 331. 1834. Stems 3-6 dm. high, from creeping rootstocks; herbage pubescent, the stems and peduncles commonly hirsute or villous: lower leaves long-petioled, deeply cordate to ovate, obtuse, dentate; upper leaves small, sessile: heads either solitary and terminating the simple stem or several and long-peduncled in a loose cyme; involucre about $15 \mathrm{~mm}$. high: rays about $2.5-3 \mathrm{~cm}$. long: achenes somewhat hirsute.-In the mountains; Colorado to Montana and west to the Sierras.

2. Arnica paniculata A. Nels. Stems rather stout, 4-7 dm. high, granularpuberulent and sparsely ciliate-hirsute: leaves softly and sparsely hirsute; the radical long-petioled, triangular-lanceolate, mostly with cordate base, the blade 6-10 cm. long; stem leaves 3-4 pairs, ovate-lanceolate; the lower on petioles longer than the blades, smaller and shorter petioled (or sessile) upward: inflorescence an open foliar-bracted panicle of several to many rather large heads, glandular-pubescent on the peduncles and the linear-lanceolate involucral bracts: pappus obscurely scabro-plumose: achenes dark, with short, sparse pubescence.-Mountains of southern Wyoming.

3. Arnica ventorum Greene, Pitt. 4: 173. 1900. Stems 2-4 dm. high, slender, with thin and delicate glabrous foliage: radical leaves orbicular to cordate-ovate, $5-8 \mathrm{~cm}$. long, on petioles as long; the cauline ovate or oblongovate, mostly in 2 pairs only, sessile; all repand-denticulate, delicately ciliolate, otherwise glabrous: heads 1-3, long-peduncled; involucres narrow and somewhat turbinate, of about 10 thin and green elliptic-lanceolate, acuminate, ciliolate, and slightly glandular-puberulent bracts: rays rather few, deep yellow, 7-nerved, 3-dentate, the middle tooth notably larger than the other two: achenes glandular-scabrellous; pappus fine, white. A. latifolia in part. [A. platyphylla A. Nels. Bot. Gaz. 31: 407. 1901; A. grandifolia Greene, 1. c. 172 (?).]-Subalpine; Colorado to Montana and northwestward.

4. Arnica gracilis Rydb. Bull. Torr. Bot. Club 24: 297. 1897. Stem slender, 1-2 dm. high; whole plant glabrous, except a little glandular puberulence on the pedicels and involucre: basal leaves broadly ovate, petioled, dentate, 3-ribbed; stem leaves about 2 pairs, similar, the upper sessile: heads 1-3; disk 10-15 mm. high; bracts 12-15, oblong-lanceolate, acuminate: rays about $15 \mathrm{~mm}$. long: achene almost glabrous. A. latifolia in part.-In the mountains of our range.

5. Arnica pumila Rydb. Mem. N. Y. Bot. Gard. 1: 432. 1900. Stem low, generally 1-2 dm., seldom $3 \mathrm{dm}$. high, more or less hirsute, and the upper portion somewhat woolly and glandular: leaves comparatively firm, ovate, the basal ones petioled; stem leaves 1-2 pairs, very short-petioled or sessile; all puberulent: head turbinate or campanulate, about $2 \mathrm{~cm}$. high; bracts oblonglanceolate, acute, puberulent and slightly villous at the base: achenes slightly 
tapering upward, puberulent. [A. parvifolia Greene, Pl. Baker. 3: 28. 1901; A. coloradensis Rydb. 1. c. 32: 131 (?).]-In the mountains of our range.

6. Arnica subplumosa Greene, Pitt. 3: 104. 1896. Stems erect, 4-8 dm. high, the internodes long, often $10-15 \mathrm{~cm}$., exceeding the leaves or rarely shorter; pubescence of two kinds, a short, dense, glandular puberulence and some scattering white crisped hairs: leaves $3-5$ pairs, denticulate; the lowest oblong-oblanceolate, 6-10 cm. long, on slender petioles often as long; the upper pairs sessile by a broad base, ovate to oblong, 3-12 $\mathrm{cm}$. long: heads 1-3, mostly single and long-peduncled, large; disk 15-20 mm. high, 20-30 $\mathrm{mm}$. broad; rays $10-15,20-30 \mathrm{~mm}$. long, 6-8 $\mathrm{mm}$. broad; involucral bracts 14-20, lanceolate, acute, shorter than the disk: achenes striate, nearly linear, obscurely short-hispid, about $5 \mathrm{~mm}$. long, equaling the sordid, subplumose pappus. A. chamissonis, largely, as to our range. (A. chamissonis longinodosa A. Nels. Bot. Gaz. 30: 199. 1900; A. rivularis Greene, 1. c. 4: 163. 1900.) - Boggy stream banks in the mountains of our range and northwestward.

6a. Arnica subplumosa sylvatica (Greene) A. Nels. Smaller throughout, clammy glandular-pubescent, the internodes shorter than the leaves. ( $A$. sylvatica Greene, Pl. Baker. 3: 27. 1901.) - Wet places in pine and spruce woods.

6b. Arnica subplumosa macillenta (Greene) A. Nels. As tall as the species but less stout, thinner leaved, and less glandular, the pappus scarcely less plumose. (A. macillenta Greene, Pitt. 4: 161. 1900.)-Stream banks at lower stations.

7. Arnica mollis Hook. 1. c. Softly villous, puberulent, or nearly glabrous, 2-4 dm. high: lower leaves broadly ovate or oblanceolate, obtuse, mostly 5-nerved, abruptly tapering into a short, margined petiole, more or less dentate: heads rather larger; the involucral bracts broadly oblong or narrower, acute or obtuse, somewhat villous: rays light yellow: achenes lightly pubescent or glabrate. A. chamissonis in part, but mostly A. latifolia as to our range. (A. latifolia Gray, Bot. Cal. 1: 415. 1885; A. tomentulosa Rydb. 1. c. 28: 20. 1901.) - Northern Wyoming and Montana to the Pacific States.

8. Arnica rhizomata A. Nels. 1. c. 31: 409. June, 1901. Conspicuously rhizomatous, the creeping rootstocks sheathing-bracteate at the nodes, giving rise at intervals to the erect leafy stems and a few fleshy roots; pubescence whitish, soft, almost arachnoid, minutely granular-glutinous underneath the pubescence on the inflorescence; stems 2-5 dm. high: leaves 5-7 pairs, rather uniformly distributed, oblong-lanceolate, obtuse to acute; the lowest pair with short scarious-margined petioles, early deciduous; the next 1 or 2 pairs 6-9 cm. long, about $2 \mathrm{~cm}$. broad, on short, margined petioles which dilate at base to form the short sheaths; the upper pairs sessile, shorter: heads $3-5,10-12 \mathrm{~mm}$. high, or sometimes more numerous and then smaller; peduncles mostly short, erect, the lateral often exceeding the terminal; involucre campanulate, the bracts much shorter than the disk, narrowly oblong, obtusish: corolla long-pubescent on the tube, sometimes a few straggling hairs on the lobes: achenes linear, almost glabrous: pappus fulvous or dirty-white. [A. anulosa Greene, Pl. Baker. 3: 26. Nov., 1901.]-In the mountains of our range.

9. Arnica foliosa Nutt.* Trans. Am. Phil. Soc. 7: 407. 1841. Stems from slender horizontal rootstocks, slender, 3-4 dm. high, erect, leafy, more or less finely granular-glandular and pubescent: leaves 6-10 pairs, ascending or erect, broadly to narrowly lanceolate, entire, subacute or obtuse, smaller upward, all but the uppermost much exceeding the short internodes; petioles slender, dilated at the base and connate, the pair forming a sheath which in the lowest leaves is $2-3 \mathrm{~cm}$. long, the sheath and petioles gradually shorter upward to about the middle of the stem where both become wholly absent: heads 1 -several; if more than 3 , mostly somewhat racemose; terminal head

* A. exigua A. Nels. Bot. Gaz. 30: 202. 1900, may or may not be distinct from this. It is dwarf, branched, and polycephalous, and with the pubescence of A. rhizomata.-Shores of Yellowstone Lake. 
largest; disk 10-12 mm. high, exceeding the oblong, obtusish bracts, about 15 $\mathrm{mm}$. broad; rays about $1 \mathrm{~cm}$. long; lateral heads somewhat reduced; pedicels variable, rather slender, very lightly woolly-pubescent: achenes nearly glabrous, lightly striate, about equaling the soft pappus. (A. ocreata A. Nels. l. c. 30: 201, from which this description is drawn.) - On moist bottom lands at middle altitudes; Colorado to Montana and westward.

10. Arnica celsa A. Nels. 1. c. 31: 408. Stems from horizontal rootstocks, erect, tall, 4-6 dm. high, lightly striate, sparsely pubescent with flat spreading hairs, upwardly becoming also obscurely glandular-viscid: leaves (exclusive of the foliar bracts) 6-8 pairs, puberulent and sprinkled with microscopic, shining resin particles, narrowly oblong or oblanceolate, tapering to both ends, many of them 3-nerved; the lower small, $2-3 \mathrm{~cm}$. long, equaled by the slender petioles which abruptly dilate into the equally long sheaths; middle stem leaves longest $(8-10 \mathrm{~cm}$.), sessile or with short petioles and sheaths; lower internodes short, much exceeded by the leaves, gradually longer upwards and above much exceeding the leaves: heads $3-5$, on rather slender leafy-bracted peduncles; involucral bracts uniserial, oblong, shorter than the $12-15 \mathrm{~mm}$. high disk: rays $12-20,10-14 \mathrm{~mm}$. long: tube of disk-corollas slender and pubescent below: achenes subglabrous, nearly linear.-Rich, moist soils of stream banks; Wyoming and Colorado.

11. Arnica longifolia Eat. in Wats. Bot. King's Exp. 186. 1871. Minutely scabrous-puberulent; stems 3-6 dm. high, many from a scaly caudex: leaves in 5-6 pairs, elongated-lanceolate, acuminate, $15-20 \mathrm{~mm}$. broad, entire or denticulate; the upper pairs sessile and slightly connate-amplexicaul; the lower with sheathing connate petioles; the very lowest reduced to sheathing scales: heads few-many, not large; involucral bracts lanceolate, acute: achenes minutely glandular but not hispid. (A. polycephala A. Nels. 1. c. 30: 202.) In dense clumps among the rocks; infrequent; Colorado to Montana and far westward.

12. Arnica arcana A. Nels. 1. c. 37: 276. 1904. Tufted or caespitose in rock crevices, about $3 \mathrm{dm}$. high, minutely granular-glandular: leaves dark green, denticulate; root leaves oblong-oblanceolate, $2-4 \mathrm{~cm}$. long, on slender petioles longer than the blade; lower stem leaves small, broadly oblong, subacute at apex, abruptly narrowed at base to short-margined connate-sheathing petioles; middle stem leaves lanceolate, sessile or nearly so, $3-5 \mathrm{~cm}$. long: heads usually 3 , on subequal peduncles $5-10 \mathrm{~cm}$. long; rarely 1 or 2 smaller ones; involucre turbinate-campanulate, about $1 \mathrm{~cm}$. high, the bracts in 2 series; the outer broadly linear, short-acuminate, minutely glandular; the inner narrower, subscarious: rays orange-yellow, obscurely 3-toothed: disk-corollas with narrow, minutely pubescent tube as long as the gradually dilated throat: achenes linear, dark, sparsely hispidulous.-Big Horn Mountains, Wyoming.

13. Arnica Rydbergii Greene, Pitt. 4: 37. 1899. Generally 2-4 dm. high, striate, sparingly hirsute, usually with 3 or 4 pairs of stem leaves, and 3 heads: basal leaves ovate-lanceolate with a winged petiole, sinuately dentate, acute; stem leaves similar, sessile, with a broad, clasping, sometimes slightly dilated base: heads decidedly turbinate, 12-15 mm. high; the bracts rather few, 8-16, lanceolate, sparingly hirsute and puberulent: achenes silky-pubescent. ( $A$. caespitosa A. Nels. 1. c.; A. tenuis Rydb. 1. c.; A. aurantiaca Greene, Torreya 1: 42. 1901.)-On dry mountain slopes; Colorado to Montana and Washington.

14. Arnica fulgens Pursh, Fl. 2: 527. 1814. Pubescent, hirsute, or at summit villous; stems $2-4 \mathrm{dm}$. high, strict, simple, usually monocephalous: leaves thickish, narrowly oblong to lanceolate or the radical oblong-spatulate and small, uppermost linear, entire or denticulate, 3-nerved; base of the cauline barely or not at all connate: heads conspicuously radiate, solitary or very few, mostly long-peduncled: achenes hirsute-pubescent, rarely glabrate. A. alpina. (4. pedunculata Rydb. Bull. Torr. Bot. Club 24: 297. 1897; A. monocephala Rydb. Mem. N. Y. Bot. Gard. 1: 435. 1900.)-Colorado to Montana and far northwestward.

15. Arnica stricta A. Nels. 1. c. $31: 407$. Very erect, 2-3 dm. high, tomentose-pubescent throughout: leaves about 5 pairs, the lower 2 or 3 pairs petioled, 
exceeding the internodes; the upper and smaller pairs sessile and distant, giving the upper half of the stem a naked-scapose appearance: inflorescence of about 5 heads in a close corymb; terminal head much the largest, 10-12 mm. high and about as broad; involucral bracts in 2 series, narrowly oblong, obtusish, the tip tinged with purple and tomentose-ciliate: rays few, short, broad: tube of disk-corollas pubescent, the glabrous throat scarcely dilated: achenes very minutely pubescent: pappus dirty-white, minutely scabrous.--Southern Wyoming (Saratoga) and Colorado (Sapinero).

16. Arnica Parryi A. Gray, Am. Nat. 8: 213. 1874. Stems 2-5 dm. high, slender, simple, somewhat hirsutely pubescent and above glandular: leaves commonly denticulate; radical oval to ovate-oblong, 3-8 cm. long, abruptly or cuneately contracted at base into a short-margined petiole; the cauline remote, narrower: involucre hirsute and glandular, $10-14 \mathrm{~mm}$. high; heads rayless, occasionally some outermost corollas ampliate: achenes glabrous or with a few sparse hairs. [A. eradiata (Gray) Heller.]-Throughout our mountains and westward.

\section{TETRADYMIA DC.}

Low rigid shrubs of arid districts. Herbage clothed with dense and matted or floccose wool which is deciduous in some species. Leaves alternate, entire, solitary or fascicled, the primary ones often modified into spines. Involucre cylindric to oblong, composed of 4-6 firm, concave, overlapping bracts which are often enlarged and thickened at base. Heads discoid, 4-9-flowered. Receptacle flat, small. Corollas yellow; lobes spreading, longer than the shortcampanulate throat, much shorter than the elongated tube. Anthers exserted, sagittate at base, the tips triangular-lanceolate. Style-branches flat, obtuse. Achenes terete, faintly 5-nerved. Pappus of fine and soft scabrous capillary bristles, white or whitish.

Involucres 4-flowered; pappus very copious; achenes either villous or glabrate.

Wholly unarmed shrubs.

Leaves permanently woolly-canescent

Leaves small, fascicled, green

Spinescent from the axils

Involucres 5-9-flowered; pappus less copious; achenes white-tomentose

1. T. inermis.

2. T. glabrata.

3. T. Nuttallii.

4. T. spinosa.

1. Tetradymia inermis Nutt. Trans: Am. Phil. Soc. 7: 415. 1841. Wholly unarmed, the shrubby base tufted, much-branched, spreading-assurgent; the herbaceous annual stems numerous, somewhat fascicled, simple or branched, erect, 8-15 cm. long, permanently canescent with a dense, appressed tomentum: leaves numerous but not fascicled, narrowly oblong with tapering ends, acute at apex, nearly sessile, like the stems permanently canescent, 15-25 mm. long, midrib usually evident, the pair of lateral nerves obscure: flowers in very compact terminal clusters of $10-20$ heads with bract-like leaves intermingled: heads 12-14 mm. high, 4-bracted and 4-flowered: pappus copious; achenes villous. (T. multicaulis A. Nels. Bull. Torr. Bot. Club 26: 482. 1899; T. linearis Rydb. Bull. Torr. Bot. Club 32: 130. 1905.)-Throughout our range and scarcely distinguishable from $T$. canescens DC., which is confined mostly to the Pacific States.

2. Tetradymia glabrata Gray, Pacif. R. R. Rep. 11: 122. pl. 5. 1855. Shrub 3-10 dm. high with slender spreading branches, whitened with loose at length deciduous tomentum: leaves at length naked and green, primary ones slendersubulate, cuspidate, on young shoots appressed, $12 \mathrm{~mm}$. long; those of the fascicles in their axils spatulate-linear, fleshy, pointless: heads mostly shortpedunculate; involucre often glabrate: achenes villous.- Scarcely in our range, but reaching Utah from the west.

3. Tetradymia Nuttallii T.\& G.Fl.2: 447. 1841. Shrubby, much-branched, woolly when young, canescent: primary leaves mostly converted into subulate spines; the others densely fascicled in their axils, thickish, linear-spatulate, obtuse, the tomentum somewhat deciduous: heads fascicled and in corymbose 
clusters, on very short peduncles; scales of the involucre 4-5.-Wyoming to Idaho and Utah.

4. Tetradymia spinosa H. \& A. Bot. Beech. 360. 1840. A rigidly branched shrub 6-12 dm. high; stems densely white-tomentose: primary leaves modified into rigid spines which may be either straight or recurved, 1-4 cm. long, tomentose or glabrate; secondary fascicled leaves commonly present, small, linear-clavate, glabrous or early glabrate: heads on stout peduncles arising from the leaf-axils; involucre about $8 \mathrm{~mm}$. high, usually 6 or 7-flowered; bracts 5 or 6 , the outer ones oblong, the inner ones broadly oblong to nearly orbicular, all obtuse: achenes with soft white wool nearly equaling the rigid pappus-bristles.-Desert areas; from Wyoming and Colorado to California and Oregon.

\section{SENECIO L.}

Herbs or woody plants with alternate leaves and with heads in terminal cymes or rarely solitary. Heads many-flowered, radiate or discoid; flowers in our species yellow. Involucre cylindrical to campanulate, of several or numerous connivent-erect herbaceous equal bracts, mostly with 1 or 2 rows of outer erect bracteoles at base, which are elongated and exceed the proper involucre in a few species. Receptacle flat, naked. Anthers mostly rounded at base. Style-branches truncate. Achenes terete. Pappus of abundant white and soft bristles.

Heads large, 15-25 mm. high, usually more or less nodding. Rayless.

Heads 15-20 mm. long.

Heads 8-12 $\mathrm{mm}$. long

Rays present.

Stem leaves clasping

Stem leaves usually short-petioled, not clasping.

Leaves tapering gradually to the petiole.

Plant glabrous

Plant arachnoid-tomentose

Leaves tapering abruptly into the petiole

Heads smaller, less than $15 \mathrm{~mm}$. high, not noticeably nodding.

Biennials or perennials.

Leaves not at all pinnate or pinnatifid.

Stems often numerously and always nearly equably leafy to the top.

Leaves not linear.

Leaves obovate to elliptic, entire to repand-dentate, obtuse.

Peduncles very short

Peduncles distinctly surpassing the leaves :

Leaves triangular to lance-linear, acute.

Some or all of the leaves triangular or lance-cordate .

None of the leaves triangular or lance-cordate.

Stems 5-12 dm. high; leaves sessile, serrate.

Stems $4 \mathrm{dm}$. or less high; leaves petioled. Rays present

Leaves linear
1. S. Bigelovii.

- 2. S. cernuus.

3. S. amplectens.

4. S. Holmii.

5. S. taraxacoides.

6. S. Soldanella.
7. S. carthamoides.

8. S. Fremontii.

9. S. triangularis.

10. S. serra.

11. S. crassulus.

12. S. rapifolius.

40. S. spartioides.

13. S. hydrophilus.

12. S. rapifolius.

11: S. crassulus.

16. S. integerrimus

14. S. glaucescens.

15. S. anacletus.

16. S. integerrimus. 
Teeth of leaves callous-tipped

Teeth of leaves not calloused

Permanently tomentose or hoary.

Stems tall ( $4 \mathrm{dm}$. or more); leaves denticulate or dentate.

Stems leafy to the summit

Stems subnaked above

Stems lower (less'than $4 \mathrm{dm}$.); at least the lower leaves entire . . . . .

Stems scapose, the leaves mostly rosulate on the crowns.

Leaves elliptic to linear-oblanceolate, mostly entire. Leaves linear-spatulate

Leaves elliptic

Leaves reniform, orbicular or obovate, toothed at least at the apex

Leaves, or some of them pinnate or pinnatifid.

Leaves more or less reduced upward.

Stem and leaves more or less floccose, tardily glabrate.

Basal leaves entire, white-tomentose .

Basal leaves, at least some of them, toothed or pinnatifid.

Basal leaves only dentate or crenate.

Plants more or less tufted

Plants usually solitary (not tufted)

Basal leaves, or some of them, more or less pinnatifid. At least some of the tomentum persisting.

Some of the basal leaves simple and serrate or, if pinnate, the terminal lobe much the largest

All of the basal leaves pinnately toothed

All of the tomentum wanting at maturity

Stems and leaves glabrous, or slightly floccose when young only.

Rays present.

Heads several to many.

Leaves fleshy-thickened.

Basal leaves tapering gradually to the petiole, variously toothed

Basal leaves abruptly contracted into the petiole, some of them deeply toothed or pinnately lobed.

Upper leaves sessile by an enlarged base

Upper leaves not dilated at base

Leaves thin

Heads solitary (rarely two)

Basal leaves cordate, oval, or obovate.

Basal leaves larger than the others

Basal leaves small and soon deciduous.

Basal leaves obovate to oblanceolate, never cordate.

Stem leaves closely pinnatifid

Stem leaves with few short broad pinnae

Rays wanting

Leaves equable in size and distribution.

Leaves pinnately or bipinnately toothed

Leaves with few to many linear-filiform lobes.

Plants more or less permanently tomentose

Plants glabrous or soon glabrate.

Most of the leaves pinnately divided

Annual, often a weed.
14. S. glaucescens.

17. S. perplexus.

18. S. atratus.

19. S. altus.

20. S. canus.

21. S. werneriaefolius.

22. S. perennans.

23. S. petrocallis.

20. S. canus.

24. S. Nolsonii.

25. S. Fondleri.

26. S. plattensis.

25. S. Fendleri.

27. S. uintahensis.

30. S. cymbalarioides.

27. S. uintahensis.

31. S. subnudus.

32. S. pseudaureus.

33. S. longipetiolatus.

34. S. Balsamitae.

35. S. mutabilis.

36. S. discoideus.

37. S. eremophilus.

38. S. filifolius.

39. S. Riddellii.

40. S. spartioides.

41. S. vulgaris.

1. Senecio Bigelovii Gray, Pacif. R. R. Rep. 4: 111. 1857. Robust, 4-8 $\mathrm{dm}$. high, leafy nearly to the racemiform or simply paniculate inflorescence, at length glabrate: leaves elongated-oblong to lanceolate, denticulate or dentate, acute or acuminate; the radical and lower cauline 1-2 dm. long, abrupt at base and naked-petioled, or tapering into a winged petiole or partly clasping base; the upper cauline lanceolate with partly clasping base: heads rayless, nodding, in small plants few or solitary. S. contristatus Greene, Pl. Baker. 3: 24. 1901; S. chloranthus Greene, Pitt. 4: 118. 1900.-In the mountains of southern Colorado, and in adiacent New Mexico and Arizona.

1a. Senecio Bigelovii Hallii Gray, Proc. Phila. Acad. 67. 1863. Leaves almost all lanceolate, more or less woolly-pubescent, hairs articulated; cauline leaves all sessile or the lowest contracted into a winged petiole: heads 
few-several, rarely solitary. (S. scopulina Greene, 1. c. 117.)-In the mountains of Colorado and southern Wyoming.

2. Senecio cernuus Gray, Am. Journ. Sci. 33: 239. 1862. Quite glabrous, 4-8 dm. high: leaves lanceolate or the larger oblong-lanceolate, entire, denticulate, rarely with a few scattered coarser teeth, all tapering at base into a barely margined petiole, or the upper into a narrowed not clasping base: heads several or numerous in the panicle, most of them decidedly nodding: flowers pale yellow. (S. pudicus Greene, 1. c. 118; S. accedens Greene, Erythea 3: 105. 1895, probably.) - In the mountains of Colorado and New Mexico.

3. Senecio amplectens Gray, 1. c. 240. Lightly floccose-woolly at first, soon glabrate, 2-3 dm. high, few-several-leaved, terminated by 1 or 2 longpedunculate nodding heads: leaves denticulate to conspicuously and sharply dentate; the radical obovate to spatulate, tapering into a winged petiole; the cauline as large or larger, oblong or narrower, half-clasping or more, the upper by a broad base: involucre dark-pubescent, 15-20 mm. high, of linear bracts and a few loose calyculate ones: rays linear, $2 \mathrm{~cm}$. or more long, acute or acutely 2-3-toothed at tip.-Alpine and subalpine region; mountains of Colorado.

4. Senecio Holmii Greene, Pitt. 4: 120. 1900. Commonly 1-2 dm. high, the stoutish stems mostly several from a branching rootstock, leafy at base only, the pedunculiform stem with only 1 or 2 reduced leaves; herbage appearing glabrous, minutely hirtellous at base of involucre, on the peduncles, and occasionally the leaf-margins: leaves ovate to obovate and oblonglanceolate, callous-dentate or denticulate, 5-10 cm. long, on petioles nearly as long: heads 1-5, large and nodding: rays $20 \mathrm{~mm}$. long or more, 5-7-nerved. (S. pagosanus Heller, Muhl. 1: 7. 1900; S. lactucinus Greene, 1. c. 121. 1900, not S. lactucinus Greene, Erythea 3: 223. 1893. 1. c.)-In the alpine regions of Colorado.

5. Senecio taraxacoides (Gray) Greene, 1. c. 119. Dwarf, the leafy and usually monocephalous stem only $5-8 \mathrm{~cm}$. high, erect from an erect rather stout and fleshy rootstock; herbage, the involucre excepted, permanently arachnoid-tomentulose: leaves $3-5 \mathrm{~cm}$. long, more or less runcinate-pinnatifid, the whole leaf-margin commonly revolute: head only horizontally nodding; involucre dark green, glabrous except for a few white arachnoid hairs: rays 10-14 mm. long, light yellow, 4-nerved.-Alpine in the Colorado mountains.

6. Senecio Soldanella Gray, Proc. Acad. Phila. 67. 1863. Apparently glabrous from the first, $8-14 \mathrm{~cm}$. high, somewhat succulent: leaves mostly radical and long-petioled, round-reniform to spatulate-obovate, denticulate or entire; the cauline 1, or 2 , or none: head solitary, erect, $18-25 \mathrm{~mm}$. high; involucral bracts lanceolate and a very few calyculate ones: rays 6-10, oblong, 7-10 mm. long.-High alpine, in the mountains of Colorado.

7. Senecio carthamoides Greene, 1. c. 122 . Stems tufted, decumbent, and becoming leafless below, the whole plant 1-3 dm. high: leaves variously obovate and obovate-oblong, commonly $4-5 \mathrm{~cm}$. long or more, sessile by a broad somewhat hastate and clasping base, the margin coarsely and doubly dentate, the teeth callous-tipped: heads 10-14 mm. high, erect, subcampanulate, either very short-peduncled or subsessile and scarcely exceeding the subtending foliage, few-many: rays short, not as long as the diameter of the head: achenes short, canescent with a minute strigillose pubescence. S. Fremontii. (S. blitoides Greene and S. invenustus Greene, 1. c. 123 \& 124.)-Among the rocks in alpine stations; Colorado.

8. Senecio Fremontii T. \& G. Fl. 2: 445. 1842. Very near the preceding, smaller, the stems persistently leafy to the base: leaves smaller, relatively broader, often oval to orbicular: heads on longer peduncles distinctly surpassing the foliage. (S. Fremontii occidentalis Gray in part, not S. occidentalis Greene, l. c., which is a plant of Nevada and California; S. occidentalis rotundatus Rydb. Mem. N. Y. Bot. Gard. 1: 438. 1900.)-High mountains; northwest Wyoming and in Idaho and Montana.

9. Senecio triangularis Hook. Fl. Bot. Am. 1: 332. 1834. Rather stout, glabrate; stem simple, 6-15 dm. high, bearing several or somewhat numerous heads in a corymbiform open cyme: leaves all more or less petioled and 
thickly dentate, deltoid-lanceolate or the lower triangular-hastate or deltoidcordate and the uppermost lanceolate with cuneate base: heads about $12 \mathrm{~mm}$. high; involucre campanulate, mostly 25-30-flowered, the oblong-linear rays 6-12. (S. saliens Rydb. Bull. Torr. Bot. Club 24: 298. 1897; S. trigonophyllus Greene, Pitt. 3: 106. 1896.) - Wet places in the mountains of our range and westward to the coast States.

10. Senecio serra Hook. 1. c. 333 . Strict, 7-12 dm. high, very leafy, commonly branching at summit, and bearing numerous corymbosely paniculate smaller heads: leaves 8-14 cm. long, all lanceolate and tapering to both ends, sessile by a narrow base, or the lowest short-petioled, usually with the whole margin thickly serrate or serrulate with very acute salient teeth: involucre oblong-campanulate, $20-30$-flowered: rays $5-8$, oblong-linear. ( $S$. andinus Nutt. Trans. Am. Phil. Soc. 7: 409. 1841; S. serra integriusculus Gray, Syn. Fl. 1: 387. 1886.)-Along streams, middle elevations and upward; Northern Wyoming, northward and westward.

10a. Senecio serra admirabilis (Greene) A. Nels. Not constantly separable from the species, usually of more vigorous growth and with fewer and larger heads but these often 40 or more. (S. admirabilis Greene, Erythea 3: 23. 1895.) - In the mountains of Colorado and southern Wyoming.

11. Senecio crassulus Gray, Proc. Am. Acad. 19: 54. 1883. Stems 2-4 dm. high, glabrous, 5-7-leaved, bearing 3-8 pedunculate rather large and thick heads: leaves oblong-lanceolate, apiculate-acute, 5-21 cm. long; the radical and lowest cauline spatulate or obovate-oblong, narrowed into a short-winged petiole; the upper sessile by partly clasping or decurrent base: involucre 40-50flowered, of 12 fleshy-thickened but thin-edged bracts, the base also thickened, the whole becoming conical and many-angled in fruit: rays about 8. (S. semiamplexicaulis Rydb. Mem. N. Y. Bot. Gard. 1: 440. 1900; S. lapathifolius Greene, Pl. Baker. 3: 25. 1901.) - In the mountains of our range.

12. Senecio rapifolius Nutt. Trans. Am. Phil. Soc. 7: 409. 1841. Stem rather low, only $2-4 \mathrm{dm}$. high: leaves ovate or oblong, very sharply and unequally dentate throughout, somewhat fleshy; the radical tapering into a petiole; the cauline clasping by a broad subcordate base: heads numerous, cymose-paniculate, only $5-6 \mathrm{~mm}$. high, always rayless, about 15 -flowered.Middle elevations on the eastern slope of the Rocky Mountains.

13. Senecio hydrophilus Nutt. 1. c. Very glabrous and smooth, tall, strict and simple-stemmed, with a cluster of coarse fibrous roots, $5-15 \mathrm{dm}$. high: leaves fleshy-coriaceous, all entire or barely denticulate, mostly lanceolate; the radical oblanceolate and stout-petioled, sometimes $3 \mathrm{dm}$. long; the upper cauline sessile or partly clasping: heads numerous in a branching cyme; bracts 8-12: disk-flowers 15-30: rays $3-6$ and small, or none. (S. hydrophiloides Rydb. 1. c. 441.; - In wet or partially flooded grounds; throughout our range and northward and westward.

14. Senecio glaucescens Rydb. 1. c. The short caudex with a cluster of fibrous roots, glabrous or at first slightly hairy; stem $2-7 \mathrm{dm}$. high, striate, shining, often tinged with red: basal leaves and lower stem leaves $5-10 \mathrm{~cm}$. long, spatulate or oblanceolate or even oval, callous, dentate or very rarely subentire, acute or obtuse, with a distinct winged petiole, rather thick and often somewhat glaucous; upper stem leaves reduced, lanceolate and sessile: cyme corymbiform; heads about $1 \mathrm{~cm}$. high; bracts linear-lanceolate, acute, with conspicuous black tips: rays about $8 \mathrm{~mm}$. long: achenes oblong-cylindric, glabrous. (S. exaltatus Nutt. 1. c. as to our range; S. Flintii Rydb. Bull. Torr. Bot. Club 33: 157. 1906.)-Colorado and Utah to Montana and Idaho.

15. Senecio anacletus Greene, Pitt. 4: 307. 1901. Stem 3-6 dm. high, from a short rootstock or caudex: leaves thickish and firm; the radical obovate to oblong, obscurely veiny, mostly acute, numerously denticulate, $5-15 \mathrm{~cm}$. long, tapering into shorter wing-margined petioles; the cauline sessile, few and oblong-lanceolate, or commonly only 1 or 2 small and bract-like ones subtending the rather few-headed branches of the cyme: heads 10-12 mm. high; involucral bracts linear: rays 6-10, conspicuous. (S. microdontus Heller, Bull. Torr. Bot. Club 24: 497. 1897.)—Southern Colorado, New Mexico, and Arizona. 
16. Senecio integerrimus Nutt. Gen. 2: 165. 1818. Stem simple, strict, 3-5 dm. high: leaves somewhat fleshy, wholly glabrous and entire; the lower oblong-lanceolate or elongated-oblong; the upper becoming gradually much reduced and linear-lanceolate: heads few, mostly in a simple corymb or in a subumbellate cyme, medium size with rather conspicuous rays; bracts of the involucre narrow.-This species seems to occur in just the form originally characterized, and when thus limited it is a plant of the plains region adjacent to the "Great Bend" of the Missouri, hence scarcely in our range.

17. Senecio perplexus A. Nels. Bull. Torr. Bot. Club 27: 271. 1900. Rootstock short, with numerous semifleshy roots; the single stem erect, rather stout, 2.5-5 dm. high, loosely arachnoid or floccose-woolly when young as are also the leaves, becoming glabrate but usually some of the woolly hairs persisting even at maturity, rather leafy below; leaves entire or denticulate, often crisped on the margin; the lower leaves oblanceolate or broader or tapering uniformly to both ends, mostly obtuse, 5-10 cm. long, the margined petiole usually shorter than the blade; the middle leaves mostly sessile and narrower; the uppermost small and bract-like: heads several (8-15), in a cymose corymb, 10-12 mm. high, the central peduncles very short, the lower or outermost elongating and often overtopping the others; the rays conspicuous, few (5-10); the involucral bracts linear, black-tipped, about $7 \mathrm{~mm}$. long: achenes brownish, finely striate, glabrous, linear, equaling or longer than the fine soft pappus. S. lugens of the Manual and of Gray's Syn. Fl., in large part. (S. columbianus Rydb. in FI. Col., not S. columbianus Greene, of which S. atriapiculatus Rydb. is a synonym.)-Exceedingly common at middle elevations in our range.

$17 a$. Senecio perplexus dispar A. Nels. Merely one of the many forms of this variable species, characterized by its somewhat greater size, the somewhat longer and slender petioles, and the striking inequality in the length of the rays of the subumbellate cyme. (S. dispar A. Nels. 1. c. $272 ;$ S. Hookeri $\mathrm{Rydb}$. in Fl. Col., not of Gray.) - Same range as species.

18. Senecio atratus Greene, Pitt. 3: 105. 1896. Stems 'several or many, tufted, decumbent at base, stoutish, 3-6 dm. high, leafy up to the dense compound corymbiform cyme of small heads; herbage finely tomentose even in maturity: radical leaves $1.5-2.5 \mathrm{dm}$. long, oblanceolate, acutish, dentate or denticulate, those of the stem smaller and gradually diminished in size toward the inflorescence: bracts of the narrow involucre only 8 or 10 , firm, oblong, obtuse, either wholly black or the inner ones with blackened midvein and tip: rays few or none; disk-corollas salmon-color: achenes greenish, glabrous; pappus firm, persistent. S. lugens foliosus in part. (S. milleflorus Greene, Pitt. 4: 116. 1900.)-In the mountains of Colorado.

19. Senecio altus Rydb. Mem. N. Y. Bot. Gard. 1: 443. 1900. Stems 6-10 dm. high, striate, sparingly woolly when young, leafy below: basal leaves 2-3 dm. long, rather firm, oblanceolate, tapering into a winged petiole, sinuately dentate, more or less woolly when young; lower stem leaves similar, smaller, short-petioled or subsessile, the upper much reduced, bract-like, linear-lanceolate, distant: heads in a contracted corymbiform cyme, about $1 \mathrm{~cm}$. high; bracts linear, rather thick, brownish and tipped with black: rays about $8 \mathrm{~mm}$. long: achenes hispidulous, especially on the angles, short. $S$. lugens foliosus in part.-Wet meadows at middle altitudes; Wyoming, Montana, and Idaho.

20. Senecio canus Hook. Fl. Bor. Am. 1: 333. pl. 116. 1834. Perennial, densely and persistently white-tomentose to the inflorescence; stems slender, usually tufted, 1-3 dm. high: basal and lower leaves spatulate or oval, entire, or rarely somewhat repand, very obtuse, $3-5 \mathrm{~cm}$. long, narrowed into petioles; upper leaves oblong or spatulate, obtuse or acute, mostly sessile, smaller, entire or dentate: heads several or numerous, $10-14 \mathrm{~mm}$. broad, usually slenderpeduncled; involucre campanulate, or at first short-cylindric; the bracts linearlanceolate, acute, sparingly tomentose or glabrate, usually with no exterior smaller ones: rays 8-12: achenes glabrous, at least below. (S. Harbourii Rydb. Bull. Torr. Bot. Club 33: 158. 1906; S. Howellii Greene, Bull. Torr. 
Bot. Club 8: 98. 1881.)-Dry hills; Colorado to Montana and far northwestward.

$20 a$. Senecio canus Purshianus' (Nutt.) A. Nels. Usually lower, more densely tufted, and the leaves largely linear. (S.'Purshianus Nutt. Trans. Am. Phil. Soc. 7: 412. 1841.)-Dry slopes and ravines; Colorado to Montana and Oregon.

21. Senecio werneriaefolius Gray, Proc. Am. Acad. 19: 54. 1883. Woolly and canescent, tardily glabrate: leaves thick and coriaceous, tapering into a petiole, crowded on the multicipital caudex, quite entire, erect or ascending, spatulate-linear ( $5-8 \mathrm{~cm}$. long, including the petiole-like base) to elongatedoblong and short-petioled, the margins sometimes revolute: scape about $1 \mathrm{dm}$. high, rather stout, bearing $2-8$ heads, which are $8-10 \mathrm{~mm}$. high: rays $10-12$, oblong, 3-4 mm. long, rarely few or wanting.-Alpine; mountains of Colorado.

22. Senecio perennans A. Nels. 1. c. Caespitose in habit or surculosespreading, forming large mats; stems simple, 1-2 dm. high: leaves crowded on the crowns of the caudex and at the base of the scapose stems, of 2 forms; the larger narrowly elliptic to oblong, $2-4 \mathrm{~cm}$. long, obtuse or acute or more rarely 3 -toothed, tapering into a petiole as long as the blade or longer, nearly glabrous at flowering; the smaller leaves tomentose, interspersed bractlike among the larger ones; bract-like leaves of the scape small, linear from a broad tomentose base: heads $3-8$, or rarely only 1 or 2 , cymose-corymbose, the terminal one overtopped by most of the others, $9-12 \mathrm{~mm}$. high: rays $5-9$, oblong-elliptic, 5-7 mm. long: achenes glabrous.-Moist places on cañon sides; Wyoming and Colorado, at middle elevations.

23. Senecio petrocallis Greene, Pitt. 4: 116. 1900. Glabrous or early glabrate: leaves orbicular-obovate or oval (7-14 mm. long) to cuneate-oblong, entire or 3-7-crenate-toothed at the broad summit, abruptly petioled: scapes 3-10 mm. high, bearing solitary or several clustered heads, which are 8-10 $\mathrm{mm}$. high: rays 6-10, golden-yellow, 5-6 mm. long. S. petraeus.-High alpine throughout our range.

24. Senecio Nelsonii Rydb. 1. c. 26: 483. 1899. Many-stemmed from a densely tufted caudex whose numerous branches are reduced to short leafy crowns, green and becoming glabrate, the thin tomentum in part deciduous: leaves numerous, crowded on the crowns, and several on the stems, oblong, lanceolate, or oblanceolate, pinnately toothed to deeply lobed or sometimes divided nearly to the midrib; the segments obtuse or acute, often incisely toothed; stem leaves slightly reduced upward: stems $2-4 \mathrm{dm}$. high, simple, terminating in a crowded corymbose cyme, the upper pedicels subumbellate: heads $7-10 \mathrm{~mm}$. high; calyculate bracts small, only 1 or 2: rays few (6-12), rather large: achenes brown, glabrous, distinctly striate, $2-3 \mathrm{~mm}$. long. (S. rosulatus Rydb. 1. c. 27: 188. 1900.)-Gravelly banks and slopes; Wyoming and Colorado.

25. Senecio Fendleri Gray, Pl. Fendl. 108. 1848. Very cañescent with floccose wool, the stem in part and the leaves on the upper surface becoming glabrate in age; stem solitary or few from the crown, erect, $2-5 \mathrm{dm}$. high: leaves rosulate on the crown and scattered on the stem, generally all of them sinuate or pectinate-dentate, but the lower of ten barely sinuate: heads several, in corymbose cyme: rays 6-9, usually less than $1 \mathrm{~cm}$. long: achenes glabrous. [S. salicinus and S. canovirens Rydb. Bull. Torr. Bot. Club 27: 186 \& 187. 1900; S. lanatifolius Osterh. Bull. Torr. Bot. Club 32: 612. 1905 (?). The last has been collected but once and the specimens look as if they might be abnormal.] Southern Colorado, New Mexico, and probably Arizona.

26. Senecio plattensis Nutt. l. c. Perennial, more or less densely and persistently tomentose or woolly-canescent; stems rather stout, solitary, or sometimes tufted, 3-4 dm. high: basal leaves oval, ovate, or oblong, some or all of them more or less pinnatifid, with the terminal segment much larger than the lateral ones, crenulate or dentate, long-petioled: heads several or numerous, compactly or loosely corymbose, conspicuously radiate.-In the eastern part of our range to the Missouri.

27. Senecio uintahensis A. Nels. Perennial from a short caudex, which is 
often branched at summit, generally early glabrate throughout; stems few or many and tufted, $2-4 \mathrm{dm}$. high: leaves crowded on the crowns, rather remote on the stems, Jyrately pinnatifid, the lobes either obtusely or acutely and irregularly toothed: heads few to many in a corymbose cyme, 8-10 mm. high; calyculate bracts small, few or wanting: achenes glabrous. (S. Nelsonii uintahensis A. Nels. 1. c. 26: 484.) Closely allied to S. multilobatus T. \& G. Pl. Fendl. 109. 1848, which is a winter annual or biennial, extending from southern Utah to Arizona and western Texas.-Western Colorado and eastern Utah to Wyoming and Idaho.

28. Senecio Rydbergii A. Nels. Simple and glabrous perennial with a very short caudex; stem $2-3 \mathrm{~cm}$. high: basal leaves oblanceolate, thick and somewhat fleshy, with the petiole about as long as the blade, dentate or subentire; lower stem leaves spatulate, with a winged petiole, coarsely dentate; upper stem leaves sessile, with an auricled base, lobed with triangular or triangularlanceolate lobes, acute: cyme corymbose and rather dense; heads about $8 \mathrm{~mm}$. high; bracts about 15, acute, the lanceolate ones few, lanceolate: achene striate, glabrous: rays 4-5 mm. long. (S. fulgens Rydb. l.c. 177, not S. fulgens Nichols.)-Throughout the mountains of northern Wyoming into Idaho and Montana.

29. Senecio crocatus Rydb.1. c. 24: 299. 1897. A glabrous perennial with a short erect rootstock; stem 1.5-3 dm. high: basal leaves $2-3 \mathrm{~cm}$. long, obovate or spatulate, crenate or subentire, with a winged petiole; lower stem leaves similar, but with broader winged petioles which are somewhat auricled at the base, or else oblong without distinction between blade and petiole and then more auricled; upper stem leaves ovate or triangular, with very large and large-toothed auricles: cyme small and compact with heads, which are 8-10 $\mathrm{mm}$. high; bracts about 20 , linear: rays $7-8 \mathrm{~mm}$. long, orange to pale yellow: achenes striate, glabrous. S. aureus croceus. (S. dimorphophyllus Greene, Pitt. 4: 109. 1900; S. heterodoxus Greene, acc. to Rydb. Fl. Col.)-Colorado and Wyoming.

30. Senecio cymbalarioides Nutt. Trans. Am. Phil. Soc. 7: 412. 1841. Closely allied to the preceding, generally lower but sometimes $4 \mathrm{dm}$. high: radical leaves thickish, obovate, cuneate-spatulate and oval, the petioles not wing-margined, and the upper leaves not auricled-clasping: corymb of few or numerous heads with rays varying from yellow to orange: achenes angled, glabrous. S. aureus borealis. (S. Jonesii, S. subcuneatus, S. acutidens Rydb. l. c. 179 \& 180 , and $S$. oodes Rydb. l.c. $33: 158$ seem to be impossible to discriminate satisfactorily.) - In the mountains of our range.

31. Senecio subnudus DC. Prodr. 7: 428. 1837. Very glabrous throughout; stems often decumbent at base, simple, slender, 1-3 dm. high, nearly leafless above and usually bearing a single head: radical leaves obovate, slenderpetioled, coarsely dentate; the cauline very few, sessile, oblong to linear, incised or somewhat pinnatifid: involucre open-campanulate, $8-10 \mathrm{~mm}$. high, of linearacute bracts: rays 8-12, elongated-oblong: achenes glabrous, striate. $S$. aureus subnudus. (S. solitarius Rydb. Mem. N. Y. Bot. Gard. 1: 444. 1900.)In marshy grounds; from Wyoming and Montana to California and Oregon.

32. Senecio pseudaureus Rydb. Bull. Torr. Bot. Club 24: 298. 1897. Perennial from a creeping rootstock, perfectly glabrous except the tips of the bracts; stem 5-8 dm. high: basal leaves broadly ovate, somewhat cordate at the base, serrate, 4-7 cm. long, long-petioled; stem leaves more or less laciniate at the base, the upper sessile: inflorescence corymbose, flat-topped, of 8 or more heads about $8 \mathrm{~mm}$. high; bracts linear; rays orange, about $8 \mathrm{~mm}$. long. S. aureus. (S. platylobus Rydb. 1. c. 27: 181; S. Hartianus Heller, Bull. Torr. Bot. Club 26: 622, 1899.)-Replacing the true S. aureus throughout our range.

33. Senecio longipetiolatus Rydb. 1. c. 176. A tall, simple, perfectly glabrous perennial, with a short, erect rootstock; stem strict, 3-6 dm. high, terete: basal leaves oblanceolate, 5-12 cm. long, with a slender petiole, serrate to subentire; lower stem leaves similar; the upper reduced, lanceolate, sessile, sharply serrate or laciniate-dentate, often auricled at the base: cyme 
dense, corymbiform; heads $8-9 \mathrm{~mm}$. high; bracts about 20 , linear, acute, the calyculate ones few, minute: rays dark orange, 4-7 $\mathrm{mm}$. long, 3-4-nerved: achenes angled, glabrous. (S. pyrrhochrous Greene, Pl. Baker. 3: 24. 1901; S. Tracyi Rydb. 1. c. 33: 159.)-Wyoming and Colorado.

34. Senecio Balsamitae Muhl. Willd. Sp. Pl. 1999. 1804. Light or yellowishgreen slender perennial, in age glabrate or slightly floccose at the base of the leaves; stem 3-4 dm. high, striate, pale: basal leaves $3-8 \mathrm{~cm}$. long, obovate or broadly oval, generally tapering into the petioles, but sometimes truncate at. the base, obtuse, crenate or sinuate, light green; lower stem leaves oblanceolate in outline and petioled; the upper lanceolate or linear in outline and sessile; all deeply pinnatifid with narrow oblong or linear segments: cymes corymbiform; heads 7-8 mm. high; bracts linear, acute; calyculate ones few, linear, small and crisped: rays yellow, about $6 \mathrm{~mm}$. long: achenes hispid-puberulent on the angles. S. aureus Balsamitae. (S. flavulus Greene, Pitt. 4: 108. 1900; S. flavovirens and S. aurellus Rydb. l. c. $181 \& 182$.)-Across the continent; ours thought by some to be distinct; if so, the name S. flavulus will stand.

35. Senecio mutabilis Greene, 1. c. 113. Stems in a small dense tuft, erect or ascending, 1-3 dm. high; pubescence varied, from tomentulose or loosely floccose-hoary to almost or quite wanting: leaves obovate-spatulate to broadly linear or lanceolate, nearly entire or serrate to sinuately or pectinately or even somewhat lyrately pinnatifid, the apex often tridentate: heads few to many, 8-10 mm. high, the involucres glabrous: rays mostly tridentate and 4-nerved, light yellow to nearly orange-color. S. aureus compactus. (S. compactus Rydb. Mem. Torr. Bot. Club 5: 342. 1893, not S. compactus Kirk; S. oblanceolatus and S. tridenticulatus Rydb. Bull. Torr. Bot. Club 27: 175 \& 176. $1900 ;$ S. condensatus Rydb. Fl. Col., not S. condensatus Greene, which is a plant of the Blue Mountains, Washington.)-Wyoming to New Mexico and Utah.

36. Senecio discoideus (Hook.) Brit. Ill. Fl. 3: 479. 1898. Perennial, glabrous except for small tufts of wool in the axils of the lower leaves; stem rather stout, 3-6 dm. tall: basal leaves oval to ovate, obtuse, thin, sharply dentate, abruptly narrowed into petioles longer than the blade; stem leaves few, small, more or less laciniate: heads few or several, slender-peduncled, corymbose; bracts of the involucre narrowly linear, 6-10 $\mathrm{mm}$. long: rays usually very short, or none. S. aureus discoideus. (S. fedifolius Rydb. l. c. 183; S. nephrophyllus Rydb. Mem. N. Y. Bot. Gard. 1: 446. 1900.)-Wet places in the valleys in our range; across the continent northward.

37. Senecio eremophilus Rich. App. Frankl. Journ. 2: 31. 1823. Stems freely branching, leafy up to the inflorescence: leaves mostly oblong in outline, laciniately pinnatifid or pinnately parted, the lobes usually incised or acutely dentate: heads numerous in corymbiform cymes, $8-10 \mathrm{~mm}$. high, shortpeduncled; involucre campanulate or narrower, minutely bracteolate; proper bracts commonly purple-tipped: rays $7-9,4-6 \mathrm{~mm}$. long: achenes either minutely papillose-cinereous or glabrous. (S. MacDougallii Heller, 1. c. 592.)Extending southward through the Rocky Mountains (from British America) to New Mexico and Arizona.

38. Senecio filifolius Nutt. Trans. Am. Phil. Soc. 7: 414. 1841. More or less permanently tomentose; stems suffruticose at base, much-branched, the branches diffuse, very leafy to the summit: leaves pinnately 5-9-parted; the segments very narrowly linear, entire, obtusish, often unequal, mostly with revolute margins: heads (rather large) corymbose, on short peduncles, calyculate with a few small subulate scales: rays about 7, linear, somewhat elongated: achenes strigose-canescent.-In valleys; from Colorado and Utah to Arizona and Texas.

39. Senecio Riddellii T. \& G. Fl. 2: 444. 1842. Glábrous throughout; stem terete, very leafy, corymbose at the summit: cauline leaves pinnately 5-9parted; the segments narrowly linear, obtuse, entire, flat, somewhat dilated towards the apex (thickish and rather rigid): heads (large and showy) on short peduncles, disposed in a compound corymb, calyculate with subulate bracts: rays about 12 , linear, elongated: achenes minutely puberulent. ( $S$, 
multicapitatus Greenm. ex Rydb. 1. c. 33: 160.)-Nebraska and Colorado to Texas and Arizona.

40. Senecio spartioides T. \& G. 1. c. 438 . Glabrous throughout; stems suffruticose, $2-4 \mathrm{dm}$. high, very numerous from the same ligneous taproot, rigid, corymbose at the summit, leafy: leaves fleshy, narrowly linear, perfectly entire or sparingly pinnately parted, rather obtuse, sessile: heads (large and showy) fastigiate-corymbose, on short minutely bracteolate peduncles: the calyculate bracts subulate, minute; bracts of the cylindrical involucre about 12, lanceolate-linear, acutish: rays mostly 7 , oblong-linear, elongated: achenes silky-canescent. This and the two preceding were included in the Manual under S. Douglasii, a Californian species.-Wyoming to Arizona and Texas.

41. Senecio vulgaris L. Sp. Pl. 867. 1753. An erect annual, 1-3 dm. or more high; herbage somewhat succulent, glabrous or with a little loose tomentum: leaves sessile, auricled, pinnatifid, the lobes oblong and with irregularly dentate margin: heads in terminal cymose clusters; involucre 6 or $7 \mathrm{~mm}$. high; principal bracts about 20, their tips black and often penicillate; small outer bracts several, black: achenes slightly pubescent.-Occasionally found in waste grounds; introduced from Europe; flowering the whole season through; commonly called GROUNDSEL.

\section{CARDUUS L. ThistLe}

Stout herbs, mostly biennial. Leaves mostly sessile or decurrent, and with sharply spinose lobes or teeth. Heads large, ovoid or subglobose; the pluriserial and imbricated involucral bracts usually prickly tipped. Receptacle densely villous-setose. Flowers all alike, crimson, purple, or white, the segments of the corblla long and linear-filiform. Achenes obovate or oblong, compressed, smooth, not striate. Pappus a single series of long and barbellate or plumose slender bristles united at base and deciduous in a ring, often clavellate-dilated at the naked tip.-Cnicus.

Dioecious; heads small; perennial by spreading rootstocks

Hermaphrodite; heads larger; biennials or rarely perennials.

Bracts of the involucre (at least most of them) with notably dilated fringed tips.

Bracts conspicuously arachnoid-pubescent; foliage green and becoming glabrate

Bracts not arachnoid-pubescent or only slightly so on the edges; foliage green above, more or less white-lanate be-

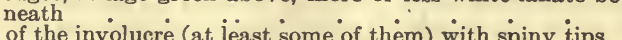

Bracts of the involucre (at least some of them) with spiny tips.

Bracts not with a glandular dorsal ridge.

Bracts conspicuously arachnoid-pubescent .

Bracts not arachnoid or only moderately so on the edges. Inner bracts innocurous, long-attenuate.

More or less dilated, crisped, twisted, or laciniate .

Usually not at all dilated, crisped or twisted.

Erect or only the tips or spines squarrose.

Stem simple, very strict (or wanting); heads solitary, few, glomerate

Stem more or less branched; heads less crowded : Bracts squarrose or the lower even reflexed Inner bracts also spine-tipped.

Bracts with a glandular dorsal ridge.

Flowers ochroleucous.

Spine of involucral bracts short, flat, widely spreading

Spine of involucral bracts long, not flattened, mostly erect

Flowers rose or purple.

Leaves permanently tomentose on both sides.

Involucres usually less than $4 \mathrm{~cm}$. broad

Involucres usually 4-6 $\mathrm{cm}$. broad.

Spines half as long as the bracts

Spines as long as the bracts

Leaves becoming green and glabrate on the upper side
1. C. arvensis.

2. C. Parryi.

3. C. americanus.

4. C. Hookerianus.

5. C. foliosus.

6. C. Drummondii.

7. C. bipinnatus.

8. C. neo-mexicanus.

9. C. lanceolatus.
11. C. plattensis.

12. C. undulatus.

13. C. megacephalus.

14. C. ochrocentrus.

15. C. filipendulus.

1. Carduus arvensis (L.) Robs. Brit. Fl. 163. 1777. Stems 3-8 dm. high, from creeping perennial rootstocks, corymbosely branching, usually glabrate 
and green: leaves lanceolate, pinnatifid and toothed, furnished with abundant weak prickles: heads loosely cymose, $2-3 \mathrm{~cm}$. high, dioecious; in staminate plants ovate-globular, with the flowers well exserted; the pistillate oblongcampanulate, the flowers less exserted; bracts of the involucre appressed, short, with very small, weak, prickly points.-A troublesome weed introduced from Europe; becoming too common in Canada and our range.

2. Carduus Parryi (Gray) Greene, Proc. Am. Acad. Sci. Phila. 362. 1892. Green, lightly arachnoid and villous when young, 3-7 dm. high: leaves lanceolate, sinuate-dentate, not decurrent, moderately prickly: heads several and spicately glomerate or more racemosely paniculate, more or less bractoseleafy at base; accessory and outer proper bracts or some of them pectinately fimbriate-ciliate down the sides; the innermost with more or less dilated or margined, mostly lacerate-fimbriate tips: corollas pale yellow, the lobes longer than the throat: pappus of fine, soft bristles, none of them obviously clavellate. Cnicus Parryi. (C. viridiflorus Greene, in herb.)-Colorado and Utah to New Mexico and Arizona.

3. Carduus americanus (Gray) Greene, 1. c. Stems rather slender, 3-8 dm. high, branching above, the branches bearing solitary or scattered naked heads: leaves white-tomentose beneath, lanceolate or broader, sinuately pinnatifid or some merely dentate, others pinnately parted, weakly prickly: heads erect, about $25 \mathrm{~mm}$. high; principal bracts of the involucre naked-edged or merely fimbriate-ciliate below, and the dilated scarious apex as broad as long, fimbriate-lacerate, tipped with barely exserted cusp or mucro; innermost with lanceolate, nearly entire, scarious tips: flowers ochroleucous: stronger pappus-bristles dilated-clavellate at tip. (C. Centaureae Rydb. Bull. Torr. Bot. Club 28: 507. 1901; C. erosus Rydb. 1. c.; C. griseus Rydb. l. c.)Mountains of our range and northwestward.

3a. Carduus americanus perplexans (Rydb.) A. Nels. Leaves oblanceolate to lanceolate, merely toothed, and with weak, yellowish prickles: flowers sometimes pink or purplish; the bracts slightly glandular on the back. $C$. perplexans Rydb. 1. c. 32: 132. 1905.)-Wyoming and Colorado.

4. Carduus Hookerianus (Nutt.) Heller, Cat. N. A. Plants 7. 1898. Arachnoid white-woolly to glabrate, stout: leaves pinnatifid; the short lobes rather distant, sparsely prickly base little or not at all decurrent: heads few and sessile in a terminal cluster or scattered, $3-4 \mathrm{~cm}$. high, somewhat bracteoseleafy at base; proper bracts tapering from a broadish base into a rather rigid, subulate, prickly point, also somewhat viscidly long-woolly: corollas white or whitish: pappus-bristles not clavellate-tipped. (C. Osterhoutii Rydb. 1. c. 32: 131. 1905; C. Kelseyi Rydb. Mem. N. Y. Bot. Gard. 1: 449. 1900.)-Mountains of our range and farther northward.

4a. Carduus Hookerianus eriocephalus (Gray) A. Nels. More arachnoidpubescent on the involucre and the leaves usually greener and more glabrate. (Cnicus eriocephalus Gray; Carduus scopulorum Greene, 1. c.; C. Tweedyi Rydb. l. c.; C. araneosus Osterh. Bull. Torr. Bot. Club 32: 612. 1905; C. Eatonii Gray, a form usually more glabrate on the involucre though often arachnoidwoolly on the herbage; C.canovirens Rydb.1.c. (?); C. pulcherrimus Rydb. Bull. Torr. Bot. Club 28: 510. 1901.)-Same range as the species.

4b. Carduus Hookerianus hesperius (Eastw.) A. Nels. The anthers pubescent, not essentially different otherwise. (Cnicus hesperius Eastw. Proc. Cal. Acad. Sci. III. 1: 122. 1898.)-On Mt. Hesperus, Colorado.

5. Carduus foliosus Hook. Fl. Bor. Am. 1: 303. 1833. Stems erect, strict, striate, 3-5 dm. high, somewhat woolly, leafy to the cluster of few sessile heads: leaves commonly elongated, linear-lanceolate, laciniately dentate, owith rather rigid prickles, arachnoid-tomentose beneath: heads broad, 4-5 $\mathrm{cm}$. high, leafy-bracteose; involucral bracts thin-coriaceous, some of the inner with more conspicuous, erose, scarious tips: corollas pale or white, with lobes equaling or longer than the throat. [C. scariosus (Nutt.) Heller, is merely the more tomentose form; $C$. coloradensis Rydb. 1. c. 132.]-Colorado to Montana and Oregon.

6. Carduus Drummondii (T. \& G.) Coville, Contr. U. S. Nat. Herb. 4: 142. 
1893. Stem simple, $4 \mathrm{dm}$. or less high, glabrous and leafy up to the heads, which are terminally clustered: leaves oblong or oblanceolate, deeply sinuatepinnatifid with spinulose lobes to nearly entire, somewhat arachnoid-woolly, especially beneath: involucre $3.5-4 \mathrm{~cm}$. high; the bracts chartaceous, the inner with weak scarious tips which vary from entire and acute to obviously dilated and fimbriate, the outer gradually shorter and becoming ovate, the tips acute and short-spinose: corollas white, the lobes not longer than the throat: anthers very acuminate. (C. oreophilus Rydb. 1. c. 28: 509. 1901.) - Mountain valleys of our range and far westward and northward.

6a. Carduus Drummondii acaulescens (Gray) Coville, 1. c. Includes the low forms of the species, in which the stem may be wholly wanting, and the usually smaller heads sessile in the rosette of radical leaves. In the same patch may of ten be found the normal form and all stages to the depressed rosette type. (C. americanus Rydb. and C. acaulescens Rydb. 1. c. 508.)Mountain meadows; range of the species.

7. Carduus bi pinnatus (Eastw.) Heller, Cat. N. A. Plants 5. 1900. Glabrous except for some arachnoid tomentum; stems leafy, 3-7 cm. high, branching: leaves with numerous linear-lanceolate divisions which are 2-6 cm. long, margin laciniate-dentate, spiny; radical leaves petiolate, $2-3 \mathrm{dm}$. long; the cauline, sessile, 10-15 cm. long: heads at the ends of the leafy branches, almost sessile; involucre of appressed, imbricated bracts, in several ranks successively shorter, the lower ones pointed with a weak prickle, the upper attenuate to a scarious tip, puberulent: flowers purple; corolla with throat about one third as long as the linear divisions: stamens surpassing the corolla: achenes glabrous, flattened, obovate-oblong. $[C$. pulchella and $C$. truncatus Greene (?); C. spathulatus Osterh. 1. c.]-In mountain parks; Colorado.

8. Carduus neo-mexicanus (Gray) Greene, 1. c. Stout, 5-10 dm. high; herbage and commonly squarrose involucre copiously white-woolly: leaves sinuate-dentate to pinnatifid, not very prickly: heads solitary, terminating the stem and branches, often $4-5 \mathrm{~cm}$. high and broad; principal bracts of the involucre with spinescent, rigid, reflexed tips, or the bracts in part reflexed: corolla white to pale purple. (C. leucopsis Greene.) - Plains of Colorado and New Mexico to Utah and Arizona.

9. Carduus lanceolatus L. Sp. PI. 821. 1753. Stems stout, 4-10 dm. high, much-branched, more or less villous-hirsute: leaves lanceolate, deeply pinnatifid with lanceolate lobes, rigidly prickly, upper face strigose-setulose; the base decurrent on the stem into interrupted prickly wings: heads obovoid, $3-5 \mathrm{~cm}$. high, terminating the stems and branches; bracts of the involucre arachnoid-woolly, lanceolate and mostly attenuate into slender, spreading spines: corollas rose-purple.-Pastures and waste places throughout the northern United States; naturalized from Europe; CoMmoN THISTLE or often called Bull Thistre.

10. Carduus Nelsonii Pammel, Proc. Iowa Acad. Sci. 8: 22. 1901. A branching biennial, 4-10 dm. high, bearing numerous ochroleucous heads, which terminate the branches; stems prominently striate, white-woolly at first, becoming smoothish with age: radical leaves 1-3 dm. long, deeply pinnatifid, the prominent lobes with yellow spines; lower surface densely tomentose; the upper woolly, becoming glabrate with age; stem leaves sessile and decurrent, with prominent spiny lobes: heads $3-4 \mathrm{~cm}$. high, or rarely larger; involucre somewhat turbinate, the bracts with a promincnt glutinous ridge tipped with a yellow spine; outer bracts ovate-lanceolatc; inner long-acuminate and straw-colored, tips minutely serrated: corolla-tube twice as long as the lobes, strongly clavate: anther-tips acute, bases sagittate; filaments hairy: achene light brown throughout, with dark Iongitudinal striae; pappus of outer flowers merely barbellate, inner plumose with strongly clavate tips." (C. Tracyi Rydb. 1. c. 32: 133. 1905.)-Frequent on the plains of Wyoming; probably more widely distributed.

11. Carduus plattensis Rydb. Contr. U. S. Nat. Herb. 3: 167. pl. 2. 1895. Perennial or biennial, the root thick and deep-set; stem stout, simple, or little branched, 4-7 dm. high, densely white-felted: leaves deeply pinnatifid, white- 
tomentose beneath, green, loosely tomentose, or glabrate above; the lower 12-17 cm. long, the lobes lanceolate to oblong, acute, prickly tipped and margined: heads few, $4-5 \mathrm{~cm}$. high and broad; outer bracts of the involucre lanceolate to ovate-lanceolate, firm, dark, tipped with short, weak, spreading prickles; the inner linear-lanceolate, unarmed, tipped with scarious, reflexed, crose appendages: pappus of outer flowers merely barbellate.-Sandy soil; Nebraska to Wyoming and Montana.

12. Carduus undulatus Nutt. Gen. 2: 130. 1818. Persistently whitetomentose, 3-10 dm. high: leaves lanceolate or oblong-lanceolate, sessile or decurrent, or the lowest petioled, undulate, lobed or pinnatifid; the lobes dentate, triangular, often very prickly: heads $3-4 \mathrm{~cm}$. broad, nearly as high, solitary at the ends of the branches; principal bracts of the involucre mostly thickened on the back by the broad glandular-viscid ridge, comparatively narrow, tipped with short, spreading prickles: corollas rose-color or pale purple to white, with lobes equaling or longer than their throats. (C. nebraskensis Brit. in Brit. \& Brown Fl. 3: 487. 1898; C. floccosus Rydb. Bull. Torr. Bot. Club 32: 133. 1905.)-Dry plains of our range and extending both eastward and westward north of our range.

12a. Carduus undulatus canescens (Nutt.) Porter, Mem. Torr. Club 5: 345. 1894. Apparently a perennial form from rhizomes or thickened roots: heads mostly smaller, and the leaves varying from deeply pinnatifid to subentire. (Cirsium canescens Nutt.; Cnicus undulatus canescens Gray.) - Same range as the species, but infrequent.

13. Carduus megacephalus (Gray) A. Nels. Stems low, 3-5 dm. high, simple or branched, the stem or branches each bearing one large pedunculate head 6-8 cm. high and broad: leaves rather broadly lanceolate, more or less deeply laciniate-toothed, each tooth tapering into the stout, yellowish spine: otherwise like $C$. undulatus. (Cnicus undulatus megacephalus Gray, Proc. Am. Acad. 10: 42. 1874.) -Nebraska and Wyoming to Kansas, New Mexico, and Texas.

14. Carduus ochrocentrus (Gray) Greene, 1. c. Similar to Carduus undulatus, but commonly taller and more leafy, often $2 \mathrm{~m}$. high, equally whitetomentose: leaves oblong-lanceolate in outline, usually very deeply pinnatifid into triangular-lanceolate, serrate or entire segments, armed with numerous long yellow prickles; lower leaves often 15-30 cm. long: heads about $5 \mathrm{~cm}$. broad, 4-5 cm. high, solitary at the ends of the branches; outer bracts of the involucre lanceolate, tipped with stout yellow prickles of nearly or quite their own length; the inner narrowly lanceolate, long-acuminate: flowers purple.Dry plains; Nebraska to Nevada and Texas.

15. Carduus filipendulus (Engelm.) Rydb. 1. c. 33: 157. 1906. Stem comparatively slender, 5-10 dm. high, somewhat angled and striate, more or less covered with a cottony pubescence: leaves more or less floccose, but green above, densely white-tomentose beneath, deeply divided into linearoblong or lanceolate acute lobes tipped with rather weak, yellowish spines: heads campanulate or sometimes nearly cylindric; bracts imbricated, the outer much shorter, ovate, the inner lanceolate, all more or less floccose on the margins, especially when young, and with a narrow glandular ridge, all but the innermost tipped with a weak, erect or slightly spreading spine: corolla rose or reddish-purple: achenes striate; pappus plumose. (C. Flodmanii Rydb. Mem. N. Y. Bot. Gard. 451. 1900; C. oblanceolatus Rydb. Bull. Torr. Bot. Club 28: 510. 1901.)-Wyoming to New Mexico and eastward to the Missouri.

\section{CICHORIUM L. CHICORY}

Erect herbs, the leaves mostly near the base, those of the stiff branching stem reduced and bract-like. Receptacle without bracts. Bracts of the oblong involucre herbaceous, in 2 series; the outer somewhat spreading; the inner erect, the lower part half infolding the marginal achenes. Achenes 5-angled, truncate, beakless. Pappus of 1-3 series of short blunt scales. 
1. Cichorium Intybus L. Sp. Pl. 813. 1753. Perennial from a long deep-set taproot; stems slightly hispid, stiff, branched, 3-9 dm. high: basal leaves spreading on the ground, runcinate-pinnatifid, spatulate in outline, 8-16 cm. long, narrowed into long petioles; upper leaves much smaller, lanceolate or oblong, lobed or entire, clasping or auricled at the base: heads numerous, 25-40 $\mathrm{mm}$. broad, 1-4 together in sessile clusters on the nearly naked or bracted branches: flowers bright blue, rarely white.-Naturalized from Europe; rare in our range.

\section{STEPHANOMERIA Nutt.}

Mostly smooth and glabrous, with branching or rarely virgate and often rigid or rush-like stems, small or merely scale-like leaves on the flowering branches, and usually paniculate heads of rose-colored or flesh-colored flowers. Heads 3-20-flowered. Involucre cylindraceous or oblong, of several appressed and equal plane membranaceous bracts and some short calyculate ones, not rarely with 2 or 3 of intermediate length, thus becoming imbricate. Achenes 5 -angled or ribbed, sometimes with intermediate ribs. Pappus a series of plumose bristles.-Ptiloria Raf.

Perennials.

Pappus plumose to the base; stems herbaceous, slender, erect

Pappus plumose nearly to the base; stems woody at the base, shorter and numerous

Annuals or biennials.

Pappus plumose to the base; leaves entire or sinuate.

Pappus plumose above the middle only; lower leaves more or less pinnatifid

1. S. tenuifolia.

2. S. pauciflora.

3. S. virgata.

4. S. exigua.

1. Stephanomeria tenuifolia (Torr.) Hall, Comp. S. Cal. 256. 1907. Stems herbaceous, from a perennial root, erect, with numerous ascending slender branches, the whole plant 1-5 dm. high; herbage pale, glabrous: leaves commonly erect, slender and almost grass-like, even the rameal mostly $2-5$ $\mathrm{cm}$. long; the early lower ones more or less runcinate: heads terminal; involucre $8-10 \mathrm{~mm}$. high, usually of 5 principal bracts and 5 -flowered: achenes striate; pappus-bristles 15-25, white or sordid, plumose throughout. $S$. minor. (Ptiloria ramosa Rydb. Mem. N. Y. Bot. Gard. 1: 453. 1900.)Throughout our range, west to the Sierras, and north to the Canadian boundary.

2. Stephanomeria pauciflora (Torr.) Nels. Similar to the preceding, usually lower, smaller in all of its parts, and somewhat woody at the base: the lower leaves at least more or less runcinate-pinnatifid: pappus plumose nearly to the base. S. runcinata in part. (Ptiloria pauciflora Raf. Atl. Journ. 145. 1832.) - Sparingly if at all in our range; on the plains; from Nebraska to Texas.

3. Stephanomeria virgata Benth. Bot. Sulph. 32. 1844. Stems rigid, virgate or usually with virgate branches, sometimes widely and paniculately branched, 3-20 or even $40 \mathrm{dm}$. high; herbage usually glabrous: lower leaves oblong or spatulate, often sinuate or pinnatifid; upper leaves linear, small and entire: heads subsessile along the naked branches, mostly 4-16-flowered; involucre $7 \mathrm{~mm}$. high: ligules reddish-purple on the back, lighter on the upper surface, sometimes clear white: achenes subclavate or oblong, longitudinally ribbed, the intervening spaces more or less rugose and traversed by a deep narrow groove: pappus clear white, plumose almost throughout, fragile but the base commonly persistent.-Probably reaching our range from the west.

4. Stephanomeria exigua Nutt. Trans. Am. Phil. Soc. 7: 428. 1841. Plant 2-6 dm. high; stem with numerous ascending or spreading branches, glabrous below, often minutely glandular-pubescent above: lower leaves narrowly oblong, remotely lobed, auriculate-clasping, the upper cauline small and bractlike: heads scattered or somewhat paniculate, numerous; involucre 6 or $7 \mathrm{~mm}$. high, of about 5 principal bracts, mostly 5 -flowered: ligules at first rose-color, soon turning sordid-yellow, $5 \mathrm{~mm}$. long: achenes linear-oblong, 5-angled, with a double row of tubercles between the angles; principal pappus-bristles 8-18, 
plumose above, naked on the lower third.-In the desert areas of our range, and westward.

\section{TRAgOPOGON L. Salsify. Oyster Plant}

Tall and erect perennial herbs, with slender fleshy taproots, alternate grasslike flaceid leaves clasping at the base, and large heads of purple or yellow flowers which are open only during the morning. Involucral bracts in a single series, united at the very base. Rays 5 -toothed at the truncate apex. Receptacle naked. Achenes muricate, 5-10-ribbed, long-beaked or the outermost beakless. Pappus-bristles connate at the base, plumose with interwebbed branches.

1. Tragopogon porrifolius L. Sp. Pl. 789. 1753. Commonly 5-8 dm. high: peduncle strongly clavate-thickened and fistulous for $5-8 \mathrm{~cm}$. beneath the head, which becomes $7-8 \mathrm{~cm}$. high: flowers violet-purple, mostly surpassed by the involucre: outermost achenes squamellate-muricate.-Sparingly in fields and near dwellings, as an escape from cultivation.

$T$. pratensis L., very similar but with yellow flowers, the bracts not exceeding the ligules, has been reported also as an escape from cultivation within our range.

\section{KRIGIA Schreb.}

Low herbs, with rather large heads of yellow flowers on slender naked peduncles or scapes. Ours belongs to the section Cynthia, in which the involucral bracts are 9-18 and thin, and pappus of 10-15 oblong scales and 15-20 slender capillary bristles. Achenes short-columnar, many-ribbed, terete or somewhat angular, with broad truncate summit.

1. Krigia virginica (L.) A. Nels. Caulescent, not tuberiferous, glaucous; stem 3-5 dm. high, 1-3-leaved, bearing one or two or few somewhat umbellate heads on moderately long peduncles: leaves oblong or oval, obtuse, entire, repand and denticulate, or radical somewhat lyrately lobed; these contracted into winged petioles; the cauline partly clasping by a broad base. $K$. amplexicaulis [Adopogon virginicum (L.) Kuntze, Rev. Gen. Pl. 304. 1891.]-In the eastern border of our range to the Atlantic States.

\section{NOTHOCALAIS Greene}

Perennials, with linear-attenuate undulate or crisped radical leaves marked by white-tomentulose margins and monocephalous scapose peduncles. Involucre oblong-campanulate; bracts in two series, narrowly lanceolate, membranaceous, with thinner somewhat hyaline margins, nearly equal, none calyculate. Receptacle flat, alveolate. Achenes fusiform, contracted or rostrate-attenuate at summit, 10 -striate-ribbed. Pappus very white and soft, of 10-30 scabrous-margined, narrow, unequal scales, with or without some capillary bristles.-(Microseris \& Nothocalais Gray.)

1. Nothocalais cuspidata (Pursh) Greene, Bull. Cal. Acad. 2: 55. 1886. Leaves linear, long-acuminate, thick, pubescent or glabrate, 1-2 dm. long, 4-10 mm. wide, somewhat conduplicate, the margins conspicuously whitetomentose and crisped, or entire: scape stout, tomentose, at least above, shorter than or equaling the leaves: head $3-5 \mathrm{~cm}$. broad; involucre usually quite glabrous, nearly $25 \mathrm{~mm}$. high: achenes slightly contracted at the summit, about $6 \mathrm{~mm}$. long; pappus of 40-50 unequal scales and bristles. Troximon cuspidatum.-From Montana to Colorado and eastward to the Mississippi.

\section{PTILOCALAIS Greene}

Glabrous perennials, with fusiform roots, stems mostly leafy at base with laciniate foliage, and long-peduncled heads which are nodding in the bud. 
Involucre campanulate; bracts herbaceous, imbricated in several series, the inner long-acuminate, the outer successively shorter and acute. Receptacle flat or convex, foveolate or alveolate. Achenes linear or somewhat turbinate, 8-10-costate or -striate, truncate at summit, the basal callosity acute and not expanded; areola lateral. Pappus bright white, soft and fragile, double, namely, of a single short external bristle, and 15-20 short truncate or emarginate scales terminating in a long gracefully recurving soft-plumose capillary bristle or awn.-Microseris.

1. Ptilocalais nutans (Geyer) Greene, Bull. Cal. Acad. 2: 54. 1886. Slender, 1-3 dm. high; fusiform roots either fascicled or solitary: leaves entire and spatulate-obovate to pinnately parted into narrow linear lobes: heads 8-20-flowered, slender-peduncled; involucre of 8-10 linear-lanceolate, gradually acuminate principal bracts: bristles of pappus several times longer than the oblong scale at the base. Microseris nutans.-From British Columbia and Montana to southwestern Colorado and California.

\section{MALACOTHRIX DC.}

Leafy-stemmed or sometimes ssapose herbs, with alternate or all radical leaves and long-peduncled paniclad or solitary heads of yellow or white flowers that are usually nodding in the bud. Involucre many-flowered, the bracts either imbricated or only calyculatc. Receptacle with or without delicate capillary bristles among the flowerś. Achenes not flattened, short-oblong or columnar, glabrous, terete and striately 5-15-costate, or 4-5-angled by the prominence of the stronger ribs, slightly if at all narrowed either way, with broad truncate apex having an entire or denticulate border or sharp edge. Pappus a series of soft and scabrous, or near the base barbellulate bristles, which are deciduous more or lass in connection, and commonly 1-8 outer and stouter ones which are more persistent and smoother.

The outer pappus of $2-8$ persistent bristles

The pappus a single series and all deciduous.

Summit of achene bordered by 15 minute teet'.

Summit of achene cupulate but entire

\section{M. Torreyi.}

2. M. sonchoides. 3. M. Fendleri.

1. Malacothrix Torreyi Gray, Proc. Am. Acad. 9: 213. 1874. Stems 1-3 $\mathrm{dm}$. high, from an annual root, branching from the base: lower leaves oblong, rather short, pinnatifid with short and dentate lobes, teeth and lobes callousmucronate: heads seldom less than $12 \mathrm{~mm}$. high, broadish-campanulate, shortpeduncled on the leafy branches; bracts of the involucre lanceolate, acuminate: achenes linear-oblong, 5-angled by as many salient of ten almost wing-like ribs, a much less prominent pair in each interval: outer pappus of 2-8 stout persistent bristles, between the thickish bases of which are minute teeth.Southeastern Oregon to Nicvada and Utah.

2. Malacothrix sonchoices (Nutt.) T. \& G. Fl: 2: 486. 1843. Stem freely branching, the branches ascending and sparsely leafy except near the base; herbage glabrous or early glabrate: leaves oblong or the upper narrowly lanceolate, pinnatifid with short callous-toothed lobes: peduncles $3 \mathrm{~cm}$. or less long: involucre about $8 \mathrm{~mm}$. high; the bracts linear-acuminate: ligules bright yellow, a full cm. long: achenes 15-striate, 5 of the ribs stronger than the others, rendering the achene somewhat 5-angled, crowned with a 15-denticulate white border; permanent pappus-bristles none. (M. runcinata A. Nels. Bull. Torr. Bot. Club 26: 485. 1899.)-From Wyoming and Colorado to California.

3. Malacothrix Fendleri Gray, Pl. Wright. 2: 104. 1852. Low, glabrate; stems from a slender root, few or several, diffuse: earliest leaves sparsely arachnoid; the radical runcinate-pinnatifid, the teeth and lobes cuspidatemucronate; the cauline few, linear, the uppermost entire: achenes cylindrical, equally 15-costate the summit bordered by a cupulate crown, white within and with entire margin; all the pappus deciduous or rarely with 1 or 2 persistent bristles.-New Mexico and westward. 


\section{LYGODESMIA Don}

Mostly smooth and glabrous, with usually rush-like rigid or tough stems, linear or scale-like leaves, and terminal or scattered heads which are always erect. Heads 3-12-flowered, erect, the flowers pink or rose-color. Achenes terete, obscurely few-striate or angled, commonly linear or slender-fusiform. Pappus of copious and usually unequal capillary bristles, either soft or rigidulous, sordid-whitish to white.

\section{Erect perennials.}

None of the branchlets spine-like.

Involucres 5-flowered, about $10 \mathrm{~mm}$, high Inyolucres 6-10-flowered, 15-25 mm. high

Some of the branches spine-like

Paniculately branched annual; leaves long and linear

1. L. juncea.
2. L. grandiflora.
3. L. spinosa.
4. L. rostrata.

1. Lygodesmia juncea Don. Edinb. Phil. Journ. 6: 311. 1829. Perennial by a thick woody root; stems stiff, much-branched, 1-4 dm. high, striate-angled, not spinescent: lower leaves lanceolate, rigid, entire, acute or acuminate, 1-4 cm. long; the upper similar but smaller, or reduced to subulate scales: heads mostly 5 -flowered, solitary at the ends of the branches; involucre about 10-12 mm. high, the bracts usually gland-tipped: achenes narrowly columnar or shortly tapering to the summit; pappus light brown.-Dry plains; widely distributed west of the Missouri.

2. Lygodesmia grandiflora T. \& G. Fl. 2: 485. 1842. Stems separate or few from the root, simple below, 1-3 dm. high; the larger plants leafy; corymbosely branched above, and bearing few or numerous short-pedunculate heads: leaves all entire, of firm and thickish texture, linear-attenuate, $5-10 \mathrm{~cm}$. long, only the very uppermost reduced to scales: involucre fully $20-25 \mathrm{~mm}$. long, 6-10-flowered: ligules of equal length, showy, rose-red.-Gravelly hills; Wyoming and Colorado to Utah.

3. Lygodesmia spinosa Nutt. Trans. Am. Phil. Soc. 7: 444. 1841. Stems slender, rigid, low, much-branched from an indurated and matted-woolly perennial base, otherwise glabrous; branchlets divergent, spinescent, bearing minute scales in place of leaves, and lateral, very short-peduncled heads: lower cauline leaves linear, entire, thickish, above soon reduced to scales: involucre 3-5-flowered; the principal bracts not more numerous, rather loose, lanceolate; the unequal and more imbricated calyculate ones comparatively broad and large: achenes much shorter than the pappus, not at all narrowed upward, 4-5-costate; pappus white, of unequal bristles.-Gravelly hills and plains; eastern Oregon to California, Nevada, and Idaho.

4. Lygodesmia rostrata Gray, Proc. Am. Acad. 9: 217. 1874. Stem erect, 2-7 dm. high, striate, leafy, corymbose-paniculate: leaves narrowly linear, attenuate to both ends, entire, obscurely 3-nerved; the cauline 8-15 cm. long, barely 3-4 $\mathrm{mm}$. wide; the uppermost slender-subulate: heads numerous, on scaly-bracteolate erect peduncles; involucre 8-9-flowered, of as many very narrowly linear bracts: rays small and narrow, probably purplish: achenes slender-fusiform, distinctly attenuate at summit, longer than the soft, rather dull white pappus.-Plains; from the Saskatchewan to Wyoming and Colorado.

\section{PRENANTHELLA Rydb.}

Low diffusely branched annuals, with numerous small heads terminating the branches. Lower leaves ample, oblong or spatulate in outline, more or less runcinate; the upper reduced and bract-like. Involucres oblong, 4-5flowered, with as many oblong bracts and 1 or 2 small calyculate ones. Achenes gradually tapering downward from the truncate summit, 4-5-ridged. Pappus of white, soft, capillary bristles.

1. Prenanthella exigua (Gray) Rydb. Bull. Torr. Bot. Club 33: 161. 1906. Stems 1-2 dm. high, effusely paniculate from the base, bearing numerous small heads terminating short-filiform divergent branchlets or peduncles; 
branches not striate: radical leaves spatulate or oblong, from nearly entire to runcinate-pinnatifid; the cauline small and entire, soon reduced to minute bracts: involucre oblong, $4 \mathrm{~mm}$. high, 4-5-flowered, of as many bracts and 1 or 2 very small calyculate ones: achenes $2-3 \mathrm{~mm}$. long, gradually tapering from the truncate summit to base, broadly 4-5-costate, or rather narrowly 4-5-sulcate, somewhat longer than the bright white pappus. (Lygodesmia exigua Gray.) - Southern Colorado through the desert areas to California.

\section{PRENANTHES Vaill. Rattlesnake Root}

Perennial herbs, with alternate, mostly petioled, dentate, lobed, or pinnatifid leaves, or the upper auriculate and clasping, and numerous small heads of ligulate white, yellowish, or purplish flowers in open or spike-like terminal panicles, or also in axillary clusters, usually drooping. Involucre cylindric, usually narrow, the principal bracts in 1 or 2 series, nearly equal, with a few smaller exterior ones at the base. Receptacle flat, naked. Rays truncate and 5-toothed at the summit. Style-branches slender. Achenes oblong or narrowly columnar, truncate, terete or 4-5-angled, mostly 10-ribbed. Pappus of copious, rather rigid, simple, white, or reddish-brown bristles.

Basal leaves obovate

Basal leaves triangular-sagittate

1. P. racemosa.

1. Prenanthes racemosa Michx. Fl. Bor. Am. 2: 83. 1803. Stems simple, 3-12 dm. high, leafy up to the inflorescence, with the leaves glabrous and glaucous: leaves ordinarily only denticulate; radical and lower leaves spatulateoblong to obovate, tapering into winged petioles; the upper cauline lanceolate to ovate, partly clasping the broader ones by a cordate or auriculate base: heads not at all drooping, crowded in an elongated thyrsus, 1-5 dm. long; involucre loosely hirsute: flowers purplish: achenes about 15-nerved, somewhat angled by 4 or 5 of the stronger nerves. Nabalus racemosus DC.-From Colorado to the Saskatchewan, thence eastward across the continent.

2. Prenanthes sagittata (Gray) A. Nels. Glabrous or nearly so, 2-5 dm. high, the larger plants branching: leaves sagittate or hastate, with basal lobes mostly slender and prolonged: heads in a virgate panicle; involucre pale green, very glabrous: achenes slender, about $6 \mathrm{~mm}$. long, usually tapering a little upwards. $P$. alata sagittata. (Nabalus sagittatus Rydb. Mem. N. Y. Bot. Gard. 1: 463. 1900.)-Montana and Idaho and probably in Wyoming.

\section{CREPIS L.}

Perennial or annual herbs, with alternate or all radical mostly toothed or pinnatifid leaves and small or middle-sized heads of yellow flowers. Involucre few- to many-flowered, cylindric, campanulate, or swollen at base, the principal bracts in one series, equal, with a number of exterior small ones. Receptacle mostly flat, naked or short-fimbrillate. Achenes columnar to fusiform, 10-20-ribbed or -nerved, not transversely rugose, narrowed at the base and apex. Pappus of copious white and usually soft capillary bristles.

Achenes dilated or discoid at the insertion of the pappus; low glaucous plants, with entire or merely repand leaves.

From running rootstocks; leaves mainly radical

From a taproot; leaves mainly cauline

Achenes not dilated or discoid at the insertion of the pappis; leaves usually more or less laciniate-pinnatifid, rarely entire.

Herbage green, glabrous or sometimes slightly hirsute, never whitepubescent or scurfy.

Leaves usually somewhat glaucous; the involucre glabrous or only puberulent when young

Leaves not glaucous, glabrous or of ten somewhat pubescent or hirsute; involucre pubescent to glandular-hispidulous. Involucre pubescent or hirsute

Involucre glandular-hispid
Herbage minutely white-pubescent or scurfy.

1. C. nana.

2. C. elegans.

Involucres glabrous, 5-7-flowered

\section{C. glauca.}

4. C. runcinata. 5. C. riparia.

6. C. acuminata. 
Involucres not glabrous.

Involucral bracts not setosely barbed.

Pubescence wholly canescent (in no. 8 , sometimes nearly wanting).

Leaf-blades and their lobes mostly lanceolate.

Leaf-blades and their lobes mostly linear-.

Pubescence canescent with intermingled black hairs.

Bristly hairs glandular

Bristly hairs not glandular

Involucral bracts setosely barbed on the carinate midrib :

7. C. intermedia.

8. C. gracilis.

9. C. occidentalis. 10. C. scopulorum. 11. C. barbigera.

1. Crepis nana Rich. App. Frank. Journ. ed. 2. 757. 1823. Forming depressed tufts on creeping rootstocks: leaves chiefly radical, obovate to spatulate, entire, repand-dentate, or lyrate, commonly equaling the clustered scapes or stems: heads in fruit nearly $12 \mathrm{~mm}$. high: achenes linear, unequally ribbed, obscurely contracted under the moderately dilated pappiferous disk.Alpine mountain summits in Colorado and California, thence far northward.

2. Crepis elegans Hook. Fl. Bor. Am. 1: 297. 1834. Many-stemmed from a taproot, diffusely branched: leaves entire or nearly so; the radical spatulate; the cauline lanceolate to linear: heads smaller: achenes linear, fusiform, minutely scabrous on the equal narrow ribs, attenuate into a short slender beak, which is discoid-dilated at summit.-From Wyoming and Dakota to the Saskatchewan.

3. Crepis glauca T. \& G. Fl. 2: 488. 1841. Perennial, scapose or rarely with 1 or 2 leaves on the stem, $2-6 \mathrm{dm}$. high, glabrous and glaucous throughout: basal leaves spatulate, oblanceolate, or obovate, gradually narrowed into margined petioles, entire, dentate, or pinnatifid, $5-15 \mathrm{~cm}$. long, 1-2 cm. wide: heads not numerous, long-peduncled, $12-25 \mathrm{~mm}$. broad: peduncles glabrous: involucre campanulate, the principal bracts lanceolate, acute, the outer ones very short, ovate, appressed: achenes oblong-cylindric, strongly 10-ribbed.-In moist saline soils; west of the Missouri to Nevada.

4. Crepis runcinata T. \& G. 1. c. Perennial, similar to the preceding species but not glaucous or scarcely so, often pubescent below; stem leafless or with 1 or 2 small leaves, 3-9 dm. high: basal leaves spatulate, obovate, or oblong, obtuse or acute, entire, repand, dentate, or rarely runcinate-pinnatifid, 5-15 cm. long, 2-3 cm. wide: heads several, long-peduncled, nearly $25 \mathrm{~mm}$. broad; involucre campanulate, the principal bracts linear-lanceolate, acute, outer ones short, lanceolate, appressed: achenes linear-oblong, 10-ribbed. (C. platyphylla Greene, Pitt. 3: 27. 1896; C. glaucella Rydb. Bull. Torr: Bot. Club 28: 512. 1901; C. tomentulosa, $C$. perplexans, and $C$. petiolata $\mathrm{Rydb}$. Bull. Torr. Bot. Club 32: $134 \&$ 135. 1905. To recognize the foregoing one would first have to assume a hypothetical $C$. runcinata.) - In wet soils; Utah and Colorado to Washington and the Saskatchewan.

5. Crepis riparia A. Nels. Bull. Torr. Bot. Club 26: 486. 1899. Stems 1. or more, $2-4 \mathrm{dm}$. high, subscapose, minutely and sparsely pubescent, upward becoming clammy or glandular: radical leaves few, rather large, oblong to elliptic, obtuse to subacute, entire or coarsely and irregularly dentate and at base more or less runcinate, $10-18 \mathrm{~cm}$. long, on petioles of about half the length, glabrous except on the petioles and midrib: inflorescence corymbosepaniculate; heads 15-20 mm. high, many-flowered; involucre dark, glandularpubescent; bracts linear, in 2 rows; the outer few and short; the inner more numerous (12-16): achenes tapering gradually from base to summit, about $6 \mathrm{~mm}$. long, rather uniformly 10-striate, light brown; pappus soft and white, shorter than the achene.-Wet grassy banks at middle elevations; throughout our range.

5a. Crepis riparia parva A. Nels. Not distinguishable from the species except by the small size, usually solitary heads, and small glabrous leaves. (C. denticulata Rydb. 1. c.; C. alpicola A. Nels. Bot. Gaz. 40: 65. 1905.)-In subalpine parks; our range.

6. Crepis acuminata Nutt. Trans. Am. Phil. Soc. 7: 437. 1841. Perennial, slender, $3-8$ or $9 \mathrm{dm}$. high, cymosely branched above; herbage cinereously puberulent but the inflorescence nearly glabrous: lower leaves $15-25 \mathrm{~cm}$. long, broadly lanceolate in outline, pinnatifid with narrow spreading or reROCKY MT. BOT.-38 
trorse lobes, attenuate below into a petiole and above into a tail-like prolongation $8 \mathrm{~cm}$. or less long: involucre narrow, 10-12 mm. high; minute outer bracts canescent; inner bracts 5-8, bright green, glabrate: flowers 5-10: achenes fusiform, somewhat narrowed at summit.-Dry ground, middle elevations; in our range and west to the Pacific States.

7. Crepis intermedia Gray, Syn. Fl. 1: 432. 1886. Habit and foliage of the preceding, or less tall, more cinereous-puberulent, usually with fewer heads: involucre $12 \mathrm{~mm}$. or more long, canescently puberulent; the bracts in age more carinate by thickened midrib: achenes acutely 10-costate at maturity, oblong-fusiform, slightly attenuate upward, longer than or equaling the pappus.-Rocky Mountains in Colorado to the Sierra Nevada, California, and north to Washington.

8. Crepis gracilis (Eat.) Rydb. Mem. N. Y. Bot. Gard. 1: 461. 1900. Closely related to the preceding but lower and very slender: the body of the leaves very narrow and with linear-attenuate apical prolongation and mostly with upwardly turned linear-acuminate lobes: as in the preceding the principal bracts of the involucre and the flowers each 7-8. (C. angustata Rydb. Bull. Torr. Bot. Club 32: 135. 1905.) - Colorado to Montana and Washington.

9. Crepis occidentalis Nutt. Journ. Acad. Phila. 7: 29. 1834. Stem stout, usually several from the strong perennial root, branching above, the whole plant 1-2 dm. high; herbage tomentose (the tomentum sometimes with a tendency to fall in age) and often glandular-hirsute above, especially on the peduncles: leaves thickish, runcinately toothed or deeply pinnatifid into linear or lanceolate lobes, the uppermost portion entire, acuminate: involucre 10-30-flowered, 12-15 mm. high, calyculate, the 8-24 bracts oblong-lanceolate: achenes brown, fusiform, 10-18-costate, 8-9 mm. long: (C. pumila Rydb. Mem. N. Y. Bot. Gard. 1: 462. 1900.)-Dry open or semi-wooded hillsides; in our range and west to the Pacific States.

10. Crepis scopulor um Coville, Contrib. Nat. Herb. 3: 563. 1896. Tomentose, often glabrate in age, and bearing toward the base scattered eglandulose bristles; stems rather slender, 1-4 dm. high, solitary or few from the same caudex, bearing 1-5 heads: leaves broadly lanceolate in outline, 10-15 cm. long, pinnately or bipinnately divided into linear-lanceolate lobes: peduncles slender, usually thickened just below the heads: involucre $12-16 \mathrm{~mm}$. high; the bracts linear-lanceolate and barely acute, or the shorter ones acuminate: achenes 8-12 mm. long, fusiform, truncate at the apex, not costate, but sometimes obscurely striate.- Same range as the preceding.

11. Crepis barbigera Leiberg, Contr. Nat. Herb. 3: 565. 1896. Slightly tomentose with a minute somewhat flocculent tomentum, not at all hirsute; stems several from the crown on a thick perennial root, 3-6 dm. high, sparingly leafy and bearing an ample corymbose cyme of rather small heads: leaves broadly lanceolate in outline, 1-2 dm. long, runcinately toothed or deeply cut into linear-lanceolate lobes: involucre $10-14 \mathrm{~mm}$. high, of linear, mostly obtuse principal bracts and a few very small ovate or lanceolate acute ones at base, all canescent-tomentose and more or less bristly with setaceous white bristles. ( $C$. atribarba Heller, Bull. Torr. Bot. Club 26: 314. 1898.) -Reaching our range in Yellowstone Park and adjacent Idaho and Montana.

\section{HIERACIUM L. HAWKWEED}

Perennial herbs, with alternate or all radical leaves and small to large erect heads of yellow rarely white or red flowers in panicles or corymbs, or solitary. Involucre several-many-flowered, of narrow equal bracts and some short calyculate ones, or sometimes imbricated, not thickened at base or with thickened midrib. Achenes oblong or columnar, smooth and glabrous, mostly 10-ribbed or striate, either terete or 4- or 5-angled, slightly contracted at the very base, commonly of the same thickness to the truncate summit. Pappus of rather rigid, scabrous, fragile bristles, brown or brownish, rarely white and soft. 
Involucre imbricated, i. e., the bracts in 2 or more successively shorter series; leaves numerous.

Leaves usually subentire and narrowly lanceolate

Leaves usually broadly lanceolate or ovate-oblong, and acutely

dentate
Involucre not regularly imbricated, a series of equal bracts and some short calyculate ones; leaves relatively few.

Achenes tapering from base to summit

Achenes cylindrical.

Flowers white or ochroleucous

Flowers yellow.

Heads small, black-hairy

Heads large, white-hairy or glabrate. Leaves densely long-hirsute Leaves nearly smooth

1. H. umbellatum.

2. H. canadense.

3. H. Fendleri.

4. H. albiflorum.

5. H. gracile.

6. H. Scouleri.

7. H. cynoglossoides.

1. Hieracium umbellatum L. Sp. Pl. 804. 1753. Stems 3-6 dm. high, strict, bearing a few somewhat umbellately disposed heads: leaves narrowly or sometimes broadly lanceolate, nearly entire, sparsely denticulate, occasionally laciniate-dentate, all narrow at base: involucre usually livid, glabrous or nearly so; outermost bracts loose or spreading. (H. columbianum Rydb. Bull. Torr. Bot. Club 28: 513. 1901.)-Across the continent through the northern part of our range.

2. Hieracium canadense Michx. Fl. 2: 86. 1803. Taller, robust, with cormybosely or paniculately cymose heads: leaves lanceolate to ovate-oblong, acute, sparsely and acutely dentate or even laciniate, at least the upper partly clasping and broad or broadish at base: involucre usually pubescent when young, becoming glabrate, occasionally glandular; the narrow outermost bracts loose: pappus sordid.-Across the continent through the northern part of oúr range, and far northward.

3. Hieracium Fendleri Schultze Bip. Bonplandia 9: 173. 1861. Subscapose, not rarely 1 or 2 leaves toward base of the simple or paniculately branching stem, sparsely setose-hirsute: radical leaves spatulate or broader; the cauline verging to lanceolate, reduced above to linear bracts: heads few and racemiform-paniculate, or more numerous and corymbosely disposed: involucre puberulent or glabrate, with or without scattered setose hairs: achenes tapering from near the base to summit, sometimes reddish, at length commonly blackish: pappus copious, soft, sordid-whitish.-Colorado and New Mexico.

4. Hieracium albiflor um Hook. Fl. Bor. Am. 1: 298. 1834. Stems 5-9 dm. high, leafy below, nearly naked above, ending in a panicle of white-flowered heads; herbage thickly beset below with tawny bristly hairs, glabrous above except for a minute glandular pubescence and sometimes a few soft hairs on the inflorescence: lower leaves oblong, narrowed at base to a winged petiole, 10-15 cm. long, 2-4 cm. broad, entire to saliently repand-dentate; upper leaves oblanceolate to linear, those of the inflorescence linear-attenuate: pappus dull white.-In open coniferous woods, in the mountains; our range and westward.

5. Hieracium gracile Hook. l. c. Pale green, in tufts: leaves nearly all in radical clusters, obovate- to oblong-spatulate and attenuate into petioles, entire or repand-denticulate: stems or scapes slender, 2-4 dm. high, cinereous above, bearing few or several racemosely disposed livid heads; the lower linear-bracteate: involucre usually blackish-hairy at base: achenes shortcolumnar.-Mountains of Colorado, Utah, and northward.

$5 a$. Hieracium gracile detonsum Gray. A reduced form with most of the dark hairs wanting, except a few on the involucre.-High mountains; western part of our range.

$5 b$. Hieracium gracile minimum A. Nels. A dwarf alpine form, sometimes but a few $\mathrm{cm}$. high and with a solitary head.- In the higher mountains.

6. Hieracium Scouleri Hook. 1. c. Strikingly pubescent with long crisp hairs, pale and more or less glaucescent; stems 3-7 dm. high, very leafy: leaves lanceolate, sessile or the lowest short-petioled, $5-15 \mathrm{~cm}$. long: heads rather few, in a loose irregular panicle; involucre $12 \mathrm{~mm}$. high; the bracts linear-lanceolate, often acuminate, imbricated in 2 or 3 series, the outer successively shorter, all beset with long bristly hairs, and more or less glandular: pappus whitish.-Coming into our range from the north Pacific States. 
6a. Hieracium Scouleri griseum (Rydb.) A. Nels. The long white hairs largely absent from the involucre. (H. griseum Rydb. Mem. N. Y. Bot. Gard. 1: 465. 1900.) - Colorado to Montana and westward.

7. Hieracium cynoglossoides Arvet-Touv. Spicil. Hier. 20. 1881. More or less pubescent with somewhat hispid hairs, and the inflorescence glandular; stems 3-6 dm. high, numerous from the crown of a perennial root, leafy: leaves lanceolate, mostly acute, $5-15 \mathrm{~cm}$. long; the upper sessile by a narrow base; the lower narrowed to a winged petiole: heads few-several in an open corymbose cyme; involucre $12-16 \mathrm{~mm}$. high; the linear-acute bracts and short peduncles rather densely hirsute with short black hairs as well as glandular: achenes rather short.-In open woods; British Columbia to California and the Rocky Mountains.

\section{LACTUCA L. LetTuCE}

Mostly tall herbs, with milky juice, leafy stems, and paniculate heads of yellow, blue, or whitish flowers. Involucre glabrous and smooth, cylindraceous, or in fruit somewhat conoidal, several-many-flowered. Achenes obcompressed, and with a beak or narrowed summit, which is more or less expanded at apex into a.pappiferous disk. Pappus of bright white or rarely sordid bristles, falling separately.

Pappus brown; achenes beakless

Pappus bright white; achenes with a slender beak

Leaves spiny-margined and often with spiny midrib and veins.

Leaves oblong-lanceolate, sinuate-pinnatifid

Leaves oblanceolate, merely irregularly denticulate :

Leaves not spinose.

Flowers yellow.

Involucre irregularly calyculate Involucre imbricated

Flowers blue (in no. 7 of ten purplish). Achenes striate-nervose Achenes 1-3-nerved, transversely rúgose :
1. L. spicata.

2. L. Scariola. 3. L. integrata.

4. L. canadensis.

5. L. ludoviciana.

6. L. pulchella.

7. L. graminifolia.

1. Lactuca spicata (Lam.) Hitch. Trans. Acad. St. Louis 5: 506. 1891. Stem 3-10 dm. high, stout, leafy up to the pyramidal rather crowded panicle: leaves ample, sinuately or runcinately pinnatifid, coarsely and irregularly or doubly dentate; the upper cauline sessile by a mostly narrowed but auriculate or partly clasping base: involucre oblong, $10 \mathrm{~mm}$. high: flowers bluish to yellowish or whitish: pappus sordid or fuscous. L. leucophaea.-Across the continent from Oregon to the mountains of Carolina and northward.

2. Lactuca Scariola L. Sp. Pl. Ed. 2. 1119. 1763. Biennial, glabrous throughout or hirsute at the base, green and glaucous; stem stout, 6-15 dm. high, leafy, usually paniculately branched: leaves lanceolate to oblong, sinuatetoothed or pinnatifid, sessile or auriculate-clasping, midrib below beset with weak prickles: heads small, 6-12-flowered, very numerous, in an open panicle: corollas pale yellow: achenes pale, obovate-oblong, several-nerved, margined, about as long as the filiform beak.-Becoming common in fields and waste places; adventive from Europe.

3. Lactuca integrata (Gren. \& Godr.) A. Nels. Similar to the preceding and confused with it: leaves oblong to oblanceolate, finely irregularly denticulate, rarely slightly sinuate: achenes dark-colored. ( $L$. virosa of Am. authors, not $L$. virosa L.) - A weed in waste ground; from our range to the Atlantic States. -

4. Lactuca canadensis L. Sp. Pl. 796. 1753. Biennial or annual, glabrous and glaucescent; stem strict, 1-2 m. high, very leafy up to the elongated narrow panicle: leaves mostly sinuate-pinnatifid, 1-3 dm. long, with margins entire or sparingly dentate, and midrib naked or rarely some sparse bristles, most of the cauline partly clasping by a sagittate or auriculate base: involucre 10-12 mm. high, 12-20-flowered: flowers yellow: achenes blackish, obscurely scabrous-rugulose, lightly 1 -nerved on the middle of each face, broadly oval, with distinct thin margins, rather longer than the beak; pappus white.-Across the continent. 
5. Lactuca ludoviciana (Nutt.) DC. Prodr..9: 141. 1838. Biennial, glabrous throughout, leafy up to inflorescence, paniculately branched, 6-15 dm. high: leaves oblong to ovate-oblong, acute or acutish, 5-10 cm. long, auriculate-clasping, spinulose-denticulate to pinnatifid with spinulose segments: heads $6-10 \mathrm{~mm}$. broad, numerous in an open panicle; involucre cylindric or ovoid-cylindric, glabrous, the bracts successively shorter and broader, the lower ones ovate: rays yellow: achenes oval to obovate, flat.-From Montana and the Dakotas to Texas.

6. Lactuca pulchella (Pursh) DC. 1. c. 131. Perennial, glabrous, more or less glaucous; stems erect, 3-7 dm. tall, corymbosely paniculate above: leaves 5-20 cm. long, numerous, linear to lanceolate, entire, toothed, or pinnatifid, acute or obtuse, those of basal and lower stem leaves sometimes with winged petioles, those of upper stem leaves sessile and partly clasping: peduncles often cópiously scaly: involucres $16-20 \mathrm{~mm}$. long; inner bracts linear-lanceolate, acute or obtusish: ligules blue or violet: achenes black, the body rather elliptic, ribbed, $4 \mathrm{~mm}$. long, beak shorter than the body. (L. sylvatica A. Nels. Bull. Torr. Bot. Club 26: 486. 1899.) - In our range, and northward almost across the continent.

7. Lactuca graminifolia Michx. Fl. Bor. Am. 2: 85. 1803. Biennial or perennial, glabrous or nearly so, glaucescent; stems erect, 6-15 dm. tall, paniculately branched above: leaf-blades elongated-linear or narrowly linearlanceolate, 10-40 cm. long, entire or with a few spreading or deflexed lobes; both the entire and pinnatifid types often on the same plant: peduncles often with minute scales: involucres $12-15 \mathrm{~mm}$. high; bracts linear-lanceolate to lanceolate, the inner scarious-margined: ligules purple, blue, or rarely white or yellowish: achenes elliptic or elliptic-oblong, $4-4.5 \mathrm{~mm}$. long, the beak much shorter than the body. - In the southeastern part of our range to South Carolina and Texas.

\section{SONCHUS L. Sow Thistle}

Leafy-stemmed, coarse, succulent herbs, chiefly smooth and glaucous. Heads cymose or umbellate, swollen at base or jug-shaped. Involucral bracts few, thin, with many shorter ones at base; these becoming callous-thickened. Flowers yellow. Achenes obcompressed, ribbed, not beaked. Pappus copious, of cottony-white exceedingly soft and fine hairs, mainly falling together.

Heads large; involucre glandular-pubescent

Heads medium-sized; involucre glabrous.

Leaves prickly toothed; auricles rounded

Leaves with soft teeth; auricles acute.
1. S. arvensis.

2. S. asper.

3. S. oleraceus.

1. Sonchus arvensis L. Sp. Pl. 793. 1753. Rootstocks creeping; stems 5-10 dm. high, naked at summit, bearing few or several and corymbosely paniculate showy heads: leaves runcinate-pinnatifid or some undivided, denticulate-spinulose; the cauline partly clasping at base: peduncles and involucre more or less glandular-bristly; head 20-25 mm. high: achenes oblong, about 10-costate, rugulose on the ribs.-This weed, naturalized from Europe, is spreading in our range.

2. Sonchus asper (L.) Hill, Herb. Brit. 1: 47. 1769. Stem often stout, 3-15 dm. high, from an annual root: leaves undivided, lobed, or pinnatifid, spinulose-dentate; the lower spatulate to lanceolate, more or less distinctly petioled; the upper clasping by an auriculate base, the auricles rounded: involucre glabrous, about $12 \mathrm{~mm}$. high: achenes smooth, 3-nerved on each side. - Common in fields and waste places; naturalized from Europe.

3. Sonchus oleraceus L. Sp. Pl. 794. 1753. Fibrous-rooted annual; stem nearly simple, 5-20 dm. high: lower leaves petioled, lyrate-pinnatifid, 1-2 dm. long, the terminal segment commonly large and triangular, the margins denticulate with mucronate or scarcely spiny teeth; the upper pinnatifid, clasping by an auriculate or sagittate base, the auricles acute: involucre 12-16 $\mathrm{mm}$. high: achenes flat, longitudinally ribbed and transversely rugose.-Common in fields and waste places; naturalized from Europe. 


\section{TROXIMON Nutt.}

Herbs, mostly acaulescent, with tufted usually sessile basal leaves and solitary heads of yellow or rarely purple flowers at the end of a naked or bracted scape. Involucre campanulate or oblong, the bracts imbricated in several rows, appressed or with spreading tips, membranous or herbaceous, not thickened after flowering, the outer ones gradually shorter and broader. Receptacle flat, naked or foveolate. Rays truncate and 5-toothed at the apex. Anthers sagittate at the base. Style-branches slender. Achenes oblong, obovate, or linear, 10-ribbed, not flattened, beaked at the summit. Pappus of copious, slender, simple, white bristles.

\section{Achenes tapering to a stout-nerved beak shorter than the body: \\ flowers yellow, of ten roseate in drying.}

Leaves entire or coarsely and irregularly toothed.

Leaves more or less pubescent even in age.

Narrowly lanceolate or linear, and often somewhat laciniatetoothed

Lanceolate or oblanceolate, often broadly so and obtuse :

Leaves glabrous at least in age; the involucre glabrous or somewhat pubescent.

Leaves not 2-ranked

Leaves 2-ranked, linear

Leaves narrowly linear, or laciniately parted into linear divisions

Achenes with slender beak, as long as or longer than the body.

Flowers orange, in age or on drying often purplish; more or less woolly-pubescent under the involucre.

Plant low (1-2 dm.); leaves tapering to a short-winged petiole, or sessile

Plant taller (2-5 dm.); leaves tapering into a long, slender, winged petiole

Flowers yellow, scarcely changing when dry.

Involucre glabrous.

Somewhat woolly-pubescent below the involucre on the peduncle

Not woolly-pubescent on the peduncle

1. T. pubescens

2. T. villosum.
3. T. glaucum.
4. T. parviflorum.
5. T. arachnoideum.

Involucre more or less pubescent

\section{T. aurantiacum, \\ 7. T. purpureum.}

1. Troximon pubescens (Rydb.) A. Nels. Perennial with a taproot and short, branching caudex: leaves narrowly oblanceolate, about $1 \mathrm{dm}$. long, 5-15 mm. wide; acuminate, slightly flaucous but even in age villous-pubescent; scape 1.5-3 dm. high, sparingly villous: involucre about $2 \mathrm{~cm}$. high, villous and somewhat viscid; bracts with a dark median line and sometimes tinged with purple, the outer ones ovate-lanccolatc, about two thirds the length of the linear-lanceolate, long-acuminate inner ones: flowers yellow, the outer often striate or tinged with purple: beaks of the achenes short and striate throughout. (Agoseris pubescens Rydb. Bull. Torr. Bot. Club 28: 511. 1901; A. attenuata Rydb. 1. c. 32: 136. 1905.) -In the foothills; Wyoming and Colorado.

2. Troximon villosum (Rydb.) A. Nels. Leaves oblanceolate, more or less pubescent, especially on the margins and veins; scape 1-2 dm. high, often sparingly hairy and villous under the head: involucre campanulate, about 2 $\mathrm{cm}$. high; outer bracts ovate or ovate-lanceolate, more or less villous especially on the margins, dotted with blackish dots; inner bracts lanceolate: ligules yellow or the outer tinged with reddish: achenes with a short striate beak. (Agoseris villosa Rydb. Mem. N. Y. Bot. Gard. 1: 458. 1900; A. maculata Rydb. Bull. Torr. Club 32: 136. 1905, the original description of which is here used.) - Colorado to Montana.

3. Troximon glaucum Nutt. Gen. 2: 128. 1818. Perennial, pale or glaucous, glabrous throughout or a little woolly below: leaves linear, lanceolate, or oblong, entire, dentate, or pinnatifid, 5-25 cm. long, 4-20 mm. wide, acuminate at the apex, narrowed at the base, sometimes into margined petioles: scapes stout, glabrous or slightly pubescent, longer than the leaves, often $4 \mathrm{dm}$. high: involucre oblong-campanulate, or broader in fruit, commonly quite glabrous, the bracts lanceolate, acuminate: achenes conspicuously beaked; pappus of rather rigid, scabrous or denticulate bristles. ( $T$. roseum Nutt. Trans. Am. Phil. Soc. 7: 434. 1841; see also Greene, Pitt. 2: 77 \& 176. 
1901 ; Agoseris agrestis Osterh. Bull. Torr. Bot. Club 28: 645. 1901; A. roseata Rydb. l. c.)-Throughout our range and northward and westward.

3a. Troximon glaucum dasycephalum T. \& G. Fl. 2: 490. 1843. "This plant differs from $T$. glaucum only in having a pubescent involucre. It is scarcely worth nomenclatural recognition." (C. V. Piper in Contrib. U. S. Nat. Herb. 11: 542. 1906.) (Agoseris scorzoneraefolia Greene, Pitt. 2: 177. 1891; A. altissima Rydb. Mem. N. Y. Bot. Gard. 1: 458. 1900.)-Same range as the species.

3b. Troximon glaucum pumilum (Nutt.) A. Nels. A low, tufted form usually with narrow and often with laciniately-toothed leaves: involucre more or less pubescent. T. glaucum laciniatum in part. (T. pumilum Nutt. Trans. Am. Phil. Soc. 7: 434. 1841; Agoseris Leontodon Rydb. l. c. 457.)-Colorado to Montana and the Dakotas.

4. Troximon parviflorum Nutt. 1. c. Caudex multicipital, the narrowly linear or broader and lanceolate leaves strictly 2-ranked, thus subtending the more or less decumbent scapes; whole plant nearly or quite glabrous: bracts of the involucre nearly equal, all lanceolate-acuminate: heads and achenes much shorter than in the last, the latter almost beakless: pappus less flaccid and more nearly approaching the deciduous. T. glaucum parviflorum.-Colorado and Utah to Montana and the Dakotas.

5. Troximon arachnoideum (Rydb.) A. Nels. Dwarf, the few stems from the crown or crowns of the rather slender root only 7-20 cm. high: leaves mostly lanceolate in outline but laciniate-pinnatifid with linear divisions, or in the smaller forms linear and entire, more or less cinereous or lanate-pubescent: rays of the rather small heads yellow, often purplish externally or in drying: the body, the beak, and the pappus of the achene each about $5 \mathrm{~mm}$. long. $T$. glaucum laciniatum in part (not T. laciniatum Gray. Proc. Am. Acad. 19: 71. 1883; Agoseris laciniata Greene, 1. c. 178; $A$. arachnoidea Rydb. Bull. Torr. Club S: 511. 1901).- Open slopes, middle elevation; in our range and west to the Sierras.

6. Troximon a urantiac um Hook. Fl. Bor. Am. 1: 300. pl. 104. 1833. Nearly glabrous, deep green and not at all glaucous: leaves oblanceolate, obtuse, entire, narrowed to a short petiole: involucre $15-20 \mathrm{~mm}$. high; the bracts broadly to narrowly lanceolate, acute, or the outer and looser ones oblong and obtuse: flowers orange, drying brownish or purple: achenes thickish, tapering gradually to a short, stout beak. (Agoseris carnea Rydb. Mem. N. Y. Bot. Gard. 1: 458. 1900.)-Mountain parks; from our range to the coast states.

7. Troximon purpureum (Gray) A. Nels. Sparsely lanate when young, in age glabrate, more or less glaucous; scapes 2-5 dm. high, enlarged and tomentose at the summit: leaves linear to lanceolate, saliently or often runcinately toothed or lobed: bracts of the involucre moderately well imbricated, '10-25 mm. long, lanceolate and long-acuminate, or the outer ones oblong and obtuse: corollas deep saffron-color, drying purple: achenes black, fusiform, with a slender beak about as long as the body: pappus white. (Macrorhynchus purpureus Gray, Pl. Fendl. 114. 1849; T. gracilens Gray, Proc. Am. Acad. 19: 72. 1883; Agoseris Greenei Rydb. as to our range.)-Colorado to Montana and westward.

8. Troximon arizonicum Greene, Pitt. 2: 78. 1890. About $3 \mathrm{dm}$. high, slender, glabrous except a woolliness under the involucre: leaves narrowly oblanceolate, entire or runcinately toothed: head about $25 \mathrm{~mm}$. high, fewflowered, more than $25 \mathrm{~mm}$. broad when expanded; involucral bracts in two series, the outer oblong, the inner lanceolate, all purple in the middle: ligules light yellow: beak of the achene very much attenuate, longer than the body; pappus fragile and deciduous. (Agoseris elongata Greene; $A$. rostrata and $A$. humilis Rydb. Bull. Torr. Bot. Club :32: 137. 1905.)-Colorado to New Mexico and Arizona.

9. Troximon elatum (Nutt.) A. Nels. Robust, scapes $2-5 \mathrm{dm}$. high: leaves thickish, lanceolate to spatulate, sparingly dentate to pinnatifid, $2-3 \mathrm{dm}$. long, glaucous: heads $25-30 \mathrm{~mm}$. high and broad; involucral bracts lanceolate, acute, more or less pubescent: corollas yellow; achene thickish, $6 \mathrm{~mm}$. 
long, with a beak as long or longer. (T. Nuttallii Gray, Proc. Am. Acad. 9: 216. 1874; Stylopappus elatus Nutt. 1. c. 433.) -From the northwestern part of our range to California and Washington.

10. Troximon montanum (Osterh.) A. Nels. Perennial from a severalstemmed rootstock; the scapes flowering when about $1 \mathrm{dm}$. high and elongating to 2.5 or $3 \mathrm{dm}$., woolly-pubescent beneath the involucre and at the base: leaves oblanceolate, 1-2 dm. long including the narrow-winged petiole, glabrous at the time of flowering or nearly so, entire or some of the larger with few teeth: flowers yellow, the ligules little exceeding the bracts, the fruiting heads about $3 \mathrm{~cm}$. high: involucral bracts woolly-pubescent, especially so on the edges, in three series, the outermost ones lanceolate-acuminate, the second series ovate, acuminate, exceeding the outermost, and equaling the narrow inmost series: achenes 10 -striate, a little less than $1 \mathrm{~cm}$. long, tapering into a slender filiform beak of the same length, which is crowned by the bright white pappus of about the same length. T. grandiflorum as to our range. (Agoseris montana Osterh. Bull. Torr. Bot Club 27: 507. 1900.)-Colorado and Wyoming.

\section{TARAXACUM Hall. Dandelion}

Perennial acaulescent herbs, with pinnatifid or toothed or rarely entire leaves all in a basal tuft and large heads of yellow flowers terminating usually simple and naked hollow scapes. Principal bracts of the involucre nearly equal, the outer much shorter and in several series. Receptacle flat, naked. Rays 5 -toothed at the truncate summit. Achenes oblong or linear-fusiform, 4 or 5-angled, 5 -10-nerved, somewhat spinulose above, tapering into a slender beak which bears at its summit a copious pappus of unequal persistent bristles.

Outer calýculate bracts appressed; a diminutive alpine plant .

1. T. scopulorum.

Outer calyculate bracts more or less spreading.

Achenes not red.

Leaves deeply runcinate; outer bracts early reflexed.

The terminal lobe of leaves large

The terminal lobe of leaves small

Leaves more or less toothed or sinuate; outer bracts tardily reflexed or with merely squarrose or reflexed tips.

Bracts conspicuously corniculate

Bracts (at least the outer ones) not corniculate Achenes red

2. T. officinale.

3. T. mexicanum.

4. T. dumetorum.

5. T. angustifolium.

6. T. ammophilum.

1. Taraxacum scopulorum (Gray) Rydb. Mem. N. Y. Bot. Gard. 1: 455. 1900. Minute, leaves and scape $3 \mathrm{~cm}$. or less long: head $6 \mathrm{~mm}$. or in fruit even $10 \mathrm{~mm}$. high, narrow, few-flowered; outer involucral bracts lanceolate, rather loose; inner somewhat corniculate.-Highest alpine region of the Rocky Mountains, Colorado to Montana.

2. Taraxacum officinale Weber, Prim. Fl. Hols. 56. 1780. Root thick and long, bitter: leaves oblong or spatulate in outline, irregularly dentate to sinuate-pinnatifid, from a few $\mathrm{cm}$. to nearly $3 \mathrm{dm}$. long, usually pubescent when young and somewhat succulent: inner bracts of the involucre linear or linear-lanceolate, acute, 10-15 mm. long; outer ones similar but shorter, reflexed: flowers yellow: pappus brownish or white, maturing into a globose mass. (T. Taraxacum Karst.) Common Dandelion.-Naturalized from Europe but finding in our range a peculiarly favorable environment, hence overrunning lawns and meadows.

3. Taraxacum mexicanum DC. Prodr. 7: 146. 1838. Very similar but usually smaller: leaves narrow and the terminal lobe small: bracts few.- Indigenous in the mountains; from Wyoming and Utah to Mexico.

4. Taraxacum dumetorum Greene, Pitt. 4: 230. 1901. Large, the crown of the root, or each of its several branches, bearing mostly 1 stout erect scape 1-3 dm. high and several upright leaves, some more than $2 \mathrm{dm}$. long; herbage glabrous: leaves oblanceolate, acutish, the margin not deeply but very unevenly and laciniately cut, the teeth spreading, seldom at all runcinate: scape under the involucre arachnoid-tomentose: outer bracts in about 3 series, 
very large, pale and thin, before the flowering almost equaling the inner and nearly concealing them, under the mature fruit relatively shorter, oblong, lanceolate, narrowed toward the summit, then again dilated into an ovate tip; inner bracts narrowly linear-lanceolate, with a dilated and bifid tip: achenes distinctly compressed, olive-green, spinulose at summit, otherwise smooth, or the 2 prominent angles and intervening ribs variously tuberculate or somewhat muricate; beak thrice the length of the achene. (T.ceratophorum and T. latilobum DC., as to our range; T. oblanceolatum A. Nels. in Herb.)Common in the mountains; from Colorado to British America.

5. Taraxacum angustifolium Greene, 1. c. 232. Glabrous throughout; crown of the root usually much-branched and the leaves and scape numerous: leaves oblong-linear, 8-15 cm. long, 1-2 cm. wide, obtuse or mucronately acute, sharply and remotely denticulate to coarsely dentate, the teeth all simple, opposite, seldom runcinate: scapes rather slender, slightly decumbent, in maturity twice the length of the leaves: involucres rather narrow and few-flowered, the outer bracts few and small, in a single series, or at least scarcely biserial, broadly lanceolate to oblong, erect: achenes chestnut-brown, spinulose-muricate at summit, smooth and obtusely costate from above the middle to the base; beak about thrice the length of the achene. T. leiospermum Rydb. Bull. Torr. Bot. Club 32: 137. 1905.)—Subalpine meadows; Colorado and Wyoming.

6. Taraxacum ammophilum A. Nels. ex Greene, Pitt. 4: 233. 1901. Stoutish, but multicipital and depressed, the leaves and numerous decumbent scapes only 5-10 cm. long; herbage wholly glabrous: leaves oblong or spatulateoblong, acutish, evenly but not strongly runcinate-toothed: outer involucral bracts in a single and even scanty series, thin and pale, oval to ovate-lanceolate, erect; the inner narrowly lanceolate, the tips slightly and somewhat scariously dilated: achenes distinctly though not strongly compressed, dark red-brown, muricate at the acute summit, the 4 principal angles tuberculate below, the intervening ones similar except as being less prominent; stipe of pappus nearly thrice the length of the achenes.-Creek banks in the mountains; southern Wyoming. 



\section{SUMMARY}

\begin{tabular}{|c|c|c|c|c|c|c|c|c|c|c|c|}
\hline \multirow{2}{*}{\multicolumn{8}{|c|}{ Family }} & \multirow{3}{*}{ Genera } & \multicolumn{2}{|c|}{ SPECIES } & \multirow{3}{*}{ VARIETIES } \\
\hline & & & & & & & & & \multirow{3}{*}{$\begin{array}{c}\text { Accepted } \\
4 \\
24\end{array}$} & \multirow{3}{*}{$\frac{\text { Synonyms }}{8}$} & \\
\hline 1. Ophioglossac & ceae & - & - & - & . & - & - & & & & \\
\hline 2. Polypodiacea & & - & - & - & . & - & - & 13 & & & \\
\hline 3. Marsileaceae & e. & • & • & • & . & - & - & 1 & 2 & & \\
\hline 4. Equisetaceae & . & - & • & - & - & - & - & 1 & 8 & & \\
\hline 5. Isoetaceae & & • & • & - & - & . & . & 1 & 2 & & 1 \\
\hline 6. Lycopodiaces & eae & - & - & - & - & - & - & 1 & 1 & & \\
\hline 7. Selaginellaces & eae & - & - & - & - & - & - & 1 & 3 & & 1 \\
\hline 8. Pinaceae & . . & - & - & - & - & - & - & 5 & 18 & 9 & 1 \\
\hline 9. Gnetaceae & . . & - & . & - & . & . & . & 1 & 3 & & \\
\hline 10. Typhaceae & . $\cdot$ & - & - & - & - & - & - & 1 & 2 & 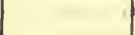 & \\
\hline 11. Sparganiacea & & - & - & - & - & - & - & 1 & 5 & & \\
\hline 12. Naiadaceae & • & - & - & - & - & . & - & 4 & 18 & 3 & \\
\hline 13. Juncaginacea & & - & - & - & - & - & - & 1 & 2 & & \\
\hline 14. Alismaceae & . & - & - & - & - & - & - & 2 & 5 & 2 & \\
\hline 15. Vallisneriacea & eae & • & - & - & - & - & - & 1 & 1 & 2 & \\
\hline 16. Gramineae . & . $\cdot$ & • & - & - & - & - & - & 65 & 206 & 82 & 13 \\
\hline 17. Cyperaceae & • & • & - & - & - & - & - & 7 & 99 & 50 & 6 \\
\hline 18. Lemnaceae & • & - & - & - & - & - & - & 2 & 7 & & $=$ \\
\hline 19. Commelinace & eae & - & - & - & - & - & - & 2 & 3 & 3 & \\
\hline 20. Pontederiacea & eae & - & - & - & - & - & - & 1 & 1 & & \\
\hline 21. Juncaceae . & . $\cdot$ & . & - & - & - & . & - & 2 & 25 & 9 & - \\
\hline 22. Liliaceae & . . & . & - & - & - & - & - & 10 & 24 & 9 & - \\
\hline 23. Melanthaceae & e. & . & - & . & . & . & - & 4 & 7 & 6 & \\
\hline 24. Convallariace & eae & • & - & - & - & . & - & 4 & 7 & 4 & 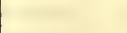 \\
\hline 25. Smilaceae . & - . & - & - & - & - & - & - & 1 & 1 & 1 & 1 \\
\hline 26. Iridaceae & . $\cdot$ & - & - & • & - & - & - & 2 & 5 & 5 & \\
\hline 27. Orchidaceae & . & - & - & - & - & - & - & 11 & 19 & 12 & 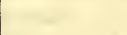 \\
\hline 28. Salicaceae . & . . & • & - & - & - & - & - & 2 & 40 & 44 & 5 \\
\hline 29. Betulaceae . & . . & • & - & - & - & . & - & 5 & 5 & 1 & \\
\hline 30. Fagaceae & - & - & - & - & - & - & - & 1 & 7 & 6 & 1 \\
\hline 31. Ulmaceae & - & - & - & - & - & - & - & 2 & 2 & 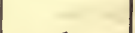 & $=$ \\
\hline 32. Moraceae & - & - & - & - & - & - & - & 1 & 1 & 1 & 1 \\
\hline 33. Urticaceae . & . . & • & - & . & - & . & - & 2 & 4 & 2 & \\
\hline 34. Loranthaceae & e. & . & - & - & - & . & - & 2 & 6 & 1 & \\
\hline 35. Santalaceae & • & - & - & - & - & - & - & 1 & 2 & & \\
\hline 36. Polygonaceae & e. & . & - & . & . & . & . & 4 & 77 & 49 & 5 \\
\hline 37. Chenopodiace & ceae & - & • & . & - & . & - & 14 & 51 & 25 & 3 \\
\hline 38. Amaranthace & eae & • & - & - & - & . & - & 4 & 12 & 3 & \\
\hline 39. Nyctaginacea & & - & • & - & - & - & - & 4 & 17 & 16 & 4 \\
\hline 40. Aizoaceae . & . $\cdot$ & • & • & - & - & - & - & 2 & 2 & 1 & \\
\hline 41. Portulacaceae & & • & • & • & - & - & - & 7 & 16 & 12 & 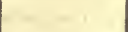 \\
\hline 42. Caryophyllace & ceae & • & - & . & - & - & - & 11 & 49 & 26 & 3 \\
\hline 43. Nymphaеacea & eae & • & • & - & - & - & . & 1 & 1 & 1 & 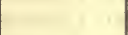 \\
\hline 44. Ceratophyllac & aceas & & • & - & - & - & . & 1 & 1 & & \\
\hline 45. Ranunculacea & eae & - & • & - & - & - & - & 15 & 87 & 52 & 3 \\
\hline 46. Berberidaceae & & • & • & - & - & . & . & 1 & 3 & 2 & \\
\hline 47. Papaveraceae & ie. & . & - & . & - & . & . & 5 & 8 & 7 & \\
\hline 48. Cruciferae & . $\cdot$ & & . & - & - & - & - & 24 & 133 & 94 & 3 \\
\hline
\end{tabular}




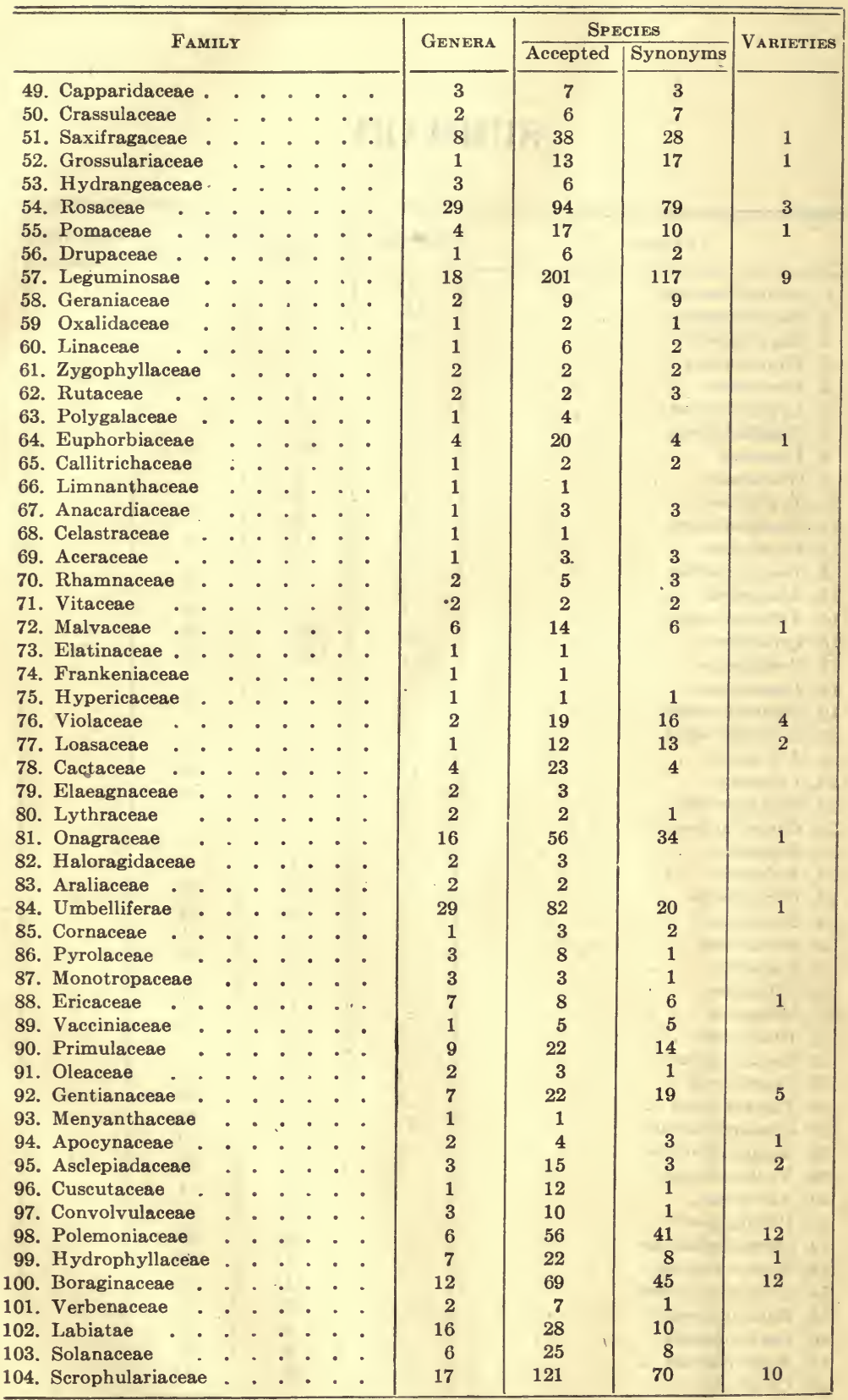




\begin{tabular}{|c|c|c|c|c|c|c|c|c|c|}
\hline \multirow{2}{*}{\multicolumn{6}{|c|}{ FAMILY }} & \multirow{3}{*}{$\frac{\text { GENERA }}{1}$} & \multicolumn{2}{|c|}{ SPECIES } & \multirow{3}{*}{ VARIETIES } \\
\hline & & & & & & & \multirow{3}{*}{$\begin{array}{c}\text { Accepted } \\
2 \\
4\end{array}$} & \multirow[t]{2}{*}{ Synonyms } & \\
\hline 105. Pinguiculaceae & . & . & . . & . . & . & & & & \\
\hline 106. Orobanchaceae & . & . & . & . . & . & 2 & & & \\
\hline 107. Martyniaceae. & . & . & . & . . & . & 1 & 1 & & \\
\hline 108. Plantaginaceae & . & . & . & - . & . & 1 & 7 & 5 & \\
\hline 109. Rubiaceae . . & . & . & . & . . & . & 2 & 10 & 2 & 1 \\
\hline 110. Caprifoliaceae . & . & . & . & . $\cdot$ & . & 5 & 16 & 9 & 4 \\
\hline 111. Adoxaceae . & . & . & - & - . & . & 1 & 1 & & \\
\hline 112. Cucurbitaceae & . & . & . & . & . & 2 & 2 & 1 & \\
\hline 113. Campanulaceae & . & • & . & •. & - & 2 & 6 & 2 & \\
\hline 114. Lobeliaceae . & . & . & . & - . & . & 2 & 3 & 3 & \\
\hline 115. Valerianaceae & . & . & . & . . & . & 1 & 4 & 10 & 2 \\
\hline 116. Compositae & . & . & . & . & . & 107 & 538 & 563 & 59 \\
\hline \multicolumn{6}{|c|}{ Totals } & 649 & 2733 & 1788 & 186 \\
\hline
\end{tabular}

Total number of accepted species
Total number of species merely mentioned or believed to be synonyms

Total number of names of species or varieties accounted for in some way 4,707 


\section{ABBREVIATIONS OF AUTHORS' NAMES}

A. Br.-Braun, Alexander.

Adans.-Adanson, Michel.

A. DC.-De Candolle, Alphonse.

Ait.-Aiton, William.

All.-Alliono, Carlo.

Anders.-Andersson, Nils Johan.

Arn.-Arnott, George A. Walker.

Baill.-Baillon, Henri Ernest.

Beauv.-Beauvois, A. M. F. J. Palisot de. Benth.-Bentham, George.

B. \& H.-Bentham, George, and Hooker, Joseph Dalton.

B. Juss.-Jussieu, Bernard de.

Bess.-Besser, Wilhelm S. J. G. von.

Bigel.-Bigelow, Jacob.

Boerh.-Boerhaave, Hermann.

Boiss.-Boissier, Edmond.

$B r ., A$. Br.-Braun, Alexander.

$B r .$, R. Br.-Brown, Robert.

Briq.-Briquet, John.

Brit.-Britton, Nathaniel Lord.

Burgsd.-Burgsdorff, F. A. L. von.

C. \& R.-Coulter, J. M., and Rose, J. N.

C. A. Mey.-Meyer, Carl Anton.

Carr.-Carrière, Élie Abel.

Cass.-Cassini, Henri.

Cav.-Cavanilles, Antonio José.

Cham.-Chamisso, Adalbert von.

Chapm.-Chapman, Alvan Wentworth.

Chois.-Choisy, Jacques-Denis.

Ckll.-Cockerell, T. D. A.

Coult.-Coulter, John Merle.

DC.-De Candolle, Augustin P.

Desf.-Desfontaines, Réné Louiche.

Desv.-Desvaux, Augustin Nicaise.

Dietr.-Dietrich, Albert.

Dougl.-Douglas, David.

Eat.-Eaton, Amos.

Ehrh.-Ehrhart, Friedrich.

Ell.-Elliott, Stephen.

Endl.-Endlicher, Stephan Ladislaus.

Engelm.-Engelmann, George.

Esch.-Eschscholtz, Johann Friedrich.

$F$. \& M.-Fischer, F. E. L. von, and Meyer, C. A.

Fisch.-Fischer, F. E. Ludwig von.
Foug.-Fougeroux, Auguste Denis.

Fourn.-Fournier, Eugène.

Fresn.-Fresenius, J. B. G. W.

Gaertn.-Gaertner, Joseph.

Gilib.-Gilibert, Jean Emmanuel.

Gmel.-Gmelin, Samuel Gottlieb.

Gmel., J. G. Gmel. - Gmelin, Johann Georg.

Good.-Goodenough, Samuel.

Good, L. N.-Goodding, Leslie Newton.

Grev.-Greville, Robert Kaye.

Griseb.-Grisebach, Heinrich R. A.

Gronov.-Gronovius, Jan Fredrik.

H. \& A.-Hooker, William Jackson, and

Arnott, G. A. Walker.

Hack.-Hackel, Eduard.

Haussk.-Haussknecht, Carl.

$H B K$.-Humboldt, F. Alexander von,

Bonpland, Aimé, and Kunth, C. S.

Hitchc.-Hitchcock, Albert Spear.

Holz.-Holzinger, John M.

Hook.-Hooker, William Jackson.

Hornem.-Hornemann, Jens Wilken.

Jacq.—Jacquin, Nicolaus Joseph.

Juss.-Jussieu, Antoine Laurent de.

Juss., B. Juss.—Jussieu, Bernard de.

Ktze.-Kuntze, Otto.

L.-Linnaeus, Carolus, or Linné, Carl von

Lag.-Lagasca, Mariano.

Lall.-Ave-Lallemant, J. L. E.

Lam.-Lamarck, J. B. A. P. Monnet.

Ledeb.-Ledebour, Carl F. von.

Lehm.-Lehmann, J. G. C.

Less.-Lessing, Christian Friedrich.

L'Hér.-L'Héritier de Brutelle, C. L.

Lindl.-Lindley, John.

MacM.-MacMillan, Conway.

Maxim.-Maximowicz, Carl Johann.

Medic.-Medicus, Friedrich Casimir.

Meisn.-Meisner, Carl Friedrich.

Merr.-Merrill, Elmer D.

Mey.-Meyer, Ernst Heinrich F.

Mey., C. A. Mey.-Meyer, Carl Anton.

Michx.-Michaux, André.

Mill.-Miller, Philip.

Moq.-Moquin-Tandon, Alfred. 
Muell. Arg.-Mueller, Jean (of Aargau). Muench.-Muenchhausen, Otto Freiherr von.

Muhl.-Muhlenberg, G. H. E.

Murr.-Murray, Johann Andreas.

Neck.-Necker, Noel Joseph de.

Nees.-Nees von Esenbeck, Christian Gottfried.

Nels., A. Nels.-Nelson, Aven.

Nels., E. Nels.—Nelson, Elias.

Nutt.-Nuttall, Thomas.

Ort.-Ortega, C. G.

Osterh.-Osterhout, Geo. E.

Pall.-Pallas, Peter Simon.

Parl.-Parlatore, Filippo.

P. Br.-Browne, Patrick.

Pers.-Persoon, Christian Hendrik.

Planch.-Planchon, Jules Émile.

Poir.-Poiret, Jean Louis Marie.

R. \& S.-Roemer, J. J., and Schultes, Augutst.

Raf.-Rafinesque-Schmaltz, C. S.

$R$. Br.-Brown, Robert.

Reichenb.-Reichenbach, H, G. L.

Retz.-Retzius, Anders Johan.

Richards.—Richardson, John.

Roem.-Roemer, M. J.

Rottb.-Rottboell, Christen Fries.

Rupp.-Ruppius, Heinrich Bernhard.

Rupr.-Ruprecht, Franz J.

Rydb.-Rydberg, Per Axel.

Salisb.-Salisbury, Richard Anthony.
Sarg.-Sargent, Charles Sprague.

Sch. Bip. Schultz, Karl Heinrich (distinguished as Bipontinus, i. e. of Zweibrucken).

Schwein.-Schweinitz, Lewis David de. Scop.-Scopoli, Johann Anton.

Scribn.-Lamson-Scribner, Frank.

Ser.-Seringe, Nicolas Charles.

Sheld.-Sheldon, Edmund P.

Sm., J.G.Sm.-Smith, Jared Gage.

Spreng.-Sprengel, Kurt.

Sternb.-Sternberg, Caspar.

Steud.-Steudel, Ernst Gottlieb.

St. Hil.-St. Hilaire, Auguste de.

Sudw.-Sudworth, Geo. B.

Sw.-Swartz, Olaf.

T. \& G.-Torrey, John, and Gray, Asa.

Thunb.-Thunberg, Carl Pehr.

Thurb.-Thurber, George.

Torr.-Torrey, John.

Tourn.-Tournefort, Joseph Pitton de.

Trel.-Trelease, William.

Trev.-Treviranus, Christian Ludolf.

Trin.-Trinius, Karl Bernhard.

Turcz.-Turczaninow, Nicolaus.

Underw.-Underwood, Lucien Marcus.

Vent.-Ventenat, Étienne Pierre.

Vill.-Villars, Dominique.

Walp.-Walpers, Wilhelm Gerhard.

Wats.-Watson, Sereno.

Willd.-Willdenow, Carl Ludwig.

Wormsk.-Wormskiold, M. von. 


\section{LIST OF NEW NAMES AND COMBINATIONS *}

[References are to pages.]

Glyceria borealis (Nash) A. Nels.

Luzula intermedia (Thuill.) A. Nels.

Spiranthes stricta (Rydb.) A. Nels.

Quercus Gambellii Fendleri (Liebm.) A. Nels.

Eriogonum umbellatum intectum A. Nels.

Corispermum imbricatum A. Nels.

Kochia vestita (Wats.) A. Nels.

Atriplex pabularis eremicola (Osterh.) A. Nels.

Salsola pestifer A. Nels.

Suaeda erecta (Wats.) A. Nels.

Suaeda Moquinii (Torr.) A. Nels.

Allionia hirsuta aggregata (Ortega) A. Nels.

Allionia pilosa decumbens (Nutt.) A. Nels.

Allionia linearis Bodinii (Holz.) A. Nels.

Lewisia minima A. Nels.

Cerastium fuegianum (Hook.) A. Nels.

Arenaria aequicaulis A. Nels.

Arenaria macrantha (Rydb.) A. Nels.

Spergularia sparsiflora (Greene) A. Nels.

Aquilegia caerulea leptocera (Nutt.) A. Nels.

Delphinium carolinianum Penhardii (Huth.) A. Nels.

Clematis pseudoalpina (Kuntze) A. Nels.

Clematis pseudoalpina tenuiloba (Gray) A. Nels.

Schoenocrambe linifolia pinnata (Greene) A. Nels.

Strepanthus coloradensis A. Nels.

Draba lapilutea A. Nels.

Arabis aprica Osterh.

Arabis perelegans A. Nels.

Arabis caduca A. Nels.

Erysimum aridum A. Nels.

Sedum integrifolium (Raf.) A. Nels.

Mitella Parryi (Piper) A. Nels.

Tellima bulbifera (Rydb.) A. Nels.

Boykinia heucheriformis (Rydb.) A. Nels.

Saxifraga austrina A. Nels.

Saxifraga micro petala (Small) A. Nels.

Physocarpus pubescens (Rydb.) A. Nels.

Physocarpus Ramaleyi A. Nels.

Physocarpus intermedius (Rydb.) A. Nels.

Physocarpus monogynus (Torr.) A. Nels.

Physocarpus malvaceus (Greene) A. Nels.

Bossekia deliciosa (James) A. Nels.

Fragaria ovalis gla uca (Wats.) A. Nels.

* Only a very few new species are proposed in this work. It has been found necessary, however, to make use of a very considerable number of new combinations and names. The list, as given, is believed to contain the names not hitherto used. 
Vicia americana oregana (Nutt.) A. Nels. . . . . . . . . 301

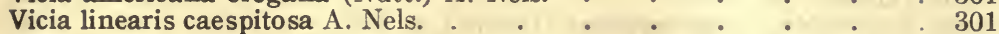

Euphorbia manca A. Nels. . . . . . . . . . . 311

Malvastrum dissectum Cockerellii A. Nels. . . . . . . . 318

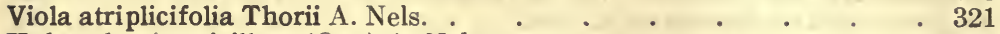

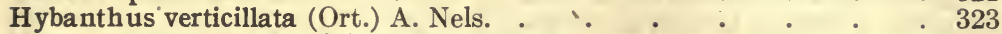

Mentzelia latifolia (Rydb.) A. Nels. . . . . . . . . 324

Mentzelia multiflora densa (Greene) A. Nels. . . . . . 325

Mentzelia pumila multica ulis (Osterh.) A. Nels. . . . . $\quad 326$

Mamillaria neo-mexicana (Engelm.) A. Nels. . . . . . . $\quad 327$

Gaurella canescens (Torr.) A. Nels. . . . . . . . 341

Phyllodoce gland uliflora intermedia (Hook.) A. Nels. . . . . 370

Drosace A. Nels. • • . . . . • . . . . 374

Drosace carinata (Torr.) A. Nels. . . . . . . . . . . 374

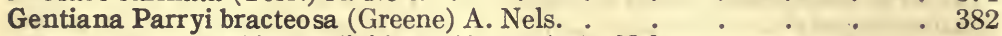

A pocynum cannabinum lividum (Greene) A. Nels. . . . . $\quad$. 386

Cuscuta Anthemi A. Nels. . . . . . . . . 390

Phlox puberula (E. Nels.) A. Nels. . . . . . . . . 397

Gilia micrantha (Kell.) A. Nels. . . . . . . . . 399

Polemonium pulcherrimum parvifolium (Nutt.) A. Nels. . . . 404

Polemonium mellitum speciosum (Rydb.) A. Nels. . . . . 405

Phacelia heterophylla alpina (Rydb.) A. Nels. . . . . . . 408

Nama angustifolia (Gray) A. Nels. . . . . . . . . 410

Lappula subdecumbens (Parry) A. Nels. ․ . . . . . $\quad$. 412

Lappula foliosa A. Nels. . . . . . . . . . . 413

Cryptanthe flexuosa A. Nels. . . . . . . . . . . 416

Oreocarya alata (Jones) A. Nels. . $\quad . \quad$. $\quad . \quad$. $\quad . \quad 4417$

Mertensia ciliata polyphylla (Greene) A. Nels. . . . . . . 421

Mertensia ciliata punctata (Greene) A. Nels. . _ _ . _ . . . . 421

Mertensia brevistyla obtusiloba (Rydb.) A. Nels. . . . _ . . . . 421

Mertensia papillosa fusiformis (Greene) A. Nels. . . . . . . . 421

Mertensia papillosa lineariloba (Rydb.) A. Nels. . . . . . 421

Mertensia lanceolata brachyloba (Greene) A. Nels. . . . . . 422

Mertensia Bakeri amoena A. Nels. . . . . . . . . . 422

Mertensia Bakeri lateriflora (Greene) A. Nels. . . . . . . 423

Pentstemon secundiflor us caudatus (Heller) A. Nels. ․ . . . . 444

Pentstemon procerus pseudoprocerus (Rydb.) A. Nels. . . . . 444

Pentstemon brevifolius (Gray) A. Nels. . . . . . . . 445

Pentstemon sepalulus A. Nels. . . . . . . . . . . 449

Synthyris wyomingensis gymnocarpa A. Nels. . . . . . . . 450

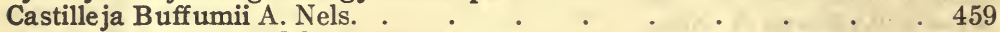

Castilleja dubia A. Nels. . . . . . . . . . $\quad .460$

Sambucus gla uca neo-mexicana (Wooton) A. Nels. . . . . . . 469

Symphoricar pos occidentalis quercifolia A. Nels. ․ . . 470

Symphoricarpos oreophilus utahensis (Rydb.) A. Nels. . . . . 471

Laurentia eximia A. Nels. . . . . . . . . 475

Valeriana micrantha wyomingensis (E. Nels.) A. Nels. . : : : $\quad$ : 476

Valeriana acutiloba ovata (Rydb.) A. Nels. . . . . . . 476

Brickellia ambigens (Greene) A. Nels. . . . . . . . . 486

Liatris ligulistylis A. Nels. • • • • • • • • 488

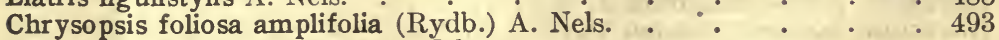

Chrysopsis foliosa imbricata A. Nels. . . . . . . 493

Chrysothamnus graveolens glabrata (Gray) A. Nels. . . . . 4496

Sideranthus spinulosus glaberrimus (Rydb.) A. Nels. . . . . . . . 499

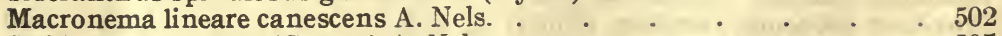

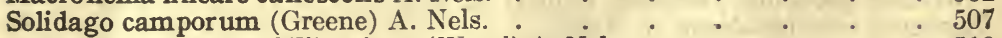

Townsendia exsca pa Wilcoxiana (Wood) A. Nels. : $\quad . \quad$ : $\quad$ - 510

Xylorhiza glabriuscula villosa (Nutt.) A. Nels. . . . . . . $\quad 511$

Aster glaucus formosus A. Nels. . . . . . . . . . 513 
Aster culminis A. Nels.

Aster adscendens armeriaefolius (Greene) $\dot{A}$. Nels.

Erigeron Garrettii A. Nels.

Erigeron ursinus gracilis (Rydb.) A. Nels. . . . . . . . 527

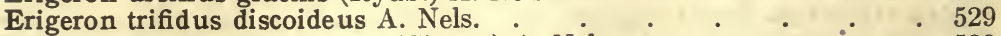

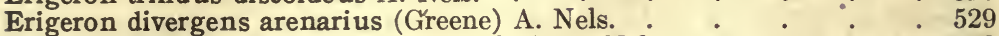

Erigeron divergens nudiflor us (Buckley) A. Nels. . . . . . 529

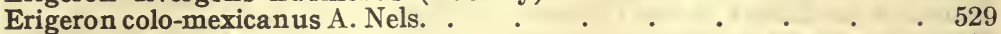

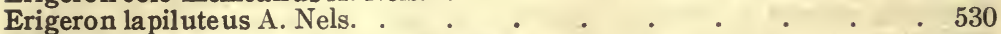

Wyomingia argentata (Gray) A. Nels. . . . . . . . . 531

Wyomingia cana (Gray) A. Nels. . . . . . . . . . 531

Wyomingia Tweedyana (Canby \& Rose) A. Nels. . . . . . . $\quad$. 531

Antennaria parvifolia bracteosa (Rydb.) A. Nels. . . . . . . 535

Franseria tomentosa (Nutt.) A. Nels. . . . . . . . . 542

Franseria Grayi A. Nels. . . . . . . . . . 542

Balsamorrhiza macrophylla terebinthacea (Nutt.) A. Nels. - . $\quad$. 546

Balsamorrhiza Hookeri hirsuta (Nutt.) A. Nels. . . . . . . 546

Chaenactis Douglasii achilleaefolia (H. \& A.) A. Nels. . . . . $\quad$. 557

Actinella acaulis caespitosa A. Nels. . . . . . . . 558

Actinella simplex A. Nels. . . . . . . . . . . . $\quad$. 558

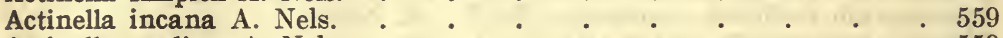

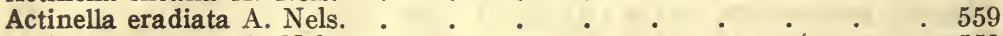

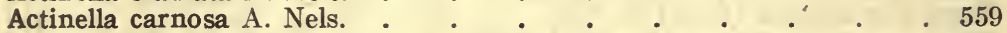

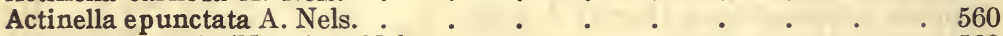

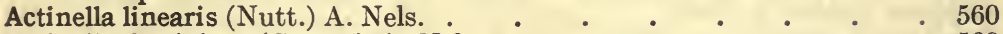

Actinella fastigiata (Greene) A. Nels. . . . . . . . $\quad$. 560

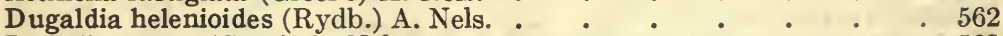

Dysodia a urea (Gray) A. Nels. . . . . . . . . . . . 563

Artemisia saxicola Parryi A. Nels. . . . . . . . . 568

Artemisia Wrightii coloradensis (Osterh.) A. Nels. . . . . 568

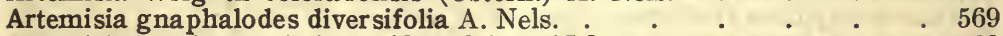

Artemisia mexicana silvicola (Osterh.) A. Nels. ․ . . . $\quad$. $\quad$. 569

Artemisia mexicana Bakeri (Greene) A. Nels. . . . . . . 569

Arnica paniculata A. Nels.

Arnica subplumosa sylvatica (Greene) A. Nels.

Arnica subplumosa macillenta (Greene) A. Nels.

Senecio serra admirabilis A. Nels.

Senecio perplexus dispar A. Nels.

Senecio canus Purshianus (Nutt.) A. Nels.

Senecio uintahensis A. Nels.

Senecio Rydbergii A. Nels.

Carduus americanus perplexans (Rydb.) A. Nels.

Carduus Hookerianus eriocephalus (Gray) A. Nels.

Carduus Hookerianus hesperius (Eastw.) A. Nels.

Carduus megacephalus (Gray) A. Nels.

Stephanomeria pauciflora (Torr.) A. Nels.

Krigia virginica (L.) A. Nels.

Prenanthes sagittata (Gray) A. Nels.

Crepis riparia parva A. Nels.

Hieracium gracile minimum A. Nels.

Hieracium Scouleri griseum (Rydb.) A. Nels.

Lactuca integrata (Gren. \& Godr.) A. Nels.

Troximon pubescens (Rydb.) A. Nels.

Troximon villosum (Rydb.) A. Nels.

Troximon gla ucum pumilum (Nutt.) A. Nels.

Troximon arachnoideum A. Nels. .

Troximon purpure um (Gray) A. Nels.

Troximon elatum (Nutt.) A. Nels.

Troximon montanum (Osterh.) A. Nels. 


\section{GLOSSARY}

$A$, as a prefix in compounds, usually signifies a negative, or the absence of something; as, a-petalous, without petals; a-phyllous, leafless, etc. If the word begins with a vowel, the prefix is an; as, an-antherous, destitute of an anther.

Abnormal. Contrary to the usual structure. Abortive. Imperfectly formed or rudimentary.

Abruptly pinnate. Pinnate without an odd leaflet at the end.

Acaulescent. Apparently stemless; the proper stem, i bearing the leaves and flowers, being very short or subterranean.

Accrescent. Growing larger after flowering, as the calyx of Physalis.

Accumbent (embryo). Cotyledons with the edges against the hypocotyl.

Acerose. Needle-shaped, as the leaves of pines.

Achene. A small, dry, hard, 1-celled, 1seeded, indehiscent fruit.

Achlamydeous (flower). Without floral envelopes.

Acicular. Needle-shaped; more slender than acerose.

Acrogenous. Growing from the apex, as the stems of ferns and mosses.

Aculeate. Armed with prickles (aculei), as the rose and brier.

Aculeolate. Armed with small prickles, or slightly prickly.

Acuminate. Taper-pointed.

Acute. Merely sharp-pointed, or ending in a point less than a right angle.

Adnate. United in growth; the anther is adnate when fixed by its whole length to the filament.

Adscendent, Ascendent, Ascending. Rising gradually upwards.

Adsurgent, Assurgent. Same as adscendent, etc.

Adventitious. Out of the usual place.

Adventive. Imperfectly naturalized.

Aequilateral. Equal-sided; opposed to oblique (in foliar organs).

Aestivation. The arrangement of parts in a flower-bud.

Ala (plural alae). A wing; the side-petal of a papilionaceous corolla.

Alate. Winged.

Albumen. An old general name for nutritive tissue in the seed.
Alliaceous. Having the smell or taste of garlic.

Alpine. Belonging to high mountains above the limit of forests.

Alternate (leaves, branches, etc.). Occurring singly at the nodes of the axis.

Alveolate. Honeycomb-like, as the receptacle of the cotton-thistle.

Ament. Same as catkin.

Amentaceous. Catkin-like, or catkin-bearing.

Amorphous. Without any definite form. Amphitropous (ovule or seed). Halfinverted and straight, with the hilum lateral.

Amplexicaul (leaves). Clasping the axis by the base.

Ampullaceous. Swelling out like a bottle or bladder.

Anastomosing. Forming a net-work (anastomosis), as the veins of leaves.

Anatropous (ovule). Inverted and straight, with the micropyle next the hilum.

Ancipital. Two-edged, as the stem of blue-eyed grass.

Androecium. The whole set of stamens.

Androgynous. Having both staminate and pistillate flowers in the same inflorescence.

Angiosperms. The great group of seedplants with ovules (and seeds) inclosed by an ovary.

Annual. Of only one year's duration. Winter annual, a plant from autumnsown seed which blooms and fruits in the following spring.

Annular. In the form of a ring, or forming a circle.

Annulate. Marked by rings.

Annulus. A ring, like that of the sporecase of most ferns.

Anterior, in the flower, is the side towards the bract (external); while posterior is the side towards the axis.

Anther. The essential part of the stamen, which contains the pollen.

Antheriferous. Anther-bearing.

Anthesis. The opening of the flower.

Apetalous (flower). Without petals.

Aphyllous. Destitute of leaves, at least of green leaves.

A piculate. Tipped with a short and abrupt point. 
A pocarpous (pistils). The carpels of a flower forming separate pistils, as in a buttercup.

Appressed. Lying close and flat.

Arachnoid. Cobwebby; consisting of soft downy fibers.

Arboreous, Arborescent. Tree-like in size or form.

Archegonium (plural archegonia). The female organ in mosses and ferns.

Arcuate. Bent or curved like a bow.

Areolate. Marked out into little areas; reticulate.

Aril. An appendage growing at or about the hilum of a seed.

Arillate (seed). Furnished with an aril.

Aristate. Awned, like the beard of barley.

Aristulate, Diminutive of aristate; shortawned.

Articulated. Jointed.

Assurgent. See adsurgent.

Auriculate. Furnished with auricles or earlike appendages.

Awl-shaped. Sharp-pointed from a broader base.

Awn. Bristle-like appendage.

Awned. Furnished with an awn or long bristle-shaped tip.

Axil. The upper angle between a leaf and the stem.

Axile. Belonging to the axis, or occupying the axis.

Axillary (bud, etc.). Occurring in an axil.

Axis. The central line of any body; the organ round which others are attached; the root and stem.

Baccate. Berry-like.

Barbed. Furnished with rigid points or short bristles, usually reflexed like the barb of a fishhook.

Barbellate. Finely barbed.

Basifixed. Attached by the base.

Bast. The fibrous portion of the inner bark.

Beaked. Ending in a prolonged narrow tip.

Bearded. With long or stiff hairs of any sort; awns of grasses are sometimes called beard.

Berry. A fruit pulpy or juicy throughout, as a currant or a grape.

$B i$, in compounds, means two or twice.

Bidentate. Having two teeth.

Biennial. Of two years' duration, springing from the seed one season, flowering and dying the next.

Bifid. Two-cleft to about the middle.

Bifoliolate (leaf). With two leaflets.

Bilabiate. Two-lipped.

Bilocular. Two-celled.

Binate. Two together.

Bipinnate (leaf). Twice pinnate.

Bipinnatifid. Twice pinnatifid.
Biserial, Biseriate. Occupying two rows, one within the other.

Biserrate. Doubly serrate, as when the teeth of a leaf are themselves serrate.

Biternate. Twice ternate (principal divisions 3 , each with 3 leaflets).

Bladdery. Thin and inflated.

Bract. In general, the leaves of an inflorescence, more or less different from ordinary leaves; specially, the small leaf or scale in the axil of which a flower or its pedicel stands.

Bractlet. A bract on the pedicel or flowerstalk.

Bristle. A stiff, sharp hair, or any very slender body of similar appearance.

Bulb. A leaf-bud with fleshy scales, usually subterranean.

Bulbiferous. Bearing or producing bulbs.

Bulblet. A small bulb, especially one borne upon the stem.

Bulbose, Bulbous. Bulb-like in form.

Bullate. Appearing as if blistered or bladdery.

Caducous. Dropping off very early, compared with other parts.

Caespitose, Cespitose. Growing in turf-like patches or tufts.

Calcarate. Furnished with a spur.

Callus. A hard protuberance or callosity; in the grasses the tough often hairy swelling at the base or insertion of the lemma or palet.

Calyculate (flower). Furnished with an outer set of bracts resembling an outer calyx.

Calyx. The outer set of floral envelopes. Campanulate. Bell-shaped.

Campylotropous (ovule or seed). Curved so as to bring the apex and base nearly together.

Canaliculate. Channeled, or with a deep longitudinal groove.

Cancellate. Latticed, resembling latticework.

Canescent. Grayish-white; hoary, usually because the surface is covered with fine white hairs. Incanous is whiter still.

Capillary. Hair-like in form; as fine as hair or slender bristles.

Capitate. Shaped like a head; collected into a bead or dense cluster.

Capitellate. Diminutive of capitate.

Capitulum. A little head.

Capsular. Relating to or like a capsule.

Capsule. A pod; any dry dehiscent seedvessel.

Carinate. Keeled; furnished with a sharp ridge or projection on the lower side.

Cariopsis, Caryopsis. The one-seeded fruit or grain of grasses.

Carneous. Flesh-colored; pale red. 
Carnose. Fleshy in texture.

Carpel. The unit of structure of the pistil, which may consist of a single carpel or of several carpels.

Carpophore. The slender prolongation of the floral axis which in the Umbelliferae supports the pendulous ripe carpels.

Cartilaginous. Firm and tough in texture, like cartilage.

Caruncle. An excrescence at the hilum of some seeds, as those of Polygala.

Carunculate. Furnished with a caruncle.

Catkin. A scaly deciduous spike of flowers; an ament.

Caudate. Tailed or tail-pointed.

Caudex. The persistent base of an otherwise annual herbaceous stem.

Caulescent. Having an obvious stem.

Cauline. Of or belonging to a stem.

Centrifugal (inflorescence). Produced or expanding in succession from the center outwards.

Centripetal. The opposite of centrifugal.

Cernuous. Nodding; the summit more or less inclining.

Chaff. Small membranous scales or bracts on the receptacle of Compositae; the glumes of grasses, etc.

Chafiy. Furnished with chaff, or of the texture of chaff.

Channeled. Hollowed out like a gutter; same as canaliculate.

Chartaceous. With the texture of paper or parchment.

Ciliate (foliar organs). Beset on the margin with a fringe.

Cinereous. Ash-grayish; the color of ashes.

Circinate. Rolled inwards from the top, like a crosier.

Circumscissile. Dehiscing by a regular transverse circular line of division.

Cirrhiferous, Cirrhose. Furnished with a tendril.

Clavate. Club-shaped; slender below and thickened upwards.

Claw. The narrow or stalk-like base of some petals.

Club-shaped. See clavate.

Coalescence. The union of parts or organs of the same kind.

Cochleate. Coiled or shaped like a snail shell.

Cohesion. The union of one organ with another of like nature.

Column. The united stamens, as in Malvaceae; or the stamens and pistils united into one body, as in Orchidaceae.

Coma. A tuft of any sort (literally, a head of hair).

Commissure. The plane of junction of two carpels, as in the fruit of Umbelliferae.

Comose. Tufted; bearing a tuft of hairs.
Compressed. Flattened on two opposite sides.

Conduplicate. Folded upon itself lengthwise.

Confluent. Blended into one, or running together.

Congested, Conglomerate. Crowded together.

Conjugate. Coupled; in single pairs.

Connate. United or grown together from the first.

Connective. The part of the anther connecting its two cells.

Connivent. Converging, or brought close together.

Contorted. Twisted together.

Convolute. Rolled up lengthwise, as the leaves of the plum in vernation.

Cordate. Heart-shaped.

Coriaceous. Resembling leather in texture.

Corm. A solid bulb, like that of Crocus.

Corneous. Of the consistence or appearance of horn, as the albumen of the seed of the date, coffee, etc.

Corniculate. Furnished with a small horn or spur.

Corolla. The floral envelope (usually showy) within the calyx.

Corona. A coronet or crown; an appendage at the top of the claw of some petals, as Silene and soapwort.

Corrugate. Wrinkled or in folds.

Cortical. Belonging to the bark (cortex).

Corymb. A flat or convex flower-cluster, with branches arising at different levels and centripetal blooming.

Corymbose. Approaching the form of a corymb, or branched in that way; arranged in corymbs.

Costa. A rib; the midrib of a leaf, etc.

Costate. Ribbed.

Cotyledons. The first leaves of the embryo.

Crateriform. Goblet-shaped; broadly cupshaped.

Creeping (stems). Growing flat on or beneath the ground and rooting.

Cremocarp. A half-fruit, or one of the two carpels of Umbelliferæ.

Crenate. With rounded teeth.

Crested, Cristate. Bearing any elevated appendage like a crest.

Cribrose. Pierced like a sieve with small apertures.

Crinite. Bearded with long hairs, etc.

Crown. See corona.

Cruciate, Cruciform. Cross-shaped, as the four spreading petals of the mustard and the petals of all the flowers of that family.

Crustaceous. Hard and brittle in texture; crust-like.

Cucullate. Hooded or hood-shaped; rolled up like a cornet of paper, as the spathe of Indian turnip. 
Culm. The stem of grasses and sedges.

Cuneate, Cuneiform. Wedge-shaped.

Cupule. A little cup; the cup of the acorn.

Cuspidate. Tipped with a sharp and stiff point.

Cut. Same as incised; or applied generally to any sharp and deep division.

Cyathiform. With the shape of a cup, or particularly of a wineglass.

Cymbiform. Boat-shaped.

Cyme. Like a corymb, but with centrifugal blooming.

Cymose. Furnished with cymes, or like a cyme.

Deciduous. Falling off, or subject to fall; applied to leaves which fall in autumn, and to a calyx and corolla which fall before the fruit forms.

Decompound. Several times compounded or divided.

Decumbent. Reclined on the ground, the summit tending to rise.

Decurrent (leaves). With blade-like extension on the stem beneath the insertion, as in thistles.

Decussate. Arranged in pairs (or whorls) which are successively at right angles (or alternate) with each other.

Deflexed. Bent downwards.

Dehiscence. The natural opening of a closed vessel, as of an anther or a pod.

Dehiscent. Opening by some method of dehiscence.

Deltoid. Triangular in shape, like the Greek capital $\Delta$.

Dentate. Toothed.

Denticulate. Furnished with very small teeth; a diminutive of dentate.

Depauperate (impoverished or starved). $\mathrm{Be}$ low the natural size.

Depressed. Flattened, or as if pressed down from above; flattened vertically.

Dextrorse. Turned to the right.

$D i$, as a prefix in compounds, means two or twice.

Diadelphous (stamens). United by filaments in two sets.

Diandrous. Having two stamens.

Dichotomous. Two-forked.

Dicotyledonous (embryo). Having a pair of cotyledons.

Didymous. Twin.

Didynamous. With two stamens longer than the others.

Diffuse. Spreading widely and irregularly.

Digitate (fingered). Where the leaflets of a compound leaf are all borne on the apex of the petiole.

Digynous (flower). Having two pistils.

Dimerous. Made up of two parts, or with organs in twos.

Dimorphous. Of two forms.
Dioecious, Dioicous. With stamens and pistils in separate flowers on different plants.

Disciform, Disk-shaped. Flat and circular, like a disk or quoit.

Disk. The face of any flat body; the central region of a head of flowers, like the sunflower, as opposed to the ray or margin; a fleshy expansion of the receptacle of a flower.

Dissected. Cut deeply into many lobes or divisions.

Dissepiment. The partition of an ovary or fruit.

Distichous. Two-ranked.

Divaricate. Very widely divergent.

Divided (leaves, etc.). Cut into divisions extending about to the base or the midrib.

Dorsal. Upon or relating to the back or outer surface of an organ.

Downy. Clothed with a coat of soft and short hairs.

Drupaceous. Like or pertaining to a drupe.

Drupe. A stone-fruit.

$E$ - or $E x$-, as a prefix in compounds, means destitute of; as e-costate, without a rib or midrib.

Eared. See auriculate.

Ebracteate. Destitute of bracts.

Echinate. Armed with prickles (like a hedgehog).

Elliptical. Oval or oblong, with the ends regularly rounded.

Emarginate. Notched at the summit.

Emersed. Raised out of water.

Ensiform. Sword-shaped, as the leaves of Iris.

Entire (foliar organs). The margin not at all toothed, notched, or divided.

Ephemeral. Lasting for a day or less.

Epigynous. Upon the ovary.

Epiphyte. A plant growing on another plant, but not nourished by it; an airplant.

Equitant. Astride; used of conduplicate leaves which infold each other in two ranks, as in Iris.

Erose. Eroded, as if gnawed.

Evergreen. Holding the leaves over winter or longer, until new ones appear.

Excurrent. Running out, as when a midrib projects beyond the apex of a leaf, or a trunk is continued to the very top of a tree.

Explanate. Spread or flattened out.

Exserted. Protruding out of, as the stamens out of the corolla.

Extrorse. Turned outwards; the anther is extrorse when fastened to the filament so as to dehisce outwards (away from the pistil), as in Iris. 
Falcate. Scythe-shaped; a flat body curved, its edges parallel.

Farinaceous. Mealy in texture.

Farinose. Covered with a mealy powder.

Fascicle. A close cluster.

Fascicled. Growing in a bundle or tuft, as the leaves of pine and larch, and the roots of peony and dahlia.

Fastigiate (branches). Close, parallel.

Faveolate, Favose. Honeycombed; sameas alveolate.

Fertile. Fruit-bearing, or capable of producing fruit; also applied to anthers when they produce good pollen.

Fiddle-shaped. Obovate with a deep recess on each side.

Filament. The stalk of a stamen; also any slender thread-shaped appendage.

Filamentose, Filamentous. Bearing or formed $\bullet$ of slender threads.

Filiform. Thread-shaped; long, slender, and cylindrical.

Fimbriate. Fringed; furnished with fringes.

Fistular, Fistulose. Cylindrical and hollow, as the leaves of onion.

Flabelliform, Flabellate. Fan-shaped; broad, rounded at the summit, and narrowed at the base.

Fleshy. Composed of firm pulp or flesh; succulent.

Flexuose, Flexuous. Bending gently in opposite directions, in a zigzag way.

Floccose. Composed of or bearing tufts of woolly or long and soft hairs.

Floret. A small flower, usually one of a dense cluster.

Foliaceous. Belonging to, or of the texture or nature of a leaf.

Foliose. Leafy.

Follicle. A simple pod, opening down the inner suture.

Foveate. Deeply pitted.

Foveolate. Diminutive of foveate.

Free. Not united with any other parts.

Fringed. The margin beset with slender appendages, bristles, etc.

Frond. The leaf of ferns and some other cryptogams; in Lemnaceae, the thalluslike stem which functions as foliage.

Fruit. The seed-bearing structure of a plant.

Fugacious. Soon falling off or perishing.

Fulvous. Tawny; dull yellow with gray.

Funiculus. The stalk of a seed or ovule.

Funnelform, Funnel-shaped. Expanding gradually upwards, like a funnel.

Furcate. Forked.

Fuscous. Deep gray-brown.

Fusiform. Spindle-shaped.

Galea. A hooded or helmet-shaped portion of a perianth, as the upper sepal of
Aconitum, and the upper lip of some bilabiate corollas.

Gamopetalous. With united petals; same as monopetalous and sympetalous.

Gamosepalous. With united sepals; same as monosepalous.

Geminate. Twin, in pairs, as the flowers of Linnaea.

Gemma. A bud.

Geniculate. Bent abruptly, like a knee, as many stems.

Gibbous. More swollen at one place or on one side than the other.

Glabrate. Becoming glabrous with age, or almost glabrous.

Glabrous. Smooth, having no hairs, bristles, or other pubescence.

Gland. A secreting surface or structure; any protuberance or appendage having the appearance of such an organ.

Glaucous. Covered with a fine white powder that rubs off (bloom), like that on a fresh plum or a cabbage leaf.

Globose. Spherical in form, or nearly so.

Globular. Nearly globose.

Glochidiate (hairs or bristles). Barbed; tipped with barbs, or with a double hooked point.

Glomerate. Closely aggregated into a dense cluster.

Glomerule. A dense head-like cluster.

Glume. The husks or floral coverings of grasses, or particularly the outer husks or bracts of each spikelet.

Gymnospermous. Naked-seeded.

Gymnosperms. The great group of seedplants with ovules (and seeds) not inclosed (naked).

Gynandrous, With stamens borne on (united with) the pistils.

Gynobase. An enlargement or prolongation of the receptacle bearing the ovary.

Gynoecium. The whole set of pistils.

Gynophore. A stalk raising a pistil above the insertion of the stamens.

Habit. The general aspect of a plant, or its mode of growth.

Habitat. The situation in which a plant grows in a wild state.

Hastate. Like an arrowhead, but with the basal lobes pointing outward nearly at right angles.

Heart-shaped. With the conventional shape of a heart.

Helmet. See galea.

Hemi-, in compounds, means half.

Herb. A plant with no persistent woody stem above ground.

Herbaceous. With the texture of common herbage; not woody. 
Hermaphrodite (flower). Having both stamens and pistils; same as perfect.

Heterogamous. Bearing two or more sorts of flowers as to their stamens and pistils, as in aster, daisy, and coreopsis.

Hexa-, in compounds, means six.

Hirsute. Hairy with stiffish or beard-like hairs.

Hispid. Bristly: beset with stiff hairs.

Hispidulous. Diminutive of hispid.

Hoary. Grayish-white; see canescent.

Homogamous. A head or cluster with flowers all of one kind.

Hood. Same as galea.

Hooded. Hood-shaped; see cucullate.

Hyaline. Transparent, or nearly so.

Hypocrateriform. Salver-shaped.

Hypogynous. Inserted under the pistil.

Imbricate. Overlapping (as shingles on a roof), either vertically or spirally, where the lower piece covers the base of the next higher; or laterally, as in the aestivation of a calyx or corolla, where at least one piece must be wholly external and one internal.

Immersed. Growing wholly under water.

Imperfect flowers. Wanting either stamens or pistils.

Inaequilateral. Unequal-sided, as the leaf of begonia.

Incanous. Hoary with white pubescence.

Incised. Cut rather deeply and irregularly.

Incumbent (embryo). Cotyledons with the back of one of them against the hypocotyl.

Indefinite (stamens, etc.). Inconstant in number or very numerous.

Indehiscent. Not splitting open.

Indigenous. Native to the country.

Indusium. The shield or covering of the sorus ("fruit-dot") of a fern.

Inflated. Turgid and bladdery.

Inflexed. Bent inwards.

Inflorescence. The arrangement of flowers on the stem; the flower-cluster as a whole.

Infundibuliform. Funnel-shaped.

Innate (anther). Attached by its base to the apex of the filament.

Innovation. An incomplete young shoot.

Insertion. The place or the mode of attachment of an organ to its support.

Internode. The part of a stem between two nodes.

Interruptedly pinnate. Pinnate with small leaflets intermixed with larger ones.

Introrse. Turned or facing inwards (towards the axis of the flower).

Involucel. An involucre of the second order.

Involucrate. Furnished with an involucre.

Involucre. A whorl or set of bracts around a flower, umbel, or head.

Involute. In vernation; rolled inwards from the edges:
Keel. A projecting ridge on a surface, like the keel of a boat; the two anterior petals of a papilionaceous corolla.

Labellum. The odd (lower) petal of orchids.

Labiate. Same as bilabiate or two-lipped. Laciniate. Slashed; cut into deep narrow lobes.

Lamellar, Lamellate. Consisting of flat plates.

Lamina. A plate or blade; the blade of a leaf.

Lanate. Woolly; clothed with long and soft entangled hairs.

Lanceolate. Lance-shaped.

Lanuginous. Cottony or woolly.

Lax. Loose in texture, or sparse; the opposite of crowded.

Leaflet. One of the divisions or blades of a compound leaf.

Legume. A simple pod, dehiscent into two pieces, like that of the pea; the fruit of the pea family (Leguminosae), of whatever shape.

Lemma. The lower of the two bracts inclosing the flower in the grasses; sometimes called the flowering glume.

Lenticular. Lens-shaped (convex on both sides).

Lepidote. Leprous; covered with scurfy scales.

Ligneous, Lignose. Woody in texture.

Ligulate. Furnished with a ligule.

Ligule. The strap-shaped corolla in many Compositae; the little membranous appendage at the summit of the leaf-sheaths of most grasses.

Limb. The blade of a leaf, petal, etc.

Linear. Narrow and flat, the margins parallel.

Lingulate, Linguiform. Tongue-shaped.

Lip. The principal lobes of a bilabiate corolla or calyx; the odd and peculiar petal in the orchis family.

Lobe. Any projection or division (especially a rounded one) of a leaf, etc.

Loculicidal (dehiscence). Splitting down through the middle of the back of each cell.

Loment. A pod which separates transversely into joints.

Lunate. Crescent-shaped.

Lunulate. Diminutive of lunate.

Lyrate. Lyre-shaped; an obovate or spatulate pinnatifid leaf with the end-lobe large and roundish and the lower lobes small.

Macrosporangium. Same as megasporangium.

Macrospore. Same as megaspore.

Marcescent. Withering without falling off. 
Masked. See personate.

Megasporangium. The sporangium which contains megaspores.

Megaspore. The larger spore of heterosporous plants (club mosses, water ferns, seed-plants).

Membranaceous, Membranous. With the texture of a membrane; thin and more or less translucent.

Microsporangium. The sporangium which contains microspores.

Microspore. The smaller spore of heterosporous plants (club mosses, water ferns, seed-plants).

Midrib. The middle or main rib of a leaf.

Monadelphous. Stamens united by their filaments into one set.

Moniliform. Necklace-shaped; a cylindrical body enlarged at intervals.

Monocotyledonous (embryo). Having only one cotyledon.

Monoecious. With stamens and pistils in separate flowers on the same plant.

Monopetalous (flower). With united petals; see gamopetalous.

Monosepalous. With united sepals; same as gamosepalous.

Mucronate. Tipped with an abrupt short point.

Mucronulate. Diminutive of mucronate.

Multi-, in compounds, means many.

Muricate. Beset with short and hard points.

Muticous. Pointless; beardless; unarmed.

Napiform. Turnip-shaped.

Naturalized. Introduced from a foreign country, but growing wild and propagating freely by seed.

Nectariferous. Nectar-bearing; having a nectary.

Nectary. An organ which secretes nectar.

Needle-shaped. Long, slender, and rigid, like the leaves of pines.

Nerve. A name for the ribs or veins of foliar organs, especially when simple and parallel.

Node. A knot; the joints of a stem, from which the leaves arise.

Nodose. Knotty or knobby.

Nodulose. Diminutive of nodose.

Nut. A hard, mostly one-seeded, indehiscent fruit, as a chestnut, butternut, acorn.

$O b-$, as a prefix, signifies inversion, as follows:

Obcompressed. Flattened the opposite of the usual way.

Obcordate. Heart-shaped with the broad and notched end at the apex instead of the base.

Oblanceolate. Lance-shaped with the tapering point downwards.
Oblong. Two to four times as long as broad, and more or less elliptical in outline.

Obovate. Inversely ovate, the broad end upward.

Obtuse. Blunt or round at the end.

Ochreate. See ocreate.

Ochroleucous. Yellowish-white; dull creamcolor.

Ocrea. A sheathing stipule.

Ocreate. Having sheathing stipules.

Octogynous. With eight pistils or styles.

Offiset. Short branch next the ground which takes root.

Operculate. Furnished with a lid or cover (operculum), as the capsules of mosses.

Opposite. Applied to leaves and branches when an opposing pair occurs at each node; to stamens when directly in front of the petals.

Orbicular, Orbiculate. Circular in outline or nearly so.

Oval. Broadly elliptical.

Ovate. Shaped like the section of an egg with the broader end downwards.

Ovoid. A solid with an ovate section.

Ovule. The body which becomes a seed after fertilization; the megasporangium of seed-plants.

Palea (plural paleae). Chaff; the inner husk of grasses; the chaff or bracts on the receptacle of many Compositae.

Palmate. Applied to a leaf whose leaflets, divisions, or main ribs all spread from the apex of the petiole, like a hand with outspread fingers.

Palmately lobed, cleft, parted, divided, etc. The varying depths of division of a palmate leaf.

Panduriform. Same as fiddle-shaped.

Panicle (inflorescence). An open cluster like a raceme, but more or less compound.

Panicled, Paniculate. Arranged in panicles, or like a panicle.

Papilionaceous. Butterfly-shaped; applied to such a corolla as that of the pea.

Papilla (plural papillae). A little nippleshaped protuberance.

Papillate, Papillose. Covered with papillae.

Pappus. The modified calyx-limb in Compositae, forming a crown of very various character at the summit of the achene.

Parietal. Attached to the walls, as of the ovary.

Parted. Separated or cleft into parts almost to the base.

Pectinate. Pinnatifid or pinnately divided into narrow and close divisions, like the teeth of a comb.

Pedate. Like a bird's foot; palmate or palmately cleft.

Pedicel. The stalk of each particular flower of a cluster. 
Pedicellate, Pediceled. Furnished with a pedicel.

Peduncle. A flower-stalk, whether of a single flower or of a flower-cluster.

Peduncled, Pedunculate. Furnished with a peduncle.

Peltate. Shield-shaped; applied to a leaf, whatever its shape, when the petiole arises from the under surface.

Pendent. Hanging.

Pendulous. Somewhat hanging or drooping.

Penicillate. Tipped with a tuft of fine hairs.

Penta-, in compounds, means five.

Perennial. Lasting from year to year.

Perfect (flower). Having both stamens and pistils.

Perfoliate. Applied to a leaf through whose base the stem appears to pass.

Perianth. The floral envelopes of the flower, especially when calyx and corolla cannot be distinguished.

Pericarp. The wall of the ripened ovary, which in many cases is the wall of the fruit.

Perigynium. The inflated sac which incloses the ovary in Carex.

Perigynous (flower). Sepals, petals, and stamens arising from the rim of a tube or cup surrounding the pistil or pistils.

Persistent. Remaining beyond the period when such parts commonly fall.

Personate. Masked; a bilabiate corolla with a projection (palate) in the throat, as of the snapdragon.

Petal. A constituent member of the corolla.

Petaloid. Petal-like; resembling or colored like petals.

Petiole. The leaf-stalk.

Petioled. Petiolate. Furnished with a petiole.

Petiolulate. Applied to a leaflet which has its own stalk (petiolule).

Pilose. Hairy; clothed with soft slender hairs.

Pinnate (leaf). Leaflets disposed along the main axis of the leaf; feather-veined (secondary veins arising from a midrib).

Pinnately lobed, cleft, parted, divided, etc. The varying depths of division of a pinnate (feather-veined) leaf.

Pinnatifid. Same as pinnately cleft.

Pinnule. A secondary pinna; one of the pinnately disposed divisions of a pinna.

Pistil. The seed-bearing organ of the flower.

Pitted. Having small depressions or pits on the surface, as many seeds.

Placenta. The surface of the ovary to which the ovules are attached.

Plicate. Folded into plaits, usually lengthwise.

Plumose. Feathery; when any slender body (such as a bristle of a pappus) is beset with hairs, like the beard on a feather.

Pluri, in compounds, means many or several.

Pod. Specially a legume; also applied to any sort of capsule.

Poly-, in compounds, means many.

Polygamous. Having some perfect and some staminate and pistillate flowers, on the same or on different individuals.

Polymorphous. Of several forms.

Polypetalous. With the petals distinct (whether few or many).

Polysepalous. When the sepals are distinct.

Pome. Afleshy fruit, such as the apple, pear, haw, etc.

Posterior. On the side towards the axis; see anterior.

Prickles. Sharp elevations of the bark, and coming off with it, as of the rose.

Procumbent. Trailing on the ground.

Produced. Extended or projecting, as the upper sepal of a larkspur is produced above into a spur.

Proliferous. A new branch arising from an older one, or one head or cluster of flowers from another.

Prostrate. Lying flat on the ground.

Pruinose, Pruinate. Frosted; covered with a powder like hoar-frost.

Puberulent. Covered with fine and short, almost imperceptible down.

Pubescence. Fine and soft'hairs.

Pubescent. With pubescence.

Pulverulent. Dusted; covered apparently with fine powder.

Pulvinate. Cushioned, or shaped like a cushion.

Punctate. Dotted, either with minute holes or apparently so.

Pungent. Very hard and sharp-pointed; prickly-pointed.

Raceme. A flower-cluster with one-flowered pedicels along the axis of inflorescence.

Racemose. Bearing racemes, or raceme-like.

Rachis. An axis bearing close-set organs; especially the axis of a spike.

Radiate, Radiant. Furnished with rayflowers.

Radical. Belonging to the root, or apparently coming from the root.

Rameal. Belonging to a branch.

Ray. The marginal flower of a head or cluster when different from the rest, especially when ligulate; the branch of an umbel.

Receptacle. The more or less expanded or produced end of an axis which bears the organs of a flower or the collected flowers of a head.

Reclined. Turned or curved downwards; nearly recumbent, 
Recurved. Curved outwards or backwards. Reflexed. Bent outwards or backwards.

Refracted. Bent suddenly, so as to appear broken at the bend.

Regular (flower). All the parts of each set similar.

Reniform. Kidney-shaped.

Repand. Wavy-margined.

Retuse. Blunted; the apex not only obtuse but somewhat indented.

Revolute. Rolled backwards, as the margins of many leaves.

Rhachis. Same as rachis.

Rhizome. A rootstock.

Ringent. Grinning; gaping open.

Rostrate. Bearing a beak or a prolonged appendage.

Rosulate (leaves). In a rosette.

Rotate. Wheel-shaped.

Rotund. Rounded or roundish in outline.

Rudimentary. Imperfectly developed, or in an early stage of development.

$R$ ugose. Wrinkled, roughened with wrinkles.

Runcinate. Coarsely saw-toothed or cut, the pointed teeth turned towards the base of the leaf, as in dandelion.

Runner. A slender and prostrate branch rooting at the end or at the joints.

Sac. Any closed membrane, or a deep purse-shaped cavity.

Sagittate. Arrow-shaped.

Salver-shaped, Salverform. With a border spreading at right angles to a slender tube.

Samara. A wing-fruit or key, as of maple.

Saw-toothed. See serrate.

Scabroùs. Rough or harsh to the touch.

Scale. A reduced leaf-like body which is not green.

Scape. A peduncle rising from the ground, naked or without ordinary foliage.

Scorpioid, Scorpioidal. Curved or circinate at the end.

Scurf, Scurfiness. Minute scales on the surface of many leaves.

Scutellate, Scutelliform. Saucer-shaped or platter-shaped.

Secund. One-sided, as where flowers, leaves, etc., are all turned to one side.

Semi-, in compounds, means half.

Sepal. A constituent member of the calyx.

Septate. Divided by partitions.

Septum (plural septa). A partition, as of a pod, etc.

Sericeous. Silky; clothed with satiny pubescence.

Serrate, Serrated. With margin cut into teeth (serratures) pointing forwards.

Serrulate. Diminutive of serrate, that is, with finer teeth.

Sessile. Without any stalk, as a leaf destitute of petiole, an anther destitute of filament, etc.
Seta. A bristle, or a slender body resembling a bristle.

Sheath. A tubular envelope, as the lower part of the leaf in grasses.

Shield-shaped. Same as peltate.

Shrub. A woody perennial, smaller than a tree, usually with several stems.

Silique. The pod of the Cruciferae.

Silky. Glossy with a coat of fine and soft, close-pressed, straight hairs.

Silvery. Shining white or bluish-gray, usually from a silky pubescence.

Simple. Of one piece; opposed to compound. Sinuate. Strongly wavy.

Sinus. The cleft or recess between two lobes.

Smooth. Without roughness or pubescence.

Soboliferous. Bearing shoots, especially from the ground.

Spadix. A fleshy spike.

Spathe. A bract which sheaths an inflorescence (especially a spadix).

Spatulate, Spathulate. Shaped like a spatula.

Spicate. Belonging to or disposed in a spike.

Spiciform. Resembling a spike in form.

Spike (inflorescence). Like a raceme, but with flowers sessile.

Spikelet. A small or a secondary spike.

Spindle-shaped. Tapering to each end, like a radish.

Spine. A sharp woody or rigid outgrowth from the stem.

Spinescent. Tipped by or degenerating into spines or thorns.

Spinose, Spiniferous. Thorny.

Sporangium, sporocarp. A spore-case, especially of ferns, mosses, etc.

Spore. A special reproductive cell, which is most obvious among cryptogams; among seed-plants pollen grains are spores (microspores), but the obvious reproductive structure is the seed.

Spur. Any projecting appendage of the flower.

Squarrose. Where scales, leaves, or any appendages spread widely from the axis on which they are thickly set.

Stamen. The pollen-bearing organ.

Staminodium. An abortive stamen or other body in the position of a stamen.

Standard. The upper petal of a papilionaceous corolla.

Stellate. Star-like; several similar parts radiating from a common center.

Sterile. Barren or imperfect.

Stigma. The region of the pistil which receives the pollen.

Stipe. The stalk-like support of a pistil; the leaf-stalk of a fern.

Stipitate. Furnished with a stipe.

Stipulate. Furnished with stipules. 
Stipules. The appendages on each side of the base of certain leaves.

Stolon. Trailing or reclined and rooting shoots.

Stoloniferous. Producing stolons.

Strap-shaped. Long, flat, and narrow.

Striate, Striated. Marked with slender longitudinal grooves or channels.

Strict. Close and narrow; straight and narrow.

Strigose, Strigillose. Beset with appressed, rigid bristles or hairs.

Strobilus. Cone; a multiple fruit in the form of a cone or head, as in hop and pine; sometimes written strobile.

Strophiole. Same as caruncle.

Style. The beak-like prolongation of the pistil above the ovary, which bears the stigma.

Stylopodium. An enlargement at the base of the style, found in Umbelliferae and some other plants.

$S u b$, as a prefix, means about, nearly, somewhat; as subcordate, slightly cordate; subserrate, slightly serrate; subaxillary, just beneath the axil, etc.

Subulate. Awl-shaped; tapering from a broadish or thickish base to a sharp point.

Succulent. Juicy or pulpy.

Sucker. A shoot from subterranean branches.

Suffrutescent. Slightly shrubby or woody at the base only.

Sulcate. Grooved longitudinally.

Surculose. Producing suckers, or shoots resembling them.

Suture. The line of junction of contiguous parts that seem to have grown together.

Sympetalous. With united petals.

Syngenesious. With stamens united by their anthers.

Taproot. A stout vertical root which continues the main axis of the plant.

Tawny. Dull yellowish, with a tinge of brown.

Tendril. A thread-shaped process used for climbing.

Terete. Same as cylindrical, only it may include tapering.

Ternate. In threes, as in leaf-divisions.

Tetra-, in compounds, means four.

Tetradynamous. With four stamens longer than the other two.

Thorn. See spine.

Throat. The orifice of a gamopetalous corolla or calyx; the region between the tube proper and the limb.

Thyrse, Thyrsus. A compact and pyramidal panicle.

Tomentose. Clothed with matted woolly hairs (tomentum).
Toothed. Furnished with teeth or short projections of any sort on the margin; used especially when these are sharp, like saw-teeth, and do not point forwards.

Torose, Torulose. Knobby; where a cylindrical body is swollen at intervals.

Torus. The receptacle of the flower.

Tri-, in compounds, means three.

Trichotomous. Three-forked.

Trifid. Three-cleft.

Trigonous. Three-angled.

Triquetrous. Sharply three-angled; and especially with the sides concave, like a bayonet.

Truncate. Ending abruptly, as if cut off transversely.

Tuber. A thickened portion of a subterranean stem or branch.

Tubercle. A small excrescence.

Tubercled, Tuberculate. Bearing excrescences or pimples.

Tuberous. Resembling a tuber.

Tumid. Swollen; somewhat inflated.

Tunicate. Coated; invested with layers, as an onion.

Turbinate. Top-shaped.

Turgid. Swollen; thick as if swollen.

Turio (plural turiones). A young shoot or sucker springing out of the ground.

Twining. Ascending by coiling round a support, like the hop.

Umbel. The umbrella-like form of inflorescences

Umbellate. In umbels.

Umbellet. A secondary or partial umbel.

Unarmed. Destitute of spines, príckles, and the like.

Uncinate. Hook-shaped; hooked at the end.

Undulate. Wavy, or wavy-margined.

Unequally pinnate. Pinnate with an odd number of leaflets.

Unguiculate. Furnished with a claw (a narrow base).

Uni-, in compounds, means one.

Unisexual. Having only one kind of sexorgans; applied also to flowers having only stamens or pistils.

Urceolate. Urn-shaped.

Utricle. A small, thin-walled, one-seeded fruit.

Utricular. Like a small bladder.

Vaginate. Surrounded by a sheath.

Valvate. Opening by valves, as a capsule; in aestivation, meeting by the edges without overlapping.

Valve. One of the pieces into which a dehiscent pod, or any similar body, șplits.

Veinlets. The smaller ramifications of veins.

Veins. The fibrovascular strands in a leaf or other organ.

Venation. The veining of leaves, etc. 
Ventral. Belonging to the anterior or inner face of an organ; the opposite of dorsal. Ventricase. Inflated or swollen on one side.

Versatile (anther). Attached near the middle and turning freely on its support.

Verticil. A whori.

Verticillate. Whorled.

Vesicle. A little bladder.

Vexillum. The standard of a papilionaceous flower.

Villose. Shaggy with long and soft hairs.
Vine. Any trailing or climbing stem.

Virgate. Wand-shaped, as a long, straight, and slender twig.

Viscid. Glutinous, sticky.

Vitta (plural vittae). The oil-tube of the fruit of Umbelliferae.

Wedge-shaped. Broad above and tapering by straight lines to a narrow base.

Wing. Any membranous expansion.

$W$ oolly. Clothed with long and entangled soft hairs. 



\section{INDEX}

Latin names of families are in sMall capitals. Synonyms and names of plants merely mentioned are in italics.

\begin{tabular}{|c|c|c|c|c|c|c|c|}
\hline Abies & 28 & Actinella & 558 & divergens & 79 & canadensis & 114 \\
\hline concolor & 28 & acaulis & 558 & Gmelini & 80 & cernuum & 114 \\
\hline lasiocarpa & 29 & carnosa & 559 & occidentale & 81 & dictyotum & 114 \\
\hline subalpina & 29 & depressa & 558 & pseudorepens & 80 & fibrosum & 114 \\
\hline Abronia & 174 & epunctata & 560 & Scribneri & 79 & Geyeri & 114 \\
\hline ammophila & 175 & eradiata & 559 & spicatum & 79 & Nuttallii & 114 \\
\hline Bakeri & 175 & fastigiata & 560 & subvillosum & 81 & recurvatum & 114 \\
\hline Carletonii & 175 & grandiflora & 561 & tenerum & 80 & reticulatum & 114 \\
\hline carnea & 175 & incana & 559 & violaceum & 80 & rubrum & 114 \\
\hline cycloptera & 175 & lanata & 559 & Agrostemma & 180 & \multicolumn{2}{|c|}{ Schoenoprasum } \\
\hline elliptica & 175 & leptoclada & 560 & Gigatho & 180 & & 114 \\
\hline fallax & 175 & linearis & 560 & Agrostis & 57 & sibiricum & 114 \\
\hline fragrans & 175 & Richardsonii & 561 & alba & 57 & Allocarya & 414 \\
\hline glabra & 175 & scaposa & 560 & asperifolia & 57 & Nelsonii & 415 \\
\hline micrantha & 175 & simplex & 558 & depressa & 57 & scopulorum & 414 \\
\hline pumila & 175 & Torreyana 5 & 559 & exarata & 57 & Alnus & 140 \\
\hline salsa & 175 & \multicolumn{2}{|c|}{ Adder's Tongue } & hiemalis & 58 & tenuifolia & 140 \\
\hline Abutilon & 318 & Family & 17 & humilis & 57 & Alopecurus & 53 \\
\hline Abutilon & 319 & Adiantum & 19 & idahoensis & 58 & fulvus & 53 \\
\hline Avicennae & 319 & capillus-veneris & 319 & melaleuca & 58 & geniculatus & 53 \\
\hline parvulum & 319 & pedatum & 19 & Rossae & 57 & occidentalis & 54 \\
\hline Acer & 313 & Adopogon & 589 & scabra & 58 & Alpine Avens & 250 \\
\hline glabrum & 314 & virginicum & 589 & Thurberiana & 57 & Alpine Fir & 29 \\
\hline \multirow{2}{*}{\multicolumn{2}{|c|}{ grandidentatum }} & Adoxa & 472 & Aira & 67 & Alsike Clover & 278 \\
\hline & 314 & Moschatellina & 472 & obtusata & 67 & Alsine & 182 \\
\hline Negundo & 314 & CEAE & 472 & Arzonceate & 176 & baicalensis & 183 \\
\hline Aceraceate & 313 & Agast & 428 & Alder & 140 & calycantha & 183 \\
\hline Acerates & 386 & anethiodorá & 428 & Aletes & 351 & Alsinopsis & 185 \\
\hline angustifolia & 387 & urticifolia & 428 & acaulis & 352 & macrantha & 186 \\
\hline auriculata & 386 & Agoseris & 598 & humilis & 352 & obtusiloba & 186 \\
\hline stenophylla & 387 & agrestis & 599 & obovata &, 352 & propinqua & 186 \\
\hline viridiflora & 386 & altissima & 599 & Alfalfa & 277 & Alumroot & 234 \\
\hline Achillea & 564 & attenuata & 598 & Alfilaria & 304 & \multicolumn{2}{|c|}{ Amaranth Family } \\
\hline alpicola & 564 & arachnoidea & 599 & Alisma & 37 & & 170 \\
\hline lanulosa & 564 & carnea & 599 & brevipes & 37 & \multicolumn{2}{|c|}{ AMARANTHACEAE } \\
\hline millefolium & 564 & jata & 599 & \multicolumn{2}{|c|}{ Plantago-aquatica } & & 170 \\
\hline Acnida & 171 & Greenei & 599 & & 37 & Amaranthus & 170 \\
\hline tamariscina & 171 & humilis & 599 & Alismacéae & 37 & albus & 171 \\
\hline tuberculata & 17 & laciniata & 599 & Allionia & 173 & blitoides & 171 \\
\hline Aconite & 195 & Leontodon & 599 & diffusa & 174 & graecizans & 171 \\
\hline Aconitum & 19 & maculata & 598 & divaricata & 174 & hybridus & 171 \\
\hline atrocyaneum & 195 & montana & 600 & floribunda & 173 & Palmeri & 171 \\
\hline Bakeri & 195 & Nuttallii & 599 & glandulifera & 174 & Powellii & 171 \\
\hline columbianum & 195 & pubescens & 598 & hirsuta & 173 & retroflexus & 170 \\
\hline insigne & 195 & rostrata & 599 & rnata & 174 & spinosus & 171 \\
\hline lutescens & 195 & roseata 5 & 599 & lanceolata & 174 & Torreyi & 171 \\
\hline ectum & 195 & scorzoneraefolia & & linearis & 174 & Wrightii & 171 \\
\hline ramosum & 195 & & 599 & nyctaginea & 173 & A marella & 382 \\
\hline Acrapteris & 22 & villosa & 598 & sa & 173 & scopulorum & 382 \\
\hline septentrionale & 22 & Agrin & 263 & sessilifolia & 174 & Ambrosia & 541 \\
\hline Acrolasia & 324 & Brittoniana & 263 & Allioniella & 172 & artemisiaefolia & \\
\hline latifolia & 324 & Eupatoria & 263 & oxybaphoides & 173 & & 541 \\
\hline Actaea & 190 & Agrimony & 263 & Allium & 113 & psilostachya & 541 \\
\hline arguta & 190 & Agropyron & 79 & acuminatum & 115 & tomentosa & 542 \\
\hline eburnea & 190 & Bakeri & 80 & arenicola & 114 & trifida & 541 \\
\hline rubra & 190 & caninum & 79 & Brandegei & 114 & Amelanchier & 265 \\
\hline viridiflora & 190 & dasystachyum & 81 & brevistylum & 114 & alnifolia & 266 \\
\hline
\end{tabular}




\begin{tabular}{|c|c|c|c|c|c|c|c|}
\hline & 266 & Roseana & 356 & hypericifolium & 386 & dispar & 294 \\
\hline crenata & 266 & Anorga & 338 & lividum & 386 & foliolosus & \\
\hline elliptica & 266 & albicaulis & 338 & scopulorum & 385 & gracilis & \\
\hline glabra & 266 & Buffumii & 338 & Apple & 265 & inflatus & 294 \\
\hline oreophila & 266 & cinerea & 399 & Family & 265 & lagopus & \\
\hline polycarpa & 266 & coronopifolia & 339 & Thorn & 436 & Lambertii & \\
\hline prunifolia & 266 & latifolia & 339 & Wild Balsam & 472 & monticola & \\
\hline pumila & 266 & neo-mexicana & 339 & Aquilegia & 190 & multiceps & \\
\hline rubescens & 266 & Nuttallii & 339 & brevistyla & 192 & nanus & \\
\hline American Aspen & 128 & pallida & 339 & caerulea & 191 & Parryi & \\
\hline American Cowslip & & rhizomata & 338 & canadensis & 191 & patens & \\
\hline & 375 & trichocalyx & 339 & chrysantha & 191 & podocarpus & \\
\hline American Ivy & 316 & violacea & 338 & Eastwoodiae & 191 & Richardsonii & \\
\hline American Laurel & 1370 & Vreelandii & 339 & ecalcarata & 191 & saximontana & \\
\hline Ammannia & 332 & Antennaria & 533 & elegantula & 191 & sericeus & \\
\hline & 332 & anaphaloides & 537 & & 191 & & \\
\hline latifolia & 332 & aprica & 536 & Jon & 192 & dulus & \\
\hline Amorpha & 29 & aride & 535 & ensis & 191 & viscidus & \\
\hline ens & 296 & bracteosa & 535 & & 191 & Aralia & \\
\hline & 29 & & 535 & & 191 & nudicaulis & \\
\hline mic & 296 & osa & 535 & ontana & 192 & & \\
\hline nan & 296 & dimorpha & 537 & thalictrifolia & 191 & obium & \\
\hline $\mathrm{mph}$ & 42 & flavescens & 534 & Arabis & 225 & icanum & \\
\hline Tor & 42 & folia & 535 & & 228 & podum & 4 \\
\hline mpelopsis & 316 & & & neriana & 225 & carpum & \\
\hline olia & 316 & & 53 & & 229 & catum & 1 \\
\hline msonia & 385 & Hor & 536 & & 228 & & \\
\hline & 385 & luz & 537 & & 227 & phylos & 37 \\
\hline DTACEAE & 312 & inata & 536 & & 226 & & 3 \\
\hline Anap & 537 & & 534 & zuinea & 228 & Aren & \\
\hline & 537 & phylla & & & 227 & icaulis & \\
\hline & 537 & ata & 53 & & 227 & bifl & \\
\hline Indr & 42 & & & & 226 & & \\
\hline & 42 & folia & 53 & & 226 & & \\
\hline & 42 & & & & 228 & odiae & \\
\hline & 42 & olata & 53 & & 229 & & \\
\hline Tor & 43 & & & & 228 & & \\
\hline ndro & 374 & & 53 & & 229 & & 18 \\
\hline & 37 & ima & & & & tha & \\
\hline jaseme & 374 & & 53 & & 227 & & \\
\hline & 375 & & & & 226 & & 1 \\
\hline & 375 & & & & 227 & & \\
\hline & 37 & & & & 228 & & \\
\hline & 375 & scariosa & 536 & & 227 & & \\
\hline & 375 & Sierrae-blancae & & & 229 & ensis & \\
\hline onalis & 375 & & 536 & & 229 & & \\
\hline bellata & 375 & & & & 226 & & 18 \\
\hline nen & 195 & Ant & & ylla & 227 & hensis & \\
\hline & & & & & 227 & & \\
\hline & & & 11 & lata & 228 & Arg & \\
\hline & & 463,4 & 46 & & 227 & atifida & \\
\hline & & & 2 & & 226 & & \\
\hline & & aulis & 27 & arpa & 228 & ras 205, & 206 \\
\hline & 196 & flex & 27 & & 228 & Arg & \\
\hline flora & & Aplopappus & & & 226 & & \\
\hline & 196 & $499,501,502$, & 504 & & 227 & & \\
\hline & & & & & 228 & mnia & \\
\hline & 10 & & 49 & & 227 & & 308 \\
\hline efolia & & & & & 229 & Aris & \\
\hline styl & 196 & & 499 & ulata & 227 & & \\
\hline & & & & & & & \\
\hline & & nosus & 498 & & 295 & Arni & 571 \\
\hline ngel & 35 & CEAE & & & & alpina & 57 \\
\hline & & Apo & & tatus & 295 & arcana & 57 \\
\hline & 35 & & 385 & & 294 & aurantiaca & 57 \\
\hline & & androsaemifoliu & um & inshipii & 294 & caespitosa & \\
\hline & 35 & & & & 293 & & \\
\hline pinnata & & cannabinum & & deflexus & 293 & chamissonis & \\
\hline
\end{tabular}




\begin{tabular}{|c|c|c|c|c|c|c|c|}
\hline coloradensis & 573 & pedatifida & 567 & \multicolumn{2}{|c|}{ ciliomarginatus } & Wootoni & 516 \\
\hline cordifolia & 572 & pudica & 569 & & 517 & xylorhiza & 511 \\
\hline eradiate & 575 & Purshiana & 569 & commutatus & 515 & Astragalus & 280 \\
\hline exigua & 573 & rhizomata & 569 & conspicuus & 514 & aboriginorum & 285 \\
\hline foliosa & 573 & saxicola & 568 & Cordineri & 515 & acerbus & 291 \\
\hline fulgens & 574 & scopulorum & 567 & corymbiformis & 517 & aculeatus & 290 \\
\hline gracilis & 572 & Scouleriana & 567 & crassulus & 515 & adsurgens & 284 \\
\hline grandifolia & 572 & silvicola & 569 & culminis & 513 & alpinus & 285 \\
\hline lanulosa & 573 & spiciformis & 570 & cusickii & 517 & americanus & 288 \\
\hline latifolia & 572 & spinescens & 566 & denudatus & 517 & amphioxus & 287 \\
\hline longifolia & 574 & spithamaea & 567 & elegans & 513 & anisus & 283 \\
\hline macillenta & 573 & stenoloba & 568 & Engelmannii & 513 & argophyllus & 287 \\
\hline mollis & 573 & subglabra & 568 & ericaefolius & 522 & & 288 \\
\hline monocephala & 574 & tridentata & 570 & exiguus & 515 & asclepiadoides & 286 \\
\hline ocreata & 574 & trifida & 570 & falcatus & 515 & Beckwithii & 287 \\
\hline paniculata & 572 & tripartita & 570 & Fendleri & 514 & Bigelovii & 283 \\
\hline Parryi & 575 & Underwoodii & 569 & fluvialis & 516 & bisulcatus & 289 \\
\hline parvifolia & 573 & viscidula & 570 & foliaceus & 518 & Bodinii & 292 \\
\hline pedunculata & 574 & Wrightii & 568 & Frem & 517 & brevicaulis & 284 \\
\hline platyphylla & 572 & Aruncus & 249 & fror & 518 & oitosus & 290 \\
\hline polycephala & 574 & Aruncus & 250 & & 513 & cosus & 284 \\
\hline & 572 & sylvester & 249 & ful & 518 & pestris & 291 \\
\hline rhizomata & 573 & ASCLEPIADACEAE & & & 516 & canadensis & 283 \\
\hline rivularis & 573 & & 386 & folius & 518 & candicans & 284 \\
\hline Rydbergii & 574 & Asclepias & 387 & glau & 513 & linianus & 283 \\
\hline stricta & $' 574$ & arenaria & 388 & Golden & 491 & ocarpus & 283 \\
\hline subplumosa & 573 & brachystephan & & griseolus & 517 & micus & 288 \\
\hline sylvatica & 573 & & 388 & grise & 515 & satus & 288 \\
\hline tenuis & 574 & cryptoceras & 388 & hebecladus & 515 & aeluce & 286 \\
\hline tomentulosa & 573 & curvipes & 388 & opilosus & 515 & us & 287 \\
\hline ventorum & 572 & galioides & 389 & & 518 & radensis & 283 \\
\hline rrow Grass $\mathrm{Fa}$ & mily & Hallii & 388 & rifolius & 514 & vallarius & 291 \\
\hline & 36 & incarnata & 388 & Kingii & 513 & entis & 291 \\
\hline head & 37 & esii & 388 & Kumleinii & 514 & icarpus & 283 \\
\hline & 565 & latifolia & 388 & & 516 & & 286 \\
\hline scula & 570 & pumila & 389 & la & 518 & mbens & 291 \\
\hline aromatica & 567 & iosa & 388 & & 516 & rens & 291 \\
\hline Bakeri & 569 & erosa & 387 & lleyanus & 516 & eratus & 285 \\
\hline biennis & 568 & icillata & 389 & chophyllus & 517 & ysus & 284 \\
\hline Bigelovii & 570 & Asclepiodora & 389 & longifolius & 517 & diversifolius & 291 \\
\hline borealis & 567 & decumbens & 389 & ijusculus & 517 & Drummondii & 285 \\
\hline Brittonii & 569 & Ash 269 , & 378 & meritus & 518 & Eastwoodiae & 288 \\
\hline cana & 570 & Green & 378 & ltiflorus & 515 & iocarpus & 289 \\
\hline nadensis & 567 & Mountain & 269 & Nelsonii & 517 & ans & 286 \\
\hline candicans & 569 & Ash Trees & 378 & angliae & 514 & ifolius & 290 \\
\hline oradensis & 568 & Aspen 127, & 128 & tallii & 517 & dleri & 292 \\
\hline lor & 569 & American & 128 & ngifolius & 514 & iflorus & 290 \\
\hline rsifolia & 569 & Aspidium & 21 & hyllus & 517 & & 290 \\
\hline dracuculoides & 567 & t-mas & 21 & Loutii & 516 & osus & 291 \\
\hline elatior & 570 & Asplenium & 22 & $p a$ & 516 & iontii & 285 \\
\hline filifolia & 567 & Andrewsii & 22 & Parry & 511 & & 288 \\
\hline floccosa & 569 & filix-foemina & 22 & florus & 513 & giganteus & 285 \\
\hline Forwoodii & 56 & septentrionale & 22 & ycephalus & 515 & gilviflorus & 292 \\
\hline franserioides & 569 & trichomanes & 22 & & 516 & glabriusculus & 285 \\
\hline frigida & 567 & viride & 22 & pratincola & 517 & glareosus & 287 \\
\hline gnaphalodes & 568 & Aster & 511 & ximus & 518 & goniatus & 284 \\
\hline cilenta & 569 & adscendens & 517 & ptarmicoides & 515 & gracilis & 290 \\
\hline ana & 568 & adsurgens & 515 & pulchellus & 522 & grallator & 291 \\
\hline latiloba & 569 & alp & 513 & Richardsonii & 518 & & 290 \\
\hline iciana & 569 & andinus & 513 & cifolius & 516 & llii & 291 \\
\hline & 56 & ewsii & 514 & ulorum & 522 & ydenianus & 289 \\
\hline natronensis & 56 & istus & 51 & hulatus & 517 & illimus & 289 \\
\hline norvegica & 56 & cus & 518 & subr & 517 & philus & 294 \\
\hline nova & 570 & armeriaefolius & 517 & subspathulatus & 517 & oglottis & 284 \\
\hline pabularis & 569 & Burkei & 517 & cetifolius & 519 & ptus & 284 \\
\hline Parryi & 568 & caerulescens & 516 & Tweedyi & 517 & jejunus & 289 \\
\hline Pattersonii & 568 & campestris & 514 & Underwoodii & 517 & junceus & 291 \\
\hline paucicephala & 569 & Canbyi & 517 & vallicola & 517 & junciformis & 291 \\
\hline
\end{tabular}




\begin{tabular}{|c|c|c|c|c|c|c|c|}
\hline Kentrophyta & 290 & Nuttallii & 168 & flaccidum & 199 & Black Willow & 129 \\
\hline leptaleus & & oblanceolata & 168 & longirostre & & Bladder Pod & \\
\hline lingulatus & 290 & occidentalis & 167 & trichophyllum & 199 & Double & 217 \\
\hline lonchocarpus & 292 & odontophora & 167 & Bean Caper Fam & & Bladderwort Far & \\
\hline lotiflorus & 289 & pabularis & 168 & & 306 & & 462 \\
\hline Macounii & 286 & patula & 166 & Bearberry & 371 & Blazing Star & 487 \\
\hline carpus & 288 & philonitra & 167 & Beard Grass 56 & 42 & Blepharineuron & 56 \\
\hline & 289 & & 166 & Beard-tongue & 439 & tricholepis & 56 \\
\hline lobus & 290 & subspicata & 166 & Beckmannia & 64 & Blepharipappus & 553 \\
\hline iensis & 286 & Suckleyana & 166 & erucaeformis & 64 & glandulosus & 553 \\
\hline llissimus & 283 & truncata & 166 & Bedstraw & 466 & Blitum & 163 \\
\hline orus & 291 & & 167 & Beech Family & 141 & capitatum & 163 \\
\hline rryi & 287 & Wolfii & 166 & Beggar's Ticks & 550 & hastatum & 163 \\
\hline & 284 & Aulospermum & 358 & Bent Grass & 57 & Bluebell Family & 473 \\
\hline lianus & 284 & angustum & 359 & BERBERIDACEAE & 204 & Blueberries & 372 \\
\hline & 283 & & 359 & Berberis & 204 & ed Grass & 122 \\
\hline & 286 & & 358 & aquifolium & 204 & & 121 \\
\hline & 287 & & 359 & Fendleri & 204 & Blue $\mathrm{G}$ & 69 \\
\hline sonii & & purpureum & 359 & Fremontii & 204 & Blu & \\
\hline & 291 & an Willow & 130 & repens & 204 & Blu & 42 \\
\hline & 289 & Aven & 61 & Berry & 332 & vain & 425 \\
\hline & 288 & ricana & 62 & Buffalo & 332 & Bo & 109 \\
\hline & 292 & & 62 & & 250 & & \\
\hline & 283 & miana & 62 & Beru & 352 & & 540 \\
\hline & & & 62 & & 352 & Family & 410 \\
\hline & 285 & & 62 & Betr & 140 & IACEAE & 410 \\
\hline & 286 & Aver & 262 & lrewsii & 140 & & 50 \\
\hline & 284 & Alp & 250 & & 140 & & 250 \\
\hline & 285 & Awlwort & 211 & & 14 & & 250 \\
\hline & 292 & & & alis & 140 & Bot & 17 \\
\hline eucus & 292 & Baccharis & 532 & yrifera & 140 & & 17 \\
\hline & 286 & & 533 & & 13 & atum & 17 \\
\hline & & & 532 & Bic & 20 & & 17 \\
\hline lius & 29 & & 532 & Bide & 550 & & 17 \\
\hline & 28 & tii & 532 & lovii & 511 & rush & 345 \\
\hline & 29 & Bahia & 556 & nata & 551 & Bou & 63 \\
\hline & 28 & chrysanthemoid & & cernu & 551 & & 63 \\
\hline scens & 284 & & 557 & chrysanthemoid & & achya & 63 \\
\hline & 290 & diss & 557 & & 551 & chya & 63 \\
\hline & 291 & xicana & 557 & & 551 & & 63 \\
\hline & 28 & & 556 & & & & 64 \\
\hline licus & 292 & folia & 556 & ens & 550 & Box & 314 \\
\hline & 288 & & 326 & & & Boy & 238 \\
\hline & 292 & & 315 & & 551 & eriform & 238 \\
\hline & 28 & untain & 315 & Bige & 496 & & 238 \\
\hline & 287 & Balsar & 128 & & 496 & Bra & 44 \\
\hline & 291 & lorrhiza & 545 & & 393 & & 44 \\
\hline & 28 & & 546 & & & atis & 511 \\
\hline & & & & & & & 516 \\
\hline & & & 546 & Birc & & & 19 \\
\hline & 29 & & & & & & 19 \\
\hline Wol & 29 & shylla & 546 & Far & 139 & & 20 \\
\hline & & & & tain Bog & & & 18 \\
\hline & 64 & aceae & & & 140 & Bra & 214 \\
\hline & & & & Rocky Mounta & & & 215 \\
\hline & & & 5 & & 140 & & 215 \\
\hline & & & 19 & & 156 & $\mathrm{Bra}$ & 543 \\
\hline trip & 16 & & 21 & & 216 & tifolia & 543 \\
\hline & & & & & 17 & Bric & 486 \\
\hline & 16 & & 215 & & 54 & & 287 \\
\hline & 16 & Family & 204 & & 25 & & 486 \\
\hline & 166 & Barl & 81 & Black Bindweed & 160 & tyloides & 487 \\
\hline rtifolia & $167^{\circ}$ & & 82 & Black Bunch-gra & & diflora & 486 \\
\hline & 168 & Barnyard Grass & 45 & & & & 487 \\
\hline & 167 & Bastard Toadflax & & Black-eyed Susar & & & 487 \\
\hline & & & 146 & & & microphylla & \\
\hline & 166 & & 198 & & 21 & & \\
\hline ortensis & & onfervoides & 19 & Black Sage & 570 & umbellatus & 486 \\
\hline
\end{tabular}




\begin{tabular}{|c|c|c|c|c|c|c|c|}
\hline Wrightii & 487 & Wild & 210 & Campion & 180 & adusta & 105 \\
\hline Bristle-cone Pine & 27 & Cactaceae & 326 & Canada Fleabane & 532 & alpina & 100 \\
\hline Brittle Fern & 21 & Cactus & 326 & Canary Grass & 47 & aperta & \\
\hline Brodiaea & 115 & Ball & 326 & Canoe Birch & 140 & aquatilis & \\
\hline Douglasii & 115 & Family & 326 & Caper Family & 231 & aristata & \\
\hline Brome Grass & 76 & Cactus & 327 & Capnoides & 206 & athrostachya & \\
\hline Quake & 77 & radiosus & 327 & Capnorea & 406 & atrata & \\
\hline Bromus & 76 & Calamagrostis & 58 & pumila & 406 & aurea. & \\
\hline breviaristatus & 78 & canadensis & 58 & CAPPARIDACEAE & 231 & Backii & \\
\hline brizaeformis & 77 & hyperborea & 59 & CaPRIFoliaceae & 468 & bella & \\
\hline ciliatus & 78 & inexpansa & 59 & Capsella & 220 & Bigelovii & \\
\hline inermis & 77 & montanensis & 59 & bursa-pastoris & 220 & Bonplandi & \\
\hline Kalmii & 78 & neglecta & 59 & Cardamine & 216 & brunnescens & \\
\hline marginatus & 78 & purpurascens & 59 & Breweri & 217 & canescens & \\
\hline polyanthus & 78 & scopulorum & 60 & cardiophylla & 217 & capillaris & \\
\hline Porteri & 78 & Scribneri & 58 & cordifolia & 217 & cephaloidea & 0 \\
\hline Pumpellianus & 77 & Suksdorfii & 59 & hirsuta & 217 & chalciolepis & \\
\hline purgans & 78 & Calamovilla & 60 & infausta & 217 & deflexa & \\
\hline racemosus & 77 & longifolia & 60 & pennsylvanica & 217 & Deweyana & 10 \\
\hline Richardsonii & 78 & Calandrinia & 179 & unijuga & 217 & disticha & \\
\hline secalinus & 77 & pygmaea & 179 & icola & 217 & Douglasii & \\
\hline tectorum & 77 & Calceolaria & 324 & Car & 584 & durifolia & \\
\hline Brookweed & 377 & verticillata & 324 & acaulescens & 586 & & 10 \\
\hline Broom Rape Fan & mily & Callirhoe & 316 & ricanus & 585 & echinata & \\
\hline & 463 & involucrata & 316 & eosus & 585 & elongata & 10 \\
\hline thus & 370 & Callisteria & 400 & sis & 584 & elynoides & \\
\hline Buchl & 64 & collina & 400 & nnatus & 586 & Engelmannii & \\
\hline dactyloides & 64 & flavida & 400 & virens & 585 & iva & 1 \\
\hline \multicolumn{2}{|c|}{ Buckbean Family } & formosissima & 400 & centaureae. & 585 & ucacea & 1 \\
\hline & 384 & leucantha & 400 & coloradensis & 585 & filifolia & \\
\hline Buckbrush & 470 & pulchella & 400 & Drummondii & 585 & filiformis & \\
\hline \multirow{2}{*}{\multicolumn{2}{|c|}{$\begin{array}{l}\text { Buckthorn Family } \\
314\end{array}$}} & \multicolumn{2}{|c|}{ Callitrichaceae } & Eatonii & 585 & foetida & 10 \\
\hline & & & 311 & & 585 & gida & \\
\hline Buckwheat 147, & 160 & Callitriche & 312 & filipendulus & 587 & yana & 1 \\
\hline \multicolumn{2}{|c|}{ Climbing False } & autumnalis & 312 & floccosus & 587 & yeri & \\
\hline & 160 & bifida & 312 & dmanii & 587 & vida & \\
\hline Family & 147 & palustris & 312 & foliosus & 585 & ocrates & \\
\hline Bud-brush & 566 & verna & 312 & & 585 & odii & \\
\hline Buffalo Berry & 332 & Calochortus & 116 & okerianus & 585 & okeriana & \\
\hline falo Bur & 436 & Gunnisonii & 117 & lseyi & 585 & tricina & \\
\hline alo Grass & 64 & Nuttal & 117 & ceolatus & 586 & & \\
\hline $\mathrm{Bu}$ & 163 & Caltha & 19 & psis & 586 & & \\
\hline $\mathrm{Bu}$ & 64 & chionop & 190 & acephalus & 587 & & \\
\hline istle & 586 & leptosep & 190 & raskensis & 587 & ina & \\
\hline Bulrush & 85 & rotundifolia & 190 & Nelsonii & 586 & iginosa & \\
\hline \multicolumn{2}{|c|}{ Bunch-flower Family } & Caltrop & 306 & \multicolumn{2}{|c|}{ neo-mexicanus } & rina & \\
\hline & 117 & Calymenia & 173 & - & 586 & talea & \\
\hline Buple & 350 & decumbens & 173 & oblanceolatus & 587 & Idonii & \\
\hline ricanum & 350 & Calypso & 123 & rocentrus & 587 & rirostris & \\
\hline purpureum & 350 & borealis & 124 & philus & 586 & marcida & 10 \\
\hline ranunculoides & 350 & bulbosa & 123 & Osterhoutii & 585 & melanocephala & 10 \\
\hline Bur $\quad 46$, & 436 & Calyptridium & 178 & Parryi & 586 & misandra & \\
\hline Buffalo & 436 & & 178 & lexans & 585 & & \\
\hline Sand & 46 & Calyxhymenia & 17 & ensis & 58 & tinoda & 10 \\
\hline Bur Marigold & 550 & & & chella & 58 & & 10 \\
\hline Bur C & 141 & Cama & & pulcherrimus & 585 & nebraskensis & \\
\hline Bur-reed Family & 32 & esculenta & & riosus & 585 & nigricans & \\
\hline Bursa & 220 & Camelina & 220 & scopulorum & 585 & & \\
\hline \multicolumn{2}{|c|}{ Bush Morning-glory } & sativa & 220 & spathulatus & 586 & obtusata & \\
\hline & 393 & Campanula & 473 & Tracyi & 586 & occidentalis & 10 \\
\hline Butter and Eggs & 438 & aparinoides & 473 & truncatus & 586 & oreocharis & \\
\hline Butterbur & 571 & Parryi & 473 & Tweedyi & 585 & Parryana & \\
\hline Buttercup & 199 & petiolata & 473 & undulatus & 587 & pennsylvanica & \\
\hline Family & 189 & planiflora & 473 & viridiflorus & 585 & petasata & 10 \\
\hline Nuttall's & 203 & rotundifolia & 473 & Carex & 89 & physocarpa & \\
\hline \multirow[t]{2}{*}{ Trailing } & 202 & uniflora & 473 & abbreviata & 94 & polytrichoides & \\
\hline & & \multirow{2}{*}{\multicolumn{2}{|c|}{ Campanulacease }} & & 95 & & \\
\hline & 210 & & & acutina & 98 & praticola & \\
\hline
\end{tabular}




\begin{tabular}{|c|c|c|c|c|c|c|c|}
\hline ulla & & ndheimeri & 459 & arvifolius & 246 & hiononhil & \\
\hline pyrenaica & 91 & $\begin{array}{l}\text { Lnaneimeri } \\
\text { linearis }\end{array}$ & 461 & $\begin{array}{l}\text { Cereus } \\
\text { Carvinus }\end{array}$ & 329 & $\begin{array}{l}\text { Jlonophila } \\
\text { Jamesii }\end{array}$ & $\begin{array}{l}449 \\
449\end{array}$ \\
\hline Redowskyana & 100 & lineata & 461 & conoideus & 329 & Chokecherry & 270 \\
\hline Reynoldsii & 99 & longispica & 460 & phoeniceus & 329 & Cholrocrambe & 211 \\
\hline rhomboidea & 98 & luteovirens & 461 & Chaenactis & 557 & hastatus & 211 \\
\hline rigida & 98 & miniata & 458 & achilleaefolia & 557 & Chondrophylla & 380 \\
\hline Rossii & 93 & minor & 458 & alpina & 557 & americana & 380 \\
\hline rupestris & 93 & obtusiloba & 460 & Douglasii & 557 & Fremontii & 380 \\
\hline Sartwellii & 102 & occidentalis & 461 & pedicularia & 557 & \multirow{2}{*}{\multicolumn{2}{|c|}{$\begin{array}{l}\text { Chrysanthemum } 565 \\
\text { Leucanthemum }\end{array}$}} \\
\hline xatilis & 96 & & 461 & & 559 & & \\
\hline idea & 92 & pallida & 459 & stevioides & 557 & & 565 \\
\hline scope & 105 & pilifera & 460 & Chaetochloa & 45 & Chrysopogon & 43 \\
\hline opulorum & 98 & pilosa & 460 & compos & 46 & nutans & 43 \\
\hline a & 102 & puberula & 461 & viridis & 46 & Chrys & 491 \\
\hline$t a$ & 104 & rhex & 460 & Chamaebatiaria & 249 & alpicola & 493 \\
\hline ylla & 101 & & 458 & millefolium & 249 & amplifolia & 493 \\
\hline st & 104 & Suk & 460 & \multicolumn{2}{|c|}{ Chamaechaenactis } & ari & 492 \\
\hline & 102 & sulp & 461 & & 559 & & 492 \\
\hline & 105 & & 459 & & 559 & & 492 \\
\hline & 100 & & 460 & erion & 334 & & 493 \\
\hline ostris & 104 & & 460 & folium & 334 & & 493 \\
\hline cula & 102 & ingensis & 461 & & 334 & & 493 \\
\hline Tolm & 98 & Cata & 67 & Cham & 252 & & 493 \\
\hline & 94 & & 67 & & 253 & inda & 492 \\
\hline & 96 & atchfly & 180 & saracha & 435 & & 493 \\
\hline & 93 & \multicolumn{2}{|c|}{ Night-blooming } & & 435 & & 493 \\
\hline & 97 & & 181 & & 435 & ssima & 492 \\
\hline & 100 & atmint & 428 & & 435 & & 527 \\
\hline & 98 & & 428 & Char & 215 & & 492 \\
\hline & 96 & amily & 31 & Cheat & 77 & & 492 \\
\hline vulgaris & 98 & ar & 210 & & 317 & $a t a$ & 493 \\
\hline rpet Weed Far & mily & llis & 210 & Cheilanthes & 20 & & 493 \\
\hline & 176 & & 210 & & 20 & & 493 \\
\hline lower & 121 & lea & 315 & & 20 & cul & 493 \\
\hline & 351 & & 31 & & 20 & & 493 \\
\hline & 351 & mus & 315 & Chei & 230 & lens & 493 \\
\hline Ineri & 351 & & 315 & & 230 & & 493 \\
\hline & 351 & & 315 & Bakeri & 230 & & 492 \\
\hline $\mathrm{Hal}$ & 352 & & 315 & \multicolumn{2}{|c|}{ Chenopodiaceae } & lenium & 237 \\
\hline montanum & 351 & & 315 & & 160 & $u m$ & 237 \\
\hline ARYOPHYLLACE & $A E$ & CEAE & 313 & Chen & 160 & & 237 \\
\hline & 180 & & 143 & & 161 & hamnus & 494 \\
\hline & 27 & ntalis & 143 & & 162 & & 496 \\
\hline & 27 & & 46 & & 161 & ulis & 496 \\
\hline ylla & 27 & ides & 46 & & & & 496 \\
\hline & 369 & & 379 & & 16 & & 496 \\
\hline iana & & & & & & & 497 \\
\hline Jas & 45 & & 18 & & 16 & & 496 \\
\hline & & naum & & & & & 496 \\
\hline & 45 & dium & 18 & & & & 495 \\
\hline & & & 18 & & & & 497 \\
\hline & 45 & & 18 & hyllum & & & 495 \\
\hline & & & 18 & & & & 497 \\
\hline & & & 18 & & & & 495 \\
\hline & & & 184 & & 16 & ens̊ & 496 \\
\hline & 458 & duncu- & & & & & 495 \\
\hline & & & 184 & & & & \\
\hline & & & 184 & & & & 497 \\
\hline & & & & Cher & & & \\
\hline & & & 185 & & 43 & dus & 495 \\
\hline & & & 185 & & & & \\
\hline & & Ceratophyllace & EAE & Wild Red & 270 & & 496 \\
\hline & 45 & & 189 & Chess & 77 & & \\
\hline & 45 & & 189 & saw Plum & 269 & philus & 497 \\
\hline & 4 & & 18 & eed 182 , & 184 & & \\
\hline & & & 24 & & & & 496 \\
\hline & & & 24 & & & & 497 \\
\hline linariaefolia & 458 & edifolius & 246 & umbellata & 368 & lattensis & 497 \\
\hline
\end{tabular}




\begin{tabular}{|c|c|c|c|c|c|c|c|}
\hline puberulus & 495 & Sweet & 277 & Cone-flower 544 & 545 & coloradoides & 268 \\
\hline pulcherrimus & 497 & White & 278 & Conioselinum & 354 & Doddsii & 268 \\
\hline pumilus & 495 & White Sweet & 277 & scopulorum & 355 & Douglasii & 267 \\
\hline scoparius & 495 & Yellow Sweet & 277 & Conmitella & 236 & erythropoda & 268 \\
\hline speciosus & 496 & \multicolumn{2}{|c|}{ Club Moss Family 25} & \multicolumn{2}{|c|}{ Convallariaceae } & occidentalis & 268 \\
\hline Vaseyi & 495 & Cnicus & 584 & & 119 & rivularis & 267 \\
\hline virens & 497 & eriocephalus & 585 & \multicolumn{2}{|c|}{ Convolvulaceae } & saligna & 267 \\
\hline wyomingensis & 497 & hesperius & 585 & & 392 & Sheridana & 268 \\
\hline hylisma & 343 & Parryi & 585 & Convolvulus & 393 & Wheeleri & 267 \\
\hline poidea & 343 & undulatus & 587 & arvenis & 393 & \multicolumn{2}{|c|}{ Creeping Winter- } \\
\hline ichorium & 587 & Cockle & 182 & incanus & 393 & green & 371 \\
\hline Intybus & 588 & Corn & 180 & repens & 393 & Creosote Bush & 306 \\
\hline inna & 56 & Wheat & 182 & sepium & 393 & Crepis & 592 \\
\hline arundinacea & 56 & Cocklebur & 542 & Corallorhiza & 126 & acuminata & 593 \\
\hline latifolia & 56 & Coeloglossum & 124 & innata & 127 & alpicola & 593 \\
\hline inquefoil & 254 & bracteatum & 124 & multiflora & 127 & angustata & 594 \\
\hline Shrubby & 251 & Cogswellia & 362 & ochroleuca & 127 & atribarba & 594 \\
\hline ircaea. & 344 & ambigua & 363 & striata & 127 & barbigera & 594 \\
\hline alpina & 345 & bicolor & 363 & Vreelandii & 127 & denticulata & 593 \\
\hline pacifica & 344 & foeniculacea & 364 & Coral Root & 126 & elegans & 593 \\
\hline irsinum & 587 & Grayi & 363 & Cord Grass & 63 & gla & 593 \\
\hline canescens & 587 & Jonesii & 364 & Cordylanthus & 462 & glaucella & 593 \\
\hline icuta & 351 & leptocarpa & 363 & $\mathrm{Ki}$ & 462 & gracilis & 594 \\
\hline maculata & 351 & macrocarpa & 364 & osus & 462 & intermedia & 594 \\
\hline occidentalis & 351 & tana & 363 & shtii & 462 & nana & 593 \\
\hline trachypleura & 351 & orientalis & 364 & Corec & 550 & occidentalis & 594 \\
\hline ladothrix & 172 & platycarpa & 364 & olata & 550 & perplexans & 593 \\
\hline lanuginosa & 172 & Coldenia & 411 & oria & 550 & petiolata & 593 \\
\hline my-weed & 232 & tallii & 411 & rmum & 163 & platyphylla & 593 \\
\hline laytonia & 177 & Coleogyne & 247 & ginatum & 164 & pumila & 594 \\
\hline aurea & 177 & ramosissima & 247 & pifolium & 164 & riparia & 593 \\
\hline caroliniana & 177 & Coleosanthus & 486 & catum & 164 & cinata & 593 \\
\hline lanceolata & 177 & ambigens & 487 & sinale & 164 & scopulorum & 594 \\
\hline megarrhiza & 177 & congestus & 486 & & 163 & tomentulosa & 593 \\
\hline multicaulis & 177 & rettii & 487 & villosum & 164 & Cress & 215 \\
\hline triphylla & 179 & petiolaris & 486 & Cor & 365 & Bitter & 216 \\
\hline lea & 466 & ulosus & 487 & ockle & 180 & & 216 \\
\hline tis & 197 & Collinsia & 439 & $1 \mathrm{a}$ & 366 & Winter & 215 \\
\hline alpina & 198 & parviflora & 439 & Corn & 366 & Croton & 308 \\
\hline Bakeri & 198 & tenella & 439 & eyi & 366 & texensis & 308 \\
\hline Douglasï & 197 & Collomia & 397 & adensis & 366 & Crowfoot & 199 \\
\hline eriophora & 197 & linearis & 398 & onifera & 366 & Water & 198 \\
\hline Jonesii & 198 & micrantha & 399 & Corydalis & 206 & Cruciferae & 207 \\
\hline lingusticifolia & 198 & tenella & 398 & aurea & 206 & Cryptanthe & 415 \\
\hline occidentalis & 198 & Colorado Rubbe & & brachycarpum & 207 & affinis & 416 \\
\hline plattensis & 197 & Plant & 561 & ndegei & 206 & ambigua & 415 \\
\hline pseudoalpina & 198 & Columbine & 190 & siliqua & 206 & crassisepala & 416 \\
\hline Scottii & 198 & Comandra & 146 & & 206 & Fendleri & 415 \\
\hline verticillaris & 198 & pallida & 147 & Cory & 139 & flexuosa & 416 \\
\hline tsia & 233 & umbellata & 146 & rata & 139 & gracilis & 416 \\
\hline dantha & 233 & Coms & 261 & n Grass & 88 & multicaulis & 416 \\
\hline leo & 231 & palt & 261 & awood 127 , & 128 & tersonii & 415 \\
\hline nata & 232 & Commelina & 107 & $w$-leaf & 128 & ramulosissima & 415 \\
\hline integrifolia & 232 & & 107 & oth-bark & 128 & Torreyana & 415 \\
\hline lutea is & 232 & virginica & 107 & Covillea & 306 & Watsonii & 416 \\
\hline serrulata & 231 & Сомmelinaceat & 107 & tridentata & 306 & Cryptogramma & 18 \\
\hline sonorae & 232 & Common Dandel & lion & Cowania & 246 & acrostichoides & 18 \\
\hline leomella & 231 & 1 & 600 & mexicana & 246 & Stelleri & 18 \\
\hline angustifolia & 231 & Common Horse & tail & Crab Grass & 4,61 & Cucurbita & 472 \\
\hline cornuta & 231 & & 24 & Cranesbill & 302 & foetidissima & 472 \\
\hline oocarpa & 231 & Common Mallow & 317 & Cras & 543 & perennis & 472 \\
\hline liff Brake & 20 & Common Mullein & 438 & ndiflora & 543 & BITACEAE & 472 \\
\hline limbing False & & Common Nights] & hade & JLACEAE & 232 & Cudweed & 538 \\
\hline Buckwheat & 160 & & 436 & Crat & 267 & Curled Dock & 154 \\
\hline lover & 277 & Common Thistle & 586 & onis & 267 & Currants & 241 \\
\hline Alsike & 278 & COMPositaE & 476 & socarpa & 268 & Golden & 243 \\
\hline Prairie & 298 & Composite Fami & & coloradensis & 268 & Missouri & 243 \\
\hline Red & 278 & & 476 & colorado & 268 & Cuscuta & 390 \\
\hline
\end{tabular}




\begin{tabular}{|c|c|c|c|c|c|c|c|}
\hline Anthemi & 390 & Delphinum & 192 & Dogtooth Violet & 116 & conval & \\
\hline arvensis & 391 & albescens & 193 & Dogwood & 366 & fissa & \\
\hline Cephalanthi & 391 & alpestre & 194 & Family & 365 & glandulosa & \\
\hline Coryli & 391 & azureum & 193 & Dondia & 170 & glutinosa & \\
\hline cuspidata & 390 & & 194 & erecta & 170 & pseudorupestris & \\
\hline glomerata & 390 & bicolor & 193 & Moquina & 170 & & \\
\hline gracilis & 390 & camporum & 193 & Door-weed & 158 & Dryopteris & \\
\hline indecora & 391 & carolinianum & 193 & Double Bladder & Pod & filix-mas & \\
\hline megalocarpa & 391 & Cockerellii & 194 & & 217 & Duckweed & \\
\hline parac & 390 & cucullatum & 194 & Douglasia & 373 & Family & \\
\hline plat & & & 193 & biflora & 374 & Greater & \\
\hline Polyg & 391 & tum & 194 & Lohnstonii & 374 & Dugaldia & \\
\hline umbe & 391 & & 193 & montana & 374 & helenioides & \\
\hline Uuscur & 389 & escens & 194 & Douglas Spruce & 29 & Hooperii & \\
\hline Cyclolo & 164 & & 194 & Draba & 220 & Dusky Willow & \\
\hline atriplicifolium & & & 192 & & 223 & Dysodia & \\
\hline platyphyllum & 164 & Pen & 193 & & 222 & aurea & \\
\hline Cymopte & 359 & orum & 194 & aur & 223 & chrysanthemoid & \\
\hline aca & 359 & & 194 & formis & 224 & & \\
\hline & 354 & & 194 & & 223 & papposa & \\
\hline Fen & 360 & & 193 & & 223 & & \\
\hline$i b a$ & & & & & 221 & Eatonia & \\
\hline lap & 360 & & 193 & chr & 223 & ob & \\
\hline & & & 193 & & 222 & ylvanica & \\
\hline rryi & 360 & & 192 & & 221 & Echina & \\
\hline Par & & um & & & 222 & Ech & \\
\hline athrum & 364 & Descl & 60 & & 224 & & \\
\hline & 365 & & 60 & & 222 & & \\
\hline $\mathbf{N}$ & 365 & & 60 & & 223 & & \\
\hline YPI & 84 & iniper & 30 & & 223 & Echi & \\
\hline yp & 8 & & 58 & & 223 & & \\
\hline & 8 & & 206 & & 223 & & \\
\hline & 85 & & 20 & & 222 & athus & \\
\hline & 85 & Dic & & & 223 & & \\
\hline itzii & 85 & gei & 54 & & 223 & & \\
\hline yppri & 123 & Dipl & 66 & $\mathrm{~m}$ & 221 & Echi & \\
\hline & 123 & & 66 & & 222 & & \\
\hline & 123 & & 66 & & 222 & Ech & \\
\hline cha & 20 & Dip & 522 & & 223 & & \\
\hline & & & & & 221 & Ech & \\
\hline & 203 & & 12 & & 222 & & \\
\hline ystopteris & 21 & arpum & 12 & & 223 & & \\
\hline fragilis & 21 & Dis & 471 & & 221 & $E d u$ & \\
\hline & & Dis & 68 & & 222 & Elax & \\
\hline Petvlis & 68 & & 68 & & 222 & & \\
\hline glom & 68 & Dit & 308 & & 223 & Elae & \\
\hline Daisy & 565 & & 30 & & 222 & & \\
\hline Oxey & 565 & Doc & & & 221 & & \\
\hline & & & & & 223 & & \\
\hline abane & & Dor & & & & & \\
\hline Dal & & & & & 223 & & \\
\hline Dar & 600 & Dod & & ventosa & 222 & Ele & \\
\hline & & & & \multicolumn{2}{|c|}{ Yellowstonensis } & & \\
\hline Dant & 62 & Cusicl & 376 & \multicolumn{2}{|c|}{222} & arpurea & \\
\hline & & cylindrocarpum & & Dracocephalum & 428 & & \\
\hline & 62 & & 376 & & 429 & & \\
\hline & 62 & & 376 & Drs & 428 & & \\
\hline & & & & & 429 & & \\
\hline & 62 & & 376 & Drop-seed & 51 & & \\
\hline & 62 & ntum & 376 & \multicolumn{2}{|c|}{ Drop-seed Grass } & & \\
\hline & 79 & & 376 & & 54 & Elep & 45 \\
\hline Dasi & & & 376 & Dros & 374 & nlandica & \\
\hline & & & & & & & \\
\hline Datu & & & 376 & & 269 & Tamily & 14 \\
\hline & & & 376 & & 250 & Elym & \\
\hline onium & & & 376 & & 250 & & \\
\hline & 43 & & 38 & Drym & 253 & & \\
\hline Day Flower & 10 & Dog Fer & 564 & grouta & 253 & canadensis & \\
\hline
\end{tabular}




\begin{tabular}{|c|c|c|c|c|c|c|c|}
\hline condensatus & 83 & Erigeron & 522 & ramosus & 529 & salicinum & 152 \\
\hline glaucus & 82 & acris & 530 & salsuginosus & 524 & salinum & 151 \\
\hline hirsutiglumis & 82 & annuus & 529 & Scribneri & 527 & salsuginosum & 148 \\
\hline innovatus & 83 & aphanactis & 528 & simplex & 526 & scoparium & 151 \\
\hline Macounii & 82 & arenarius & 529 & simulans & 527 & Simpsonii & 151 \\
\hline robustus & 82 & argentatus & 531 & spathulifolius & 526 & subalpinum & 149 \\
\hline salinus & 83 & armeriaefolius & 530 & speciosus & 525 & tenellum & 151 \\
\hline Sibiricus & & asper & 525 & striatus & 525 & tetraneuris & 150 \\
\hline simplex & & caespitosus & 528 & strigosus & 529 & triste & \\
\hline Sitanion & 84 & canadensis & 532 & subcanescens & 528 & tristichum & \\
\hline triticoides & 83 & canus & 531 & trinervis & 525 & umbellatum & 48 \\
\hline Slyna & & cinereus & 529 & erbus & 524 & umbelliferum & 149 \\
\hline Bellardii & 89 & colo-mexicanus & & & 526 & vegetius & 48 \\
\hline Emmenanthe & 410 & & 529 & dus & 528 & xanthum & 150 \\
\hline scop & & compositus & 528 & Tweedyana & 531 & Eriogynia & 249 \\
\hline salina & & concinnus & 528 & Tweedyi & 526 & uniflora & 249 \\
\hline Endolepis & 166 & consobrinus & 525 & uniflorus & 526 & Eriophorum & 88 \\
\hline ovata & 166 & conspicuus & 525 & & 527 & gracile & 89 \\
\hline Engelmann Spru & & corymbosus & 528 & & 527 & ocreatum & 88 \\
\hline & 28 & Coulteri & 524 & & 525 & polystachyon & 8 \\
\hline Enomegra & 205 & curvif & 527 & Vreelandii & 525 & Eriophyllum & 555 \\
\hline hispida & 205 & divo & 532 & ningensis & 527 & integrifolium & 556 \\
\hline Ephedra & 30 & div & 529 & vstonensis & 530 & multiflorum & 556 \\
\hline antisyphilitica & 31 & Droebachensis & 530 & Erio & 51 & Wallacei & 556 \\
\hline yana & 31 & Earlii & 525 & & 51 & Eritrichium & 414 \\
\hline trif & & Eat & 527 & data & 51 & teum & 41 \\
\hline Epilob & 335 & elat & 524 & Erio & 147 & tum & \\
\hline ocaulon & 337 & mannii & 527 & & 150 & ardii & 41 \\
\hline alpinum & 336 & exil & 525 & & 149 & Eroc & 179 \\
\hline anagallidifoliur & & olius & 529 & um & 152 & ylla & 179 \\
\hline & 336 & flag & 529 & & 148 & Ero & 304 \\
\hline stylum & 337 & ssimus & 525 & tum & 149 & arium & 304 \\
\hline um & 336 & $\mathrm{Ga}$ & 526 & & 149 & Erys & 229 \\
\hline$u m$ & 337 & glat & 525 & caespitosum & 152 & & 231 \\
\hline Drummondii & 336 & glac & 524 & \multicolumn{2}{|c|}{ campanulatum } & $u m$ & 231 \\
\hline Halleanum & 337 & losus & 526 & & 152 & & 230 \\
\hline mannii & 335 & gra & 527 & & 148 & rimum & 230 \\
\hline losum & 337 & florus & 524 & chloranthum & 150 & & 230 \\
\hline lium & 334 & & 527 & \multicolumn{2}{|c|}{ chrysocephalum. } & nthoides & 230 \\
\hline lines & 336 & ens & 525 & & 152 & spicuum & 230 \\
\hline olium & 337 & & 53 & um & 152 & & 230 \\
\hline Pal & 337 & & 53 & olium & 150 & oblanceolatum & 230 \\
\hline latum & 336 & leic & 526 & & 152 & rviflorum & 230 \\
\hline xans & & hus & 526 & & 151 & lum & 230 \\
\hline rubescens & 337 & phyllus & 530 & eriana & 152 & icatum & 230 \\
\hline saximontanum & & 3 & 527 & & 150 & Wheeleri & 230 \\
\hline & & Dougallii & 529 & $r m e$ & 148 & Eryt & 379 \\
\hline & & hus & 525 & & 148 & nica & 379 \\
\hline neum & 337 & melanocephalus & & eoides & 149 & & 379 \\
\hline ticosum & 335 & & 525 & & 148 & nium & 116 \\
\hline ingense & 336 & chus & 527 & & 149 & iflorum & 116 \\
\hline Epips & 125 & isis & 53 & & 151 & tum & 116 \\
\hline & & & 52 & ogynum & 150 & viflorum & 116 \\
\hline ACEAE & 23 & & 526 & & 149 & ohalus & 511 \\
\hline & 23 & $\mathrm{Nel}$ & 52 & ophyllum & 151 & & 513 \\
\hline & 2 & shyllus & 52 & & 151 & Euk & 211 \\
\hline & 2 & & 52 & & 15 & ifolia & 211 \\
\hline & 24 & seolatus & 52 & ctum & 149 & rium & 484 \\
\hline laevigatum & 24 & Laris & 52 & licaule & 151 & ifolium & 485 \\
\hline & 24 & Parryi & 52 & roleucum & 150 & arizonicum & 485 \\
\hline & 24 & pedunculata & 52 & dense & 152 & atromontanum & 48 \\
\hline variegatum & 24 & lelphicus & 52 & aulon & 150 & Bruneri & 485 \\
\hline Tragrostis & 66 & pinnatisectus & 529 & ifolium & 150 & Fendleri & 485 \\
\hline & 66 & platyphyllus & 525 & phyllum & 150 & maculatum & 485 \\
\hline & 66 & ermus & 52 & florum & 151 & Rydbergii & 485 \\
\hline Purshii & 66 & & 52 & & 150 & & 485 \\
\hline & & & 530 & & 151 & Euphorbia & 309 \\
\hline Iriocarpum & 498 & radicatuṣ & 526 & Rydbergii & 149 & albomarginata & 310 \\
\hline
\end{tabular}




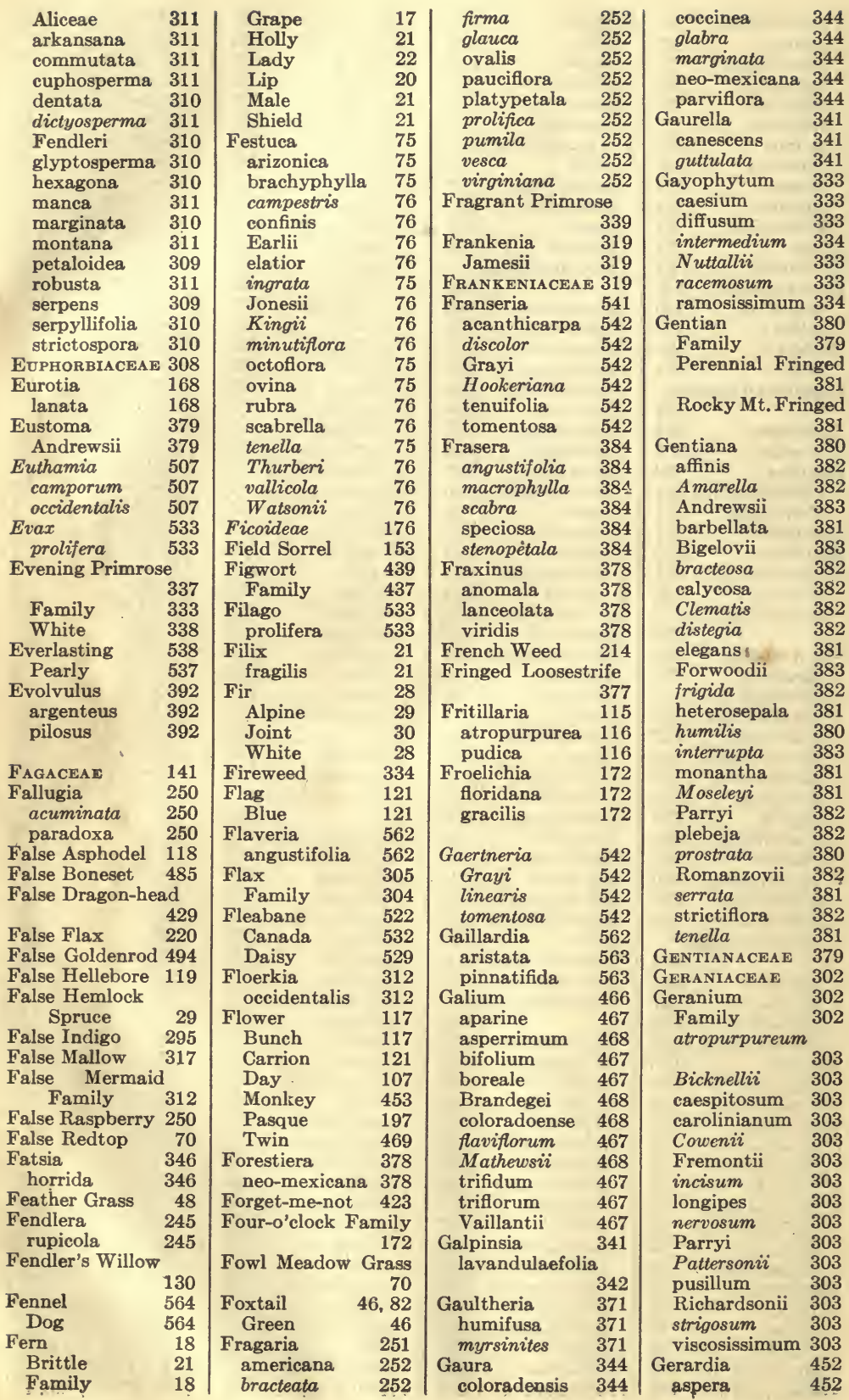




\begin{tabular}{|c|c|c|c|c|c|c|c|}
\hline Besseyana & 452 & lepidota & 295 & Marsh & 63 & linearis & \\
\hline tenuifolia & 453 & Gnaphalium 5 & 538 & Meadow & 69 & longifolia & 488 \\
\hline Germander & 426 & angustifolium 5 & 539 & Needle & 50 & microcephala & 489 \\
\hline Geum & 262 & chilense 5 & 538 & Oat & & myriacephala & 489 \\
\hline macrophyllum & 262 & decurrens & 538 & Orchard & 68 & Sarothrae & \\
\hline oregonense & 262 & palustre & 538 & Panic & 45 & scoparia & \\
\hline rivale & 262 & Sprengelii & 538 & Perennial. Rye & 78 & Gymnolomia & \\
\hline Rossii & 263 & strictum & & Porcupine & 50 & multiflora & \\
\hline scopulorum & 262 & sulphurescens & 538 & Quake Brome & 77 & Gymnosteris & \\
\hline strictum & 262 & thermale & 538 & Reed 58, & 3, 65 & nudicaulis & \\
\hline triflorum & 262 & Wrightii & 538 & Reed Canary & 47 & Gyrostachys & \\
\hline Giant Hyssop & 428 & GNETACEAE & 30 & Reed Meadow & 74 & stricta & \\
\hline Gilia & 398 & Goat's Beard & 249 & Rice & 50 & & \\
\hline aggregata & 400 & Golden Aster & 491 & Rice Cut & 46 & Habenaria & \\
\hline attenua & 400 & Golden Currant & 243 & Rush & 54 & 124,125 & \\
\hline Bakeri & 401 & Goldenrod & 504 & Smooth Brome & 77 & dilatata & \\
\hline Bran & 405 & False & 494 & Spear & 69 & hyperborea & \\
\hline caesp & 402 & Rayless & 494 & rreltail & 82 & unalaschensis & 12 \\
\hline & 400 & Golden Saxifrage & & & 45 & Hackbe & \\
\hline oidea & 401 & & 237 & Tape & 38 & Hair Gr & \\
\hline cong & 401 & Goodyera & 126 & e-awned & 47 & Halerp & \\
\hline Cran & 401 & Gooseberry Family & ily & Oat & 61 & cymbalaria & 20 \\
\hline exsert & 400 & & 241 & Vanilla & 47 & HALORAGIDACEAI & \\
\hline florib & 402 & Goosefoot Family & & Wheat & 79 & & \\
\hline & 399 & & 160 & Witch & 45 & Haploesthes & \\
\hline Harl & 402 & Goose Grass & 158 & Gratiola & 449 & & 57 \\
\hline $\mathrm{Hay}$ & 401 & Gorn & 233 & giniana & 449 & Har & \\
\hline & 399 & & 233 & Grayia & 168 & ypleura & 53 \\
\hline & 400 & Family & 472 & degei & 168 & & 47 \\
\hline & 399 & Grass & 63 & loides & 168 & & \\
\hline & 400 & GRA & 38 & & 168 & & 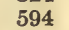 \\
\hline & 401 & Gra & 315 & Greasewood & 169 & & \\
\hline & 399 & Or & 204 & Greater Duckweec & & $\mathrm{Ha}$ & 13 \\
\hline & 399 & bank & 316 & & 107 & Heath & 37 \\
\hline & 402 & Grap & 17 & Great Ragweed & 541 & $F_{\varepsilon}$ & \\
\hline eoides & 402 & orum & 73 & & 378 & ain & \\
\hline & 400 & & 66 & xtail & 46 & Hed & \\
\hline & 40 & & 73 & & 489 & nondii & \\
\hline don & 401 & Wolfii & 73 & actis & 490 & & \\
\hline & 402 & Grass & 234 & abens & 490 & & \\
\hline & 402 & Arrov & 36 & & 490 & Bindweed & \\
\hline & 401 & yard & 45 & lata & 490 & yssop & \\
\hline & 40 & 42 , & 2,56 & lora & 490 & $\mathrm{Hed}$ & \\
\hline & 401 & Ber & 57 & & 490 & & \\
\hline & 40 & k Bunch & 43 & & 49 & & \\
\hline & 40 & & 69 & & 49 & & 30 \\
\hline & 40 & yed & 122 & pis & 490 & ens & \\
\hline & & & 76 & & & & \\
\hline & & & 6 & & 49 & & \\
\hline & & & & & & tum & 30 \\
\hline & & & & & & & \\
\hline binse & & & & & & & $3 c$ \\
\hline & & Crab & t, 61 & Gromwell & 423 & escens & \\
\hline lau & & Drop Seed & & GROSSULARIACEAE & & ense & \\
\hline & & Feather & 48 & & 241 & Hel & \\
\hline & 429 & Fowl Meadow & 70 & Grou & 433 & nale & \\
\hline & & & 158 & & 429 & & \\
\hline Slob & & & 63 & Pine & 25 & & \\
\hline Iallow & 31 & & 1,60 & & 576 & Heli & \\
\hline & 73 & $\mathrm{He}$ & 57 & & 489 & phala & \\
\hline & 7 & Holy & 47 & rrezia & & caulis & \\
\hline & 74 & Hungarian Bron & ome & & 489 & & \\
\hline & 75 & & 77 & & & uenervis & 54 \\
\hline & 74 & & 43 & niae & & & 54 \\
\hline & 74 & & 70 & & 48 & Helia & 54 \\
\hline & 74 & tucky Blue & e 70 & rella & 48 & & \\
\hline & 74 & & 82 & & & & \\
\hline Glycyrrhiza & 295 & Manna & 73 & lepidota & 488 & fascicularis & \\
\hline
\end{tabular}




\begin{tabular}{|c|c|c|c|c|c|c|c|}
\hline \multirow{2}{*}{\multicolumn{2}{|c|}{ grosse-serratus }} & Water & 432 & multiflora & 561 & castaneus & 111 \\
\hline & & Hoary Vervain & 425 & Osterhoutii & 561 & confusus & 112 \\
\hline lenticularis & 547 & Hoary Willow & 136 & Richardsonii & 560 & Dudleyi & 112 \\
\hline Maximilianus & 548 & Holly Fern & 21 & HYPERICACEAE & 320 & Drummondii & 112 \\
\hline Nuttallii & 548 & Holodiscus & 247 & Hypericum & 320 & ensifolius & 110 \\
\hline orgyalis & 548 & dumosus & 247 & formosum & & filiformis & \\
\hline petio & 547 & microphyllus & 247 & Scouleri & 320 & Hallii & \\
\hline & 548 & Holy Grass & 47 & Hypopitys & & intermedius & \\
\hline gid & 548 & Homalobus & 291 & multiflora & & & \\
\hline rimus & 547 & hylophilus & 291 & Hyssop & & longistylis & \\
\hline subrhomboideus & & Homalocenchrus & 46 & Hedge & 449 & marginatus & \\
\hline & 548 & oryzoides & 46 & & & Mertensianus & \\
\hline utahensis & 548 & Honeysuckle & 471 & Indian Hemp & 385 & densis & \\
\hline eliop & & Family & 468 & Indian Millet & 51 & osus & \\
\hline & 543 & Hop & 143 & Indian Pipe Fam & & orthophyllus & \\
\hline & 543 & Hop Tree & 306 & & 368 & Parryi & \\
\hline Ieliot & 411 & Hordeum & 81 & Indian Reed & 56 & Richardsonian & \\
\hline elio & 411 & & 82 & Ionac & 522 & & \\
\hline conv & & & 82 & alp & 522 & saximontanus & \\
\hline & 411 & pusillum & 82 & Ionidi & 324 & & \\
\hline curassavicum & 411 & Horkelia & 254 & & 324 & & \\
\hline & 411 & Gordonii & 254 & & 392 & & \\
\hline & 89 & Hornwort Family & & cea & & & \\
\hline & 89 & & 189 & & 392 & & \\
\hline Ien & 171 & Horsemint & 431 & & 39 & & \\
\hline & 171 & lor & 23 & & & & \\
\hline Ier & 36 & & 24 & & & Jun & \\
\hline & 365 & & 23 & IRII & & Jun & \\
\hline thus & 20 & Hosa & 277 & $y$ & & & \\
\hline let & 108 & Pursh & 277 & Iris & & 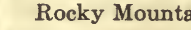 & \\
\hline & 108 & Huckleberry Fam & mily & missouriensis & 121 & & \\
\hline Heter & 209 & & 372 & & 121 & & \\
\hline & & ul & 557 & & 484 & Jun & \\
\hline & 23 & & 558. & Isoc & & & \\
\hline & 23 & Hun & 143 & & 498 & & \\
\hline & 235 & & 144 & Isor & 24 & sperma & \\
\hline & 235 & Hungarian Brom & & Isoet & 24 & & \\
\hline grossu & & & 77 & anderi & 25 & & \\
\hline & 235 & Hut & 220 & & 25 & & \\
\hline & 23 & & 220 & Iva & 540 & virginiana & \\
\hline & 23 & Hyba & 323 & & 540 & & \\
\hline & 23 & & 323 & & 540 & Kall & \\
\hline & 236 & gea Famil & & & & & \\
\hline & 235 & & 243 & Gordonii & 254 & Kaln & 37 \\
\hline & 235 & HYDRAI & & Ivy 313,316 , & 429 & & 37 \\
\hline & 235 & & 243 & American & 316 & phylla & 371 \\
\hline & 236 & HYDI & AE & Ground & 429 & & \\
\hline & 236 & & 405 & Western Poiso & & Kel & \\
\hline lierac & 594 & Hydroph & 406 & & & & \\
\hline & 595 & & 406 & Ivy-leaved Morni & & & \\
\hline & 595 & Fen & 406 & Glory & 393 & ora & \\
\hline & 595 & & 406 & & & ky Blue & \\
\hline & 596 & herum & 563 & Jame & 244 & & \\
\hline & 595 & & 563 & ricana & 244 & & 371 \\
\hline & 595 & Нуn & 554 & Jamestown Weed & & & \\
\hline & 59 & & 554 & & 437 & & \\
\hline & 59 & & & & 437 & & \\
\hline & 59 & & & & 485 & & \\
\hline tier & 47 & & & & 43 & & \\
\hline & 47 & & & Family & 30 & & 164 \\
\hline odorata & 47 & ucus & 55 & & 108 & & 16 \\
\hline High Bush Cran- & & & & & 36 & & \\
\hline & 469 & & 55 & Jun & 109 & Koel & 67 \\
\hline & 43 & & & & & stata & \\
\hline & 43 & Hymen & 560 & Jun & 109 & Kri & 589 \\
\hline & 345 & chrysanthemoide & & & 113 & icaulis & \\
\hline & 34 & & & & & & \\
\hline Hoarhound & 432 & floribunda & & canadensis & & Krynitzkia & \\
\hline
\end{tabular}




\begin{tabular}{|c|c|c|c|c|c|c|c|}
\hline californica & 414 & utahensis & 302 & prostrata & 219 & vulgaris & $43 \varepsilon$ \\
\hline crassisepala & 416 & Laurel & 370 & pruinosa & 220 & Linnaea & 469 \\
\hline Fendleri & 145 & American & 370 & rosulata & 219 & americana & 470 \\
\hline fulvocanescens & 418 & Laurentia & 475 & Shearis & 219 & borealis & 470 \\
\hline glomerata & 419 & carnosula & 475 & spathulata & 219 & Linum & \\
\hline & 417 & eximia & 475 & & 219 & arkansanum & \\
\hline leucophaea & 417 & Lavauxia & 341 & valida & 219 & australe & 305 \\
\hline Pattersonii & 415 & brachycarpa & 341 & Lesser Mistletoe & 145 & compactum & \\
\hline sericea & 418 & flava & 341 & Lettuce & 596 & Kingii & 05 \\
\hline virgata & 419 & Howardii & 341 & Leucampyx & 555 & Lewisii & \\
\hline Watsonii & 416 & Layia & 552 & Newberryi & 555 & perenne & 05 \\
\hline uhnia & 485 & glandulosa & 553 & Tounene & 522 & puberulum & \\
\hline eupatorioides & 485 & Lead Plant & 295 & & 522 & rigidum & \\
\hline glutinosa & 485 & Ledum & 371 & & 522 & Lip Fern & \\
\hline Gooc & 485 & glandulosum & 371 & & 522 & Lippia & \\
\hline Hitc & 485 & Legouzia & 474 & hirtella & 522 & cuneifolia & 25 \\
\hline & 486 & LEGUMI & 270 & & 522 & lanceolata & \\
\hline & 486 & Lemna & 106 & rinum & 113 & Listera & 125 \\
\hline folia & 486 & cyclostasa & 106 & mon & 113 & convallarioides & \\
\hline unzia & 247 & gibba & 107 & Lewisia & 179 & & 125 \\
\hline tridentata & 247 & & 106 & & & cordat & \\
\hline & & & 10 & & 179 & ophylla & 126 \\
\hline & 426 & & 106 & & 179 & Lith & \\
\hline Tea & 371 & trisc & 106 & hylla & 179 & & 237 \\
\hline & 488 & LEM & 105 & Liat & & & \\
\hline ligh & 488 & Leon & 429 & istylis & 488 & rmum & 423 \\
\hline acts & 596 & & 430 & & 488 & & \\
\hline ensis & 596 & Lepa & 545 & & 488 & ifoliun & 424 \\
\hline olia & 597 & Lepa & 332 & Lico & 295 & & \\
\hline & 596 & Lepi & 212 & Ligu & 354 & & 424 \\
\hline & 596 & aly & 212 & oodae & 354 & & \\
\hline & 597 & & 213 & Ligu & & & 42 \\
\hline & 596 & ryum & 213 & & & folium & \\
\hline & 596 & & 212 & woodae & 354 & orum & 42 \\
\hline & 596 & & 212 & & 3 & & 423 \\
\hline & 597 & & 213 & & 353 & Lloy & 116 \\
\hline & 59 & & 21 & $s c$ & 35 & & \\
\hline Tresses & 125 & & 21 & & 353 & mily & 32 \\
\hline & 22 & & 212 & lium & 353 & & 24 \\
\hline pper & 123 & & 213 & LiLI & 113 & Lob & 47 \\
\hline irters & 161 & & 213 & Liliv & 115 & & 474 \\
\hline ap & 411 & & 21 & montanum & 115 & & 474 \\
\hline & 412 & & 213 & \multicolumn{2}{|c|}{ philadelphicum } & & \\
\hline cens & 412 & & 212 & & 115 & tica & 47 \\
\hline & 413 & & 213 & Lily & 115 & LOB & \\
\hline des & 413 & imum & 213 & Family & 113 & & \\
\hline & 413 & & 213 & & 116 & & \\
\hline & 413 & & 21 & , of the & 119 & e Pole Pine & \\
\hline & 412 & Lept & 532 & Wate & 188 & Loliv & \\
\hline & 412 & & 532 & \multicolumn{2}{|c|}{ White Mountain } & & \\
\hline & 413 & & 532 & & 113 & entum & \\
\hline erma & 413 & Lept & 362 & \multicolumn{2}{|c|}{ Yellow Pond 188} & Lom & \\
\hline & 413 & & 362 & \multicolumn{2}{|c|}{ Lily of the Valley } & reum & \\
\hline & 413 & & 362 & & 119 & Lon & 471 \\
\hline & 412 & Lesq & 21 & Limber $\mathbf{P}$ & 27 & & 471 \\
\hline & 192 & & & & 312 & & 471 \\
\hline & 30 & & 21 & & 12 & & \\
\hline & & & & & & & \\
\hline at & 30 & & 21 & & & & \\
\hline & 30 & & & & & & \\
\hline & 30 & nnii & 219 & & 12 & & 33 \\
\hline & 30 & & & & & & \\
\hline & 30 & & 21 & & 124 & Lophanthus & \\
\hline & 302 & & & & & & \\
\hline deus & 302 & & 219 & & 472 & urticifolius & 428 \\
\hline & 30 & & 22 & & & LORANTHACEAE & \\
\hline & 30 & & 220 & & 438 & Lotus & 277 \\
\hline & 301 & roula & 219 & canadensis & & americanus & \\
\hline
\end{tabular}




\begin{tabular}{|c|c|c|c|c|c|c|c|}
\hline Wrightii & 277 & sinuatus & 432 & Malvastrum & 317 & gracilis & 325 \\
\hline Lousewort & 455 & Lycurus & 52 & coccineum & 317 & laciniata & 325 \\
\hline Lowellia & 563 & phleoides & 53 & Cockerellii & 318 & laevicaulis & 326 \\
\hline aureum & 563 & Lygodesmia & 591 & dissectum & 318 & latifolia & 324 \\
\hline Lucerne & 277 & exigua & 592 & elatum & 317 & multiflora & 325 \\
\hline Lupine & 272 & grandiflora & 591 & leptophyllum & 318 & Nelsonii & 324 \\
\hline Lupinus & 272 & juncea & 591 & Munroanum & 318 & nuda & 325 \\
\hline aduncus & 273 & rostrata & 591 & Mamillaria & 326 & olígosperma & \\
\hline alpestris & 275 & spinosa & 591 & missouriensis & 327 & ornata & 325 \\
\hline alsophilus & 275 & Lyme Grass & 82 & neo-mexicana & 327 & pumila & 326 \\
\hline ammophilus & 276 & Lysiella & 126 & similis & 327 & Rusbyi & 325 \\
\hline amplus & 276 & obtusata & 126 & vivipara & 327 & sinuata & 326 \\
\hline arceuthinus & 276 & LYTHRACEAE & 332 & Manna Grass & 73 & speciosa & 326 \\
\hline argenteus & 274 & Lythrum & 332 & Maple & 313 & stricta & 325 \\
\hline argentinus & 276 & alatum & 332 & Family & 313 & tenerrima & 325 \\
\hline argophyllus & 275 & & & Mountain & 314 & Tweedyi & 325 \\
\hline Bakeri & 276 & Machaeranthera & 518 & Mare's-tail & 345 & Menyanthacea & \\
\hline barbiger & 276 & aspera & 519 & Marigold & 550 & & 384 \\
\hline brevicaulis & 273 & Bigelovii & 520 & Bur & 550 & Menyanthes & 384 \\
\hline Burkei & 276 & canescens & 520 & Marsh & 190 & trifoliata & 384 \\
\hline caespitosus & 273 & cichoriacea & 519 & Marilaunidium & 410 & Menziesia & 370 \\
\hline comatus & 276 & commixta & 520 & angustifolium & 410 & ferruginea & 370 \\
\hline decumbens & 275 & coronopifolia & 519 & Mariposa Lily & 116 & glabella & 370 \\
\hline dichrous & 273 & divaricata & 521 & Marsh Grass & 63 & urceolaria & 370 \\
\hline flexuosus & 274 & Fremontii & 519 & Marsh Marigold & 190 & Meriolix & 342 \\
\hline floribundus & 274 & glabella & 521 & Marsilea & 23 & serrulata & 342 \\
\hline Greenei & 274 & latifolia & 520 & oligospora & 23 & Mertensia & 420 \\
\hline Helleri & 276 & linearis & 521 & vestita & 23 & alba & 422 \\
\hline humicola & 275 & paniculata & 520 & Marsileaceae & 23 & alpina & 420 \\
\hline ingratus & 274 & Pattersonii & 520 & Martynia & 464 & amoena & 422 \\
\hline Kingii & 273 & pulverulenta & 521 & Family & 464 & Bakeri & 422 \\
\hline Jonesii & 275 & ramosa & 521 & louisiana & 464 & brachyloba & 422 \\
\hline laxiflorus & 276 & rubricaulis & 520 & MARTYNIACEAE & 464 & brevistyla & 421 \\
\hline laxus & 276 & Selbyi & 520 & Matricaria & 564 & canescens & 423 \\
\hline leptostachyus & 274 & shastensis & 521 & discoidea & 564 & ciliata & 421 \\
\hline leucanthus & 276 & spectabilis & 520 & matricarioides & 564 & congesta & 421 \\
\hline leucophyllus & 273 & subalpina & 521 & Mayweed & 564 & coriacea & 420 \\
\hline monticola & 275 & superba & 521 & Meadow Grass & 69 & coronata & 422 \\
\hline myrianthus & 274 & cetifolia & 519 & Fowl & 70 & cynoglossoides & 421 \\
\hline oreophilus & 274 & varians & 519 & Meadow Rue & 203 & foliosa & 420 \\
\hline ornatus & 273 & viscosa & 520 & Meadowsweet & 248 & fusiformis & 421 \\
\hline parviflorus & 274 & viscosula & 520 & Medic & 277 & lanceolata & 422 \\
\hline plattensis & 273 & Macrocalyx & 407 & Medicago & 277 & lateriflora & 423 \\
\hline pseudoparviflo & rus & Nyctelea & 407 & sativa & 277 & lineariloba & 421 \\
\hline & 275 & Macronema & 501 & Melampodium & 539 & muriculata & 421 \\
\hline pulcherrimus & 276 & discoideum & 502 & cinereum & 539 & obtusiloba & 421 \\
\hline pusillus & 273 & grindelioides & 502 & leucanthum & 539 & ovata & 421 \\
\hline ramosus & 275 & lineare & 502 & MELANTHACEAE & 117 & papillosa & 421 \\
\hline rubricaulis & 275 & obovatum & 502 & Melica & 67 & Parryi & 421 \\
\hline Sileri & 273 & Madder Family & 466 & bulbosa & 68 & perplexa & 420 \\
\hline Wyethii & 276 & Madia & 552 & parviflora & 68 & picta & 421 \\
\hline Luzula & 108 & glomerata & 552 & Porteri & 68 & polyphylla & 421 \\
\hline comosa & 109 & Maidenhair & 19 & Smithii & 68 & pratensis & 422 \\
\hline intermedia & 109 & Malacothrix & 590 & tabilis & 68 & punctata & 421 \\
\hline parviflora & 109 & hoides & 590 & Melilotus & 277 & sibirica & 421 \\
\hline spicata & 109 & Fendleri & 590 & all & 277 & Tweedyi & 422 \\
\hline Lychnis & 182 & runcinata & 590 & officinalis & 277 & viridis & 422 \\
\hline Drummondii & 182 & Torreyi & 590 & Mentha & 427 & Micrampelis & 472 \\
\hline Kingii & 182 & Male Fern & 21 & canadensis & 428 & Micranthes & 241 \\
\hline montana & 182 & Mallow & 316 & spicata & 428 & arnoglossa & 241 \\
\hline striata & 182 & Common & 317 & Mentzelia & 324 & Microseris & 589 \\
\hline LYCOPODIACEAE & 25 & False & 317 & albicaulis & 324 & nutans & 590 \\
\hline Lycopodium & 25 & Family & 316 & chrysantha & 325 & Microsteris & 399 \\
\hline annotinum & 25 & Globe & 318 & compacta & 325 & micrantha & 399 \\
\hline Lycopus & 432 & Indian & 318 & phora & 325 & Milfoil & 564 \\
\hline americanus & 432 & Malva & 316 & petala & 325 & Milkweed & 387 \\
\hline asper & 432 & rotundifolia & 317 & & 326 & Family & 386 \\
\hline lucidus & 432 & Malvaceat & 316 & dispersa & 325 & Green & 386 \\
\hline
\end{tabular}


Milkwort Family

$\begin{array}{ll}\text { Mimulus } & 307 \\ \text { floribundus } & 453 \\ \text { Geyeri } & 454 \\ \text { gratioloides } & 454 \\ \text { Hallii } & 454 \\ \text { Jamesii } & 454 \\ \text { Langsdorfii } & 543 \\ \text { Lewisii } & 453 \\ \text { membranacea } & 454 \\ \text { moschatus } & 454 \\ \text { nanus } & 453 \\ \text { nasutus } & 454 \\ \text { puberulus } & 454 \\ \text { rubellus } & 453 \\ \text { thermalis } & 454 \\ \text { Tolmiei } & 453 \\ \text { Mint } & 427 \\ \text { Family } & 426 \\ \text { Wild } & 428 \\ \text { Mirabilis } & 172 \\ \text { multiflora } & 173 \\ \text { oxybaphoides } & 173\end{array}$

Missouri Currant 243

Mistletoe Lesser $\quad 145$

Mitella $\quad \mathbf{2 3 6}$

Parryi 236

pentandra 236

stauropetala 236

stenopetala 236

violacea

Miterwort

Mock Orange

Moehringia lateriflora

Mollugo verticillata

Monarda citriodora

comata

fistulosa

menthaefolia

Nuttallii

Ramaleyi

stricta

Monardella parviflora

Moneses uniflora

Monkey Flower

Monkshood

Monolepis chenopodioides 16

Nuttalliana 168 pusilla

Monotropa

Hypopitys

uniflora

MoNOTROPACEAE

Montia

Chamissonis

linearis

Viae

Moonwort

Moracear

236

244

287

187

176

176

431

431

431

431

431

431

431

431

430

430

367

367

453

195

163

63

163

369

369

368

368
178

178

178

178

17

143
Morning-glory

\begin{tabular}{lr|l} 
Morning-glory & \multicolumn{1}{|c}{ sagittata } \\
3ush & 392, 393 & Nacrea \\
Family & 393 & lanata \\
Ivy-leaved & 392 & NAIADACEA E \\
\hline
\end{tabular}

Moschatel Family

Mossy Cup

472

Motherwort $\quad 429$

141

Mountain Ash 269

Mountain Balm 315

Mountain Bog Birch 140

Mountain Heath 370

Mountain Mahogany 246

Mountain Maple 314

Mountain Sorrel 152

Mountain Timothy

Mousetail 53

Mousetail

Mudwort

Mugwort

Muhlenbergia

comata

filiculmis

gracilis

gracillima

pungens

racemosa

198

108

452

565

51

52

52

51

52

52

52
Wrightii

Tulberry Family 143

Mullein

52

Common

438

Munroa

squarrosa

Muscaria

delicatula

micropetala

Musenium

65

65

240

240

240

Musineon

349

angustifolium 349

divaricatum $\quad 349$

Hookeri

349

pedunculatum 349

tenuifolium 350

trachyspermum 349

vaginatum $\quad 350$

Musk Plant 454

Mustard

Black

Family

Plains

Tansy

Treacle

Wild

Myosotis

alpestris

sylvatica

Myosurus

apetalus

Myriophyllum

spicatum

verticillatum

214

215

207

208

224

230

215

423

423

423

198

198

345

345

Nabalus

racemosa

592 wood

Nasturtium

officinale

Naumbergia thyrsiflora

Navarretia

Breweri

intertexta

minima

Needle Grass

Negundo

aceroides

Neillia

Night-blooming Catchfly

Nuphar

advena

Nut Pine

Nuttallia

Oak

Bur

Oat Grass

592

531 Oleaster Family 331

538 Oligoneuron 507

33

36

flexilis $\quad 36$

guadalupensis 36

Nama $\quad 410$

angustifolium 410

dichotomum $\mathbf{4 1 0}$

Narrow-leaf Cotton-

128

canescens

507

rigidum $\quad 507$

Olive Family $\quad 378$

Omphalodes $\quad 414$

Howardii $\quad 414$

nana 414

Onagra $\quad 337$

Hookeri $\quad 337$

Jamesii $\quad 338$

strigosa $\quad 337$

Onagracea E 333

Onion 113

Wild 113

Onosmodium 424

carolinianum 424

nolle 424

occidentale $\quad 424$

Oonopsis $\quad 500$

argillacea $\quad 501$

condensata $\quad 501$

Engelmannii 501

foliosa 501

monocephala 501

multicaulis $\quad 500$

Wardii 501

Nelson's Willow 137

Nemexia 121

herbacea $\quad 121$

Nemophila $\quad 407$

parviflora $\quad 407$

Nepeta $\quad 428$

cataria $\quad 428$

hederacea $\quad 429$

Nettle Family 144

Nicotiana $\quad 437$

attenuata $\quad 437$

trigonophylla 437

181

Nightshade $\quad 435$

Common $\quad 436$

Nothocalais $\quad \mathbf{5 8 9}$

cuspidata $\quad \mathbf{5 8 9}$

Notholaena $\quad 19$

Fendleri $\quad 19$

188

189

27

324

Nuttall's Buttercup

NyCtaginaceas 172

Nymphaea $\quad 188$

polysepala $\quad 189$

NYMPHA EACEAE 188

141

141

Ophioglossaceae

Opulaster

17

247

bracteatus 248

glabratus , 248

intermedius 248

pauciflorus 248

pubescens 248

Ramaleyi 248

Opuntia $\quad 329$

arborescens 331

camanchica $\quad 330$

Davisii 331

fragilis $\quad 330$

humifusa $\quad 329$

polyacantha 330

Rafinesquii $\quad 329$ 


\begin{tabular}{|c|c|c|c|c|c|c|c|}
\hline aperta & 419 & caespitosus & 340 & Pearlwort & 185 & gracilis & 447 \\
\hline Bakeri & 419 & caulescens & 341 & \multicolumn{2}{|c|}{ Pearly Everlasting } & grandiflorus & 444 \\
\hline caespitosa & 418 & eximius & 340 & \multirow{2}{*}{\multicolumn{2}{|c|}{$\begin{array}{ll} & 537 \\
\text { Pectis } & 563\end{array}$}} & Hallii & 443 \\
\hline cana & 418 & glaber & 340 & & & Harbourii & 446 \\
\hline cristata & 418 & hirsutus & 340 & \multirow{2}{*}{\multicolumn{2}{|c|}{$\begin{array}{cc}\text { angustifolia } & 563 \\
\text { Pectocarya } & \mathbf{4 1 4}\end{array}$}} & Haydenii & 443 \\
\hline elata & 418 & macroglottis & 340 & & & heterophyllus & 447 \\
\hline eulophus & 417 & marginatus & 341 & \multicolumn{2}{|c|}{ miser 414} & humilis & 445 \\
\hline flava & 417 & montanus & 340 & \multicolumn{2}{|c|}{ Pedicularis $\quad 455$} & Jamesï & 447 \\
\hline flavoculata & 417 & Pachystima & 313 & \multirow{2}{*}{$\begin{array}{l}\text { bracteosa } \\
\text { canadensis }\end{array}$} & 456 & Kingii & 448 \\
\hline fulvocanescens & s 418 & myrsinites & 313 & & 455 & laricifolius & 443 \\
\hline glomerata & 419 & Panic Grass & 45 & contorta & 455 & linarioides & 446 \\
\hline longiflora & 419 & Panicularia & 74 & crenulata & 455 & Moffattii & 448 \\
\hline multicaulis & 417 & borealis & 74 & \multicolumn{2}{|c|}{ ctenophora $\quad \mathbf{4 5 5}$} & montanus & 448 \\
\hline nana & 418 & Panicum & 45 & \multicolumn{2}{|c|}{ cystopteridifolia } & oreophilus & 441 \\
\hline sericea & 418 & capillare & 45 & & Owenii & 445 \\
\hline suffruticosa & 417 & sanguinale & 44 & Grayi & 456 & procerus & 444 \\
\hline thyrsiflora & 419 & scoparium & 45 & greenlandica & 456 & procumbens & 446 \\
\hline virgata & 419 & Scribnerianum & 45 & Hallii & 456 & pseudohumilis & 445 \\
\hline Oreochrysum & 504 & virgatum & 45 & lunata & 456 & pseudoprocerus & 445 \\
\hline Parryi & 504 & Papaver & 205 & montanensis & 456 & radicosus & 447 \\
\hline Oreoxis & 354 & alpinum & 205 & Parryi & 456 & riparius & 441 \\
\hline alpina & 354 & nudicaule & 205 & procera & 456 & Rydbergii . & 445 \\
\hline Bakeri & 354 & pygmaeum & 205 & racemosa & 455 & secundiflorus & 444 \\
\hline humilis & 354 & Papaveraceat & 205 & scopulorum & 456 & sepalulus & 449 \\
\hline OROBANCHACEAE & 463 & Paper Birch & 140 & "Pe-ik" & 547 & similis & 447 \\
\hline Orobanche & 463 & Parietaria & 144 & Pellaea & 20 & speciosus & 442 \\
\hline ludoviciana & 463 & pennsylvanica & 144 & atropurpurea & 20 & strictiformis & 441 \\
\hline multiflora & 463 & Parnassia & 234 & Breweri & 20 & strictus & 441 \\
\hline Orogenia & 349 & fimbriata & 234 & densa & 20 & suffrutescens & 446 \\
\hline linearifolia & -349 & kotzebuei & 234 & gracilis & 18 & teucrioides & 446 \\
\hline Orpine Family & 232 & palustris & 234 & occidentalis & 20 & Torreyi & 441 \\
\hline Orthocarpus & 461 & parviflora & 234 & pumila & 20 & trichander & 441 \\
\hline luteus & 461 & rivularis & 234 & Wrightiana & 21 & unilateralis & 442 \\
\hline purpureo-albus & & Parnassus, Grass & of & Pennyroyal & 431 & utahensis & 441 \\
\hline & 462 & & 234 & Pentstemon & 439 & Watsonii & 445 \\
\hline Tolmiei & 462 & Paronychia & 187 & acuminatus & 444 & Xylus & 446 \\
\hline Oryzopsis & 50 & depressa & 188 & albidus & 448 & Peppergrass & 212 \\
\hline asperifolia & 51 & diffusa & 188 & alpinus & 441 & Peramium & 126 \\
\hline exigua & 50 & Jamesii & 188 & ambiguus & 443 & Menziesii & 126 \\
\hline juncea & 50 & pulvinata & 188 & angustifolius & 443 & ophioides & 126 \\
\hline micrantha & 50 & sessilifolia & 188 & arenicola & 444 & Peraphyllum & 268 \\
\hline Osmorhiza & 348 & Wardii & 188 & aridus & 443 & ramosissimum & 268 \\
\hline nuda & 348 & Parosela & 297 & azurews & 449 & Pectianthia & 236 \\
\hline OXALIDACEAE & 304 & aurea & 298 & Bakeri & 441 & Perennial Fringe & \\
\hline Oxalis & 304 & Dalea & 297 & barbatus & 441 & Gentian & 381 \\
\hline coloradensis & 304 & enneandra & 297 & brevifolius & 445 & Perennial Rye G & trass \\
\hline stricta & 304 & formosa & 298 & Bridgesii & 448 & & 78 \\
\hline violacea & 304 & Jamesii & 298 & caeruleus & 443 & Pericome & 553 \\
\hline Oxeye Daisy & 565 & lanata & 298 & caespitosus & 446 & caudata & 553 \\
\hline Oxybaphus & 173 & Porteri & 298 & caudatus & 444 & Peritoma & 231 \\
\hline angustifolius & 174 & rubescens & 298 & collinus & 447 & Persicaria & 157 \\
\hline Bodinii & 174 & Parry & 212 & coloradensis & 446 & Petalostemon & 298 \\
\hline hirsutus & 173 & Parsnip Family & 346 & comarrhenus & 442 & candidus & 299 \\
\hline nyctaginea & 173 & Parthenice & 539 & Crandallii & 446 & compactus & 299 \\
\hline Oxygraphis & 203 & mollis & 539 & crassifolius & 442 & macrostachyus & 299 \\
\hline Oxypolis & 362 & Parthenium & 540 & us & 448 & mollis & 299 \\
\hline Fendleri & 362 & alpinum & 540 & eyananthus & 442 & oligophyllus & 299 \\
\hline Oxyria & 152 & Parthenocissus & 316 & cyathophorus & 444 & pubescens & 299 \\
\hline digyna & 153 & vitacea & 316 & deustus & 442 & purpureus & 299 \\
\hline Oxytenia & 450 & Paspalum & 43 & Eatonii & 441 & tenuifolius & 299 \\
\hline acerosa & 540 & setaceum & 44 & erianthera & 448 & villosus & 299 \\
\hline Oxytropis & 292 & Pasque Flower & 197 & erosus & 445 & violaceus & 299 \\
\hline campestris & 295 & Pastinaca & 365 & exilifolius & 443 & Petasites & 571 \\
\hline splendens & 295 & sativa & 365 & Fendleri & 444 & sagittata & 571 \\
\hline Oyster Plant & 289 & Pea & 301 & Fremontii & 442 & Petradoria & 504 \\
\hline Ozomelis & 236 & Family & 270 & fruticosus & 442 & pumila & 504 \\
\hline & & Peach-leaved Wil & llow & glaber & 441 & Petrophyton & 249 \\
\hline Pachylophus & 339 & & 130 & glaucus & 445 & caespitosum & 249 \\
\hline
\end{tabular}




\begin{tabular}{|c|c|c|c|c|c|c|c|}
\hline Peucedanum & 362 & dasyphylla & 397 & Pigweed & 160 & caesia & \\
\hline graveolens & 365 & densa & 396 & Pinacean & 26 & californica & \\
\hline nudicaule & 364 & depressa & 396 & Pin-clover & 304 & callichroa & \\
\hline simplex & 64 & diapensioides & 396 & Pine & 26 & compressa & \\
\hline Phaca & & Family & 394 & Bristle-cone & 27 & croata & \\
\hline americana & 88 & glabrata & 395 & Family & 26 & epilis & \\
\hline caespitosa & 92 & Hoodii & 395 & Limber & 27 & Fendleriana & \\
\hline macrocarpa & 292 & Kelseyi & 396 & Lodge Pole & 27 & flava & \\
\hline pauciflora & 89 & longifolia & 396 & Nut & 27 & flexuosa & \\
\hline pygmaea & 87 & multiflora & 396 & Piñon & 27 & glauca & \\
\hline Phacelia & 407 & uscoides & 395 & Rock & 28 & gracillima & \\
\hline alba & 409 & & 397 & White-bark & 27 & interior & \\
\hline alpina & 408 & puberula & 397 & Pinedrops & 368 & juncifolia & \\
\hline biennis & 408 & scleranthifolia & 395 & Pinesap & 369 & laevigata & \\
\hline campestris & 409 & Stansburyi & 397 & Pinguiculaceae & & laxa & \\
\hline ciliosa & 410 & Phoradendron & 146 & & 462 & leptocoma & \\
\hline circinata & 408 & juniperinum & 146 & Pink Family & 180 & Lettermannii & \\
\hline corrugata & 409 & Phragmites & 65 & Piñon Pine & 27 & longiligula & \\
\hline deserta & 408 & communis & 65 & Single-leaf & 27 & longipeduncula & \\
\hline Franklinii & 409 & Phyllodoce & 370 & Pinus & 26 & & \\
\hline glandulosa & 409 & empetriformis & 370 & albicaulis & 27 & lucida & \\
\hline phylla & 408 & glandulifiora & 370 & aris & 27 & memoralis & \\
\hline nsis & 409 & ida & 370 & edu & 27 & nervosa & \\
\hline folia & 409 & nedia & 37 & fle & 27 & nevadensis & \\
\hline Ive & 408 & Phy: & 43 & phylla & 27 & occidentalis & 7 \\
\hline $\mathrm{Kn}$ & & leri & 435 & ayana & 27 & Pattersonii & 7 \\
\hline hylla & & efolia & 434 & pulorum & 28 & & \\
\hline line & & hylla & 434 & Piper & 125 & planifolia & \\
\hline esii & & & 433 & laschensis & 125 & platyphylla & \\
\hline exicana & 409 & eolata & 434 & Pipsissewa & 368 & pratensis & 7 \\
\hline$a$ & 409 & $l o b a$ & 435 & \multicolumn{2}{|c|}{ Plantaginaceae } & pratericola & \\
\hline dens & 408 & longifolia & 434 & & 464 & pseudopratensis & \\
\hline hala & 47 & -mexicana & 433 & Plantago & 464 & pudica & 7 \\
\hline dinacea & 47 & delphica & 433 & atica & 465 & purpurascens & 7 \\
\hline niana & 47 & yphylla & 434 & gata & 466 & reflexa & 7 \\
\hline Phego & 18 & escens & 433 & oda & 465 & rupestris & 7 \\
\hline teris & 19 & & 434 & colata & 465 & rupicola & 7 \\
\hline Phell & 356 & data & 434 & & 465 & Sandbergii & \\
\hline & 35 & vir & 434 & suroides & 466 & & \\
\hline rum & 357 & Phys & 217 & phila & 465 & nii & \\
\hline nus & 356 & ifolia & 218 & shii & 466 & ristata & 7 \\
\hline ervatus & 357 & carpa & 217 & & 466 & rpurea & 7 \\
\hline ascens & 357 & da & 218 & Rugellii & 465 & ifolia & 7 \\
\hline phus & 244 & erryi & 218 & edyi & 465 & & 71 \\
\hline iii & 244 & vit & 218 & Plan & 464 & eleri & 71 \\
\hline phyllus & 244 & Phys & 247 & nily & 464 & Pola & 232 \\
\hline is & 244 & edius & 248 & & 108 & eolens & 232 \\
\hline lentalis & 244 & aceus & 248 & tlesnake & 126 & ysperma & 232 \\
\hline Philot & 38 & gynus & 248 & chkuhria & 556 & ACEAE & 394 \\
\hline stifolia & 38 & folius & 248 & rifolia & 556 & Pole & 403 \\
\hline ensis & 38 & & 248 & Pleu & 380 & ibaldae & 404 \\
\hline & 38 & & 248 & & 380 & eei & 405 \\
\hline Phipr & 54 & To & 24 & & 38 & $c a$ & 404 \\
\hline & 54 & Phys & 429 & Pleurophragma & 209 & um & \\
\hline Phle & & parviflora & 429 & Plum & 269 & icatum & 404 \\
\hline um & 5 & Picea & 28 & Chickasaw & 269 & num & 404 \\
\hline pratense & & Engelmannii & 28 & Family & 269 & sissimum & 404 \\
\hline Phlox & 394 & Parryana & 28 & Red & 269 & & 404 \\
\hline albomarginata & 396 & pungens & 28 & Wild Yellow & 269 & anum & 405 \\
\hline ifolia & 395 & Pickerel Weed & & Poa & 69 & ydenii & 404 \\
\hline & 396 & Family & 108 & acuminata & 71 & mile. & 404 \\
\hline & 395 & Picradenia & 561 & & 71 & litum & 405 \\
\hline tosa & 395 & helenioides & 562 & & 72 & & 404 \\
\hline cens & 395 & intha & 561 & & 69 & identale & 404 \\
\hline & & & 561 & & 70 & ifolium & 404 \\
\hline & 39 & & 56 & & 73 & spermum & 405 \\
\hline condensata & 39 & Picron & 566 & paniculata & 72 & errimum & 404 \\
\hline costata & 39 & desertorum & 566 & Buckleyana & 73 & strom & 404 \\
\hline
\end{tabular}




\begin{tabular}{|c|c|c|c|c|c|c|c|}
\hline speciosum & 405 & Polypody & 19 & etomentosa & 258 & vulgaris & \\
\hline viscosum & 405 & Polypogon & 56 & fastigiata & 258 & Prunus & \\
\hline Polygala & 307 & monspeliensis & 56 & filicaulis & 261 & americana & \\
\hline acanthocarpa & 307 & Polypteris & 555 & filipes & 258 & angustifolia & \\
\hline alba & 307 & Hookeriana & 555 & flabelliformis & 258 & Besseyi & \\
\hline subspinosa & 307 & Polystichum & 21 & fruticosa & 251 & chicasa & \\
\hline verticillata & 307 & Lonchitis & 21 & glandulosa & 253 & demissa & \\
\hline Polygalaceae & 307 & Pomaceae & 265 & glaucophylla & 257 & & \\
\hline Polygonaceae & 147 & \multicolumn{2}{|c|}{ Pondweed Family 33} & & 257 & melanocarpa & \\
\hline Polygonatum & 119 & \multicolumn{2}{|c|}{ Pontederiaceat } & & 258 & pennsylvanica & \\
\hline commutatum & 120 & & 108 & Hippiana & 261 & \multicolumn{2}{|c|}{ Pseudocymopterus } \\
\hline giganteum & 120 & Poplar & 127 & humifusa & 257 & & \\
\hline Polygonum & 155 & Рoppy & 205 & jucunda & 258 & aletifolius & \\
\hline bium & 157 & Far & 205 & lateriflora & 256 & anisatus & \\
\hline & 158 & Prickly & 205 & leucocarpa & 256 & natus & \\
\hline pides & 156 & Populus & 127 & flora & 260 & & \\
\hline buxi & 158 & acuminata & 128 & lensis & 260 & & \\
\hline calor & 156 & angulata & 128 & eliensis & 256 & & \\
\hline xtum & 159 & stifolia & 128 & Nicollettii & 256 & & \\
\hline con & 159 & nifera & 128 & & 259 & difolius & \\
\hline ulus & 160 & delt & & gica & 257 & Pseudotsu & \\
\hline Do & 159 & atalis & 128 & & 258 & Douglas & \\
\hline dun & 160 & & 27 & & 256 & & \\
\hline em & 157 & & & secta & 258 & Psilc & \\
\hline anii & 159 & Grass & 50 & lvanica & 259 & & \\
\hline erec & 158 & Porte & 475 & & 259 & & \\
\hline & 15 & $e x i$ & 475 & & 260 & ina & \\
\hline ghtii & 157 & Portl & 179 & & 260 & Psor & \\
\hline Hydropiper & 158 & ole & & ricea & 259 & hylla & $2 \subseteq$ \\
\hline \multicolumn{2}{|c|}{ hydropiperoides } & & & & 258 & & \\
\hline & 158 & ACACEAE & 176 & Iuefolia & 258 & data & 29 \\
\hline atum & 160 & geton & 33 & & 256 & & 29 \\
\hline tum & 157 & & 3 & eaulis & 260 & & \\
\hline Kel & 160 & olius & 3 & & 260 & flo & 29 \\
\hline laet & 157 & ifolius & 34 & & 256 & & \\
\hline folium & 157 & & 3 & ontana & 260 & & 29 \\
\hline lila & 156 & & & & 258 & lin & \\
\hline olia & 156 & phyllus & 3 & & 256 & & \\
\hline & 159 & & 3 & $m a$ & 26 & & 29 \\
\hline bergii & 157 & & 34 & & 259 & Ptele & 30 \\
\hline lata & 157 & ius & 35 & & 259 & ustifolia & 30 \\
\hline$n$ & 157 & & 33 & cens & 257 & lata & 30 \\
\hline omissum & 157 & atus & 35 & ingensis & 260 & iata & 30 \\
\hline \multicolumn{2}{|c|}{ pennsylvanicum } & iatus & 34 & Poter & 263 & Pteri & \\
\hline & 157 & & 34 & & 263 & inum & \\
\hline ria & 157 & & 34 & lover & 298 & Pter & \\
\hline oides & 158 & & 34 & hella & 591 & Pter & 36 \\
\hline plat & 157 & Pota & & & 59 & omedea & 36 \\
\hline ides & 159 & $\mathrm{Fa}$ & 43 & Pren & 592 & Pter & 35 \\
\hline hila & 157 & $11 a^{\circ}$ & 2 & alc & 59 & all & 35 \\
\hline & 158 & ens & & & & ea & 35 \\
\hline mum & 158 & & & ta & 59 & Ptilo & \\
\hline & 158 & & & Poppy & & & \\
\hline nse & 15 & irens & & Primrose & 373 & Ptilor & \\
\hline & 160 & & & Evening & 337 & ciflora & 58 \\
\hline scopulina & 156 & ata & & Family & 372 & & 58 \\
\hline \multicolumn{2}{|c|}{ spergulariaeforme } & bier & 25 & Fragrant & 339 & Pucc & \\
\hline & 159 & chkeana & 258 & \multicolumn{2}{|c|}{ White Evening } & & \\
\hline acea & 157 & escens & 25 & & 338 & & 42 \\
\hline & 159 & & $25 \varepsilon$ & & 373 & Puls & 18 \\
\hline & 160 & loensis & 26 & icana & 37 & tissima & 19 \\
\hline & 156 & & 25 & tifolia & 373 & & 47 \\
\hline$W a$ & & & & & 373 & & 24 \\
\hline Wat & 159 & hora & & & 373 & tridentata & 24 \\
\hline & 18 & ens & 25 & Primula ceae & 372 & Purslane & 17 \\
\hline & 19 & & 257 & Prosartes & 120 & Family & 17 \\
\hline ium & 19 & diversifolia & 257 & trachycarpum & 120 & Sea & 17 \\
\hline vulgare & 19 & effusa & 261 & Prunella & 429 & Pygmy' Weed & 23 \\
\hline
\end{tabular}




\begin{tabular}{|c|c|c|c|c|c|c|c|}
\hline Pyrola & 366 & & 201 & & 241 & & \\
\hline asarifolia & 367 & glaberrimus & 200 & americanum & 243 & manca & \\
\hline chlorantha & & Grayi & 201 & aureum & 243 & Maximilianii & \\
\hline elliptica & 367 & inamoenus & 201 & brachyanthum & 242 & melina & \\
\hline $\min$ & 367 & & 201 & cereum & 243 & Nut & \\
\hline pict & 367 & auleyi & 200 & coloradense & 242 & oreophila & \\
\hline nda & 67 & & 202 & divaricatum & 241 & pratincola & \\
\hline uliginosa & 367 & $\operatorname{maxim}$ & 202 & echinatum & 242 & Sayi & \\
\hline Pyrolaceae & 366 & micropetalus & 201 & floridum & 243 & stellata & \\
\hline Pyrrocoma & 499 & ensis & 202 & Hudsonianum & 243 & Underwoodii & \\
\hline & & & 200 & rians & 243 & Woodsii & \\
\hline & & & 200 & & 241 & ROSACEAE & \\
\hline crosea & 499 & ingl & 201 & & 242 & Rose & \\
\hline & & & 201 & & 242 & Cliff & \\
\hline inuloides & 500 & ynchus & 202 & thum & 242 & Family & \\
\hline & 500 & & 201 & longiflorum & 243 & Rubacer & \\
\hline ata & 500 & pedatifidus & 201 & oxyacanthoides & 241 & parviflorum & \\
\hline uni & 500 & \multicolumn{2}{|c|}{ pennsylvanicus } & & 242 & & \\
\hline Vaseyi & 500 & & 202 & petiolare & 243 & Rubus & \\
\hline villo & 500 & Purshii & 200 & atum & 242 & americanus & \\
\hline yrus & 269 & & 201 & & 24 & deliciosus & \\
\hline sambucifolia & 269 & & 200 & & 24 & & \\
\hline & & deus & 201 & ineum & 242 & & \\
\hline Quake Brome G & Grass & & 202 & saximontanum & & trifl & \\
\hline & 77 & latus & 200 & & 242 & kia & \\
\hline uamash & 115 & Raph & 215 & saxosum & 241 & & \\
\hline dion & 173 & strum & 215 & & 24 & & \\
\hline & 173 & Casp & 251 & & 241 & & \\
\hline Que & 141 & & 250 & sissimum & 242 & niata & \\
\hline oodae & 142 & Red & 251 & Wo & 242 & & \\
\hline & 142 & Rati & 545 & t-grass & 46 & alis & \\
\hline & 142 & & 545 & Rice & 50 & Rue Far & \\
\hline & & Tagetes & 545 & Ridd & 55 & Rulac & \\
\hline lla & 142 & \multicolumn{2}{|c|}{ Rattlesnake Plan- } & tagetina & 553 & do & \\
\hline & 141 & tain & 126 & River-bank Grap & pe & & \\
\hline & 142 & \multicolumn{2}{|c|}{ Rattlesnake Root } & & 316 & Run & \\
\hline xicana & 142 & & 592 & Robinia & 280 & & \\
\hline & 143 & \multicolumn{2}{|c|}{ Rayless Goldenrod } & exicana & 280 & & \\
\hline & 142 & & 494 & & 18 & br & \\
\hline & 14 & ed $(r) r a t)$ & 278 & Rock Pine & 28 & & \\
\hline & & & 65 & \multicolumn{2}{|c|}{ Rocky Mt. Bee-plant } & & \\
\hline Vreelandii & 142 & & 65 & \multicolumn{2}{|c|}{232} & Geyeri & \\
\hline \multicolumn{2}{|c|}{ Quillwort Family 24} & $\operatorname{Rec}$ & 269 & \multirow{2}{*}{\multicolumn{2}{|c|}{$\begin{array}{l}\text { Rocky Mt. Birch } 140 \\
\text { Rocky Mt. Fringed }\end{array}$}} & \multicolumn{2}{|l|}{ hymenosepalus } \\
\hline Quincula & 435 & Redt & 57 & & & & \\
\hline \multirow{2}{*}{ lobata } & 435 & False & 70 & Gentian & 381 & maritima & \\
\hline & & \multirow{2}{*}{\multicolumn{2}{|c|}{ Red Canary Grass }} & Rocky Mt. Jun & niper & & \\
\hline rush & & & & 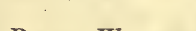 & 30 & & \\
\hline & & Reed Grass & 5,58 & Roman Wormwo & ood & & \\
\hline & & lian & 56 & & 541 & & \\
\hline $\operatorname{Rag}$ & 541 & Reed Meadow G & irass & & 215 & & \\
\hline & & & 75 & & & & \\
\hline Western & 541 & & & liqua & 21 & hizus & \\
\hline RANUNCULACEAF & & & & & & & \\
\hline & 189 & & & & 21 & olius & \\
\hline & & & & $\mathbf{N}$ & & & \\
\hline & & Rhin & & & & & \\
\hline & & & & & & & \\
\hline & 20 & Rhu & 312 & & 216 & Rupr & \\
\hline olius & 20 & & & $s p$ & 21 & arpa & \\
\hline & 20 & & & Underwoodii & 21 & mitim & \\
\hline & 20 & & 31 & Rosa & 26 & Rush & 10 \\
\hline yllus & 20 & & & & 26 & & 10 \\
\hline & 20 & & & & 26 & & \\
\hline & & & & & 26 & & \\
\hline & 20 & & & & 26 & histle & 16 \\
\hline & 20 & & 313 & & & & \\
\hline & 20 & ndron & 313 & & 265 & Rydbergia & \\
\hline - eremogenes & 20 & trilobata & 313 & MacDougalii & 265 & Brandegei & \\
\hline
\end{tabular}




grandiflora
Rye
Wild
Sage
Black
White

561
82
82
430
570
169

Sagebrush 565, 570

Sage-leaved Willow

Sagina

136

Linnaei $\quad 185$

saginoides $\quad 185$

Sagit taria

arifolia

hebetiloba

latifolia

longiloba

variabilis

SalicaceaE

Salicornia

herbacea

rubra

Salix

aemulans 139

amygdaloides 129

$\begin{array}{ll}\text { arctica } & 136 \\ \text { arogophylla } & 131\end{array}$

Barclayi 134

Barrattiana 、 135

Bebbiana 138

brachycarpa 135

candida $\quad 136$

chlorophylla 137

conjuncta $\quad 134$

cordata $\quad 132$

Covillei $\quad 137$

discolor $\quad 137$

desertorum 134

Dodgeana 131

exigua 131

Fendleriana 130

Fernaldii 139

flava

132

flavescens

fluviatilis

Geyeriana

glauca

glaucops

interior

irrorata

lasiandra

lasiolepis

linearifolia

longifolia

lutea

luteosericea

Mackenziana 133

macrocarpa 138

melanopsis 131

monticola

Nelsonii

nigra

nivalis

Nuttallii

Ormsbyensis 132

pachnophora 137

padifolia

padophylla $\begin{array}{ll}\text { petrophila } & 136 \\ \text { pellita } & 137 \\ \text { perrostrata } & 138\end{array}$

pseudolapponum

pseudomyrsinites

pseudomyrsinites 133

pyrifolia 133

reticulata 139

rotundifolia 133

saximontana 139

Scouleriana 138

Seemannii 135

serissima 130

stenophylla 131

stricta

135

subcoerulea

tenera

Tweedyi

vestita

Watsonii

Wolfii

Wrightii

136

136

135

139

wyomingensis

Salmon Berry 250

Salsify

Salsola

pestifer

Tragus

Saltbush

Salvia

lanceolata

Pitcheri

Sambucus

canadensis

glauca

132

134

129

135

50
89

89
69

169

169

165

430

431

430

468.

melanocarpa

microbotrys 469

neo-mexicana 469

racemosa $\quad 469$

Samolus $\quad 377$

floribundus $\quad 378$

Valerandi 378

Samphire

165

Sandalwood Family

146

Sandbar Willow 131

Sand Bur

Sand Cherry

46

Sandwort

Sanguisorba

270

annua

185

Sanicula

263

348

marylandica 348

SANTALACEAE 146

Saponaria

Vaccaria

Sarcobatus

vermiculatus

182

182

169

atus 169

Savastana

Saxifraga

adscendens

arguta

austrina

austromontana

?.

bronchialis

caespitosa cernua

chrysantha

cognata

debilis

flagellaris

Hirculus

integrifolia

Jamesii

micropetala

nivalis

oppositifolia

oregonensis

punctata

rhomboidea

saximontana 240

simulato

subapetala

virginiensis 240

SaxifragaceaE 233

Saxifrage 238

Family 233

Golden 237

Schedonnardus $\quad 61$

paniculatus 61

Schoenocrambe 208 decumbens 209

linifolia 209

pinnata 209

Scirpus

americana

atrovirens

caespitosus

campestris

fluviatilis

lacustris

lineatus

maritimus

microcarpus

nevadensis

Olneyi

paludosus

pauciflorus

pungens

sylvaticus

Scleropogon

Karwinskianus 65

Scouring Rush 23, 24

Scrophularia $\quad 439$

nodosa 439

occidentalis $\quad 439$

SCROPHULARIACEAE

Scutellaria

Brittoni

galericulata $\quad 427$

lateriflora $\quad 427$

resinosa

virgulata

Sea Purslane 176

Sedge

238 Family

Sedum

debile

Douglasii

84

233

233

frigidum

233

polygamum 233

rhodanthum 233

Rhodiola 233

stenopetalum 233

Selaginella $\quad 25$

densa 26

mutica 26

rupestris 26

Selaginellaceate

Self-heal $\quad 429$

Senecio $\quad 576$

accedens $\quad \mathbf{5 7 8}$

acutidens $\quad 582$

admirabilis $\quad 579$

altus $\quad \mathbf{5 8 0}$

amplectens $\quad \mathbf{5 7 8}$

anacletus $\mathbf{5 7 9}$

andinus $\quad \mathbf{5 7 9}$

atratus $\quad \mathbf{5 8 0}$

atriapiculatus $\mathbf{5 8 0}$

aurellus $\quad 583$

Balsamitae $\quad 583$

Bigelovii $\quad \mathbf{5 7 7}$

blitoides $\quad \mathbf{5 7 8}$

canovirens $\quad 581$

canus $\quad 580$

carthamoides 578

cernuus $\quad \mathbf{5 7 8}$

chloranthus $\quad \mathbf{5 7 7}$

columbianus $\quad 580$

compactus $\quad 583$

condensatus $\quad 583$

contristatus $\quad \mathbf{5 7 7}$

crassulus $\quad \mathbf{5 7 9}$

crocatus $\quad 582$

cymbalarioides

582

dimorphophyllus

discoideus $\quad 583$

dispar $\quad 580$

Douglasii $\quad 584$

eremophilus 583

exaltatus $\quad \mathbf{5 7 9}$

fedifolius $\quad 583$

Fendleri $\quad 581$

filifolius $\quad 583$

flavovirens $\quad 583$

flavulus $\quad 583$

Flintii $\quad \mathbf{5 7 9}$

Fremontii $\quad \mathbf{5 7 8}$

fulgens $\quad 582$

glaucescens $\quad \mathbf{5 7 9}$

Harbourii $\quad \mathbf{5 8 0}$

Hartianus 582

heterodoxus 582

Holmii $\quad \mathbf{5 7 8}$

Hookeri $\quad 580$

Howellii $\quad \mathbf{5 8 0}$

hydrophiloides $\mathbf{5 7 9}$

hydrophilus $\mathbf{5 7 9}$

integerrimus $\mathbf{5 8 0}$

invenustus $\quad \mathbf{5 7 8}$ 


\begin{tabular}{|c|c|c|c|c|c|c|c|}
\hline lugens & 580 & neo-mexicana & 317 & \multicolumn{2}{|c|}{ Smooth Brome Grass } & ramosa & 225 \\
\hline MacDougallii & 583 & nervata & 317 & & 77 & viscosa & 225 \\
\hline microdontus & 579 & Sideranthus & 498 & Sneezeweed & 562 & Sophora & 272 \\
\hline milleflorus & 580 & annuus & 498 & Snowberry & 470 & sericea & 272 \\
\hline multicapitatus & 582 & australis & 499 & Solanaceae & 433 & Sorbus & 269 \\
\hline multilobatus & 582 & glaberrimus & 499 & Solanum & 435 & scopulina & 269 \\
\hline mutabilis & 583 & gracilis & 498 & elaeagnifolium & 436 & Sorghastrum & 43 \\
\hline Nelsonii & 581 & grindelioides & 498 & heterodoxum & 436 & nutans & 43 \\
\hline nephrophyllus & 583 & puberulus & 499 & interius & 436 & Sorghum & 43 \\
\hline oblanceolatus & 583 & spinulosus & 499 & & 436 & halepense & 43 \\
\hline occidentalis & 578 & Sieversia & 262 & & 436 & Sorrel & 153 \\
\hline oodes & 582 & ciliata & 262 & rostratum & 436 & & 153 \\
\hline pagosanus & 578 & idea & 263 & triflorum & 436 & Mountain & 152 \\
\hline & 581 & turbi & 262 & & 436 & Sheep & 153 \\
\hline & 580 & Silene & 180 & & 436 & Sow Thistle & 597 \\
\hline & 581 & acaulis & 181 & Solid & 504 & Spanish Needles & 550 \\
\hline llis & 581 & rhina & 181 & porum & 507 & SPARganiaceae & 32 \\
\hline asis & 581 & $\mathrm{Ha}$ & 181 & sis & 506 & Spar & \\
\hline lobus & 582 & iesii & & & 505 & adum & \\
\hline laureus & 582 & aulis & & na & 506 & tifolium & 32 \\
\hline & 578 & ora & & & 505 & & 32 \\
\hline hianus & 581 & & & & 505 & & 32 \\
\hline hochrous & 583 & Sec & & & 505 & & \\
\hline ius & 579 & oides & 181 & & 506 & Spar & 63 \\
\hline ellii & 583 & ensis & 181 & escens & 506 & cynosuroides & 63 \\
\hline tus & 581 & Silver & 331 & & 506 & gracilis & 63 \\
\hline ergii & 582 & Silve & 254 & uscula & 506 & erdock & 188 \\
\hline salicinus & 581 & leaf Piñon & 27 & & 505 & Grass & 69 \\
\hline saliens & 579 & Sisymbrium. & & ulis & 505 & $\min t$ & 428 \\
\hline scopulina & 578 & 209,224 & 225 & & 507 & Spec & 474 \\
\hline semiamplexicau & ulis & linifolium & 209 & uriensis & 505 & ocarpa & 474 \\
\hline & 579 & & 225 & & 507 & oliata & 474 \\
\hline serra & 579 & Sisy & 122 & iradiata & 505 & laria & 187 \\
\hline danella & 578 & re. & 122 & & 507 & flora & 187 \\
\hline arius & 582 & & 122 & ralis & 507 & Sph & 18 \\
\hline jides & 584 & ifolium & 122 & alis & .507 & tifolia & 18 \\
\hline atus & 582 & arpum & 122 & & & & \\
\hline & 582 & num & 122 & & 505 & & \\
\hline jides & 578 & atum & 122 & & 506 & ora & 18 \\
\hline & 583 & entale & 122 & ylla & 506 & ana & 318 \\
\hline ularis & 578 & Sitan & 83 & rima & 506 & & 318 \\
\hline enticulatus & 583 & folium & 84 & & 507 & stigma & 342 \\
\hline phyllus & 579 & vides & 84 & & 507 & & 343 \\
\hline ensis & 581 & gla & 84 & rubra & 505 & tum & 343 \\
\hline vulgaris & 584 & & 84 & oulorum & 505 & iflora & 343 \\
\hline werneriaefolius & & longifolium & 83 & serotina & 506 & Nel & 343 \\
\hline . & 581 & molle & 84 & & 506 & & 343 \\
\hline berry & 265 & & 84 & $i o s a$ & 505 & & 343 \\
\hline & 176 & $p u$ & 84 & ervata & 507 & utahense & 343 \\
\hline lacastrum & & rigidum & 84 & Solomon's Seal & & Spiderwort Fami & \\
\hline & 176 & Sium & 352 & 119 &, 120 & & 107 \\
\hline & 46 & aefolium & 352 & Son & 597 & Spik & 87 \\
\hline & 46 & Skull & 427 & asis & 597 & Spir: & 248 \\
\hline Sorrel & 153 & Smel & 224 & & 597 & betulaefolia & 249 \\
\hline & 331 & icana & 224 & & 597 & siflora & 249 \\
\hline & 332 & calycina & 24 & Sophia & 224 & & 248 \\
\hline anadensis & 332 & ifolia & 224 & lrenarum & 225 & & 248 \\
\hline pherd's Purse & & SмiL & 121 & scens & 225 & Spiranthes & 125 \\
\hline & 220 & Smil & 120 & & 224 & Romanzoffiana & 125 \\
\hline & 21 & exicaulis & 120 & ulifera & 224 & & 125 \\
\hline Star & 375 & & 120 & & 225 & Spir & 107 \\
\hline Cinque & & folia & 120 & Negiana & 224 & & 107 \\
\hline & 251 & & 120 & & 224 & Sple & 22 \\
\hline & 306 & Smil & 121 & redia & 225 & Spor & 54 \\
\hline & 251 & & 121 & ylla & 225 & & 55 \\
\hline & 251 & & 121 & euca & 225 & & 55 \\
\hline & 317 & Smooth-bark Cot & & & 225 & asperifolius & 55 \\
\hline & 317 & tonwood & 128 & purpurascens & 225 & brevifolius & 54 \\
\hline
\end{tabular}




\begin{tabular}{|c|c|c|c|c|c|c|c|}
\hline & & & & nnatifida & 450 & ureugn & \\
\hline $\begin{array}{l}\text { confusus } \\
\text { cryptandrus }\end{array}$ & $\begin{array}{l}55 \\
55\end{array}$ & $\begin{array}{l}\text { mongolica } \\
\text { Nelsonii }\end{array}$ & $\begin{array}{l}48 \\
49\end{array}$ & $\begin{array}{l}\text { pinnatinca } \\
\text { plantaginea }\end{array}$ & $\begin{array}{l}400 \\
450\end{array}$ & $\begin{array}{l}\text { Torreyana } \\
\text { Teucrium }\end{array}$ & \\
\hline filiformis & 55 & neo-mexicana & 50 & reflexa & 451 & laciniatum & \\
\hline heterolepis & 55 & occidentalis & 49 & Ritteriana & 450 & occidentale & \\
\hline simplex & & Richardsonii & 48 & rubra & 450 & Texan Timothy & \\
\hline vaginaeflorus & 5 & Scribneri & 49 & wyomingensis & 450 & Thalesia & \\
\hline Wolfii & 54 & spartea & 50 & Syringa & 244 & fasciculata & \\
\hline praguea & 178 & speciosa & 49 & & & uniflora & \\
\hline multiceps & 178 & Tweedyi & 50 & Talinum & 177 & Thalictrum & \\
\hline umbellata & 179 & Vaseyi & 49 & parviflorum & 177 & alpinum & \\
\hline Spring Beauty & 177 & viridula & 49 & teretifolium & 177 & cornuti & \\
\hline Spruce & 28 & Williamsii & 49 & Tall Fescue & 76 & dasycarpum & \\
\hline Blue & 28 & St. John's-wort & & Tanacetum. & 565 & Fen & \\
\hline Douglas & 29 & Family & 320 & & 565 & occic & \\
\hline Engelmann & 28 & Stonec & 233 & Nutta & 565 & lorum & \\
\hline False Hemlock & $<29$ & Stork & 304 & simplex & 565 & venulosum & \\
\hline purge & 309 & StraY & 251 & Tansy Mustard & 224 & Thamnosma & \\
\hline Family & 308 & Streptanth & 211 & Tape Grass Fami & iily & & \\
\hline Squash & 472 & coloradensis & 211 & & 38 & Thaspium & \\
\hline Squirrel tail Gras & s 82 & & 211 & Taraxacum & 600 & trifoliatum & \\
\hline Stachys & 430 & & 211 & ammophilum & 601 & Thelesperma & \\
\hline ti. & 430 & stris & 211 & angustifolium & 601 & ambiguum & \\
\hline taff Tree Fami & & wyomingensis & 211 & ceratophorum & 601 & gracile & \\
\hline & 313 & Strep & 119 & orum & 600 & redium & \\
\hline tanle & & olius & 119 & & 601 & subn & \\
\hline & 208 & Styl & 600 & um & 601 & ten & \\
\hline & & & 600 & & 600 & tri & \\
\hline & 208 & Sua & 169 & latum & 601 & diopsis & \\
\hline & 20 & d & 170 & & 600 & Thel & \\
\hline & 20 & & 169 & um & 600 & aur & \\
\hline & & & 169 & & 600 & & \\
\hline & & & 170 & Tara & 342 & & \\
\hline & & & 170 & br & 34 & folium & \\
\hline Stan & 20 & Subr & 211. & & 34 & & \\
\hline & & & 21 & & 5 & lium & \\
\hline & & uc & 168 & & 23 & & \\
\hline teir & & & 16 & ifera & 23 & hum & \\
\hline & & & & & 237 & & \\
\hline Stell & & Suid & 36 & Gora & 23 & atum & \\
\hline & & & 366 & & 23 & & \\
\hline & & Sul & 237 & Telo. & 16 & & \\
\hline & 18 & & 237 & & 161 & & \\
\hline & & & 23 & & 57 & The & \\
\hline & & y & 31 & & 57 & rpa & \\
\hline & & & & & & & \\
\hline & 18 & & 27 & & 57 & arpa & \\
\hline & & & & & & & \\
\hline agma & 22 & & 38 & & 57 & & \\
\hline & & & & & & & \\
\hline Sten & 50 & & 38 & & 57 & & \\
\hline & & & 383 & Tetr & 55 & Ther & \\
\hline & & wit & 45 & & 55 & iforme & \\
\hline & & pos & 47 & ifolia & 56 & & \\
\hline & & & 47 & & & & \\
\hline & & & & & & & \\
\hline eria & & & 47 & & & & \\
\hline & & & & & & & \\
\hline & & & 47 & & 55 & Thl & \\
\hline & & & & & & & \\
\hline & & & 47 & & 56 & & \\
\hline & & & & iuscula & & lense & \\
\hline & & & 471 & & & & \\
\hline tick & 41 & ynt & 44 & edia & & & \\
\hline & 4 & & & & & & 214 \\
\hline & 4 & Syn & 44 & osensis & & parviflorum & \\
\hline & & & & & & rascens & \\
\hline & 48 & & 45 & & & & \\
\hline minor & 4 & aciniata & 450 & stenophylla & 560 & Thoroughwort & \\
\hline
\end{tabular}




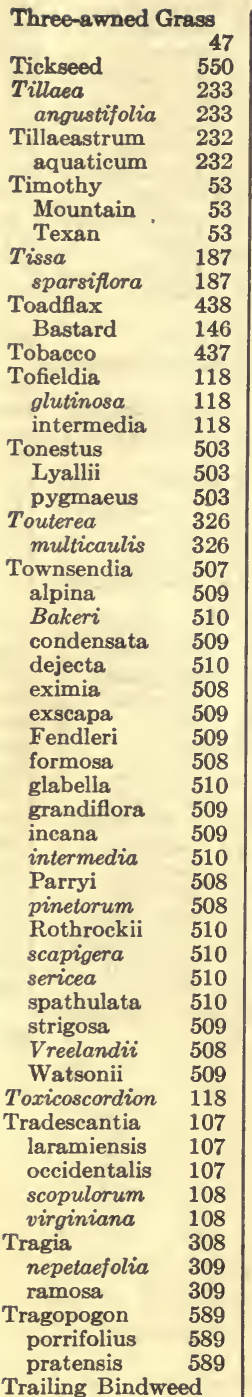

Trailing Bindweed

Trailing Buttercup

Treacle Mustard

202

Tree Ash

Trefoil Shrubby

Tribulus

230

378

378

277

306

\begin{tabular}{|c|c|}
\hline maximus & 306 \\
\hline Tricuspis & 65 \\
\hline acuminata & 65 \\
\hline Trifolium & 277 \\
\hline andinum & 279 \\
\hline anemophilum & 279 \\
\hline attenuatum & 279 \\
\hline bracteolatum & 279 \\
\hline Brandegei & 278 \\
\hline dasyphyllum & 279 \\
\hline eriocephalum & 278 \\
\hline Fendleri & 280 \\
\hline gymnocarpon & 279 \\
\hline Haydenii & 278 \\
\hline Hybridum & 278 \\
\hline
\end{tabular}

involucratum

Kingii

latifolium

longipes

montanense

nanum

nemorale

Parryi

pauciflorum

pratense

repens

Rydbergii

scariosum

stenolobum

subcaulescens

Wormsjoldii

Triglochin

maritima

palustris

Triodia

acuminata

Tripterocalyx

Trisetum

montanum

subspicatum

Trollius

albiflorus

Troximon

arizonicum $\quad 599$

aurantiacum 599

cuspidatum 589

elatum

glaucum

gracilens

grandiflorum

laciniatum

montanum

parviflorum

pubescens

pumilum

purpureum

roseum

villosum

True Oat Grass

Tumbleweed

Twayblade

Twin Flower
Twisted-stal

Typha

latifolia

ULMACEAE
Ulmus
americana
UMBELLIFERAE
Unamia
ptarmicoides
Unicorn Plant
Unifolium
liliaceum

Urtica

cardiophylla

dioica

gracilipes

gracilis

holosericea

URTICACEAE

Utah Juniper

Utricularia

minor

vulgaris

Vaccaria

Vacciniaceat

Vaccinium

caespitosum

erythrococcum

globulare

macrophyllum 372

membranaceum

Myrtillu

occidentale

oreophilum

scoparium

Vagnera

leptopetala

Valeriana

acutiloba

ceratophylla

edulis

furfurescens $\quad \mathbf{4 7 5}$

micrantha $\mathbf{4 7 5}$

occidentalis $\quad 476$

oreophila

476

ovata

476

septentrionalis 476

sitchensis $\quad 476$

sylvatica $\quad 476$

trachycarpa . 475

wyomingensis 476

VALERIANACEAE $\mathbf{4 7 5}$

Valerian Family $\mathbf{4 7 5}$

Vallisneriaceae

599

598

599
599

599

598

61

171

125

469

119

31

31

31
31
425

hastata 425

3 stricta 425

Verbenaceae 424

Verbesina $\quad \mathbf{5 5 0}$

encelioides $\quad 550$

Vernonia $\quad 484$

fasciculata $\quad \mathbf{4 8 4}$

Jamesii $\quad 484$

Veronica $\quad 451$

alpina $\quad 451$

americana $\quad 452$

anagallis-aquatica

peregrina $\quad 451$

scutellata $\quad 452$

serpyllifolia $\quad 451$

Wormsjoldii 451

Vervain $\quad 424$

Blue 425

Family $\quad 424$

Hoary 425

Vesicaria 218

Ludoviciana 218

Vetch . 280, 300, 301

Viburnum $\quad 469$

Lentago $\quad 469$

Opulus $\quad 469$

pauciflorum 469

Vicia 300

americana $\quad 301$

linearis 301

oregana 301

producta 301

truncata 301

Vine $\quad 315,392$

Family $\quad 315$

Wild Potato 392

Viola $\quad 320$

adunca 323

atriplicifolia 321

bellidifolia 323

biflora 321

biternata $\quad 321$

blanda $\quad 322$

canadensis $\quad 322$

delphinifolia 321

demissa 323

erectifolia $\quad 322$

flavovirens 322

gemphopetala 322

inamoena 323

LeConteana 322

linguaefolia 322

Macloskeyi 322

montanensis 323

monticola 323

nephrophylla 322

Nuttallii 321

odontophora 323

palustris 322

pedatifida 321

physalodes 321

Rafinesquii 323

retroscabra 323

retusa

Rydbergii $\quad 322$

Sheltonii 321 


\begin{tabular}{|c|c|c|c|c|c|c|}
\hline subvestita & 323 & French & Wild Tomato & 436 & Xanthium & 542 \\
\hline Thorii & 321 & Jamestown & \multicolumn{2}{|c|}{ Wild Yellow Plum } & canadense & \\
\hline vallicola & 321 & Jimson & & 269 & commune & 543 \\
\hline VIolaceate & 320 & Joe Pye & Willow & 128 & echinatum & 542 \\
\hline Violet & 320 & Pickerel & Autumn & 130 & Xerophyllum & 118 \\
\hline Dogtooth & 116 & Pygmy 232 & Black & 129 & tenax & 118 \\
\hline Family & 320 & Western Poison Ivy & Dusky & 131 & Ximenesia & 549 \\
\hline White Sweet & 322 & 313 & Family & 127 & encelioides & 550 \\
\hline \multirow{2}{*}{\multicolumn{2}{|c|}{ Virginia Creeper }} & Western Ragweed & Fendler's & 130 & Xylorhiza & 510 \\
\hline & & 541 & Hoary & 136 & glabriuscula & 510 \\
\hline Virgin's Bower & 197 & Western Wallflower & & 137 & Parryi & 511 \\
\hline VItACEAe & 315 & 229 & leaved & 130 & venusta & 511 \\
\hline \multirow{4}{*}{$\begin{array}{l}\text { Vitis } \\
\text { riparia } \\
\text { vulpina }\end{array}$} & 315 & Wheat Cockle & & 136 & villosa & 511 \\
\hline & 316 & t Grass & Sanc & 131 & & \\
\hline & 315 & e-bark Pine 27 & Willow & 335 & \multirow{2}{*}{\multicolumn{2}{|c|}{$\begin{array}{l}\text { Yarrow } \\
\text { Yellow Pond Lily }\end{array}$}} \\
\hline & & Clover 278 & Windflower & 195 & & \\
\hline \multirow{5}{*}{$\begin{array}{l}\text { Washingtonia } \\
\text { divaricata } \\
\text { longistylis } \\
\text { obtusa } \\
\text { occidentalis }\end{array}$} & 348 & White Fir & Winter Cress & 215 & & 188 \\
\hline & 348 & White Mountain & Winter & 169 & Yellow Rattle & 454 \\
\hline & 348 & Lily $\quad 113$ & Winterg & 366 & \multicolumn{2}{|c|}{ Yellow Sweet Clover } \\
\hline & 348 & White Sage $\quad 169$ & Cre & 371 & & 277 \\
\hline & 348 & \multirow{2}{*}{$\begin{array}{l}\text { White Sweet Clover } \\
277\end{array}$} & $\mathrm{Fa}$ & 366 & Yucca & 117 \\
\hline Water Cress & 216 & & Witc & 45 & ustifolia & 117 \\
\hline rowfoot & 198 & White Sweet-violet & Wol & 470 & & 117 \\
\hline Water Hemp & 171 & 322 & Woo & 21 & & 117 \\
\hline \multirow{2}{*}{\multicolumn{2}{|c|}{ Water Hoarhound }} & Whitlowwort 187 & oreg & 22 & Harrimaniae & 117 \\
\hline & & Wild Balsam Apple & scopulina & 22 & \multirow{3}{*}{$\begin{array}{c}\text { Zannichellia } \\
\text { palustris }\end{array}$} & \\
\hline Waterleaf & 406 & 472 & \multicolumn{2}{|c|}{ Wood Sorrel Family } & & 35 \\
\hline Family & 405 & Wild Barley & & 304 & & 35 \\
\hline \multicolumn{2}{|c|}{ Water Lily Family } & abbage & Wor & 565 & Zauschneria & 334 \\
\hline \multirow{2}{*}{\multicolumn{2}{|c|}{ Water Milfoil Family }} & adytuft 214 & & 430 & Garrettii & 334 \\
\hline & & Wild Mint $\quad 428$ & $W u l$ & 450 & Zinnia & 543 \\
\hline & 345 & tard & carpa & 450 & \multirow{2}{*}{\multicolumn{2}{|c|}{$\begin{array}{cc}\text { Zizia } & 350 \\
\text { cordata } & 350\end{array}$}} \\
\hline \multicolumn{2}{|l|}{ Water Plantain } & Wild Oats & Wye & 546 & & \\
\hline & 37 & Wild Onion $\quad 113$ & lexicaulis & 547 & \multirow{3}{*}{$\begin{array}{l}\text { Zygadenus } \\
\text { coloradensis } \\
\text { dilatata }\end{array}$} & 118 \\
\hline \multicolumn{2}{|l|}{ Water Starwort } & Wild Potato Vine & arizonica & 547 & & 118 \\
\hline & 311 & $\begin{array}{r}392 \\
9\end{array}$ & helianthoides & 546 & & 118 \\
\hline Waterweed & 38 & Wild Radish & scabra & 547 & & 118 \\
\hline \multicolumn{2}{|c|}{ Waterwort Family } & \multirow{2}{*}{$\begin{array}{l}\text { Wild Red Cherry } \\
270\end{array}$} & Wyoming Daisy & 530 & falc & 119 \\
\hline & 319 & & Wyomingia & 530 & ineus & 118 \\
\hline Wede & 174 & Wild Red Raspberry & ar & 531 & nedius & 119 \\
\hline & 174 & & & & Nuttallii & 119 \\
\hline Weed & 108 & Wild Rye & cinerea & 531 & venenosus & 118 \\
\hline & 176 & Wild Sarsaparilla & pulcherrima & & ZYGOPHYLLACEA & \\
\hline Door & & & Tweedyana & 531 & & 306 \\
\hline
\end{tabular}




\section{A TEXTBOOK OF BOTANY}

\section{For Colleges and Universities}

By JOHN MERLE COULTER, Ph.D., Professor of Plant Morphology, CHARLES REID BARNES, Ph.D., Late Professor of Plant Physiology, and HENRY CHANDLER COWLES, Ph.D., Assistant Professor of Plant Ecology, of the Botanical Staff of the University of Chicago.

Complete . . . . . . . . . . . . . . . . \$3.50

Volume I. Morphology and Physiology . . . . . . 2.00

Volume II. Ecology . . . . . . . . . . . . . 2.00

7 HIS textbook presents the fundamentals of modern 1 botany for undergraduate instruction. These fundamentals are presented under three main divisions: Morphology, Physiology, and Ecology, subjects of the varied work in botany to-day. The volumes contain selected material, general statements not confused by exceptions, and a minimum of terminology.

T In the part on morphology, the evolution of the plant, kingdom has determined the selection of material and of structures, so that every plant or group contributes something to the evolutionary sequence. Physiology is presented in its modern aspect, the explanation of plant behavior being in terms of chemistry and physics, as far as present knowledge permits. Plants are considered as expressions of matter and force. The comparatively new subject of ecology is organized for the first time as a college text.

- The work is strictly modern in its point of view. All antiquated conceptions have been carefully discarded. In all the parts the logical presentation is emphasized by frequent captions that catch the eye, and it is believed that the orderly arrangement of material will facilitate both its reception and its retention. A special feature of the book is its excellent illustrations, the majority of which are original.

\section{A MERICAN BOOK COMPANY}




\section{GRAY'S NEW MANUAL OF BOTANY-SEVENTH EDITION}

Thoroughly revised and largely rewritten. by BENJAMIN LINCOLN ROBINSON, Ph.D., Asa Gray Professor of Systematic Botany, and MERRITT LYNDON FERNALD, S.B., Assistant Professor of Botany, Harvard University, assisted by specialists in certain groups.

Regular edition. Cloth, 926 pages . . . . . . . $\$ 2.50$

Tourist's edition. Flexible leather, 926 pages . . . . 3.00

A MERICAN botanists, who had been impatiently awaitA ing the revision of this indispensable work, will be delighted to know that a seventh, completely revised, and copiously illustrated edition has now been issued. The revision has entailed years of work by skilled specialists. No effort has been spared to attain the highest degree of clearness, terseness, and accuracy. The plant families have been rearranged in a manner to show the latest view of their affinities, and hundreds of species have been added. The synonomy is copious, and the ranges are stated in considerable detail. T The nomenclature has been brought into thorough accord with the important international rules recently established-a feature of great significance. Indeed, the Manual is the only work of its scope which in the matter of nomenclature is free from provincialism and rests upon a cosmopolitan basis of international agreement. Nearly a thousand figures, specially designed for this edition, have been added, and scores of brief and lucid keys have been introduced in a manner which greatly simplifies the problem of plant identification. The work has been extended to include Ontario, Quebec, and the maritime provinces of Canada.

\section{A MERICAN BOOK COMPANY}




\section{SCIENTIFIC MEMOIRS}

Edited by JOSEPH S. AMES, Ph.D., Johns Hopkins University

The Free Expansion of Gases. Memoirs by Gay-Lussac, Joule, and Joule and Thomson. Edited by Dr. J. S. Ames. \$0.75.

Prismatic and Diffraction Spectra. Memoirs by Joseph von Fraunhofer. Edited by Dr. J. S. Ames. \$o.6o.

Röntgen Rays. Memoirs by Röntgen, Stokes, and J. J. Thomson. Edited by Dr. George F. Barker. \$o.6o.

The Modern Theory of Solution. Memoirs by Pfeffer, Van't Hoff, Arrhenius, and Raoult. Edited by Dr. H. C. Jones. \$1.00.

The Laws of Gases. Memoirs by Boyle and Amagat. Edited by Dr. Carl Barus. \$0.75.

The Second Law of Thermodynamics. Memoirs by Carnot, Clausius, and Thomson. Edited by Dr. W. F. Magie. \$0.90.

The Fundamental Laws of Electrolytic Conduction. Memoirs by Faraday, Hittorf, and Kohlrausch. Edited by Dr. H. M. Goodwin. \$0.75.

The Efrects of a Magnetic Field on Radiation. Memoirs by Fara day, Kerr, and Zeeman. Edited by Dr. E. P. Lewis. \$0.75.

The Laws of Gravitation. Memoirs by Newton, Bouguer, and Cavendish. Edited by Dr. A. S. Mackenzie. \$1.00.

The Wave Theory of Light. Memoirs by Huygens, Young, and Fresnel. Edited by Dr. Henry Crew. \$1.00.

The Discovery of Induced Electric Currents. Vol. I. Memoirs by Joseph Henry. Edited by Dr. J. S. Ames. \$0.75.

The Discovery of Induced Electric Currents. Vol. II. Memoirs by Michael Faraday. Edited by Dr. J. S. Ames. \$0.75.

The Foundations of Stereo-chemistry. Memoirs by Pasteur, Le Bel, and Van't Hoff, together with selections from later memoirs by Wislicenus, and others. Edited by Dr. G. M. Richardson. \$1.00.

The Expansion of Gases. Memoirs by Gay-Lussac and Regnault. Edited by Prof. W. W. Randall. \$1.00.

Radiation and Absorption. Memoirs by Prévost, Balfour Stewart, Kirchhoff, and Kirchhoff and Bunsen. Edited by Dr. DeWitt B. Brace. $\$ 1.00$.

A M ERICAN BOOK COMPANY 


\section{HUNTER'S ELEMENTS OF BIOLOGY}

By GEORGE WILLIAM HUNTER, A. M., Instructor in Biology, DeWitt Clinton High School, New York City.

$$
\$ I .25
$$

7 HIS work presents such a correlation of botany, zoöl1 ogy, and human physiology as constitutes an adequate first-year course in biology. The foundation principles, upon which the present correlation of subjects is made, are that the life processes of plants and of animals are similar, and in many respects identical ; that the properties and activities of protoplasm are the same whether in the cell of a plant or of an animal; and that the human body is a delicate machine, built out of that same mysterious living matter, protoplasm. With such a foundation this correlation is simple and natural. T The course is designed to give to students a general conception of the wide range of forms in plant and animal life; to lead them to observe the various processes carried on by plants and animals, and to study only so much of structure as is necessary for a clear comprehension of these processes; and to help them to understand the general structure of the human body, and the way to care for it.

7. The treatment follows the order in which the topics are likely to be taken up when the wowk is begun in the fall. The laboratory and field work is interesting and readily comprehended. The questions are few and simple; they apply to structures easily found, and deal with externals only. The experiments outlined in the book do not require an extensive laboratory equipment. Excellent results may be obtained with little or no apparatus, except that made by the pupils and teacher working together.

T The course combines in excellent proportion text-book study, laboratory experiments, field work, and work for oral recitation, and is attractive, accurate, and informative.

\section{AMERICAN BOOK COMPANY}




\section{H E R R I C K'S G E N E R A L Z O Ö L O G Y}

By GLENN W. HERRICK, B.S.A., Assistant Professor of Economic Entomology, Cornell University.

Text-Book

$\$ 1.20$

Laboratory Exercises .60

7 HIS comprehensive course is adapted to any modern 1 system of animal study, and because of the method of treatment and the types selected it may be used advantageously in all schools from the Atlantic to the Pacific. The animal forms selected for study give the pupil a good conception of a wide range of forms and also a proper view of the extent and variety of the animal kingdom. At the same time they have been chosen for the purpose of giving point to the modern theories of development and animal history.

T Each group is in turn treated with a type form as a basis, and the related forms are sufficiently numerous to permit of the division of each group. Provision is thus made for a brief or an extensive course. Each group may be studied as a unit, thus enabling the teacher to arrange the order of the topics to suit the needs of any particular locality, climate, etc. Ample directions for field work are given, particular attention being paid to forms of economic importance.

I In the laboratory manual a typical member of each animal group has been selected for purposes of illustration, but structural details have been reduced to the minimum in order to afford a clear understanding of the physiological processes. In most cases, however, a sufficient number of alternative forms are given under each group to permit the selection of a type familiar to the pupils of any locality. The laboratory directions are clear and explicit, and recognize fully the extent and limitations of the average student.

\section{AMERICAN BOOK COMPANY}




\section{AN ELEMENTARY TEXT- BOOK OF THEORETICAL MECHANICS}

By GEORGE A. MERRILL, B.S., Principal of the California School of Mechanical Arts, and Director of the Wilmerding School of Industrial Arts, San Francisco

$$
\$ 1.50
$$

WERILL'S MECHANICS is intended for the upper

1 classes in secondary schools, and for the two lower classes in college. Only a knowledge of elementary algebra, plane geometry, and plane trigonometry is required for a thorough comprehension of the work.

T By presenting only the most important principles and methods, the book overcomes many of the difficulties now encountered by students in collegiate courses who take up the study of analytic mechanics, without previously having covered it in a more elementary form. It treats the subject without the use of the calculus, and consequently does not bewilder the beginner with much algebraic matter, which obscures the chief principles.

Tा The book is written from the standpoint of the student in the manner that experience has proved to be the one most easily grasped. Therefore, beyond a constant endeavor to abide by the fundamental precepts of teaching, no one method of presentation has been used to the exclusion of others. The few necessary experiments are suggested and outlined, but a more complete laboratory course can easily be supplied by the instructor.

T) The explanation of each topic is followed by a few wellchosen examples to fix and apply the principles involved. A number of pages are devoted to the static treatment of force, with emphasis on the idea of action and reaction. Fourplace tables of the natural trigonometric functions are included.

\section{AMERICAN BOOK COMPANY}




\section{THE MODERN \\ MATHEMATICAL SERIES}

LUCIEN AUGUSTUS WAIT, General Editor

Analytic Geometry. By J. H. Tanner, Ph.D., Professor of Mathematics, Cornell University, and Joseph Allen, A.M., Instructor in Mathematics, College of the City of New York. \$2.00.

Differential Calculus. By James McMahon, A. M., Professor of Mathematics, Cornell University, and Virgil Snyder, Ph.D., Assistant Professor of Mathematics, Cornell University. \$2.00.

Integral Calculus. By D. A. Murray, Ph.D., Professor of Mathematics, Dalhousie College. \$2.00.

Differential and Integral Calculus. By Virgil Snyder, Ph.D., Assistant Professor of Mathematics, Cornell University, and John Irwin Hutchinson, Ph. D., Instructor in Mathematics, Cornell University. \$2.00.

Elementary Geometry-Plane. By James McMahon, A.M., Professor of Mathematics, Cornell University. $\$ 0.90$.

Elementary Algebra. By J. H. Tanner, Ph.D., Professor of Mathematics, Cornell University. \$1.00,

High School Algebra. By J. H. Tanner, Ph. D., Professor of Mathematics, Cornell University. \$1.00.

Elementary Geometry-Solid. By James McMahon, A.M., Professor of Mathematics, Cornell University.

$7 \mathrm{HE}$ advanced books treat their subjects in a way that is simple and practical, yet thoroughly rigorous, and attractive to both teacher and student. They meet the needs of all students pursuing courses in engineering and architecture. The elementary books implant into secondary schools the spirit of the more advanced books, and make the work from the very start, continuous and harmonious.

AMERICAN BOOK COMPANY 


\title{
INTRODUCTION TO POLITICAL SCIENCE
}

\author{
By JAMES WILFORD GARNER, Ph. D., Professor of \\ Political Science, University of Illinois \\ $\$ 2.50$
}

$T$

HIS systematic treatise on the science of government covers a wider range of topics on the nature, origin, organization, and functions of the state than is found in any other college textbook published in the English language. The unusually comprehensive treatment of the various topics is based on a wide reading of the best literature on the subject in English, German, French, and Italian, and the student has opportunity to profit by this research work through the bibliographies placed at the head of each chapter, as well as by means of many additional references in the footnotes.

9 An introductory chapter is followed by chapters on the nature and essential elements of the state; on the various theories concerning the origin of the state; on the forms of the state; on the forms of government, including a discussion of the elements of strength and weakness of each; on sovereignty, its nature, its essential characteristics, and its abiding place in the state; on the functions and sphere of the state, including the various theories of state activity; and on the organization of the state. In addition there are chapters on constitutions, their nature, forms, and development; on the distribution of the powers of government; on the electorate; and on citizenship and nationality.

9ा Before stating his own conclusions the author gives an impartial discussion of the more important theories of the origin, nature, and functions of the state, and analyzes and criticises them in the light of the best scientific thought and practice. Thus the pupil becomes familiar with the history of the science as well as with its principles as recognized to-day.

\section{A M ERICA N BOOK COMPANY}




\title{
PLANE SURVEYING
}

\author{
$\$ 3.00$
}

By WILLIAM G. RAYMOND, C. E., member American Society of Civil Engineers, Professor of Geodesy, Road Engineering, and Topographical Drawing in Rensselaer Polytechnic Institute.

T $\mathbf{N}$ this manual for the study and practice of surveying the 1 subject is presented in a clear and thorough manner; the general method is given first and afterward the details. Special points of difficulty have been dwelt on wherever necessary. The book can be mastered by any student who has completed trigonometry, two formulas only being given, the derivation of which requires a further knowledge. The use of these is, however, explained with sufficient fullness.

I In addition to the matter usual to a full treatment of land, topographical, hydrographical, and mine surveying, particular attention is given to system in office-work, labor-saving devices, the planimeter, slide-rule, diagrams, etc., coördinate methods, and the practical difficulties encountered by the young surveyor. An appendix gives a large number of original problems and illustrative examples.

वा The first part describes the principal instruments and deals with the elementary operations of surveying, such as measurement of lines, leveling, determination of direction and measurement of angles, stadia measurements, methods of computing land surveys, etc.

T In the second part are treated general surveying methods, including land surveys, methods adapted to farm surveys, United States public land surveys, and city surveys, curves, topographical surveying, ordinary earthwork computations, hydrographic and mine surveying, etc.

ๆ Both four-place and five-place tables are provided. They are unusually numerous and practical, and are set in large, clear type. The illustrations are particularly helpful.

\section{AMERICAN BOOK COMPANY}




\section{DE SCR I P T I V E \\ CA T A LOGUE OF HIGH SCHOOL AND COLLEGE TEXT-BOOKS}

Published Complete and in Sections

ХV issue a Catalogue of High School and College TextBooks, which we have tried to make as valuable and as useful to teachers as possible. In this catalogue are set forth briefly and clearly the scope and leading characteristics of each of our best text-books. In most cases there are also given testimonials from well-known teachers, which have been selected quite as much for their descriptive qualities as for their value as commendations.

9) For the convenience of teachers this Catalogue is also published in separate sections treating of the various branches of study. These pamphlets are entitled: English, Mathematics, History and Political Science, Science, Modern Languages, Ancient Languages, and Philosophy and Education.

- In addition we have a single pamphlet devoted to Newest Books in every subject.

T Teachers seeking the newest and best books for their classes are invited to send for our Complete High School and College Catalogue, or for such sections as may be of greatest interest.

T) Copies of our price lists, or of special circulars, in which these books are described at greater length than the space limitations of the catalogue permit, will be mailed to any address on request.

T) All correspondence should be addressed to the nearest of the following offices of the company: New York, Cincinnati, Chicago, Boston, Atlanta, San Francisco.

\section{A M ERICAN BOOK COMPANY}







\section{THE UNIVERSITY LIBRARY UNIVERSITY OF CALIFORNIA, SANTA CRUZ SCIENCE LIBRARY}

This book is due on the last DATE stamped below.

To renew by phone, call 459-2050.

Books not returned or renewed within 14 days after due date are subject to billing.
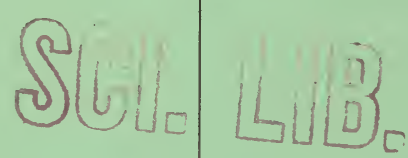


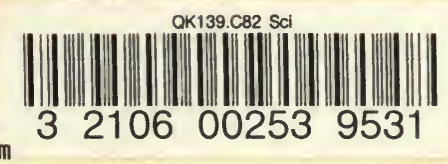


